Fi.

six

.

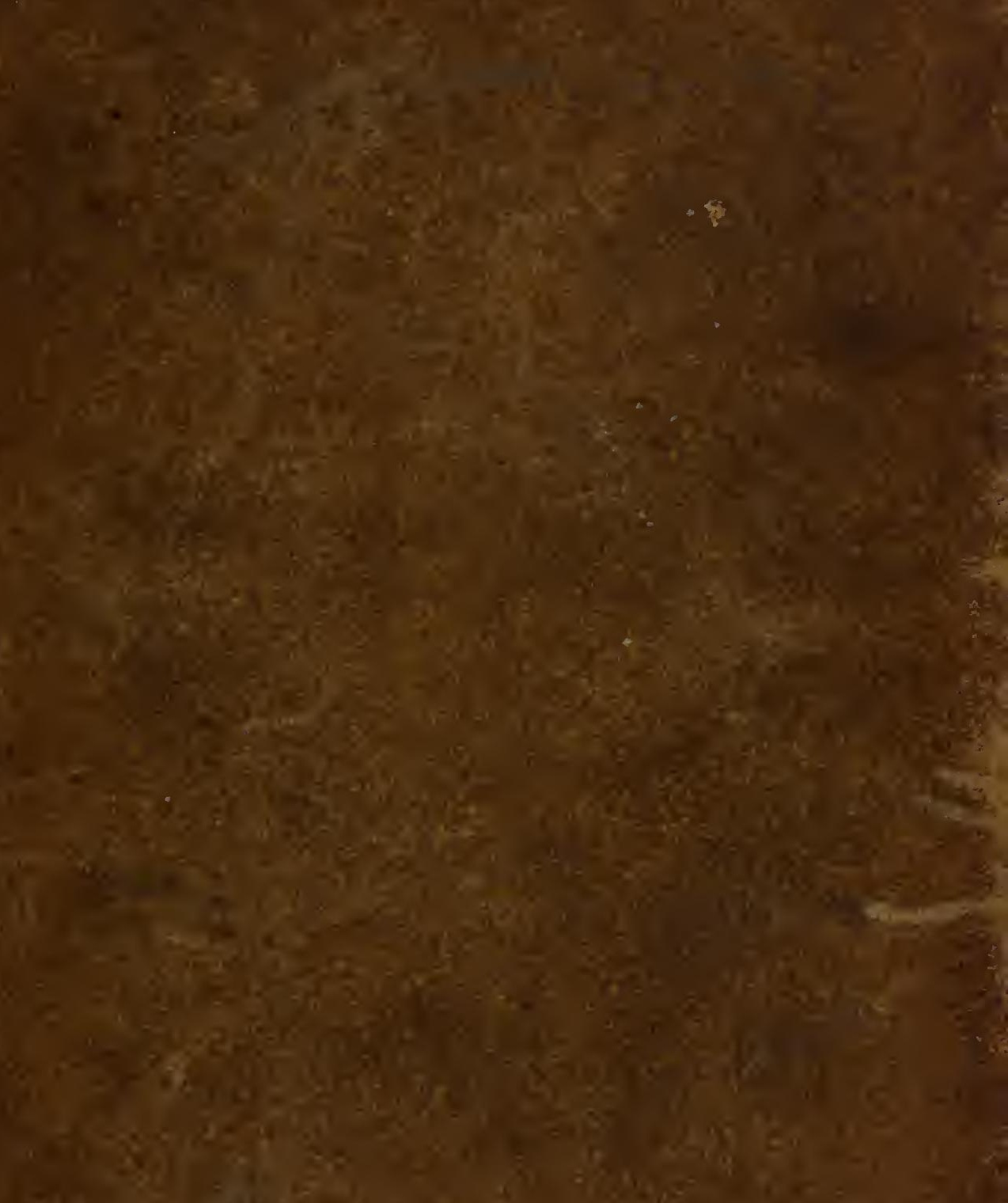

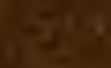

anc.

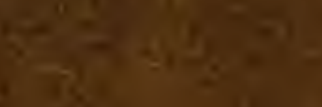

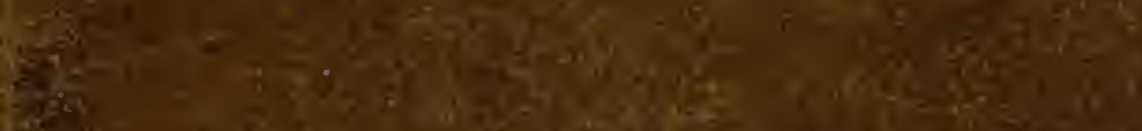

(c. 
NATIONAL LIBRARY OF MEDICINE Bethesda, Maryland
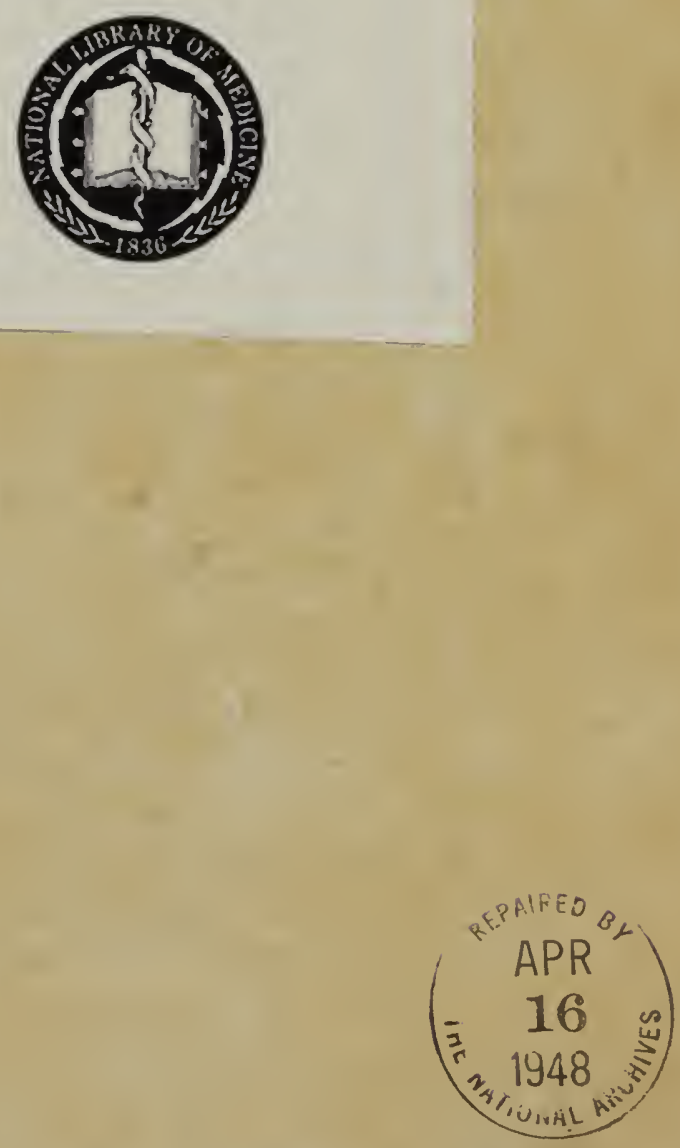


$$
\frac{A-1}{S-12}
$$




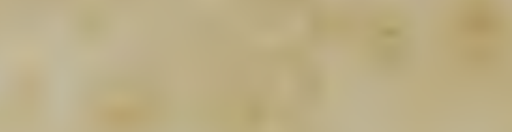

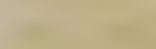

(n)

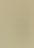

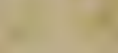

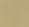





\section{T H E H O R S E,}

\section{BY YOUATT.}

E D ITED BY SKIN NER. 



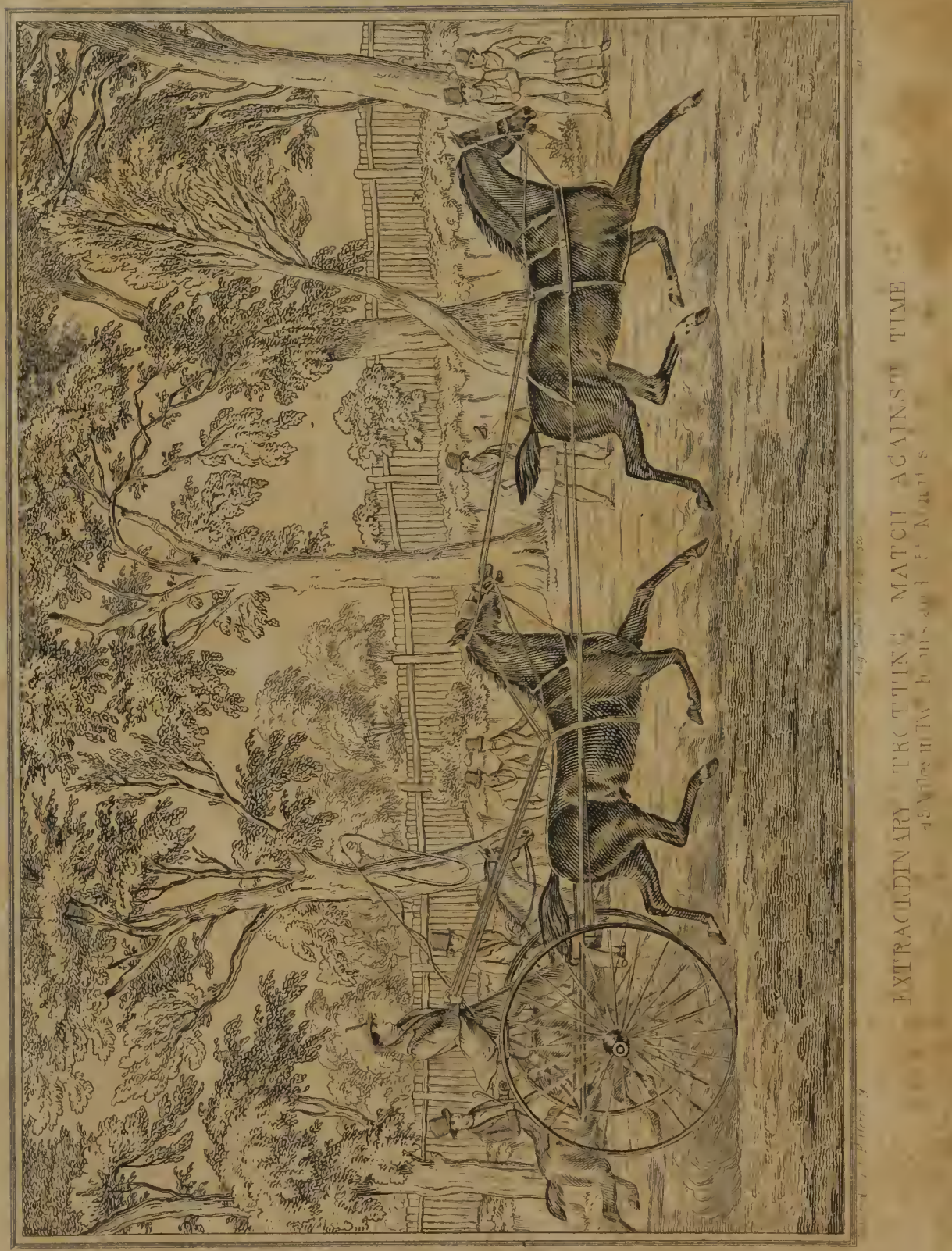




\section{TH E H 0 R S E,}

BY WILLIANI YOUATT.

A NEIV EDITION, WITH NUMEROUS ILIUSTRATIONS.

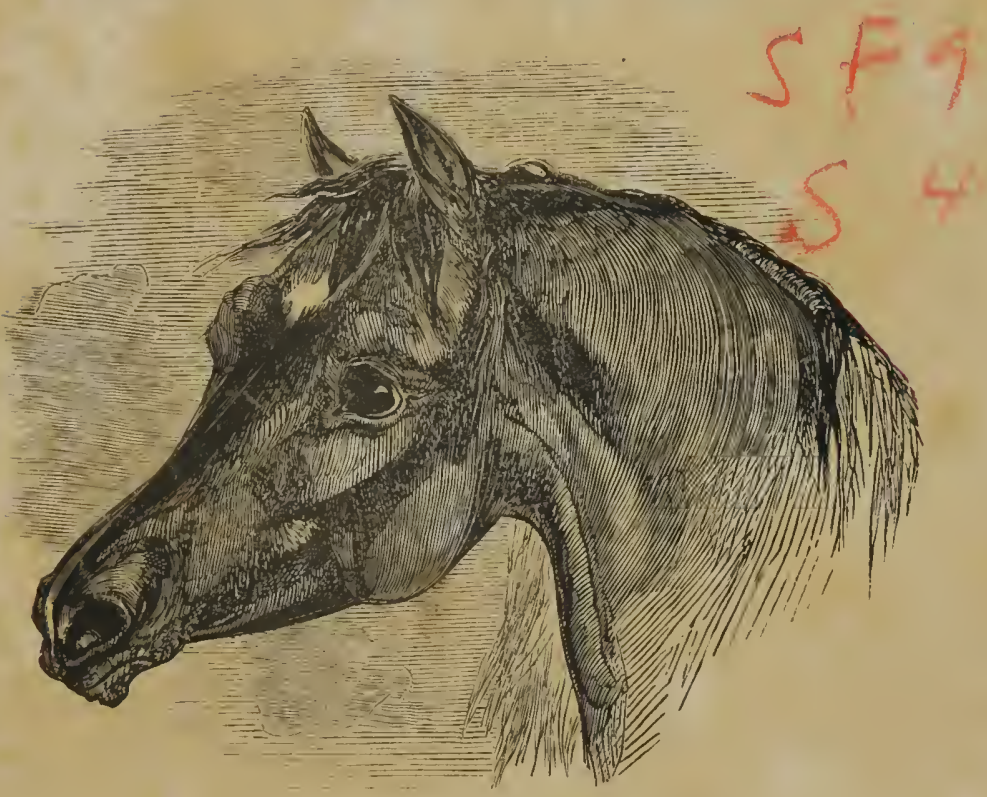

TOGETHER WIT H A

GENERAL HISTORY OF THE HORSE;

A DISSERTATION ON

THE AMERICAN TROTTING HORSE,

HOW TRAINED AND JOCKEYED,

AN ACCOUNT OF HIS REMARKABLE PERFORMANCES;

A N D

AN ESSAY ON THE ASS AND THE MULE,

BY J. S. SKINNER,

ASSISTANT POST MASTER GENERAL, AND EDITOR OF THE TURF REGISTER.

PHILA DEL P H I A :

LEA AND BLANCHARD, FOR G. W. GORTON.

1843. 


\section{SF \\ Y67h \\ 1843}

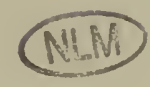

Entered, according to the Act of Congress, in the year 1843, by LEA AND BLANCHARD,

in the office of the clerk of the District Court of the United States in and for the Eastern District of Pennsylvania.

J. FAGAN, STEREOTYPER,

I. ASHMEAD, PRINTER. 


\section{PREFACE TO THE LONDON EDITION.}

PUBLISHED UNDER THE SUPERINTENDENCE OF THE SOCIETY FOR THE DIFFUSION OF USEFUL KNOWLEDGE.

The First Edition of The Horse, which was completed in the year 1831, has since had a large and continued sale: and in acknowledging the valuable communications which have been made for the improvement of the work, it is satisfactory to the Committee to be able to state, that no grave errors in it have been pointed out.

Veterinary science has, however, made great progress in the last twelve years; the Structure of the Horse, the Injuries and Diseases to which he is subject, and the Treatment of these, have been investigated, in this country and abroad, with much diligence and success, both at Colleges and in Societies devoted to the cultivation of Veterinary knowledge, and by practitioners whose education and experience render their observations worthy of great respect.

In these circumstances, the Society intrusted to the Author the preparation of a New Edition of this Treatise; and he has subjected it to so complete a revision, as to render it in many respects a new work. This remark applies especially to the chapters relating to the Diseases of the Horse.

Respectfully submitted,

By order of the Committee, THOMAS COATES, Sec.

42 Bedford Square, London, 1 st March 1843. 


\section{PREFACE,}

\section{BY THE AMERICAN EDITOR.}

IN undertaking, at the instance of the American publishers, to prepare a new edition of the last London copy of the work here presented, on the Horse ; it has been my endeavour to adapt it more exactly to the circumstances of our own country; and by omitting some portions of the original, not immediately illustrative of the principal subject, to reduce the volume, without impairing its value for practical uses.

Few things have occurred, serving better at once to characterize and accelerate the march of intellect and benevolence which distinguishes the age in which we live, than the well-known formation, in England, of a "Society for the diffusion of Useful Knowledge;" composed, as it is, of men of the highest repute in the various departments of learning and industry; headed by the Lord Chancellor himself.

Their proceedings, as far as published, all show them to be animated by a generous desire to collect, simplify, and publish in the cheapest form, the latest and most authentic discoveries and improvements in science, and in arts promotive of the comfort and happiness of the human race. Under their auspices, several series of publications have appeared, one of which is denominated the "Farmer's Series." Of this class, the first is the book on the Horse. That the Horse should have been placed at the head of the list of domestic animals, having in view a treatise on the breeds, properties and uses of each, is a distinction to which he is justly entitled, in reference as well to the beautiful symmetry of his form, and his extraordinary physical powers, as to his admirable docility of temper, and high moral qualities, fitting him eminently for the various purposes of pleasure and of business.

In the work to which we are now introducing the reader, pruned, as it has been, of some preliminary chapters, he will find little to amuse him, of a character merely curious and speculative; the mysteries of charlatanry, and the nostrums of empiricism, have been carefully excluded; and where terms of anatomical and medical science have been necessarily employed, they are explained, and applied with a degree of plainness and precision, which bring them within the ready comprehension of every reader. 
The task of preparation to render the present edition inore useful for American readers, has consisted chiefly in what will be found prefixed to it, on the various stages which have marked and acts which have contributed to the improvement of the English stock of horses; some of the best of which, as is more particularly shown, have been imported into the United States, from time to time, for the last century or moreas also, and more particularly, of what is said of the AMErican TrotTING Horse. To these have been added, a dissertation on the natural history and uses of the Ass and the Mule; the last named animal being deeensed worthy of especial notice, on account of its utility and economy, in American agriculture; and the yet greater extent to which it is believed it might be employed with advantage in this, as it is known to be in some other countries.

But without presuming to recommend the work on account of any observations of his own, the American Editor, who has himself written volumes to illustrate and defend the interests of American husbandry, does venture, with the utmost confidence, to pronounce the work itself to be one which every gentleman may read with certainty of instructionleaving, as it does, in truth, nothing untold, which need be known of the Horse, in his minutest anatomy, with full directions as to breeding and breaking, food and exercise; as, also, plain descriptions of his various diseases, and their most simple and certain cures. Such a work ought to be in the possession, for convenient reference, of every owner of horses, whether for the coach, the saddle, the cart, or the plough. The great value attached to this work, and its entire success in England, may be understood, when we state that the new edition just published in London, and from which the present is reprinted, has been nearly rewritten by the author, and improved by the insertion of many new cuts, prepared for it by a distinguished artist.

J. S. S.

Washington, May, 1843. 


\section{LIST OF ILLUSTRATIONS.}

1. TROTTING MATCH IN HARNESS................. FrontISPIECE.

2. HEAD OF THE BLACK ARABIAN ...................... Title.

3. SKELETON OF THE HORSE.......................... Page 68

4. BONES OF THE HORSE'S HEAD ........................ 70

5. SECTION OF THE HORSE'S HEAD..................... 72

6. DIAGRAM OF THE SKULL........................... 75

7. OCCIPITAL BONE OF THE HORSE...................... 77

8. SPINAL CHORD, WITH BRANCHING NERVES.............. 80

9. SECTION OF THE EYE................................ 86

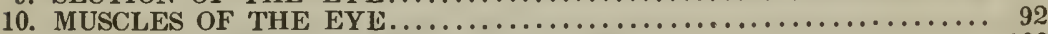

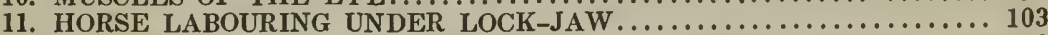

12. ANATOMY OF THE LEG AND FOOT $\ldots \ldots \ldots \ldots \ldots \ldots \ldots \ldots \ldots \ldots \ldots$

13. SECTION OF THE UPPER JAW BONE..................... 123

14. MUSCLES, NERVES, AND BLOOD.VESSELS OF THE HEAD AND

UPPER PART OF THE NECK ......................... 125

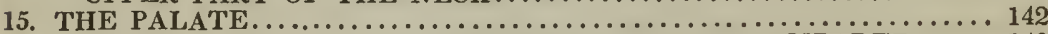

16. GLENOID CAVITY OF THE HORSE AND TIGER COMPARED..... 143

17. TEETH OF A FOAL A FEW DAYS AFTER BIRTH............ 144

18. TEETH OF A FOAL AT TWO MONTHS.................... 144

19. TEETH OF A FOAL AT TWELVE MONTHS................ 145

20. TRANSVERSE SECTION OF A GRINDER.................. 145

21. TEETH AT THE AGE OF A YEAR AND A HALF............. 146

22. TEETH AT THE AGE OF THREE YEARS................. 147

23. TEETH AT THE AGE OF THREE YEARS AND A HALF........ 147

24. TEETH AT THE AGE OF FIVE YEARS...................... 148

25. TEETH AT THE AGE OF SIX YEARS.................... 148

26. TEETH AT THE AGE OF SEVEN YEARS................. 149

27. TEETH AT THE AGE OF EIGHT OR NINE YEARS._Bishoped...... 149

28. FINEST SHAPE FOR THE NECK AND HEAD $\ldots \ldots \ldots \ldots \ldots \ldots \ldots, 159$

29. THE RIBS AND VERTEBRE........................... 167

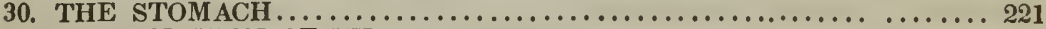

31. TERMINATION OF THE ESOPHAGUS .................... 222

32. THE BOT-FLY IN ITS VARIOUS STAGES.................. 224

33. THE INTESTINES $\ldots \ldots \ldots \ldots \ldots \ldots \ldots \ldots \ldots \ldots \ldots \ldots \ldots \ldots \ldots \ldots \ldots \ldots \ldots \ldots \ldots, 228$

34. SECTION OF THE BLIND GUT .......................... 229

35. ENTANGLEMENT OF THE SMALL INTESTINES............. 239

36. CURVED AND STRAIGHT CATHETER.................... 247

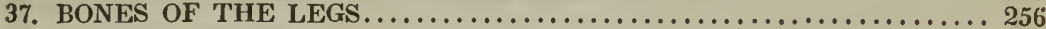

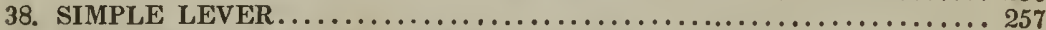

39. MUSCLES OF THE OUTSIDE OF THE SHOULDER ............... 259

40. MUSCLES OF THE INSIDE OF THE SHOULDER AND FOREARM... 260

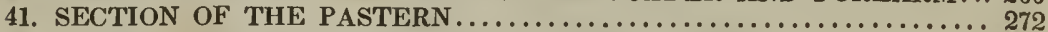

42. INSIDE VIEW OF THE BONES OF THE PASTERN ............. 276

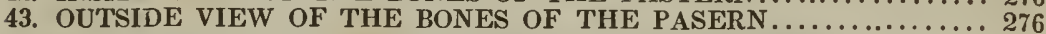

14. ATTACHMENTS OF THE MUSCLES OF THE PASTERN........... 276

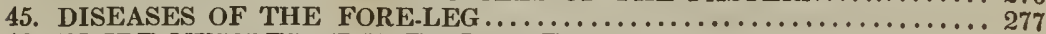

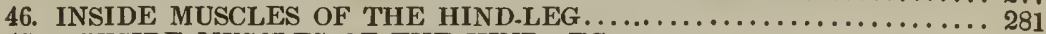

47. OUTSIDE MUSCLES OF THE HIND.LEG................... 282

48. THE HAUNCH AND HIND-LEGS.......................... 283

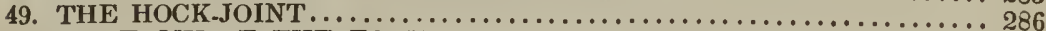

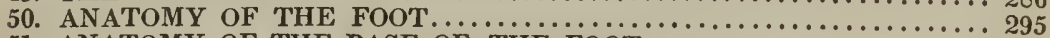

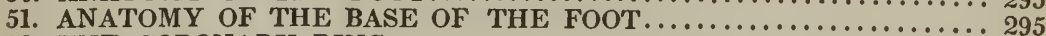

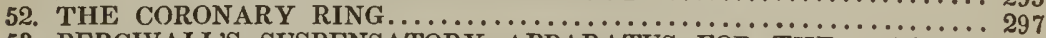

53. PERCIVALL'S SUSPENSATORY APPARATUS FOR THE CURE OF

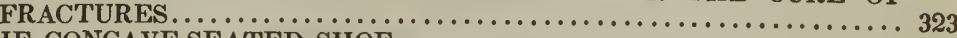

54. THE CONCAVE-SEATED SHOE........................... 338

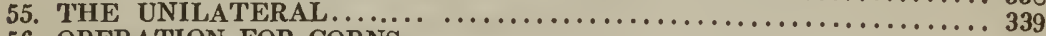

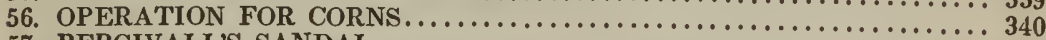

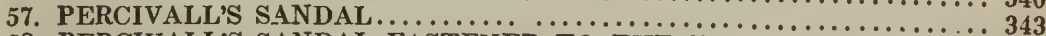

58. PERCIVALL'S SANDAL FASTENED TO THE FOOT .............. 344 


\section{CONTENTS.}

\section{INTRODUCTION, BY J. S. SKINNER.}

The Horse, in England and America-as he has been, and as he is. . Page 17 Lindsey's Arabian............................ 34

The best Races in America.......................... 35

Best Races-Mile Heats ........................... 36

Best Races at Two-Mile Heats ....................... 37

Best Races at Three-Mile Heats ....................... 38

Best Races at Four-mile Heats ........................ 39

Lengths of the principal Race-Courses in England............. 41

Rules and Regulations of the New York Jockey Club ........... 42

The Hunter ................................. 48

The American Trotter........................... 49

Rules and Regulations of the New York Trotting Club .......... 54

Trotting at Mile Heats........................... 57

Trotting at Two-Mile Heats ........................ 57

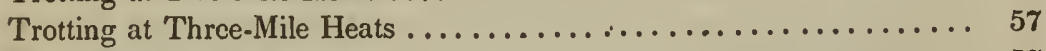

Trotting at Four-Mile Heats ....................... 57

Best Pacing in America on Record.................... 58

Miscellaneous Examples of Extraordinary Performances of American Trotters ...................................... 58

Extraordinary Trotting Match $. . \ldots \ldots \ldots \ldots \ldots \ldots \ldots \ldots, 60$

Trotting on the Beacon Course........................ 63

Centreville (L. I.) Trotting Course...................... 63

Trotting on the Hunting Park Course $\ldots \ldots \ldots \ldots \ldots \ldots \ldots \ldots \ldots .64$

Height of Trotting Horses $. . \ldots \ldots \ldots \ldots \ldots \ldots \ldots \ldots \ldots \ldots . .64$

THE HORSE,

HIS ANATOMY - WITH HIS DISEASES AND REMEDIES.

BY WILLIAM YOUATT.

CHAPTER I.

The Zoologrcal Cuassification of the Horse

CHAPTER II.

The Sensorial function. 
CHAPTER III.

Injuries and Diseases of the Skull-the Brain-the Ears-and THe Eyes $\ldots \ldots \ldots \ldots \ldots \ldots \ldots \ldots \ldots \ldots \ldots \ldots \ldots \ldots . \ldots \ldots$

Fracture $\ldots \ldots \ldots \ldots \ldots \ldots \ldots \ldots \ldots \ldots \ldots \ldots \ldots \ldots \ldots . \ldots \ldots \ldots$

Exostosis ................................. 94

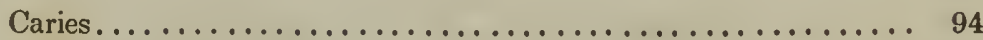

Compression of the Brain ..................... 94

Pressure on the Brain ....................... 94

Megrims............................... 94

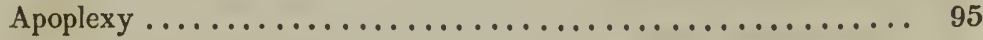

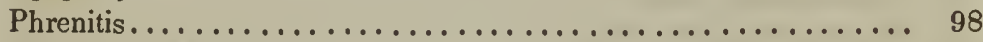

Rabies, or Madness......................... 100

Tetanus, or Locked Jaw ........................ 103

Cramp................................ 106

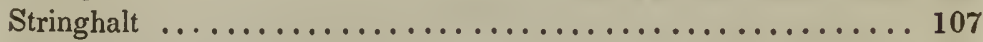

Chorea................................. 109

Fits, or Epilepsy ......................... 109

Palsy................................ 109

Rheumatism .............................. 110

Neurotomy ........................... 111

Insanity . . . . . . . . . . . . . . . . . . . . . 115

Diseases of the Eye $\ldots \ldots \ldots \ldots \ldots \ldots \ldots \ldots \ldots \ldots \ldots \ldots \ldots$

Common Inflammation of the Eye ................ 117

Specific Ophthalmia, or Moon-Blindness .............. 117

Gutta Serena ............................ 121

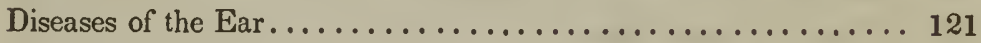

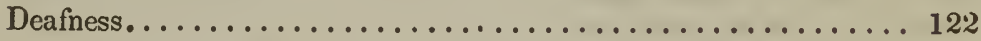

\section{CHAPTER IV.}

The Anatomy and Diseases of the Nose and Mouth ........ 122

Nasal Polypus . . . . . . . . . . . . . . . . . . . . 126

Nasal Gleet, or Discharge from the Nose . . . . . . . . . . 127

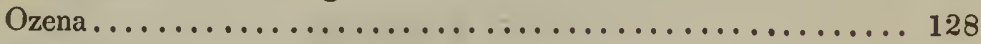

Glanders ................................. 129

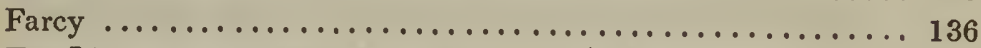

The Lips. . . . . . . . . . . . . . . . . . . . . . 139

The Bones of the Mouth...................... 141

The Palate .............................. 141

Lampas ................................... 142

The Lower Jaw . . . . ...................... 142

Diseases of the Teeth........................ 151 
The Tongue ................................... 152

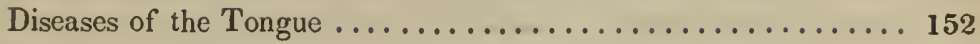

The Salivary Glands ....................... 153

Strangles............................... 154

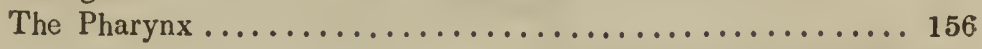

\section{CHAPTER V.}

The Anatomy and Diseases of the Neck and Neighbouring Parts 157

Poll-Evil. . . . . . . . . . . . . . . . . . . . . 157

The Muscles and proper form of the Neck ............ 158

The Blood.Vessels of the Neck . . . . . . . . . . . . . . . 161

The Veins of the Neck ..................... 161

Inflammation of the Vein................... 161

The Palate .............................. 163

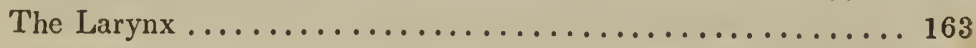

The Trachea or Windpipe ................... 164

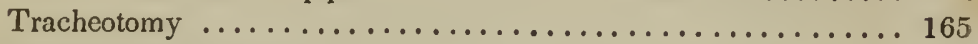

The Bronchial Tubes ...................... 166

CHAPTER VI.

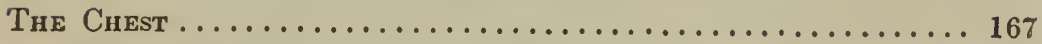

The Spine and Back........................ 171

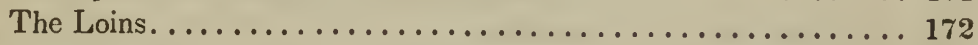

The Withers ................................... 173

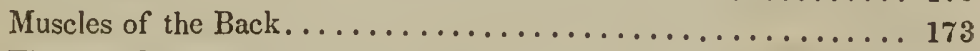

Fistulous Withers........................ 174

Warbles, Sitfasts, and Saddle Galls................ 174

Muscles of the Breast...................... 175

Chest.Founder ......................... 175

CHAPTER VII.

The Contents of the Chest ................... 175

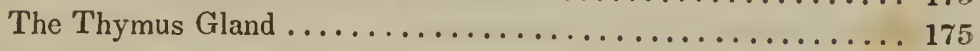

The Diaphragm. ............................. 176

Rupture of the Diaphragm................... 177

The Pleura................................. 179

The Lungs ................................ 181

The Heart. .............................. 181

Diseases of the Heart ...................... 182

The Arteries............................ 184

The Pulse $\ldots \ldots \ldots \ldots \ldots \ldots \ldots \ldots \ldots \ldots \ldots \ldots \ldots \ldots \ldots \ldots 184$

Inflammation $\ldots \ldots \ldots \ldots \ldots \ldots \ldots \ldots \ldots \ldots \ldots \ldots \ldots \ldots \ldots$

Fever............................... 187 
The Veins................................. 188

Bog and Blood Spavin ....................... 188

Bleeding ................................. 189

\section{CHAPTER VIII.}

The Membrane of the Nose $\ldots \ldots \ldots \ldots \ldots \ldots \ldots \ldots \ldots \ldots, 191$

Catarrh, or Cold .......................... 192

Inflammation of the Larynx...................... 193

Inflammation of the Trachea .................... 194

Roaring.................................. 194

Bronchocele................................ 197

Epidemic Catarrh .. ........................ 197

The Malignant Epidemic ....................... 203

Bronchitis............................. 205

Pneumonia-Inflammation of the Lungs............. 206

Chronic Cough ............................ 211

Thick Wind .............................. 212

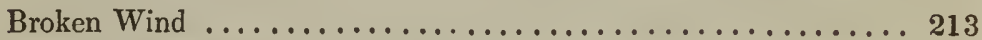

Phthisis Pulmonalis, or Consumption................. 215

Pleurisy ................................ 217

CHAPTER IX.

The Abdomen and its Contexts.................... 221

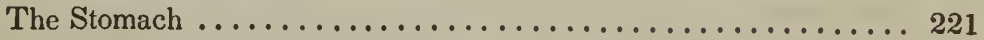

Bots.... ........................... 224

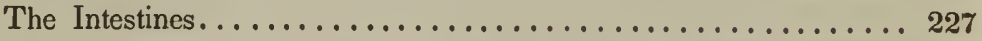

The Liver............................... 230

The Pancreas ............................... 231

The Spleen ............................... 231

The Omentum............................ 231

CHAPTER X.

The Diseases of the Intestines ............... 232

The Duodenum............................ 232

Spasmodic Colic ............................. 232

Flatulent Colic ............................ 234

Inflammation of the Bowels.................... 235

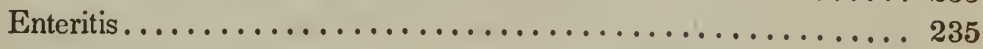

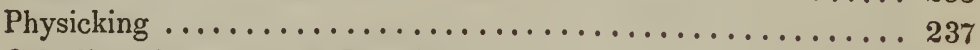

Calculi, or Stones, in the Intestines ................. 238

Introsusception of the Intestines................. 238

Entanglement of the Bowels ..................... 239

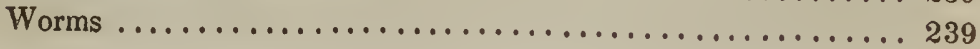


Hernia, or Rupture......................... 240

Diseases of the Liver. . . . . . . . . . . . . . . . 241

Jaundice ............................... 242

The Kidneys ............................. 243

Inflammation of the Kidneys.................. 244

Diabetes, or Profuse Staling . . . . . . . . . . . . . . . 245

Bloody Urine-Hæmaturia . . . . . . . . . . . . . . . . . . . 245

Albuminous Urine ......................... 245

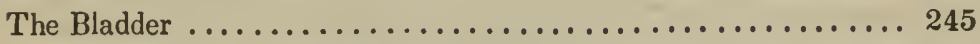

Inflammation of the Bladder ................. 246

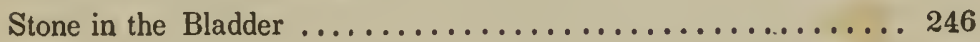

CHAPTER XI.

Breeding, Castration, \&c...................... 248

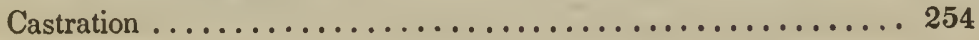

\section{CHAPTER XII.}

The Fore Legs .............................. 255

The Shoulder............................. 255

Sprain of the Shoulder ...................... 255

Slanting direction of the Shoulder ................ 256

The Humerus, or Lower Bone of the Shoulder. . . . . . . . . . 260

The Arm ................................. 261

The Knee................................. 264

Broken Knees .............................. 265

The Leg. ............................... 267

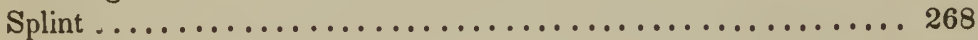

Sprain of the Back-Sinews ..................... 269

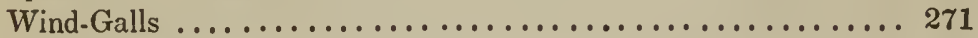

The Pasterns.............................. 272

Lesions of the Suspensory Ligament............... 274

The Fetlock............................... 275

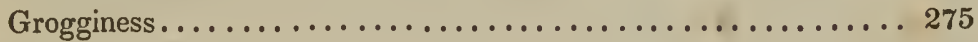

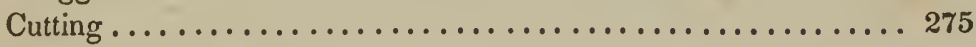

Sprain of the Coffin.Joint ..................... 277

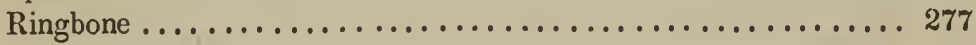

CHAPTER XIII.

The Hrnd Legs.............................. 279

The Haunch $\ldots \ldots \ldots \ldots \ldots \ldots \ldots \ldots \ldots \ldots \ldots \ldots \ldots \ldots . \ldots \ldots$

The Thigh............................... 279

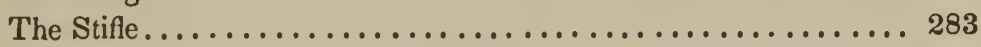

Thorough-Pin ............................ 285

The Hock ............................... 285 
Enlargement of the Hock .................... 286

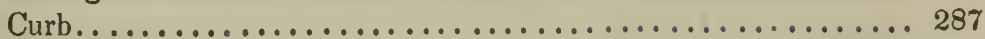

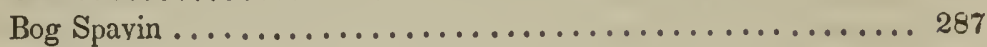

Bone Spavin . . . . . . . . . . . . . . . . . . . . 288

Capped Hock ............................. 290

Mallenders and Sallenders ...................... 291

Swelled Legs . . . . . . . . . . . . . . . . . . . . . . . 291

Grease .................................... 292

\section{CHAPTER XIV.}

The Foot ................................... 295

The Crust or Wall of the Hoof ................. 296

The Coronary Ring ........................ 297

The Bars................................. 297

The Horny Laminæ. . . . . . . . . . . . . . . . . . . 298

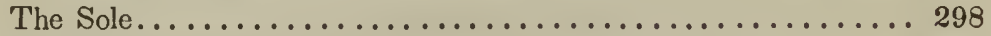

The Frog .............................. 299

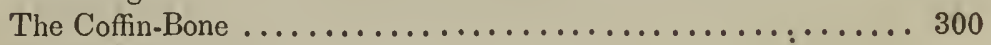

The Sensible Sole .......................... 300

The Sensible Frog.......................... 301

The Navicular Bone . . . . . . . . . . . . . . . . . . . . 301

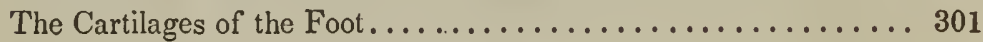

CHAPTER XV.

The Diseases of the Foot ...................... 302

Inflammation of the Foot, or Acute Founder. . . . . . . . . 302

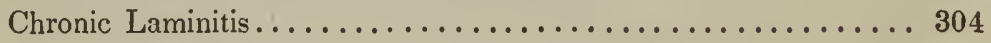

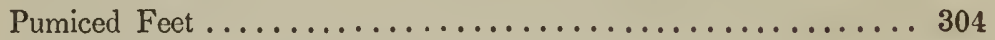

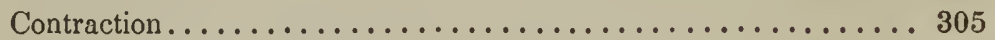

The Navicular-Joint Disease .................... 309

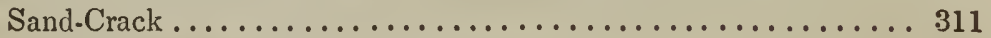

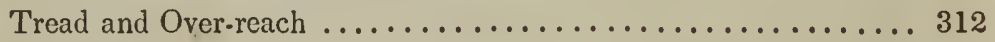

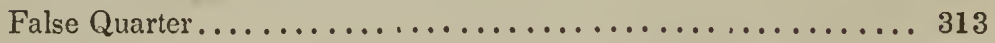

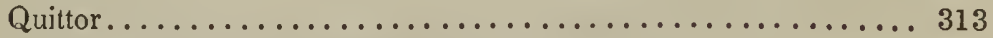

Prick or Wound in the Sole or Crust............... 315

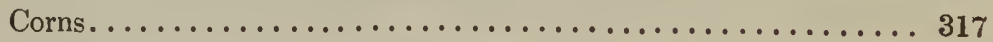

Thrush........................................ 318

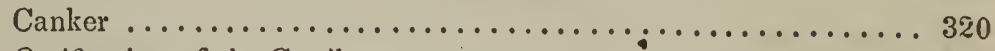

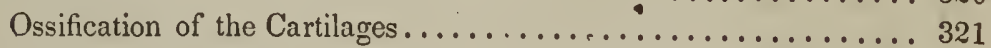

Weakness of the Foot $\ldots \ldots \ldots \ldots \ldots \ldots \ldots \ldots \ldots \ldots \ldots$

CHAPTER XVI.

Fractures 
CHAPTER XVII.

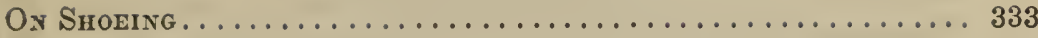

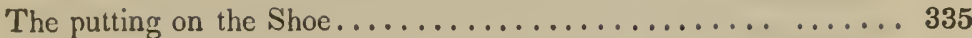

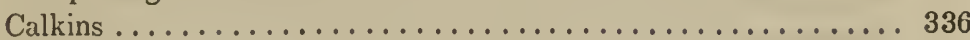

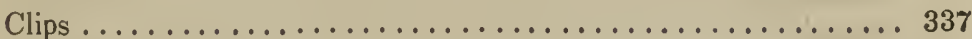

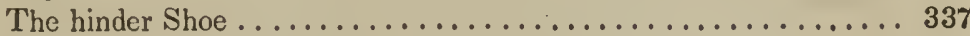

Different kinds of Shoes...................... 337

The Concave-seated Shoe...................... 337

The Unilateral, or one side nailed Shoe............... 339

The Hunting Shoe. . . . . . . . . . . . . . . . . . . . . 340

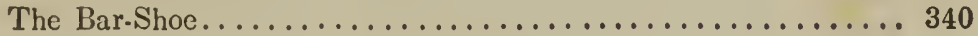

Tips...................................... 341

The Expanding Shoe ...................... 341

Felt or Leather Soles ............................. 341

CHAPTER XVIII.

Operatrons ................................. 344

Bleeding .................................. 345

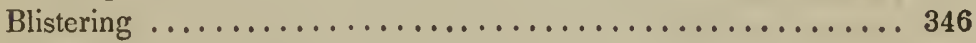

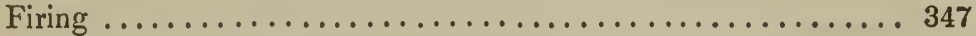

Setons ................................. 349

Docking ............................... 350

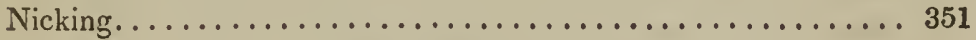

CHAPTER XIX.

Tile Vices and Disagreeable or Dangerous Habits of the Horse 353

Restiveness............................ 353

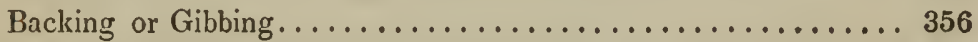

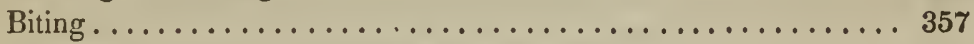

Getting the Cheek of the Bit into the Mouth............. 358

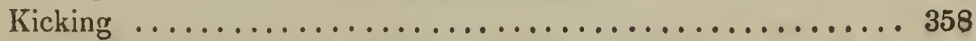

Unsteadiness while being Mounted.................. 359

Rearing . . . ............................ 359

Running Away............................ 359

Vicious to Clean ............................ 360

Vicious to Shoe........................... 360

Swallowing without Grinding .................. 360

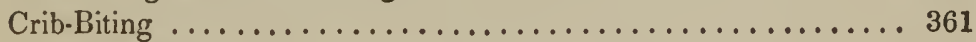

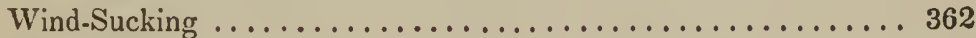

Cutting ................................ 362

Not Lying Down . .......................... 362

Overreach . ................................ 362

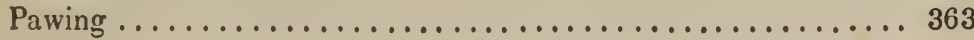




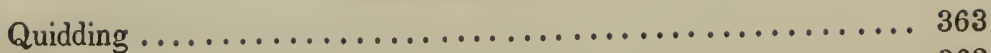

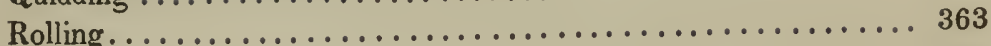

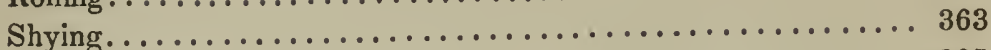

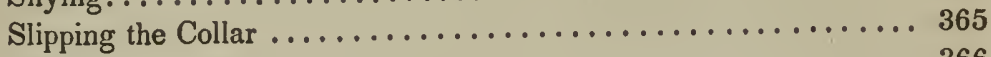

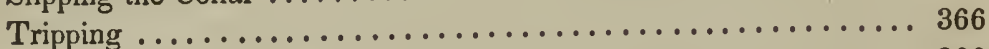

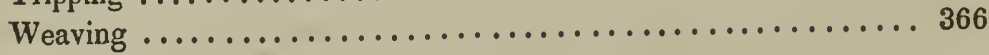

\section{CHAPTER XX.}

The General Management of the Horse ............. 366

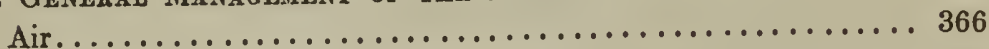

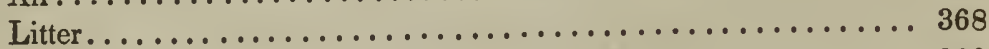

Light. ............................... 369

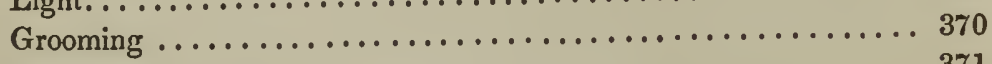

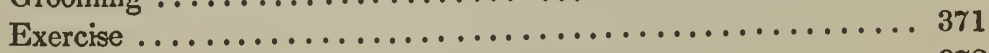

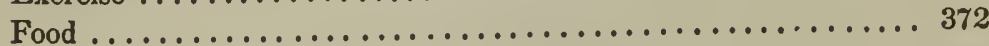

CHAPTER XXI.

The Skin and its Diseases ...................... 381

Hide-bound $\ldots \ldots \ldots \ldots \ldots \ldots \ldots \ldots \ldots \ldots \ldots \ldots \ldots \ldots \ldots \ldots \ldots \ldots$

Pores of the Skin .............................. 385

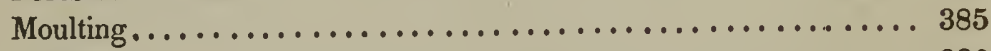

Colour .................................. 386

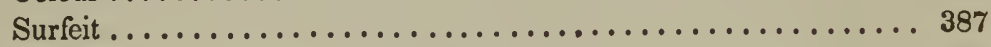

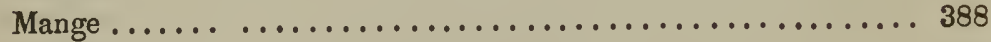

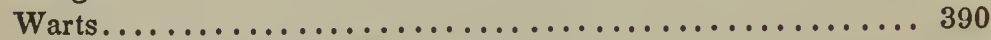

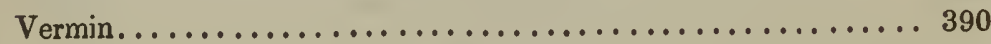

CHAPTER XXII.

On Soundness, and the Purchase and Sale of Horses ....... 390

CHAPTER XXIII.

A List of the Medicines used in the Treatment of the DisEASES of the HoRse............................ 398

AN ESSAY ON THE ASS AND MULE, BY J. S. SKINNER. .. 419 


\title{
THE HORSE,
}

\section{IN ENGLAND AND AMERICA-AS HE HAS}

\author{
BEEN, AND AS HE IS.
}

OF all the beasts of the field, which, as we are told, the Lord formed out of the earth, and brought unto Adam to see what he would call them, none lias more engaged the attention of the historian and the philosopher-none has figured more in poetry and romance, than the horse.

Coeval with their domestication, and the knowledge of their admirable capacities to minister to our comforts and pleasures, according to Plutarch, the sentiment has been common to all good men, to treat the horse and the dog with especial kindness, and to cherish them carefully, even when the infirmities of age and long service have rendered them useless.

For the volumes which have been written on the Horse, whether more or less authentic, as to his original country, his natural history, the time of his subjugation to the use of man, and the various purposes for which he has been employed, whether in the homely gear of field-labour, or in the gorgeous trappings of the tournament or chariot of war on all these points of his history and his uses, we might refer the curious reader to various works, some of them elegant, alike in their embellishments and their literature; but to quote and to collate them here, would be to depart from the line of praclical utility prescribed for the execution of our task; hence, keeping that object constantly in view, we shall merely glance at what has been written of his early history and services, and so come down rapidly to the period in the history of the English horse where, after successive importations of foreign stallions, and the observance of judicious systems of brceding, the stock of the mother country, from which ours is derived, had attained about the days of Flying Childers, in the beginning of the last century, a high degree, if not its maximum of excellence. It was when so improved that the horse was imported into our then British Colonies; and what, after all, it may be asked, is there economical and thrifty in our agricultural and domestic habits-or good in our political and social institutions, the elements and general outline of which we have not derived from Old England? Some orchardists contend that a branch cut from an old trunk and grafted on a young scion, will, nevertheless, sympathize with the parent stock, and under the laws of vegetable life, will decay as the parent tree declines! Does the theory sometimes apply to countries and governments? or shall we thrive nationally, as plants grow larger and more robust when transplanted from the seed-bed into wider space and freer circulation? But these are questions for the politician.

None of the writings to which we could point the reader contain more frequent mention, or more glowing descriptions of the power and beauty of the Horse, than the great book of books! 'The Bible teaches us that from whatever land this animal may have been originally brought into Egypt, that country had already become a great horse market, even before horses were known in Arabia; the country with which we are apt to associate all that is most interesting in the history of this noble beast. Geological researches, however, have discovered fossil remains of the horse in almost 
every part of the world, "from the tropical plains of India to the frozen regions of Siberia-from the northern extremities of the new world to the southern point of America." But amongst the Hebrews, horses were rare previous to the days of Solomon, who had horses brought out of Egypt after his marriage with the daughter of Pharoah, and so rapidly did he multiply them by purchase and by breeding, that those kept for his own use required, as it is written, "four thousand stables, and forty thousand stalls." Hence, when honoured by a visit from the beautiful Queen of Sheba, bringing with her "camels bearing spices," and "very much gold and precious stones," it was doubtless in the contemplation of his magnificent stud of horses and chariots, kept for the amusement of his wives and concubines, as well as of his other vast displays of power and magnificence, that her majesty exclaimed, in the fullness of her admiration,- "Howbeit I believed not the words until I came, and mine eyes had seen it, and behold the half was not told me!"'

This gallant monarch appears to have enjoyed a large monopoly of the horse trade with Egypt, for which he was probably indebted to his having an Egyptian Princess for one of his wives. His merchants supplied horses in great numbers to the Hittite Kings of Northern Phœnicia. The fixed price was one hundred and fifty sliekels for one horse, and six hundred shekels for a set of chariot horses. Thus early was in vogue, as it seems, the gentleman-like fashion to drive four-in-hand, which came down to the good old days when in our Republican country the Tayloes, and the Ridgelys, and the Lloyds, and Hamptons still figured and flourished on the race-courses at Annapolis and Washington.

That there was in the "olden time," something remarkably luxurious in the style of living and equipage at the ancient metropolis of Maryland, may be gathered from the following remarks in "New Travels throvgh America," in the year 1781, by the Abbé Robin, chaplain to the French army.- "Their furniture here is constructed of the most costly kind of wood, and the most valuable marble, enriched by the elegant devices of the artist's hand. Their riding machines are light and handsome, and drawn by the fleetest coursers, managed by slaves richly dressed. 'This opulence was particularly observable at Annapolis. Female luxury here exceeds what is known in the provinces of France-a French hair-dresser is a man of importance among them; a certain dame here hires one of that craft at a thousand crowns a year salary."

Before the days of Solomon, their honours, the Judges and Princes of Israel, used generally to ride on Asses and Mules; no less patient and faithful servants of man than the horse; and to whom the editor will endeavour to render justice, in the course of this introduction to the English work.

It is not, be it said, with all our partiality for the Horse, that he possesses any one physical or moral trait, in higher excellence than some other animals. In sagacity, he falls short of the ponderous and drowsy Elephant; in muscular development and grace of limb, he surpasses not the Stag; in ardour and constancy of devotion, he can scarcely be said to equal his friendly companion and rival for his master's affections, the faithful Dog; and his courage fails him at sight of a "Lion in the way,"-while in the humbler qualities of patience and availability to the very last, even to the hair and the hoof, that unambitious drudge, the $\mathrm{Ox}$, may well assert his pretensions to comparison, if not to superiority. It is the admirable combination of the several qualities which, taken singly, serve to confer distinction on other quadrupeds, that united in him, fits the horse for employments so various : giving him pre-eminence alike in the wagon or the plough-the coach and the battle-field. While on the one hand, with a flight of speed, compared in Scripture to " the swiftness of the Eagle," he submits his neck, clothed in thunder, to be restrained by a silken rein in the hands of a Di Vernon, his courage in war is thus eloquently described by Job. We give what is esteemed the best translation of a passage often quoted, no less for its appositeness than for its sublimity.

"Hast thou given mettle to the horse?

And clothed his neck with ire?

Dost thou command him to spring like a grasshopper ?

The grandeur of his neighing is terror:

With his feet he beats the ground,

Rejoicing in his strength;

And goes forth to meet the embattled foe. 
The fearful sight he scorns, and trembles not,

Nor from the sword doth he draw back.

Above him rattle the quiver, the glittering spear, and arrow;

Under him trembles the earth; yet he hardly touches it.

He doubts if it be the sound of the trumpet he hears,

But when it becomes more distinct, then he exults,

And from afar, pants for the battle,

The word of command, and the war-cry."

And then as to his gallantry ; where, in all nature, does she exhibit such a magnificent display of that conservative passion, by which alone the Great Jehovah has secured the perpetuity of all his creatures, as in the high-formed, pampered stallion, under the impulse of amatory anticipations !-affording in this resistless necessity of animal organization, proof that should dispel, even in a land of Atheists, all doubt of an overruling design or Providence,

\section{"Whose work is without labour ; whose designs \\ No flaw deforms, no difficulty thwarts; \\ And whose beneficence no charge exhausts."}

It may be the force of early association, but we apprehend it is almost indispensable to have been born and "raised in the country" to estimate fully the attachment which can there alone grow up in all its power, between a man and his horse! What conqueror, "from Macedonia's madman to the Swede," so proud as the boy and his horse "Button" or "Bright-Eye," that can beat all competitors in a quarter-race! Alexander was a fool, and Bucephalus a garron, compared to these two great characters, in playtime at a country school. "Haud experientia loquor!"

To the valetudinarian, how delightful to escape from his sick room, and once more throw himself in his saddle, to ride abroad and snuff the fresh air of the morning; or no less to one in the manly vigour of health, to mount his sure-footed, high-mettled steed, and go bounding, at three-quarter speed,

$$
\text { "Over the hills and far away," }
$$

under the reckless excitement of the chase, or sometimes even solitary and alone, yet most agreeably exhilarated by that cheerful turn of thought educed by rapid horseback motion, in the bracing air of the country! He, at least, must have felt these sensations, who described them so happily and with so much enthusiasm, in the old American Turf Register and Sporting Magazine; a work since much improved, and now conducted with rare taste and elegance by W. T. PorTer, of New York.

In strong fear of reproach for departing from the strict line of utility laid down for our observance, we cannot forbear to appropriate space enough here to multiply copies of this beautiful tribute

$$
\text { “T O MY HORSE." }
$$

WITH a glancing eye and curving mane,

He neighs and champs on the bridle-rein;

One spring, and his saddled back I press,

And ours is a common happiness!

'T is the rapture of motion! a hurrying cloud

When the loosened winds are breathing loud :-

A shaft from the painted Indian's bow-

A bird-in the pride of speed we go.

Dark thoughts that haunt me, where are ye now?

While the cleft air gratefully cools my brow,

And the dizzy earth seems reeling by,

And nought is at rest, but the arching sky:

And the tramp of my steed, so swift and strong,

Is dearer than fame and sweeter than song?

There is life in the breeze as we hasten on;

With each bound some care of earth has gone,

And the languid pulse begins to play,

And the night of my soul is turned to day ;

A richer verdure the earth o'erspreads,

Sparkles the streamlet more bright in the meads; 
And its voice to the flowers that bend above, Is soft as the whisper of early love;

With fragrance spring flowers have burdened the air,

And the blue-bird and robin are twittering clear.

Lovely tokens of gladness, I marked ye not, When last I roamed o'er this self-same spot. Ah ! then the deep shadows of sorrow's mien Fell, like a blight, on the happy scene;

And nature, with all her love and grace,

In the depths of the spirit could find no place.

So the vexed breast of the mountain lake,

When wind and rain mad revelry make,

Turbid and gloomy, and wildly tost,

Retains no trace of the beauty lost.

But when through the moist air, bright and warm,

The sun looks down with his golden charm,

And clouds have fled, and the wind is lull,

Oh! then the changed lake, how beautiful!

The glistening trees, in their shady ranks,

And the ewe with its lamb, along the banks,

And the kingfisher perched on the wither'd bough,

And the pure blue heaven, all pictured below!

Bound proudly my steed, nor bound proudly in vain,

Since thy master is now himself again.

And thine be the praise when the leech's* power

Is idle, to conquer the darkened hour

By the might of the sounding boof, to win

Beauty without and joy within;

Beauty else to my eyes unseen,

And joy, that then had a stranger been.

We return without further preliminary to trace the progressive improvements which have ended in giving us the horse of all usork of the present day, and as now employed for ordinary uses. These uses require hardiness and strength for economical and laborious drudgery, and activity and speed for light harness and the saddle; while for every purpose it is essential that he should have good wind. The work itself, to which these remarks are but introductory, it will be remembered treats more particularly and fully, and leaves nothing more to be learned about the anatomy and diseases of the Horse. How the qualities designated above have been gradually established and preserved from deterioration, it would be impracticable to ascertain and relate without going back as we propose to trace the outline at least of the history of the English Horse, from which ours are descended - and here, before proceeding further, it is deemed proper the better to indicate its importance to every practical husbandman, that we lay it down as a principle, that the horse, in his domesticated condition, where his propagation is conducted arbitrarily and without rule-where the male and female are brought together capriciously, and without care or judgment as to the qualities of each, constant and wide-spread deterioration must be the consequence. On this point, upon which we insist as of the highest consideration, we shall dwell again, to show why it is that animals in a state of nature will preserve a higher standard than when unskilfully and carelessly bred in a state of domestication. In the meantime, in sketching the history of the English horse, it is not deemed essential to go back anterior to the Invasion of England by Julius Cæsar. Even at that period it is clear that there existed in that island a good substratum for forming a superior race, for that observant and accomplished warrior spoke in the highest terms of the horses he found there. So well was he convinced of their excellence, that he took back with him many of them to Rome, where English horses soon grew into great demand; and thus early was an inducement offered to the hardy and enterprising Briton, which since then has suffered no abatement, to pay strict attention to this important source of agricultural wealth.

* Leech, in old poetic dialect, means physician. 
Hugh Capet, king of France, in the ninth century, proposing to himself by intermarriage with Etheldista, to infuse more vivacity into the breed of these semi-barbarous islanders, sent over to her brother Prince Athelstan, a supply of German " running horses," as they were called, this being the first mention of the race-horse in English annals. It is to be supposed that in all cases of male horses thus spoken of, "entire" horses are to be understood ; for then it was not common, as it is now, to violate wantonly the Mosaic Law, which says, "a beast that is crushed, bruised, evulsed, or excised, (these being the four modes of castration,) you shall not bring unto Jehovah, nor shall you make it so in your land." A practice as doubtful, as to its necessity or utility in respect to the horse, as it is inhuman wherever it is useless. In the case of edible animals, where emasculation promotes size and fatness, and improves the flavour for the table, as with the hog and the sheep, this execrable mutilation is necessary, and therefore more excusable; but this is not the case with the horse. In France, where he is remarkable for strength in proportion to size, the post and the farm horse is rarely, if ever, castrated ; and when horses for the road undergo this operation, it is done in a manner and with such reservations as not to destroy the external appearance of this sexual development; the suppression of which is there considered a striking disfigurement. Descending next to the epoch of William the Conqueror, whose charger was of the Spanish breed, and whose cavalry won for him the victory at the Battle of Hastings — one of his subjects, Roger de Belseme, justly obtained popularity as a national benefactor, by the importation of Spanish stallions into England. So decidedly beneficial was the result of this munificent act of an individual subject, that it may well be noted as an era in its way, for it is not to be doubted that these Spanish stallions partook largely of the blood of the Barb, brought into Spain by the Moors, as the Norman-French horse in Canada does, of the same blood, carried from Spain and Palestine to Normandy. To show how largely this new infusion of foreign blood must have refined and thinned the wind, so to say, of the English strain of horses, at that juncture, it is sufficient that we exhibit a well-drawn portrait, ready to our hand, of the Barbary horse, more nearly allied than any other to the Arabian, and quite his equal at least in form, if not in spirit-of the same stock, in fact, as Godolphin, commonly called the "Godolphin Arabian."

1. "The fore hand of the Barb is generally long and slender, and his mane long and rather scanty. His ears are small, beautifully shaped, and placed in such a manner as to give him great expression; his shoulders are light, flat, and sloping backwards, withers fine and standing high; loins short and straight; flanks and ribs round and full, without giving him too large a belly ; his haunches strong and elastic ; the croup is sometimes long to a fault, the tail is placed high, thighs well turned and rounded, legs clean and beautifully formed, and the hair thin, soft, and silky; the tendons are detached from the bone, but the pasterns are often too long and bending; the feet rather small, but in general sound."

In this delineation of the barb, what reader will fail to recognise most of the genuine and well-established cliaracteristics of the high form and breeding so much prized by all good judges?

The English Stock, to which a little too much heaviness had already been given by the dash of German blood, was now approaching that stage which demanded but one more dip of the long-winded, light-footed, silken-coated Eastern courser, such as it received some centuries after with such palpable and finishing effect, from the Darley Arabian; and again from Godolphin, endowing it with both speed and stoutness in a measure, to which no addition has been made by any subsequent sprinkle of exotic blood. When we reach in the progress of these remarks the point where it will be proper to speak more particularly of this effective agency of these two celebrated stallions in elevating the character of the English blood horse, we shall give some reasons, drawn from the true principles of breeding, and which we do not recollect to have seen anywhere asserted, why it was that they contributed so much to that end, and how it is that similar results have not attended later experiments of the same kind. In the meantime it is necessary to linger on the way in our review, that the chain may not be broken which connects the series of particular importations and other important incidents to which we are indebted for the advantages and delights that spring from the possession of the existing stock of sure-footed, long-winded 
cattle. With your permission then, kind reader, to use an expression familiar to the votaries of the chase, let us "try back."

While the government of one man would be a dangerous experiment until we can have "Angels in the shape of men to govern us," yet when the monarch happens to be enlightened and virtuous, then the more absolute his power the better, perhaps, for his country. Even bad ones, sometimes by freak or passion, confer great good on particular interests or branches of industry. We have already seen how, under the reign of William the Conqueror, the munificence of a subject gained him renown as a patriot by the introduction of Spanish horses into England. Subsequently, King John, with all his bad qualities, established for himself at least one claim to honourable notoriety, by his various measures to better the strain of horses in use at that time, and especially by the introduction of the Flanders Horse, to give more weight and substance to the heavy coach-horse, needed for, and adapted to the unwieldy carriages and bad roads then in use. "To this monarch too," says an English writer, "we are unquestionably indebted for the foundation of our unrivalled draught horses. Aware of the superiority in bulk and strength of the Flemish breed, he imported, at one time, an hundred of the finest stallions." Subsequently, Edward II. imported thirty war, and twelve heavy draught horses, from Lombardy ; and these again were well crossed at a later period, when Edward III. of warlike temper, brought over fifty Spanish horses, at a cost of thirteen pounds six shillings, equivalent, in our day of luxury and paper money, to $\$ 800$ each. It is fairly to be presumed, that in his great passion for the chase, His Royal Majesty perceived the necessity of giving more speed to the hunter, by throwing off some of the sluggish blood and massiveness of the Flemish stock, which is in general "large in the carcass, pretty clean in the leg, and patient and enduring, but slow. They are good at a dead pull, but very heavy in the forehand; inclined to get fat, but wanting in activity. They fall off in the rump, and the hips stand out too much from the ribs. The most unsightly part is the setting-on of the tail, which comes out low and points downwards." Such are the general characteristics of the Flemish horse. "Flanders Mare," as every one knows, is a common term to express the opposite of grace and delicacy. They were imported into England, as above stated, to give size to coach-horses, when roads were bad and coaches of enormous weight; but, as cause and effect are connected, and the one infallibly fol. lows and is controlled by the other, coaches have become lighter, and coach-horses quicker and more airy, as roads have been improved. The policy of this change from heavy to lighter horses, however, was again necessarily restrained and limited by the then still existing necessity for having chargers of great stamina to carry, besides their rider, the heavy armour weighing over three hundred pounds, as did that in com mon use before the invention of gunpowder!

How often public policy, the exterior relations of a country, and various accidents and events apparently altogether extrinsic, serve to establish historical facts, and to influence the courses of national industry, literature, and arts! Thus, the representation of a man driving a horse attached to a harrow, woven in a piece of tapestry, is the evidence relied upon to prove that about contemporaneously with the Norman con. quest, horses had got to be employed in that sort of labour; and here again we see, at a subsequent period, a revolution in the whole system of breeding horses in Britain, brought about by the invention of gunpowder! While in our own day, we have beheld steam so applied as to drive horse-power from all her great thoroughfares, and to do in her factories the labour of some millions of men? Truly, these are the days of progress!

We come now to the period when horses were first distinctly classified and disciplined expressly for war, and the turf, the chase, the road, and the coach; and here we may safely leave the subject as far as relates to the introduction of foreign horses into England, for the most part judicious, and well calculated, as the reader must have perceived, to pave the way for what has since been accomplished in the melioration of this favourite animal, and in adapting his structure and properties, from time to time, to his new and more various employments, Some particular enactments, however, designed to accomplish the same objects, are well worthy of being mentioned; and, it might be added, of being imitated - in our own country and time. In the reign of Henry VIII., even the size and form of Stallions were prescribed by Statute; and 
severe penalties were inflicted for every deviation from the lawful standard. We have often thought, and elsewhere maintained, that the Legislatures of the several States would do well to impose a tax on Stallions; and, moreover, provide that none should be allowed to propagate their race, but under license granted by judges, connoisseurs of horses, who should have power to condemn the worthless as the Inspector condemns a hogshead of rotten tobacco; leaving a tax of fixed arnount upon all such as could pass inspection - or the amount should be light or heavy, in proportion to the perfection or defectiveness of the animal. All thick, straight-shouldered, cat-hammed garrans, and all overgrown beasts "sixteen hands or upwards, under the standard," should be condemned to celibacy! This would go far, in a few years, to diminish the number of ungainly monsters, to be found at every cross-road, propagating their own wretched deformities, and vices of shape and temper. That horses do propagate physical and moral defects, there can be no doubt-were it not invidious, living examples might be given of both as to curbs and sulks! one of which defects may have endangered, and the other have caused on a recent occasion, the loss of many thousands.

Without having, as we hope, omitted anything material to show the reader how abundant have been the materials, and how judicious the use of them, to secure the excellence of the English Horse up to the period at which we have arrived-here we reach the epoch when we are told that public races were established, and horses that had given proof of their superior swiftness 'became known and celebrated throughout the kingdom. "The breed was cultivated, and their pedigree as well as those of their posterity, (in imitation of the Arabian manner,) was preserved and recorded with exactness."

Here then, at last, as we contend, in this establishment and patronage of the turf, as an exact and severe test of equestrian power, and in the faithful preservation of pedigrees, we discover at once the source and the guarantee for preserving all that is excellent in this noble animal, distinguished as we have said, in his rare combination of strength, swiftness, beauty, lastingness, docility, and courage. The prescription of weight to age-the measurement of the track, and the opening of the Stud-book, have done for English horses, what Magna Charta did for English-men !

As with man, "'tis liberty alone that gives to life its lustre and perfume," so there would seem to be something in his aristocratic blood, that inspires the thorough-bred courser with an indomitable pride and courage. To look at is but to admire him as he walks, "rejoicing in his strength!" but both man and horse will degenerate in character and value when in their government there is provided no test for their capacity - no stimulus to virtue-no reward for their ambition, nor restraint upon its vicious indulgence!

Nothing is easier than to declaim against the turf, on account of the abuse which too often attends the use of that, and other institutions. We might consent to its abatement or suppression, if those who desire it will tell us how, except by its exciting hazards and hopes, and its infallible test as a measure of equestrian power, men can be prevailed upon to breed systematically, to acquire skill in training, and to encounter the expense and trouble of carefully testing the capacities of horses; dooming the most worthless to the plough, and sending, finally, the very best only into the breeding stud, to perpetuate their fine qualities! How, except by thus ascertaining and breeding from the most perfect, can he be kept up to the standard he has reached, and finally, how but by such anthentic annals, and proofs to refer to, can even the practical farmer employ any given degree of the pure blood, some of which all admit to be advantageous and desirable for every service, even the most humble and laborious to which the Horse can be subjected? In respect of the reliance to be placed on the English Stud-Book for pedigrees, and the good effects of sprinkling the horse of all work with more or less of the warm blood of the Eastern Courser, we covet for our own conviction no better support or authority than the views adopted and sanctioned by B. O. TAYLOE, Esq. of Washington, a gentleman and scholar, who has done more than any writer of whom we have any knowledge, to throw light upon the obscure but interesting annals of the American turf, consisting until then of a confused mass of scattered materials - rudis indigesta quc moles - arranging them in 
chronological order, and imparting to them all the perspicuity and weight of digested and authentic history.

"Additional attention was given to blood during the reigns of Elizabeth and James. The latter had his running horses, and with great judgment, imported from Arabia. A south-eastern horse was brought into England and purchased by James of Mr. Place, who was afterwards Stud-master to Oliver Cromwell. This beautiful animal was called Place's While Turk. Shortly after appeared the Helmsly Turk, imported by the Duke of Buckingham. Charles I. ardently pursued the amusements of the turf, now a favourite diversion with English gentlemen. With but few execptions, the oldest English pedigrees end in Place's White Turk. At the Restoration a new impulse was given to breeding and running fine horses. The system of improvement was thenceforth zealously pursued. Every variety of Eastern blood was engrafted upon the English; and the superiority of the produce, above the very best of the original stock, began to be evident. Their beauty of form, speed, and stoutness, greatly surpassed the original breed. In the latter part of Queen Anne's reign there was still further improvement caused by the introduction of the Darby Arabian. Having to contend with prejudice, it was some time before he attracted notice. From him sprung a strain of unequalled beauty, speed, and strength. The Darby Arabian has been properly termed the parent of the racing stock. The present English thorough-bred horse is of foreign extraction, improved and perfected by the influence of climate and diligent cultivation.

"The pedigree of English Eclipse affords a singular illustration of the descent from pure Eastern blood, both of himself and his ancestors, Marske, Regulus, Squirt, and Childers. The strictest attention has been paid to pedigree. In the descent of almost every modern racer, not the slightest flaw can be discovered; or when, with the splendid exceptions of Sampson, and his son Bay Malton, one common drop has mingled in the pure stream, it has been speedily detected in the degeneracy of their progeny. The Stud-Book, which is authority acknowledged by every English breeder, traces all the old pedigrees to some Eastern courser, or until they are lost in the uncertainty of early breeding.

"The thorough-bred horse enters into every other breed, and adds or often gives to it its only value. For a superior charger, hunter, or saddle-horse, three parts, or onehalf should be of pure blood; but for the horse of all work, less will answer. The road-horse, according to the work required of him, should, like the hunter, possess different degrees of blood. The best kind of coach-horse is derived from mares of some blood, crossed with a three-fourth or thorough-bred stallion of sufficient size and substance. Even the dray-horse, and every other class of horse, is improved by a partial mixture of the thorough-bred."

The late John Randolph, a connoisseur as well as an amateur in all such matters, used to say, that the long, slouching walk of the blood horse would tell, even in the plongh, in a hot summer's day.

A retrospective glance at the low condition of the turf, and of the blood horse in this country, at the date of the establishment of the American Turf Register and Sporting Magazine, by Mr. Skinner, at Baltimore, in 1829, will show how the influence of that official record of blood and of performance, revived this ancient amuseinent, and, as if by magic, retrieved and brought into demand again, the still pure but long-neglected descendants of illustrious ancestors. Pedigrees were thenceforth strictly scrutinized, the grain was winnowed from the chaff; and while some bastards, claiming high family pretensions, were exposed and repudiated, the rust which, through time and carelessness, had accumulated on the bright escutcheon of the real Simon Pure, was brushed away, and the mark of legitimacy indelibly stamped upon his brow.

Prior to the establishment of the Turf Register, the dam of Kate Kearney and of Sussex, two among the best nags ever bred in the Old Dominion, was sold at public auction, for thirteen pounds, tobacco currency, and was afterwards bouglit out of a cart for $\$ 50$, by Col. J. M. Selden, a fair specimen, himself, of the good old Virginia stock; without, at the time, it is true, a knowledge of her pedigree. She was used as a common farm hack, in the heaviest and hardest work, going in the wagon and breaking up heavy James' River bottom-lands in the plough; and, as Col. S. has 
assured us, was the only horse on the estate, whereof there were many much larger, that never lost a day's work, or required to be turned out and rested occasionally, from sickness or exhaustion. Being informed of her blood, she was rescued from these "base uses" and sent to Sir Archy, by whom she produced Kate Kearney, and to Sir Charles, and produced the renowned, but ill-fated Sussex, sire of Lady Clifden. Lady Lightfoot went out of a common livery-stable at $\$ 500$; and old Eclipse, not long before his race with Sir Charles, was offered to the writer of these remarks for $\$ 2,500$. At an advanced age he sold for $\$ 10,000$, and is now, at twenty-seven years old, in vigorous health, covering in Kentucky at $\$ 100$. One of his get by Lady Lightfoot was sold to a gentleman of Pennsylvania for $\$ 10,000$, and that only on condition, as it was rumoured, that the buyer would reciprocate the favour, by letting the gallant owner of him have one hundred bottles of his old Bingham wine, for ten times that number of dollars.

Sir Archy was in a great measure indebted to his fame, if not to his great value as a stallion, during his declining years, to the establishment of the Turf Register, in which were heralded the brilliant achievements of his renowned get and their descendants. He had been made but a mere addition in the exchange, for but so-so high-bred cattle, by his brceder, the late Col. John Tayloe, of Mount Airy; and thus passed into the hands of his nephew, the late Ralph Wormley, Esq., of Rosegill, at whose death, shortly thereafter, he was purchased in his three year old form, after being beaten, by our renowned turfinan, W. R. J., Esq., of Chesterfield, Virginia, who soon placed him the head of the turf, with the reputation of being as good a four-miler as had ever run in America. Such fame soon supplied his Harem-and at once he acquired a higher name in the Stud than any stallion that had ever been in our country ; and now, thanks to the Register, is very generally regarded as our Godolphin Arabian-the ancestor of Boston, and Fashion, and Wagner, and Grey Eagle, and J. Bascom, and Postboy, and Mingo, and Lady Clifden, and Fanny, and Sarah Washington, and Grey Medoc, and Jim Bell, \&c.

It would here be unjust, not to say ungrateful, in one who has so often been the honoured medium of his favours in that way, not to make acknowledgments to the truly venerable JudGe G. Duvalu, for the light shed by him on the earlier annals of the American Turf. So wonderful is his memory, that he can place each horse as he saw them come out in remarkable races before the revolution! How gratifying to his friends to behold this old Maryland-borm advocate of our revolutionary claims; compatriot of Washington, and Tilghman, and Howard; asserter of all we have achieved that is good in political-examplar of all that is commendable in private morals; approaching his centenary, and yet erect in port and in spirit, like one of our majestic old poplars, sparsely surviving the ravages of the axe and the peltings of the pitiless storm-memorials of the virgin soil and better days in which its roots were struck.

When we insist that the great objects to be aimed at, action and power of endurance, are only to be secured with certalnty, by exact trials of speed and the preservation of authentic pedigrees, we may perhaps be met by the suggestion that this theory is at war with all observation as to the effect of indiscriminate intercourse among wild horses, which are said to display high powers and excellence, not only on the plains and pampas of North and South America, but yet more in the deserts of Arabia, where this animal is generally supposed to be found in his highest finish. As to the fine specimens of their race, which are taken with the lasso, from immense herds roaming at large on the plains of this continent, it is to be borne in mind, that while none but the best are thus selected, the basis of these herds was originally brought, like that of the fine cattle of Louisiana, from old Spain; being deeply imbucd with the fine blood of the Andalusian or Barb Horse. That such a race, running at large, in a country highly adapted to its constitution, should not have degenerated and become worthless in form and spirit, is not so discordant with the principles of artistical breeding, for which we contend, as may at first sight appear-for it is well known that in these wild herds, the work of procreation is conceded not indiscriminately to all, but is fought for and engrossed by the most spirited and vigorous stallions among them; following, in this case, the laws that govern all animated nature, where might takes the place of right, and courage and strength, there, as elsewhere, usurp the Lion's share-hence, though in general the size, too often made a matter of primary consideration, may be below the medium standard of the domesticated Horse, the more estimable qualities 
of fine proportion, activity, and game of the sire, are transmitted to his get. It may well be supposed, too, that this monopoly of sexual enjoyment is rarely allowed to continue more than one or two years. As the season of love opens with the budding of the leaf, in the genial warmth of spring weather, this envied privilege becomes again a prize for the most desperate rivalry; the fiercest conflicts, often mortal, then ensue; and the delights of the harem are at last yielded for a time to the victor who prores himself the possessor, in a superior degree, of the very qualities-strength, spirit, and activity-which, under the best management, we should desire to impart! This sufficiently accounts, as we apprehend, for such excellence in several points, as is admitted to be often found in the horse of the desert and the pampas; preserving him from that degeneracy, both moral and physical, which, under the system of breeding "in-and-in" too closely, is seen to show itself in monstrous sliapes, in King's evil, sometimes in idiotcy. Lord Byron, himself a nobleman, and unfortunately not exempt from personal deformity, could not forbear sarcastic allusion to the effects of this in-and-in system, which, prompted by reasons of state and of family aggrandizement, is sometimes followed too far in the royal and noble families of Europe:

" they breed in-and-in, as might be known;

Marrying their cousiris, nay, their aunts and nieces,

Which always spoils the breed, if it increases."

The natural-born children of high-born sires are often observed to be more sprightly and energetic than those which spring lawfully from parents so nearly allied; it may be because they are made like the Frenchman's incomparable shoe, in a " moment of enthusiasm," which, in more enterprises than one, is the guarantee of a fortunate issue.

There has been, since long before the American Revolution, on the islands along the sea-board of Maryland and Virginia, a race of very small, compact, hardy horses, usually called beach-horses, which, in a sketch like this, deserve a passing notice. They run wild throughout the year, and are never fed. When the snow sometimes covers the ground for a few days in winter, they dig through it in search of food. They are very diminutive, but many of them are of perfect symmetry and extraordinary powers of action and endurance. The Hon. H. A. W. of Accomac, has been heard to say that lie knew one of these beach-horses, which served as pony and hack for the boys of one family, for several generations; and another that could trot his 15 miles within the hour, and was yet so small that a tall man might straddle him, and with his toes touch the ground on cach side. He spoke of another that he believes could have trotted 30 miles in two hours. As an instance of their innate horror of slavery, he mentions the fact of a herd of them once breaking indignantly from a pen into which they had been trapped, for the purpose of being marked and otherwise cruelly mutilated; and rather than submit to their pursuers, they swam off at once into the wide expanse of the ocean, preferring a watery grave, to a life of ignominious celibacy and subjugation! Why might not ore of these small but symmetrical stallions, on the principles which we shall hereafter explain, beget superior stock, if put to large, well-formed, high-bred mares ? Mr. W. is clearly of opinion, from all circumstances and appearances, that these small horses, smaller even than the Canada Stallion, possessing such powers as he describes, are descendants of thorough-bred stock! Other animals in a wild state, no less than the Horse, are doubtless preserved from degeneracy under the same conservative polity of nature. Thus we sce the graceful stag loses in the wilderness none of his exquisite symmetry of form, delicacy and hardness of bone, and matchless swiftness of foot. When Autumn is first seen to put on the "sere and yellow leaf," the Doe, having then performed her maternal office, feels the sexual passion revive in her bosom; but its indulgence is postponed, until the rival bucks have settled again for the season, the question of physical superiority by actual, sometimes deadly combat. So desperate are these encounters, that Stags have not unfrequently been found dead, as related by that scientific officer, Col. Long, upon his own observation, with their antlers inextricably interlocked, presenting striking and melancholy pictures of the universal passion "strong in death." A large pair of antlers thus entangled were found, in a western wilderness, and sent to Nicholas Biddle, Esq, and may be seen over the door of his studio at Andalusia, overgrown with ivy. The same reason- 
ing accounts for the great size and beauty observable in cattle that roam at large, in South America, as indicated by the hides we often see on the wharves in our large seaports-thougl at other times the males mingle in all kindness and social harmony, yet in these affairs of love, still more than in trade, all nature proclaims there is " no friendship." How much of truth to nature, in the chaste and pious Thomson's description of the effect of this vernal influence on the temper of the Bull!

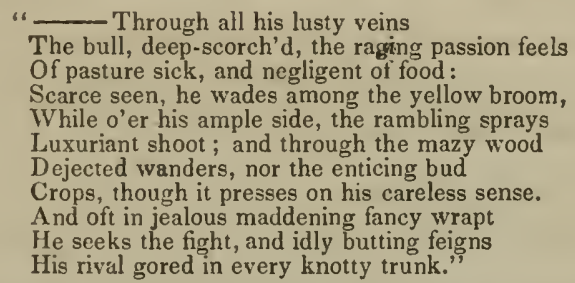

In these cases, where nature is left without disturbance to preserve herself from decay, Providence, which never works in vain, will take care that all goes right; but how different the result when animals tamed and domesticated by the cunning of man, are brought together for reproduction, arbitrarily, and, as is generally done in our country, perhaps above all others, in utter disregard of everything like rule or system, and in total ignorance or carelessness of their respective points and qualities, as well as of their adaptation or relationship, the one to the other! With this ignorance and carelessness almost universal, there is constant danger, as we have before stated, of general deterioration; and in introducing a work intended to promote the health and improvement of this animal, it cannot be too strongly urged that this everexisting tendency is only to be counteracted by presenting those strong incentives which alone can prompt a few to devote the time and the skill which are indispensable to maintain the blood horse, sans tache, and in the highest perfection. Nothing can more clearly show the wise and benevolent order of Providence that man should excreise his superior intellect for the improvement of all around him, than the ease and certainty with which it is seen that, by close attention, we can modify and meliorate all organized existences in the animal and vegetable kingdoms. Hence the most acid and worthless grape is by skilful culture rendered sweet and luscious ; flowers without attraction are gradually nurtured into beauty and fragrance; the cat may be made to present all the rich colours of tortoise-shell, and the pigeon may be "bred to a feather." These remarks might appear foreign or superfluous, but for their obvious design to enforce the necessity of breeding the horse with incessant regard to an ever-existing susceptibility of improvement on the onc hand, and liability to degenerate on the other. Without some such strong incentives as above referred to, in a few years, one might as well look among the black Dutch for a dancing-master, as to look anywhere for breeding horses that will insure speed, and stoutness, and spirit.

In regard to the prevalent impression that the Arabian horse runs wild in the desert, breeding promiscuously, and that where he has been domesticated, no attention is paid to pedigree, and no recourse had to racing to test their powers,-all accounts go to show, on the contrary, that no people preserve their equestrian family trees with more sedulous care. To reach the root of some, they go down many centuries. Although, according to Strabo, an historian of high repute, who lived in the time of Augustus and Tiberius, much about the era of Christ's appearance, Arabia was still without horses; yet it is undoubtedly a fact that they soon took the most effectual methods to improve them to the utmost, and among these, says a very learned commentator on the Mosaic Code, "I am inclined to consider the spirit of horse-racing, an exercise in which the Arabs cagerly sought for renown, as the primary cause of that perfection which the art of horse-breeding so rapidly attained among them; but I by no means exclude soil and climate, and food, as contributing causes."- "Wherever, (says the same writer,) racing is cstablished either as a source of fame or profit, good horses will be sought for, and the breed improved in the first instance by the best foreign stallions, and then 
by those home-bred ones which show the best qualities; and thus the country will by degrees acquire an excellent breed."

"That races (says he, were introduced among the Arabs, very soon after they began to breed horses, appears from the very names of the coursers. Ten horses started together, and from the victor to the last, each has its own proper name or epithet; - one of their best scholiasts enumerates them in the following manner as they came out in the race:-

Sabek, the foremost-the inspirer of joy and banisher of care-because his master can behold the race with delight, and without concern, . . . . . . 1

Mutgalli-because he had his head on the back of the winner, . . . . . 2

Musalli-because he satisfies his owner, . . . . . . . . . . 3

Tali-the pursuer, . . . . . . . . . . . . . . . . 4

Murtach - the ardent, or mettlesome, . . . . . . . . . . . . 5

Atif - the keen, or well disposed, . . . . . . . . . . . . . . 6

Muvaimnal - the inspirer of future hopes, . . . . . . . . . . 7

Hadi-the lazy, . . . . . . . . . . . . . . . . 8

Latim - the belaboured, because taken into the stable with blows, . . . . 9

Lucait-or whose name is not to be named, and of whom nothing is said, because the case is too bad, . . . . . . . . . . . . 10

The admitted excellence to which the general stock of English horses has been brought, is then the result, as has been seen, of a good foundation to build upon; of successive and in most cases judicious crosses, by the use of foreign stallions, most frequently Barbs; and of superabundant wealth employed in the breeding and training of stud; those addicted to all the luxurious uses of the horse, having besides other facilities a wide latitude before them, in the various strains to select and breed from.

The reason why the Darley Arabian, and after him the celebrated Barb, Godolphin, contributed more decidedly than any Arabians have done since, to the improvement of the race-horse, is, that they were imported at the very juncture when the British stock was in a condition to need a cross that would impart more muscle and harder bone, and give better wind; while it diminished the size and weight of the carcass, which had been made too heavy by repeated uses of the Flemish and German breed. In our own country we know, and probably in all others, the progress of improvement of domestic animals has been much retarded and counteracted, by the vulgar persuasion that the largest males should be selected for the purpose of procreation.Than this common impression no error could be more pernicious. 'This fallacy is the source of the disappointment and mortification experienced by farmers who give enormous prices for overgrown bulls and rams, and who always give the preference to stallions that measure "full sixteen hands and upwards under the standard."-On this point we cannot do better than refer to an able essay of Professor Cline of London, on the form of animals, published in the third volume of the American Farmer. With the principles laid down in that essay, every farmer should make himself familiar. A few passages may be quoted, no less for their appositeness to the point here made, than for their general applicability and value in the study of all animal economy.

"Muscles.-The muscles, and tendons which are their appendages, should be large; by which an animal is enabled to travel with greater facility.

"The bones.-The strength of an animal does not depend on the size of the bones, but on that of the muscles.-Many animals with large bones are weak, their muscles being small. Animals that were imperfectly nourished during growth, have their bones disproportionably large. If such deficiency of nourishment originated from a constitutional defect, which is the most frequent cause, they remain weak during life. Large bones therefore generally indicate an imperfection in the organs of nutrition.

"On the improvement of the form.-When the male is much larger than the female, the offspring is generally of an imperfect form. If the female be proportionably larger, the offspring is of an improved form.-For instance, if a well-formed large ram be put to ewes proportionably smaller, the lambs will not be so well shaped as their 
parents; but if a small ram be put to larger ewes, the lambs will be of an improved form.

"The proper method of improving the form of animals consists in selecting a well. formed female, proportionably larger than the male. The improvement depends on this principle; that the power of the female to supply her offspring with nourishment is in proportion to her size, and to the power of nourishing herself from the excellence of her own constitution.

"The size of the fotus is generally in proportion to that of the male parent, and thercfore when the female parent is disproportionately small, the quantity of nourishment is deficient, and her offspring has all the disproportions of a starveling. But when the female from her size and good constitution is more than adequate to the nourishment of a fotus of a smaller male than herself, the growth must be proportionably greater. The large female has also a greater quantity of milk, and her offspring is more than abundantly supplied with nourishment after birth.

"'To produce the most perfect formed animal, abundant nourishment is necessary from the earliest period of its existence until its growth is complete.

"The power to prepare the greatest quantity of nourishment from a given quantity of food depends principally upon the magnitude of the lungs, to which the organs of digestion are subservient.

"To obtain animals with large lungs, crossing is the most expeditious method, bccause well formed females may be selected from a variety of large size to be put to a well-formed male of a variety that is rather smaller.

"Examples of the good effects of crossing the breeds.-The great improvement of the breed of horses in England arose from crossing with those diminutive Stallions, Barbs, and Arabians; and the introduction of Flanders mares into this country was the source of improvement in the breed of cart-horses.

"Examples of the bad effccts of crossing the breed.-When it became the fashion in London to drive large bay horses, the farmers in Yorkshire put their mares to much larger stallions than usual, and thus did infinite mischief to their breed, by producing a race of small-chested, long-legged, large-boned, worthless animals."

Such, we believe, was the ill effect of the cross by a large "Cleveland bay" stallion, imported and sent to Carroll's Manor in Frederick County, Maryland, some years since, by the late Robert Patterson. His younger brother, George, a gentleman of fortune by inheritance, but a farmer by choice, and of uncommon sagacity and judgment, would have foreseen the result of such a cross. Nowhere so systematically as on his estate, have we ever seen so fully carried out and completely illustrated, this important principle in breeding as already quoted from Professor Cline, that "to produce the most perfect formed animal, abundant nourishment is necessary from the earliest period of its existence until its growth is complete." So thoroughly is Mr. P. impressed too with the expediency of getting as much blnod as you can into the horse of all work, consistently with the weight which is indispensable for slow and heavy draught, that he seelis to have as much of it as can be thrown into his plough and wagon horses. Werc the question doubtful, the argument must preponderate which is supported by the practice of an agriculturist, rare in all countries, who is ready with his reason for everything he does, and "no mistake at that."

Fnough, it is believed, has already been said to show how exactly opportune was the cross of the Arabian and the Barb, on the English stock; nor does it require any further reasoning to sustain the position before laid down, that these males of exquisite form, but proportionably smaller than the females of their day in England, having accomplished their purposes by enlarging the lungs and improving the conformation of their progeny, giving more muscle and less bone; the same stallions, could they rise, phonix-like from their ashes, could probably not now be employed with the same beneficial effects.

A review of his most distinguished performances, leads us to think that in cultivating the powers of the horse, the ne plus ultra of success was reached in the days of Flying Childers, in the beginning of the last century, and was sustained with unfailing excellence to the time of Highflyer in 1774 (perhaps we might say to the present day!) - a period embracing, consecutively, the wonderful performances 
and progeny of others besides Matchem, Marsk, the sire of Shark (who won in matches upwards of $\$ 80,000$ ), Mirza, Bay Malton (who in seven matches won $\$ 30,000$ ), King Herod, whose get in nineteen years won more than a million of dollars; Shark himself, afterwards imported to the U. States, who, besides a cup of the value of one hundred and twenty guineas, and eleven hogsheads of claret, won the vast amount of $\$ 77,000$. Eclipse is said to have run the four miles at York in 1770, in eight minutes, carrying one hundred and sixty-eight pounds, being fortytwo pounds over the standard weight-making the result equal to four milcs in $6 \mathrm{~m}$. $27 \mathrm{~s}$. If, according to the opinion of experienced sportsmen, the correctness of which is questionable, seven pounds weight be equal to a distance of two hundred and forty yards in a four-mile race; and giving him a right to dispute the palın of superiority with Flying Childers himself.

It is to be remembered that neither of these two paragons of the English Turf, as they are generally esteemed, were trained before they were five years old. Some assuming as a fact, what we consider problematical - a falling off, in stoutness, of the English racer, since the days of Highflyer, - have ascribed it to the modern practice of bringing horses forward too young; but it must not be forgotten that Highflyer himself, who won and received little less than $\$ 50,000$, and who was never beaten, nor ever paid forfeit, came on the turf in his three year old form, carrying one hundred and twelve pounds, and ran his last race on the 14 th of September, 1779, when, though lame and out of condition, he won easy, and retired to the breeding stud at five years old! But may we not with more reason, attribute the reality, or the assumption, as it may be, of less bottom, or to speak more distinctly, less capacity to carry weight and repeat long distances, in the modern English courser, rather to the modem fashion of training for short racing, and to their reliance on the foot of the horse, and the skill of the rider to bring him out in a brush at the run home, than to any real degeneracy of the stock? On these points we find some observations in a journal which well sustains the title of "The SPIRIT of the Trmes." The remarks by the Editor are regarded by us as of such high authority, and so apposite, that we cannot forbear giving them a place."

"The superiority of the English horses over the American, as regards speed, is almost universally allowed by those American turf-men and amateurs who have witnessed their performances at home. We might name Captain Stockton, Major Davie, Judge Porter, Mr. Corbin, Mr. Neil, the late Mr. Colden, Mr. Kirkman, and many other gentlemen with whom we have conversed upon the subject. The forte of the English horse of the present day is speed, beyond a doubt; and while Americans give up the point, as to short distances, they think our four-mile horses can beat the English in races of heats at that distance. There is no encouragement offered to the English turf-man to breed a four-mile horse, save here and there a plate of 100 guineas value; all, or nearly all the valuable prizes are offered for two and three year olds, so that the object of the breeder is to bring out a colt in the fall of his two year old form, having such strength and substance as shall enable him to take up heavy weights, and go from half to three-quarters of a mile at a flight of speed. As colts that have won frequently, beating good fields, as three year olds, are subsequently very heavily handicapped so as to place them upon an equality with indifferent performers, they almost invariably give way in competing for the valuable public prizes offered, such as the cups at Goodwood, Liverpool, Ascot, \&c. A very fine frurmile horse in England would not command one-quarter of the price which could be obtained for a tric dwo year old. He would soon be broken down by having twenty or thirty pounds extra clapped upon his back, to place him on a level with an untricd three year old carrying a feather."

"Investigator," who we cannot doubt is Mr. B. O. T. of Washington, explains conclusively, to our ininds, "the yet unexplained difference between the time of the racing in the two countries," when he attributes it, in a great measure, to the shape and soil of the English courses, \&c., emphatically called the turf.

In confirmation of this opinion of the effects of soil, it may be mentioned that a gentleman amateur has just remarked to us, that when Miss Foote lately won a fourmile heat on the Melaric Course, New Orleans, in $7 \mathrm{~m} .35 \mathrm{~s}$., the slortest time in America until now beaten by Fashion and Boston on Leng Island, the course was 
quite elastic, and that though the surface was dry, water might have been found within a few feet, if not inches, anywhere below it.

We apprehend, however, that these "very fine four-mile King's plate horses" are exactly such as ought to have been sclected for importation to this country, instead of the fashionable stock, bred to speed, under the influences before mentioned.

The question has been raised, and may well be entertained without implying any narrow or unbecoming feeling of national jealousy ; - whether the turf-horse of English stock does not degenerate in America? Referring to the controling influences of climate, soil, and food, there is certainly no reason to infer that he should; but, from the very nature of these, quite the contrary; and why may we not believe that there is in nature, a power which will cnerce animal, as we know it will vegetable productions, to forego their original peculiarities, and partially conform themselves, in process of time, to the more immutable laws of soil and climate! We recollect to have heard Mr. Jefferson, in proof of the influence of soil over vegetables, state, that he knew a French gentleman, on his inheritance of a famous and very profitable wine estatc, impair at once the quality of the wine, and his own incomc, materially, by employing some crude and unsuitable manure to fertilize his vineyard. The vines bore more abundantly, but the wine lost its flavour, and the vineyard its wonted rcpute. So it is with other vcgetables. The celebrated white wheat will change from white to red, on being transplanted into any other from its natale solum-the eastern shore of Maryland and Virginia ; and the celebrated Havana tobacco, with change of soil and climate, loses both its fine texture and rich fragrance. Thus, without any violence of presumption, we may assert the influence of hoth soil and climate on the constitution and temper of the horse. How long would the satin-coated, thin-skinned, flint-footed, hard-boned, muscular and proud-spirited Arabian, accustomed to a short bite, and delighting in a hot sun, rctain, after being transferred to the rich and succulent pastures of the "low countries," the high and peculiar characteristics which have given him pre-eminence over all the families of his race?

Exposed in rigorous climates, the horse could not long survive in a state of nature, but when protected and well supplied with food, it is difficult to determine how far towards the pole he might be sustained; and we may here quote from good authority, "That this animal existed before the flood, the researches of geologists afford abundant proof. There is not a portion of Europe, nor scarcely any part of the globe, from the tropical plains of India, to the frozen regions of Siberia - from the northern extremities of the new world to the very southern point of America, in which the fossil remains of the Horse have not been found mingled with the bones of the Hippopotamus, the Elephant, the Rhinoceros, the Bear, the Tiger, the Deer, and various other animals, some of which, like the Mastodon, have passed away."

In point of fact, however, every other circumstance being nearly similar, the Horse thrives best in countries within or near the torrid zone. In the mild climates of Northwestern Europe, this noble animal reaches a high development. The wild horse of this continent, brought from Texas, or the more remote provincias internas, and tamed, we have been told, though in general unsightly when compared to the high-bred horse of the United States, is greatly superior in hardiness and ease of support. We may further sustain these reflections on the influence of climate, with the opinion of a gentleman of great observation and knowledge of geography and natural history, Mr. Darby, who thinks that " in the zone of North America, comprising Western Louisiana, Texas, \&c., to the Gulf of California, this most splendid auxiliary of man, with anything like equal care and skill, will reach his utmost development of form, strength, beauty, and affectionate docility."

In additional support of our hypothesis, that climate and food have their influence on the form and character of animals, and that these influences in England are less auspicious to high perfection of the Horse than the warmer and dryer climates of the United States, we may adduce the remarks of English writers of authority. The effect indeed of climate and soil on wool-bearing animals is asserted by all naturalists. Bakewell, who bestowed particular attention on the subject, contends that the softness of wool depends chiefly on the soil on which the sheep are fed. Professor Cline, whose able disquisition we have already freely quoted, says " the pliancy 
of the animal economy is such as that an animal will gradually accommodate itself to great vicissitudes in climate and alterations in food, and by degrees undcrgo great changes in constitution. The size of animals is commonly adapted to the soil which they inhabit. Where produce is nutritive and abundant, the animals are large, having grown proportionably to the quantity of food which for generations they have been accustomed to obtain." To these respectable authors it will be sufficient to add the observations of Captain Thomas Brown, in his Biographical Sketches of the Horse, that " the degenerating effects of a British atmosphere and pasturage, can only be successfully combated, by the occasional introduction of Asiatic blood. A permanently excellent breed can never be expected in this climate " except, we would add, as has been well and truly said of Liberty itself, by eternal vigilance.

On the soundness of these views, may not the opinion safely rest, that on this continent the Horse ought to reach and retain powers at least equal to any he has ever attained in England? And were truth to compel the admission, which is by no means certain, of any deficiency or falling off, might it not be fairly ascribed to the want, in this country, of the vast mcans and the leisure, the science and the skill, which English Aristocracy can command and afford to bcstow on the turf, and all the appointments and accommodations, requisite for the pursuit and enjoyment of that and other field sports ; all of which create wide and constant demand, at high prices, for honest and stout nags, that can go both the pace and the distance? If money " makes the mare go," so will it the horse, and by its agcney, what may not be achieved in a country where a nobleman finds amusement in spending, like the Duke of Richmond, at Goodwood, fifty thousand dollars on his dog kennel? If the superiority claimed by some for English over American horses, cannot be the fruit of climate, neither can it be ascribed to any want on our part of their best blood. Our importations go back more than a century. On this point we are glad again to borrow and adopt the views of that accomplished amateur, Mr. B. O. Tayloe, of Washington, by whom the public has been well reminded that "at a very early period of its Colonial Government, fine horses were introduced into Virginia - encouragement was given by Legislative enactments, and speed was particularly attended to-Bull-Rock, a famcd son of the Darby Arabian, and wholly of Eastcrn blood, was imported as far back as 1730, the year that the Godolphin Arabian (Barb), was introduced into England; and many other English horses and mares were imported, long before any Stud-Book appeared in England." Bcfore and soon after the Revolutionary War, and again, since the establishment of the American Turf Register, the importations into New York, New Jersey, Pennsylvania, Maryland, Virginia, and South Carolina, have embraced many of the most distinguished familics that have adorned the English Turf; bringing streams pure and copious, from the great fountains of Matchem and Eclipse, with an ample infusion from the loins of Herod himself; in whose stock, above all, is united "the two essential qualities of speed and bottom." To go more into detail in proof of our abundant resources, if well husbanded, for sustaining a stock of horses cqual in all desirable points, and for all manner of work, to that which any other country can exhibit, would here be out of place-else it would be easy to present a list not much short of three hundred importcd horses, among the very best which in thcir day could be found in the "fast-anchored isle," beginning, as before stated, near half a century before the American Revolution.

Let it suffice to name a few, such, for example, as Shark, at the close of the last century, and shortly thereafter those Derby winners, Saltram, (one of the best sons of the famed Eclipse,) Diomed, Spread-Eagle, and Sir Harry; the equally famed race-horses Gabriel, Buzzard, Eagle, and Chance; and latterly the renowned winners of the Derby-Priam, St. Giles, and some others-and of the St. Leger, Rowton, Margrave, and Barefoot, that with their close competitors, also imported to this country, Sarpedon, Cætus, Trustee, and Emancipation; together with Glencoe, Riddleworth, and Leviathan; Chateau-Margaux, and perhaps some others, were racehorses of the very highest repute in their day, in England.

Soon after the last revival of the turf in America, and before there was time to witness its effects on our existing stock, it was deemcd expedient to import again, at very great cost, some of the most fashionable horses of the "old country," with a view to the regeneration, as it was supposed, of our native stock, but it is questionable how far it was 
needed; for, as very recently observed in the "Spirit of the Times,"- "Notwithstanding the immense chance they have had, (having generally had the choice of the finest mares,) but seven of them have a winner at four-mile heats last year, while thirteen of native stallions have winners that won thirty-two races."-True, the winner of the race of races, Fashion, is by imported Trustee; but how much of her stoutness may not have come down to her from her grand-dam, Old Reality, of Medley blood-a blood illustrated in so many fields in contests of four-mile heats? Witness the extraordinary achievements of his g. g. g. son, (through Duroc, Amanda, and Grey Diomed, son of Medley) American Eclipse in 1823, three heats of four miles, in $23 \mathrm{~m} .50 \mathrm{~s}$. , and his competitor Henry, tracing to Medley through his grand-dam by Bellair, son of Medley. Sir Hal, at Broad Rock, winning the four mile day from Cup Bearer, in one heat, $7 \mathrm{~m} .40 \mathrm{~s}$.- Cup Bearer breaking down. Oscar, near Baltimore, in 1806, beating First Consul in $7 \mathrm{~m} .40 \mathrm{~s}$.- each winning horse, as well as Cup Bearer, partaking largely of the Medley blood, though no two were by the same horse. It is also worthy of remark as warranting the assumption that Fashion owes her vast powers as much to the old English imported Medley blood, Americanized, as to her recently imported sire, that two days after her immortal victory, her halfbrother-grandson of Old Reality, and by Shark, a son of American Eclipse, in a second heat drove the unrivalled son of Timoleon to the winning post in $7 \mathrm{~m} .46 \mathrm{~s}$., running the next heat and ending a doubtful contest in $7 \mathrm{~m} .58 \frac{1}{2} \mathrm{~s}$.

As already stated, the object in thus dwelling on the wonderful capabilities of the bred horse, and of endeavouring to show that with proper inducements and precaution to measure his foot and to gauge his bottom, and to record faithfully his genealogy and performances, there need not be, as there has not been any general decay-and in insisting that without a portion of his blood we can reckon on no general or permanent supply of good nags for saddle or harness, is to impress upon American husbandmen generally, the absolute necessity of keeping these ulterior but important objects always in view. Those who are opposed to all field sports, on account of the dissipation and vice with which some of them are too often accompanied, might yet learn to tolerate what they cannot enjoy. The whole business of life is mixed with good and evil, and full of compromises.- Shall we forego the use of gunpowder, because that "villanous compound" sometimes charges the pistol of the duellist; or throw up altogether the use of steam, because human life is occasionally sacrificed by the careless use of it?

But it is not only as a question of individual comfort, or of agricultural resource, that this subject is to be looked at. It is worthy, too, of the serious regard of the statesman, in the higher and more important aspect it presents in a military point of view, and as thus connected with our national defences. In cavalry, perhaps more than in any other weapon, our locality must always give us an advantage over any invading force. An enemy cannot bring cavalry with him. With something like a well arranged system in breeding our horses, this advantage may be turned to great account in time of war. With the forecast that distinguished his military administration, Napoleon had the sagacity to establish Haras, or studs, in the several departments of France, where thorough-bred stallions were placed at the service of the common farmer, on terms which barely paid the expense of their keep. But to come nearer home, while every one at all familiar with the incidents of our own Revolution, knows how much was effected in the South, by Lee's famous "Legion;" few, comparatively, may be aware to what that celebrated corps chiefly owed its efficiency - and yet it is undeniable that in a great measure the prevalence of blood in his horses made it at once the scourge and the terror of the enemy. Wonderful in their endurance of hunger, thirst, and fatigue; prompt to strike a blow where it was least expected, and, when forced, as quick to retreat; they may be said to have well earned the description applied to the Parthian steed :-

\section{"Quot sine aqua Parthus nullia currat equus, \\ How many miles can run the Parthian horse, \\ Nor quench his thirst in the fatiguing course!"}

It was not, however, generally known, until the Repository offered by the "ToRr REGISTER" for the record of all extraordinary facts connected with these subjects, 
that to the remarkably accidental importation of the celebrated Lindsey's .Arabian may be traced some brilliant exploits of the battle-field, as well as of the turf in America. The curious history of that renowned Arabian is worthy of preservation here, as it was thus related to the editor, by a meritorious Maryland officer of the Revolution, the venerable General T. M. Forman, a yet living monument of the "times that tried men's souls."

\section{LINDSEY'S ARABIAN.}

Aвоuт the year $\mathbf{1 7 7 7}$ or '78, General H. I.ee, of the Cavalry, and his officers, had their attention drawn to some uncommonly fine Eastern horses employed in the public service-horses of such superior form and appearance, that the above officers were led to make much inquiry respecting their history; and this proved so extraordinary, that Captain Lindsey was sent to examine and make more particular inquiry respecting the fine cavalry, which had been so much admired, and with instructions, that if the sire answered the description given of him, the Captain was to purchase him, if to be sold.

The Captain succeeded in purchasing the horse, who was taken to Virginia, where he covered at a high price and with considerable success.

It was not until this fine horse became old and feeble that the writer of these recollections rode thirty miles expressly to see him. He was a white horse, of the most perfect form and symmetry, rather above fifteen hands high, and although old and crippled, appeared to possess a high and gallant temper, which gave him a lofty and commanding carriage and appearance.

The history of this horse, as given to me during the Revolutionary war, by several respectable persons from Connecticut, at various times, is :-

For some very important service, rendered by the Commander of a British frigate, to a son of the then Emperor of Morocco, the Emperor presented this horse (the most valuable of his stud) to the Captain, who shipped him on board the frigate, with the sanguine expectation of obtaining a great price for him, if safely landed in England. Either in obedience to orders, or from some other cause, the frigate called at one of the English West India islands, where being obliged to remain some time, the Captain, in compassion to the horse, landed him for the purpose of exercise. No convenient securely inclosed place could be found but a large lumber-yard, into which the horse was turned loose; but delighted and playful as a kitten, his liberty soon proved nearly fatal to him. He ascended one of the piles, from which and with it he fell, and broke three of his legs. At this time in the same harbour, the English Captain met with an old acquaintance from one of our now Eastern states. To him he offered the horse, as an animal of inestimable value could he be cured. The Eastern Captain gladly accepted the horse, and knowing he must be detained a considerable time in the Island before he could dispose of his assorted cargo, got the horse on board his vessel, secured him in slings, and very carefully set and bound up his broken legs. It matters not how long he remained in the harbour, or if quite cured before he arrived on our shore; but he did arrive, and he must certainly have covered several seasons, before he was noticed as first mentioned.

When the writer of these remarks went to see the horse, his first attention was to examine his legs, respecting the reported fracture, and he was fully satisfied, not merely by seeing the lumps and inequalities on the three legs, but by actually feeling the irregularities and projections of broken bones.

In Connecticut (I think) this horse was called Ranger; in Virginia (as it should be) he was called Lindsey's Arabian. He was the sire of Tulip and many good runners; to all his stock he gave great perfection of form; and his blood flows in the veins of some of the best horses of the present day. Make what use you please of this statement; I will stand corrected in my narrative, by any person who can produce better testimony respecting Lindsey's Arabian.

September 10, 1827.

Your obedient servant,

F. 
Although this dissertation has been already extended somewhat beyond the limits prescribed by our publisher and our own anticipation, we hope to render it more acceptable as well as more useful by appending to it, in tabular form for greater convenience, and for comparison hereafter, an account of some of the most remarkable achievements, of comparatively modern date, of the turf horse in America at all distances. -In truth, we feel confident that every reflecting reader will regard but as the natural sequel to all the observations which have preceded it, the following synopsis of

\section{THE BEST RACES IN AMERICA.}

It will yet be necessary however to premise a few observations, lest the reader should draw inaccurate conclusions from the statistics laid before him.

In the United States, owing not only to the great territorial extent of the country, but to the natural obstacles which divide its remote sections, and the extreme differences of climate, there never has been, and probably never will be, established central race courses, where horses from all parts of the States may habitually meet, and test their relative superiority by actual contest. We are compelled therefore to adopt other criteria for the relative speed and stoutness of horses. But there is one which has almost swallowed up all others, and is most universal and most popular in its application. We allude to the time in which races are run. If it be admitted that this is the best single criterion we can have, it must equally be admitted that it is often fallacious. It is only necessary to name the different causes by which time is affected and modified.

The most obvious is the difference in the soils of different courses. This is so well understood, that it would not be difficult to make a tolerably accurate scale of the comparative adaptation of our different courses for speed.-Again, in comparing races at different periods, to arrive at accurate conclusions, it must not be forgotten that great improvements have been made in the old established courses within a few years. This improvement commencing with the Union Course on Long Island, which by levelling it and grading the turns, has been made much faster than of yore, has been very generally introduced upon rival courses.-The more obvious consideration of the different condition, in which the same course may be on different days, will present itself to every mind. Great regard should be paid, too, to the state of the atmosphere, whether clear, balmy and calm, or raw, damp and windy; for this state notoriously affects in a great degree the speed of a horse. These are several of the considerations which must be taken into account in estimating the powers of horses by a comparison of the time, in which they have run different races; indeed the test of mere time, however more popular and perhaps more unerring than any one other, is not very much relied upon by a consummate judge of racing. And if a horse, who performed a given distance in remarkable time may fairly lay claim to distinction, it is undeniable that there will be other racers of equal powers in the eyes of the judicious, whom the nature of a course upon the day of a race will prevent from making great time. With one other suggestion we will come to the tables.

The reader must not only note the period of the year in which a race is run, as affecting the age of the horse, but he will recollect that in one portion of the United States, horses take their age from the first of January, and in others from the first of May. In these tables, for uniformity's sake, the English and Northern rule has been pursued, giving the ages from the first of January. Another consideration must be borne in mind-that the interval between the heats has been diminished, of late years; and at the present day, horses at the South have ten minutes more time for recovery between four-mile heats than on Northern courses. 
MILE HEATS.

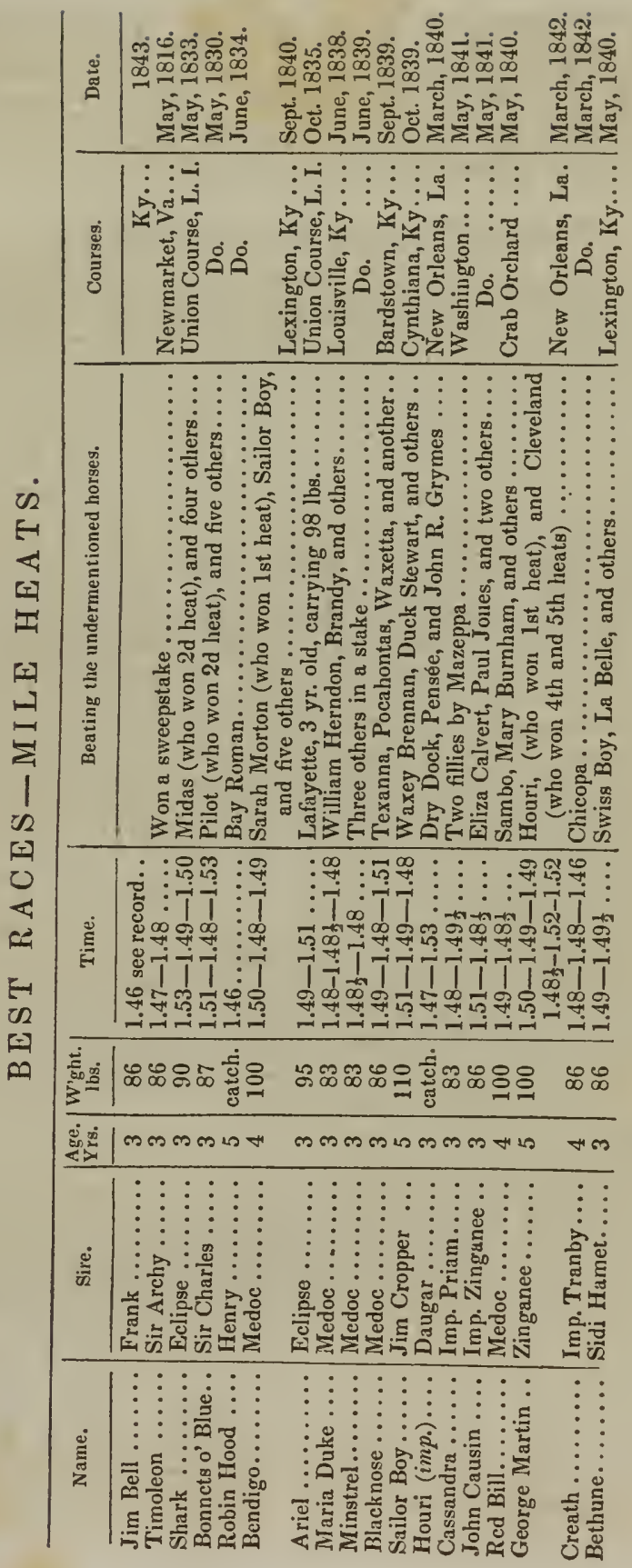


TW O-MILE HEATS.

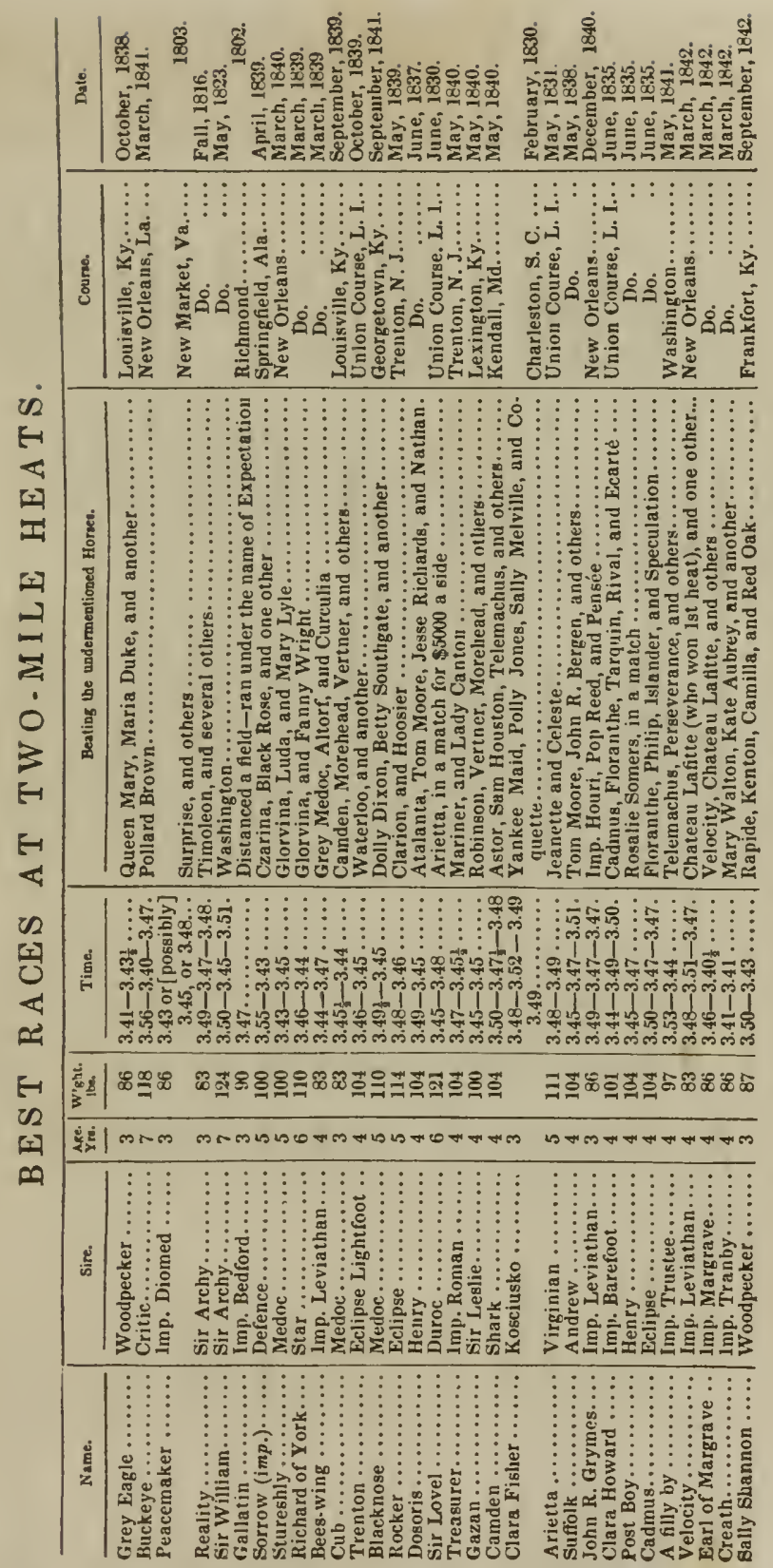




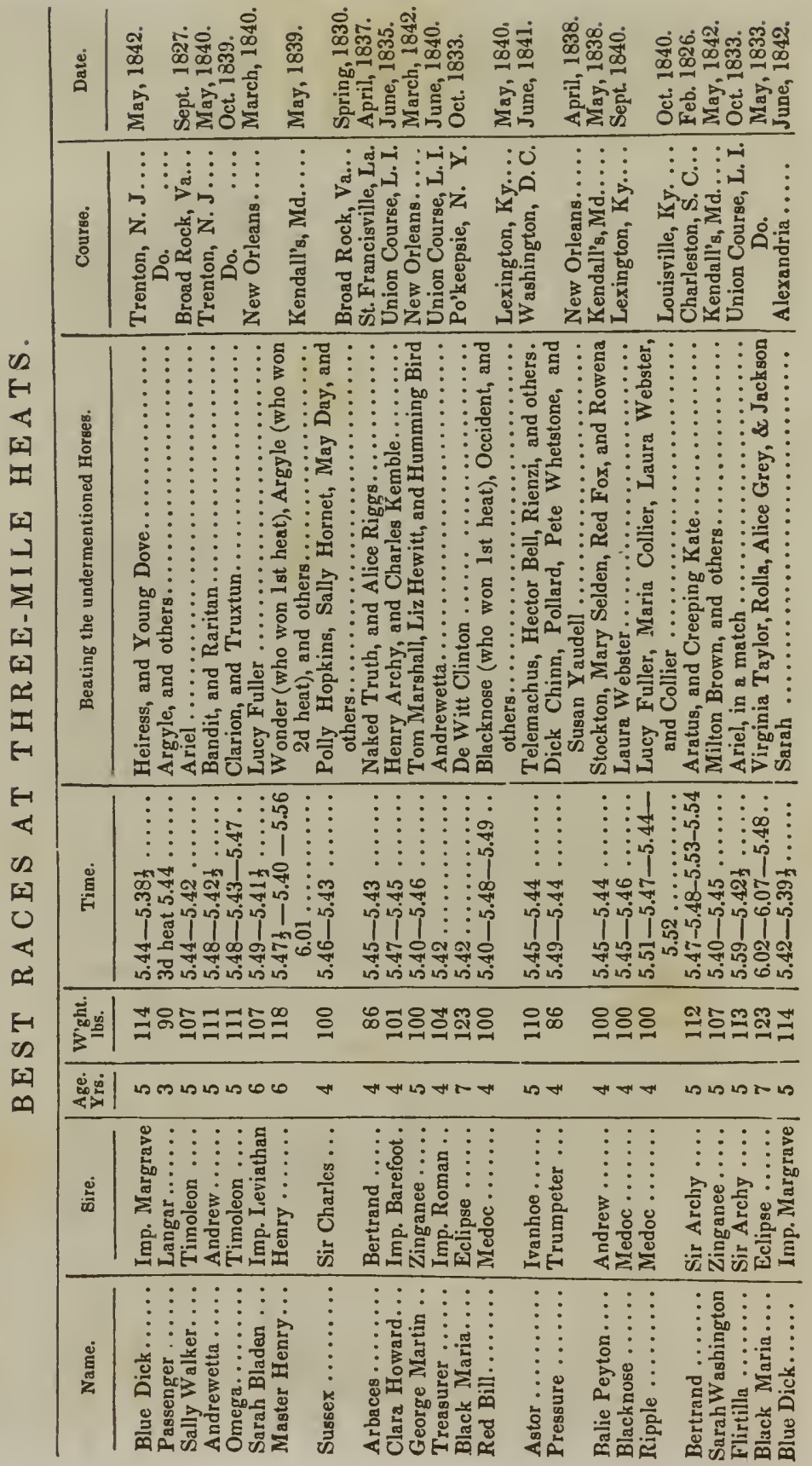




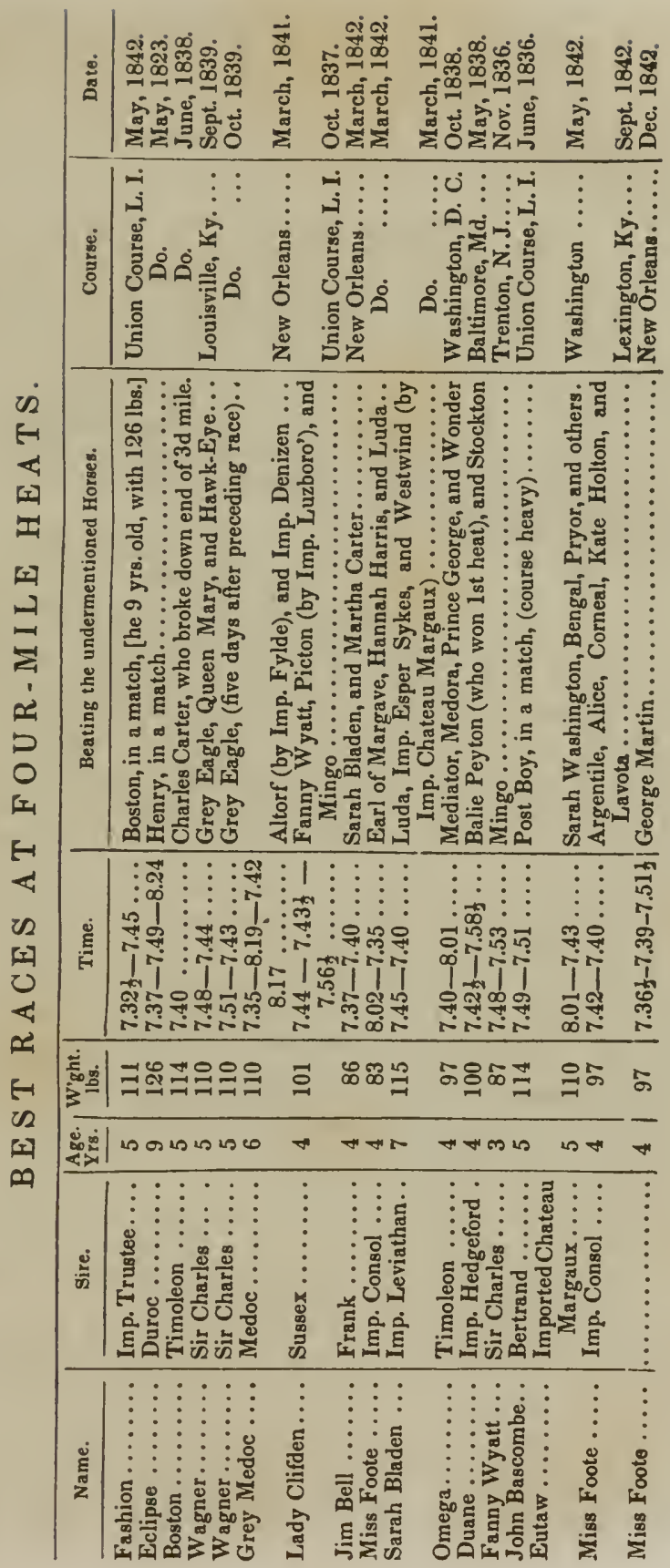


From the above tables have been excluded all races made over courses notoriously short of a mile in length. By adhering to this rule, very many excellent races at Norfolk have been omitted;-as Andrew's, Betsey Ransom's, Polly Hopkins', and others; Mercury's race in $7 \mathrm{~m} .40 \mathrm{~s} .-7 \mathrm{~m} .42 \mathrm{~s}$., at New Orleans, is omitted for the same reason.

Again, we have inserted in the tables only the winners of the different races; winners of a single heat are omitted. But it would be unjust not to note one or two winners of single heats.

Bee's-wing, by imported Leviathan, 5 years old, carrying 97 pounds, in March 1840 , won a first heat from Grey Medoc, in $7 \mathrm{~m}$. 38s. As she pulled up lame, she was drawn. Kate Aubrey, by Eclipse, 4 years old, carrying 83 pounds, in March 1842 , won a three-mile heat in $5 \mathrm{~m} .39 \mathrm{~s}$., but was distanced the next heat.

'The reader will note that the great races made at New Orleans have been run generally in March; according to their rule, their horses taking their ages from May, have run a year under their true age, and carried weight accordingly. In the above tables their proper age has been given, and attention is called to the subject again, for the purpose of pointing to Sarah Bladen's race, which she lost with Jim Bell-the first heat by a length and a half, and the second by but eighteen inches; time, $7 \mathrm{~m}$. $37 \mathrm{~s} .-7 \mathrm{~m}$. 40s.-The mare ran as aged, and carried 121 pounds-but two less than she would have to carry at the North.

Again, the best time ever made at two and three miles, has been in four-mile races. Thus Boston and Charles Carter ran the first and third miles in $3 \mathrm{~m} .41 \mathrm{~s}$., and the first three miles of their great race in $5 \mathrm{~m} .36 \frac{1}{2} \mathrm{~s}$. ; Fashion and Boston ran the first two miles in $3 \mathrm{~m} .43 \mathrm{~s}$., and three miles in $5 \mathrm{~m}$. $37 \frac{1}{2} \mathrm{~s}$.; Wagner and Grey Eagle, it is said, ran the last three miles of their best heat in $5 \mathrm{~m} .35 \mathrm{~s}$. Gallatin is said to have run the two middle miles of a four-mile heat in $3 \mathrm{~m} .43 \mathrm{~s}$, , and Trifle the last two miles of a four-mile heat in the same time. Mingo and Post Boy are believed by the writer to have run a mile of a four-mile heat at Trenton, in $1 \mathrm{~m} .48 \mathrm{~s}$.; the former and Mary Blunt ran their twelfth mile in $1 \mathrm{~m} .47 \mathrm{~s}$., and a third four-mile heat in $7 \mathrm{~m} .46 \mathrm{~s}$. The higher estimation placed upon their great performances at the longer distance, renders it superfluous to note further the rate of speed in the different miles.

Finally, it will not have escaped the observation of attentive readers, that while the horse may appear by these tables, exhibiting as they do, his utmost capacity for a series of years, to have been brought, by careful attention to blood, and by great skill and nicety in training, up to the probable maximum of his powers; it is yet as clear as it is encouraging to see, that by unremitting recourse to the same means, and by that alone, he may be kept up fully to the standard of capacity which these records have established as the measure of his attainable speed and stoutness.

If with an eye to the fact, that "the last" is "the first," and the fastest on the record, (Fashion and Boston at L. I.) the hope should spring up in the bosom of the sanguine, that the "end is not yet," and that the thread may be drawn yet a little finer; without wishing to repress an iota of exertion to make good that conclusion, it may be well to remember, that as before stated, according to the opinion of some whose judgments we are bound to respect, a few of our principal courses have been improved at the rate of more than a second to the mile! Thus it may be doubted whether, if we could meet again in the club-room, or at the social board which they were wont to ornament and enliven, the Fathers of the American turf,- the Sharpes, the Ogles, the Taskers, the Tayloes, Hamptons, Ridgelys, Lloyds, Spriggs, Bowies, Ducketts, Duvalls, Seldens, \&c., they would not remind us of these our advantages, and be prompt to match and freely back some of their favourite old nags against the best on these lists of more modern performers.

To some of these ancestors of our present stock the tribute is due that their name be here recorded as well for their achievements as for having transmitted their powers to their descendants, viz.: 'Tasker's Selima, by the Godolphin Arabian, never beat; the dam of Galloway's Selim, the best Maryland horse of the last century; Fitzhugh's Regulus, Semmes' Wildair, Goode's Brimmer, Tayloe's Virago, Bell Air, Grey Diomed, Black Maria, Leviathan, and Gallatin; Hoomes' Fairy, sister to Gallatin, Ogle's Oscar, Ridgely's Post Boy, Bond's First Consul, Willis's Maid of the Oaks, Edelin's Floretta, Ball's Florizel, Sir Archy; these last nine were at the head of the turf early 
in the present century. With these no competitor or rival deserves to be named, until the revival of the best days of the turf by the get of Sir Archy, as exhibited by the match of his son Henry with Eclipse. By every test of comparison Henry was no better race-horse than several of the get of Sir Archy, nor as good a one as Timoleon, Virginian, Sir Charles, and Bertrand. In those days, Hoomes, Selden, Tayloe, Ridgely, and Bond were at the head of the turf.

Though not strictly belonging to a work intended as this is, not for a particular class but for all owners of horses and for every day's reference and use, yet we have said so much of the race-horse, whose blood we consider it essential to preserve in its purity and to be used as occasion may require, as every good house-keeper preserves and uses good yeast to leven the mass, that we may as well add the lengths of the principal race-courses in England, and the rules of the jockey club lately established for the Long Island race-course. These will occupy but little space and may prove acceptable to those of our readers who take an interest in the amusements of the turf.

\begin{tabular}{|c|c|c|c|}
\hline & Miles: & ur. & \\
\hline The Beacon Course is & 4 & 1 & \\
\hline . . . . . . . & 3 & 4 & 178 \\
\hline miles of Beacon Course . . . . . . . & 3 & 0 & \\
\hline . . • $\cdot$. & 2 & 0 & 97 \\
\hline and a distance of Beacon Course . & 1 & I & 15 \\
\hline - $\cdot$ & 1 & 0 & 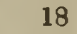 \\
\hline of the lands in & 0 & $\mathbf{5}$ & 18 \\
\hline $\begin{array}{l}\text { from the Ditch to the Duke's Stand } \\
\text { from the starting-post of the T.Y.C. }\end{array}$ & 1 & 5 & 21 \\
\hline $\begin{array}{l}\text { the starting-post } \\
\text { con Course }\end{array}$ & & 6 & \\
\hline at . . . . & & & 2 \\
\hline le.............. & & 0 & \\
\hline . . . . . . . . . . . & & 7 & 178 \\
\hline & & 7 & 21. \\
\hline es of Beacon Course & & 7 & \\
\hline urse (on the flat) & & & \\
\hline (he Banbury mile) & & 5 & 136 \\
\hline . . . . . . . & 0 & 2 & 47 \\
\hline . . . . . . . & 0 & 7 & 248 \\
\hline
\end{tabular}

"Previously to 1753 there were only two meetings in the year at Newmarket for the purpose of running horses, one in the Spring and another in October. At present there are seven. - The Craven, instituted in 1771, in compliment to the late Earl Craven, and commencing on Easter Monday; the First Spring, on the Monday fortnight following, and being the original Spring Meeting; the Second Spring, a fortnight after that, and instituted in 1753; the July, commonly early in that month, instituted also in 1753 ; the First October, on the first Monday in that manth, being the original October meeting; the Second October, on the Monday fortnight following-instituted in 1762; and the Third October, or Houghton, a fortnight after that, and instituted 1770. With the last-mentioned meeting, which, weather permitting, generally lasts a week, and at which there is a great deal of racing, the sports of the Turf close for the year, with the exception of Tarporley, a very old hunt-meeting in Cheshire, now nearly abandoned; and a Worcester autumn meeting, chiefly for hunters and horses of the gentlemen and farmers within the hunt."-Nimrod-The Turf, 152.

\section{ASCOT IIEATH.}

The two-mile course is a circular one, of which the last half is called the old mile. The new mile is straight and up-hill all the way. The T.Y.C. is five furlongs and 136 yards.

\section{EPSOY.}

The old course, now seldom used except for the cup, is two miles of an irregular circular form, the first mile up-hill. The new Derby course is exactly a mile and a half, and somewhat in the form of a horse-shoe: the first three-quarters of a mile may 
be considered as straight running, the bend in the course being very trifling, and the width very great; the next quarter of a mile is in a gradual turn, and the last halfmile straight; the first half-mile is on the ascent, the next third of a milc lcrel, and the remainder is on the descent, till within the distance, where the ground again rises.

The new T.Y.C. is six furlongs; the old T.Y.C., or Woodcot course, is somewhat less than four.

The Craven course is one mile and a quarter.

\section{DONCASTER}

Is a circular and nearly flat course of about one mile, seven furlongs, and seventy yards.

The shorter courses are portions of this circle.

\section{LIYERPOOL.}

The ncw course, now used for both meetings, is flat, a mile and a half round, and with a straight run-in of ncarly three quarters of a mile, and a very gradual rise.

\section{MLANCIIESTER}

Is one mile, rather oval, with a hill, and a finc run-in.

A Distance is the length of two hundred and forty yards from the winning post. In the gallery of the winning post, and in a little gallery at the distance post, are placed two men holding crimson flags. As soon as the first horse has passed the winning post, the man drops his flag; the other at the distance post drops his at the same moment, and the horse which has not then passed that post is said to be distanced, and cannot start again for the same plate or prize.

A Feather-weight is the lightest weight that can be put on the back of a horse. - A Give and Take Plate is where horses carry wcight according to their height, Fourteen hands are taken as the standard height, and the horse must carry nine stone (the horseman's stone is fourtcen pounds). Seven pounds are taken from the weight for every inch below fourtecn hands, and seven pounds added for every inch above fourteen hands. A few pounds additional weight is so serious an evil, that it is said, seven pounds in a mile-race are equivalent to a distance.

A Post Match is for horses of a certain age, and the parties possess the privilege of bringing any horsc of that age to the post.

A Produce M M $\mathrm{M}_{\mathrm{ATCH}}$ is that between the produce of certain mares in foal at the time of the match, and to be decided when they arrive at a certain age specified.

Rules and regulations approved and adopted by the New York Jockey Club, on the 13th September, 1842; to continue in full force and effect until the close of the last Fall Meeting in the year 1844, subject to such alterations as may be made from time to time, according to the discretion of the Club.

Rule 1st.- There shall be two regular meetings held by the New York Jockey Club at the Union Course, on Long Island, to be called and known as the Spring and Fall Meeting. The Spring Meeting shall commence on the second Tuesday of May, and the Fall Meeting shall commence on the first Tuesday of Octobcr, in each year.

Iiule $2 d$.-There shall be a President, four Vice Presidents, a Secretary and Treasurer, to be appointed annually by ballot.

Rule $3 d$.- It shall be the duty of the President to preside at all meetings of the Club ; to act as presiding Judge at each day's race; appoint his Assistant Judges on the evening preceding each day's race, report and publish the results of each day's race, and act as Judge in all Sweepstakes, with such other persons as the parties may appoint.

Rule 4th.- It shall be the duty of the Vice Presidents to attend all meetings of the Club, and assist the President in the discharge of his duties. In the absence of the Prcsident, the first Vice President, and in his absence, the 2d, 3d, or 4th Vice President, shall act as President pro tem. 
Rule 5th.-It shall be the duty of the Secretary to attend at all meetings of the Club, also to attend the Judges of each day's race, assist them with his counsel, and furnish them with all the requisite information connected with each day's race; keep a book, in which he shall record the Members' names, the Rules and Orders of the Club, and add to them any Resolutions or Amendments which may change the character of either; also record the proceedings at each meeting of the Club, whether a special or a regular meeting; he shall also record all the entries of horses, Matches, and Swcepstakes, in which shall be set forth the names of the respective owners, the colour, name, age, sex, and name of sire and dam of each horse; record an account of each day's race, including the time of running each heat, and after the races are over for a meeting, report the same to the President of the Club for his official publication. He shall also put up, and keep up during every Meeting, at some convenient place, at or near the Judges' Stand, a copy of the Rules and Regulations of the Club then in force.

Rule 6 th.-It shall be the duty of the Treasurer to collect all the money due the Club, whether from subscriptions of members, entries of horses, or from any other source, pay the same over from time to time upon the order of the President of the Club, and in case of his absence, upon the order of the acting Vice President; and within thirty days after the closing of every regular meeting, he shall furnish the President, or in his absence, the acting Vice President, a full statement of the receipts and disbursements of the funds of the Club, from the date of the last statement up to the date of that which he then renders, showing the balance of money in hand, subject to the order of the President, or acting Vice President, which statement shall be deposited with the Secretary of the Club, as one of the records of the Club, and so be entered by him.

Rule 7th.-At each regular meeting there shall be appointed four Stewards, who shall serve for one meeting succeeding their appointment. They shall wear some appropriate badge of distinction, to be determined upon by themselves. It shall be the duty of the Stewards to attend on the Course, to preserve order, clear the track, keep it clear, keep off the crowd of persons from the horses coming to the stand after the close of each heat, and they may employ in their discretion, at the expense of the Club, a sufficient number of able-bodied men to assist them in the effectual dis. charge of their dutiès.

Rule 8th.- There shall be three Judges in the starting stand, consisting of the President and two Assistant Judges, assisted by the Secretary, and in case of the absence of the President of the Club, then the first Vice President, and in his absence, the second Vice President. The Judges shall keep the stand clear of any intrusion during the pendency of a heat, see that the Riders are dressed in Jockey style, weigh the riders bcfore starting in the race, and after each heat, instruct the riders as to their duty under the rules before starting in the race, and proclaim from the stand the time and result of cach heat, and also the result of the race.

Rule 9th.-There shall be two Distance Judges, and three Patrol Judges, appointed by the Judges in the starting stand, who shall repair to the Judges' stand immediately after each heat, and report to the Judges the horses that are distanced, and foul riding, if there be any.

Rule 10th.-All the disputes shall be decided by the Judges of the day, from whose decision there shall be no appeal, unless at the discretion of the Judges, and no evidence of foul riding shall be received except from the Judges and Patrols.

Rule 11th. - When in the opinion of the majority of the Officers of the Club, any good causc may require the postponement of a race, they may postpone any Purse race, but in casc of a postponement of a race, no new entries shall be received for that race. A postponement of a Purse race sliall give no authority to postpone any Swecpstake or Mfatch made or advertised to be run on that day; and in the event of the Club postponing a regular Meeting, it shall give them no powcr to postpone any Matches or Swcepstakes made to be run at that Meeting.

Rule 12th.-All Swcepstakes and Matches advertised to be run on the Course on any day of a regular Meeting of the Club, shall be under the cognizance and control of the Club, and no change of entries once made shall be allowed after closing, unless by consent of all parties. Sweepstakes and Matches made to be run at a particula: 
Meeting, without the parties specifying the day, the Secretary must give ten days notice of what days they will be run during the meeting, in case he is informed of it in time. And no Sweepstake or Match shall be run on the Course during a regular meeting without being first reported to the Secretary, to bring it under the cognizance and control of the Club.

Rule 13th.-The age of horses shall be computed from the first day of January next, prcceding their being foaled; that is, a colt or filly foaled on any day in the year 1841, will be considered one year old on the first day of January, 1842 .

Rule 14th.-No person shall start or enter a horse for any purse offered by, or under the control of, the Club, other than a Member of the Club, and producing, if required, satisfactory evidence or proof of his horse's age; nor shall any Member start a horse if his entrance money, subscription money, and all forfeits incurred on the Union Course, are not paid hefore starting. Nor shall any person start a horse, during a rcgular meeting of the Club, who is in arrears to any member of the Club for a forfcit incurred on the Union Course.

Rule 15th.-All entries of horses for a purse shall be made in writing under seal, addressed to the Secretary of the Club, and deposited in a box, kept for that purpose, at the usual place of Meeting of the Club, before five o'clock in the afternoon of the day of the race, for which the entry is made. Each entry shall contain the entrance m.ney, and state the name, age, colour, sex, and pedigree, of the horse entered, and describe the dress of the rider of such horse. After five o'clock of the afternoon of the day preceding a Purse Race, no other or additional entry shall be allowed to be made for that race, and no entry shall be reccived or recorded, that does not contain the entrance money. The entries so received, sliall be drawn from the box by the Secretary, and declared at five o'clock of the afternoon of the day preceding the day of the race, in the presence of at least three Members of the Club, and the horses so entered shall be entitled to the track in the order in which their names are drawn; in Sweepstakes and Matches, the Judges shall draw for the track at the stand.

Rule 16th.-Any person desirous of becoming a member only for the purpose of entering a horse, may do so, he being approved by the Club, and paying double entrance.

Rule 17th.-The distance to be run shall be 'Two-mile heats, Three-mile heats, and Four-mile heats, and a purse shall be put up to be run for during each regular meeting, for each of the named distances. Not more than five per cent. shall be charged as entrance upon any amount that may be put up for a purse.

Rule 18th.-Every horse shall carry weight, according to age, as follows :-

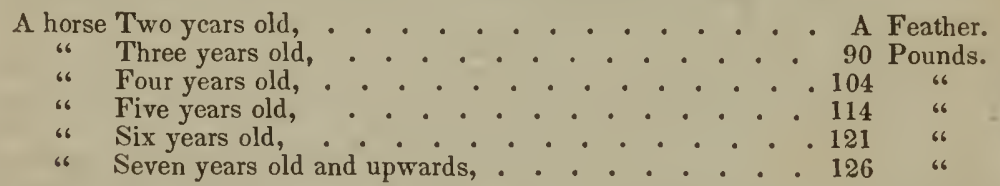

An allowance of three pounds to mares, fillies, and geldings. The Judges shall see that each rider has his proper weight before he starts, and that each rider has within one pound, after each heat.

Rule 19th.-C'atch weights are, where each person appoints a rider without weighing. Feather weights signifies the same. A Post Stake is to name at the starting post. Handicap weights arc weights according to the supposed ability of the horses. An Untried stallion, or mare, is one whose get or produce has never run in public. A maiden horse or mare is one that never won.

Rule 20th. - No horse shall carry more than five pounds over his stipulated weight without the Judges being informed of it, which shall be publicly dcclared by them, whereupon all bets shall be void, except those made between the parties who enter the horses. Fivery rider shall declare to the Judges who weighs him, when and how his extra weights, if any, are carried. The member of the Club who enters the horse shall be responsible for putting up, and bringing out the proper weight. He shall be bound to weigh the rider of his horse in the presence of the Judges before starting, and if he refuscs or neglects to do so, he shall be preverted from starting his horse. 
Rule 21st.-When in running a race, a distance is

In one mile, . . . . . . . . . . . . . . . 45 yards.

In two miles, . . . . . . . . . . . . . 70 ,

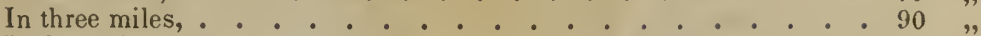

In four miles, . . . . . . . . . . . . . . . . 120 ,",

Rule 22d.-In a Match Race of heats, there shall be a distance, but none in a single heat.

Kule $23 d$. The time between lieats shall be

For one mile heats, . . . . . . . . . . . 20 minutes.

For two milc heats, . . . . . . . . . . . . . . 25 ,

For three milc heats, . . . . . . . . . . . . . 30 ",

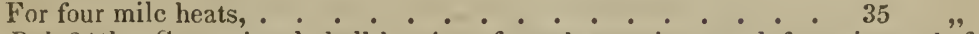

Rule 21 th.- Some signal shall be given from the starting stand, five minutes beforc the period of starting, after the lapse of which time, the Judges shall give the word start to such riders as are then ready, but should any horse prove restive in being brought up to the stand, or in starting, the Judges may delay the word a short interval, at their own discretion.

Rule 25th.-Any horse winning a purse of this Club, shall not be allowed to start for any other purse during the same meeting.

Rule $26 \mathrm{th}$.- If a horse be entered without being properly identified, he shall not be allowed to start, but be liable to forfeit, or the whole, if play or pay, and all bets on a horse so disqualified, shall be declared void.

Rule 27th. - Where more than one nomination has been made by the same individual, in any Sweepstake to be run on the Union Coursc, and it shall be made to appear to the satisfaction of the Club, that all interest in such nomination has becn bona fide disposed of before the time of starting, and the horses have not been traincd in the same stable, all may start although standing in the same name in the list of rominations.

Rule 28th.-No conditional nomination or entry shall be received.

Rule 29th.-Should any person who has entered a horse formally, declare to the Judges that his horse is drawn, he shall not be permitted to start his horse.

Rule 30th.-Any person entcring a horse younger than he really is shall forfeit his entrance money, and if the horse wins a heat or race, the heat or race shall be given to the next best horse if the objection be made to the age of the horse after the heat or race is run. The disqualification must be proved by the person making the objection.

Rule 31st.-If an entcred horse die, or a subscriber entering him, die, before the race, no forfeit shall be required.

Rule 32d.-No compromise or agreement between any two persons entering horscs, or by their agents and grooms not to oppose each other upon a promised division of the purse or stake, or for any other purpose, shall be permitted or allowed, and no persons shall run thcir horses in conjunction, that is with a determination to oppose jointly any other horse that may run against them. In either case upon satisfactory evidence produced before the Judges, the purse or stake shall be awarded to the next best horse-and the persons so offending shall ncver again be permitted to enter a horse to run on the Union Course.

Rule $33 d$. When the tap of the drum is once given by the Starting Judge, there shall be no calling back, unless the signal flag shall be hoisted for that purpose, and when so hoisted it shall be no start. To remedy the inconvenience of false starts, there shall be a signal flag placed at a point which can be readily seen by the riders at from one to three hundred yards from the Judges' stand. When a start is given and recalled, a flag from the Judges' stand shall be displayed, and the person having in charge the signal flag shall hoist the same as a notice to pull up. It shall be the duty of the Starting Judge to give this rule in charge to the riders.

Rule 34 th. - No two riders from the same stable shall be allowed to ride in the same racc. No two horses trained in the same stable, or owned in whole or in part by the same person, shall be allowed to enter or start in the same race: both the entrics shall be void and the entrance money forfeited to the Club.

Rule $35 t h .-N o$ rider shall be permitted to ride unless well dressed in Jockcy style. 
To wit, Jockey cap, coloured jacket, pantaloons, and boots. Liveries to be recorded in the Secretary's Book, and not permitted to be assumed by others.

Rule 36th.-Every rider after a heat is ended must repair to the Judges' stand, and not dismount from his horse until so ordered by the Judges, and then themselves carry their saddles to the scales to be weighed, nor shall any groom or other person, approach or touch any horse until after his rider shall have dismounted and rcmoved his saddle from the horse by order of the Judges. A rider dismounting without such permission, or wanting more than one pound of his proper weight, shall be declared distanced.

Rule 37th.-The horse who has won a heat shall be entitled to the track in the next heat, and the foremost be entitled to any part of the track, he leaving sufficient space for a horse to pass him on the outside. But he shall not when locked by another horse leave the track he may be running in to press him to the inside or outside, and having selected his position in a straight stretch, he shall not leave it so as to press his adversary to either side, the doing of either of which shall be deemed foul riding. Should any rider cross, jostle or strike an adversary or horse, or run on his heels intentionally, or do anything else that may impede the progress of his adversary, he will be deemed distanced although he may come out ahead, and the race awarded to the next best horse. Any rider offending against this rule, shall never be permitted to ride over or attend any horse on this Course again.

Rule 38 th.-Every horse that shall fail to run outside of every pole, shall be deemed distanced, although he may come out ahead, and the race shall be awarded to the next best horse.

Rule 39th.-If a rider fall from his horse, and another person of sufficient weight rides the horse in to the Judges' stand, he shall be considered as though the rider had not fallen-provided he returns to the place where the rider fell.

Rule 40th.-A horse that does not win one heat out of three heats, shall not be allowed to start for the fourth heat, al though he may have saved lis distance, but shall be considered better than a horse that is distanced in the third heat.

Rule 41st.-A distanced horse in a dead heat shall not be allowed to start again in the race.

Rule 42d.-When a dead heat is made, all the horses not distanced in the dead heat, may start again, unless the dead heat be made by two horses, that, if either had been winner of the heat the race would have been decided; in which case the two only must start to decide which shall be entitled to the purse or stake. Such horses as are prevented from starting by this Rule shall be considered drawn, and all bets made on them against each other shall be drawn, excepting those that are distanced.

Rule 43d.-A horse receiving forfeit, or walking over, shall not be deemed a winner.

Rule 44 th. $-\Lambda$ bet made after the heat is over, if the horse betted on does not start again, is no bet.

Rule 45th.-A confirmed bet cannot be off without mutual consent.

Rule 46th.-If either party be absent on the day of a race, and the money be not staked, the party present may declare the bet void in the presence of the Judges, before the race commences; but if any person present offer to stake for an absentee, it is a confirmed bet.

Rule 47th.-A bet made on a heat to come, is no bet, unless all the horses qualified to start shall run, and unless the bet be between such named horses as do start.

Rule 48th.-The person who bets the odds may choose the horse or the field: when he has chosen his horse, the field is what starts against him, but there is no field unless one starts against him.

Rule $49 t h$. - If odds are bet without naming the horses before the race is over, it must be determined as the odds were at the time of naming it.

Rule 50th.-Bets made in running, are not determined till the purse is won, if the heat is not specified at the time of betting.

Rule 51st. - Bets made on particular horses are void, if neither of them be the winner of the race, unless specified to the contrary.

Rule 52d.-Horses that forfeit are beaten horses, where it is play or pay, and not otherwise. 
Rule 53d.-All bets, matches, and engagements are void on the decease of either party before determined.

Rule 54th.-Horses drawn before the purse is won are distanced.

Rule 55th. - A bet made on a horse is void if the horse betted on does not start.

Rule 56th.-When a bet is made on a heat, the horse that comes first to the ending post is best, provided no circumstance shall cause him to be deemed distanced.

Rule 57th.-All bets are understood to relate to the purse or stake, if nothing is said to the contrary.

Rule 58th. - When a bet is made upon two horses against each other for the purse, if each win a heat, and neither are distanced, they are equal-if neither win a heat, and neither distanced, they are equal. But if one wins a heat, and the other does not, the winner of the heat is best unless he shall be distanced, in which case the other, if he saves his distance, shall be considered best. If a horse wins a heat and is distanced, he shall be better than a horse that does not win a heat and is distanced; so too if one be distanced the second heat, he shall be better than one distanced the first heat.

Rule 59th.-The words "absolutely," or "play or pay," are necessary to be used to make a bet play or pay. "Done" and "Done" are also necessary to confirm a bet. If a bet be made, using the expression "play or pay," and the horse die, the bet shall stand. But if the person entering the horse, or making the engagement on him, dies, then the bet is void.

Rule 60th.-All members, and such of their families as reside with them, shall pass the gates free; and the members themselves shall have free admission to the members' stand.

Rule 61 st.- New members can only be admitted on recommendation. Any person wishing to become a member, must be so for the unexpired term of the Club, and must be balloted for. 'Three black balls shall reject. A non-resident of New York introduced by a member, can have the privilege of the inclosed space and members' stand, by paying five dollars for the meeting.

Rule $62 d$.- Ten members of the Club shall be deemed a quorum for the transaction of ordinary business and admission of members, but not less than twenty to alter a fundamental rule, unless public notice shall have been given ten days of such contemplated meeting. The President or Secretary may call a meeting, and the President and Vice President failing to attend, a Chairman may be selected. Members of the Club privileged to invite their friends to the Jockey Club Dinners, by paying for the same. No ladies admitted to the Ladies' Pavilion unless introduced by a member. No citizen of the State of New York can be admitted to the privileges of the inclosed space, Members' Stand, or Ladies' Pavilion, unless he be a member.

Rule $63 d$. - No person shall be permitted to pass into the inclosed space, on the Union Course, without showing his ticket at the gate, nor shall any person be permitted to remain within the inclosure, or Members' Stand, unless he wears a badge, that the officers on duty may be enabled to distinguish those privileged. Officers who shall permit the infraction of this rule shall forfeit all claim to compensation, and must be employed on this express condition.

Rule 64th.-Membership of the New York Jockey Club, shall be for three years, commencing Spring 1842-subscription Ten Dollars per annum, payable each Spring - subscription to be paid whether present or absent. Members joining at any time, whether by original signature, or on nomination, will be bound for the unexpired term of the Club from the period of joining.

'The following gentlemen comprised the Executive Officers of the New York Jockey Club, at the period (Sept. 13th, 1842,) when the foregoing Rules and Regulations were adopted:-

J. Prescott Hall, Esq., President.

Jolin C. Stevens, Esq., lst Vice President.

John A. King, Esq., 2d ", ",

J. Hamilton Wilkes, Esq., 3d " ",

Gerard H. Coster, Esq., 4th ", ",

Hexry K. Toler, Esq., Secretary and Treasurer. 
Having now with some care and, as we trust, with accuracy noted how the stock of English horses has been modified from time to time, being made heavier or lighter, with more or less of bone and muscle; according to the nature of their vehicles and roads, the implements and modes of warfare in use, their national amusements and other uses to which the horse was applied; we come now to speak of him very bricfly in one of his finest and most finished forms, and one in which, from influcnces to which we have before referred, England certainly does and must ever excel all rivals -we allude to

\section{THE HUNTER,}

which is but a combination of the race-horse thorough-bred, witl one of less blood, possessing however more strength and substance with less length of body. His jaws should bc clear and wide, nostrils large, broad thin shoulders, thighs long, strong and muscular, deep chest, affording free play for the lungs; back short, ribs large and wide, large and strong, but hard and clean bone and sinew, tail coming out high and stiff, gaskins well spread, and hind-quarters lean and hard. The right sort of hunter, it has been further and more sententiously observed, should have as far as possible strength without weight, courage without fire or flashiness, speed without labour, a free breath, a strong walk, a nimble, light but large gallop, and a swift trot, to give change and ease to the spcedy muscles.

\section{"Firm let him tread, and just, and move along \\ Upon a well-grown hoof, compact and strong; \\ Proud of the sport, with too much fire to yield,- \\ Such be the horse to bear me to the field."}

And such an one the writer of this had once the pleasure to own-bred in Prince George's County, Maryland ; a noble son of Ogle's Oscar, and the best saddle-horse we ever backed. Alas, old Rasper, we ne'er shall look upon your like again.

"Pride of thy race! with worth far less than thine,

Full many human leaders daily shine!"

As in all things supply follows demand, it may here be noted that the high perfection of the English Hunter, his great speed, stoutness and power of leaping, has been brought about in a great degree, by a change in the character of the English fox-hound. 'The old-fashioned, slow, big-headed, southern or Talbot hound, as described by Shakspeare,

$$
\text { "With ears that sweep away the morning dew," }
$$

has given way to a dog so fleet, that he who is not mounted on one among the fleetest and the strongest, dare not hope for the honour and delight of being " in at the death !" The chase in modern style is in fact but a burst, sometimes running with the game in view to the death, and for which they have bred a hound with a light ear, a squealing notc and a power of spced, to which the ancient hound bcars no more resemblance than a cow to a courser. The reader may judge what sort of a nag is necessary to keep way with the fine-spun descendants of such a bitch as MIerkin, property of the celcbrated Col. Thornton, who challenged to run her against any hound of her year, five miles over New Market, giving 220 yards, for $\$ 50,000$ ! 'This famous bitch is said to have run a trial of four miles in seven minutes and a half second! Under the influence of this change in the face of the country, and in the qualities of the ancient fox-hound, and in the character of this most noble and splendid diversion, a corresponding modification has ensued in the hunter, and so the price for the best has advanced from forty, to three hundred guineas! nor is it easy to imagine any show of animals like that of a stable of English hunters led out for "the mount," either for the fox or the St. Albans Steeple-chase; every nag perfectly well conditioned and dressed off as nicely as a wedding party coming up to the altar. 


\section{THE AMERICAN TROTTER.}

Having, as it is believed, described and accounted for the successive modifications and general improvement of the English horse, from many of the best of which ours have been bred-and for the excellence especially of their high-bred courser and hunter; and having adverted incidentally to the high national importance to be attached to maintaining the horse in all his capabilities, as giving elasticity and vigour to one great arm of national defence-cavalry - the use of which has sometimes decided the issue of battles and the fate of empires, -we pass now to contemplate this interesting animal in a form in which Nimrod (Mr. Apperly) himself, one of the most voluminous and authentic writers on these subjects, and one not prone to make admissions of English inferiority in anything, does admit that we excel, to wit, in our Trotting Horses.

Instances which will hereafter be given of the performance of American trotters, such as have been trained to that pace and timed with exactness, in trials instituted for that purpose by numerous trotting clubs, will leave no doubt of our having well established our claim for the excellence conceded to us in that class of horses-and as speed in that gait, combined with lastingness, is a desideratum in public stages, and for all kinds of light harness and quick travelling, it becomes an interesting inquiry, and is deemed to be well worthy of the space here assigned it-whence has resulted the superiority illustrated by these examples? Is it that we possess a particular strain of horses not to be found in other countries, not thorough-bred, but yet of a specific breed, which has been found or made in America, and which may be kept separate and distinct from all others, the root whereof is not necessarily to be looked for, like that of our thorough-bred stock, in the English Stud-Book, or in the blood of some Eastern ancestor-a breed to which, in a word, recourse may be had as a stock of horses sui generis, and one that may be relied upon to supply fast goers in this pace? Or is it that we owe the number that can go their mile under 2.30 , to the higher estimate which is placed on excellence in that way, in this country; and to the greater pains taken and skill exercised in educating and training horses to go ahead in the trot? We confess that reflection and all the lights we possess, lead us to the adoption of this latter theory.

There are various reasons why this property in the horse should be more attended to in this, than perhaps any other country. May it not be referred in some measure, to our political institutions, as we have already seen, in the review which has been taken of the progressive improvement of horses in England, how their qualities have, from time to time, been influenced and modified by their field-sports, the state of their roads, the form of their coaches, and changes in their warlike and agricultural habits and implcments. Under the effect of our political institutions, which create frequent division of estates, it is next to impossible that there should exist in America a class of men with sufficient and extended wealth, either hereditary or acquired, to maintain the costly and magnificent arrangements for the sports of the turf and the chase - such as have for centuries existed in England. Yet men must have amusements, and those which are found a-field are at once the most attractive and salutary. If one may be allowed to quote himsclf, we may repeat from the introduction to the Sporting Magazine, the ideas there expressed that "the knowledge of mankind so essential in every practical pursuit, nay the yet more essential knowledge of ourselves, is not to be found alone in solitary labour, nor in solitary meditation; neither is it in a state of isolation from society that the heart most quickly learns to answer to the calls of benevolence;-sympathy springs from habits of association, and a sense of mutual dependence on each other; and the true estimate of character, and friendly and generous dispositions, are under no circumstances more certainly acquired, nor more assuredly improved and quickened, than by often meeting each other in the friendly contentions and rivalries that characterize field-sports."

Recurring to the influence of political institutions and national amusements, it may be very safely affirmed, that while there can exist in this country no permanent class or men possessing the wealth which affords the time, and cherishes the taste, for the 
more expensive diversions of the Turf and the Chase; it must yet always abound far beyond all other countries, under their existing governments, in citizens of middling, and yet easy circumstances, with means enough to indulge in other sports involving moderate outlay, including the ownership of a good old squirrel gun; and the luxury of a good horse; and hence the use of both is as familiar to the great mass of American people, from their childhood, as it is strange to the common people of any other country; except as to the employment of the horse, in his lowest offices of field-labour and common drudgery. No southern boy at least, just entering his teens, desires better fun than to be allowed to catch and mount any horse in the most distant pasture, and ride him home at the top of his speed, without saddle or bridle-and as to the use of fire-arms, it was remarked to the writer during the late war with England, both by General Ross and Admiral Cockburn, that in no country had they ever witnessed any fire so deadly as that of the American militia, as long as they would stand! In the towns, there is not a sober and industrious tradesman, who cannot manage to keep his hackney; and these considerations sufficiently account for the number of regularly constituted Trotting Clubs of easy access, with courses that serve as so many nurseries, where the horse is educated exclusively for the trot, and his highest physical capacities drawn out in that form. These associations are composed, for the most part, of respectable and independent mechanics, and others, especially victuallers, among whom in all times there has existed a sort of esprit de corps, or monomania on this subject, which leads them to spare neither pains nor expense to gain a reputation for owning a crack goer. This sort of emulation so infects the class, as to have given rise to a common saying that " a butcher always rides a trotter."

According to the theory here maintained, the great number of trotters in America that can go as before said, their mile under 3 minutes, and the many that do it under $2 \mathrm{~m} .40 \mathrm{~s}$. and even in some cases under $2 \mathrm{~m} .30 \mathrm{~s}$. - as for instance in the case of Ripton and Confidence, whose performances have given so much gratification to sportsmen, is to be explained in the same way that we account for the great number of superb hunters that are admitted to abound in England above all countries, not excepting our own. There, in every county in the Kingdom, there are organized "Hunts," with their whippers-in, and huntsmen, and earth-stoppers, and costly appointments of every kind to accommodate some fifty or an hundred couple of highbred hounds, whose pedigrees are as well preserved as those of Priam or Longwaist; and a wide district of country is reserved and assigned exclusively to each hunt. Fox-hunting is there termed par excellence, a princely amusement, and gentlemen of the most exalted rank and largest fortune, take pride in the office of "Master of the hounds," and assuredly in all the wide field of manly exercises, none can compare with an English fox or steeple-chase, for union of athletic vigour and daring skill, and magnificence of equitation; unless perhaps it were some splendid charge de cavalrie, like those we used to read of, made by the gallant Murat at a critical moment of the battle, when he was wont in his gorgeous uniform and towering plumes to fall with his cavalry like an avalanche upon his adversary, confounding and crushing him at a blow ! Truly, it would well be worth a trip across the Atlantic, to see a single "turn out" of an English hunt, all in their fair tops, buckskin smalls, and scarlet coats, mounted on hunters that under Tattersall's hammer would command from one to two hundred guineas! Imagine such a field with thirty couple of staunch hounds, heads up and sterns down, all in full cry, and well away with their fox!!

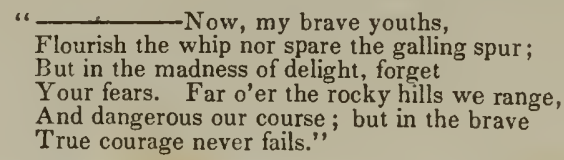

To indicate more strongly the prevalence of this partiality for trotting-horses, and emulation to own the fastest goer, and the number and extent of associations and arrangements for this sort of trial and amusement, it need only be mentioned that the "Spirit of the Times," published in New York, contains lists of hundreds of matches and purses, and of thousands on thousands of dollars in small purses, won and lost on these performances on trotting-courses! A number of these performances will be 
selected, enough to show that the excellence which is conceded to American trotters, is not founded on a solitary achievement or very rare cases, nor to be ascribed to the possession of any distinct and peculiar breed of horses; but is the natural and common fruit of that union of blood and bone, which forms proverbially the desideratum in a good hunter, with the superaddition of skilful training, much practice, and artful jockeying for the trotting course. Who can doubt that if Hiram Woodruff were to go to England, having the run of their hunting-stables, he might select nags enough which could soon be made under his training and consummate jockeyship, to go along with Edwin Forrest and Lady Suffolk, Ripton, Rattler, Confidence, and the Dutchman? On this point the following may be aptly extracted from the highest authority - our Bell's Life in London-To wit: Porter's Spirit of the Times.

"Nimrod, in 'admitting the superiority of our Trotting-Horses to the 'English,' claims that the English 'approach very near to the Americans,' even in this breed of cattle. Possibly the characteristic national vanity would not allow him to make a farther concession. But there is no comparison whatever, between the TrottingHorses of the two countries. Mr. Wheelan, who took Rattler to England last season, and doubly distanced with ease every horse that ventured to start against him, as the record shows, informs us that there are twenty or more roadsters in common use in this city, that could compete successfully with the fastest trotters on the English Turf. They neither understand the art of training, driving or riding, there. For example: some few years since, Alexander was purchased by Messrs. C. \& B. of this city, for a friend or acquaintance, in England. Alexander was a well-known roadster here, and was purchased to order, at a low rate. The horse was sent out and trials made of him; but so unsuccessful were they, that the English importers considered him an imposition. Thus the matter stood for a year or more. When Wheelan arrived in England, he recognised the horse, and learned the particulars of his purchase and subsequent trials there. By his advice the horse was nominated in a Stake at Manchester (we believe) with four or five of the best trotters in England, he (Wheelan) engaging to train and ride him. When the horses came upon the ground, the odds were 4 and 5 to 1 against Alexander, who won by nearly a quarter of a mile! Wheelan says he took the track at starting, and widened the gap at his ease-that near the finish, being surprised that no horse was anywhere near him, as his own had not yet made a stroke, he got frightened, thinking some one might outbrush him-that he put Alexander up to his work, and finally won by an immense way, no horse, literally, getting to the head of the quarter stretch, as he came out at the winning stand? The importers of Alexander, at any rate, were so surprised and delighted at his performance, that they presented Wheelan with a magnificent gold timing-watch, and other valuable presents, and sent Messrs. C. \& B. a superb service of plate, which may be seen at any time at their establishment in Maiden Lane."

Here it is clearly shown that the comparative speed of American horses is to be attributed not to breed, but to management, on which we the rather insist, as it is to be desired that American agriculturists and all breeders and trainers of horses, should understand practise upon some fixed and rational principles, rather than rely for success on some imaginary strain of horses, of no certain origin or established blood. After all, we have accounts of performances in trotting, by English horses, that may be considered as extraordinary as those of our own, when allowance is made for the greater value placed, and the more attention and skill bestowed, upon trottcrs in this country than in that.

'The cclebrated English trotter Archer, descended from old Shields, a remarkable strong horse and master of fifteen stone (two hundred and ten pounds), trotted his sixtcen miles in a very severe frost in less than fifty-five minutes. In 1791, a brown marc, trotted in England on the Essex road, sixtecn miles in fifty-eight minutes and somc seconds, being then 18 years old-and while we are writing we learn from an official report that Lady Hampton on the 2d of May, 1842, in England, trotted seventeen miles in $58 \mathrm{~m} .37 \mathrm{~s}$. in harness. She was driven by Burke, of great English trotting celcbrity. On the 13th of October, 1799, a trotting match was decided over Sunbury Common between Mr. Dixon's brown gelding and Mr. Bishop's grey gelding, carrying twelve stone (one hundred and sixty-eight pounds) each, which 
was won by the former in twenty-seven minutes and ten seconds. - A Mr. Stevens made a bet which was decided 5th October, 1796 , that he would produce a pair of horses, his own property, that should trot in tandem from Windsor to Hampton Court, a distance of sixteen miles, within the hour ; notwithstanding the cross country road, and great number of turnings, they performed it with ease in fifty-seven minutes and thirteen seconds. Phenomena trotted nineteen miles in an hour.-These examples are adduced to show the fallacy of that impression which would lead the public to look to any but the true and rational sources of superiority-for mankind has ever been prone to the marvellous, preferring to look for all that does not lie on the surface, to some mysterious influence, unconnected with known and rational causes. The trotter, according to the distance prescribed as the measure of his capacity, needs the combination of form and blood-of bone and of muscle, which give distinction to the hunter; and the reason, if it be asked, why the thorough-bred cannot be relied upon for a hard run over a rough country, is, that he rarely combines these requisites, and is moreover put to his work when too young; but does any one doubt that Sir Archy, or Timoleon, or Eclipse, or imported Tranby, or Leviathan would have made first-rate hunters or trotters, if, before they were put to hard work, their frames had been left to ripen, and their bones and joints and muscles to get firm and solid, and at the same time pliant and supple by gentle and moderately increasing exercise until five or six years old-for here it is to be noted, that as to the age at which the trotter should be put in training, and that at which he reaches his maximum of power, though there would seem to be some difference of opinion, all agree that the trotter is not in his prime until he is eight or nine years old. The Abdallahs, great-grandsons of old Messenger, trot much younger; Hiram Woodruff, and there can be no better authority, would commence a horse's training for the trot at five or six years of age, giving him light work however, but going on increasing his work from year to year, and expecting increasing excellence up to nine or ten years, and with kind usage he might continue up to this mark for three or four years longer, and they often last to perform admirably until after twenty-for example, Columbus, Paul Pry, Topgallant, \&c.

The stoutest horses, of whatever kind or degree of blood, might be expected to give way if put at three or four, as the race-horse is, into severe training under heavy weights, for trotting stakes or the chase; but on the other hand, without blood to give him wind and courage, what would avail his "bag of bones," in a trial to trot his hundred miles in ten hours? Johnson, author of the Sportsman's Cyclopedia, justly esteemed high authority on such subjects, remarks that "thorough-bred horses, and particularly those of the best blood, are seldom possessed of sufficient bone to render them pre-eminently calculated for the chase; yet I am free to confess that the very best hunters that have fallen under my observation have been remarkably well and very highly bred, but yet not absolutely thorough-bred." The same remark it is not doubted might be made as generally applicable to our first-rate trotters, at long distances. The case of Abdallah and Messenger have been instanced to show, that great trotters not thorough-bred, may and do beget trotters, and hence some would argue that a distinct race of horses may or does exist. But it is to be remembered that both Abdallah and Messenger are sons of Mambrino, son of old Messenger, and of Messenger mares, though not thorough-bred; and nothing is better known by all who have been in the habit of attending to these subjects, than that the Messenger family is distinguished for making first-rate coach-horses-quick in light harness, and remarkable for endurance and long life. That Abdallah, therefore, himself deep in the Messenger blood, should be himiself a trotter and a getter of trotters, only proves that like begets like, and that of a distinct breed, like the thorough-bred horse, characterized by the possession of general properties belonging only to and constituting that breed, there may be particular families, distinguished for some peculiar qualities not possessed in the same degree by other families of the same brced. Thus we have the three classes of the English thorough-bred stock, to wit: the Herod, the Matchem, and the Eclipse, that have served as crosses for each other. In like manner, it may be said of the improved short-horn cattle-their general characteristic is early maturity and propensity to fat, without being generally remarkable is deep milkers, though there are families of the short-horns esteemed for that quality; - a dash 
of the blood of old Messenger imparts high form and action for the state coach, and the eye of the connoisseur can detect the signs in a horse in whose veins flow even one-eighth of his blood; so the fact is generally known to old gentlemen in the South, and especially avouched by the Sporting and Agricultural Society in South Carolina, that the stock of old Janus (there called Genius,) was so remarkable as road and saddle horses, as to have gotten to be considered a distinct breed; so the Topgallant stock made fine saddle-horses, excelling in the canter. The blood horse, too, is remarkable for longevity - the Messenger stock particularly so. If the truth could be known, it is probable it flowed in larger or smaller streams in each of the four thorough-breds which the late General Hampton, (sire of that paragon of sportsmen and gentlemen, Col. Wade Hampton,) drove in his coach all together for sixteen years.

Here may be aptly introduced some extracts from a familiarletter received by the editor from Col. N. Goldsborough, of Talbot, Maryland, who has an eye for the fine points of a horse, as quick as a hawk's for a fish-one who has thought much and with effect on all matters that give dignity and attraction to rural life-himself of the pure old stock in fashion when it meant something to be called a "Maryland" or "Virginia gentleman." He, in confirmation of our hypothesis, says, speaking of Tom Thumb"But whence came his lastingness, his powers of endurance, as well as speed ? I have been in the habit of thinking, that no horse could long continue exertion, especially at a rapid pace, without a good tincture of the blood. At about the same time therc went to England a horse ealled Rattler, of great speed as a trotter-he was represented as the cross of a full-bred horse on the Canadian mare. What a magnificent picture "Whalebone" makes in his trotting action, and how different from the abovcnamed horses! When a boy, I have seen Phil Hemsly mounted on his trotting mare, bred on the borders of Qucen Anne's County. She was much in the style of the famous Phenomena Mare of England-about fourteen and a half hands high.He could keep up with a pack of hounds all day in a trot-and she could pass over the largest oak bodies lying in a wood, without breaking up. I was informed two years ago in Philadelphia by Mr. Allen, son-in-law of Badger of the Marshall House -that some of the best trotters then in New Jersey, were the offspring of Monmouth Eclipse-the Messenger blood you see! I know of no other family of the pure blood horse which may be said empliatically to produce trotters-the exception confirms the rule. Col. Lloyd's Vingtun and old Topgallant got fine racking and cantering horses. Is there more than one out of twenty thorough-breds, that makes really a racer? And are there not as many trotters at the North, and more, than there are racers at the South, \&c., where the most systematic efforts have been persevered in for years, exclusivcly for the production of racers? I have often wondered where they of the North derived their horses-from what I have seen and heard, they have a peculiar family, different in appearance, in form strikingly from ours. They of the North have had some method in this matter-as well as the breeders of short-horns, Lcicester sheep, \&c. About the lakes they have a horse of great speed and power, as I am informed, called the 'Frencher.' The English officers bring over from the mother country, fine blooded stallions for troopers and parade. It is the cross of these and the Canadian mares, which produces the 'Frencher, - blood is indispensable. But what is the Canadian? unde venit? They are descended from the horses of Normandy carried over by the French settlers. Napoleon's coach when captured was being drawn by four Norman horses, and I guess the Emperor was not fond of sitting behind slow cattle. When the Spaniards were in possession of the Low Countries, they carried with them their Andalusian horses-these were crossed on the Normans, which produced great improvement. When the Spaniards were expelled, the breeding in-and-in from this stock must have produced a distinct family, as Bakewell produced with other races of quadrupeds. Climate necessarily produced a change in the Norman horse, when transferred to the rigour of Canadian wintershence the thick coat of hair, \&c. The Andalusian, you know, is of Arabian descent. So far as I have been able to learn, Vermont is indebted to Canada for her distinguishrd race of roadsters, as well as the neighbouring States. They liave one distinct family, the 'Morgan,' descended from a little Canadian, famous too for running quarter races. This family has been cherished for years, and is as distinguished 
among them as old Arehy was in Virginia. I have some indistinct recolleetion to have seen, years ago, an aeeount of a horse among them got by, or out of a mare by, Cock of the Roek-Messenger blood again."

It is now in proof that this Morgan breed is deseended from a horse that was stolen from General de Laneey, importer of Wildair, and there is every reason to believe that though he may not have been thorough-bred, he was well steeped in the best blood of the Anglo-Ameriean turf-horse.

While it has been found impraetieable to obtain any preeise information as to the pedigree of some of our very best trotters, in other eases where more is known, they are found to be deep in the blood.-Awful, whose performanees will be seen in the tables annexed, is known to have been gotten by a thorough-bred "Ameriean boy." Lady Suffolk is by Engineer, but what Engineer not known. Abdallah, as before mentioned, is by Mambrino, and he again, a great trotter, by Messenger; but Dutchman, one of our best trotters, has no known pedigree, though we have some reason to think he was by Young Osear, then at Carlisle. He was taken out of a elay-yard, and was transferred to the trotting-turf from a Pennsylvania wagon-team.-Woodruff thinks blood does not give thęm length, or the power to go the long distanees; but in this it is believed he must be mistaken. These Canadian or Norman-Freneh stallions, small and eompaet, which on well-formed large mares give sueh fine harness horses, and trotters, are, as before said, deeply imbued with the blood of the barb taken from Spain into Normandy. We have been told lately by an intelligent Englishman, that the infusion of blood into their eoaeh-horses has enabled them to lengthen their stages, and in very observable proportion to the degree of blood. Finally, as where the blood of the trotter when known, is seen to flow in so many instanees from a spring of pure blood, is it not fair to infer a similar origin in eases where the blood eannot be traeed? espeeially as the universal experienee of all times proves that in other paees, the eases have been extremely rare, in which a horse of impure blood has been known to keep up a great flight of speed? A horse of mixed blood may be a great trotter at a long distanee, beeause his speed at his best is greatly behind that of the best speed on the turf; but it would, aeeording to all prineiples of reasoning, be unreasonable to expeet great exeellenee even as a trotter, in horses altogether free from the blood whieh gives foot and wind to the Eastern eourser. Though we may not be able to traee it, and though in solitary cases a horse without it, may possess great speed and lastingness in the trot, from exeellent aeeidental eonformation, we repeat that the possession of the two, warrants the presumption of the third, however obseure the traees, or remote the origin;-this is our themry! But the action to be cultivated in the raeer and the trotter is of itself suffeient to explain why a raeer should not sueeeed at onee on the turf and on the trotting. eourse. All refleeting and observant men will admit that "as there is no royal way to mathematies," so there is but one way for a horse to exeell in his business; and with rare exeeptions there is but one in whieh any individual horse ean exeel.Whatever that business may be, to be perfeet in it he should be edueated and kept to it-and to it only. A trotting-horse should do nothing but trot.

As what has been said may promote a disposition to form clubs in order to cultivate more generally and eertainly the powers of the trotting horse, with the view of praetieal utility in the business of life, it is deemed well to submit at this point, the Rules of the Trotling Club at New York. The rules whieh prevail elsewhere are essentially the same, or so little variant that the difference is not deemed worthy of
notiee.

\section{Rules and Regulations adopted by the New York Trotting Club for the Beacon and Centreville Courses. - September 1st, 1841.}

1.-All Matehes or Sweepstakes whieh shall come off over a Course, under the jurisdietion of this Club, will be governed by these Rules, unless the contrary is mutually agreed upon by the parties making such mateh or stake.

2.-All Purses, Matehes, or Sweepstakes to which the Club or Proprietors contribute, they shall have the power to postpone, should the weather prove unfavourable on the day previously named for the trotting of the same. 
3.-None but Members shall be allowed to trot a horse for any limited Purse given by this Association.

4.-Horses trained in the same stable or owned in part by the same person, shall not start for a Purse; and horses so entered shall forfeit their entrance. A horse starting alone shall receive but one-half the Purse. Horses deemed by the Judges not fair trotting horses, shall be ruled off previous to, or distanced at the termination of a beat.

5.-All entries shall be made under a seal, inclosing the entrance money, (ten per cent. on the Purse,) and addressed to the Secretary, at such time and place as may have been previously designated by advertisement.

6.-Wvery 'Trotting horse starting for Match, Purse, or Stake, shall carry 145lbs.if in harness, thic weight of the vehicle not to be considered. Pacing horses to be allowed 5lbs.; Wagons to weigh $250 \mathrm{lbs}$.

7.-A distance for mile heats, best three in five, shall be one hundred yards; for onc-mile heats, eighty yards, and for every additional mile an additional eighty yards.

8.-The timc between heats shall be-for one mile, twenty minutes, and for every additional mile, an additional five minutes.

9. -There shall be chosen by the Proprietors of the Course, or Stewards, Three Judges, to preside over a race for Purses, and by them two additional Judges shall be appointed for the distance stand ; they may also, during, or previous to a race, appoint Inspectors at any part of the Course, whose report shall be received of any foul riding or driving.

10. - Should a difference of opinion exist between the Judges in the starting stand, on any question, a majority shall govern.

11.- 'The Judges shall order the horses saddled or harnessed, five minutes previous to the time appointed for starting, or at the expiration of the time allowed between heats. Any rider or driver causing undue detention, after being called up, by making false starts or otherwisc, the Judges may give the word to start, without reference to the situation of the horse so offending, unless convinced such delay is unavoidable on the part of the rider or driver; in which case not more than thirty minutes shall be consumed in attempts to start.

12.-The Pole shall be drawn for by the Judges. The horse winning a heat, shall, for the succeeding heat, be entitled to a choice of the track. On coming out on the last stretch, each horse shall retain the track first selected; any horse deviating shall bc distanced.

13. - In all cases of dispute, and not provided for by these Rules, the Judges for the day will decide finally. In casc of a race or match being proved to their satisfaction to have been made or conducted improperly and dishonestly, on the part of the principals, they shall have the power to declare all bets void. They shall also have the power to mitigate the penalty of a rider or driver's disobeying these rules, by giving the next best horse a heat, instead of distancing the person so offending, should circumstances justify them in such mitigation.

14.-Riders and drivers shall not be permitted to start unless dressed in Jockey style.

15.-Riders and Drivers shall weigh in the presence of one or more Judges, previous to starting; and after a heat, are to come up to the starting stand, and not to dismount until so ordered by the Judges. Any rider or driver disobeying, shall, on weighing, be precluded from the benefit of the weight of his saddle and whip-and if not full weight, shall be distanced.

16. - $\Lambda$ rider or driver committing any act which the Judges may deem foul riding or driving, shall be distanced.

17.-Should any horse break from his trot or pace, and gain by such break, twice the distance so gained shall be taken from him on coming out. A horse breaking on the score shall not lose the heat by so doing.

18.-A horse must win two heats to be entitled to the Purse-unless he distance all other horses in one heat.-A distanced horse in a dead heat shall not start again.

19. - A horse not winning one heat in three, shall not start for a fourth heat, unless such horse shall have made a dead heat. When a dead heat is made between two horses, and if EITIIER had won the heat, the race would have been decided, they rwo 
only shall start again. Such horses as are prevented from starting by this Rule, shall be considered DRAWN and not DISTANCED.

20.-If two horses each win a heat, and neither are distanced in the race, they are equal; if neither win a heat, and neither distanced, they are equal; but if one wins a heat, and the other does not, the winner of a heat is best, unless he shall be distanced subsequently, in which case the other, if not distanced, shall be the best. A horse that wins a heat and is distanced, is better than one not making a heat and being distanced. A horse distanced the second heat, than one distanced the first heat, \&c.

21.-Horses drawn before the conclusion of a race, shall be considered distanced. 22.-Horses that forfeit, are the beaten horses, when it is pay or play.

23. - All bets are understood to relate to the Purse, Match, or Stake, if nothing is said to the contrary.

2.1. - A confirmed bet cannot be let off without mutual consent. If either party be absent at the time of trotting, and the money be not staked, the party present may declare the bet void, in the presence of the Judges, unless some party will stake the money betted for the absentee.

25.-A bet made on a heat to come, is no bet, if ALL the horses qualified to start do nct; unless the bet be between such horses as do start. A bet made after the heat is iver, is void, if the horse bet upon does not start.

26.- The person who bets the odds, has a right to choose the horse or the field. When he has chosen his horse, the field is what starts against him; but there is no field unless one starts with him. If odds are bet without naming the horses before the trot is over, it must be determined as the odds were at the time of making it. Bets made in trotting are not determined till the Purse is won, if the heat is not specified at the time of betting. Bets made between particular horses are void, if neither of them be winner, unless specified to the contrary.

27.-All bets made on horses precluded from starting, by (Rule No. 19, ) being distanced in the race; or on such horses against each other, shall be drawn.

28.-All engagements are void upon the decease of either party, before being determined.

Under the preceding Rules, the following performances have been achieved, according to the official record-the New York Spirit of the Times.

It may be proper, however, for the due appreciation of the performances included in these tables, to make some preliminary remarks upon weights carried by trotting horses, and on their comparative speed in hamess and under the saddle, \&c. The weight carried on the Northern courses, where a majority of our trotting takes place, is 145 pounds, without any distinction for age or sex; and the same weight has to be carried by the driver, exclusive of the weights of his sulky or match-cart, as by the same jockey in the saddle. These match-carts are of the neatest construction, and weigh generally nearly ninety pounds, though they often weigh twenty pounds less, and there are one or two which weigh but fifty-three pounds! But the mere weight to be carried or drawn by a trotter, is much less regarded by the sportsman than in the case of the race-horse. On the Hunting Park Course, near Philadelphia, the weight was formerly 147 pounds in the saddle, and in harness catch-weights, but they have now adopted the New York scale. But in far the greater number of the cases below, unless the weight be expressly named, it may be presumed to be from 115 to 155 pounds. Hiram Woodruff weighs without his saddle 160 pounds. On the Beacon and Centreville Courses, pacers are allowed five pounds, and wagons, in distinction from sulkeys or match-carts, must weigh 250 pounds.

As a matter of course, from the difference of weights carried along by him, the trotter generally makes better time under the saddle than in harness, though there are some exceptions to this rule. Another consideration has great influence upon this difference in time. Under the saddle, the jockey can hug the pole of our ovalshaped courses more closely than in harness, and thus he actually goes over less ground. And for an obvious reason the speed of a horse in going "round the turns" is more retarded in a sulkey than under the saddle. As before stated, no allowance of weights is made for age, and in consequence no note is taken of the age of trotters
in official reports of their performances. 
TROTTING AT MILE HEATS.

\begin{tabular}{|c|c|c|c|c|c|}
\hline Name. & Colonr. & $\begin{array}{l}\text { Saddle or } \\
\text { Haruese. }\end{array}$ & Time. & Course. & Dale. \\
\hline Edwin Forrest. & bl. g.. & saddle. . & $2.31 \frac{1}{8}-2.33$ & Centreville, L. I. & May, 1834. \\
\hline Edwin Forrest. & bl. g.. & saddle. . & $2.37^{2}-2.36-2.39-2.40$ & Trenton, N. J... & Spring, 1834. \\
\hline Burster............ & gr. g.. & saddle.. & $2.32 \ldots \ldots \ldots \ldots \ldots$ & Hunting Park, Pa.... & Fall, 1830. \\
\hline Dutchman .... & b. g... & harness. & $2.35-2.32-2.35 \ldots \ldots \ldots \ldots$ & Beacon Course, N. J. & July, 1839. \\
\hline Dutchman........ & b. $g$... & saddle. . & $2.36-2.35-2.33-2.33-2.40$ & Trentou, N. J........ & Sept. 1836 . \\
\hline Norman Leslie.... & bl. g.. & saddle.. & $2.38-2.36 \frac{1}{8}-2.38-2.39-2.38$ & Do. & June, 1836 . \\
\hline Confidence $\ldots \ldots \ldots$ & b. g... & haruess. & $2.35-2.37-2.36 \ldots \ldots \ldots \ldots$ & Beacon Course, N. J. & June, 1841. \\
\hline Locomotive..$\ldots \ldots$ & ch. g.. & $\begin{array}{l}\text { saddle.. } \\
\text { saddle.. }\end{array}$ & $\begin{array}{l}2.38-2.36-2.37 \ldots \ldots \ldots \ldots \\
2.42-2.41-2.40-2.401-2.40\end{array}$ & Centreville, L. I...... . & Oct. 1837 . \\
\hline & & saune. & $2.38 \ldots \ldots \ldots \ldots \ldots \ldots \ldots \ldots$ & Do. & May, 1841. \\
\hline Sally Miller......... & b. $\mathrm{m} .$. & saddle.. & $2.37 \frac{1}{4}-237-2.40-2.42-2.44$ & Hunting Park, Pa. & Nov, 1833 . \\
\hline & II). & saddle & $2.39-2.38-2.39-2.40 \ldots \ldots$ & Do. & Nov. 1834 \\
\hline
\end{tabular}

\section{TROTTING AT TWO-MILE HEATS.}

Lady Sufolk...... g. m.. | saddle.. $\mid 4.59-5.03^{1} \ldots \ldots \ldots \ldots \ldots \ldots$ Centreville, L. I...... Sept, 1810.

lady Sutfolk......

Lady Suffolk ........ $\begin{aligned} & \text { g. } \mathrm{g} . . \\ & \text { harness. }\end{aligned}$

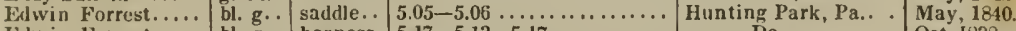

Edwin Porrest.... bl. g. . harness. $5.17-5.13-5.17 \ldots \ldots \ldots \ldots$.

W. D. Toupkins.... ch. g. . saddle.. $5.16 \frac{1}{2}-5.11 \ldots \ldots \ldots \ldots \ldots$. Centreville, L. J...... Oct. 1837.

lipton ........... br. g. . harness. $5.10 \frac{1}{8}-5.12 \frac{1}{3} \ldots \ldots \ldots \ldots \ldots$. Beacon Course, N. J. May, 1842.

Ripton ........... br. g.. harness. $5.07-5.15 \ldots \ldots \ldots \ldots \ldots \ldots$ Hunting Park, Pa.... May, 1842.

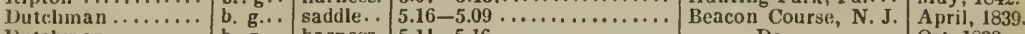

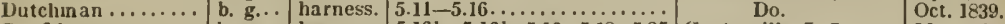

Confidence....... b. b... harness. 5.16! $5.16 \frac{1}{8}-5.16-5.18-5.25$ Centreville, L. I..... May, 1841

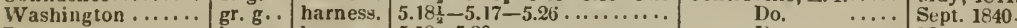

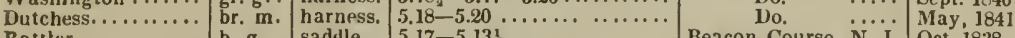

Rattler ........... b. g... $\quad$ saddle.. $5.17-5.13 \frac{1}{2} \ldots \ldots \ldots \ldots \ldots$ Beacon Course, N. J. Oct. 1838.

Rattler .......... b. g... saddle. $5.29-5.17-5.40 \ldots \ldots \ldots \ldots$. $50 . \quad$ July, 1838.

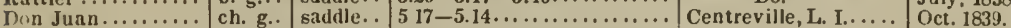

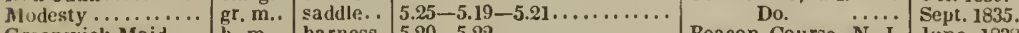

Greenwicl Maid ... $\quad$ b. m.. harness. $5.20-5.22 \ldots \ldots \ldots \ldots \ldots \ldots$ Beacon Course, N. J. June, 1838.

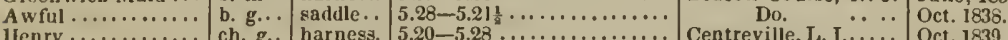

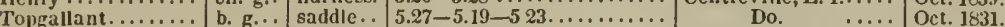

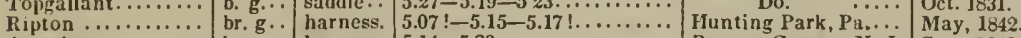

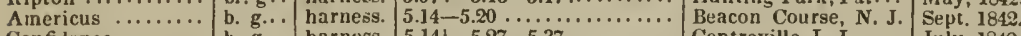

Confidence....... $\mid$ b. g...

But the most extraordinary performance is yet to be recorded. We should have omitted it, as being perhaps apochryphal, lad it not been well avouched to us by a respectable looker-on, who may be believed-us follows: D. Bryan's Lady Suffolk and Rifle-double-harness-Hunting Park-31st May, 1842, two miles in 5.191 !

\section{TROTTING AT THREE-MILE HEATS.}

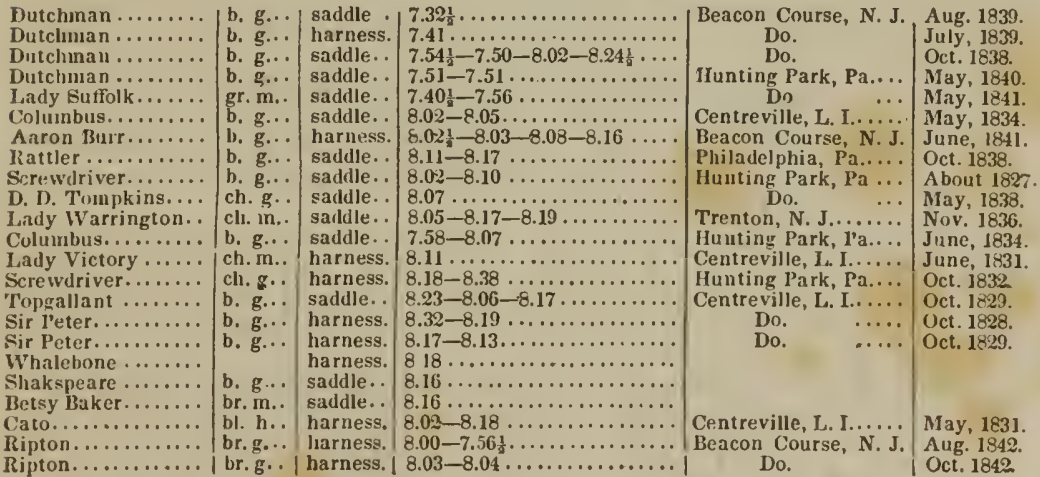

TROTTING AT FOUR-MILE HEATS. Lady Siıffolk....... gr. in.. saddle.. $11.15-11.58 \ldots \ldots \ldots \ldots \ldots . .$. Lady Suffolk...... gr. $m . ._{\text {saddle. . }} 11.22-11.34 \ldots \ldots \ldots \ldots \ldots$.

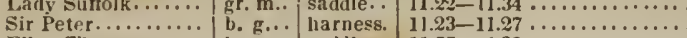

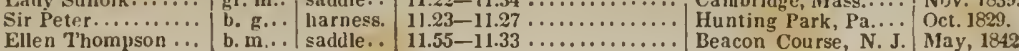


BEST PACING IN A MERICA ON RECORD.

\begin{tabular}{|c|c|c|c|c|c|}
\hline Name. & $\begin{array}{l}\text { Saddle or } \\
\text { Harness. }\end{array}$ & Distance. & Time. & Course. & Date. \\
\hline $\begin{array}{l}\text { Drover............ } \\
\text { Top Sawyer........ } \\
\text { Oneida Chief....... } \\
\text { Volcano ......... } \\
\text { Billy............. } \\
\text { Oneida Chief..... } \\
\text { Oneida Chief...... } \\
\text { Oneida Chief....... } \\
\text { Bonny Boy........ } \\
\text { Stranger........... }\end{array}$ & $\begin{array}{l}\text { saddle.. } \\
\text { saddle.. } \\
\text { saddle: } \\
\text { saddle.. } \\
\text { saddle.. } \\
\text { saddle.. } \\
\text { saddle. } \\
\text { harness. } \\
\text { saddle.. } \\
\text { saddle.. }\end{array}$ & $\begin{array}{ll}1 & \text { mile. } \\
1 & \text { do. } \\
1 & \text { do. } \\
1 & \text { do. } \\
1 & \text { do. } \\
2 & \text { miles } \\
3 & \text { do. } \\
3 & \text { do. } \\
2 & \text { do. } \\
2 & \text { do. }\end{array}$ & 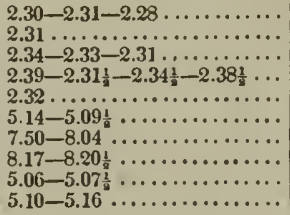 & $\begin{array}{l}\text { Beacon Course, N. J. } \\
\text { Centreville, L. I...... } \\
\text { Harlaem, N. Y....... } \\
\text { Beacon Course, N. J. } \\
\text { Do. } \\
\text { Do. } \\
\text { Do. } \\
\text { Do. } \\
\text { Centreville, L. I...... } \\
\text { Do. } \quad \ldots . . .\end{array}$ & $\begin{array}{l}\text { Oct. } 1839 . \\
\text { Oct. } 1835 . \\
\text { Oct. } 1835 . \\
\text { June, } 1841 . \\
\text { July, } 1841 . \\
\text { June, } 1838 . \\
\text { Nov. } 1841 . \\
\text { June, } 1840 . \\
\text { Sept. } 1829 . \\
\text { Oct. } 1829 .\end{array}$ \\
\hline
\end{tabular}

\section{MISCELLANEOUS EXAMPLES OF EXTRAORDINARY PERFORM-} ANCES OF AMERICAN TROTTERS.

On the 21st of October, 1841, a match came off on the Centreville Course, L. I., for $\$ 5500$, five-mile heats, between Americus, a bay gelding, and Lady Suffolk, so often named in the preceding tables. Americus won in two heats, and in the following time, believed to be the best on record:

FIRST HEAT.

Time of first mile.......... $2.54 \frac{1}{2}$

"6 "6 second $66 \ldots \ldots \ldots \ldots . . \ldots 2.50 \frac{1}{2}$

66 "6 third $66 \ldots \ldots \ldots \ldots . . \ldots 2.46$

"6 "6 fourth $66 \ldots \ldots \ldots \ldots . . .2 .42 \frac{1}{2}$

"6 "fifth "6 $\ldots \ldots \ldots \ldots \ldots .2 .44 \frac{1}{2}$

Time of first heat . ........ 13.58
SECOND HEAT.

Time of first mile .........2.51

66 "6 second $66 \ldots \ldots \ldots \ldots . . \ldots 2.50$

"6 $"$ third $"$ " $\ldots \ldots \ldots \ldots \ldots . . \ldots 2.46$

"6 6 fourth $66 \ldots \ldots \ldots \ldots . . \ldots 27$

"6 6 fifth "6 .........2.44

Time of second heat ......

Topgallant, by Hambletonian, trotted in lıarness 12 miles in 38 minutes. - See Turf Register, vol. 1. p. 124.

Ten miles have been repeatedly trotted in America within two or three seconds of thirty minutes.

A roan mare called Yankee. Sal trotted, as has been stated without contradiction, in a match against time, on the Course at Providence, R. I., which was at the time heavy and deep, fifteen miles and a half in $48 \mathrm{~m}$., 43s. - a rate of speed so prodigious under the circumstances, that we have often suspected there may have been an error as to the time.

Lady Kate, a bay mare, 15 hands high, trotted on the Canton Course near Baltimore 16 miles in $56 \mathrm{~m} .13 \mathrm{~s}$., and the reporter adds "she could have done seventeen with ease."

In October, 1831, Jerry performed 17 miles on the Centreville Course, L. I., in 58 minutes under the saddle.

In September, 1839, Tom Thumb, an American horse, was driven in England $16 \frac{1}{2}$ miles in $56 \mathrm{~m} .45 \mathrm{~s}$. We shall have more to say of this phenomenon, when we come to his performance of 100 miles.

In 1836, the grey gelding Mount Holly was backed at $\$ 1000$ to $\$ 500$, to trot twenty miles within the hour. The attempt was made on the 10th of October, on the Hunting Park Course, Pa., but failed. He performed 17 miles in $53 \mathrm{~m} .18 \mathrm{~s}$., without the least distress. He was miserably jockeyed for the first five miles, doing no one of them in less than five minutes.

Pelham, a large bay gelding, in a match to go 16 miles within the hour, performed that distance without any training in $58 \mathrm{~m} .28 \mathrm{~s}$. He went in harness seven miles in $26 \mathrm{~m} .29 \mathrm{~s}$., when, the sulkey being badly constructed, he was taken out and saddled, and mounted by Wallace (riding $160 \mathrm{lbs}$. without his saddle) and won his match.

Paul Pry, a bay gelding, was backed to perform $17 \frac{3}{4}$ miles within the hour, under the saddle. On the 9 th of November, 1833, on the Union Course, L. I., he won the match, performing 18 miles in $58 \mathrm{~m}$. 52s. Hiram Woodruff, weighing then $138 \mathrm{lbs}$, jockeyed him. Paul Pry was nine years old, bred on Long Island, and got by Mount Holly, dam by Hambletonian. 
In 1831, Chancellor, a grey gelding, ridden by a small boy, performed 32 miles on the Hunting Park Course, Pa., in 1 hour, $58 \mathrm{~m}$. 31s. The last mile, to save a bet, was trotted in $3 \mathrm{~m} .7 \mathrm{~s}$.

In October of the same year, George Woodruff drove Whalebone on the same Course, the same distance in 1 hour, $58 \mathrm{~m}$. $5 \mathrm{~s}$. He commenced the match in a light sulkey, which broke down on the 14th mile, and was replaced by one much heavier. 'This Course is fifty feet more than a mile in the saddle track, and much more than that in the harness track.

On the 11 th of September, 1839, Mr. McMann's bay mare, Empress, on the Beacon Course, in a match against time, $\$ 600$ a side, performed in harness 33 miles in 1 hour, $58 \mathrm{~m} .55 \mathrm{~s}$.

The American horse Rattler was ridden by Mr. Osbaldistone in England, in a match against Driver, 34 miles in 2 hours, $18 \mathrm{~m} .56 \mathrm{~s}$. - Mr. Osbaldistone rode 125 lbs.; Rattler was $15 \frac{1}{2}$ hands high.

In July, 1835, Black Joke was driven in a match against time, on the Course at Providence, R. I., 50 miles in 3 hours, $57 \mathrm{~s}$.

A gray roadster is reported to have performed the same distance on the Hunting Park Course, $\mathrm{Pa}$., in 3 hours, $40 \mathrm{~m}$. It was a private match.

A grey mare, Mischief, by Mount Holly, out of a Messenger mare, 8 years old, in July, 1837 , performed about $84 \frac{1}{2}$ miles in 8 hours, $30 \mathrm{~m}$. in harness, on the road from Jersey City to Philadelphia. The owner would not allow a whip to be used. The day was excessively warm, and the mare lost her match (to perform 90 miles in 10 hours) through the stupidity of a groom who dashed a pail of water over her with a view of cooling her.

Tom Thumb, before mentioned, performed on 2d February, 1829, on Sunbury Common, England, 100 miles in 10 hours, $7 \mathrm{~m}$. in harness. He was driven by William Haggerty (weighing over 140 lbs.) in a match-cart weighing 108 lbs. This performance, so extraordinary, demands more than a passing notice, and we accordingly abridge from an English paper the following description:

Tom Thumb was brought from beyond the Missouri, and is reported to have been an Indian pony, caught wild and tamed. Others again, allowing him to have been thus lomesticated, think him to have been not the full-bred wild horse of the Western prairies, but to have had some cross of higher and purer blood. But too little is known of his breeding, saving his western origin, to justify any satisfactory speculation.

His height was $14 \frac{1}{2}$ hands, and his appearance, when standing still, rough and uncouth. From his birth, he had never been shorn of a hair. He was an animal of remarkable hardihood, a hearty feeder, and though accustomed to rough usage, was free from vice, playful and good-tempered. He was eleven years old when he performed his match, and had never had a day's illness. At full speed his action was particularly beautiful-he threw his fore-legs well out, and brought up his quarters in good style; he trotted square, though rather wide behind, and low. He was driven without a bearing rein, which is going out of use in England, and simply with a snaffle-bit and martingale. He pulled extremely hard-his head being, in consequence, well up and close to his neck, and his mouth wide open. He did his work with great ease to himself, and at 11 miles the hour, seemed to be only playing, while horses accompanying laboured hard.

The whole time allowed for refreshments during his great performance, amounted to but 37 minutes, including taking out and putting to the cart, taking off and putting on the harness, feeding, rubbing down and stalling. The day before and the day after the match, he walked full twenty miles. His jockey provided himself with a whip, but made no use of it in driving him; a slight kick on the hind-quarters was quite sufficient to increase his speed when necessary.

In February, 1828, a pair of horses trotted against time 100 miles on the Jamaica turnpike, on Long Island, and won in 11 hours, $54 \mathrm{~m}$.

But in June, 1834, a pair of horses belonging to Mr. Theal, trotted that distance in harness on the Centreville Course, within 10 hours, and immediately after Mr. Boffered to bet $\$ 5500$ that he would produce a pair of horses that could trot 110 miles in harness within the same time!-The bet was taken, but afterwards abandoned by 
the backers of time, who paid forfeit.-Another gentleman offered to produce for a wager a pair of horses that should trot 100 miles in nine hours in harness, but no one would back time against the performance.

Having thus gone through with these numerous details, let us dwell for a moment upon some of the most extraordinary performances noted in the tables. Probably the most remarkable trotting performance on record is Dutchman's match against time. But we will first give the report of his match with Rattler, which we compile from the "Spirit of the "Times."

\section{EXTRAORDINARY TROTTING MATCH.}

A trotting матсH, for $\$ 1000$ a-side, Three mile heats, under the saddle, came off on Saturday,Oct. 6, 1838, at 4 o'clock, over the Beacon Course, opposite this city. The annals of the turf furnish no parallel to it; every foot of the ground was severely contested, and the time made is by far the best on record.

Dutchman and Ratller were the contending horses; the first is a handsome bay gelding, of great size and substance, about 16 hands high; he is what is termed "a meaty horse," and looks, when in fine condition, like an ordinary roadster in "good order." He was trained for the match and ridden by Hiram Woodrufr. Rattler is a brown gelding, of about $15 \frac{1}{2}$ hands, and "a rum 'un to look at;" he was drawn very fine, though one of those that seldom carry an ounce of superfluous flesh; we hear that his feed of late has seldom exceeded six quarts per day, while Dutchman's has been between twelve and sixteen. Rattler was trained and ridden by William WheELaN. His style of going is superior to Dutchman's; he spreads himself well, and strikes out clear and even. Dutchman does not appear to have perfect command of his hind legs: instead of throwing them forward, he raises them so high as to throw up his rump, and consequently falls short in his stride. The main dependence of his backers was based upon his game; and a gentleman who "put on the pot" to a heavy amount on Rattler, offered 2 to 1 on Dutchman before the start, provided the heats were broken.

The odds before the horses came upon the track were 5 to 4 on Dutchman; after the riders were up, 5 to 3 was current, and at length 2 to 1 . As they were ridden up and down in front of the stand previous to starting, both appeared to be in superb condition, and to have their action perfectly. The track was so hard and smooth that the nails in the shoes of the horses could be seen every step they made. A great many bets were made on time; even bets were made that it would be better than any on record. To determine what the best time on record was, it was shown that in 1833, Columbus trotted a three mile heat, under the saddle, over the Hunting Park Course, Philadelphia, in 7:57 $\frac{1}{2}$, - but to prevent any dispute about the fractions of a second, 7:58 was declared to be the best time made. On the 10 th of October, 1837, Daniel D. Tompkins, in a match, literally vs. the world, beat Rattler, over the Centreville Course, in 7:59 - 8:09, three mile heats, under the saddle. Both Dutchman and Rattler are owned by gentlemen of this city; the latter was ridden without a spur.

The Race.-Rattler drew the track, but resigned it to Dutchman on the first quarter; he came in front on the backside, and at the half-mile post led by two lengths; he soon after broke up, when Dutchman headed him and led past the stand (2:42) round to the straight stretch on the backside, where the ground being descending, and more favourable to him, Rattler passed. Dutchman waited upon him, close up, to near the three-quarter mile post, where Rattler shook him off, and led past the stand (2:38) by four lengths; keeping up his rate, he led down the backside and round the turn to the straight stretch in front, where Hiram caught Dutchman by the head, and laid in the spurs up to the gaffs; the brush home was treinendous, but Rattler won by nearly a length, trotting the $3 \mathrm{~d}$ mile in $2: 34 \frac{1}{2}$, and the heat in $7: 54 \frac{1}{2}$.

Second heat.-Dutchman broke at starting, and 2 to 1 was offered against him. Down the backside the horses were lapped all the way; on the ascending ground, within about ten rods of the half-mile post, Dutchman gained a little, and came first to the stand (2:37). He drew out two lengths ahead round the 1st turn on the $2 d$ mile, but Rattler gallantly challenged him down the backside and lapped him; at the halfmile post Dutchman was again clear, but by a desperate effort Rattler lapped him when they got into straight work in front, and thus they came to the stand (2:33). On the backside Rattler, as usual, drew out clear, but for an instant only; the spurs 
were well laid into D., and the struggle was desperate; Dutchman hung upon Rattler's quarter, and gradually gained to the half-mile post, when they were locked as perfectly as if in double harness. The contest was almost too much for Rattler, who skipped several times, and was only prevented from breaking by Bill's holding him up. They came up the quarter stretch at an immense pace, but opposite the four mile distance stand, Rattler unfortunately broke up, when nearly a length ahead, and Dutchman won the heat by six or eight lengths. When Rattler skipped, Wheelan should have taken him in hand, but he was so much ahead, and so near home, (within $180 \mathrm{yards,}$ ) that under the intense excitement of the moment, he neglected doing so; had he done so, however, at the rate Dutchman was going he would probably have won by a few feet, for Rattler could not have made up any lee-ivay, caused by pulling him up; nothing but his breaking lost him the heat. The instant Rattler broke, Hiram pulled up Dutchman, and he would have walked out had not the people in the stand called out to him to "come on." The last mile was performed in $2: 40$, and therheat in $7: 50$; had Dutchman kept up his stroke, the time of the heat would have been 7:48.

Third heat.-Dutchman went off with a fine stride ( 2 to 1 offered on him) and led about half-way down the backside, when Rattler caught him; at the half mile post they were locked, and thus they came to the stand (in 2:42); they made the turn in the same position, and nothing but repeated injunctions from the Judges to keep silent, prevented cheers from the stands that would have made the welkin ring; it was a beautiful sight; both were going, $\mathrm{D}$. under the spur, at a flight of speed, neck and neck; half-way down the backside, Rattler got almost clear, but Dutchman soon after lapped, and when they came to the stand $\left(2: 38 \frac{1}{2}\right)$ was half a length ahead. When they got into straight work on the backside, Rattler again collared him, and they went locked to near the half mile post, when Dutchman once more got in front, Wheelan having taken Rattler in hand for a brush up the straight side. This he made soon after; they were lapped as they swung round the turn, and the struggle that ensued revived recollections of Bascombe and Post-Boy. Profound silence was preserved on the stand, that neither horse might be excited or frightened into a break, and the interest of the scene was so great, that each of the spectators seemed to hold his breath as the horses neared the stand; it was a brush to the end, Dutchman coming out a throatlatch in front, caused by Hiram's giving up his pull, and giving him a push a $l a$ Chifney, which made him clearly the winner by a foot. The excited feelings of the crowd in the stand could no longer be repressed, but burst out in a tumultuous cheer that might have been heard three miles off. The last mile was done in 2:41 $\frac{1}{2}$, and the heat in 8:02. The Judges, after some discussion, pronounced it a dead heat.

Great odds were now offered on Dutchman, though he exhibited more "signals of distress" than Rattler; his trainer, however, informed us that he "hung out" these after taking his ordinary exercise; "it was a way he had," rather than any severe exertion whlch produced them. Both sweated freely, and came to the post a fourth time "about as good as new." The performance of the match commenced at 4 o'clock; it was six, and almost dark, when they started on the

Fourth heat.-Dutchman led off from the score to half-way down the backside, by three lengths; Rattler, however, lapped him at the half mile post, but Dutchman soon after drew out in front again; Hiram kept him at his work from this point to the finish, and Rattler never got up to him afterwards, that we could see, for it was now so dark, neither horse nor rider could be distinguished; Rattler subsequently fell off in his stride, and was finally beaten handily by six lengths, after as game and honest a race as we ever saw, and by far the best, in point of time, on record.

As a matter of reference, we give the time of each mile of this great performance: Saturday, Oct. 6, 1838. - Beacon Course, N. J. - Match, $\$ 1000$ a side, under the Saddle; weight $145 \mathrm{lbs}$. on each. Three mile heats.

Mr. E. M.'s hr.g. Dutchman.................. Hiram Woodruff. $2 \begin{array}{lllll}2 & 1 & 0 & 1\end{array}$ Messrs. V. \& M.'s b. g. Rattler..............Wm. Wheelan... 1 1st mile.....2:42 .1st mile....2:37..1st mile....2:42 ..1st mile ...2:53 $2 \mathrm{~d}$ mile....2:39 ..2d mile.....2:33..2d mile....2:381 ..2d mile ....2:43

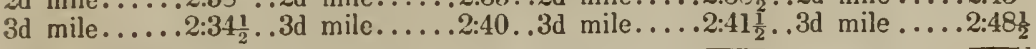
First heat . . . $\overline{7: 54 \frac{1}{2}}$. . Second heat . . $\overline{7: 50}$. . Third heat . .8:02 . Fourth heat . $\overline{8: 24 \frac{1}{2}}$ 
From the above it will be seen that the average time of the $2 \mathrm{~d}$ heat was $2: 36$ and two-thirds of a second per mile, and that of the four heats 2:40 and five-sixths of a second.

A great number of people were assembled to witness the match, and we were struck with the number of gentlemen in attendance. Every one seemed delighted, and as they will no doubt be induced to turn out on any similar occasion, the match cannot fail to exercise a salutary and beneficial influence upon our "Associations for the Improvement of Road Horses." In closing our account, we must not omit to speak of the admirable condition in which Woodruff and Wheelan brought their horses to the post; they jockeyed them, too, "like a knife," displaying the most consummate skill and judgment; a superior exhibition of horsemanship has not been seen here since the day PurDy stripped to throw a leg over the saddle of old Eclipse.

From the same paper we compile a report of the match against time which came off in the following year, 1839.

This match, for $\$ 1000$ a side, vs. time, was made on the 11 th July, on the evening of the day on which Dutchman beat $A w f u l$, three-mile heats, in harness, in a match of $\$ 5000$ vs. $\$ 2500$. The backers of time staked their money against Dutchman's trotting three miles in 7:49. He was allowed to perform the match in harness or under the saddle-to make two trials if necessary, and to have two hours intermission between them; the match was appointed to come off on the 1st day of August, provided the weather and track were unexceptionable; weight according to the rules of the course, or $145 \mathrm{lbs}$.

Fortunately the track was in pretty good order, though dusty; the weather all day had been excessively warm, but as the match came off late in the afternoon, the air was cooler and more bracing. After being walked for some time up and down in front of the stand in his match cart, with his hood and sheet on, he was taken out of harness and groomed; at a quarter to seven o'clock, was led to the judges' stand; and Hiray WoopruFr, coming out of the weighing-room, threw his leg over the saddle. A fine thorough-bred grey mare was also mounted at the same time by Isaac Woodruff to keep him company, and at a steady racing pace. The Judge and the two official Timers now selected a third, who having taken his place in their stand, the horses were called up. Dutchman was the favourite at odds.

The race.-At precisely 10 minutes to 7 o'clock the signal was given, and Dutchman went off with a long, clean stroke, that kept the mare up to three parts racing speed; Dutchman went to the quarter mile post in 40 seconds, and did the 1st half

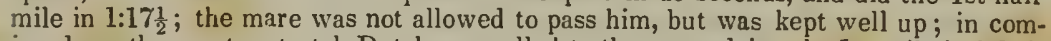
ing down the quarter-stretch Dutchnian pulled to the mare, doing the 1st mile in 2:34 $\frac{1}{2}$. At the stand Hiram told her rider to "go along," and as she locked him, old Dutchman, like a trump as he is, made a tremendous burst, doing the 1st quarter of the $2 \mathrm{~d}$ mile in 38 seconds, and the half mile in 1:15. Going down the backside Hiram bade Isaac "let the mare out," and so immense was Dutchman's rate for a few hundred yards, that it seemed as if the mare could not have passed had she tried. From the half mile post to the stand there was no faltering, and but little falling off in the pace, the mile being done in 2:28-the best time on record. Dutchman was kept at his work from the stand, and came to the quarter mile post on the $3 \mathrm{~d}$ mile in 39 seconds, and to the half mile post in 1:16, which showed a falling off but of a second from the time of the previous 1st quarter and 1st half nile. Hiram feeling confident now that he had won the match, and all bets against time, came home at an easier pace, finishing the third and last mile in 2:30, having performed the last two miles in 4:58, and the heat in 7:321 - being sixteen and a half seconds inside of his time.

Dutchman, in this match, has made the best time on record, at one, two, and three miles. He was in superb condition, and never broke up from the start to the end we need hardly add, he was jockeyed most admirably. We add, for convenience of
reference, a summary of this wonderful performance :-

Thursday, Aug. 1, 1839 - Match, $\$ 1000$ a side, Dutchman vs. Time-Three miles in $7: 49$, in harness or under the saddle; weight 145 lbs.

Won by Messrs. _ 's b. g. Dutchman.... ridden by Hiram Woodruff, as follows:-

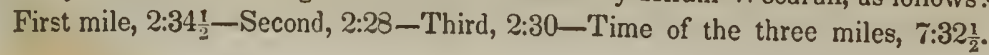


We will conclude the details of fast trotting with the performances of the extraordinary animals in the current year. They are, it will be seen, the best on record at the distance of two miles in harness.

\section{TROTTING ON THE BEACON COURSE.}

Saturday, May 7.-Purse $\$ 300$, of which $\$ 50$ to go to the second best horse in the race. Two-mile heats, in harness.

Hiram Woodruff's br. g. Ripton.....................W. Woodruff 1

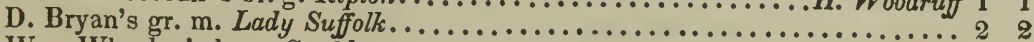

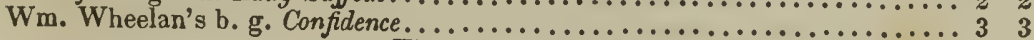

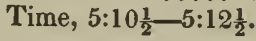

This was the great event. As they were driven up and down in front of the stand previous to starting, they all appeared to be in superb condition, and to have their action perfectly. Confidence had the call in betting. Ripton drew the track, Confidence second, and the Lady outside. After two or three false starts they got off well together, but on making the first turn Confidence broke. Ripton drew out two lengths ahead around the first turn, the Lady close up. Confidence soon got into his work again, made up his lost ground, and taking the inside down the back stretch, he soon drew out in front. They all swung into the straight side well together, coming up the quarter stretch at an immense pace, Confidence passing the Judges' stand a little ahead, Ripton close upon his wheel, making the first mile in 2:34. As they swung around the turn, into the back stretch in the second mile, Ripton gallantly challenged him down the backside at a flight of speed, neck and neck; at the half mile post Ripton drew out a length in front. Confidence subsequently fell off in his stride, but the Lady taking up the running the remaining part of the heat, made Ripton come home in $2: 36 \frac{1}{2}$.

Second Heat.-They all came up to the scratch for mischief. Confidence broke again on the turn, Ripton taking the lead for the first quarter, and then resigning it to the Lady, who kept it, passing the Judges' stand about a length ahead, Ripton well up, and Confidence considerably in the rear. As they entered the back stretch, Hiram made play for the lead, and the Lady having broke, he soon took it, closely followed by the mare. On making the turn for the straight side home, Ripton made a skip, and lost about two lengths; the mare came up and took the track on the inside, and got about a length ahead, but Hiram soon got Ripton into his work again, and caught the mare near the draw gate, passed her, and won the heat in $5: 12 \frac{1}{2}$ !

\section{CENTREVILLE (L. I.) TROTTING COURSE.}

Tuesday, May 10, 1842.-Purse $\$ 300$. Two-mile heats, in harness.

D. Bryan's gr. m. Lady Suffolk...................... Owner 1

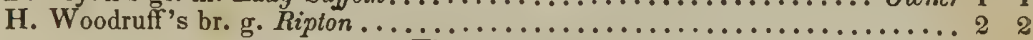

Time, 5:10-5:15.

Wonders will never cease-the grey mare has proved the better horse, and no mistake. No longer ago than last Saturday, Ripton popt it to the mare and Confidence over the Beacon Course in the quick time of $5: 10 \frac{1}{2}-5: 12 \frac{1}{2}$.

On the present occasion Ripton was the favourite at 100 to 70 . At the start they went off well together at the top of their rate, making play from the score; on reaching the first turn Ripton broke, and the mare took the lead by several lengths, going finely. Hiram made several efforts to make up his loss, but all was of no avail, the mare kept snugly to her work, and led throughout the heat, making the quick time of 5:10.

Second Heat.-They both cooled off well, and came up ripe for mischief. They got off well together at a flight of speed; Ripton broke, as usual, on the first turn, and lost several lengths, the mare taking the lead. Hiram got Ripton snugly to his work again, and caught the mare in the last quarter of the first mile, both coming down the 
straight side at a tremendous flight of speed; on making the turn Ripton broke, and lost about fifty yards, and before the mare got out Hiram made up his lost ground, lapt the mare coming down the quarter stretch, but was unable to win the heat, for Hiram had taken the kink out of his horse to make up the lost ground. Ripton was very restless, and broke several times during each heat.

SAME DAY._Sweepstakes of $\$ 50$ each. Mile heats, in harness.

Henry Jones' gr. g. Grey Eagle.............................. Jones 1

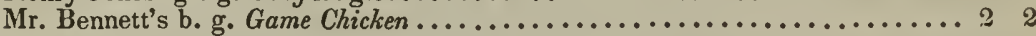

Time, 2:56-2:56.

Thursdar, May 12.-Purse $\$$ - Mile heats, best 3 in 5, under the saddle.

Hiram Woodruff's bl. g. Brandywine..................... Woodruff 11

Wm. Wheelan's gr. g. Fourth of July $\ldots \ldots \ldots \ldots \ldots \ldots \ldots \ldots \ldots \ldots \ldots \ldots \ldots$ dist.

N. Carroll's gr. m. Hantz ............................. dist.

Mr. Carll's b. m. Betsey Baker............................ dist.

Time, 2:36.

Fourth of July was the favourite at 2 to 1 at the start. Brandywine took the lead, and distanced the field the first heat.

Friday, May 13. - Match for $\$ 200$, to which the proprietor will add a purse of $\$ 50$. Two-mile heats, under the saddle.

Wm. Wheelan's ch. m. Brooklyn Maid..................... Owner 1

A. Conklin's b. g. Homer............................... 2

Time, 5.16-5:22.

Brooklyn Maid won both heats with ease.

SAME DAY._Purse \$_. Mile heats, best 3 in 5 , in harness.

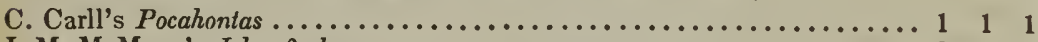

J. M. McMann's John Anderson.......................... $22_{2}$

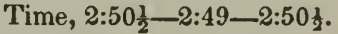

It is not a little singular, that within three weeks after the last mentioned performance, the same paper should have to report another trial between these horses, more extraordinary than either of the previous ones, and which restores to Ripton his supremacy.

\section{TROTTING ON THE HUNTING PARK COURSE.}

On Tuesday last a splendid trot came off over the Hunting Park Course, two-mile heats, between Ripton and Lady Suffolk, in which they made the best time on record at this distance, in harness. Hiram Woodruff on Ripton won the last heat by six inches only!

Hiram Woodruff's br. g. Ripton...................... Owner 121 David Bryan's gr. m. Lady Suffolk ............................. 2

Time, 5:07-5:15-5:17.

The following table has been made with care, and we should despair of commanding the attention of the reader to the general subject, who will not consider it worthy of insertion. It will be seen that while in this list of about thirty great performers, not one is over 16 hands, only two are under 15.

\section{HEIGHT OF TROT TING HORSES.}

The annexed list gives the height of many celebrated horses, estimated only, but by two most experienced men, one of whom had groomed or ridden almost every one named, and the other is an old amateur, who has the quickest eye for a horse, and who rode after most of those named, and has seen them all repeatedly. Of the thirty in the list, they differed only about eight, and of these only by one inch, save in a single case. In the eight cases we have given the estimate of the jockey who had ridden or driven them, and have great faith in its accuracy. 


\begin{tabular}{|c|c|c|c|c|c|}
\hline \multirow{2}{*}{$\frac{\text { Names. }}{\text { Dutchman } \ldots \ldots \ldots \ldots}$} & \multicolumn{2}{|c|}{ hands inchs. } & Names. & \multicolumn{2}{|c|}{ handsjinchs. } \\
\hline & 15 & $3 \frac{1}{2}$ & Cato. & 16 & - \\
\hline Lady Suffolk........... & 15 & $2^{2}$ & Edwin Forrest ... & 15 & - \\
\hline bus . & 16 & 1 & r & 15 & - \\
\hline & 15 & 1 & . & 15 & 3 \\
\hline e late & 15 & 2 & nce (latest) & 15 & 2 \\
\hline rewdriv & 16 & 一 & & 16 & - \\
\hline Do. & 15 & - & $\mathrm{Sa}$ & 15 & 3 \\
\hline D. D. Tompkin & 15 & - & Temple. & 15 & - \\
\hline La & 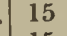 & 1 & gto & 16 & - \\
\hline Lady Vict & 15 & 2 & M & 14 & 2 \\
\hline Topgallant & 15 & 3 & icl & 15 & - \\
\hline & 4 & 2 & 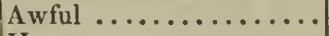 & 15 & 3 \\
\hline Whaleb & 15 & 3 & & 15 & 1 \\
\hline Shakspe & 15 & 2 & Paul Pry....... & 16 & - \\
\hline Betsy Baker. & 15 & 3 & & & \\
\hline
\end{tabular}

The acknowledged superiority of the performances of the American over English trotters, or to speak with more precise accuracy, extraordinary performances in a greater number of cascs, has been already attributed to superior skill in training, but on that we must not bc understood as laying so much stress, as upon superior jockeyship in this particular department; for the training of the trotting horse, so far as we can learn, requires no considerable skill, save as it is connected with the skill of the jockey who usually acts in both capacities. For training, the whole code is said to consist of three words-air, exercise, and food. The work given him in training is severe according to his constitution, and consists in walking him from twelve to twenty miles daily, and giving him "sharp work" three or four times a week. This "sharp work" is usually a distance of two miles, or sometimes threc. 'The horse is not put to his spced this entire distance, but taught to rouse himself at intervals, at the call of his jockey, who encourages him and brings out his utmost capacity by his voice, not less scarccly than by the usual persuasion of whip and spur. This fcature of trotting jockeyship is peculiar and not a little amusing. The jockey is continually talking or rather growling to his horse, and at times he bursts out into shouts and yclls, that would bc terrific if not so ludicrous. The object would appear to be twofold-first, to encourage his horse to the utmost possible exertion of his powers when called upon, and again, so to accustom him to this harsh shouting, that he may not break up when he hcars it from the opposing jockey-for it is deemed not unsportsmanlikc for one jockey to break up the pace of another's nag by thus actually frightening him. Many a victory has Hiram Woodruff won by thus rousing his own horse and breaking up his opponent's on the last quarter. 'These two-mile drives are not repcated as is usual in training the race-horse. Nor is the work of the trotter given at intervals so regular as in the case of the other, nor is he kept in such habitual quiet; the trainer consults his own convenience to a great degrec as to the time when he will give his nag cxercisc, and he never hesitates about taking him out and showing him at any hour.

In other respects too, the treatment of the trotting-horse differs from that of the more high-bred racer. Less dclicate in constitution and form, he is less delicately fed and groomed. Allowed to eat when and what they please, trotting horses are groomed with much the same carc as well-kept town coach-horses, or perhaps the English huntcr. In the two grand points of keeping them in robust health and giving them hard work cnough, the training of the trotter and the racer is identical. But for the trotter from six to eight wceks' training is deemed sufficient. We arc inclined to belicve tliat very much of the superiority of the American trotter and roadster is attributable to the skill of the jockey. Our mode of driving them differs essentially from the English, and though neither easy nor elegant, it succeeds admirably in developing the capabilities of a horsc at this pacc. The case already cited of Wheelan and the horse Alexander in England, is in point, and it is practically illustrated every 
day in New York, many English residents of which city are trotting amateurs; they one and all, after a little experience, adopt the Yankee mode of driving.

It has long been a question exciting much interest, whether twenty miles has been, or can be, trotted in one hour. There is no record of any such performance, al though there have been many attempts to do it. But men of great judgment and long experience, are so fully confident of the ability of our horses to go that distance at the required rate, that large odds would be laid that it can be done. The difficulty is to find an individıal who will at this day back him to an adequate amount; for it will readily occur that a horse that can accomplish the feat must be of great value, and the risk of injury to him is of course very considerable. It is believed that $\$ 10,000$ to $\$ 5,000$ would readily be laid that Dutchman can do it, and probably Americus would be backed at less odds likewise to do it. The trotting amateurs in New York profess to entertain no doubt at all upon the subject, and it is believed they have suffcient reason for the opinion.

Here, most patient reader, we close these our remarks, preliminary to what we may fairly denominate the great work on THE HoRse. It is for you to say if they have served either to instruct or amuse; but whatever may be your judgment as to this our Introduction, let it not affect your inclination to make yourself acquainted with the principal work, to which it is no more essential, than a handle to a pitcher, and that you know may long continue useful though the handle be broken off. This work on the Horse, however, is not a book to be read for entertainment, like a novel, and then to be thrown aside. It is one which every man who owns "the hair of a horse," should have at his elbow to be turned to for useful instruction, and to be consulted like your family physician in every case of need for the means of understanding the anatomy, mitigating the disorders, and prolonging the life, of the most interesting and useful of all domestic animals.

J. S. S. 


\section{THE HORSE,}

\section{HIS ANATOMY-WITH HIS DISEASES AND R E M E D I S.}

\section{CHA P TER I. \\ THE ZOOLOGICAL CLASSIFICATION OF THE HORSE.}

'I'Here are so many thousand species of living beings, some so much resembling each other, and others so strangely and altogether different, that it would have been impossible to have arranged them in any order, or to have given any description that could be understood, had not naturalists agreed on certain peculiarities of form which should characterise certain classes, and other lesser peculiarities again subdividing these classes.

The first division of animals is into vertebrated and invertebrated.

Vertebrated animals are those which have a cranium, or bony cavity containing the brain, and a succession of bones called the spine, and the divisions of it named vertebra, proceeding from the cranium, and containing a prolongation of the brain, denominated the spinal marrow.

Invertebrated animals are those which have no vertebræ.

The horse, then, belongs to the division vertebrated, because he has a cranium or skull, and a spine or range of vertebræ proceeding from it.

The vertebrated animals are exceedingly numerous. They include man, quadrupeds of all kinds, birds, fishes, and many reptiles. We naturally look for some subdivision, and a very simple line of distinction is soon presented. Certain of these vertebrated animals have mammæ or teats, with which the females suckle their young. The liuman female has two, the mare has two, the cow four, the bitch ten or twelve, and the sow more than twelve.

This class of vertebrated animals having mammæ or teats is called mammalia; and the horse belongs to the division vertebrata, and the class mammalia.

The class nammalia is still exceedingly large, and we must again subdivide it. It is stated (Library of Entertaining Knowledge, vol. i. p. 13, ) that "this class of quadrupeds, or mammiferous quadrupeds, admits of a division into two Tribes.

"I. Those whose extremities are divided into fingers or toes, scientifically called unguiculata, from the Latin word for nail; and II. Those whose extremities are hoofed, scientifically called ungulata, from the Latin word for honf.

"The extremities of the first are armed with claws or nails, which enable them to grasp, to climb, or to burrow. 'The extremities of the second tribe are employed merely to support and move the body."

The extremities of the horse are covered with a hoof by which the body is supported, and with which he cannot grasp anything; and therefore he belongs to the tribe angulata or hoofed.

But there is a great variety of hoofed animals. The elephant, the rhinoceros, the hippopotamus, the swine, the horse, the sheep, the deer, and many others, are ungulated or hoofed; they admit, however, of an easy division. Some of them masticate, or chew their food, and it is immediately received into the stomach and digested; but in others the food, previous to digestion, undergoes a very singular process. It is returned to the mouth to be remasticated, or chewed again. These are called rumi- 
nuntia, or ruminants, from the food being returned from one of the stomachs (for they have four), called the rumen or paunch, for the purpose of remastication.

The ungulata that do not ruminate are, somewhat improperly, called pachydermata, from the thickness of their skins. The horse does not ruminate, and therefore belongs to the order pachydermala.

The pachydermata, who have only one toe, belong to the family solipeda-singlefooted. Therefore, the horse ranks under the division vertebrata-the class mammalia - the tribe ungulata-the order pachydermata_and the family solipeda.

The solipeda consist of several species, as the horse, the ass, the mule, and the quagga.

First stands the Equus Caballus, or Common Horse.

Animals are likewise distinguished according to the number, description, and situation of their teeth. The horse has six incisors or cutting teeth in the front of each jaw ; and one canine tooth or tusk.

On each side, above and below-at some distance from the incisors, and behind the canines, and with some intervening space-are six molar teeth, or grinders; and these molar teeth have flat crowns, with ridges of enamel, and that enamel penetrating into the substance of the tooth.

The whole is thus represented by natural historians :-

HoRse.-Incisors $\frac{6}{6}$, canines $\frac{1-1}{1-1}$, molar $\frac{6-6}{6-6}$. Total, forty teeth.

To this short chapter we may properly append The Skeleton of the HoRse.

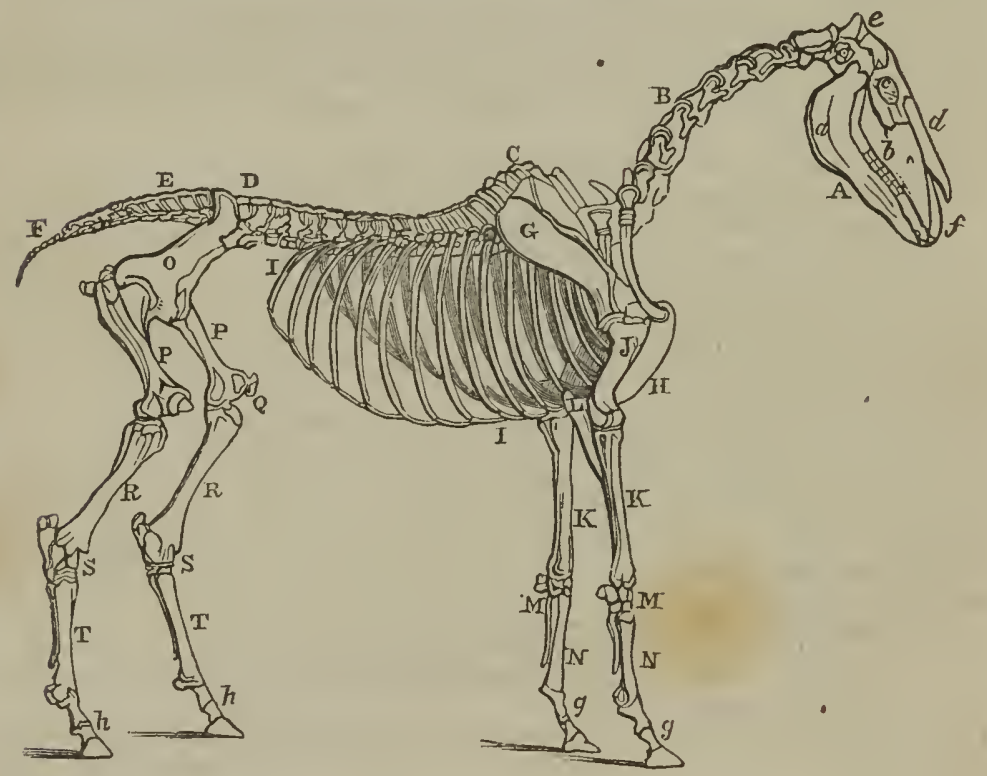

A The Head.

a The posterior maxillary or under jaw.

$b$ The superior maxillary or upper jaw. A little lower down than the letter is a foramen, through which pass the nerves and blood-vessels which chiefly supply the lower part of the face.

c The orbit, or cavity containing the eye.

$d$ The nasal bones, or bones of the nose.

$e$ The suture dividing the parietal bones below from the occipital bones above. 
$f$ The inferior maxillary bone, containing the upper incisor teeth.

$B$ The Seven Cervical Vertebra, or bones of the neck.

C The Eighteen Dorsal Vertebre, or bones of the back.

D The Six Lumbar Vertcbræ, or bones of the loins.

E The Five Sacral Vertebra, or bones of the hauncl.

$\mathrm{F}$ The Caudal Vertebræ, or bones of the tail, generally about fifteen.

G The Scapula, or shoulder-blade.

H The Sternum, or fore-part of the chest.

I The Costæ or ribs, seven or eight articulating with the sternum, and called the true ribs, and tcn or clcven united together by cartilage, called the false ribs.

$\mathrm{J}$ The Humcrus, or upper bone of the arm.

I The Radius, or upper bone of the arm.

L T'he Ulna, or elbow. The point of the elbow is called the Olecranon.

M The Carpus, or knee, consisting of seven bones.

$\mathrm{N}$ The metacarpal bones. 'The larger metacarpal or cannon or shank in front, and the smaller metacarpal or splint bone behind.

The fore pastern and foot, consisting of the Os Suffraginis, or the upper and larger pastern bone, with the sesamoid bones behind, articulating with the eannon and greater pastcrn; the Os Coronx, or lesser pastern; the Os Pedis, or coffin bone; and the Os Naviculare, or navicular, or shuttle-bone, not seen, and articulating with the smaller pastern and coffin bones.

$\hbar$ The corresponding bones of the hind-feet.

O The Haunch, consisting of three portions, the Ilium, the Ischium, and the Pubis.

$\mathrm{P}$ The Femur, or thigh.

Q The stille joint with the Patella.

$\mathrm{R}$ The 'Tibia, or proper leg bone-behind is a small bone called the fibula.

$\mathrm{S}$ The Tarsus, or hock, composed of six bones. The prominent part is the Os Calcis, or point of the hock.

T The Metatarsals of the hind leg.

\section{CHAPTER II.}

\section{THE SENSORIAL FUNCTION.}

BEAUTIFUL as is the horse, and identified so much with our pleasure and our profit, hc has been the object of almost universal regard; and there are few persons who do not pretend to be somewhat competent judges of his form, qualities, and worth. From the nobleman, with his numerous and valuable stud, to the meanest helper in the stable, therc is scarcely a man who would not be offended if he were thought altogether ignorant of horse-flesh. There is no subject on which he is so positive; there is no subject on which, generally speaking, he is so deficient; and there are few horscs, on some points of which these pretended and self-sufficient judges would not give a totally opposite opinion.

The truth is, that this supposed knowledge is rarely founded on principle, or the result of the slightest acquaintance with the actual structure of the animal-the form and connexion of parts on which strength, or fleetness, or stoutness, must necessarily depend.

In speaking of the structure of this animal, and the points which guide the opinion of rcal judges of him, we shall, as briefly and as simply as we are able, explain thosc fundamental principles on which his usefulness and bcauty must depend. We require one kind of horse for slow and heavy draught, and another for lighter and quicker work; one as a pleasant and safe roadster-another, with more speed and equal continuance, as a hunter-and another still is wanted for the race-course. What is the peculiarity of structure-what are the particular points that will fit cach for his proper business, and, to a ccrtain degree, unfit him for everything else? The farmer will require a horse of all-work, that can carry him to market and take him round his farm - on which he can occasionally ride for pleasure, and which he must sometimes degrade to the dung-cart or the harrow. What combination of powers will enable the animal to discharge most of these duties well, and all of them to a certain extent profitably? 
Much time spent among horses, an acquired love of them, and a little, sometimes possibly too dearly-bought experience, may give the agriculturist some insight into these matters. We will try whether we cannot assist him in this affair-whether we cannot explain to him the reason why certain points must be good, and why a horse without them must of necessity be good for nothing. Perhaps some useful rules may thus be more deeply impressed upon his memory, or some common but dangerous prejudices may be discarded, and a considerable degree of error, disappointment, and expense avoided.

If we treat of this at considerable length, let it be remembered that the horse is our noblest servant, and that, in describing the structure and economy of his frame, we are in a great measure describing that of other domestic quadrupeds, and shall hereafter have to speak only of points of difference required by the different services and uses for which they were destined. And further, let it be remembered, that it is only by being well acquainted with the structure and anatomy of the horse, that we can appreciate his shape and uses, or understand the different diseases to which he is liable. It is from the want of this that much of the mass of ignorance and prejudice which exists as to the diseases to which he is subject is to be referred.

The nervous system will first pass in review, for it is the moving power of the whole machine. It consists of the brain, to which all sensation is referred or carried, and from which all voluntary motion is derived - the spinal cord, a prolongation of the brain, and thus connected with sensation and voluntary motion, governing all the involuntary motions of the frame, and by power from which the heart beats, and the lungs heave, and the stomach digests ; and one other system of nerves-the ganglionic - presiding over the functions of secretion and of nutrition, and the repair and the welfare of the frame generally.

The following cut represents the head of the horse divided into the numerous bones of which it is composed, and the boundaries of each bone clearly marked by the sutures which connect it with those around.

The upper and broadest part is the cranium or skull in which the brain is contained, and by which it is protected. It is composed of nine bones : the two frontals, $a a$; the two parietals, $c c$; the two temporals, $d d$; the occipital $g$, and the ethmoid and sphenoid, which will be found delineated at figures $k$ and $l$, and will be better seen in the cut on page 72.

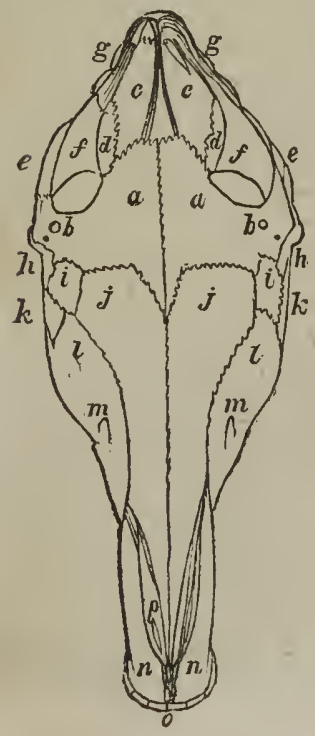

a $a$ The frontal bones, or bones of the forehead.

b 6 The supra-orbital foramina or holes above the orbit, through which the nerves and blood-vessels supplying the forehead pass out. The small hole beneath receives the vessels which dip into and supply the bone.

$c c$ The parietal bones, or walls of the skull.

$d d$ The temporal bones, or bones of the temples.

$e e$ The zygomatic, or yoke-shaped arch.

$f f$ The temporal fossa, or pit above the eye.

$g g$ The occipital bone, or bone of the hinder part of the head.

The orbits containing and defending the eye.

The lachrymal bones belonging to the conveyance of the tears from the eyes.

$j j$ The nasal bones, or bones of the nose.

$k k$ The malar, or cheek-bones.

$i l$ The superior maxillary, or that portion of the upper jaw containing the molar teeth or grinders.

$m m$ The infra-orbital foramen-a hole below the orbit, through which pass branches of nerves and blood-vessels to supply the lower part of the face.

$n n$ The inferior maxillary, the lower part of the upper jaw bone - a separate bone in quadrupeds, containing the incisor or cutting teeth, and the upper tushes at the point of union between the superior and inferior maxillaries.

- The upper incisor or cutting teeth.

$p \quad$ The openings into the nose, with the bones forming the palate. 
There is an evident intention in this division of the head into so many bones. When the fœtus - the unborn foal - first begins to have life, that which afterwards becomes bone, is a mere jelly-like substance. This is gradually changed into a harder material-cartilage ; and, before the birth of the animal, much of the cartilage is taken away by vessels called absorbents, and bone deposited in its stead. In flat bones, like those of the head, this deposit takes place in the centre, and rays or radiations of bone extend thence in every direction. Then, by having so many bones, there are so many centres of radiation; and, consequently, the formation of bone is carried on so much the more rapidly, and perfected at the time when the necessities of the animal require it. At the period of birth, however, this process is not completed, but the edges of the bones remain somewhat soft and pliant, and therefore, in parturition, they yield a little and overlap each other, and thus, by rendering the birth more easy, they save the mother much pain, and contribute to the safety of the foal.

The first of these bones, or the first pair of them, occupying the broad expanse of the forchead, are called the frontal bones, $a$ a. They are united together by a most curious and intricate dove-tailing, to defend from injury the brain which lies beneath the upper part of them. Lower down, and where the cavity of the nose is to be dcfended, their union is sufficient, but far less complicated. Thus, at first starting, there is an evident proof of design, an illustration of that adaptation to circumstances which will again and again present itself in the most interesting points of view. Peculiar strength of union is given where a most important organ is to be defended-the suture is there intricate and laboured. Where less important parts are covered, it is of a far simpler character.

Few things more clearly indicate the breed or blood of the horse than the form of the frontal bones. Who has not remarked the broad angular forehead of the blood horse, giving him a beautiful expression of intelligence and fire, and the face gradually tapering from the forehead to the muzzle, contrasted with the large face of the cart or dray-horse, and the forehead scarcely wider than the face?

At $f$, between the frontal bones, is the pit or cavity above the eye, and by the depth of which we form some idea of the age of the horse. There is placed at the back of the eye, a considerable quantity of fatty substance, on which it may revolve easily and without friction. In aged horses, and in diseases attended with general loss of condition, much of this disappears; the eye becomes sunken, and the pit above it deepens. It is said that some of the lower class of horse-dealers puncture the skin, and, with a tobacco pipe or small tube blow into the orifice, until the depression is almost filled up. This, with the aid of a bishopped tooth, may give a false appearance of youth, that will remain during some hours, and may deceive the unwary, but the trickery may easily be detected by pressing on the part.

These bones, however, are not solid, but a considerable portion of them is composed of two plates receding from each other, and leaving numerous and large vacuitics or cells. These vacuities are called the frontal sinuses. They are shown in the following cut. 


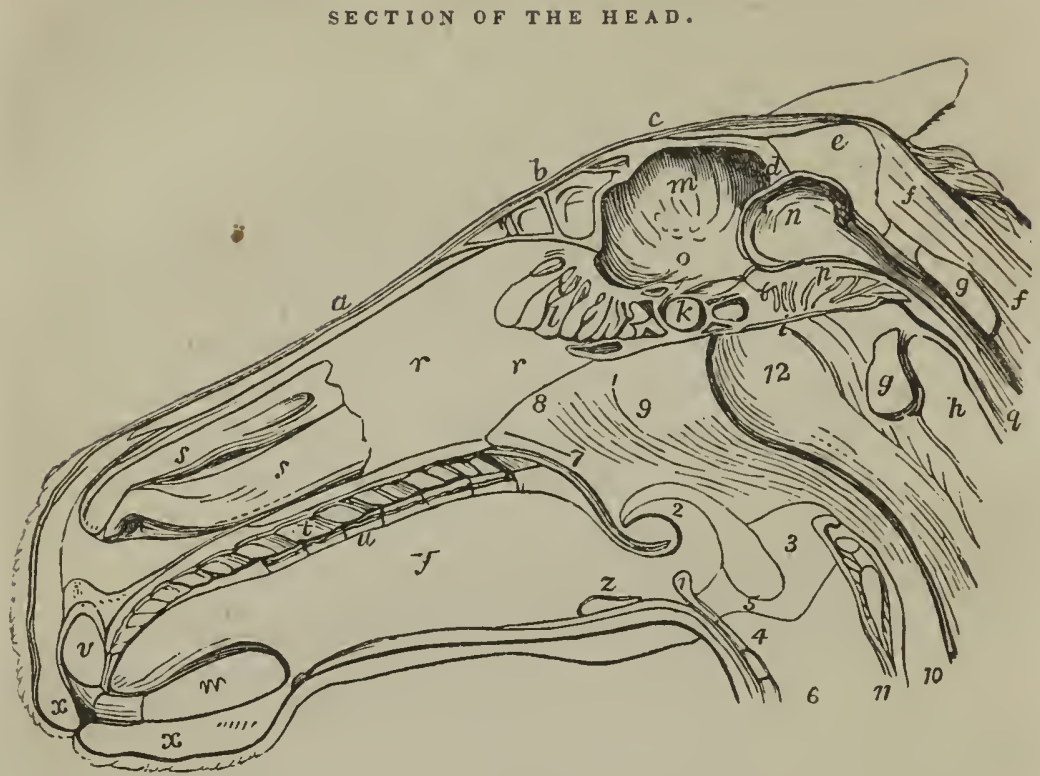

a The nasal bone, or bone of the nose.

$b$ The frontal bone. The cavities or cells beneath are called the frontal sinuses.

c The crest or ridge of the parietal bones.

$d$ The tentorium or bony separation between the cerebrum and cerebellum.

$e$ The occipital bone.

$f$ The ligament of the ncck, or pack-wax, by which the head is chiefly supported.

$g$ The atlas, sustaining or carrying : the first bone of the neck.

$h$ The dentata, tooth-like, or second bone of the neck.

$i$ The cuneiform, or wedge-shaped process, or base of the occipital bone. Between it and the other portion of the occipital bone $e$, lies the great foramen or aperture through which the prolongation of the brain-the spinal marrow-issues from the skull.

$k$ The sphenoid, wedge-like, bone, with its cavities.

$l$ The ethmoid, sieve-like, bone, with its cells.

$m$ The cerebrum, or brain, with the apncarance of its cortical and medullary substance.

$n$ The cerebellum, or little brain, with its beautiful arborescent appearance.

- A portion of the central medullary, marrow-like, substance of the brain, and the prolongation of it under the name of the crus cerebri, leg of the brain, and from which many of the nerves take their origin.

p The medulla oblongata-the prolongation of the brain after the medullary substance of the cerebrum and cerebellum have united, and forming the commencement of the spinal marrow. The columnar appearance of this portion of the brain is represented, and the origins of the respiratory nerves.

$g$ The spinal marrow extending through a canal in the centre of the bones of the neck, back, and loins, to the extremities of the tail, and from which the nerves of feeling and of motion, that supply every part of the frame except the head, arise.

$r$ The septum narium, or cartilaginous division between the nostrils.

$s$ The same cut off at the lower part, to show the spongy turbinated, turban-shaped, bones, $t$ The palate. filling the cavity of the nostril.

$u$ The molar teeth, or grinders.

$v$ The inferior maxillary bone, containing the incisor teeth or nippers. The canine tooth, or tush, is concealed by the tongue.

$w$ The posterior maxillary, or lower jaw with its incisors.

$x$ The lips.

y The tongue.

z A portion of the os hyoides, or bone of the tongue, like a Greek $u, v$. 
1 The thyroid, helmet-shaped, cartilage, inclosing and shielding the neighbouring parts.

2 'The epiglottis, or covering of the glottis, or aperturc of the wind-pipe.

3 'I'he arytcnoid, funnel-shaped, cartilages, having between them the aperture leading into the trachea or wind-pipe.

4 One of the chorda vocales, cords or ligaments concerned in the formation of the voice.

5 The sacculus laryngis, sac or ventricle of the larynx, or throat, to modulate the voice.

6 The trachea, or wind-pipe, with its different rings.

7 'The soft palate at the back of the mouth, so constructed as almost to prevent the possibility of vomiting.

8 The opening from the back part of the mouth into the nostril.

9 The cartilage covering the entrance into the eustachian tube, or conmunication between the inouth and internal part of the ear.

10 The asophagus, or gullet.

11 The cricoid, ring-like, cartilage, below and behind the thyroid.

12 Muscle of the neck, covered by the membrane of the back part of the mouth.

The sinus on the different sides of the forehead do not eommunicate with each other, but with other sinuses in the ethmoid, and spenoid, and upper jaw-bones, and also with the eavities of the nose on their respective sides. 'These sinuses afford a somewhat increased proteetion to the brain beneath; and by the eontinuous and slightly projecting line which they form, they give beauty to the forchead; but their prineipal use probably is, like the windings of the Freneh horn, to inerease the clearness and loudness of the neighing. It will be remarked that they are very irregular in depth, which at one place is an inch or more.

In the sheep, and oceasionally in the ox-rarcly in the horse-the larvæ of maggots produced by certain species of flies, crawl up the nose, lorlge themselves in these sinuses, and produce intolerable pain.

Veterinary surgeons have availed themselves of these sinuses, to detect the existence of glanders, that diseasc so infectious and so fatal. 'They may suspect that a horse respecting whieh they are eonsulted is glandered. It is of great eonsequence to be sure about this. 'The safety of the whole team may depend upon it. It may be a puzzling ease. There may be no uleeration of the nose within sight. The glands under the jaw may not be elose to and seemingly sticking to the bone, which is a common symptom, yet for a considcrable time there may have been a discharge from the nostril, and the horse is out of condition. On the other hand, some slight uleeration may be detected in the nostril, but the horse eats well, works well, and is in good plight. It is possible that from the closest examination of the animal, no horseinan or veterinary surgeon can give a decided opinion.

If, however, tne horse is glandered, there will probably be eonsiderable ulceration in the upper part of the eavity of the nose, and a eollection of matter there. 'To ascertaiu this the veterinary surgeon sometimes makes an opening into these sinuses. He may do it with perfect safety. On that part of the frontal bone, which lies between the eye and the pit above it, and above the inner corner of the eye, there is, on either side, a small depression or hole (see fig. $b$, cut, page 70 ), which may be easily felt in the living horse. It is what anatomists call a foramen-the supra-orbital foramen. It gives passage to the blood-vessels and nerves of the forehead.

Supposing a line to be drawn across the forehead, from one of these depressions to the other on that line, and about half an inch from the eentre of it-it matters not on which side-the frontal sinuses will be found an inch in depth (compare fig. $b, \mathrm{pp}$. 70 and 72 . There a perforation may be easily and safely made. A little way above, the brain would he endangered, and a little below this line, the eavity of the nose would be piereed. Some warm water may be injected into this hole, with a eommon squirt, and it will run out at the nose. If there is maller in the frontal sinuses, or any part of the eavity of the nose, below the indireet opening from the sinus into the nose under the superior turbinated tone, it will appear mixed with the water, and the owner may be assured that the horse is glandered; but if the water flows uneoloured, or simply inixed with blood or mueus, the horse may be considered as free from this disease. The thiek ereamy eonsistence of pus, its sinking in water, and its capability of being perfeetly, although not readily, mixed with water, will distinguish it sufficiently from the natural diseliarge from the nose, which is ropy, lighter than water, and, when mixed with it, still preserves a kind of stringiness. 
It was formerly the practice to inject various liquids into the nostrils in this way, for the cure of glanders. Some of them were harmless enough, but others were cruelly acrid. This practice is now, however, abandoned by the scientific practitioner; for it would only be a portion of the cells of the head, and a portion only of the cavity of the nose, and that least likely to be diseased, with which the fluid could be brought into contact.

As the frontal sinuses are lined by a continuation of the membrane of the nose, they will sympathise with many of the affections of that cavity; but the membranc of the sinuses is susceptible of an inflammation peculiar to itself. The disease is rare, and the cause of it has not been fully ascertaincd. It is oftenest metastasis of inflammation of the brain, - shifting of inflammation from the brain to the membrane of the sinus, or communication of inflammation from the brain by proximity of situation.

The attack is usually sudden-the horse is dull, lethargic, and almost as comatosc as in stomach-staggers. The first thing that excites suspicion of the actual charactcr of thc disease, is heat in the situation of the frontal sinus, when the hand is placed on the forehead. The lethargy soon passes over, and a state of the highest excitation succeeds. The conjunctiva and the membrane of the nose are injected-the pulse is quick and hard-the horse becomes violent and dangerous; he kicks, plunges, and, half conscious and half unconscious, he endeavours to do all the mischief that he can. The disease is now evidently combined with, or is essentially, inflammation of the brain. It is distinguished from madness by this half-consciousness, and also by his being more disposed to bite than he is in pure phrenitis.

The disease is usually fatal. It rarely lasts more than eight-and-forty hours.

The post-mortem appearances are, great infiammation of the brain, with frequent eftusions of blood. 'The sinuses are sometimes filled with coagulated blood. The brain seems to be affected just in proportion to the violence which the animal has exhibited.

The treatment should consist of copious bleeding, application of ice to the head, blistering the head, and physic. The trephine is scarcely admissible, from the danger of producing greater irritation.

Sometimes the disease assumes a more chronic form. There is ulceration of the membrane, but not cerebral affection. A purulent discharge then appears from the nose, evidently not of a glanderous character, and none of the submaxillary glands are enlarged. In both the acute and chronic form, it is usually confined to one sinus. We are indebted to the late Mr. Jolın Field for the principal knowledge that we have of this disease.* The inner plate of the frontal bone covers a considerable portion of the anterior part of the brain, and it is studded with depressions corresponding with irregularities on the surface of the brain.

Immediately above the frontal, and extending from the frontal to the poll, are the parietal bones. They are two, united together by a suture when the animal is young, but that suture soon becoming obliterated. They have the occipital, g, p. 72, above, the frontals, $a$, below, and the temporals, $d d$, on either side. They are of a closer and harder texture than the frontals, because they are more exposed to injury, and more concerned in defending the brain.

A very small portion only of the parietals is naked, and that is composed of bone even harder than the other part, and with an additional layer of bone rising in the form of a crest or ridge externally. Every other part of these bones is covered by a thick mass of muscle, the temporal muscle, which is principally concerned in chewing the food, but which likewise, by its yielding resistance, speedily and effectually breaks the force of the most violent blow. A wool-pack hung oxer the wall of a fortress, when the enemy is battering to effect a breach, renders the heaviest artillery almost harmless. So the yielding resistance of the temporal muscle affords a sure defence to the brain, however sudden or violent may be the blow which falls on the parietal. These benevolent provisions will not be disregarded by the reflecting mind.

On the side of the head, and under the parietals $(d d, p . ; 2)$ are the temporal bones, 
one on each side, $f f$. These again are divided into two parts, or consist of two distinct bones; the petrous portion, so called from its great or stony hardness, and containing the wonderful mechanism of the ear, and the squamous portion from the appearance of its union with the parietal, overlapping it like a great scale.

From the latter there projects a portion of bone, $e$, which unites with the frontal, and forms a strong arch-the zygomatic-distinctly to be felt at the side of the head immediately above the eye. This arch is designed to protect the upper part of the lower jaw, the motion of which may very plainly be seen beneath it when the horse is feeding. It is very strong, and it ought to be, for if it were depressed or forced inward, the horse would starve. There is one species of violence which causes this arch to require no common strength; and that is, the brutal manner in which the collar is often forced over the head.

At the base of the arch is an important cavity not visible in the cut, receiving into it, and forming a joint with, the head of the lower jaw-it will be presently described.

Having reached the base of the temporal bone, it is found united to the parietal, not by a simple suture, as the lower part of the frontals, or the bones of the nose (see fig. $a$ and $j$, p. 70 ), nor by a dove-tailed suture, as the upper part of the frontals (see the same cut), but it is spread over the parietal in the form of a large scale, and hence, as before observed, called the squamous portion of the temporal bone. In fact, there are two plates of bone instead of one. Was there design in this? Yes, evidently so. In the first place, to increase the strength of the base of the zygomatic arch. This extensive union between the temporal and parietal bones, resembles the buttress or mass of masonry attached to the base of every arch, in order to counteract its lateral pressure. 'The concussion, likewise, which might be communicated by a blow on the top of the arch, is thus spread over a large surface, and consequently weakened and rendered comparatively harmless; and that surface is composed of the union of two bones of dissimilar construction. The hard stony structure of the parietal is very different from the tougher material of the temporal; and thus, as a finger acts on a sounding-glass, the vibration communicated to the temporal is at once stopped, and the brain receives no injury.

There is another proof of admirable design. Where is this squamous portion of the temporal bone situated? On the side of the head. And what is the figure of the cranium or skull, and principally that part of it which contains the cerebrum or brain? It is an elliptical or oval arch (sec fig. $m, n, 0, \mathrm{p} .72$ ). If pressure is made on the crown of that arch-if a blow is received on the suture between the parietals sufficient to cause the elastic materials of which the skull is composed to yield-the seat of danger and injury is at the side. If a man rcceives a violent blow on the crown or back part of the head, the fracture, if thcre is any, is generally about the temple, and the extravasation of blood is oftenest found there. The following figure will explain this :-

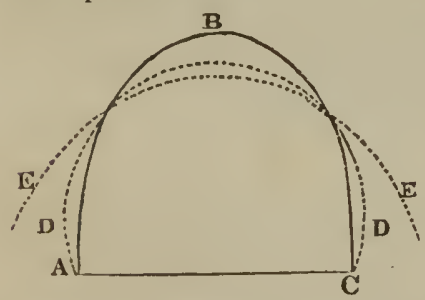

Let the line A B C represent an elliptical arch, composed of elastic materials. Some force shall be applied at B, sufficient to cause it to yield. We cannot compress it into smaller compass; but just in proportion as it yields at $\mathbf{B}$, will it spur or bulge out at $\mathrm{D}$, and give way sometimes as represented at $\mathbf{E}$. In a dome the weight of the materials constantly acting may be considered as representing the force applied at $\mathrm{B}$; and so great is the lateral pressure, or tendency to bulge out (vide $\mathbf{D}$ and $\mathbf{E}$ ), that it is necessary either to dove-tail the materials into one another, or to pass strong iron chains round them. For want of sufficient attention to this, "the dome of St. Sophia, in Constantinople, built in the time of the Emperor Justinian, fell three times during its erection; and the dome of the cathedral of Florence stood unfinished an hundred and twenty years, for want of an architect."

Nature, in the construction of the horse's head, has taken away the pressure, or removed the probability of injury, by giving an additional layer of bone, or a mass of muscle, where alone there was danger, and has dove-tailed all the materials. Farther 
than this, in order to make assuranee doubly sure, she has placed this effectual girder at the base, in the overlapping of the squamous portion of the temporal bone.

Above the parictals, and separated from them by a suturc (fig. $g, p .70$, and fig. $e$, p. 72 ), is the occipital bone. Superiorly it covers and protects the smaller portion of the brain, the ccrebellum; and as it there constitutes the summit or crest of the head, and is particularly exposed to danger, and not protected by muscles, it is interesting to see what thickness it assumes. The head of the horse does not, like that of the human being, ride upright on the neek, with all its weight supported by the spinal eolumn, and the only offiee of the museles of the neek being to move the head forward, or backward, or horizontally on its pivot; but it hangs in a slanting position from the extremity of the neck, and the neck itself projeets a eonsiderable distance from the chest, and thus the whole weight of the head and neck is suspended from the ehest, and require very great power in order to support them. In addition to the simple weight of the head and ncck, the latter projeeting from the eliest, and the head hanging from the extremity of the neek, act with enormous meehanical force, and inerease more than a hundred-fold the power necessary to support them.

The head and neck of the horse, and partieularly of some horses of a coarse brced, are of no little bulk and weight. It will hereafter be shown in what breeds and for what purposes a light or heavy head and neck are advantageous; hut it may be safely affirmed, that, projecting so far from the chest, and being eonsequently at so great a distance from the fulerum or support, the lightest head will act or bear upon the joint between the last bone of the neck and the first rib with a force equal to many thousand pounds.

How is this weight to be supported? Is muscular power equal to the task ? The muscles of the animal frame can act for a certain time with extraordinary force; but as the exertion of this power is attended with the consumption of vital energy, the period soon arrives when their aetion is remitted or altogether suspended. A provision, however, is made for the purpose, simple and complete.

From the back of the occipital bone (fig. $f, \mathrm{p} .72$ ), and immediately below the erest, proeeeds a rourd eord of considerable bulk, and eomposed of a ligamentous substanee, which reaehes down and is seeurely attached to the spines of the vertebræ, or bones of the baek; and by this ligament-the ligamentum colli, ligament of the neck, eommonly called the pack-wax-the head is supported.

There are, however, some almirable centrivanees eonneeted with this ligament. As it proceeds from the head, it is in the form of a round cord. It passes over the atlas, or first bone of the neck, without touching it, and then, attaching itself strongly to the seeond bone, principally supports the head by its union with this bone. The mechanical disadvantage is incrcased; but the head is turned more freely on the first and seeond bones. The prineipal stress is on the dentata or sccond bone, so much so, that, in poll-evil, this ligament may be divided without serious inconvenience to the horsc. It then suddenly sinks deeper, and communicates with all the other vertebræ. Each of these communications becomes a separate point of support, and as they approach nearer to the base, the mechanieal disadvantage, or the force with whieh the weight of the head and neck presses and arts, is materially lessence.

The head, then, whilc the animal is in a state of rest, is supported by this ligament, without any aid from muscular energy.

There is, however, something yet wanting. The head must not be always elevated. The animal has his food to seek. In a state of nature this food lies principally on the ground, and the head must be lowered to enable the horse to get at it. How is this effected? This ligament, as it has been called, because it resembles in appearanee the other ligaments of the body, possesses a property which they have not, and which they must not have, or they would be useless. No well-knit joint could exist if it had this property. It is elastic. It will yield to a force impressed upon it, and will resume its natural dimensions when that foree is removed. It sustains perfectly the weight of the head. 'That portion of tenacity or strength is given to it which will not give way to the simple weight of the head, but which will yield to a very little ardditional weight. Its resisting power is so admirably adjusted to that which it has to sustain, that when certain muscles, whose action is to depress or lower the head, begin to act, and add their power to the previous weight it had to bear, the ligament 
stretches, and when the horse is browsing it is full two inches longer than when the head is erect.

When the animal has satisfied himself, these depressing muscles cease to act, and other muscles, which are designed to assist in raising the head, begin to exert themselves; and by their aid - but more by the inherent elasticity of the ligament - the head is once more elevated, and remains so without the slightest exertion of muscular power. This is one of the many applications of the principle of elasticity which will be discovered and admired in the construction of the animal frame.

The ligament of the neck is inserted into the centre of the back part of the occipital bone, and immediately below the vertex or trest of that bone; and therefore the bone is so thick at this part (see fig. e, p. 72).

Many large and powerful muscles are necessary to turn the head in various directions, as well as to assist in raising it when depressed. The occipital bone, as will be seen in the cut, presents a spine running down the centre, $\mathrm{B}$, and a large roughened surface for the attachment of these muscles, $\mathbf{C}$ C.

A

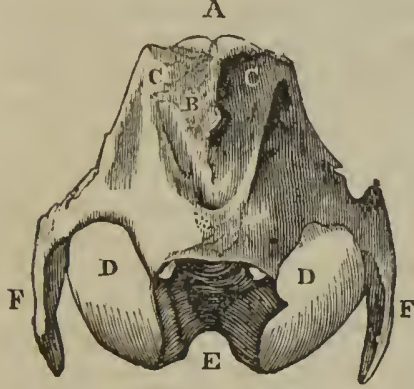

Lower down, and still at the back of the occipital bone, are two rounded protuberances $\mathrm{D} \mathrm{D}$, by which the head is connected with the atlus, or upper or first vertebra, or bone of the neck; and these are called the condyloid, cup-shaped, processes of the occipital bone. All the motions of the head are partly, and many of them wholly, performed by this joint.

Between them is a large hole, the foramen magntım, or great aperture, $\mathbf{E}$, through which the continuation of the brain, termed the spinal cord or marrow, passes out of the skull.

As an additional contrivance to support the enormous weight of the head, are two other projections of the occipital bone, peculiar to animals whose heads are set on in a slanting direction, and into which powerful muscles are inserted. 'They are called the coracoid, beak-like, processes or prolongations, F F, of the occipital bone.

Running forward, and forming outwardly a part of the base, and inwardly a portion of the floor of the skull, is what, from its wedge-like shape, is called the cuneiform process of the occipital bone (fig. $i, p$. 72 ). It is thick, strong, and solid, and placed at the bottom of the skull, not only to be a proper foundation for, and to give additional strength to, the arch on either side, but speedily to stop all vibration and concussion.

At the base of the skull, and anterior to or below the occipital, lies the sphenoid, wedge-like bonc (fig. $k$, p. 72). Its body, likewise called the cuneiform or wedgeshaped process, is a continuation of the same process of the occipital, and, like it, is thick and solid, and for the same important purpose. This bone branches out into four irregular bodies or plates, two of which are called the wings, and two running to the palate, the legs. 'They could not be represented in the cut, and there is nothing important belonging to them, so far as this work is concerned. Internally (fig. $k$ ), the sphenoid forms a portion of the cavity of the skull.

Of the ethmoid, sieve-like, bone, little can be seen outwardly. A small portion is found in the back part of the orbit, and in the cavity of the cranium; but the most important part of it is that which is composed of a great number of thin plates, forming numerous cavities or cells (fig. $l, p .72$ ), lined with the membrane of the nose, and entering into its cavity. The upper portion is called the cribriform or sieve-shaped plate, from its being perforated by a multitude of little holes, through which the nerve connected with smelling passes and spreads over the nose.

Altogether these bones form a cavity of an irregular oval shape, but the tentorium penetrating into it, gives it the appearance of being divided into two $(d, \mathrm{p} .72)$.

The cavity of the skull may be said to be arched all round. The builder knows the strength which is connected with the form of an arch. If properly constructed, it is equal to a solid mass of masonry. 'The arch of the horse's skull has not much 7* 
weight to support, but it is exposed to many injuries from the brutality of those by whom he sliould be protected, and from accidental causes.

The roof of the skull is composed of two plates of bone: the outer one hard and tough, and the different parts dove-tailed together, so as not to be easily fractured; the inner plate being clastic. 13y the union of these two substances of different construction, the vibration is damped or destroyed, so far as safety requires.

On raising any part of the skull of the horse, the dense and strong membrane which is at once the lining of the cranium and the covering of the brain - the dura mater-presents itself. It is united to the membranes below by numerous little cords or prolongations of its substance, conveying blood and communicating strength to the parts beneath. Between this membrane, common to the cranium and the brain, and the proper investing tunic of that organ, is found that delicate gossamers' web, appropriately called the arachnoid - the spider's membrane - and which is seen in other animals, designed either to secrete the fluid which is interposed, for the purpose of obviating injurious concussion, or, perhaps, to prevent the hrain from readily sympathising with any inflammatory action produced by injury of the skull.

Beneath is the proper investing membrane of the brain-the pia mater-which not only covers the external surface of the brain, but penetrates into every depression, lines every ventricle, and clothes every irregularity and part and portion of the brain.

We now arrive at the brain itself. The brain of the horse corresponds with the cavity in which it is placed $(m, p .72)$. It is a flattened oval. It is divided into two parts, one much larger than the other - the cerebrum or brain, and the cerebellum or little brain $(n, \mathrm{p}, 72)$. In the human being the cercbrum is above the cerebellum, in the quadruped it is below; and yet in both they retain the same relative situation. The cerebellum is nearer to the foramen through which the brain passes out of the sliull $(n, p .72)$, and the continuation of the cerebrum passes under the cerebcllum $(p, p .72)$, in order to arrive at this foramen. In the human head this foramen is at the base of the skull; but in the quadruped, in whom the head is placed slanting, it is necessarily elevated.

He who for the first time cramines the brain of the horse will be struck with its comparative diminutive size. The human being is not, generally speaking, more than one-half or one-third of the size and weight of the horse; yet the brain of the biped is twice as large and as heavy as that of the quadruped. If it had been the brain of the ox that had been here exposed, instead of that of the horse, it would no: have been of half the luulk of that of the horse. If the dog had been the subject, it would have been very considerably larger, comparing the general bulk of each animal. This is singular. The human brain largest in comparative bulk; then the brain of the dog, the horse, the ox. 'Thus would they be classed in the scale of intelligence.

If the brain is more closely examined, it will be found that there is none of the roundness and the broadness of that in the human being; it is comparatively tame and flat. There is some irregularity of surface, some small projections and depressions; but they, too, are comparatively diminutive and inexpressive. Were the brain of the beaver, of the hare, or the rabbit, or of almost any bird, substituted for it, there would be no convolutions or irregularities at all.

These irregularities are not so bold and so deep in the ox as in the horse, nor in the horse as in the dog. We do not know enough of the functions of any part of the brain to associate these convolutions with any particular powers of mind, or good or bad propensities, although some persons, who are wise above that which is written, have pretended to do so. It would occupy too great a portion of this volume to enter into these questions; but there are some discases to which the horse is subject, and a very useful operation - the division of some of the nerves for certain purposes, and which could not be understood without a previous slight account of this important organ.

When the brain is cut, it is found to be composed of two substances very unlike in appearance ( $m$, p. 72$)$; onc, principally on the outside, grey, or ash-coloured, and therefore called the cortical (bark-like) from its situation, and cineritious (ashen) from its colour; and the other, lying deeper in the brain, and from its pulpy nature called the medullary substance. Although placed in apposition with each other, and seem. 
ingly mingling, they never rum into the same mass, or change by degrees into one another, but are essentially distinet in construetion as well as in function.

'I'le medullary portion is conneeted with the nervous system. The nerves are prolongations of it, and are concerned in the diseharge of all the offices of life. They give motion and energy to the limbs, the heart, the lungs, the stomach, and every part connected with life. They are the medium through which sensation is eonveyed; and they supply the mind with materials to think and work upon.

'I'he cinerilious part has a different appearanee, and is differently constituted. Some have supposed, and with much appearance of truth, that it is the residenee of the mind-receiving the impressions that are eonveyed to the brain by the sensitive nerves, and directing the operation and action of those which give motion to the limbs. In accordance with this, it happens that, where superior intelligence is found, the cineritious portion prevails, and where little beside brute strength and animal appetite exist, the medullary portion is enlarged. 'There is, comparing bulk with bulk, less of the medullary substance in the horse than in the ox, and in the dog than in the horse. 'The additional bulk of brain is composed of eineritious matter; and how different is the eharacter of these animals !-the sluggisl, stupid ox, and the intelligent horse; the silly sheep, and the intellectual, companionable dog!

In a work like this, it would be somewhat out of place to enter deeply into any metiphysical speeulation; but the connexion between the cincritious part of the brain and the intellectual principle, and that between the medullary portion and the mere animal principle, do seem highly probable. The latter is the medium through whieh the impression is conveyed, or the motion is effected; the former is the substance to which that impression is referred-where it is received, registered, and compared, and by which the operation of the motor nerves is influenced and governed.

"The cortical substanee is small in the quadruped; for in their wild state brutes have no coneern and no idea beyond their faod and reproduetion; and in their domesticated state they are destined to be the servants of man. 'The aeuteness of their senses, and the preponderanee of animal power, qualify them for this purpose; but were proportionate intellcetual eapacity added to this-were they made conscious of their strength, they would burst their bonds, and man would, in his turn, be the victim and the slave. The cortieal part is found in each in the proportion in which it would seem to be needed for our purposes, in order that intelligence should be added to animal power. Almost every mental faculty, and almost every virtue, too, may be traced in the brute. The difierence is in degree, and not in kind. The one being improved by eircumstanees, and the other contaminated, the quadruped is decidedly the superior.

From the medullary substance-as already stated - proeeed certain cords or prolongations, termed nerves, by which the animal is enabled to reeeive impressions from surrounding objects, and to connect himself with them; and also to possess many pleasurable or painful sensations. One of them is spread over the membrane of the nose, and gives the sense of smell ; another expands on the back of the eye, and the faeulty of sight is gained; and a thirl goes to the internal structure of the ear, and the animal is conseious of sound. Other nerves, proeeeding to different parts, give the faeulty of motion, while an equally important one bestows the power of feeling:

One division of nerves, $(h, p, 72)$ springing from a prolongation of the brain, and yet within the skull, wanders to different parts of the frame, for important purposes conneeted with respiration or breathing. 'The aet of breathing is essential to life, and were it to eease, the animal would die. These are nerves of involuntary motion; so that, whether he is awake or asleep, conseious of it or not, the lungs heave and life is supported. Isastly, from the spinal eord $q-a$ farther prolongation of the brain, and running through a cavity in the bones of the neek, baek, and loins, and extending to the very tip of the tail-other nerves are given off at eertain intervals. The cut at the. top of the following page delineates a pair of them. The spinal eord $a$, is combined of six distinet columns or rods, running through its whole length-three on either side. The two upper eolumns - the portion of spinal marrow represented in our cut, is supposed to be placed with its inner or lower surface toward us - proeeed from those traeks of the brain devoted to sensation. Numerous distinet fibres spring abruptly from the column, and whieh eolleet together, and, passing through a little ganglion or cnlargement, $d$-an enlargement of a nervous eord is called a ganglion-become a 


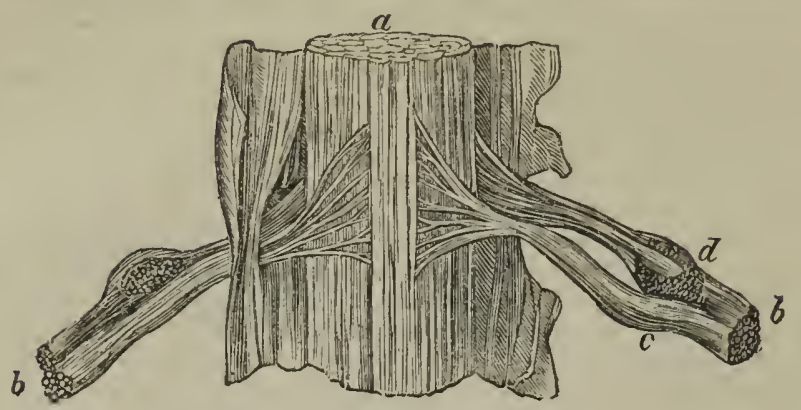

nerve of sensation. From the lower or inner side, - a prolongation of the track devoted to moiion,-proceed other fibres, which also collect gradually together, and form a nervous cord, $c$, giving the power of motion. Beyond the ganglion the two unite, and form a perfect spinal ncrve, $b$, possessing the power both of sensation and motion; and the fibres of the two columns proceed to their destination, enveloped in the same sheath, and apparently one nerve." Each portion, however, continues to be wrapped in its own membrane. They arc united, yet distinct; they constitute one nerve, yet neither their substance nor their office is confounded. Our cut, closely examined, will give at $b$ some idea of the manner in which these distinct fibres are continued; - each covered by its own membrane, but all enveloped in a common envelope.

All these nerves are organs of sensation and motion alone; but there are others whose origin seems to be outside of and below the brain. These are the sympathetic, so called from their union and sympathy with all the others, and identified with life itself. They proceed from a small ganglion or enlargement in the upper part of the ncck, or from a collection of little ganglia in the abdomen. They go to the heart, and it beats, and to the stomach, and it digests. They form a nct-work round each bloodvessel, and the current flows on. They surround the very minutest vessels, and the frame is nourished and built up. They are destitute of sensation, and they are perfectly beyond the control of the will.

The reader, we trust, will now comprehend this wonderful, yet simple machinery, and be able, by and by, to refer to it the explanation of several diseases, and particularly of the operation to which we have referred.

Two of the senses have their residence in the cavity of the cranium-those of hearing and sight.

They who know anything of the horse, pay much attention to the size, setting on, and motion of the ear. Ears rather small than large-placed not too far apart-erect and quick in motion, indicate both breeding and spirit; and if a horse is frequently in the labit of carrying one ear forward, and the other backward, and especially if he does so on a journcy, he will generally possess both spirit and continuance. The stretching of the ears in contrary directions shows that he is attentive to everything that is taking placc around him, and, while he is doing this, he cannot be much fatigued, or likely soon to become so. It has been remarked that few horses sleep without pointing one ear forward and the other backward, in order that they may receive notice of the approach of objects in every direction.*

The ear of the horse is one of the most beautiful parts about him, and by few things is the temper more surely indicated than by its motion. The ear is more intelligible even than the eye, and a person accustomed to the horse, and an observer of him, can

* "When horses or mules march in company at night, those in front direct their ears for. wards; those in the rear direct them backward; and those in the centre turn them laterally or across; the whole troop seeming thus to be actuated by one feeling, which watches the general safety." - Arnott's Elemen/s of Physic, vol. i., p. 478. 
tell by the expressive motion of that organ, almost all that he thinks or means. It is a common saying, that when a horse lays his ears flat back upon his neck, and keeps them so, he most assuredly is meditating mischief, and the stander-by should beware of his heels or his teeth. In play, the ears will be laid back, but not so decidedly, or so long. A quick change in their position, and more particularly the expression of the eye at the time, will distinguish between playfulness and vice.

The external ear is formed by a cartilage of an oval or cone-like sliape, flexible, yet firm, and terminating in a point. It has, directed towards the side, yet somewhat pointing forward, a large opening extending from the top to the bottom. The intention of this is to collect the sound, and convey it to the interior part of the ear.

'The hearing of the horse is remarkably acute. A thousand vibrations of the air, too slight to make any impression on the human ear, are readily perceived by him. It is well known to every hunting-man, that the cry of the hounds will be recognised by the horse, and his cars will be erect, and he will be all spirit and impatience, a considerable time before the rider is conscious of the least sound. Need anything more be said to expose the absurdity of cropping?

This custom of cutting the ears of the horse originated, to its shame, in Great Britain, and for many years was a practice cruel to the animal, depriving him of much of his beauty; and so obstinately pursued, that at length the deformity became in some hereditary, and a breed of horses born without ears was produced. Fortunately for this too-often abused animal, cropping is not now the fashion. Some thoughtitless or unfeeling young men endeavoured, a little while ago, again to introduce it, but the voice of reason and humanity prevailed.**

'This eartilage, the conch or shell, is attached to the liead by ligaments, and sustained by muscles, on which its action depends. It rests upon another cartilage, round without, and irregular within, called the annular, ring-like, cartilage, and conducting to the interior of the ear; and it is likewise supported and moved by a third small cartilage, placed at the fore part of the base of the conch, and into which several muscles are inscrted.

The ear is covered by skin thinner than in most other parts of the body, and altogether destitute of fat, in order that it may not be too bulky and heary, and may be nore easily moved. Under the skin lining the inside of the cartilage are numerous glands that secrete or throw out a scaly white greasy matter, which may be rubbed off with the finger and is destined to supple this part of the ear and to keep it soft and smooth. Below this are other glands which pour out a peculiar, sticky, bitter fluid-the wax-probably displeasing to insects, and therefore detcring them from crawling down the ear and annoying the animal, or by its stickiness arresting their procress.

The internal part of the conch is covered with long hair which stands across the passage in evcry direction. This likewise is to protect the ear from insects, that can with difficulty penetrate through this thick defence. The cold air is likewise prevented from reaching the interior of the ear, and the sound is moderated, not arrested -penetrating readily but not violently-and not striking injuriously on the membrane covering the drum of the ear. Can these purposes be accomplished, when it is the custom of so many carters and grooms to cut out the hair of the ear so closely and industriously as they do? The groom who singes it to the root with a candle must either be very ignorant or very brutal. It can scarecly be accomplished without singeing the ear as well as the hair. Many a troublesome sore is occasioned by this; and many a liorse, that was perfectly quict before, rendered difficult to handle or to halter, and even disposed to be otherwisc vicious, from a recollection of the pain which he suffered during the absurd and barbarous operation.

* Professor Grognier, in his excellent work, "Précis d'un Cours d'Hygiène Vétérinaire," speaking of this abominable custom, says, "And thus the English completely destroy or disfigure two organs which embellish the head of the most beautiful of all animals, and which, by their various motions, indicate the thoughts that are passing through his mind-the passions which agitate him, and, especially, the designs which he may be meditating, and which it is often of great importance to learn, in order to guard against the danger which may be at hand." 
The sound collected by the outer ear, passes through the lower or annular ringshaped, cartilage, and through irregularities which, while they break and modify it, convey it on to another canal, partly cartilaginous and partly bony, conducting iminediately to the internal mechanism of the ear. This canal or passage, is called the external auditory passage, and at the base of it is placed, stretching across it, and closing it, a thick and elastic membrane, membrana tympani, called the membrane of the drum. This membrane is supplied with numerous fibres, from the fifth pair, or sensitive nerve of the head, for it is necessary that it should possess extreme sensibility.

Between this membrane and a smaller one almost opposite, leading to the still interior part of the ear, and on which the nerve of hearing is expanded, are four little bones, united to these membranes, and to each other. Their office is to convey, more perfectly than it could be done through the mere air of the cavity, the vibrations that have reached the membrana tympani.

These bones are highly elastic; and covered by a cartilaginous substance, elastic also in the greatest degree, by means of which the force of the vibration is much increased.

It is conveyed to a strangely irregular cavity, filled with an aqueous fluid, and the substance or pulp of the portio mollis or soft portion of the seventh pair of nerves, the auditory nerve, expands on the membrane that lines the walls of this cavity.

Sound is propagated far more intensely through water than through air; and therefore it is that an aqueous fluid occupies those chambers of the ear on the walls of which the auditory nerve is expanded. By this contrivance, and by others, which we have not space now to narrate, the sense of hearing is fully equal to every possible want of the animal.

The Eye is a most important organ, and comes next under consideration, as inclosed in the bones of the skull. The eye of the horse should be large, somewhat but not too prominent, and the eyelid fine and thin. If the eye is sunk in the head, and apparently little-for there is actually a very trifling difference in the size of the eye in animals of the same species and bulk, and that seeming difference arises from the larger or smaller opening between the lids - and the lid is thick, and especially if there is any puckering towards the inner corner of the lids, that eye either is diseased, or has lately been subject to inflammation; and, particularly, if one eye is smaller than the other, it has at no great distance of time, been inflamed.

The eye of the horse enables us with tolerable accuracy to guess at his temper. If much of the white is seen, the buyer should pause ere he completes his bargain; because, although it may, yet very rarely, happen that the cornea or transparent part is unnaturally small, and therefore an unusual portion of the white of the eye is seen, experience has shown that this display of white is dangerous. The mischievous horse is slyly on the look out for opportunities to do mischief, and the frequent backward direction of the eye, when the white is most perceptible, is only to give surer effect to the blow which he is about to aim.

A cursory description of the eye, and the uses of its different parts, must be given.

The eyes are placed at the side of the head, hut the direction of the conoid cavity which they occupy, and of the sheath hy which they are surrounded within the orbit, gives them a prevailing direction forwards, so that the animal has a very extended field of vision. We must not assert that the eye of the horse commands a whole sphere of vision; but it cannot be denied that his eyes are placed more forward than those of cattle, sheep, or swine. He requires an extensive field of vision to warn him of the approach of his enemies in his wild state, and a direction of the orbits considerably forward, in order to enable him to pursue with safety the headlong course to which we sometimes urge him.

The eye-ball is placed in the anterior and most capacious part of the orbit, nearer to the frontal than the temporal side, with a degree of prominence varying with different individuals, and the will of the animal. It is protected by a bony socket beneath and on the inside, but is partially exposed on the roof and on the outside. It is, however, covered and secured by thick and powerful muscles - by a mass of adipose matter which is distributed to various parts of the orbit, upon which the eye 
may be readily moved without friction, and by a sheath of considerable density and firmness, and especially where it is most needed, on the external and superior portions.

The adipose matter exists in a considerable quantity in the orbit of the eye of the horse, and enables that organ readily to revolve by the slightest contraction of the muscles. By the absorption of this fatty matter in sickness or old age, the eye is not only to a certain degree sunk in the orbit, but the roof of the orbit posterior to the frontal bone, being deprived of its support, is considerably depressed. Our work shall not be disgraced by any farther reference to the rascally contrivance by which this indication of age is in some degree removed.

In front the eye is supported and covered by the lids, which closing rapidly, protect it from many an injury that threatens - supply it with that moisture which is necessary to preserve its transparency-in the momentary act of closing give a certain and sufficient respite to a delicate organ, which would otherwise be fatigued and worn out by the constant glare of day-defend it when the eye labours under inflammation from the stimulus of light, - and, gradually drooping, permit the animal to enjoy that repose which nature requires.

Extending round both lids, and, it may be almost said, having neither origin nor insertion, is a muscle called the orbicularis, or circular muscle. Its office is to close the lids in the act of winking or otherwise, but only while the animal is awake. When he sleeps, this is effected by another and very ingenious mechanism. The natural state of the eyelids is that of being closed; and they are kept open by the energy of the muscles whose office it is to raise the upper lid. As sleep steals upon the animal, these muscles cease to act, and the lids close by the inherent elasticity of the membrane of which they are composed.

The skin of the lid is, like that of the ear, exceedingly fine, in order to prevent unnecessary weight and pressure on such a part, and to give more easy and extensive motion. The lids close accurately when drawn over the eye, and this is effected by a little strip of cartilage at the edge of each of them, which may be easily felt with the finger, and preserves them in a hoop-like form, and adapts them closely to the eye and to each other. The lower cartilage, however, does not present, towards the inner corner of the eye, the whole of its flat surface to the upper, but it evidently slopes inward, and only the outer edge of the under lid touches the upper. By this means, a little gutter is formed, through which the superfluous moisture of the eye flows to the inner corner, where there is a canal to convey it away. By this contrivance it neither accumulates in the eye, nor unpleasantly runs down the cheek.

Nlong the edges of the lids are placed numerous little hollows, which can be plainly distinguished even in the living horse by slightly turning down the lid. These are the openings into numerous small cells containing a thick and unctuous fluid, by means of which the eyes are more accurately closed, and the edges of the lids defended from the acrimony of the tears.

The horse has no eyebrows, and the eyelashes are very peculiarly arranged. The rows of hair are longest and most numerous on the upper lid, and especially towards the outer or temporal corner, because the light comes from above; and, as the animal stands, particularly when he is grazing, and from the lateral situation of his eyes, the greater portion of the light, and the attacks of insects, and the rolling down of inoisture, would chiefly be from the outside or temples. Towards the inner corner of the upper lid there is little or no eyelash, because there is no probable langer or nuisance in that direction. Only a small quantity of light can enter from below, and therefore the lashes are thin and short; but as, in the act of grazing, insects may more readily climb up and be troublesome to the eye, towards the inner angle, there the principal or only hair is found on the lower lid. These apparently trifling circumstances will not be overlooked by the careful observer.

'They who are unacquainted with the absurdities of stable management, or who have not carefully examined the abuses that may exist in their own establishments, can scarcely believe the foolish and cruel practices of some carters and grooms. When the groom is anxious that his horse should be as trim and neat all over as art can make lim, the very eye-lashes are generally sacrificed. Wliat has the poor animal suffered, when, travelling in the noon of day, the full blaze of the sun has 
fallen upon his eycs; and how many accidents have probably happened from his being dazzled by the light, which have been attributed to other eauses !

If the horse has no eyebrow, there are several hairs or bristles scattered on the upper eyelid, and there is a projeeting fold of the lid which discharges nearly the same office. It is more eonspicuous in old horses than in young ones. Some horsemen do not like to see it, and associate the idea of it with weakness or disease of the eyc. This is perfectly erroneous. It is a provision of nature to accomplish a certain purpose, and has nothing to do either with health or disease.

On the lower lid is a useful provision to warn the horse of the near approach of any object that might incommode or injure him, in the form of long projecting liairs or bristles, which are plenteously embued with nervous influence, so that the slightest touch should put the animal on his guard. We would request our readers to touch very slightly the extremity of one of these hairs. They will be surprised to observe the sudden convulsive twitching of the lid, rendering the attack of the insect absolutely impossible. 'The grooms, lowever, who cut away the eye-lashes, do not spare these useful feelers.

The eye is exposed to the action of the atmospheric air, and the process of evaporation, destructive of its transparency, is continually going on. The eye of the horse, or the visible part of the eye, is, likewise, more prominent and larger than in the human being, and the animal is often subjeet to extreme annoyance from dust and insects, while he has no hands or other guard to defend himself from the torture whieh they oecasion. What is the provision of nature against this? Under, and a little within, the outer corner of the upper lid, is an irregular body, the lacrymal gland, comparatively larger than in the human being, secreting an aqueous fluid, which, slowly issuing from the gland, or occasionally pressed out of it by the act of winking, flows over the eye, supplies it with moisture, and cleanses it from all impurities. Human ingenuity could not have selected a situation from which the fluid could be conveyed over the eye with more advantage for this purpose.

When this fluid is secreted in an undue quantity, and flows over the eye, it is called tears. An inereased flow of tears is produced by anything that irritates the eye, and, therefore, a constant accompaniment and symptom of inflammation. A horse with any degree of weeping should be regarded with much suspieion. In the human bcing an unusual secretion of tears is often caused by bodily pain, and emotions of the mind; and so it is occasionally in the horse. We have seen it repeatedly under aeute pain or brutal usage. John Lawrence, spealing of the cruelty exercised by some dealers in what they call "firing" a horse before he is led out for sale, in order to rouse every spark of mettle, says, "more than fifty years have passed away, and I have before my eyes a poor mare stone blind, exquisitely shaped, and showing all the marks of high blood, whom I saw unmereifully cut with the whip a quarter of an hour before the sale, to bring her to the use of her stiffened limbs, while the tcars were trickling down her checks."

Having passed over the eye, the fluid is conveyed by the littlc eanal to which we have alluded, formed by the sloping of the under lid, towards the corner of the eye; and there are two little orifices that conduct it to a small reservoir within, and at the upper part of the lacrymal bone, (fig. $i$, p. 70 ). A little protuberance of a black or pied colour, called the caruncle, placed in the very comer of the eye, and to be seen without opening the lids, is situated between these orifiees, and guides the fluid into them. From this reservoir the tears are eonveyed by a long canal, the lacrymal duct, partly bony, and partly membranous, to the lower part of the nose. A little within the nostril, and on the division between the nostrils, is seen the lower opening of this canal; the situation of which should be carefully observed, and its real use bome in mind, for not only horsemen, but even some careless veterinary surgeons, have mistaken it for a glanderous ulcer, and have condemned a useful and valuable animal. It is found just before the skin of the muzzle terminates, and the more delicate memhrane of the nostril commences. The opening of the canal is placed thus low beeause the membrane of the nose is exceedingly delicate, and would be irritated and made sore by the frequent or constant running down of the tears.

There is, howcver, something yet wanting. We have a provision for supplying the eye with requisite moisture, and for washing from off the transparent part of it 
insects or dust that may annoy the animal. What becomes of these impurities when thus washed off? Are they carried by the tears to the corner of the eye, and so pass down this duct, and irritate and obstruct it; or do they accumulate at the inner angle of the eye? There is a beautiful contrivance for disposing of them as fast as they acccumulate. Concealed within the inner corner of the eye, or only the margin of it, black or pied, visible, is a triangular-shaped cartilage, the haw, with its broad part forwards. It is concave within, exactly to suit the globe of the eye; it is convex without, accurately to adapt itself to the membrane lining the lid; and the base of it is reduced to a thin or almost sharp edge. At the will of the animal this is suddenly protruded from its hiding-place. It passes rapidly over the eye, and shovels up every nuisance mixed with the tears, and then, being speedily drawn back, the dust or insect is wiped away as the cartilage again passes under the corner of the eye.

How is this managed? The cartilage has no muscle attached to it; and the limbs and the different parts of the body, when put into motion by the influence of the will, are moved invariably by muscles. The mechanism, however, is simple and effectual. There is a considerable mass of fatty matter at the back of the eye, in order that this organ may be easily moved; and this fat is particularly accumulated about the inner corner of the eye, and beneath, and at the point of this cartilage. The eye of the horse has likewise very strong muscles attached to it, and one, peculiar to quadrupeds, of extraordinary power, by whose aid, if the animal has not hands to ward off a danger that threatens, he is at least enabled to draw the eye back almost out of the reach of that danger.

Dust, or gravel, or insects, may have entered the eye, and annoy the horse. This muscle suddenly acts: the eye is forcibly drawn back, and presses upon the fatty matter. 'That may be displaced, but cannot be reduced into less compass. It is forced violently towards the inner corner of the eye, and it drives before it the haw ; and the haw, having likewise some fat about its point, and being placed between the eye and an exceedingly smooth and polished bone, and being pressed upon by the eye as it is violently drawn back, shoots out with the rapidity of lightning, and, guided by the eyelids, projects over the eye, and thus carries off the offending matter.

In what way shall we draw the haw back again without muscular action? Another principle is called into play, of which mention has already been made, and of which we shall have much to say,-elasticity. It is that principle by which a body yields to a certain force impressed upon it, and returns to its former state as soon as that force is removed. It is that by which the ligament of the neck (p. 75), while it supports the head, enables the horse to graze-by which the heart expands after closing on and propelling forward the blood in its ventricles and the artery contracts on the blood that has distended it, and many of the most important functions of life are influenced or governed. This muscle ceases to act, and the eye resumes its natural situation in the orbit. There is room for the fatty matter to return to its place, and it immediately returns by the elasticity of the membrane by which it is covered, and draws after it this cartilage with which it is connected, and whose return is as rapid as was the projection.

The old farriers strangely misunderstood the nature and design of the haw, and many at the present day do not seem to be much better informed. When, from sympathy with other parts of the eye labouring under inflammation, and becoming itself inflamed and increased in bulk, and the neighbouring parts likewise thickened, it is either forced out of its place, or voluntarily protruded to defend the eye from the action of light and cannot return, they mistake it for some injurious excrescence or tumour, and proceed to cut it out. The "haw in the eye" is a disease well known to the majority of grooms, and this sad remedy for it is deemed the only cure. It is a barbarous practice, and if they were compelled to walk half a dozen miles in a thick dust, without being permitted to wipe or to cleanse the eye, they would feel the torture to which they doom this noble animal. A little patience having been exercised, and a few cooling applications made to the eye while the inflammation lasted, and afterwards some mild astringent ones, and other proper means being employed, the tumour would have disappeared, the haw would have returned to its place, and the animal would have discharged the duties required of him without inconvenience to 
himself, instead of the agony to which an unguarded and unprotected eye must now expose nim.

The loss of blood occasioned by the excision of the haw may frequently relieve the inflammation of the eye; and the evident amendment which follows induces these wise men to believe that they have performed an excellent operation; but the same loss of blood by scarification of the overloaded vessels of the conjunctiva would be equally beneficial, and the animal would not be deprived of an instrument of admirable use to him.

The eye is of a globular figure, yct not a perfect globe. It is rather composed of parts of two globes; the half of one of them smaller and transparent in front, and of the other larger and the coat of it opaque, behind. We shall most conveniently begin with the coats of the eye.

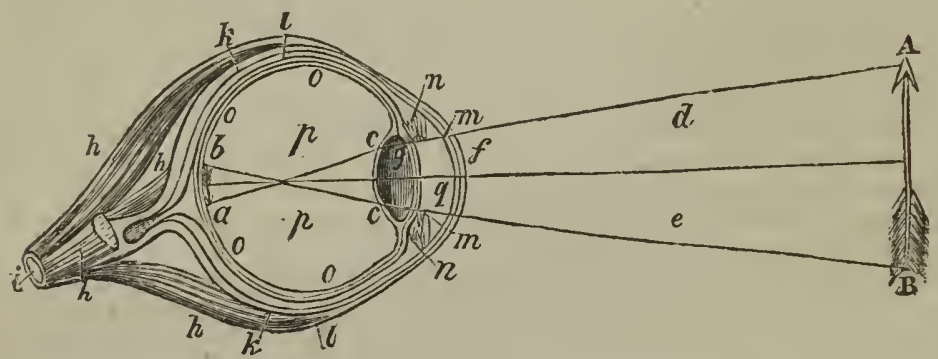

A B a supposed object viewed by the animal, and an inverted image of which, $a, b$, is thrown on the retina at the back of the eye.

cc The points where the rays, having passed thc cornes and lcns, converge by the refractive power of the lens.

$d e$ The rays proceeding from the extremities of the object to the eye.

$f e$ The cornea, or horny and transparent part of the eye, covered by the conjunctive, uniting different parts together.

g The crystalline (crystal or glassy) lens, behind the pupil, and in front of the vitreous humour.

$h h$ Muscles of the eye.

$i$ The optic nerve, or nerve of sight.

$k$ The sclerotica (hard firm coat) covering the whole of the eye except the portion occupied by the cornea, and being a seeming prolongation of the covering of the optic nerve.

$l$ The choroides (receptacle or covering), or choroid coat, covered with a black secretion or paint.

$m m$ The iris or rainbow-coloured circular membrane under the cornea, in front of the eye, and on which the colour of the eye depends. The duplicature behind is the uvea, from being coloured like a grape. The opening in the centre is the pupil.

$n n$ The ciliary (hair-like) processes.

$o$ The retina, or net-like expansion of the optic nerve, spread over the whole of the choroides as far as the lens.

$p$ The vitreous (glass-like) humour filling the whole of the cavity of the eye behind the lens.

$q$ The aqueous (water-like) humour filling the space between the cornea and the lens.

The conjunctiva, $f$, is that membrane which lines the lids, and covers the fore part of the eye. It spreads over all that we can see or feel of the eye, and even its transparent part. It is itself transparent, and transmits the colour of the parts beneath. It is very susceptible of inflammation, during which the lining of the lids will become intensely red, and the white of the eye will be first streaked with red vessels, and then covered with a complete mesh of them, and the cornea will become cloudy and opaque. It is the seat of various diseases, and, particularly, in it commences that sad inflammation of the horse's eye which bids defiance to the veterinary surgeon's skill and almost invariably terminates in blindness.

1 The examination of the conjunctiva, by turning down the lid, will enable us to form an accurate judgment of the degree of inflammation which exists in the eye.

Covering the back part of the eye, and indeed four-fifths of the globe of it, is the 
sclerolica, $k$. It is an exceedingly strong membrane, composed of fibres interweaving with each other, and almost defying the possibility of separation. An organ so delicate and so important as the eye requires secure protection.

It is a highly elastic membrane. It is necessary that it should be so, when it is considered that the eye is surrounded by several and very powerful muscles, which must temporarily, and even for the purposes of vision, alter its form. The elasticity of the sclerotica is usefully exhibited by its causing the globe of the eye to resume its former and natural shape, as soon as the action of the muscle ceases.

The sclerotica has very few blood-vessels-is scarcely sensible-and its diseases, except when it participates in general disturbance or disorganisation, are rarely brought under our notice.

'The cornea is, or we should wish it to be, the only visible part of the horse's eye, for the exhibition of much white around it is a sure symptom of wickedness. The cornea fills up the vacuity which is left by the sclerotica in the fore part of the eye, and, although closely united to the sclerotica, may be separated from it, and will drop out like a watch-glass. It is not round, but wider from side to side than from top to the bottom; and the curve rather broader towards the inner than the outer corner of the eye, so that the near eye may be known from the off one after it is taken from the head.

The convexity or projection of the cornea is a point of considerable importance. The prominence of the eye certainly adds much to the beauty of the animal, but we shall sec presently, when we consider the eye as the organ of sight, that by being too prominent the rays of light may be rendered too convergent, and the vision indistinct; or, if the cornea is small and flat, the rays may not be convergent enough, and perfect vision destroycd. In either case the horse may unpleasantly start, or suddenly and dangcrously turn round. An eye ncither too prominent nor too flat will be nearest to perfection.

It should be perfectly transparent. Any cloudiness or opacity is the consequence of discasc. It is an exceedingly firm and dense membrane, and can scarcely be pierced by the sharpest instrument. The cornea is composed of many different plates, laid over one anot' i.x tile causc of its transparency, and the evaporation of which, after death, produces the leaden or glazed appearance of the eye. When it appears to be opaque, it is not often, and never at first, that the cornca has undergone uny change.

There is nothing that deserves attention from the purchaser of a horse more than the perfect transparency of the cornea over the whole of its surface. The eye should he examined for this purpose, both in front, and with the face of the examiner close to the cheek of the horse, under and behind the cye. The latter method of looking through the cornea is the most satisfactory, so far as the transparency of that part of the eye is concerned. During this examination the horse should not be in the open air, but in the stable standing in the doorway and a little within the door. If any small, faint, whitish lines appear to cross the cornea, or spread over any part of it, they arc assuredly the remains of previous inflammation; or, although the centre and bulk of the cornea should be perfectly clear, yet if around the edge of it, where it unites with the sclerotica, there should be a narrow ring or circle of haziness, the conclusion is equally true, but the inflammation occurred at a more distant period. Whether however the inflammation has lately existed, or several weeks or months havc elapsed since it was subdued, it is too likely to recur.

There is one caution to be added. The cornea in its natural state is not only a bcautiful transparent structure, but it reflects, even in proportion to its transparency, many of the rays which fall upon it; and if there is a white object immediately before the eye, as a light waistcoat, or much display of a white neckcloth, the reflection may puzzlc an expcrienced observer, and has misled many a careless one. The coat should be buttoned up, and the white cravat carefully concealed.

Within the sclerotica, and connected with it by innumerable minute fibres and vessels, is the choroid coat, $l$. It is a very delicate membranc, and extcnds over the whole of the internal part of the eye, from the optic nerve to the cornea. It secretes a dark-coloured substance or paint, by which it is covered; the intention of which, like the inside of our telescopes and microscopes, is probably to absorb any wander- 
ing rays of light which might dazzle and confuse. The black paint, pigmentum nigrum, seems perfectly to discharge this function in the human eye. It is placed immediately under the retina or expansion of the optic nerve. The rays of light fall on the retina, and penetrating its delicate substance, are immediately absorbed or destroyed by the black covering of the choroides underneath. For the perfection of many of his best pleasures, and particularly of his intellectual powers, man wants the vivid impression which will be caused by the admission of the rays of light into a perfectly dark chamber; and when the light of the sun begins to fail, his superior intelligence has enabled him to discover various methods of substituting an artificial day, after the natural one has closed. Other animals, without this power of kindling another, although inferior light, have far more to do with the night than we have. Many of them sleep through the glare of day, and awake and are busy during the period of darkness. The ox occupies some hours of the night in grazing; the sheep does so when not folded in his pen; and the horse, worked during the day for our convenience and profit, has often little more than the period of night allotted to him for nourishment and repose. Then it is necessary that, by some peculiar and adequate contrivance, these hours of comparative or total darkness to us should be partially yet sufficiently illuminated for them; and therefore in the horse the dark brown or black coat of the choroides does not extend over the whole of the internal part of the eye, or rather it is not found on any part on which the rays proceeding from the objects could fall. It does not occupy the smallest portion of what may be called the field of vision; but, in its place a bright variegated green is spread, and more over the upper part than the lower, because the animal's food, and the objects which it is of consequence for him to notice, are usually below the level of his head-thus, by suffering the impression to remain longer on the retina, or by some portion of light reflected from this variegated bed on which the retina reposes, or in some other inexplicable but efficient way, enabling the animal, even in comparative darkriess, to possess the power of vision equal to his wants.

The reader may see in the dusk, or even when duskiness is fast yielding to utter darkness, the beautiful sea-green reflection from the eye of the horse. It is that lucid variegated carpet of which we are now speaking.

Who is unaware that in the fading glimmering of the evening, and even in the darker shades of night, his horse can see surrounding objects much better than his rider; and who, resigning himself to the guidance of that sagacious and faithful animal, has not been carried in safety to his journey's end, when he would otherwise have been utterly bewildered?

If the reader has not examined this beautiful pigment in the eye of the horse, he should take the earliest opportunity of doing so. He will have a beautiful illustration of the care which that Being who gave all things life has taken that each shall be fitted for his situation. The horse has not the intelligence of man, and may not want for any purpose of pleasure or improvement the vivid picture of surrounding objects which the retina of the human being presents. A thousand minute but exquisite beauties would be lost upon him. If, therefore, his sense of vision may not be so strong during the day, it is made up to him by the increased power of vision in the night.

Perfectly white and cream-coloured horses have a peculiar appearance of the eyes. The pupil is red instead of black. There is no black paint or brilliant carpet. It is the choroid coat itself which we see in them, and not its covering; and the red appearance is caused by the numerous blood-vessels which are found on every part of that coat.

When we have to treat of other domestic animals, we shall see how this carpet is varied in colour to suit the situation and necessity of each. In the ox it is of a dark green. He has not many enemies to fear, or much difficulty in searching for nourishment, and the colour of the eye is adapted to his food. In the cat and all his varieties, it is yellow. We have heard of the eyes of the lion appearing like two flaming torches in the night. There are few of our readers who have not seen the same singular glare from the eyes of the domestic cat. In the wolf, and likewise in the dog, who, in his wild state, prowls chiefly at night, it is grey. In the poor unjustlypersecuted badger, who scarcely dares to crawl forth at night, although sheltered by 
the thickest darkness, it is white; and the ferret, who is destined to hunt his prey through all its winding retreats, and in what would be to us absolute darkness, has no paint on the choroides.

Tracing the choroides towards the fore part of the eye, we perceive that it is reflected from the side to the edge of the lens, $n$, and has the appearance of several plaits or folds. They are actually foldings of the membrane. It is not diminished in size, but it lias less space to cover, and there must be duplicatures or plaits. They are usefully employed in the place in which we find them. They prevent the passage of any rays of light on the outside of the lens, and which, proceeding forward in various directions, and uncondensed by the power of the lens, would render vision confused or imperiect. These folds of the choroides are called the ciliary processes.

Within the cornea, and occupying the fore part of the eye, is the aqueous humour, $p$, so termed from its resemblance to pure water. It is that by which the cornea is preserved in its proiuberant and rounded form. It extends to the crystalline lens $q$, and therefore a portion of it, although a very small one, is behind the iris $(m, \mathrm{p} .86)$. Floating in this fluid is a membrane, with an oblong aperture, called the Iris. It is that which gives colour to the eye. The human eye is said to be black, or hazel, or blue, according to the colour of this membrane or curtain; and it is denominated the iris, or rainbow, from its beautiful, intermingling hues. The colour varies little in the horse, except that it always bears some analogy to that of the skin. We rarely see it lighter than a hazel, or darker than a brown. Horses perfectly white, or creamcoloured, have the iris white and the pupil red. When horses of other colours, and that are usually pied, have a white iris and a black pupil, they are said to be walleyed. Vulgar opinion has decided that a wall-eyed horse is never subject to blindness, but this is altogether erroneous. There is no difference of structure that can produce this exemption; but the wall-eyed horse, from this singular and unpleasant appearance, and his frequent want of breeding, may not be so much used and exposed to many of the usual causes of inflammation.

The aperture in the iris is termed the pupil, and through it light passes to the inner chamber of the eye. The pupil is oblong, and variable in size. It differs with the intensity or degree of light that falls upon the eye. In a dark stable the pupil is expanded to admit a great proportion of the light that falls upon the cornea; but when the horse is brought towards the door of the stable and more light is thrown upon the eye, the pupil contracts in order to keep out that extra quantity which would be painful to the animal, and injurious to vision. When opposed directly to the sun, the aperture will almost close.

This alteration of form in the pupil is effected by the muscular fibres that enter into the composition of the iris. When these fibres are relaxed, the pupil must proportionably diminish. The motions of the iris are not at all under the control of the will, nor is the animal sensible of them. They are produced by sympathy with the state of the retina. When, however, a deficient portion of light reaches the retina, and vision is indistinct, we are conscious of an apparent effort to bring the object more clearly into view, and the fibres then contract, and the aperture enlarges, and more light is admitted.

This dilatation or contraction of the pupil gives a useful method of ascertaining the existence of blindness in one eye or in both. The cornea and crystalline lens remain perfectly transparent, but the retina is palsied, and is not affected by light; and many persons have been deceived when blindness of this description has been confined to one eye. A horse blind in both eyes will usually have his ears in constant and rapid notion, directing them in quick succession to every quarter. He will likewise hang back in his lialter in a peculiar way, and will lift his feet high as if he were stepping over some obstacle, when there is actually nothing to obstruct his passage, and there will be an evident uncertainty in the putting down of his feet. In blindness of one eyc, little or nothing of this characteristic gait and manner can be perceived. Although a one-cyed horse may not be absolutely condemned for the common business of the carriage or the road, he is generally deteriorated as a hunter, for he cannot measure his distances, and will run into his leaps.* Many a sportsman, puzzled and angry

* Mr. W. Percirall, however, in his excellent Lectures on the Veterinary Art, vol. iii. p. $8 *$ 
at the sudden blundering of his horse, or injured by one or more stunning falls, has found a very natural although unexpected explanation of it in the blindness of one eye, and that perhaps produced through his own fault, by over-riding his willing and excellent servant, and causing a determination of blood to the eye, which proved fatal to the delicate texture of the retina. Even for the carriage or the road he is considerably deteriorated, for his field of observation must be materially lessened.

Let the size of both pupils be carefully noticed before the horse is removed from the stable, and, as he is led to the door, observe whether they both contract, and equally so, with the increase of light. If the horse should be first seen in the open air, let it be observed whether the pupils are precisely of the same size; then let the hand be placed over each eye alternately and held there for a little while, and let it be observed whether the pupil dilates with the abstraction of light, and equally in each eye.

Hanging from the upper edge of the pupil of the horse, are two or three round black substances, as large as millet seeds. When the horse is suddenly brought into an intense light, and the pupil is closed, tliey present a singular appearance, as they are pressed out from between the edges of the iris. An equal number, but much smaller, are attached to the edge of the lower portion of the iris. Their general use is probably to intercept rays of light which would be troublesome or injurious, and their principal function is accomplished during the act of grazing. They are larger on the upper edge of the iris, and are placed on the outer side of the pupil, evidently to discharge the same function which we have attributed to the eyelashes, viz., to obstruct the light in those directions in which it would come with greatest force, both from above and even from below, while, at the same time, the field of view is perfectly open, so far as it regards the pasture on which the horse is grazing.

In our cut, $m$ gives a duplicature of the iris, or the back surface of it. This is called the uvea, and it is covered with a thick coat of black mucus, to arrest the rays of light, and to prevent them from entering the eye in any other way than through the pupil. The colour of the iris is, in some unknown way, connected with this black paint behind. Wall-eyed horses, whose iris is white, have no uvea.

We now arrive at a body on which all the important uses of the eye mainly depend, the crystalline lens, $g$, so called from its resemblance to a piece of crystal, or transparent glass. It is of a yielding jelly-like consistence, thicker and firmer towards the centre, and convex on each side, but more convex on the inner than the outer side. It is enclosed in a delicate transparent bag or capsule, and is placed between the aqueous and the vitreous humours, and received into a hollow in the vitreous humour, with which it exactly corresponds. It has, from its density and its double convexity, the chief concern in converging the rays of light which pass into the pupil.

The lens is very apt to be affected from long or violent inflammation of the conjunctiva, and either its capsule becomes cloudy, and imperfectly transmits the light, or the substance of the lens becomes opaque. The examination of the horse, with a view to detect this, must either be in the shade, or at a stable door, where the light shall fall on the animal from above and in front; and in conducting this examination we would once more caution the intended purchaser against a superfluity of white about his neck. Holding the head of the animal a little up, and the light coming in the direction that has been described, the condition of the lens will at once be evident. The confirmed cataract, or the opaque lens of long standing, will exhibit a pearly appearance, that cannot be mistaken, and will frequently be attended with a change of form - a portion of the lens being forced forwards into the pupil. Although the disease may not have proceeded so far as this, yet if there is the slightest cloudiness of the lens, either generally, or in the form of a minute spot in the centre, and with or without lines radiating from that spot, the horse is to be condemned; for, in ninetynine cases out of a hundred, the disease will proceed, and cataract, or complete opacity of the lens, and absolute blindness, will be the result.

201, says, "The loss of one eye does not enfeeble sight, beeause the other acquires greater energy, though it much contracts the field of vision. It is said to render the conception erring, and the case of misjudgment of distanees is the one commonly brought forward to show this. All I can say on this point is, that the best hunter I ever possessed, a horse gifted with extraordinary powers for leaping, was a one-eyed horse, and this animal carried me through a hunting season, without, to my recollection, making one single blunder in leaping." 
Cataraet in the human being may, to a very considerable extent, be remedied. The opaque lens may be extracted, or it may be forced into the vitreous humours, and thcre existing as a foreign body, it will soon be absorbed and disappear. These operations are impossible in the horse; for, in the first place, there is a muscle of which we have already spoken, and to be presently more particularly described, that is peculiar to quadrupeds, and of such power as generally to draw back the eye too far into its socket for the surgeon to be enabled to make his incision; or could the incision be made, the action of this muscle would force out the greater part of the contents of the eye, and this organ would speedily waste away. If, however, the opaque lens could be withdrawn or depressed, and the mechanism of the eye were not othcrwise injured, the operation would be totally useless, for we could not make the horse wear those convex glasses whose converging power might compensate for the loss of the lens.

Behind the lens, and occupying four-fifths of the cavity of the eye, is the vitreous humour (glassy, or resembling glass). It seems, when first taken from the oye, to be of the consistence of a jelly, and of beautiful transparency; but if it is punctured a fluid escapes from it as limpid and as thin as water, and when this has been suffered completely to ooze out, a mass of membraneous bags or cells remains. The vitreous humour consists of a watery fluid contained in these cells; but the fluid and the cells form a body of considerably greater density than the aqueous fluid in the front of the eye.

Last of all, between the vitreous hummer and the choroid coat, is the retina, o, or netlike membrane. It is an expansion of the substance, $g$, of the optic nerve. When that nerve has reached the back of the eye, and penetrated through the sclerotic and choroid coats, it first enlarges into a little white prominence, from which radiations or expansions of nervous matter proceed, which spread over the whole of the choroid coat, and form the third investment of the eye. The membrane by which this nervous pulp is supported, is so exceedingly thin and delicate, that it will tear with the slightest touch, and break even with its own weight. The membrane and the pulp are perfectly transparent in the living animal. The pupil appears to be black, because in the daytime it imperfectly reflects the colour of the choroid coat beneath. In the dusk it is greenisl, beeause, the glare of day being removed, the actual green of the paint appears.

On this expansion of nervous pulp, the rays of light from surrounding objects, condensed by the lens and the humours, fall, and, producing a certain image corresponding with these objects, the animal is conscious of their existence and presence.

It may, however, so happen that from the too grcat or too little convexity of the eye or a portion of it, the place of most distinct vision may not be immediately on the retina, but a little before or behind it. In proportion as this is the case, the sight will be indistinct and imperfect; nor shall we be able to offer any remedy for this defect of sight. There is a shying, often the result of cowardice or playfulness, or want of work, but at other times proving, beyond contradiction, a defect of sight even more dangerous than blindness. A blind horse will resign himself to the guidance of his rider or driver; but against the misconception and starting of a shying horse there is no defence. That horses grow shy as they grow old, no one accustomed to them will deny; and no intelligent person will be slow in attributing it to the right cause-a decay in the organ of vision, - a loss of convexity in the eye, lessening the convergency of the rays, and throwing the perfect image beyond, and not on, the retina. There is a striking difference in the convexity of the cornea in the colt and the old horse; and both of them, probably, may shy from opposite causes-the one from a cornea too prominent, and the other from one too flat. In the usual examination of the horse previously to purchase, sufficient attention is not always paid to the convexity of the cornea.

The remedy for shying will be considered when we speak of the vices of horses.

There is a provision yet wanting. The horse has a very extended field of view, but many persons are not perhaps aware how little of it he can command at a time. Thcre is not one of our readers who can make out a single line of our trcatise without changing the direction of the eye. It is curious to follow the motion of the eyes of a rapid reader. Nature has given no less than seven muscles to the horse, in order to 
turn this little but important organ; and, that they may act with sufficient power and quickness, no fewer than six nerves are directed to the muscles of the eye generally, or to particular ones-while the eye rests on a mass of fat, that it may be turned with little exertion of power, and without friction.

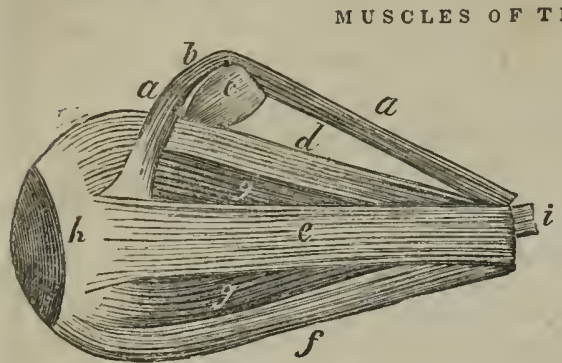

There are four straight muscles, three of which, $d, e$, and $f$, are represented in our cut, rising from the back of the orbit, and inserted into the ball of the eye, opposite to, and at equal distances from each other. One, $d$, runs to the upper part of the eye, just behind the transparent and visible portion of it, and its office is clearly to raise the eye. When it contracts, the eye must be drawn upward. Another, $f$, is inserted exactly opposite, at the bottom of the eye; and its office is as clearly to depress the eye, or enable the animal to look downwards. A third, $e$, is inserted at the outer corner, and by means of it the eye is turned outward, and, from the situation of the eye of the horse, considerably backward; and the fourth is inserted at the inner corner, turning the eye inward. 'They can thus rotate or turn the eye in any direction the animal wishes, and by the action of one, or the combined power of any two of them, the eye can be immediately and accurately directed to every point.

These muscles, however, have another duty to discharge. They support the eye in its place. In the usual position of the head of the horse, they must be to a certain degree employed for this purpose; but when "he is grazing or feeding, the principal weight of the eye rests upon them. Another muscle is therefore added, peculiar to quadrupeds, called the retractor (drawer-back), or the suspensorius (suspensory) muscle, g. It arises from the edge of the foramen through which the optic nerve enters the orbit - surrounds the nerve as it proceeds forward, and then, partially dividing into forr portions, is attached to the back part of the eye. Its office is evidently to support the eye generally, or, when suddenly called into powerful action, and assisted by the straight muscles, it draws the eyc back out of the reach of threatening danger, and in the act of drawing it back causes the haw to protrude, as an additional defence.

The power of this muscle is very great. It renders some operations on the eye almost impossible. It is an admirable substitute for the want of hands, to defend the eye from many things that would injure it; and, being partially separated into four divisions, it assists the straight muscles in turning the eye.

These muscles discharge another and a most important office. If we examine near and distant objects through a telescope, we must alter the focus; i.e., we must increase or diminish the length of the tube. We must shorten it a little when we examine distant objects, because the rays, coming to us from them in a less divergent direction, are sooner brought to a point by the power of the lens. Thus the straight and retractor muscles drawing back the eye, and forcing it upon the substance behind, and in a slight degree flattening it, bring the lens nearer to the retina, and adapt the eye to the observation of distant objects.

Still, however, being constantly employed in supporting the weight of the eye, these muscles may not be able to turn it so rapidly and so extensively as the wishes or wants of the animal require; therefore two others are superadded which are used solely in turning the eye. They are called oblique muscles, because their course is obliquely across the eye. The upper one is most curiously constructed, $a, b$. It comes from the back part of the orbit, and takes a direction upwards and towards the inner side, and there, just under the ridge of the orbit, it passes through a perfect mechanical pulley, and, turning round, proceeds across the eye, and is inserted rather beyond the middle of the eye, towards the outer side. Thus the globe of the eye is evidently directed inward and upward. Something more, however, is accomplished by this singular mechanism. The eye is naturally deep in the orbit, that it may be 
more perfectly defended; but it may be necessary occasionally to bring it forward, and enlarge the field of vision. The eye is actually protruded under the influence of fear. Not only are the lids opened more widely, but the eye is brought more forward. How is this accomplished? There are no muscles anterior to, or before the eyethere is no place for their insertion. The object is readily effected by this singular pulley, $b, c$. By the power of this muscle-the trochlearis, or pulley-muscle-and the straight muscles at the same time not opposing it, or only regulating the direction of the eye, it is really brought somewhat forward. The lower oblique muscle rises just within the lacrymal bone $(i$, p. 70$)$, and, proceeding across the eye, is fixed into the part of the sclerotica opposite to the other oblique muscle, and it turns the eye in a contrary direction, assisting, however, the upper oblique in bringing the eye forward from its socket.

\section{CHAPTER III.}

\section{INJURIES AND DISEASES OF THE SKULL-THE BRAIN - THE EARS-AND THE EYES.}

WE havc now arrived at a convenient resting-place in our somewhat dry but necessary description of the structure of the horse, and we willingly turn to more practical matter. We will consider the injuries and diseases of the parts we have surveyed. In entering, however, on this division of our work, we would premise, that it is impossible for us to give the farmer such an account of the nature and treatment of the diseases of horses as will enable him with safety to practise for himself, except in the commonest cases. The causes of most diseases are so obscure, their symptoms so variable, and their connexion with other maladies so complicated and mysterious, that a life devoted to professional study will alone qualify a man to become a judicious and successful practitioner on the diseases of the horse and other domestic animals. Our object will be to communicate sufficient instruction to the farmer to enable him to act with promptness and judgment when he cannot obtain professional assistance, to qualify him to form a satisfactory opinion of the skill of the veterinary surgeon whom he may employ, and, more especially, to divest him of those strange and absurd prejudices which in a variety of cases not only produce and prolong disease, but bring it to a fatal termination.

\section{F R A C T UR E.}

We have described the cavity of the skull of the horse as being so defended by the hardness of the parietal bones, and those bones so covered by a mass of muscle, and the occipital bone as so exceedingly thick (see page 92), that a FracturE of the skull is almost impossible. It can only occur from brutal violence, or when a horse falls in the act of rearing. When, however, fracture of the skull does occur, it is almost invariably fatal. A blow of sufficient violence to break thesc bones must likewise irreparably injure the delicate and important organ which they protect.

The ridge, or outer and upper part of the orbit of the eye, is occasionally fractured. It happens from falling, or much oftener from violent blows. 'The slightest examination will detect the loosened pieces; but a professional man alone can render effectual assistance.

Mr. Pritchard, in the second volume of the "Veterinarian," relates an interesting case of fracture of the orbit of the eye. "A chestnut mare," he says, "received a blow which fractured the orbit from the superciliary foramen, in a line through the zygomatic processes of the temporal and malar bones to the outer angle of the eye. The detached bone, together with the divided integument, hung over the eye so as to intercept vision. On examining the place where the accident occurred, two portions of bone were found belonging to the orbital arch. After carefully inspecting the wound, and finding no other detached portions, nor any spiculæ which might irritato 
or wound, the adjacent portions of the skin were carefully drawn together, and secured by a silver wire, which closed the wound, and confined the detached portion of bone in its proper place. A mash diet was ordered.

" On the following day there was considerable inflammation. The eye was bathed with warm water, and a dose of physic administered. On the third day the inflammation and swelling had still more increased. Blood was abstracted from the vein at the angle of the eye. The swelling and inflammation now speedily abated; and on the fifteenth day the wound had quite healed."

If a fracture of this kind is suspected, its existence or non-existence may be easily determined by introducing the thumb under, and keeping the fore-finger upon, the edge of the orbit.

\section{EXOSTOSIS.}

Bony enlargements of the orbital arch sometimes arise from natural predisposition or local injury. They should be attacked in the earliest stage, for they are too apt rapidly to increase. Some preparation of iodine, as described in the account of medicines, will be useful in this case.

\section{A R I ES.}

Inflammation and enlargement of the injured bones, followed by abscess and the production of certain bony growths, are of occasional occurrence. A skilful practitioner can alone decide whether a cure should be attempted, or the sufferings of the animal terminated by death.

\section{COMPRESSION OF THE BRAIN.}

Hydatids are often found within the cranial cavity, and lying upon or imbedded in the brain of oxen and sheep. Their existence is usually fatal to the animal. There is no well-authenticated account of the existence of an hydatid in the cranial cavity of the horse ; but cysts, containing a serous or viscid fluid, are occasionally observed. The following is the history of one:-A horse exhibited symptoms of vertigo, or staggers, which disappeared after copious bleeding and purgatives. About twelve months afterwards the same complaint was evident. He carried his head low and inclined to the right side. He staggered as he walked, and the motion of his limbs was marked by a peculiar convulsive action, confined to the fore extremities. He moved by a succession of spasmodic boundings. He was completely deaf; and rapidly lust flesh, though he ate and drank voraciously. He remained in this state, to the shame of the owner and the practitioner, several months, and then he had a fresh attack of vertigo, and died suddenly. On examination of the brain, its membranes were found to be completely reddened; and, between the two lobes of the brain, was a round cyst as large as a pullet's egg. The pressure of this was the manifest cause of the mischief.

\section{PRESSURE ON THE BRAIN.}

This may be produced by some fluid thrown out between the membranes, or occupying and distending the ventricles of the brain. In the full-grown horse it rarely occurs; but it is well known to breeders as an occasional disease of the foal, under the name of "water in the head." The head is either much enlarged, or strangely deformed, or both; and the animal dies, either in the birth, or a few days after it.

\section{E G R I M S.}

There is another kind of pressure on the brain, resulting from an unusual determination or flow of blood to it. This organ requires a large supply of blood to enable it to discharge its important functions. Nature, in the horse more than in many other animals, has made some admirable provisions to cause this stream to flow into the brain with little velocity, and thereby to lessen the risk of suddenly overloading it or rupturing its vessels. " The arteries pursue their course to the brain in a strangely winding and circuitous manner; and they enter the skull through bony apertures that will admit of the enlargement of the vessels only to a very limited extent. From various causes, however, of which the most common is violent exercise on a hot day, 
and the horse being fat and full of blood, more than the usual quantity is sent to the head; or, from some negligence about the harness-as the collar being too small, or the curb-rein too tight - the blood is prevented from returning from the head. The larger vessels of the brain will then be too long and injuriously distended; and, what is of more consequence, the small vessels that permeate the substance of the brain will be enlarged, and the bulk of the brain increased, so that it will press upon the origins of the nerves, and produce, almost without warning, loss of power and consciousness.

The mildest affection of this kind is known by the name of Megrims. It comparatively rarely happens when the horse is ridden; but should he be driven, and perhaps rather quickly, he may perform a part of his journey with his usual cheerfulness and ease : he will then suddenly stop, shake his head, and exhibit evident giddiness, and half-unconsciousness. In a minute or two this will pass over, and he will go on again as if nothing had happened.

Occasionally, however, the attack will be of a more serious nature. He will fall without the slightest warning, or suddenly run round once or twice, and then fall. $\mathrm{He}$ will either lie in a state of complete insensibility, or struggle with the utmost violence. In tive or ten minutes he will begin gradually to come to himself; he will get up and proceed on his journey, yet somewhat dull, and evidently affected and exhausted by what had happened, although not seriously or permanently ill.

At the moment of attack, a person who is competent to the task should abstract three or four quarts of blood from the neck-vein; or cut the bars of the palate in the manner to be explained when we describe that part, and whence a considerable and sufficient quantity of blood may be readily obtained. The driver should pat and soothe the animal, loosen the curb-rein, if possible ease the collar, and pursue his journey as slowly as circumstances will permit. When he gets home, a dose of physic should be administered if the horse can be spared, the quantity of dry food lessened, and mashes given, or green meat, or he should be turned out to grass for two or three months.

Is all this necessary because a horse has happened to have a fit of the megrims? Yes, and more too, in the mind of the prudent man; for it is seldom that a horse has the megrims without the predisposition to a second attack remaining. These overdistended vessels may be relieved for a while, but it is long before they perfectly recover their former tone. It requires but a little increased velocity or force in the vital current once more to distend them, and to produce the same dangerous effects. The testimony of experience is uniform with regard to this ; and he would not do justice to himself or his family who trusted himself behind a horse that had a second attack of megrims.

\section{A P O PLEXY.}

MEgrims is Apoplexy under its mildest form. In the latter affection, the determination of blood, if not so sudden, is greater, or differently directed, or more lasting. It is seldom, however, that there are not timely warnings of its approach, if the carter or the groom had wit enough to observe them. The horse is a little off his feed-he is more than usually dull-there is a degree of stupidity about him, and, generally, a somewhat staggering gait. This goes of when he has been out a little while, but it soon returns under a more decided character, until, at length, it forces itself on the attention of the most careless.

The actual illness is perhaps first recognised by the horse standing with his head lepressed. It bears upon, or is forced against the manger or the wall, and a considerable part of the weight of the animal is evidently supported by this pressure of the head. As he thus stands, he is balancing himself from one side to the other as if he were ready to fall; and it is often dangerous to stand near to him, or to move him, for he falls without warning. If he can get his muzzle into a corner, he will sometimes continue there motionless for a considerable time, and then drop as if he were shot; but, the next monient, he is up again, with his feet almost in the rack. He sleeps or seems to do so as he stands, or at least he is nearly or quite unconscious of surrounding objects. When he is roused, he looks vacantly around him. Perhaps he will take a lock of hay if it is offered to him; but ere it is half masticated, the eye 
closes, and he sleeps again with the food in his mouth. Soon afterwards he is, perhaps, roused once more. The eye opens, but it has an unmeaning glare. The hand is moved before him, but the eye closes not; he is spoken to, but he hears not. The last act of voluntary motion which he will attempt is usually to drink; but he has little power over the muscles of deglutition, and the fluid returns through the nostrils.

He now begins to foam at the mouth. His breathing is laborious and loud. It is performed by the influence of the organic nerves, and those of animal life no longer lend their aid. The pulse is slow and oppressed - the jugular vein is distended almost to bursting - the muzzle is cold, and the discharge of the fæces involuntary. He grinds his teeth-twitchings steal over his face and attack his limbs-they sometimes proceed to convulsions, and dreadful ones too, in which the horse beats himself about in a terrible manner; but there is rarely disposition to do mischief. In the greater number of cases these convulsions last not long. All the powers of life are oppressed, and death speedily closes the scene.

On examination after death, the whole venous system is usually found in a state of congestion, and the vessels of the brain are peculiarly turgid with black blood. Occasionally, however, there is no inflammation of the brain or its membranes; but either the stomach contains a more than usual quantity of food, or the larger intestines are loaded with foul matter.

This disease is found more frequently in the stable of the postmaster and the farmer than anywhere else. Thirty years ago it was the very pest of these stables, and the loss sustained by some persons was enormous; but, as veterinary science progressed, the nature and the causes of the disease were better understood, and there is not now one case of staggers where twenty used to occur.

Apoplexy is a determination of blood to the head, and the cause is the over-condition of the animal and too great fulness of blood. Notions of proper condition in the horse now prevail very different from those by which our forefathers were guided. It no longer consists in the round, sleek carcase, fat enough for the butcher, but in fulness and hardness of the muscular fibre, and a comparative paucity of cellular and adipose matter-in that which will add to the power of nature, and not oppress and weigh her down.

The system of exercise is better understood than it used formerly to be. It is proportioned to the quantity and quality of the food, and more particularly the division of labour is more rational. The stage-horse no longer runs his sixteen or eighteen, or even two-and-twenty miles, and then, exhausted, is turned into the stable for the next twenty hours. The food is no longer eaten voraciously; the comparatively little stomach of the animal is no longer distended, before nature has been able sufficiently to recruit herself to carry on the digestive process; the vessels of the stomach are no longer oppressed, and the flow of blood through them arrested, and, consequently, more blood directed to other parts, and to the brain among the rest.

The farmer used to send his horses out early in the morning, and keep them at plough for six or eight hours, and then they were brought home and suffered to overgorge themselves, and many of them were attacked by staggers and died. If the evil did not proceed quite to this extent, the farmer's horse was notoriously subject to fits of heaviness and sleepiness-he had half-attacks of staggers. From this frequent oppression of the brain-this pressure on the optic nerves as well as other parts, another consequence ensued, unsuspected at the time, but far too prevalent-the horse became blind. The farmer was notorious for having more blind horses in his stable than any other person, except, perhaps, the postmaster.

The system of horse management is now essentially changed. Shorter stages, a division of the labour of the day, and a sufficient interval for rest, and for feeding, have, comparatively speaking, banished sleepy staggers from the stables of the postmaster. 'The division of the morning and afternoon labour of the farmer's horse, with the introduction of that simple but invaluable contrivance, the nose-bag, have rendered this disease comparatively rare in the establishment of the agriculturist. To the late Professor Coleman we are indebted for some of these important improvements.

Old horses are more subject to staggers than young ones, for the stomach has be- 
come weak by the repetition of the abuses just described. It has not power to digest and expel the food, and thus becomes a source of general, and particularly of cerebral, disturbance.

Horses at grass are occasionally attacked by this disease; but they are generally poor, hard-worked, half-starved animals, turned on richer pasture than their impaired digestive organs are equal to. Pcrliaps the weather is hot, and the sympathy of the brain with the undue labour of the stomach is more easily excited, and a determination of blood to the brain more readily effected.

Mr. Percivall gives a very satisfactory illustration of the production of staggers in this way. He says that "when his father first entered the service of the Ordnance, it was the eustom to turn horses which had hecome low in condition, but were still well upon their legs, into the marshes, in order to recruit their strength. During the months of July, August, and September, nothing was more common than an attack of staggers among these horses, and which was naturally attributed to the luxuriant pasture they were turned into, combined with the dependent posture of the liead, and the sultry heat to which they were exposed."

Occasionally it will be necessary for the owner or the veterinary attendant to institute very careful inquiry, or he will not detcet the real causes of the disease. Does it arise from improper management, to which the horse lias been in a manner lıabituated? Had he been subjected to long labour and fasting, and had then the opportunity of gorging to excess? Did it proeeed from accidental repletion-from the animal having got loose in the night, and found out the corn or the chaff bin, and filled himself almost to bursting? 'There is nothing in the appearance of the animal which will lead to a discovery of the cause-no yellowness nor twitchings of the skin, no local swellings, as some have described; but the practitioner or the owner must get at the truth of the matter as well as he can, and then proceed accordingly.

As to the treatment of staggers, whatever be the cause of the disease, bleeding is the first measure indieated-the overloaded vessels of the brain must be relieved. The jugular vein should be immediately opened. It is easily got at-it is large-the blood may be drawn from it in a full stream, and, being also the vessel through which the blood is returned from the head, the greater part of the quantity obtained will be taken immediately from the overloaded organ, and therefore will be most likely to produce the desired effect. No definite quantity of blood should be ordered to he abstracted. The effect produced must be the guide, and the bleeding must be continued until the horse falters, or begins to hlow-or, perhaps, with more assured success, until he falls. Some persons select the temporal artery. This is very unscientifie practice. It is difficult, or impossible, to obtain from this vessel a stream that promises any decisive success. It is likewise difficult to stop the bleeding from this artery; and, after all, the blood is not drawn from the actual seat of the diseasethe brain.

The second step is to ascertain what is the cause of the apoplexy. Has the animal got at the corn or the chaff bin? Had he been over-fed on the evening before, and is his stomach probably distended to the utmost by what he has eaten? In such a case, of what avail can physic be, introduced into a stomach already crammed with indigestive food? Or what effect can twelve or twenty drachms of aloes produce, a small portion only of which ean penetrate into the stomach? Recourse must be had to the STOMAC1I-PUMP, one of the most valuable discoveries of modern times, and affording the means of combating several diseases that had previously set all medical skill at defiance. Warm water must be injected. The horse is now incapable of offering much resistance, and the injection may be continued not only until the contents of the stomach are so far diluted that a portion of them can escape through the lower orifice of that viscus, but until the obstruction to vomiting offered by the contracted entrance of the stomach is overcome, and a portion of the food is returned through the nostrils or mouth.

This being effected, or it having been ascertained that there was no extreme distension of the stomach, recourse should be had to aloes, and from eight to twelve drachms of it may be administered. It will be proper to add some stimulating medicine to the alocs, with a view of restoring the tone of the stomach, and inducing it to contract on its contents. Gentian and ginger are most likely to effect this purpose. 
The after-treatment must be regulated by circumstances. For some time the horse should be put on a restricted diet; mashes should be given; green meat in no great quantity; a moderate allowance of hay, and very little corn. When sufficiently recovered, he may be turned out with advantage on rather bare pasture. One circumstance, however, should never be forgotten-that the horse who has once been attacked with staggers is liable to a return of the complaint from causes that otherwise would not affect him. The distended vessels are weakened-the constitution is weakened, and prudence would dictate that such an animal cannot be too soon disposed of.

Let no farmer delude himself with the idea that apoplexy is contagious. If his horses have occasionally slight fits of staggers, or if the disease carries off several of them, he may be assured that there is something wrong in his management. One horse may get at the corn-bin and cram himself to bursting; but if several are attacked, it is time for the owner to look about him. The general cause is too voracious feeding-too much food given at once, and perhaps without water, after hard work and long fasting.

There is one consequence of this improper treatment, of which persons do not appear to be sufficiently aware, although they suffer severely from it. A horse that has frequent half-attacks of staggers very often goes blind. It is not the common blindness from cataract, but a peculiarly glassy appearance of the eye. If the history of these blind horses could be told, it would be found that they had been subject to fits of drooping and dulness, and these produced by absurd management respecting labour and food.

\section{PHRENITIS.}

Primary inflammation of the brain or its membranes, or both, sometimes occurs, and of the membranes oftenest when both are not involved.

Whatever be the origin of phrenitis, its early symptoms are scarcely different from those of apoplexy. The horse is drowsy, stupid; his eye closes; he sleeps while he is in the act of eating, and dozes until he falls. The pulse is slow and creeping, and the breathing oppressed and laborious. This is the description of apoplexy. The symptoms may differ a little in intensity and continuance, but not much in kind.

The phrenitic horse, however, is not so perfectly comatose as another that labours under apoplexy. The eye will respond a little to the action of light, and the animal is somewhat more manageable, or at least more susceptible, for he will shrink when he is struck, while the other frequently cares not for the whip.

In the duration of the early symptoms there is some difference. If the apoplexy proceeds from distension of the stomach, four-and-twenty or six-and-thirty hours will scarcely pass without the cure being completed, or the stomach ruptured, or the horse destroyed. If it proceeds more from oppression of the digestive organs than from absolute distension of the stomach, and from that sympathy which subsists between the stamach and the brain, the disease will go on-it will become worse and worse every hour, and this imperfect comatose state will remain during two or three days. The apoplexy of the phrenitic horse will often run its course in a few hours.

In a case of evident phrenitis, blood-letting and physic must be early carried to their full extent. The horse will often be materially relieved, and, perhaps, cured by this decisive treatment; but, if the golden hour has been suffered to pass, or if remedial measures have become ineffectual, the scene all at once changes, and the most violent reaction succeeds. The eye brightens-strangely so; the membrane of the eye becomes suddenly reddened, and forms a frightful contrast with the transparency of the cornea; the pupil is dilated to the utmost; the nostril, before scarcely moving, expands and quivers, and labours; the respiration becomes short and quick; the ears are erect, or bent forward to catch the slightest sound; and the horse, becoming more irritable every instant, trembles at the slightest motion. The irritability of the patient increases-it may be said to change to ferocity - but the animal has no aim or object in what he does. He dashes himself violently about, plunges in every direction, rears on his hind legs, whirls round and round, and then falls backward with dreadful force. He lies for a while exhausted-there is a remission of the symptoms, but perhaps only for a minute or two, or possibly for a quarter of an hour. 
Now is the surgeon's golden time, and his courage and adroitness will be put to the test. He must open, if he can, one or both jugulars: but let him be on his guard, for the paroxysm will return with its former violence and without the slightest warning.

The second attack is more dreadful than the first. Again the animal whirls round and round, and plunges and falls. He seizes his clothing and rends it in pieces; perhaps, destitute of feeling and of consciousness, he bites and tears himself. $\mathrm{He}$ darts furiously at everything within his reach ; but no mind, no design, seems to mingle with or govern his fury.

Another and another remission and a return of the exacerbation follow, and then, wearied out, he becomes quiet; but it is not the quietness of returning reason-it is mere stupor. 'This continues for an uncertain period, and then he begins to struggle again; but he is now probably unable to rise. He pants-he foams-at length, completely exhausted, he dies.

There are but two diseases with which phrenitis can be confounded, and they are cholic and rabies. In cholic, the horse rises and falls; he rolls about and kicks at his belly; but his struggles are tame compared with those of the phrenitic horse. There is no involuntary spasm of any of the limbs; the animal is perfectly sensible, and, looking piteously at his flanks, seems designedly to indicate the seat of pain. 'The beautiful yet fearfully excited countenance of the one, and the piteous, anxious gaze of the other, are sufficiently distinct; and, if it can be got at, the rapid, bounding pulse of the one, and that of the other scarcely losing its natural character in the early stage, cannot be mistaken.

In rabies, when it does assume the ferocious form, there is even more violence than in phrenitis; but there is method, and treachery too, in that violence. There is the desire of mischief for its own sake, and there is frequently the artful stratagem to allure the victim within the reach of destruction. There is not a motion of which the rabid horse is not conscious, nor a person whom he does not recognise; but he labours under one all-absorbing feeling-the intense longing to devastate and destroy.

The post-mortem appearances are altogether uncertain. There is usually very great injection and inflammation of the membranes of the brain, and even of portions of the substance of the brain; but in other cases there is scarcely any trace of inflammation, or even of increased vascularity.

The treatment of phrenitis has been very shortly hinted at. The first-the indispensable proceeding - is to bleed; to abstract as much blood as can be obtained; to let the animal bleed on after he is down; and indeed not to pin up the vein of the phrenitic horse at all. 'The patient will never be lost by this decisive proceedirg, but the inflammation may be subdued, and here the first blow is the whole of the battle. The physic should be that which is most readily given and will most speedily act. The farina of the croton will, perhaps, have the preference. Half a drachm or two scruples of it may be fearlessly administered. The intense inflammation of the brain gives sufficient assurance that no dangerous inflammation will be easily set up in the intestinal canal. 'This medicine can be formed into a very little ball or drink, and in some momentary remission of the symptoms, administered by means of the probang, or a stick, or the horn. Sometimes the phrenitic horse, when he will take nothing else, and is unconscious of everything else, will drink with avidity gruel or water. Repeated doses of purgative medicine may perhaps be thus given, and they must be continued until the bowels respond. The forehead should be blistered, if it can in any way be accomplished; yet but little service is to be expected from this manipulation. 'The bowels having been well opened, digitalis should be administered. Its first and most powerful action is on the heart, diminishing both the number and strength of its pulsations. To this may be added emetic tartar and nitre, but not a particle of hellebore; for that drug, if it acts at all, produces an increased determination of blood to the brain.

While the disease continues, no attempt must be made to induce the horse to feed; and even when appetite returns with the abatement of inflammation great caution must be exercised both with regard to the quantity and quality of the food. 


\section{RABIES, OR MADNESS.}

This is another and fearful disease of the nervous system. It results from the bite of a rabid animal, and, most commonly, of the companion and friend of the horsethe coach-dog. The account now given of this malady is extracted from lectures which the author of the present work delivered to his class.

"There is occasional warning of the approach of this disease in the horse, or rather of the existence of some unusual malady, the real nature of which is probably mistaken. A mare, belonging to Mr. Karslake, had during ten days before the recognition of the disease been drooping, refusing her food, heaving at the flanks, and pawing occasionally. It was plain enough that she was indisposed, but at length the furious fit came upon her, and she destroyed almost everything in the stable in the course of an hour. The late Mr. Moneyment had a two-years old colt brought to his establishment. It was taken ill in the afternoon of the preceding day, when it first attracted attention by refusing its food, and throwing itself down and getting up again immediately. From such a description, Mr. Moneyment concluded that it was a case of cholic; but, when he went into the yard, and saw the pony, and observed his wild and anxious countenance, and his excessive nervous sensibility, he was convinced that something uncommon was amiss with him, although he did not at first suspect the real nature of the case.

The early symptoms of rabies in the horse have not been carefully observed or well recorded; but, in the majority of cases, so far as our records go, there will not often be premonitory symptoms sufficiently decisive to be noticed by the groom.

The horse goes out to his usual work, and, for a certain time and distance, performs it as well as he had been accustomed to do; then he stops all at once - trembles, heaves, paws, staggers, and falls. Almost inmediately he rises, drags his load a little farther, and again stops, looks about him, backs, staggers, and falls once more. This is not a fit of megrims - it is not a sudden determination of blood to the brain, for the horse is not for a single moment insensible. The sooner he is led home the better, for the progress of the disease is as rapid as the first attack is sudden; and, possibly, he will fall twice or thrice before he reaches his stable.

In the great majority of cases - or rather, with very few exceptions - a state of excitation ensues, which is not exceeded by that of the dog under the most fearful form of the malady, but there are intervals when, if he had been naturally goodtempered and had been attached to his rider or his groom, he will recognise his former friend and seek his caresses, and bend on him one of those piteous, searching looks which, once observed, will never be forgotten: but there is danger about this. Presently succeeds another paroxysm, without warning and without control ; and there is no safety for him who had previously the most complete mastery over the animal.

I was once attending a rabid horse. The owner would not have him destroyed, under the vain hope that I had mistaken a case of phrenitis for one of rabies, and that the disease might yield to the profuse abstraction of blood that $\mathbf{I}$ had been prevailed on to effect, and the purgative influence of the farina of the croton-nut with which he had been abundantly supplied in an early stage of the malady. I insisted upon his being slung, so that we were protected from injury from his kicking or plunging. $\mathrm{He}$ would bend his gaze upon me as if he would search me through and through, and would prevail on me, if I could, to relieve him from some dreadful evil by which he was threatened. He would then press his head against my bosom, and keep it there a minute or more. All at once, however, the paroxysm would return. He did not attempt to bite me; but, had it not been for the sling, he would have plunged furiously about, and I might have found it difficult to escape.

I had previously attended another horse, which the owner refused to have destroyed, and to which attendance I only consented on condition of the animal being slung. He had been bitten in the near hind-leg. When I approached him on that side, he did not attempt to bite me, and he could not otherwise injure me; but he was agitated and trembled, and struggled as well as he could; and if I merely touched him with my finger, the pulsations were quickened full ten beats in a ininute. When, however, I went round to the off side, he permitted me to pat him, and I had to encounter his imploring gaze, and his head was pressed against me-and then presently would 
come the paroxysm; but it came on almost before $I$ could touch him, when I approacherl him on the other side.

These mild cases, however, are exceptions to a general rule. They are few and far between. The horse is the servant, and not the friend of man; and if his companion, yet an oppressed one. In proportion to his bulk he has far less of that portion of the brain witl which intelligence is connected-less attachment-less gratitude. He is nevertheless a noble animal. I am not speaking disparagingly of him; but I am comparing him with-next to man-the most intellectual of all quadrupeds. There is neither the motive for, nor the capability of, that attachment which the dog feels for his master, and therefore, under the influence of tlis disease, lie abandons limself to all its dreadful excitement.

The mare of Mr. Karslake, when the disease was fully developed, forgot her former drooping, dispirited state: her respiration was accelerated-her mouth was covered with foam-a violent perspiration covered every part of her, and her screams would cow the stoutest heart. She presently demolished all the wood-work of the stable, and then she employed herself in beating to pieces the fragments, no human being daring to expose himself to her fury.

The symptoms of the malady of Mr. Moneyment's pony rapidly increased - he bit everything within his reach, even different parts of his own body - he breathed laboriously - his tail erect- screaming dreadfully at short intervals, striking the ground with his fore-feet, and perspiring most profusely. At length he broke the top of his manger and rushed out of the stall with it hanging to his halter. He made immediately towards the medical attendant, and the spectators who were standing by. They fortunately succeeded in getting out of his way, and he turned in the next stall,
and dropped and died.

A young veterinary friend of mine very incautiously and fool-hardily attempted to ball a rabid horse. The animal had previously shown himself to be dangerous, and had slightly bitten a person who gave him a ball on the preceding evening: he now seized the young student's hand, and lifted him from the ground, and shook him, as a terrier would shake a rat. It was with the greatest difficulty, and not until the grooms had attacked the ferocious animal with their pitchforks, that they could compel him to relinquish his hold; and, even then, not before he had bitten his victim to the bone, and nearly torn away the whole of the flesh from the upper and lower surfaces of the hand.*

There is also in the horse, whose attachment to his owner is often comparatively small, a degree of treachery which we rarely meet with in the nobler and more intel. lectual dog. A horse that had shown symptoms of great ferocity was standing in the corner of his box, with a heaving flank, and every muscle quivering from the degree of excitement under which he laboured. A groom, presuming on the former obedience of the animal, ventured in, and endeavoured to put a headstall upon him. Neither the master nor myself could persuade him to forbear. I was sure of mischief, for I had observed the ear lying flat upon the neck, and I could see the backward glance of the eye; I therefore armed myself with a heavy twitch stick that was at hand, and climbed into the manger of the next box. The man had not advanced two steps into the box before I could see the shifting position of the fore feet, and the preparation to spring upon lis victim; and he would have sprung upon him, but my weapon feli with all the force I could urge upon his head, and he dropped. The man escaped, but the brute was up again in an instant, and we trembled lest the partition of the box should yield to his violence, and he would realize the graphic description of $\mathrm{Mr}$. Blaine, when he speaks of the rabid horse as "levelling everything before him, himself sweating, and snorting, and foaming amidst the ruins."

I have had occasion more than once to witness the evident pain of the bitten part, and the manner in which the horse in the intervals of his paroxysms employs himself in licking or gnawing the cicatrix. One animal had been bitten in the chest, and he, not in the intervals between the exacerbation, but when the paroxysm was most

* In the Museum of the Veterinary School at Alfort, is the lower jaw of a rabid horse, which was fractured in the violent efforts of the animal to do mischief. 
violent, would bite and tear himself until his breast was shoekingly mangled, and the blood flowed from it in a strean.

The most interesting and satisfactory symptom is the evident dread of water whiel exists in the deeided majority of cases, and the impossibility of swallowing any considerable quantity. Professor Dupuy gives an account of this circumstance : - A rabid horse was eonfined in one of the sick boxes. His food was given to him through an opening over the door, and a bucket was suspended from the door, and supplied with water by means of a copper tube. As soon as he heard the water falling into the pail, he fell into violent eonvulsions, seized the tube, and crushed it to pieees. When the water in his bueket was agitated, the eonvulsions were renewed. He would oeeasionally approaeh the bucket as if he wished to drink, and then, after agitating the water for an instant, he would fall on his litter, uttering a hoarse ery ; but he would rise again almost immediately. These symptoms were dreadfully inereased if water was thrown upon his head. He would then endeavour to seize it as it fell, and bite with fury at everything within his reach, his whole frame being dreadfully convulsed."

As the disease progresses, not only is the animal rapidly debilitated, but there is the peculiar staggering gait which is observable in the dog-referrible to evident loss of power in the muscles of the lumbar region. I onee saw a mare sitting on her haunches, and unable to rise; yet using her fore feet with the utmost fury, and suffering no one to eome within her reaeh. She, too, would sometimes plunge her muzzle into the offered pail; and immediately withdraw it in evident terror, while every limb trembled. At other times the lowering of the pail would affright her, and she would fall on her side and struggle furiously. Although this symptom is not often observed in the dog, it is a satisfactory identification of the disease, when it is so frequently seen in the horse, and so invariably in the human being.

The earliest and perhaps the most decisive symptom of the near approaeh of rabies in the horse, is a spasmodic movement of the upper lip, partieularly of the angles of the lip. Close following on this, or contemporaneous with it, is the depressed and anxious eountenanee, and inquiring gaze, suddenly however lighted up and beeoming fieree and menacing, from some unknown cause, or at the approaeh of a stranger. From time to time different parts of the frame-the eyes-the jaws-partieular limbs -will be convulsed. The eye will occasionally wander after some imaginary objeet, and the horse will snap again and again at that which has no real existence. Then will eome the irrepressible desire to bite the attendants or the animals within its reaeh. To this will sueeed the demolition of the rack, the manger, and the whole furniture of the stable, aeeompanied by the peeuliar dread of water which has been already described.

Towards the elose of the disease there is generally paralysis, usually eonfined to tho loins and the hinder extremities, or involving those organs which derive their nervous influence from this portion of the spinal eord;-henee the distressing tenesmus which is oeeasionally seen.

The disease rarely extends beyond the third day.

After death, there is uniformly found inflammation at the baek part of the mouth, and at the top of the windpipe, and likewise in the stomaeh, and on the membrane eovering the lungs, and where the spinal marrow first issues from the brain.

When the disease can be clearly connected with a previous bite, the sooner the animal is destroyed the better, for there is no cure. If the symptoms bear eonsiderable resemblance to rabies, although no bite is suspected, the horse should at least be slung, and the medicine, if any is administered, given in the form of a drink, and with the hand well protected; for if it should be seratched in balling the horse, or the skin should have been previously broken, the saliva of the animal is capable of eommunieating the disease. Several farriers have lost their lives from being bitten or seratched in the aet of administering medieine to a rabid horse.

It is always dangerous to encourage any dogs about the stable, and especially if they become fond of the horses, and are in the habit of jumping up and lieking them. The eorners of the mouth of the horse are often sore from the pressure of the bit; and when a eoaeh-dog in a gentleman's stablo_and it is likely to happen in every stable, 
and with every dog-beeomes rabid and dies, the horse too frequently follows him at no great distanee of time.

If a horse is bitten by a dog under suspicious circumstances, he should be carefully examined, and every wound, and even the slightest scratch, well burned with the lunar caustic (nitrate of silver). The scab should be removed and the operation repeated on the third day. The hot iron does not answer so well, and other caustics are not so manageable. In the spring of 1827 , four horses were bitten near Hyde Park, by a mad dog. To one of them the lunar eaustie was twice severely appliedhe lived. 'The red-hot iron was unsparingly used on the others, and they died. The caustic must reach every part of the wound. At the expiration of the fourth month, the horse may bc considered to be safe.

\section{TETANUS, OR LOCKED JAW.}

Thtanus is one of the most dreadful and fatal diseases to which the horse is subject. It is called LOCKED JAw, because the muscles of the jaw are earliest affected, and the mouth is obstinately and immovably closed. It is a constant spasm of all the voluntary muscles, and partieularly of those of the neck, the spine, and the head. It is generally slow and treacherous in its attack. The horse, for a day or two, does not appcar to be quite well; he does not feed as usual; he partly chews his food, and drops it ; and he gulps his water. The owner at length finds that the motion of the jaws is eonsiderably limited, and somc saliva is drivelling from the mouth. If he tries he ean only open the mouth a very littlc way, or the jaws are perfectly and rigidly elosed; and thus the only period at which the disease eould have been successfilly eombated is lost. A cut of a horse labouring under this disease is here given, which the reader will do well to examine carefully.

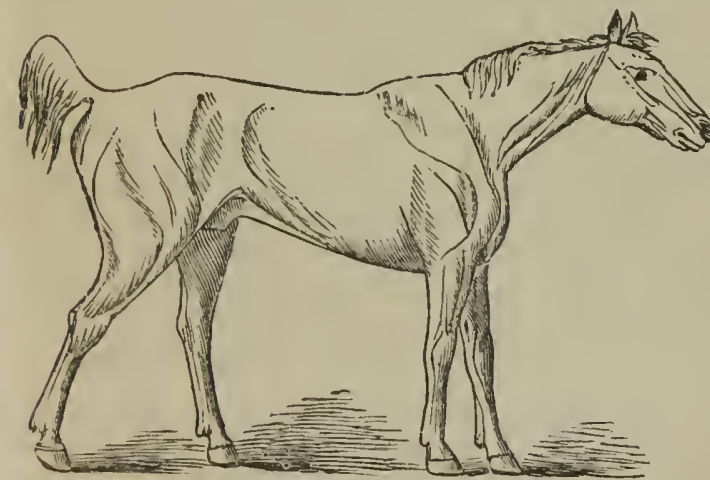

The first thing that strikes the observer is a protrusion of the muzzle, and stiffness of the neck; and, on passing the hand down it, the muscles will be found singularly prominent, distinct, hard, knotty, and unyielding. There is diffieulty in bringing the head round, and still greater difficulty in bending it. The eye is drawn deep within the socket, and, in eonsequence of this, the fatty matter behind the eye is pressed forward; the haw is also protruded, and there is an appearanee of strabismus, or squinting, in an outward direction.

The ears are ereet, pointed forward, and immovable; if the horse is spoken to, or threatened to be struek, they ehange not their position. Considering the beautiful play of the ear of the horse when in health, and the kind of eonversation which he maintains by the motion of it, there is not a more characteristic symptom of tetanus than this immobility of the ear. The nostril is expanded to the utmost, and there is little or no play of it, as in hurried or even natural breathing. The respiration is usually accelerated, yet not always so ; but it is uniformly laborious. The pulse gives little indieation of the severity of the disease. It is sometimes scarcely afferted. It will be rapidly accelerated when any one approaches the animal and offers to touelk him, but it presently quiets down again almost to its natural standard. After a while, however, the heart begins to sympathise with the general excitation of the system, and the pulse increases in frequeney and force until the animal beeomes debilitated, when it beats yet quicker and quicker, but diminishes in power, and gradually flutters and dies away. 
The countenance is eager, anxious, haggard, and tells plainly enough what the animal suffers.

The stiffness gradually extends to the back. If the horse is in a narrow stall, it is impossible to turn him; and, even with room and scope enough, he turns altogether like a deal-board.

The extremities begin to participate in the spasm-the hinder ones generally first, but never to the extent to which it exists in the neck and back. The horse stands with his hind leys straddling apart in a singular way. The whole of the limb moves, or rather is dragged on, together, and anxious care is taken that no joint shall be flexed more than can possibly be helped. The fore limbs have a singular appearance; they are as stiff as they can possibly be, but stretched forward and straddling. They have not unaptly bcen compared to the legs of.a form.

The abdominal muscles gradually become involved. They seem to contract with all the power they possess, and there is a degree of "hide-bound" appearance, and of tucking up of the belly, which is seen under no other complaint. The tail becomes in constant motion from the alternate and violent action of the muscles that elevate and depress it.

Constipation, and to an almost insurmountable degree, now appears. The abdominal muscles are so powerfully contracted, that no portion of the contents of the abdomen can pass on and be discharged.

By degrees the spasm extends and becomes everywhere more violent. The motion of the whole frame is lost, and the horse stands fixed in the unnatural posture which he has assumed. 'The countenance becoines wilder and more haggard-its expression can never be effaced from the memory of him who cares about the feelings of a brute. The violent cramp of a single muscle, or set of muscles, makes the stoutest heart quail, and draws forth the most piteous cries-what, then, must it be for this torture to pervade the whole frame, and to continue, with little respite, from day to day, and from week to week! When his attendant approaches and touches him, he scarcely moves; but the despairing gaze, and the sudden acceleration of the pulse, indicate what he feels and fears.

Tetanus then is evidently an affection of the nerves. A small fibre of some nerve has been injured, and the effect of that injury has spread to the origin of the nervethe brain then becomes affected-and universal diseased action follows. Tetanus is spasm of the whole frame-not mercly of one set of muscles, but of their antagonists also. The fixidity of the animal is the effect of opposed and violent muscular contraction. It belongs to the lower column of nerves only. The sensibility is unimpaired-perhaps it is heightened. The horse would eat if he could; he tries to suck up some moisture from his mash; and the avidity with which he lends himself to assist in the administering of a little gruel, shows that the feelings of hunger and thirst remain unimpaired.

If the disease terminates fatally, it is usually from the sixth to the eighth day, when, if there has been no remission of the spasms, or only a slight one, the horse dies exhaustcd by hard work. The task extorted by the whip and spur of the most brutal sportsman is not to be compared with it.

About or a little before this time, there are occasionally evident remissions. The spasm does not quite subside, but its force is materially lessened. The jaw is not sufficiently relaxed to enable the animal to eat or to drink, or for advantage to be taken of an opportunity for the administration of medicine, while the slightest disturbance or fright, recalls the spasmodic action with all its violence. If, however, the remission returns on the following day, and is a little lengthened, and particularly if there is more relaxation of the lower jaw, there yet is hope. If the patient should recover, it will be very slowly, and he will be left sadly weak, and a mere walking skeleton.

On post-mortem examination the muscular fibre will exhibit sufficient proof of the labour which has been exacted from it. The muscles will appear as if they had been macerated - their tcxture will be softened, and they will be torn with the greatest easc. The lungs will, in the majority of cases, be highly inflamed, for they have been labouring long and painfully, to furnish arterial blood in sufficient quantity to support this great expenditure of animal power. The stomach will contain patches 
of inflammation, but the intestines, in most cases, will not exhibit much departure from the hue of health. The examination of the brain will be altogether unsatisfactory. There may bc slight injection of some of the membrancs, but, in the majority of cases, there will not be any morbid change worthy of record.

Tetanus is usually the result of the injury of some nervous fibre, and the effect of that lesion propagated to the brain. The foot is the most frequent source or focus of tetanic injury. It has been pricked in shoeing, or wounded by something on the road. The horse becomes lame-the injury is carelessly treated, or not treated at all -thc lameness, however, disappears, but the wound has not healed. Therc is an unhcalthiness about it, and at the expiration of eight or ten days, tetanus appears. Some nervous fibre has been irritated or inflamed by the accident, slight as it was.

Docking and nicking, especially when the stump was seared ton severely in the former, or the bandage had not been loosened sufficiently early in the latter, used to be frequent caises of tetanus. It is frequently connected with castration, when the colt liad not been properly prepared for the operation, or the searing-iron has been applied too sevcrely, or the animal has been put to work too soon after the operation, or cxposed to unusual cold. The records of veterinary proceedings contain accounts of tetanus following labour, brutally exacted beyond the animal's natural strength, in the draught of heavy loads. Horses that have becn matched against time have too frequently died of tetanus a little while afterwards. Sudden exposure to cold after being heated by exercise has produced this dreadful state of nervous action, and cspccially if the horse has stood in a partial draught, or cold water has been dripping on the loins.

'The treatincnt of tetanus is simple, and would be oftener successful if carried to its full extent. The indication of cure is plain enough-the system must be tranquillized. The grand agent in accomplishing this is the copious abstraction of blood. There is not a more powerful sedative in cascs of muscular spasm than venesection. A double purpose is effected. The determination of blood to the origins of the nerves, and by which they wcre enabled to secrete and to pour out this torrent of nervous influcnce, is lesscned. The supply of blood to the muscular system is also diminished. The pabulum of the nervous and muscular system-the life of both of them-the capability of acting in the one, and of being acted upon by the other, is taken away. The proper course to be pursued, whether theory or experience be consulted, is, on the first access of tetanıs, to bleed, and to bleed until the horsc falters or falls. No attention should be paid to any specific quantity of blood to be abstracted, but the animal should blecd on until he drops, or the pulse evidently falters. Twenty pounds have been taken before the object of the practitioner was accomplished, but he never had occasion to repent of the course which he pursued. Inflammatory action like this must be subdued by the promptest and most efficient means; and there is one unerring guide - the pulse. While that remains firm, the bleeding should continue. The practitioner is attacking the disease, and not in the sliglitest degree hazarding the permanent strength of the patient.

Next in order, and equal in importance, is physic. The profuse bleeding just recommended will gencrally relax the muscles of the jaw so far as to enable a dosc of physic to be given. Eight or ten drachms of aloes should be administered. If the remission of the spasm is slight, there is another purgative - not so certain in its action, but more powerful when it does act-the farina of the Croton nut. There is little or no danger of exciting inflammation of the mucous membrane of the intestines by this prompt and energetic administration of purgative medicine, for there is too much detcrmination of vital power towards the nervous system-too much irritation there-to leave cause for dreading the possibility of metastasis elsewhere. It would be desirable if a certain degree of inflammation could be excited, becausc to that extent the irritation of the nervous system might be allayed. There is another reason, and a very powerful one-time is rapidly passing. The tetanic action may extend to the intestines, and the co-operation of the abdominal muscles in kceping up the peristaltic motion of the bowels, and expelling their contents, may be lost.

Clysters will be useful in assisting the action of the purgative. A solution of Epsom salts will constitute the safest and best injection. As to medicine, opium is 
not only a valuable drug, but it is that on which alone dependence can be placed in this disease. It will be borne in doses, from half a drachm to two drachms.

Blisters are completely out of the question in a disease the very essence of which is nervous irritability.

The application of sheep-skins warm from the animal, and applied along the whole course of the spine, may somewhat unload the congested vessels of the part, and diminish the sufferings of the animal. They should be renewed as soon as they become offensive, and the patient should be covered from the poll to the tail with double or treble clothing.

There is one kind of external application that has not been so much used, or so highly valued as it deserves, - gentle friction with the hand over the course of the spine, beginning with the slightest possible pressure and never increasing it much. The horse is a little frightened at first, but he soon gets reconciled to it, and when at the same time an opiate liniment is used, relief has been obtained to a very marked degree.

One thing should not be forgotten, namely, that a horse with locked jaw is as hungry as when in health, and every possible contrivance should be adopted to furnish him with that nutriment which will support him under his torture, and possibly enable him to weather the storm. If a pail of good gruel is placed within his reach, how will he nuzzle in it, and contrive to drink some of it too! If a thoroughly wet mash is placed before him in a pail, he will bury his nose in it, and manage to extract no small portion of nutriment. By means of a small horn, or a bottle with a very narrow neck, it will often be possible to give him a small quantity of gruel; but the flexible pipe that accompanies Read's patent pump will render this of easier accomplishment, for the nutriment may be administered without elevating the head of the horse, or inflicting on him the extreme torture which used to accompany the act of drenching. If the jaw is ever so closely clenched, the pipe may be introduced between the tushes and the grinders, and carried tolerably far back into the mouth, and any quantity of gruel or medicine introduced into the stomach.

It will also be good practice to let a small portion of food be in the manger. The horse will not at first be able to take up the slightest quantity, but he will attempt to do so. Small portions may be placed between his grinders, and they will presently drop from his mouth, scarcely or at all masticated : but some good will be done there is the attempt to put the muscles of the jaw to their proper use. On the following day he will succeed a little better, and make some trifling advance towards breaking the chain of spasmodic action. Experience will teach the careful groom the value of these minutiæ of practice; and the successful termination of many a case may be traced to the careful nursing of the patient.

When the horse is getting decidedly better, and the weather will permit, there can be no better practice than to turn him out for a few hours in the middle of the day. His toddling about will regain to him the use of his limbs; the attempt to stoop in order to graze will diminish the spasm in his neck; the act of grazing will relax the muscles of the jaws; and he can have no better food than the fresh grass.

\section{R A M P.}

This is a sudden, involuntary and painful spasm of a particular muscle or set of muscles. It differs from tetanus in its shorter duration, and in its occasionally attacking the muscles of organic life. It may be termed a species of transitory tetanus, affecting mostly the hind extremities. It is generally observed when the horse is first brought out of the stable, and especially if he has been hardly worked. One of the legs appears stiff, inflexible, and is, to a slight degree, dragged after the animal. After he has proceeded a few steps, the stiffness nearly or quite disappears, or only a slight degree of lameness remains during the greater part of the day.

Cramp proceeds from an accumulation of irritability in the muscles of the extensors, and is a sudden spasmodic action of them in order to balance the power which their antagonists have gained over them during the night.

If a certain degree of lameness remains, the attendant on the horse should endeavour to find out the muscle chiefly affected, which he may easily do by a feeling of hardness, or an expression of pain, when he presses on the extensors of the hock 
somewhat above that joint. He should then give plenty of good hand-rubbing, or a little more attention to the grooming generally, or a wider or more comfortable stall, as the circumstances of the case may appear to require.

\section{S TR I N G H A L T.}

This is a sudden and spasmodic action of some of the muscles of the thigh when the horse is first led from the stable. One or both legs are caught up at every step with great rapidity and violence, so that the fetlock sometimes touches the belly; but, after the horse has been out a little while, this usually goes off and the natural action of the animal returns. In a few cases it does not perfectly disappear aftcr exercise, but the horse continues to be slightly lame.

Stringhalt is not a perfectly involuntary action of a certain muscle, or a certain set of muscles. The limb is flexed at the command of the will, but it acts to a greater extent and with more violence than the will had prompted. There is an accumula. tion of excitability in the muscle, and the impulse which should have called it into natural and moderate action causes it to take on a spasmodic and, perhaps, a painful one.

Many ingenious but contradictory theories have been advanced in order to account for this peculiarity of gait. What muscles are concerned? Clearly those by which the thigh is brought under the belly, and the hock is flexed, and the pasterns are first flexcd, and then extended. But by which of them is the effect principally produced? What muscle, or, more properly, what nerve is concerned? Instead of entering into any useless controversy on this point, a case shall be related, and one of the most interesting there is on record: the author was personally cognisant of every particular.

Guildford, first called Roundhead, and then Landlord, was foaled in 1826. He was got by Hampden out of a Sir Harry Dimsdale mare. In 1828, and being two years old, and the property of the Duke of Richmond, he won a 50l. plate at Goodwood. In 1829, and belonging to Lord W. Lennox, he won 55 guineas at Hampton. Being then transferred to Mr. Coleman, he won 50 guineas at Guildford; and in the same year, having been purchased by Mr. Pearce, he won 60 guineas at Basingstoke.

In the course of this year stringhalt began to appear in a slight degree, and it evidently, although slowly, increased. There soon began to be a little difficulty in getting him off; but when he had once started, neither his speed nor his stoutness appeared to be in the slightest degree impaired. He continued on the turf until $\mathbf{1 8 3 6}$, and won for his different owners seventeen races, the produce of which, exclusive of bets, amounted to 1435 .

The difficulty and loss of advantage in starting had now increased to a degrec which rendered it prudent to withlraw him from the turf, and he came into the possession of Dockeray, who used him for the purpose of leading the young horses that he had under training. This is well known to be hard work, and his rider was a man of some weight. In addition to this, he was gencrally hunted twice in the week. His first starting into a gallop had something singular about it. It was a horrible kind of convulsive action, and so violent that he frequently knocked off his shoes on the very day that they were put on: but when he got a little warmed, all this disappeared. Ile gallopped beautifully, and was a very sure fencer. The sport, however, being over, and he returning to a slow pace, the stringhalt was as bad as ever.

At length the old horse became artful, and it was with great difficulty that he could be made to lead. Sometimes he refused it altogether. In consequence of this he was sent to St. Martin's Lane, to be sold. The highest bidding for him was $3 l .11 \mathrm{~s}$. , and the hero of the turf and the field was doomed to the omnibus. There he was cruelly used, and this spasmodic convulsion of his hind legs sadly aggravated his torture. The skin was presently rubbed from his shoulders, his hips and haunches were bruised in every part, and his stifles were continually and painfully coming in contact with the pole.

In this situation he was seen by the veterinary surgeon to "The Society for the Prevention of Cruelty to Animals." There is a fund at the disposal of that scciety for the purchase of worn-out horses, who are immediately released from their misery by 
the pole-axe of the knacker. The horse was bought for this purpose, another and laudable motive influencing the purchase,--the wish to ascertain what light the dissection of an animal that had had stringhalt to such an aggravated extent, and for so long a period, would cast on the nature of this disease.

The author of this work saw him a little while before he was slaughtered. He was still a noble-looking animal, and seemed to possess all his former strength and spirit unimpaired; but he was sadly scarred all over, in consequence of his being put to a kind of work for which his spasmodic complaint so entirely incapacitated him. So aggravated a case of stringhalt had rarely been seen. Both hind legs were affected, and both in an equal degree; and the belly was forcibly struck by the pastcrn joints every time the hind feet were lifted. The belly and the pastern joint were both denuded of hair, in consequence of this constant battering.

He was destroyed by the injection of prussic acid into the jugular vein, and the dissection of him was conducted by Professor Spooner, of the Royal Veterinary College.

On taking off the skin, all the muscles presented their perfect healthy character. There was not the slightest enlargement or discolouration of the fascix. The muscles of both extremities were dissected from their origins to their tendinous terminations, and their fibrous structure carefully examined. 'They were all beautifully developed, presenting no inequality or irregularity of structure, nor aught that would varrant the suspicion that any one of them possessed an undue power or influence beyond the others. The only abnormal circumstance about them was that they were of a rather darker yellow in colour than is usually found. This referred to them gencrally, and not to any particular muscle or sets of muscles. .

The lumbar, crural, and sciatic nerves were examined from the spot at which they emerge from the spinal cord to their ultimate distributions. 'The crural and lumbar nerves were perfectly healthy. The sciatic nerve, at the aperture through which it escapes from the spine, was darker in colour than is usual, being of a yellowishbrown hue. Its texture was softened, and its fibrillæ somewhat loosely connected together. The ncrve was of its usual size; but on tracing it in its course through the muscles of the haunch, several spots of ecchymosis presented themselves, and were more particularly marked on that part of the nerve which is connected witl the sacro-sciatic ligament. As the nerve approached the hock, it assumed its natural colour and tone; and the fibres given off from it to the muscles situated infcrior to the stifle-joint were of a perfectly healthy character.

On dissecting out a portion of the nerve where it appeared to be in a discascd state, it was found that this ecchymosis was confined to the membranors investiture of the nerve, and that its substance, when pressed from its sheath, presented a perfectly natural character.

The cavity of the cranium, and the whole extent of the spinal canal, were next laid open. The brain and the spinal marrow were deprived of their membranous coverings, and both the thecæ and their contents diligently examined. There was no lesion in any part of them, not even at the lumbar region.

'The articulations of every joint of the hind extremities, then underwent inspection, and no disease could bc detected in either of them.

Professor Spooner was of opinion that this peculiar affection was not referrible to any diseased state of the brain or spinal cord, nor to any local affection of the muscles of the limbs, but simply to a morbid affection of the sciatic nerve. He had not dissected a single case of stringhalt in which he had not found disease of this nerve, which mainly contributes to supply the hind extremities with sensation and the power of voluntary motion.

Now comes a very important question. What connexion is there betwecn stringhalt and the supposed value or deterioration of the horse? Some experienced practitioners have maintained that it is a pledge of more than usual muscular power. It is a common saying that "there never was a horse with stringhalt that was incapable of doing the work required of him." Most certainly we continually meet with horses having stringhalt that pleasantly discharge all ordinary, and even extraordinary, service; and although stringhalt is excess or irregular distribution of nervous power, it at least shows the existence of that power, and the capability in the mus- 
cular system of being acted upon by it. Irrcgular distributions of vital energy are not, however, things to be desired. 'They argue disease and derangement of the system, and a predisposition to greater derangement. They materially interfere with the speed of the horse. This was decidedly the case with regard to the poor fellow whose history has becn related.

Stringhalt is decided unsoundness. It is an irregular supply of the nervous influence, or a diseased state of the nervous or muscular system, or both. It prevents us from suddenly and at once calling upon the horse for the full exercise of his speed and power, and therefore it is unsoundness; but generally speaking, it so little interferes with the services of the animal, that although an unsoundness, it would not weigh a great deal against other manifest valuable qualities.

\section{CHOREA.}

This is a convulsive, involuntary twitching of some muscle or set of muscles. A few, and very few, cases of it in the horse are recorded. Professor Gohier relates one in which it attacked both fore legs, and espccially the left, but the affection was not constant. During five or six mınutes the spasms were most violent, so that the horse was scarcely able to stand. The convulsions then became weaker, the interval between them increased, and at length they disappeared, leaving a slight but temporary lameness. All means of cure were fruitlessly tried, and the disease continucd until the horse dicd of some other complaint. In another case it followed sudden suppression of the discharge of glanders and disappearance of the enlarged glands. This also was intermittent during the life of the animal.

\section{FITS, OR EPILEPSY.}

The stream of nervous inflnence is sometimes rapid, or the suspensions are considerable. 'This is the theory of Fits, or EpILEPsy. Fortunately the horse is not often afflicted with this disease, although it is not unknown to the breeder. The attack is not sudden. The animal stops - trembles - looks vacantly around him, and falls. Occasionally the convulsions that follow are slight; at other times they are terrible. The head and fore part of the horse are most affected, and the contortions are very singular. In a few minutes the convulsions cease; he gets np; looks around him with a kind of stupid astonishment; shakes his ears; urines; and cats or drinks as if nothing had happened.

The only hope of cure consists in discovering the cause of the fits; and an experienced practitioner must be consulted, if the animal is valuable. Generally speaking, however, the cause is so difficult to discover, and the habit of having fits is so soon formed, and these fits will so frequently return, even at a great distance of time, that he who values his own safety, or the lives of his family, will cease to use an epileptic horse.

\section{$\mathrm{P} \wedge \mathrm{L} \mathrm{S} \mathrm{Y}$.}

The stream of nervous influence is sometimcs stopped, and thence results palsy. The power of the inuscle is unimpaircd, but the nervous energy is deficient. In the human being, general palsy sometimes occurs. The whole body - every organ of motion and of sense is paralysed. The records of our practice, however, do not afford us a single instance of this; but of partial paralysis there are several cases, aud most untractable ones they were. The cause of them may be altogether unknown. In the human being there is yct another distinction, Hemiplegia and Paraplegia. In the former the affection is confined to one side of the patient; in the latter the posterior extremity on both sides is affected. Few cases of hemiplegia occur in the horse, and they are more manageable than those of paraplegia; but if the affection is not removed, they usually degenerate into paraplegia before the death of the animal. It would appear singular that this should be the most common form of palsy in the human being, and so rarely seen in the quadruped. There are some considerations, however, that will partly account for this. Palsy in the horse usually proceeds from injury of the spinal cord; and that cord is more developed, and far larger than in the human being. It is more exposed to injury, and to injury that will affect not one side unly, but the whole of the cord. 
Palsy in the horse generally attacks the hind extremities. The reason of this is plain. The fore limbs are attached to the trunk by a dense mass of highly elastic substance. This was placed between the shoulder-blade and the ribs for the purpose of preventing that concussion, which would be annoying and even dangerous to the horse or his rider. Except in consequence of a fall, there is scarccly the possibility of any serious injury to the anterior portion of the spine. The case is very different with regard to the hind limbs and their attachinent to the trunk; they are necessarily liable to many a shock and sprain injurious to the spine and its contents. The loins and the back oftenest exhibit the lesions of palsy, because there are some of the most violent muscular efforts, and there is the greatest morement and the least support. It may consequently be taken as an axiom to guide the judgment of the practitioner that palsy in the horse almost invariably proceeds from disease or injury of the spine.

On inquiry it is almost invariably found that the horse had lately fallen, or had been worked exceedingly hard, or that, covered with perspiration, he had been left exposed to cold and wet. It commences generally in one hind leg, or perhaps both are equally affected. The animal can scarcely walk - he walks on his fetlocks instead of his soles-he staggers at every motion. At length he falls. He is raised with difficulty, or he never rises again. The sensibility of the part seems for a while to be dreadfully increased; but, in general, this gradually subsides-it sinks below the usual standard-it ceases altogether.

If he is examined after death, there will usually, about the region of the loins, be inflammation of the membranes of the spinal cord, or of the cord itself. The medullary matter will be found of a yellow colour, or injected with spots of blood, or it will be softened, and have become semifluid.

The treatment is simple enough. It should commence witl bleeding, and, as has been already recommended in inflammatory cases, until the circulation is evidently affected - until the pulse begins to falter or the horse to reel. To this should follow a dose of physic-strong compared with the size of the animal. The loins should be covered with a mustard poultice frequently renewed. The patient should be warmly clothed, supplied plentifully with mashes, but without a grain of corn in them; and frequent injections should be had recourse to. This will soon render it evident whether the patient will recover or die. If favourable symptoms appear, the horse must not be in the slightest degree neglected, nor the medical treatment suspended. There is no disease in which the animal is more liable to a relapse, or where a relapse would be so fatal. No misapprehension of the disease, or false humanity, should induce the attendant to give the smallest quantity of corn or of tonic medicine. Palsy in the horse is an inflammatory complaint, or the result of inflemm?tion.

If the heat and tenderness are abating, and the animal regains, to a slight degree, the use of his limbs, or if it is becoming a case of chronic palsy, an extensive and stimulating charge over the loins should be immediately applied. It will accomplish three purposes: there will be the principle of counter-irritation-a defence against the cold-and a useful support of the limbs.

\section{R H E U M A T IS M.}

It is only of late years that this has been admitted into the list of the diseases of the horse, although it is in truth a very common affection. It is frequent in old horses that have been early abused, and among younger ones whose powers have been severely taxed. The lameness is frequently excessive, and the pain is evidently excruciating. The animal dares not to rest the slightest portion of its weight on the limb, or even to touch the ground with his toe. He is heaving at the flanks, sweating profusely, his countenance plainly indicative of the agony he feels; but there is at first no heat, or swelling, or tenderness. With proper treatment, the pain and the lameness gradually disappear; but in other instances the fasciæ of the muscles become thickened - the ligaments are also thickened and rigid - the capsules of the joint are loaded with a glairy fluid, and the joint is evidently enlarged. This is simply rheumatism; but if it is neglected, palsy soon associates itself with, or succeeds to, the complaint; and the loss of nervous power follows the difficulty or pain of moving. 
Every horseman will recollect cases in which the animal that seemed on the preceding day to be perfectly sound becomes decidedly lame, and limps as though he had lost the use of his limbs; yet there is no thickening of the tendons, nor any external inflammatory action to show the seat of the complaint. Mr. Cooper, of Coleshill, relates a case very applicable to the present subject. A farmer purchased a horse, to all appcarance sound, and rode him home - a distance of ten miles. He was worked on the two following days, withont showing the least lameness. On the third day it was with great difficulty that he managed to limp out of the stable. Mr. Cooper was sent for to examine him. The horse had clean legs and excellent feet. The owner would have him blistered all around. It was done. The horse was turned out to grass for two months, and came up perfectly sound. 'The weather soon afterwards became wet and cold, and the horse again was lame; in fact, it presently appeared that the disease was entirely influenced by the changes of the atmosphere. "Thus," adds Mr. C., "in the summer a horse of this description will be mostly sound, while in the winter he will be generally lame."

An account of acute rheumatism, by Mr. Thompson, of Beith, is too valuable to be omitted :- "I have had," says he, "fourteen cases of this disease. The muscles of the shoulders and arms were generally the parts affected. The cure was effected in a few days, and consisted of a good bleeding from the jugular, and a sharp purge.

"One of these cases was uncommonly severe. The disease was in the back and loins. The horse hrought forward his hind-legs under his flanks, roached his back, and drew up his flanks with a convulsive twitch accompanied by a piteous groan, almost every five minutes. The sympathetic fever was alarming, the pulse was 90 , and there was obstinate constipation of the bowels. The horse literally roared aloud if any one attempted to shift him in the stall, and groaned excessively when lying. He was bled almost to fainting ; and three moderate doses of aloes were given in the course of two days. Injections were administered, and warm fomentations were frequently applied to the back and loins. On the third day the physic operated briskly, accompanied by considerable nausea and reduction of the pulse. From that time the animal gradually recovered.

"These horses are well fed, and always in good condition; but they are at times worked without mercy, which perhaps makes them so liable to these attacks."

\section{NEUROTOMY.}

To enable the liorse to accomplish many of the tasks we exact from him, we have nailed on his fcet an iron defence. Without the protection of the shoe, he would not only be unable to travel over our hard roads, but he would speedily become useless to us. While, however, the iron protects his feet from being battered and bruised, it is necessarily inflexible. It cramps and confines the hoof, and often, without great care, entails on our valuable servant bad disease and excessive torture.

The division of the nerve, as a remedy for intense pain in any part of the frame, was systematically practised by human surgeons more than a-century ago. Mr. Moorecroft has the honour of introducing the operation of neurotomy in the veterinary school.

He had long devoted his powerful energies to the discovery of the causes and the cure of lameness in the fore-foot of the horse. It was a subject worthy of him, for it involved the interest of the proprietor and the comfort of the slave. He found that, partly from the faulty construction of the shoe, and more from the premature and cruel cxaction of labour, the horse was subject to a variety of diseases of the foot: all of them accompanied by a greater or less degree of pain - often of a very intense naturc, and ceasing only with the life of the animal.

He frequently met with a strangely formidable disease, in what was called "coffinjoint lameness," but to which Mr. James Turner afterwards gave the very appropriate name of " navicular-joint disease." It was inflammation of the synovial membrane, cither of the flexor tendon or navicular bone, or both, where the tendon plays over that bone; and it was accompanied by pain, abrasion, and gradual destruction of these parts.

For a long time he was foiled in every attempt which he made to remove or even to alleviate the disease. At length he turned his thoughts to the probability of sub- 
duing the increased sensibility of the part, by diminishing the proportion of nervous influence distributed on the foot. He laid bare one of the metacarpal nerves, and divided it with a pair of scissors. There was always an immediate and decided diminution of the lameness, and, sometimes, the horse rose perfectly sound. This happy result, however, was not always permanent, for the lameness returned after the lapse of a few weeks, or on much active exertion. He next cut out a small piece of the nerve. The freedom from lameness was of longer duration, but it eventually returned.

He then tried a bolder experiment. He excised a portion of the nerves going both to the inner and outer metacarpals. We transcribe his own account of the result of the first case of complete neurotomy-excision of the nerve on both sides of the legthat ever was performed.

"The animal, on rising, trotted boldly and without lameness, but now and then stumbled with the foot operated on. The wounds healed in a few days, and the patient was put to grass. Some weeks afterwards a favourable account was reccived of her soundness; but she was soon brought again to us, on account of a large sore on the bottom of the foot operated on, and extending from the point of the frog to the middle and back part of the pastern. The mare, in galloping over some broken glass bottles, had placed her foot upon a fragment of the bottom of one of them, and which had cut its way through the frog and tendon into the joint, and stuck fast in the joint for some seconds, while the animal continued its course apparently regardless of injury. The wound bled profusely, but the mare was not lame. Many days had elapsed before I saw her, and large masses of loose flesh were cut from the edges of the wound, without the animal showing the slightest sign of suffering pain. "The processes usually attending sores went on, with the same appearances that took place in sores of parts not deprived of sensibility. Such extensive injury, however, had been done to the joint as rendered the preservation of free motion in it very improbable, even were the opening to close, which was a matter of doubt, and therefore she was destroyed. It appeared clearly from this, that by the destruction of sensibility the repairing powers of the part were not injured; but that the natural guard against injury being taken away by the division of both the nerves, an accident was rendered destructive which, in the usual condition of the foot, might have been less injurious." *

The cut in the next page gives a view of the nerve on the inside of the leg, as it approaches the fetlock. -It will be seen that branches are given off above the letlock, which go to the fore part of the foot and supply it with feeling. The. continuation of the nerve below the fetlock is given principally to the quarters and hinder part of the foot. The grand consideration, then, with the operator is - does he wish to deprive the whole of the foot of sensation, or is the cause of lameness principally in the hinder part of the foot, so that he can leave some degree of feeling in the fore part, and prevent that alteration in the tread and going of the horse, which the horseman so much dislikes?

-The horse must be cast and secured, and the limb to be operated on removed from the hobbles and extended - the hair having been previously shaved from the part. The operator then feels for the throbbing of the artery, or the round firm body of the nerve itself, on the side of the shank bone or the larger pastern. The vein, artery, and nerve here run close together, the vein nearest to the front of the leg, then the artery, and the nerve behind. He cautiously cuts through the skin for an inch and a half in length. The vessels will then be brought into view, and the nerve will be distinguished from them by its lying behind the others, and by its whiteness. A crooked needle, armed with silk, is then passed under it, in order to raise it a little. It is dissected from the cellular substance beneath, and about three quarters of an incli of it cut out,- the first incision being made at the upper part, in which case the second incision will not be felt. The horse must then be turmer, and the operation performed on the other side; for there is a nervous trunk on both sides. The wounds are now closed with strips of adhesive plaster, a bandage placed over them, the head tied up for a couple of days, and the animal kept rather low, and as quiet as possible. The incisions will generally rapidly heal; and in three weeks or a month, and sometimes earlier, the horse will be fit for work. 


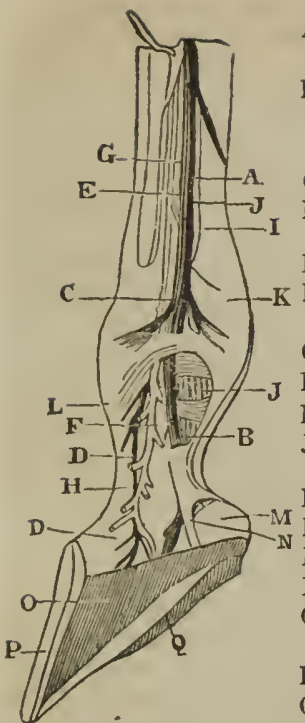

A The metacarpal nerve on the inside of the off leg at the edge of the shank bone, and behind the vein and artery.

$B$ The continuation of the same nerve on the pastern, and proceeding downward to supply the back part of the foot with feeling.

C The division of the nerve on the fetlock joint.

D The branch which supplies with feeling the fore part of the foot.

E The artery between the vein and nerve.

The continuation of the artery on the pastern, close to, and before the nerve.

G The vein before the artery and nerve.

$H$ 'The same vein spreading over the pastern.

I One of the flexor tendons, the perforatus (perforated).

$\mathrm{J}$ The deeper flexor tendon, the perforans (perforating, contained within the other).

$\mathrm{K}$ The tendinous band in which the flexors work.

L One of the extensors of the foot.

M The internal or sensible frog.

$\mathrm{N}$ The posterior lateral ligament.

O The fleshy or sensible lamina covering the coffin bone, the horny crust being removed.

$\mathrm{P}$ The horny crust.

Q The sole.

For ring-bone-the side cartilages becoming bony, and there heing partial stiffness of the pastern and coffin joints-the operation of nerving will probably be beneficial. The sense of pain being taken away, the animal will use these parts more, and they will gradually recover their natural action and motion. For the same reason, in old contraction of the feet, it is highly beneficial. The torture occasioned by the pressure of the horny crust on the sensible parts within being no longer felt, and the foot coming fully and firmly in contact with the ground, not only is lameness relieved, but the elasticity and form of the foot partially restored. Where lameness has long existed, unattended with heat of the foot or alteration of shape, and the seat of whicl could not be asccrtained, although probably existing between the navicular bone and the back tendon that plays over it, neurotomy may be resorted to with decided advantage.

Mischief, however, will result from the operation if the pastern or coffin joints are perfectly stiff, because the concussion occasioned by the forcible contant of the foot with the ground, and unbroken by the play of the joints, must necessarily still more injure the bone. When the sole of the foot is convex or pumiced, the effect of neurotomy will be most destructive. The sole scarcely able to bear the pressure of the coffin-bone, even when pain induccs the animal to put his foot as gently as possible on the ground, bcing forced below its natural situation, would be speedily worn through and destroyed. So if inflammation existed, although its pain might be removed, yet its progress would be quickened by the bruising to which the parts might be subjected; and more especially would this be the case, if there was any ulceration of the ligaments or cartilages.

The unfettered shoe of Mr. Turner being adopted, at least so far as we can have it unfettered - attached to the foot on one side alone, and the inner quarter being left frec - the foot gradually regains its original healthy form, and, when, in process of time, a new portion of nerve is produced, and the sensibility of the foot re-established, the horse continues to be sound. To some extent, immediate good effect is produced as it regards the actual disease. We remove that general constitutional irritability which long-continued pain occasions, and which heightens and perpetuates local disease. Wc obtain for the patient an interval of repose, and every local ailment soon suhsides or disappears, and the whole constitution become invigorated.

Mr. Percivall relates two valuable cases of this. A mare with contracted feet was $10^{*}$ 
never subject to periodical cstrum, and her owner lamented in vain that he could not breed from her. She underwent the operation of neurotomy, and became an excellent brood mare. A stallion with many a good point about him was useless in the stud: he was suffering from some disease in the feet. $\Lambda$ portion of the nerve was excisedhis constitution underwent a complete change, and he became sire to a numerous and valuable progeny.

By thc operation of neurotomy we destroy pain; and we may safely calculate on the simple effect of that, whether local or constitutional; and, limiting our expectations to this, we shall rarely be disappointed.

The operation of neurotomy having been performed, has the veterinary surgeon nothing else to do? He has got rid of the pain which attended the ossified cartilage - the ring-bone and the anchylosis of the pastern and the coffin-joints; shall he be satisfied with the benefit he has obtained, great as it is? He will, or he should now try whether his former means and appliances have not more power. He will sce whether, by means of his blister or his firing-iron-the effect of which humanity forbade him to put to the full test before - he cannot rouse the absorbents to increascd and more efficient action, and not only arrest the progress of the bony tumour, but remove it. He will not merely sufier the uscfulness of his patient to depend on the continued suspension of feeling, but he will assure it by the partial or total removal of the morbid growth.

In contraction of the foot, shall he be satisfied with removing the agony occasioned by the corstant pressurc of the horn on the sensitive substance interposed between it and the coffin-bone? Shall he leave future improvcment to the slow process of naturc, or shall he not take advantage of the insensibility which he has produced, and pare the sole thoroughly out, and rasp the quarters to the vcry quick, and apply the unfettered shoe? When he has produced a disposition to contraction, and some degree of it, should he not actively blister the coronets, and usc all other fitting means to hasten the growth of the horn to its pristine dimensions and its original quality?

In navicular disease, after he has removed, by the application of neurotomy, that irritation which had so much to do with the perpctuation, if not the origin, of the complaint, should he not, with the assured hope of success, pass his seton ncedle through the frog, in order to get rid of every rcinaining lurking tendency to inflammation? The blister and the firing-iron will have as much power in abating inflammation and producing a hcalthy state of the foot, after that foot had been rendered insensible to pain, as it had before. We should fearlessly say that it would have much more effect, one grand source of irritation having been removed. The vetcrinary surgeon and the owner of the horse are becoming more and more convinced of this; and the dawning of a better day has commenced.

The principle of reurotomy is plain and simple-it is the removal of pain. Taken on this ground, it is a noble operation. It is that in which every friend of humanity will rcjoice. It may be abused. If no auxiliary means are adopted-if in canker or quittor, or inflammation of the laminæ, no means are used to lessen the concussion and the pressure-the destruction of the part and the utter ruin of the horse are the inevitable consequences. The primary result is the rcmoval of pain. It is for the operator to calculate the bearing of this on the actual disease, and the futurc usefulness of the animal.

On the question of the reproduction of the nerves there is no doubt. A horse is lame, and hc undergoes the operation of neurotomy. At the expiration of a certain time the lameness rcturns, and he is probably destroycd. In the majority of cascs it is found that the nerves had united, or rather that a new veritablc nervous substance had becn interposed. The time at which this is effected is unknown. There have not been any definite experiments on the point.

Can the horse that has undergone the opcration of neurotomy be afterwards passed as sound? Most certainly not. There is altered, impaired structurc; there is impaired acticn; and there is the possibility of the return of lamcness at some indefinite period. He has been diseased. He possibly is diseased now; but the pain being rcinoved, there are no means by which the mischief can always be indicated. Beside, by the very act of neurotomy, he is peculiarly exposed to various injuries and affections of the foot from which he would otherwise escape. 


\section{N S A N I T Y .}

There is no doubt that the animals which we have subjugated possess many of the same montal faculties as the human being-volition, memory, attachment, gratitude, resentment, fear, and hatred. Who has not witnessed the plain and inanifest display of these principles and feelings in our quadruped dependants? The simple possession of these faculties implies that they may be used for purposes good or bad, and that, as in the human being, they may be deranged or destroyed by a multitude of causes which it is not necessary to particularise. In the quadruped as in the biped, the lesion or destruction of a certain part of the brain may draw after it the derangement, or disturbance, or perversion of a certain faculty of the mind. It is only because the mental faculties, and good as well as had properties of the inferior beings, have been so lately observed and acknowledged, that any doubt on this point can for a moment be entcrtaincd. 'The disordered actions, the fury, the caprices, the vices, and more particularly the frenzy and total abandonment of reason, which are occasionally shown by the brute, are in the highest degree analogous to eertain acts of insanity in man. It is merely to complete our subject that they are here introduced.

The reader is indebted to Professor Rodct, of Toulouse, for the anecdotes which follow : $\mathbf{A}$ horse, seven ycars old, was remarkable for an habitual air of stupidity, and a peculiar wandering expression of countenance. When he saw anything that he had not bcen accustomed to, or heard any sudden or unusual noise, whether it was near or at a distance, or somctimes when his corn was thrown into the manger without the precaution of speaking to him or patting him, he was frightencd to an almost incredible degrec; he recoiled prccipitatcly, evcry limb trembled, and he struggled violently to escape. After several useless efforts to get away, he would work himself into the highest degree of rage, so that it was dangerous to approach him. This state of cxcitement was followed by dreadful convulsions, which did not cease until he had broken his halter, or otherwise detached himself from his trammels. $\mathrm{He}$ would then become caim, and suffer himself to be led back to his stall: nor would anything more be seen but an almost continual inquietude, and a wandering and stupid expression of countenance. He had belonged to a brutal soldier, who had beaten him shamcfully, and before which time he had been perfectly quiet and tractable.

A Piedmontese officer possessed a beautiful and in other respects serviceable mare; but which one peculiarity rendered exceedingly dangerous - that was a decided aversion to paper, which she recognised the moment she saw it, and even in the dark if two leaves were rubbed together. The effect produced by the sight or sound of it was so prompt and violent, that she several times unhorsed her ridcr. She had not the slightest fear of objects that would terrify most horses. She regarded not the music of the band, the whistling of the balls, the roaring of the cannon, the fire of the bivouacs, or the glittering of arms. The confusion and noise of an engagement made no impression upon her; the sight of no other white object affected her. No other sound was regarded; but the view or the rustling of paper roused her to madness.

A mare was perfectly manageable and betraycd no antipathy to the human being, nor to other aninals, nor to horses, cxcept they wcre of a light-grcy colour; but the moment she saw a grey horse, shc rushed towards it, and attacked it with the greatest fury. It was the samc at all times, and everywhere. She was all that could be wished on the parade, on the route, in the ranks, in action, and in the stable; but if she once eaught a glimpse of a grey or white horse, she rested not until she had thrown her rider or broken her halter, and then she rushed on her imagined foe with the greatest fury. She generally contrived to scize the animal by the head or throat, and held him so fast that she would suffocate him, if he were not promptly released from her bite.

Another marc exhibited no terror except of white inanimate objects, as white mantles or coats, and particularly white plumes. She would fly from them if she could; but if she was unable to accomplish this, she would rush furiously upon them, strike at them with her fore feet, and tear them with her teeth.

These instances are selected from various others, because they approach so nearly to wliat would be termed insanity in the human being. It is confined to one object, - 
it is a species of monomania, and as decided insanity as ever the biped discovered. One of these horses, the second, was by long and kind attention divested of this insane terror, and became perfectly quiet and useful; but the other three bid defiance to all means of cure and to coercion among the rcst. If sufficient attention wcre paid to the subject, many of the obstinate caprices and incxplicable aversions which we can neither conquer nor change would be classed under the term insanity. There cannot he a more remarkable analogy than that which sometimes exists between the insanity of man and thesc singularly capricious fancies in animals. The subject is worthy of attention. Has the principle of hereditary predisposition been applicd to any of these anomalies?

\section{DISEASES OF THE EYE.}

The diseases of the eye constitute a very important, but a most unsatisfactory division of our work, for the maladies of this organ, although few in number, are frequent in their appearance. 'They are sadly obstinate, and often baffle all skill.

We have spoken of Fracture of the orbit, and its treatment. Occasionally a wound is inflicted by a passionate or careless scrvant. The eye itself is rarely injured. It is placed on a mass of fat, and it turns most readily, and the prong of the fork glances off; but the substance round the eye may be decply wounded, and very considerable inflammation may cnsue. This should be abated by poultices, and bleeding, and physic; but no probe should bc used under the foolish idca of ascertaining the depth of the wound in the lid, supposing that there should be one, for, from the constant motion of the eye, it is almost impossible to pass the probe into the original wound, and the effort to accomplish it would give a great deal of pain, and increase the inflammation.

The eyclids are subject to occasional inflammation from blows or other injuries. Fomentation with warm water will be serviceable here.

The horse has occasionally a scaly eruption on the edges of the eyelids, attended with great itching, in the effort to allay which, by rubbing the part, the eye may be blemished. The nitrated ointment of quicksilver, mixed with an equal quantity of lard, may be slightly rubbed on the edges of the lids with considerable good cffect.

The eyelids will sometimes become œdematous. Horses that are fed in low and humid pastures are subject to this. It is also the consequence of inflammation badly treated. The eyelids are composed of a lax structure, and the tissue is somewhat deficient in vitality-hence this disposition to enfiltration. Sometimes the collection of fluid accumulates so rapidly, and so extensively, that the eyes are closed. They should be well bathed with warm water mingled with an aromatic tincture. The cellular substance of the lids will thus be disposed to contract on their contents and cause their absorption.

Old carriage horses are subject to this œdema; and it frequently accompanies both chronic and common ophthalmia.

Weakness and dropping of the upper lid is caused by diminution or loss of power in its muscles. Dry frictions and aromatic lotions will frequently restore the tone of the parts.

The eyelids are subject to occasional injury from their situation and office. In small incised wounds of them great care should be taken that the divided edges unite by the first intention. This will hasten the cure, and prevent deformity. If any of the muscles are divided, it is usually the ciliary or orbicularis palpebrarum. This lesion must be healed, if possiblc, by the first intention, and either by means of adhesive plaster or the suture. The suture is probably the preferable agent.

Suppurating wounds in the cyelids may be the consequence of the necessary abstraction of a considerablc surface of the skin, in the removal of warts or tumours. The principal thing to be attended to is the frequent removal of the pus by means of tow or cotton wool. The rest may generally be left to nature.

Inversion of the lids is of very rare occurrence in the horse.

Warts are sometimes attached to the edges of the lids, and are a source of great irritation. When rubbed they bleed, and the common opinion is true-that they are propagated by the blood. They should be taken off with a sharp pair of scissors, and their roots touched with the lunar caustic. 
The membranc which covers the Haw is subject to inflammation. It is, indecd, a continuation of the conjunctiva, the inflammation of which constitutes ophthalmia. An account of this inflammation will be better postponcd until the nature and treatment of ophthalmia come under particular notice.

The Haw, or Membrana Nictitans, is subject to inflammation peculiar to itself, arising from the introduction of foreign bodics, or from blows or other accidents. The cntire substance of the haw becomes inflamed. It swells and protrudes from the inner anglc of the eye. 'The heat and redness gradually disappear, but the membrane often continues to protrude. The inflammation of this organ often assumes a chronic character in a very short time, on account of the structure of the parts, which are in general littlc susceptible of reaction.

The ordinary causes of this disease in the horse are repeated and periodical attacks of ophthalmia, and blows on the part. Young and old horses are most subject to it.

linollient applications, bleeding, and restricted diet will be proper at the commencement of the disease, and, the inflammation being abated, slight astringents will be useful in preventing the engorgement of the part. Rose-water with subacetate of lead will form a proper collyrium. If the protruding body does not diminish after proper means liave becn tried, and for a sufficient period, it must be removed with a curved pair of scissors. No danger will attend this operation if it is performed in timc; but if it is neglected, ulceration of the part and the growth of fungous vegetations will give a serious character to the affair. A second operation may also be necessary, and even a third, and fungus hæmatodes will probably be established.

Ulceration and caries of the cartilage will sometimes be accompanied by ulceration of the conjunctiva. This will frequently prove a very serious affair, demanding, at least, the removal of the haw.

'The Caruncula Lacrymalis, or Tubercle, by means of which the tears are directed into the canal through which they are to escape from the nostril, is sometimes enlarged in consequence of inflammation, and the Puncta Lacrymalia, or conduits into which the tears pass from the eye, are partially or complctely closed. The application of warm and emollient lotions will generally remove the collected mucus or the inflammation of the parts; but if the passage of a stylet or other more complicated mcans are required, the assistance of a veterinary surgeon should be immediately obtained. The lacrymal sac into which the tears pass from the puncta has occasionally participated in the inflammation, and been distended and ruptured by the tears and mucus. This lesion is termed Fistula Lacrymalis. It has occasionally existed in colts, and will require immediate and peculiar treatment.

\section{COMMON INFLAMMATION OF THE EYE.}

The conjunctiva is occasionally the seat of great disease, and that which is too often destructive to the eye. Inflammation of the eye may be considered under two forms-thc common and manageable, and the specific and fatal. The Common Inflammation is generally sudden in its attack. The lids will be found swelled and the cyes partially closed, and some weeping. The inside of the lid will bc red, some red strcaks visible on the white of the eye, and the cornea slightly dim. This is occasionally connectcd with some degree of catarrh or cold; but it is as often unaccompanied by this, and depends on external irritation, as a blow, or the presence of a bit of hay-seed or oat-husk within the lid, and towards the outer corner where the haw cannot reach it: therefore the lids should always be carefully examined as to this possible source of the complaint. The health of the animal is generally unaffccted-he feeds well, and performs his work with his usual spirit. Cooling applications to the eye, as the Goulard's extract or tincture of opium, with mash-diet, and gentlc physic, will usually abate the evil; or the inflammation will subside without medical trcatment.

\section{SPECIFIC OPHTHALMIA, OR MOON-BLINDNESS.}

Should three or four days pass, and the inflammation not be abated, we may begin to suspect that it is Ophthalmia, especially if the eye is very impaticnt of light, and the cornea is considerably clouded. The aqueous humour then often loses its trans- 
parency-even the iris changes its colour, and the pupil is excredingly contracted. The veterinary surgeon has now an obstinate disease to combat, and one that will generally maintain its ground in spite of all his efforts. For three, or four, or five weeks, the inflammation will remain undiminished; or if it appears to yield on one day, it will return with redoubled violence on the next. At length, and often unconnected with any of the means that have been used, the eye begins to bear the light, the redness of the membrane of the lid disappears, the cornea clears up, and the only vestige of disease which remains is a slight thickening of the lids and apparent uneasiness when exposed to a very strong light.

If the owner imagines that he has got rid of the disease, he will be sadly disappointed, for, in the course of six weeks or two months, either the same eye undergoes a second and similar attack, or the other one becomes affected. All again seems to pass over, except that the eye is not so perfectly restored, and a slight, deeply-seated cloudiness begins to appear; and after repeated attacks, and alternations of disease from eye to eye, the affair terminates in opacity of the lens or its capsule, attended with perfect blindness either of one eye or both. This affection was formerly known by the name of moon-blindness, from its periodical return, and some supposed influence of the moon. That body, however, has not, and cannot have anything to do with it.

What is the practitioner doing all this while? He is an anxious and busy, but almost powerless spectator. He foments the eyes with warm water, or applies cold lotions with the extract of lead or opium, or poultices to which these drugs may be added; he bleeds, not from the temporal artery, for that does not supply the orbit of the eye, but from the angular vein at the inner corner of the eye, or he scarifies the lining of the lid, or subtracts a considerable quantity of blood from the jugular vein. The scarifying of the conjunctiva, which may be easily accomplished with. out a twitch, by exposing the inside of the lids, and drawing a keen lancet slightly over them, is the most effectual of all ways to abate inflammation, for we are then immediately unloading the distended vessels. He places his setons in the cheek, or his rowels under the jaw; and he keeps the animal low, and gives physic or fever medicine (digitalis, nitre, and emetic tartar.) The disease, however, ebbs and flows, retreats and attacks, until it reaches its natural termination, blindness of one or both eyes.

The horse is more subject to this disease from the age of four to six years than at any other period. He has then completed his growth. He is full of blood, and liable to inflammatory complaints, and the eye is the organ attacked from a peculiar predisposition in it to inflammation, the nature or cause of which cannot always be explained. Every affection of the eye appearing about this age must be regarded with much suspicion.

It is a common opinion that black horses are more subject to blindness than others. There is considerablc doubt about this, or rather it is probable that that colour has no influence either in producing or aggravating the disease.

As this malady so frequently destroys the sight, and there are certain periods when the inflammation lias seemingly subsided and the inexperienced person would be deceived into the belief that all danger is at an end, the eye should be most carefully observed at the time of purchase, and the examiner should be fully aware of all the minute indications of previous or approaching disease. They are a slight thickening of the lids, or puckering towards the inner corner of the eye; a difference in the apparent size of the eyes; a cloudiness, although perhaps scarcely perceptible, of the surface of the cornea, or more deeply seated, or a hazy circle round its edge; a gloominess of eye generally, and dulness of the iris ; or a minute, faint, dusky spot in the centre, with or without minute fibres or lines diverging from it.

The cause of this inflammation is undoubtedly a strong predisposition to it in the eye of the horse, but assisted by the heated and empoisoned air of many stables. The heated air has much to do with the production of the disease; the empoisoned air a great deal more: for every one must have observed, on entering a close stable early in the morning, strong fumes of hartshorn which were painful to his eyes and caused the tears to flow. What must be the constant action of this on the eyes of the horse? The dung of the horse, and the litter of the stables, when becoming putrid, emit 
fumes of volatile alkali or hartshorn. Often, very soon after they are voided, they begin to yield an immense quantity of this pungent gas. If we are scarcely able to bear this when we stand in the stable for only a few minutes, we need not wonder at the prevalence of inflammation in the eye of the stabled horse, nor at the difficulty of abating inflammation while this organ continues to be exposed to such painful excitement. Stables are now much better ventilated than they used to be, and ophthalmia is far from being so prevalent as it was fifty years ago.

The farmer may not be aware of another cause of blindness, to which his horse is more particularly exposed, viz., confinement in a dark stable. Many stables in the country have no glazed windows, but there is a flap which is open for a few hours in the day, or while the carter is employed in the stable, and when that is shut down almost total darkness prevails. Let our reader consider what are his sensations when he suddenly emerges from a dark room into the full glare of light. $\mathrm{He}$ is dazzled and bewildered, and some time passes before his vision is distinct. Let this be repeated several times daily, and what will be the consequence? The sight will be disordered, or the eye irreparably injured. Then let him think of his poor horse, who often stumbles and starts through no fault of his own, although he is corrected for his blundering, but because his eyes are necessarily weakened by these sudden transitions, and disposed to take on sudden inflammation with all its fatal results.

The propagation of various diseases, and this more than any other, from the sire to his progeny, has not been sufficiently considered by breeders. Let a stallion that is blind, or whose sight is defective, possess every other point and quality that can be wished, yet he is worse than useless ; for a very considerable proportion of his offspring will most assuredly inherit weak eyes or become totally blind. There is no fact better established than this.

Mr. Baker of Reigate puts this in a very strong point of view. He was called upon to examine a foal only a few days old, which seemed to have some affection of the head, as from its birth it was totally unconscious of any object, although it appeared to the owner to have good eyes. It ran its head against the wall and the standers by, in such a way as to convince the surgeon that it was quite blind, and on examining the pupil of each eye, he found them greatly dilated and motionless, but beyond this there was no unhealthy appearance.

He inquired about the sire, and found that his vision was very defective, and that of all the stock which he got in that part of the country not one colt escaped the direful effects of his imperfect sight. He persuaded the owner to have the youngster destroyed, and in tracing the optic nerve in its passage from the base of the brain, he found it in a complete state of atrophy. 'There was scarcely any nervous substance within the tube that led from the brain to the eye.

The most frequent consequences of this disease are cloudiness of the eye, and cataract. The cloudiness is singular in its nature. It will change in twenty-four hours from the thinnest film to the thickest opacity, and, as suddenly, the eye will nearly regain its perfect transparency, but only to lose it, and as rapidly, a second time.

'The most barbarous methods have been resorted to for the purpose of removing this cloudiness. Chalk, and salt, and sugar, and even pounded glass have been introduced into the eye mechanically to rub off the film. It was forgotten that the cloudiness was the effect of inflammation - that means so harsh and cruel were very likely to recall that inflammation - that these rough and sharp substances must of necessity inflict excruciating pain; and that, after all, it generally was not a film on the surface of the cornea, but a dimness pervading its substance, and even sinking deep within it, and therefore not capable of being removed. Where the cloudiness can be removed, it will be best effected by first abating inflammation, and then exciting the absorbents to take up ise grey deposit, by washing the eye with a very weak solution of corrosive sublimate.

Opacity of the lens is another consequence of inflammation. A white speck appears on the centre of the lens, which gradually spreads over it, and completely covers it. It is generally so white and pearly as not to be mistaken-at other times it is inore hazy, deceiving the inexperienced, and occasioning doubt in the mind of professional men. We have seen many instances in which the sight has been considerably 
affected or almost lost, and yet the horse has been pronounced sound by very fair judges. The eye must be exposed to the light, and yet under the kind of shelter which has been already described, in order to discover the defect. The pupil of the horse is seldom black, like that of the human being, and its greyish hue conceals the recent or thin film that may be spreading over the lens.

Confirmed cataract in the eye of the horse admits of no remedy, for two obvious reasons: the retractor muscle draws the eye back so powerfully and so deeply into the socket, that it would be almost impossible to perform any operation; and, could an operation be performed, and the opaque lens removed, the sight would be so imperfect, from the rays of light not being sufficiently converged, that the horse would be worse to us than a blind one. The man who has undergone the operation of couching may put a new lens before his eye, in the form of a convex spectacle; but we cannot adapt spectacles to the eye of the horse, or fix them there.

Since the publication of the first edition of "The Horse," some controversy has taken place with regard to the occasional appearance and disappearance of cataract without any connexion with the common moon-blindness. Mr. Clay deposed in evidence, that cataracts might be formed in a fortnight or three weeks - that he had known many instances in which they had been completed in less time, and without any previous apparent disease of the eyes; and that he had detected them when the owners had not the slightest suspicion of disease in the cye.*

Mr. Cartwright adds, that he has known two similar cases. The first was of a loorse that had two cataracts in each eye-two of tliem of the size of a large pin's head, and the other two treble that size. There was no vestige of former inflammation; and the person who bred him said that he never had been subject to inflammation of the eye. In December 1831, these cataracts were plain enough; but in the autumn of 1832 , they had completely vanished.

In November 1832, Mr. Cartwright saw a five-years old mare, and detected a cataract in the right eye, of the size of a coriander seed. He advised the owner to get rid of her, thinking that she would go blind; but, being a useful animal, he kept her. In August 1833, Mr. Cartwright saw her again. The cataract had disappeared and the eyes were perfect.

That excellent veterinarian, Mr. Percivall, had a somewhat similar case. A gentleman brought a horse one morning to the hospital, in consequence of its having fallen in his way to town, and grazed his eyebrow. On examining him carefully, the cornea was partially nebulous, and a cataract was plainly visible. Neither of these defects was sufficient to attract the notice of any unprofessional observer, and both were unconnected with the slight bruise produced by the fall. The owner was told that the corneal opacity might possibly be removed; but as for the cataract, he might regard this as beyond the reach of medicine. He returned with his horse on the fifth day, saying that the physic had operated well, and that he thought the eye was as clear as ever. Mr. Percivall examined the eye, and could discover no relic either of the corneal opacity or of the cataract.

The opinion respecting cataract is therefore essentially modified. It is not necessarily the result of previous inflammation, although in the great majority of cases it is so, nor does it always lead to blindness. Still it is a serious thing at all times, and, although existing in the minutest degree, it is unsmendness, and very materially lessens the value of the horse.

"Were I asked," says Mr. Percivall, " how the practitioner could best distinguish a cataract of the above description from that which is of ordinary occurrence, and known by us all to constitute the common termination of periodical ophthalmia, I should say that the unusually lucid and heal thy aspect which every other part of the eye presents is our best diagnostic sign; the slightest indication, however, or the slightest suspicion of prior or present inflammation, being a reason for coming to a different conclusion. As to the period of time a cataract of this species, supposing it to be membranous, would require for its formation, I should apprehend that its production might be, as its disappearance often would seem to be, the work of a very short interval, perhaps not more than five or six days." As to the cause and treatment of it, 
we are at present completely in the dark. If it does not soon disappear, the hydriodate of potash administered internally might offer the best prospect of success.

\section{G U T'T A S ER ENA.}

Another species of blindness, and of which mention was made when describing the retina, is Gutta Serena, commonly called glass eye. The pupil is more than usually dilated : it is immovable, and bright, and glassy. This is palsy of the optic nerve, or its expansion, the retina ; and is usually produced by determination of blood to the head. We have described it as a consequence of staggers. So much pressure has been occasioned on the base of the brain, that the nerve has been injured, and its function destroyed. The treatment of Gutta Serena is quite as difficult as that of cataract. We have heard of successful cases, but we never saw one; nor should we be disposed to incur much expense in endeavouring to accomplish impossibilities. Reasoning from the causc of the disease, we should bleed and physic, and administer the strychnine in doses, commencing at half a grain, and not exceeding two grains, morning and night-very carefully watching it. If we succeed, it must be by constitutional treatment. As to local treatment, the seat of disease is out of our reach.

\section{DISEASES OF THE EAR.}

Wounds of the ear are usually the conscquence of careless or brutal trcatment. The twitch may be applied to it, when absolute nccessity requircs this degree of coercion; but troublesome ulcers and bruises have been the consequence of the abuse of this species of punishment, and more especially has the farrier donc irreparable mischief when he has brutally made use of his plyers.

These bruises or wounds will generally - fortunately for the animal, and fortunately, perhaps, for the brute that inflicted the injury-speedily heal; but occasionally sinuses and abscesses will result that bid defiance to thc most skilful treatment. A simple laceration of the cartilage is easily remedied. The divided edges are brought into apposition, and the hcad is tied up closely for a few days, and all is well; but, occasionally, ulceration of the integument and cellular substance, and caries of the cartilage, will take place-deep sinuses will be formed, and the wound will bid defiance to the most skilful treatment. The writer of this work had once a case of this kind under his carc more than two months, and he was at length compelled to cut off the ear, the other ear following it, for the sake of uniformity of appearance. The lunar caustic, or the muriate of antimony, or the hcated iron, must bc early cmploycd, or the labour of the practitioncr will be in vain.

It has been the misfortune of the same person to witncss two cases in which the auditory passagc was closed and the faculty of hearing destroyed, by blows on the ear violently inflicted. No punishment can be too severe for these brutes in human shape. Whencver there is considerable swelling about the root of the ear, and the fluctuation of a fiuid within can be detected, it should be immediately opened with a lanect, and the purulent fluid liberated.

The abscess usually begins to fonn about the middle of the conch, or rather nearer the base than the point. 'The incision should bc of considerable length, or the opening will close again in four-and-twenty hours. The purulent matter having been evacuated, the incision should not be permitted to close until the parietes of the ulcer have adhered to cach other, and the abscess is obliterated.

The size and the carrying of the ear do not always plcase. The cars may be larger and more dependent than fashion requires them to be, and this is remedied by paring cr clipping them to the requisite sizc. On eithcr side of the projection of the occipital bone, and in a straight line forward and backward, a fold of the skin is pinchcd up and cut away. The divided edges on either side are then brought together, and confined by two or three stitches - they presently unite, and the owner has a betterlooking horsc, and soon forgcts or cares not about the punishment which he has inflicted on him.

'The ears of other horses may be supposed to be too close to each other. This fault is corrected by another piece of cruelty. Similar slips of skin are cut away on the outside of the base of the ear, and in the same direction. The edges of the wound 
are then brought together, confined by sutures, and the ears are drawn further apart from each other, and have different directions given to them. A very slight examination of either of the horses will readily detect the imposition.

\section{E A F N ES S.}

Of the occasional existence of this in the horse, there is no doubt. The beautiful play of the ears has ceased, and the horse hears not the voice of his master, or the sound of the whip. Much of the apparent stupidity of a few horses is attributable to their imperfect hearing. It occasionally appears to follow the decline of various diseases, and especially of those that affect the head and the respiratory passages. It has been the consequence of brutal treatment closing the conduit of the ear, or rupturing the tympanum; and it is certainly, as in other domesticated animals, the accompaniment of old age.

In the present state of veterinary knowledge, it is an incurable complaint; the only thing that can be done is not to punish the poor slave for his apparent stupidity, produced perhaps by over-exertion in our service, or, at least, the natural attendant of the close of a life devoted to us.

\section{CHAPTER IV.}

\section{THE ANATOMY AND DISEASES OF THE NOSE AND MOUTH.}

We now proceed to a description of the face, or lower part of the head of the Horse. The nasal bones, or bones of the nose $(j j, \mathrm{p} .70$, and $a, \mathrm{p} .72)$, are connected with the frontal bones above, and with the lacrymal, $i$, and the bones of the upper jaw, $l l$, on either side. They are united together by a plain suture, which is a continuation of the frontal, and they terminate in a point at the nostril $(p, p, 70)$. They are rounded and arched above, because they are exposed to occasional violence and injury, which the arch-form will enable them best to resist; and at the base of the arch, where the main strength should be, they are overlapped by the upper jaw-bone, as the temporal bone overlaps the base of the parietal. 'These bones form a principal part of the face; and the length, or shortness, and the character of the face, depend upon them. Sometimes there is an appearance of two little arches, with a depression between them along the sutures. 'This is often found in the blood-horse with his comparatively broad head and face. The single elevated arch is found in the long and narrow face of the heavy draught-horse.

The nasal bones pursue their course down the face, in some horses in a straight line-in others, there is a slight prominence towards the upper part, while in a considerable number, a depression is observed a little lower down. Some persons have imagined that this deviation in the line of the face affords an indication of the temper of the animal, and there may be a little truth in this. 'The horse with a straight profile may be good or bad tempered, but not often either to any great excess. The one with the prominent Roman nose will generally be an easy, good-tempered kind of beast-hardy-ready enough to feed, not always, perhaps, so ready to work, but may be made to do his duty without any cruel urging, and having no extraordinary pretension to speed or blood. On the other hand, a depression acrcss the centre of the nose generally indicates some breeding, especially if the head is small, but occasionally accompanied by a vicious, uncontrollable disposition.

There is another way, however, in which the nasal bones do more certainly indicate the breed, viz., by their comparative length or shortness. 'There is no surer criterion of a well-bred horse, than a broad angular forehead, prominent features, and a short face; nor of a horse with little breeding, than a narrow forehead, small features, and lengthened nose. The comparative development of the head and face indicates, with little error, the preponderance of the animal or intellectual principle.

Fracture of the nasal bones of the horse will sometimes occur from falling, or a kick 
from the companion, or the brutality of the attendant. It is generally followed by laceration of the lining membrane of the nostrils, and by hæmorrhage. The hæmorrhage may usually be arrested by the application of cold water externally. In spontaneous hæmorrhage this does not often succeed until a considerable quantity of blood is lost.

In cases of fracture of the nasal bones, the assistance of a veterinary surgeon is indispensable. He alone knows the precise anatomy of the parts, and will have recourse to the elevator or the trephine, as circumstances may require.

The owner nust not be too sanguine with regard to cases of this kind, for ozena,ulceration attended by a peculiar and almost insufferable stench-is too often the consequence, or foundation may be laid, for the appearance, of glanders.

Spontaneous bleeding from the nose must be carefully attended to. It may proceed from over-fulness of the capillaries of the membrane of the nose, or determination of blood to the head, or general plethora of the system. Those that are overfed and overfat are most liable to it, as troop-horses, brewers' horses, and horses kept for pleasure. It is not common in young horses, or in such as are out of condition, or worked hardly. It is always desirable to know whence the bleeding proceeds - if from the nostril alone, it will usually be confined to one side-if from the lungs, the discharge is from both nostrils, and generally mingled with mucus, or spume,--there is also a quickened respiration, and more or less cough.

If it is apparently connected with some slight cause, a dose of physic and quietness for a day or two will be sufficient, and, if aecessary, a slight solution of alum may be injected up the nostril. If the bleeding is apparently from the lungs, a more serious evacuation will be required.

These bones form the roof of an important cavity (see $\alpha, \mathrm{p} .72$ ). The sides are constituted above by the nasal bones, and, lower down, by the upper jaw-bones, (superior maxillaries), while plates from these latter bones project and compose the palate, which is both the floor of the nose and the roof of the mouth $(t, \mathrm{p} .72)$. Above (near fig. 8), not visible in our cut, is a bone called the palatine, although it contributes very little to the formation of the palate. It is the termination of the palate, or the border of the opening where the cavities of the mouth and nose meet (fig. 8). The frontal sinuses, $b$, and large vacuities in the upper jaw-bone, and in the æthmoid, $l_{2}$ and sphenoid bones, $k$, communicate with and enlarge the cavity of the nose.

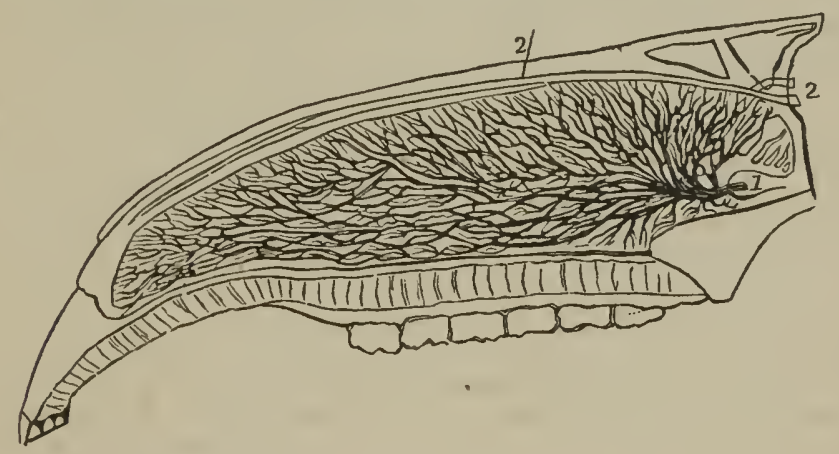

This cavity is divided into two parts by a cartilage called the Septum (see $a$, p. 72). It is of considerable thickness and strength, and divides the cavity of the nose into two equal parts. It is placed in the centre for the purpose of strength, and it is formed of cartilage, in order that, by its gradual yielding resistance, it may neutralize almost any force that may be applied to it.

When we open the nostril, we see the membrane by which the cartilage, and the whole of the cavity of the nose, is lined, and by the colour of which, much more than by that of the lining of the eyelids, we judge of the degree of fever, and par- 
ticularly of inflammation of the lungs, or any of the air-passages. The cut on the preceding page shows the ramifieations of the blood-vessels, both arterial and venous, on the membrane of the nose. It beautifully accounts for the accuratc connexion which we trace between the colour of the nasal membrane, and various diseases or states of the circulation. By the sore places or ulcerations discovered on this $\mathrm{mcm}$ brane, we likewise determine respecting the existence of glanders ; and the interposition of the septum is a wise and benevolent provision to hinder the spread of the mischief, by cutting off all communication with the neighbouring parts, and also to preserve one nostril pervious, when the other is diseased or obstructed. 'The nasal eavity is, on either side, occupied by two bones, which, from their being rolled up somewhat in the form of a turban, are called the turbinated or turban-shaped bones, $s s, p .72$; part of the cartilage is cut away in our cut in order to display them. They are as thin as gauze, and perforated, like gauze, with a thousand holes. Between them are left sufficient passages for the air.

If they were unrolled, they would present a very considcrable surface; and on every part of them is spread the substance or pulp of the olfactory, or first pair of ncrves. These bones, lined with delicate membranes, and covered by the olfactory nerves, are the seat of smell; and they are thus expanded, beeause the sense of smell in the horse must, to a very considerable degree, supply the place of the sense of touch and the lessons of expericnce in the human being. By this alone he is enabled to select, amongst the nutritive and poisonous herbage of the meadow, that which would support and not destroy him. The troops of wild horses are said to smell the approach of an enemy at a very considerable distance. In his domestic state, the horse does not examine the different food which is placed before him with his eye, but with his nose; and if the smell displeases him, no coaxing will induce him to eat. He examines a stranger by the smell, and, by very intelligible signs, expresses the opinion which he forms of him by this inquisition. The horse will evidently recognise his favourite groom when he has nothing else to indicate his approach but the sense of smell. These cavities are likewise organs of voice. The sound reverberates through them, and increases in loudness, as through the windings of a French horn.

The extension of the nostril at the lower part of these cavities is an important part of the face, and intimately connected with breeding, courage, and speed. The horse ean breathe only through the nose. All the air which goes to and returns from the lungs must pass through the nostrils. In the common act of breathing, these are sufficiently large; but when the animal is put on lis speed, and the respiration is quickened, these passages must dilate, or he will be much distressed. The expanded nostril is a striking feature in the blood-horse, especially when he has been excited and not over-blown. The sporting man will not forget the sudden effect which is given to the countenance of the hunter, when his ears become erect, and his nostrils dilate as he first listens to the cry of the hounds, and snorts, and scents them afar off. The painful and spasmed stretching of this part, in the poor, over-driven post-horse, will show how necessary it is that the passage to the lungs should be free and open. 'The nostril should not only be largc, but the membranous substance which covers the entrance into the nose should be thin and elastic, that it may more readily yield when the nccessity of the animal requires a greater supply of air, and afterwards return to its natural dimensions. Therefore, nature, which adapts the animal to his situation and use, has given to the cart-horse, that is seldom blown, a confined nostril, and surrounded by much cellular snbstance, and a thick skin; and to the horse of more breeding, whose use consists in his speed and his continuance, a wider nostril, and one much more flexible.

The inhabitants of some countries were accustomed to slit the nostrils of their horses, that they might be less distressed in the severe and long-continued exertion of their speed. The Icelanders do so to the present day. There is no necessity for this, for nature has made amplc provision for all the ordinary and even extraordinary exertion we can require from the horse.

Some very powerful muscles proceed from different parts of the face to the neighbourhood of the nostrils, in order to draw them back and dilate them. Four of these are given in the following cut, which is inserted to complete our present subject, and which 
will be often referred to in the course of our work; $l, m, o$, and $p$, are muscles employed for this purpose.

THE MUSCLES, NERVES, AND BLOOD-VESSELS OF THE HEAD AND UPPER PART OF THE NECK.

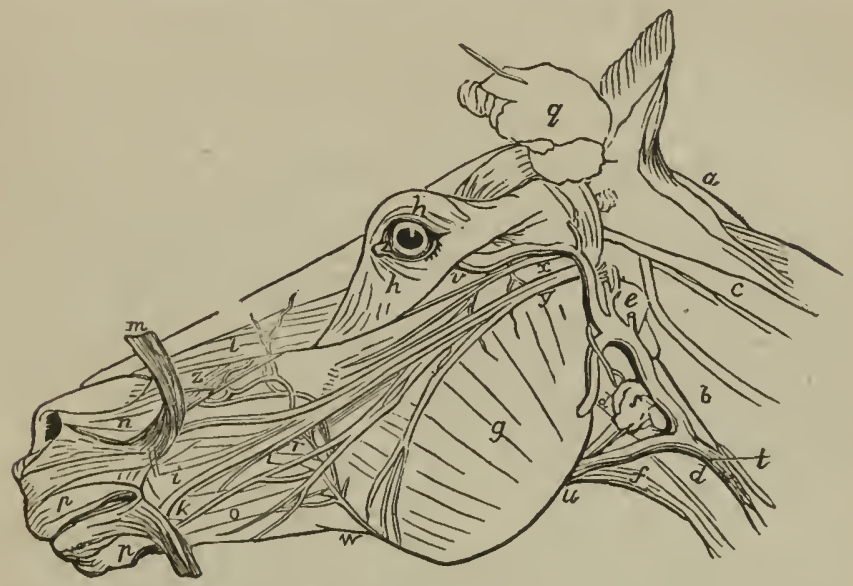

$a$ The upper part of the ligament of the neck.

$b$ The levalor humeri (elevator of the shoulder), arising from the tubercle of the occiput, the mastoid (nipple-shaped) process of the temporal bone, and the transverse processes (cross projections) of the four first bones of the neck, and the ligament of the neck, and going to the muscles of the shoulders, and the upper bone of the arm: to draw forward the shoulder and arm; or turn the head and neck; and, when the two levators aet, to depress the head.

$c$ The tendon common to the complexus major (larger complicated), and splenius (splint-like): to the mastoid process of the temporal bonc, to hold up the head, or, the museles on one side alone acting, to turn it.

$d$ The sterno-maxillaris (belonging to thc breast-bone) and upper jaw, from the cartilage in front of the chcst to the angle of the lower jaw: to bend the head, or, if one only acts, to bend it on one side.

$\boldsymbol{e}$ The stylo-maxillaris, from the styloid (peneil-shaped) or coracoid (beak-shaped) process of the occiput, to the angle of the jaw : to pull the jaw backward and open it.

$f$ The subscapulo hyoideus, from under the shoulder-blade, to the body of the os hyoides (the bone at the root of the tongue formed like a Greek $u, v)$ : to draw back that bone.

g The masseter (chewing); a most powerful muscle, constituting the cheek of the horse:from the upper jaw bone into the rough surface round the angle of the lower: in conjunction with the temporal muscle to close the mouth and chew the food.

$h$ The orbicularis (circular) surrounding the eye and closing the lids.

$i$ The zygomaticus, from the zygomatic arch and masseter to the corner of the mouth, to draw back the angle of the mouth.

$k$ The buccinalor (trumpeter), from the inside of the mouth and cheeks, to the angle of the mouth, to draw it back.

$l$ The vasalis labii superioris (belonging to the nose and upper lip), from a depression at the junction of the superior maxillary and malar bones, to the angle of the nostril: to raise the lip, and dilate the nostrils.

$m$ Dilator naris lateralis (side dilator of the nostril), reversed to show the vessels and nerves which it covers, going from the covering of the nasal and frontal bones, to the angle of the mouth, and side of the nostril : to retract the upper lip and dilate the nostrils.

$n$ Dilator magnus (great dilator), assisting in the same office.

- Depressor labii inferioris (puller down of the under lip), to the sides of the under lip : to pull it down.

p Orbicularis oris (eircular muscle of the mouth), surrounding the mouth: to elose the lips and dilate the nostrils.

$q$ The upper portion of the parotid gland (gland near the ear) reversed, to show the blood-ves. sels and nerves beneath it.

$r$ The parotid duet piercing the eheek, to discharge the saliva into the mouth. 11* 
$s$ The maxillary gland (gland of the lower jaw) with its duct.

$t$ The jugular (neck) vein, after the two branches have united.

$u$ At this letter, the submaxillary artery, a branch of the jugular, and the parotid duct, pasa under and within the angle of the lower jaw; they come out again at $w$, and climb up the cheek to be distributed over the face.

$v$ The vein and artery, passing under the zygomatic arch.

$x \mathrm{~A}$ branch of the fifth pair, the sensitive nerve of the face, emerging from under the parotid gland.

$y$ The main branch of the portio dura (hard portion) of the seventh pair, the motor (moving) nerve of the face coming out from beneath the parotid gland, to spread over the face.

$\approx$ Branches of both nerves, with small blood-vessels.

There are also four distinct cartilages attached to the nostrils, which, by their elasticity, bring back the nostrils to their former dimensions, as soon as the muscles cease to act. The bones of the nose ( $a a, \mathrm{p} .70$, and $p .72)$ are also sharpened off to a point, to give wider range for the action of the muscles; while the cartilages are so contrived, as not only to discharge the office we have mentioned, but to protect this projection of bone from injury.

There are two circumstances, which, more than any others, will enable the veterinary surgeon, and the owncr of a horse, accurately to judge of the character and degree of many diseases, and to which very few persons pay sufficient attention; these are the pulse, of which we shall presently speak, and the colour of the membrane of the nose. It is the custom of most veterinary surgeons and horsemen to lift the upper eyelid, and to form their opinion by the colour which its lining presents. If it is very red, there is considerable fever;-if it is of a pale pinkish hue, there is little danger. The nose, however, is more easily got at; - the surface presented to the view is more extensive;-its sympathy with almost all the important organs is greater; - and the changes produced by disease are more striking and more conclusive. Let the rcader first make himself well acquainted with the uniform pale pink appearance of that portion of the membrane which covers the lower part of the cartilaginous partition between the nostrils, when the horse is in health and quiet; then the increased blush of red, betokening some excitement of the system-the streaked appearance of inflammation commenced, and threatening to increase-the intense florid red, of acute inflammation-the pale ground with patches of vivid red, showing the half-subdued, but still existing fever-the uniform colour, although somewhat redder than natural, predicting a return to healthy circulation-the paleness approaching to white, marking the stage of debility, and sometimes intermingled with radiations of crimson, inducing the suspicion of lurking mischief; and the dark livid colour of approaching stagnation of the vital current. These, with all their shades of difference, will be the guides to his opinion and treatment, which every one, who has studied them, will highly appreciate.

\section{NASAL POLY PUS.}

By the polypus, is meant an excrescence or tumour, varying in size, structure, and consistcnce, and attached by a pedicle to a mucous surface. The true polypus is attached to mucous membranes, and is usually found in the nostrils, the pharymx, the uterus, or the vagina. Tumours have been seen hanging loose in the veins and ventricles of the heart; and in the larger blood-vessels there have been accumulations of the fibrine of the blood, with peduncular attachments.

The nasal polypus usually adheres to some portion of the superior turbinated bone, or it has come from some of the sinuses connected with that cavity. It escaped, while small, through the valvular opening under the superior turbinated bone, into the cavity of the nose, and there attained its full growth.

No better account, however, can be given of the cause of their appearance, than that of tumours in cther parts of the body. They evidently have a constitutional origin: they are frequently hereditary, and the animal in which they have once appearcd, is subjcet to a return of them.

By some means, probably the increasing weight of the tumour, and being in a dependent situation, the polypus is gradually detached from its base, and forces with it the soft and easily distensible membrane of the nose. As it continues to descend, this portion of membrane is farther elongated, and forms the pedicle or root of the 
tumour; -if that may be termed a root which is a mere duplicate of its investing membrane.

The polypus, when it hangs free in the nasal cavity, is usually of a pyriform or pear-like shape; and it varies in weight, from a few drachms to three or four pounds.

How is the surgeon to proceed? Can he lay hold of the polypus by the finger, or the forceps, or (for these tumours do not possess much sensibility) the tenaculum? To ascertain this, he will cast the horse, and fix the head in a position to take the greatest advantage of the light. If he cannot fairly get at the tumour by any of these means, he will let it alone. It will continue to grow-the membrane constituting the pedicle will be lengthened - and the polypus will at length descend, and be easily got at. Time and patience will effect wonders in this and many similar cases.

Supposing it to have grown, and the surgeon is endeavouring to extract it, he must not use any great force. It must not be torn out by the root. The tumour must be gently brought down, and a ligature passed round the pedicle, as high up as it can conveniently be placed. If the polypus can then be returned to the nose, the animal will suffer very little inconvenience; and in a few days it will slough off, and the pedicle will contract, and gradually disappear.

If the polypus is so large that it cannot be well returned after it has been brought down, we must, notwithstanding, use the ligature, passing it round the pedicle suffciently tightly to cut off the supply of blood to the tumour. We may then immediately excise it. Except the pedicle is exceedingly thick, there will be little or no hæmorrhage. Should some bleeding occur, it will probably soon stop, or may be stopped by the cautery, which should, however, be avoided if possible; for our object is to produce as little irritation as may be in the membrane, and the actual cautery will be applied with considerable difficulty in the cavity of the nose.

In very bad cases, when the tumour cannot be drawn out of the nose, it may be necessary to slit up the ala or side of the nostril. It will he better, however, not to cut through the false nostril ; for that consists of a duplicature of such thin integument, that the stitches can hardly be retained in it, when the horse will be continually snorting at the least inconvenience. It will also be difficult to bring the edges of this thin membrane accurately together again; or if this be effected, there is scarcely life enough in it for the parts readily to unite. The false nostril should be avoided, and the incision made along the lateral edge of the nasal bone, beginning at its apex or point. The flap will then conveniently turn down, so as to expose the cavity beneath ; and there will be sufficient muscular substance to secure an almost certain union by the first intention. 'The nostril being opened, the pedicle will probably be displayed, and a ligature may be passed round it, as already recommended; or if it is not actually in sight, it may probably gradually be brought within reach.

\section{NASAL GLEET, OR DISCHARGE FROM THE NOSE.}

There is a constant secretion of fluid to lubricate and moisten the membrane that lines the eavity of the nose, and which, under catarrh or cold, is increased in quantity, and altered in appearance and consistence. This will properly belong to the account of catarrh or cold; but that which is immediately under consideration, is a continued and oftentimes profuse discharge of thickened mucus, when every symptom of catarrh and fever has passed away. If the horse is at grass, the discharge is almost as green as the food on which he lives; - or if he is stabled, it is white, or straw-coloured, or brown, or even bloody, and sometimes purulent. It is either constantly running, or snorted out in masses many times a day; teazing the horse, and becoming a perfect nuisance in the stable, and to the rider. This has been known to continue several months, and eventually to destroy the horse.

If the discharge is not offensive to the smell, nor mixed with purulent matter, it is probably merely an increased and somewhat vitiated secretion from the cavities of the nose; and, all fever lhaving disappeared, will frequently yield to small doses of blue vitriol, given twice in the day. If fever or cough remains, the cough medicine that will hereafter be described must be combined with the tonic. If the discharge is mingled with pus, and very offensive, the vegetable tonics, gentian and ginger, may be added to the copper; but there is now reason to apprehend that the discharge will 
not be controlled, and will terminate in glanders. Turning into a salt marsh will occasionally effect a cure, when both the mineral and the vegetable tonics have failed.

\section{O Z E N A.}

OzENA is ulceration of the membrane of the nose, not always or often visible, but recognised by the discharge of muco-purulent matter, and the peculiar fætor from which the disease derives its name. It resembles glanders, in being confined, in most instances, to one nostril, and the submaxillary gland on the same side being enlarged; but differs from it in the gland not being adherent, and the discharge, from its earliest stage, being purulent and stinking.

'There is sometimes a fotid discharge from the nostril, in consequence of inflammation of the lungs, or produced by some of the sequelæ of pheumonia; distinguished, however, from ozena, by its usually flowing irregularly, being coughed up in great quantities, more decidedly purulent, and the gland or glands seldom affected. The discharge from ozena is constant, muco-purulent, and attended by enlargement of the glands. It is of immense consequence that we should be enabled to distinguish the one from the other; for while ozena may, sometimes at least, be manageable, the other is too frequently the precursor of death.

The cause of ozena cannot always be discovered. Chronic inflammation of the membrane may assume another and malignant character. In severe catarrh, the membrane may become abraded, and the abrasions may degenerate into foul and fotid ulcers. It is not an unfrequent consequence of epidemic catarrh. It has been produced by caustic applications to the lining membrane of the nose. It has followed hæmorrhage, spontaneous, or the consequence of injury.

In some cases, and those as obstinate as any, it cannot perhaps be traced to any probable cause, and the health of the animal has not appeared to be in the slightest degree affected.

The membrane of the nose is highly sensitive and irritable, and an ulcer, in whatever way formed on it, does not readily heal. It often runs on to gangrene, and destroys not only the membrane, but the bone beneath, and even the cartilaginous septum. This is rarely the ease in glanders; and the ravages of the chancrous ulcers are usually confined to the membrane. The ulceration proceeds to a certain pointits progress is then arrested, usually by nature alone-the discharge gradually lessens. -it loses its oflensive character, and at length ceases.

Local applications are seldom available in the treatment of this disease; for we know not the situation of the ulcer; and if we did, we probably could not get at it. Some have recommended setons. Where are they to be applied? If the seat of ulceration is unknown, the seton may only give useless pain. Several post-mortem examinations have shown that the frontal sinuses are a frequent seat of the disease. Yet what injection could we use? An emollient one would be thrown away. A stimulating injection might convert ozena into glanders. Other examinations have shown that the superior portion of the central meatus was diseased. What instrument can be contrived to reach that? Internal medicines are almost thrown avay in this complaint : yet something, perhaps, may be done under the form of a local application. The discarded nose-bag (undervalued at least by too many practitioners) will afford the means of employing an emollient fomentation. The steam from a bran-mash, scalding hot, will probably reach every part of the nasal cavity, and so afford some chance of being beneficially applied to the ulcer. It will, at least, thoroughly cleanse the part. By means of the nose-bag and the warm mash, the chloride of lime may be introduced into the cavity; not only combining with the extricated gases, and removing the fotor, but arresting the tendency to decomposition.

Then there is a digestive - a gentle stimulus to abraded and ulcerated surfaces, rousing them to healthy action, and without too much irritating them - turpentine. This may be applied in the form of vapour, and, in the best of all ways, by using the fresh yellow deal shavings instead of bran. This digestive may be brought into contact with every part of the Schneiderian membrane, and has been serviceable.

There is another resource, and one that bids fairer to be successful than any other with which we are acquainted - the spring grass. It is the finest alterative, depura- 
tive, and restorative, in our whole materia medica; and if it is accessible in the form of a salt marsh, there is no better chance of doing good.

\section{G L A N D E R S.}

The most formidable of all the diseases to which the horse is subject, is Glanders. It has been recognised from the time of Hippocrates, of $\mathrm{Cos}$; and few modern veterinary writers have given a more accurate or complete account of its symptoms, than is to be found in the works of the father of medicine. Three-and-twenty hundred years have rolled on since then, and veterinary practitioners are not yet agreed as to the tissue primarily affected, nor the actual nature of the disease: we only know that it is at the present day, what it was then, a loathsome and an incurable malady.

We shall therefore, in treating of this disease, pursue our course slowly and cautiously.

'The earliest symptom of Glanders is an increased discharge from the nostril, small in quantity, constantly flowing, of an aqueous character, and a little mucus mingling with it.

Connected with this is an error too general, and highly mischievous with regard to the character of this discharge in the earliest stage of the disease, when, if ever, a cure might be effected, and when, too, the mischief from contagion is most frequently produced. 'The discharge of glanders is not sticky when it may be first recognised. It is an aqueous or mucous, but small and constant discharge, and is thus distinguished from catarrh, or nasal gleet, or any other defluxion from the nostril. It should be impressed on the mind of every horseman that this small and constant defluxion, overlooked by the groom and by the owner, and too often by the veterinary surgeon, is a most suspicious circumstance.

Mr. James 'Turner deserves much credit for having first or chiefly directed the attention of horsemen to this important but disregarded symptom. If a horse is in the highest condition, yet has this small aqueous constant discharge, and especially from one nostril, no time should be lost in separating him from his companions. No harm will be done by this, although the defluxion should not ultimately betray lurking mischief of a worse character.

Mr. Turner relates a case very much in point. A farmer asked his opinion respecting a mare in excellent condition, with a sleek coat, and in full work. He had had her seven or eight montlis, and during the whole of that time there had been a discharge from the right nostril, but in so slight a degree as scarcely to be deemed worthy of notice. He now wanted to sell her, but, like an honest man, he wished to know whether he might warrant her. Mr. 'Turner very properly gave it as his opinion, that the discharge having existed for so long a time, he would not be justificd in sending her into the market. A farrier, however, whose ideas of glanders had always been connected with a sticky discharge and an adherent gland, bouglit her, and led her away.

Three months passed on, when Mr. Turner, examining the post-horses of a neighbouring inn, discovered that two of them were glandered, and two more farcied, while, standing next to the first that was attacked, and his partner in work, was his old acquaintance, the farmer's mare, with the same discharge from her nostril, and who liad, beyond question, been the cause of all the mischief.

The peculiar viscidity and gluiness which is generally supposed to distinguish the discharge of glanders from all other mucous and prevalent secretions belongs to the second stage of the disease, and, for many months before this, glanders may havo existed in an insidious and highly contagious form. It must be acknowledged, however, that, in the majority of cases, some degree of stickiness does characterise the discharge of glanders from a very early period.

It is a singular circumstance, for which no satisfactory account has yet been given, that when one nostril alone is attacked, it is, in a great majority of cases, the near, or lcft. M. Dupuy, the director of the veterinary school at Toulouse, gives a very singular account of this. He says, that out of eighty cases of glanders that came under his notice, only one was affected in the right nostril. The difference in the affected nostril does not exist to so great an extent in Great Britain; but, in two horses out of three, or three out of four, the discharge is from the left nostril alone. We might 
account for the left leg failing oftener than the right, for we mount and dismount on the left side; the horse generally leads with it, and there is more wear and tear of that limb : but we cannot satisfactorily account for this usual affection of the left nostril. It is true that the reins are held in the left hand, and there may be a little more bearing and pressure on the left side of the mouth; but this applies only to saddlehorses, and even with them does not sufficiently explain the result.

'This discharge, in cases of infection, may continue, and in so slight a degree as to be scarcely perceptible, for many months, or even two or three years, unattended by any other disease, even ulceration of the nostril, and yet the horse being decidedly glandered from the beginning, and capable of propagating the malady. In process of time, however, pus mingles with the discharge, and then another and a characteristic symptom appears. Some of this is absorbed, and the neighbouring glands become affected. If there is discharge from both nostrils, the glands within the under jaw will be on both sides enlarger. If the discharge is from one nostril only, the swelled gland will be found on that side alone. Glanders, however, will frequently exist at an early stage without these swelled glands, and some other diseases, as catarrh, will produce them. Then we must look out for some peculiarity about these glands, and we shall readily find it. The swelling may be at first somewhat large and diffused, but the surrounding enlargement soon goes off, and one or two small distinct glands remain; and they are not in the centre of the channel, but adhere closely to the jaw on the affected side.

The membrane of the nose should now be examined, and will materially guide our opinion. It will either be of a dark purplish hue, or almost of a leaden colour, or of any shade between the two; or if there is some of the redness of inflammation, it will have a purple tinge: but there will never be the faint pink blush of health, or the intense and vivid red of usual inflammation. Spots of ulceration will probably appear on the membrane covering the cartilage of the nose-not mere sore places, or streaks of abrasion, and quite superficial, but small ulcers, usually approaching to a circular form, deep, and with the edges abrupt and prominent. When these appearances are observed, there can be no doubt about the matter. Care should be taken, however, to ascertain that these ulcers do actually exist, for spots of mucus adhering to the membrane have been more than once taken for them. The finger should, if possible, be passed over the supposed ulcer, in order to determine whether it can be wiped away; and it should be recollected, as was hinted when describing the duct that conveys the tears to the nose, that the orifice of that duct, just within the nostril, and on the inner side of it, has been mistaken for a chancrous ulcer. This orifice is on the continuation of the common skin of the muzzle which runs a little way up the nostril, while the ulcer of glanders is on the proper membrane of the nose above. The line of separation between the two is evident on the slightest inspection.

When ulcers begin to appear on the membrane of the nose, the constitution of the horse is soon evidently affected. The patient loses flesh - his belly is tucked up his coat unthrifty, and readily coming off-the appetite is impaired-the strength fails - cough, more or less urgent, may be heard-the discharge from the nose will increase in quantity; it will be discoloured, bloody, offensive to the smell - the ulcers in the nose will become larger and more numerous, and the air-passages being obstructed, a grating, choking noise will be heard at every act of breathing. There is now a peculiar tenderness about the forehead. The membrane lining the frontal sinuses is inflamed and ulcerated, and the integument of the forehead becomes thickened and somewhat swelled. Farcy is now superadded to glanders, or glanders has degenerated into farcy, and more of the absorbents are involved.

At or before this time little tumours appear about the muscles, and face, and neck, following the course of the veins and the absorbents, for they run side by side; and these the tumours soon ulcerate. Tumours or buds, still pursuing the path of the absorbents, soon appear on the inside of the thighs. They are connected together by a corded substance. This is the inflamed and enlarged lymphatic; and ulceration quickly follows the appearance of these buds. The deeper-seated absorbents are next affected ; and one or both of the hind-legs swell to a great size, and become stiff, and hot, and tender. The loss of flesh and strength is more marked every day. The membrane of the nose becomes of a dirty livid colour. The membrane of the mouth 
is strangely pallid. The eye is infiltrated with a yellow fluid; and the discharge from the nose becomes more profuse, and insufferably offensivc. The animal presents one mass of putrefaction, and at last dies exhausted.

The enlargement of the submaxillary glands, as connected with this disease, may, perhaps, require a little farther consideration. A portion of the fluid secreted by the membrane of the nose, and altered in character by the peculiar inflammation there existing, is absorbed; and, as it is conveyed along the lymphatics, in order to arrive at the place of its destination, it inflames them, and causes them to enlarge and suppurate. There is, however, a peculiarity accompanying the inflammation which they take from the absorption of the virus of glanders. They are rarely large, except at first, or hot, or tender; but they are characterised by a singular hardness, a proximity to the jaw-bone, and, frequently, actual adhesion to it. The adhesion is produced by the inflammatory action going forward in the gland, and the effusion of coagulable lymph. This hardness and adhesion accompanying discharge from the nostril, and being on the same side with the nostril whence the discharge proceeds, afford proof not to be controverted that the horse is glandered. Notwithstanding this, however, there are cases in which the glands are neither adherent nor much enlarged, and yet there is constant discharge from one or both nostrils. The veterinary surgeon would have little hesitation in pronouncing them to be cases of glanders. He will trust to the adhesion of the gland, but he will not be misled by its looseness, nor even by its absence altogether.

Glanders have often been confounded with strangles, and by those who ought to have known better. Strangles are peculiar to young horses. The early stage resembles common cold, with some degree of fever and sore throat - generally with distressing cough, or at least frequent wheezing; and when the enlargement appears beneath the jaw, it is not a single small gland, but a swelling of the whole of the substance between the jaws, growing harder towards the centre, and, after a while, appearing to contain a fluid, and breaking. In strangles, the membrane of the nose will be intensely red, and the discharge from the nose profuse and purulent, or mixed with matter almost from the first. When the tumour has burst, the fever will abate, and the horse will speedily get well.

Should the discharge from the nose continue, as it sometimes does, for a considerable time after the horse has recovered from strangles, there is no cause for fear. Simple strangles need never degenerate into glanders. Good keep, and small doses of tonic medicine, will gradually perfect the cure.

Glanders have been confounded with catarrh or cold; but the distinction between them is plain enough. Fevcr, and loss of appetite and sore throat, accompany coldthe quidding of the food and gulping of the water are sufficient indications of the latter of these; the discharge from the nose is profuse, and perhaps purulent; the glands under the jaw, if swelled, are moveable, there is a thickening around them, and they are tender and hot. With proper treatment the fever abates; the cough disappears; the swellings under the throat subside; and the discharge from the nose gradually ceases, or, if it remains, it is usually very different from that which characterises glanders. In glanders, there is seldom cough of any consequence, and generally no cough at all.

$\Lambda$ running from the nose, small in quantity, and, from the smallness of its quantity, drying about the edges of the nostril, and presenting some appearance of stickiness, will, in a few cases, remain after severe catarrh, and especially after the influenza of spring; and thcse have gradually assumed the character of glanders, and more particularly when they have been accompanied by enlarged glands and ulceration in the nosc. Here the aid of a judicious veterinary surgeon is indispensable; and he will sometimes experience considerable difficulty in deciding the case. One circumstance will principally guide him. No disease will run on to glanders which lias not, to a considcrablc and palpable degree, impaired and broken down the constitution; and every disease that does this will run on to glanders. He will look then to the general state and condition of the horsc, as well as to the situation of the glands, the nature of the discharge, and the character of the ulceration.

If, after all, he is in loubt, an experiment may be resorted to, which wears indeed the appearance of cruelty, and which only the safety of a valuable animal, or of a 


\section{ANATOMY AND DISEASES OF THE NOSE AND MOUTH.}

whole team, can justify. He will inoculate an ass, or a horse already condemned to the hounds, with the matter discharged from the nose. If the horse is glandered, the symptoms of glanders or farcy will appear in the inoculated animal in the course of a few days.

The post mortem examination of the horse will remove every doubt as to the character of the disease. The nostril is generally more or less blanched, with spots or lines of inflammation of considerable intensity. Ulceration is almost invariably found, and of a chancrous character, on the septum, and also on the æthmoid and turbinated bones. The ulcers evidently follow the course of the absorbents, sometimes almost confined to the track of the main vessel, or, if scattered over the membrane generally, thickest over the path of the lymphatic. The æthmoid and turbinated bones are often filled with pus, and sometimes eaten throngh and carious; but, in the majority of cases, the ulceration is confined to the external membrane, although there may be pus within. In aggravated cases the disease extends through all the cells of the face and head.

The path of the disease down the larynx and windpipe is easily traced, and the ulcers follow one line-that of the absorbents. In aggravated cases, this can generally be traced on to the lungs. It produces inflammation in these organs, characterised in some cases by congestion; but in other cases, the congestion having gone on to hepatisation, in which the cellular texture of the lungs is obliterated. Most frequently, when the lungs are affected at all, tubercles are found - miliary tubercles - minute granulated spots on the surface, or in the substance of the lungs, and not accompanied by much inflammation. In a few cases there are larger tubercles, which soften and burst, and terminate in cavities of varying size.

In some cases, and showing that glanders is not essentially or necessarily a disease of the lungs, there is no morbid affection whatever in those organs.

The history thus given of the symptoms of glanders will clearly point out its nature. It is an affection of the membrane of the nose. Some say, and at their head is Professor Dupuy, that it is the production of tubercles, or minute tumours in the upper cells of the nose, which may long exist undetected, except by a scarcely perceptible running from the nostril, caused by the irritation which they occasion. These tubercles gradually become more numerous; they cluster together, suppurate and break, and small ulcerations are formed. The ulcers discharge a poisonous matter, which is absorbed and taken up by the neighbouring glands, and this, with greater or less rapidity, vitiates the constitution of the animal, and is capable of communicating the disease to others. Some content themselves with saying that it is an inflammation of the membrane of the nose, which may assume an acute or chronic form, or in a very short time, or exceedingly slowly, run on to ulceration.

It is inflammation, whether specific or common, of the lining membrane of the nose - possibly for months, and even for years, confined to that membrane, and even to a portion of it-the health and the usefulness of the animal not being in the slightest degree impaired. Then, from some unknown cause, not a new but an intenser action is set up, the inflammation more speedily runs its course, and the membrane becomes ulcerated. The inflammation spreads on either side down the septum, and the ulceration at length assumes that peculiar chancrous form which characterises inflammation of the absorbents. Even then, when the discharge becomes gluey, and sometimes after chancres have appeared, the horse is apparently well. There are hundreds of glandered horses about the country with not a sick one among them. For months or years this disease may do no injury to the general health. The inflammation is purely local, and is only recognised by the invariable accompaniment of inflammation and increased secretion. Its neighbours fall around, but the disease affects not the animal whence it came. At length a constitutional inflammation appears; farcy is established in its most horrible form, and death speedily closes the scene.

What, then, is the cause of this insidious dreadful disease? Although we may be in a manner powerless as to the removal of the malady, yet if we can trace its cause and manner of action, we may at least be able to do something in the way of prevention. Much has been accomplished in this way. Glanders does not commit onetenth part of the ravages which it did thirty or forty years ago, and, generally speak- 
ing, it is now only found as a frequent and prevalent disease where neglect, and filth, and want of ventilation exist.

Glanders may be either bred in the horse, or communicated by contagion. What we have farther to remark on this malady will be arranged under these two heads.

Improper stable management we believe to be a far more frequent cause of glanders than contagion. The air which is necessary to respiration is changed and empoisoned in its passage through the lungs, and a fresh supply is necessary for the support of life. That supply may be sufficient barely to support life, but not to prevent the vitiated air from again and again passing to the lungs, and producing irritation and disease. The membrane of the nose, possessed of extreme sensibility for the purposes of smell, is easily irritated by this poison, and close and ill-ventilated stables oftenest witness the ravages of glanders. Professor Coleman rclates a case which proves to demonstration the rapid and fatal agency of this cause. "In the expedition to Quiberon, the horses had not been long on board the transports before it became necessary to shut down the hatchways for a few hours; the consequence of this was, that some of them werc suffocated, and that all the rest were disembarked either glandcred or farcied."

In a close stable, the air is not only poisoned by being repeatedly breatled, but there are other and more powerful sources of mischief. The dung and the urine are snffered to remain fermenting, and giving out injurious gases. In many dark and ill-managed stables, a portion of the dung may be swept away, but the urine lies for days at the bottom of the bed, the disgusting and putrefying nature of which is ill-concealed by a little fresh straw which the lazy horsekeeper scatters over the top.

The stables of the gentleman are generally kept hot enough, and far too hot, although, in many of them, a more rational mode of treatment is beginning to be adopted; but they are lofty and roomy, and the horses are not too much crowded together, and a most scrupulous regard is paid to cleanliness. Glanders seldom provail there. The stables of the farmer are ill-managed and filthy enough, and the ordure and urine sometimes remain from week to week, until the horse lies on a perfect dunghill. Glanders seldom prevail there; for the samc carelessness which permits the filth to accumulate leaves many a cranny for the wind to enter and sweep away the deleterious fumes from this badly-roofed and unceiled place.

The stables of the horse-dealer are hot enough ; but a principle of strict cleanliness is enforced, for there must be nothing to offend the eye or the nose of the customer, and there glanders are seldom found; but if the stables of many of our post-horses, and of those employed on our canals, are examined, almost too low for a tall horse to stand upright in them-too dark for the accumulation of filth to be perceived-too far from the eye of the master - ill-drained and ill-paved - and governed by a false principle of economy, which begrudges the labour of the man, and the cleanliness and comfort of the animal; these will be the very hotbeds of the disease, and in many of these cstablishments it is an almost constant resident.

Glanders may be produced by anything that injures, or for a length of time acts upon and weakens, the vital energy of this membranc. They have been known to follow a fracture of the bones of the nose. They have bcen the consequence of violent catarrh, and particularly the long-continued discharge from the nostrils, of which we have spoken. They have been produced by the injection of stimulating and acrid substances up the nostril. Everything that weakens the constitution generally will lead to glanders. It is not only from bad stable management, but from the hardships which they endure, and the exhausted state of their constitution, that post and machine horses are so subject to glanders; and there is scarcely an inflammatory disease to which the horse is subject that is not occasionally wound up and terminated by the appearance of glanders.

Among the causes of glanders is want of regular exercise. The connexion, although not evident at first glance, is too certain. When a horse has been worked with peculiar severity, and is become out of spirits, and falls away in flesh, and refuses to eat, a little rest and a few mashes would make all right again; but the groom plies him with cordials, and adds fuel to fire, and aggravates the state of fever that has commenced. What is the necessary consequence of this? The weakest gocs to the wall, and either the lungs or the feet, or this membrane-that of the nose 
-the weakest of all, exposed day after day to the stimulating, debilitating influences that have been described, becomes the principal seat of inflammation that terminates in glanders.

It is in this way that glanders have so frequently been known to follow a hard day's chase. The seeds of the disease may have previously existed, but its progress will be hastened by the general and febrile action excited - the absurd measures which are adopted not being calculated to subdie the fever, but to increase the stimulus.

Every exciting cause of disease exerts its chief and its worst influence on this membrane. At the close of a severe campaign the horses are more than decimated by this pest. At the termination of the Peninsular war the ravages of this disease were dreadful. Every disease will predispose the membrane of the nose to take on the inflammation of glanders, and with many, as strangles, catarrh, bronchitis, and pneumonia, there is a continuity of membrane, an association of function, and a thousand sympathies.

There is not a disease which may not lay the foundation for glanders. Weeks, and months, and years, may intervene between the predisposing cause and the actual evil ; but at length the whole frame may become excited or debilitated in many a way, and then this debilitated portion of it is the first to yield to the attack. Atmospheric influence has somewhat to do with the prevalence of glanders. It is not so frequent in summer as in the winter, partly attributable, perhaps, to the different state of the stable in the summer months, neither the air so close or so foul, nor the alternations of temperature so great.

There are some remarkable cases of the connexion of moisture, or moist exhalations, that deserve record. When new stabling was built for the troops at Hythe, and inhabited before the walls were perfectly dry, many of the horses that had been removed from an open, dry, and healthy situation, became affected with glanders; but, some time having passed over, the horses in these stables were as heal thy as the others, and glanders ceased to appear. An innkeeper at Wakefield built some extensive stabling for his horses, and, inhabiting them too soon, lost a great proportion of his cattle from glanders. There are not now more healthy stables in the place. The immense range of stables under the Adelphi, in the Strand, where light never enters, and the supply of fresh air is not too abundant, were for a long time notoriously unhealthy, and many valuable horses were destroyed by glanders; but now they are n̂lled with the finest wagon and dray-horses that the metropolis or the country contains, and they are fully as healthy as in the majority of stables above-ground.

There is one more cause to be slightly mentioned-hereditary predisposition. This has not been sufficiently estimated, with regard to the question now under consideration, as well as with respect to everything connected with the breeding of the horse. There is scarcely a disease that does not run in the stock. There is that in the structure of various parts, or their disposition to be affected by certain influences, which perpetuates in the offspring the diseases of the sire; and thus contraction, ophthalmia, roaring, are decidedly hereditary, and so is glanders. M. Dupuy relates some decisive cases. A mare, on dissection, exhibited every appearance of glanders ; her filly, who resembled her in form and in her vicious propensities, died glandered at six years old. A second and a third mare, and their foals, presented the same fatal proof that glanders are hereditary.

Glanders are highly contagious. The farmer cannot be too deeply impressed with the certainty of this. Considering the degree to which this disease, even at the present day, often prevails, the legislature would be justified in interfering, by some severe enactments, as it has done in the case of the small-pox in the human subject.

The early and marked symptom of glanders, is a discharge from the nostrils of a peculiar character; and if that, even before it becomes purulent, is rubbed on a wound, or on a mucous surface, as the nostrils, it will produce a similar disease. If the division between two horses were sufficiently high to prevent all smelling and snorting at each other, and contact of every kind, and they drank not out of the same pail, a sound horse might live for years, uninfected, by the side of a glandered one. The matter of glanders has been mixed up into a ball, and given to a healthy horse, without effect. Some horses have eaten the hay left by those that were glandered, 
and no bad consequence has followed; but others have been speedily infected. The glanderous matter must come in contact with a wound, or fall on some membrane, thin and delicate, like that of the nose, and through which it may be absorbed. It is easy, then, accustomed as horses are to be crowded together, and to recognise each other by the smell-eating out of the same manger, and drinking from the same pailto imagine that the disease may be very readily communicated. One horse has passed another when he was in the act of snorting, and has become glandered. Some fillies have received the infection from the matter blown by the wind across a lane, when a glandered horse, in the opposite field, has claimed acquaintance by neighing or snorting. It is almost impossible for an infected horse to remain long in a stable with others without irreparable mischief.

If some persons underrate the danger, it is because the disease may remain unrecognised in the infected horse for some months, or even years, and therefore, when it appears, it is attributed to other causes, or to after inoculation. No glandered horse should be employed on any farm, nor should a glandered horse be permitted to work on any road, or even to pasture on any field. Mischief may be so easily and extensively effected, that the public interest demands that every infected animal should be summarily destroyed, or given over for experiment to a veterinary surgeon, or recognised veterinary establishment.

'There are a few instances of the spontaneous cure of chronic glanders. The discharge has existed for a considerable time. At length it has gradually diminished, and has ceased; and this has occurred under every kind of treatment, and without any medical treatment : but in the majority of these supposed cases, the matter was only pent up for a while, and then, bursting from its confinement, it flowed again in double quantity : or, if glanders have not re-appeared, the horse, in eighteen or twentyfour months, has become farcied, or consumptive, and died. These supposed cures are few and far between, and are to be regarded with much suspicion.

As for medicine, there is scarcely a drug to which a fair trial has not been given, and many of them have had a temporary reputation; but they have passed away, one after the other, and are no longer heard of. The blue vitriol and the Spanish-fly have held out longest; and in a few cases, either nature or these medicines have done wonders, but in the majority of instances they have palpably failed. The diniodide of copper has lately acquired some reputation. It has been of great service in cases of farey, but it is not to be depended upon in glanders.

Where the life of a valuable horse is at stake, and the owner adopts every precaution to prevent infection, he may subject the horse to medical treatment; but every humane man will indignantly object to the slitting of the nostril, and the scraping of the cartilage, and searing of the gland, and firing of the frontal and nasal bones, and to those injections of mustard and capsicum, corrosive sublimate and vitriol, by which the horse has been tortured, and the practitioner disgraced. At the veterinary school, and by veterinary surgeons, it will be most desirable that every experiment should be tried to discover a remedy for this pest; but, in ordinary instances, he is not faithful to his own interest, or that of his neighbours, who does not remove the possibility of danger in the most summary way.

If, however, remedial measures are resorted to, a pure atmosphere is that which should first be tried. Glanders is the peculiar disease of the stabled horse, and the preparation for, or the foundation of a cure, must consist in the perfect removal of every exciting cause of the malady. The horse must breathe a cool and pure atmosphere, and he must be turned out, or placed in a situation equivalent to it.

$\Lambda$ salt marsh is, above all others, the situation for this experiment; but there is much caution required. No sound horse must be in the same pasture, or a neighbouring one. The palings or the gates may receive a portion of the matter, which may harden upon them, and, many a month afterwards, be a source of mischief-nay, the virus may cling about the very herbage, and empoison it. Cattle and sheep should not be trusted with a glandered horse ; for the experiments are not sufficiently numerous or decided as to the exemption of these animals from the contagion of glanders.

Supposing that glanders have made their appearance in the stables of a farmer, is there any danger after he has removed or destroyed the infected horse? Certainly there is; but not to the extent that is commonly supposed. 'There is no necessity for 
pulling down the racks and mangers, or even the stable itself, as some have done. The poison resides not in the breath of the animal, but in the nasal discharge, and that can only reach certain parts of the stable. If the mangers, and racks, and bales, and partitions, are first well scraped, and scoured with soap and water, and then thoroughly washed with a solution of the chloride of lime, (one pint of the chloride to a pailfull of water, ) and the walls are lime-washed, and the head-gear burned, and the clothing baked or washed, and the pails newly painted, and the iron-work exposed to a red heat, all danger will cease.

Little that is satisfactory can be said of the prevention of glanders.

The first and most effectual mode of prevention will be to keep the stables cool and well ventilated, for the hot and poisoned air of low and confined stables is one of the most prevalent causes of glanders.

Next to ventilation stands cleanliness ; for the foul air from the fermenting litter, and urine, and dung, must not only be highly injurious to health generally, but irritate and predispose to inflammation that delicate membrane which is the primary seat of the disease. If to this be added regular exercise, and occasional green meat during the summer, and carrots in the winter, we shall have stated all that can be done in the way of prevention.

Glanders in the human being. - It cannot be too often repeated, that a glandered horse can rarely remain among sound ones without serious mischief ensuing; and, worse than all, the man who attends on that horse is in danger. The cases are now becoming far too numerous in which the groom or the veterinary surgeon attending on glandered horses becomes infected, and in the majority of cases dies. It is, however, somewhat more manageable in the human being than in the quadruped. Some cases of recovery from farcy and glanders stand on record with regard to tlie human being, but they are few and far between.

\section{F A R C Y.}

Farcy is intimately connected with glanders; they will run into each other, or their symptoms will mingle together, and before either arrives at its fatal termination its associate will almost invariably appear. An animal inocculated with the matter of farcy will often be afflicted with glanders, while the matter of glanders will frequently produce farcy. They are different types or stages of the same disease. There is, however, a very material difference in their symptoms and progress, and this most important one of all, that while glanders are generally incurable, farcy, in its early stage and mild form, may be successfully treated.

While the capillary vessels of the arteries are everywhere employed in building up the frame, the absorbents are no less diligently at work in selecting and carrying away every useless or worn-out portion or part of it. There is no surface - there is no assignable spot on which thousands of these little mouths do not open. In the discharge of their duty, they not only remove that which is become useless, and often that which is healthy, but that which is poisonous and destructive. They open upon the surface of every glanderous chancre. They absorb a portion of the virus which is secreted by the ulcer, and as it passes along these little tubes, they suffer from its acrimonious quality; hence the corded veins, as they are called by the farrier, or, more properly, the thickened and inflamed absorbents following the course of the
veins.

At certain distances in the course of the absorbents are loose duplicatures of the lining membrane, which are pressed against the side of the vessel and permit the fluid to pass in a direction towards the chest, but belly out and impede or arrest its progress from the chest. The virus at these places, and the additional inflammation there excited, is to a greater or less degree evident to the eye and to the feeling. They are'usually first observed about the lips, the nose, the neck, and the thighs. They are very hard - even of a scirrhous hardness, more or less tender, and with
perceptible heat about them.

The poisonous matter being thus confined and pressing on the part, suppuration and ulceration ensue. The ulcers have the same character as the glanderous ones on the membrane of the nose. 'They are rounded, with an elevated edge and a pale surface. They are true chancres, and they discharge a virus as infectious and as 
dangerous as the matter of glanders. While they remain in their hard prominent state, they are called buttons or farcy buds; and they are connected together by the inflamed and corded veins.

In some cases the horse will droop for many a day before the appearance of the corded veins or buds-his appetite will be impaired-his coat will stare-he will lose flesh. The poison is evidently at work, but has not gained sufficient power to cause the absorbents to enlarge. In a few cases these buds do not ulcerate, but become hard and difficult to disperse. The progress of the disease is then suspended, and possibly for some months the horse will appear to be restored to health; but he bears the seeds of the malady about him, and in due time the farcy assumes its virulent form, and hurries him off. These buds have sometimes been confounded with the little tumours or lumps termed surfeit. They are generally higher than these tumours, and not so broad. They have a more knotty character, and are principally found on the inside of the limbs, instead of the outside.

Few things are more unlike, or more perplexing, than the different forms which farcy assumes at different times. One of the legs, and particularly one of the hinder legs, will suddenly swell to an enormous size. At night the horse will appear to be perfectly well, and in the morning one leg will be three times the size of the other, with considerable fever, and scarcely the power of moving the limb.

At other times the head will be subject to this enlargement, the muzzle particularly will swell, and an offensive discharge will proceed from the nose. Sometimes the horse will gradually lose flesh and strength; he will be hide-bound ; many eruptions will appear in different parts; the legs will swell; cracks will be seen at the heels, and an inexperienced person may conceive it to be a mere want of condition, combined with grease.

By degrees the affection becomes general. The virus has reached the termination of the absorbents, and mingles with the general circulating fluid, and is conveyed with the blood to every part of the frame. 'There are no longer any valves to impede its progress, and consequently no knots or $b u d s$, but the my riads of capillary absorbents that penetrate every part become inflamed, and thickened, and enlarged, and cease to discharge their function. Hence arises enlargement of the substance of various parts, swellings of the legs, and chest, and head - sudden, painful, enormous, and distinguished by a heat and tenderness, which do not accompany other enlargements.

It is a question somewhat difficult to answer, whether farcy can exist without previous glanders. Probably it cannot. There is the long-continued insidious progress of glanders - the time which may elapse, and often does, before the owner is a ware or the veterinary surgeon sure of it-the possibility that minute ulceration may have for a long while existed in some of the recesses of the nose - or that the slight discharge, undreaded and unrecognised, yet vitiated, poisoned, and capable of communicating the disease, may have been long travelling through the frame and affecting the absorbents, and preparing for the sudden display of farcy.

One thing, however, is undeniable, that farcy does not long and extensively prevail without being accompanied by glanders - that even in the mild stages of farcy, glanders may be seen if looked for, and that it never destroys the animal without plainly associating itself with glanders. They are, in fact, stages of the same disease.

Glanders is inflammation of the membrane of the nose, producing an altered and poisonous secretion, and when sufficient of this vitiated secretion has been taken up to produce inflammation and ulceration of the absorbents, farcy is established. Its progress is occasionally very capricious, continuing in a few cases for months and years, the vigour of the horse remaining unimpaired; and, at other times, running on to its fatal termination with a rapidity perfectly astonishing.

Farcy has been confounded with other diseases; but he must be careless or ignorant who mistook sprain for it. The inflammation is too circumscribed and too plainly connected with the joint or the tendon.

It may be readily distinguished from grease or swelled legs. In grease there is usually some crack or scurfiness, a peculiar tenseness and redness and glossiness of the skin, some ichorous discharge, and a singular spasmodic catching up of the leg.

In farcy the engorgement is even more sudden than that of grease. The horse is 
well to-day, and to-morrow he is gorged from the fetlock to the haunch, and although there is not the same redness or glossiness, there is great tenderness, a burning heat in the limb and much general fever. It is simultaneous inflammation of all the absorbents of the limb.

Surfeit can scarcely be confounded with farcy or glanders. It is a pustular eruption-surfeit-bumps, as they are called, and terminating in desquamation, not in ulceration, although numerous, yet irregularly placed, and never following the course of the absorbents, but scattered over the skin.

Local dropsy of the cellular membrane, and particularly that enlargement beneath the thorax which has the strange appellation of water-farcy, have none of the characters of real farcy. It is gencral debility to a greater or less degree, and not inflammation of the absorbents. If properly treated, it soon disappears, except that, occasionally, at the close of some serious disease, it indicates a breaking up of the constitution.

Farcy, like glanders, springs from infection and from bad stable managersent. It is produced by all the causes which give rise to glanders, with this difference, that it is inore frequently generated, and sometimes strangely prevalent in particular districts. It will attack, at the same time, several horses in the same ill-conducted stable, and others in the neighbourhood who have been exposed to the same predisposing causes. Some have denied that it is a contagious disease. They must have had little experience. It is true that the matter of farcy must come in contact with a wound or sore, in order to communicate the disease ; but accustomed as horses are to nibble and play with each other, and sore as the corners of the mouth are frequently rendered by the bit, it is easy to imagine that this may be easily effected; and experience tells us, that a horse having farcy ulcers cannot be suffered to remain with others without extreme risk.

The treatment of farcy differs with the form that it assumes. As a general rule, and especially when the buttons or buds are beginning to appear, a mild dose of physic should first be administered. The buds should then be carefully examined, and if any of them have broken, the budding-iron, at a dull red heat, should be applied. If pus should be felt in them, showing that they are disposed to break, they should be penetrated with the iron. These wounds should be daily inspected, and if, whien the slough of the cautery comes off, they look pale, and foul, and spongy, and discharge a thin matter, they should be frequently washed with a strong lotion of corrosive sublimate, dissolved in rectified spirit. When the wounds begin to look red, and the bottom of them is even and firm, and they discharge a thick white or yellow matter, the Friar's balsam will usually dispose them to heal.

As, however, the constitution is now tainted, local applications will not be sufficient, and the disease must be attacked by internal medicine as soon as the physic has ceased to operate.

Corrasive sublimate used to be a favourite medicine, combined with tonics, and repeated morning and night until the ulcers disappeared, unless the month became sore or the horse was violently purged, when the sulphate of copper was substituted for the corrosive sublimate. During this treatment the animal was placed, if possible, in a large box, with a free circulation of air; and green meat or carrots, and particularly the latter, were given, with a full allowance of corn. If he could be turned out in the day, it was deemed highly advantageous. It is related by Mr. Blaine, that a horse, so reduced as not to be able to stand, was drawn into a field of tares, and suffered to take his chance. The consequence was, that, when he had eaten all within his reach, he contrived to move about and search for more, and eventually recovered. Many horses recover under the use of the sublimate, but the great majority of them die.

Mr. Vines introduced a more effective medicine - cantharides, in combination likewise with the vegetable bitters-as a cure for farcy and glanders. It cannot be denied, that many animals labouring under the former, and a few under the latter, were to all appearance radically cured. The medicine was suspended for a while if affection of the lidneys supervened.

A still more effectual medicine has been introduced by Professor Morton, namely, the diniodide of copper, and it has been found of essential service in farcy and in diseases simulating glanders. He says that its action is that of a stimulant to the 
absorbent vessels, and a tonie. The gentian root is usually eombined with it. Cantharides, in small quantities, may be advantageously added. An indieation of its influenee is a soreness of the diseased parts arising from the absorbent vessels being roused into inereased aetion: the agent should then be for a time withheld.*

WATER-FARCY, eonfounded by name with the common farey, and by whieh much eonfusion has been caused, and a great deal of misehief done, is a dropsieal affection of the skin, either of the chest or of the limbs, and belongs to another part of our subject.

\section{THE L I PS.}

The lips of the horse are far more important organs than many suppose. They are the hands of the animal; and if any one will take the trouble to observe the manner in which he gathers up his eorn with them, and eolleets together the grass before he divides it with his nippers, he would be satisfied that the horse would be no more able to eonvey the food to his mouth without them, than the human being eould without his hands. 'This has even been put to the test of experiment. 'The nerves which supply the lips were divided in a poor ass, to illustrate some point of physiology. 'The sensibility of the lips was lost, and he knew not when he touehed his food with them. The motion of the lips was lost, and he eould not get the oats between his teetl, although the manger was full of them: at length, driven by hunger, he eontrived to liek up a few of them with his tongue; but when they were on his tongue, the greater part of them were rubbed off before he eould get them into his mouth.

It is on account of this use of the lips, and that they may be brought into contaet with the food without inconvenience or injury to other parts of the face, that the heads of most quadrupeds are so lengthened. Several muscles go to the lips from different parts of the jaw and face. Some of them are shown in the eut, p. 125. The orbicularis or eireular musele, $p$, employed in pushing out the lips and closing them, and enabling the horse to seize and hold his food, is partieularly evident; and in the explanation of the cut, the action of other museles, $i, k, m$, and $o$, was deseribed. 'The nerves likewise, $y$, taking their course along the eheek, and prineipally supplying the lips with the power of motion, and those, $z$, proeeeding from the foramen or hole in the upper jaw, deserve attention.

'The lips are eomposed of a museular substanee for the sake of strength, and a

* A very interesting case of the cure of farey in the human being occurred in January, 1840, in the practice of Mr. Curtis, a respectable surgeon of Camden Town:-

"Mr. G., a student at the Veterinary College, had, about three wceks before, received a slight wound on the forefinger of the right hand, while dissecting a glandered horse. The wound healed; but, about nine days afterwards, a small abseess formed in the part, which he would not consent to have opened; the pus was therefore absorbed, and the finger got well, and neither thc lymphatics nor the glands appeared to be affected.

"Ten days afterwards, he was attacked with giddiness while attending the lecture, and obliged to leave the room. He immcdiately applied to Mr. Curtis. He had three blotches of inflain mation of the skin of the right leg, varying in extent from two to four inches in diameter. The leg was very painful when he walked; and he had also some small blotches on the left leg. He had headache and thirst. His ease was sufficiently plain - farcy was beginning to develop itself. A perient medicine was administered.

"On the following day, there were numerous small blotches over both legs and thighs. In many of them the centre was of a pale green colour, having a somewhat gangrenous appearance. The headache was worse; there was a sensation of weight over the eyes, and tenderness over the left fiontal.

"Mr. Curtis determined to put him under a course of iodine, of the tincture of which eight minims were ordered every fourth hour, the bowels being kept in a relaxed state.

"On thc fourth day, the centre of the blotehes, which were still green, appeared to form cavitics, containing a fluid, from about the size of a shilling to that of a half-crown. The blotehcs werc surrounded by hard, defined edges, covered with cuticle, but the thickening of which was gradually disappearing.

"Two days after this, the fluid in the cavities was absorbed, but round their edges were lumps, or tubercles, about the size of peas. Several weeks passed before the tubercles quite disappeared.

"Mr. Curtis remarks, that so far as a single case will go, the intractable nature of this dis. ease seems to arise rathcr from neglect in its early stage, than from any impossibility of sub. duing it."-The Veterinarian, vol. xii. p. 353. 
multitude of small glands, which secrete a fluid that covers the inside of the lips and the gums, in order to prevent friction, and likewise furnish a portion of the moisture so necessary for the proper chewing of the food. The skin covering the lips is exceedingly thin, in order that their peculiar sensibility may be preserved, and for the same purpose they are scantily covered with hair, and that hair is fine and short. Long hairs or feelers, termed the beard, are superadded with the same intention. The horse is guided and governed principally by the mouth, and therefore the lips are endowed with very great sensibility, so that the animal feels the slightest motion of the hand of the rider or driver, and seems to anticipate his very thoughts. The fineness or goodness of the mouth consists in its exquisite feeling, and that depends on the thinness of this membrane.

The lips of the horse should be thin, if the beauty of the head is regarded; yet, although thin, they should evidently possess power, and be strongly and regularly closed. A firm, compressed mouth gives a favourable and no deceptive idea of the muscular power of the animal. Lips apart from each other and hanging down, indicate weakness or old age, or dullness and sluggishness.

The depth of the mouth, or the distance from the fore-part to the angle of the lips, should be considerable. A short, protuberant mouth would be a bad finish to the tapering face of the blood-horse. More room is likewise given for the opening of the nostril, which has been shown to be an important consideration. The bridle will not be carried well, and the horse will hang heavy on hand, if there is not considerable depth of mouth.

The corners or angles of the lips are frequently made sore or wounded by the smallness, or shortness, or peculiar twisting of the snaffle, and the unnecessary and cruel tightness of the bearing-rein. This rein was introduced as giving the horse a grander appearance in harness, and placing the head in that position in which the bit most effectually presses upon the jaw. There is no possibility of safely driving without it, for, deprived of this control, many horses would hang their heads low, and be disposed every moment to stumble, and would defy all pulling, if they tried to run away. There is, and can be no necessity, however, for using a bearing-rein so tight as to cramp the muscles of the head, or to injure and excoriate the angles of the lips.

The following is the opinion of Nimrod, and to a more competent judge we could not appeal :- "As to the universal disuse of the bearing-rein with English horses, it can never take place. The charge against it of cruelty at once falls to the ground, because, to make a team work together in fast work, every horse's head must be as much restrained by the coupling-rein as it would be and is by the bearing-rein. Its excellence consists in keeping horses' mouths fresh - in enabling a coachman to indulge a horse with liberty of rein, without letting him be all abroad, which he would be with his head quite loose, and of additional safety to the coach-horse, as proved by the fact of either that or the crupper always giving way when he falls down. There are, however, teams in which it may be dispensed with, and the horses have an advantage in their working against hills. As to the comparison of the road coach-horses on the Continent and our own, let any one examine the knees of the French diligence and post horses, which are allowed perfect liberty of head, and he will be convinced that the use of the bearing-rein does not keep them on their legs."

The mouth is injured much oftener than the careless owner suspects by the pressure of a sharp bit. Not only are the bars wounded and deeply ulcerated, but the lower jaw, between the tush and the grinders, is sometimes worn even to the bone, and the bone itself affected, and portions of it torn away. It may be necessary to

* New Sporting Magazine, vol. xiii. p. 99.

The author of the "Essay on Humanity to Brutes," takes the same view of the subject. "It is not," says he, "to the extent that has been supposed an instrument of torture. It is absolutely necessary in fast work, and useful on level ground. The objection to it is the tightness with which it is sometimes applied, and then it is a sad confinement to the head, and a source of very great pain. It is also disadvantageous when the horse is going up-hill, because it prevents him from throwing his whole weight into the collar. It cannot, however, be done without, especially in the horse that is once accustomed to it; but the poor animal needs not to be so tightly reined." - The Obligation and Extent of Humanity to Brutes, by
W. Youatt, p. 149. 
have a sharp bit for the headstrong and obstinate beast; yet if that bit is severely and unjustifiably called into exercise, the animal may rear, and endanger himself and his rider. There can, however, be no occasion for a thousandth part of the torment which the trappings of the mouth often inflict on a willing and docile servant, and which either render the mouth hard, and destroy all the pleasure of riding, or cause the horse to become fretful or vicious.

Small ulcers are sometimes found in the various parts of the mouth, said to be produced by rusty bits, but oftener arising from contusions inflicted by the bit, or from inflammation of the mouth. If the curb-bit is in fault, a snaffle or Pelham-bit should be used. If there is inflammation of the mouth, a little cooling medicine may be administered; and to the ulcers themselves, tincture of myrrh, diluted with water, or alum dissolved in water, may be applied with advantage.

\section{THE BONES OF THE MOUTH.}

The bones in, and giving form to the mouth, are the superior maxillary or upper jaw (b, p. 68, and $l$, p. 70$)$, containing the grinders: the anterior maxillary, or lower part of the upper jaw $(b$, p. $68, n$, p. $70, r$, p. 72), containing the upper-nippers or cutting-tecth; the palatine bone (below $8, \mathrm{p} .72$ ), and the posterior maxillary or under jaw ( $a, \mathrm{p} .68$, and $w, \mathrm{p} .72)$, containing all the under-teeth.

'The superior maxillary is, with the exception of the lower jaw, the largest bone in the face. It unites above with the lachrymal bone $(i, \mathrm{p} .70)$; and, more on the side, with the malar, or cheek bone, $k$; and a portion of it, continued upward and underneath, enters into the orbit. Above, and on the front of the face, it unites witl the bones of the nose, $j$, and below, with the inferior maxillary, $n$. That which most deserves notice in it externally, is the ridge, or spine, seen at $b, \mathrm{p} .68$, but better delineated in the cut of the head, p. 72, continued from the base of the zygomatic arch, and across the malar bone. It, and the surface beneath, serve to give attachment to the masseter muscle, concerned, almost as much as the temporal one, in the act of chewing. The dark spot ( $m$, p. 70, and seen likewise at p. 68) marks the foramen, or hole, through which a branch of the fifth pair of nerves proceeds, to give sensibility to the lower part of the face. As it approaches the teeth, this bone separates into two plates, and these are divided by long partitions, which contain and firmly hold the upper grinders. The lower plate then projects inwards, and forms ( $t, \mathrm{p} .72)$ the principal portion of the roof of the mouth, and the floor of the cavity of the nose. The corresponding bonc on the other side, meets its fellow in the centre of the palate. The upper jaw-bone contains in it large cavities besides those for the teeth, and these open into, and cnlarge the cavity of the nose. They are connected with the voice, but not with the smcll; for the expansion of the olfactory, or smelling nerve, has never been traced beyond the bones and membranes of the proper cavity of the nosc. The maxillary sinuses are generally filled with matter in bad cases of glanders.

Below these, are the anterior maxillary bones $(f, \mathrm{p} .68, a, \mathrm{p} .68)$, containing the upper cutting teeth, with the tushes belonging to both the upper and anterior bones. These are the bones to which (see cut, p. 72) the upper lip is attached. The superior and anterior maxillary bones are separated in animals with long faces, like the horse, that, by overlapping each other, strength might be gained.

The palatine bone forms but a very small portion of the palate. It surrounds the edge of the communication between the cavity of the nose and the back parts of the mouth.

\section{THE PALATE.}

Adhering to a portion of the three bones just described, and constituting the lining of the roof of the mouth, is the palate $(t, \mathrm{p} .72)$, composed of an elastic and dense substance, divided into several ridges called bars. The following cut gives a view of them.

It will also point out the bleeding place, if it should occasionally be deemed advisable to abstract blood from the mouth; or if the horsc should be attacked with megrims on a journey, and the driver, having no lancet, should bc compelled to make use of his knife, the incision should be made between the central and second nippers on either side, about an inch witlin the mouth, and cutting through the second bar. 


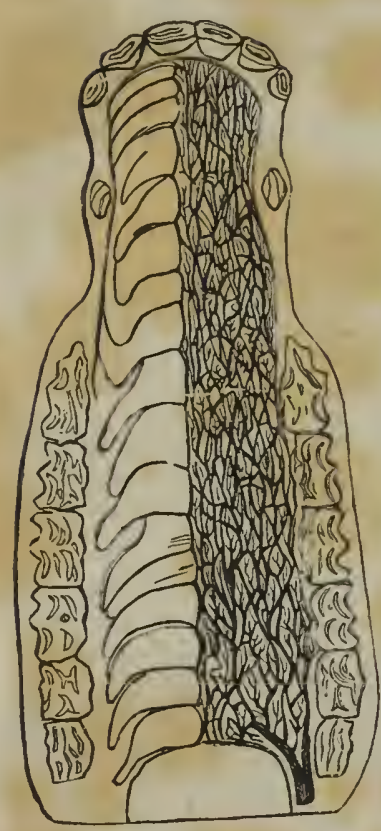

A stream of blood will be thus obtained, which will usually cease to flow when two or three quarts have escaped, or may generally be arrested by the application of a sponge filled with cold water.

This, however, is a make-shift sort of bleeding that may be allowable on a journey, and possibly in some cases of lampas, but which is decidedly objectionable as the usual mode of abstracting blood. The quantity withdrawn cannot be measured, the degree of inflammation cannot be ascertained by the manner in which it coagulates, and there may be difficulty to the operator, and annoyance and pain to the horse, in stopping the bleeding.

This cut likewise depicts the appearance of the roof of the mouth, if the bars were dissected off, and of the numerous vessels, arterial and venous, which ramify over it.

\section{A M P A S.}

The bars occasionally swell, and rise to a level with, and even beyond the edge of, the teeth. They are very sore, and the horse feeds badly on account of the pain he suffers from the pressure of the food on them. This is called the Lampas. It may arise from inflammation of the gums, propagated to the bars, when the horse is shedding his teeth - and young horses are more subject to it than others - or from some slight febrile tendency in the constitution generally, as when a young horse has lately been taken up from grass, and has been over-fed, or not sufficiently exercised. At times, it appears in aged horses; for the process of growth in the teeth of the horse is continued during the whole life of the animal.

In the majority of cases, the swelling will soon subside without medical treatment; or a few mashes, and gentle alteratives, will relieve the animal. A few slight incisions across the bars with a lancet, or penknife, will relieve the inflammation, and cause the swelling to subside; indeed, this scarification of the bars in lampas will seldom do harm, although it is far from being so necessary as is supposed. The brutal custom of the farrier, who sears and burns down the bars with a red-hot iron, is most objectionable. It is torturing the horse to no purpose, and rendering that part callous, on the delicate sensibility of which all the pleasure and safety of riding and driving depend. It may be prudent, in case of lampas, to examine the grinders, and more particularly the tushes, in order to ascertain whether either of them is making its way through the gum. If it is so, two incisions across each other should be made on the tooth, and the horse will experience immediate relief.

\section{THE LOWER JAW.}

The posterior or lower jaw may be considered as forming the floor of the mouth, ( $a$, p. 68 , or $w$, p. 72). The body, or lower part of it, contains the under cutting teeth and the tushes, and at the sides are two flat pieces of bone, containing the grinders. On the inside, and opposite to $a, \mathrm{p} .68$, is a foramen, or hole, through which blood-vessels and nerves enter to supply the teeth, and some of which escape again at another orifice on the outside, and near the nippers. The branches are broader and thinner, rounded at the angle of the jaw, and terminating in two processes. One, the coracoid, from its sharpness, or supposed resemblance to a beak, passes under the zygomatic arch (see p. 68); and the temporal muscle, arising from the whole surface of the parietal bone (see p. 74), is inserted into it, and wrapped round it; and by its action, principally, the jaw is moved, and the food is ground. The other, the condyloid, or rounded process, is received into the glenoid (shallow) cavity of the temporal bone, at the base of the zygomatic arch, and forms the joint on which the lower jaw moves. This joint is easily seen in the cut at p. 68 ; and being placed 
so near to the insertion of the muscle, or the centre of motion, the temporal muscle must act with very considerable mechanical disadvantage, and, consequently, must possess immense power.

This joint is admirably contrived for the purpose which the animal requires. It will admit freely and perfectly of the simple motion of a hinge, and that is the action of the jaw in nipping the herbage and seizing the corn. But the grass, and more particularly the corn, must be crushed and bruised before it is fit for digestion. Simple champing, which is the motion of the human lower jaw, and that of most beasts of prey, would very imperfectly break down the corn. It must be put into a mill; it must be actually ground.

It is put into the mill, and as perfect a one as imagination can conceive.

The following cuts represent the glenoid cavity, in a carnivorous or flesh-eating, and herbivorous or grass-eating, animal, viz. the tiger and the horse: the one requiring a simple hinge-like motion of the lower jaw to tear and crush the food; the other, a lateral or grinding motion to bring it into a pulpy form. We first examine this cavity in the tiger represented at $\mathbf{B}$. At the root of the zygomatic process $D$, is a hollow with a ridge along the greater part of the upper and inner side of it, standing to a considerable height, and curling over the cavity. At the lower and opposite
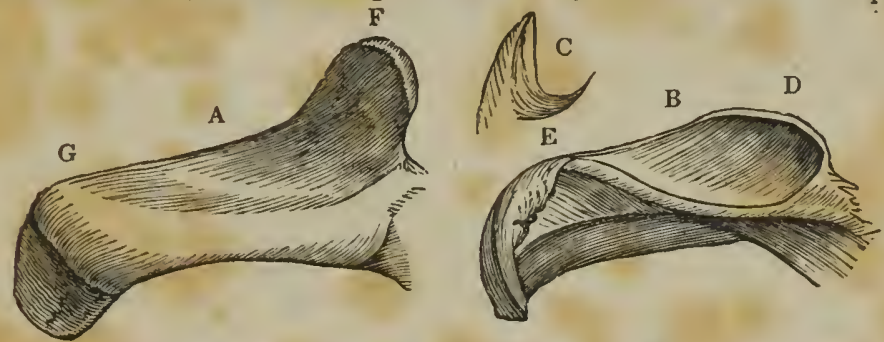

edge of the cavity, but on the outside, is a similar ridge, $\mathbf{E}$, likewise rising abruptly and curling over. At $\mathrm{C}$ is another and more perfect view of this cavity in a different direction. The head of the lower jaw is received into this hollow, and presses against these ridges, and is partially surrounded by them, and forms with them a very strong joint where dislocation is searcely possible, and the hinge-like or cranching motion is admitted to its fullest extent; permitting the animal violently to seize his prey, to hold it firmly, and to crush it to pieces; but from the extent and curling form of the ridges, forbidding, except to a very slight degree, all lateral and grinding motion, and this, because the animal does not want it.

As before mentioned, the food of the horse must be ground. Simple bruising and champing would not sufficiently comminute it for the purposes of digestion. We then observe the different construction of the parts to effect this. A gives the glenoid cavity of the horse. First, there is the upper ridge assuming a rounded form, $\mathbf{F}$, and therefore called the mastoid process; and - a peculiarity in the horse - the mastoid process of the squamous portion of the temporal bone: sufficiently strong to support the pressure and action of the lower jaw when cropping the food or seizing an enemy, but not encircling the head of that bone, and reaching only a little way along the side of the cavity, where it terminates, having its edges rounded off so as to admit, and to be evidently destined for, a circular motion about it. At the other and lower edge of the cavity, and on the outside, $G$ is placed-not a curling ridge as in the tiger, but a mere tubercle: and for what reason? evidently to limit this lateral or circular motion - to permit it as far as the necessities of the animal require it, and then to arrest it. How is this done? Not suddenly or abruptly; but the tubercle, of which we have already spoken as strengthening this portion of the zygomatic arch, now discharging another office, has a smooth and gradual ascent to it, up which the lower jaw may climb to a certain extent, and then, by degrees, be stopped. We speak not now of the moveable cartilage which is placed in this cavity, and between the bones, to render the motion easier and freer. It is found in this joint in every quadruped; and it is found wherever motions are rapid and of long continuance. 


\section{ANATOMY AND DISEASES OF THE NOSE AND MOUTH.}

So great is the conformity between the structure of the animal and his destination, that a tolerable student in comparative anatomy, by a mere inspection of the glenoid cavity, would at once determine whether the animal to which it belonged was carnivorous, and wanted no lateral motion of the jaw ; or omnivorous, living occasionally on all kinds of food, and requiring some degree of grinding motion; or herbivorous, and needing the constant use of this admirably-constructed mill.

At $g, p .125$, is represented the masseter muscle, an exceedingly strong one, constituting the cheek of the horse - arising from the superior maxillary under the ridge continued from the zygomatic arch, and inserted into the lower jaw, and particularly round the rough border at the angle of the jaw. This acts with the temporal muscle in closing the jaw, and in giving the direct cutting or champing motion of it.

Within the lower jaw, on either side, and occupying the whole of the hollowed portion of them, and opposite to the masseters, are the pterygoid muscles, going from the jaws to bones more in the centre of the channel, likewise closing the mouth, and also, hy their alternate action, giving that grinding motion which has been described.

The space between the branches of the lower jaw, called the channel, is of considerable consequence. It may be a little too wide, and then the face will have a clumsy appearance: but if it is too narrow, the horse will never be able to bend his head freely and gracefully; he will be always pulling or boring upon the hand, nor can he possibly be well reined in.

The jaws contain the teeth, which are the millstones employed in comminuting the food. The mouth of the horse at five years old contains forty teeth, viz. six nippers or cutting teeth in front, a tush on each side, and six molars, or grinding teeth, above and below. They are contained in cavities in the upper and lowcr jaws, surrounded by bony partitions, to which they are accurately fitted, and by which they are firmly supported. For a little way ahove these hony cavities, they are surrounded by a hard substance called the gum, so dense, and adhcring so closely to the teeth and the jaws as not to be separated without very great difficulty - singularly compact, that it may not be wounded by the hard or sharp particles of the food, and almost devoid of feeling, for the same purpose.

Seven or eight months before the foal is born, the germs or beginnings of the teeth are visible in the cavities of the jaws. The tooth grows, and

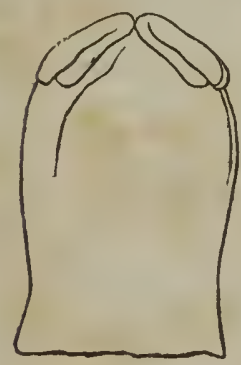
presses to the surface of the gum, and forces its way through it; and, at the time of birth, the first and second grinders have appeared, large compared with the size of the jaw, and seemingly filling it. In the course of seven or eight days the two central nippers are seen as here represented. They likewise appear to be large, and to fill the front of the mouth; although they will afterwards be found to be small, compared with the permanent teeth that follow. In the course of the first month the third grinder appears above and below, and, not long after, and generally bcfore six weeks have expired, anothcr incisor above and below will be seen on each side of the two first, which have now considerably grown, but not attained their perfect height. The second cut will represent the appearance of the mouth at that time.

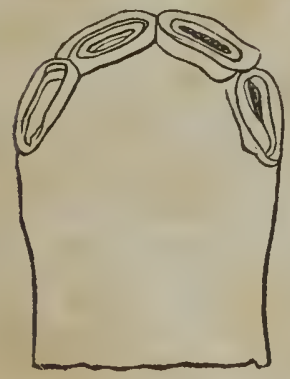

At two months, the central nippers will have reached their natural level, and between the second and third month the second pair will have overtaken them. They will then begin to wear away a little, and the outer edge, which was at first somewhat raised and sharp, is brought to a level with the inner one, and so the mouth continues until some time between the sixth and ninth month, when another nipper begins to appear on each side of the two first, making six above and below, and completing the colt's mouth; after which, the only observable difference, until bctween the second and third year, is in the wear of these teeth.

The term nipper is familiar to the horseman and the farrier, and much better expresses the action of these teeth than the word incisor or cutter, which is adopted by anato- 
mists. Whoever has observed a horse in the act of browsing, and the twitch of the head which accompanies the separation of each portion of grass, will perceive that it is nipped or torn rather than cut off.

These teeth are covered with a polished and exceedingly hard substance, called the enamcl. It spreads ovcr that portion of the teeth which appears above the gum, and not only so, but as thcy are to be so much employed in nipping the grass, and gathcring up the animal's food, and in such employment even this hard substance must be gradually worn away, a portion of it, as it passes over the upper surface of the teeth, is bent inward, and sunk into the body of the teeth, and forms a little pit in them. The inside and bottom of this pit being blackened by the food, constitutes the mark of the teeth, by the gradual disappearance of which, in consequence of the wearing down of the cdge, we are enabled, for several years, to judge of the age of the animal.

'The colt's nipping teeth are rounded in front, somewhat hollow towards the mouth, and present at first a cutting surface, with the outer edge rising in a slanting direction above the inner edge. This, however, soons begins to wear down until both surfaces are level, and the mark, which was originally long and narrow, becomes shorter, and wider, and fainter. $\mathrm{At}$ six months the four nippers are beginning to wear to a level. 'The annexed cut will convey some idea of the appearance of the teeth at twelve months. The four middle tceth are almost level, and the corner ones becoming so.

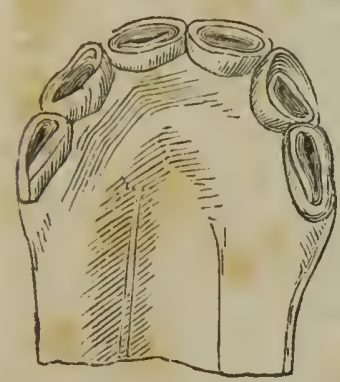
The mark in the two iniddle teeth is wide and faint; in the two next teeth it is darker, and longer, and narrower; and in the corner teetli it is darkest, and longgest, and narrowest.

The back teeth, or grinders, will not guidc us far in asccrtaining the age of the arimal, for we cannot easily inspect them; but there arc some interesting particulars connccted with them. The foal is born with two grinders in cach jaw, above and below; or they appcar within three or four days after the birth. Bcfore the expiration of a month they are succeeded by a third, more backward. The crowns of the grinders are entirely covered with enamel on the top and sides, but attrition soon wears it away from the top, and there remains a compound surface of alternate layers of crusted petraser, enamel, and ivory, which are employed in grinding down the hardest portion of the food. Nature has, therefore, made an additional provision for their strength and endurance.

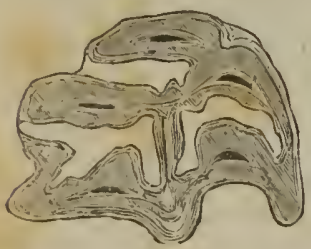

'This cut represents a grinder sawed across. It seems to bc a most irregular and intricate structure; but the explanation of it is not difficult. The tooth is formed and prepared in cavities within the jaw-bones. A delicate membranous bag, containing a jelly-like substance, is found, in the unborn animal, in a little cell within the jaw-bone. It assumes, by degrees, the form of the tooth that is to appear, and then the jelly within the membrane begins to change to bony mattter, and a hard and beautiful crystallization is formed on the membrane without, and so we have the cutting tooth covered by its enamel. In the formation, however, of each of the grinders of the horse, there are originally five membranous bags in the upper jaw, and four in the lower, filled with jelly. This by degrees gives place to bony matter, which is thrown out by little vessels penetrating into it, and is represented by the darker portions of the cut with central black spots. The crystallization of cnamel can be traced around each, and there would be five distinct bones or teeth. A third substance, however, is now secreted (which is represented by the white spaces), and is a powcrful cement, uniting all these distinct bones into onc body, and making one tooth of the five. This being donc, another coat of enamel spreads over tbe sides, but not the top, and the tooth is completcd. By no other contrivance could we have the grinding tooth capable, without injury and without wearing, to rub down the hay, and oats, and beans, which constitute the stable-food of horses.

The grinders in the lower jaw, having originally but four of these bags or shells, 13 
are smaller, and narrower, and more regular, than the upper ones. They are placed horizontally in either jaw; but in the lower the higher side is within, and shelving gradually outward; in the upper jaw the higher side is without, and shelving inward, and thus the grinding motion is most advantageously performed. There is also an evident difference in the appearance and structure of each of the grinders, so that a careful observer could tell to which jaw every one belonged, and what situation it occupied.

At the completion of the first year, a fourth grinder usually comes up, and the yearling has then, or soon afterwards, six nippers, and four grinders above and below in each jaw, which, with the alteration in the appearance of the nippers that we have just described, will enable us to calculate nearly the age of the foal, subject to some variations arising from the period of weaning, and the nature of the food.

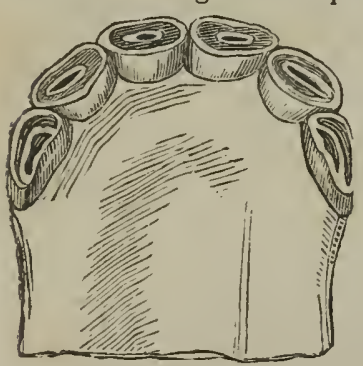

At the age of one year and a-half, the mark in the central nippers will be much shorter and fainter; that in the two other pairs will have undergone in evident change, and all the nippers will be flat.

At two years this will be more manifest. The accompanying cut deserves attention, as giving an accurate representation of the nippers in the lower jaw of a two-years-old colt.

About this period a fifth grinder will appear, and now, likewise, will commence another process. The first teeth are adapted to the size and wants of the young animal. They are sufficiently large to occupy and fill the colt's jaws; but when these bones have expanded with the increasing growth of the animal, the teeth are separated too far from each other to be useful, and another and larger set is required. Evident provision is made for them, even before the colt foaled. In cavities in the jaw, beneath the first and temporary teeth, are to be seen the rudiments of a second and permanent set. These gradually increase, some with greater rapidity than others, and, pressing upon the roots or fangs of the first teeth, do not, as would be imagined, force out the former ones, but the portion pressed upon gradually disappears. It is absurbed - taken up and carried away, by numerous minute vessels, whose office it is to get rid of the worn-out or useless part of the system. This absorption continues to proceed as the second teeth grow and press upwards, until the whole of the fang is gone, and the crown of the tooth, or that part of it which was above the gum, having no longer firm hold, drops out, and the second teeth appear, larger and stronger and permanent. In a few instances, however, the second teeth do not rise immediately under the temporary or milk teeth, but somewhat by their side; and then, instead of this gradual process of absorption and disappearance from the point of the root upwards, the root being compressed sideways, diminishes throughout its whole bulk. The crown of the tooth diminishes with the root, and the whole is pushed out of its place, to the fore part of the first grinder, and remains for a considerable time, under the name of a wolf's tooth, causing swelling and soreness of the gums, and frequently wounding the cheeks. They would be gradually quite absorbed, but the process might be slow and the annoyance would be great, and, therefore, they are extracted.

The change of the teeth commences in those which earliest appeared, and, therefore, the front or first grinder gives way at the age of two years, and is succeeded by a larger and permanent tooth.

During the period between the falling out of the central milk nippers, and the coming up of the permanent ones, the colt, having a broken mouth, may find some difficulty in grazing. If he should fall away considerably in condition, he should be fed with mashes and corn, or cut meat.

The next cut will represent a three-years-old mouth. The central teeth are larger than the others, with two grooves in the outer convex surface, and the mark is long, narrow, deep and black. Not having yet attained their full growth, they are rather lower than the others. The mark in the two next nippers is nearly worn out, and it is wearing away in the corner nippers. Is it possible to give this mouth to an early two-years-old? The ages of all horses used to be reckoned from May, but some are foaled even so early as January, and being actually four months over the two years, 
if they have been well nursed and fed, and are strong and large, they may, with the inexperienced, have an additional year put upon them. The central nippers are

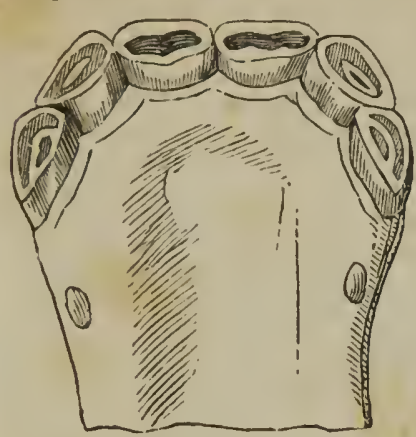
punched or drawn out, and the others appear three or four months earlier than they otherwise would. In the natural process, they could only rise by long pressing upon, and causing the absorption of, the first set. But opposition from the first set being removed, it is easy to imagine that their progress will be more rapid. Three or four months will be gained in the appearance of the teeth, and these three or four months may enable the breeder to term him a late colt of a preceding year. To him, however, who is accustomed to horses, the general form of the animal-the little developement of the fore-hand - the continuance of the mark on the next pair of nippers-its more evident existence in the corner ones, some enlargement or irregularity about the gums from the violence used in forcing out the teeth-the small growth of the first and fifth grinders and the non-appearance of the sixtl grinder, which if it is not througl the gum at three years old, is swelling under it, and preparing to get through - any or all of these circumstances, carefully attended to, will be a sufficient security against deception.

A horse at three years old ought to have the central permanent nippers growingthe other two pairs wasting - six grinders in each jaw, above and below - the first and fifth level with the others, and the sixth protruding. The sharp edge of the new incisors, although it could not be well expressed in the cut, will be very evident when compared with the neighbouring teeth.

As the permanent nippers wear, and continue to grow, a narrower portion of the cone-shaped tooth is exposed to the attrition, and they look as if they had heen compressed, but it is not so. The mark, of course, gradually disappears as the pit is worn away.

At three years and a half, or between that and four, the next pair of nippers will be changed, and the mouth at that time cannot be mistaken. The central nippers will have attained nearly their full growth. A vacuity will be left where the second stood, or they will begin to peep above the gum, and the corner ones will be diminished

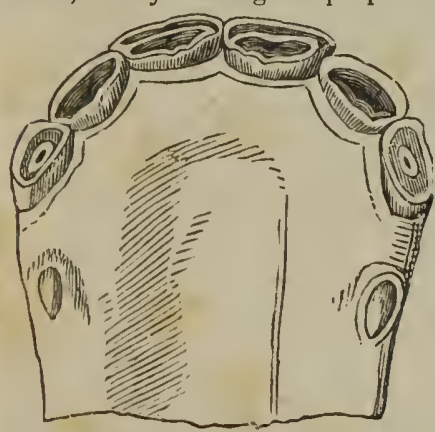
in breadth, worn down, and the mark becoming small and faint. At this period, likewise, the second pair of grinders will be shed. Previously to this may be the attempt of the dealer to give to his three-years-old an additional year, but the fraud will be detected by an examination similar to that which has been already described.

At four years, the central nippers will he fully developed; the sharp edge somewhat worn off and the mark shorter, wider, and fainter. The next pair will be up, but they will be small, with the mark deep, and extending quite across them. The corner nippers will be larger than the inside ones, yet smaller than they were, and flat, and the mark nearly effaced. The sixth grinder will have risen to a level with the others, and the tushes will begin to appear.

Now, more than at any other time, will the dealer be anxious to put an additional year upon the animal, for the difference between a four-years-old colt, and a five-yearsold horse, in strength, utility, and value, is very great; but, the want of wear in the other nippers-the small size of the corner ones-the little growth of the tush - the smallness of the second grinder - the low fore-hand - the legginess of the colt, and the thickness and little depth of the mouth, will, to the man of common experience among horses, at once detect the cheat.

The tushes (see p. 142) are four in number, two in each jaw, situated between the nippers and the grinders-much nearer to the former than the latter, and nearer in the 
lower jaw than in the upper, but this distance increasing in both jaws with the age of the animal. In shape it somewhat resembles a cone; it protrudes about an inch from the gum, and has its extremity sharp-pointed and curred. At the age now under consideration, the tushes are almost peculiar to the horse, and castration docs not appear to prevent or retard their development. All mares, however, have the germs of them in the chambers of the jaw, and they appear externally in the majority of old mares. Their use is not evident. Perhaps in the wild state of the animal they are weapons of offence, and he is enabled by them more firmly to seize, and more deeply wound his enemy.

The breeder often attempts to hasten the appearance of the tush, and he cuts deeply through the gum to remove the opposition which that would afford. To a little extent he succeeds. He may possibly gain a few weeks, but not more. After all, there is much uncertainty as to the appearance of the tush, and it may vary from the fourth year to four years and six months. It belongs, in the upper jaw, both to the inferior and superior maxillary bones (see n. p. 70); for, while its fang is deeply imbedded in the inferior maxillary, the tooth penetrates the process of the superior maxillary at the union of those bones.

At four years and a half, or between that and five, the last important change takes place in the mouth of the horse. The corner nippers are shed, and the permanent ones begin to appear. The central nippers are considerably worn, and the next pair are commencing to show marks of usage. The tush has now protruded, and is generally a full half-inch in height; externally it has a rounded prominence, with a groove on either side, and it is evidently hollowed within. The reader needs not to be told that after the rising of the corner nipper the animal clianges its name-the colt becomes a horse, and the filly a mare.

At five years the horse's mouth is almost perfect. 'The corner nippers are quite up,

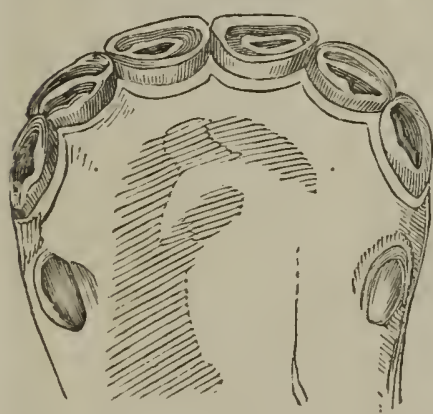
with the long deep mark irregular on the inside; and the other nippers bearing evident tokens of increasing wearing. The tush is much grownthe grooves have almost or quite disappeared, and the outer surface is regularly convex. It is still as concave within, and with the edge nearly as sharp as it was six months before. The sixtl molar is quite up, and the third molar is wanting. This last circumstance, if the general appearance of the animal, and particularly his forehead and the wearing of the centre nippers, and the growth and shape of the tushes, are likewise carefully attended to, will prevent deception, if a late fouryears-old is attempted to be substituted for a five. The nippers may be brought up a few months before their time, and the tushes a few weelis, but the grinder is with difficulty displaced. The three last grinders and the tushes are never shed.

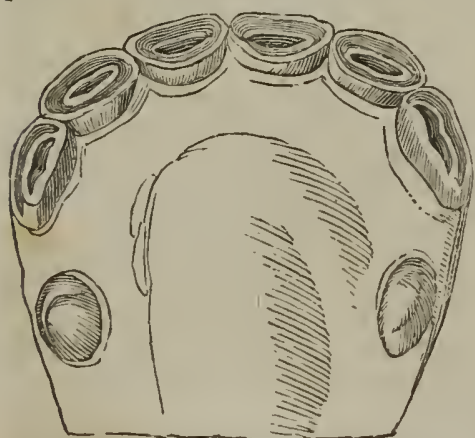

At six years the mark on the central nippers is worn out. There will still be a difference of colour in the centre of the tooth. 'The cement filling the hole, made by the dipping in of the enamel, will present a browner hue than the other part of the tooth, and it will be evidently surrounded by an edge of enamel, and there will even remain a little depression in the centre, and also a depression round the case of enamel: but the deep hole in the centre of the teeth, with the blackened surface which it presents, and the elevated edge of enamel, will have disappeared. Persons not much accustomed to horses have heen puzzled here. They expected to find a plain surface of a uniform colour, and knew not what con. clusion to draw when there was both discolouration and irregularity. 
In the next incisors the mark is shorter, broader, and fainter; and in the corner teeth the edges of the enamel are more regular, and the surface is evidently worn. The tush has attained its full growth, being nearly or quite an inch in length ; convex outward, concave within; tending to a point, and the extremity somewhat curved. The third grinder is fairly up; and all the grinders are level.

The horse may now be said to have a perfect mouth. All the teeth are produced, fully grown, and have hitherto sustained no material injury. During these important changes of the teeth, the animal has suffered less than could be supposed possible. In children, the period of teething is fraught with danger. Dogs are subject to convulsions, and hundreds of them die, from the irritation caused by the cutting or shed-

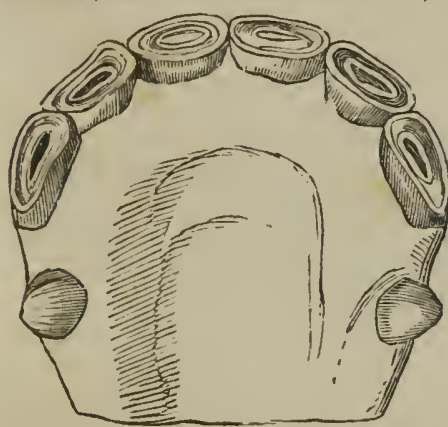

ding of their teeth; but the horse appears to feel little inconvenience. The gums and palate are occasionally somewhat hot and swollen; but the slightest searification will remove this. The teeth of the horse are more necessary to him than those of the other animals are to them. The child may be fed, and the dog will bolt his food; but that of the horse must be well ground down, or the nutriment cannot be extracted from it.

At seven years, the mark, in the way in which we have described it, is worn out in the four central nippers, and fast wearing away in the corner teeth; the tush also is beginning to be altered. It is rounded at the point; rounded at the edges; still round without; and beginning to get round inside.

At eight years old, the tush is rounder in every way; the mark is gone from all the bottom nippers, and it may almost be said to be out of the mouth. There is nothing remaining in the bottom nippers that can afterwards clearly show the age of the horse, or justify the most experienced examiner in giving a positive opinion.

Dishonest dealers have been said to resort to a method of prolonging the mark in the lower nippers. It is called bishoping, from the name of the scoundrel who invented.

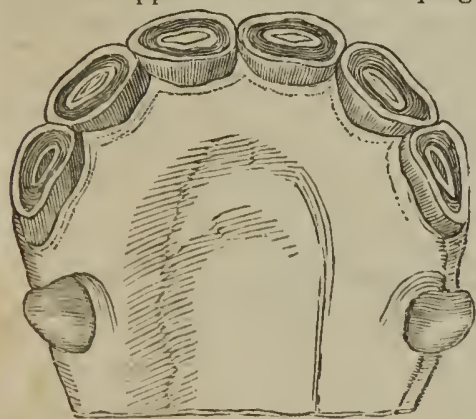
it. The horse of eight or nine years old is thrown, and with an engraver's tool a hole is dug in the now almost plain surface of the corner teeth, and in shape and depth resernbling the mark in a seven-years-old horse. The hole is then burned with a heated iron, and a permanent black stain is left. The next pair of nippers are sometimes lightly touched. An ignorant man would be very easily imposed on by this trick: but the irregular appearance of the cavity-the diffusion of the black stain around the tushes, the sharpened edges and concave inner surface of which can never be given again - the marks on the upper nippers, together with the general conformation of the horse, can never deceive the careful examiner.

Horsemen, after the animal is eight years old, are accustomed to look to the nippers in the upper jaw, and some conclusion has been drawn from the appearances which they present. It cannot be doubted that the mark remains in them for some years after it has been obliterated from the nippers in the lower jaw ; because the hard substance, or kind of cement, by which the pit, or funnel, in the centre of the tooth is occupied, does not reach so high, and there is a greater depth of tooth to be worn away, in order to come at it. To this, it may be added that the upper nippers are not so much exposed to friction and wear as the under. The lower jaw alone is moved, and pressed forcibly upon the food: the upper jaw is without motion, and has only to resist that pressure.

There are various opinions as to the intervals between the disappearance of the $13 *$ 
marks from the different cutting-teeth in the upper jaw. Some have averaged it at two years, and others at one. 'The author is inclined to adopt the latter opinion, and then the age will be thus determined: at nine years, the mark will be worn out from the middle nippers - from the next pair at ten, and from all the upper nippers at eleven. During these periods, the tush is likewise undergoing a manifest changeit is blunter, shorter, and rounder. In what degree this takes place in the different periods, long and most favourable opportunities for observation can alone enable the horscman to decide.

The tushes are exposed to but little wear and tear. 'The friction against them must be slight, proceeding only from the passage of the food over them, and from the motion of the tongue, or from the bit; and their alteration of form, although generally as we have described it, is frequently uncertain. The tush will sometimes be blunt at eiglit ; at other times it will remain pointed at eighteen. The upper tush, although the latest in appearing, is soonest worn away.

Are there any circumstances to guide our judgment after this? There are those which will prepare us to guess at the age of the horse, or to approach within a few years of it, until he becomes very old; but there are none which will enable us accurately to detcrmine the question, and the indications of age must now be taken from the shape of the upper surface of the nippers. At eight, they are all oval, the length of the oval running across from tooth to tooth; but as the horse gets older, the teetl diminish in size - and this commencing in their width, and not in their thickness. They become a little apart from each other, and their surfaces are rounded. At nine, the centre nippers are evidently so; at ten, the others begin to have the oval shortened. At eleven, the second pair of nippers are quite rounded; and at thirteen, the corner ones have that appearance. At fourteen, the faces of the central nippers become somewhat triangular. At seventeen, they are all so. At nineteen, the angles begin to wear off, and the central teeth are again oval, but in a reversed direction, viz. from outward, inward; and at twenty-one, they all wear this form. This is the opinion of some Continental veterinary surgeons, and Mr. Percivall first presented them to us in an English dress.

It would be folly to expect perfect accuracy at this advanced age of the horse, when we are bound to confess that the rules which we have laid down for determining this matter at an earlier period, al though they are recognised by horsemen generally, and referred to in courts of justice, will not guide us in cvery case. Stabled horses have the mark sooner worn out than those that are at grass; and a crib-biter may deceive the best judge by one or two years. The age of the horse, likewise, being formerly calculated from the 1st of May, it was exceedingly difficult, or almost impossible, to determine whether the animal was a late foal of one year, or an early one of the next. At nine or ten, the bars of the mouth become less prominent, and their regular diminution will designate increasing age. At elcven or twelve, the lower nippers change their original upright direction, and project forward or horizontally, and become of a yellow colour. They are yellow, because the teeth must grow, in order to answer to their wear and tear; but the enamel which covered their surface when they were first produced cannot be repaired; and that which wcars this yellow colour in old age, is the part which in youth was in the socket, and therefore destitute of enamel.

The general indications of old age, independent of the teeth, are deepening of the hollows over the eyes; grey hairs, and particularly over the eyes and about the muzzle; thinness and hanging down of the lips; sharpness of the withers; sinking of the back; lengthening of the quarters; and the disappearance of windgalls, spavins, and tumours of every kind.

of the natural age of the horse, we should form a very erroneous estimate from the early period at which he is now worn out and destroyed. Mr. Blaine speaks of a gentleman who had three horses that died at the ages of thirty-five, thirty-seven, and thirty-nine. Mr. Cully mentions one that reccived a ball in his neck, at the battle of Preston, in 1715, and which was extracted at his death, in 1758; and Mr. Percivall gives an account of a barge-horse that died in his sixty-second year.

There cannot be a severer satire on the English nation than this, that, from the absurd practice of running our race-horses at two and three years old, and working others, in various ways, long befcre their limbs are knit or their strength developed, 
and cruelly exacting from them services far beyond their powers, their age does not average a sixth part of that of the last-mentioned horse. The scientific author of the "Animal Kingdom" declares, that "it may be safely asserted, that more horses are consumed in England, in every ten years, than in any other country in the world in ten times that period, except those which perish in war."

This affair has, with the English, been too long considered as one of mere profit and loss; and it has been thought to be cheaper to bring the young horse early into work, and prematurely to exhaust his strength, than to maintain him for a long period, and at a considerable expense, almost useless. The matter requires much consideration, and much reformation, too.

\section{DISEASES OF THE TEETH.}

Of the diseases of the teeth in the horse, we know little. Carious or hollow teeth are occasionally, but not often, seen; but the edges of the grinders, from the wearing off of the enamel, or the irregular growth of the teeth, becomc rough, and wound the inside of the cheek; it is then necessary to adopt a summary, but effectual method of cure; namely, to rasp them smooth. Many had ulcers have been produced in the mouth by the neglect of this.

The teeth sometimes grow irregularly in length, and this is particularly the case with the grinders, from not being in exact opposition to each other when the mouth is shut. 'The growth of the teeth still going on, and there being no mechanical opposition to it, one of the back teeth, or a portion of one of them, shoots up considerably above the others. Sometimes it penetrates the bars above, and causes soreness and ulceration; at other times it interferes partially, or altogether, with the grinding motion of the jaws, and the animal pines away without the cause being suspected. Here the saw should be used, and the projecting portion reduced to a level with the other teeth. 'The horse that has once been subjected to this operation should afterwards be frequently examined, and especially if he loses condition : and, indecd, every horse that gets thin or out of condition, without fever, or other apparent cause, should have his teeth and mouth carefully examined, and esperially if, without any indication of sore throat, he quids-partly chewing and then dropping-his food, or if hc holds his head somewhat on one side, while he eats, in order to get the food between the outer edges of the teeth. $\Lambda$ horse that has once had very irregular tceth is materially lessened in value, for, although they may be sawn down as carefully as possible, they will project again at no great distance of time. Such a horse is to all intents and purposes unsound. In order to be fit for servicc, he should be in possession of his full natural powers, and thesc powers cannot be sustained without perfect nutrition, and nutrition would be rendered sadly imperfect by any defect in the operation of mastication. Not only do some diseases of the teeth render the act of mastication difficult and troublesome, but, from the food acquiring a foetid odour during its detention in the mouth, the horse acquires a distaste for aliment altogether.

The continuance of a carious tooth often produces disease of the neighbouring ones, and of the jaw itself. It should therefore be removed, as soon as its real state is evident. Dreadful cases of fungus hæmatodes have arisen from the irritation caused by a carious tooth.

The mode of extracting the teeth requires much reformation. The hammer and the punch should never be had recourse to. The keyed instrument of the human subject, but on a larger scale, is the only one that should be permitted.

This is the proper place to speak more at length of the effect of dentition on the system generally. Horsemen in general think too lightly of it, and they scarcely dream of the animal suffering to any considerable degree, or absolute illness being produced; yet he who has to do with young horses will occasionally discover a considerable degree of febrile affection, which he can refer to this cause alone. Fever, cough, catarrhal affections generally, disease of the eyes, cutaneous affections, diarrhœa, dysentery, loss of appetite, and general derangement, will frequently be traced by the careful observer to irritation from teething.

It is a rule scarcely admitting of the slightest deviation, that, when young horses are labouring under any febrile affection, the mouth should be examined, and if the tushes are prominent and pushing against the gums, a crucial incision should be 
made across them. "In this way," says Mr. Percivall, "I have seen catarrhal and bronchial inflammations abated, coughs relieved, lymphatic and other glandular tumours about the head reduced, cutaneous eruptions got rid of, deranged bowels restored to order, appetite returned, and lost condition repaired."*

\section{THE TONGUE.}

The tongue is the organ of taste. It is also employed in disposing the food for being grcund between the teeth, and afterwards collecting it together, and conveying it to the back part of the mouth, in order to be swallowed. It is likewise the main instrument in deglutition, and the canal through which the water passes in the act of drinking. The root of it is firmly fixed at the bottom of the mouth by a variety of muscles; the fore part is loose in the mouth. It is covered by a continuation of the membrane that lines the mouth, and which, doubling beneath, and confining the motions of the tongue, is called its frænum, or bridle. On the back of the tongue, this membrane is thickened and roughened, and is covered with numerous conical papilix, or little eminences, on which the fibres of a branch of the fifth pair of nerves expand, communicating the sense of taste. The various motions of the tongue are accomplished by means of the ninth pair of nerves. The substance of the tongue is composed of muscular fibres, with much fatty matter interposed between them, and which gives to this organ its peculiar softness.

\section{DISEASES OF THE TONGUE.}

The tongue is sometimes exposed to injury from carelessness or violence in the act of drenching or administering a ball, it being pressed against and cut by the edges of the grinders. A little diluted tincture of myrrh, or alum dissolved in water, or even nature unassisted, will speedily heal the wound. The horse will sometimes bite his tongue, most frequently in his sleep. If the injury is trifling, it requires little care; but, in some instances, a portion of the tongue has been deeply lacerated or bitten off. The assistance of a veterinary practitioncr is here required.

There are some interesting accounts of the results of this lesion. Mr. Dickens of Kimbolton found a portion of the tongue of a mare, extending as far as the frænulum beneath, lying in the manger in a strangely lacerated condition, and fast approaching to decomposition. He had her cast, and, excising all the unhealthy portions, he dressed the wound with chloride of soda and tincture of myrrh. In less than a week the laceration was nearly healed, and, soon afterwards, she could eat with very little difficulty, and keep herself in good condition. The injury was proved to have been inflicted by a brutal horsebreaker, in revenge of some slight affront. $\dagger$

A curious case is recorded in the Memoirs of the Society of Calvados. A horse was difficult to groom. The soldier who had the care of him, in order the better to manage him, fixed in his mouth and on his tongue a strong chain of iron, deeply serrated, while another man gave to this chain a terrible jerk whenever the horse was disposed to be rebellious. The animal, under such torture, became unmanageable, and the man who held the chain sawing away with all his strength, the tongue was completely cut off at the point which separates its base from the free portion of it. The wound healed favourably, and he was soon able to manage a mash. After that some hay was given to him in small quantities. He took it and formed it into a kind of pellet with his lips, and then, pressing it against the bottom of his manger, he gradually forced it sufficiently back into the mouth to be enabled to seize it with his grinders.

Another horse came to an untimely end in a singular way. He had scarcely eaten anything for three weeks. He seemed to be unable to swallow. The channel beneath the lower jaw had much enlargement about it. There was not any known cause for this, nor any account of violence done to the tongue. At length a tumour appeared under the jaw. Mr. Young of Muirhead punctured it, and a considerable quantity of purulent matter escaped. The horse could drink his gruel after this, but not take any solid food. A week afterwards he was found dead. Upon separating the head from the trunk, and cutting transversely upon the tongue, nearly opposite to

\footnotetext{
* Percivall's Hippopathology, vol. ii., p. 173.
}

+ Veterinarian, vol. vi., p. 22. 
the sccond grinder, a needle was found lying longitudinally, and which had penetrated from the side to the inferior portion of the tongue. It was an inch and a quarter in length, and the neighbouring substance was in a state of gangrene.

$V$ csicles will somctimes appear along the under side of the tongue, which will increasc to a considerable size. The tongue itself will be much enlarged, the animal will be unable to swallow, and a great quantity of ropy saliva will drivel from the mouth. 'This disease often exists without the nature of it being suspected. If the mouth is opencd, one large bladder, or a succession of bladders, of a purple hue, will be seen extending along the whole of the under side of the tongue. If they are lanced frecly and deeply, from end to end, the swelling will very rapidly abate, and any little fever that remains may be subdued by cooling medicine. The cause of this disease is not clearly known.

\section{THE SALIVARY GLANDS.}

In order that the food may be properly comminuted preparatory to digestion, it is necessary that it should be previously moistened. The food of the stabled horse, however, is dry, and his meal is generally concluded without any fluid being offered to him. Nature has made a provision for this. She has placed in the neighbourhood of the mouth various glands to secrete, and that plentifully, a limpid fluid, somewhat saline to the taste. This fluid is conveyed from the glands into the mouth, by various ducts, in the act of chewing, and, being mixed with the food, renders it more easily ground, more easily passed afterwards into the stomach, and better fitted for digestion.

The principal of these is the parotid gland (see cut p. 125). It is placed in the hollow which extends from the root of the ear to the angle of the lower jaw. A portion of it, $q$, is represented as turned up, to show the situation of the blood-vessels underneath. In almost every case of cold connected with sore throat, an enlargement of the parotid gland is cvident to the feeling, and even to the eye. It is composed of numerous small glands connected together, and a minute tube proceeding from each, to carry away the secreted fluid. 'These tubes unite in one common duct. At the letter $u$, the parotid duct is seen to pass under the angle of the lower jaw, together with the subinaxillary artery, and a branch of the jugular vein, and they come out again at $w$. At $r$, the duct is seen separated from thc other vessels, climbing up the cheek, and piercing it to discharge its contents into the mouth, opposite to the second grinder. The quantity of fluid thus poured into the mouth from each of the parotid glands amounts to a pint and a half in an hour, during the action of mastication; and, sometimes, when the duct has been accidentally opened, it has spirted out to the distance of several fect.

'The parotid gland syinpathises with every inflammatory affection of the upper part of the throat, and therefore it is found swollen, hot, and tender, in almost every catarrh or cold. The catarrh is to be treated in the usual way; while a stimulating application, almost amounting to a blister, well rubbed over the gland, will best subdue the inflammation of that body.

In bad strangles, and, sometimes, in violent cold, this gland will be much enlarged and ulccrated, or an obstruction will take place in some part of the duct, and the accumulating fluid will burst the vessel, and a fistulous ulcer will be formed that will be very difficult to heal. A veterinary surgeon alone will be competent to the treatment of either case; and the principle by which he will be guided, will be to heal the abscess in the gland as spectily as he can, and, probably, by the application of the heatcd iron: or, if the ulcer is in the duct, either to restore the passage through the duct, or to form a new one, or to cut off the flow of the saliva by the destruction of the gland.

$\Lambda$ second source of the saliva is from the submaxillary glands, or the glands under the jaw. Onc of them is represented at $s$, p. 125. The submaxillary glands occupy the spacc underneath and between the sides of the lower jaw, and consist of numerous sinall bodies, cach with its proper duct, uniting together, and forming on each side a common duct or vessel that pierces through the muscles at the root of the tongue, and opens in little projections, or hcads, upon the frxnum, or bridle of the tongue, about an incli and a half from the front teeth. When the horse has catarrl 
or cold, these glands, like the parotid gland, enlarge. This is often to be observed after strangles, and several distinct kernels are to be felt under the jaw. It has already been stated that they may be distinguished from the swellings that accompany or indicate glanders, by their being larger, generally not so distinct, more in the centre of the channel, or space between the jaws, and never adhering to the jawbones. The farriers call them vives, and often adopt cruel and absurd methods to disperse them, - as burning them with a lighted candle, or hot iron, or even cutting them out. They will, in the majority of instances, gradually disperse in proportion as the disease which produced them subsides; or they will yield to slightly stimulating embrocations; or, if they are obstinate in their continuance, they are of no further consequence, than as indicating that the horse has laboured under severe cold or strangles.

During catarrh or inflammation of the moutl, the little projections marking the opening of these ducts on either side of the bridle of the tongue are apt to enlarge, and the mouth under the tongue is a little red, and hot and tender. The farriers call these swellings BARBS or PAPS; and as soon as they discover them, mistaking the effect of disease for the cause of it, they set to work to cut them close off. The bleeding that follows this operation somewhat abates the local inflammation, and affords temporary relief; but the wounds will not speedily heal. The saliva continues to flow from the orifice of the duct, and, running into the irregularities of the wound, causes it to spead and deepen. Even when it heals, the mouth of the duct being frequently closed, and the saliva continuing to be secreted by the submaxillary gland, it accumulates in the duct until that vessel bursts, and abscesses are formed which eat deeply under the root of the tongue, and long torment the poor animal. When, after a great deal of trouble, they are closed, they are apt to break out again for months and years afterwards.

All that is necessary with regard to these paps or barbs is to abate the inflammation or cold that caused them to appear, and they will very soon and perfectly subside. He who talks of cutting them out is not fit to be trusted with a horse.

A third source of saliva is from glands under the tongue - the sublingual glands, which open by many little orifices under the tongue, resembling little folds of the skin of the mouth, hanging from the lower surface of this organ, or found on the bottoin of the mouth. These likewise sometimes enlarge during catarrh or inflammation of the mouth, and are called gigs, and bladders, and flaps in the mouth. They have the appearance of small pimples, and the farrier is too apt to cut them away, or burn them off. The better way is to let them alone-for in a few days they will generally disappear. Should any ulceration remain, a little tincture of myrrh, or a solution of alum, will readily heal them.

Beside these three principal sources of saliva, there are small glands to be found on every part of the mouth, cheeks, and lips, which pour out a considerable quantity of fluid, to assist in moistening and preparing the food.

\section{STR A N G L ES.}

- This is a disease principally incident to young horses-usually appearing between the fourth and fifth year, and oftener in the spring than in any other part of the year. It is preceded by cough, and can at first be scarcely distingushed from common cough, except that there is more discharge from the nostril, of a yellowish colour, mixed with pus, and generally without smell. There is likewise a considerable discharge of ropy fluid from the mouth, and greater swelling than usual under the throat. This swelling increases with uncertain rapidity, accompanied by some fever, and disinclination to eat, partly arising from the fever, but more from the pain which the animal feels in the act of mastication. There is considerable thirst, but after a gulp or two the horse ceases to drink, yet is evidently desirous of continuing his draught. In the attempt to swallow, and sometimes when not drinking, a convulsive cough comes on, which almost threatens to suffocate the animal-and thence, probably, the name of the disease.*

* Old Gervase Markham gives the following description of this disease, and of the origin of its name. "It is," says he, "a great and hard swelling between a horse's nether chaps, 
The tumour is under the jaw, and about the centre of the channel. It soon fills the whole of the space, and is evidently one uniform body, and may thus be distinguished from glanders, or the enlarged glands of catarrh. In a few days it becomes more prominent and soft, and evidently contains a fluid. This rapidly increases; the tumour bursts, and a great quantity of pus is discharged. As soon as the tumour has broken, the cough subsides, and the horse speedily mends, although some degree of weakness may hang about him for a considerable time. Few horses, possibly none, escape its attack; but, the disease having passed over, the animal is free from it for the remainder of his life. Catarrh may precede, or may predispose to, the attack, and, undoubtedly, the state of the atmosphere has much to do with it, for both its prevalence and its severity are connected with certain seasons of the year and changes of the weather. There is no preventive for the disease, nor is there anything contagious about it. Many strange stories are told with regard to this ; but the explanation of the matter is, that when several horses in the same farm, or in the same neighbourhood, have had strangles at the same time, they have been exposed to the same powerful but unknown exciting cause.

Messrs. Percivall and Castley have come the nearest to a satisfactory view of the nature of strangles. Mr. Castley* says, that "the period of strangles is often a much more trying and critical time for young horses than most people seem to be aware of; that when colts get well over this complaint, they generally begin to thrive and improve in a remarkable manner, or there is sometimes as great a change for the worse : in fact, it seems to effect some decided constitational change in the animal."

Mr. Percivall adds, "the explanation of the case appears to me to be, that the animal is suffering more or less from what I would call strangle-fever, - a fever the disposition and tendency of which is to produce local tumour and abscess, and, most commonly in that situation, underneath the jaws, in which it has obtained the name of strangles."

Professor Dick, of Edinburgh, adds that which is conclusive on the subject, that "although the disease commonly terminates by an abscess under the jaw, yet it may, and occasionally does, give rise to collections of matter on other parts of the surface."

To this conclusion then we arc warranted in coming, that strangles is a specific affection to which horses are naturally subject at some period of their lives, and the natural cure of which seems to be a suppurative process. From some cause, of the nature of which we are ignorant, this suppurative process usually takes place in the space between the branches of the maxillary bone, and occurring there it appears in the mildest form, and little danger attends. When the disease is ushered in by considerable febrile disturbance, and the suppuration takes place elsewhere, the horse too frequently sinks under the attack.

'The treatment of strangles is very simple. As the essence of the disease consists in the formation and suppuration of the specific tumour, the principal, or almost the sole attention of the practitioner, should be directed to the hastening of these processes: therefore, as soon as the tumour of strangles is decidedly apparent, the part should be actively blistered. Old practitioners used to recommend poultices, which, from the thickness of the horse's skin, must have very little effect, even if they could be confined on the part; and from the difficulty and almost impossibility of this, and their getting cold and hard, they necessarily weakened the energies of nature, and delayed the ripening of the tumour. Fomentations are little more effectual. A blister will not only secure the completion of the process, but hasten it by many days, and save the patient much pain and exhaustion. It will produce another good effect - it will, previously to the opening of the tumour, abate the internal inflammation and soreness of the throat, and thus lessen the cough and wheezing.

As soon as the stvelling is soft on its summit, and evidently contains matter, it should be freely and deeply lanced. It is a bad, although frequent practice, to suffer the tumour to burst naturally, for a ragged ulcer is formed, very slow to heal, and

upon the rootes of his tongue, and about his throat, which swelling, if it be not prevented, will stop the horse's windpipe, and so strangle or choke him: from which effect, and none other, the name of this disease tooke its derivation."

- Vet., iii., 406, and vi., 607. 
difficult of treatment. If the incision is deep and large enough, no second collection of matter will be formed: and that which is already there may be suffered to run out slowly, all pressure with the fingers being avoided. The part should be kept clean, and a little friar's balsam daily injected into the wound.

The remainder of the treatment will depend on the symptoms. If there is much fever, and evident affection of the chest, and which should carefully be distinguished from the oppression and choking occasioned by the pressure of the tumour, it will be proper to bleed. In the majority of cases, however, bleeding will not only be unnecessary, but injurious. It will delay the suppuration of the tumour, and increase the subsequent debility. A few cooling medicines, as nitre, emetic tartar, and perhaps digitalis, may be given, as the case requires. The appetite, or rather the ability to eat, will return with the opening of the abscess. Bran-mashes, or fresh-cut grass or tares, should be liberally supplied, which will not only afford sufficient nourishmerit to recruit the strength of the animal, but keep the bowels gently open. If the weakness is not great, no farther medicine will be wanted, except a dose of mild physic in order to prevent the swellings or eruptions which sometimes succeed to strangles. In cases of debility, a small quantity of tonic medicine, as chamomile, gentian, or ginger, may be administered.*

\section{THE PHARYNX.}

Proceeding to the back of the mouth, we find the PHARyNX (carrying or conveying the food towards the stomach). It commences at the root of the tongue (see 7, 8 and 9 , p. 72); is separated from the mouth hy the soft palate (7), which hangs down from the palatine bone at 8 , and extends to the epiglottis or covering to the windpipe. When the food has been sufficiently ground by the teeth, and mixed with the saliva, it is gathered together by the tongue, and by the action of the cheeks and tongue, and back part of the mouth, forced against the soft palate, wlich, giving way, and being raised upwards towards the entrance into the nostrils, prevents the food from proceeding that way. It passes to the pharynx, and the soft palate again falling down, prevents its return to the mouth, and also prevents, except in extreme cases, the act of vomiting in the horse. Whatever is returned from the stomach of the horse, passes through the nose, as the cut will make evident.

The sides of the pharynx are lined with muscles which now begin powerfully to contract, and by that contraction the bolus is forced on until it reaches the gullet (10), which is the termination of the pharynx. Before, however, the food proceeds so far, it has to pass over the entrance into the windpipe (3), and should any portion of it enter that tube, much inconvenience and danger might result; therefore, this opening is not only lined by muscles which close it at the pleasure of the animal, but is likewise covered by a heart-like elastic cartilage, the epiglottis (2), with its back towards the pharynx, and its hollow towards the aperture. The epiglottis yields to the pressure of the bolus passing over it, and lying flat over the opening into the windpipe, and prevents the possibility of anything entering into it. No sooner, however, has

* Mr. Percivall gives the following description of some untoward cases:- "The submaxillary tumour is often knotted and divided on its first appearance, as if the glands received the primary attack. As it spreads, it becomes diffused in the cellular tissue included in the space between the sides and branches of the lower jaw, involving all the subcutaneous parts contained in that interval indiscriminately in one uniform mass of tumefaction. While this general turgescence is going on, various parts in the immediate vicinity often take on the same kind of action. In particular, the salivary glands, the parotid, sublingual, the throat, the pharynx and larynx, the nose, the lining membrane, the nostrils, the sinuses, the mouth, the tongue, the cheeks, the lips - in fine, in some violent cases, the whole head appears to be involved in one general mass of tumefaction, while every vent is running over with discharge. The patient experiencing this violent form of disease is in a truly pitiable plight. While purulent matter is issuing in profusion from his swollen nostrils, and slaver foams out from between his tumefied lips, it is distressing to hear the noise that he makes in painful and laboured efforts to breathe. There is imminent danger of suffocation in such a case as this ; and even although some relief, so far as the breathing is concerned, may be obtained from the operation of bronchotomy, yet, from the pain and irritation he is suffering, added to the impossibility of getting aliment into his stomach, he must speedily sink to rise no more." Veterinarian, vol. vi, p. 611. 
the food passed over it, than it rises again by its own elasticity, and leaves the upper part of the windpipe once more open for the purpose of breathing. The voice of animals is produced by the passage of air through this aperture, communicating certain vibrations to certain folds of the membrane covering the part, and these vibrations being afterwards modified in their passage through the cavitics of ihe nose. In order to understand the diseases of these parts, the anatomy of the neck generally must be considered.

\section{CHAPTER V. \\ THE ANATOMY AND DISEASES OF THE NECK AND NEIGHBOURING PARTS.}

THE neck of the horse, and of every animal belonging to the class mammalia, except one species, is composed of seven bones called vertebræ, moveable or turning upon each other (see cut, p. 68). They are connceted together by strong ligaments, and form so many distinct joints, in order to give sufficiently extensive motion to this important part of the body. The bone nearest to the sliull is called the atlas (see cut, p. 68, and $g, p .72$ ), because, in the human being, it supports the head. In the horse the head is suspended from it. It is a mere ring-shaped bone, with broad projections sideways; but without the sharp and irregular processes which are found on all the others. 'The pack-wax, or ligament, by which the head is principally supported ( $f$, p. 72$)$, and which is strongly connected with all the other bones, passes over this without touching it, by which ineans the head is much more easily and extensively moved. The junction of the atlas with the head is the scat of a very serious and troublesome ulcer, termed

\section{POL L-E VIL .}

From the horse rubbing and sometimes striking his poll against the lower edge of the manger, or hanging back in the stall and bruising the part with the halter-or from the frequent and painful stretching of the ligaments and muscles by unnccessary tight reining, and, occasionally, from a violent blow on the poll, carelessly or wantonly inflicted, inflammation ensues, and a swelling appears, hot, tender, and painful. It used to be a disease of frequent occurrence, but it is now, from better treatment of the animal, of comparatively rare occurrence.

It has just becn stated, that the ligament of the neck passes over the atlas, or first bone, without being attached to it, and the seat of inflammation is between the ligament and the bone bencath; and being thus deeply situated, it is serious in its nature and difficult of treatment.

The first thing to be attempted is to abate the inflammation by bleeding, physic, and the application of cold lotions to the part. In a very early period of the case a blister might have considerable effect. Strong purgatives should also be employed. By thesc means the tumour will sometimes be dispersed. 'This system, however, must not be pursued too far. If the swelling increases, and the lieat and tenderness likewise increasc, inatter will form in the tumour; and then our object should be to hasten its formation by warm fomentations, poultices, or stimulating embrocations. As soon as the matter is formed, which may be known by the softness of the tumour, and before it has time to spread around and eat into the neighbouring parts, it should be evacuated. Now comes the whole art of trcating poll-evil; the opening into the tumour must be so contrived that all the matter shall run out, and continue afterwards to run out as quickly as it is formed, and not collect at the bottom of the ulcer, irritating and corroding it. This can be effected by a seton alone. The needle should enter at the top of the tumour, penetrate through its bottom, and be brought out at the side of the neck, a little below the abscess. Without anything more than this, except 
frequent fomentation with warm water, in order to keep the part clean, and to obviate infiammation, poll-evil in its early stage will frequently be cured.

If the ulcer has deepened and spread, and threatens to eat into the ligaments of the joints of the neck, it may be necessary to stimulate its surface, and perhaps painfully so, in order to bring it to a healthy state, and dispose it to fill up. In extreme cases, some highly stimulating application may be employed, but nothing resembling the scalding mixture of the farriers of the olden time. This is abominable! horrible!! All measures, however, will be incffectual, unless the pus or matter is, by the use of setons, perfectly evacuated. The application of these setons will require the skill and anatomical knowledge of the veterinary surgeon. In desperate cases, the wound may not be fairly exposed to the action of the caustic without the division of the ligament of the neck. This may be effected with perfect safety; for although the ligament is carried on to the occipital bone, and some strength is gained by this prolongation of it, the main stress is on the second bone; and the head will continue to be supported. The divided ligament, also, will soon unite again, and its former uscfulness will be restored when the wound is healed.

The second bone of the neck is the dentata, having a process like a tooth, by which it forms a joint with the first bone. In the formation of that joint, a portion of the spinal marrow, which runs through a canal in the centrc of all these bones, is exposed or covered only by ligament; and by the division of the marrow at this spot an animal is instantly and humanely destroyed. The operation is called pithing, from the name (the pith) given by butchers to the spinal marrow.

The other neck, or rack bones, as they are denominated by the farrier, (B. p. 68,) are of a strangely irregular shape, yet bearing considerable resemblance to each other. They consist of a central bone, perforated for the passage of the spinal marrow with a ridge on the top for the attachment of the ligament of the neck, and four irregular plates or processes from the sides, for the attachment of muscles; at the base of onc of which, on either side, are holes for the passage of the large artcries and veins. At the upper end of each, is a round head or ball, and at the lower end, a cavity or cup, and the head of the one being received into the cup of the other, they are united together, forming so many joints. - They are likewise united by ligaments from thesc processes, as well as the proper ligaments of the joints, and so securcly, that no dislocation can take place between any of them, except the first and second, the conscquence of which would be the immediate death of the animal.

The last, or seventh bone, has the elevation on the back or top of it continued into a long and sharp prolongation ( $a$ spinous process), and is the beginning of that ridge of bones denominated the withers (see cut, pp. 68 and 167); and as it is the base of the column of neck bones, and there must be a great pressure on it from the weight of the head and neck, it is curiously contrived to rest upon and unite with the two first ribs.

\section{THE MUSCLES AND PROPER FORM OF THE NECK.}

The bones of the neck serve as the frame-work to which numerous muscles concerned in the motions of the head and neck are attached. The weight of the head and neck is supported by the ligament without muscular aid, and without fatigue to the animal; but in order to raisc the head higher, or to lower it, or to turn it in every direction, a complicated system of muscles is necessary. 'Those whose office it is to raise the head are most numerous and powerful, and are placed on the npper and sidc part of the neck. The cut in p. 125 contains a few of them.

$c$ marks a tendon common to two of the most important of them, the splenius, or splint-like muscle, and the complexus major, or larger complicated muscle. The splenius constitutes the principal bulk of the neck above, arising from the ligament of the neck all the way down it, and going to the processes of all the bones of the neck, but the first, and tendons running from the upper part of it, to the first bone of the neck, and to a process of the temporal bone of the head. Its action is sufficiently evident, namely, very powerfully to elevate thc head and neck. The principal beauty of the neck depends on this muscle. It was admirably developed in the horse of whose neck the annexcd cut gives an accurate delineation.

If the curve were quite regular from the poll to the withers, we should call it a 
perfect neck. It is rather a long neck, and we do not like it the less for that. In the

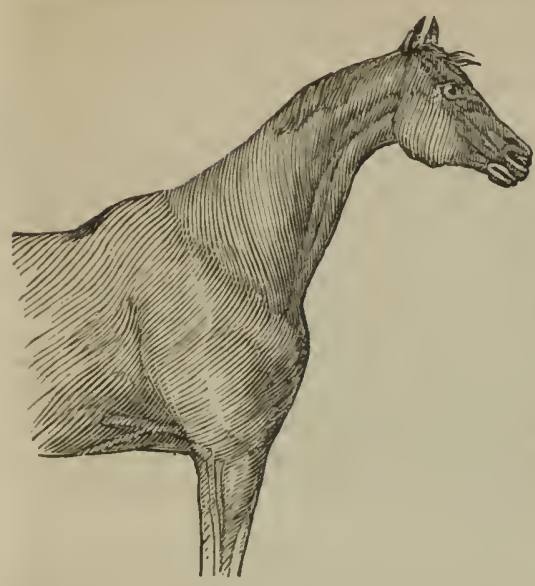
carriage-horse, a neck that is not half concealed by the collar is indispensable, so far as appearance goes; and it is only the horse with a neck of tolerable length that will bear to be reined up, so as to give this part the arched and beautiful appearance which fashion demands. It is no detriment to the riding-horse, and there are few horses of extraordinary speed that have not the neck rather long. The race-horse at the top of his speed not only extends it as far as he can, that the air-passages may be as straight as he can make them, and that he may therefore be able to breathe more freely, but the weight of the head and neck, and the effect increasing with their distance from the trunk, add materially to the rapidity of the animal's motion. It has been said, that a horse with a long neck will bear heavy on the hand; neither the length of the neck nor even the bulk of the head has any influence in causing this. They are both counterbalanced by the power of the ligament of the neck. The setting on of the head is most of all connected with heavy bearing on the hand, and a short-necked horse will bear heavily, because, from the thickness of the lower part of the neck, consequent on its shortness, the head cannot be rightly placed, nor, generally, the shoulder.

Connected with the splenius muscle, and partly produced by it, are the thickness and muscularity of the neck, as it springs from the shoulders, in this cut; the height at which it comes out from them forming nearly a line with the withers; and the manner in which it tapers as it approaches the head. 'The neck of a well-formed horse, however fine at the top, should be muscular at the bottom, or the horse will generally be weak and worthless. Necks devoid of this muscularity are called loose necks by horsemen, and are always considered a very serious objection to the animal. If the neck is thin and lean at the upper part, and is otherwise well shaped, the horse will usually carry himself well, and the head will be properly curved for beauty of appearance and ease of riding. When an instance to the contrary occurs, it is to be traced to very improper management, or to the space between the jaws being unnaturally small.

The splenius muscle, although a main agent in raising the head and neck, may be too large, or covered with too much cellular substance or fat, thus giving an appearance of heaviness, or even clumsiness to the neck. This peculiarity of form constitutes the distinction between the perfect horse and the mare, and also the gelding, unless castrated at a very late period.

This tendon, $c$, belongs also to another muscle, which makes up the principal bulk of the lower part of the neck, and is called the complexus major, or larger complicated muscle. It arises partly as low as the transverse processes of the four or five first bones of the back, and from the five lower bones of the neck; and the fibres from these various sources uniting together, form a very large and powerful muscle, the largest and strongest in the neck. As it approaches the head, it lessens in bulk, and terminates partly with the splenius, in this tendon, but is principally inserted into the back part of the occipital bone, by the side of the ligament of the neck. In the cut, p. 125, almost its whole course can be distinctly traced. Its office is to raise the neck and elevate the head; and being inserted into such a part of the occiput, it will more particularly protrude the nose, while it raises the head. Its action, however, may be too powerful; it may be habitually so, and then it may produce deformity. The back of the head being pulled back, and the muzzle protruded, the horse cannot by possibility carry his head well. He will become what is technically called a star-gazer; 
-heavy in hand, boring upon the bit, and unsafe. To remedy this, recourse is had, and in the majority of cases without avail, to the martingale, against which the horse is continually fighting, and which is often a complete annoyanee to the rider. Sucl a horse is almost useless for harness.

Inseparable from this is another sad defeet, so far as the beauty of the horse is concerned; - he beeomes ewe-necked; $i$. e. he has a neek like a ewe - not arehed above and straight below, until near to the head, but hollowed above and projecting below; and the neck rising low out of the chest, even lower, sometimes, than the points of the shoulders. There can scarcely be anything more unsightly in a horse. His head can never be got fairly down; and the bearing rein of harness must be to him a source of constant torture. In regarding, however, the length and the form of the neck, referenee must be had to the purpose for which the horse is intended. In a hackney, few things can be more abominable than a neck so disproportioned-solong, that the hand of the rider gets tired in managing the head of the horse. In a racehorse, this lengthening of the neck is a deeided advantage.

Among the museles employed in raising the head, are the complexus minores (smaller complieated), and the recti (straight), and the oblique muscles of the upper part of the neck, and belonging prineipally to the two first bones of the neck, and portions of which may be seen under the tendon of the splenius $c$, and between it and the ligament $a$.

Among the muscles employed in lowering the head, some of which are given in the same eut, is the sterno-maxillaris, $d$, belonging to the breast-bone, and the upper jaw. It can likewise be traeed, although not quite distinetly, in the cut, p. 159. It lies immediately under the skin. It arises from the eartilage projeeting from, or constituting the front of the breast-bone $(H, p .68)$, and proeeeds up the neck, of no great bulk or strength. At about three-fourths of its length upward, it changes to a flat tendon, which is seen $(d, p .125)$ to insinuate itself between the parotid and submaxillary glands, in order to be inserted into the angle of the lower jaw. It is used in bending the head towards the chest.

Another muscle, the termination of which is seen, is the levator humeri, raiser of the shoulder, $b$. This is a much larger musele than the last, beeause it lias more duty to perform. It rises from the back of the head and four first bones of the neek and the ligament of the neck, and is carried down to the shoulder, mixing itself partly with some of the museles of the shoulder, and finally continued down to, and terminating on, the humerus $(J, p .68)$. Its office is double. If the horse is in aetion, and the head and neek are fixed points, the eontraetion of this muscle will draw forward the shoulder and arm; if the horse is standing, and the shoulder and arm are fixed points, this muscle will depress the head and neek.

The muscles of the neek are all in pairs. One of them is found on each side of the neck, and the office which has been attributed to them ean only be aecomplished when both aet together; but supposing that one alone of the elevating muscles should act, the head would be raised, but it would at the same time be turned towards that side. If one only of the depressor muscles were to act, the head would be bent downwards, but it would likewise be turned towards that side. Then it will be easily seen, that by this simple method of having the muscles in pairs, provision is made for every kind of motion, upwards, downwards, or on either side, for whieh the animal can possibly have oceasion. Little more, of a praetieal nature, could be said of the museles of the neck, although they are proper and interesting studies for the anatomist.

This is the proper place to speak of the mane; that long hair which covers the crest of the neck, and adds so mueh to the beauty of the animal. This, however, is not its only praise. In a wild state, the horse has many battles to fight, and his neck, deprived of the mane, would be a vulnerable part. The hair of the mane, the tail, and the legs, is not shed in the same manner as that on the body. It does not fall so regularly, nor so often; for if all were shed at once, the parts would be left for a long time defenceless.

The mane is generally dressed so as to lie on the right side - some persons divide it equally on both sides. For ponies, it used to be cut off near the roots, only a few stumps being left to stand perpendicularly. This was termed the hog-mane. The 
groom sometimes bestows a great deal of pains in getting the mane of his horse into good and fashionable order. It is wetted, and plaited, and loaded with lead; and every hair that is a little too long is pulled out. The mane and tail of the heavy draught-horse are seldom thin; but on the well-bred horse, the thin, well-arranged mane is very ornamental.*

\section{THE BLOOD-VESSELS OF THE NECK.}

Running down the under part of the neck, are the principal blood-vessels, going to and returning from the head, with the windpipe and gullet. Our cut could not give a view of the arteries that carry the blood from the heart to the head, because they are too deeply seated. The external arteries are the carotid, of which there are two. They ascend the neck on either side, close to the windpipe, until they have reached the middle of the neck, where they somewhat diverge, and lie more deeply. They are covered by the sterno-maxillaris muscle, which has been just described, and are separated from the jugulars by a small portion of muscular substance. Having reached the larynx, they divide into two branches, the external and the internal ; the first goes to every part of the face, and the second to the brain.

The vertebral arteries run through canals in the bones of the neck, supplying the neighbouring parts as they climb, and at length enter the skull at the large hole in the occipital bone, and ramify on and supply the brain.

Few cases can happen, in which it would be either necessary or justifiable to bleed from an artery. Even in mad-staggers, the bleeding is more practicable, safer, and more effectual, from the jugular vein, than from the temporal or any other artery. If an artery is opened in the direction in which it runs, there is sometimes very great difficulty in stopping the bleeding; it has even been necessary to tie the vessel, in order to accomplish this purpose. If the artery is cut across, its coats are so elastic, that the two ends are often immediately drawn apart under the flesh at each side, and are thereby closed; and after the first gush of blood, no more can be obtained.

\section{THE VEINS OF THE NECK.}

The external veins which return the blood from the head to the heart are the jugulars. The horse has but one on either side. The human being and the ox have two. The jugular takes its rise from the base of the skull; it then descends, receiving other branches in its way towards the angle of the jaw and behind the parotid gland; and emerging from that, as seen at $t, \mathrm{p} .125$, and being united to a large branch from the face, it takes its course down the neck. Veterinary surgeons and horsemen have agreed to adopt the jugular, a little way below the union of these two branches, as the usual place for bleeding ; and a very convenient one it is, for it is easily got at, and the vessel is large. The manner of bleeding, and the states of constitution and disease in which it is proper, will be hereafter spoken of; an occasional consequence of bleeding being at present taken under consideration.

\section{INFLAMMATION OF THE VEIN.}

It is usual and proper, after bleeding, to bring the edges of the wound carefully together, and to hold them in contact by inserting a pin through the skin, with a little tow twisted round it. In ninety-nine cases out of a hundred the wound quickly heals, and gives no trouble; but in a few instances, from using a blunt instrument, or a dirty or rusty one; or striking too hard and bruising the vein; or, in the act of pinning up, pulling the skin too far from the neck and suffering some blood to insinuate itself into the cellular texture; or neglecting to tie the horse up for a little while, and thus enabling him to rub the bleeding place against the manger and tear out the pin; or from the animal being worked immediately afterward; or the reins of the bridle rubbing against it; or several blows having been clumsily given, and a large and ragged wound made; or from some disposition to inflammation about the horse (for the bleeder is not always in fault) the wound does not heal, or if it closes for a little while, it re-opens. A slight bleeding appears-some tumefaction commences-the edges of the orifice separate, and become swollen and red-a discharge of sanious, 
bloody fluid proceeds from the wound, followed, perhaps, in a few days by purulent matter. The neck swells, and is lot and tender both above and below the incision. The lips of the wound become everted-the swelling increases, particularly above the wound, where the vein is most hard and cordy-the horse bcgins to loathe his food, and little abscesses form round the orifice. The cordiness of the vein rapidly increases. Not only the vein itself has become obstructed and its coats thickened, but the cellular tissue inflamed and hardened, and is an additional source of irritation and torture.

The thickening of the vein extends to the bifurcation above: it occupies both branches, and extends downward to the chest-even to the very heart itself, and the patient dies.

'The two grand questions here are, the cause and the cure. The first would seem to admit of an easy reply. A long list of circumstances has been just given which would seem to refer the matter entirely to the operator; yet, on the other hand, experience tells us that he has little to do with these morbid effects of bleeding. Mr. Percivall states, that Mr. Cherry tried several times to produce inflammation by the use of rusty lancets, and escharotics of various kinds, and ligatures, and frequent separation and friction of the granulating edges, hut in vain. Professor Spooner tried to produce the disease, but could not.

On the other hand, it is well known that while inflammation rarely or never follow's the opcration of bleeding by some practitioners, others are continually getting into scrapes about it. The writer of this work had three house-pupils, two of whom he used to trust to bleed his patients, and no untoward circumstance ever occurred; but as surely as he sent the third, he had an inflamed vein to take care of.

There is something yet undivulged in the process of healing the vein, or in the circumstances by which that healing is prevented. The most powerful causes probably are, that the lips of the wound have not been brought into immediate apposition, or that a portion of the hair-a single hair is sufficient-has insinuated itself. The horse has not, perhaps, had his head tied up to the rack after bleeding, which should always be done for at least an hour, during which time the extravasated blood will become firmly coagulated, and the flow of blood to the heart will establish its uninterrupted course. It is also probable that atmospheric agency may be concerned in the affair, or a diseased condition of the horse, and particularly a susceptibility of taking on inflammatory action, although the exciting cause may be exceedingly
slight.

Of the means of cure it is difficult to speak confidently. The wound should be carefully examined - the divided edges brought into exact apposition, and any hair interposed between them removed-the pin withdrawn or not, according to circumstances - the part carefully and long fomented, and a dose of physic administered. If two or three days have passed and the discharge still remains, the application of the budding-iron-not too large or too hot-may produce engorgement of the neighbouring parts, and union of the lips of the wound. This should be daily, or every or as far as the mischief extends, will of ten be serviceable. Here, likewise, the parts will be brought into contact, with each other, and pressed together, and union may be effected. "Sometimes," says Mr. Cartwright, "when the vein is in an ulcerative state, I have laid it open, and applied caustic dressing, and it has healed up. I have lately had a case in which five or six abscesses had formed above the original wound, and the two superior ones burst through the parotid gland, the extent of the ulceration being evident in the quantity of saliva that forved through each
orifice."* The owner of the horse will find it his interest to apply to a veterinary practitioner
as soon as a case of inflamed vein occurs.

Should the vein be destroyed, the horse will not be irreparably injured, and perhaps, at no great distance of time, scarcely injured at all; for nature is ingenious in making provision to carry on the circulation of the blood. All the vessels conveying the blood from the heart to the different parts of the frame, or bringing it back

* Abstract of the Veterinary Medical Association, rol. iv. p. 185. 
again to the heart, communicate witl each other by so many channels, and in such various ways, that it is impossible by the closure or loss of any one of them long matcrially to impede the flow of the vital current. If the jugular is destroyed, the blood will circulate through other vessels almost as freely as before; but the horse could not bc considered as sound, for he might not be equal to the whole of the work required of him.

\section{THE PALATE-(RESUME).}

$\Lambda$ the back of the palate (see p. 72), and attached to the crescent-shaped border of the palatine bone, is a dense membranous curtain. Its superior and back surface is a continuation of the lining membrane of the nose, and its anterior or inferior one, that of the palate. It is called the velum palati, or veil of the palate. It extends as far back as the larynx, and lies upon the dorsum of the epiglottis, and is a perfect veil or curtain interposed between the cavities of the nose and mouth, cutting off all comurnication between them. Tied by its attachment to the palatine bone, it will open but a little way, and that only in one direction. It will permit a pellet of food to pass into the cesophagus; but it will close when any pressure is made upon it from bchind. Two singular facts nccessarily follow from this : the horse breathes through the nostrils alonc, and these are capacious and easily expansible to a degree secn in no other animal, and fully commensurate to the wants of the animal.

It is also cvident that, in the act of vomiting, the contents of the stomach must be returned through the nostril, and not through the mouth. On this account it is that the horse can with great difficulty be excitcd to vomit. There is a structure at the entrance of the stomach which, except under very peculiar circumstances, prevents its return to the throat, and consequently to the mouth.

The inuscles of this singular curtain are very intelligibly and correctly described by Mr. Pcreivall, in his "A natomy of the Horse," to which the reader is referred. The same remark is applicable to a very singular and important bone, and its muscular apparatus, the os hyoides.

\section{THE LARYNX}

Is placed on the top of the windpipe (see 1, p. 72), and is the inner guard of the lungs, if any injurious substance should penetrate so far; it is the main protection against the passage of food into the respiratory tubcs, and it is at the same time the instrument of voice. In this last character it loses much of its importance in the quadruped, bccause in the dumb animal it is a beautiful piece of mechanism.

Tile EPIglotтls (see 2, p. 72) is a heart-sliaped cartilage, placed at the extremity of the opening into the windpipc, with its back opposed to the pharynx, so that when a pellet of food passes from the pliarynx in its way to the csophagus, it presses down the epiglottis, and by this means, as already described, closes the aperture of the larynx, and prevents any portion of the food from entering it. The food having passed over the epiglottis, from its own elasticity and that of the membrane at its basc, and more particularly the power of the hyo-epiglotideus muscle, rises again and resumes its former situation.

"The 'Thyroid Cartilage (sec 1, p. 72) occupies almost the whole of the external part of the larynx, both anteriorly and laterally. It envelopes and protects all the rest; a point of considerable importance, considering the injury to which the larynx is exposed, by our system of curbing and tight reining. It also forms a point of attacliment for the insertion of the greater part of the delicate muscles by which the other cartilages are moved.

The beautiful mechanism of the larynx is governed or worked by a somewhat complicated system of muscles, for a description of which the reader is referred to the 5 tl vol. of The Veterinarian, p. 447. It is plentifully supplied with nerves from the respiratory systcm, and there are also frequent anastomoses with the motor nerves of the spinal cord. The sole process of respiration is partly under the control of the will, and the muscles of the larynx concerned in one stage of it are likewise so, but they also act independently of the will, for during sleep and unconsciousness the machine continues to work.

'The origin of the artery whicl supplies these parts with blood is sometimes derived from the main trunk of the carotid, but oftener it is a branch of tlic thyroideal artery. 
The lining membrane is a continuation of that of the pharynx above and the trachea below. It is covered with innnmerable follicular glands, from whose mouths there oozes a mucous fluid that moistens and lubricates its surface. It is possessed of very great sensibility, and its function requires it. It is, as has been already stated, the inner guard of the lungs, and the larynx must undergo a multitude of changes of form in order to adapt itself to certain changes in the act of respiration, and in order to produce the voice. The voice of the horse is, however, extremely limited, compared with that of the human being; the same sensibility, therefore, is not required, and exposed as our quadruped slaves are to absurd and barbarous usage, too great sensibility of any part, and particularly of this, would be a curse to the animal.

\section{THE TRACHEA OR WINDPIPE.}

The course of the inspired air from the larynx to the lungs is now to be traced, and it will be found to be conveyed through a singularly constructed tube (6, p. 72), passing along the anterior portion of the neck, and reaching from the lower edge of the cricoid cartilage (11, p. 72) to the lungs. In the commencement of its course it is somewhat superficially placed, but as it descends towards the thorax it becomes gradually deeper and more concealed. In order to discharge its functions as an airtube, it is essential that it should always be pervious, or, at least, that any obstruetion to the process of respiration should be but momentary. Attached to a part endowed with such extensive motion as the neck, it is also necessary that it should be fiexible. It is composed of cartilage, an exceedingly elastic substance, and at the same time possessing a certain degree of flexibility.

The windpipe is composed of cartilage, but not of one entire piece, for that would necessarily be either too thick and firm to be flexible, or if it were sufficiently flexible to accommodate itself to the action of the neck, it would be too weak to resist even common pressure or injury, and the passage through it would often be inconveniently or dangerously obstructed. Besides, it is necessary that this tube should occasionally admit of elongation to a considerable degree. When the neck is extended in the act of grazing or otherwise, the trachea must be lengthened.

The structure of the cartilage of the windpipe is admirably adapted to effect every purpose. It is divided into rings, fifty or fifty-two in number, each possessing sufficient thickness and strength to resist ordinary pressure, and each constituting a joint with the one above and below, and thus admitting of all the flexibility that could be required. These rings are connected together by an interposed fibro-ligamentous substance, extensible, elastic, and yet so strong that it is scarcely possible to rupture it; and the fibres of that ligament not running vertically from one to another, and therefore admitting of little more motion than the rotation of the head, but composed of two layers running obliquely, and in contrary directions, so as to adapt themselves to every variety of inotion.

These rings are thickest in front, and project circularly, opposing an arch-like form. There, too, the ligament is widest, in order to admit of the greatest motion in the direction in which it is most needed, when the head is elevated or depressed. Laterally these rings are thinner, because they are, to a great degree, protected by the surrounding parts; and, posteriorly, they overlap each other, and the overlapping portions are connected together by a strong ligamentous substance. This, while it does not impede the motion of the tube, gives firmness and stability to it.

Within the trachea is another very curious structure. At the points at which, posteriorly, the rings begin to bend inwardly, a muscle is found stretching across the windpipe, dividing the canal into two unequal portions-the anterior one constituting the proper air-passage, and the posterior one occupied by cellular texture. It is to give additional strength to parts. It is the tie which prevents the arch from spurring out. In the natural state of the windpipe this muscle is, probably, quiescent; but when any considerable pressure is made on the crown of the arch at the upper part by tight reining, or at the lower by an ill-made collar, or any where by brutal or accidental violence, this muscle contracts, every serious expansion or depression of the arch is prevented, and the part is preserved from serious injury.

It may also be readily imagined that, when in violent exertion, every part of the respiratory canal is on the stretch, this band may preserve the windpipe from injury 
or laceration. There are many beautiful points in the physiology of the horse which deserve much greater attention than has hitherto been paid to them.

The windpipe should project from the neck. It should almost seem as if it were detached from the neck, for two important reasons: first, that it may easily enter between the channels of the jaw, so that the horse may be reined up without suffering inconvenience; and next, that being more loosely attached to the neck, it may more readily adapt itself to the changes required than if it were enveloped by fat, or muscle to a certain degree unyielding : therefore, in every well-formed neck - and it will be seen in the cut $(\mu .159)$ - it is indispensable that the windpipe should be prominent and loose on the neck. This is not required in the heavy cart-horse, and we do not often find it, bccause he is not so much exposed to those circumstances which will hurry respiration, and require an enlargement in the size of the principal air-tube.

When the trachea arrives at the thorax, it suddenly alters its form, in order to adapt Itself to the narrow triangular aperture through which it has to pass. It preserves the same cartilaginous structure; for if it has not the pressure of the external muscles, or of accidental violence, to resist, it is exposed to the pressure of the lungs when they are inflating, and it shares in the pressure of the diaphragm, and of the intercostal muscles, in the act of expiration. Having entered the chest, it passes a little to the right, leaving the œsophagus, or gullet, on the left; it separates from the dorsal vertebra; it passes through the duplicature of the mediastinum to the base of the heart, and it divides beneath the posterior aorta. Its divisions are called the bronchial tubcs, and have much to do with the well-being of the horse.

Its rings remain as perfect as before, but a new portion of cartilage begins to prescnt itself: it may be traced as high as the tenth ring from the bottom; it spreads over the union between the posterior terminations of the rings; it holds them in closer and firmer connexion with each other; it discharges the duty of the transverse muscle, which begins here to disappear, and the support of the cervical and dorsal vertebræ; it prevents the separation of the rings when the trachea is distended; it spreads down upon, and defends the commencement of the bronchial tubes. Some other small plates of cartilage reach a considerable way down the divisions of the bronchi, and the last ring has a central triangular projection, which covers and defends the bifurcation of the trachea.

\section{TRACHEOTOMY.}

The respiratory canal is occasionally obstructed, to an annoying and dangerous degrce. Polypi have been described as occupying the nostrils; long tumours have formed in them. Tumours of other kinds have pressed into the pharynx. The tumour of strangles has, for a while, occupied the passage. The larynx has been distorted; the membrane of the windpipe, on the larynx, has been thickened, and ulcers have formed in one or both, and have been so painful that the act of breathing was laborious and torturing. In all these cases it has been anxiously inquired whether there might not be established an artificial opening for the passage of the air, when the natural one could no longer be used; and it has been ascertained that it is both a simple and safe operation, to excise a portion of the trachea, on or below the point of obstruction.

The operation must be performed while the horse is standing, and secured by a side-line, for he would, probably, be suffocated amidst the struggles with which lie would resist the act of throwing. The twitch is then firmly fixed on the muzzle; the operator stands on a stool or pail, by which means he can more perfectly command the part, and an assistant holds a scalpel, a bistoury, scissors, curved needles armed, and a moist sponge.

The operator should once more examine the whole course of the windpipe, and the different sounds which he will be able to detect by the application of the ear, and likewise the different degrees of temperature and of tenderness which the finger will detect, will guide to the seat of the evil.

The hair is to be closely cut off from the part, the skin tightened across the trachea with the thumb and fingers of the left hand, and then a longitudinal incision cautiously made through the skin, three inches in length. This is usually effected when there is no express indication to the contrary on the fifth and sixth rings; a slip from which, and the connecting ligament above and below, about half the width of each ring, should 
be excised with the intervening ligament. The remaining portion will then be strong enough to retain the perfect arched form of the trachea.

If the orifice is only to be kept open while some foreign body is extracted, or tumour removed, or ulcer healed, or inflammation subdued, nothing more is necessary than to keep the lips of the wound a little apart, by passing some thread through each, and slightly everting them, and tying the threads to the mane.

If, however, there is any permanent obstruction, a tube will be necessary. It should be two or three inches long, curved at the top, and the external orifice turning downwards with a little ring on each side, by which, through the means of tubes, it may be retained in its situation.

The purpose of the operation being answered, the flaps of integument must be brought over the wound, the edges, if necessary, diminished, and the parts kept in apposition by a few stitches. The cartilage will be perfectly reproduced, only the rings will be a little thicker and wider.

The following account will illustrate the use and the danger of the tracheotomy tube. A mare at Alfort had great distortion of the rings of the trachea. She breathed with difficulty. She became a roarer almost to suffocation, and was quite useless. Tracheotomy was effected on the distorted rings, and a short canula introduced. She was so much relieved that she trotted and galloped immediately afterwards without the slightest distress. Six months later she again began to roar. It seemed that the rings were now distorted below the former place.

M. Barthélemy introduced another canula, seven inches long, and which reached below the new distortion. She was once more relieved. Slie speedily improved in condition, and regularly drew a cabriolet at the rate of seven or eight miles in the hour; and this she continued to do for three years, when the canula became accidentally displaced in the night, and she was found dead in the morning.

\section{THE BRONCHIAL TUBES.}

The windpipe has been traced through its course down the neck into the chest. It is there continued through the mediastinum to the base of the heart, and then divided into two tubes corresponding with the two divisions of the lungs-the BroncHial TubEs. These trunks enter deeply into the substance of the lungs. They presently subdivide, and the subdivision is continued in every direction, until branches from the trachea penetrate every assignable portion and part of the lungs. They are still airpassages, carrying on this fluid to its destination, for the accomplishment of a vital purpose.

They also continue exposed to pressure; but it is pressure of a new kind, a pressure alternately applied and removed. The lungs in which they are emberded alternately contract and expand; and these tubes must contract and expand likewise. Fmbedded in the lungs, the cartilaginous ring of the bronchi remains, but it is divided into five or six segments connected with each other. The lungs being compressed, the segments pverlap each other, and fold up and occupy little space; but the principle of elasticity is still at work; and as the pressure is removed, they start again, and resume their previous form and calibre. It is a beautiful contrivance, and exquisitely adapted to the situation in which these tubes are placed, and the functions they have to discharge.

But we must pause a little and consider the structure and functions of the chest. 
CHAPTER VI.

THE CHEST.

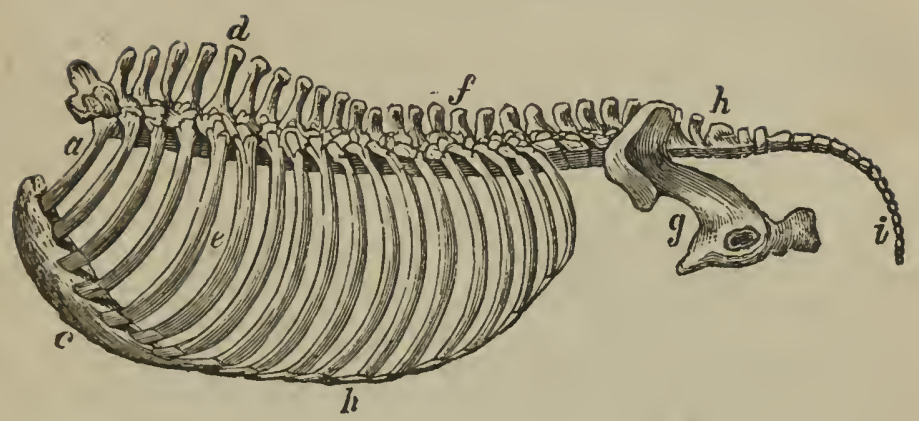

a The first rib.

$b$ 'I he cartilages of the eleven hindermost, or false ribs, connected together, and uniting with that of the seventh or last true rib.

c The breast-bone.

$d$ The top, or point, of the withers, which are formed by the lengthened spinous, or upright processes of the ten or eleven first bones of the back. The bones of the back are eightcen in number.

e The ribs, usually eighteen on each side; the seven first united to the breast-bone by cartilage ; the cartilages of the remaining eleven united to each other, as at $b$.

$f$ That portion of the spine where the loins commence, and composed of five bones.

$g$ The boncs forming the hip, or haunch, and into the hole at the bottom of which the head of the thigh-bone is received.

$h$ The portion of the spine belonging to the haunch, and consisting of five pieces.

$i$ The bones of the tail, usually fifteen in number.

The chest, in the horizontal position in which it is placed in the cut, is of a somewhat oval figure, with its extremities truncated. The spine is its roof; the sternum, or breast, its floor; the ribs, its sides; the trachea, esophagus, and great bloodvessels passing through its anterior extrcmity and the diaphragm, being its posterior. It is contracted in front, broad and deep towards the central boundary, and again contracted posteriorly. It encloses the lieart and the lungs, the origin of the arterial, and the tcrmination of the venous trunks and the collected vessels of the absorbents. 'The windpipe penetrates into it, and the csophagus traverses its whole extent.

A cavity whose contents are thus important should be securely defended. The roof is not composed of one unyielding prolongation of bone, which might possibly liave been strong enough, yet would have subjected it to a thousand rude and dangerous shocks; but there is a curiously-contrived series of bones, knit together by strong ligaments and dense cartilaginous substance, forming so many joints, each possessed but of little individual motion, but the whole united and constituting a column of such exquisitcly-contrived flexibility and strength, that all concussion is avoided, and no external violence or weight can injure that which it protects. It is supported chiefly by the anterior extremities, and beautiful are the contrivances adopted to prevent injurious connexion. There is no inflexible bony union between the shoulders and the chest; but while the spine is formed to neutralise much of the concussion that might be rcceived - while the elastic connexions between thc vertebræ of the back, alternately affording a yielding resistance to thc shock, and regaining their natural situation when the external force is removed, go far, by this playful motion, to render harmless the rudest motion - there is a provision made by the attachment of the shoulder-blade to the chest calculated to prevent the possibility of any rude concussion reaching the thorax.*

" "Had," says Mr. Pcrcivall, "thc entire rib bcen one solid piece of bone, a violent blow might have broken it to pieces. On the other hand, had the ribs been composed from end to 
At the shoulder is a muscle of immense strength, and tendinous elastic composition, the serratus major, spreading over the internal surfacc of the shoulder-blade and a portion of the chest. A spring of easier play could not have been attached to the carriage of any invalid. It is a carriage hung by springs between the scapulæ, and a delightful one it is for easy travelling; while there is combined with it, and the union is not a little difficult, strength enough to resist the jolting of the roughest road and the most rapid pace.

Laterally there is sufficient defence against all common injury by the expansion of the shoulder over the chest from between the first and second to the seventh rib; and behind and below that there is the bony structure of the ribs, of no little strength; and their arched form, although a flattened arch; and the yielding motion at the base of each rib, resulting from its jointed connexion with the spine above and its cartilaginous union with the sternum below.

$\Lambda$ still more important consideration with regard to the parietes of the thorax is the manner in which they can adapt themselves to the changing bulk of the contents of the cavity. The capacity of the chest is little affected by the external contraction and dilatation of the heart, for when its ventricles are collapsed its auricles are distended, and when its auricles are compressed its ventricles expand; but with regard to the lungs it is a very different affair. In their state of collapse and expansion they vary in comparative bulk, one-sixth part or more, and, in either state, it is necessary for the proper discharge of the function of respiration that the parietes of the chest should be in contact with them.

The ribs are eighteen in number on either side. Nine of them are perfect, and commonly called the true, or, more properly, sternal ribs, extending from the spine to the sternum. The remaining nine are posterior and shorter, and are only indirectly connected with the sternum.

The ribs are united to the corresponding vertebræ, or bones of the spine, so as to form perfect joints - or, rather, each rib forms two joints. The head of the rib is received between the vertebræ and bones of the spine, before and behind, so that it shall always present two articulating surfaces; one opposed to the vertebra immediately before, and the other to that immediately behind, and both forming one joint, with a perfect capsular ligament, and admitting of a rotary motion. The head of the rib seems to be received into the cartilaginous ligamentous substance between the vertebræ. Nothing could be more admirably devised for motion, so far as it is required, and for strength of union, that can scarcely be broken.

Before the ribs reach the sternum, they terminate in a cartilaginous prolongation, or the lower part of the rib may be said to be cartilaginous. There is between the bony part and this cartilage, a joint with a true capsular ligament, and admitting of a certain degree of motion; and where it unites with the sternum, there is a fourth joint, with a perfect and complete capsular ligament.

The cartilages of the posterior ribs are united to the bony portion by a kind of joint. They are not, however, prolonged so far as the stcrnum; but the extremity of one lies upon the body of that which is immediately before it, bound down upon it by a cellular substance approaching to the nature of ligament, yet each having some separatc motion, and all of them connected indirectly with the sternum, by means of the last sternal rib. It is an admirable contrivance to preserve the requisite motion which unust attend every act of breathing, every extension and contraction of the chest, with a degree of strength which scarcely any accident can break through.

The sternum, or breast-bone, is more complicated than it at first appears to bc. It constitutes the floor of the chest, and is a long flat spongy bone, fixed between the ribs on either side, articulating with these cartilages, and serving as a point of support to them. It is composed of from seven to nine pieces, united together by cartilage; and whatever changes may take place in other parts of the frame, this cartilage is not converted to bone, even in extreme old age, although there may, possibly, be some spots of ossific matter found in it.

end of cartilage only, the form of the arch could not have been sustained, but, sooner or later, it must have bent inward, and so have encroached upon the cavity of the chest as to have compressed the organs of respiration and circulation to that degree that could not but have ended in suffocation and death of the animal. It was only the judicious and well-arranged combination of bone and gristle in the construction of the chest thit could answer the ends an all-wise Providence had in view." - Veterinarian, vol. xv. p. 184. 
The point of the breast-bone may be occasionally injured by blows, or by the pressure of the collar. It has been, by brutal violence, completely broken off from the sternum; but oftencr, and that from some cruel usage, a kind of tumour has been formed on the point of it, which has occasionally ulcerated, and proved very difficult to heal.

The front of the chest is a very important consideration in the structure of the horse. It should be prominent and broad, and full, and the sides of it well occupied. When the breast is narrow, the chest has generally the same appearance: the animal is flatsided, the proper cavity of the chest is diminished, and the stamina of the horse are materially diminished, although, perhaps, his speed for short distances may not be affected. When the chest is narrow, and the fore legs are too close together, in addition to the want of bottom, they will interfere with each other, and therc will be wounds on the fetlocks, and bruises below the knee.

A chest too broad is not desirable, but a fleshy and a prominent one; yet even this, perhaps, may require somc explanation. When the fore legs appear to recede, and to shelter themsclves under the body, there is a faulty position of the fore limbs, a bend, or standing over, an unnatural lengthiness about the fore parts of the breast, sadly disadvantagcous in progression.

'There is also a posterior appendix to the sternum, which is also cartilaginous. It is called the ensiform cartilage, although it bears little resemblance to a sword. It is flat and flexible, yet strong, and serves as the commencement of the floor, or support of the abdomen. It also gives insertion to some of the abdominal muscles, and more conveniently than it could have bcen obtained from the body of the sternum.

The Intercostal Muscles. - The borders of the ribs are anteriorly concave, thin and sharp - posteriorly rounded, and presenting underneath a lnngitudinal depression, or channel, in which run both blood-vessels and ncrves. The space between them is oceupied by muscular substance, firmly attached to the borders of the ribs. These muscles are singularly distributed; their fibres cross each other in the form of an X. There is a manifest advantage in this. If the fibres ran straight across from rib to rib, they might act powerfully, but their action would be exceedingly limited. A short muscle can contract but a little way, and only a slight change of form or dimension can be produced. By running diagonally from rib to rib, these muscles are double the length they could otherwise have bcen. It is a general rulc, with regard to muscular action, that the power of the muscle depends on its bulk, and the extent of its action on its length.

The ribs, while they protect the important viscera of the thorax from injury, are powerful agents in extending and contracting the chest in the alternate inspiration and expiration of air. In what proportion they discharge the labour of respiration, is a disputed question, and into the consideration of which we cannot enter, until something is known of the grand respiratory muscle - the diaphragm. Thus far, however, may be said, that they are not inactive in natural respiration, although they ccrtainly act only a secondary part; but in hurried respiration, and when the demand for artcrialised blood is increased by violent exertion, they are valuable and powerful auxiliaries.

This leads to a very important consideration, the most advantageous form of the chest for the proper discharge of the natural or extraordinary functions of the thoracic viscera. 'The contents of the chest are the lungs and the heart: - the first, to render the blood nutrient and stimulating, and to give or restore to it that vitality which will enable it to support every part of the frame in the discharge of its function, and devoid of which, the complicated and beautiful machine is inert and dcad; and the sccond, to convey this purified arterialised blood to every part of the frame.

In order to produce, and to convey to the various parts, a sufficient quantity of blood, these organs must be large. If it amounts not to hypertrophy, the larger the lieart and the larger the lungs, the more rapid the process of nutrition, and the more perfect the discharge of every animal function.

Then it might be imagined that, as a circle is a figure which contains more than any other of equal girth and admeasurement, a circular form of the chest would be most advantagcous. Not exactly so; for the contents of the chest are alternately expanding and contracting. The circular chest could not expand, but every change of form would bc a diminution of capacity.

That form of chest which approaches nearest to a circle, while it admits of sufficient 
expansion and contraction, is the best - certainly for some animals, and for all under peculiar circumstances, and with reference to the discharge of certain functions. This was the grand principle on which Mr. Bakewell proceeded, and on which all our improvements in the breeding of cattle were founded.

This principle holds good with regard to some breeds of horses. We value the heavy draught-horse not only on account of his simple muscular power, but the weight which, by means of that power, he is able to throw into the coller. A light horse may be preferable for light draught; but we must oppose weight to weight, when our loads are heavy. In the dray-horse, we prize this circular chest, not only that he may be proportionably heavier before - to him no disadvantage - but that, by means of the increased capacity of his chest, he may obtain the bulk and size which best fit him for our service. But he would not do for speed - he would not do for ordinary quick exertion; and if he were pushed far beyond his pace, he would become broken-winded, or have inflamed lungs.

Some of our saddle-horses and cobs have barrels round enough, and we value them on account of it, for they are always in condition, and they rarely tire. But when we look at them more carefully, there is just that departure from the circular form of which mention has been made-that happy medium between the circle and the ellipse, which retains the capacity of the one and the expansibility of the other. Such a horse is invaluable for common purposes, but he is seldom a horse of speed. If he is permitted to go his own pace, and that not a slow one, he will work on for ever; but if he is too much hurried, he is soon distressed.

The Broad Deep Chest.-Then for the usual purposes of the road, and more particularly for rapid progression, search is made for that form of the chest which shall unite, and to as great a degree as possible, considerable capacity in a quiescent state, and the power of increasing that capacity when the animal requires it. There must be the broad chest for the production of muscles and sinews, and the deep chest, to give the capacity or power of furnishing arterial blood equal to the most rapid exhaustion of vitality.

This form of the chest is consistent with lightness, or at least with all the lightness that can be rationally required. The broad-chested horse, or he that, with moderate depth at the girth, swells and barrels out immediately behind the elbow, may have as light a forehead and as elevated a wither as the horse with the narrowest chest; but the animal with the barrel approaching too near to rotundity is invariably heavy abont the shoulders and low in the withers. It is to the mixture of the Arabian blood that we principally owe this peculiar and advantageous formation of the chest of the horse. The Arab is light; some would say too much so before: but immediately behind the arms the barrel almost invariably swells out, and leaves plenty of room, and where it is most wanted for the play of the lungs, and at the same time where the weight does not press so exclusively on the fore-legs, and expose the feet to concussion and injury.

Many horses with narrow chests, and a great deal of daylight under them, have plenty of spirit and willingness for work. They show themselves well off, and exhibit the address and gratify the vanity of their riders on the parade or in the park, but they have not the appetite nor the endurance that will carry them through three successive days' hard work.

Five out of six of the animals that perish from inflamed lungs are narrow-chested, and it might be safely affirmed that the far greater part of those who are lost in the field after a hard day's run, have been horses whose training has been neglected, or who have no room for the lungs to expand. The most important of all points in the conformation of the horse is here elucidated. An elevated wither, or oblique shoulder, or powerful quarters, are great advantages; but that which is most of all connected with the general health of the arimal, and with combined fleetness or bottom, is a deep, and broad, and swelling chest, with sufficient lengthening of the sternum, or
breast-bone, beneath.

If a chest that cannot expand with the increasing expansion and labour of the lungs is so serious a detriment to the horse, everything that interferes with the action of the intercostal muscles is carefully to be avoidnd. Tight girthing ranks among these, and foremost among them. The closeness with which the roller is buckled on in the stable must be a serious inconvenience to the horse; and the partially depriving these muscles of their power of action, for so many hours in every day, must indispose 
them for labour when quicker and fuller respiration is required. At all events, a tight girth, though an almost necessary nuisance, is a very considerable one, when all the exertion of which he is capable is required from the horse. Who has not perceived the address with which, by bellying out the chest, the old horse renders every attempt to girth him tight comparatively useless; and when a horse is blown, what immediate relief has ungirthing him afforded, by permitting the intercostals to act with greater power?

A point of consequence regarding the capacity of the chest, is the length or shortness of the carcase; or the extent of the ribs from the elbow backward. Some horses are what is called ribbed home; there is but little space (see cuts pp. 68 and 167) between the last rib and the hip-bone. In others the distance is considerably greater, and is plainly evident by the falling in of the flank. The question then is, what service is required from the horse? If he has to carry a heary weight, and has much work to do, he should be ribbed home-the last rib and the hip-bone should not be far from each other. There is more capacity of chest and of belly-there is less distance between the points of support - and greater strength and endurance. A hackney (and we would almost say a hunter) can scarcely be too well ribbed home.

If speed, however, is required, there must be room for the full action of the hinder limbs; and this can only exist where there is sufficient space between the last rib and the hip-bone. The owner of the horse must make up his mind as to what he wants from him, and be satisfied if he obtains that; for, let him be assured that he cannot have everything, for this would require those differences of conformation that cannot possibly exist in the same animal.

The thorax, or chest, is formed by the spine $f$, above (p. 167) the ribs $e$, on either side; and the sternum, or breast-bone, $c$, beneath.

\section{THE SPINE AND BACK.}

The spine, or back, consists of a chain of bones from the poll to the extremity of the tail. It is made up of twenty-three bones from the neck to the haunch; eighteen, called dorsal vertebrx, composing the back; and five lumbar vertebr $x$, occupying the loins. On this part of the animal the weight or burden is laid, and there are two things to be principally considered, easiness of carriagc and strength. If the back were composed of unyiclding materials-if it resembled a bar of wood or iron, much jarring or jolting, in the rapid motion of the animal, could not possibly be endured. In order to avoid this, as well as to assist in turning, the back is divided into numerous bones; and between each pair of bones there is interposed a cartilaginous substance, most highly elastic, that will yield and give way to every jar, not so much as to occasion insecurity between the bones, or to permit considerable motion between any one pair, but forming altogether an aggregate mass of such perfect elasticity, that the rider sits almost undisturbed, however high may be the action, or however rapid the pace.

Strength is as important as ease; therefore these bones are united together with pcculiar firmness. 'The round head of one is exactly fitted to the cup or cavity of that immediately before it; and between them is placed the elastic ligamentous substance, which has becn just described, so strong, that in endeavouring to separate the bones of the back, they will break before this substance will give way. In addition to this therc are ligaments running along the broad under-surface of these bones-ligaments between each of the transverse processes, or side projections of the bones-ligaments between the spinous processes or upright projections, and also a continuation of the strong ligament of the neck running along the whole course of the back and loins, lengthening and contracting, as in the neck, with the motions of the animal, and forning a powerful bond of union between the bones.

By these means the hunter will carry a heavy man without fatigue or strain through a long chase; and those shocks and jars are avoided which would be annoying to the rider, and injurious and speedily fatal to the horse.

These provisions, however, although adequate to common or even severe exertion, will not protect the animal from the consequences of brutal usage; and, therefore, if the horse is much overweighted, or violently exercised, or too suddenly pulled upon his haunches, these ligaments are strained. Inflammation follows. The ligaments become changed to bone, and the joints of the back lose their springiness and ease of 
motion; or rather, in point of fact, they cease to exist. On account of the too hard service required from them, and especially before they had gained their full strength, there are few old horses who have not some of the bones of the back or loins anchylosed-united together by bony matter and not by ligament. When this exists to any considerable extent, the horse is not pleasant to ride - he turns with difficulty in his stall - he is unwilling to lie down, and when down to rise again, and he has a singular straddling action. Such horses are said to be broken-backed or chinked in the chine.

Fracture of the bones of the back rarely occurs, on account of their being so strongly united by ligaments, and defended by muscular substance. If a fracture of these bones does happen, it is during the violent struggles after the horse has been cast for an operation.

The length of the back is an important consideration. A long-backed horse will be easy in his paces, because the increased distance between the fore and hind legs, which are the supports of the spine, will afford greater room for the play of the joints of the back. A long spring has much more play than a short one, and will better obviate concussion. A long-backed horse is likewise formed for speed, for there is room to bring his hinder legs more under him in the act of gallopping, and thus more powerfully propel or drive forward the body: but, on the other hand, a long-backed horse will be comparatively weak in the back, and easily overweighted. A long spring may be easily bent or broken. The weight of the rider, likewise, placed farther from the extremities, will act with mechanical disadvantage upon them, and be more likely to strain them. A short-backed horse may be a good hackney, and able to carry the heaviest weight, and possess great endurance; but his paces will not be so easy, nor his speed so great, and he may be apt to overreach.

The comparative advantage of a long or short carcase depends entirely on the use for which the horse is intended. For general purposes the horse with a short carcase is very properly preferred. He will possess health and strength; for horses of this make are proverbially hardy. He will have sufficient easiness of action not to fatigue the rider, and speed for every ordinary purpose. Length of back will always be desirable when there is more than usual substance generally, and particularly when the loins are wide, and the muscles of the loins large and swelling. The two requisites, strength and speed, will then probably be united.

The back should be depressed a little immediately behind the withers; and then continue in an almost straight line to the loins. This is the form most consistent with beauty and strength. Some horses have a very considerable hollow behind the withers. They are said to be saddle-backed. It seems as if a depression were purposely made for the saddle. Such horses are evidently easy goers, for this curve inward must necessarily increase the play of the joints of the back: but in the same proportion, they are weak and liable to sprain. To the general appearance of the horse, this defect is not in any great degree injurious; for the hollow of the back is uniformly accompanied by a beautifully arched crest.

A few horses have the curve outward. They are said to be roach-backed, from the supposed resemblance to the arched back of a roach. This is a very serious defect; -altogether incompatible with beauty, and materially diminishing the usefulness of the animal. It is almost impossible to prevent the saddle from being thrown on the shoulders, or the back from being galled; - the elasticity of the spine is destroyed; - the rump is badly set on;-the hinder legs are too much under the animal; - he is continually overreaching, and his head is carried awkwardly low.

\section{THE L O INS.}

The loins are attentively examined by every good horseman. They can scarcely be too broad and muscular. The strength of the back, and especially, the strengtli of the hinder extremities, will depend materially on this. The breadth of the loins is regulated by the length of the transverse or side processes of that part. The bodies of the bones of the loins are likewise larger than those of the back; and a more dovetailed kind of union subsists between these bones than between those of the back. Every provision is made for strength here. The union of the back and loins should be carefully observed, for there is sometimes a depression between them. A kind of line is drawn across, which shows imperfection in the construction of the spine, and is regarded as an indication of weakness. 


\section{THE WITHERS.}

The spinous or upright processes of the dorsal vertebræ, or bones of the back, above the upper part of the shoulder, are as remarkable for their length as are the transverse or side processes of the bones of the loins. They are flattened and terminated by rough blunted extremities. The elevated ridge which they form is called the withers. It will be scen in the cuts (pp. 68 and 167), that the spine of the first bone of the back has but little elevation, and is sharp and upright. The second is longer and inclined backward; the third and fourth increases in length, and the fifth is the longest; - they then gradually shorten until the twelfth or thirteenth, which becomes level with the bones of the loins.

High withers have been always, in the mind of the judge of the horse, associated with good action, and generally with speed. The reason is plain enough : - they afford larger surface for the attachment of the muscles of the back; and in proportion to the elevation of the withers, these muscles act with greater advantage. The rising of the fore parts of the horse, even in the trot, and inore especially in the gallop, depends not merely on the action of the muscles of the legs and shoulders, but on those of the loins, inserted into the spinous processes of these bones of the back, and acting with greater power in proportion as these processes, constituting the withers, are lengthened. The arm of the lever to which the power is applied will be longer; and in proportion to the length of this arm will be the ease and the height to which a weight is raised. Therefore good and high action will depend much on elevated withers.

It is not difficult to understand how speed will likewise be promoted by the same conformation. The power of the horse is in his hinder quarters. In them lies the main spring of the frame, and the fore-quarters are chiefly elevated and thrown forward to receive the weight forced on them by the action of the linder quarters. In proportion, however, as the fore-quarters are elevated, will they be thrown farther forward, or, in other words, will the stride of the horse be lengthened. Yet many racers have the forehand low. The unrivalled Eclipse was a remarkable instance of this; but the ample and finely proportioned quarters, and the muscularity of the thigh and fore-arm, rendered the aid to be derived from the withers perfectly unnecessary. The heavy draught-horse does not require elevated withers. His utility depends on the power of depressing his fore-quarters, and throwing their weight fully into the collar; but for common work in the hackney, in the farmer's horse, and in the hunter, well-formed withers will be an essential advantage, as contributing to good and safe action, and likewise to speed.

\section{MUSCLES OF THE BACK.}

The most important muscles which belong to this part of the frame are principally those which $\epsilon$ xtend from the continuation of the ligament of the neck, along the whole of the back and loins; and likewise from the last cervical bone;-the superficialis and transversalis cosiarum, or superficial and transversc muscles of the ribs, going from this ligament to the upper part of the ribs to elevate them, and to assist in the expansion of the chest; also the large mass of muscle, the longissimus dorsi, or longest muscle of the back, from the spinous and transverse processes of the vertebræ to the ribs, and by which all the motions of the spine, and back, and loins, to which allusion has been made, are principally produced; by which the fore-quarters are raised upon the hind ones, or the hind upon the fore ones, according as either of them is the fixed point. This is the principal agent in rearing and kicking.

The last muscle to be noticed is the spinalis dorsi, the spinal muscle of the back, from the spinous processes of some of the last bones of the back to those of the fore part; - thick and strong ahout the withers, and broadly attached to them; and more powerfully attached, and more strongly acting in proportion to the elevation of the withers; and procecding on to the three lowest bones of the neck, and therefore mainly concerned, as already described, in elevating the fore-quarters, and producing high and safe action, and contributing to speed.

Before the roof of the chest is left,some accidents or diseases to which it is exposed must be mentioned. The first is of a very serious nature. 


\section{FISTULOUS WITHERS.}

When the saddle has been suffcred to press long upon the withers, a tumour will be formed, hot and exceedingly tender. It may sometimes be dispersed by the cooling applications recommended in the treatment of poll-evil ; but if, in despite of these, the swelling should remain stationary, and especially if it should become larger and more tender, warm fomentations and poultices, and stimulating embrocations, should be diligently applied, in order to hasten the formation of pus. As soon as that can be fairly detected, a seton should be passed from the top to the bottom of the tumour, so that the whole of the matter may be evacuated, and continue to be discharged as it is afterwards formed; or the knife may be freely used, in order to get at the bottom of every sinus. The knife has succeeded many a time when the seton has failed. The after treatment must be precisely that which was recommended for a similar disease in the poll.

In neglected fistulous withers the ulcer may be larger and deeper, and more destructive than in poll-evil. It may burrow beneath the shoulder-blade, and the pus appear at the point of the shoulder or the elbow; or the bones of the withers may become carious.

Very great improvement has taken place in the construction of saddles for common use and in the cavalry service. Certain rules have now been laid down from which the saddler should never deviate, and attending to which the animal is saved from much suffering, and the mechanic from deserved disgrace.

The first rule in the fitting of the saddle is, that it should bear upon the back, and not on the spine or the withers, for these are parts that will not endure pressure.

Next in universal application is the understanding that the saddle should have everywhere an equal bearing, neither tilting forward upon the points nor backward upon the seat.

When the saddle is on, and the girths fastened, there should remain space sufficient between the withers and the pommel for the introduction of the hand underneath the latter.

The points of the tree should clip or embrace the sides without pinching them, or so standing outward that the pressure is all downwards, and upon one place, instead of being in a direction inwards as well as downwards, so as to be distributed uniformly over every part of the point that touches the side. Horses that have low and thick withers are most likely to have them injured, in consequence of the continual riding forward of the saddle, and its consequent pressure upon them. Fleshy and fat shoulders and sides are also subject to become hurt by the points of the trees either pinching them from being too narrow in the arch, or from the bearing being directly downward upon them.

Injury occasionally results from the interruption which a too forward saddle presents to the working or motion of the shoulder, and the consequent friction the soft parts sustain between the shoulder-blade inwardly, and the points of the saddle-tree outwardly.*

\section{WARBLES, SITFASTS, AND SADDLE GALLS.}

On other parts of the back, tumours and very troublesome ulcers may be produced by the same cause. Those resulting from the pressure of the saddle are called warbles, and, when they ulcerate, they frcquently become sitfasts. Warbles are small circular bruises, or extravasations of blood, where there has been an undue pressure of the saddle or harness. If a horse is subject to these tumours, the saddle should remain on him two or three hours after he has returned to the stable. It is only for a certain timc, however, that this will perfectly succeed, for by the frequent application of the pressure the skin and the cellular substance are bruised or otherwise injured, and a permanent sore or tumour, of a very annoying description, takes place. The centre of the sore gradually loses its vitality. A separation takes place from the surrounding integument, and there is a circular piece of dried and hard skin remaining in the centre. This is curiously called a navel gall, because it is opposite to the navel. No effort must be made to tear or dissect it off, but stimulating poultices or fomentations, or, if these fail, a mild blister, will cause a speedy separation; and the

* Percivall's Hippopathology, vol. i., p. 199. 
wound will then readily heal by the use of turpentine dressings, more or less stimulating, according to circumstances.

Saddle galls are tumours, and sometimes galls or sores, arising also from the pressure and chafing of the saddle. They differ little from the warble, except that there is very seldom the separation of the dead part in the centre, and the sore is larger and varying in its form. The application of cold water, or salt and water, will generally remove excoriations of this kind.

With regard, however, to all these tumours and excoriations, the humane man will have the saddle eased and padded as soon as it begins to be of the least inconvenience to the horse.

\section{MUSCLES OF THE BREAST.}

There are some important muscles attached to the breast connected with that expansion of the chest which every horse should possess. In the cut, page 159, are seen a very important pair of muscles, the pectorales transversi, or pectoral muscles, forming two prominences in the front of the chest, and extending backward between the legs. They come from the fore and upper part of the breast-bone; pass across the inward part of the arm, and reach from the elbow almost down to the knee. They confine the arm to the side in the rapid motion of the horse, and prevent him from bcing, what horsemen would call, and what is seen in a horse pushed beyond his natural power, "all abroad." Other muscles, pectorales magni et parvi, the great and little pectorals, rather above but behind these, go from the breast-bone to the arm, in order to draw back the point of the shoulder, and bring it upright. Another and smaller muscle goes from the breast-bone to the shoulder, to assist in the same office. A horse, therefore, thin and narrow in the breast, must be deficient in important muscular power.

Between the legs and along the breast-bone is the proper place in which to insert rowels, in cases of inflamed lungs.

\section{H E S T - F O U N D ER.}

These muscles are occasionally the seat of a singular and somewhat mysterious disease. The old farriers used to call it anticor and chest-founder. The horse has considerable stiffness in moving, evidently not referable to the feet. There is tenderness about the muscles of the breast, and, occasionally, swelling. We believe it to be nothing more than rheumatism, produced by suffering the horse to remain too long tied up, and exposed to the cold, or riding him against a very bleak wind. Sometimes a considerable degree of fever accompanies this; but bleeding, physic, a rowel in the chest, warm embrocations over the parts affected, warm stabling, and warm clothing, with occasional doses of antimonial powder, will soon subdue the complaint.

\section{CHAPTER VII. \\ THE CONTENTS OF THE CHEST.}

\section{THE THYMUS GLAND.}

A $\mathrm{T}$ the entrance of the trachea into the thorax, and ere it has scarcely penetrated between the first ribs in the young subject, it comes in contact with an irregular glandular body, situated in the doubling of the anterior mediastinum. It is "the thymus gland," or, in vulgar language, the sweet-bread. In the early period of utero-gestation, it is of very inconsiderable bulk, and confined mostly to the chest; but, during the latter months, it strangely developes itself,-the superior cornua protrude out of the thorax and climb up the neck, between the carotids and the trachea. They are evidently connected with the thymus gland, and become parts and portions of the parotid glands.

We are indebted to Sir Astley Cooper for the best account of the anatomical strucsure, and possible function of the thymus gland. It presents, on being cut into, a 
great number of small cavities, in which the abundant white fluid of the gland is in part contained. From those cavities the fluid is transmitted into a general reservoir, which forms a common connecting cavity, and is lined by a delicate membrane. Sir Astley, and in this he is supported by Professor Müller, believes that a peculiar albuminous fluid is conveyed by the thymus gland to the veins, through the medium of the lymphatics. It has nothing to do with the formation of the blood, in the foetus or the child.

These two eminent physiologists exert the better part of discretion, by declining to give any hypothesis of its function beyond this, that it supplies the lymphatics with an albuminous fluid.

This gland continues to grow for some time after birth, and remains of considerable size during the first year; it then gradually diminishes, and, about the period of puberty, usually disappears. It has, however, been found in a mare between five and six years old.

\section{THE DIAPHRAGM.}

Bounding the thorax posteriorly, - the base of the cone in the human subject,- the interposed curtain between the thorax and the abdomen in the horse, is the diaphragm. It is an irregular muscular expansion, proceeding from the inferior surface of the lumbar vertebræ posteriorly and superiorly, adhering to the ribs on either side, and extending obliquely forward and downward to the sternum; or, rather it is a flattened muscle arising from all these points, with its fibres all converging towards the centre, and terminating there in an expansion of tendinous substance. It is lined anteriorly by the pleura or investing membrane of the thoracic cavity, and posteriorly by the peritoneum or investing membrane of the abdominal cavity.

Anatomy of the Diaphragm.-In the short account which it is purposed to give of the structure of the diaphragm, the description of Mr. Percivall will be closely followed. "The diaphragm may be divided into the main circular muscle, with its central tendinous, expansion forming the lower part, and two appendices, or crura, as they are called, from their peculiar shape, constituting its superior portion. The fleshy origin of the grand muscle may be traced laterally and inferiorly, commencing from the cartilage of the eighth rib anteriorly, and closely following the union of the posterior ribs with their cartilages; excepting, however, the two last. The attachment is peculiarly strong; it is denticulated; it encircles the whole of the lateral and inferior part of the chest, as far as the sternum, where it is connected with the ensiform cartilage. Immediately under the loins are the appendices of the diaphragm, commencing on the right side, from the inferior surfaces of the five first lumbar vertebræ by strong tendons, which soon become muscular, and form a kind of pillar; and, on the left, proceeding from the two first lumbar vertebræ only, and from the sides rather than the bodies of these vertebræ, and these also unite and form a shorter pillar, or leg. The left crus or appendix is shorter than the right, that it may be more out of the way of pressure from the left curvature of the stomach, which, with the spleen, lies underneath. Opposite to the 17th dorsal vertebra, these two pillars unite and form a thick mass of muscles, detached from the vertebræ, and leaving a kind of pouch between them and the vertebræ. They not only unite, but they decussate : their fibres mingle and again separate from each other, and then proceed onward to the central tendinous expansion towards which the fibres from the circular muscle, and the appendices, all converge."

The diaphragm is the main agent, both in ordinary and extraordinary respiration; it assists also in the expulsion of the urine, and it is a most powerful auxiliary in the act of parturition. In its quiescent state, it presents its convex surface towards the thorax, and its concave one towards the abdomen. The anterior convexity abuts upon the iungs; the posterior concavity is occupied by some of the abdominal viscera. The effect of the action of this muscle, or the contraction of its fibres, is to lessen the convexity towards the chest, and the concavity towards the abdomen: or perhaps, by a powerful contraction, to cause it to present a plane surface either way. The abdominal viscera that must be displaced in order to effect this, have considerable bulk and weight; and when the stomach is distended with food, and the motion required from the diaphragm in rapid breathing is both quick and extensive, there needs some strong, firm, elastic, substance to bear it. The forcible contact and violent pressure would bruise and otherwise injure a mere muscular expansion; and therefore we have this tendi- 
nous expansion, comparatively devoid of sensibility, to stand the pressure and the shock which will always be greatest at the centre.

Yct it is subject to injury and disease of a serious and varied character. Whatever may be the original seat of thoracic or abdominal ailment, the diaphragm soon becomes irritable and inflamed. 'This accounts for the breathing of the horse being so much affected under every inflammation or excitement of the chest or belly. The irritability of this muscle is often evinced by a singular spasmodic action of a portion, or the whole of it.

Mr. Castley thus describes a case of it:- "A horsc had been very much distressed in a run of nearly thirtecn miles, without a check, and his rider stopped, on the road towards home, to rest him a little. With difficulty he was brought to the stable. Mr. Castley was sent for, and he says,- When I first saw the animal, his breathing and attitude indicated the greatest distress. 'The prominent symptom, however, was a convulsive motion, or jerking of the whole body, audible at several yards' distance, and evidently procecding from his inside; the beats appeared to be about forty in a minute. On placing $m y$ hand over the heart, the action of that organ could be felt, but very indistinctly ; the beating evidently came from behind the heart, and was most plainly to be felt in the direction of the diaphragm. Again placing my hand on the abdominal muscles, the jerks appeared to come from before, backwards; the impression on my mind, therefore, was, that this was a spasmodic affection of the diaphragm, brought on by violent distress in running.' "*

Mr. Castley's account is inserted thus at length, because it was the first of the kind on record, with the exception of an opinion of Mr. Apperley, which came very near to the truth. "When a horse is very much exhausted after a long run with hounds, a noise will sometimes be heard to proceed from his inside, which is often erroneously supposed to be the beating of his heart, whereas it proceeds from the excessive motion of the abdominal muscles." $\dagger$

Mr. Castley shall pursue his case, (it will be a most useful guide to the treatment of these cases):- "Finding that there was little pulsation to be felt at the submaxillary artery, and judging from that circuinstance that any attempt to bleed at that time would be worse than useless, I ordered stimulants to be given. We first administered three ounces of spirit of nitrous ether, in a bottle of warm water; but this producing no good effect, we shortly afterwards gave two drachms of the sub-carbonate of ammonia in a ball, allowing the patient, at the same time, plenty of white water to drink. About a quarter of an hour after this, he broke out into a profuse perspiration, which continued two hours, or more. 'The breathing became more tranquil, but the convulsive motion of the diaphragm still continued without any abatement. After the sweating had ccased, the pulse became more perceptible, and the action of the heart more distinct, and I considered this to be the proper time to bleed. When about ten pounds had been extracted, I thought that the beating and the breathing seemed to increase; the bleeding was stopped, and the patient littered up for the night. In the morning, the affection of the diaphragm was much moderated, and about eleven o'clock it ceased, after continuing eighteen or nineteen hours. A little tonic medicine was afterwards administered, and the horse soon recovered his usual appetite and spirits." $\neq$

Later surgeons administer, and with good effect, opium in small doses, together with ammonia, or nitric ether, and have recourse to bleeding as soon as any reaction is perceived.

Over-fatigue, of almost every kind, has produced spasm of the diaphragm, and so has over-distension of the stomach with grass.

\section{RUPTURE OF THE DIAPHRAGM.}

This is an accident, or the consequence of disease, very lately brought under the cognizance of the vctcrinary surgeon. The first communication of its occurrence was from Mr. King, a friend of Mr. Percivall. $\$$ It occurred in a mare that had been ridden sharply for half a dozen miles, when she was full of grass. She soon afterwards exhibited symptoms of broken-wind, and, at length, died suddenly, while standing in the stable. The diaphragm was lacerated on the left side, through its whole extent, throwing the two cavities into one.

* The Veterinarian, 1831, p. 247.

\$ The Veterinarian, 1831, p. 248.
† Nimrod on the Condition of Hunters, p. 185

o The Veterinarian, 1828, p. 101. 
Since that period, from the increasing and very proper habit of examining every dead lorse, cases of this accident have rapidly multiplied. It seems that it may follow any act of extraordinary exertion, and efforts of every kind, particularly on a full stomach, or when the bowels are distended with green or other food likely to generate gas.* Considerable caution, however, should be exercised when much gaseous fluid is present; for the bowels may be distended, and forced against the diaphragm to such a degree, as to threaten to burst.

An interesting case of rupture of the diaphragm was related by Professor Spooner, at one of the meetings of the Veterinary Medical Association. A horse having been saddled and bridled for riding, was turned in his stall and fastened by the bit-straps. Something frightened him-he reared, broke the bit-strap, and fell backward. On the following morning, he was evidently in great pain, kicking, heaving, and occasionally lying down. Mr. S. was sent for to examine him, but was not told of the event of the preceding day. He considered it to be a case of enteritis, and treated it accordingly. He bled him largely, and, in the course of the day, the horse appeared to be decidedly better, every symptom of pain having vanished. The horse was more lively - he ate with appetite, but his bowels remained constipated.

On the following day there was a fearful change. The animal was suffering sadly -the breathing was laborious, and the membrane of the nose intensely red, as if it were more a case of inflammation of the lungs than of the bowels. The bowels were still constipated. The patient was bled and physicked again, but without avail. He died; and there was found rupture of the diaphragm, protrusion of intestine into the thoracic cavity, and extensive pleural and peritoneal inflammation.

In rupture of the diaphragm, the horse usually sits on his haunches, like a dog; but this is far from being an infallible symptom of the disease. It accompanies introsusception, as well as rupture of the diaphragm. The weight of the intestines may possibly cause any protruded part of them to descend again into the abdomen.

This muscle, so important in its office, is plentifully supplied with blood-vessels. As the posterior aorta passes beneath the crura of the diaphragm, it gives out sometimes a single vessel which soon bifurcates; sometimes two branches, which speedily plunge into the appendices or crura, while numerous small vessels, escaping from them, spread over the central tendinous expansion. As the larger muscle of the diaphragm springs from the sides and the base of the chest, it receives many ramifications from the internal pectoral, derived from the anterior aorta; but more from the posterior intercostals which spring from the posterior aorta.

The veins of the diaphragm belong exclusively to the posterior vena cava. There are usually three on either side; but they may be best referred to two chief trunks which come from the circumference of the diaphragm, converge towards the centre, and run into the posterior cava as it passes through the tendinous expansion.

The functional nerve of the diaphragm, or that from which it derives its principal action, and which constitutes it a muscle of respiration, is the phrenic or diaphragmatic. Although it does not proceed from that portion of the medulla oblongata which gives rise to the glosso-pharyngeus and the par vagum, yet there is sufficient to induce us to suspect that it arises from, and should be referred to, the lateral column between the superior and inferior, the sensitive and motor nerves, and which may be evidently traced from the pons varolii to the very termination of the spinal chord.

The diaphragm is the main agent in the work of respiration. The other muscles are mere auxiliaries, little needed in ordinary breathing, but affording the most important assistance, when the breathing is more than usually hurried. The mechanism of respiration may be thus explained :-Let it be supposed that the lungs are in a quiescent state. The act of expiration has been performed, and all is still. From some cause enveloped in mystery - connected with the will, but independent of it some stimulus of an unexplained and unknown kind - the phrenic nerve acts on the diaphragm, and that muscle contracts; and, by contracting, its convexity into the chest is diminished, and the cavity of the chest is enlarged. At the same time, and by some consentaneous influence, the intercostal muscles act - with no great force, indeed, in undisturbed breathing; but, in proportion as they act, the ribs rotate on their axes, their edges are thrown outward, and thus a twofold effect ensues:- the posterior margin of the chest is expanded, the cavity is plainly enlarged, and also, by the partial rotation of every rib, the cavity is still more increased.

* Percivall's Hippopathology, vol. ii., No. 1, p. 152. 
By some other consentaneous influence, the spinal accessory nerve likewise exerts its power, and the sterno-maxillaris muscle is stimulated by the anterior division of it, and the motion of the head and neck corresponds with and assists that of the chest; while the posterior division of the accessory nerve, by its anastamoses with the motor nerves of the levator humeri and the splenius, and many other of the muscles of the neck and the shoulder, and by its direct influence on the rhomboideus, associates almost every muscle of the neck, the shoulder, and the chest, in the expansion of the thorax. These latter are muscles, which, in undisturbed respiration, the animal scarcely needs; but which are necessary to him when the respiration is much disturbed, and to obtain the aid of which he will, under pneumonia, obstinately stand until he falls exhausted or to die.

The cavity of the chest is now enlarged. But this is a closed cavity, and between its contents and the parietes of the chest a vacuum would be formed; or rather an inequality of atmospheric pressure is produced from the moment the chest begins to dilate. As thc diaphragm rccedes, there is nothing to counterbalance the pressure of the atmospheric air communicating with the lungs through the medium of the nose and mouth, and it is forced into the respiratory tubes already described, and the lungs are expanded and still kept in contact with the receding walls of the chest. There is no sucking, no inhalent power in the act of inspiration; it is the simple enlargement of the chest from the entrance and pressure of the air.

From some cause, as inexplicable as that which produced the expansion of the chest, the respiratory nerves cease to act; and the diaphragm, by the inherent elasticity of its tendinous expansion and muscular fibres, returns to its natural form, once more projecting its convexity into the thorax. The abdominal muscles, also, which had been put on the stretch by the forcing of the viscera into the posterior part of the abdomen by means of the straightening of the diaphragm, contract, and accelerate the return of that muscle to its quiescent figure; and the ribs, all armed with elastic cartilages, regain their former situation and figure. The muscles of the shoulder and the chest relax, a portion of the lungs are pressed on every side, and the air with which they were distended is again forced out. There is only one set of muscles actively employed in expiration, namely, the abdominal: the elasticity of the parts displaced in inspiration being almost sufficient to accomplish the purpose.

The lungs, however, are not altogether passive. The bronchial tubes, so far as they can be traced, are lined with cartilage, divided and subdivided for the purpose of folding up when the lungs are compressed, but elastic enough to afford a yielding resistance against both unusual expansion and contraction. In their usual state the air-tubes are distended beyond their natural calibre; for if the parietes of the thorax are perforated, and the pressure of the atmosphere rendered equal within and without them, the lungs immediately collapsc.

\section{THE PLEURA.}

The walls of the chest are lined, and the lungs are covered by a smooth glistening membrane, the pleura. It is a serous membrane, so called from the nature of its exhalation, in distinction from the mucous secretion yielded by the membrane of the air-passages. The serous membrane generally invests the most important organs, and always those that are essentially connected with life; while the mucous membrane lines the interior of the grcater part of them. The pleupe is the investing membranc of the lungs, and a mucous membrane the lining one of the bronchial tubes.

Among the circumstances principally to be noticed, with regard to the pleura, is the polish of its external surface. The glistening appearance of the lungs, and of the inside of the chest, is to be attributed to the membrane by which they are covered, and by means of which the motion of the various organs is freer and less dangerous. Although the lungs, and the bony walls which contain them, are in constant approximation with each other, both in expiration and inspiration, yet in the frequently hurried and violent motion of the animal, and, in fact, in every act of expiration and inspiration, of dilatation and contraction, much and injurious friction would ensue if the surfaces did not glide freely over each other by means of the peculiar polish of this membrane.

Every serous membrane has innumerable exhalent vessels upon its surface, from which a considerable quantity of fluid is poured out. In life and during health it exists in the chest only as a kind of dew, just sufficient to lubricate the surfaces. 
When the chest is opened soon after death, we recognize it in the steam that arises, and in a few drops of fluid, which, being condensed, are found at the lowest part of the chest.

The quantity, however, which is exhaled from all the serous membranes, must be very great. It is perhaps equal or superior to that which is yielded by the vesscls on the surface of the body. If very little is found in ordinary cases, it is because the absorbents are as numerous and as active as the exhalents, and, during health, that which is poured out by the one is taken up by the other; but in circumstances of disease, either when the exhalents are stimulated to undue action, or the power of the absorbents is diminished, the fluid rapidly and greatly accumulates. Thus we have hydrothorax or dropsy of the chest, as one of the consequences of inflammation of the chest; and the same disturbed balance of action will produce similar effusion in other cavities.

The extensibility of membrane generally is nowhere more strikingly displayed than in the serous membranes, and particularly in that under consideration. How different the bulk of the lungs before the act of inspiration has commenced, and after it has been completed, and especially in the laborious respiration of disease or rapid exertion! In either state of the lungs the pleura is perfectly fitted to that which it envelopes.

The pleura, like other serous membranes, is possessed of very little sensibility: Few nerves from the sensitive column of the spinal chord reach it. Acute feeling would render these membranes generally, and this membrane in particular, unfit for the function they have to discharge. It has too much motion, even during sleep; and far too forcible friction with the parietes of the thorax in morbid or hurried respiration, to render it convenient or useful for it to possess much sensation. Some of those anatomists whose experiments on the living animal do no credit to their humanity, have given most singular proof of the insensibility, not only of these serous membranes, but of the organs which they invest. Bichat frequently examined the spleen of dogs. He detached it from some of its adhesions, and left it protruding from the wound in the abdomen, in order "to study the phenomena;" and he saw "them tearing off that organ, and eating it, and thus feeding upon their own substance." In some experiments, in which part of their intestines were left out, he observed them, as soon as they had the opportunity, tear to pieces their own viscera without any visible pain.

Although it may be advantageous that these important organs shall be thus devoid of sensibility when in health, in order that we may be unconscious of their action and motion, and that they may be rendered perfectly independent of the will, yet it is equally needful that, by the feeling of pain, we should be warned of the existence of any dangerous disease: and thence it happens that this membrane, and also the organ which it invests, acquire under inflammation the highest degree of sensibility. The countenance of the horse labouring under pleurisy or pneumonia will sufficiently indicate a state of suffering; and the spasmed bend of his neck, and his long and anxious and intense gaze upon his side, tell us that that suffering is extreme.

Nature, however, is wise and benevolent even here. It is not of every morbid affection, or morbid change, that the animal is conscious. If a mucous membrane is diseased, he is rendered painfully aware of that, for neither respiration nor digestion could be perfectly carried on while there was any considerable lesion of it; but, on the other hand, we find tubercles in the parenchyma of the lungs, or induration or hepatization of their substance, or extensive adhesions, of which there were few or no indications during life.

The pleura adheres intimately to the ribs and to the substance of the lungs; yet it is a very singular connexion. It is not a continuance of the same organisation; it is not an interchange of vessels. The organ and its membrane, although so closely connected for a particular purpose, yet in very many cases, and where it would least of all be suspected, have little or no sympathy with each other. Inflammation of the lungs will sometimes exist, and will run on to ulceration, while the pleura will be very little affected: and, much oftener, the pleura will be the seat of inflammation and will be attended by increased exhalation to such an extent as to suffocate the animal, and yet the lungs will exhibit little other morbid appearance than that of mere compression. The disease of a mucous membrane spreads to other parts-that 
THE I.UNGS-THE HEART.

of a serous one is generally isolated. It was to limit the progress of disease that this difference of structure between the organ and its membrane was contrived.

The investing membrane of the lungs and that of the heart are in continual contact with each other, hut they are as distinct and unconnected, as if they were placed in different parts of the frame. Is there no meaning in this ?

It is to preserve the perfect independence of organs equally important, yet altogether different in structure and function - to oppose an insuperable harrier to hurtful sympathy between them, and especially to cut off the communication of disease.

Perhaps a little light begins to be thrown on a circumstance of which we have occasional painful experience. While we may administer physic, or mild aperients at least, in plcurisy, not only with little danger, but with manifest advantage, we may just as well give a dose of poison as a physic-ball to a horse labouring under pneumonia. The pleura is connected with the lungs, and with the lungs alone, and the organisation is so different, that there is very little sympathy between them. A physic-ball may, therefore, act as a counter-irritant, or as giving a new determination to the vital current, without the propagation of sympathetic irritation; but the lungs or the bronchial tubes that ramify through them are continuous with the mucous membranes of the digestive as well as all the respiratory passages; and on account of the continuity and similarity of organisation, there is much sympathy between them. If there is irritation excitcd at the same time in two different portions of the same membrane, it is probable that, instead of being shared between them, the one will be transferred to the other - will inerease or double the other, and act with fearful and fatal violence.

\section{THE LUNGS.}

The lungs are the seat of a peculiar circulation. They convey through their comparatively little bulk the blood, and other fluids scarcely transformed into blood, or soon separated from it, which traverse the whole of the frame. They consist of countless ramifications of air-tubes and blood-vessels connected together by intervening cellular substance.

They form two distinct bodies, the right somewhat larger than the Icft, and are divided from each other by the duplicature of the pleura, which has been already described-the mediastinum. Each lung has the same structure, and properties, and ises. Each of them is subdivided, the right lobe consisting of three lobes, and the left of two. The intention of these divisions is probably to adapt the substance of the lungs to the form of the cavity in which they arc placed, and to enable them more perfectly to occupy and fill the chest.

If onc of these lobes is cut into, it is found to consist of innumerable irregularly formed compartments, to which anatomists have given the name of lobules, or little lobes. They are distinct from each other, and impervious. On close examination, they can be subdivided almost without end. There is no communication between them, or if perchance such communication exists, it constitutes the discasc known by the name of broken wind.

On the delicate membrane of which these cells arc composed, innumerable minute hlood-vesscls ramify. They proceed from the heart, through the medium of the pulmonary artery - they follow all the subdivisions of the bronchial tubes-they ramify upon the membrane of these multitudinous lobules, and at length return to the heart, through the medium of the pulmonary veins, the character of the blood which they contain being esscntially changed. The mechanism of this, and the effect produced, inust be briefly considered.

\section{THE HEART.}

The heart is placed between a doubling of the pleura-the mediastinum; by means of which it is supported in its natural situation, and all dangerous friction between thesc important organs is avoided. It is also surrounded by a membrane or bag of its own, called the pericardium, whose office is of a similar nature. By means of the heart, the blood is circnlated through the frame.

It is composed of four cavities-two above, called auricles, from their supposed resemblance to the ear of a dog; and two below, tcrmed rentricles, occupying the substance of the heart. In point of fact, there are two hearts-the one on the left side implling the blood through the frame, the other on the right side conveying it through 
the pulmonary system; but, united in the manner in which they are, their junction contributes to their mutual strength, and both circulations are carried on at the same time.

The first is the arterial circulation. No function can be discharged-life cannot exist, without the presence of arterial blood. The left ventricle that contains it contracts, and by the power of that contraction, aided by other means, which the limits of our work will not permit us to describe, the blood is driven through the whole arterial circulation - the capillary vessels and the veins-and returns again to the heart, but to the right ventricle. The other division of this viscus is likewise employed in circulating the blood thus conveyed to it, but is not the same fluid which was contained in the left ventricle. It has gradually lost its vital power. As it has passed along, it has changed from red to black, and from a vital to a poisonous fluid. Ere it can again convey the principle of nutrition, or give to each organ that impulse or stimulus which enables it to discharge its function, it must be materially changed.

When the right ventricle contracts, and the blood is driven into the lungs, it passes over the gossamer membrane of which the lobules of the lungs have been described as consisting; the lobules being filled with the air which has descended through the bronchial tubes in the act of inspiration. This delicate membrane permits some of the principles of the air to permeate it. The oxygen of the atmosphere attracts and combines with a portion of the superabundant carbon of this blood, and the expired air is poisoned with carbonic acid gas. Some of the constituents of the blood attract a portion of the oxygen of the air, and obtain their distinguishing character and properties as arterial blood, and being thus revivified, it passes on over the membrane of the lobes, unites into small and then larger vessels, and at length pours its full stream of arterial blood into the left auricle, thence to ascend into the ventricle, and to be diffused over the frame.

\section{DISEASES OF THE HEART.}

It may be readily supposed that an organ so complicated is subject to disease. It is so to a fearful extent; and it sympathises with the maladies of every other part. Until lately, however, this subject has been shamefully neglected, and the writers on the veterinary art have seemed to be unaware of the importance of the organ, and the maladies to which it is exposed. The owner of the horse and the veterinary profession generally, are deeply indebted to Messrs. Percivall and Pritchard* for much valuable information on this subject. The writer of this work acknowledges his obligation to both of these gentlemen. To Dr. Hope also, and particularly to Laennec, we owe much. Mr. Percivall well says, "This class of diseases may be regarded as the least advanced of any in veterinary medicine- a circumstance not to be ascribed so much to their comparative rarity, as to their existing undiscovered, or rather being confounded during life with other disorders, and particularly with pulmonary affections."

The best place to examine the beating of the heart is immediately behind the elbow, on the left side. The hand applied flat against the ribs will give the number of pulsations. The ear thus applied will enable the practitioner better to ascertain the character of the pulsation. The stethoscope affords an uncertain guide, for it cannot be flatly and evenly applied.

Pericarditis.-The bag, or outer investing membrane of the heart, is liable to inflammation, in which the effused fluid becomes organized, and deposited in layers, increasing the thickness of the pericardium, and the difficulty of the expansion and contraction of the heart. The only symptoms on which dependence can be placed, are a quickened and irregular respiration; a hounding action of the heart in an early stage of the disease; but that, as the fluid increases and becomes concrete, assuming a feeble and fluttering character.

Hydrops Pericardil is the term used to designate the presence of the fluid secreted in consequence of this inflammation, and varying from a pint to a gallon or more. In addition to the symptoms already described, there is an expression of alarm and anxiety in the countenance of the animal which no other malady produces. The horse generally sinks from other disease, or from constitutional irritation, before the

\footnotetext{
* See Pritchard's papers in the Veterinarian, vol. vi., and Percivall's Hippopathology, vol.
Part I. ii., Part I.
} 
cavity of the pericardium is filled; or if he lingers on, most dreadful palpitations and throbbings accompany the advanced stage of the disease. It is seldom or never that this disease exists alone, but is combined with dropsy of the chest or abdomen.

CARDitis is the name given to inflammation of the muscular substance of the heart. A well authenticated instance of inflammation of the substance of the heart does not stand on record. Some other organ proves to be the chief seat of mischief, even when the disturbance of the heart has been most apparent.

Inflammation of the Lining of the Heart.-Mr. Simpson relates, in the Veterinarian for 1834 , a case in which there were symptoms of severe abdominal pain; the respiration was much disturbed, and the action of the heart took on an extraordinary character. Three or four beats succeeded to each other, so violently as to shake the whole frame, and to be visible at the distance of several yards, with intervals of quietude for five minutes or more. At length this violent beating became constant.

On dissection both lungs were found to be inflamed, the serum in the pericardium increased in quantity, and the internal membrane of the heart violently inflamed, with spots of ecchymosis.

This would seem to be a case of inflammation of the heart; but in a considerable proportion of tbe cases of rabies, these spots of ecchymosis, and this general inflammation of the heart, are seen.

HyPERTHRophy is an augmentation or thickening of the substance of the heart; and although not dreamed of a few years ago, seems now to be a disease of no rare occurrence among horses. The heart has been known to acquire double its natural volume, or the auricle and ventricle on one side have been thus enlarged. Mr. Thomson of Bath relates, in The Veterinarian, a very singular case. A horse was brought with every appearance of acute rheumatism, and was bled and physicked. On the following day he was standing with his fore legs widely extended, the nostrils dilated, the breathing quick and laborious, the eyes sunk in their orbits, the pupils dilated, his nose turned round almost to his elbow, sighing, and his countenance showing approaching dissolution.

The pulse had a most irregular motion, and the undulation of the jugular veins was extending to the very roots of the ears. He died a few hours afterwards.

The lungs and pleura were much inflamed; the pericardium was inflamed and distended by fluid; the heart was of an enorinous size and greatly inflamed; both the auricles and ventricles were filled with coagulated blood; the greater part of the chordæ tendinex had given way; the valves did not approximate to perform their function, and the heart altogether presented a large disorganized mass, weighing thirty-four pounds. The animal worked constantly on the farm, and had never been put to quick or very laborious work.

Dilatation is increased capacity of the cavities of the heart, and the parietes being generally thinned. It is probable that this is a more frequent disease than is generally supposed; and from the circulating power being lessened, or almost suspended, on account of the inability of the cavities to propel their contents, it is accompanied by much and rapid emaciation. In the Gardens of the Zoolngical Society of London this is a disease considerably frequent, and almost uniformly fatal. It attacks the smaller animals, and particularly the quadrumana, and has been found in the deer and the zebra. It is characterised by slow emaciation, and a piteous expression of the countenance; but the mischief is done when these symptoms appear.

Ossification of the Heart.-There are but too many instances of this both in the right and the left auricles of the heart, the aortic valves, the abdominal aorta, and also the bronchial and other glands. Mr. Percivall observes of one of these cases, that "the cavity could have been but a passive receptacle for the blood, and the current must have been continued without any or with hardly any fresh impulse."

Of AIR IN THE HEART destroying the horse, there are some interesting accounts; and also of rupture of the heart, and aneurism, or dilatation of the aorta, both thoracic and abdominal, and even farther removed from the heart and in the iliac artery. The symptoms that would certainly indicate the existence of aneurism are yet unknown, except tenderness about the loins and gradual inability to work, are considered as such: but it is interesting to know of the existence of these lesions. Ere long the veterinary surgeon may possibly be able to guess at them, although he will rarely 
have more power in averting the consequences of aneurism than the human surgeon possesses with regard to his patient.

This will be the proper place to describe a little more fully the circulation of the blood, and various circumstances connected with that most important process.

\section{THE ARTERIES.}

The vessels which carry the blood from the heart are called arteries (keeping airthe ancients thought that they contained air). They are composed of three coats; the outer or elastic is that by which they are enabled to yield to the gush of blood, and enlarge their dimensions as it is forced along them, and by which also they contract again as soon as the stream has passed; the middle coat is a muscular one, by which this contraction is more powerfully performed, and the blood urged on in its course; the inner or membranous coat is the mere lining of the tube.

This yielding of the artery to the gush of blood, forced into it by the contraction of the heart, constitutes

\section{THE PULSE.}

The pulse is a very useful assistant to the practitioner of human medicine, and much more so to the veterinary surgeon, whose patients cannot describe either the seat or degree of ailment or pain. The number of pulsations in any artery will give the number of the beatings of the heart, and so express the irritation of that organ, and of the frame generally. In a state of health, the heart beats in a farmer's horse about thirty-six times a minute. In the smaller, and in the thorough-bred horse, the pulsations are forty or forty-two. This is said to be the standard pulse-the pulse of health. It varies singularly little in horses of the same size and breed, and where it beats naturally there can be little materially wrong. The most convenient place to feel the pulse, is at the lower jaw (p.68) a little behind the spot where the submaxillary artery and vein, and the parotid duct, come from under the jaw. There the number of pulsations will be easily counted, and the character of the pulse, a matter of fully equal importance, will be clearly ascertained. Many horsemen put the hand to the side. They can certainly count the pulse there, but they can do nothing more. We must be able to press the artery against some hard body, as the jaw-bone, in order to ascertain the marner in which the blood flows through it, and the quantity that flows.

When the pulse reaches fifty or fifty-five, some degree of fever may be apprehended, and proper precaution should be taken. Seventy or seventy-five will indicate a dangerous state, and put the owner and the surgeon not a little on the alert. Few horses long survive a pulse of one hundred, for, by this excessive action, the energies of nature are speedily worn out.

Some things, however, should be taken into account in forming our conclusion from the frequency of the pulse. Exercise, a warm stable, and fear, will wonderfully increase the number of pulsations.

When a careless, brutal fellow goes up to a horse, and speaks hastily to him, and handles him roughly, he adds ten beats per minute to the pulse, and will often be misled in the opinion he may form of the state of the animal. A judicious person will approach the patient gently, and pat and soothe him, and even then the circulation, probably, will be a little disturbed. He should take the additional precaution of noting the number and quality of the pulse, a second time, before he leaves the animal.

If a quick pulse indicate irritation and fever, a slow pulse will likewise characterise diseases of an opposite description. It accompanies the sleepy stage of staggers, and every malady connected with deficiency of nervous energy.

The heart may not only be excited to more frequent, bilt also to more violent action. It may contract more powerfully upon the blood, which will be driven with greater force through the arteries, and the expansion of the vessels will be greater and more sudden. Then we have the hard pulse-the sure indicator of considerable fever, and calling for the immediate and free use of the lancet.

Sometimes the pulse may be hard and jerking, and yet small. The stream though forcible is not great. The heart is so irritable that it contracts before the ventricle is properly filled. The practitioner knows that this indicates a dangerous state of disease. It is an almost invariable accompaniment of inflammation of the bowels. 
A weak pulse, when the arterial stream flows slowly, is caused by the feeble action of the heart. It is the reverse of fever, and expressive of debility.

The oppressed pulse is when the arteries seem to be fully distended with blood. There is obstruction somewhere, and the action of the heart can hardly force the stream along, or communicate pulsation to the current. It is the case in sudden intlammation of the lungs. They are overloaded and gorged with blood, which cannot find its way through their minute vessels. This accounts for the well-known fact of a copious bleeding increasing a pulse previously oppressed. A portion being removed from the distended and choked vessels, the remainder is able to flow on.

There are many other varieties of the pulse, which it would be tedious here to particularise; it must, however, be observed, that during the act of bleeding, its state should be carefully observed. Many veterinary surgeons, and gentlemen too, are apt to order a certain quantity of bloor to be taken away, but do not condescend to superintend the operation. This is unpardonable in the surgeon and censurable in the owner of the horse. The animal is bled for some particular purpose. There is some state of disease, indicated by a peculiar quality of the pulse, which we are endeavouring to alter. The most experienced practitioner cannot tell what quantity of blood must be abstracted in order to produce the desired effect. The change of the pulse can alone indicate when the object is accomplished; therefore, the operator should have his finger on the artery during the act of bleeding, and, comparatively regardless of the quantity, continue to take blood, until, in inflammation of the lungs, the oppressed pulse becomes fuller and more distinct, or the strong pulse of considerable fever is evidently softer, or the animal exhibits symptoms of faintness.

The artcries divide as they proceed through the frame, and branch out into innumerable minute tubes, termed capillaries (hair-like tubes), and they even become so small as to elude the sight. The slightest puncture cannot be inflicted without wounding some of them.

In these little tubes, the nourishment of the body and the separation of all the various secretions is performed, and in consequence of this, the blood is changed. When these capillaries unite together, and begin to enlarge, it is found to be no longer arterial, or of a florid red colour, but venous, or of a blacker hue. Therefore the principal termination of the arteries is in veins. The point where the one ends, and the other commences, cannot be ascertained. It is when red arterial blood, having discharged its function by depositing the nutritious parts, is changed to venous or black blood.

Branches from the ganglial or sympathetic nerves wind round these vessels, and endue them with energy to discharge their functions. When the nerves cnmmunicate too much energy, and these vessels consequently act with too much power, inflammation is produced. If this disturbed action is confined to a small space or a single organ, it is said to be local, as inflammation of the eye, or of the lungs; but when this inordinate action spreads from its original seat, and embraces the whole of the arterial system, fever is said to be present, and this usually increases in proportion as the local disturbance is observable, and subsides with it

\section{N F L A M M A T I O N.}

Local inflammation is characterised by redness, swelling, heat, and pain. The redness proceeds from the greater quantity of blood flowing through the part, occasioned by the increased action of the vessels. The swelling arises from the same cause, and from the deposit of fluid in the neighbouring substance. The natural heat of the body is produced by the gradual cliange which takes place in the blood, in passing from an arterial to a venous state. If more blood is driven through the capillaries of an inflamed part, and in which this change is effected, more heat will necessarily be produced there; and the pain is easily accounted for by the distension and pressure which must be nroduced, and the participation of the nerves in the disturbance of the surrounding parts.

If inflammation consists of an increased flow of "blood to and through the part, the ready way to abate it is so lessen the quantity of blood. If we take away the fuel, the fire will go out. All other means are comparatively unimportant, contrasted with bleeding. Blood is generally abstracted from the jugular vein, and so the general quantity may be lessencd; but if it can be taken from the neighbourhood of the diseased part, it will be productive of tenfold benefit. One quart of blood abstracted from 
the foot in acute founder, by unloading the ressels of the inflamed part, and enabling them to contract, and, in that contraction, to acquire tone and power to resist future distension, will do more good than five quarts taken from the general circulation. An ounce of blood obtained by scarifying the swelled vessels of the inflamed eye, will give as much relief to that organ as a copious bleeding from the jugular. It is a principle in the animal frame which should never be lost sight of by the veterinary surgeon, or the horseman, that if by bleeding the process of inflaminatron can once bc checked,-if it ean be suspended but for a little while,-although it may return, it is never with the same degree of violence, and in many cases it is got rid of entirely. Hence the necessity of bleeding early, and bleeding largely, in inflammation of the lungs, or of the bowels, or of the brain, or of any important organ. Many horses are lost for want or insufficiency of bleeding, but we never knew one materially injured by the most copious extraction of blood in the early stage of acute inflammation. The horse will bear, and with advantage, the loss of an almost incredible quantity of blood, -four quarts taken from him, will be comparatively little more than one pound talien from the human being. We can scarcely conceive of a considerable inflammation of any part of the horse, whether proceeding from sprains, contusions, or any other cause in which bleeding, local (if possible), or general, or both, will not be of essential servicc.

Next in importance to blceding, is purging. Something may be removed from the bowels, the retention of which would increase the general irritation and fever. The quantity of blood will be materially lessened, for the serous or watery fluid which is separated from it by a brisk purge, the action of which in the horse continues probably more than twenty-four hours, is enormous. While the blood is thus determined to the bowels, less even of that which remains will flow through the inflamed part. When the circulation is directed to one set of vessels, it is proportionately diminished in other parts. It was first directed to the inflamed portions, and they were overloaded and injured, - it is now directed to the bowels, and the inflamed parts are relieved. While the purging continues, some degree of languor and sickness is felt; and the force of the circulation is thereby diminished, and the general excitement lessened. The importance of physic in every case of considerable external inflammation, is suff:ciently evident. If the horse is laid by for a few days from injury of the foot, or sprain, or poll-evil, or wound, or almost any cause of inflammation, a physic-ball should be given.

In eases of internal infiammation, much judgment is required to determine when a purgative may be beneficial or injurious. In inflammation of the lungs or bowels, it should never be given. There is so strong a sympathy between the various contents of the cavity of the chest, that no one of them can be inflamed to any great extent, without all the others being disposed to become so; and, therefore, a dose of physic in inflamed lungs, would perhaps be as fatal as a dose of poison. The excitement produced on the bowels by the purgative may run on to inflammation, which no medical skill can stop.

The means of abating external inflammation are various, and seemingly contradictory. The heat of the part very naturally and properly led to the application of cold embrocations and lotions. Heat has a strong tendency to equalize itself, or to leave that substance which has a too great quantity of it, or little capacity to retain it, for another which has less of it, or more capacity. Hence the advantage of cold applications, by which a great deal of the unnatural heat is speedily abstracted from the inflamed part. The foot labouring under inflammation is put into cold water, or the horse is made to stand in water or wet clay. Various cold applications are also used to sprains. 'The part is wetted with diluted vinegar, or goulard, or salt and water. When benefit is derived from these applications, it is to be attributed to their coldness alone. Water, especially when cooled bclow the natural temperature, is as good an application as any that can be used. Nitre dissolved in water, will lower the tenperature of the fluid many degrees; but the lotion must be applied immediately after the salt has bcen dissolved. A bandage may be afterwards applied to strengthen the limb, but during the continuance of active inflammation, it would only confine the heat of the part, or prevent it from benefiting by the salutary influence of the cold produced by the evaporation of the water.

Sometimes, however, we resort to warm fomentations, and if benefit is derived from their use, it is to be traced to the warmth of the fluid, more than to any medicinal pro- 
perty in it. Warm water will do as much good to the horse, who has so thick a skin, as any decoction of chamomile, or marsh-mallow, or poppy heads, or any nostrum that the farrier may reconimend. Fomentations increase the warmth of the skin, and open the pores of it, and promote perspiration, and thus lessen the tension and swelling of the part, assuage pain, and relieve inflammation. Fomentations, to be beneficial. should be long and frequently applied, and at as great a degree of heat as can be used without giving the animal pain. Poultices are more permanent, or longer-continued fomentations. The part is exposed to the influence of warmth and moisture for many hours or days without intermission, and perspiration being so long kept up, the distended vessels will be very materially relieved. The advantage derived from a poulticc is attributable to the heat and moisture, which, by means of it, can be long applied to the skin, and it should be composed of materials which will best retain this moisture and heat. The bran poultice of the farrier is, consequently, objectionable. It is never perfectly in contact with the surface of the skin, and it becomes nearly dry in a fcw hours, after which it is injurious rather than beneficial. Linseed-meal is a much better material for a poultice, for, if properly made, it will remain moist during many hours.

It is occasionally very difficult to decide when a cold or a hot application is to be used, and no general rule can be laid down, except that in cases of superficial inflammation, and in the early stage, cold lotions will be preferable; but, when the inflammation is deeper seated, or fully established, warm fomentations will be most serviceable.

Stimulating applications are frequently used in local inflammation. When the disease is deeply seated, a stimulating application to the skin will cause some irritation and inflammation there, and lessen or sometimes remove the original malady; hence the use of rowcls and blisters in inflammation of the chest. Inflammation to a high degree, cannot exist in parts that are near each other. If we excite it in one, we shall abate it in the other, and also, by the discharge which we estahlish from the one, we shall lessen the determination of blood to the other.

Stimulating and blistering applications should never be applied to a part already inflamed. $\Lambda$ fire is not put out by heaping more fuel upon it. Hence the mischief which the farrier often does by rubbing his abominable oils on a recent sprain, hot and tender. Many a horse has been ruined by this absurd treatment. When the heat and tenderness have disappeared by the use of cold lotions or fomentations, and the leg or sprained part remains enlarged, or bony matter threatens to be deposited, it may be right to excite inflammation of the skin by a blister, in order to rouse the decper-seated absorbents to action, and enable them to take up this deposit; but, except to hasten the natural process and effects of inflammation, a blistcr, or stimulating applicatlon, should never be applied to a part already inflamed.

\section{FEVER.}

Fever is general increased arterial action, either without any local affection, or in consequence of the sympathy of the system with inflammation in some particular part.

The first is pure fever. Some have denied that that exists in the horse, but they must have been strangely careless observers of the diseases of that animal. The truth of the matter is, that the usual stable management and general treatment of the horse are so absurd, and various parts of him are rendered so liable to take on inflammation, that pure fever will exist a very little time without degenerating into inflammation. The lungs are so weakened by the heated and foul air of the ill-ventilated stable, and by sudden changes from almost insufferable heat to intense cold, and the feet are so injured by liard usage and injudicious shoeing, that, sharing from the beginning in the general vascular excitement which characterises fever, they soon become excited far beyond other portions of the frame; and that which commenced as fever becomes intlammation of the lungs or feet. Pure fever, however, is sometimes seen, and runs its course regularly.

It frequently begins with a cold or shivering fit, although this is not essential to fever. The horse is dull, unwilling to move, has a staring coat, and cold legs and fect. This is succeeded by warmth of the body; unequal distribution of warmth to the legs; one hot, and the other three cold, or one or more unnaturally warm, and the others unusually coid, but not the deathlike coldness of inflammation of the lungs; 
the pulse quick, soft, and often indistinct; the breathing somewhat laborious; but no cough, or pawing, or looking at the flanks. The animal will scarcely eat, and is very costive. While the state of pure fever lasts, the shivering fit returns at nearly the same hour every day, and is succeeded by the warm one, and that often by a slight degree of perspiration; and these alternate during several days until local inflammation appears, or the fever gradually subsides. No horse ever died of pure fever. If he is not destroyed by inflammation of the lungs, or feet, or bowels succeeding to the fever, he gradually recovers.

What has been said of the treatment of local inflammation will sufficiently indicate that which should be resorted to in fever. Fever is general increased action of the heart and arteries, and therefore evidently appears the necessity for bleeding, regulating the quantity of blood by the degree of fever, and usually keeping the finger on the artery until some evident and considerable impression is made upon the system. The bowels should be gently opened; but the danger of inflammation of the lungs, and the uniformly injurious consequence of purgation in that disease, will prevent the administration of an active purgative. A small quantity of aloes may be given morning and night, with the proper fever medicine, until the bowels are slightly relaxed, after which nothing more of an aperient quality should be administered. Digitalis, emetic tartar, and nitre should be given morning and night, in proportions regulated by the circumstances of the case. The horse ehould be warmly clothed, but be placed in a cool and well-ventilated stable.

Symptomatic fever is increased arterial action, proceeding from some local cause. No organ of consequence can be much disordered or inflamed without the neighbouring parts being disturbed, and the whole system gradually participating in the disturbance. Inflammation of the feet or of the lungs never existed long or to any material extent, without being accompanied by some degree of fever.

The treatment of symptomatic fever should resemble that of simple fever, except that particular attention must be paid to the state of the part originally discased. If the inflammation which existed there can be subdued, the general disturbance will usually cease.

The arteries terminate occasionally in openings on different surfaces of the body. On the skin they pour out the perspiration, and on the different cavities of the frame they yield the moisture which prevents friction. In other parts they terminate in glands, in which a fluid essentially different from the blood is secreted or separated: such are the parotid and salivary glands, the kidneys, the spleen, and the various organs or laboratories which provide so many and such different secretions, for the multifarious purposes of life; but the usual termination of arteries is in veins.

\section{THE VEINS.}

These vessels carry back to the heart the blood which had been conveyed to the different parts by the arteries. They have two coats, a muscular and a membranous one. Both of them are thin and comparatively weak. They are more numerous and much larger than the arteries, and consequently the blood, lessened in quantity by the various secretions separated from it, flows more slowly through them. It is forced on partly by the first impulsc communicated to it by the heart; also, in the extremities and external portions of the frame, by the pressure of the muscles; and in the cavity of the chest, its motion is assisted or principally caused by the sudden expansion of the ventricles of the heart, after they have closed upon and driven out their contents, and thereby causing a vacuum which the blood rushes on to fill. There are curious valves in various parts of the veins which prevent the blood from flowing backward to its source.

\section{BOG AND BLOOD SPAVIN.}

The veins of the horse, although their coats are thin compared with those of the arteries, are not subject to the enlargements (varicose veins) which are so frequent, and often so painful, in the legs of the human being. The legs of the horse may exhibit many of the injurious consequences of hard work, but the veins will, with one exception, be unaltered in structurc. Attached to the extremities of most of the tendons, and between the tendons and other parts, are little bags containing a mucous substance to enable the tendons to slide over each other without friction, and to move easily on the neighbouring parts. From violent exercise these vessels are liable to 
enlarge. Windgalls and thoroughpins are instances of this. There is one of them on the inside of the hock at its bending. This sometimes becomes considerably increased in size, and the enlargement is called a bog-spavin. A vein passes over this bag, which is pressed between the enlargement and the skin, and the passage of the blood through it is impeded; the vein is consequently distended by the accumulated blood, and the distension reaches from this bag as low down as the next valve. This is called a blood-spavin. Blood-spavin then is the consequence of bog-spavin. It very rarely occurs, and is, in the majority of instances, confounded with bog-spavin.

Blood-spavin does not always cause lameness, except the horse is very hardworked, and then it is doubtful whether the lameness should not be attributed to the enlarged mucous bag rather than to the distended vein. Both of these diseases, however, render a horse unsound, and materially lessen his value.

Old farriers used to tie the vein, and so cut off altogether the flow of the blood. Some of them, a little more rational, dissected out the bag which caused the distension of the vein : but the modern and more prudent way is to endeavour to promote the absorption of the contents of the bag. This may be attempted by pressure long applied. $\Lambda$ bandage may be contrived to take in the whole of the hock, except its point; and a compress made of folded linen being placed on the bog-spavin, may confine the principal pressure to that part. It is, however, very difficult to adapt a bandage to a joint which admits of such extensive motion; therefore most practitioners apply two or three successive blisters over the enlargement, when it usually disappears. Unfortunately, however, it returns if any extraordinary exertion is required from the horse.

\section{BLEEDING.}

This operation is performed with a fleam or a lancet. The first is the common instrument, and the safest, except in skilful hands. The lancet, however, has a more surgical appearance, and will be adopted by the veterinary practitioner. A bloodstick - a picce of hard wood loaded at one end with lead-is used to strike the fleam into the vein. This is sometimes done with too great violence, and the opposite side of the coat of the vein is wounded. Bad cases of inflammation have resulted from this. If the fist is doubled, and the fleam is sharp and is struck with sufficient force with the lower part of the hand, the bloodstick may be dispensed with.

For general bleeding the jugular vein is selected. The horse is blindfolded on the side on which he is to be bled, or his head turned well away. The hair is smoothed along the course of the vein with the moistened finger; then, with the third and little fingers of the left hand, which holds the fleam, pressure is made on the vein sufficient to bring it fairly into view, but not to swell it too much, for then, presenting a rounded surface, it would be apt to roll or slip under the blow. The point to be selected is about two inches below the union of the two portions of the jugular at the angle of the jaw (see cut, p. 125). The fleam is to be placed in a direct line with the course of the vein, and over the precise centre of the vein, as close to it as possible, but its point not absolutely touching the vein. A sharp rap with the bloodstick or the hand on that part of the back of the fleam immediately over the blade, will cut through the vein, and the blood will flow. A fleam with a large blade should always be preferred, for the operation will be materially shortened, and this will he a matter of some consequence with a fidgety or restive horse. A quantity of blood drawn speedily will also have far more effect on the system than double the weight slowly taken, while the wound will heal just as readily as if made by a smaller instrument. There is no occasion to press so hard against the neck with the pail, or can, as some do; a slight pressure, if the incision has been large enough and straight, and in the middle of the vein, will cause the blood to flow sufficiently fast; or, the finger being introduced into the mouth between the tushes and the grinders, and gently moved about, will keep the mouth in motion, and hasten the rapidity of the stream by the action and pressure of the neighbouring muscles.

When sufficient blood has been taken, the edges of the wound should be brought closely and exactly together, and kept together by a small sharp pin being passed through them. Round this a little tow, or a few hairs from the mane of the horse, should be wrapped, so as to cover the whole of the incision; and the head of the horse should be tied up for several hours to prevent his rubbing the part against the manger. In bringing the edges of the wound together, and introducing the pin, care 
should not be taken to draw the skin too much from the neck, otherwise blood will insinuate itself between it and the muscles beneath, and cause an unsightly and sometimes troublesome swelling.

The blood should be received into a vessel, the dimensions of which are exactly known, so that the operator may be able to calculate at every period of the bleeding the quantity that is subtracted. Care likewise should be taken that the blood flows in a regular stream into the centre of the vessel, for if it is suffered to trickle down the sides, it will not afterwards undergo those changes by which we partially judge of the extent of inflammation. The pulse, however, and the symptoms of the case collectively, will form a better criterion than any change in the blood. Twenty-four hours after the operation, the edges of the wound will have united, and the pin should be withdrawn. When the bleeding is to be repeated, if more than three or four hours have elapsed, it will be better to make a fresh incision rather than to open the old wound.

Few directions are necessary for the use of the lancet. They who are competent to operate with it, will scarcely require any. If the point is sufficiently sharp the lancet can scarcely be too broad-shouldered; and an abscess lancet will generally make a freer incision than that in common use. Whatever instrument is adopted, too much care cannot be taken to have it perfectly clean, and very sharp. It should be carefully wiped and dried immediately after the operation, otherwise, in a very short time, the edges will begin to be corroded.

For general bleeding the jugular vein is selected as the largest superficial one, and most easily got at. In every affection of the head, and in cases of fever or extended inflammatory action, it is decidedly the best place for bleeding. In local inflammation, blood may be taken from any of the superficial veins. In supposed affections of the shoulder, or of the fore-leg or foot, the plate vein, which comes from the inside of the arm, and runs upwards directly in front of it towards the jugular, may be opened. In affections of the hind extremity, blood is sometimes extracted from the saphæna, or thigh-vein, which runs across the inside of the thigh. In foot cases it may be taken from the coronet, or, much more safely, from the toe; not by cutting out, as the farrier does, a piece of the sole at the toe of the frog, which sometimes causes a wound difficult to heal, and followed by festering, and even by canker; but cutting down with a fine drawing-knife, called a searcher, at the union between the crust and the sole at the very toe until the blood flows, and, if necessary, encouraging its discharge by dipping the foot in warm water. The mesh-work of both arteries and veins will be here divided, and blood is generally obtained in any quantity that may be needed. The bleeding may be stopped with the greatest ease, by placing a bit of tow in the little groove that has been cut, and tacking the shoe over it.*

* A great improvement has lately been introduced in the method of arresting arterial hæmorrhage. The operation is very simple, and, with common care, successful. The instrument is a pair of artery forceps, with rather sharper teeth than the common forceps, and the blades held close by a slide. The vessel is laid bare, detached from the cellular substance around it, and the artery then grasped by the forceps, the instrument deviating a very little from the line of the artery. The vessel is now divided close to the forceps, and behind them, and the forceps are twisted four or five times round. The forceps are then loosened, and, generally speaking, not more than a drop or two of blood will have been lost. This method of arresting bleeding has been applied by several scientific and benevolent men with almost constant success. It has been readily and effectually practised in docking, and our patients have escaped much torture, and tetanus lost many a victim. The forceps have been intro. duced, and with much success, in castration, and thus the principal danger of that operation, as well as the most painful part of it, is removed. The colt will be a fair subject for this experiment. On the sheep and the calf it may be readily performed, and the operator will have the pleasing consciousness of rescuing many a poor animal from the unnecessary infliction of torture. 


\section{CHAPTER VIII.}

WE now proceed to the consideration of the diseases of the respiratory system.

\section{THE MEMBRANE OF THE NOSE.}

The mucous membrane of the nose is distinguished from other mucous surfaces, not only by its thickness, but its vascularity. The blood-vessels are likewise superficial; they are not covered even by integument, but merely by an unsubstantial mucous coat. They are deeper seated, indeed, than in the human being, and they are more protected from injury; and therefore there is far less hæmorrhage from the nostril of the horse than from that of the human being, whether spontaneous or accidental. Lying immediately under the mucous coat, these vessels give a peculiar, and, to the horseman, a most important tinge to the membrane, and particularly observable on the septum. They present him with a faithful indication of the state of the circulation, and especially in the membranes of the other respiratory passages with which this is continuous.

The horseman and the veterinary surgeon do not possess many of the auxiliaries of the human practitioner. Their patients are dumb; they can neither tell the seat nor the degree of pain; and the blunders of the practitioner are seldom buried with the patient. Well, he must use greater diligence in availing himself of the advantages that he does possess; and he las some, and very important ones, too. The varying hue of the Schneiderian membrane is the most important of all; and, with regard to the most frequent and fatal diseases of the horse-those of the respiratory passagesit gives almost all the information with regard to the state of the circulation in those parts that can possibly be required. Veterinarians too generally overlook this. It has not yet been sufficiently taught in our schools, or inculcated in our best works on the pathology of the horse.

It is the custom with almost every horseman who takes any pains to ascertain the state of his patient, to turn down the lower eyelid, and to form his opinion of the degree of general inflammation by the colour which the lining membrane of the lid presents. If it is very red, he concludes that there is considerable fever; if it is of a pale pinkish hue, there is comparatively little danger. This is a very important examination, and the conclusion which he draws from it is generally true: but on the septum of the nose he has a membrane more immediately continuous with those of the respiratory organs-more easily got at-presenting a larger surface-the ramifications of the blood-vessels better seen, and, what is truly important, indicating not only the general affection of the membranes, but of those with which he is most of all concerned.

We would then say to every horseman and practitioner, study the character of that portion of the membrane which covers the lower part of the membrane of the nosethat which you can most readily bring into view. Day after day, and under all the varying circumstances of health and disease, study it until you are enabled to recognise, and you soon will, and that with a degree of exactitude you would have scarcely thought possible, the pale pink hue when the horse is in health-the increasing blush of red, and the general and uniform painting of the membrane, betokening some excitement of the system - the streaked appearance when inflammation is threatening or commencing - the intensely florid red of inflammation becoming acute - the starting of the vessels from their gossamer coat, and their seeming to run bare over the membrane, when the inflammation is at the highest-the pale ground with patches of vivid red, showing the half-subdued but still existing fever-the uriform colour, but somewhat redder than natural, indicating a return to a healthy state of the circulation-the paleness approaching to white, accompanying a state of debility, and yet some radiations of crimson, showing that there is still considerable irritability, and that mischief may be in the wind-the pale livid colour warning you that the disease is assuming a typhoid character-the darker livid announcing that the typhus is established, and that the vital current is stagnating - and the browner, dirty painting, intermingling with and subduing the lividness, and indicating that the game is up. These appear- 
ances will be guides to our opinion and treatment, which we can never too highly appreciate.

\section{A T A R R H, OR C OLD.}

Catarrh, or Cold, is attended by a slight defluxion from the nose - now and then, a slighter weeping from the eyes, and some increased labour of breathing, on account of the uneasiness which the animal experiences from the passage of the air over the naturally sensitive, and now more than usually irritable surface, and from the airpassage being diminished by a thickening of the membrane. "When this is a simply local inflammation, attended by no loss of appetite or increased animal temperature, it may speedily pass over.

In many cases, however, the inflammation of a membrane naturally so sensitive, and rendered so morbidly irritable by our absurd treatment, rapidly spreads, and involves the fauces, the lymphatic and some of the salivary glands, the throat, the parotid gland, and the membrane of the larynx. We have then increased discharge from the nose, greater redness of the membrane of the nose, more defluxion from the eycs, and loss of appetite, from a degree of fever associating itself with the local affection; and there also being a greater or less degree of pain in the act of swallow: ing, and which, if the animal feels this, he will never eat. Cough now appears more or less frequent or painful; but with no great acceleration of the pulse, or heaving of the flanks.

Catarrh may arise from a thousand causes. Nembranes, subjected to so many sources of irritation, soon become irritable. Exposure to cold or rain, change of stable, change of weather, change of the slightest portion of clothing, neglect of grooming, and a variety of circumstances apparently trifling, and which they who are unaccustomed to horses would think could not possibly produce any injurions effect, are the causes of catarrh. In the spring of the year, and while moulting, a great many young horscs have cough ; and in the dealers' stables, where the process of making up the horse for sale is carrying on, there is scarcely one of them that escapes this disease.

In the majority of cases, a few warm mashes, warm clothing, and a warm stablc-a faver-ball or two, with a drachm of aloes in each, and a little antimony in the evening, will set all right. Indeed, all would soon be right without any medicine; and much more speedily and perfectly than if the cordials, of which grooms and farriers are so fond, had been given. Nineteen horses out of twenty with common catarrh will do well; but in the twentieth case, a neglected cough may be the precursor of bronchitis, and pneumonia. These chest affections often insidiously creep on, and inflammation is frequently established before any one bclonging to the horse is aware of its existence. If there is the least fever, the horse should be bled. A common cold, attended by heat of the mouth or indisposition to feed, should never pass without the abstraction of blood. A physic-ball, however, should not be given in catarrh without much consideration. It can scarcely be known what sympathy may exist between the poriion of membrane already affected, and the mucous membranes generally. In severe thoracic affection, or in that which may soon become so, a dose of physic would be little better than a dose of poison. If, however, careful investigation renders it evident that there is no affection of the lungs, and that the disease has not proceeded beyond the fauces, small doses of aloes may with advantage be united with other medicines, in order to evacuate the intestinal canal, and reduce the fæcal discliarge to a pultaceous form.

If catarrh is accompanied by sore throat; if the parotids should enlarge and become tender - there are no tonsils, amygdalx, in the horse-or if the submaxillary glands should be inflamed, and the animal should quid his food and gulp his water, this will be an additional reason for bleeding, and also for warm clothing and a comfortable stable. A hot stable is not meant by the term comfortable, in which the foul air is breathed over and over again, but a tempcrature some degrees above that of the external air, and where that determination to the skin and increased action of the pxhalent vessels, which in these cases are so desirable, may take place. Every stable, both for horses in sickness and in health, should have in it a thermometer.

Some stimulating liniment may be applied over the inflamed gland, consisting of turpentine or tincture of cantharides, diluted with spermaceti or neat's-foot oil-strong enongh to produce considerable irritation on the skin, but not to blister, or to destroy 
the hair. An embrocation sufficiently powerful, and yet that never destroys the hair, consists of equal parts of hartshorn, oil of turpentine, and camphorated spirit, with a small quantity of laudanum.

\section{N F A M A TION OF THE LARYNX.}

Strictly speaking, this refers to inflammation confined to the larynx; but either catarrh or bronchitis, or both, frequently accompany the complaint.

Its approach is often insidious, scarcely to be distinguished from catarrh, except by being attended with more soreness of throat, and less enlargement of the parotid glands. There are also more decided and violent paroxysms of coughing than in common catarrh, attended by a gurgling noise, which may be heard at a little distance from the horse, and which, by auscultation, is decidedly referrible to the larynx. The breathing is shorter and quicker, and evidently more painful than catarrh; the membrane of the nose is redder; it is of a deep modena colour; and the horse shrinks, and exhibits great pain when the larynx is pressed upon. The paroxysms of coughing become more frequent and violent, and the animal appears at times almost suffocated.

As the soreness of the throat proceeds, the head of the animal is projected, and the neck has a peculiar stiffness. There is also much difficulty of swallowing. Considerable swelling of the larynx and the pharynx ensue, and also of the parotid, sublingual, and submaxillary glands. As the inflammation increases, the cough becomes hoarse and feeble, and in some cases altogether suspended. At the commencement, there is usually little or no nasal defluxion; but the secretion soon appears, either pure or mixed with an unusual quantity of saliva.

Auscultation is a very important aid in the discovery of the nature, and serious or trifling character of this disease. It cannot be too often repeated, that it is one of the most valuable means which we possess of detecting the seat, intensity, and results of the maladies of the respiratory passages. No insrument is required; the naked ear can be applied evenly and fiatly, and with a very slight pressure, on any part that it is of importance to examine. 'The healthy sound, when the ear is applied to the windpipe, is that of a body of air passing uninterruptedly through a smooth tube of somewhat considerable calibre : it very much resembles the sound of a pair of forge bellows, when not too violently worked.

He who is desirous of ascertaining whether there is any disease in the larynx of a horse, should apply his ear to the lower part of the windpipe. If he finds that the air passes in and out without interruption, there is no disease of any consequence either in the windpipe or the chest; for it would immediately be detected by the loudness or the interruption of the murmur. Then let him gradually proceed up the neck, with his ear still upon the windpipe. Perhaps he soon begins to recognise a little gurgling, grating sound. As he continues to ascend, that sound is more decisive, mingled with an occasional wheezing, whistling noise. He can have no surcr proof that here is the impediment to the passage of the air, proceeding from the thickening of the membrane and diminution of the passage, or increased secretion of mucus, which bubbles and rattles as the breath passes. By the degree of the rattling or whistling, the owner will judge which cause of obstruction preponderates-in fact, he will have discovered the seat and the state of the disease and the sooner he has recourse to professional advice the better.

Chronic laryngitis is of more frequent occurrence than acute. Many of the coughs that are most troublesome are to be traced to this source.

In violent cases laryngitis terminates in suffocation; in others, in thick wind or in roaring. Occasionally it is necessary to have recourse to the operation of tracheotomy.

In acute laryngitis the treatment to be pursued is sufficiently plain. Blood must be abstracted, and that from the jugular vein, for there will then be the combined advantage of general and local bleeding. The blood must be somewhat copiously withdrawn, depending on the degree of inflammation - the practitioner never for a moment forgetting that he has to do with infiammation of a mucous membrane, and that what he does he must do quickly. He will have lost the opportunity of struggling successfully with the disease when it has altered its character and debility has succeeded. The cases must be few and far between when the surgeon makes up his mind to any determinate quantity of blood, and leaves his assistant or his groom 
to abstract it; he must himself bleed, and until the pulse flutters or the constitution is evidently affected.

Next must be given the fever medicine already recommended: the digitalis, nitre, and emetic tartar, with aloes. Aloes may here be safely given, because the chest is not yet implicated. To this must be added, and immediately, a blister, and a sharp one. The surgeon is sure of the part, and he can bring his counter-irritant almost into contact with it.

Inflammation of the larynx, if not speedily subdued, produces sad disorganization in this curiously formed and important machine. Lymph is effused, morbidly adhesive, and speedily organised-the membrane becomes thickened, considerably, permanently so-the submucous cellular tissue becomes cedematous; the inflammation spreads from the membrane of the larynx to the cartilages, and difficulty of breathing, and at length confirmed roaririg, ensue.

\section{INFLAM MATION OF THE TRACHEA.}

Inflammation of the membrane of the larynx, and especially when it has run on to ulceration, may rapidly spread, and involve the greater part or the whole of the lining membrane of the trachea. Auscultation will discover when this is taking place. If the disease is extending down the trachea, it must be followed. A blister must reach as low as the rattling sound can be detected, and somewliat beyond this. The fever medicines must be administered in somewhat increased doses; and the bleeding must be repeated, if the state of the pulse does not indicate the contrary.

Generally speaking, however, althongh the inflammation is now approaching the chest, its extension into the trachea is not an unfavourable symptom. It is spread over a more extended surface, and is not so intense or untractable. It is involving a part of the frame less complicated, and where less mischief can be effected. True, if the case is neglected, it must terminate fatally; but it is coming more within reach, and more under command, and, the proper means being adopted, the change is rather a favourable one.

The disorganizations produced in the trachea are similar to some which have been described in the larynx. The same formation of organised bands of coagulated lymph, the same thickening of membrane, diminution of calibrc, and foundation for roaring.

\section{R O A R I N G.}

The present will be the proper place to speak of that singular impairment of the respiratory function recognised by this name. It is an unnatural, loud grunting sound made by the animal in the act of breathing when in quick action or on any sudden exertion. On carefully listening to the sound, it will appear that the roaring is produced in the act of inspiration, and not in that of expiration. If the horse is briskly trotted on a level surface, and more particularly if he is hurried up hill, or if he is suddenly threatened with a stick, this peculiar sound will be heard and cannot be mistaken. When dishonest dealers are showing a horse that roars, but not to any great degree, they trot away gently, and as soon as they are too far for the sound to be heard, show off the best paces of the animal; on returning, they gradually slacken their speed when they come within a suspicious distance. 'This is sometimes technically called "the dealers' long trot."

Roaring is exceedingly unpleasant to the rider, and it is manifest unsoundness. It is the sudden and violent rushing of the air through a tube of diminished calibre; and if the impediment, whatever it is, renders it so difficult for the air to pass in somewhat increased action, sufficient cannot be admitted to give an adequate supply of ing the function of respiration, although, somctimes, only on extraordinary occasions, it is unsoundness. In as many cases as otherwise, it is a very serious cause of unsoundness. The roarer, when hardly pressed, is often blown even to the hazard of suffocation, and there are cases on record of his suddenly dropping and dying when
urged to the top of his speed.

It must not, however, be taken for granted that the roarer is always worthless. There are few hunts in which there is not one of these horses, who acquits himself very fairly in the field; and it has occasionally so happened that the roarer has been 
the very crack horse of the hunt; yet he must be ridden with judgment, and spared a little when going up-hill. 'There is a village in the West Riding of Yorkshire, through which a band of smugglers used frequently to pass in the dead of night; the horse of the leader, and the best horse of the troop, and on which his owner would bid defiance to all pursuit, was so rank a roarer, that he could be heard at a considerable distance. The clattering of all the rest scarcely made so much noise as the roaring of the captain's horse. When this became a little too bad, and he did not fear immediate pursuit, the smuggler used to halt the troop at some convenient hayrick on the roadside, and, having suffered the animal to distend his stomach with this dry food, as he was always ready enough to do, he would remount and gallop on, and, for a while, the roaring was scarcely heard. It is somewhat difficult to account for this. Perhaps the loaded stomach now pressing against the diaphragm, that muscle had harder work to displace this viscus in the act of enlarging the chest and producing an act of inspiration, and accomplished it more slowly, and therefore, the air passing more slowly by, the roaring was diminished. We do not dare to calculate what must have been the increased labour of the diaphragm in moving the loaded stomach, nor how much sooner the horse must have been exhausted. This did not enter into the owner's reckoning, and probably the application of whip and spur would deprive him of the means of forming a proper calculation of it.

Ficlipse was a "high-blower." He drew his breath hard, and with apparent difficulty. The upper air-passages, perhaps those of the head, did not correspond with his unusually capacious chest; yet he was never beaten. It is said that he never met with an antagonist fairly to put him to the top of his speed, and that the actual effect of this disproportion in the two extremities of the respiratory apparatus was not thoroughly tested. Mares comparatively seldom become roarers. It appears to he difficult, if not impossible, to assign any satisfactory reason for this; but the fact is too notorious among horsemen, to admit of doubt.

Roaring proceeds from obstruction in some portion of the respiratory canal, and oftcnest in the larynx, for there is least room to spare-that cartilaginous box being occupied by the mechanism of the voice: next in frequency it is in the trachea, but, in fact, obstruction anywhere will produce it. Mr. Blaine, quoting from a French journalist, says, that a piece of riband lodged within one of the nasal fossæ produced roaring, and that even the displacement of a molar tooth has been the supposed cause of it. Polypi in the nostrils have been accompanied by it. Mr. Sewell found, as an evident cause of roaring, an exostosis between the two first ribs, and pressing upon the trachea; and Mr. Percivall goes farther, and says that his father repeatedly blistered and fired a horse for bad roaring, and even performed the operation of tracheotomy, and at length the roaring being so loud when the horse was led out of the stable, that it was painful to hear it-the poor animal was destroyed. No thickening of the membrane was found, no disease of the larynx or trachea; but the lungs were hepatized throughout the greater part of their substance, and many of the smaller divisions of the bronchi were so compressed, that they were hardly pervious.

Bands of Coagulated Lymph.-A frequent cause of roaring is bands of coagulated lymph, morbidly viscid and tenacious, adhering firmly on one side, and by some act of coughing brought into contact with and adhering to the other side, and becoming gradually organized. At other times there have been rings of coagulated lymph adhering to the lining of the trachea, but not organized. In either case they form a mechanical obstruction, and will account for the roaring noise produced by the air rushing violently through the diminished calibre, in hurried respiration. Thickening - of the membrane is a more frequent cause of roaring than the transverse bands of coagulated lympl. In many inorbid specimens it is double or treble its natural thickness, and covered with manifold ulcerations. This is particularly annoying in the upper part of the windpipe, where the passages, in their natural state, are narrow. Thus it is that roaring is the occasional consequence of strangles and catarrh, and other affections of the superior passages.

There is scarcely a horse of five or six years old who has not a portion of the thyroid cartilage ossified. In some cases the greater part of the cartilages are becoming bony, or sufficiently so to weaken or destroy their elastic power, and consequently to renter it impossible for them to be freely and fully acted upon by the delicate muscles of the larynx.

Chronic cough occasionally terminates in roaring. Some have imagined that the 
dealers' habit of coughing the horse, i. e. pressing upon the larynx to make him cough, in order that they may judge of the state of his wind by the sound that is emitted, has produced inflammation about the larynx, which has terminated in roaring, or assisted in producing it. That pain is given to the animal by the rough and violent way in which the object is sometimes attempted to be accomplished, is evident enough, and this must, in process of time, lead to mischief; but sufficient inflammation and subsequent ossification of the cartilages would scarcely be produced, to be a cause of roaring.

The Disease of Draught-Horses generally.-There can be no dollbt of the fact, that the majority of roarers are draught-horses, and horses of quick draught. They are not only subject to the usual predisposing causes of this obstruction, but there is something superadded,-resulting from their habits or mode of work,-not indeed necessarily resulting, but that which the folly as well as cruelty of man has introduced-the system of tight-reining. To a certain extent, the curb-rein is necessary. Without it there would be scarcely any command over a wilful horse, and it would need a strong arm occasionally to guide even the most willing. Without the curb-rein the horse would carry himself low; he would go carelessly along; he would become a stumbler; and if he were disposed at any time to run away, the strongest arm would have little power to stop him; but there is no necessity for the tight rein, and for the long and previous discipline to which the carriage-horse is subjected. There is no necessity that the lower jaw, whether the channel is wide or narrow, should be so forced on the neck, or that the larynxand the portion of the windpipe immediately beneath it should be flattened, and bent, and twisted, and the respiratory passage not only obstructed, but in a manner closed. The mischief is usually done when the horse is young. It is effected in some measure by the impatience of the animal, unused to control, and suffering pain. In the violent tossing of his head he bruises the larynx, and produces inflammation. The head of the riding-horse is gradually brought to its proper place by the hands of the breaker, who skilfully increases or relaxes the pressure, and humours and plays with the mouth; but the poor carriage-horse is confined by a rein that never slackens, and his nose is bent in at the expense of the larynx and windpipe. The injury is materially increased if the head is not naturally well set on, or the neck is thick, or the jaws narrow.

Connected with this is the common notion that crib-biting is a cause of roaring. That is altogether erroneous. There is no possible connexion between the complaints : but one of the methods that used to be resorted to in order to cure crib-biting might be a cause of roaring, namely, the strap so tightly buckled round the upper part of the neck as to compress, and distort, and paralyse the larynx.

Facts have established the hereditary predisposition to roaring, beyond the possibility of doubt.

In France it is notorious that three-fourths of the horses from Cottentin are roarers, and some of them are roarers at six months old; but about La Hague and Le Bocase, not a roarer is known. There is certainly a considerable difference in the soil of the two districts; the first is low and marshy, the latter elevated and dry : but tradition traces it to the introduction of some foreign horses into Cottentin, who bequeathed this infirmity to their progeny.

In our own country, there is as decisive a proof. There was a valuable stallion in Norfolk, belonging to Major Wilson, of Didlington. He was a great favourite, and seemed to be getting some excellent stock; but he was a roarer, and some of the breeders took alarm at this. They had occasionally too painful experience of the communication of the defects of the parent to his progeny ; and they feared that roaring might possibly be among these hereditary evils. Sir Charles Bunbury was requested to obtain Mr. Cline's opinion on the subject. Mr. Cline was a deservedly eminent human surgeon : he had exerted limself in the establishment of the Veterinary College: he was an examiner of veterinary pupils, and therefore it was supposed that he must be competent to give an opinion. He gave one, and at considerable length :- "The disorder in the horse," said he, "which constitutes a roarer, is caused by a membranous projection in a part of the windpipe, and is the consequence of that part having been inflamed from a cold, and injudiciously treated. A roarer, therefore, is not a diseased horse, for his lungs and every other part may he perfectly sound. The existence of roaring in a stallion cannot be of any consequence. It cannot be propagated any more than a broken bone, or any other accident."-A fair specimen 
of the horse-knowledge of one of the best of the medical examiners of veterinary pupils.

Sir Charles returned full of glee; the good people of Norfolk and Suffolk were satisfied; Major Wilson's horse was in high request: but in a few years a great part of the two counties was overrun with roarers, and many a breeder half ruined. Roaring is not, however, necessarily hereditary. Mr. Goodwin, whose name is great authority, states that 'Taurus, a celebrated racer that had become a roarer, had covered several mares, and their produce all turned out well, and had won several races. In no instance did his progeny exhibit this defect, notwithstanding that his own family were notorious for being roarers. Eclipse also is said to have been a roarer.

What then is to be done with these animals? Abandon them to their fate? No, not so; but there is no necessity rashly to undertake a hopeless affair. All possible knowledge must be obtained of the origin of the disease. Did it follow strangles, catarrh, bronchitis, or any affection of the respiratory passages? Is it of long standing? Is it now accompanied by cough or any symptoms of general or local irritation? Can any disorganization of these parts be detected? Any distortion of the larynx? Did it follow breaking-in to harness? The answer to these questions will materially guide any future proceedings. If there is plain distortion of the larynx or trachea, or the disease can be associated, in point of time, with breaking-in to harness, or the coachinan or proprietor has been accustomed to rein the animal in too tightly or too cruelly, or the sire was a roarer, it is almost useless to have anything to do with the case. But if it is of rather recent date, and following closely on some disease with which it can be clearly connected, careful examination of the patient may be commenced. Is there cough ? Can any heat or tenderness be detected about the larynx or trachea? Is there in every part the same uniform rushing noise; or, on some particular spot, can a more violent breathing, a wheezing or whistling, or a rattling and guggling, be detected? Is that wheezing or rattling either confined to one spot, or less sonorous as the ear recedes from that spot above or below; or is it diffused over a considerable portion of the trachea?

In these cases it would be fair to bleed, purge, and most certainly to blister. The ear will guide to the part to which the blister should be applied. The physic having set, a course of fever medicine should be commenced. It should be considered as a case of chronic inflammation, and to be subdued by a continuance of moderate deple tory measures. Probably blood should again be abstracted in less quantity; a second dose of physic should be given, and, most certainly, the blister sliould be repeated, or kept discharging by means of some stimulating unguent. The degree of success which attends these measures would determine the farther pursuit of thom. If no relief is obtained after a fortnight or three weeks, perhaps the experimenter would ponder on another mode of treatment. He would again carefully explore the whole extent of the trachea, and if he could yet refer the rattling or wheezing to the same point at which he had before observer it, he would boldly propose tracheotomy, for he could certainly cut upon the seat of disease.

If he found one of these organised bands, the removal of it would afford immediate relief; or if he found merely a thickened membrane, no harm would be done; or the loss of blood might abate the local inflammation. No one would eagerly undertake a case of roaring; but, having undertaken it, he should give the measures that he adopts a fair trial, remembering that, in every chronic case like this, the only hope of success depends on perseverance.

\section{BRON C HOCELE.}

Mr. Percivall is almost the only author who takes notice of enlargement of the thyroid glands - two oval bodies below the larynx, and attached to the trachea. The use of them has never been satisfactorily explained. They sometimes grow to the size of an egrg, or larger, but are unattended by cough or fever, and are nothing more than an eye-sore. The iodine ointment has occasionally been applied with success. The blister or the seton may also be useful.

\section{EPIDEMIC CATARRH.}

Various nanes are given to this disease-influenza, distemper, catarrhal fever, and epidemic catarrh. Its usual history is as follows.

In the spring of the year-a cold, wet spring-and that succeeding to a mild winter, $17 *$ 
and especially among young horses, and those in high condition, or made up for sale, or that have been kept in hot stables, or exposed to the usual causes of inflammation, this disease principally, and sometimes almost exclusively, prevails. Those that are in moderate work, and that are correspondingly fed, generally cscape; or even when it appears in most of the stables in a narrower or wider district, horses in barracks, regularly worked and moderately fed, although not entirely exempt, are comparatively seldom diseased.

If it has been observed from the beginning, it will be found that the attack is usually sudden, ushered in by shivering, and that quickly succeeded by acceleration of pulse, heat of mouth, staring coat, tucked-up belly, diminution of appetite, painful but not loud cough, heaving at the flanks, redness of the membrane of the nose, swelled and weeping eye, dejected countenance-these are the symptoms of catarrh, but under a somewhat aggravated form.

It clearly is not inflammation of the lungs; for there is no coldness of the extremities, no looking at the flanks, no stiff immorable position, no obstinate standing up. It is not simple catarrh; for as early as the second day there is evident debility. The horse staggers as he walks.

It is inflainmation of the respiratory passages generally. It commences in the membrane of the nose, but it gradually involves the whole of the respiratory apparatus. Before the disease has been established four-and-twenty hours, there is frequently sorethroat. The horse quids his hay, and gulps his water. There is no great enlargement of the glands; the parotids are a little tumefied, the submaxillary somewhat more so, but not at all equivalent to the degree of soreness. 'That soreness is excessive, and day after day the horse will obstinately refuse to eat. Discharge from the nose soon follows in considerable quantity: thick, very early purulent, and sometimes foetid. The breathing is accelerated and laborious at the beginning, but does not always increase with the progress of the disease-nay, sometimes, a deceitful calm succeeds, and the pulse, quickened and full at first, soon loses its firmness, and although it usually maintains its unnatural quickness, yet it occasionally deviates from this, and subsides to little more than its natural standard. The extremities continue to be comfortably warm, or at least the temperature is variable, and there is not in the manner of the animal, or in any one symptom, a decided reference to any particular part or spot, as the chief seat of disease.

Thus the malady procecds for an uncertain period : cccasionally for several daysin not a few instances through the whole of its course, and the animal dies exhausted by extensive or general irritation: but in other cases the inflammation assumes a local determination, and we have bronchitis or pnenmonia, but of no very acute character, yet difficult to treat, from the general debility with which it is connected. Sometimes there are considerable swellings in various parts, as the chest, the belly, the extremities, and particularly the head. The brain is occasionally affected; the horse grows stupid; the conjunctiva is alarmingly red; the animal becomes gradually unconscious, and delirium follows. A curious thickening, that may be mistaken for severe sprain, is sometimes observed about the tendons. It is seen under the knee or about the fetlock. It is hot and tender, and the lameness is considerable. The feet occasionally suffer severely. There is a determination of fever to them far more violent than the original disease, and separation of the laminæ and descent of the sole ensue. It may be easily imagined how roaring may be connected with epidemic catarrh ; but it is rarely or never followed by glanders. These changes of situation are not fatal, but the practitioner is rather glad to see them, except indeed when the feet arc attacked; for the disease seems inclined to shift its situation or character, and is more easily subdued.

The most decided character in this disease is debility. Not the stiff, unwilling motion of the horse with pneumonia, and which has been mistaken for debilityevery muscle being needed for the purposes of respiration, and therefore imperfectly used in locomotion-but actual loss of power in the muscular system generally. The liorse staggers from the second day. He threatens to fall if he is moved. He is sometimes down, permanently down, on the third or fourth day. The emaciation is also occasionally rapid and extreme.

At length the medical treatment which has been employed succeeds, or nature begins to rally. The cough somewhat subsides; the pulse assumes its natural standard; the countenance acquires a little more animation; the horse will eat a 
small quantity of some choice thing; and health and strength slowly, very slowly indeed, return: but at other times, when there had been no decided change during the progress of the disease, no manageable metastasis of inflammation while there was sufficient power left in the constitution to struggle with it, a strange exacerbation of symptoms accompanies the closing scene. The extremities become deathly cold; the llanks heave; the countenance betrays greater distress; the membrane of the nose is of an intense red; and inflammation of the substance of the lungs and congestion and death speedily follow.

At other times the redness of the nostril suddenly disappears; it becomes purple, livid, dirty brown, and the discharge is bloody and fœtid, the breath and all the excretions bccoming fotid too. The mild character of the disease gives way to malignant typhus : swellings, and purulent ulcers, spread over different parts of the frame, and the animal is soon destroyed.

Post-mortem Examination.-Examination after death sufficiently displays the real character of the disease, inflammation first of the respiratory passages, and, in fatal or aggravated cascs, of the mucous mernbranes generally. From the pharynx, to the termination of the small intestines, and often including even the larger ones, there will not be a part frec from inflammation; the upper part of the trachea will be filled with adhesive spume, and the lining niembrane thickened, injected, or ulcerated ; the lining tunic of the bronchi will exhibit unequivocal marks of inflamimation; the substance of thc lungs will be engorged, and often inflamed; the heart will partake of the same affection; its external coat will be red, or purple, or black, and its internal one will exhibit spots of ecchymosis; the pericardium will be thickened, and the pericardiac and pleuritic bags will contain an undue quantity of serous, or bloodyserous, or purulent fluid.

The csophagus will be inflamed, sometimes ulcerated - the stomach always so; the small intestines will uniformly present patches of inflammation or ulceration. The liver will be inflamed - the spleen enlarged-no part, indeed, will have escaped; and if the malady has assumed a typhoid form in its latter stages, the universality and malignancy of the ulceration will be excessive.

This discase is clearly attributable to atmospheric influence, but of the precise nature of this influence we are altogether ignorant. It is some foreign injurious principle which mingles with and contaminates the air, but whence this poison is derived, or how it is diffused, we know not. It is engendered, or it is most prevalent, in cold ungenial weather; or this weather may dispose the patient for catarrh, or prepare the tissues to be affected by causes which would otherwise be harmless, or which may at all times exist.

It is most frequent in the spring of the year, but it occasionally rages in autumn and in winter. It is epidemic; it spreads over large districts. It sometimes pervades the whole country. Scarcely a stable cscapes. Its appearance is sudden, its progress rapid. Mr. Wilkinson had 36 new cases in one day. It is said that a celebrated practitioncr in London had nearly double that number in less than twenty-four hours.

At other times it is endemic. It pervades onc town; one little tract of country. It is confined to spots cxceedingly circumscribed. It is dependent on atmospheric agency, but this requires some injurious adjuvant and the principle of contagion must probably be called into play. It has been rife enough in the lower parts of the metropolis, while in the upper and north-western districts scarcely a case has occurred. It has occasionally been confined to a locality not extending half-a-mile in any direction. In one of the cavalry barracks the majority of the horses on one side of the yard were attacked by epidcmic catarrh, while there was not a sick horse on the other side. These prevalences of disease, and these exceptions, are altogether unaccountable. The stables, and the systcm of stable management, have been most carcfully inquired into in the infected and the healthy districts, and no satisfactory differcnce could he ascertained. One fact, however, has been established, and a very important one it is to the horse proprictor as well as the practitioner. The probability of the disease seems to be in proportion to the number of horses inhabiting the stable. Two or tlirec horses shut up in a comparatively close stable may escape. Out of thirty horses, distributed through ten or fifteen little stables, not one inay be affected; but in a stable containing ten or twelve horses the disease will assuredly appear, although it may be proportionally larger and well ventilated. It is on this account that postmasters and horse-dealers dread its appearance. In a sickly season their 
stables are never free from it; and if, perchance, it does enter one of their largest stables, almost every horse will be affected. Therefore also it is that grooms have so much dread of a distempered stable, and that the odds are so seriously affected if distemper has broken out in a racing establishment.

Does this lead to the conclusion that epidemic catarrh is contagious? Not necessarily, but it excites strong suspicion of its being so; and there are so many facts of the disease following the introduction of a distempered horse into an establishment, that this malady must rank among those that are both contagious and epidemic. 'There are few well-informed grooms, or extensive owncrs of horses, and living much among them, or veterinary surgeons of considerable practice, who entertain the least doubt about the matter. Then every necessary precaution should be adopted. The horse that exhibits symptoms of epidemic catarrh should be removed as soon as possible. The affected horses should be removed, and not the sound ones, for they, although apparently sound, may have the malady lurking about them, and may more widely propagate the disease.

With regard to the treatment of epidemic catarrh, thcre may be, and is at times, considerable difficulty. It is a disease of tlic mucous membrane, and thus connected with much debility; but it is also a disease of a febrile character, and the inflammation is occasionally intense. The veterinary surgeon, therefore, must judge for himself. Is the disease in its earliest stage marked by evident inflammatory action? Is there much redness of the membrane of the nose-much acceleration of the pulse $\rightarrow$ much heaving of the flanks? If so, blood must be abstracted. The orifice should be large that the blood may flow quickly, and the circulation be sooner affected; and the medical attendant should be present at this first renesection, that he may close the orifice as soon as the pulse begins to falter. This attention to the first bleeding is indispensablc. It is the carelessness with which it is performed - the ignorance of the object to be accomplished, and the effect actually produced, that destroys half the ' horses that are lost from this malady. The first faltcr of the pulse is the signal to suspend the bleeding. Every drop lost afterwards may be wanted.

If there is no appcarance of febrile action, or only a very slight one, small doses of aloes may be given, combined with the fever medicines recommended for catarrh. As soon as the fæces are pultaceous, or even before that, the aloes should be omitted and the fever medicine continued. It will rarely be prudent to continue the aloes beyond the third drachm.

A stricter attention must be paid to diet than the veterinarian usually enforces, or the groom dreams of. No corn must be allowed, but mashes and thin gruel. The water should be entirely taken away, and a bucket of gruel suspended in the box. This is an excellent plan with regard to every sick horse that we do not wish to reduce too much; and when he finds that the morning and evening pass over, and his water is not offered to him, he will readily take to the gruel, and drink as much of it as is good for him. Green mcat should be early offered; such as grass, tares (the latter cspecially), lucerne, and, above all, carrots. If these cannot be procured, a little hay may be wetted, and offered morsel after morsel by the hand. Should this be refused, the hay may be damped with water slightly salted, and then the patient will generally seize it with avidity.

Should the horse refuse to eat during the two or three first days, there is no occasion to be in a hurry to drench with gruel; it will make the mouth sore, and the throat sore, and tease and disgust: but if he should long continue obstinately to refuse his food, nutriment must be forced upon him. Good thick gruel must he horned down, or, what is better, given by means of Read's pump.

The practitioner will often and anxiously have rccourse to auscultation. He will listen for the mucous rattle, creeping down the windpipe, and entering the bronchial passages. If he cannot detect it helow the larynx, he will apply a strong blister, reacling from ear to ear, and extending to the sccond or third ring of the trachea. If he can trace the rattle in the windpipe, he must follow it,- he must blister as far as the disease has spread. This will often have an excellent effect, not only as a counter-irritant, but as rousing the languid powers of the constitution. A rowel of tolerable size between the fore-legs cannot do harm. It may act as a derivative, or it may take away a disposition to inflammation in the contiguous portion of the chest.

The inflammation which characterizes the early stage of this disease is at first confined to the membrane of the mouth and the fauces. Can fomentations be applied? 
Yes, and to the very part, by means of a hot mash, not thrown into the manger over which the head of the horse cannot be confined, but placed in that too-much-undervalued and discarded article of stable-furniture, the nose-bag. The vapour of the water will, at every inspiration, pass over the inflamed surface. In the majority of cases relief will speedily be obtained, and that suppuration from the part so necessary to the permanent removal of the inflammation-a copious discharge of mucus or purulent matter from the nostrils-will be hastened. If the discharge does not appear so speedily as could be wished, a stimulant should be applied to the part. The vapour impregnated with turpentine arising from fresh yellow deal saw-dust, used instead of bran, will have very considerable effect in quickening and increasing the suppuration. It may even be resorted to almost from the beginning, if there is not evidently mucl irritability of membrane.

A hood is a useful article of clothing in these cases. It increases the perspiration from the surface covering the inflamed part-a circumstance always of considerable moment.

An equable warmth should be preserved, if possible, over the whole body. The hand-brush should be gently used every day, and harder and more effectual rubbing applied to the legs. The patient should, if possible, be placed in a loose box, in which he may toddle about, and take a little exercise, and out of which he should rarely, if at all, be taken. The exercise of which the groom is so fond in these cases, and which must in the most peremptory terms be forbidden, has destroyed thousands of horses. The air should be fresh and uncontaminated, but never chilly; for the object is to increase and not to repress cutaneous perspiration; to produce, if possible, a determination of blood to the skin, and not to drive it to the part already too much overloaded. In order to accomplish this, the clothing should be rather warmer than usual.

The case may proceed somewhat slowly, and not quite satisfactorily to the practitioner or his employer. There is not much fever - there is little or no local infiammation; but there is great emaciation and debility, and total loss of appetite. The quantity of the sedative may then be lessened but not omitted altogether; for the fire may not be extinguished, although for a little while concealed. There are no diseases so insidious and treachcrous as these. Mild and vegetable tonics, such as gentian and ginger, may be given. Two days after this the sedative may be altogether omitted, and the tonic gradually increased.

The feeding should now be sedulously attended to. Almost every kind of green meat that can be obtained should be given, particularly carrots nicely scraped and sliced. The food should be changed as often as the capricious appetite prompts; and occasionally, if necessary, the patient should be forced with gruel as thick as it will run from the horn, but the gradual return of health should be well assured, before one morsel of corn is given.*

A very few weeks ago, the author received from his friend, Mr. Percivall, the following account of a new and destructive epidemic among horses :-

"From the close of the past year and the beginning of the present, up to the time I am writing, the influenza among horses has continued to prevail in the metropolis and different parts of the country with more or less fatality. In London it has assumed the form of laryngitis, associated in some instances with bronchitis; in others - in all I believe where it has proved fatal - with pleurisy. The parenchymatous structure of the lungs has not partaken of the disease, or but consecutively and slightly. The earliest and most characteristic symptom has been sure throat; causing troublesome dry short cough, but rarely occasioning any difficulty of deglutition, and, in no instance that I bave seen, severe or extensive enough to produce anything like disgorgement or return of the masticated matters through the nose, and yet the slightest pressure on the larynx has excited an act of coughing. But seldom has any glandular enlargement appeared. The symptom secondarily remarkable after the sore throat and cough has been a dispiritedness or dulness, for which most epidemics of the kind are remarkable. The animal, at the time of sickening, has hung his head under the manger, with his eyes half shut, and his lower lip pendent, without evincing any

\footnotetext{
* An interesting account of epidemic among horses will be found in the Association Part of "The Veterinarian," vols. xii. and xv. A work, by the author of this volume, is in prepara. tion, on the epidemics that have prevailed among all our domesticated animals. 
alarm or even much notice, though a person entered his abode or approached him; and if in a box, his head is often found during his illness turned toward the door or window. Fever, without any disturbance of the respiration, has always been present ; the pulse has bcen accelerated, though rather small and weak in its beat than indicative of strength; the mouth has been hot, sometimes burning hot, afterwards moist, and perhaps saponaceous; the skin and extremities in general have been warm. Now and then the prostration and appearance of debility have been such, and so rapid in their manifestation, that, shortly after being attacked, a horse has staggeringly walked twenty yards only-the distance from his stable into an infirmary-box. The appetite, though impaired much, has seldom been altogether lost. Generally, if a little fresh hay has been offered, it has been taken and eaten; but to mashes there has been commonly great aversion. During the long continuance of the wind in the east, the sore throat and cough have been unattended by any flux from the nose; but since the wind has shifted within this last fortnight or three weeks, discharges from the nostrils have appeared, profuse even in quantity, and purulent in their nature; in fact, the disease has assumed a more catarrhal character-ergo, I might add, a more favourable one.

"The disorder has exhibited every phase and degree of intensity, from the slightest perceivable dulness, which has passed off with simply a change in the diet, to an insidious, unyielding, unsubduable pleurisy, ending in hydrothorax, in spite of everything that could be done, and most timely done. So long as the disease has confined itself to the throat, and that there has been along with that only dejection, prostration, and fever, there has existed no cause for alarm; but when such symptoms have, after some days' continuance, not abated, and have, on the contrary, rather increased, and others have arisen which but too well have authorised suspicions that ' mischief was brewing in the chest,' then there became the strongest reasons for alarm for the safety of the patient. What is now to be done? The practitioner durst not bleed a second time, at least not generally, for the patient's strength would not endure it, al though he is certain a pleurisy is consuming his patient. He possesses no effectual means for topical blood-letting. Neither blisters nor rowels, nor plugs nor setons, will take any effect. Cathartic medicine he must not administer; nauseants are uncertain and doubtful in their efficacy; sedatives, tonics, and stimulants and narcotics, appear counter-indicated, inflammation existing, and, when tried under such circumstances, have, I believe, never failed to do harm.

"Dissatisfied with one and all of these remedies in the late influenza - though the losses I have experienced have, after all, not been so very comparatively great, being no more, since the beginning of the year, than three out of nearly forty cases - I repeat, having, as I thought, reason to be dissatisfied for losing even these three cases, considering that they came under my care at the earliest period of indisposition, I determined, in any similar cases that might occur, to have recourse to that medicine which, in all membranous inflammations in particular, is the physician's sheet-anchor, and which I had exhibited, and still continue to do, myself, in other disorders, though I had never given it a fair trial in epidemics having that tendency which I have described the present one uniformly to have indicated, viz., the destruction of life by an inflammation attacking membranous parts, of a nature over which, being forbidden to bleed, we appeared to possess little or no power. Could we have drawn blood from the sides or breast, by cupping or by leeches, in any tolerable quantity, we might have had some control over the internal disease; but barred from this, and without any remedy save a counter-irritant, which we could not make act, or an internal medicine, whose action became extremely dubious, if not positively hurtful, what was to be done? I repeat, I made up my mind to experiment with the surgeon's remedy in the same disease, namely, mercury; and that $I$ have had reason to feel gratified at the result will, I think, appear from the following cases:-

"Case I.-A pril 8. Every symptom of the prevailing epidemic : and considerably ag gravated on the 10th, when the horse laboured under much prostration of strength, and staggered considerably in his gait. The following ball was then ordered to be given him twice a day: R Hydrarg. chlorid. 3i, farin. avenæ 3 ss. terebinth. vulg. ๆ. s. ut fiat bol. One to be given morning and night. He soon began to improve and was returned to the stable on the $26 \mathrm{th}$, convalescent. A second patient of the same character was cured in eighteen days, and a third in nineteen days." The author of this work had the pleasure of witnessing these cases.

Mr. Percivall adds, "Lest it should be said, after the perusal of these three cases, 
that they do not appear to have been of a dangerous character, or to have required anything out of the ordinary line of treatment, I beg to observe, that at the periods at which I submitted them to the action of mercury, they so much resembled three others that had preceded them, and the disease had proved fatal, that, under a continuance of treatment of any ordinary kind, I certainly should have entertained fears for their safety.

"It must be remembered that they were cases in which blood-letting, except at the commencement, was altogether forbidden; and that, at the critical period when mercury was introduced, they had taken an unfavourable turn, and that nothing in the shape of remedy appeared available, save internal medicine and counter-irritation, and that the latter had not, and did not, show results betokening the welfare of the patients. Under these circumstances, the mercury was exhibited. That it entered the system, and must have had more or less influence on the disease, appears evident from its effcct on the gums. That it proved the means of cure, I cannot, from so few cases, take upon myself to assert; but I would recommend it in similar cases to the notice of practitioners."

\section{THE MALIGNANT EPIDEMIC.}

Continental veterinarians describe a malignant variety or termination of this disease; and the imperfect history of veterinary medicine in Britain is not without its records of it. So lately as the year 1815, an epidemic of a malignant character reigned among horses. Three out of fivc who were attacked died. It reappeared in 1823, but was not so fatal. It was said that the horses that died, were ultimately farcied: the truth was, that swellings and ulcerations, with fœtid discharge, appeared in various parts, or almost all over them-the natural swellings of the complaint which has just been considered, but aggravated and malignant. Our recollection of the classic lore of our early years will furnish us with instances of the same pest in distant times and countries. We have not forgotten the vivid description of Apollo darting his fiery arrows among the Greeks, and involving in one common destruction, the human being, the mule, the horse, the ox, and the dog. Lucretius, when describing the plague at Athens, speaks of a malignant epidemic affecting almost every animal-

Nor longer birds at noon, nor beasts at night
Their native woods deserted; with the pest
Remote they languished, and full frequent died :
But chief, the dog his generous strength resigned.

In 1714, a malignant epidemic was imported from the Continent, and in the course of a few months destroyed 70,000 horses and cattle. It continued to visit other countries, with but short intervals, for fifty years afterwards. Out of evil, however, came good. The Continental agriculturists were alarmed by this destruction of their property. The different governments participated in the terror, and veterinary schools were cstablished, in which the anatomy and diseases of these animals might be studied, and the cause and treatment of these periodical pests discovered. From the time that this branch of medical science began to receive the attention it deserved, these epidemics, if they have not quite ceased, have changed their character, and have become comparatively mild and manageable. As, however, they yet occur, and are far too fatal, we must endeavour to collect the symptoms, and point out the treatisent of them.

'The malignant epidemic was almost uniformly ushered in by inflammation of the inucous membrane of the respiratory passages, but soon involving other portions, and then ensued a diarrhœa, which no art could arrest. The fever, acute at first, rapidly passed over, and was succeeded by great prostration of strength. The inflammation then spread to the cellular texture, and there was a peculiar disposition to the formation of phlegmonous tumours: sometimes there were pustular eruptions, but, oftener, dcep-seated tumours rapidly proceeding to suppuration. Connected with this was a strong tendency to dccomposition, and unless the animal was relieved by some critical flux or evacuation, malignant typhus was establishcd, and the horse speedily sunk.

The most satisfactory account of one of these epidemics is given us by Professor Brugnone, of 'Turin. It commenced with loss of appetitc, staring coat, a wild and 
wandering look, and a staggering from the very commencement. The horse would continually lie down and get up again, as if tormented by colic ; and he gazed alternately at both flanks. In the moments of comparative ease, there wcre universal twitchings of the skin, and spasms of the limbs. The temperature of the ears and feet was variable. If there happened to be about the animal any old wound or scar from setoning or firing, it opened afresh and discharged a quantity of thick and black blood. Very shortly afterwards the flanks, which were quiet before, began to heave, the nostrils were dilated, the head extended for breath. The horse had by this time become so weak that, if he lay or fell down, he could rise no more; or if he was up, he would stand trembling, staggering, and threatening to fall every moment. The mouth was dry, the tongue white, and the breath fœtid; a discharge of yellow or bloody foetid matter proceeded from the nose, and fotid blood from the anus. The duration of the disease did not usually exceed twelve or twenty-four hours; or if the animal lingered on, swellings of the head and throat, and sheath, and scrotum, followed, and he died exhausted or in convulsions.

Black spots of extravasation were found in the cellular membrane, in the tissue of all the membranes, and on the stomach. The mesenteric and lymphatic glands were engorged, black, and gangrenous. The membrane of the nose and the pharynx was highly injected, the lungs were filled with black and frothy blood, or with black and livid spots. The brain and its meninges were unaltered.

It commenced in March 1783. The barracks then contained one hundred and sixteen horses; all but thirteen were attacked, and seventy-eight of them died. The horses of both the officers and men were subject to the attack of it; and three horses from the town died, two of which had drawn the carts that conveyed the carcasses a way, and the other stood under a window, from which the dung of an infected stable had been thrown out. The disease would probably have spread, but the most summary measures for arresting its progress were adopted; every horse in the town was killed that had had the sliglitest communication with those in the barracks. One horse was innculated with the pus discharged from the ulcer of an infected horse, and he died. A portion of his thymus gland was introduced under the skin of another liorse, and he also died.

Cause.-The disease was supposed to be connected with the food of the horses. All the oats had been consumed, and the lolium temulentum, or awned darnel, had been given instead. It is said that the darnel is occasionally used by brewers to give an intoxicating quality to their malt liquor. For fifteen days no alteration of health was perceived, and then, in less than eighteen hours, nearly forty perished. The stables were not crowded, and there was no improper treatment. A man disinterred some of the horses to get at the fat; swellings rapidly appeared in his throat, and he died in two days. A portion of their flesh was given to two pigs and some dogs, and they died.

II. Brugnone found that bleeding only accelerated the death of the patient. He afterwards tried, and ineffectually, acids, cordials, purgatives, vesicatories, and the actual cautery; and he frankly attributes to the power of nature the recovery of the few who survived.

Gilbert's Account of the Epidemic of 1795.-M. Gilbert describes a malignant epidemic which appeared in Paris in 1795, characterized by dulness, loss of appetite, weakness, pulse at first rapid and full, and afterwards continuing rapid, but gradually becoming small, weak, and intermittent. The bowels at first constipated, and then violent purging succeeding. The weakness rapidly increasing, accompanied by fœetid hreath, and fœid evacuations. Tumours soon appeared about the limbs, under the chest, and in the head, the neck and loins. If they suppurated and burst, the animal usually did well; but otherwise he inevitably perished. The formation of these tumours was critical. If they rapidly advanced, it was considered as a favourable symptoin; but if they continued obscure, a fatal termination was prognosticated.

Bleeding, even in an early stage, seemed here also to be injurious, and increased the debility. Physic was given, and mild and nutritious food, gruel, and cordials. Deep incisions were made into the tumours, and the cautery applied. Stimulating
frictions were also used, but all were of little avail.

These cases have been narrated at considerable length, in order to give some idea of the nature of this disease, and because, with the exception of a short but very 
excellent account of the malignant epidemic in the last edition of Mr. Blaine's Veterinary Outlines, there will not be found any satisfactory history of it in the writings of our English veterinarians. It is evidently a disease of the mucous membranes, both the respiratory and digestive. It is accompanied by early and great debility, loss of all vital power, vitiation of every secretion, effusions and tumours everywhere, and it runs its course with fearful rapidity. If it was seen at its outset, the practitioner would probably bleed; but if a few hours only had elapsed, he would find with Messrs. Brognone and Gilbert, that venesection would only hasten the catas trophe. Stimulants should be administered mingled with opium, and the spirit of nitrous ether in doses of thrce or four ounces, with an ounce or more of laudanum. The quantity of opium should be regulated by the spasms and the diarrhoea. These medicines should be repeated in a few hours, combined, perhaps, with ginger and gentian. If these failed, there is little else to be done. Deep incisions into the tulmours, or blisters over them, miglit be proper measures; but the principal attention should be directed to the arresting of the contagion. The infected should be immediately removed from the healthy. All offensive matter should be carefully cleared away, and no small portion of chloride of lime used in washing the animal, and particularly his ulcers. It might vith grcat propricty be administered internally, while the stable, and everything that belonged to the patient, should undergo a careful ablution with the same powerful disinfectant.

\section{BRO NCHITIS.}

This is not generally a primary disease. That inflammation of the superior respiratory passages, constituting catarrh, gradually creeps downwards and iuvolves the larynx and the trachea, and at length, possibly, the farthest and the minutest ramifcations of the air-tubcs. When it is found to be thus advancing, its progress should be carefully watched by the assistance of auscultation. 'The distant murmur of the healthy lung cannot be mistaken, nor the crepitating sound of pneumonia; and in bronchitis the blood may be heard filtering or breaking through the divisions of the lobuli, and accounting for that congestion or filling of the cells with mucus and blood, which is found after intense inflammation. Inflammation precedes this increased discharge of mucus. Even that may be detected. The inflamed membrane is thickened and tense. It assumes an almost cartilaginous structure, and the murmur is not only louder, but has a kind of snoring sound. Some have imagined that a sound like a metallic ring is mingled with it; hut this is never very distinct.

The interrupted whizzing sound has often and clearly indicated a case of bronchitis, and there are many corroborative symptoms which should be regarded. The variable temperature of the extremities will be an important guide-not deathly cold as in pneumonia, nor of increased tempernture, as often in catarrh, but with a tendency to coldness, yet this varying much. 'The pulse will assist the diagnosis-more rapid than in catarrh, much more so than in the early stage of pneumonia: not so hard as in pleurisy, more so than in catarrh, and much more so than in pneumonia. The respiration should next be examined, abundantly more rapid than in catarrh, pneumonia, or pleurisy; generally as rapid and often more so than the pulse, and accompanied hy a wheezing sound, heard at some distance. Mr. Percivall rclates a case in which the respiration was more than one hundred in a minute. Mr. C. Percivall describes an interesting case in which the respiration was quick in the extreme; and he remarks, that he does "not remember to have seen a horse with his respiration so disturbed."

In addition to these clearly characteristic symptoms, will be observed a liaggard countenance, to which the anxious look of the horse labouring under inflammation of the lungs cannot for a moment be compared; also an evident dread of suffocation, expressed, not by inability to move, as in pneumionia, but frequently an obstinate refusal to do so; cough painful in the extreme; breath hot, yet no marked pain in the part, and no looking at the side or flanks.

As the disease proceeds, there will be considerable discharge from the nostrils, much nore than in eatarrh, because greater extent of membrane is effected. It will be inuco-purulent at first, but will soon become amber-coloured or green, or greyish green; and that not from any portion of the food being returned, but from the peculiar hue of the secretion from ulcers in the bronchial passages. Small organised pieces will iningle with the discharge,-portions of mucus condensed and hardened, 
and forced from the inside of the tube. If the disease proceeds, the discharge becomes bloody, and then, and sometimes earlier, it is fœtid.

The natural termination of this disease, if unchecked, is in pneumonia. Although we cannot trace the air-tubes to their termination, the inflammation will penetrate into the lobuli, and affect the membranes of the air-cells or divisions which they contain. There is metastasis of inflammation of tener here than in pure pneumonia, and the disease is most frequently transferred to the feet. If, however, there is neither pneumonia nor metastasis of inflammation, and the disease pursues its course, the animal dies from suffocation. If the air-passages are clogged, there can be no supply of arterialized blood.

Like every other inflammation of the respiratory passages, bronchitis is clearly epidemic. There is a disposition to inflammation in the respiratory apparatus generally, but it depends on some unknown atmospheric influence whether this shall take on the form of catarrh, bronchitis, or pneumonia. It has not, however, been yet proved to be contagious.

Here again the first step will be to bleed; and here too will be the paramount necessity of the personal attendance of some well-informed person while the animal is bled. This is a disease of a mucous, - and an extended mucous surface; and while our measures must be prompt, there is a tendency to debility which we should never forget. Although the horse may be distressed quite to the extent which Mr. Charles Percivall describes, yet he would not bear the loss of four pounds of blood without fainting. No determinate quantity of blood will therefore be taken, but the vein will not be closed until the pulse falters, and the animal staggers, and in a minute or two would fall. This may probably effect the desired object; if it does not, it is possible that the practitioner may' not have a second opportunity.

The medical attendant should be cautious in the administration of purgatives, for the reasons that have again and again been stated; but if the bowels are evidently constipated, small doses of aloes must be given with the febrifuge medicine, and their speedy action promoted by injections, so that a small quantity may suffice.

A blister is always indicated in bronchitis. It can never do harm, and it not unfrequently affords decided relief. It should extend over the brisket and sides, and up the trachea to the larynx. The food, if the horse is disposed to eat, should be mashes. No corn should be offered, nor should the horse be coaxed to eat.

\section{PNEUMONIA - INFLAMMA'TION OF THE LUNGS.}

The intimate structure of the lungs has never been satisfactorily demonstrated. They appear, however, to be composed of minute cells or pouches, into which the air is at length conducted, and over the delicate membrane constituting the divisions of which myriads of minute blood-vessels are ramifying. The blood is not merely permeating them, but it is undergoing a vital change in them; there is a constant decomposition of the air, or of the blood, or of both; and, during the excitement of exercise, that decomposition proceeds with fearful rapidity. Then it can readily be conceived that a membrane so delicate as this must be, in order that its interposition shall be no hindrance to the arterialisation of the blood; so fragile also, and so loaded with blood-vessels, will be exceedingly subject to inflammation, and that of a most dangerous character.

Inflammation of the substance of the lungs is the not unfrequent consequence of all the diseases of the respiratory passages that have been treated on. Catarrh, influenza, bronchitis, if neglected or badly managed, or, sometimes in spite of the most skilful treatment, will spread along the mucous membrane, and at length involve the termination of the air-passages. At otler times, there is pure pneumonia. This cellular texture is the primary seat of inflammation. It is often so in the over-worked horse. After a long and hard day's hunt, it is very common for horses to be attacked by pure pneumonia. A prodigiously increased quantity of blood is hurried through these small vessels, for the vast expenditure of arterial blood in rapid progression must be provided for. These minutest of the capillaries are distended and irritated, their contractile power is destroyed, inflammation is produced, mechanical injury is effected, the vessels are ruptured, blood is poured into the interstitial texture, and intense inflammation and congestion, with all their train of fatal consequences, ensue.

The following are the most frequent causes of pneumonia. A sudden transition from heat to cold; a change from a warm stable to a colder one; a neglect of the usual 
clothing; a neglect even of some little comforts ; riding far and fast against a cold wind, especially in snowy weather; loitering about when unusual perspiration has been excited ; loitering tediously by the side of a covert on a chilly blowing morning.

It has not unfrequently happened that when horses have been turned out too early to grass, or without gradual preparation, pneumonia has supervened. Few are, under any management, so subject to pneumonia as those who, in poor condition and without preparation, are turned into a salt-marsh.

On the other hand, a sudden and considerable change from cold to heat may be followed by inflammation of the lungs. Many horses perish in the dealers' stables from this cause. The circulation is considerably quickened; more blood, and that with more than natural rapidity, is driven through the lungs, previously disposed to take on inflammatory action. The sudden removal from a heated stable to the cold air, for the purpose of examination, has also much to do with the production of disease.

Whether it is the consequence of previous disease of the respiratory passages, or that inflammation first appears in the cellular texture of the lungs, pneumonia is usually ushered in by a shivering fit. The horse is cold all over; this, however, soon passes off, and we have general warmth, or heat of the skin above the usual temperature, but accompanied by coldness of the extremities - intense deathy coldness. This is a perfectly diagnostic symptom. It will never deceive. It is an early symptom. It is found when there is little or no constitutional disturbance; when the pulse is scarcely affected, and the flanks heave not at all, but the horse is merely supposed to be dull and off his feed. It is that by which the progress of the disease may be unhesitatingly marked, when many scarcely suspect its existence.

The pulse is not always at first much increased in rapidity, and but rarely or never hard; but it is obscure, oppressed. The heart is labouring to accomplish its object; the circulation through the lungs is impeded; the vessels are engorged - they are often ruptured; blood is extravasated into the air-cells; it accumulates in the right side of the heart and in the larger vessels; and in the venous circulation generally there is a mechanical obstruction which the heart has not power to overeome. Hence the obscure, oppressed pulse; the ineffectual attempt to urge on the blood; and hence, too, the remarkable result of bleeding in inflammation of the lungs, for the pulse becomes rounder, fuller, quicker. When blood is abstracted, a portion of the opposing force is removed, and the heart being enabled to accomplish its object, the pulse is developed.

It is only, however, in the early insidious stage that the flanks are occasionally quiet. If the compressibility of the lungs is diminished by the thickening of the membrane, or the engorgement of the vessels, or the filling of the cells, it will be harder work to force the air out; there must be a stronger effort, and that pressure which cannot be accomplished by one effort is attempted over and over again. The respiration is quickened-laborious; the inspiration is lengthened; the expiration is rapid; and when, after all, the lungs cannot be compressed by the usual means, every muscle that can be brought to bear upon the part is called into action. Hence the horse will not lie down, for he can use the muscles of the spine and the shoulder with most advantage as he stands; hence, too, the very peculiar stiffness of position - the disinclination to move. The horse with decided pneumonia can scarcely be induced to move at all ; he cannot spare for a moment the assistance which he derives from certain muscles, and he will continue obstinately to stand until he falls exhausted or dying. How eagerly does the veterinarian ask when he goes into the stable "Was he down last night?" And he concludes, that much progress has not been made towards amendment in the case when the answer is in the negative. When the patient, wearied out, lies down, it is only for a moment; for if the inflammation is not subdued, he cannot dispense with the auxiliary muscles. He frequently, and with doleful expression, looks at his sides-at one side or at both, accordingly as one or both are involved. There is not, however, the decidedly haggard countenance of bronchitis; and in bronchitis the horse rarely or never gazes at his flanks. His is a dread of suffocation more than a feeling of pain. The head is protruded, and the nostrils distended, and the mouth and the breath intensely hot. The nose is injected from the earliest period; and soon afterwards there is not merely injection, but the membrane is uniformly and intensely red. The variation in this intensity is anxiously 
marked by the observant practitioner; and he regards with fear and despair the livid or dirty brownish hue that gradually creeps on.

The unfavourable symptoms are, increased coldness of the ears and feet, if that be possible; partial sweats, grinding of the teeth, evident weakness, staggering, the animal not lying down. The pulse becomes quicker, and weak and fluttering; the membrane of the nose paler, but of a dirty hue; the animal growing stupid, comatose. At length he falls, but he gets up immediately. For awhile he is up and down almost every minute, until he is no longer able to rise; he struggles severely; he piteously groans; the pulse becomes more rapid, fainter, and he dies of suffocation. The disease sometimes runs its course with strange rapidity. A horse has been destroyed by pure pneumonia in twelve hours. The vessels ramifying over the cells have yielded to the fearful impulse of the blood, and the lungs have presentcri wie mass of congestion.

The favourable symptoms are, the return of a little warmth to the extremities-the circulation beginning again to assume its natural character, and, next to this, the lying down quietly and without uneasiness; showing us that he is beginning to do without the auxiliary muscles. These are good symptoms, and they will rarely deceive.

Congestion is a frequent termination of pneumonia. Not only are the vessels gorged-the congestion which accompanies common inflammation-but their parietes are necessarily so thin, in order that the change in the blood may take place although they are interposed, that they are easily ruptured, and the cells are filled with blood. This effused blood soon coagulates, and the lung, when cut into, presents a black, softened, pulpy kind of appearance, termed, by the farrier and the groom, rottenness, and being supposed by them to indicate an old disease. It proves only the violence of the disease, the rupture of many a vessel surcharged with blood; and it also proves that the disease is of recent date, for in no great length of time, the serous portion of the blood becomes absorbed, the more solid one becomes organized, the cells are obliterated, and the lung is hepatized, or bears considerable resemblance to liver.

In every case of pneumonia, early and anxions recourse should be had to auscultation. Here, again, is the advantage of being perfectly acquainted with the deep distant murmur presented by the healthy lung. "This sound is most distinct in the young horse, and especially if he is a little out of condition. On such a horse the tyro should commence his study of the exploration of the chest. There he will make himself best acquainted with the respiratory murmur in its full state of development. He should next take an older and somewhat fatter horse; he will there recognize the same sound, but fainter, more distant. In still older animals, there will sometimes be a little difficulty in detecting it at all. Repeated experiments of this kind will gradually teach the examiner what kind of healthy murmur he should expect from every horse that is presented to him, and thus he will be better enabled to appreciate the different sounds exhibited under disease.

If pneumonia exists to any considerable degree, this murmur is soon changed for, or mingled with, a curious crepitating sound, which, having becn once heard, cannot afterwards be mistaken. It is caused by the infiltration of blood into the air-cells. Its loudness and perfect charactcr will characterize the intensity of the disease, and the portion of the chest at which it can be distinguished will indicate its extent.

The whole lung, however, is not always affected, or there are only portions or patches of it in which the inflammation is so intense as to produce congestion and hepatization. Enough remains either unaffected, or yet pervious for the function of respiration to be performed, and the animal lingers on, or perhaps recovers. By careful examination with the ear, this also may be ascertained. Where the lung is impervious-where no air passes-no sound will be heard, not even the natural murmur. Around it the murmur will be heard, and loudly. - It will be a kind of rushing sound; for the same quantity of blood must be arterialized, and the air must pass more rapidly and forcibly through the remaining tubes. If there is considerable inflammation or tendency to congestion, the crepitating, crackling sound will be recognized, and in proportion to the intensity of the inflammation. The advantages to be derived from the study of auscultation are not overrated. It was strong language lately applied by an able critic to the use of auscultation, that "it converts the organ of hearing into an organ of vision, enabling the listener to observe, with the clearness of ocular demon- 
stration, the ravages which disease occasionally commits in the very centre of the rib-cased cavity of the body."

A horse with any portion of the lungs hepatized cannot be sound. He cannot be capable of continued extra exertion. His imperfect and mutilated lung cannot supply the arterialized blood which long-continued and rapid progression requires, and that portion which is compelled to do the work of the whole lung must be exposed to injury and inflammation from many a cause that would otherwise be harmless.

Another consequence of inflammation of the substance of the lungs is the formation of tubercles. A grcater or smaller number of distinct cysts are formed-cells into which some fluid is poured in the progress of inflammation: these vary in size from a pin's point to a large egg. By degrees the fluid becomes concrete; and so it continues for a while-the consequence and the source of inflammation. It occupies a space that should be employed in the function of respiration, and by its pressure it irritates the neighbouring parts, and exposes them to inflammation.

By and by, however, another process, never sufficiently explained, commences. The tubcrcle begins to soften at its centre, - a process of suppuration is set up, and proceeds until the contents of the cyst become again fluid, but of a different character, for they now consist of pus. The pus increases; the cyst becomes more and more distended; it encroaches on the substance of the lungs; it comes into contact with other tubercles, and the walls opposed to each other are absorbed by their mutual pressure; they run together, and form one cyst, or regular excavation, and this sometimes proceeds until a considerable portion of the lung is, as it were, hollowed out. By and by, however, the vomica presses upon some bronchial passage; the cyst gives way, and the purulent contents are poured into the bronchix, and got rid of by the act of coughing. At other times the quantity is too great to be thus disposed of, and the animal is suffocated. Occasionally it will break through the pleuritic covering of the lung, and pour its contents into the thorax.

Abscesses may exist in the lungs undiscovered.-It is scarcely conceivable to what extent they sometimes exist in animals of slow work, without being detected by the usual means of examination. Mr. Hales says that he gave a physic-ball to a cartmare with a bad foot, and she soon afterwards died suddenly. When inquiring as to the cause of death, he was told, and not very good-humouredly, that his physic had killed her. He asked if it had purged her violently? "No!" it was replied, "it had not operated at all." She was opened, and the mystery was all unravelled. The thorax was deluged with pus, and there were then in the lungs several large abscesses, one of which contained at least a quart of pus. The mare had not shown a symptom of chest affection, and the gentleman to whom she belonged declared that he had believed her to be as sound as any horse he had in his possession.

The resolution or gradual abatement of inflammation is the termination most to be desired in this state of diseasc, for then the engorgement of the vessels will gradually cease, and the thickening of the membrane and the interstitial deposit be taken up, and the effusion into the cells likewise absorbed, and the lungs will gradually resume their former cellular texture, yet not perfectly; for there will be some induration, slight but general; or some more perfect induration of certain parts; or the rupture of some of the air-cells ; or an irritability of membrane predisposing to renewed inflammation. The horse will not always bc as useful as before; there will be chronic cough, thick wind, broken wind; but these merit distinct consideration; and, for the present, we proceed to the treatment of pneumonia.

There is inflamination of that organ through which all the blood in the frame passes - that organ most of all subject to congestion. Then nothing can be so important as to lessen the quantity of blood which the heart is endeavouring to force through the minute vessels of the lungs, distended, irritated, breaking. Immediate recourse must be had to the lancet, and the stream of blood must be suffered to flow on until the pulse falters, and the animal bears heavy upon the pail. This blood must be extracted as quickly as possible, and the lancet should be broad-shouldered, and the orifice large. This is the secret of treating inflammation of a vital organ. The disease is weakcned or destroyed, without permanently impairing the strength of the patient; whereas, by small bleedings, and with a small stream, the strength of the patient is sapped, while the disease remains untouched.

Next comes purging, if we dared ; for by having recourse to it some cause of excitement would be got rid of, the circulating fluid would be lessened, and a new determi18 * 
nation of the vital current produced; but expericnce teaches, that in pneumonia there is so much sympathy with the abdominal viscera, - there is such a fatal tendency in the inflammation to spread over every mucous membrane, that purging is almost to a certainty followed by inflammation, and that inflammation bids defiance to every attempt to arrest it. It may be said with perfect confidence that, in the majority of cases, a physic-ball would be a dose of poison to a horse labouring under pneumonia.

May we not relax the bowels? Yes, if we can stop there. 'We may, after the inflammation has evidently a little subsided, venturc upon, yet very cautiously, small doses of aloes in our fever medicine, and we may quicken their operation by frequent injections of warm soap and water; omitting the purgative, however, the inoment the freces are becoming pultaceous. We must, however, be assured that the inflammation is subsiding, and there nust be considerable constipation, or the purgative had better be let alone.

If we must not give physic, we must endeavour to find some other auxiliary to the blecding, and we have it in the compound of digitalis, nitre, and emetic turtar, which has been so often rccommended.

The greatest care should be taken of the patient labouring under this complaint. His legs should be well hand-rubbed, in order to restore, if possible, the circulation to the extremities. Comfortable flannel rollers should encase the legs from the foot to the knee. He should be covered up warm. There cannot be a doubt about this. As for air, in warm weather he cannot have too much. In cold weather, his box must be airy, but not chilly. We want to determine the bloorl to the extremities and the skin, but not all the clothing in the world will keep our patient warm, if he is placed in a cold and uncomfortable situation.

As for food, we think not of it. In nine cases out of ten he will not touch anything; or if he is inclined to eat, we give lim nothing but a bran-mash, or a little green meat, or a few carrots.

We now look about us for some counter-irritant. We wish to excite some powerful action in another part of the frame, and which shall divert the current of blood from that which was first affected. We recognise it as a law of nature, and of which we here eagerly avail ourselves, that if we have a morbid action in some vital organ - an unusual determination of blood to it - we can abate, perhaps wc can at once arrest, that morbid action by exciting a similar or a greater disturbancc in some contiguous and not dangerous part. Therefore we blister the sides and the brisket, and produce all the irritation we can on the integument; and in proportion as we do so, we abate, or stand a chance of abating, the inflammation within.

We have recourse to a blister in preferenee to a scton; and decidedly so, for our stimulus can be spread over a larger surfacc,--there is more chance of its being applied to the immediate neighbourhood of the original inflammation - and, most assuredly, from the extent of surface on which we can act, we can employ a quantity of stimulus beyond comparison greater than a seton would permit us to do. Rowels aie frequently excellent adjuvants to the blister, but should not be depended upon alone.

In the latter stagc of discase the blister will not act, because the powers of nature are exhausted. We must repeat it,-we must rouse the sinking energies of the frame, if we can, although the effort will generally be fruitless. The not rising of a blister, in the latter stage of the disease, may, too often, be regarded as the precursor of deatl, especially if it is accompanied by a livid or brown colour of the membrane of the nose.

Pneumonia, like bronchitis, requires anxious watching. 'The first object is to subdue the inflammation, and our measures must be prompt and decisive. If the mouth continues hot, and the extrcmities cold, and the nose red, we must bleed again and again, and that in rapid succession. 'The good which we can do must be done at first, or not at all.

When we have obtained a little returning warmth to the extremities, we must continue to administer our sedative medicines without one grain of a carminative or a tonic; and the return of the deathy-cold font will be a signal for farther depletion.

The commencement of the state of convalescence requires the same guarded practice, as in bronchitis. As many horses are lost by impatience now, as by want of decision at first. If we have subdued the disease, we should let well alone. We should guard against the return of the foe by the continued administration of our sedatives in smaller quantities; but give no tonics unless debility is rapidly succeeding. When we have apparently weathered the storm, we must still be cautious; we must 
consider the nature and the seat of the disease, and the predisposition to returning inflammation. If the season will permit, two or three months' run at grass should succeed to our medical treatment; but if this is impracticable, we must put off the period of active work as long as it can be delayed; and even after that, permit the horse to return as gradually as may be to his usual employment and food. is

Most frequent in occurrence among the consequences of inflammation of the lungs,

\section{CHRONIC COUGH.}

It would occupy more space than can be devoted to this part of our subject, to treat of all the causes of obstinate cough. The irritability of so great a portion of the airpassages, occasioned by previous and violent inflammation of them, is the most frequent. It is sometimes connected with worms. There is much sympathy between the lungs and the intestines, and the one readily participates in the irritation produced in the other. 'That it is caused by glanders can be easily imagined, because that disease is, in its early stage, seated in or near the principal air-passages, and little time passes before the lungs become affected. It is the necessary attendant of thick wind and broken wind, for thesc proceed from alterations of the structure of the lungs.

Notwithstanding the clearncss of the cause, the cure is not so evident. If a harsh hollow cough is accompanied by a staring coat, and the appearance of worms, -a few worm-balls may expel these parasites, and remove the irritation of the intestinal canal. If it proceeds from irritability of the air-passages, which will be discovered by the horse coughing after drinking, or when he first gocs out of the stable in the morning, or by his occasionally snorting out thick mucus from the nose, medicines may be given, and sometines with advantage, to diminish irritation generally. Small doses of digitalis, emetic tartar, and nitre, administered every night, frequently have a beneficial effect, especially when mixed with tar, which seems to have a powerful influence in allaying the irritation. These balls should, if necessary, be regularly given for a considerablc time. They are sufficiently powcrful to quiet slight excitement of this kind, but not to nanseate the horse, or interfere with his food or his work. A blister, extending from the root of one ear to that of the other, taking in the whole of the channel, and reaching six or eight inches down the windpipe, has been tried, and often with good effect, on the supposition that the irritation may exist in the fauces or the larynx. The blister has sometimes bcen extended through the whole course of the windpipe, until it enters the chest.

Fecding has much influence on this complaint. Too much dry meat, and especially chaff, increase it. It is aggravated when the horse is suffered to cat his litter; and it is often relieved when spring tares are given. Carrots afford decided relief.

'The seat of the discase, however, is so uncertain, and all our means and appliances so inefficacious, and the cough itself so little interfering, and sometimes interfering not at all with the health of the animal, that it is scarcely worth while to persevere in any mode of treatment that is not evidently attended with benefit. The principal consideration to induce us to meddle at all with chronic cough is the knowledge that horses aflicted with it are more liable than others to be affected by changes of tempcraturc, and that inflammation of the lungs, or of the respiratory passages, often assumes in them a very alarming character; to which, perhaps, may be added, that a horse with chronic cough cannot be warranted sound.

When chronic congh chiefly occurs after eating, the seat of the disease is evidently in the substance of the lungs. The stomach distended with food presses upon the diaphragm, and the diaphragm upon the lungs; and the lungs, already labouring under some congestion, are less capable of transmitting the air. In the violent effort to discharge their function, irritation is produced ; and the act of coughing is the conscquence of that irritation.

The Veterinary Surgeon labours under great disadvantage in the treatment of his patients. IIe must not only subdue the malady, but he must remove all its consequences. He must leave lis patient perfectly sound, or he has done eomparatively nothing. This is a task always difficult, and sometimes impossible to be accomplished. Thie two inost frequent consequences of severe chest affections in the horse are recognised under the terms thick wind and broken wind. The breathing is hurried in both, and the horse is generally much distressed when put upon his speed; but it is simply quick breathing in the first, with a peculiar sound like half roaring-the inspirations 
and expirations being rapid, forcible, but equal. In the second, the breathing is also hurried, but the inspiration does not differ materially from the natural one, while the expiration is difficult, or doubly laborious. The changes of structure which accompany these states of morbid respiration are as opposite as can be imagined. Induration of the substance of the lungs, diminution of the number or the calibre of the airpassages, are the causes of thick-wind. If the portion of lung employed is lessened, or the bronchial tubes will not admit so much air, the quick succession of efforts must make up for the diminished effect produced by each. In broken-wind there is rupture of the air-cells, and an unnatural inter-communication between them in the same lobule, or between those of the neighbouring lobuli. The structure of the lung, and the discharge of function, and the treatment, too, being so different, these diseases require separate consideration.

\section{T H I C K - W I N D.}

When treating of pneumonia, it was observed, that not only are the vessels which ramify over the delicate membrane of the air-cells gorged with blood, but they are sometimes ruptured, and the cells are filled with blood. The black, softened, pulpy appearance of the lungs thus produced, is the rottenness of the groom and farrier, proving equally the intensity of the inflammation, and that it is of recent date. If the horse is not spcedily destroyed by this lesion of the substance of the lungs, the serous portion of the effused blood is absorbed, and the solid becomes organised. The cells are obliterated, and the lung is hepatized, - its structure bears considerable resemblance to that of the liver. This may pccur in patches, or it may involve a considerable portion of the lung.

If a portion of the lung is thus rendered impervious, the remainder will have additional work to perform. The same quantity of blood must be supplied with air ; and if the working part of the machine is diminished, it must move with greater velocity as well as force - the respiration must be quicker and more laborious. This quick and laboured breathing can be detected even when the animal is at rest; and it is indicated plainly enough by his sad distress when he is urged to unusual or continued speed. The inspirations and the expirations are shorter, as well as more violent; the air must be more rapidly admitted, and more thoroughly pressed out; and this is accompanied by a peculiar sound that can rarely be mistaken.

We may guess at the commencement of the evil, by the laborious heaving of the flanks; but by auscultaticn alone can we ascertain its progress. The increase of the crepitus will tell us that the mischief is beginning, and the cessation of the murmur will clearly mark out the extent of the congestion.

The inflammatory stagc of the disease having passed, and comparative health being restored, and some return to usefulness having been established-the horse being now thick-winded - auscultation will be far more valuable than is generally imagined. It will faithfully indicate the quantity of hepatization, and so give a clue to the degree of usefulness, or the extent to which we may tax the respiratory system; and it will also serve to distinguish, and that very clearly, between this cause of thick-wind, and the morbid changes that may have resulted from bronchitis, or thickening of the parietes of the air-passages, and not the obliteration of the air-cells.

of the treatment, little can be said. We know not by what means we can excite the absorbents to take up the solid organised mass of hepatization, or restore the membrane of the cells, and the ininute vesscls ramifying over them, now confounder and lost. We have a somewhat better chance, and yet not much, in removing the thickening of the membrane, for counter-irritants, extensively and perseveringly applied to the external parietes of the chest, may do something. If thick-wind immediately followed bronchitis, it would certainly be justifiable practice to blister the brisket and sides, and that repeatedly; and to administer purgatives, if we dared, or diuretics, more effectual than the purgatives, and always safe.

Our attention must be principally confined to diet and management. A thickwinded horse should have his full proportion, or rather more than his proportion of corn, and a diminished quantity of less nutritious food, in order that the stomach may never be overloaded, and press upon the diaphragm, and so upon the lungs, and increase the labour of these already over-worked organs. Particular care should be taken that the horse is not worked immediately after a full meal. The overcoming 
of the pressure and weight of the stomach, will be a serious addition to the extra work which the lungs already have to perform from their altered structure.

Something may be done in the palliation of thick-wind, and more than has bcen generally supposed, by means of exercise. If the thick-winded horse is put, as it were, into a regular system of training; if he is daily exercised to the fair extent of his power, and without seriously distressing him, his breathing will become freer and deeper, and his wind will materially improve. We shall call to aur aid one of the most powerful excitants of the absorbent system - pressure, that of the air upon the tube-the working part of the lung upon the disorganised - and, adjusting this so as not to excite irritation or inflammation, we may sometimes do wonders. This is the very secret of training, and the power and the durability of the hunter and the racer depend entirely upon this.

Thick-wind, however, is not always the consequence of disease. There are certain cloddy, round-chested horses, that are naturally thick-winded, at least to a certain cxtent. 'They are capable of that slow exertion for which nature designed them, but they are immediately distressed if put a little out of their usual pace. A circular chest, whether the horse is large or small, indicates thick-wind. The circular chest is a capacious one, and the lungs which fill it are large, and they supply sufficient artcrialised blood to producc plenty of flesh and fat, and these horses are always fat. 'This is the point of proof to which we look, when all that we want from the animal is flesh and fat; but the expanding form of the chest is that which we require in the animal of speed-the deep as well as the broad chest-always capacious for the purpose of muscular strength, and becoming considerably more so when arterialised blood is rapidly expended in quick progression. We cannot enlarge the capacity of a circle; and if more blood is to be furnished, that which cannot be done by increase of surface, must be accomplished by frequency of action. Therefore it is that all our heavy draught-horses are thick-winded. It is of little detriment to them, for their work is slow; or rather it is an advantage to them, for the circular chest, always at its greatest capacity, enables them to acquire that weight which it is so advantageous for them to throw into the collar.

\section{B R O K E N - WIND.}

This is immediately recognisable by the manner of breathing. The inspiration is performed in somewhat less than the natural time, and with an increasen degree of labour: but the expiration has a peculiar difficulty accompanying it. It is accomplished by a double effort, in the first of which, as Mr. Blaine has well explained it, "the usual muscles operate; and in the other, the auxiliary muscles, particularly the abdominal, are put on the stretch to complete the expulsion more perfectly ; and that bcing done, the flank falls, or the abdominal muscles relax with a kind of jerk or spasm."

The majority of veterinary surgeons attribute broken-wind to an emphysematous state of the lungs. In almost every broken-winded horse which he has examined after death, the author of this work has found dilatation of somc of the air-cells, and particularly towards the edges of the lobes. There has been rupture through the parietes of some of the cells, and they have evidently communicated with one another, and the air could be easily forced from one portion of the cells to another. There was also a crepitating noise while this pressure was made, as if the attenuated membrane of some of the cells had given way. These were the true broken cells, and hence the derivation of the name of the disease.

Broken-wind is preceded or accompanied by cough-a cough perfectly characteristic, and by which the horscman would, in the dark, detect the existence of the disease. It is short-seemingly cut short-grnnting, and followed by whcezing. When the animal is suddenly struck or threatened, there is a low grunt of the same nature as that of roaring, but not so loud. Broken-wind is usually preceded by cough; the cough becomes chronic, leads on to thick-wind, and then there is but a step to brokenwind. It is the consequence of the cough which accompanies catarrh and bronchitis oftener than that attending or following pneumonia; and of inflammation, and probably, thickening of the membrane of the bronchix, rather than of congestion of the air-cells.

Lacnnec, whose illustrations of the diseases of the chest are invaluable to the human surgeon, comes to our assistance, and, while describing emphyscma of the lungs 
of the human being, gives us an explication of broken-wind, more satisfactory than is to be found in any of our veterinary writers. He attributes what he calls dry catarrh "to the partial obstruction of the smaller bronchial tubes, by the swelling of their inner membrane. The muscles of inspiration are numerous and powerful, while expiration is chiefly left to the elasticity of the parts: then it may happen that the air which, during inspiration, had overcome the resistance opposed to its entrance by the tumid state of the membrane, is unable to force its way through the same obstacle during expiration, and remains imprisoned in the cells, as it were, by a valve. The succeeding inspirations introduce a fresh supply of air, and gradually dilate the cclls to a greater or less extent; and if the obstruction is of some continuance, the dilated condition of the cells becomes permanent."

Some circumstances attending this disease may now, probably, be accounted for. A troublesome cough, and sometimes of long continuance, is the foundation of the disease, or indicates that irritable state of the bronchial membrane with which brokenwind is almost necessarily associated. Horses that are greedy feeders, or devour large quantities of slightly nutritious food, or are worked with a stomach distended by this food, are very subject to broken-wind. More depends upon the management of the food and exercise than is generally supposed. The post-horse, the coach-horse, and the racer, are comparatively seldom broken-winded. They are fed, at stated periods, on nutritious food that lies in little compass, and their hours of feeding and of exertion are so arranged that they seldom work on a full stomach. The agricultural horse is too often fed on the very refuse of the farm, and his hours of feeding, and his hours of work, are frequently irregular; and the carriage-horse, although fed on more nutritious food, is often summoned to work, by his capricious master, the moment his meal is devoured.

A rapid gallop on a full stomach has often produced broken-wind. When the exertion has been considerable and long-continued, we can easily conceive a rupture of the air-cells of the soundest lungs; but we are inclined to believe, that, were the history of these cases known, there would be found to have been a gradual preparation for this result. There would have been chronic cough, or more than usually disturbed respiration after exercise, and then it required little more to perfect the mischief. Galloping after drinking has been censured as a cause of broken-wind, yet we cannot think that it is half so dangerous as galloping with a stomach distended by solid food. It is said that broken-winded horses are foul feeders, because they devour almost everything that comes in their way, and thus impede the play of the lungs; but there is so much sympathy between the respiratory and digestive systems, that one cannot be much deranged without the other evidently suffering. Flatulence, and a depraved appetite, may be the consequence as well as the cause of broken-wind; and there is no pathological fact of more frequent occurrence than the co-existence of indigestion and flatulence with broken-wind. Flatulence seems so invariable a concomitant of broken-wind, that the old farriers used to think the air found its way from the lungs to the abdomen in some inexplicable manner; and hence their "holes to let out broken-wind." They used literally to make a hole near to or above the fundament in order to give vent to the imprisoned wind. The sphincter muscle was generally divided; and although the trumping ceased, there was a constant, although silent, emission of fœtid gas, that made the remedy worse than the disease.

The narrow-chested horse is more subject to broken-wind than the broader and deeper chested one, for there is not so much room for the lungs to expand when rapid progression requires the full discharge of their function.

Is broken-wind hereditary? We believe so. It may be referred to hereditary conformation-to a narrower chest, and more fragile membrane - and predisposition to take on those inflammatory diseases which end in broken-wind; and the circular chest, which cannot enlarge its capacity when exertion requires it, must render both thick and broken-wind of more probable occurrence.

Is there any cure for broken-wind? None! No medical skill can repair the broken-down structure of the lungs.

If, however, we cannot cure, we may in some degree palliate broken-wind ; and, first of all, we must attend carefully to the feeding. The food should lie in little compass-plenty of oats and little hay, but no chaff. Chaff is particularly objectionable, from the rapidity with which it is devoured, and the stomach distended. Water should be given in moderate quantities, but the horse should not be suffered to drink 
as much as he likes until the day's work is over. Green meat will always be serviceable. Carrots are particularly useful. They are readily digested, and appear to have a peculiarly beneficial effect on the respiratory system.

It is from the want of proper attention to the feeding that many horses become broken-winded, even in the straw-yard. There is little nutriment in the provender which they find there; and in order to obtain enough for the support of life, they are compelled to keep the stomach constantly full, and pressing upon the lungs. It has been the same when they have becn turned out in coarse and innutritive pasturage. The stomach was perpetually gorged, and the habitual pressure on the lungs cramped and confined their action, and inevitably ruptured the cells when the horse gambolled with his companions, or was wantonly driven about.

Next in importance stands exercise. The pursive or broken-winded horse should not stand idle in the stable a single day. It is almost incredible how much may be done by attention to food and exercise. The broken-winded horse may thus be rendered comfortable to himself, and no great nuisance to his owner; - -but inattention to feeding, or one hard journey - the animal unprepared, and the stomach full - may bring on inflammation, congestion, and deatl. Occasional physic, or alterative medicine, will often give considerable relief.

Thick-wind and broken-wind exist in various degrees, and many shades of difference. Dealers and horsemen generally have characterised them by names that can boast no elegance, but are considerably expressive of the state of the animal. Our readcrs should not be ignorant of them. Some horses make a shrill noise when in quick action-they are said to be Pipers. This is a species of Roaring. There is usually a ring of coagulated matter round the inside of the windpipe, by which the cavity is materially diminished, and the sound produced in quick breathing must evidently be shriller. Sometimes the piping is produced by a contraction of the small passages of the lungs.

The WHeEzer utters a sound not unlike that of an asthmatic person when a little hurried. This is a kind of thick wind, and is caused by the lodgment of some mucous fluid in the small passages of the lungs. It frequently accompanies bronchitis. Wheezing can be heard at all times, even when the horse is at rest in the stable; roaring is confined to the increased breathing of considerable exertion.

The Whistuer utters a shriller sound than the wheezer, but only when in exercise, and that of some continuance. A sudden motion will not always produce it. It seems to be referable to some contraction in the windpipe or the larynx. The sound is a great nuisance to the rider, and the whistler very speedily becomes distressed. A sharp gallop up-hill will speedily detect the ailment.

When the obstruction seems to be principally in the nose, the horse loudly puffs and blows, and the nostrils are dilated to the utmost, while the flanks are comparatively quiet. This animal is said to be a HigH-BLower. With all his apparent distress, he often possesses great speed and endurance. The sound is unpleasant, but the lungs may be perfectly sound.

Evcry horse violently excrcised on a full stomach, or when overloaded with fat, will grunt almost like a hog. The pressure of the stomach on the lungs, or that of the fat accumulated around the heart, will so much impede the breathing, that the act of forcible expiration will be accompanied with this kind of sound : but there are some horses who will at all times emit it, if suddenly touched with the whip or spur. They are called Grunters, and should be avoided. There is some altered structure of the lungs, which prevents them from suddenly accommodating themselves to an unexpected demand for exertion. It is the consequence of previous disease, and is frequently followed by thick or broken wind, or roaring.

\section{PHTHISIS PULMIONALIS, OR CONSUMPTION.}

When describing the accompaniments and consequences of inflammation of the lungs in the horse, mention was made of this fatal complaint. It is usually connected with or the consequence of pneumonia or pleurisy, and especially in horses of a peculiar formation or tempcrament.

If a narrow-chested, flat-sided horse is attacked by inflammation of the lungs, or severe catarrhal fever, experience tells us that we shall have more difficulty in subduing the disease in him, than in one deeper in the girth or rounder in the chest The lungs, deficient in bulk according to the diminished contents of the chest, lave 
been overworked in supplying the quantity of arterial blood expended in the various purposes of life, and particularly that which has been required under unusual and violent exertion. Inflammation of the lungs has consequently ensued, and that inflammatory action has acquired an intensc character, under circumstances by which another horse would be scarcely affected.

When this disease has been properly treated, and apparently subducd, this horse cannot be quickly and summarily dismissed to his work. He is sadly emaciatedhe long continues so - his coat stares - his skin clings to his ribs - his belly is tucked up, notwithstanding that he may have plenty of mashes, and carrots, and green meat, and medicine - his former gaiety and spirit do not return, or if he is willing to work he is easily tired, sweating on the least exertion, and the sweat most profuse about the chest and sides-his appetite is not restored, or, perhaps, never has becn good, and the slightest exertion puts him completely off his feed.

We observe him more attentively, and, even $\mathrm{cs}$ he stands quiet in his stall, the flanks heave a little more laboriously than they should do, and that heaving is painfully quickened when sudden excrtion is required. He coughs sorely, and discharges from the nose a mucus tinged with bloed, or a fluid decidedly purulent - the breath becomes offensive - the pulsc is always above 40, and strangely increased by the slightest exertion.

When many of these symptoms are developed, the animal will exhibit considerable pain on being gently struck on some part of the chest; the cough then becomes more frequent and painful; the discliarge from the nose more abundant and fotid, and the emaciation and consequent debility more rapid, until death closes the scene.

The lesions that are presented after death are very uncertain. Gencrally there are tubercles; sometimes very minute, at other times large in size. They are in different states of softening, and some of them have burst into the bronchial passages, and exhibit abscesses of enormous bulk. Other portions of the lungs are shrunk, flaccid, indurated or hepatized, and of a palc or red-brown colour; and there are occasional adhesions between the lungs and the sides of the chest.

Is this an hereditary disease? There is some difficulty in deciding the point. It has been scarcely mooted among the horsemen. One thing only is known, that the side has been flat, and the belly tucked up, and the animal has had much more ardour and willingness than physical strength. These conformations, and this disposition, we know to be hereditary, and thus far phthisis may be said to be so too. Low and damp situations, or a variable and ungenial climate, may render horses peculiarly susceptible of chest affections. All the absurd, or cruel, or accidental causes of pneumonia lay the foundation for phthisis; and, particularly, those causes which tend to debilitate the frame generally, render the horse more liable to chest affections, and less able to ward off their fatal consequences. The most numerous instances of phthisis occur in those poor persecuted animals that are worn out before their time, and they are frequent enough among cavalry horses after the deprivations and fatigues of a long campaign.

What is the medical treatment of confirmed phthisis? The practitioner must be guided by circumstances. If the horse is not very bad, and it is the spring of the year, a run at grass may be tried. It will generally seem to renovate the animal, but the apparent amelioration is too often treacherous. It should always be tried, for it is the best foundation for other treatment. 'The summer, however, having set in, the medicinal effect of the grass ceases, and the flies tease and irritate the animal.

The medical treatment, if any is tried, will depend on two simple and uncrring guides, the pulse and the membrane of the nose. If the first is quick and hard, and the second streaked with red, venesection should be resorted to. Small bleedings of one or two quarts, omitted when the pulsc is quieted and the nostril is pale, may be effected. Counter-irritants will rarely do harm. They should be applied in the form of blisters, extending over the sides, and thus brought as near as possible to the affected part. Sedative medicines should be perseveringly administered: and here, as in acute inflammation, the chief dependence will be placed on digitalis. It should be given in small doses until a slightly intermittent pulse is produced, and that state of the constitution should be maintained by a continued exhibition of the medicine. Nitre may be added as a diuretic, and pulvis antimmialis as a diaphoretic.

Any tonics here? Yes, the tonic effect of mild and nutritious food-green meat of almost every kind, carrots particularly, mashes, and now and then a malt mash. 
Nothing further than this ? We may try, but very cautiously, those tonics which stimulate the digestive system, yet comparatively little affect the circulatory one. Small doses of chamomile and gentian may be given, but carefully watched and omitted if the flanks should heave more, or the cough be aggravated.

The treatment of phthisis is a most unsatisfactory subject of consideration as it regards the practice of the veterinarian. If, after the human being has been subjected to medical treatment for a long course of time and at very considerable expense, he so far recovers that life is rendered tolerably comfortable to him, he and his connexions are thankful and satisfied, and he will submit to inany a privation in order to ward off the return of a disease, to which he is conscious there will ever be a strong predisposition : but the case is different with the horse; and this, the scope and bound of the human practitioner's hope, is worthless to the veterinarian. His patient must not only live, but must be sound again. Every energy, every capability must be restored. Can we cause the tubercles of the lungs to be absorbed ? Can we disperse or dispel the hepatization? Can we remodel the disorganised structure of the lungs? Our consideration, then, will be chiefly directed to the detection of the disease in its earliest state, and the allaying of the irritation which causes or accompanies the growth of the tubercles. 'This must be the scope and bound of the veterinarian's practice-always remcmbering that the owner should be forewarned of the general hopelessness of the case, and that the continuance of his efforts should be regulated by the wish of the proprietor and the value of the patient.

\section{P L E U R IS Y.}

The investing membrane of the lungs, and of the thoracic cavity, namely, the pleura, now demands consideration. We are indebted to Mr. John Field, one of the noblest ornaments of the veterinary profession-but cut off in the prime of his days-for the greater part of our knowledge of this disease, and for the power of distinguishing between it and pneumonia, as readily and as surely as we do between pneumonia and bronchitis and epidemic catarrh.

The prevailing causes of pleurisy are the same as those which produce pneumonia - exposure to wet and cold, sudden alterations of temperature, partial exposure to cold, riding against a keen wind, immersion as high as the chest in cold water, drinking cold water, and extra work of the respiratory machine. To thesc may be added, wounds penetrating into the thorax and lacerating the pleura, fracture of the ribs, or violent contusions on the side, the inflammation produced by which is propagated through the parietes of the chest.

It is sometimes confined to one side, or to one of the pleura on either side, or even to patches on that plcura, whether pulmonary or costal. 'The inflammation of the lungs which occasionally accompanies rabies is characterised by a singular patchy appearance. 'That produced on the costal pleura, arising from violence or other causes, rarely reaches the pulmonary covering; and that which is communicated to the tnnic of the lungs, by means of the intensity of the action within, does not often involve the costal pleura. In some cases, however, it affects both pleuræ and both sides, and spreads rapidly from one to the other.

The first symptom is rigor, followed by increased heat and partial sweats : to these succeed loss of appetite aad spirits, and a low and painful cough. The inspiration is a short, sudden effort, and broken off before it is fully accomplished, indicating the pain felt from the distention of the irritable, because inflamed, membrane. This symptom is exceedingly characteristic. In the human being it is well expressed by the term stitch, and an exceedingly painful feeling it is. The expiration is retarded as much as possible, by the use of all the auxiliary muscles which the animal can press into the service; but it at length finishes abruptly in a kind of spasm. This peculiarity of breathing, once carefully observed, cannot be forgotten. The next character is found in the tenderness of the sides when the costal pleura is affected. This tenderness often exists to a degree scarcely credible. If the side is pressed upon, the horse will recede with a low painful grunt; he will tremble, and try to get out of the way before the hand touches him again. Then comes another indication, both of pain and the region of that pain, - the intercostal muscles, affected by the contiguous pleura, and in their turn affecting the panniculus carnosus, or subcutaneous muscular expansion without - there are twitchings of the skin on the side - corrugations waves creeping over the integument. This is never seen in pneumonia. 'There is, 
however, as we may expect, the same disinclination to move, for every motion must give intense pain.

The pulse should be anxiously studied. It presents a decided difference of character from that of pneumonia. It is increased in rapidity, but instead of being oppressed and sometimes almost unappreciable, as in pneumonia, it is round, full, and strong. Even at the last, when the strength of the constitution begins to yield, the pulse is wiry, although small.

The extremities are never deathy cold; they may be cool, they are oftener variable, and they sometimes present increased heat. The body is far more liable to variations of temperature; and the cold and the hot fit more frequently succeed each other. The mouth is not so hot as in pneumonia, and the breath is rarely above its usual temperature.

A difference of character in the two diseases is here particularly evident on the membrane of the nose. Neither the crimson nor the purple injection of pneumonia is seen on the lining of the nose, but a somewhat darker, dingier hue.

Both the pneumonic and pleuritic horse will look at his flanks, thus pointing out the seat of disease and pain; but the horse with pneumonia will turn himself more slowly round, and long and steadfastly gaze at his side, while the action of the horse with pleurisy is more sudden, agitated, spasmodic. The countenance of the one is that of settled distress; the other brightens up occasionally. The pang is severe, but it is transient, and there are intervals of relief. While neither will lie down or willingly move, and the pneumonic horse stands fixed as a statue, the pleuritic one shrinks, and crouches almost to falling. If he lies down, it is on the affected side, when the disease is confined to one side only. The head of the horse with inflammation of the substance of the lungs hangs heavily; that of the other is protruded.

We here derive most important assistance from Auscultation. In a case of pleurisy we have no crepitating, crackling sound, referable to the infiltration of the blood through the gossamer membrane of the air-cells; we have not even a louder and distincter murmur. Perhaps there is no variation from the sound of health, or, if there is any difference, the murmur is fainter; for the pleural membrane is thickened, and its elasticity is impaired, and the sound is not so readily transmitted. There is sometimes a slight rubbing sound, and especially towards the superior region of the chest, as if there was friction between the thickened and indurated membranes.

To this may be added the different character of the cough, sore and painful enough in both, but in pneumonia generally hard, and full, and frequent. In pleurisy it is not so frequent, but faint, suppressed, cut short, and rarely attended by discharge from the nose.

These are sufficient guides in the early stage of the disease, when it is most of all of importance to distinguish the one from the other.

If after a few days the breathing becomes a little more natural, the inspiration lengthened and regular, and the expiration, although still prolonged, is suffered to be completed-if the twitchings are less evident and less frequent-if the cough can be fully expressed-if the pulse softens, although it may not diminish in frequency, and if the animal begins to lie down, or walks about of his own accord, there is hope of recovery. But if the pulse quickens, and, although smaller, yet possesses the wiry character of inflammation - if the gaze at the flanks, previously by starts, becomes fixed as well as anxious, and the difficulty of breathing continues (the difficulty of accomplishing it, although the efforts are of tener repeated)-if patches of sweat break out, and the animal gets restless-paws-shifts his posture every minute-is unable longer to stand, yet hesitates whether he shall lie down-determines on it again and again, but fears, and at length drops, rather than lies gently down, a fatal termination is at hand. For some time before his death, the effusion and its extent will be evident enough. He not only walks unwillingly, but on the slightest exercise his pulse is strangely accelerated; the feeling of suffocation comes over him, and he stops all of a sudden, and looks wildly about and trembles; but he quickly recovers himself and proceeds. There is also, when the effusion is confirmed, œdema of some extcrnal part, and that occasionally to a very great extent. This is oftenest observed in the abdomen, the chest, and the point of the breast.

The immediate cause of death is effusion in the chest, compressing the lungs on every side, rendering expiration difficult and at length impossible, and destroying the animal by suffocation. The very commencement of effusion may be detected by aus- 
cultation. There will be the cessation of the respiratory murmur at the sternum, and the increased grating - not the crepitating, crackling noise as when congestion is going on-not the feebler murmur as congestion advances; but the absence of it, beginning from the bottom of the chest.

It is painfully interesting to watch the progress of the effusion-how the stillness creeps up, and the murmur gets louder above, and the grating sound louder too, until at length there is no longer room for the lungs to play, and suffocation ensues.

The fluid contained in the chest varies in quantity as well as appearance and consistence. Many gallons have been found in the two sacs, pale, or yellow, or bloody, or often differing in the two sides of the thorax; occasionally a thick adventitious coat covering the costal or the pulmonary pleura - rarely much adhesion, but the lungs purple-coloured, flaccid, compressed, not one-fourth of their usual size, immersed in the fluid, and rendered incapable of expanding by its pressure.

Hcre, as in pneumonia, the bleeding should be prompt and copious. Next, and of great importance, aperient medicine should be administered-that, the effect of which is so desirable, but which we do not dare to give when the mucous membrane of the respiratory passages is the seat of disease. Here we have to do with a serous membrane, and there is less sympathy with the mucous membranes of either cavity. Small doses of alocs should be given with the usual fever medicine, and repeated morning and night until the dung becomes pultaceous, when it will always be prudent to stop. The sedative medicine is that which has been recommended in pneumonia, and in the same doses. Next should follow a blister on the chests and sides. It is far preferable to setons, for it can be brought almost into contact with the inflamed surface, and extended over the whole of that surface. An airy, but a comfortable box, is likcwise even more necessary than in pneumonia, and the practice of exposure, uncovered, to the cold, even more absurd and destructive. The blood, repelled from the skin by the contractile, depressing influence of the cold, would rush with fatal impetus to the neighbouring membrane, to which it was before dangerously determined. Warm and comfortable clothing cannot be dispensed with in pleurisy.

'The sedative medicines, however, should be omitted much sooner than in pneumonia, and succeeded by diuretics. The common turpentine is as good as any, made into a ball with linseed meal, and given in doses of two or three drachms twice in the day. If the constitution is much impaired, tonics may be cautiously given, as soon as the violence of the disease is abated. The spirit of nitrous ether is a mild stimulant and a diuretic. Small quantities of gentian and ginger may be added, but the turpentine must not be omitted.

By auscultation and other modes of examination, the existence of effusion in the chest is pcrhaps ascertained, and, possibly, it is increasing. Is there any mechanical way of getting rid of it? There is one to which recourse should be had as soon as it is cvident that there is considerable fluid in the chest. 'The operation of Paracentesis, or tapping, should be performed; it is a very simple one. The side-line may be had recourse to, or the twitch alone may be used. One of the horse's legs being held up, and, counting back from the sternum to between the seventh and eighth ribs, the surgeon should pass a moderate-sized trochar into the chest immediately above the cartilages. He will not have selected the most dependent situation, but as near it as he could with safety select; for there would not have been room between the cartilages if the puncture had been lower; and these would have been injured in the forcing of the instrument between them, or, what is worse, there would have been great hazard of wounding the pericardium, for the apex of the heart rests on the sternum. Through this aperture, close to the cartilages, the far greater part of the fluid may be evacuated. The operator will now withdraw the stilette, and let the fluid run through the canula. He will not trouble himself afterwards about the wound; it will heal readily enough; perhaps too quick, for, could it be kept open a few days, it might act as a very useful drain. It should be attempted early. Recourse should be had to the operation as soon as it is ascertained that there is considerable fluid in the chest, for the animal will at least be relieved for a while, and some time will have been given for repose to the overlaboured lungs, and for the system generally to be recruited. The fluid will be evacuated before the lungs are too much debilitated by laborious action against the pressure of the water, and a state of collapse brought on, from which they will be incapable of recovering. They only who have seen the collapsed and condensed state 
of the lung that had been long compressed by the fluid, can conceive of the extent to which this is carried. It should be added - a fact important and alarming-that the records of veterinary surgery contain very few cases of permanently successful performance of the operation. This should not discourage the practitioner from atteinpting it, but should induce him to consider whether he may not perform it under happier auspices, before the lungs and the serous membrane which lines the cavity have been too much disorganised, and the constitution itself sadly debilitated. There could not be any well-founded objection to an earlier resort to paracentesis, and he must be a bungler indeed who wounded any important part.

It should be ascertained by auscultation whether there is fluid in both cavities. If there should be, and in considerable quantity, it will not be prudent to operate on both sides at once. If much fluid is discharged, there will be acceleration and difficulty of respiration to a very great degree. The practitioner must not be alarmed at this; it will pass over, and on the next day he may attack the other side; or open both at once, if there is but little fluid in either.

Having resorted to this operation, a course of diuretics with tonics should be immediately commenced, and the absorbents roused to action before the cavity fills again.

There is in pleurisy a far greater tendency to relapse than in pneumonia. The lungs do not perfectly recover from their state of collapse, nor the serous membrane from its long maceration in the effused fluid: œedema, cough, disinclination to work, incapability of rapid progression, colicky pains - as the unobservant practitioner would call them - but in truth pleuritic stitches; these are the frequent sequelæ of pleurisy. This will afford another reason why the important operation of paracentesis should not be deferred too long.

There is much greater disposition to metastasis than in pneumonia: indeed it is easy to imagine that the inflammation of a mere membrane may more readily and oftener shift than that of the substance of so large a viscus as the lungs. The inflammation shifting its first ground, attacks almost every part indiscriminately, and appears under a strangly puzzling variety of forms. Dropsy is the most frequent change. Effusion in the abdomen is substituted for that of the chest, or rather the exhalent or absorbent vessels of the abdomen, or both of them, soon sympathise in the debility of those of the thorax. 


\section{CHAPTER IX.}

\section{THE ABDOMEN AND ITS CONTENTS.}

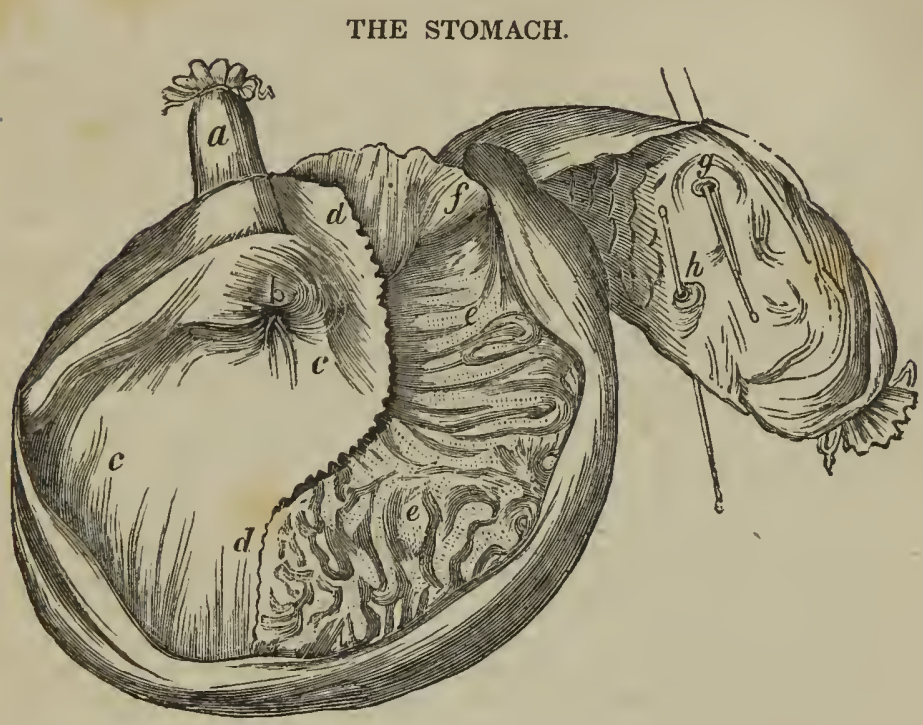

a The csophagus or gullet, extending to the stomach.

$b$ The entrance of the gullet into the stomach. The circular layers of the muscles are very thick and strong, and which, by their contractions, help to render it difficult for the food to be returned or vomited.

c The portion of the stomach which is covered by cuticle, or insensible skin.

$d d$ The margin, which separates the cuticular from the villous portion.

e e The inucous, or villous (velvet) portion of the stomach, in which the food is principally

$f$ The communication bctween the stomach and the first intestine.

$g$ The common orifice through which the bile and the secretion from the pancreas pass into the first intestine. The two pins mark the two tubes here united.

$h$ A sinaller orificc, through which a portion of the secretion of the pancreas enters the intestines.

THe œsophagus, as has already been stated, consists of a muscular membranous tube, extending from the posterior part of the mouth down the left side of the neck, pursuing its course through the chest, penetrating through the crura of the diaphragm, and reaching to and terminating in the stomach. It does not, however, enter straight into the stomach, and with a large open orifice; but there is an admirable provision made to prevent the regurgitation of the food when the stomach is filled and the horse suddenly called upon to perform unusually hard work. The œsophagus enters the stomach in a somewhat curved direction-it runs obliquely through the muscular and cuticular coats for some distance, and then its fibres arrange themselves around the opening into the stomach. Close observation has shown, that they form themselves into segments of circles, interlacing each other, and by their contraction plainly and forcibly closing the opening, so that the regurgitation of the food is almost impossible.

The following is a simple but accurate delineation of the structure of the termination of the csophagus, and the manner in which it encircles the orifice of the stomach. We are indebted to Mr. Ferguson, of Dublin, for this interesting discovery. 
A microscope of very feeble power will beautifully show this singular construction.

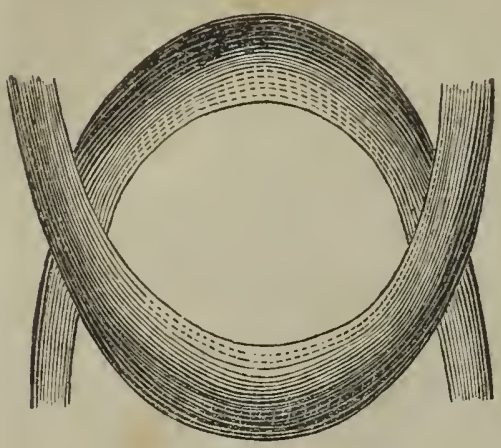
It is not precisely either a sphineter muscle or a valve, but it is a strong and almost insuperable obstacle to the regurgitation of the food. The left side of the stomach is in contact with the diaphragm. It is pressed upon by every motion of the diaphragm, and hence the reason why the stomach is so small compared with the size of the animal. It is indeed strangely small, in order that it might not press too hardly upon the diaphragm, or painfully interfere with the process of respiration, when the utmost energies of the horse are occasionally taxed immediately after he has been fed.

At the lower or pyloric orifice, the muscles are also increased in number and in size. These are arranged in the same manner, with sufficient power to resist the pressure of the diaphragm, and retain the contents of the stomach until they have undergone the digestive process.

The situation of the stomach will at once explain the reason why a horse is so much distressed, and sometimes irreparably injured, if worked hard immediately after a full meal. The stomach must be displaced and driven back by every contraction of the diaphragm or act of inspiration; and in proportion to the fulness of the stomach will be the weight to be overcome, and the labour of the diaphragm, and the exhaustion of the animal. If the stomach is much distended, it may be too weighty to be forced sufficiently far back to make room for the quantity of air which the animal in a state of exertion requires. Hence the frequency and labour of the breathing, and the quickness with which such a horse is blown, or possibly destroyed. Hence also the folly of giving too full a meal, or too much water, before the horse starts on a journey or for the chase; and, in like manner, the absurdity and danger of that unpardonable custom of some grooms to gallop the horse after his drink, in order to warm it in his belly, and prevent gripes.

The horse was destined to be the servant of man, and to be always at his call whether fasting or full : it would seem, therefore, that, to lessen much inconvenience or danger, a smaller stomach, in proportion to his size, is given to the horse than to almost any other animal. The bulk of the horse, and the services required of him, demand much nutriment, and that of such a nature as to occupy a very considerable space; yet his stomach, compared with his bulk, is not half so large as that of the human being: therefore, although he, like every other animal, feels inconvenience from great exertion immediately after a full meal, he suffers not so much as other quadrupeds, for his stomach is small, and his food passes rapidly through it, and descends to a part of the intestines distant from the diaphragm, and where the existence and pressure of the food cannot cause him any annoyance.

The stomach has four coats. The outermost is the lining of the cavity of the belly, and the common covering of all the intestines-that by which they are confined in their respective situations, and from which a fluid is secreted that prevents all friction between them. This is called the peritoneum-that which stretches round the inside of the stomach.

The second is the muscular coat, consisting of two layers of fibres, one running lengthways, and the other circularly, and by means of which a constant gentle motion is communicated to the stomach, mingling the food more intimately together, and preparing it for digestion, and by the pressure of which the food when properly prepared is urged on into the intestines.

The third, or cuticular (skin-like) coat, $c$, covers but a portion of the inside of the stomach. It is a continuation of the lining of the gullet. There are numerous glands on it, which secrete a mucous fluid; and it is probably intended to be a reservoir in which a portion of the food is retained for a while, and softened and better prepared for the action of the other or true digestive portion of the stomach. The cuticular coat occupies nearly one-half of the inside of the stomach.

The fourtl coat is the mucous or villous (velvet) coat, $c$, where the work of digestion 
properly commences. The mouths of numerous little vessels open upon it, pouring out a peculiar fluid, the gastric (stomach) juice, which mixes with the food already softened, and converts it into a fluid called chyme. As this is formed, it passes out of the other orifice of the stomach, the pylorus (doorkeepers), $f$, and enters the first small intestine; the harder and undissolved parts being turned back to undergo farther action.

Livery portion of the muscular coat has the power of successively contracting and relaxing, and thus, in the languagc of Dr. Bostock, "the successive contraction of each part of the stomach, by producing a series of folds and wrinkles, serves to agitate the alimentary mass, and, by bringing every part of it in its turn to the surface, to expose it to the influence of the gastric juice, while at the same time the whole of the contents are gradually propelled forwards, from the orifice which is eonnected with the œsophagus to that by which they are discharged."

The cerebro-visceral nerve is the agent in producing thesc alternate contractions and relaxations. It is the motor nerve belonging to these parts. It has to keep the parietes of the stomach in contact with the food, and the food in contact with the gastric juice. It has to bring the different parts of the food in successive contact with the stomach, and to propel them through this portion of the alimentary canal in order that they may be discharged into the duodenum.

A viscus thus situated and thus employed must occasionally be subject to inflammation, and various other lesions. The symptoms, however, are obscure and frequently mistaken. They resemble those of colic more than anything else, and should be met by blecding, oleaginous purges, rnashes, tepid gruel, and the application of the stomach-pump: but when, in addition to the colicky pains, there appear indistinctness of the pulse-and a very characteristic symptom that is-pallidness of the membranes, coldness of the mouth, frequent lying down, and in such position that the weight of the horse may rest on the chest, frequently pointing with his muzzle at the seat of pain, and, especially, if these symptoms arc accompanied or followed by romiting, rupture of the stomach is plainly indicated. Considering the situation of the stomach, and the concussions and violence to which it is exposed from the diaphragm and from the viscera around it, this accident will not appear extraordinary. The horse does not necessarily die as soon as this accident occurs. In a case related by Mr. Rogers, the animal died in about four hours after the accident;* but in one that occurred in the practice of the author, three days elapsed between the probable rupture of the stomach, from a sudden and violent fall, and the death of the animal, and in which interval he several times ate a little food. The rupture was at the right extremity of the stomach, and there were several distinct layers of impacted food between it and the liver. The liver seemed to have acted as a kind of valve. 'The stomach was found still distended, the edges of the rupture having the dull and sodden appearance of an old wound. There was comparatively little fluid in the abdominal cavity, and no disposition to vomit occurred during any period. $\dagger$

A case slowing the insensibility of the stomach, wisely and kindly given, considering the shocks and dangers to which this viscus is exposed, is recorded by Mr. Hayes. I A drench was ordered for a horse. For want of a horn, the stable-keeper made usc of a wine-bottle, without examining whether it was clean or foul. Shortly afterwards it was discovered that the bottle had contained three or four ounces of liquid blister. This was kept a profound secret until the death of the animal, and that did not happen until twelve days aftcrwards. The horse had eaten his provender in the same manner as usual, and had performed his usual work until about two hours before his death, when he lay down, rolled about, bruised himself sadly, and died. The food, consisting of hay, oats, and beans, was lodged and impacted between the folds of the intestincs, and the whole abdominal viscera appeared as if they had been thus surrounded a considerable time before death. The stomach was ruptured in many dircetions, and almost decomposed. Its coats were nearly destroyed, and hung like rags about the orifice through which the food was received, and that through which it naturally was expelled. This account proves how little we are to depend upon any apparent symptoms as indicating the real state of the stomach in the horse.

Mr. Brown relates a case of polypus found in the stomach, and which had remained

* The Farrier and Naturalist, rol. ii., p. 9.

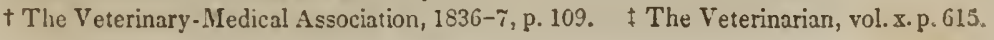


there unsuspected until it weighed nearly half-a-pound, it then became entangled in the pyloric orifice, and prevented the passage of the food, and destroyed the horse.*

\section{B O T S.}

In the spring and early part of the summer, horses are much troubled by a grub or caterpillar, which crawls out of the anus, fastens itself under the tail, and seems to cause a great deal of itching or uneasiness. Grooms are sometimes alarmed at the appearance of these insects. Their history is curious, and will dispel every fear with regard to them. We are indebted to Mr. Bracy Clark for almost all we know of the bot.

\section{UT OF THE BOT.}

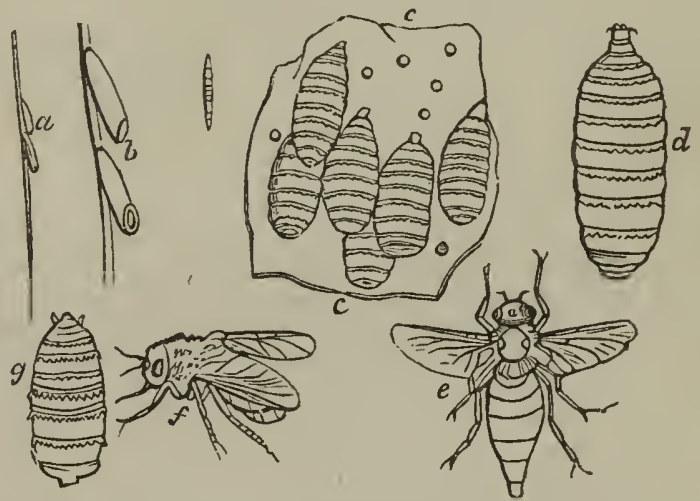

$a$ and $b$ The eggs of the gad-fly, adhering to the hair of the horse.

$c$ The appearance of the bots on the stomach, firmly adhering by their hooked mouths. The marks or depressions are seen which are left on the coat of the stomach when the bots are detached from their hold.

$d$ The bot detached.

$e$ The female of the gad-fiy, of the horse, prepared to deposit her eggs.

$f$ The gad-fly by which the red bots are produced.

$g$ The smaller, or red bot.

A species of gad-fly, $e$, the ætrus equi, is in the latter part of the summer exceedingly busy about the horse. It is observed to be darting with great rapidity towards the knees and sides of the animal. The females are depositing their eggs on the hair, and which adhere to it by means of a glutinous fluid with which they are surrounded $(a$ and $b)$. In a few days the eggs are ready to be hatched, and the slightest application of warmth and moisture will liberate the little animals which they contain. The horse in licking himself touches the egg; it hursts, and a small worm escapes, which adheres to the tongue, and is conveyed with the food into the stomach. There it clings to the cuticular portion of the stomach, $c$, by means of a hook on either side of its mouth; and its hold is so firm and so obstinate, that it must be broken before it can be detached. It remains there feeding on the mucus of the stomach during the whole of the winter, and until the end of the ensuing spring; when, having attained a considerable size, $d$, and being destined to undergo a certain transformation, it disengages itself from the cuticular coat, is carried into the villous portion of the stomach with the food, passes out of it with the chyme, and is evacuated with the dung.

The larva or maggot seeks shelter in the ground, and buries itself there; it contracts in size, and becomes a chrysalis or grub, in which state it lies inactive for a few weeks, and then, bursting from its confinement, assumes the form of a fly. The female, becoming impregnated, quickly deposits her eggs on those parts of the horse which he is most accustomed to lick, and thus the species is perpetuated.

There are several plain conclusions to be drawn from this history. The bots can- 
not, while they inhabit the stomach of the horse, give the animal any pain, for they have fastened on the cuticular and insensible coat. They cannot stimulate the stomach, and increase its digestive pawcr, for they are not on the digestive portion of the stomach. They cannot, by their roughness, assist the trituration or rubbing down of the food, for no such office is performed in that part of the stomach-the food is softened, not rubbed down. They cannot be injurions to the horse, for he enjoys the most perfect health when the cuticular part of his stomach is filled with them, and their presence is not even suspected until they appear at the anus. They cannot be removed by medicine, because they are not in that part of the stomach to which medicine is usually conveyed; and if they were, their mouths are too deeply buried in the inucus for any medicine, that can be safely administered, to affect them; and, last of all, in due course of time they detach themselves, and come away. Therefore, the wise man will leave them to themselves, or content himself with picking them off when they collect under the tail and annoy the animal.

The smaller bot, $f$ and $g$, is not so frequently found.

Of inflammation of the stomach of the horse, except from poisonous herbs, or drugs, we know little. It rarely occurs. It can with difficulty be distinguished from inflammation of the bowels; and, in either case, the assistance of the veterinary surgeon is required.

Few horses are destroyed by poisonous plants in our meadows. Natural instinct teaches the animal to avoid the greater part of those that would be injurious.

We cannot do better than abbreviate the list of poisonous agents, and the means of averting their fatal influence, given by Mr. Morton, the Professor of Chemistry and Materia Medica at the Royal Veterinary College.* It will occasionally be exceedingly useful to the proprietor of horses.

He begins with the Animal Poisons. The bite of the viper has been occasionally fatal to dogs and sheep. A horse was brought to the Veterinary College that had been bittcn in the hind leg while hunting. 'There was considerable swelling, and the place of the bite was evident enough. Mr. Armstrong mentions a case in which a horse, bitten by a viper, sunk into a kind of coma, from which he could not be roused. The antidote, which seldom or never fails, is an alkaline solution of almost any kind, taken internally and applied externally. There is no chemical effect on the circulation, but the alkali acts as a powerful counter-irritant. In very bad cases, opium may be added to the alkaline solution.

HoRnETS, W ASPS, \&c.- These are spoken of, because there are records of horses being attacked by a swarm of them, and destroyed. The spirit of turpentine is the best external application, and, if given in not undue quantities and guarded by an admixture with oil, may be useful.

Cantharides constitute a useful drug in some few cases. It is one of the applications used in order to excite the process of blistering. It was occasionally employed as a medicine in small quantities, and, combined with vegetable tonics, it has been given in small doses, for the cure of glanders, farcy, and nasal gleet. It is valuable in cases of general and extreme debility. It is a useful general stimulant when judiciously applied: but it must be given in small doses, and never except under the direction of a skilful practitioner. A drachm of the powdered fly would destroy almost any horse. In the breeding season it is too often shamefully given as an excitement to the horse and the mare, and many a valuable animal has been destroyed by this abominable practice. It is usually given in the form of ball, in which case it may be detected by the appearance of small glittering portions of the fly, which are separated on the inner side of the dung-ball in hot water. If the accidental or too powerful administration of it is suspected, recourse should be had to bleeding, purging, and plentiful drenching with oily and demulcent fluids.

The leaves of the Yew are said to be dangerous to the horse, as well as to many other animals. "Two horses that had been employed in carrying fodder, were thoughtlcssly placed under a large yew-tree, which they cropped with eagerness. In three hours they began to stagger - both of them dropped, and before the harness could be taken off, they were dead. A great quantity of yew-leaves were found in the stomachs, which were contracted and inflamed." $†$ Mr. W. C. Spooner mentions

* Veterinary Medical Association, 1836-7, p. 41.

t Loudon's Magazine of Natural History, vol. viü. p. 81 . 
a case of violent suspicion of the poisoning of an ass and a mare in the same way:* On the other hand, Professor Sewell says, that on the farm on which he resided in his early years, the horses and cattle had every opportunity of eating yew. They pastured and slept under the shelter of yew-trees, and were often observed to browse on the branches. $\dagger \mathrm{He}$ thinks that these supposed cases of poisoning have taken place only when enormous quantities of the yew had been eaten, and that it was more acute indigestion than poisoning. There are, however, too many cases of horses dying after feeding on the yew, to render it safe to cultivate it in the neighbourhood of a farm, either in the form of tree or hedge.

The Hydrocyanic, or Prussic Acid, belongs to the class of vegetable poisons, but it is scarcely possible for the horse to be accidentally injured or destroyed by it. Ten grains of the farina of the croton nut should be given as soon as the poison is suspected, and the patient should be drenched largely with equal parts of vinegar and thin gruel, and the croton repeated after the lapse of six hours, if it has not previously operated.

The Water Dropwort (Enanthe fistulosa), common in ditches and marshy places, is generally refused by horses; but brood mares, with appetite somewhat vitiated by their being in foal, have been destroyed by it. The antidote would be vinegar and gruel, and bleeding, if there is inflammation.

The Water Parsley, (Æthusa Cynapium) deserves not all the bad reputation it has acquired; although, when eaten in too great quantities, it has produced palsy in the horse, which has been strangely attributed to a harmless beetle that inhabits the stem.

Of the Common Hemlock (Conium maculatum), and the Water Hemlock (Onanthe crocata), the author knows no harm, so far as the horse is concerned. He has repeatedly seen him eat the latter without any bad effect; but cows have been poisoned by it.

The Euphorbium, or Spurge, so common and infamous an ingredient in the Farrier's Blister, has destroyed many a horse from the irritation which it has set up, and the torture it has occasioned, and should never find a place in the Veterinary Pharmacopœia.

Colocynth and Elaterium fairly rank among the substances that are poisonous to the horse; and so does the Bryony Root (Bryonia dicica), notwithstanding that it is frequently given to horses, in many parts of the country, as a great promoter of condition. Many a young horse has been brought into a state of artificial condition and excitement by the use of the Bryony. It is one of the abominable secrets of the horsebreaker. This state of excitation, however, soon passes away, and is succeeded by temporary or permanent diminution of vital power. We have occasionally traced much mischief to this infamous practice.

Not less injurious is the Savin (Juniperus Sabina). It is well known as a vermifuge in the human subject, and it is occasionally given to the horse for the same purpose; but it is a favourite with the carter and the groom as a promoter of condition. A very great proportion of farmers' servants regard it as a drug effecting some good purpose, although they can scarcely define what that purpose is ; and there is scarcely a country stable in which it is not occasionally found, and in which the horse is not endangered, or perhaps destroyed, by its use. It is high time that the horse-master looked more carefully to this, and suffered no drug to be administered to his horses and cattle, except by his direction or that of the medical attendant. The farmer and the gentleman can scarcely conceive to what an abominable extent this vile practice prevails. The presence of savine will be best detected in the stomach of a horse that has died under suspicious circumstances, by the black-currant-leaf smell of the contents, when boiled in a little water, or beaten in a mortar.

The Common Brake (Pteris aquilina), and the Stone Fern (Pteris crispa), are violent and dangerous diuretics, and, on account of their possessing this property, are probably favourites with the horse-keeper and the groom. The diuretic influence is usually evident enough, but not the injurious effect which it has on the lining membrane of the bladder, and the predisposition to inflammation which it excites in the urinary organs. This has been too much underrated, even by those who have inquired into the subject. If the cuticular coat of the stomach is found not merely in

* Veterinarian, vol. x. p. 685.

† Abstract of the Vet. Med. Association, vol. i. p. 62. 
a state of great inflammation, but will readily peel or wash off, it must necessarily be a dangerous medicament, and should be banished entirely from the stable.*

Of the mineral poisons, it will be necessary to mention only two. Arsenic was once in great repute as a tonic and vermifuge. Doses sufficient to kill three or four men were daily administered, and generally with impunity. In some cases, however, the dose was too powerful, and the animal was destroyed. Two of the pupils of the author were attending the patients of a veterinary surgeon, who was confined in consequence of a serious accident. Among them was a valuable horse, labouring under inflammation of the lungs. The disease was subdued, and the patient was convalescent. At this period, our friend began to regain sufficient strength to travel a short distance. The first patient that he visited was this horse, whose ailments had all passed away. He could not, however, let well alone, but sent some arsenic balls. In less than a week this noble animal was taken to the knacker's. There are far better vermifuges and tonics than this dangerous drug, which will probably soon be discarded from veterinary practice.

Corrosive Sublimate is given internally, and occasionally with advantage, in farcy, and, as an external application, it is used to destroy vermin, to cure mange, and to dispose deep and fistulous ulcers to heal.

It may, however, be given in too large a dose, the symptoms of which are, loss of appetite, discharge of saliva from the mouth, pawing, looking eagerly at the flanks, rolling, profuse perspiration, thready pulse, rapid weakness, violent purging and straining, convulsions, and death.

The stomach will be found intensely inflamed, with patches of yet greater inflammation. The whole course of the intestines will be inflamed, with particular parts black and gangrenous.

The antidote, if it is not too late to administer it, would be-for arsenic, lime-water, or chalk and water, or soap and water, given in great quantities by means of the stomach-pump; and for corrosive sublimate, the white of eggs mixed with water, or thick starch, or arrow-root.

Is there really occasion for the owner of horses to be acquainted with these things? Long experience has taught the author that poisoning with these drugs is not so rare a circumstance as some imagine. In the farmer's stable, he has occasionally been compelled unwillingly to decide that the death of one or more horses has been attributable to arsenic or corrosive sublimate, and not to any peculiar disease, or to anything wrong in the manner of feeding. A scoundrel was executed in 1812, for administering arsenic and corrosive sublimate to several horses. He had been engaged in these enormities during four long years. The discarded or offended carter has wreaked his revenge in a similar way; but oftener, in his eagerness to get a more glossy coat on his horses than a rival servant could exhibit, he has tampered with these dangerous drugs.

The owner may easily detect this. "Arsenic, if mixed with charcoal and heated, emits a very perceptible smell of garlic. Sulphuretted hydrogen, added to a watery solution of arsenic, throws down a yellow precipitate-lime-water a white one-and the ammoniaco-sulphate of cupper a green one." $\dagger$

The following are the tests of corrosive sublimate:- "It is sublimed by heat, leaving no residuum, and is soluble in water, alcohol, and sulphuric ether. Lime-water gives either a lemon-yellow precipitate, or a brick-dust red one. The iodide of potash occasions a scarlet precipitate. The most curious test is, however, by means of galvanism. A drop of the suspected solution is placed on a sovereign, and a small key being brought into contact simultaneously with both the gold and the solution, an electric current is produced which decomposes the bichloride of mercury, for such it is. The chlorine unites with the iron, and the mercury with the gold."

\section{THE INTESTINES.}

'The food having been partially digested in the stomach, and converted into chyme, passes through the pyloric orifice into the intestines.

\footnotetext{
* See an acconnt of some experiments on these substances, by Mr. Cupiss, in the early numbers of "The Sportsman."

+ Manual of Pharmacy, by Professor Morton, Lecturer on Veterinary Medicine at the St. Pancras Veterinary College, p. 42.

; Ditto, page 184 .
} 


\section{CUT OF THE INTESTINES.}

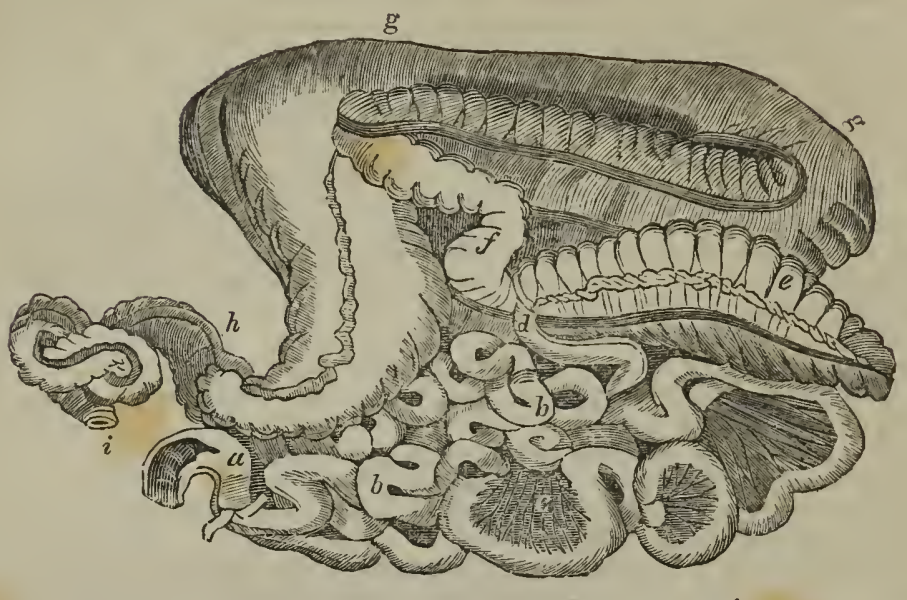

a The commencement of the small intestines. The ducts which convey the bile and the secretion from the pancreas are seen entering a little below.

$b \quad b$ The convolutions or winding of the small intestines.

$c$ A portion of the mesentery.

$d$ The small intestines, terminating in the cæcum.

$e$ The cæcum, or blind gut, with the bands running along it, puckering and dividing it into numerous cells.

$f$ The beginning of the colon.

$g \mathrm{~g}$ The continuation and expansion of the colon, divided, like the cæcum, into cells.

$h$ The termination of the colon in the rectum.

$\imath$ The termination of the rectum at the anus.

The intestines of a full-grown horse are not less than ninety feet in length. The length of the bowels in different animals depends on the nature of the food. The nutritive matter is with much more difficulty extracted from vegetable than animal substances; therefore the alimentary canal is large, long, and complicated in those which, like the horse, are principally or entirely fed on corn or herbs. They are divided into the small and large intestines; the former of which occupy about sixtysix feet, and the latter twenty-four.

The intestines, like the stomach, are composed of three coats.

The outer one consists of the peritoneum - that membrane which has been already described as investing the contents of the abdomen. By means of this coat, the intestines are confined in their proper situations; and, this membrane being smooth and moist, all friction and concussion are prevented. Did the bowels float loosely in the abdomen, they would be subject to constant entanglement and injury amid the rapid and violent motions of the horse.

The middle coat, like that of the stomach, is muscular, and composed of two layers of fibres, one running longitudinally and the other circularly; and by means of these muscles, which are continually contracting and relaxing in a direction from the upper part of the intestines to the lower, the food is propelled along the bowels.

The inner coat is the mucous or villous one. It abounds with innumerable small glands, which secrete a mucous fluid to lubricate the passage and defend it from irritating or acrimonious substances; and it is said to be villous from its soft velvetlike feeling. This coat is crowded with innumerable minute orifices that are the commencement of vessels by which the nutritive part of the food is taken up; and these vessels, uniting and passing over the mesentery, carry this rutritive matter to a proper receptacle for it, whence it is conveyed into the circulation, and distributed to every part. 
The intestines are chiefly retained in their relative positions by the mesentery, $c$ (middle of the intestines), which is a doubling of the peritoneum, including each intestine in its folds, and also inclosing in its duplicatures the arteries, the veins, the nerves, and the vessels which convey the nutriment from the intestines to the circulation.

The first of the small intestines, and commencing from the right extremity of the stomach, is the duodenum, a, a very improper name for it in the horse, for in that animal it is nearly two feet in length. It is the largest and shortest of all the small intestines. It receives the food partially converted into chyme by the digestive power of the stomach,* and in which it undergoes another and very important change; a portion of it being converted into chyle. It is here mixed with the bile and the secretion from the pancreas, which enter this intestine about five inches from its commencement. The bile seems to be the principal agent in this cliange, for no sooner does it mingle with the chyme than that fluid begins to be separated into two distinct ingredients-a white, thick liquid termed chyle, and containing the nutritive part of the food, and a yellow, pulpy substance, the innutritive portion, which, when the chyle is all pressed from it, is evacuated through the rectum.

The next portion of the small intestines is the Jejunum, so called because it is generally found to be empty. It is smaller in bulk and paler in colour than the duodenum. It is more loosely confined in the abdomen - floating comparatively unattached in the cavity of the abdomen, and the passagc of the food being comparatively rapid through it.

There is no separation or distinction betwcen it and the next intestinc-the Ilcum. There is no point at which the jejunum can be said to terminate and the ileum commence. Together they form that portion of the intestinal tube which floats in the umbilical region: the latter, however, is said to occupy three-fifths, and the former two-fifths, of this portion of the intestincs, and the five would contain about eleven gallons of fluid. 'The ileum is evidently less vascular than the jejunum, and gradually diminishes in size as it approaches the larger intestines.

These two intestines are attached to the spine by a loosc doubling of the peritoneum, and float freely in the abdominal cavity, their movements and their relative positions being regulated only by the size or fulness of the stomach, and the stagc of the digestive process. $\dagger$

The small intestines derive their blood from the anterior mesenteric artery, which dividès into innumerable minute branches that ramify between their muscular and villous coats. Their veins, which are destitute of valves, return the blood into the vena cava. The prime agent in producing all these effects is the cerebro-visceral nerve. $\neq$

The large intestincs are three in number:- the cxcum, the colon, and the reclun.

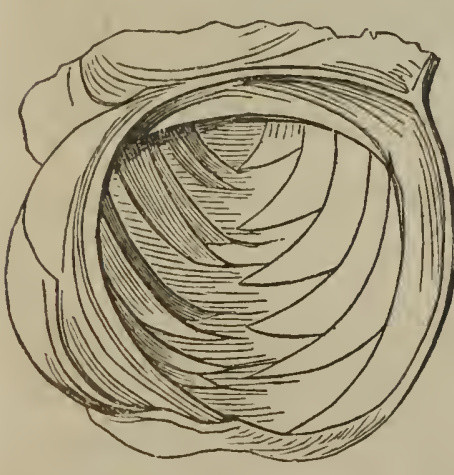
The first of them is the cxcum (blind gut), $e$, - it has but one opening into it, and consequently every thing that passes into it, having reached the blind or closed end, must return, in order to escapc. It is not a continuation of the ileum, but the ileum pierces the hcad of it, as it werc, at right angles, $(d$,$) and projects$ some way into it, and has a valre-the valvula coli - at its extremity, so that what has traversed the ileum, and entercd the head of the colon, cannot return into the ileum. Along the outside of the cæcum run thrce strong bands, each of them shorter than that intestine, and thus puckcring it up, and forming it into three sets of cells, as shown in the accompanying sidc cut.

That portion of the food which has not becn

* The conversion of food into chyme is very imperfectly performed in the stomach of the horse, on account of the smallness of that viscus, and the portion of it which is occupied by cuticle: therefore, he needs in the upper part of the duodenum a kind of second stomach, to mix up and dissolve the food. That apparatus is evident enough until we arrive at the pancreatic and biliary orifices.

+ Percivall's Anatomy of the Horse, p. 256.

$\$$ Youatt's Lectures on the Nervous System, Veterinarian, vol. vii. p. 354. 
taken up by the lacteals or absorbent vessels of the small intestines, passes through this valvular opening of the ileum, and a part of it enters the colon, while the remainder flows into the cæcum. Then, from this being a blind pouch, and from the cellular structure of this pouch, the food must be detained in it a very long time; and in order that, during this detention, all the nutriment may be extracted, the cæcum and its cells are largely. supplied with blood-vessels and absorbents. It is principally the fluid part of the food that seems to enter the crcum. A horse will drink at one time a great deal more than his stomach will contain; or even if he drinks a less quantity, it remains not in the stomach or small intestines, but passes on to the cæcum, and there is retained, as in a reservoir, to supply the wants of the system. In his state of servitude, the horse does not often drink more than twice or thrice in a day, and the food of the stabled horse being chiefly dry, this water stomach is most useful to him. The cæcum will hold four gallons.

The colon is an intestine of exceedingly large dimensions, and is capable of containing no less than twelve gallons of liquid or pulpy food. At its union with the cæcum and the ileum, although larger than the latter intestine $(f)$, it is of comparatively small bulk; but it soon swells out to an enormous extent. It has likewise, in the greater part of its course, three bands like the cacum, which also divide it, internally, into the same description of cells. The intention of this is evident, - to retard the progress of the food, and to give a more extensive surface on which the vessels of the lacteals may open; and therefore, in the colon, all the chyle is finally separated and taken up. When this is nearly accomplished, the construction of the colon is somervhat changed: we find but two bands towards the rectum, and these not puckering the intestine so much, or forming such numerous or deep cells. The food does not require to be much longer detained, and the mechanism for detaining it is gradually disappearing. The blood-vessels and absorbents are likewise rapidly diminishing. The colon, also, once more contracts in size, and the chyle having been all absorbed, the remaining mass, being of a harder consistence, is moulded into pellets or balls in its passage through these shallower cells.

At the termination of the colon, the rectum (straight gut) commences. It is smaller in circumference and capacity than the colon, although it will contain at least three gallons of water. It serves as a reservoir for the dung until it is evacuated. It has none of these bands, because, all the nutriment being extracted, the passage of the excrement that remains should be hastened and not retarded. The fæces descend to the rectum, which somewhat enlarges to receive them; and when they have accumulated to a certain extent, the animal, by the aid of the diaphragm and the muscles of the belly, presses upon them, and they are evacuated. A curious circular muscle, and always in action, called the sphincter (constrictor muscle), is placed at the anus, to prevent the constant and unpleasant dropping of the fæces, and to retain them until the horse is disposed voluntarily to expel them. This is effected by the efforts of the animal, assisted by the muscular coat of the rectum, which is stronger than that of any of the other intestines, and aided by the compression of the internal oblique and transverse muscles.

The larger intestines derive their blood from the posterior mesenteric artery. Their veins terminate ill the vena portæ.

\section{THE LIVER.}

Between the stomach and the diaphragm-its right lobe or division in contact with the diaphragm, the duodenum and the right kidney, and the middle and left divisions with the stomach-is the liver. It is an irregularly-shaped, reddish-brown substance, of considerable bulk, and performs a very singular and important office.

It has been already stated ( $p .163$ ) that the blood, which has been conveyed to the different parts of the body by the arteries, is brought back to the heart by the veins; but that which is returned from the stomach and intestines and spleen and pancreas, and mesentery, instead of flowing directly to the heart, passes first through the liver. It enters by two large vessels that spread by means of innumerable minute branches through every part of the liver. As the blood traverses this organ, a fluid is separated from it, called the bile. It is probably a kind of excrement, the continuance of which in the blood would be injurious; but while it is thrown off, another important purpose is answered-the process of digestion is promoted, by the bile changing the nutritive 
portion of the food from chyme into chyle, and separating it from that which, containing little or no nutriment, is voided as excrement.

Almost every part of it is closely invested by the peritoneum, which seems to discharge the office of a capsule to this viscus. Its arteries are very small, considering the bulk of the liver; but their place is curiously supplied by a vein - the vena portæ - a vessel formed by the union of the splenic and mesenteric veins, and which seems, if it does not quite usurp the office and discharge the duty of the artery, to be far more concerned than it in the secretion of the bile. There is a free intercouse between the vessels of the two.

There are, scattered through the substance of the liver, numerous little granules, called acini, from their resemblance to the small stones of certain berries. They are united together by a fine cellular web, whose intimate structure has never yet been satisfactorily explained. From the blood which enters the liver there is a constant secretion of a yellow bitter fluid, called bile. The separation of the bile from the blood probably takes place within the acini; the secreting vessels are the penicelli, or those which compose this fine cellular web, and the fluid - the bile - is taken up by the pori biliarii, small vessels, from which a yellowish fluid is seen exuding into whatever part of the liver we cut, and is carried by them into the main vessel, the hepatic duct.

The bile, thus formed, is in most animals received into a reservoir, the gall-bladder, whence it is conveyed into the duodenum $(g, p .221)$ at the times, and in the quantities, which the purposes of digestion require; but the horse has no gall-bladder, and, consequently, the bile flows into the intestine as rapidly as it is separated from the blood. The reason of this is plain. A small stomach was given to the horse, in order that the food might quickly pass out of it, and the diaphragm and the lungs might not be injuriously pressed upon, when we require his utmost speed, and also that we might use him with little danger compared with that which would attach to other animals, even when his stomach is distended with food. Then the stomach, so small, and so speedily emptied, must be oftener replenished; the horse must be oftener eating, and food oftener or almost continuously passing out of his stomach. How admirably does this comport with the uninterrupted supply of bile!

\section{THE PANCREAS.}

In the domestic animals which are used for food, this organ is called the sweet-bread. It lies between the stomach and left kidney. It much resembles in structure the salivary glands in the neighbourhood of the mouth, and the fluid which it secretes has been erroneously supposed to resemble the saliva in its properties. The pancreatic fluid is carried into the intestines by a duct which enters at the same aperture with that from the liver. It contains a large proportion of albumen, caseous matter, and a little free acid. Its use, whether to dilute the bile or the chyme, or to assist in the separation of the chyme from the feculent matter, has never been ascertained : it is, however, clearly employed in aiding the process of digestion.

\section{THE SPLEEN.}

This organ, often called the melt, is a long, bluish-brown substance, broad and thick at one end, and tapering at the other; lying along the left side of the stomach, and between it and the short ribs. It is of a spongy nature, divided into numerous little cells not unlike a honeycomb, and over which thousands of minute vessels thickly spread. The particular use of this organ has never been clearly ascertained, for in some cruel experiments it has been removed without apparent injury to digestion or any other function. It is, however, useful, at least occasionally, or it would not have been given to the animal. It is perhaps a reservoir or receptacle for any fluid that may be conveyed into the stomach beyond that which is sufficient for the purposes of digestion.

\section{THE OMENTUM,}

Or cawl, is a doubling of the peritoneum, or rather consists of four layers of it. It has been supposed to have been placed between the intestines and the walls of the belly, in order to prevent concussion and injury during the rapid movement of the animal. That, however, cannot he its principal use in the horse, from whom the most rapid movements are required; for in him it is unusually short, extending only 
to the pancreas and a small portion of the colon. Being, however, thus short, the horse is exempt from a very troublesome and, occasionally, fatal species of rupture, when a portion of the omentum penetrates through some accidental opening in the covering of the belly.

The structure of the urinary organs and the diseases to which they are exposed will be hereafter considered.

\section{CHAPTER X.}

\section{THE DISEASES OF THE INTESTINES.}

These form a very important and mysterious class of ailments. They will be considered in the order in which the various contents of the abdomen have been described.

\section{THE DUODENUM.}

This intestine is subject to many more diseases than are included in the present imperfect veterinary nosology. The passage of the food through it has been impeded by stricture. A singular case is related by Mr. Tombs :- "An aged horse was taken suddenly ill. He lay down, rolled upon his back, and perspired profusely, with a pulse quick and hard; presently he became sick, and the contents of the stomach were voided through the mouth and nostrils. Blood-letting, purgatives, fomentations, \&c., were resorted to, but in sixteen hours after the first attack the horse died. The stomach was distended with food, and there was a complete stricture of the duodenum, three inches posterior to the entrance of the hepatic duct. The portion of the intestine anterior to the stricture was distended, and in a gangrenous state." **

Mr. Dickens records a somewhat similar case. "A horse was attacked by apparent colic. Proper treatment was adopted, and he got seemingly well. Nine days afterwards the apparent colic returned. He threw himself down, rolled upon his back, beating his chest with his fore feet, or sitting upon his haunches like a dog. All possible remedial measures were adopted, but he died thirty-six hours after the second attack. At the distance of ten inches from the stomach was a stricture which would scarcely admit of the passage of a tobacco-pipe, and about which were marks of mechanical injury, as if from a nail or other hard substance. The anterior portion of the intestines was strangely distended." $f$

It has been perforated by bots. Mr. Brewer describes a case the symptoms of which were similar to those already related. "On examining the patient after death, the intestines were found to be altogether free from disease, except a portion of the duodenum which was perforated by bots, several of which had escaped into the abdomen. Around the aperture the duodenum was in a gangrenous state." $\neq$

The diseases of the jejunum and the ileum consist either of spasmodic affection or inflammation.

\section{SPASMODIC COLIC.}

The passage of the food through the intestinal canal is effected by the alternate contraction and relaxation of the muscular coat of the intestines. When that action is simply increased through the whole of the canal, the food passes more rapidly, and purging is produced; but the muscles of every part of the frame are liable to irregular and spasmodic action, and the muscular coat of some portion of the intestines may be thus affected. The spasm may be confined to a very small part of the canal. The gut has been found, after death, strangely contracted in various places, but the contraction not exceeding five or six inches in any of them. In the horse, the ileum is the usual seat of this disease. It is of much importance to distinguish between spasmodic colic and inflammation of the bowels, for the symptoms have considerable resemblance, although the mode of treatment should be very different.

\footnotetext{
* Veterinarian, vol. viii. p. $329 . \quad$ † Ibid. vol. x. p. $553 . \quad$ † Ibid. vol. v. p. 493.
} 
The attack of colic is usually very sudden. There is often not the slightest warning. The horse begins to shift his posture, look round at his flanks, paw violently, strike his belly with his feet, and crouch in a peculiar manner, advancing his hind limbs under him; he will then suddenly lie, or rather fall down, and balance himself upon his back, with his feet resting on his belly. The pain now seems to cease for a little while, and he gets up, and shakes himself, and begins to feed; the respite, however, is but short-the spasm returns more violently-every indication of pain is increased - he heaves at the flanks, breaks out into a profuse perspiration, and throws himself more recklessly about. In the space of an hour.or two, either the spasms begin to relax, and the remissions are of longer duration, or the torture is augmented at every paroxysm; the intervals of ease are fewer and less marked, and inflammation and death supervene. The pulse is but little affected at the commencement, but it soon becomes frequent and contracted, and at length is scarcely tangible.

It will presently be seen that many of the symptoms very closely resemble those of inflammation of the mucous membrane of the bowels: it may therefore be useful to point out the leading distinctions between them.

colic.

Sudden in its attack.

Pulse rarely much quickened in the early period of the disease, and during the intervals of ease; but evidently fuller.

Legs and ears of the natural temperature.

Relief obtained from rubbing the belly.

Relief obtained from motion.

Intervals of rest.

Strength scarcely affected.
INFLAMMATION OF THE BOWELS.

Gradual in its approach, with previous indications of fever.

Pulse very much quickened, but small, and often scarcely to be felt.

Legs and ears cold.

Belly exceedingly tender and painful to the touch.

Motion evidently increasing the pain.

Constant pain.

Rapid and great weakness.

Among the causes of colic are, the drinking of cold water when the horse is heated. There is not a surer origin of violent spasm than this. Hard water is very apt to produce this effect. Colic will sometimes follow the exposure of a horse to the cold air or a cold wind after strong exercise. Green meat, although, generally speaking, most beneficial to the horse, yet, given in too large a quantity, or when he is hot, will frequently produce gripes. Doses of aloes, both large and small, are not unfrequent causes of colic. In some horses there seems to be a constitutional predisposition to colic. They cannot be hardly worked, or exposed to unusual cold, without a fit of it. In many cases, when these horses have died, calculi have been found in some part of the alimentary canal. Habitual costiveness and the presence of calculi are frequent causes of spasmodic colic. The seat of colic is occasionally the duodenum, but oftener the ileum or the jejunum; sometimes, however, both the cæcum and colon are affected.

Fortunately, we are acquainted with several medicines that allay these spasms; and the disease often ceases almost as suddenly as it appeared. Turpentine is one of the most powerful remedies, especially in union with opium, and in good warm ale. The account that has just been given of the cæcum will not be forgotten here. A solution of aloes will be advantageously added to the turpentine and opium.

If relief is not obtained in half-an-hour, it will be prudent to bleed, for the continuance of violent spasm may produce inflammation. Some practitioners bleed at first, and it is far from bad practice; for although the majority of cases will yield to turpentine, opium, and aloes, an early bleeding may occasionally prevent the recurrence of inflammation, or at least mitigate it. If it is clearly a case of colic, half of the first dose may be repeated, with aloes dissolved in warm water. The stimulus produced on the inner surface of the bowels by the purgative may counteract the irritation that caused the spasm. The belly should be well rubbed with a brush or warm cloth, but not bruised and injured by the broom-handle rubbed over it, with all their strength, by two great fellows. The horse should be walked about, or trotted moderately. The motion thus produced in the bowels, and the friction of one intestine over the other, may relax the spasm, but the hasty gallop might speedily cause inflammation to succeed to colic. Clysters of warm water, or containing a solution of aloes, should be injected. 'The patent syringe will here be exceedingly useful. A clyster of tobaccosmoke may be thrown up as a last resort. 
When relief has been obtained, the clothing of the horse, saturated with perspiration, should be removed, and fresh and dry clothes substituted. He should be well littered down in a warm stable or box, and have bran mashes and lukewarm water for the two or three uext days.

Some persons give gin, or gin and pepper, or even spirit of pimento, in cases of gripes. This course of proceeding is, however, exceedingly objectionable. It may be useful, or even sufficient, in ordinary cases of colic; but if there should be any inflammation or tendency to inflammation, it cannot fail to be highly injurious.

\section{FLATULENT COLIC.}

This is altogether a different disease from the former. It is not spasm of the bowels, but inflation of them from the presence of gas emitted by undigested food. Whether collected in the stomach, or small or large intestines, all linds of vegetable matter are liable to ferment. In consequence of this fermentation, gas is evolved to a greater or less extent - perhaps to twenty or thirty times the bulk of the food. This may take place in the stomach; and if so, the life of the horse is in immediate danger, for, as will plainly appear from the account that has been given of the osophagus and upper orifice of the stomach, the animal has no power to expel this dangerous flatus by eructation.

This extrication of gas usually takes place in the colon and cæcum, and the distention may be so great as to rupture either the one or the other, or sometimes to produce death, without either rupture or strangulation, and that in the course of from four to twenty-four hours.

In some ill-conducted establishments, and far oftener on the north than the south of the Tweed, it is a highly dangerous disease, and is especially fatal to horses of heavy draught. An overloaded stomach is one cause of it, and particularly so when water is given either immediately before or after a plentiful meal, or food to which the horse has not been accustomed is given.

The symptoms, according to Professor Stewart, are, "the horse suddenly slackening his pace-preparing to lie down, or falling down as if he were shot. In the stable he paws the ground with his fore feet, lies down, rolls, starts up all at once, and throws himself down again with great violence, looking wistfully at his flanks, and making many fruitless attempts to void his urine."

Hitherto the symptoms are not much unlike spasmodic colic, but the real character of the disease soon begins to develope itself. It is in one of the large intestines, and the belly swells all round, but mostly on the right flank. As the disease proceeds, the pain becomes more intense, the horse more violent, and at length death closes the scene.

The treatment is considerably different from that of spasmodic colic. The spirit of pimento would be here allowed, or the turpentine and opium drink; but if the pain, and especially the swelling, do not abate, the gas, which is the cause of it, must be be got rid of, or the animal is inevitably lost.

This is usually or almost invariably a combination of hydrogen with some other gas. It has a strong affinity for chlorine. Then if some compound of chlorine-the chloride of lime-dissolved in water, is administered in the form of a drink, the chlorine separates from the lime as soon as it comes into contact with the hydrogen, and muriatic gas is formed. This gas having a strong affinity for water, is absorbed by any fluid that may be present, and, quitting its gaseous form, either disappears, or does not retain a thousandth part of its former bulk. All this may be very mpidly accomplished, for the fluid is quickly conveyed from the mouth to every part of the intestinal canal.

Where these two medicines are not at hand, and the danger is imminent, the trochar may be used, in order to open a way for the escape of the gas. The trochar should be small but longer than that which is used for the cow, and the puncture should be made in the middle of the right flank, for there the large intestines are most easily reached. In such a disease it cannot be expected that the intestines shall always be found precisely in their natural situations, but usually the origin of the ascending portion of the colon, or the base of the cæcum, will be pierced. The author of this work, however, deems it his dnty to add, that it is only when the practitioner despairs of otherwise saving the life of the animal that this operation should be attempted. Much of the danger would be avoided by using a very small trochar, and by withdrawing 
it as soon as the gas has escaped. The wound in the intestines will then probably close, from the innate elasticity of the parts.

\section{INFLAMMATION OF THE BOWELS.}

There are two varieties of this malady. The first is inflammation of the external coats of the intestines, accompanied by considerable fever, and usually costiveness. 'The sccond is that of the internal or mucous coat, and almost invariably connected with purging.

\section{ENTERITIS.}

The muscular coat is that which is oftenest affected. Inflammation of the external coats of the stomach, whether the peritoneal or muscular, or both, is a very frequent and fatal diseasc. It speedily runs its course, and it is of great consequence that its early symptoms should be known. If the horse has been carefully observed, restlessness and fever will have been seen to precede the attack. In many cases a direct shivcring fit will occur: the mouth will be hot, and the nose red. The animal will soon express the most dreadful pain by pawing, striking at his belly, looking wildly at his flanks, groaning, and rolling. The pulse will be quickened and small; the ears and legs cold; the belly tender, and sometimes hot; the breathing quickened; the bowcls costive; and the animal becoming rapidly and fearfully weak.

The reader will probably here recur to the sketch given in page 233 of the distinction between spasmodic colic and inflammation of the bowels, or enteritis.

The causes of this disease are, first of all and most frequently, sudden exposure to cold. If a horse that has been highly fed, carefully groomed, and kept in a warm stable, is heated with exercise, and has been during some hours without food, and in this state of exhaustion is suffered to drink freely of cold water, or is drenched with rain, or have his legs and belly washed with cold water, an attack of inflammation of the bowcls will often follow. An overfed horse, subjected to severe and longcontinued exertion, if his lungs were previously weak, will probably be attacked by inflammation of them; but if the lungs were sound, the bowels will on the following day be the seat of disease. Stones in the intestines are an occasional cause of inflammation, and colic neglected or wrongly treated will terminate in it.

The horse paws and stamps as in colic, but without the intervals of ease that occur in that disease. The pulse also is far quicker than in colic. The breathing is more hurried, and the indication of suffering morc cvident. "The next stagc," in the graphic language of Mr. Percivall, "borders on delirium. 'The eye acquires a wild, haggard, unnatural stare-the pupil dilates-his heedless and dreadful throes render approach to him quite perilous. He is an object not only of compassion but of apprehension, and seems fast hurrying to his end; when, all at once, in the midst of agonising torments, he stands quict, as though every pain had left him, and he were going to recover. His breathing becomes tranquillised - his pulse sunk beyond all perception - lis body bedewed with a cold clammy sweat-he is in a tremour from head to foot, and about the legs and ears has even a death-like feel. The mouth feels deadly chill; the lips drop pendulous; and the eye seems unconscious of objects. In fine, death, not recovery, is at hand. Mortification has seized the inflamed bowcl pain can no longer be felt in that which a few minutes ago was the seat of exquisite suffering. He again bccomes convulsed, and in a few more struggles less violent than the former he expires."*

'The treatment of inflammation of the bowels, like that of the lungs, should be prompt and encrgetic. 'The first and most powerful means of cure will be bleeding. From six to eight or ten quarts of blood, in fact as much as the horse can bear, should be abstracted as sonn as possiblc; and the bleeding repeated to the extent of four or five quarts more, if the pain is not relicved and the pulse has not become rounder and fuller. The speedy weakness that accompanics this disease should not deter from bleeding largely. 'That weakness is the consequence of violent inflammation of these parts; and if that inflammation is subdued by the loss of blood, the weakness will disappear. The bleeding should be effected on the first appearance of the disease, for there is no malady that more quickly runs its course.

\footnotetext{
* Percivall's Hippopathology, vol. ü. p. 246.
} 
A strong solution of aloes should immediately follow the bleeding, but, considering the irritable state of the intestines at this period, guarded by opium. This should be quickly followed by back-raking, and injections consisting of warm water, or very thin gruel, in which Epsom salts or aloes have been dissolved; and too much fluid can scarcely be thrown up. If the common ox-bladder and pipe is used, it should be frequently replenished; but with Read's patent pump, already referred to, sufficient may be injected to penetrate beyond the rectum, and reach to the colon and cæcum, and dispose them to evacuate their contents. The horse should likewise be encouraged to drink plentifully of warm water or thin gruel; and draughts, each containing a couple of drachms of dissolved aloes, with a little opium, should be given every six hours, until the bowels are freely opened.

It will now be prudent to endeavour to excite considerable external inflammation as near as possible to the seat of internal disease, and therefore the whole of the belly should be blistered. In a well-marked case of this disease, no time should be lost in applying fomentations, but the blister at once resorted to. The tincture of Spanish flies, whether made with spirit of wine or turpentine, should be thoroughly rubbed in. The legs should be well bandaged in order to restore the circulation in them, and thus lessen the flow of blood to the inflamed part; and, for the same reason, the horse should be warmly clothed; but the air of the stable or box should be cool.

No corn or hay should be allowed during the disease, but bran mashes, and green meat if it can be procured. The latter will be the best of all food, and may be given without the slightest apprehension of danger. When the horse begins to recover, a handful of corn may be given two or three times in the day; and, if the weather is warm, he may be turned into a paddock for a few hours in the middle of the day. Clysters of gruel should be continued for three or four days after the inflammation is beginning to subside, and good hand-rubbing applied to the legs.

The second variety of inflammation of the bowels affects the internal or mucous coat, and is generally the consequence of physic in too great quantity, or of an improper kind. The purging is more violent and continues longer than was intended; the animal shows that he is suffering great pain; he frequently looks round at his flanks; his breathing is laborious, and the pulse is quick and small - not so small, however, as in inflammation of the peritoneal coat, and, contrary to some of the most frequent and characteristic symptoms of that disease, the moutl is hot and the legs and ears are warm. Unless the purging is excessive, and the pain and distress great, the surgeon should hesitate at giving any astringent medicine at first; but he should plentifully administer gruel or thin starch, or arrow-root, by the mouth and by clyster, removing all hay and corn, and particularly green meat. He should thus endeavour to soothe the irritated surface of the bowels, while he permits all remains of the purgative to be carried off. If, however, twelve hours have passed, and the purging and the pain remain undiminished, he should continue the gruel, adding to it chalk, catechu, and opium, repeated every six hours. As soon as the purging begins to subside, the astringent medicine should be lessened in quantity, and gradually discontinued. Bleeding will rarely be necessary, unless the inflammation is very great, and attended by symptoms of general fever. The horse should be warmly clothed, and placed in a comfortable stable, and his legs should be hand-rubbed and bandaged.

Violent purging, and attended with much inflammation and fever, will occur from cther causes. Green meat will frequently purge. A horse worked hard upon green meat will sometimes scour. The remedy is change of diet, or less labour. Young horses will often be strongly purged, without any apparent cause. Astringents should be used with much caution here. It is probably an effort of nature to get rid of something that offends. A few doses of gruel will assist in effecting this purpose, and the purging will cease without astringent medicine.

Many horses that are not well-ribbed home-having too great space between the last rib and the hip-bone-are subject to purging if more than usual exertion is required from them. They are recognised by the term of washy horses. They are often free and fleet, but destitute of continuance. They should have rather more than the usual allowance of corn, with beans, when at work. A cordial ball, with catechu and opium, will often be serviceable either before or after a journey. 


\section{PHYSICKING.}

This would seem to be the proper place to speak of physicking horses-a mode of treatment necessary under various diseases, often useful for the augmentation of health, and yet which has often injured the constitution and absolutely destroyed thousands of animals. When a horse comes from grass to hard meat, or from the cool, open air to a heated stable, a dose or even two doses of physic may be useful to prevent the tendency to inflammation which is the necessary consequence of so sudden and great a change. 'To a horse that is becoming too fat, or has surfeit, or grease, or inange, or that is out of condition from inactivity of the digestive organs, a dose of physic is often most serviceable ; but the reflecting man will enter his protest against the periodical physicking of all horses in the spring and the autumn, and more particularly against that severe system which is thought to be necessary in order to train them for work, and also the absurd method of treating the animal when under the operation of physic.

A horse should be carefully prepared for the action of physic. Two or three bran mashes given on that or the preceding day are far from sufficient when a horse is about to be physicked whether to promote his condition or in obedience to custom. Alashes should be given until the dung becomes softened. A less quantity of physic will then suffice, and it will more quickly pass through the intestines, and be more readily diffused over them. Five drachms of aloes, given when the dung has thus been softened, will act much more effectually and much more safely than seven drachms, when the lower intestines, are obstructed by hardened fæces.

On the day on which the physic is given, the horse should have walling exercise, or may be gently trotted for a quarter of an hour twice in the day ; but after the physic begins to work, he should not be moved from his stall. Exercise would then produce gripes, irritation, and, possibly, dangerous inflammation. The common and absurd practice is to give the horse most exercise after the physic has begun to operate.

$\Lambda$ little hay may be put into the rack. As much mash should be given as the horse will eat, and as much water, with the coldness of it taken off, as he will drink. If, however, he obstinately refuses to drink warm water, it is better that he should have it cold, than to continue without taking any fluid; but in such case he should not be suffered to take more than a quart at a time, with an interval of at least an hour between each draught.

When the purging has ceascd, or the physic is set, a mash should be given once or twice every day until the next dose is taken, bctween which and the setting of the first therc should bc an interval of a week. 'The horse should recover from the languor and debility occasioned by the first dose, before he is harassed by a second.

Eight or ten tolerably copious motions will be perfectly sufficient to answer every good purpose, although the groom or the carter may not be satisfied unless double the quantity are procured. The consequence of too strong purgation will be, that wcakness will hang about the animal for several days or weeks, and inflammation will often ensue from the over-irritation of the intestinal canal.

Long-continued custom has made ALOES the almost invariable purgative of the horse, and very properly so; for there is no other at once so sure and so safe. The Barbadocs aloes, although sometimes very dear, should alone be used. The dose, with a horse properly prepared, will vary from four to seven drachms. The preposterous doses of nine, ten, or even twelve drachms, are now, happily for the horse, generally abandoned. Custom has assigned the form of a ball to physic, but good sense will in due time introduce the solution of aloes, as acting more speedily, effectually, and safely.

The only other purgative on which dependence can be placed is the croton. The farina or meal of the nut is generally used; but from its acrimony it should be giren in the form of ball, with linseed meal. The dose varies from a scruple to half a drachm. It acts more speedily than the aloes, and without the nausea which they produce; but it causes more watery stools, and, consequently, more debility.

LINSEED-01L is an uncertain but safe purgative, in doses from a pound to a pound and a half. OLIVE-olL is more uncertain, but safe; but CASTOR-OlL, that mild apericnt in the human being, is both uncertain and unsafe. Epsom-salts are inefficacious, except in the immense dose of a pound and a half, and then they are not always safe. 


\section{CALCULI, OR STONES, IN THE INTESTINES.}

These are a cause of inflammation in the bowels of the horse, and more frequently of colic. They are generally found in the cœecum or colon, varying considerably in shape according to the nucleus round which the sabulous or other earthy matter collects, or the form of the cell in which they have been lodged. They differ in size and weight, from a few grains to several pounds. From the horizontal position of the carcase of the horse, the calculus, when it begins to form, does not gravitate so much as in the human being, and therefore calculous concretions remain and accumulate until their very size prevents their expulsion, and a fatal irritation is too frequently produced by their motion and weight. They are oftenest found in heavy draught, and in millers' horses. In some of these horses they have the appearance of grit-stone or crystallized gneiss. It is probable that they partly consist of these very minerals, combined with the bran which is continually floating about. An analysis of the Calculi favours this supposition. They are a source of continual irritation wherever they are placed, and are a fruitful cause of colic. Spasms of the most fearful kind have been clearly traced to them.*

Professor Morton, of the Royal Veterinary College, in his Essay on Calculous Concretions, - a work that is far too valuable to be withdrawn from the public view, -gives an interesting account of these substances in the intestinal canal of the horse. Little advance has been or can be made to procure their expulsion, or even to determine their existence; and even when they have passed into the rectum, although some have been expelled, others have been so firmly impacted as to resist all medicinal means of withdrawal, and a few have broken their way through the parietes of the rectum, and lodged in the abdominal cavity. Mr. Percivall, in his "Elementary Lectures on the Veterinary Art," has recorded several fearful cases of this. $\dagger$

Other concretions are described under the title of oat-hair calculi. Their surface is tuberculated and their forms irregular. They are usually without any distinct nuclei, and are principally composed of the hairy fibrous matter which enters into the composition of the oat. The professor very properly adds, and it is a circumstance which deserves much consideration, that such oats as are husky, with a deficiency of farinaceous matter, are likely to give rise to these accumulations, whenever impaired digestion exists. It is also an undoubted fact, that a great proportion of horses affected with calculi are the property of millers, or brewers. A third species of concretion too frequently existing is the dung-ball, or mixed calculus. It is made up of coarse, indigestible, excrementitious matter, mixed with portions of the "oat-hair calculus," and many foreign substances, such as pieces of coal, gravel, \&c., and the whole agglutinated together. They are commonly met with in horses that are voracious feeders, and mingled with particles of coal and stone.

\section{INTROSUSCEPTION OF THE INTESTINES.}

The spasmodic action of the ileum being long continued, may be succeeded by an inverted one from the cœcum towards the stomach, more powerful than in the natural direction; and the contracted portion of the intestine will be thus forced into another above it that retains its natural calibre. The irritation caused by this increases the inverted action, and an obstruction is formed which no power can overcome. Even the natural motion of the bowels will be sufficient to produce introsusception, when the contraction of a portion of the ileum is very great. There are no symptoms to indicate the presence of this, except continued and increasing pain; or, if there were, all our means of relief would here fail.

Introsusception is not confined to any particular situation. A portion of the jejunum has been found invaginated within the duodenum, - and also within the ileum, and the ileum within the cœcum-and one portion of the colon within another, and within the rectum. The ileum and jejunum are occasionally invaginated in various places. More than a dozen distinct cases of introsusception have occurred in one animal, and sometimes unconnected with any appearance of inflammation; but in other cases, or in other parts of the intestinal canal of the same animal, there will be inflammation of the most intense character. In the majority of cases, perhaps it is an accidental 
consequence of pre-existing disease, and occasioned by some irregular action of the muscular tunic, or some irritation of the mucous surface.

A more formidable, but not so frequent disease is

\section{ENTANGLEMENT OF THE BOWELS.}

This is another and singular consequence of colic. Although the ileum is enveloped in the mesentery, and its motion to a considerable degree confined, yet under the spasm of colic, and during the violence with which the animal rolls and throws himself about, portions of the intestine become so entangled as to be twisted into nooses and knots, drawn together with a degree of tightness scarcely credible. Nothing but the extreme and continued torture of the animal can lead us to suspect that this has taken place, and, could we ascertain its existence, there would be no cure.

An interesting case occurred in the practice of Mr. Spooner of Southampton. A mare at grass was suddenly taken ill. She discovered symptoms of violent colic, for which anti-spasmodic and aperient medicines were promptly administered, and she was copiously bled. The most active treatment was had recourse to, but without avail, and she died in less than four-and-twenty hours without a momentary relief from pain.

The small intestines were completely black from inflammation, and portions of them were knotted together in the singular way delineated in this cut. The parts are a little loosened in order better to show the entanglement of the intestines, but in the a nimal they were drawn into a tight knot, and completely intercepted all passage.

The cause of this was probably some acrid principle in the grass, and many a horse is thus destroyed by the abominable and poisonous drinks of the farrier.*

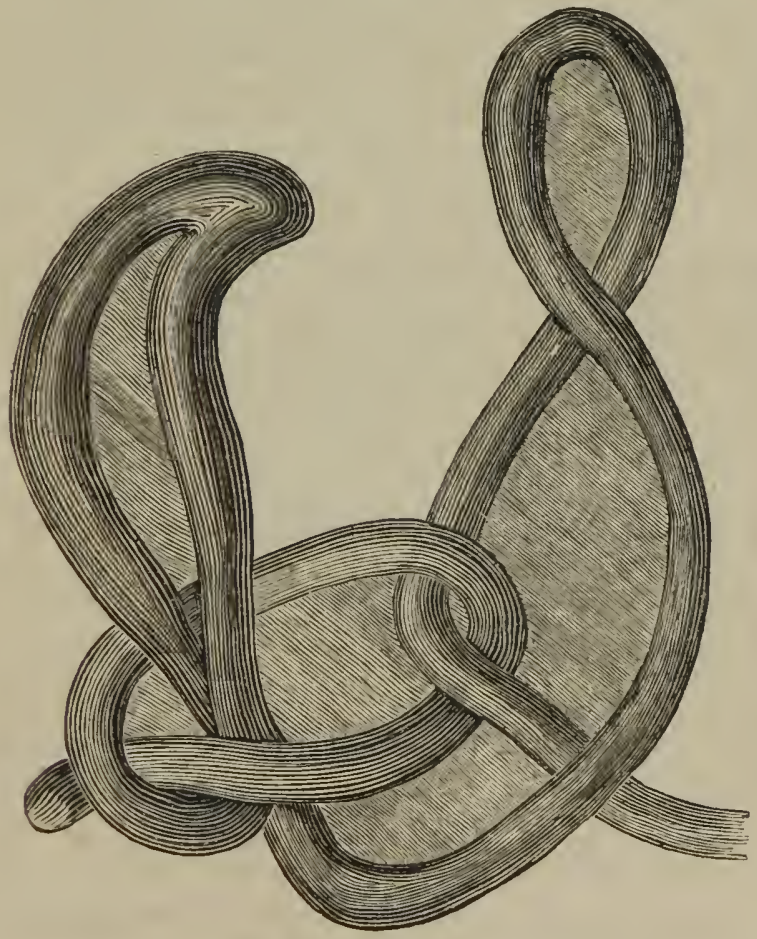

WORMS.

Worms of different kinds inhabit the intestines; but, except when they exist in very great numbers, they are not so hurtful as is generally supposed, although the

* Veterinarian, VI. 12. 
groom or carter may trace to them, hidcbound, and cough, and loss of appetite, and gripes, and megrims, and a variety of otlier ailments. Of the origin, or mode of propagation of these parasitical animals, we can say little; neither writers on medicine, nor even on natural history, have given us any satisfactory account of the matter.

The long white worm (lumbricus teres) much resembles the common carth-worm, and, being from six to ten irches in length, inhabits the small intestines. It is a formidable looking animal; and if there are many of them, they may consume more than can be spared of the nutritive part of the food, or the mucus of the bowels. A tight skin, and rough coat, and tucked-up belly, are somctimes connected with their presence. They are then, howcver, voided in large quantities. A dose of physic will sometimes bring away almost incredible quantities of them. Calomel is frequently given as a vermifugc. The seldomer this drug is administered to the horse the better. It is the principal ingredient, in some quack medicines, for the expulsion of worms in the human subject, and thence, perhaps, it came to be used for the horse; but in him we believe it to be inert as a vermifuge, or only uscful as quickening the operation of the aloes. When the horse can be spared, a strong dose of physic is an cxcellent vermifuge, so far as the long round worm is concerned; but a better medicine, and not interfering with either the feeding or work of the horse, is emetic tartar, with ginger, made into a ball with linseed meal and treacle, and given every morning, half an hour before the horse is fed.

A smaller, darker-coloured worm, called the needle-worm, or ascaris, inhabits the large intestines. Hundreds of them sometimes descend into the rectum, and immense quantities have been found in the cœcum. These are a more serious nuisance than the former, for they cause a very troublesome irritation about the fundament, which sometimes sadly annoys the horse. Their existence can generally be discovered by a small portion of mucus, which, hardening, is found adhering to the anus. Physic will sometimes bring away grcat numbers of thesc worms; but when there is much irritation about the tail, and much of this mucus, indicating that they have descended into the rectum, an injection of linsecd oil, or of aloes dissolved in warm water, will be a more effectual remedy.

The tape-worm is seldom found in the horse.

\section{HERNIA, OR RUPTURE.}

A portion of the intestine protrudes out of the cavity of the belly, either through some natural or artificial opcning. In some cases it may be returned, but, from the impossibility of applying a truss or bandage, it soon escapes again. At other times, the opening is so narrow, that the gut, gradually distended by fæces, or thickened by inflammation, cannot be returned, and sirangulated hernia is then said to exist. The seat of hernia is either in the scrotum of the perfect horse, or the groin of the gelding. 'The causes are violent struggling when under operations, over-exertion, kicks, or accidents. The assistance of a veterinary surgeon is here indispensablc.*

* The following case of operation for hernia will be acceptable to the owner of horses as well as to the veterinary surgcon. It occurred in the practice of Professor Simonds, of the Royal Veterinary Colllege. We borrow his account of it from "The Veterinarian."

"The patient was an aged black cart-mare, that had been lent by the owner to a neighbour for a day or two. I cannot speak positively as to the cause of the injury which she received, but I believe that it resultcd from her falling in the shafts of a cart laden with manure. Shc was brought to my infirmary on the next dny, October $18,1837$.

"The most extensive rupture I had ever seen presonted itself on the left side. The sac formcd by the skin, which was not broken, nor even the hair rubbed off, extended as far forwards as the cartilages of the false ribs, and backwards to the udder. A perpendicular line drawn from the superior to the inferior part of the tumour measured more than twelve inclies. It appeared, from its immense size and weight, as if by far the larger part of the colon had protruded.

To my surprise, there was comparatively littlc constitutional disturbance. The pulse was 45 , and full, with no other indication of fever, and no expression of pain on pressing the tumour.

"She was bled until the pulse was considerably lowered. A cathartic was given, and the sac ordered to be kept constantly wet with cold water, and to be supported by a wide band. age. She was placed on a restricted and mash diet.

"On the next day, bcing honoured with a visit by Messrs. Morton, Spooncr, and Youatt, I had the plcasure and advantage of submitting the case to their examination, and obtaining their opinion. They urged me to attempt to return the protruding viscera, and secure them by 


\section{DISEASES OF THE LIVER.}

As veterinary practice has improved, much light has been thrown on the diseases of the liver - not perhaps on the more advanced and fatal stages; but giving us the promise that, in process of time, they may be detected at an earlier period, and in a more manageable state.

a surgical operation; and Mr. Spooner kindly offered to be present, and to give me his valuable assistance.

"On the 24th, our patient was considered to have had sufficient preparatory treatment, and she was operated upon. WVe availed ourselves of the opportunity of putting to the test that which some among us had doubted, and others had positively denied, but which had always becn maintained by our talented chemical lecturer- ihe power of opium to lull the sensation of pain in the horse. We therefore gave her two ounces and a half of the tincture of opium, shortly before she was led from the box to the operating house, and the power of the drug was evident through the whole of the operation.

"After a careful examination, externally, as wcll as per rectum, in order to ascertain the situation and probable size of the laceration of the muscles, an incision was earefully made through the intcgument into the sac, in a line with the inferior border of the cartilage of the false ribs, which incision was about seven inches in length. This, as we had hoped, proved to be directly upon the aperture in the muscular parietes of the abdomen. The intestines wcre exposed; and, after having sufficiently dilated the opening to permit the introduction of the hand, they were quickly returned, porion after portion, into their proper cavity, together with a part of the omentum, which we found soméwhat annoying, it being frequently forced back again through the laceration.

"At times, it required the exertion of our united strength to prevent the cscape of the intestines, and which was only effected by placing our hands side by side, covering and pressing upon the opening. By these means we succeeded in kecping in the viscera, until we were satisfied that wc had placed them all within their proper cavity. At about the cclltral part of the aperturc, we decidedly found the grcatest pressure of the intestines to effeet an escape.

"A strong metallic suture of flexible wire was then passed through the cdges of the laceration, taking in the peritoneum and portions of the transversalis, rectus, and internal abdominal muscles; and other suturcs, embracing the same parts, were placed at convenient dis. tances, so as nearly to close the aperture. Two sutures of smaller mctallic wire, and three of stont silk cord, wcre then passed through the external abdominal muscles, and their aponeuroses, which effectually shut up the opcning into the abdomen. The integument was then brought together by the interrupted suture, taking care to bring out the ends of the other sutures, and which had been purposely left long, so that in case of supervening inflam. mation, or swelling, they might be readily examined. The whole operation occupied rather less than an hour, our poor patient being occasionally refreshcd with some warm grucl.

"The hobbles were now quietly removed, and, after lying a few minutes, she got up, and was placed in a large loose box. A compress and a suspensory bandage, that could be tightened at pleasure, were applied to the wound. The pulse was now 84 . She was ordercd to be watchcd, and to have some tepid water placed within her reach, but on no account to be disturbed.

"At 10, P. M., the pulse had sunk to 66 . The respiration, which had been much accelerated, was quieter. She was resting the leg on the side operated upon, but did not appear to be suffering any great pain. Some faccs had passed, and she had taken a small quantity of bran mash. The parts were well fomented with tepid water, an oleaginous draught was administered, and likewise an enema.

" 25 th. - The pulse is a little guickened; the sac which had contained the protruded intestine was filled with a serous effusion. I made a dependent orifice in it, and from three to four pints of fluid cscaped. This much relieved her, and she continued to go on favourably throughout the day.

"26th. -Suppuration now began to be cstablished, and the parts were dressed with the compound tincture of myrrh.

"30th. - She was enabled to take a little walking exercise; and on this day some of the intcgumental sutures came away.

"Nov. 4th.-The sloughing process being now set up, three of the smaller metallic sutures, that had been used to bring the edges of the laceretion together in the external abdominal muscles, came away. The parts were minutely examined, and we detected a sinus running towards the mammæ, and filled with pus. With some little difficulty it was opened, and a tape passed through it, so as to allow the pus to escape as quickly as it was formcd. The appetite was tolerably good, and the pulse ranged from 52 to 56 .

" 6 th. - The patient was so far recovered that I ventured to turn her into one of the paddocks for a few hours' excrcise, taking carc to avoid any cxposure to cold, if the wcather was stormy.

"11th.-An incident óccurred which nearly brought our hitherto successful case to a fatal termination. I saw her safe about 1, P. M.; but at two o'clock a messenger came in haste to apprise me that she was in a pond at the botton of the paddock, and fixed in the mud. 
If horses, destroyed on account of other complaints, are examined when they are not more than five years old, the liver is usually found in the most heal thy state; but when they arrive at eight or nine, or ten years, this viscus is frequently increased in size-it is less elastic under pressure-it has assumed more of a granulated or brokendown appearance - the blood does not so readily permeate its vessels, and, at length, in a greater or less quantity, it begins to exude, and is either confined under the peritoneal covering, or oozes into the cavity of the belly. There is nothing, for awhile, to indicate the existence of this. The horse feeds well, is in apparent health, in good condition, and capable of constant work, notwithstanding so fatal a change is taking place in this important viscus; but, at length, the peritoneal covering of the liver suddenly gives way, and the contents of the abdomen are deluged with blood, or a sufficient quantity of this fluid has gradually oozed out to interfere with the functions of the viscera.

The symptoms of this sudden change are-pawing, shifting the posture, distension of the belly, curling of the upper lip, sighing frequently and deeply, the mouth and nostrils pale and blanched, the breathing quickened, restlessness, debility, fainting, and death.

On opening the abdomen, the intestines are found to be deluged with dark venous blood. The liver is either of a fawn, or light yellow, or brown colour - easily torn by the finger, and, in some cases, completely broken down.

If the hæmorrhage has been slight at the commencement, and fortunately arrested, yet a singular consequence will frequently result. The sight will gradually fail; the pupil of one or both eyes will gradually dilate, the animal will have gutta serena, and become perfectly blind. This will almost assuredly take place on a return of the affection of the liver. Little can be done in a medical point of view. Astringent and styptic medicines may, however, be tried. Turpentine, alum, or sulphuric acid, will afford the only chance. The veterinary world is indebted to the late Mr. John Field for almost all that is known of this sad disease.

\section{JAUNDICE,}

Commonly called THE Yellows, is a more frequent, but more tractable disease. It is the introduction of bile into the general circulation. This is usually caused by

There, indeed, I found her, at a considerable distance from the bank, and making the most violent efforts to release herself. With considerable difficulty, and after many unsuccessful attempts, we succeeded in dragging her ashore, so much exhaustcd as to be utterly incapable of rising. A gate was procured, and being well covered with straw, she was drawn homeward by two horses; I following, regretting what had occurred, and not a little blaming myself for having exposed her to this misfortune.

"Having placed her in her box, our first object was her restoration and comfort. Men were set to work to rub her perfectly dry, and some warm gruel, with a little cordial medicine, was given. The state of the wound was next examined, and it was well cleaned with tepid water. It was very dark-coloured. The vitality of the young granulations was apparently destroyed, and it emitted, in some degree, perhaps from the mud which had been so long in contact with it, an offensive effluvium. It was well dressed with the spirit of nitrous ether, and properly bandaged-in order to prevent its receiving any further injury in her ineffectual attempts to rise.

"We soon, however, began to fear some ill consequence from the continuance of these efforts, and we determined to raise her with the slings, those useful appendages to every vete. rinary establishment. This was soon effected. We allowed very little bearing on the abdomen, except when she was compelled, in order to ease her hind extremities, which were yet unable to support their share of the weight of the body. Frictions, stimulants, and bandages, were applied to the extremities. An enema was given, the wound again attended to, and some gruel placed within her reach.

"At midnight she was standing at ease in what may not inappropriately be called her cradle. The legs were tolerably warm: the pulse 60 , and full; the enema had done its duty, and she was in a much more comfortable state than I had any right to expect. I ordered her a warm mash and some gruel, for hope began once more to cheer me.

"On the following and succeeding days she continued gradually to regain her strength, but she required great care and attention, and it was not until the expiration of the fourth day that I dared to remove her from the slings, and then only for a few hours during the day, carefully replacing her in them at night. Some slight sloughing took place from the wound; but the principal effect of her immersion was a severe catarrh. She required occasional attendance to the wound; and it was not until the 12th of January-more than twelve weeks after the operation - that the last of the metallic sutures came away. She soon afterwards returned to her usual work." 
THE KIDNEYS.

some obstruction in the ducts or tubes that convey the bile from the liver to the intestines. The horse, however, has but one duct, through which the bile usually flows as quickly as it is formed, and there is no gall-bladder in which it can become thickened, or hardened into masses so firm as to be appropriately called gall-stones. Jaundice does, however, occasionally appear either from an increased flow or altered quality of the bile, or obstruction even in this simple tube. The yellowness of the eyes and mouth, and of the skin where it is not covered with hair, mark it sufficiently plainly. The dung is small and hard; the urine highly coloured; the horse languid, and the appetite impaired. If he is not soon relieved, he sometimes begins to express considerable uneasiness; at other times he is dull, heavy, and stupid. A characteristic symptom is lameness of the right fore leg, resembling the pain in the right shoulder of the human being in hepatic affections. The principal causes are overfeeding or over-exertion in sultry weather, or too little work generally speaking, or inflammation or other disease of the liver itself.

It is first necessary to inquire whether this affection of the liver is not the consequence of the sympathy of that organ with some other part, for, to a very considerable degree, it frequently accompanies inflammation of the bowels and the lungs. These diseases being subdued, jaundice will disappear. If there is no other apparent disease to any great extent, an endeavour to restore the natural passage of the bile by purgatives may be tried, not consisting of large doses, lest there should be some undetected inflammation of the lungs or bowels, in either of which a strong purgative would be dangerous; but, given in small quantities, repeated at short intervals, and until the bowels are freely opened. Bleeding should alivays be resorted to, regulated according to the apparent degree of inflammation, and the occasional stupor of the animal. Plenty of water slightly warmed, or thin gruel, should be given. The horse should be warmly clothed, and the stable well ventilated, but not cold. Carrots or green meat will be very beneficial. Should the purging, when once excited, prove violent, we need not be in any haste to stop it, unless inflammation is beginning to be connected with it, or the horse is very weak. The medicine recommended under diarrhoea may then be exhibited. A few slight tonics should be given when the horse is recovering from an attack of jaundice.

The Spleen is sometimes very extraordinarily enlarged, and has been ruptured. We are not aware of any means by which this may be discovered, except manual examination by means or the aid of the rectum. The state of the animal would clearly enough point out the treatment to be adopted.

The Pancreas. We know not of any disease to which it is liable.

The blood contains a great quantity of watery fluid unnecessary for the nutriment or repair of the frame. There likewise mingle with it matters that would be noxious if suffered to accumulate too much.

\section{THE KIDNEYS}

Are actively employed in separating this fluid, and likewise carrying off a substance which constitutes the peculiar ingredient in urine, called the urea, and consisting principally of that which would be poisonous to the animal. The kidneys are two large glandular bodies, placed under the loins, of the shape of a kidney-bean, of immense size. The right kidney is most forward, lying under the liver; the left is pushed more backward by the stomach and spleen. A large artery runs to each, carrying not less than a sixth part of the whole of the blood that circulates through the frame. This artery is divided into innumerable little branches most curiously complicated and coiled upon each other; and the blood, traversing these convolutions, has its watery parts, and others the retaining of which would be injurious, separated from it.

The fluid thus separated varies materially both in quantity and composition, even during health. There is no animal in which it varies so much as in the horse, - there is no organ in that animal so much under our command as the kidney ; and no medicines are so useful, or may be so injurious, as diuretics-such as nitre, and digitalisnot only on account of their febrifuge or sedative effects, but because of the power which they exert. They stimulate the kidneys to separate more aqueous fluid than they otherwise would do, and thus lessen the quantity of blood which the heart is labouring to circulate through the frame, and also that which is determined or driven to parts already overloaded. The main objects to be accomplished in these diseases is to reduce the force of the circulation, and to calm the violence of excitement. Diu- 
retics, by lessening the quantity of blood, are uscful assistants in accomplishing these purposes.

The horse is subject to effusions of fluid in particular parts. Swelled legs are a disease almost peculiar to him. The ox, the sheep, the dog, the ass, and cven the mule, seldom have it, but it is for the removal of this deposit of fluid in the cellular substance of the legs of the horse that we have recourse to diuretics. 'The legs of many horses cannot be rendered fine, or kept so, without the use of diuretics; nor can grease-often connected with these swellings, producing them or caused by them -be otherwise subdued. It is on this account that diuretics are ranked among the most useful of veterinary medicines.

In injudicious hands, however, these medicines are sadly abused. Among the absurdities of stable-management there is nothing so injurious as the frequent use of diuretics. Not only are the kidneys often over-excited, weakened, and disposed to disease, but the whole frame becomes debilitated; for the absorbents have carried away a great part of that which was necessary to the health and condition of the horse, in order to supply the deficiency of blood occasioned by the inordinate discharge of urinc. There is likewise one important fact of which the groom or the horseman seldom thinks, viz.:-That, when he is removing these humours by the imprudent use of diuretics, he is only attacking a symptom or a consequence of discasc, and not the disease itself. The legs will fill again, and the grease will return. While the cause remains, the effect will be produced.

In the administration of diuretics, one thing should be attended to, and the good effect of which the testimony of every intelligent man will confirm: the horse should have plenty to drink. Not only will inflammation be prevented, but the operation of the medicine will be much promoted.

\section{INFLAMMATION OF THE KIDNEYS.}

This is no uncommon disease in the horse, and is more unskilfully and fatally treated than almost any other. The early symptoms are those of fever generally, but the seat of the disease soon becomes evident. The horse looks anxiously round at his flanks; stands with his hinder legs wide apart; is unwilling to lie down; straddles as he walks; expresses pain in turning; shrinks when the loins are pressed, and some degree of heat is felt therc. The urine is voided in small quantities; frequently it is high-coloured, and sometimes bloody. The attempt to urinate becomes more frequent, and the quantity voided smaller, until the animal strains painfully and violently, but the discharge is nearly or quite suppressed. The pulse is quick and hard; full in the early stage of the disease, but rapidly becoming small, yet not losing its character of hardness. These symptoms clearly indicate an affection of the urinary organs; but they do not distinguish inflammation of the kidney from that of the blad. der. In order to effect this, the hand must be introduced into the rectum. If the bladder is felt full and hard under the rectum, there is inflammation of the neck of it; if it is empty, yet on the portion of the intestines immediately over it there is more than natural heat and tenderness, there is inflammation of the body of the bladder; and if the bladder is empty, and there is no increased heat or tenderness, there is inflammation of the kidney.

Among the causcs of diabetes are improper food, and particularly hay that has been mow-burnt, or oats that are musty. The farmer should look well to this. Oats that have been dried on a kiln acquire a diuretic property, and if horses are long fed on them, the continual excitement of this organ which they produce will degenerate into inflammation. Too powerful or too often repeated diuretics induce inflammation of the kidney, or a degree of irritation and weakness of that organ that disposes to inflammation from causes that would otherwise havc no injurious effect. If a horse is sprained in the loins by bcing urged on, far or fast, by a heavy rider, or compelled to take too wide a leap, or by being suddenly pulled up on his haunches, the inflammation of the muscles of the loins is often speedily transferred to the kidneys, with which they lie in contact. Exposure to cold is another frequent origin of this malady, especially if the horse is drenched with rain, or the wet drips upon his loins; and, more particularly, if he was previously disposed to inflammation, or these organs had been previously weakened. For this reason, hackney-coach horses and others, exposed to the vicissitudes of the weather, and often fed on unwholesome provender, have, or should have, their loins protected by leather or some other clothing. The grand cause, 
however, of nephritis, is the unnecessary quantity or undue strength of the diuretic medicines that are forced on the horse by the ignorant groom. This is an evil carried to an infamous extent, and against which every horseman should sternly oppose himself.

The treatment will only vary from that of inflammation of other parts by a consideration of thc peculiarity of the organ affected. Bleeding must be promptly resorted to, and carried to its full extent. An active purge should next be administered; and a counter-inflammation excited as nearly as possible to the seat of disease. For this purpnse the loins should be fomented with hot water, or covered with a mustardpoultice - the horse should be warmly clothed; but no cantharides or turpentine should be used, and, most of all, no diuretic be given internally. When the groom finds this difficulty or suppression of staling, he immediately has recourse to a diuretic ball to force on the urine; and by thus needlessly irritating a part already too much excited, he adds fuel to fire, and frequently destroys the horse. The action of the purgative having begun a little to cease, white hellebore may be administered in small doses, with or without emetic tartar. The patient should be warmly clothed; his legs well bandaged; and plenty of water offered to him. The food should be carefully examined, and anything that could have excited or that may prolong the irritation carefully removed.

\section{DIABETES, OR PROFUSE STALING}

Is a comparatively rarc disease. It is generally the consequence of undue irritation of the kidney by bad food or strong diuretics, and sometimes follows inflammation of that organ. It can seldom be traced in the horse to any disease of the digestive organs. The treatment is obscure, and the result often uncertain. It is evidently increased action of the kidneys, and therefore the most rational plan of treatment is to endeavour to abate that action. In order to effect this, the same course should be pursued in the early stage of diabetes as in actual inflammation; but the lowering system must not be carried to so great an extent. To bleeding, purging, and counterirritation, medicines of an astringent quality should succeed, as catechu, the powdered leaf of the whortleberry (uva ursi), and opium. Very careful attention should be paid to the food. The hay and oats should be of the best quality. Green meat, and especially carrots, will be very serviceable.

\section{BLOODY URINE-HEMATURIA.}

The discharge of urine of this character is of occasional occurrence. Pure blood is sometimes discharged which immediately coagulates-at other times it is more or less mixed with the urine, and does not coagulate. The cause of its appearance and the source whence it proceeds cannot always be determined, but it is probably the result of some strain or blow. It may or may not be accompanied by inflammation.

Should it be the result of strain or violence, or be evidently attended by inflammatinn, soothing and depleting measures should be adopted. Perhaps counter-irritation on the loins might be useful. If there is no apparent inflammation, some gentle stimulus may be administered internally.

\section{ALBUMINOUS URINE.}

A peculiar mucous state of the urine of some horses has lately attracted attention. It has been associated with stretching out of the legs, stiffness, disinclination to move, a dcgree of fever, and costiveness. Slight bleeding, mild physic, the application of gentle stimulants to the loins, quietness, and gentle opiates, have been of service. We are indebted to Mr. Percivall for what we do know of the disease. It is a subject worthy of the attention of the vetcrinary surgeon.

\section{THE BLADDER.}

The urine separated from the blood is discharged by the minute vessels, of which we have spoken, into some larger canals, which terminate in a cavity or reservoir in the body of each kidney, designated its pelvis. Thence it is conveyed by a duct called the ureter, to a larger reservoir, the bladder. It is constantly flowing from the kidney through the ureter; and were there not this provision for its detention, it would be incessantly and annoyingly dribbling from the animal. The bladder lies in, and when distended by urine ncarly fills, the cavity of the great bones of the haunch, 
termed the pelvis. It has three coats, the outer one covering the greater part of it. and being a portion of the peritoneum : the muscular, consisting of two layers of fibres, as in the stomach; the external, running longitudinally, and the inner circularly, so that it may yield to the pressure of the urine as it enters, and contract again into an exceedingly small space as it runs out, and by that contraction assist in the cxpulsion of the urinc. The inner coat contains numcrous little glands, which secrete a mucous fluid to defend the bladder from the acrimony of the urinc. 'The bladder terminates in a small neck, round which is a strong muscle, keeping the passagc closed, and retaining the urine until, at the will of the animal, or when the bladder contains a certain quantity of fluid, the muscular coat begins to contract, the diaphragm is rendered convex towards the intestincs, and presses them on the bladder, and by these united powers the fluid is forced through the sphincter muscle at the neck of the bladder, and escapes.

\section{INFLAMMATION OF THE BLADDER.}

There are two varicties of this disease, inflammation of the body of the bladder, and of its neck. The symptoms are nearly the same with those of inflammation of the kidney, except that therc is rarely a total suppression of urine, and there is heat felt in the rectum over the situation of the bladder. The causes are the presence of some acrid or irritant matter in the urine, or of calculus or stone in the bladder. With reference to inflammation of the body of the bladder, mischief has occasionally been done by the introduction of cantharides or some other irritating matter, in order to hasten the period of horsing in the mare. The treatment in this case will be the same as in inflammation of the kidneys, cxcept that it is of more consequence that the animal should drink freely of water or thin gruel.

In inflammation of the neck of the bladder there is the same frequent voiding of urine in small quantities, generally appearing in an advanced stage of the disease, and often cnding in alınost total suppression. There is also this circumstance, which can never be mistaken by him who will pay sufficient attention to the case, that the bladder is distended with urine, and can be distinctly felt under the rectum. It is spasm of the part, closing the neck of the bladder so powerfully that the contraction of the bladder and the pressure of the muscles are unable to force out the urine.

Here the object to he attempted is sufficicntly plain. This spasm must be relaxed, and the most likely means to effect it is to blecd largely, and even to fainting. This will sometimes succeed, and there will be at once an end to the disease. To the exhaustion and loss of muscular power occasioned by copious bleeding, should be added the nausea consequent on physic. Should not this speedily have effect, another mode of abating spasm must be tried - powdered opium, made into a ball or drink, should be given every two or three hours; while an active blister is applied externally. 'The evacuation of the bladder, both in the mare and the horse, should be effected through the medium of a veterinary surgeon.

\section{STONE IN THE BLADDER.}

The urine is a very compound fluid. In a state of health it contains several acids and alkalies variously combined, which, under disease, are increased both in number and quantity. It is very easy to conceive that some of these may be occasionally separated from the rest, and assume a solid form both in the pelvis of the kidncy and in the bladder. This is known to be the case both in the human being and the brute. These calculi or stones are in the horse oftener found in the kidney than in the bladder, contrary to the experience of the human surgeon. The explanation of this however is not difficult. In the human being the kidney is sitnated above the bladder, and these concretions descend from it to the bladder by their weight. The belly of the horse is horizontal, and the force of gravity can in no way affect the passage of the calculus; therefore it occasionally remains in the pelvis of the kidney, until it has increased so much in size as to fill it. We know not of any symptoms that would satisfactorily indicate the presence of a stone in the kidney; and if the disease conld be ascertained, we are unable to say what remedial measures could be adopted. 
The symptoms of stone in the bladder much resemble those of spasmodic colic, except that, on careful inquiry, it will be found that there has been much irregularity in the discharge of urine and occasional suppression of it. When fits of apparent colic frequently return, and are accompanied by any peculiarity in the appearance or the discharge of the urine, the horse should be carefully examined. For this purpose he must be tlirown. If there is stone in the bladder, it will, while the horse lies on its back, press on the rectum, and may be distinctly felt if the hand is introduced into the rcctum. Several cases have lately occurred of successful extraction of the calculus; but to cffect this it will always be necessary to have recourse to the aid of a veterinary practitioner.

Both the practitioner and the amateur will be gratified by the description of a catheter, invented by Mr. Taylor, a veterinary surgeon of Nottingham, which may be introduced into the bladder without difficulty or pain, and the existence and situation of the calculus readily ascertained.

It is made of polished round iron, three feet long, one and a half inch in circumference, and with eight joints at its farther extremity. The solid part between each joint is one and a quarter inch in length, and one and a half in circumference, the moveable part being ten inches, and the solid part two feet two inches. The latter has a slight curve cominencing one foot from the handle, and continuing to the first joint of the moveable part, in order to give it facility in passing the urethra, where it is attached to the parietes of the abdomen. 'The joints are on the principle of a half joint, so that the moveable part would only act in a straight line, or curve in one dircction. The joints are perfectly rounded and smooth when acting either in a straight line or a curve. It is represented both in its straight and curved state in the following cuts.
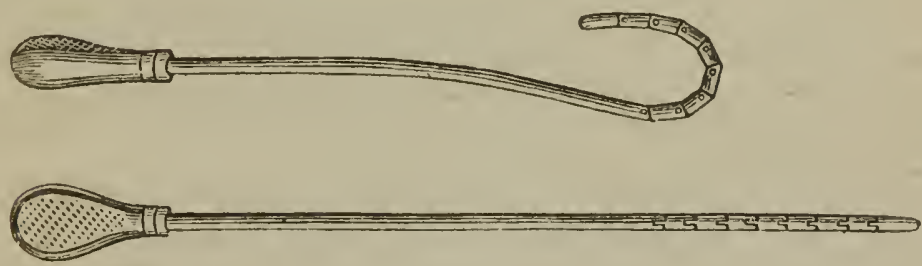

Many horses occasionally void a considerable quantity of gravel, sometimes without inconvenience, and at others with evident spasm or pain. A diuretic might be useful in such case, as incrcasing the flow of urine, and possibly washing out the concretions before they become too numerous or bulky.

'The urine having passed the neck of the bladder, flows along the urethra, and is discharged. The sheath of the penis is sometimes considerably enlarged. When at the close of acute disease, there arc swellings and effusions of fluid, under the chest and belly, this part seldom escapes. Diuretics, with a small portion of cordial medicine, will he beneficial, but in extreme cases slight scarifications may be necessary. 'The inside of the sheath is often the seat of disease. The mucous matter, naturally secreted there to defend the part from the acrimony of the urine, accumulates and becomes exceedingly offensive, and produces swelling, tenderness, and even excoriation, with considerable discharge. Fomentation with warm water, and the clcansing of the part with soap and water, aided perhaps by the administration of a diuretic ball, will speedily remove every inconvenience. Carters are too apt to neglect cleanliness in this respect. 
CHAPTER XI.

B REEDING, CASTRATION, \&c.

THis may be a proper period to recur to the subject of breeding, and peculiarly important when there cannot be a doubt that our breed of horses has, within the last twenty years, undcrgone a matcrial change. Our running-horses still maintain their speed, although their endurance is, generally speaking, considerably diminished; our draught and carriage horses are perhaps improved in value; but our hunters and hackneys are not what they used to be.

Our observations on this will be of a general nature, and very simple. The first axiom we would lay down is, that "like will produce like," and that the progeny will inherit the general or mingled qualities of the parents. There is scarcely a disease by which either of the parents is affected that the foal does not often inherit, or at least occasionally show a predisposition to it. Even the consequences of ill usage or hard work will descend to the progeny. There has been proof upon proof, that blindness, roaring, thick wind, broken wind, spavins, curbs, ringbones, and founder, have been bequeathed to their offspring, both by the sire and the dam. It should likewise be recollected that although these blemishes may not appear in the immediate progeny, they frequently do in the next, or even more distant generatton. Hence the necessity of some knowledge of the parentage both of the sire and the dam.

Peculiarity of form and constitution will also be inherited. This is a most important but neglected consideration; for, however desirable or even perfect may have been the conformation of the sire, every good point may be neutralized or lost by the defective structure of the mare. The essential points should be good in both parents, or some minor defect in either be met, and got rid of, by excellence in that particular point in the other. The unskilful or careless breeder too often so badly pairs the animals, that the good points of each are almost lost: the defects of both increased, and the produce is far inferior to both sire and dam.

Mr. Paker, of Reigate, places this in a striking point of view. He speaks of his own experience: "A foal had apparently clear and good eyes, but the first day had not passed, before it was evident that it was totally blind. It had gutta serena.

"Inquiry was then made about the sire, for the mare had good eyes. His were, on the slightest inspection, evidently bad, and not one of his colts had escaped the direful effects of his imperfect vision.

"A mare had been the subject of farcial enlargements, and not being capable of performing much work, a foal was produced from her. She survived; but the foal soon after birth evinced symptoms of farcy, and died.

"A mare was lame from navicular disease. A foal was bred from her that at five years could scarcely go across the country, and was sold for a few pounds. The mare was a rank jib in single hamess ; the foal was as bad."

It is useless to multiply these examples. They occur in the experience of every one, and yet they are strangely disregarded.

The mare is sometimes put to the horse at too early an age; or, what is of more frequent occurrence, the mare is incapacitated for work by old age. The owner is unwilling to destroy her, and he detcrmines that she shall bear a foal, and thus remunerate him for her keep. What is the consequence? The foal exhibits an unkindliness of growth, - corresponding weakness, - and there is scarcely an organ that possesses its natural and proper strength.

Of late years, these principles have been much lost sight of in the breeding of horses for general use; and the following is the explanation of it. There are nearly as good stallions as there used to be. Few but well-formed and valuable horses will be selected and used as stallions. 'They are always the very prime of the breed: but the mares are not what they used to be. Poverty has induced many of the breeders to part with the mares from which they used to raise their stock, and which were worth their weight in gold; and the jade on which the farmer now rides to market, or which he uses in his farm, costs him but little money, and is only retained because he cannot get much money for her. It has likewise become the fashion for gentlemen to ride mares, almost as frequently as geldings; and thus the better kind are taken 
BREEDING, CASTRATION, \&c.

from the breeding service, until old age or injury renders them worth little for it. An intelligent veterinary surgeon, Mr. Castley, has placed this in a very strong light.*

It should be impressed on the minds of breeders, that peculiarity of form and constitution are inherited from both parents, - that the excellence of the mare is a point of quite as much importance as that of the horse, - and that, out of a sorry mare, let thc horse be as perfect as he may, a good foal will rarely be produced. All this is recognised upon the turf, though poverty or carelessness have made the general breeder neglect or forget it.

'That the constitution and endurance of the horse are inherited, no sporting man ever doubted. The qualities of the sire or the dam descend from generation to generation, and the excellences or defects of certain horses are often traced, and justly so, to some peculiarity in a far-distant ancestor.

It may, perhaps, be justly affirmed, that there is more difficulty in selecting a good mare to breed from than a good horse, because she should possess somewhat opposite qualities. Her carcase should be long, in order to give room for the growth of the foetus; and yet with this there should be compactness of form and shortness of leg. What can they expect whose practice it is to purchase worn-out, spavined, foundered marcs, about whom they fancy there have been some good points, and send them far into the country to breed from, and, with all their variety of shape, to be covered by the same horse? In a lottery like this there may be now and then a prize, but there must be many blanks. If horse-breeders, possessed of good judgment, would pay the same attention to breed and shape as Mr. Bakewell did with his sheep, they would probably attain their wishes in an equal degree, and greatly to their advantage, whether for the collar or the road, for racing or for hunting.

As to the shape of the stallion, little satisfactory can be said. It must depend on that of the mare, and the kind of horse wished to be bred; but if there is one point absolutely essential, it is "compactness" - as much goodness and strength as possible condensed into a little space.

Next to compactness, the inclination of the shoulder will be regarded. A huge stallion, with upright shoulders, never got a capital hunter or hackney. From him the brecder can obtain nothing but a cart or dray horsc, and that, perhaps, spoiled by the opposite form of the mare. On the other hand, an upright shoulder is desirable, if not absolutely necessary, when a mere slow draught-horse is required.

On the subject of breeding in and in, that is, persevering in the same breed, and selecting the best on either side, much has been said. The system of crossing, requires more judgment and experience than breeders usually posscss. The bad qualities of the cross are too soon engrafted on the original stock, and once engrafted there, are not, for many generations, eradicated. The good qualities of both are occasionally neutralized to a most mortifying degree. On the other hand, it is the fact, however some may deny it, that strict confinement to one breed, however valuable or

* "Any one," says hc, "who, during the last twenty or five-and-twenty years, has had frequent opportunities of visiting some of our great horse-fairs in the north of England, must be struck with the sad falling-off there is everywhere to be remarked in the quality of the onehalf and thrce-part bred horses, exhibited for sale. The farmers, when taxcd with this, com. plain that breeding horscs does not sufficiently repay them; and yet we find large sums of money always given at fairs for any horses that are really good, but bad ones are not at any time likcly to pay for rearing, and less now than ever, on account of the advanced rate of land, and the increased expense of production. The truth is, that farmers do not, now-a-days, breed horses so generally good as they used to do, and this is owing to the inferior quality of the mares which they now commonly employ in breeding. They have, to a great degrec, been tempted to part with their best mares, and thus breed from the refuse. The stock consequently deteriorates, and they are disappointed.

"The great demand for mares has also contributed to get the best material for breeding out of the farmer's hands. Thirty years ago few gentlemen would be seen riding a mare-it was unfashionable. There was, consequently, but little demand for her, and she was left for the most part in the farmers' hands, who were then to be seen riding to market, mounted on the fincst mares, and from among which they selected the best for the purpose of breeding. Like will produce like, and the stock would seldom disappoint them.

"Then there is the demand for the foreign market. Within the last twenty years, a great number of our finest three-parts-brcd mares have been exported to various portions of the Continent, and particularly to France and Germany. They never find their way back again. The money brought into our country by their export is a mere trifle-a drop in the oceanwhile we are doing ourselves incalculable mischief by allowing some of our best materials to pass out of our hands for ever."-Veterinarian, III., p. 371. 
perfect, produces gradual deterioration. Crossing should be attempted with great caution. The valuable points of the old breed should be retained, but varied or improved by the introduction of some new and valuable quality, with reference to beauty, strength, or speed. This is the secret of the turf. The pure south-eastern blood is never left, but the stock is often changed, with manifest advantage.

A mare is capable of breeding at three or four years old. Some have injudiciously commenced at two years, before her form or her strength is sufficiently developed, and with the development of which this early breeding will materially interfere. If a mare does little more than farm-work, she may continue to be bred from until she is nearly twenty; but if she has been hardly-worked, and bears the marks of it, let her have been what she will in her youth, she will deceive the expectations of the breeder in her old age.

From the time of covering, to within a few days of the expected period of foaling, the cart-mare may be kept at moderate labour, not only without injury, but with decided advantage. It will then be prudent to release her from work, and keep her near home, and under the frequent inspection of some careful person.

When nearly half the time of pregnancy has elapsed, the mare should have a little better food. She should be allowed one or two feeds of corn in the day. This is about the period when they are accustomed to slink their foals, or when abortion occurs : the eye of the owner should, therefore, be frequently upon them. Good feeding and moderate exercise will be the best preventives of this mishap. The mare that has once aborted, is liable to a repetition of the accident, and therefore should never be suffered to be with other mares between the fourth and fifth months; for such is the power of imagination or of sympathy in the mare, that if one suffers abortion, others in the same pasture will too often share the same fate. Farmers wash, and paint, and tar their stables, to prevent some supposed infection; - the infection lies in the imagination.

The thorough-bred mare - the stock being intended for sporting purposes - should be kept quiet, and apart from other horses, after the first four or five months. When the period of parturition is drawing near, she should be watched, and shut up during the night in a safe yard or loose box.

If the mare, whether of the pure or common breed, be thus taken care of, and be in good health while in foal, little danger will attend the act of parturition. If there is false presentation of the fœtus, or difficulty in producing it, it will be better to have recourse to a well-informed practitioner, than to injure the mother by the violent and injurious attempts that are often made to relieve her.

The parturition being over, the mare should be turned into some well-sheltered pasture, with a hovel or shed to run into when she pleases; and as, supposing that she has foaled in April,* the grass is scanty, she should have a couple of feeds of corn daily. The breeder may depend upon it, that nothing is gained by starving the mother and stinting the foal at this time. It is the most important period of the life of the horse; and if, from false economy, his growth is arrested, his puny form and want of endurance will ever afterwards testify the error that has been committed. The corn should be given in a trough on the ground, that the foal may partake of it with the mother. When the new grass is plentiful, the quantity of corn may gradually be diminished.

The mare will usually be found again at heat at or before the expiration of a month from the time of foaling, when, if she is principally kept for breeding purposes, she may be put again to the horse. At the same time, also, if she is used for agricultural purposes, she may go again to work. The foal is at first shut in the stable during the hours of work; but as soon as it acquires sufficient strength to toddle after the mare, and especially when she is at slow work, it will be better for the foal and the dam that they should be together. The work will contribute to the health of the mother; the foal will more frequently draw the milk, and thrive better, and will be hardy and tractable, and gradually familiarised with the objects among which it is afterwards to live. While the mother, however, is thus worked, she and the foal should be well fed; and two feeds of corn, at least, should be added to the green food which they get when turned out after their work, and at night.

* By the present rules of the jockey-club, the age of turf-horses is reckoned from the lst of January ; but this has not by any common consent extended to the half-breds. The lst of May is nearest to the general time of foaling, and the age of the cavalry-horses is dated from that period. 
In five or six montlis, according to the growth of the foal, it may be weaned. It should then be housed for three weeks or a month, or turned into some distant rickyard. There can be no better place for the foal than the latter, as affording, and that without trouble, both food and shelter. The mother should be put to harder work, and have drier meat. One or two urine-balls, or a physic-ball, will be useful, if the milk should be troublesome, or she should pine after her foal.

There is no principle of greater importance than the liberal feeding of the foal during the whole of his growth, and at this time in particular. Bruised oats and bran should form a considerable part of his daily provender. The farmer may be assured that the money is well laid out which is expended on the liberal nourishment of the growing colt; yet while he is well fed, he should not be rendered delicate by excess of care.

A racing colt is often stabled; but one that is destined to be a hunter, a hackney, or an agricultural horse, should have a square rick, under the leeward side of which he may shelter himself; or a hovel, into which he may run at night, and out of the rain. Too often, however, the foal, after weaning, is left to struggle on as he can, and becomes poor and dispirited. He is to be seen shrinking under a hedge, cold and almost shivering, his head hanging down, and rheum distilling from his eyes. If he is made to move, he listlessly drags his limbs along, evidently weak, and generally in pain. He is a sad specimen of poverty and of misery. This is the first scene of cruelty to the horse of inferior breed, and destined for inferior purpose.*

The process of breaking-in should commence from the very period of weaning. The foal should be daily handled, partially dressed, accustomed to the halter when led about, and even tied up. The tractability, and good temper, and value of the horse, depend a great deal more upon this than breeders are aware.

Everything should be done, as much as possible, by the man who feeds the colt, and whose management of him should be always kind and gentle. There is no fault for which a breeder should so invariably discharge his servant as cruelty, or even harshness, towards the rising stock; for the principle on which their after usefulness is founded, is early attachment to, and confidence in man. and obedience, implicit obedience, resulting principally from this.

After the second winter the work of breaking-in may commence in good earnest. The colt may be bitted, and a bit selected that will not hurt his mouth, and much smaller than those in common use. With this he may be suffered to amuse himself, and to play, and to champ it for an hour, on a few successive days.

Having become a little tractable, portions of the harness may be put upon him, concluding with the blind winkers; and, a few days afterwards, he may go into the team. It would be better if there could be one horse before, and one behind him, beside the shaft horse. There should at first be the mere empty wagon. Nothing should be done to him, except that he should have an occasional pat or kind word. The other horses will keep him moving, and in his place; and no great time will pass, sometimes not even the first day, before he will begin to pull with the rest. 'The load may then be gradually increased.

The agricultural horse is sometimes wanted to ride as well as to draw. Let his first lesson be given when he is in the team. Let his feeder, if possible, be first put upon him. He will be too much hampered by his harness, and by the other horses, to make much resistance; and, in the majority of cases, will quietly and at once subinit. We need not to repeat, that no whip or spur should be used in giving the first lessons in riding.

When he begins a little to understand his business, backing - the most difficult part of his work - may be taught him; first to back well without anything behind him, and then with a light cart, and afterwards with some serious load-always taking the greatest care not seriously to hurt his mouth. If the first lesson causes much soreness of the gums, the colt will not readily submit to a second. If he has been previously rendered tractable by kind usage, time and patience will do everything that can he wished. Some carters are in the habit of blinding the colt when teaching him to back. This may be necessary with a restive and obstinate one, but should be used only as a last resort.

'The colt having been thus partially broken-in, the necessity of implicit obedience 
must be taught him, and that not by severity, but by firmness and steadiness. The voice will go a great way, but the whip or tie spur is sometimes indispensable-not so severely applied as to excite the animal to resistance, but to convince him that we have the power to enforce submission. Few-it may almost be said, no horses, are naturally vicious. It is cruel usage which has first provoked resistance. That resistance has been followed by greater severity, and the stubbornness of the animal has increased. Open warfare has ensued, in which the man has seldom gained advantage, and the horse has been frequently rendcred unserviceable. Correction may, or must be used, to enforce implicit obedience after the education has proceeded to a certain extent, but the early lessons should be inculcated with kindness alone. Young colts are sometimes very perverse. Many days will occasionally pass before they will permit the bridle to be put on, or the saddle to he worn; and one act of harshness will double or treble this time : patience and kindness, however, will always prevail. On some morning, when he is in a better humour than usual, the bridle may be put on, and the saddle may be worn; and, this compliance being followed by lindness and soothing on the part of the breaker, and no inconvenience or pain being suffered by the animal, all resistance will be at an end.

The same principles will apply to the breaking-in of the horse for the road or the chase. The handling, and some portion of instruction, should commence from the time of weaning. The future tractability of the horse will much depend on this. At two years and a half, or three years, the regular process of breaking-in should commence. If it is delayed until the animal is four years old, his strength and obstinacy will be more difficult to overcome. The plan usually pursued by the breaker cannot perhaps be much improved, except that there should be much more kindness and patience, and far less harshness and cruelty, than these persons are accustomed to exhibit, and a grcat deal more attention to the form and natural action of the horse. A headstall is put on the colt, and a cavesson (or apparatus to confine and pinch the nose) affixed to it, with long reins. He is first accustomed to the rein, then led round a ring on soft ground, and at length mounted and taught his paces. Next to preserving the temper and docility of the horse, there is nothing of so much importance as to leach him every pace, and every part of his duty, distinctly and thoroughly. Each must constitute a separate and sometimes long-continued lesson, and that tauglit by a man who will never suffer his passion to get the better of his discretion.

After the cavesson has been attached to the headstall, and the long rein put on, the colt should be quietly led about by the breakcr - a steady boy following behind, by occasional threatening with the whip, but never by an actual blow, to keep him moring. When the animal follows readily and quietly, he may be taken to the ring, and walked round, right and left, in a very snall circle. Care should be taken to teach him this pace thoroughly, never suffering him to break into a trot. The boy with his whip may here again be necessary, but not a single blow should actually fall.

Becoming tolerably perfect in the walk, he should be quickened to a trot, and kept steadily at it; the whip of the boy, if needful, urging him on, and the cavesson restraining him. These lessons should be short. The pace should be kept perfect, and distinct in each; and docility and improvement rewarded with frequent caresses, and handfuls of corn. The length of the rein may now be gradually increased, and the pace quickened, and the time extended, until the animal bccomes tractable in these his first lessons, towards the conclusion of which, crupper-straps, or something similar, may be attached to the clothing. These, playing about the sides and flanks, accustom him to the flapping of the coat of the rider. The annoyance which they occasion will pass over in a day or two; for when the animal finds that no harm comes to hin, he will cease to regard them.

Next comes the bitting. The bit should be large and smooth, and the reins buckled to a ring on either side of the pad. There are many curious and expensive machines for this purpose, but the simple rein will be quite sufficient. It should at first be slack, and then very gradually tightened. This will prepare for the more perfect manner in which the liead will be afterwards got into its proper position, when the colt is accustomed to the saddle. Occasionally the breaker should stand in front of the colt, and take hold of each side rein near to the mouth, and press upon it, and thus begin to teach him to stop and to back on the pressure of the rein, rewarding every act of docility, and not being too eager to punish occasional carelessness or waywardness. 
The colt may now be taken into the road or street to be gradually accustomed to the objects among which his services will be required. Here, from fear or playfulness, a considerable degree of starting and shying may be exhibitsd. As little notice as possible should be taken of it. The same or a similar object should be soon passed again, but at a greater distance. If the colt still shies, let the distance be farther increased, until he takes no notice of the object. Then he may be gradually brought nearer to it, and this will be usually effected without the slightest difficulty: whereas, had there been an attempt to force him close to it in the first instance, the remembrance of the contest would have been associated with every appearance of the object, and the habit of shying would have been established.

Hitherto, with a cool and patient breaker, the whip may have been shown, but will scarcely have been used; the colt must now, however, be accustomed to this necessary instrument of authority. Let the breaker walk by the side of the animal, and throw his right arm over his back, holding the reins in his left, occasionally quickening his pace, and at the moment of doing this, tapping the horse with the whip in his right hand, and at first very gently. The tap of the whip and the quickening of the pace will soon become associated in the mind of the animal. If necessary, these reminders may gradually fall a little heavier, and the feeling of pain be the monitor of the necessity of increased exertion. 'The lessons of reining in and stopping, and backing on the pressure of the bit, may continue to be practised at the same time.

He may now be taught to bear the saddle. Some littlc caution will be necessary at the first putting of it on. The breaker should stand at the head of the colt, patting him, and engaging lis attention, while one assistant, on the off-side, gently places the saddle on the back of the animal; and another, on the near-side, slowly tightens the girths. If he submits quietly to this, as he generally will when the previous process of breaking-in has been properly conducted, the ceremony of mounting may be attempted on the following, or on the third day. The breaker will need two assistants in order to accomplish this. He will remain at the head of the colt, patting and making much of him. The rider will put his foot into the stirrup, and bear a little weight upon it, while the man on the off-side presses equally on the other stirrup-leather; and, according to the docility of the animal, he will gradually increase the weight, until he balances himself on the stirrup. If the colt is uneasy or fearful, he should be spoken to kindly and patted, or a monthful of corn be given to him: but if he offers serious resistance, the lessons must terminate for that day. He inay probably be in better humour on the morrow.

When the rider has balanced limself for a ininute or two, he may gently throw his leg over, and quietly seat himself in the saddle. The breaker will then lead the animal round the ring, the rider sitting perfectly still. After a few minutes he will take the reins, and handle them as gently as possible, and guide the horse by the pressure of them; patting him frequently, and especially when he thinks of dismounting-and, after having dismounted, offering him a little corn or green meat. "The use of the rein in checking him, and of the pressure of the leg and the touch of the heel in quickening his pace, will soon be taught, and his education will be ncarly completed.

The horse having thus far submitted himself to the breaker, these pattings and rewards must be gradually diminished, and implicit obedience mildly but firmly enforced. Severity will not often be necessary. In the great majority of cases it will be altogether uncalled for: but should the animal, in a moment of waywardness, dispute the command of the breaker, he must at once be taught that he is the slave of man, and that we have the power, by other means than those of kindness, to bend him to our will. 'The education of the horse should be that of the child. Pleasure is, as much as possible, associated with the early lessons; but firmness, or, if need be, coercion, must establish the habit of obedience. Tyranny and cruelty will, more speedily in the horse than even in the child, provoke the wish to disobey; and, on every practicable occasion, the resistance to command. The restive and vicious horse is, in ninety-nine cases out of a hundred, made so by ill-usage, and not by nature. None but those who will take the trouble to try the experiment are aware how absolute a command the due admixture of firmness and kindness will soon give us over any horse. 


\section{CASTRATION.}

The period at which this operation may be best performed depends much on the breed and form of the colt, and the purpose for which he is destined. For the common agricultural horse the age of four or five months will be the most proper timc, or, at least before he is weaned. Few horses are lost when cut at that age. Care, however, should be taken that the weather is not too hot, nor the flies too numerous. We enter our decided protest, however, against the recommendation of valuable but incautious agricultural writers, that "colts should be cut in the months of June or July, when flies pester the horses, and cause them to be continually moving about, and thereby prevent swelling." One moment's reflection will convince the reader that nothing can be more likely to produce inflammation, and consequent swelling and danger, than the torture of the flies hovering round and stinging the sore part.

If the horse is designed either for the carriage or for heavy draught, the farmer should not think of castrating him until he is at least a twelve-month old; and, even then, the colt should be carefully examined. If he is thin and spare about the neck and shoulders, and low in the withers, he will materially improve by remaining uncut another six months; but if his fore-quarters are fairly developed at the age of a twelve-month, the operation should not be delayed, lest he become heavy and gross before, and perhaps has begun too decidedly to have a will of his own. No specific age, then, can be fixed; but the castration should be performed rather late in the spring or early in the autumn, when the air is temperate, and particularly when the weather is dry. No preparation is necessary for the sucking colt, but it may be prudent to bleed and to physic one of more advanced age. In the majority of cases, no after-treatment will be necessary, except that the animal should be sheltered from intense heat, and more particularly from wet. In temperate weather he will do much better runnirg in the field than nursed in a close and hot stable. The moderate exercise that he will take in grazing will be preferable to perfect inaction. A large and well-ventilated box, however, may be permitted.

The manner in which the operation is performed will be properly left to the vetcrinary surgeon. The haste, carelessness, and brutality of the common gelder should no longer be permitted; but the veterinary surgeon should be able and willing to discharge every portion of his duty. The old method of opening the scrotum on either side, and cutting off the testicles, and preventing hæmorrhage by a temporary compression of the vessels while they are seared with a hot iron, must not, perhaps, be abandoned; but there is no necessity for that extra pain, and that appearance, at least, of brutality, which occur when the spermatic cord (the blood-vessels and the nerve) is as tightly compressed between two picces of wood as in a powerful vice, and left there until either the testicle drops off, or is removed on the following day by the operator.

To the practice of some farmers, of twitching their colts at an early periorl, sometimes even so early as a month, there is stronger objection. When the operation of twitching is performed, a small cord is drawn as tightly as possible round the bag, between the testicle and the bclly. The circulation is thus stoppcd; and, in a few days, the testicles and tlie bag drop off; but not until the animal has sadly suffered. It is occasionally necessary to tighten the cord on the second or third day, and inflammation and death have frequently cnsued.

Another mode of castration has been lately introduced which bids fair to supersede every other: it is called the operation by Torsion. An incision is made into tle scrotum as in the other modes of operation, and the vas deferens is cxposed and divided. The artery is then seized by a pair of forceps contrived for the purpose, and twisted six or seven times round. It retracts as soon as the hold on it is quitted, the coils are not untwisted, and all bleeding has ceased. The testicle is removed, and there is no sloughing or danger. 'The most painful part of the operation-the application of the firing-iron or the clams-is avoided, and the wound readily heals. 


\section{CHAPTER XII.}

\section{THE FORE LEGS.}

$W_{E}$ arrive now at those parts of the frame which are most essentially connected with the action and value of the horse, and oftenest, and most annoyingly, the subjects of disease. The extremities contain the whole apparatus of voluntary motion, with which the action, and speed, and strength of the horse are most concerned.

We commence with the upper portion, of which the fore extremity, the shoulder, is seen at G, p. 68 .

\section{THE SHOULDER.}

The scapula or shoulder-blade, situated forward on the side of the chest, is a bone of a somewhat triangular shape, with its apex or narrowest point downward, and its broad and thin expansion upward. The point of the shoulder lies opposite to the first and second ribs; the hinder expansion of the base reaches as far back as the seventh rib; it therefore extends obliquely along the chest. It is divided, externally, into two unequal portions by a ridge or spine running through almost the whole of its extent, and designed, as will be presently seen, for the attachment of important muscles. The broad or upper part having no muscles of any consequence attached to it, is terminated by cartilage.

The shoulder-blade is united to the chest by muscle alone. There is one large muscle, with very remarkable tendinous fibres and of immense strength (the serratus major, greater saw-shaped muscle), attached to the chest, and to the extensive smooth internal surface of the shoulder-blade, and by which, assisted, or rather strengthened, by the muscles of the breast, the weight of the body is supported, and the shock of thic widest lcap, or the most rapid motion, sustained. Had there been a bony union between the shoulder and the boly, the vital parts contained in the chest could not have endurcd the dreadful shock which they would occasionally have experienced; nor could any bone have long remained whole if exposed to such violence. The muscles within the shoulder-blade act as powerful and safe springs. They yield, as far as necessary, to the force impressed upon them. By their gradual yielding they destroy the violence of the shock, and then by their elastic power, immediately regain their former situation.

\section{SPRAIN OF THF SHOULDER.}

These muscles are occasionally injured by some unexpected shock. Although in not more than one case in twenty is the farrier right when he talks of his shoulderlameness, yet it cannot be denied, that the muscles of the shoulder are occasionally sprained. This is effected oftener by a slip or side-fall, than by fair, although violent exertion. It is of considerablc importance to be able to distinguish this shoulderlameness from injuries of other parts of the fore extremity. There is not much tenderness, or heat, or swelling. It is a sprain of muscles deeply seated, and where these symptoms of injury are not immediately evident. If, on standing before the horse, and looking at the size of the two shoulders, or rather their points, onc should appear evidently larger than the other, this must not be considered as indicative of sprain of the muscles of the shoulder. It probably arises from bruise of the point of the shoulder, which a slight examination will determine.

The symptoms, however, of shoulder-lameness can scarcely be mistaken; and, when we relate them, the farmer will recollect that they very seldom occurred when the village smith pointed to the shoulder as the seat of disease, and punished the animal to no purpose. In sprain of the shoulder the horse evidently suffers extreme pain while moving, and, the muscle underneath being inflamed and tender, he will extend it as little as possible. He will drag his toe along the ground. It is in the lifting of the foot that the shoulder is principally moved. If the foot is lifted high, let the horse be ever so lame, the shoulder is little, if at all affected. In sprain of the back sinews, it is only when the horse is in motion that the injured parts are put to most pain ; the pain is greatest here when the weight rests on the limb in shoulderlameness, and thcre is a peculiar quickness in catching up the limb the moment the 
weight is thrown on it. This is particularly evident when the horse is going down hill, and the injured limb bears an additional portion of the weiglit. In the stable, too, when, in other cases, the horse points or projects one foot before the other, that foot is usually flat on the ground. In shoulder-lameness, the toe alone rests on the ground. The circumstance which most of all characterises this affection is, that when the foot is lifted and then brought considerably forward the horse will express very great pain, which he will not do if the lameness is in the foot or the leg. This point has been longer dwelt upon, in order that the reader may be enabled to put to the test the many cases of shoulder-lameness, which exist only in the imagination of the groom or the farrier.

In sprain of the internal muscles of the shoulder, few local measures can be adopted. The horse should be bled from the vein on the inside of the arm (the plate vein), because the blood is then abstracted more immediately from the inflamed part. A dose of physic should be given, and fomentations applied, and principally on the inside of the arm, close to the chest, and the horse should be kept as quiet as possible. The injury is too deeply seated for external stimulants to have very great effect, yet a blister will properly be resorted to, if the lameness is not speedily removed. The swimming of the horse is an inhuman practice; it tortures the animal, and increases the inflammation. The pegging of the shoulder (puncturing the skin, aud blowing into the cellular structure beneath until it is considerably puffed up) is another relic of ignorance and barbarity.

\section{SLANTING DIRECTION OF THE SHOULDER.}

The lessening or breaking of the shock, from the weight being thrown violently on the fore legs, is effected in another way. It will be observed, that (see $\mathbf{G}$ and $J, p$. 68 ) the shoulder-blade and the lower bone of the shoulder are not connected together in a straight line, but form a very considerable angle with each other. This will be more evident from the following cut, which represents the fore and hind extremities in the situations which they occupy in the horse.

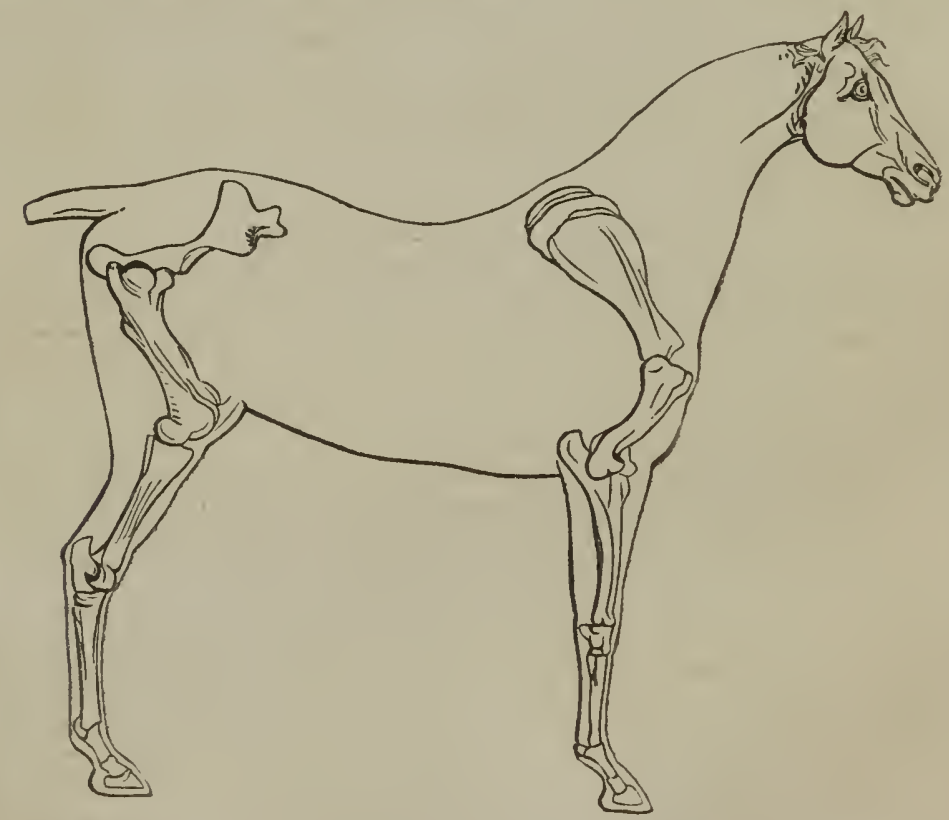

This angular construction of the limbs reminds us of the similar arrangement of the springs of a carriage, and the ease of motion, and almost rerfect freedom from jolting, which are thereby obtained. 
It must not perhaps be said, that the form of the spring was borrowed from this construction of the limbs of the horse, but the effect of the carriage-spring beautifully illustrates the connexion of the different bones in the extremities of this quadruped.

The obliquity or slanting direction of the shoulder effects other very useful purposes. 'That the stride in the gallop, or the space passed over in the trot, may be extensive, it is necessary that the fore part of the animal should be considerably elevated. 'The shoulder, by means of the muscles which extend from it to the inferior part of the limb, is the grand agent in effecting this. Had the bones of the shoulder been placed more upright than we see them, they could not then have been of the length which they now are,- their connexion with the chest could not have been so secure, -and their movements upon each other would have been comparatively restricted. The slightest inspection of the preceding cut, or of that at page 68 , will sliow that, just in proportion as the point of the shoulder is brought forward and elevated, will be the forward action and elevation of the limb, or the space passed over at every effort.

The slanting shoulder accomplishes a most useful object. The muscles extending from the shoulder-blade to the lower bone of the shoulder are the powers by which motion is given to the whole of the limb. The extent and energy of that motion depend much on the force exerted or the strength of the muscle; but there are circumstances in the relative situations of the different bones which have far greater influericc.

Let it be supposed that, by means of a lever, some one is endeavouring to raise a certain weight.

$\mathrm{A}$ is a lever, resting or turning on a pivot B; C is the weight to be raised; and D is the power, or the situation at which the power is applied. If the strength is applied in a direction perpendicular to the lever, as represented by the line $\mathbf{E}$, the power which must be exerted can easily be calculated.

A

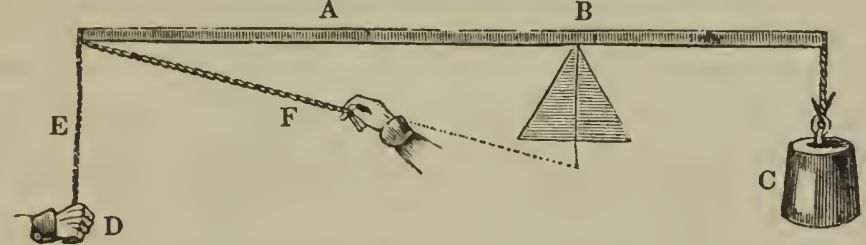

In proportion as the distance of the power from the pivot or centre of motion exceeds that of the weight from the same place, so will be the advantage gained. The power here is twice as far from the centre as the weight is, and therefore advanvantage is gained in the proportion of two to one : or if the weight is equal to $200 \mathrm{lbs}$, a force of $100 \mathrm{lbs}$. will balance it. If the direction in which the power is applied is altered, and it is in that of the linc F, will $100 \mathrm{lbs}$. effect the purpose? No; nothing like it. How, then, is the necessary power to be calculated? The line of direction must be prolonged, until another line, falling perpendicularly from the lever, and commencing at the centre of motion, will cut it; and the length of that line will give the actual effect of the strength employed. Now, this new line is but half as long as the distance of the weight from the centre of motion, and therefore advantage is lost in the proportion of two to one; or a strength equal to $400 \mathrm{lbs}$. must be exerted to raise the 200lbs., and so on in proportion to the deviation from the right or perpendicular line.

Let the shoulder of the horse be considered. The point of the shoulder - the shoulder joint - is the pivot or centre of motion; the leg attached to the bone of the arm is the weight; the shoulder-blade being more fixed is the part whence the power emanates; and the muscles extending from the one to the other are the lines in which that power is exerted. These lines approach much more nearly to a perpendicular in the oblique than in the upright shoulder (see cut). In the upright one, the shoulder-blade and the bone of the arm are almost in a straight line, and the real action and power of the muscle are most strangely diminished. In this point of view the oblique shoulder is most important. It not only gives extensive action, but facility of action. The power of the muscles is more than doubled by being exerted in a line approaching so much nearer to a perpendicular. 
There is yet another advantage of the oblique shoulder. The point of the shouldes is projected forward; and therefore the pillars which support the fore-part of the horse are likewise placed proportionably forward, and they have less weight to carry. They are exposed to less concussion, and especially concussion in rapid action. The horse is also much safer; for having less weight situated before the pillars of support, he is not so likely to have the centre of gravity thrown before and beyond them by an accidental trip; or, in other words, he is not so likely to fall; and he rides more pleasantly, for there is far less weight bearing on the hand of the rider, and annoying and tiring him. It likewise unfortunately happens that nature, as it were to supply the deficiency of action and of power in an upright shoulder, has sccumulated on it more inuscle, and therefore the upright shoulder is proverbially thick and cloddy; and the muscles of the breast which were designed to strengthen the attachment of the shoulders to the chest, and to bind them together, must, when the point of the shoulder lies backward, and under the horse, be proportionably thickened and strengthened, and the horse is thus still more heavy before, more unpleasant, and more unsafe to ride.

Then, ought every horse to have an oblique shoulder? No! The question has relation to those horses that are designed to ride pleasantly, or from which extensive and rapid action is required. In them it has been said that an oblique shoulder is indispensable: but there are others which are seldom ridden; whose pace is slow, and who have nothing to do but to throw as much weight as possible into the collar. To them an upright shoulder is an advantage, because its additional thickness gives them additional weight to throw into the collar, which the power of their hinder quarters is fully sufficient to accomplish; and because the upright position of the shoulder gives that direction to the collar which enables the horse to act upon every part of it, and that inclination of the traces which will enable his wreight or power to be most advantageously employed.

An improved breed of our heavy draught-horses has of late years been attempted, and with much success. Sufficient uprightness of shoulder is retained for the purposes of draught, while a slight degree of obliquity has materially quickened the pace and improved the appearance.

Above its junction with the humerus, or lower division of the limb, the shoulderblade forms what is called the point of the shoulder. There is a round blunted projection, best seen in the cut (p.256). The neck of the shoulder-blade there forms a shallow cavity, into which the head of the next bone is received.

The cavity is shallow because extensive motion is required, and because both of the bones being so moveable, and the motion of the one connected so much with that of the other, dislocation was less likely to occur. A capsular ligament, or one extending round the heads of both bones, confines them securely together.

This joint is rarely or never dislocated ; and, should it suffer dislocation, the muscles of the shoulder-blade and the lower bone of the shoulder are so strong, that the reduction of it would be impossible. The point of the shoulder, however, projecting considerably, is much exposed to injury from accident or violence. Even turning in a narrow stall has inflicted a serious bruise. Fomentations of warm water will usually remove the tenderness and lameness, but should they fail, blood should be taken from the plate vein, or, in very obstinate cases, a blister should be resorted to.

A description of the principal muscles of the shoulder-blade, their situation, attachments, and use, may not be uninteresting to the lover of the horse, and may guide his judgment as to the capability and proper form of that noble animal.

CUT OF MUSCLES ON THE OUTSIDE OF THE SHOULDER.

$a$ and $b$, in the following cut, represent a portion of the Trapezius muscle attached to the longer bones of the withers broadly and strongly and to the ligament and fascix of the neck (a portion of which is seen at $b$ ), narrowing below, terminating almost in a point, and inserted into a tubercle on the spine or ridge of the shoulder-blade. It occupies the space between the witlers and the upper part of the shoulder-blade, and is large and strong in proportion to the height of the withers, and the slanting of the shoulder. Its use is evidently to elevate and support the scapula-to raise it, and likew ise to draw it backward; therefore, constituting one of the most important muscles connected with the action of the horse, and illustrating the advantage of high withers and a slanting shoulder. A portion of it is represented as turned back, in 
orier to show other muscles beneath. A moment's inspection will convince the reader that although a low forehand and thick shoulder are very properly objected to,

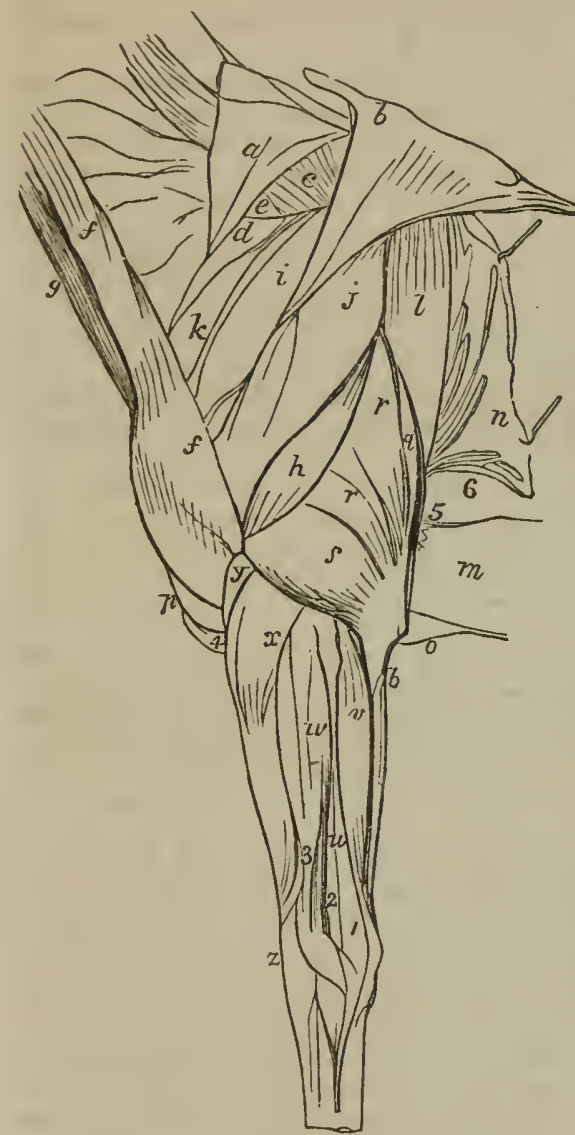
yet still some fulness and fleshiness are necessary, even about the withers; otherwise, although there may be height of withers, and obliquity of shoulder, to give extensive action, there will not be sufficient muscular power to work the machine with either quickness or continuance.

At $c$ is a portion of the levator humeri (the raiser of the shoulder), descending from the tubercle of the head (see cut, page 68), and from the base of the temporal bone, and attaching itself to the first four bones of the neck, and to the ligament of the neck; inserting itself into the covering of the muscles of the shoulder, and those about the point of the shoulder, and at length terminating in a ridge on the body of the humerus, arising from the greater tubercle. It is a muscle of immense power and great utility, raising and drawing forward the shoulder and the arm, or, when these are fixed, turning the head and neck if one only acts, and depressing them if the muscles on both sides act at the same time.

At $d$ is a portion of the serratus magnus muscle, between the shoulder and side of the chest, and constituting the bulk of the lower part of the neck. It is deeply seated, arising from the fourth, fifth, sixth, and sever.th bones of the neck anteriorly, and attached posteriorly to the eight first ribs. All its fibres tend towards and are inserted into the inner surface of the shoulder, and by means of them the shoulder is attached to the chest, and the immense weight of the body supported. 'The use of this muscle in obviating concussion, has already becn spoken of.

When the horse is standing, this muscle occasionally discharges another important function. The shoulders and legs are then rendered fixed points by the weight of the body, and this muscle exerts all its power in dilating the cavity of the chest, and thus niaterially assists in the act of breathing. Therefore, as was stated when that disease was treated of, a horse labouring under inflammation of the lungs will obstinately stand night and day, in order that he may obtain the assistance of this muscle in respiration, which is become laborious and painful; and for the same reason it is that we regard his lying down as one of the most favourable symptoms, because it shows us that the breathing is so much relieved as not to need the assistance of this inuscle.

At $e$ is a small portion of the splenius muscle, which was spoken of when the neck was described, p. 159.

$f$ represents a muscle sometimes described as a portion of the levator humeri, or elevator of the shoulder, arising from the nipple-shaped process or tubercle of the temporal bouc, running down the somcwhat lateral but fore part of the neck, inserted into the upper and middle part of the lower bone of the shoulder, and thence con- 
tinued down to the arm. Its office is to bend the head; or, the head and neck being fixed, to elevate and bring forward the arm. It is in powerful action when the horse is running at his speed, with the head projected.

At $g$ is a portion of the sterno maxillaris, or muscle common to the fore part of the chest and the lower jaw, and described at p. 159.

$h$ designates the principal portion of this muscle, extending from the shoulder to the humerus, and employed in drawing this bone towards the shoulder-blade, and bending the whole of the limb. Exceedingly powerful action is required from this muscle; therefore it is very tendinous, and inserted in such a direction as to act with great mechanical advantage, and that advantage increased in proportion to the slanting position of the shoulder.

The muscle $i$, antea spinatus, is situated on the outer and anterior part of the shoulder, below and behind the muscle next mentioned; and its office is to extend the humerus on the scapula. It is also attached to the greater tubercle of the humerus, and to a bony ridge extending from it to the capsular-ligament of the shoulder-joint. Its action is to assist in flexion of the humerus, and to give it a motion outwards.

The muscle $j$, postea spinatus, behind the spine or ridge, occupies that space of the shoulder, and is inserted into the outer and upper head of the hone. It draws this bone outward and upward.

At $k$, is a muscle common to the breast and the shoulder-blade, and called the pectoralis parvus. It arises from the breast-bone, and reaches to the covering of the shoulder-joint, and the inuscles of the shoulder. Its action, in common with that of a larger muscle, seen at $m$, the great pectoral, is to draw the head of the shoulder backward, and also the lower part of the shoulder-blade, and to give the latter a more upright position.

At $q$, is the tendon of a very important muscle, the extensor longus of the ann, reaching from the upper angle and the posterior border of the shoulder-blade to the point of the elbow and the inside of the arm, and which will be presently described. At $r$ and $s$, are the three divisions of another muscle concerned in the same office, arising from the shoulder-blade and the lower bone of the shoulder, and likewise an!l! attached to the point of the elbow by a very strong tendon.

This cut represents the muscles on the inside of the shoulder and fore-arm. $a$ is a very prominent one. It is called the pectoralis transversus (the muscle crossing the breast). It arises from the first four bones of the sternum, and runs across to the inner part of the arm; it is also attached to the inferior part of the body of the humerus, and to the fascia covering the arm, and reaching a considerable way down the arm. The use of this muscle is obvious and important. It binds the arm to the side of the horse; it keeps the legs straight before the borse when he is at speed, that the weight of the body may be received on them in a direction most easy and safe to the horse and to the rider, and most advantageous for the full play of all the muscles concerned in progression. Considering the unevenness of surface over which a horse often passes, and the rapid turnings which are sometimes necessary, these muscles have enough to do; and when the animal is pushed beyond his strength, and these muscles are wearied, and the fore-legs spread out, and the horse is "all abroad," the confused and unpleasant manner of going, and the sudden falling-off in speed, are well known to every rider. Mr. Percivall very properly observes, that this inuscle has probably more to do in enabling the arm to support weight than to give it motion.

\section{THE HUMERUS, OR LOWER BONE OF THE SHOULDER.}

Forming a joint with the shoulder-blade, at the point of the shoulder, is the humerus. It is a short, strong bone, slanting backward in an opposite direction to the shoulder- 
blade. At the upper part it has a large round head, received into the shallow eavity of the shoulder-blade; or, as Mr. Percivall has graphically described it, "it is the segment of a globe, smooth and polished, evidently for the purpose of playing like a spherical hinge within the cup-like concavity occupying the place of the apex of the scapula. There are no two bones in the skeleton whose articular connexion is of a nature to admit more varied and extensive motion than exists between the scapula and the humerus. If we attempt to lift a horse's fore-leg, we cannot merely bring it forward and backward, but we can also, to a considerable extent, make it perform a sort of rotatory motion, in consequence of the mobility existing in this joint between the socket of the scapula and the head of the humerus." It has several protuberances for the inscrtion of muscles, and is terminated below by two condyles, or heads, which in front receive the principal bone of the arm between them, as in a groove, thus adding to the security and strength of the joint, and limiting the action of this joint and of the limb below to mere bending and extension, without any side motion. Farther behind, these heads receive the elbow deep between them, in order to give more extensive action to the arm. In a well-formed horse, this bonc can scarcely be too short, in order that the fore-legs may be as forward as possible, for reasons already stated, and because, when the lower bone of the shoulder is long, the shoulder must be too upright. Dislocation can scarcely occur in either of the attachments of the bone, and fracture of it is almost impossible. The lower bone of the shoulder and the shoulder-blade are by horsemen confounded together, and included under the appellation of the shoulder, and in compliance with general usage, we have described them as combining to form the shoulder.

Among the muscles arising from the humerus, are two short and very strong ones, seen at $r$ and $s, \mathrm{p} .259$, the first proceeding from the upper part of this bone to the elbow, and the second from the internal part, and likewise going to the elbow, and both of them being powerful agents in extending the leg.

In front, at $y$, is one of the muscles of the humerus, the external one employed in bending the arm, arising from the inner and back part of the neck and body of the humerus, turning obliquely round that bone, and inserted into the inner and upper part of the bone of the arm.

\section{THE ARM.}

The arm extending from the elbow to the knee (see $K$ and $L, p .68$, and also cut, p. 259), consists, in the young horse, of two distinct bones. The long and front bone, called the radius, is nearly straight, receiving into its upper end the lower heads of the humerus; and the lower end corresponding with the upper layer of the bones of the knee. The short and hinder bone is called the ulna. It has a very long and powerful projection, received between the heads of the humerus, and called the elhow; it then stretches down, narrowing by degrees (see L, p. 68, and the cut, p. 259) to below the iniddle of the front bone, where it terminates in a point. The two bones are united together by cartilage and ligament; but these are by degrees absorbed and changed to bone, and before the horse becomes old the whole of the arm consists of one bone only.

It will be pcrceived that, from the slanting direction of the humerus, the weight of the horse, and the violence of the concussion, will be shared between the radius and the ulna, and therefore less liable to injure either. The circumstance, also, of so much weight and jar heing communicated to them, will account for the extensive and peculiarly strong union between these bones in the young horse; the speedy inflamination of the uniting substance and absorption of it, and the substitution of bone, and complete bony union between the radius and ulna, in the old horse. 'The immense inuscles that are attached to the point of the elbow likewise render it necessary that the union between these bones should be very strong.

The arm is a most important part of the horse, as will be seen when we describe the muscles that belong to it. 'The muscles $q, r$, and $s$, proceeding from the shoulderblade and the humerus, and inserted into the elbow, have been already spoken of. They are the grand agents in extending the arm; and in proportion to the power which they exert, will be the quickness and the length of the stride. The strength of the horse, so far as his fore-limbs are concerned, principally resides here. Then

* Veterinarian, vol. xv. p. 307. 
there will naturally be a large and muscular arm, and such a formation of the limb, and particularly of the elbow, as will enable these muscles to act with most advantage.

The principle of the lever (referred to at p. 257) is here beautifully applicable. The elbow-joint is the centre of motion; the whole of the lower part of the leg is the weight to be raised; and the power by which it is to be raised in one act of progression, the extending of the limb, is the muscles inserted into the elbow. In proportion as the weight is more distant than the power from the centre of motion, as it is in the construction of this limb, so will be the greater degree of energy requisite to be exerted. Supposing that the weight, taking the knee to be the centre of it, is eighteen inches from the elbow-joint-that the limb weighs $60 \mathrm{lbs}$, and that the elbow projects two inches from the joint-then an energy equal to nine times the weight, or 540lbs., will be needed to move and extend the limb, because the weight is nine times farther from the centre of motion than the power is. If in another horse the point of the elbow projects three inclies from the joint, the weight of the leg remaining the same, only six times the force, or $360 \mathrm{lbs}$., will be required, making a difference in, or saving of, muscular action, equal to $180 \mathrm{lbs}$. in each extension of the arm. If a few pounds in the weight of the rider tell so much for or against the horse in a long race, this saving of power must make an almost incalculable difference; and therefore, judges of the horse rightly attach so much importance to the depth of the elbow, or the projection of the point of the elbow from the joint.

When describing the proper obliquity of the shoulder, it was stated that the power was exerted with most advantage in a line perpendicular to the arm of the lever, and that the slightest deviation from that line was manifestly disadvantageous. If the reader will examine the cut, he will perceive that muscles from the shoulder and the bone of the arm take a direction much nearer to a perpendicular line in the long than in the short elbow, and therefore act with proportionably greater advantage; and if this advantage from the direction in which the power is applied to that which we gain from the increased length of the bone is considered, it will be plain that the addition of one-third to the length or projection of the elbow would be attended by a saving of one-half in the expenditure of muscular power. There is, however, a limit to this. In proportion as the elbow is lengthened, it must move over a greater space in order to give the requisite extension to the limb; and consequently the muscles which act upon it must be lengthened, otherwise, although the action might be easy it would be confined. There must be harmoriy of proportion in the different parts of the limb, but a deep elbow, within a certain range, is always connected with increased power of action.

The elbow is sometimes fractured. If the animal is placed in the hands of a skilful veterinarian, although the chances of cure are certainly against the horse, yet the owner needs not to despair. The treatment of fracture of the elbow-joint will be considered in its proper place.

Enlargements sometimes appear about the elbow, either the consequence of a violent blow, or from the calkins of the shoes injuring this part when the horse sleeps with his legs doubled under him. If a seton is passed through the tumour, it will sometimes rapidly diminish, and even disappear; but if it is of considerable magnitude, the skin should be opened along the middle of the swelling, and the tumour dissected out.

The elbow-joint is sometimes punctured, either accidentally, or through the brutality of the groom or carter. The swelling is often rapid and extensive, and fatal inflamination may ensue. Rest, and the closure of the wound, are the most important considerations.

'There are other muscles of the fore-arm employed in extending the limb. At $x$, page 259 , is the principal one, called the extensor metacarpi. It is attached superiorly to the outer and fore parts of the external condyle of the humerus, and also to the capsular ligament, and inferiorly to the antero-superior part of the great metacarpal bone. Its superior attachments are principally fleshy, with a few tendinous fibres interposed. These diminish towards the centre, but a little lower down is a tendon, round at its origin, but gradually growing flat and expanding in breadth towards its termination. Its office is to extend the leg.

The next muscle in situation and importance is seen at $w$, and called the extensor pedis. It rises from the fore part of the external condyle of the humerus, and pursues its course down the leg, and expanding after it has passed the fetlock, it serves the 
purpose of a capsular ligament, covering and adhering to the pastern joints. Its office is to extend the foot and pasterms, and, at the same time, to assist in the extension of the knee.

At $u$, page 259, is the tendon of another extensor muscle, and at $z$ a curious oblique one, passing over the tendon of $x$, confining it in its situation, and likewise assisting in extending or straightening the leg.

The muscles employed in bending the leg are both numerous and powerful. Two of the superficial ones are given in the cut, page 260 . The first is at $t$, page 259 ; it is also seen at $b$, page 259. It is called the flexor medius metacarpi, because its office is to bend the leg. The other is seen at $v$, page 259. It is called the flexor metacarpi externus, and is also designed to flex the leg.

The internal flexor is seen at $e$. Its office is also to bend the leg.

A portion of one of the most powerful of the flexor muscles, and powerful indeed they must be, is delineated at $c$, page 259. It is the flexor brachii. It rises from the extremity of the ridge of the shoulder-blade in the form of a large and round tendon, which rums between two prominences in the upper part of the front of the lower bone of the shoulder, and in as perfect a groove or pulley as art ever contrived. This groove is lined with smooth cartilage; and between it and the tendon there is a secretion of oily fluid, so that the tendon may play freely in the pully without friction. Having escaped from this pully, and passed the head of the lower bone of the shoulder, the cord swells out into a round fleshy body, still containing many tendinous fibres. Deeply seated, it contributes materially to the bulk of the front of the arm, and is inserted into the head and neck of the bone of the arm, and likewise into the capsular ligament of the elbow-joint. It is the muscle by which, almost alone, the whole of the leg below the arm is bent, and carried forward and upward.

It acts at great disadvantage. It is inserted into the very head of the bone of the arm, and expanded even upon the joint. Then the power is applied almost close to the centre of motion, while the weight to be raised is far distant from it. 'The power is thirty times nearer the centre of motion than is the weight; and, calculating as before, the.weight of the arm and the rest of the limb at $60 \mathrm{lbs}$., it must act with a force of thirty times sixty, or $1800 \mathrm{lbs}$. In addition to this, the line of the direction of the force strangely deviates from a perpendicular. The direction of the muscle is nearly the same as that of the limb, and the mechanical disadvantage is almost incalculably great. If it is calculated at only ten times more, this muscle, and its feeble coadjutors, act with a force of ten times 1800 , or $18,000 \mathrm{lbs}$.

Why this almost incredible cxpenditure of muscular power? That the beauty of the limb might be preserved, and the joint be compact. If the tendon had been inserted half-way down the arm, the elbow-joint would have offered a very unsightly appearance.

Beauty of form, however, is the least result of this conformation. Extensive and rapid motion are among the excellences of the horse. He is valuable in proportion as he has them combined with stoutness; and by this conformation of the limb could he alone obtain them. Therefore the tendon is at first unusually strong; it plays through the natural but perfect pulley of the bone of the arm without friction; the hody of the muscle is mixed with tendinous fibres, and the insertion into the fore-arm is rery extensive, lest the application of such immense force should tear it from its adhesions. There is sufficient strength in the apparatus; the power may be safely applied at this mechanical disadvantage; and it is applied close to the joint to give an extent and rapidity of motion which could not otherwise have been obtained, and without which the horse would have been comparatively useless.

At the back of the arm are other flexor muscles of great power, to bend the lower portions of the limb. Two of them have been described belonging to the arm and tile leg, and same very peculiar ones acting on the feet must not be omilled. Only a small portion of one of them can be scen in our cut, p. 259, at 1 .

The first is the flexor pedis perforalus. It is deeply seated in the posterior part of the arm, where, with the pcrforans, it forms a thick fleshy mass, the tendons issuing from which are adapted to the convexity and concavity of each other. As it riescends along the bone of the arm, it becomes tendinous; and, approaching the knee, it is bound down by arches or bands of ligament, that it may not start in sudden and violent action. Proceeding from the knee, it widens, and partly wraps round the iendon of the perforating muscle, and they run down together in contact, 
yet not adhering; freely playing over each other, and a mucous fluid obviating all friction. Both of them are inclosed in a sheath of dense cellular substance, attached to them by numerous fibrils; and they are likewise supported by various ligamentous expansions.

Near the fetlock the tendon still further expands, and forms a complete ring round the tendon of the perforating muscle. This is seen at $\mathbf{J}, \mathrm{p} .113$. The use of this will be best explained when the fetlock is treated of.

The perforated tendon soon afterwards divides, and is inserted into the smaller and larger pastern bones, and scrves to flex or bend the fetlock and joints, as it had previously assisted in the flexion of the knee.

The flexor perforuns muscle lias nearly the same origin as the perforatus; but it continues muscular farther down the arm than it, and lies before it. At the knee its tendon passes, like the perforatus, under strong ligamentary arches, which confine it in its situation. It then becomes round, and is partly enveloped in the perforatus, and at the fetlock is entirely surrounded by it. It emerges from the perforatus when that tendon divides, and continues its progress alone after the other has inserted itself into the pasterns, and, passing over the navicular bone, is broadly implanted into the posterior cavity of the foot.

It is sufficiently plain that the arm should be large and muscular, otherwise it could not discharge all these duties. Horsemen differ on a variety of other points, but here they are agreed. A full and swelling fore-arm is the characteristic of every thoroughbred horse. Whatever other good points the animal may possess, if the arm is narrow in front and near the shoulder, flat on the side, and altogether deficient in muscular appearance, that horse is radically defective. He can neither raise his knee for rapid action, nor throw his legs sufficiently forward.

The arm should likewise be long. In proportion to the length of the muscle is the degree of contraction of which it is capable; and in proportion also to the degree of contraction will be the extent of motion in the limb beneath. A racer, with a short arm, would be sadly deficient in stride; a hunter, with the same defcct, would not be able to double his legs well under him in the leap. There is, however, a medium in this, and the advantage of length in the arm will depend on the use to which the horse is applied. The lady's horse, the cavalry horse, every horse in which prancing action is esteemed a beauty, and in which utility is, to a certain degree, sacrificed to appearance, must not be too long in the arm. If he is long there, he will be proportionably short in the leg; and although this is an undoubted excellence, whether speed or continuance is regarded, the short leg will not give the grand and imposing action which fashion may require. In addition to this, a horse with short legs may not have quite so easy action as another whose length is in the shank rather than in the arm.

\section{THE KNEE.}

The Knee (M, p. 68, and cut, p. 256), answering to the human wrist, constitutes the joint or joints between the arm and the shank or leg; and is far more complicated than any joint that has been yet considered. Beside the lower heads of the bone of the arm, and the upper heads of the three bones of the leg, there are no less than six other bones interposed, arranged in two rows, three in each row, and the seventh placed behind.

What was the intention of this complicated structure? A joint between the elbow and the fetlock was absolutely necessary to the action of the horse. An inflexible pillar of that length could scarcely have been lifted from the ground, much less far enough for rapid or safe motion. It was likewise necessary, that the interposing joint should be so constituted as to preserve this part of the limb in a straight direction, and possess sufficient strength to resist all common work and accidents. Being in a straight direction, the shock or jar between the ends of the bones of the arm and the leg would be dreadful, and would speedily inflict irreparable injury. The heads of all bones are covered with elastic cartilage, in order to protect them from injury by concussion; but this would be altogether insufficient here. Six distinct bones are therefore placed here, each covered above and below by a thick coating of cartilage, connected together by strong ligaments, but separated by interposed fluids and membranes. The concussion is thus spread over the whole of them-shared by the whole of them ; and, by the peculiarity of their connexion, rendered harmless. 
These six distinct bones, united to eaeh other by numerous and powerful ligaments, will also afford a far stronger joint than the apposition of any two bones, however perfect and strong might be the capsular ligament, or by whatever other ligaments it might be strengthened. In addition to the eonnexion between the individual bones, there is a perfect capsular ligament here, extending from the bone of the arm to those of the leg; and the result of the whole is, that the hardest work and the severest aecidents produce little deformity, and no dislocation in the knee: nor do the shocks and jars of many a year cause inflammation or disease. It is an undeniable faet, that such is the perfect construction of this joint, and to so great a degree does it lessen concussion, that the injuries resulting from hard work are, almost without an exeeption, found below the knee, which seems to escape the injuries of the lock. There is a remarkable difference in the effects of work on the knee and the hock. The knee is subject to enormous eoncussion in its strict sense. The hock to a somewhat different work. The knee altogether escapes bony enlargements and inflammations of the ligaments, like spavins; and, what is more remarkable, it also escapes the damages to which the anterior fetloek is liable from precisely the same coneussion as the knee.

The seventh bone, the trapezium, so ealled from its quadrangular figure, is placed (sce M, p. 68) behind the others, and does not bear the slightest portion of the weight. It, however, is exceedingly useful. 'Two of the flexor inuscles, already described, proeeed from the bone of the arm, and are inserted into it; and being thus thrown off the limb, have a less oblique direction given to them, and, therefore, according to the principle of the lever, act with considerably more power. It is also useful in another way. $\Lambda \mathrm{s}$ the tendons of the various muscles descend the limbs, they are tied down, as we have described, by strong ligamentous bands: this is particularly the case in the neighbourhood of the joints. The use of it is evident. The extensor tendons, which lie principally on the front of the leg, are prevented from starting and strengthened and assisted in their action; but the flexor tendons which are at the back would be liable to friction, and their motion impeded, if they were bound down too tightly. This projecting bone prevents the annular or ring-like ligament from pressing too closely on the main flexor tendons of the foot; and, while it leaves them room to play, leaves room likewise for a little bag filled with mucus to surround them, which mueus oozing slowly out, supplies the course of the tendons with a fluid that prevents mueh injurious friction.

The knee should be broad. It should present a very considerable width, eompared with the arm above, or the shank below. In proportion to the breadth of the knee is the space for the attachment of muscles, and for the accumulation of ligamentous expansions and bands. In proportion to the breadth of the knee there will be more strength; and likewise the direetion of some muscles will be less oblique, and the course of others will be more removed from the eentre of motion, in either of which cases mueh power will be gained.

\section{BROKEN KNEES.}

The treatment of broken knees is a subject of considerable importanee, for many horses are sadly blemished, and others are destroyed, by wounds in the knee-joint. The horse, when falling, naturally throws his knees forward; they receive all his weight and are sometimes very extensively lacerated. The first thing to be done is, by very eareful washing with warm water, to cleanse the wound from all gravel and dirt. It must then be ascertaincd whether the joint is penetrated. The grating of the probe on one of the bones of the knee, or the depth to which the probe enters the wound, will too plainly indicate that the joint has been opened. Should any doubt exist, a linseed-meal poultice must be applied. This will at least act as a fomentation to the wound, and will prevent or abate inflammation; and when, twelve hours afterwards, it is taken off, the synovia or joint-oil, in the form of a glairy, yellowish, transparent fluid, will be seen, if the eapsular ligament has been penetrated. Should doubt remain after the first poultice, a seeond ought to be applied.

It having been aseertained that the interior of the joint is not injured, attention must be paid to the wound that is actually made. The horse should wear a cradle to prevent his getting at the wound. A stimulating application-the common blackoil of the farrier is as good as any-should be lightly applied every day until healthy 
pus is produced on the wound, and then a little friar's balsam will probably effect a cure.

The opening of the joint, however, being ascertained, the first and immediate care is to close the orifice; for the fluid which separated and lubricated the bones of the knee being suffered to escape, they will be brought into contact with and will rub upon each other; the delicate membrane with which they are covered will be highly inflamed; the constitution will be speedily affected, and a degree of fever will ensue that will destroy the horse: while, in the mean time, of all the tortures that can be inflicted on the poor animal, none can equal that which accompanies inflammation of the rnembranes lining the joints.

The manner of closing the orifice must be left to the judgment of the veterinary surgeon, who alone is capable of properly treating such a case. It may be effected by a compress enclosing the whole of the wound, and not to be removed for many days; or it may be attempted by the old and generally successful method of applying the hot iron over the wound, and particularly over the spot where the ligament appears to be lacerated. A poultice may then be placed on the part, and the case treated as a common wound. The surgeon will find no difficulty in determining whether the sharp edge of the common firing-iron should be used-as would be the case if the laceration is considerable, or whether the budding-iron should be resorted to. After the use of the cautery, the application of a blister may, in some cases, be serviceable. Should the joint-oil continue to flow, the iron may be applied a second, or even a third time. By its application, so much swelling is produced on the immediate puncture, and in the neighbouring parts, as mechanically to close and plug up the orifice.

If, however, the opening into the joint is extensive, and the joint-oil continues to flow, and the horse is evidently suffering much pain, humanity will dictate that he should be destroyed. The case is hopeless. A high degree of fever will ere long carry him off, or the inflammation will cause a deposit of matter in the cavity of the joint that will produce incurable lameness.

The pain caused by the iron is doubtless great; it is, however, necessary : but let no reader of "The Horse" permit the torturing experiments of the farrier to be tried, who will frequently inject stimulating fluids, and even oil of vitriol, into one of the most sensible and irritable cavities in the whole frame.

A person well acquainted with the anatomy of the part will judge of the probability of a favourable result, not merely by the extent, but by the situation of the wound. If it is low down, and opposite to the bottom row of the bones of the knee, a small opening into the joint will be easily closed. A larger one needs not to cause despair, because there is little motion between the lower row and the bones of the leg. If it is high up, there is more danger, because there is more motion. If it is situated opposite to the union of the two rows, the result is most to be dreaded, because between these is the principal motion of the joint, and that motion will not only disunite and irritate the external wound, but cause a dreadful friction between the bones brought into actual contact with each other, through the loss of the jointoil.

Among the various methods of treating opened knee-joint, where the lesion is very considerable, is one introduced by Mr. Turner, of Croydon, which must not be passed over in silence. The wound having been cleansed, a paste is prepared composed of wheaten flour and table-becr, which are stirred togcther and boiled for fire minutes, or until they become of the consistence commonly used by paper-hangers. This is spread on the wound, and round the joint, and four inches above and below it. Pledgets of tow are passed over this and confined in their places by means of a stocking, and over the whole is another layer, and another stocking or bandage. This is not removed until the joint has closed, and the synovia ceases to flow. On the second or third day the bandage will become dry and hard, and cause considerable pain. It must not be meddled with before or behind, but four longitudinal incisions may be made through the bandages on each side, which will sufficiently liberate the joint and remove the pain.*

When the knee has been much lacerated, although the wound may be healed, some blemish will remain. 'The extent of this blemish will depend on that of the original

*A full account of this interesting operation may be found in the Veterinarian for 1829. 
wound, and more especially on the nature of the treatment that has been adopted. Fivery caustic application will destroy a portion of the skin, and leave a certain mark. Should the blemish be considerable, a mild blister may be applied over the part, after the wound has healed. It will stimulate the hair to grow more rapidly and thickly round the scar, and particularly hair of the natural colour; and, by contracting the skin, it will lessen the scar itself. Many persons have great faith in ointments that are said to promote the growth of the hair. If they have this property, it must be from their stimulating the skin in which the roots of the hair are imbedded. These ointments usually contain a small portion of blistering matter, in the form of turpentine, or the Spanish-fly. The common application of gunpowder and lard may, by blackening the part, conceal the blemish, but can have no possible effect in quickening the growth of the hair.

In examining a horse for purchase, the knees should be very strictly scrutinised. A small blemish on them should not induce us at once to condemn the animal for a bad rider, for the merest accident may throw the safest horse. A broken knee, however, is a suspicions circumstance, and calls for the most careful observation of the makc and action of the horse. If it is accompanied by a thick and upright shoulder, and legs far under the horse, and low slovenly action, he is unwise who does not take the hint. This faulty conformation has produced its natural consequence. But if the shoulder is oblique, and the pastern of the proper length and inclination, and the forc-arm strong, the good judge will not reject the animal because he may have been accidentally thrown.

\section{THE LEG.}

The part of the limb between the knee and the fetlock consists of three bones - a large one before, called the cannon or shank, and two smaller or splint bones behind ( $\sec N$, p. 68). The shank-bone is rounded in front, and flattened, or even concave, behind. It is the straightest of the long bones, as well as the most superficially situated, for in some parts it is covered only by the skin. The upper head is flat, witl slight depressions corrcsponding with the lower row of the bones of the knee. The lower head is differently and curiously formed. It resembles a double pulley. There are three elevations; the principal one in the centre, and another on each side. Between them arc two slight grooves, and these so precisely correspond with deep depressions and slight prominences in the upper head of the larger pastern, and are so enclosed and guarded by the clevated edges of that bone, that when the shank-bone and the pastern are fitted to each other, they form a perfect hinge. They admit of the bending and extension of the limb, but of no lateral or side motion. This is a circumstance of very great importance in a joint so situated, and having the whole weight of the horse thrown upon it.

The smaller bones are placed behind the larger ones on either side. A slight projection of the head of each can alone be seen in front. The heads of these bones are enlarged, and receive part of the weight conveyed by the lower row of the bones of the knee. They are united to the larger bone by the same kind of substance which is found in the colt between the bone of the elbow and the main bone of the arm; and which is designed, by its great elasticity, to lessen the concussion or jar when the weight of the animal is thrown on them. They reach from one-half to two-thirds of the length of the shank-bone, and, through their whole extent, are united to it by this substance; but, as in the elbow, from the animal being worked too soon, or too violently, inflammation ensues-bony matter is deposited in the room of the ligamentous, and a bony union takes place instead of the natural one. There is no doubt that the ease of motion is somewhat lessened by this substitution of bone, but other elastic principles are probably called into more powerful action, and the value of the horse is not perceptibly impaired, although it is hard to say what secret injury may he done to the neighbouring joints, and the cause of which, the lameness not appearing until a distant period, is not suspected.

In this process, however, mischief does often immediately extend to the neighbouring parts. The disposition to deposit bone reaches beyond the circumseribed space between the larger and smaller bones of the leg, and a tumour, first callous, and afterwards bony, is found, with part of its base resting on the line of union betwcen these bones. This is called a 


\section{SPLINT.}

The splint is invariably found on the outside of the small bones and generally on the inside of the leg $(c, p .277)$. Why it should appear on the outside of the small bones it is difficult to explain, except that the space between these bones is occupied by an important mechanism, which will be presently described; and, as in the case of abscess, a natural tendency was given to them to determine outward, that vital parts might not be injured. The cause of their almost exclusive appearance on the inside of the leg admits of easier explanation. The inner splint-bone is placed nearer the centre of the weight of the body than the other, and, from the nature of its connexion with the bones of the knee, actually receives more of the weight than does the outer bone, and therefore is more liable to injury, and inflammation, and this consequent deposit of bony matter. The inner bone receives the whole of the weight transmitted to the small bone of the knee. It is the only support of that bone. A portion only of one of the bones rests on the outer splint-bone, and the weight is shared between it and the shank. In addition to this, there is the absurd practice of many smiths of raising the outer heel of the shoe to an extravagant degree, which throws still more of the weight of the horse on the inner splint-bone. Bony tumours occasionally appear on other parts of the shank-bone, being the consequence of violent blows or other external injuries, and are commonly called splints.

When the splint of either sort is forming, the horse is frequently lame, for the periosteum or membrane covering the hone is painfully stretched; but when this membrane has accommodated itself to the tumour that extended it, the lameness subsides, and altogether disappears, unless the splint be in a situation in which it interferes with the action of some tendon or ligament, or in the immediate neighbourhood of a joint. Pressing upon a ligament or tendon, it may cause inflammation of those substances; or, being close to a joint, it may interfere with its action. Splints, then, do not necessarily cause unsoundness, and may not lessen in the slightest degree the action or value of the horse. All depends on their situation.

The treatment of splints, if it is worth while to meddle with them, is exceedingly simple. The hair should be closely shaved off round the tumour; a little strong mercurial ointment rubbed in for two days; and this followed by an active blister. If the splint is of recent formation, it will generally yield to this, or to a second blister. Should it, however, resist these applications, it can rarely be advisable to cauterize the part, unless the tumour materially interferes with the action of the suspensory ligament, or the flexor tendon; for it not unfrequently happens, that, although the splint may have apparently resisted this treatment, it will afterwards, and at no great distance of time, begin rapidly to lessen, and quite disappear. There is also a natural process by which the greater part of splints disappear when the horse grows old.

The hydriodate of potash, made into an ointment with lard, and a small quantity of mercurial ointment being added, will frequently cause the disappearance of a splint of either sort.

As for the old remedies, many of them brutal enough - bruising the splint with a hammer, boring it with a gimlet, chipping it off with a mallet, sawing it off, slitting down the skin and periosteum over it, sweating it down with hot oils, and passing setons over it-the voice of humanity, and the progress of science, will consign them to speedy oblivion.

Professor Sewell has introduced a new treatment of splints, which is certainly ingenious, and generally successful. He removes any inflammation about the part by the use of poultices or fomentations, and then, the horse heing cast, the operation is commenced by pinching up the skin, immediately above the bony enlargement, with the finger and thumb of the left hand, and with the knife, or lancet, or scissors, making an orifice sufficient to introduce a probe-pointed bistoury, with the edge on the convex side. This is passed under the skin along the whole length of the ossification beneatl, cutting through the thickened periosteum down to the bone; and this being effectually completed by drawing the knife backwards and forwards several times, a small tape or seton is inserted, and if the tumour is of long standing, kept in during a few days. The operation is attended with very slight pain to the animal. Perhaps slight inflammation may appear, which subsides in a few days, if fomentation 
is used. The inflammation being removed, the enlargement considerably subsides, and in many cases becomes quite absorbed.*

The inside of the leg, immediately under the knee, and extending to the head of the inner splint-bone, is subject to injury from what is termed the speedy cut. A horse with high action, and in the fast trot, violently strikes this part, either with his hoof or the edge of the shoe. Sometimes bony enlargement is the result; at others, great heat and tenderness; and the pain from the blow seems occasionally to be so great, that the horse drops as if he were shot. The only remedy is to take care that no part of the shoe projects beyond the foot ; and to let the inner side of the shoe-except the country is very deep, or the horse used for hunting - have but one nail, and that near the toe. This part of the hoof, being unfettered with nails, will expand when it comes in contact with the ground, and contract when in air and relieved from the pressure of the weight of the body; and, although this contraction is to no great extent, it will be sufficient to carry the foot harmlessly by the leg. Care should likewise be taken that the shoe is of equal thickness at the heel and the toe, and that the bearing is equal on both sides.

Immediately under the knee, is one of those ligamentous rings by which the tendons are so usefully bound down and secured; but if the hinder bone of the knee, the trapezium, described at p. 266 , is not sufficiently prominent, this ring will confine the flexor tendons of the foot too tightly, and the leg will be very deficient in depth under the knee. This is called heing tied, in below the knee $(b, \mathrm{p}, 277)$. Every horseman recognises it as a most serious defect. It is scarcely compatible with speed, and most assuredly not with continuance. Such a horse cannot be ridden far and fast, without serious sprain of the back sinews. The reason is plain. The pressure of the ring will produce a degree of friction inconsistent with the free action of the tendons; more force inust, therefore, be exerted in every act of progression; and although the muscles are powerful, and sufficiently so for every ordinary purpose, the repetition of this extra exertion will tire and strain them.

A more serious evil, however, remains to be stated. When the back sinews, or tendons, are thus tied down, they are placed in a more oblique direction, and in which the power of the muscles is exerted with greater disadvantage. A greater degree of exertion is required, and fatigue and sprain will not unfrequently result. There are few more serious defects than this tying-in of the tendons immediately below the knee. The fore-leg may be narrow in front, but it must be deep at the side, in order to render the horse valuable; for then only will the tendons have free action, and the muscular force be exerted in the most advantageous direction. There are few good race-horses whose legs are not deep below the knee. If there are exceptions, it is because their exertion, although violent, is but of short continuance. The race is decided in a few minutes, and, during that short period, the spirit and energy of the animal may successfully struggle with the disadvantages of form: but where great and long-continued exertion is required, as in the hunter or the hackney, no strength can long contend with a palpably disadvantageous misapplication of muscular power.

As they descend the back part of the leg, the tendons of the perforated and perforating flexor muscles should be far and distinctly apart from the shank-bone. There slould be space free from thickening for the finger and thumb on either side to be introduced between them and the bone, and that extending from the knee to the fetlock. In a perfect leg, and towards its lower part, there should be three distinct and perfect projections visible to the eye, as well as perceptible by the finger - the sides of the shank-bone being the most forward of the three; next, the suspensory ligament; and, hindermost of all, the flexor tendons. When these are not to be distinctly seen or felt, or there is considerable thickening about them and between them $(d, \mathrm{p}$. 277 ), and the leg is round instead of flat and deep, there has been what is commonly, but improperly, called

\section{SPRAIN OF THE BACK-SINEWS.}

These tendons are enclosed in a sheath of dense cellular substance, in order to confine them in their situation, and to defend them from injury. Between the tendon and the sheath, there is a mucous fluid to prevent friction; but when the horse has been over-worked, or put to sudden or violent exertion, the tendon presses upon the delicate 
membrane lining the sheath, and inflammation is produced. A different fluid is then thrown out, which coagulates, and adhesions are formed between the teridon and the sheath, and the motion of the limb is more difficult and painful. At other times, from violent or long-continued exertion, some of the fibres which confine the tendons are ruptured. A slight injury of this nature is called a sprain of the back-sincws or tendons; and, when it is more serious, the horse is said to have broken down. It should be remembercd, however, that the tendon can never be sprained, because it is inelastic and incapable of extension; and the tendon, or its sheath, are scarcely ever ruptured, even in what is called breaking down. The first injury is confined to inflammation of the sheath, or rupture of a few of the attaching fibres. This inflammation, however, is often very great, the pain intense, and the lamcness excessive. The anguish expressed at every bending of the limb, and the local swelling and heat, will clearly indicate the seat of injury.

In every serious affection of this kind, care should be taken that the local inflammation does not produce general disturbance of the systcm; and, therefore, the horse should be bled and physicked. The bleeding may be at the toe, by which an important local, as well as general, effect will be produced. The vessels of the heart will be relieved, while fever will be prevented. Let not the bleeding be performed in the farrier's usual way of first paring down the sole, and then taking out a piece of it at the toe of the frog; in which case a wound is made often difficult to heal, and through which furigous granulations from the sensible parts beneath will obstinately spring: but, after the sole has been well thinned, let a groove be cut with the rounded head of a small drawing-knife, at the junction of the sole and the crust (see $z$, in the next cut, p. 272). 'The large vein at the toe will thus be opened, or the groove may be widencd backward until it is found. When the blood begins to appear, the vein may be more freely opened by a small lancet thrust horizontally under the sole, and almost any quantity of blood may be easily procured. The immersion of the foot in warm water will cause the blood to flow more rapidly. A sufficient quantity having been withdrawn, a bit of tow should be placed in the groove, and a patten shoe tacked on, by which the heels may be raised from the ground, and much tension removed from the sinews. The bleeding will, thus, be immediately stopped, and the wound will readily heal.

As a local application, no hot farrier's oil should come near the part, but the leg should be well fomented with warm water two or three times in the day, and half an hour at each time. Between the fomentations, the leg should be enclosed in a poultice of linseed-meal. Any herb that pleases the owner may be added to the fomentation, or vinegar or Goulard's extract to the poultice; for the beneficial effect of both depends simply on the warmth of the water and the moisture of the poultice. All stimulating applications will infallibly aggravate the mischief.

The horse begirning to put his foot better to the ground, and to bear pressure on the part, and the heat having disappeared, the object to be accomplished is changed. Recurrence of the inflammation must be prevented, the enlargement must be got rid of, and the parts must be strengthened. The two latter purposes cannot be better effected than by using an elastic bandage-one of thin flannel will be the best. This will sustain and support the limb, while by few means are the absorbents sooner induced to take up the effused coagulable matter of which the swelling is composed, than by moderate pressure. If the bandage is kept wet with vinegar-to each pint of which a quarter of a pint of spirit of wine has been added - the skin will be slightly stimulated and contracted, and the cold produced by the constant evaporation will tend to subdue the remaining and deep-seated inflammation. This bandage should be daily tightened in proportion as the parts are capable of bearing increased pressure, and the treatment should be persisted in for a fortnight. If, at the expiration of that period, there is no swelling, tenderness, or heat, the lorse may gradually, and very cautiously, be put to his usual work.

Should there, however, remain the slightest lameness or considerable enlargement, the leg must be blistered, and, indeed, it would seldom be bad practice to blister after every case of severe sprain, for the inflammation may lie deep in the sheath of the tendons, and the part once spraincd may long remain weak, and subject to renewed injury, not only fron! unusual, but even ordinary exertion. If a blister is resorted to, time should be given for it to produce its gradual and full effect, and the horse sliould be afterwards turned out for one or two months. We must here 
be permitted to repeat that a blister should never be used while any heat or tenderness remains about the part, otherwise the slightest injury may be, and often is, converted into incurable lameness.

Very severe sprains, or much oftener, sprains badly ' wated, may require the application of the cautery. If from long-continued inflammation the structure of the part is materially altered - if the swelling is becoming callous, or the skin is thickened and prevents the free motion of the limb, no stimulus short of the heated iron will be sufficient to rouse the absorbents to remove the injurious deposit. The principal use of firing is to rouse the absorbents to such increased action that they shall take up and remove the diseased thickness of the skin, and likewise the unnatural deposit in the cellular substance beneath. The firing should be applied in straight lines, because the skin, contracting by the application of the cautery, and gradually regaining its elastic nature, will thus form the best bandage over the weakened part. It should likewise be as deep as it can be applied without penetrating the skin. Here, even more particularly than in the blister, time should be given for the full action of the firing. 'This removal of diseased matter is a work of slow progress. Many weeks pass away before it is perfectly accomplished; and, after firing, the horse should have at least a six months', and it wonld be better if he could be given a twelve months' run at grass. When the animal has been set to work in a few weeks, and the enlargement remains, or lameness returns, the fault is to be attributed to the impatience of the owner, and not to the want of power in the operation or skill in the operator.

Farriers are apt to blister immediately after firing. A blister may be useful six wceks or two months after firing, if lameness remains; but can never be wanted immediately after the severe operation of the cautery. If the iron has been skilfully applied, subsecruent blistering inflicts on the animal, already sufficiently tortured, much unnccessary and useless pain, and should never be resorted to by him who possesses the slightest feeling of humanity.

In cxamining a horse for purchase, the closest attention should be paid to the appearance of these flexor tendons. If there is any thickness of cellular substance around them, that horse has been sprained violently, or the sprain has not been properly treated. This thickening will probably fetter the motion of the tendon, and dispose the part to the recurrence of inflammation and lameness. Such a horse, although at the time perfectly free from lameness, should be regarded with suspicion, and cannot fairly be considered as sound. He is only patched up for a while, and will probably fail at the close of the first day's hard work.

\section{WIND.GALLS.}

In the neighbourhood of the fetlock there are occasionally found considerable enlargcments, oftener on the hind-leg than the fore-one, which are denominated, wind-galls (e, p. 277). Between the tendons and other parts, and wherevcr the tendons are exposed to pressure or friction, and particularly about their extremities, little bags or sacs are placed, containing and suffcring to ooze slowly from them a mucous fluid to lubricate the parts. From undue pressure, and that most frequently caused by violent action and straining of the tendons, or, often, from some predisposition about the horse, these little sacs are injured. 'They take on inflammation, and sometimes become large and indurated. There are few horses perfectly free from them. When they first appear, and until the inflammation subsides, they may he accompanied by some degree of lameness; but otherwise, except when they attain a great size, they do not interfere with the action of the animal, or cause any considerable unsoundness. The farriers used to suppose that they contained wind - hence their name, wind-galls; and hence the prartice of opening them, by which dreadful inflamination was often produced, and many a valuable horse destroyed. It is not uncommon for wind-galls entirely to disappear in aged horses.

A slight wind-gall will scarcely be subjected to treatment; but if these tumours are numerous and large, and seem to impede the notion of the limb, they may be attacked first by bandage. The roller should be of flannel, and soft pads should be placed on each of the enlargements, and bound down tightly upon them. The bandage should also be wetted with the lotion recommended for sprain of the back-sinews. The wind-gall will often diminish or disappear by this treatment, but will too fre- 
quently return when the horse is again hardly worked. A blister is a more effectual, but too often temporary remedy. Wind-galls will return with the renewal of work. Firing is still more certain, if the tumours are sufficiently large and annoying to justify our having recourse to measures so severe; for it will not only effect the immediate absorption of the fluid, and the reduction of the swelling, but, by contracting the skin, will act as a permanent bandage, and therefore prevent the reappearance of the tumour. The iodine and mercurial ointments have occasionally been used with advantage in the proportion of three parts of the former to two of the latter.

\section{THE PASTERNS.}

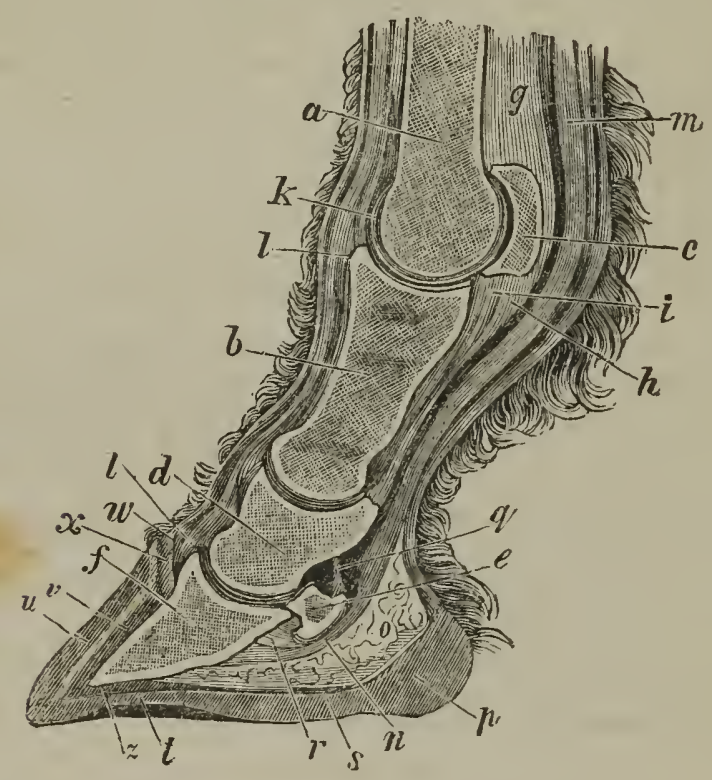

a The shank-bone.

$b$ The upper and larger pastern-bone.

$c$ The sessamoid-bone.

$d$ The lower or smaller pastern-bone.

$e$ The navicular or shuttle-bone.

$f$ The coffin-bone, or bone of the foot.

$g$ The suspensory ligament, inserted into the sessamoid-bone.

$h$ A continuation of the suspensory ligament, inserted into the smaller pastern-bone.

$i$ The small inelastic ligament, tying down the sessamoid-bone to the larger pastern-bone.

$k$ A long ligament reaching from the pastern-bone to the knee.

$l$ The extensor tendon inserted into both the pasterns and the coffin-bone.

$m$ The tendon of the perforating flexor insertcd into the coffin-bone, after having passed over the navicular bone.

$n$ The seat of the navicular joint lameness.

- The inner or sensible frog.

$p$ The cleft of the horny frog.

$q$ A ligament uniting the navicular bone to the smaller pastern.

$r$ A ligament uniting the navicular bone to the coffin-bone.

$s$ The sensible sole, between the coffin-bone and the horny sole.

$t$ The horny sole.

$u$ The crust or wall of the foot.

$v$ The sensible laminx to which the crust is attached.

whe coronary ring of the crust.

$x$ The covering of the coronary ligament from which the crust is secreted.

$z$ Place of bleeding at the toe. 
At the back of the shank just below the knee, and in the space between the two splint-bones, is found an important ligament, admirably adapted to obviate concussion. It originates from the head of the shank-bone, and also from the heads of the splint-bones; then, descending down the leg, it fills the groove between the splintbones, but is not attached to either of them. A little lower down it expands on either side, and, approaching the pasterns, bifurcates, and the branches are inserted into two little bones found at the back of the upper pastern, one on eacli side, called the sessamoid bones. (See page 272 , and in this cut which represents the pastern and foot, sawn through the centre.) The bones form a kind of joint both with the lower head of the shank-bone and the upper pastern-bone, to both of which they are united by ligaments ( $i$ and $g)$, but much more closely tied to the pastern than to the shank. 'The flexor tendons pass down.between them through a large mucous bag to relieve them from the friction to which, in so confined a situation, they would be exposed. The suspensory ligament is continued over the sessamoids, and afterwards obliquely forward over the pastern to unite with the long extensor tendon, and downward to the perforated tendon, which it surrounds and fixes in its place, and also to the smaller pastern-bone.

It will be easy to perceive, from this description of the situation of the suspensory ligament, why splints placed backward on the leg are more likely to produce lameness than those which are found on the side of it. They may interfere with the motion of this ligament, or, if they are large, may bruise and wound it.

The principal action of these ligaments is with the sessamoid bones, which they seem to suspend in their places, and they are therefore called the suspensory ligaments. The pasterns (see cut p. 272) are united to the shank in an oblique direction, differing in degree in the different breed of horses, and in each adapted to the purpose for which that breed was designed. The weight falls upon the pastern in the direction of the shank-bone, and the pastern being set on obliquely, a portion of that weight must be communicated to the sessamoids. Much concussion is saved by the yielding of the pasterns, in consequence of their oblique direction; and the concussion which would be produced by that portion of weight which falls on the sessamoid bones is completely destroyed, for there is no bone underneath to receive it. 'They are suspended by this ligament - an elastic ligament, which gradually yields to, and is lengthened by, the force impressed upon it, and in this gradual yielding and lengthening, materially lessening, or generally preventing, all painful or dangerous concussion.

If the ligament lengthens, the sessamoid bones must descend when the weight is thrown on them, and it would appear that they do so. If the thorough-bred horse with his long pasterns is carefully observed as lie stands, the tuft at the fetlock will be some inches from the turf; but when he is in rapid motion, and the weight is thrown violently on this joint, the tuft descends and sweeps the very ground. This, however, is from the combined action of the fetlock and pastern-joints, and the sessamoid-bones. The sessamoids do not actually descend; but they revolve, they partly turn over. The strong ligament by which they are attached to the pastern-bone acts as a hinge, and the projecting part of the bone to wr ${ }^{\circ}$ ch the suspensory ligament is united, turns round with the pressure of the rreight; so that part of the bone becomes lower. How is it raised again? This ligament, strangely constructed as a ligament, is elastic. It yields to the force impressed upon it and lengthens; but as soon as the foot is lifted from the ground, and the weight no longer presses, and the force is removed, its elastic power is exerted, and it regains its former dimensions, and the sessamoid-bone springs back into its place, and by that forcible return assists in raising the limb.*

It may be supposed that ligaments of this character, and discharging such functions,

* Mr. Pcrcivall very clearly describes this: "Furthermore it seems to us that these elastic parts assist in the elevation of the feet from the ground in those paces in which they are called into sudden and forcible action. The suspensory ligament, by its rcaction, instantaneously after its extension, aids the flexor muscles in bending the pastern-joints. The astonishing activity and expedition displayed in the movements of the race-horse at speed, seem to be referable, in part, to the promptitude with which the suspensory ligament can act before the flexor muscles are duly prcpared; the latter, we should say catch, as it were, and then direct the limb first snatched from the ground by the powers of elasticity."-Percivall's Lectures on the Veterinary Art, vol. i. p. 334. 
will occasionally be subject to injury, and, principally to strains. Mr. W. C. Spooner* gives a very satisfactory account of this. He says that "hunters and race-horses are considerably more liable to lesions of the suspensory ligament than any other description of horses. The character of these strains is very rarely so acute as that of the tendons. They generally come on gradually with little inflammation or lameness. Occasionally the injury is sudden and severe, but then it is rarely confined to these ligaments, for although they may be principally involved, the neighbouring parts are generally implicated. The ustral symptoms are a slight enlargement and lameness at first, or there may be the former without the latter. The enlargement is commonly confined to the ligament below the place of bifurcation, and sometimes one division alone is affected. With the exception of strains of the flexor sinews, this unfits more animals for racing than any other cause-indeed horses are rarely or never fit for the turf after the suspensory ligaments have been diseased," or for hunting.

The case being evidently a lesion of the suspensory ligament, nothing short of firing will be of service.

The length and obliquity of the pastern vary in the different breeds of horses, and on it depends the elastic action of the animal, and the easiness of his paces. The pastern must be long in proportion to its obliquity, or the fetlock will be too close to the ground, and, in rapid action, come violently into contact with it. It is necessary that the fetlock should be elevated a certain distance from the ground, and this may be effected either by a short and upright, or a long and slanting pastern. In proportion as the pastern is oblique or slanting, two consequences will follow, less weight will be thrown on the pastern, and more on the sessamoid, and, in that proportion, concussion will be prevented.

Every advantage, however, has, to a certain extent, its corresponding disadvantage. In proportion to the obliquity or slanting of the pastern, will be the stress on the fetlock-joint, and, therefore, the liability of that joint to injury and strain; and also the liability to sprain of the back-sinews from the increased action and play of the flexor tendons; and likewise to injuries of the pastern-joints, for the ligaments will be weak in proportion to their length. The long and slanting pastern is advantageous in the -race-horse, from the springiness of action and greater extent of stride by which it is accompanied. A less degree of it is given in the hunter who is to unite continuance of exertion with ease of pace. For the hackney there should be sufficient obliquity to give pleasantness of going, but not enough to endanger continuance and strength. Experience among horses will alone point out the most advantageous direction of the pastern, for the purpose required ; but the slightest observation will show the necessity of considerable variety in the structure of this part. Let the reader imagine the heavy dray-horse with his short and upright pasterns contending in the race; or the race-horse with his long and weak pasterns, endeavouring to dig his toe into the ground in order to move some heavy weight. The concussion which attends the common action of the cart-horse is little, because his movements are slow, and therefore the upright and strong pastern is given to him, which he can force into the ground, and on which he can throw the whole of his immense weight. 'The oblique pastern is given to the race-liorse because that alone is compatible with extent of stride and great speed. Except a horse for general purposes, and particularly for riding, is very hardly used, a little too much obliquity is a far less evil than a pastern too upright. While the jolting of the upright pastern is an insufferable nuisance to the rider, it is injurious and most unsafe to the horse, and produces many diseases in the feet and legs, and particularly ringbone, ossification of the cartilages, and contracted feet.

Strains of the pastern-joint are not so frequent, nor so severe as those of the fetlock, but they are not uncommon, especially in horses with pasterns naturally too upright. By careless observers they are not so readily detected as in the fetlock-joint, for the increased heat round the pastern-joint may be overlooked.

The treatment will not differ materially from that of the fetlock-joint.

\section{LESIONS OF THE SUSPENSORY LIGAMENT.}

The suspensory ligament is sometimes strained and even ruptured by extraordinary exertion. 'The sessamoids, which in their natural state are suspended by it, and from which function its name is derived, are in the latter case let down, and the fetlock

${ }^{*}$ Mr. W. C. Spooner on the Foot and Leg of the horse. 
almost touches the ground. This is generally mistaken for rupture of the flexor tendon; but one circumstance will sufficiently demonstrate that it is the suspensory ligament which is concerned, viz. : that the horse is able to bend his foot. Rupture of this ligament is a bad, and almost desperate case. The horse is frequently lame for life, and never becomes perfectly sound. Keeping him altogether quiet, bandaging the leg, and putting on a high-heeled shoe, will afford the most probable means of relief.

'The common injury to this ligament is sprain, indicated by lameness, and swelling, and heat, more or less severe in proportion as the neighbouring parts are involved. This will sometimes yield to rest and cooling treatment; but if the case is obstinate, it will be necessary to have recourse to the actual cautery. The hunter and the racehorse are most subject to lesions of these ligaments - the hunter from leaping the fence, and the race-horse from the violent efforts which are occasionally demanded from him. In both cases, the neighbouring parts usually share in the injury, and a cure is rarely completely effected.

The means of cure are the same as in lesions of other joints, but they must be more seriously and perseveringly applied.

\section{THE FETLOCK.}

The fetlock-joint is a very complicated one, and from the stress which is laid on it, and its being the principal seat of motion below the knee, it is particularly subject to injury. There are not many cases of sprain of the back-sinew that are not accompanied by inflammation of the ligaments of this joint; and numerous supposed cases of sprain higher up are simple affections of the fetlock. It requires a great deal of care, and some experience, to distinguish the one from the other. The heat about the part, and the point at which the horse least endures the pressure of the finger, will be the principal guides. Occasionally, by the application of cooling lotions, the inflammation may be subdued, but, at other times, the horse suffers dreadfully, and is unable to stand. A serious affcction of the fetlock-joint demands treatmeut more prompt and severe than that of the sheaths of the tendons.

\section{GROGGINESS.}

The peculiar knuckling of the fetlock-joint, and the tottering of the whole of the fore-leg, known by the name of grogginess, and which is so often seen in old and over-ivorked horses, is seldom an affection of either the fetlock or the pastern-joints simply. Indeed it is diffienlt to fix on any particular joint, unless it is that which is deep in the foot, and where the flexor tendon runs over the navicular bone. It seems oftenest to be a want of power in the ligaments of the joints generally, produced by frequent and severe sprains, or by ill-judged and cruel exertion. Professor Stewart very truly says, that "it is common among all kinds of fast workers, and long journeys at a fast pace will make almost any horse groggy. Bad shoeing and want of stable care may help to increase, but never can alone produce grogginess. It is one of the evils of excessive work." * In the majority of cases it admits of no remedy.

\section{CUTTING.}

The inside of the fetlock is often bruised by the shoe or the hoof of the opposite foot. Many expedients user to be tried to remove this; the inside heel has been raised and lowered, and the outside raised and lowered; and sometimes one operation has succeeded, and sometimes the contrary; and there was no.point so involved in obscurity or so destitute of principles to guide the practitioner. The most successful remedy, and that which in the great majority of cases supersedes all others, is Mr. 'Turner's shoe, of equal thickness from heel to toe, and having but one nail, and that near the toe on the inside of the shoe; care being taken that the shoe shall not extend beyond the edge of the crust, and that the crust shall be rasped a little at the quarters.

There are some defects, however, in the natural form of the horse, which are the causes of cutting, and which no contrivance will remedy; as when the legs are placed too near to each other, or when the feet are turned inward or outward. A

* Stewart's Stable CEconomy, p: 385 . 
horse with these defeets should be carefully examined at the inside of the fetloek, and if there are any sore or callous places from cutting, there will be sufficient reason for rejecting the animal. Some horses will cut only when they are fatigued or lame, and old; many colts will cut before they arrive at their full strength.

A consideration of the pasterns will throw more light upon this and other diseases of the extremities.

The upper pastern bone $(b, \mathrm{p} .2 \% 2$, and $a$ in the first figure, and $b$ in the second in the following cuts) receives the lower pulley-like hcad of the shank-bone, and forms a hinge-joint admitting only of bending and extension, but not of side motion; it likewise articulates with the sessamoid-bones. Its lower head has two rounded protuberances, which are received into corresponding depressions in the lower pastern. On either side, above the pastern-joint, are roughened projections for the attachment of very strong ligaments, both in capsular ligaments, and many cross ligaments, which render the joint between the two pasterns sufficiently secure.

Fig. 1.

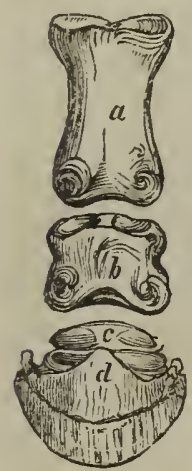

Fig. 2.

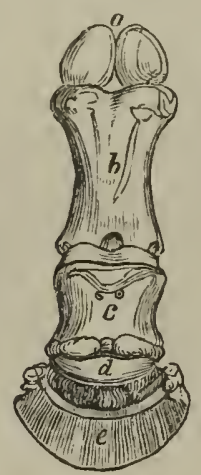

Fig. 1.

a The upper pastcrn.

$b$ The lowcr pastern.

c The navicular bone.

$d$ The coffin-bone.

Fig. 2.

a The sessamoid bone.

$b$ The upper pastern.

c The lower pastern.

$d$ The navicular bone.

$e$ The coffin-bone, with the horny laminæ.

The lower pastern ( $d$, p. 272, and $b$ in the first figure, and $c$ in the second in this cut) is a short and thick bone with its larger head downward. Its upper head has two depressions to receive the protuberances on the lower head of the upper bone, bearing some resemblance to a pulley, but not so decidedly as the lower head of the shank-bone. Its lower head-resembles that of the other pastern, and has also two prominences, somewhat resembling a pulley, by which it articulates with the coffinbone; and a depression in front, corresponding with a projection in the coffin-bone. There are also two slight depressions behind, rcceiving eminences of the navicular lone. Neither of these joints admits of any lateral motion. The ligaments of this

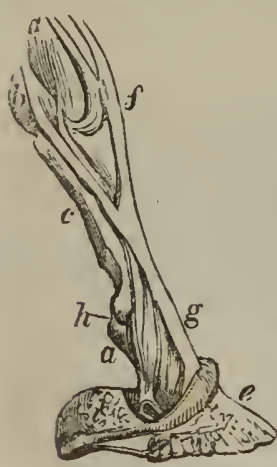
joint, both the capsular and the cross ones, are like those of the pastern-joint, exceedingly strong. The tendon of the extensor muscle is inserted into the fore part, both of the upper and lower pastern-bones as well as into the upper part of the coffin-bone $(l, \mathrm{p} .272)$; and at the back of these bones the suspensory ligament is expanded and inserted, while a portion of it goes over the fore part of the upper pastern to reach the extensor tendon. These attachments in front of the bones are seen in the accompanying cut, in which $a$ represents the lower part of the shank-bone; $b$ the scssamoidbones; $c$ the upper pastern; $d$ the lower pastern; and $e$ the coffin-bone; $f$ are the branehes of the suspensory ligaments going to unite with the extensor tendon; $g$ the long extensor tendon; $h$ ligarnents connecting the two pastern-bones together; and $i$ the lateral eartilages of the foot. 


\section{SPRAIN OF THE COFFIN-JOINT}

The proof of this is when the lameness is sudden, and the heat and tenderness are principally felt round the coronet. Bleeding at the toe, physic, fomentation, and hlisters are the usual means adopted. This lameness is not easily removed, even by a blister; and if removed, like sprains of the fetlock and of the back sinews, it is apt to return, and finally produce a great deal of disorganization and mischief in the foot.

Sprain of the coffin-joint sometimes becomes a very

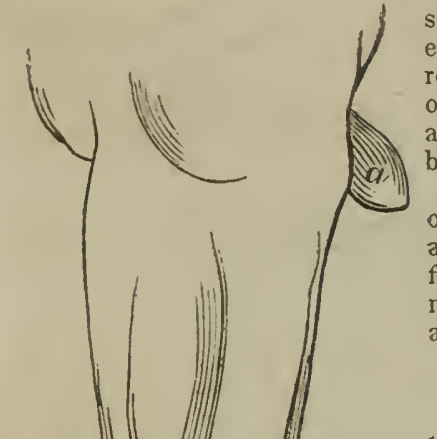

serious affair. Not being always attended by any external swelling and being detected only by heat round the coronet, the seat of the lameness is often overlooked by the groom and the farrier; and the disease is suffered to become confirmed before its nature is discovered.

From violent or repeated sprains of the pastern or coffin-joints, or extension of the ligaments attached to other parts of the pastern-bones, inflammation takes place in the periosteum, and bony matter is formed, which often rapidly increases, and is recognized by the name of

\section{RINGBONE.}

Ringbone is a deposit of bony matter in one of the pasterns, and usually near the joint. It rapidly spreads, and involves not only the pastern-bones, but the cartilages of the foot, and spreading around the pasterns and cartilages, thus derives its name. When the first deposit is on the lower pastern, and on both sides of it, and produced by violent inflammation of the ligaments of the joints, it is recomnised by a slight enlargement, or bony tumour on each side of the foot, and just above the coronet. (See $f$ in the accompanying cut.) Horses with short upright joints, and with small feet and high action, are oftenest, as may be supposed, the subjects of this disease, which is the consequence either of concussion or sprain of the pastern-joints. It is also more frequent in the hind foot than the fore, because, from the violent action of the hind legs in propelling the horse forward, the pasterns are more subject to ligamentary injury behind than before; yet the lameness is not so great there, because the disease is confined principally to the ligaments, and the bones have not been injured by concussion; while from the position of the fore limbs, there will generally be in them injury of the bones to be added to that of the ligaments. In its early stage, and when recognized only by a bony enlargement on both sides of the pastern-joint, or in some fèv cases on one side only, the lameness is not very considerable, and it is not impossible to remove the disease by active blistering, or by the application of the cautery : but there is so much wear and tear in this part of the animal, that the inflammation and the disposition to the formation of bone rapidly spread. The pasterns first becoune connected together by bone instead of ligament, and thence results what is called an anchylosed or fixed joint. From this joint the disease proceeds to the cartilages of the foot, and to the union between the lower pastern, and the coffin and 
navicular bones. The motion of these parts likewise is impeded or lost, and the whole of the foot becomes one mass of spongy bone. From a disposition to spread, and at first around the pastern-joint, which is situated just above the coronet, the disease has acquired the name of ringbone.

On the preceding page we have introduced a bird's-eye view of some of the principal lamenesses to which the fore extremities of the horse are subject.

At $a$ is a representation of the capped hock, or enlargement of the joint of the elbow. $b$ is the tying-in of the leg below the knee.

$c$ is the most frequent situation of splint on the side of the shank-bone, and not producing lameness after its first formation, because it does not interfere with the motion of the knee, nor injure the suspensory ligament.

$d$ is the situation and appearance of the enlargement accompanying sprain of the back sinews. This, however, is an aggravated case; and the sprain may be great, and the lameness distressing, without all this swelling.

$e$ is the place of wind-gall.

$f$ gives the appearance of ringbone when it first appears on the side of the pastern, about the joint, and where there is naturally some prominence of bone.

$g$ is the situation of sand-crack in the fore-leg.

$h$ the situation of mallenders.

The fore-legs, when viewed in front, should be widest at the chest, and should gradually approach to each other as we descend towards the fetlock. The degree of width must depend on the purpose for which the horse is wanted. The legs of a heavy draught-horse can scarcely be too far apart. His rounded chest enables him to throw more weight into the collar; and not being required for speed, he wants not that occasionally increased expansion of chest which the circular form is not calculated to give. A hunter, a hackney, and a coach-horse should have sufficient expansion of the chest, or the legs sufficiently wide apart, to leave room for the play of the lungs ; but depth more than roundness of chest is here required, because the deep chest admits of most expansion when the horse, in rapid action, and the circulation proportionally quickened, needs most room to breathe: yet if the breast is too wide, there will be considerable weight thrown before, and the horse will be heavy in hand and unsafe.

Whether the legs are near to each other or wide apart, they should be straight. The elbow should not have the slightest inclination inward or outward. If it inclines towards the ribs, its action will be confined, and the leg will be thrown outward when in motion, and describe a curious and awkward curve. This will give a peculiar solling motion, unpleasant to the rider and unsafe to the animal. The toe will likewise be turned outward, which will not only prevent the foot from coming flat on the ground in its descent, but be usually accompanied by cutting, even more certainly than when the toe turns inward. If the elbow is turned outward, the toes will necessarily be turned inward, which is a great unsightliness, and to a considerable degree injurious, for the weight cannot be perfectly distributed over the foot-the bearing cannot be true. There will also be undue pressure on the inner quarter, a tendency to unsafeness, and a disposition to splint and corn. The legs should come down perpendicularly from the elbow. If they incline backward and under the horse, there is undue stress on the extensor muscles; and, the legs being brought nearer the centre of gravity, too great weight is thrown forward, and the horse is liable to knuckle over and become unsafe. If the legs have a direction forward, the flexor muscles are strained, and the action of the horse is awkward and confined. The toe should be found precisely under the point of the shoulder. If it is a little more forward, the horse will probably be deficient in action; if it is more under the horse, unsafeness will be added to still greater defect in going. 


\title{
CHAPTER XIII.
}

\author{
THE HIN D L E GS.
}

\section{THE HAUNCH.}

THE haunch (see 0, p. 68, and the cut, p. 256, ) is composed of three bones. The first is the ilium, principally concerned in the formation of the haunch. Its extended branches behind the flanks are prominent in every loorse. When they are niore than usually wide, the animal is said to be ragged-hipped. A branch runs up to the spine at the commencement of the sacral vertebræ $(\mathbf{E})$, and here the haunch-bones are firmly united with the bones of the spine. The ischium, or hip-bone, is behind and below the ilium. Its tuberosities or prominences are seen under the tail (cut, p. 68). The pubis unites with the two former below and behind.

From the loins to the setting-on of the tail a line should be carried on almost straight, or rounded only in a slight degree. Thus the haunch-bones will be most oblique, and will produce a corresponding obliquity, or slanting direction, in the thighbone-a direction in which, as stated when the fore legs were described, the muscles act with most advantage. This direction of the haunch is characteristic of the thorough-bred horse ; and by the degree in which it is found, we judge to a considerable extent of the breeding of the animal. If the bones at $\mathrm{D}$ and $\mathrm{E}, \mathrm{p} .68$, take a somewhat arched form, as they do in the cart-horse, it is evident that the haunchbone $\mathrm{O}$ would be more upright. The thigh-bone $\mathrm{P}$ would likewise be so. The stifle $\mathrm{Q}$ would not be so far under the body, and the power of the horse would be considerably impaired. The oblique direction of the haunch and thigh-bones, produced by the straightness of the line of the spine, does not, as is commonly supposed, afford increased surface for the attachment of muscles, but places the muscles in a direction to act with great advantage. It is in the advantagenus direction, quite as mnch as in the bulk of the muscle, that the strength of the horse consists.

It will be seen, from the different cuts, that the angles formed by the fore and hind extremities have different directions. One points forward, and the other backward. The action of the fore legs thus least interferes with the chest, and that of the hind legs with the belly.

Width of haunch is a point of great consequence, for it evidently affords more room for the attachment of muscles; and even though it should be so wide as to subject the horse to the charge of being ragged-hipped, and may somewhat offend the eye, it will not often be any detriment to action. If the loins are broad and the horse well ribbed home, the protuberances of the ilium can scarcely be too far apart. Many a ragged-hipped horse has possessed both fleetness and strength, while but few that were narrow across the haunch could boast of the latter quality.

The opening in the centre of these bones, which constitutes the passage through which the young animal is expelled from the mother, is large in the mare, and in every quadruped, because there cannot, on account of the form of the animal, be any danger of abortion from the weight of the fotus pressing on the part.

The only portion of these bones exposed to injury or fracture are the tuberosities or prominences of the haunch. A fall or blow may chip off or disunite a portion of them, and, if so, there are no means of forcibly bringing the disunited parts together again, and retaining them in their natural position. The power of nature, however, will gradually unite them, but that union will be attended by deformity and lameness. A charge, or very strong adhesive plaster, across the haunch may be useful, as helping, in some slight degree, to support the parts, and hold them together.

\section{THE THIGH.}

In the lower and fore part of the hip-bones is a deep cavity or cup for the reception of the head of the thigh-hone.* Although in the movement of the hind legs there

* T'his, although the true thigh-bone, is so concealed by thick muscles that its situation and shape are not visible to the eye. It is therefore frequently overloolsed by horsemen, who call the next bone, extending from the stifle to the hock, the thigh. 
cannot be the concussion to which the fore legs are exposed (for the weight of the body is never thrown violently upon them); yet in the powerful action of these limbs there is much strain on the joints, and we shall, therefore, find that there are, in all of them, admirable provisions against injury. 'The head of the upper bone of the thigh is received into a deep cup (the acetabulum), by which it is surrounded on every side, and dislocation from which would seem almost impossible. But the bony cup may give way? Not so, provision is made against this. All three of the haunch-bones unite in the formation of this cup, and the sutures by which they are held together are of such a nature, that, generally speaking, no shock, or exertion, or accident, can disunite them. There is even something more in order to make the attachment doubly sure. In addition to the usual capsillar and other ligaments, a singularly strong one rises from the base of the cup, and is inserted into the head of the thigh-bone, seeming as if it would render separation or dislocation altogether impossible. Such, however, is the strange power of the muscles of the hind limbs, that, with all these attachments, sprain of the ligaments of the thigh, or the round bone, as horsemen call it, and even dislocation of it, are occasionally found.

The thigh-bone is both the largest and strongest in the frame. It is short and thick, and exhibits the most singular prominences, and roughnesses, and hollows, for the insertion of the immense muscles that belong to it. Four prominences, in particular, called by anatomists trochanters, two on the outside, one on the inside, and one near the head of the bone, afford attachment to several iinportant muscles. The head of the bone is placed at right angles with its body, by which this important advantage is gained, that the motion of the thigh-joint is principally limited to the act of bending and extending, although it possesses some slight lateral, and even some rotatory action. The lower head of the thigh-bone is complicated in its form. It consists of two prominences, which are received into corresponding depressions in the next bone, and a hollow in front, in which the bone of the knee or stifle plays as over a perfect pulley.

A short description of the muscles of the hinder extremities may not be uninteresting to the horseman. The next cut will contain a few of them.

The muscles of the hinder extremity are more powerful than tlose of any other part of the frame; therefore an extraordinary provision is made to confine them in their respective situations, and thus contribute to their security and strength. When the skin is stripped from any part, we do not at once arrive at the muscles, but they are thickly covered by a dense, strong, tendinous coat, intended to confine them to their places. This membranc, called the fascia, is of extraordinary strength in the hind quarter, and reaches over the whole of the haunch and thigh, and only ceases to be found at the hock where there are no muscles to be protected. If the power of the muscles is sufficient to dislocate or fracture the thigh-bone, they need the suppor: and confinement of this tendinous coat. When this tendinous band is dissected off, another is found beneath, which is represented at $a$, in the cut at p. 281, raised and turned back, larger than the former, thicker and more muscular. It proceeds from the haunch-bones to the stifle, upon the fore and onter part of the haunch and thigh, and is intended to tighten and strengthen the other.

Under the part of this flat and binding muscle, which is represented in our cut as raised from its natural situation, is a large round one, proceeding from the ilium, not far from the cup which receives the upper bone of the thigh, and running straight down this bone, and thence its name rectus. It is inserted into the bone of the stifle. An inspection of the cut, p. 68 , will show that it is so situated as to be enabled to exert its great power in the most advantageous way. It is a very prominent muscle, and possesses immense strength. It terminates in a tendon, which is short and very strong, and which is, before its insertion into the patella, united with the prolongation of the tendinous substance at $g$, in the cut, p. 282, and also with the tendon of the muscle at $i$, in that cut, and at $c$, in that on page 281 , and which is properly called vasitus, from its great bulk. Some have divided this into two muscles : the external and internal. The external arising from the outer surface of the upper bone of the thigh; the internal, from the inner surface; and they are inserted into the upper part of the bone of the stifle, both on the inner and outer side. These muscles act at considerable mechanical disadvantage. They form a very slight angle, not at all approaching to a right angle; but they are muscles of immense size, and occupy all the fore part of the thigh, from the stifle upwards. They are powerful extensors of 


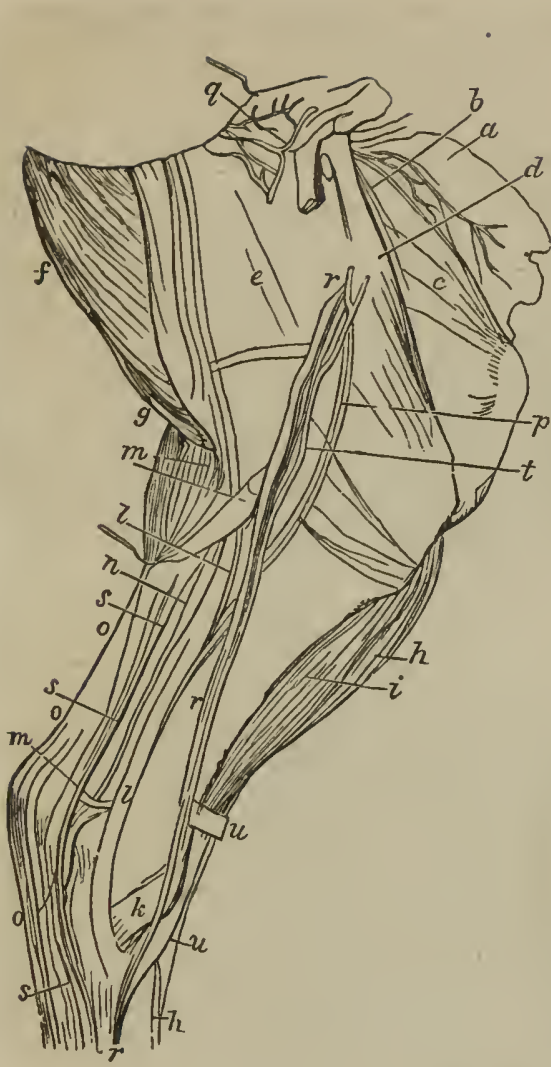

the thigh, and of the hinder leg generally; for they are all inserted into the bone of the knee, and that is connected by strong tendons with the bone of the true leg.

$\mathrm{On}$ the inside of the thigh are several other large fleshy muscles, which will be easily recognized on the thigh of the living horse. First is a long, narrow, prominent muscle, the sartorius, $d$, arising partly from the lumbar vertebræ, and extending down the thigh - assisting in binding the leg, and turning it inwardgiving it a rotatory motion, and also aiding in many of the natural actions of the horse.

Next comes a broad, thin muscle, the gracilis, $e$, occupying the greater portion of the surface of the inner part of the thigh, and particularly the prominent part of it. It arises from the lower portion of the haunch-bone, and, in its passage downward uniting with the last muscle, is inserted with it into the inner and upper part of the tibia. It acts with great mechanical disadvantage, but its power is equal to the task. It bends the leg, and rotates it inward.

Still, on the inside of the thigh, and forming the posterior edge of the thigh inwards, and contributing much to its bulk, is another important muscle, the pectineus. Part of it acts with very great mechanical advantage, and powerfully flexes the thigh on the pelvis, and lifts and bends the leg. It is one of the most cffectual of the cxtensor muscles. Considering the weight of limb which it has to raise and flex, it had need to possess great power.

We now turn to some of the muscles that are evident to the cye on the outside of the thigh.

First is the glutaus externus, situated in the middle of the external part of the haunch. It is of a triangular figure, attaclied to the antero-superior and to the inferior spines of the ilium, and is inserted into the smaller outer prominence of the upper bone of the thigh. Next is the great glutxus muscle, arising from the spinous and transverse processes of several of the bones of the loins, and from the sacrum, and from the different edges of the ilium, and inserted into the great protuberance of the upper bone of the thigh (page 68), behind and a little above the joint that unites the thigh to the haunch-bone. It is seen at $c$, in the cut on the following page. It constitutes the upper and outer part of the haunch, and gives that fulness and roundness to it which good judges so much admire in the quarters of the horse. It is one of the main instruments in progression. When the thigh has been brought forward under the body by the muscles already described, the plain action of these glutæi muscles is to extend the haunch, and force or project the body onward. To effect this, they must be very powerful, and therefore they are so large, and rise from such an extensive surface. They ought, also, to act at great mechanical advantage, and so, in one sense, they do. Springing from the loins and the ilium, and the sacrum, they act almost in a right, or perpendicular line; in that line in which we have seen that the greatest power is gained. 
CUT OF THE MUSCLES OF THE OUTSIDE OF THE THIGH.

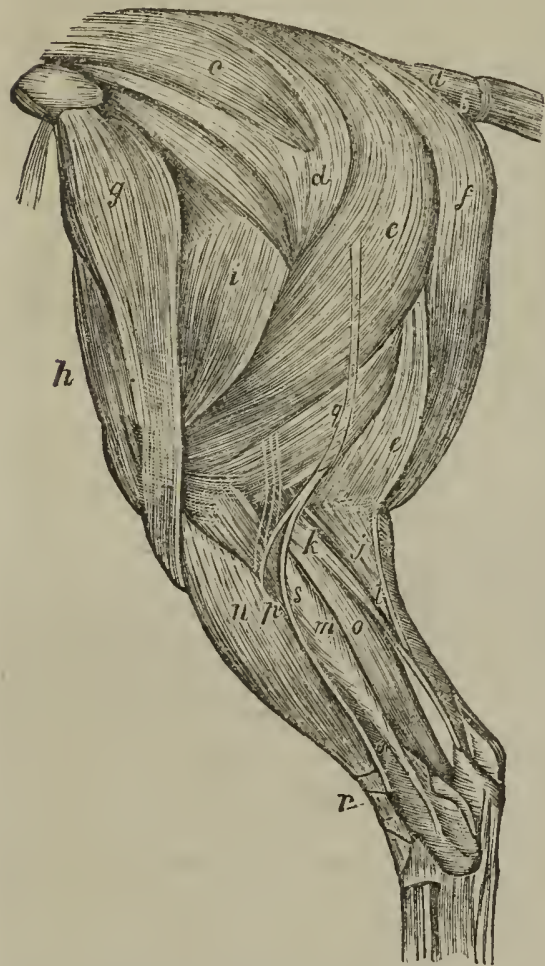

There is another and smaller glutars muscle under that which has been last described, arising likewise from the back of the ilium, inserted into the saine protuberance of the thigh-bone, and assisting in the same office. It is not visible in the cut.

These muscles, as Mr. Percivall well explains it, are extensors either of the femoris upon the pelvis, or the pelvis and loins upon the hind quarter. When the limb has been carried in advance under the body by the muscles of the anterior femoral region, and the toe firmly set down upon the ground, the glutei, by extending the haunch, will carry the trunk forward; thus becoming potent agents in progression, and the maximus being the most powerful of them.

In the acts both of rearing and kiching, these muscles are thrown into violent and forcible contraction. In the former action, the limbs become the fixed points, and the trunk the weight moved, and vice versa in the latter.*

There are also several other muscles proceeding from different parts of the haunch-bones, and inserted about the heads of the upper thigh-bone, and performing the same work; but there are two muscles to which we must particularly refer. The first occupies the outer part of the quartcr behind, and is beautifully developed in the bloodhorse; it is found at $e$, above. It rises high up from the bones of the spine, from others at the root of the tail, from the protuberances of the ischium (vide cut, $p$. 68), and from other bones of the pelvis. It in fact consists of two muscles, but is usually described as one muscle with two heads, biceps femoris, the two-headed muscle of the thigh. It is situated on the postero-external side of the haunch and thigh, where, being superficial, it is well marked in the living animal. The two divisions of it have an opposite action. The anterior or superior one assists the vasti in extending the thigh - the posterior one flexes it. They both, however, co-operate in abducting the limb, and also in rotating it forward, the hock, at the same time, turning outwards.

Those muscles alone have been selected which are particularly prominent in the thorough-bred horse, and are the source of his strength and speed. The following cut, containing one cxcellence above and many defects below, will not be unacceptable here:-

The Os Femoris, or Thigh Bone (see P, page 68), is long and cylindrical, taling an oblique direction from above, downwards, and from behind, forwards. At its upper extremities, and projecting from the body, is a thick flattened neck, terminating in a large smooth hemispherical head, adapted to a hollow, or acetabulum, in the superior point of the haunch.

This bone is commonly called the Round Bone. It has, in some rare instances, been dislocated and fractured. It is much oftener sprained, but not so frequently as the groom or farrier imagines. There is nothing peculiar in the lameness to detect injury of this part, except, that the horse will drag his leg after him. Injury of the

* Percivall's Anatomy, p. 148. 
THE STIFLE.

CUT OF THE HAUNCH AND HIND LEGS. round bone will be principally discovered by

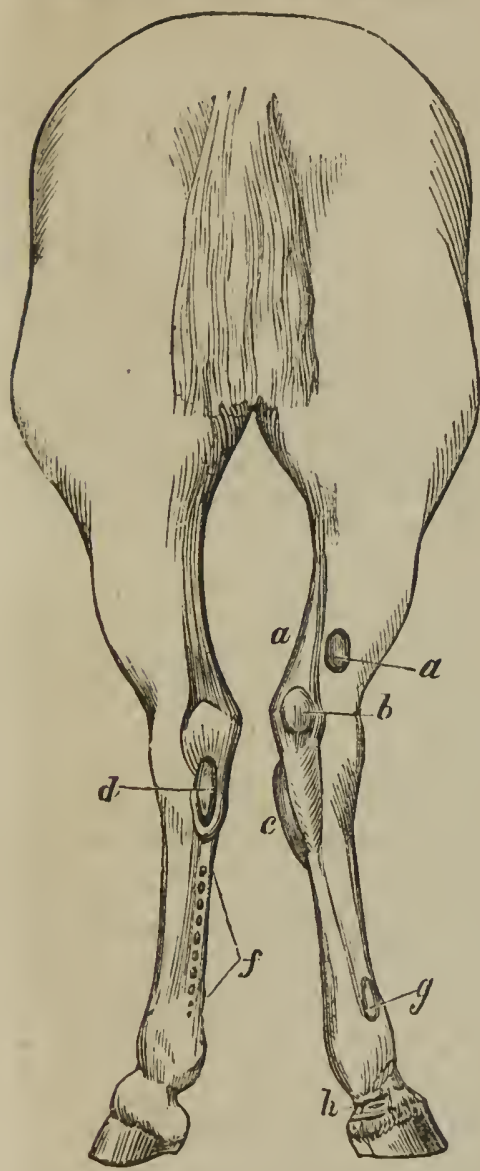
heat and tenderness in the situation of the joint.

A part so deeply situated is treated with difficulty. Fomentions should at first be used to abate the inflammation, and, after that, an active blister should be applied. Strains of this joint are not always immediately relieved, and the muscles of the limb in some cases waste considerably : it therefore may be necessary to repeat the blister, while absolute rest should accompany every stage of the treatment. It may even be requisite to fire the part,-or, as a last resort, a charge may be placed over the joint; and the horse turned out for two or three months.

Proceeding from the body of the bone is a large irregular projection, rising from a kind of pyramidal eminence (see p. 68), and into which are implanted various powerful muscles.

\section{THE STIFLE.}

The inferior extremity presents a pulleylike articulatory surface in front, over which plays the patella, and two condyles, rounded and smooth, presenting inferiorly and posteriorly, and which are received into slight depressions on the upper surface of the lower bone; while in front is a curious groove, over which plays a small irregular bone, the patella, or stifle bone. The whole is commonly called the stifle joint. 'The patella (Q, p. 68) answers to the kneepan in the human subject. Some of the tendons of the strongest muscles of the upper bone of the thigh are inserted into it, and continucd from it over the lower bone. This important joint is hereby much strengthened; for the proper ligaments between the upper and lower bones, and these additional tendons and liganents from the patella, must form altogether a very powerful union. The patella likewise answers another and even more important purpose. The tendons of some strong inuscles are inserted into it. When these muscles are not in action, the patella lies in the groove which nature has contrived for it; but when they begin to contract, it starts from its partial hiding-place, bccomes prominent from the joint, and alters the line of direction in which the muscles act. It increases the angle, and thus very materially increases the power of the muscles.

The lower bone of the thigh is double. The larger portion, in front, extending from the stifle to the hock, is called the Tibia. The smaller bone, or fibula, behind (see $R, p .68$ ), reaches not more than a third of the way down. It is united to the shank-bone, like the splint-bone, by a cartilaginous substance, which is soon changed into a bony one. Of the use of these little bones we cannot speak.

'The lower bone of the thigh forms an angle with the upper one, being the reverse of that which exists between the upper bone and the pelvis. The object of this is tw ofold, - to obviate concussion, and to give a direction to the muscles favourable to their powerful action; and in proportion to the acuteness of the angle, or the degree in which the stifle is brought under the horse, will these purposes be accomplished. There is much difference in this in different horses, and the construction of this part of the frame is a matter worthy of more regard than is generally paid to it.

This part of the thigh should likewise be long. In proportion to the length of the 
muscle is the degree of contraction of which it is capable; and also in proportion to the contraction of the muscle is the extent of motion in the limb; but it is still more necessary that this part of the thigh should have considerable muscle, in order that strength may be added to such extent or compass of motion. Much endurance would not be expected from a horse with a thin arm. A horse with thin and lanky thighs will not possess the strength which considerable exertion would sometimes require. In the cuts p. 281 and 282 , the principal muscles of this part of the thigh are delineated. They are usually somewhat prominent, and may readily be traced in the living animal : a very brief notice of them may not be uninteresting.

The continuation from $g$, p. 282, is the tendinous expansion given to bind and strengthen these muscles.

$n$ is a very important muscle. It is the principal extensor muscle of the hind leg (extensor pedis, extensor.of the foot). It commences by a small flat tendon, common to it, and the flexor metatarsi. Passing over the tibia it becomes fleshy : but a little above the hock it changes to a flat tendon, and pursues its course in front of the hock in union with the tendon of the peronæus. On the fetlock joint they disunite. It now begins to expand, and is finally inserted into the upper part of the coffin-bone, or bone of the foot, after having given various fibres to both the pasterns. The course of the corresponding tendon in the hind leg is given in the cut p. 282, fig. $l$. It helps to flex the hock joint, but is principally concerned in the extension of the foot, and also the pastern and fetlock joints.

At $m$, p. 282, is another of the extensor muscles, called the peronæus, from a name given to the fibula. It arises from the whole course of the fibula, and also becomes tendinous before it reaches the hock. About half-way down the shank it is found in the same sheath with the principal extensor muscle, and is inserted with it into the coffin-bone. Its office is to co-operate with the extensor pedis in raising the foot from the ground, and bringing it forward under the body.

At $o$ is the flexor pedis, one of the principal flexor muscles of the foot, arising from the upper part of the tibia. As it approaches the hock it is distinguished by its large round tendon, which is seen to enter into a groove at the back of the hock. Its tendon passes down the back of the leg like that of a similar muscle in the fore leg. It is the perforating flexor muscle of the hind leg, and assists in flexing the pastern and fetlock.

$k$ is a very slender muscle, arising from the head of the fibula, and proceeding over the external part of the thigh, and, just above the hock, its tendon unites with that of the perforating muscle.

$j$ is a very powerful muscle, springing from the head of the upper bone of the thigh, and, midway down the lower bone of it, ending in a flat tendon, which is inserted into the point of the hock. Its use is to extend the hock. It is evidently most advantageously situated for powerful action; for it acts almost at right angles, and its effect is increased in proportion to the projection of the point of the hock.

We will now turn to the inner side. See cut, p. 281.

$m$ gives a portion of the muscle which has been just described.

$n$ is an inside view of the perforating flexor muscle of the foot.

$l$ is the peronæus.

$o$ is the flexor perforatus muscle, having its origin from near the lower head of the upper bone of the thigh - becoming tendinous as it passes down the thigh - expanding over and surrounding the point of the hock, and assisting in extending it. After this the tendon pursues its course down the posterior part of the leg, in a manner so much resembling that of similar tendons in the fore leg, that it will be sufficient to refer to a description of the perforated and perforating flexor tendons at page 280.

At $e$ is a continuation of the gracilis muscle, p. 281, over the stifle.

At $h$ is the extensor pedis, already described, p. 282 , with its tendon.

At $i$ is a muscle used to bend the hock, the flexor metatarsi, or hender of the leg; arising from the external condyle of the os femoris, and inserted into the large and small metatarsal bones. It is a muscle of considerable power, although disadvantageously situated, both as to its direction and its being inserted so near to the joint. It flexes the hock, the joint turning somewhat inwards.

At $k$ is a short muscle extending from the upper to the lower thigh-bones (the popliteus), bending the stifle and turning the limb inward. 
These euts represent the situation of some of the prineipal blood-vessels and nerves of the hind extremities.

In the cut of the inside of the thigh, page $281, p$ represents the course of the prineipal artery ; at $q$ are blood-vessels belonging to the groin; at $r$ is the large eutaneous vein, or the vein immediately under the skin. The principal nerves on the fore part of the inside of the thigh pursue their eourse at $t$, in the direction of the subcutaneous vein; and those of the posterior part are seen at $s$, while at $u$ are those important ligamentous bands at the bending of the hock which eonfine the tendons.

In the eut of the outside of the thigh, page $282, p$ will give the eourse of the anterior arteries and veins; $q$ that of the prineipal nerves, and eoming into sight below; and $r$ the bands deseribed in the former plate.

Also, in the cut of the outside of the shoulder and arm, p. 259, the figures 1,2 , and 3 , designate the plaees of the prineipal artery, nerve, and vein of the leg; 4 gives the subcutaneous vein running within the arm; and 5 the subeutaneous vein of the side of the ehest.

In the cut of the inside of the arm, p. 260, the lines above represent, in the order from the front, the principal nerves, arteries, and veins of the shoulder and arm; and, on the museles, $k$ represents the principal subeutaneous vein of the inside of the arm, and $i$ the artery by which it is aecompanied.

The stifle joint is not often subject to sprain. The heat and tenderness will guide to the seat of injury. Oecasionally, disloeation of the patella has oceurred, and the horse drags the injured limb after him, or rests it on the fetloek; the aid of a veterinary surgeon is here requisite. The museles of the inside of the thigh have sometimes bcen sprained. This may be deteeted by diffused heat, or heat on the inside of the thigh above the stifle. Rest, fomentations, bleeding, and physic, will be the proper means of cure.

\section{THOROUGH.PIN.}

Mention has been made of wind-galls and their treatment. A similar enlargement is found above the hoek, between the tendons of the flexor of the foot and the extensor of the hock. As from its sitıation it must neeessarily projeet on both sides of the hoek, in the form of a round swelling, it is ealled a thorough-pin, a, p. 283. It is an indieation of eonsiderable work, but is rarely attended by lameness. The mode of treatment must resemble that for wind-galls. Although thorough-pin eannot, perhaps, be pronounced to be unsoundness, it behoves the buyer to examine well a horse that is disfigured by it, and to ascertain whether undue work may not have injured lim in other respeets.

\section{THE HOCK.}

This is a most important joint, oeeasionally the evident, and mueh of tener the unsuspected seat of lameness, and the proper formation of which is essentially conneeted with the value of the horse. It answers to the ancle in the human being.

'The inferior head of the tibia is formed into two deep grooves, with three sharpened ridges, one separating the grooves, and the other two eonstituting the sides of them. It is seen at $a$ in the following eut. It rests upon a singularly-shaped bone, $b$, the astralgus, which has two eireular risings or projections, and, with a depression between them, answering exaetly to the irregularities of the tibia. These are reeeived and mortised into each other. At the posterior part its convex surface is reeeived into a eoneavity near the base of another bone, and with whieh it is united by very strong ligaments. This bone, $c$, is ealled the os ealeis, or bone of the heel, and it projeets upwards, flattened at its sides, and reeeives, strongly implanted into it, the tendons of powerful museles. These bones rest on two others, the os cuboides, $d$ (cube-formed), behind, and the larger cuneiform or wedge-shaped bone $e$, in front. 'The larger wedge-shaped bone is supported by two smaller ones, $f$, and these two smaller ones and the euboides by the upper heads of the shank-bone $g$, and the splintbones $h$. The euboides is placed on the external splint-bone, and the cannon-bone, or principal bone of the leg; the small wedge-bone is principally evident on the inner splint-bone, not seen in the eut; and the middle wedge-bone on the shank-bone only, g. 'These bones are all eonnected together by very strong ligaments, which prevent dislocation, but allow a slight degree of motion between them, and the surfaces which are opposed to each other are thickly eovered by elastic eartilage. 
Considering the situation and action of this joint, the weight and stress thrown

CUT OF THE HOCK.

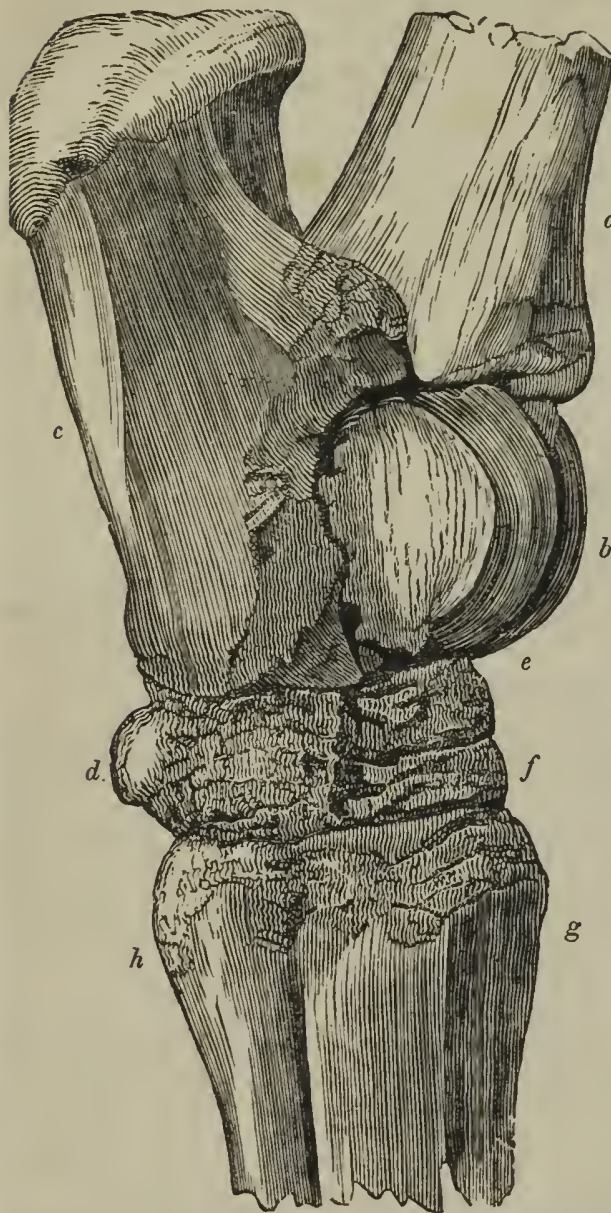
upon it must be exceedingly great, and it is necessarily liable to much injury in rapid and powerful motion. What are the provisions to prevent injury? The grooved or pulley-like heads of the tibia and the astragalus, received deeply into one another, and confined by powerful ligaments, admitting freely of hinge-like action; but of no side motion, to which the joint would otherwise be exposed in rapid movement, or on an uneven surface. A slight inspection of the cut will show that the stress or weight thrown by the tibia $a$ on the astragalus $b$, does not descend perpendicularly, but in a slanting direction. By this much concussion is avoided, or more readily diffused among the different bones; and, the joint consisting of six bones, each of them covered with elastic cartilage, and each admitting of a certain degree of motion, the diminished concussion is diffused among them all, and thereby neutralised and rendered comparatively harmless. Each of these bones is covered not only by cartilage, but by a membrane secreting synovia; so that, in fact, these bones are formed into so many distinct joints, separated from each other, and thereby guarded from injury, yet united by various ligamentspossessing altogether sufficient motion, yet bound together so strongly as to defy dislocation. When, however, the work which this joint has to perform, and the thoughtlessness and cruelty with which that work is often exacted, are considered, it will not excite any surprise if this necessarily complicated mechanism is sometimes deranged. The hock, from its complicated structure and its work, is the principal seat of lameness behind.

\section{ENLARGEMENT OF THE HOCK.}

First, there is inflammation, or sprain of the hock-joint generally, arising from sudden violent concussion, by some check at speed, or over-weight, and attended with enlargement of the whole joint, and great tenderness and lameness. This, however, like other diffused inflammations, is not so untractable as an intense one of a more circumscribed nature, and by rest and fomentation, or, perchance, firing, the limb recovers its action, and the horse becomes fit for ordinary work.

The swelling, however, does not always subside. Enlargement, spread over the whole of the hock-joint, remains. A horse with an enlarged hock must always be regarded with suspicion. In truth, he is unsound. The parts, altered in structure, must be to a certain degree weakened. The animal may discharge his usual work 
during a long period, without return of lameness; but if one of those emergencies should occur when all his energies require to be exerted, the disorganised and weakened part will fail. The purchase, therefore, of a horse with enlarged hock will depend on circumstances. If he has other excellences, he will not be uniformly rejected; for he may be ridden or driven moderately for many a year without inconvenience, yet one extra hard day's work may lame him for ever.

\section{CURB.}

There are often injuries of particular parts of the hock-joint. Curb is an affection of this kind. It is an enlargement at the back of the hock, three or four inches below its point. It is represented at $d$, p. 283, and is either a strain of the ring-like ligament which binds the tendons in their place, or of the sheath of the tendons; oftener, however, of the ligament than of the sleath. Any sudden action of the limb of more than usual violence may produce it, and therefore horses are found to 'throw out curbs' after a hardly-contested race, an extraordinary leap, a severe gallop over heavy ground, or a sudden check in the gallop. Young horses are particularly liable to it, and horses that are cow-hocked (vide cut, p. 283), - whose hocks and legs resemble those of the cow, the hocks being turned inward, and the legs forming a considerable angle outwards. This is intelligible enough; for in hocks so formed, the annular ligament must be continually on the stretcl, in order to confine the tendon.

Curbs are generally accompanied by considerable lameness at their first appearance, but the swelling is not always great. They are best detected by observing the leg sideway.

'The first object in attempting the cure is to abate inflammation, and this will be most readily accomplished by cold evaporating lotions frequently applied to the part. Equal portions of spirit of wine, water, and vinegar, will afford an excellent application. It will be almost impossible to keep a bandage on. If the heat and lameness are considerable, it will be prudent to give a dose of physic, and to bleed from the subcutaneous vein, whose course is represented at $r, \mathrm{p} .281$; and whether the injury is of the annular ligament, or the sheath of the tendon, more active means will be necessary to perfect the cure. Either a liquid blister should be rubbed on the part, consisting of a vinous or turpentine tincture of cantharides, and this daily applied until some considerable sivelling takes place; or, what is the preferable plan, the hair should be cut off, and the part blistered as soon as the heat has been subdued. The blister should be repeated until the swelling has disappeared, and the horse goes sound. In severe cases it may be necessary to fire; but a fair trial, however, should be given to milder measures. If the iron is used, it should be applied in straight lines.

'There are few lamenesses in which absolute and long-continued rest is more requisite. It leaves the parts materially weakened, and, if the horse is soon put to work again, the lameness will frequently return. No horse that has had curbs, should be put even to ordinary work in less than month after the apparent cure; and, even then, he should very gradually resume his former habits.

A horse witl a curb, is manifestly unsound. A horse with the vestige of curb, should be regarded with much suspicion, or generally condemned as unsound.

Curb is also an hereditary complaint; and therefore a horse that has once suffered from it, should always be regarded with suspicion, especially if either of the parents has exhibited it.

\section{BOG SPAVIN.}

The hock is plentifully supplied with reservoirs of mucus, to lubricate the different portions of this complicated joint. Some of these are found on the inside of the joint, which could not be represented in the cut, p. 286. From over-exertion of the joint, they become inflamed, and considerably enlarged. They are wind-galls of the hock. The subcutaneous vein passes over the inside of the hock, and over some of these enlarged mucous reservoirs, and is compressed between them and the external integument - the course of the blood is partially arrested, and a portion of the vein below the impediment, and between it and the next valve, is distended, and causes the soft tumour on the inside of the hock, called Bog or Blood spavin.

'This is a very serious disease, attended with no great, but often permanent lameness, and too apt to return when the enlargement has subsided under medical treat- 
ment. It must be considered as decided unsoundness. In a horse for slow draught, it is scarcely worth while even to attack it. And in one destined to more rapid action, the probability of a relapse should not be forgotten, when the chances of success and the expenses of treatment are calculated.

The cause of the disease - the enlarged mucons capsule - lies dcep, and is with difficulty operated upon. Uniform pressure would sometimes cause the absorption of the fluid contained in cysts or bags like these, but in a joint of such extensive motion as the hock, it is difficult, or almost impossible, to confine the pressure on the precise spot at which it is required. Could it be made to bear on the enlarged bag, it would likewise press on the vein, and to a greater degree hinder the passage of the blood, and increase the dilatation below the obstruction. The old and absurd method of passing a ligature above and below the enlarged portion of the vein, and then dissecting out the tumour, is not, in the advanced stage of veterinary science, practised by any surgeon who regards his reputation. The only method of relief which holds out any promise even of temporary success, is exciting considcrable inflammation on the skin, and thus rousing the deeper-seated absorbents to carry away the fluid effused in the enlarged bag. For this purpose, blisters or firing may be tried: but in the majority of cases, the disease will bid defiance to all appliances, or will return and baffle our hopes when we had seemed to be accomplishing our object.

A horse with bog spavin will do for ordinary work. He may draw in a cart, or trot fairly in a lighter carriage, with little detriment to his utility; but he will never do for hard or rapid work.

\section{BONE SPAVIN.}

A still more formidable disease ranks under the name of Spavin, and is an affection of the bones of the hock-joint. It has been stated that the bones of the leg, the shank-bone, $g$, p. 286, and the two small splint-bones behind, $h$, support the lower layer of the bones of the hock. The cube-bone, $d$, rests principally on the shankbone, and in a slight degree on the outer splint-bone. The middle wedge-bone, $f$, rests entirely upon the shank-bone, and the smaller wedge-bone presses (not seen in the cut) in a very slight degree on the shank-bone, but principally, or almost entirely, on the inner splint-bone. Then the splint-bones sustain a very unequal degree of concussion and weight. Not only is the inner one placed more under the body, and nearer the centre of gravity, but it has almost the whole of the weight and concussion communicated to the smaller cunciform bone carried on to it. It is not, therefore, to be wondered at that, in the violent action of this joint in galloping, leaping, heavy draught, and especially in young horses, and before the limbs have become properly knit, the inner splint-bone, or its ligaments, or the substance which connects it with the shank-bone, should suffer material injury.

The smith increases the tendency to this by his injudicious management of the fcet. It is a common notion that cutting, and wounds in the feet-from one foot treading on the other - are prevented by putting on a shoe with a calkin on the outer heel - that is, the extremity of the heel being considerably raised from the ground. It is not unusual to see whole teams of horses with the outer heel of the hind foot considerably raised above the other. This unequal bearing, or distribution of the weight, cannot fail of being injurious. It places an unequal strain on the ligaments of the joints, and particularly of the hock-joint, and increases the tendency to spavin.

The weight and concussion thus thrown on the inner splint-bone, produce inflammation of the cartilaginous substance that unites it to the shank-bone. In consequence of it, the cartilage is absorbed, and bone deposited; the union betwcen the splint-bone and the shank becomes bony, instead of cartilaginous; the degrce of elastic action between them is destroyed, and there is formed a splint of the hind leg. This is uniformly on the inside of the hind leg, because the greatest weight and concussion are thrown on the inner splint-bones. As in the fore leg, the disposition to form bony matter having commenced, and the cause which produced it continuing to where the head of the splint-bone is united with the shank, and in front of that union. It is seen at $c, \mathrm{p} .283$. This is called cove spavis. Inflammation of the ligaments of any of the small boncs of the hock, proceeding to bony tumour, would equally cise spot that has been described. 
While spavin is forming, there is always lameness, and that frequently to a very great degree: but when the membrane of the bone has accommodated itself to the tumour that extended it, the lameness subsides or disappears, or depends upon the degree in which the bony deposit interferes with the motion of the joint. It is well known to horscmen, that many a hunter, with spavin that would cause his rejection by a veterinary surgeon, stands his work without lameness. The explanation is this : there is no reason why an old bony tumour on the outside of any of the bones of the hock, free from connexion with the next bone, and from any tendon, should be at all injurious ; as, for instance, one immediately under $e$ or $f$, p. 286 : but, from the complicated nature of the hock, it is difficult, if not impossible, to be quite sure of the place, or extent, from inspection, of the tumour ; and, besides, the disposition to throw out bone covered by the tumour, may continue and extend to the joint. The surgeon, therefore, cannot be perfectly safe in pronouncing a bone spavin to be of no eonsequence. Horses with exceedingly large spavins, are often seen that are only slightly lame, or that merely have a stiffness in their gait at first starting, but which gradually goes off after a little motion; while others, with the bony tumour coinparatively small, have the lameness so great as to destroy the usefulness of the horse. There is always this peculiarity in the lameness of spavin, that it abates, and sometimes disappears, on cxercise ; and, therefore, a horse, with regard to which there is any suspicion of this affection, should be examined when first in the morning it is taken from the stable.

If the spavin continues to increase, the bony deposit first spreads over the lower wedge-bones, $f$, page 286 , for these are nearest to its original scat. They are capable of slight motion, and share in every action of the joint, but their principal design is to obviate concussion. The chief motion of the joint, and that compared with which the motion of the other bones is scarcely to be regarded, is confined to the tibia $a$, and the astragalus $b$, and therefore stiffness rather than lameness may accompany spavin, even when it is beginning to affect the small bones of the joint. Hence, too, is the advantage of these bones having each its separatc ligaments and membranes, and constituting so many distinct joints, since injury may happen to some of them, without the effect being propagated to the rest. When the bony deposit continues to enlarge and takes in the second layer of bones-the larger wedgebones $c$-and even spreads to the cuboid bones on the other side, the lameness may not be very great, because these are joints, or parts of the joint, in which the motion is small; but when it extends to the union of the tibia $a$, and the astragalus $b$-when the joint, in which is the chief motion of the hock, is attacked - the lameness is indeed formidable, and the horse becomes nearly quite uselcss.

Spavined liorses are generally eapable of slow work. They are equal to the greater part of the work of the farm, and therefore they should not be always rejected by the sinall farmer, as they may generally be procured at little price. These horses are not only capable of agricultural work, but they generally improve under it. The lameness in some degree abates, and even the bony tumour to a certain degree diminishes. There is sufficient moderate motion and friction of the limb to rouse the absorbents to action, and cause them to take up a portion of the bony matter thrown out, but not enough to renew or prolong inflammation. It cannot be said that the plough affords a cure for spavin, hut the spavined horse often materially improves while working at it.

For fast work, and for work that must be regularly performed, spavined horses are not well calculated; for this lameness behind produces great difficulty in rising, and the consciousness that he will not be able to rise without painful effort occasionally prevents the horse from lying down at all; and the animal that cannot rest well eannot long travel far or fast.

The treatment of spavin is simple enough, but far from being always effectual. The owner of the horse will neither consult his own interest, nor the dictates of humanity, if he suffers the chisel and mallet, or the gimlet, or the pointed iron, or arscnic, to be used; yet measures of considerable severity must be resorted to. Repeated blisters will usually cause either the absorption of the bony deposit, or the abatement or removal of the inflammation of the ligaments, or, as a last resource, the heated iron may be applied.

The account of the diseases of the hock is not yet completed. It is well known that the horse is frequently subject to lameness behind, when no ostensible cause for 
it can be found, and there is no external heat or enlargement to indicate its seat. Farriers and grooms pronounce these to be affections of the stifle, or round bone; or, if the gait of the horse and peculiar stiffness of motion point out the hock as the affected part, yet the joint may be of its natural size, and neither heat nor tenderness can be discovered. The groom has his own method of unravelling the mystery. $\mathrm{He}$ says that it is the beginning of spavin; but months and years pass away, and the spavin does not appear, and the horse is at length destroyed as incurably lame.

Horsemen are indebted to Mr. W. J. Goodwin, V. S. to Her Majesty, for the discovery of the seat of frequent lameness behind. The cut, p. 286, represents the two layers of small bones within the hock-the larger wedge-like bone $e$, above; and the middle $f$, and the smaller one below, and it will be seen that almost the whole of the weight of the horse, communicated by the tibia $a$, is thrown upon these bones. The cube-bone $d$ does little more than support the point of the hock $c$. It is then easy to imagine that, in the concussion of hard work or rapid travelling, these bones, or the delicate and sensible membranes in which they are wrapped, may be severely injured. Repeated dissections of horses that have been incurably lame behind, without anything external, during life, to point out the place or cause of lameness, have shown that inflammation of the membranes lining these joints, and secreting the fluid that lubricates them, has taken place.

Mr. Goodwin narrates a very interesting case in corroboration of this account of hock lameness. 'The author of this work had the honour of being present when the examination took place. "The patient was a harness horse of unusual perfection, both in shape and action, and was a great favourite with an illustrious personage. He suddenly became lame behind on the off-leg, but without the least accident or alteration of structure to account for it. He was turned out for a short time, and the lameness disappeared. He was then incautiously made to perform his usual work, until perfectly incapacitated for it by returning and aggravated lameness. Suspecting the seat of lameness to be in the hock, although the joint was perfectly unaltered in form, he was, three months after the commencement of the lameness, blistered and fired, and placed either in a loose place or paddock, as circumstances seemed to require. Not the least amendment took place at the end of six months, even in his quiescent state, and, after twelve months from the time of his being given up for treatment, he was destroyed, his case being naturally considered a hopeless one. Ulceration of the synovial membrane was found, taking its origin between the two cuneiform bones. These bones had become carious, and the disease had gradually extended itself to other parts of the joint. Mr. Goodwin had no doubt that if the animal had been suffered to work on for any greater length of time, necrosis, or anchylosis of every bone concerned in the hock, would have been the result." *-(Veterinarian, iii. 158.)

Much more depends, than they who are not well accustomed to horses imagine, on the length of the os calcis, or projection of the hock. In proportion to the length of this bone will two purposes be effected. The line of direction will be more advantageous, for it will be nearer to a perpendicular, and the arm of the lever to which the power is applied will be lengthened, and thus mechanical advantage will he gained to an almost incredible extent. The slightest lengthening of the point of the hock will wonderfully tell in the course of a day's work, and therefore it is that the character of the os calcis is of such immense importance.

The point of the hock is sometimes swelled. A soft, fluctuating tumour appears on it. This is an enlargement of one of the mucous bags of which mention has been made, and that surrounds the insertion of the tendons into the point of the hock. It is termed,

\section{CAPPED HOCK.}

It is seldom accompanied by lameness, and yet it is a somewhat serious business, for it is usually produced by blows and mostly by the injuries which the horse in-

* These opinions of the seat and nature of obscure hock-lameness are now maintained by the majority of veterinary surgeons, although some of them differ a little with regard to the articulation that is generally affected, and the manner in which the depressions or excavations on the surface of these bones is effected. In the 10th volume of the "Veterinarian," are some valuable observations on this subject by Professor Dick, and Messrs. Pritchard and
Spooner. 
flicts upon himself in the act of kicking: therefore it is that a horse with a capperl hock is very properly regarded with a suspicious eye. The whole of the hock should be carefully examined in order to discover whether there are other marks of violence, and the previous history of the animal should be carefully inquired into. Does he kick in harness or in the stall, or has he been lying on a thin bed, or on no bed at all; and thus may the hock have been bruised, and the swelling produced?

It is exceedingly difficult to apply a bandage over a capped hock; and puncturing the tumour, or passing a seton through it, would be a most injudicious practice. Blisters, or iodine, repeated as often as may be necessary, are the best means to be employed. Occasionally the tumour will spontaneously disappear; but at other times it will attain a large size, or assume a callous structure, that will bid defiance to all the means that can be employed.

\section{MALLENDERS AND SALLENDERS.}

On the inside of the hock, or a little below it, as well as at the bend of the knee ( $h$, p. 277), there is occasionally a scurfy eruption, called mallenders in the fore leg, and sallenders in the hind leg. They seldom produce lameness; but if no means are taken to get rid of them, a discharge proceeds from them which it is afterwards difficult to stop. They usually indicate bad stable management.

A diuretic ball should be oceasionally given, and an ointment of sugar-of-lead and tar, with treble the quantity of lard, rubbed over the part. Should this fail, a weak mercurial ointment may be used. Iodine has here also been useful.

The line of direction of the legs beneath the hocks should not be disregarded. The leg should descend perpendicularly to the fetlock. The weight and stress will thus be equally diffused, not only over the whole of the hock, but also the pasterns and the foot. Some horses have their hocks closer than usual to each other. The legs take a divergent direction outward, and the toes also are turned outward. 'These horses are said to be Cat or Cow hocked. 'They are generally supposed to possess considerable speed. Perhaps they do so; and it is thus accounted for. The cowhocked horse has his legs not only turned more outward, but bent more under him, and this increases the distance between the point of the hock and the tendons of the perforating muscle: see $b$, in the cut, page 283. It increases the space which is usually occupied by thoroughpin, see $a$, in the same parge. Then the point of the hock, moved by the action of the muscles, is enabled to describe a greater portion of a circle; and in proportion to the increased space passed over by the point of the hock, will the space traversed by the limb be increased, and so the stride of the horse may be lengthened, and, thus far, his speed may be increased. But this advantage is morc than counterbalanced by many evils. This increased contraction of the muscles is an expenditure of animal power; and, as already stated, the weight and the concussion being so unequally distributed by this formation of the linibs, some part must be over-strained and over-worked, and injury must ensue. On this account it is that the cow-hocked horse is more subject than others to thoroughpin and spavin; and is so disposed to curbs, that these hocks are denominated by horsemen curly hocks. The mischief extends even farther than this. Such a horse is peculiarly liable to windgall, sprain of the fetlock, cutting, and linuckling.

A slight inclination to this form in a strong powerful horse may not be very objectionable, but a horse decidedly cow-hocked should never be selected.

\section{SWELLED LEGS.}

The fore legs, but oftener the hind ones, and especially in coarse horses, are sometimes subject to considerable enlargement. Occasionally, when the horse does not seem to labour under any other disease, and sometimes from an apparent shifting of disease from other parts, the hind legs suddenly swell to an enormous degree from the hock and almost from the stifle to the fetlock, attended by a greater or less degree of heat, and tenderness of the skin, and sometimes excessive and very peculiar lameness. The pulse likewise becomes quick and hard, and the horse cvidently labours under considerable fever. It is acute inflammation of the cellular substance of the legs, and that most sudden in its attack, and most violent in its degree, and therefore attended by the effusion of a considerable quantity of fluid into the cellular membrane. It occurs in young horses, and in those which are over-fed and little exercised. 
Fomentation, diuretics, or purgatives, or, if there is much fever, a moderate bleeding will often relieve the distension almost as suddenly as it appeared.

The kind of swelled legs most frequently occurring and most troublesome is of a different nature, or rather it is most various in its kind and causes, and consequences and mode of treatment. Sometimes the legs are filled, but there is little lameness or inconvenience. At other times the limbs are strangely gorged, and with a great degree of stiffness and pain. Occasionally the horse is apparently well at night, but, on the following morning, one or both of the legs are tremendously swollen; and on its being touched, the horse catches it up suddenly, and nearly falls as he does so. Many horses, in seemingly perfect health, if suffered to remain several days without exercise, will have swelled legs. If the case is neglected, abscesses appear in various parts of the legs; the heels are attacked by grease, and, if proper measures are not adopted, the horse has an enlarged leg for life.

'The cure, when the case has not been too long neglected, is sufficiently plain. Physic or diuretics, or both, must be had recourse to. Mild cases will generally yield to their influence; but, if the animal has been neglected, the treatment must be decisive. If the horse is in high condition, these should be preceded or accompanied by bleeding; but if there are any symptoms of debility, bleeding would only increase the want of tone in the vessels.

Horses taken from grass and brought into close stables very speedily have swelled legs, because the difference of food and increase of nutriment rapidly increase the quantity of the circulating fluid, while the want of exercise takes away the means by which it might be got rid of. The remedy here is sufficiently plain. Swelled legs, however, may proceed from general debility. They may be the consequence of starvation, or disease that has considerably weakened the animal; and these parts, being farthest from the centre of circulation, are the first to show the loss of power by the accumulation of fluid in them. Here the means of cure would be to increase the general strength, with which the extremities would syrnpathise. Mild diuretics and tonics would therefore be evidently indicated.

Horses in the spring and fall are subject to swelled legs. The powers of the constitution are principally employed in providing a new coat for the animal, and the extremities have not their share of vital influence. Mingled cordials and diuretics are indicated here - the diuretic to lessen the quantity of the circulating fluid, and the cordial to invigorate the frame.

Swelled legs are often teasing in horses that are in tolerable or good health : but where the work is somewhat irregular the cure consists in giving more equal exercise, walking the horse out daily when the usual work is not required, and using plenty of friction in the form of hand-rubbing. Bandages have a greater and more durable effect, for nothing tends more to support the capillary vessels, and rouse the action of the absorbents, thran moderate pressure. Hay-bands will form a good bandage for the agricultural horse, and their effect will probably be increased by previously dipping them in water.

\section{GREASE.}

The physic, or the diuretic ball, may occasionally be used, but very sparingly; and only when they are absolutely required. In the hands of the owner of the horse, or of the veterinary surgeon, they may be employed with benefit; but in those of the carter or the groom they will do far more harm than good. The frequent and undue stimulus of the urinary organs by the diuretic ball, will be too often followed by speedy and incurable debility. If the swelling bids defiance to exercise and friction and bandage, the aid of the diuretic may be resorted to, but never until these have failed, unless there is an evident tendency to humour or grease.

Swelled legs, although distinct from grease, is a disease that is apt to degenerate into it. Grease is a specific inflammation of the shin of the heels, sometimes of the fore-feet, but oftener of the hinder ones. It is not a contagious disease, as some have asserted, although when it once appears in a stable it frequently attacks almost every horse in it. Bad stable management is the true cause of it.

There is a peculiarity about the skin of the heel of the horse. In its healthy state there is a secretion of greasy matter from it, in order to prevent excoriation and chapping, and the skin is soft and pliable. 'Too often, howryer, from bad management, the secretion of this greasy matter is stopped, and the skin of the heel becomes red, 
and dry, and scurfy. The joint still continuing to be extended and flexed, eracks of the skin begin to appear, and these, if neglected, rapidly extend, and the heel becomes a mass of soreness, ulceration, and fungus.

The distance of the lieel from the centre of circulation, and the position of the hind limbs, render the return of blood slow and difficult. There is also more variation of temperature here than in any other part of the frame. As the horse stands in the closed stablc, the heat of this part is too often increased by its being embedded in straw. When the stable door is open, the heels are nearest to it, and receive first, and inost powerfully, the cold current of air. When he is taken from his stable to work, the heels are frequently covered with mire and wet, and they are oftenest and most intensely chilled by the long and slow process of evaporation which is taking place from them. No one, then, can wonder at the frcquency with which the heels are attacked by inflammation, and the difficulty there is in subduing it.

Much error has prevailed, and it has led to considerable bad practice, from the notion of humours flying about the horse, and which, it is said, nust have vent somewhere, and attack the heels as the weakest part of the frame. Thence arise the physicking, and the long course of diuretics, which truly weaken the animal, and often do irreparable mischicf.

Grease is a local complaint. It is produced principally by causes that act locally, and it is most successfully treated by local applications. Diuretics and purgatives may be useful in abating inflammation; but the grand object is to get rid of the inflammatory action which exists in the skin of the heel, and to heal the wounds, and remedy the mischief which it has occasioned.

The first appearance of grease is usually a dry and scurfy state of the skin of the heel, with redness, heat, and itchiness. The heel should be well but gently washed with soap and water, and as much of the scurf detached as is easily removable. An ointment, composed of one part plumb. diacet. and seven of adeps suillæ, will usually supple, and cool, and heal the part.

When cracks appear, the mode of treatment will depend on their extent and depth. If they are but slight, a lotion, composed plumbi sulph. 3ij. et aluminis 3iiij., dissolved in a pint of water, will often speedily dry them up, and close them. There is sometimes considerable caprice in the application of this lotion, which has induced Professor Morton to have recourse to alumen et terebinthinus vulgaris one part each, and adeps suillæ three parts, made into an ointment.

If the cracks are deep, with an ichorous discharge and considerable lameness, it will be necessary to poultice the heel. A poultice of linseed meal will be generally effective, unlcss the discharge is thin and offensive, when an ounce of finely-powdered charcoal should be mixed with the linseed meal; or a poultice of carrots, boiled soft and mashed. The efficacy of a carrot-poultice is seldom sufficiently appreciated in cases like this.

When the inflammation and pain have evidently subsided, and the sores discharge good matter, the calanine ointment may be applied with advantage; and the cure will generally be quickened if a very diluted vitriolic or alum solution is applied.

The best medicine will consist of mild aloetic balls; gentle diuretics being given towards the close of the treatment.

After the chaps or cracks have healed, the legs will sometimes continue gorged and swelled. A flannel bandage, evenly applied over the whole of the swelled part, will bc very serviceable; or, should the season admit of it, a run at grass, particularly spring grass, should be allowed. A blister is inadmissible, from the danger of bringing back the inflammation of the skin, and the dischargc from it; but the actual cautery, special care heing taken not to penetrate the skin, may occasionally be resorted to.

In some cases the cracks are not confined to the centre of the heels, but spread over tlem, and extend on the fetlock, and even up the leg, while the legs are exceedingly swelled, and there is a watery discharge from the cracks, and an apparent oozing through the skin at other places. The legs are exceedingly tender and sometimes hot, and there is an appearance which the farrier thinks very decisive as to the state of the disease, and which the better informed man should not overlook - the heels smoke-the skin is so hot, that the watery fluid partly evaporates as it runs from the cracks or oozes through the skin.

There will be great danger in suddenly stopping this discharge. Inflammation of $25 *$ 
a more important part has rapidly succeeded to the injudicious attempt. The local application should be directed to the abatement of the inflammation. The poultices just referred to should be diligently used night and day, and especially the carrotpoultice; and when the heat, and tenderness, and stiffness of motion have diminished, astringent lotions may be applied-either the alum lotion, or a strong decoction of oakbark, changed, or used alternately, but not mixed. The cracks should likewise be dressed with the ointment above-mentioned; and, the moment the horse can bear it, a flannel bandage should be put on, reaching from the coronet to three or four inclies above the swelling.

The merlicine should be confined to mild diuretics, mixed witl one-third part of cordial mash ; or, if the horse is gross, and the inflammation runs high, a dose of physic may be given. If the horse is strong, and full of flesh, physic should always precede and sometimes supersede the diuretics. In cases of much debility, diuretics, with aromatics or tonics, will be preferable.

The feeding should likewise vary with the case, but with these rules, which admit of no exception, that green meat should be given, and more especially carrots, when they are not too expensive, and mashes, if the horse will eat them, and never the full allowance of corn.

Walking exercise should be resorted to as soon as the horse is able to bear it, and this by degrees may be increased to a gentle trot.

From bad stable management at first, and neglect during the disease, a yet worse kind of grease occasionally appears. The ulceration extends over the skin of the heel and the fetlock, and a fungus springs from the surface of both, highly sensible, bleeding at the slightest touch, and interspersed with scabs. By degrees, portions of the fungus begin to be covered with a horny substance protruding in the form of knobs; and collected together in bunches. These are known by the name of grapes. A foetid and very peculiar exudation proceeds from nearly the whole of the unnatural substance. The horse evidently suffers much, and is gradually worn down by the discharge. The assistance of a reterinary surgeon is here indispensable.

Some horses are more subject to grease than others, particularly draught-horses, both heary and light, but particularly. the former, and if they have no degree of blood in them. It was the experience of this which partly contributed to the gradual change of coach and other draught-horses to those of a lighter brecd. In the great majority of cases, grease arises from mismanagement and neglect.

Everything that has a tendency to excite inflammation in the skin of the heel is a cause of grease. 'Therefore want of exercise is a frequent source of this disease. The fluid which accumulates about the extremities and is unable to return, is a source of irritation by its continual pressure. When high feeding is added to irregular or deficient exercise, the disease is evidently still more likely to be produced. Want of cleanliness in the stable is a fruitful source of grease. When the heels are embedded in filth, they are weakened by the constant moisture surrounding themirritated by the acrimony of the dung and the urine, and little prepared to endure the cold evaporation to which they are exposed when the horse is taken out of the stable. The absurd practice of washing the feet and legs of horses when they come from their work, and either carelessly sponging them down afterwards, or leaving them to dry as they may, is, however, the most common origin of grease.

When the horse is warmed by his work, and the heels share in the warmth, the momentary cold of washing may not be injurious, if the animal is immediately rubbed dry; yet even this would be better avoided: but to wash out the heels, and then leave them partially dry or perfectly wet, and suffering from the extreme cold that is produced by evaporation from a moist and wet surface, is the most absurd, dangerous, and injurious practice that can be imagined. It is worse when the post-horse or the plough-horse is plunged up to his belly in the river or pond, immediately after his work. The owner is little aware how many cases of inflammation of the lungs, and bowels, and feet, and heels follow. After they have been suffered to stand for twenty minutes in the stable, during which time the horse-keeper or the carter may be employed in taking care of the harness, or carriage, or beginning to dress the horse, the greater part of the dirt which had collected about the heels may be got rid of with a dry brush; and the rest will disappear a quarter of an hour afterwards under the operation of a second brushing. The trouble will not be great, and the heels will not be chilled and subject to inflammation. 
There has been some dispute as to the propriety of cutting the hair from the heels.* Custom has very properly retained the hair on our farm-horses. Nature would not have given it, had it not been useful. It guards the heel from being injured by the inequalities of the ploughed field; it prevents the dirt, in which the heels are constantly enveloped, from reaching and caking on, and irritating the skin; it hinders the usual moisture which is mixed with the clay and mould from reaching the skin, and it preserves an equal temperature in the parts. If the hair is suffered to remain on the heels of the farm-horses, there is greater necessity for brushing and hand-rub. bing the heels, and never washing them.

Fashion and utility have removed the hair from the heels of our hackney and car. riage horses. When the horse is carefully tended after his work is over, and his legs quickly and completely dried, the less hair he has about them the better, for then both the skin and the hair can be made perfectly dry before evaporation begins, or proceeds so far as to deprive the legs of their heat. Grease is the child of negligence and mismanagement. It is driven from our cavalry, and it will be the fault of the gentleman and the farmer if it is not speedily banished froin every stable.

\section{CHAPTER XIV.}

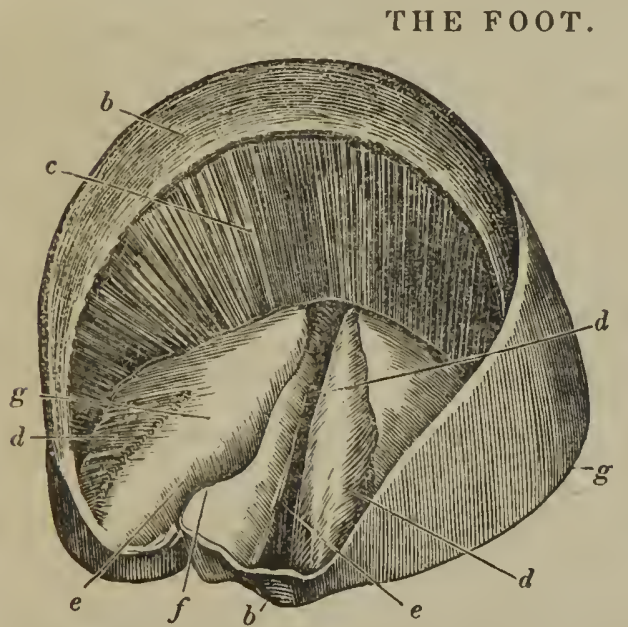

a The external crust seen at the quarter.

$b$ The coronary ring.

c The little horny plates lining the erust.

$d$ The same continued over the bars.

e $e$ The two concave surfacen of the inside of the horny frog.

$f$ That which externally is the cleft of the frog.

g The bars.

$h$ The rounded part of the heels, belonging to the frog.

This smaller cut exhibits, in as satisfactory a manner, the mechanism and structure of the base of the foot.

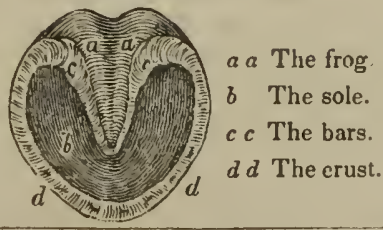

* Professor Stewart has the following observations:- "During two very wet wintera I had opportunity of observing the results of trimming and no trimming, among upwards of 500 horses. More than 300 of these have been employed in coaching and posting, or work of a similar kind, and about 150 are cart-horses. Grease, and other skin diseases of the hecls have been of most frequent occurrence where the horses are both trimmed and washed; they have been common where the horses were trimmed but not washed, and there have been very few cases where wasling or trimming were forbidden or neglected." - Stable OEconomy, page 116. 
The foot is composed of the horny box that covers the extremities of the horse, and the contents of that box. The hoof or box is composed of the crust or wall, the coronary ring and band, the bars, the horny laminæ, the sole, and the horny frog.

\section{THE CRUST OR WALL OF THE HOOF.}

The crust, or wall, is that portion which is seen when the foot is placed on the ground, and reaches from the termination of the hair to the ground. It is deepest in front, where it is called the toe, measuring there about three inches and a half in depth (see cut, p. 297), shallower at the sides, which are denominated the quarters, and of least extent behind, where it is seldom more than an inch and a half in height, and is termed the lieel. The crust in the healthy foot presents a flat and narrow surface to the ground, ascending obliquely backwards, and possessing different degrees of obliquity in different horses. In a sound hoof the proper degree of obliquity is calculated at forty-five degrees, or the fourth part of a semicircle, at the front of the foot. When the obliquity is greater than this, it indicates undue flatness of the sole, and the crust is said to have "fallen in." If the obliquity is very much increased, the sole projects, and is said to be pumiced or convex.

If the foot is more upright, or forms a greater angle than forty-five degrees, it indicates much contraction, and a sole too concave; and this difference of obliquity is often so great, that the convexity or concavity of the sole may be affirmed without the trouble of raising the foot for the purpose of examination.

It is of some importance to observe whether the depth of the crust appears rapidly or slowly to decrease from the front to the heel. If the decrease is little, and even at the heel the crust is high and deep, this indicates a foot liable to contraction, sandcrack, thrush, and inflammation. The pasterns are upright, the paces of that horse are not pleasant. On the other hand, if the crust rapidly diminishes in depth, and the heels are low, this is accompanied by too great slanting of the pastern, and disposition to sprain in the back sinew. The foot, generally, is liable to be wieak and flat, and bruised, and there is more tendency to the frequent, but obscure lameness, of which there will presently be occasion to treat-the navicular-joint disease.

The crust is composed of numerous horny fibres, connected together by an elastic membranous substance, and extending from the coronet to the base of the hoof. It differs materially in its texture, its elasticity, its growth, and its occasional fragility, according to the state in which it is kept, and the circumstances that are acting upon it.

The exterior wall of the hoof should be smooth and level. Protuberances or rings round the crust indicate that the horse has had inflammation in the feet, and that to such a degree, as to produce an unequal growth of horn, and probably to leave some injurious consequences in the internal part of the foot. If there is a depression or hollow in front of the foot, it betrays a sinking of the coffin-bone, and a flat or pumiced sole. If there is a hollow at the quarters, it is the worst symptom of bad contraction.

The thickness of the crust, in the front of the foot, is rather more than half an inch; it becomes gradually thinner towards the quarters and heels, but this often varies to a considerable extent. In some hoofs, it is not more than half the above thickness. If however there is not, in the majority of horses, more than half an inch for nail-hold at the toe, and not so much at the quarters, it will not appear surprising that these horses are occasionally wounded in shoeing, and especially as some of them are very unmanageable while undergoing this process.

While the crust becomes thinner towards both quarters, it is more so at the inner quarter than at the outer, because more weight is thrown upon it than upon the outer. It is more under the horse. It is under the inner splint-bone, on which so much more of the weight rests than on the outer; and, being thinner, it is able to expand more. Its elasticity is called more into play, and concussion and injury are avoided. When the expansion of the quarters is prevented by their being nailed to an unbending shoe, the inner quarter suffers most. Coms are oftenest found there; contraction begins there; sand-crack is seated there. Nature meant that this should be the most yielding part, in order to obviate concussion, because on it the weight is principally thrown, and therefore when its power of yielding is taken away it must be the first to suffer.

A careful observer will likewise perceive that the inner quarter is higher than the 
outer. While it is thin to yield to the shock, its increased surface gives it sufficient strength.

On account of its thinness, and the additional weiglit which it bears, the inner heel wears away quicker than the outer; a circumstance that should never be forgotten by the smith. His object is to give a plane and level bearing to the whole of the crust. To accomplish this, it will be often scarcely necessary to remove anything from the inner heel, for this has already been done by the wear of the foot. If he forgets this, as he too often seems to do, and cuts away with his knife or his buttress an equa! portion all round, he leaves the inner and weaker quarter lower than the outer; he throws an uneven bearing upon it; and produces corns and sand-cracks and splints, which a little care and common sense might have avoided.

\section{THE CORONARY RING.}

The crust does not vary much in thickness (see $\alpha$, page 295 , and $b$, in the accompanying cut), until near the top, at the coronet, or union of the horn of the foot with the skin of the pasterns, where ( $w$, page 272$)$, it rapidly gets thin. It is in a manner scooped and hollowed out. It likewise

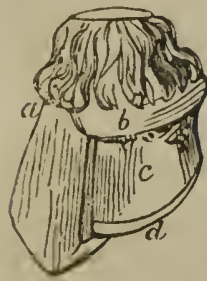
changes its colour and consistence, and seems almost like a continuation of the skin, but easily separable from it by maceration or disease. This thin part is called the coronary ring, $x$, p. 272 . It extends round the upper portion of the hoofs, and receives, within it, or covers, a thickened and bulbous prolongation of the skin, called the coronary ligament (see $b$, in the accompanying cut). This prolongation of the skin - it is nothing more - is thickly supplied with blood-vessels. It is almost a mesh of blood-vessels connected together by fibrous texture, and many of them are employed in secreting or forming the crust or wall of the foot. Nature has enabled the sensible laminæ of the coffin-bone, $c$, which will bc presently described, to secrete a certain quantity of horn, in order to afford an immediate defence for itself when the crust is wounded or taken away. Of this there is proof when in sand-crack or quittor it is necessary to remove a portion of the crust. A pellicle of horn, or of firm hard substance resembling it, soon covers the wound; but the crust is principally formed from this coronary ligament. Hence it is, that in sand-crack, quittor, and other diseases in which strips of the crust are destroyed, it is so long in being renewed, or growing down. It must proceed from the coronary ligament, and so gradually creep down the foot with the natural growth or lengthening of the horn, of which, as in the human nail, a supply is slowly given to answer to the wear and tear of the part.

Below thc coronary ligament is a thin strip of horny matter, which has been traced to the frog, and has been supposed by some to be connected with the support or action of that body, but which is evidently intended to add to the security of the part on which it is found, and to bind together those various substances which are collected at the coronet. It resembles, more than anything else, the strip of skin that surrounds the root of the human nail, and which is placed there to strengthen the union of the nail with the substance from which it proceeds.

\section{THE BARS.}

At the back part of the foot the wall of the hoof, instead of continuing round and forming a circle, is suddenly bent in as in the small cut, in page 295, where $d$ represents the base of the crust, and $e$ its inflection or bending at the heel. The bars are, in fact, a continuation of the crust, forming an acute angle, and meeting at a point at the toe of the frog - see $a, b$, and $c$, in the smaller cuts - and the inside of the bars, like the inside of the crust-see the first and larger cut-presents a continuance of the horny leaves, showing that it is a part of the same substance, and helping to discharge the same office.

It needs only the slightest consideration of the cut, or of the natural hoof, to show the importance of the bars. The arch which these form on either side, between the frog and the quarters, is admirably contrived both to admit of, and to limit to its proper extent, the expansion of the foot. When the foot is placed on the ground, and the weight of the animal is thrown on the leaves of which mention has just been made, 
these arches will shorten and widen, in order to admit of the expansion of the quarters - the bow returning to its natural curve, and powerfully assisting the foot in regaining its usual form. It can also be conceived that these bars must form a powerful protection against the contraction, or wiring in, of the quarters. A moment's inspection of the cut $(g, p .295)$ will show that, if the bars are taken away, there will be nothing to resist the contraction or falling in of the quarters, when the foot is exposed to any disease, or bad management, that would induce it to contract. One moment's observation of them will also render evident the security which they afford to the frog $(f)$, and the effectual protection which they give to the lateral portions of the foot.

Then appears the necessity of passing lightly over them, and leaving prominent, when the foot is pared for shoeing, that which so many smiths cut perfectly away. They imagine that it gives a more open appearance to the foot of the horse. Horses shod for the purpose of sale, have usually the bars removed with this view; and the smiths in the neighbourhood of the metropolis and large towns, shoeing for dealers, too often habitually pursue, with regard to all their customers, the injurious practice of removing the bars. The homy frog, deprived of its guard, will speedily contract, and become elevated and thrushy; and the whole of the heel, having lost the power of resilience or reaction which the curve between the bar $c$ and the crust $d$ gave it (vide p. 295, cut), will speedily fall in.

\section{THE HORNY LAMINA.}

The inside of the crust is covered by thin horny leaves (c, p. 295), extending all round it, and reaching from the coronary ring to the toe. They are about 500 in number, broadest at their base, and terminating in the most delicate expansion of horn. They not a little resemble the inner surface of a mushroom. In front, they run in a direction from the coronet to the toe, and towards the quarters they are more slanting from behind forwards. They correspond, as will be presently shown, with similar cartilaginous and fleshy leaves on the surface of the coffin-bone, and form a beautiful elastic body, by which the whole weight of the horse is supported.

\section{THE SOLE}

Is under, and occupies the greater portion of the concave and elastic surface of the foot (see $b$, p. 295), extending from the crust to the bars and frog. It is not so thick as the crust, because, notwithstanding its situation, it does not support so much weight as the crust; and because it was intended to expand, in order to prevent concussion, when, by the descent of the bone of the foot, the weight was thrown upon it. It is not so brittle as the crust, and it is more elastic than it. It is thickest at the toe (see $t$, p. 272), because the first and principal stress is thrown on that part. The coffin-bone, $f$, is driven forward and downward in that direction. It is likewise thicker where it unites with the crust than it is towards the centre, for a similar and evident reason, because there the weight is first and principally thrown. In a state of nature it is, to a certain degree, hollow. The reason of this is plain.
It is intended to descend or yield with the weight of the horse, and by that gradual descent or yielding, most materially lessen the shock which would result from the sudden action of the weight of the animal in rapid and violent exercise ; and this descent can only be given by a hollow sole. A flat sole, already pressing upon the ground, could not be brought lower; nor could the functions of the frog be then discharged; nor would the foot have so secure a hold. Then if the sole is naturally hollow, and hollow because it must descend, the smith should not interfere with this important action. When the foot will bear it, he must pare out sufficient of the horn to preserve the proper concavity; also a small portion at the toe and near the crust, and cutting deeper towards the centre. He must put on a shoe which shall not prevent the descent of the sole, and which not only shall not press upon it, but shall leave sufficient room between it and the sole to admit of this descent. If the sole is pressed upon by the coffin-bone during the lengthening of the elastic laminæ, and the shoe will not permit its descent, the sensible part between the coffin-bone and the horn will necessarily be bruised, and inflammation and lameness will ensue. It is from this cause, that if a stone insinuates itself between the shoe and the sole, it produces so much lameness. Of the too great concavity of the sole, or the want of concavity in
it, we shall treat when we arrive at diseases of the foot. 


\section{THE FROG.}

In the space between the bars, and accurately filling it, is the Frog. It is a triangular portion of horn, projecting from the sole, almost on a level with the crust, and covering and defending a soft and elastic substance called the sensible frog. It is wide at the heels, and there extending beyond a portion of the crust; narrowing rapidly when it begins to be confined between the bars, and terminating in a point at somewhat more than half the distance from the heel to the toe. It consists of two rounded or projecting surfaces, with a fissure or cleft between them, reaching halfway down the frog, and the two portions again uniting to form the point or toe of the frog.

The frog is firmly united to the sole, but it is perfectly distinct from it. It is of a different nature, being softer, and far more elastic ; and it is secreted from a different surface, for it is thrown out from the substance which it covers. It very much resembles a wedge, with the sharp point forwards; and it is placed towards the back part of the foot. The foot is seldom put flush and flat upon the ground, but in a direction downwards, yet somewhat forwards; then the frog evidently gives safety to the tread of the animal, for it oecasionally ploughs itself into the ground, and prevents the horse from slipping. This is of considerable conseqnence, when some of the paces of the horse are recollected, in which his heels evidently come first to the ground, and in which the danger from slipping would be very great. Refcrence needs only be made to the gallop, as illustrative of this.

The frog being placed at, and filling the hinder part of the foot, discharges a portion of the duty sustained by the crust; for it supports the weight of the animal. It assists, likewise, and that to a material degree, in the expansion of the foot. It is formed internally of two prominences on the sides (see $a, \mathrm{p} .295$ ), and a cleft in the centre, presenting two concavities with a sharp projection in the middle, and a gradually rounded one on each side. It is also composed of a substance peculiarly flexible and elastic. What can be so wcll adapted for the expansion of the foot, when a portion of the weight of the body is thrown on it? How easily will these irregular surfaces yield and spread out, and how readily return again to their natural state! In this view, therefore, the horny frog is a powerful agent in opening the foot; and the diminution of the substance of the frog, and its elevation above the ground, are both the cause and the consequencc of contraction - the cause, as being able no longer powerfully to act in expanding the heels; and thc consequence, as obeying a law of nature, by which that which no longer discharges its natural function is gradually removed. It is, however, the cover and defence of the internal and sensible frog, which will be presently treated of; enough, however, has been said to show the absurdity of the common practice of unsparingly cutting it away. In order to discharge, in any degrec, some of the offices which we have assigned to it, and fully to discharge even one of them, it must come in occasional contact with the ground. In the unshod horse, it is constantly so: but the additional support given by the shoes, and more especially the hard roads over which the horse is now compelled to travel, render this complete exposure of the frog to the ground not only unnccessary, but injurious. Being of so much softer consistence than the rest of the foot, it would be speedily worn away: occasional pressure, however, or contact with the ground, it inust have.

The rough and detached parts should be cut off at each shoeing, and the substance of the frog itself, so as to bring it just above or within the level of the shoe. It will then, in the descent of the sole, when the weight of the horse is thrown upon it in the putting down of the foot, descend likewise, and pressing upon the ground, do its duty; while it will be defended from the wear, and bruise, and injury that it would receive if it came upon the ground with the first and full shock of the weight. This will be the proper guide to the smith in shoeing, and to the proprietor in the direction which he gives. The latter should often look to this, for it is a point of very great moment. A few smiths carry the notion of frog pressure to an absurd extent, and leave the frog beyond the level of the sole, - a practice which is dangerous in the horse of slow draught, and destructive to the hackney or the hunter; but the majority of them crr in a contrary way, and, cutting off too much of the frog, lift it above the gronnd, and destroy its principal use. It should be left just above, or within the level of the shoe. 


\section{THE COFFIN-BONE.}

The interior part of the foot must now be considered. The lower pastern, a small portion of which (see $d$, page 272) is contained in the horny box, has been already described, p. 276.-Beneath it, and altogether inclosed in the hoof, is the coffin-bone, or proper bone of the foot, (see $f$, page 272 , and $d$, fig. 1, page 276). It is fitted to, and fills the fore part of the hoof, occupying about half of it. It is of a light and spongy structure (see $d$, fig. 1, page 276), and filled with numerous minute foramina. Through these pass the blood-vessels and nerves of the foot, which are necessarily numerous, considering the important and various secretions there carrying on, and the circulation through the foot which conld not possibly be kept up if these vessels did not run through the substance of the bone. Considering the manner in which this bone is inclosed in the horny box, and yet the important surfaces around and below it that are to be nourished with blood, the circulation which is thus carried on within the very body of the bone is one of the most beautiful provisions of nature that is to be found in the whole frame. No inconvenience can arise from occasional or constant pressure, but the bone allows free passage to the blood, and protects it from every possible obstruction.

The fore part of the coffin-bone is not only thus perforated, but it is curiously roughened for the attachment of the numerous minute laminæ about to be described. On its upper surface it presents a concavity for the head of the lower pastern, p. 276. In front, immediately above $d$, is a striking prominence, into which is inserted the extensor tendon of the foot. At the back, $e$, p. 272, it is sloped for articulation with the navicular bone, and more underneath, is a depression for the reception of the perforating flexor tendon, $m$, continued down the leg, passing over the navicular bone at $n$, and at length inserted into this bone. On either side, as seen 1.276 , are projections called the wings, or heels of the coffin-bone, and at the bottom it is hollowed to answer to the convexity of the internal part of the sole.

That which deserves most attention in the coffin-bone is the production of the numorous laminæ round its front and sides. They are prolongations of the thick and elastic membrane covering it, and consist of cartilaginous, fleshy plates, proceeding from it, running down the coffin-bone, and corresponding with and received between the horny leaves that line the inside of the hoof-bone - each horny plate being received between two sensitive plates, and vice versâ. These laminæ are exceedingly sensitive and vascular, and elastic, and, as first simply and beautifully explained by Mr. Percivall, their elasticity is not inherent in the laminæ, but in the substance which connects these laminæ with the coffin-bone, and which, while it contains highly elastic properties, affords a convenient bed for the numerous vessels that secrete the laminæ. While the animal is at rest, the whole weight of the horse is supported by them, and not by the sole. 'This extraordinary fact has been put to the test of experiment. The sole, bars, and frog were removed from the foot of a horse, and yet as he stood, the coffin-bone did not protrude, or in the slightest degree descend; but when the rapidity with which the foot descends is added to the weight of the horse, these little leaves, horny and fleshy, gradually lengthen, and suffer the hones to press upon the sole. 'The sole then descends, and in descending, expands; and so, by an admirable mechanism, the violent shock which would be produced by the pressure of such a weight as that of the horse, and the velocity with which it descends, is lessened or destroyed, and the complicated apparatus of the foot remains uninjured. When the foot is again lifted, and the weight which pressed upon it is removed, the principle of elasticity is called into exercise, and by it the sole resumes its concavity, and the horny frog its folded state;-the quarters return to their former situation,-the leaves regain their former length, and everything is prepared for a repetition of action.

\section{THE SENSIBLE SOLE.}

Between the coffin-bone and the horny sole is situated the sensible sole, p. 272, formed above of a substance of a ligamentous or tendinous nature, and below of a cuticular or skin-like substance, plentifully supplied with blood-ressels. It was placed between the coffin-bone and the sole, by its yielding structure to assist in preventing concussion, and also to form a supply of horn for the sole. It extends bevond the coffin-bone, but not at all under the frog. Leaving a space for the frog, it 
proceeds over the bars, and there is covered by some laminæ, to unite with those that have been described, page 295, as found in the bars. It is here likewise thicker, and more clastic, and by its elasticity is evidently assisting in obviating concussion. It is supplied with nervous fibres, and is highly sensible, as the slightest experience in horses will evince. The lameness which ensues from the pressure of a stone or of the shoe on the solc is caused by inflammation of the sensible sole. Corns result from bruise and inflammation of the sensible sole, between the crust and the bar.

\section{THE SENSIBLE FROG.}

The coffin-bone does not occupy more than one-half of the hoof. 'The posterior part is filled by a soft mass, partly ligamentous, and partly tendinous $(0, p .272)$. Its shape below corresponds with the cavities of the horny frog; in front it is attached to the inferior part of the coffin-bone; and farther back, it adheres to the lower part of the cartilages of the heels, where they begin to form the rounded protuberances that constitute the heel of the foot. It occupies the whole of the back part of the foot above the horny frog and between the cartilages. Running immediately above the frog, and along the greater part of it, we find the perforans flexor tendon, which passes over the navicular bone, $e, \mathrm{p} .2 \% 2$, and is inserted into the heel of the coffinbone.

\section{THE NAVICULAR BONE}

Is placed behind and beneath the lower pastcrn-bone, and behind and above the heel of the coffin-bone, $e, p .272$, so that it forms a joint with both bones, and answers a very important office in strengthening the union between thesc parts, in receiving a portion of the weight which is thrown on the lower pastern and in enabling the flexor tendon to act with more advantage. Supposing that this tendon were inserted into the coffin-bone swithout the intervention of the navicular bone, it would act at great mechanical disadvantage in bending the pastern, for it is inserted near the end of the coffin-bone, and the weight, concentrated about the middle of the bone, is far off, and requires a great power to raise it; but when the navicular bone is interposed, the centre of motion becomes the posterior edge of that bone, where it is in contact with the tendon, and then it will be seen that the distance of the power from the centre of motion is nearly or quite the same as the weight, and very great expenditure of muscular power will be saved. In the one case, the power must be at least donble the weight, in the other they will be nearly equal; and also the angle at which the tendon is inserted, is considerably more advantagcous. Perhaps this is the principal use of the navicular bone; yet at the same time we are aware of the benefit which accrucs (see page 272) from a portion of the weight bcing taken from the coffin-bone, and thrown on the navicular bonc, and from it on the tendon, and the tendon resting on the elastic frog underncath. The navicular bone is sometimes, but inaccurately, said to descend with the motion of the foot. It does not do that. It cannot; for it is connected both with the pastern and coffin-bones by inelastic ligaments. Wlien, however, the horny bulb, with its tuft of hair, at the back of an oblique fetlock, descends in the rapid gallop, and almost tonches the ground, the navicular bone, being, as it were, a part of the pastern, must descend with it. With this execption, both in the extending and the bending of the pastcrn, the navicular bone turns or rolls upon the other bones rather than desccnds or ascends, and with this rcmarkable advantage, that when the pastern is extended (see page 272), the navicular bone is placed in that situation which enables the flexor tendon to act with grcatest advantage in again bending the foot.

\section{TIE CARTILAGES OF THE FOOT.}

'There is a groove cxtending along the upper part of the coffin-bone and on either side, except at the protuberance which receives the extensor tendon $e$, page 272 , occupied by cartilage, which, like the crust, is convex outwards and concave inwards. It extends to the very posterior part of the foot, rising about the quartcrs half an inch or more above the hoof, and diminishing in height forward and backward. Thesc cartilages occupy a greater portion of the foot than docs the coffin-bone, as will be seen in the lowest cut, pagc 276 , where they are represcnted as extending far behind the coffin-bone. They are held in thcir situation not merely by this groove, but by other 
connexions with the coffin-bone, the navicular bone, and the flexor tendon, and are thus perfectly secured.

Below are other cartilages connected with the under edges of the former, and on either side of the frog.

Between these cartilages is the sensible frog, filling up the whole of the space, and answering several important purposes, being an elastic bed on which the navicular bone and the tendon (see page 272) can play with security, and without concussion or shock, by which all concussion communicated to the cartilages of the foot are destroyed-by which these cartilages are kept asunder, and the expansion of the upper part of the foot preserved. As the descent of the sole increases the width of the lower part of the foot, so the elevation of the frog, a portion of it being pressed upward and outward by the action of the navicular bone and tendon, causes the expansion of its upper part. Precisely as the strong muscle peculiar to quadrupeds at the back of the eye (see page 86), being forcibly contracted, presses upon the fatty matter in which the eye is embedded, which may be displaced, but cannot be squeezed into less compass, and which, being forced towards the inner corner of the eye, drives before it that important and beautiful mechanism the haw, so the elastic and yielding substance the frog, being pressed upon by the navicular bone and the tendon, and the pastern, and refusing to be condensed into less compass, forces itself out on either side of them, and expands the lateral cartilages, which again, by their inherent elasticity, recur to their former situation, when the frog no longer presses them outward. It appears, that by a different mechanism, but both equally admirable, and referable to the same principle, viz. : that of elasticity, the expansion of the upper and lower portions of the hoof are effected, the one by the descent of the sole, the other by the compression and rising of the frog.

It is this expansion upward, which contributes principally to the preservation of the usefulness of the horse, when our destructive methods of shoeing are so calculated to destroy the expansion beneath. In draught-horses, from the long-continued as well as violent pressure on the frog, and from the frog on the cartilage, inflammation is occasionally produced, which terminates in the cartilages being changed into bony matter.

\section{CHAPTER X V.}

\section{THE DISEASES OF THE FOOT.}

OF these there is a long list. That will not be wondered at by those who have duly considered the complicated structure of the foot, the duty it has to perform, and the injuries to which it is exposed. It will be proper to commence with that which is the cause of many other diseases of the foot, and connected with almost all.

\section{INFLAMMATION OF THE FOOT, OR ACUTE FOUNDER.}

The sensible laminæ, or fleshy plates on the front and sides of the coffin-bone, being replete with blood-vessels, are, like every other vascular part, liable to inflammation, from its usual causes, and particularly from the violence with which, in rapid and long-continued action, these parts are strained and bruised. When in a severely contested race they have been stretched to their utmost, while, at the fullest stride of the horse, his weight has been thrown on them with destructive force; or, when the feet have been battered and bruised in a hard day's journey, it will be no wonder if inflammation of the over-worked parts should ensue, and the occurrence of it may probably be produced and the disease aggravated by the too prevalent absurd mode of treating the animal. If a horse that has been ridden or driven hard is suffered to stand in the cold, or if his feet are washed and not speedily dried, he is very likely to have "fever in the feet." There is no more fruitful source of inflammation in the human being, or the brute, than these sudden changes of temperature. This has been explained as it regards grease, but it bears more immediately on the point now under consideration. The danger is not confined to change from heat to cold. Sudden transition from cold to heat is as injurious, and therefore it is that so many horses, after having been ridden 
far in frost and snow, and placed immediately in a hot stable, and littered up to the knees, are attacked by this complaint. The feet and the lungs are the organs oftenest attacked, because they have previously suffered most by our mismanagement, and are most disposed to take on disease, and that which would cause slight inflammation of other parts, or trifling general derangement, will produce all its mischief on these organs; therefore it is that horses, the crust or laminæ of whose feet are warped or obliquely placed, are most subject to it.

Sometimes there is a sudden change of inflammation from one organ to another. A horse may have laboured for several days under cvident inflammation of the lungs; all at once that will subside, and the disease will appear in the feet, or inflammation of the feet may follow similar affections in the bowels or the eyes. In cases of severe inflammation of the lungs, it may not be bad practice to remove the shoes and poultice the feet.

To the attentive observer the symptoms are clearly marked, and yet there is no disease so often overlooked by the groom and the carter, and even by the veterinary surgeon. The disease may assume an acute or chronic form. The earliest symptoms of fever in the feet are fidgetiness, frequent shifting of the fore-legs, but no pawing, much less any attempts to reach the belly with the hind-fect. The pulse is quickened, the flanks heaving, the nostrils red, and the horse, by his anxious countenance, and possibly moaning, indicating great pain. Presently he looks about his litter, as if preparing to lie down, but he does not do so immediately; he continucs to shift his weight from foot to foot; he is afraid to draw his feet sufficiently under him for the purpose of lying down: but at length he drops. The circumstance of his lying down at an early period of the disease will sufficiently distinguish inflammation of the feet from that of the lungs, in which the horse obstinately persists in standing until he drops from mere exhaustion. His quietness when down will distinguish it from colic or inflammation of the bowels, in both of which the horse is up and down, and frequently rolling and kicking when down. When the grievance is in the feet, the horse experiences so much relief, from getting rid of the weight painfully distending the inflamed and highly sensible laminæ, that he is glad to lie as long as he can. He will likewise, as clearly as in inflammation of the lungs or bowcls, point out the seat of disease by looking at the part. His muzzle will often rest on the feet or the affected foot. He must be inattentive who is not aware of what all this indicates.

If the feet are now cxamined, thcy will be found evidently hot. The patient will express pain if they are slightly rapped with a hammer, and the artery at the pastern will throb violently. No great time will now pass, if the disease is suffered to pursuc its course, before he will be perfectly unable to rise ; or, if he is forced to get up, and one foot is lifted, he will stand with difficulty on the other, or perhaps drop at once from intensity of pain.

The treatment will resemble that of other inflammations, with such differences as the situation of the disease may suggest. Bleeding is indispensable; and that to its fullest extent. If the disease is confined to the fore-feet, four quarts of blood should be taken as soon as possible from the toe of each at the situation pointed out, fig. $z$, p. 272, and in the manner already described; care being taken to open the artery as well as the vein. 'The feet may likewise be put into warm water, to quicken the flow of the blood, and increase the quantity abstracted. Poultices of linseed meal, made very soft, should cover the whole of the foot and pastern, and be frequently renewed, which will promote evaporation from the neighbouring parts, and possibly through the pores of the hoof, and, by softening and rendering supple the hoof, will relieve its painful pressure on the swelled and tender parts beneath. More fully to accomplish this last purpose, the shoe should be removed, the sole pared as thin as possible, and the crust, and particularly the quarters, well rasped. All this must be done gently, and with a great deal of patience, for the poor animal can scarcely bear his fect to be meddled with. There used to be occasional doubt as to the administration of physic, from fear of metastasis of inflammation which has sometimes occurred, and been generally fatal. When, however, there is so much danger of losing the patient from the original attack, we must run the risk of the other. Sedative and cooling medicines should be diligently administered, consisting of digitalis, nitre, and emetic tartar.

If no amendment is observed, three quarts of blood should be taken from each foot 
on the following day. In extreme cases, a third bleeding of two quarts may be justifiable, and, instead of the poultice, cloths kept wet with water in which nitre has been dissolved immediately before, and in the proportion of an ounce of nitre to a pound of water, may be wrapped round the feet. About the third day a blister may be tried, taking in the whole of the pastern and the coronet; hut a cradle must previously be put on the neck of the horse, and the feet must be covered after the blister, or they will probably be sadly blemished. 'The horse should be kept on mash diet, unless green meat can be procured for him; and even that should not be given too liberally, nor should he, in the slightest degree, be coaxed to eat. When he appears to be recovering, his getting on his feet should not be hurried. It should bc left perfectly to his own discretion; nor should even walking exercise be permitted until he stands firm on his feet. When that is the case, and the scason will permit, two months' run at grass will be very serviceable.

It is not always, however, or often, that inflammation of the feet is thus easily subdued; and, if it is subdued, it sometimes leaves after it some fearful consequences. The loss of the hoof is not an unfrequent one. About six or seven days from the first attack, a slight separation will begin to appear between the coronet and the hoof. This should be carefully attended to, for the separated horn will never again unite with the parts beneath, but the disunion will extend, and the hoof will be lost. It is true that a new hoof will be formed, but it will be smaller in size and weaker than the first, and will rarely stand hard work. When this separation is observed, it will be a matter of calculation with the proprietor of the horse whether he will suffer the medical treatment to proceed.

\section{CHRONIC LAMINITIS.}

This is a species of founder, insidious in its attack, and destructive to the horse. It is a milder form of the preceding disease. There is lameness, but it is not so severe as in the former case. The horse stands as usual. The crust is warm,-and that warmth is constant, but it is not often probably greater than in a state of health. The surest symptom is the action of the animal. It is diametrically opposite to that in the navicular disease. 'The horse throws as much of his weight as he can, on the posterior parts of his fect.

The treatment should be similar to that recommended for the acute disease-bloodletting, cataplasms, fomentations, and blisters, and the last much sooner and much more frequently than in the former disease.

\section{PUMICED FEET.}

The sensible and horny little plates which were elongated and partially separated during the intensity of the inflammation of founder, will not always perfectly unite again, or will have lost much of their elasticity, and the coffin-bone, no longer fully supported by them, presses upon the sole, and the sole becomes flattened, or convex, from this unnatural weight, and the horse acquires a PUniced Foot. This will also happen when the animal is used too soon after an attack of inflammation of the feet, and before the laminæ have regained sufficient strength to support the weight of the horse, or to contract again by their elastic power when they have yielded to the weight. When the coffin-bone is thus thrown on the sole, and renders it pumiced, the crust at the front of the hoof will "fall in," leaving a kind of hollow about the middle of it.

Pumiced feet, especially in horses with large, wide feet, are frequently produced without this acute inflammation. Undue work, and especially much battering of the feet on the pavement, will extend and sprain these laminx so mueh, that they will not have the power to contract, and thus the coffin-bone will be thrown backward on the sole. $\Lambda$ very important law of nature will unfortunately soon be active here. When pressure is applied to any part, the absorbents become busy in removing it; so, when the coffin-bone begins to press upon the sole, the sole becomes thin from the incrcased wear and tcar to which it is subjected by contact with the ground, and also because these absorbents are rapidly taking it away.

This is one of the diseases of the feet for which there is no cure. No skill is competent to effect a reunion between the separated fleshy and horny laminæ, or to restore to them the strength and elasticity of which they have been deprived, or to take up that hard, horny substance which speedily fills the space between the crust 
and the receding coffin-bone. Some efforts have been made to palliate the disease, but they have been only to a slight degree successful. If horses, on the first appearance of flat feet, were turned out in a dry place, or put into a box for two or three months, sufficient stress would not be thrown on the laminæ to increase the cvil, and time might be given for the growth of horn enough in the sole to support the coffin-bone; yet it is much to be doubted whether these horses would ever be useful, even for ordinary purposes. The slowest work required of them would drive the coffin-bone on the sole, and the projection would gradually reappear, for no power and no length of time can again unite the separated leaves of the coffin-bone and the hoof. All that can be done in the way of palliation is by shoeing. Nothing must press on the projecting and pumiced part. If the projection is not considerable, a thick bar shoe is the best thing that can be applied; but should the sole have much descended, a shoe with a very wide web, bevelled off so as not to press on the part, may be used. These means of relief, however, are only temporary, the disease will proceed; and, at no great distance of time, the horse will be useless.

The occasional removal of the shoe, and compelling the horse to stand for a while on the crust and laminæ, has been resorted to. The bar shoe and the leathern sole, and occasional dressing with tar ointment have had their advocates, and it is suffciently plain that the pumiced foot should have plenty of cover.

A somewhat similar affection, known by the name of a "Seedy Toe," is thus described by Mr. W. C. Spooner:- "It can scarcely be called a disease, but it is rather a natural defect, which may be considerably increased by labour and bad shoeing. It arises from too great dryness of the horn, which renders it brittle, and causes its fibres to separate. There is a want of that tough, elastic material which connects the longitudinal fibres together, and produces that strong bond of union between them and the horny laminæ and the sole. There is a hollow space within the foot, which sometimes extends upward and around, so as to admit a large probe. Neither the bone nor the laminæ, however, are exposed, but are still protected by the internal portion of the crust. The only thing to be done is to anoint the foot occasionally, particularly the affected part, with tar and grease. A blister may also be applied to excite the developement of a new growth of horn, that which is become dry and brittle being occasionally cut away."**

\section{CONTRACTION.}

The cut, page 295, will give a fair idea of the young healthy foot, approaching nearly to a circle, and of which the quarters form the widest part, and the inner quarter (this is the near foot) rather wider than the outer. This shape is not long preserved in many horses, but the foot increases in length, and narrows in the quarters, and particularly at the heel, and the frog is diminished in width, and the sole becomes more concave, and the heels higher, and lameness, or at least a shortened and feeling action, ensues.

It must be premised that there is a great deal more horror of contracted heels than there is occasion for. Many persons reject a horse at once if the quarters are wiring in; but the fact is, that although this is an unnatural form of the hoof, it is slow of growth, and nature kindly makes that provision for the slowly altered form of tho hoof which she does in similar cases-she accommodates the parts to the change of form. As the hoof draws in, the parts beneath, and particularly the coffin-bone, and especially the heels of that bone, diminish; or, after all, it is more a change of form than of capacity. As the foot lengthens in proportion as it narrows, so does the coffin-bone, and it is as perfectly adjusted as before to the box in which it is placed. Its laminæ are in as intimate and perfect union with those of the crust as before the hoof had begun to change. On this account it is that many horses, with very contracted feet, are perfectly sound, and no horse should be rejected merely because he has contraction. He should undoubtedly be examined more carefully, and with considerable suspicion; but if he has good action, and is otherwise unexceptionable, there is no reason that the purchase should not be made. A horse with contracted feet, if he goes sound, is better than another with open but weak heels.

The opinion is perfectly erroneous that contraction is the necessary consequence of shoeing. There can be no doubt that an inflexible iron ring being nailed to 
the foot prevents, to a very considerable degree, the descent of the sole and the expansion of the heels below; and it is likewise probable, that when the expansion of the heels is prevented they often begin to contract. But herc again nature, cut off from one resource, finds others. If one of the jugular veins is lost, the blood pursues its course by other channels, and the horse does not appear to suffer in the slightest degree. Thus also if the expansion of the hecls below is diminished, that of the cartilages above is made more use of. If the coffin-bone has not so much descent downward, it probably aciquires one backward, and the functions of the foct are usefully if not perfectly performed. T'he plain proof of this is, that although therc are many horses that are injurcd or ruined by bad shoeing, there are others, and they are a numerous class, who suffer not at all from good shoeing, and scarcely cven from bad. Except it be from accident, how seldom is the farmer's horse lame! and it might even be farther asked, how scldom is his foot much contracted? Some gentlemen who are careful of their horses have driven them twenty years, and principally over the rough pavcment of towns, without a day's lameness. Shoeing may be a necessary evil, but it is not the evil which some speculative persons have supposer it to be; and the undoubted fact is, that when the horse is put to real hard work, and when the injury produced by shoeing in destroying the expansibility of the foot would most of all show itself, the foot lasts a great deal longer than the ler; nay, horsemen tell us that one pair of good feet is worth two pairs of legs.

Having thus premised that contraction is not inevitably accompanied by lameness, and that shoeing, with all its evils, does not necessarily injurc the foot, those cases of contraction, too numerous, which are the consequencc of our stable management, and which do cripple and ruin the horse, may be considered. There is nothing in the appearance of the feet whicl would enable us to decide when contraction is or is not destructive to the usefulness of the animal; his manner of going, and his capability for work, must be our guides. Lameness usually accompanies the beginning of contraction; it is the invariable attendant on rapid contraction, but it does not always exist when the wiring in is slow or of long standing.

A very excellent writer, particularly whien treating of the foot of the horse, Mr. Blaine, has given us a long and correct list of the causes of injurious contraction, and most of them are, fortunately, under the control of the owner of the animal. He places at the head of them, neglect of paring. 'The hoof is continually growing, the crust is lengthening, and the sole is thickening. This is a provision for the wear and tear of the foot in an unshod state; but when it is protected by a shoe, and nore of the liorn can be worn away by coming in contact with the ground, and the growtl of horn continues, the hoof grows high, and the solc gets thick, and, in consequence of this, the descent of the sole and the expansion of the heels are prevented, and cortraction is the result. The smith might lessen, if not prevent the cvil, by carefully thinning the sole and lowering the heels at each shoeing; but the first of these is a matter of considerable labour, and the sccond could not be done effectually without being accompanied by the first, and therefore they are both neglected. 'The prejudice of many owners of horses assists in increasing the evil; they imagine that a great deal of mischief is done by cutting away the foot. Mischief may be the result of injudicious cutting, when the bars are destroyed and the frog is elevated from the ground; but more evil results from the unyielding thickness of horn impairing the elastic and expansive principle of the foot. If gentlemen would accasionally stand by, and see that the sole is properly thinned, and the heels lowered, they would be amply repaid in the comfort and usefulness of the horse.

Ill-judged economy is another source of this disease. If the shces of one smitll will, with ordinary work, last a little more than three weeks, while another contrives to makc his last six weeks, he is supposed to be the better workman and the more honest man, and he gets the greater part of the custom. His shoe is sufferer to remain on during the whole time, to the manifest injury of the feet, and that injury is materially increased by the greatcr thickness and weight of these sloes, and the tightncss with which they are fastened on, the nails being ncccssarily placed nearer to the quarters, and possibly an additional nail or two used in the fastening, and these also applied at the quarters. There is no rule whicl admits of so little exception, as that, once in about every three weeks, the growth of horn wilich the natural wear of the foot cannot get rid of, should be pared away-the toe slionld be shortened in most feet-the sole should be thinned, and the heels lowered. Erery cne who has carefully 
observed the shape of the horse's foot, must have seen that in proportion to its height or neglected growth, it contracts and closes round the coronet. A low-heeled horse might have other serious defects, of which it will be our duty to speak, but he has seldom a contracted foot.

A nother source of contraction is the want of natural moisture. The unshod colt has seldom contracted feet, nor does the horse at grass acquire them, because the hoof is kept cool and damp by occasional rain, and by the regular dew. It is thus rendered supple, and its elasticity is preserved, and the expansive power of the foot is uninjured. The hoof of the stabled horse sometimes has not one drop of moisture on it for several days. The effect of this, in the contraction of the horn, is sufficiently evident. Hence the propriety of stopping the feet where there is the least tendency to contraction. The intelligent and careful groom will not omit it a sirgle night. Cow-dung, with a sinall portion of clay to give it consistence, is a common and very good stopping. A better one is a piece of thick felt cut to the shape of the sole and soaked in water. 'I'he common stopping of tar and grease is peculiarly objectionable, for it closes the pores of the fcet, and ultimately increases the dryness and brittleness which it was desirned to remedy.

The usual management of the farmer's horse that is often turned out after his daily task is exacted, or whose work is generally performed where the feet are exposed to moisture, is an excellent preventive against contraction.

Some persons have complained much of the influence of titter. If the horse stands mally hours in the day with his feet embedded in straw, it is supposed that the hoof nust be unnaturally heated; and it is said that the horn will contract under tlie influence of heat. It is seldom, however, that the foot is so surrounded by the litter that its heat will be sufficiently increased to produce this effect. It will be difficult to produce the case in which contraction, or thrush, or tenderness, has been produced by the horse standing on dry litter. There are thousands of horses that stand upon straw twenty hours out of the twenty-four, without receiving the slightest injury from it. 'The author of this work is not one of those who would, during the day, remove all litter from under the horse. It gives a naked and uncomfortable appearance to the stablc. 'There is a considerable difference in our own feelings whether we stand for an hour or two on the hard stones, or a soft carpet, and especially whether we beat our feet upon the one or the other. Humanity and a proper eare of the foot of the horse should induce the owner to keep some litter under the animal during the day; hut his feet need not sink so dceply in it that their temperature bccomes much affected. If the straw is suffered to remain until it is wet, hot, and rotten, the effluvia proceeding from it may produce cough, or inflammation of the eyes, or thrushes in the feet; but a light bed of straw, with tolerable attention to cleanliness, can never do harm. "There are horses," says Professor Stewart, "that, in the habit of pawing and stamping, slip about and sometimes lame themselves on the bare stones; many disposed to lie down during the day, will not, or ought not, to do it, with a slight portion of litter under them. It is a frequent observation with regard to road horses, and inany others, that the more a horse lies the better he works. Lame or tender-footed horses cannot lie too much, and a great deal of standing ruins the best legs and feet. Some horses, indeed, do not nced this day-bedding, but many are the better for it, and none are the worse."*

'Thrushes arc much oftener the consequence than the cause of contraction. The horny frog, yielding to the pressure of the contracted quarters, is diminished in size, and the lower portion of the fieshy frog bccomes imprisoned, irritated, and inflamed, and pus or matter is discharged at the cleft; yet there are many heels in the last stage of contraction that are not thrushy. On the other hand, thrush never long existed, accompanied by much discharge, without producing a disposition to contraction; therefore, thrush may be considered as both the cause and consequence of contraction.

The removal of the bars takes away a main impediment to contraction. Their use in assisting the cxpansion of the foot has been already stated, and should a disposition to contraction be produced by any other causc, the cutting away of the bars would hasten and aggravate the evil; but the loss of the bar would not of itself produce contraction. 
The contraction, however, that is connected with permanent lameness, althougli increased by the circumstances which we have mentioned, usually derives its origin from a different source, and from one that acts violently and suddenly. Inflammation of the little plates covering the coffin-bone is the most usual cause; and a degree of inflammation not sufficiently intense to be characterised as acute founder, but quickly leading to sad results, may and does spring from causes almost unsuspected. There is one fact to which we have alluded, and that cannot be doubted, that contraction is exceedingly rare in the agricultural horse, but frequently occurs in the stable of the gentleman and the coach-proprietor. It is rare where the horse is seemingly neglected and badly shod; and frequent where every care is taken of the animal, and the shoes are unexceptionable and skilfully applied. Something may depend upon the breed. Blood horses are particularly liable to contraction. Not only is the foot naturally small, but it is disposed to become narrower at the heels. On the other hand, the broad, flat foot of the cart-horse is subject to diseases enough, but contraction is seldom one of the number.* In horses of equal blood, not a little seems to depend upon the colour, and the dark chestnut is proverbially prone to contraction.

Whatever is the cause of that rapid contraction or narrowing of the heels which is accompanied by severe lameness, the symptoms may be easily distinguished. While standing in the stable the horse will point with, or place forward, the contracted foot, or, if both feet are affected, he will alternately place one before the other. When he is taken out of the stable, he will not, perhaps, exhibit the decided lameness which characterises sprain of the flexor tendon, or some diseases of the foot; but his step will be peculiarly short and quick, and the feet will be placed gently and tenderly on the ground, or scarcely lifted from it in the walk or the trot. It would seem as if the slightest irregularity of surface would throw the animal down, and so it threatens to do, for he is constantly tripping and stumbling. If the fore-feet are carefully observed, one or both of them will be narrowed across the quarters and towards the heels. In a few cases the whole of the foot appears to be contracted and shrunk; but in the majority of instances, while the heels are narrower, the foot is longer. The contraction appears sometimes in both heels: at other times in the inner heel only; or, if both are affected, the inner one is wired in the most, either from the coronet to the base of the foot, or only or principally at the coronet - oftener near the base of the foot - but in most cases the hollow being greatest about mid-way between the coronet and the bottom of the foot. This irregularity of contraction, and uncertainty as to the place of it, prove that it is some internal disorganization, the seat of which varies with the portion of the attachment between the hoof and the foot that was principally strained or injured. In every recent case the contracted part will be hotter than the rest of the foot, and the sole will, in the majority of cases, be unnaturally concave.

of the treatment of contraction attended with lameness little can be said that will be satisfactory. Numberless have been the mechanical contrivances to oppose the progress of contraction, or to force back the foot to its original shape, and many of them have enjoyed considerable but short-lived reputation. A clip was placed at the inside of each heel, which, resting on the bars, was intended to afford an insurmountable obstacle to the further wiring in of the font, while the heels of the shoe were bevelled outward in order to give the foot a tendency to expand. The foot, liowever, continued to contract, until the clip was embedded in the horn, and worse lameness was produced.

A shoe jointed at the toe, and with a screw adapted to the heels, was contrived, by which, when softened by poulticing, or immersion in warm water, the quarters were to be irresistibly widened. They were widened by the daily and cautious use of the screw until the foot seemed to assume its natural form, and the inventor began to exult in having discovered a cure for contraction: but, no sooner was the common

* A valued correspondent suggests, that the difference between these two kinds of horses may perhaps throw some light on the subject. The long-continued and heavy pressure on the frog in the cart-horse produces ossification of the cartilages, from which the blood-horse is free. In the quickness of the action of the blood-horse, the expansion of the frog is not sufficiently continued to produce this effect; but the concussion is severe, and the frog and the shorter lamina towards the heel are the first to suffer, and contraction ensues. We do not find contraction in the hind feet, where there is little contraction, nor ossification, because the pressure is chiefly on the toe. Quick draught-horses have it both ways, but chiefly in contraction.

The reader will form his own opinion on this subject. 
shoe again applied, and the horse had returned to his work, than the heels began to narrow, and the foot became as contracted as ever. Common sense would have foretold that such must have been the result of this expansive process; for the heels could have been only thus forced asunder at the expense of partial or total separation from the interior portions of the foot with which they were in contact.

The contracted heel can rarely or never permanently expand, for this plain reason, that although we may have power over the crust, we cannot renew the laminæ, or restore the portion of the frog that has been absorbed.

If the action of the horse is not materially impaired, it is better to let the contraction alone, be it as great as it will. If the contraction has evidently produced considcrable lameness, the owner of the horse will have to calculate between his value if cured, the expense of the cure, and the probability of failure.

'The medical treatment should alone be undertaken by a skilful veterinary surgeon, and it will principally consist in abating any inflammation that may exist, by local bleeding and physic, paring the sole to the utmost extent that it will bear; rasping the quarters as deeply as can be, without their being too much weakened, or the coronary ring (see $b$, p. 272) injured; rasping deeply likewise at the toe, and perhaps scoring at the toe. The horse is afterwards made to stand during the day in wet clay, placed in one of the stalls. He is at night moved into another stall, and his fect bound up thickly in wet cloths; or he is turned out into wet pasturage, with tips, or, if possible, without them, and his fect are frequently pared out, and the quarters lightly rasped. In five or six months the horn will generally have grown down, when he may be taken up, and shod with shoes unattached by nails on the inner side of the foot, and put to gentle work. The foot will be found rery considerably enlarged, and the owner will, perhaps, think that the cure is accomplished. The horse may, possibly, for a time stand very gentle work, and the inner side of the foot being left at liberty, its natural expansive process may be resumed: the internal part of the foot, however, has not been healthily filled up with the expansion of the crust. If that expansion has been effected forward on the quarters, the crust will no longer be in contact with the lengthened and narrowed heels of the coffin-bone. There will not be the natural adhesion and strength, and a very slight cause, or even the very habit of contraction, will, in spite of all care and the freedom of the inncr quarter, in very many instances, canse the foot to wire in again as badly as before.

\section{THE NAVICULAR.JOINT DISEASE.}

Many horses with well-formed and open fect become sadly and permanently lame, and vcterinary surgeons have been puzzled to discover the cause. The farrier has had his convenient explanation "the shoulder;" but the scientific practitioner may not have been able to discover an ostensible cause of lameness in the whole limb. There is no one accustomed to horses who does not recollect an instance of this.

By referencc to the cut, $e$, page 272 , it will be scen that, behind and beneath the lower pastern-bone, and behind and above the heel of the coffin-bone, is a small bone called the navicular or shuttle bone. It is so placed as to strengthen the union between the lower pastern and the coffin-bone, and to enable the flexor tendon, which passes over it in order to be inserted into the bottom of the coffin-bone, to act with more advantage. It forms a kind of joint with that tendon. There is a great deal of weight thrown on the navicular-bone, and from the navicular-bone on the tendon; and there is a great deal of motion or play between them in the bending and extension of the pasterns. It is very easy to conceive that, from sudden concussion, or from rapid and overstrained motion, and that, perhaps, after the animal has been sometime at rest, and the parts have not adapted themselves for motion, there may be too much play between the bone and the tendon-the delicate membrane which covers the bone, or the cartilage of the bone, may be bruised, and inflamed, and destroyed; that all the painful effects of an inflamed and opencd joint may ensue, and the horse be irrecoverably lame. Numerous dissections have shown that this joint, formed by the tendon and the bone, has been the frequent, and the almost invariable, seat of these obscure lamenesses. The membrane covering the cartilage of the bone has been found in an ulcerated state; the cartilage has bcen ulcerated and eaten away; the bone has become carious or decayed, and bony adhcsions have taken place between the navicular and the pastern and the coffin-bones, and this part of the foot has often become completely disorganised and useless. This joint is probably the seat of lameness, not only in 
well-formed and perfect feet, but in those which become lame after contraction; for in proportion as the inner frog is compressed by the contraction of the heels, and is absorbed by that pressure, and the sole is become concave, and the horny frog, and the coffin-bone too, thereby elevated, there will be less room for the action of this joint, and more danger of the tendon and the delicate membrane of the navicular-bone being crushed between that bone and the horny frog.

Stable management has little to do with the production of this disease, any farther than if a horse stands idle in the stable several days, and the structure of the foot, and all the apparatus connected with motion, become unused to exertion, and indisposed for it, and he is then suddenly and violently exercised, this membrane is very liable to be bruised and injured. This, amongst other evils, will be lessened by a loose box, in which a horse will always take some exercise.*

The cure of navicular disease is difficult and uncertain. The first and all-important point is the removal of the inflammation in this very susceptible membrane. Local bleeding, poulticing, and physic will be our principal resources. If there is contraction, this must, if possible, be removed by the means already pointed out. If there is no contraction, it will nevertheless be prudent to get rid of all surrounding pressure, and to unfetter, as much as possible, the inside heel of the coffin-bone, by paring the sole and rasping the quarters, and using the shoe without nails on the inner quarter, and applying cold poultices to the coronet and the whole of the foot. This is a case, however, wlich must be turned over to the veterinary surgeon, for he alone, from his knowledge of the anatomy of the foot, and the precise seat of the disease, is competent to treat it. If attacked on its earliest appearance, and before ulceration of the membrane of the joint has taken place, it may be radically cured: but ulceration of the membrane will be with difficulty healed, and caries of the bone will for ever remain.

Blistering the coronet will of ten assist in promoting a cure by diverting the inflammation to another part, and it will materially quicken the growth of the horn. A seton passed through the frog by a skilful operator, and approaching as nearly as possible to the seat of disease, has been serviceable.

In cases of old contraction, attended by a short and feeling step, neurolomy, or the excision of a portion of the nerve (for an explanation of the nature and effects of which see page 113), may be resorted to with decided advantage. Not only will the lameness be removed, but, by the foot being again brought fully and firmly upon the ground, the inner side of the shoe being unfettered by nails, a portion of the contraction may be removed by the sole being allowed to descend and the foot to expand at each contact with the ground.

Even when the navicular-joint is particularly suspected, if there is no apparent inflammation (and that wonld be readily detected by the heat of the foot), neurotomy may be practised with the hope of alleviating the sufferings of the animal, and thus

* To Mr. James Turner the veterinary profession is indebted for a knowledge of the seat and cause of this lameness. In the year 1816, he first alluded to it, and the truth and import. ance of his discovery is now universally allowed.

According to Mr. Turner, 'contraction of the hoof is more or less apparent in the majority of horscs that have been accustomed to be shod. This is often long before they have attained the highest value for work, and not unfrequently before they are five years old. This contraction is not, however, necessarily connected with lameness-a large proportion of horses, in the very midst of labour, are perfectly free from lameness.

The next deviation from nature is the passive state to which the foot is submitted at least twenty-two or twenty-three hours out of the twenty-four, and sometimes for several consecutive days. Let this be compared with the few hours during which the feet of a horse at pasture are in a quiescent state, and there will be no cause of surprise in the change of form and position, and character, and the state of contraction - which takes place in the foot deprived of its natural pressure and motion.

The first consequence of contraction is the gradual displacement of the navicular and coffinbones. They ascend within the hoof. An unnatural arch is formed by the ascent of the frog, and the delicate synovial membrane lining the joint is crushed and bruised by the very material which nature has bestowed as a defence. This bruise of the synovial membrane lining the joint is the veritable source of this complaint, the actual cause of the whole not consisting in the wear and tear of the part, but having its origin in rest. It is engendered in the stable, but it becomes permanently established by sudden violence out of it. General contraction of the foot of the horse may take place to a great exient with comparative impunity, but it is a partial contraction or pressure which is the root of the evil.-Turner on the Navicular Disease, Veterinarian, vol. ii, p. 53. 
removing a portion of the lameness; but if the lameness is extreme, either with or without contraction, and especially if there is heat about the foot, the operation is dangerous. There is, probably, ulceration of the membrane-possibly, decay of the bone; and the additional friction to which the parts would be subjected, by the freer action of the horse, the sense of pain being removed, would cause that ulceration or decay to proceed more rapidly until the foot would be completely disorganised, or the tendon would be gradually worn through by rubbing against the roughened surface of the bone.

\section{SAND-CRACK.}

This, as its name imports, is a crack or division of the hoof from above downward, and into which sand and dirt are too apt to insinuate themselves. It is so called, because it most frequently occurs in sandy districts, the heat of the sand applied to the feet giving them a disposition to crack. It occurs both in the fore and the hind feet. In the fore feet it is usually found in the inner quarter (see $g$, page 278), but occasionally in the outer quarter, because there is the principal stress or effort towards expansion in the foot, and the inner quarter is weaker than the outer. In the hind feet the crack is almost invariably found in the front, because in the digging of the toe into the ground in the act of drawing, the principal stress is in front.

This is a most serious defect. It indicates a brittleness of the crust, sometimes natural, but oftener the consequence of mismanagement or disease, which, in spite of every means adopted, will probably be the source of future annoyance. On a hoof that has once been thus divided, no dependence can be placed, unless, by great care, the natural suppleness of the horn has been restored and is retained.

Sand-crack may happen in an instant, from a false step or over-exertion, and therefore a horse, although he may spring a sand-crack within an hour after the purchase, cannot be returned on that account.

It is always necessary to examine the inner quarter of the foot at the time of purchase; for it has more than once occurred that, by low dealers, and particularly at fairs, a sand-crack has been neatly covered with pitch, and then, the whole of the hoof having been oiled, the injury was so adroitly concealed, that an incautious person might be easily deceived.

The crack sometimes does not penetrate through the horn. It then causes no lameness; nevertheless, it must not be neglected. It shows that there is brittleness, which should induce the purchaser to pause; and, if proper means are not taken, it will generally soon penetrate to the quick. It should be pared or rasped fairly out; and if the paring or rasping has been deep, the foot should be strengthened by a coating of pitch, with coarse tape bound over it, and a second coating of pitch covering this. Every crack should be pared or rasped, to ascertain its depth. If it penetrates through the crust, even although no lameness exists, a firing-iron, red-hot, should be passed somewhat deeply above and below it, in order to prevent its lengthening-the edges should be thinned, to remove any painful or injurious pressure, and the foot should be bound up in the manner directed, care being taken that the shoe does not press upon the crust immediately under the sand-crack.

If the crack has penetrated through the crust, and lameness has ensued, the case is more serious. It must be carefully examined, in order to ascertain that no dirt or sand has grot into it; the edges must be more considerably thinned, and if any fungus is beginning to protrude through the crack, and is imprisoned there, it must be destroyed by the application of the butyr (chloride) of antimony. This is preferable to the cautery, because the edges of the horn will not be thickened or roughened, and thus become a source of after-irritation. The iron must then be run deeply across, above, and below the crack, as in the other case; a pledget of dry tow being placed in the crack, in and over it, and the whole bound down as tightly as possible. On the third day the part should be examined, and the caustic again applied, if necessary : but if the crack is dry, and defended by a hard horny crust, the sooner the pitch plaster is put on the better.

The most serious case is, when, from tread or neglect, the coronet is divided. The growth of horn proceeds from the coronary ligament, and unless this ligament is sound, the horn will grow down disunited. The method to be here adopted, is to run the back of the firing-iron over the coronet where it is divided. Some inflammation will ensue; and when the scab produced by the cautery peels off, as it will in a few 
days, the division will be obliterated, and sound and united horn will grow down. When there is sufficieut horn above the crack, a horizontal line should be drawn with a firing-iron between the sound horn and the crack. The connexion between the sound part and the crack will thus be prevented, and the new horn will gradually and safely descend, but the horse should not be used until sufficient horn has grown down fairly to isolate the crack. In this case, as in almost every one of sand-crack, the horse should be kept as quiet as possible. It is not in the power of the surgeon to effect a perfect cure, if the owner will continue to use the animal. When the horn is divided at the coronet, it will be five or six months before it will grow fairly down, and not before that, should the animal be used even for ordinary work. When, however, the horn is grown an.inch from the coronct, the horse may be turned out - the foot being well defended by the pitch plaster, and that renewed as often as it becomes loose - a bar-shoe being worn, chambered so as not to press upon the hoof immediately under the crack, and that shoe bcing taken off, the sole pared out, and any bulbous projection of new horn being removed once in every three weeks.

To remedy the undue brittleness of the hoof, there is no better application than that recommended in page 303 , the sole being covered at the same time with the common cow-dung, or felt stopping.

\section{TREAD AND OVER-REACH.}

Under these terms are comprised bruises and wounds of the coronet, inflicted by the other feet.

A TREAD is said to have taken place, when the inside of the coronet of one hind foot is struck by the calkin of the shoe of the other, and a bruised or contused wound is inflicted. The coronary ring is highly vascular externally, and within it is cartilaginous; the blow, therefore, of ten produces much pain and hemorrhage, and contision and destruction of the parts. The wound may appear to be simple, but it is often of a sadly complicated nature, and much time and care will need to be expended in repairing the mischief. Mr. Percivall very accurately states that "the wound has, in the first place, to cast off a slough, consisting of the bruised, separated, and deadened parts; then the chasm thereby exposed has to granulate; and finally, the sore has to cicatrize, and form new horn."*

A tread, or wound of the coronet, must never be neglected, lest gravel should insinuate itself into the wound, and form deep ulcerations, called sinuses or pipes, and which constitute quitlor. Although some mildly stimulating escharotic may be occasionally required, the caustic, too frequently used by farriers, should be carefully avoided, not only lest quittor should be formed, but lest the coronary ligament should be so injured as to be afterwards incapable of secreting perfect horn. When properly treated, a tread is seldom productive of much injury. If the dirt is well washed out of it, and a pledget of tow, dipped in Friar's balsam, bound over the wound, it will, in the majority of cases, speedily heal. Should the bruise be extensive, or the wound deep, a poultice may be applied for one or two days, and then the Friar's balsam, or digestive ointment. Sometimes a soft tumour will form on the part, which will be quickly brought to suppuration by a poultice; and when the matter has run out, the ulcer will heal by the application of the Friar's balsam, or a weak solution of blue vitriol.

An ovER-REACH is a tread upon the heel of the coronet of the fore foot by the shoe of the corresponding hind foot, and either inflicted by the toe, or by the inner edge of the inside of the shoe. The preventive trcatment is the bevelling, or rounding off, of the inside edge or rim of the hind shoes. The cure is, the cutting away of the loose parts, the application of Friar's balsam, and protection from the dirt.

There is a singular species of over-reaching, termed Fonglxg or cLicking. The horse, in the act of trotting, strikes the toes of the hind shoes against the fore ones. This noise of the clicking is unpleasant, and the trick or habit is not altogether free from danger. It is most frequent in young horses, and is attributable to too great activity, or length of stride in the hind legs. 'The rider may do something by keeping the head of the horse well up; but the snith may effect more by making the hind shoes of clicking horses short in the toe, and having the web broad. When they are

*Percivall's Hippopathology, vol. i. p. 243. 
too long, they are apt to bc torn off - when too narrow, the hind foot may bruise the sole of the fore one, or may be locked fast between the branches of the fore shoe.*

\section{FALSE QUARTER.}

If the coronary ligament, by which the horn of the crust is secreted, is divided by some cut or bruise, or eaten througl by any caustic, there will occasionally be a division in the horn as it grows down, either in the form of a permanent sand-crack, or onc portion of the horn overlapping the other. It occcasionally follows neglected sand-crack, or it may be the consequence of quittor. This is extcriorly an evident fissure in the horn, and extending from the coronet to the sole, but not always penetrating to the laminx. It is a very serious defect, and exceedingly difficult to remedy; for occasionally, if the horse is over-weighted or hurried on his journey, the fissure will open and blecd, and very serious inconvenience and lameness may ensue. Grit and dirt may insinuate itsclf into the aperture, and penetrate to the sensible laminæ. Inflammation will alınost of neccssity be produced; and much mischief will be effected. While the energies of the animal are not severely taxed, he may not experience much inconvenience or pain; but the slightest exertion will cause the fissure to expand, and painful lameness to follow.

This is not only a very serious defect, but one exceedingly difficult to remedy. The coronary ligainent must bc restorcd to its perfect state, or at least to the discharge of its perfect function. Much danger would attend the application of the caustic in order to effect this. A blister is rarely sufficiently active : but the application, not too severcly, of a licated flat or rounded iron to the coronet at the injured part affords the best chance of success - the edges of thc horn on either side of the crack being thinned, the hoof supported - and the separated parts held together by a firm encascment of pitch, as described when speaking of the treatment of sand-crack. The coronet must be examined at least once in every fortnight, in order to ascertain whether the desired union has taken place; and, as a palliative during the treatment of the case, or if the treatment should be unsuccessful, a bar-shoe may be used, and care taken that there be no bearing at or immediately under the separation of the horn. This will be best effected, when the crust is thick and the quarters strong, by paring off a little of the bottom of the crust at the part, so that it will not touch the shoe; but if the foot is weak, an indentation or hollow sliould be made in the shoe. Strain or concussion on the immediatc part will thus be avoided, and, in sudden or violent exertion, the crack will not be so likely to extend upward to the coronet, when whole and sound horn lias begun to bc formed therc. $\dagger$

In some cases false quarter assumes a less scrious character. The horn grows down whole, but the ligament is unablc to sccrete that which is perfectly healthy, and, therefore, a narrow strip of horn of a different and lighter colour is produced. 'This is somctimes the best result that can be procured when the surgeon has been able to obliterate the absolute crack or scparation. It is, however, to be regarded as a defect, not sufficient to condeinn the horse, but indicating that he has had sandcrack, and that a disposition to sand-crack may possibly remain. There will also, in the generality of cases, be some degree of tenderness in that quarter, which may produce slight lameness when unusual exertion is required from the horse, or the shoe is suffered long to press on the part.

\section{QUITTOR.}

This has been described as being the result of neglected or bad tread or over-reach; but it may be the consequence of any wound in the foot, and in any part of the foot. In the natural process of ulceration, matter is thrown out from the wound. It precedes the actual healing of the part. The matter which is secreted in wounds of the foot is usually pent up there, and, increasing in quantity, and urging its way in every direc-

* Stewart's Stable Economy, p. 393.

+ Jamcs Clark, whose works have not been valued as they deserve, expresscs in a few words the real state of the case, and the course that should be pursued:-

"We Inay so far palliate the complaint as to render the horse something useful by using a shoe of such a construction as will support the limb without resting or pressing too much upon the weakened quarter." A proper stopping should also cover the sole, on which some coarse tow may be placed, and a piece of lcather over that; the whole being confined by a broad web-shoe. 
tion, it forces the little fleshy plates of the coffin-bonc, from the horny ones of the crust, or the horny sole from the fleshy sole, or even eats deeply into the internal parts of the foot. These pipes or sinuses run in every direction, and constitute the essence of quittor.

If it arises from a wound at the bottom of the foot, the purulent matter which is rapidly formed is pent up there, and the nail of the shoe or the stub remains in the wound, or the small aperture which was made is immediately closed again. 'This matter, however, continues to be secreted, and separates the horny sole from the fleshy one to a considerable extent, and at length forces its way upwards, and appears at the coronet, and usually at the quarter, and there slowly oozes out, while the aperture and the quantity discharged are so small that the inexperienced person would have no suspicion of the extent of the mischief within, and the difficulty of repairing it. The opening may scarcely admit a probe into it, yet over the greater part of the quarter and the sole the horn may have separated from the foot, and the matter may have penetrated under the cartilages and ligaments, and into the coffin joint. Not only so, but two mischievous results may have been produced,- the pressure of the matter wherever it has gone has formed ulcerations that are indisposed to heal, and that require the application of strong and painful stimulants to induce them to heal; and, worse than this, the horn, once separated from the sensible parts beneath, will never again unite with them. Quittor may occur in both the fore and the hind feet.

It will be sufficiently plain that the aid of a skilful practitioner is here requisite, and also the full exercise of patience in the proprietor of the horse. It may be necessary to remove much of the horny sole, which will be speedily reproduced when the fleshy surface beneath can be brought to a healthy condition; but if much of the hom at the quarters must be taken away, five or six months may probably elapse before it will be sufficiently grown down again to render the horse useful.

Measures of considerable severity are indispensable. The application of some caustic will alone produce a healthy action on the ulcerated surfaces; but on the ground of interest and of humanity we protest against that brutal practice, or at least the extent to which it is carried, and is pursued by many ignorant smiths, of coring out, or deeply destroying the healthy as well as the diseased parts-and parts which no process will again restore. The unhealthy surface must be removed; but the cartilages and ligaments, and even portions of the bone, need not to be sacrificed.

The experienced veterinary surgeon will alone be able to counsel the proprietor of the horse when, in cases of confirmed quittor, there is reasonable hope of permanent cure. A knowledge of the anatomy of the foot is necessary to enable him to decide what parts, indispensable to the action of the animal, may have been irreparably injured or destroyed, or to save these parts from the destructive effect of torturing caustics. When any portion of the bone can be felt by the probe, the chances of success are diminished, and the owner and the operator should pause. When the joints are exposed, the case is hopeless, although, in a great many instances, the bones and the joints are exposed by the remedy and not by the disease. One hint may not be necessary to the practitioner, but it may guide the determination and hopes of the owner; if, when a probe is introduced into the fistulous orifice on the coronet, the direction of the sinuses or pipes is backward, there is much probability that a perfect cure may be effected; but if the direction of the sinuses is forward, the cure is at best doubtful. In the first instance, there is neither bone nor joint to be injured; in the other, the more important parts of the foot are in danger, and the principal action and concussion are found.

Neglected bruises of the sole sometimes lay the foundation for quittor. When the foot is flat, it is very liable to be bruised if the horse is ridden fast over a rough and stony road; or, a small stone, insinuating itself between the shoe and the sole, or confined by the curvature of the shoe, will frequently lame the horse. The heat and tenderness of the part, the occasional redness of the horn, and the absence of puncture, will clearly mark the bruise. The sole must then be thinned, and particularly over the bruised part, and, in neglected cases, it must be pared even to the quick, in order to ascertain whether the inflammation has run on to suppuration. Bleeding at the toe will be clearly indicated; and poultices, and such other means as have either been described under "Inflammation of the Feet," or will be pointed out under the next head. The principal causes of bruises of the foot are leaving the sole too much exposed by means of a narrow-webbed shoe, or the smith paring out the sole too 
closely, or the pressure of the shoe on the sole, or the introduction of gravel or stones between the shoe and the sole.

The author subjoins the mode of cure in this disease, as it has been practised by two veterinary surgeons. They are both excellent, and, so far as can well be the case, satisfactory.

Mr. Percivall says:- "The ordinary mode of cure consists in the introduction of caustic into the sinus; and so long as the cartilage preserves its integrity-by which I mean, is free from caries-this is perhaps the most prompt and effectual mode of proceeding. The farrier's practice is to mix about half a drachm of corrosive sublimate in powder with twice or thrice the quantity of flour, and make them into a paste with water. This he takes up by little at a time with the point of his probe, and works it about into the sinus until the paste appears rising in the orifice above. After this is done he commonly has the horse walked about for an hour or two, or even sent to slow work again, which produces a still more effectual solution of the caustic, at the same time that it tends greatly to its uniform and thorough diffusion into every recess and winding of the sinus. The consequence of this sharp caustic dressing is a general slough from the sinus. Every part of its interior surface is destroyed, and the dead particles become agglutinated, and cast off along with the discharges in the form of a dark, firm curdled mass, which the farrier calls the core; and so it commonly proves, for granulations follow close behind it, and fill up the sinus."*

The other mode of treatment is that of Mr. Newport, a surgeon of long standing: - "After the shoe has been removed, thin the sole until it will yield to the pressure of the thumb; then cut the under parts of the wall in an oblique direction from the heel to the anterior part, immediately under the seat of complaint, and only as far as it extends, and rasp the side of the wall thin enough to give way to the pressure of the over-distended parts, and put on a bar shoe rather elevated from the frog. Ascertain with a probe the direction of the sinuses, and introduce into them a saturated solution of sulphate of zinc, by means of a small syringe. Place over this dressing the common cataplasm, or the turpentine ointment, and renew the application every twenty-four hours. I have frequently found three or four such applications complete a cure. I should recommend that when the probe is introduced, in order to ascertain the progress of cure, that it be gently and carefully used, otherwise it may break down the new-formed lymph. I have found the solution very valuable, where the synovial fluid has escaped, but not to be used if the inflammation of the parts is great." $\dagger$

\section{PRICK OR WOUND IN THE SOLE OR CRUST.}

This is the most frequent cause of quittor. It is evident that the sole is very liable to be wounded by nails, pieces of glass, or even sharp flints. Every part of the foot is subject to injuries of this description. The usual place at which these wounds are found is in the hollow between the bars and the frog, or in the frog itself. In the fore fect the injury will be generally recognized on the inner quarter, and on the hind feet near the toe. In fact these are the thinnest parts of the fore and hind feet. Much more frequently the laminæ are wounded by the nail in shoeing; or if the nail does not penetrate through the internal surface of the crust, it is driven so close to it that it presses upon the fleshy parts beneath, and causes irritation and inflammation, and at length ulceration. When a horse becomes suddenly lame, after the legs have been carefully examined, and no cause of lameness appears in them, the shoe should be taken off. In many cases the offending substance will be immediately detected, or the additional heat felt in some part of the foot will point out the seat of injury; or, if the crust is rapped with the hammer all round, the flinching of the horse will discover it; or pressure with the pincers will render it evident.

When the shoe is removed for this examination the smith should never be permitted to wrench it off, but each nail should be drawn separately, and examined as it is drawn, when some moisture appearing upon it will not unfrequently reveal the spot at which matter has been thrown out.

Sudden lameness occurring within two or three days after the horse has been shod

* Percivall's Hippopathology, vol. i. p. 248.

† The Veterinarian, vol. i. p. 329. 
will lead to the suspicion that the smith has been in fault; yet no one who considers the thinness of the crust, and the difficulty of shocing many feet, will blame him for sometimes pricking the animal. His fault will consist in concealing or denying that of which he will almost always be aware at the time of shoeing, from the flinching of the horse, or the dead sound, or the peculiar resistance that may be noticed in the driving of the nail. We would plead the causc of the honest portion of an humble class of men, who discharge this mechanical part of their business with a skill and good fortune scarcely credible; but we resign those to the reproaches and the punishment of the owner of the horse who too often, and with bad policy, deny that which accident, or possibly momentary carelessness, might have occasioned, and the neglect of which is fraught with danger, although the mischief resulting from it might at the time have been easily remedied.

When the seat of mischief is ascertained, the sole should be thinned round it, and at the nail-hole, or the puncture, it should be pared to the quick. The escape of some matter will now probably tell the nature of the injury, and remove its consequences. If it be puncture of the sole effected by some nail, or any similar body, picked up on the road, all that will be necessary is a little to enlarge the opening, and then to place on it a pledget of tow dipped in Friar's balsam, and over that a little common stopping. If there is much heat and lameness, a poultice sheuld be applied.

The part of the sole that is wounded and the depth of the wound should be taken into consideration. It will be seen, by reference to the cut in page 272 , that a deop puncture towards the back part of the sole, and penetrating even into the sensible frof? may not be productive of serious consequence. There is no great motion in the part, and there are no tendons or bones in danger. A puncture near the toe may not be followed by much injury. There is little motion in that part of the foot, and the internal sole covering the coffin-bone will soon heal. A purcture, however, about the centre of the sole may wound the flexor tendon where it is inscrted into the coffin-bone, or may even penetrate the joint which unites 'the navicular-bone with the coffin-bone, or pierce through the tendon into the joint which it forms with the navicular-bone, and a degree of inflammation may cnsue, that, if neglected, may be fatal. Many horses have been lost by the smallest puncture of the sole in these dangerous points. All the anatomical skill of the veterinarian should be called into requisition, when he is examining the most trifling wound of the foot.

If the foot has been wounded by the wrong direction of a nail in shoeing, and the sole is well-pared out over the part on the first appearance of lameness, little more will be necessary to be done. The opening should be somewhat enlarged, the Friar's balsam applied, and the shoe tacked on, with or without a poultice, according to the deyree of lameness or heat, and on the following day all will often be well. It may, however, be prudent to keep the foot stopped for a few days. If the accident has been neglected, and matter begins to be formed, and to be pent up, and to press on the neighbouring parts, and the horse evidently suffers extreme pain, and is sometimes scarcely able to put his foot to the ground, and much mattcr is poured out when the opening is enlarged, further precautions must be adopted. The fact must be recollected that the living and dead horn will never unite, and every portion of the horny sole that has separated from the fleshy sole above must bc removed. The separation must be followed as far as it reaches. Much of the success of the treatment depends on this. No small strip or edge of separated horn must be suffered to press upon any part of the wound. The exposed fleshy sole must then be touched, but not too severely, with the butyr (chloride) of antimony, some soft and dry tow being spread on the part, the foot stopped, and a poultice placed ovcr all if the inflammation seems to require it. On the following day a thin pellicle of hom will frequently be found over a part or the whole of the wound. This should be, yet very lightly, again touched with the caustic; but if there is an appearance of fungus sprouting from the exposed surface, the application of the butyr must be more severe, the tow being again placed over it, so as to afford considerable yet uniform pressure. Many days do not often elapse before the new horn covers the whole of the wound. In these extensive openings the Friar's balsam will not always be successful, but the cure must be effected by the judicious and never-too-severe use of the caustic. Bleeding at the toe, and physic, will be resorted to as useful auxilarics when much inflammation arises. 
In searching the foot in order to ascertain the existence of prick, there is often something very censurable in the carelessness with which the horn is cut away between the bottom of the crust and the sole, so as to leave little or no hold for the nails, although some months must elapse before the horn will grow down sufficiently far for the shoe to be securely fastened.

When a free opening has been made below, and matter has not broken out at the coronet, it will rarcly be necessary to remove any portion of the horn at the quarters, although we may be able to ascertain by the use of the probe that the separation of the crust extends for a considerable space above the sole.

\section{CORNS.}

In the angle between the bars (c, p. 297) and the quarters, the horn of the sole has sometimes a red appearance, and is more spongy and softer than at any other part. The horse flinches when this portion of the horn is pressed upon, and occasional or permanent lameness is produced. This disease of the foot is termed conss : bearing this resemblance to the corn of the human being, that it is produced by pressure, and is a cause of lameness. When corns are neglected, so much inflammation is produced in that part of the sensible sole, that suppuration follows, and to that, quittor succeeds, and the matter either undermines the horny sole, or is discharged at the coronet.

The prcssure hereby produced manifests itself in various ways. When the foot becomes contracted, the part of the sole inclosed between the external crust that is wiring in, and the bars that are opposing that contraction (see cut, p. 297), is placed in a kind of vice, and becomes inflamed; hence it is rare to see a contracted foot witlout corns. When the shoe is suffered to remain on too long, it becomes embedded in the hecl of the foot : the external crust grows down on the outside of it, and the bearing is thrown on this angular portion of the sole. No part of the sole can bear continued pressure, and inflammation and corns are the result. From the length of wear the sloe sometimes becomes loosened at the heels, and gravel insinuates itself between the shoe and the crust, and accumulates in this angle, and sometimes seriously wounds it.

The bars are too frequently eut away, and then the heel of the shoe must be bevelled inward, in order to answer to this absurd and injurious shaping of the foot. By this slanting direction of the hecl of the shoe inward, an unnatural disposition to contraction is given, and the sole must suffer in two ways, -in being pressed upon by the shoc, and squeezed between the outer crust and the external portion of the bar. The shoe is often made unnecessarily narrow at the heels, by which this angle, seemingly less disposed to bear pressure than any other part of the foot, is exposed to accidental bruises. If, in the paring out of the foot, the smith should leave the bars prominent, lie too frequently neglects to pare away the horn in the angle between the bars and the external crust; or if he cuts away the bars, he scarcely touches the horn at this point; and thus, before the horse has bcen shod a fortnight, the shoe rests on this angle, and produces corns. The use of a shoe for the fore feet, thickened at the heels, is, and especially in weak feet, a source of corns, from the undue bearing there is on the heels, and the concussion to which they are subject.

The unshod colt rarely has corns. The heels have their natural power of expansion, and the sensible sole at this part can scarcely be imprisoned, while the projection of the heel of the crust and the bar is a sufficient defence from external injury. Corns seem to he the almost inevitable consequence of shoeing, which, by limiting, or in a manner destroying, the expansibility of the foot, must, when the sole attempts to descend, or the coffin-bone has a backward and downward direction (see cut, p; 272), imprison and injure this portion of the sole. This evil consequence is increased when the shoe is badly formed, or kept on too long, or when the paring is omitted or injudiciously extended to the bars. By this unnatural pressure of the sole, blood is thrown out, and enters into the pores of the soft and diseased horn which is then secreted; therefore the existence and the extent of the corn is judged of by the colour and softness of the horn at this place.

Corns are most frequent and serious in horses with thin horn and flat soles, and low weak heels. They do not often occur in the outside heel. It is of a stronger construction than the inside one. The method adopted by shoeing-smiths to ascertain the existence of corn by the pain evinced when they pinch the bar and crust with 
their irons, is rery fallacious. If the horn is naturally thin, the horse will shrink under no great pressure although he has no corn, and occasionally the bars are so strong as not to give way under any pressure.

The cure of old corns is difficult; for as all shoeing has some tendency to produce pressure here, the habit of throwing out this diseased horn is difficult to get rid of when once contracted; rccent corns, however, will yield to good shoeirig.

'The first thing to be done is well to pare out the angle between the crust and the bars. Two objects are answered by this : the extent of the disease will be asccrtained, and one cause of it removed. A very small drawing-knife must be used for this purpose. The corn must be pared out to the very bottom, taking care not to wound the sole. It may then be discovered whether there is any effusion of blood or matter underneath. If this is suspected, an opening must be made through the horn, the matter evacuated, the separated horn taken away, the course and extent of the sinuses explored, and the treatment recommended for quittor adopted. Should there be no collection of fluid, the butyr of antimony should be applied over the whole extent of the corn, after the horn has been thinned as closely as possible. The object of this is to stimulate the sole to throw out more healthy horn. In bad cascs a bar-shoe may be put on, so chambered, that there sliall be no pressure on the diseased part. This may be worn for one or two shoeings, but not constantly, for there are few frogs that would bear the constant pressure of the bar-shoe; and the want of pressure on the heel, generally occasioned by their use, would produce a softened and bulbous state of the heels, that would of itself be an inevitable source of lameness.

Mr. Turner is in the habit of using a shoe that promises to lessen to a very material degree the sufferings of the horsc. The ground surface of the shoe is so bevclled off, that it does not come into contact with the ground, and thus much concussion is saved to the horse. A slight space, however, should be left between the heel of the foot, and that of the shoe; and which cannot be better occupied than by the leather sole, preventing the insinuation of foreign bodies, and yet preserving the heel from concussion.

In unusually troublesome cases of corns, recourse should be had to the bar-shoe.

Mr. Spooner, of Southampton, very properly states, that the corns occasionally fester, and the purulent matter which is secreted, having no dependent orifice, ascends, torturing the animal to a dreadful extent, and breaks out at the coronct. These cases are very troublesome. Sinuses are formed, and the evil may cnd in quittor. A large and free dependent orifice must then be made, and a poultice applied; to which should succeed a solution of sulphate of zinc, with the application of the compound tar ointment.

The cause of corn is a most important subject of inquiry, and which a careful examination of the foot and the shoe will easily discover. The cause being ascertained, the effect may, to a great extent, be afterwards removed. Turning out to grass, after the horn is a little grown, first with a bar-shoe, and afterwards with the shoe fettered on one side, or with tips, will often be serviceable. A horse that has once had corns to any considerable extent should, at every shoeing, have the seat of corn well pared out, and the butyr of antimony applied. The seated shoe (hereafter to be described) should be used, with a wcb sufficiently thick to cover the place of corn, and extending as far back as it can be madc to do without injury to the frog.

Low weak heels should be rarely touched with the knife, or anything more be done to them than lightly to rasp them, in order to give them a level surface. The inner heel should be particularly spared. Corns are seldom found in the hind feet, because the heels are stronger, and the feet are not exposed to so much concussion; and when they are found there, they are rarely or never productive of lameness. There is nothing perhaps in which the improvement in the veterinary art has relieved the horse from so much suffering as shoeing. Where corns now exist of any consequence, they are a disgrace to the smith, the groom, and even to the owner.

\section{THRUSH.}

This is a discharge of offensive matter from the cleft of the frog. It is inflammation of the lower surface of the scnsible frog, and during which pus is secreted together with, or instead of horn. When the frog is in its sound state, the cleft sinks but a little way into it ; but when it becomes contracted or otherwise diseased, it extends in length, and penetrates even to the sensible horn within, and through this unnatu- 
sally deepened fissure the thrushy discharge proceeds. A plethoric state of the body may be a predisposing cause of thrush, but the immediate and grand cause is moisture. This should never be forgotten, for it will lead a great way towards the proper treatment of the disease. If the feet are habitually covered with any moist application-his standing so much on his own dung is a fair example-thrush will inevitably appear. It is caused by anything that interferes with the healthy structure and action of the frog. We find it in the hinder feet oftener and worse than in the fore, because in our stable management the hinder feet are too much exposed to the pernicious cffects of the dung and the urine, moistening, or as it were macerating, and at the same time irritating them. The distance of the hind feet from the centre of circulation would also, as in the case of grease, more expose them to accumulations of fluid and discharges of this kind. In the fore feet thrushes are usually connected with contraction. We have stated that they are both the cause and the effect of contraction. The pressure on the frog from the wiring in of the heels will produce pain and inflammation; and the inflammation, by the increased heat and suspended function of the part, will dispose to contraction. Horses of all ages, and in almost all situations, are subject to thrush. 'The unshod colt is frequently thus diseased.

Thrushes are not always accompanied by lameness. In a great many cases the appearance of the foot is scarcely, or not at all altered, and the disease can only be detected by close cxamination, or the pcculiar smell of the discharge. The frog may not appear to be rendered in the slightest degree tender by it, and therefore the horse may not be considered by many as unsound. Every disease, however, should be considered as legal unsoundness, and especially a disease which, although not attended with present detriment, must not be neglected, for it will eventually injure and lame the horse. All other things being right, a horse should not be rejected because he has a slight thrush, for if the shape of the hoof is not altcred, experience tells us that the thrush is easily removed; but if this is not soon done, the shape of the foot and the action of the horse will be altered, and manifest unsoundness will result.

'The progress of a neglected thrush, although sometimes slow, is sure. The frog hegins to contract in size-it becomes rough, ragged, brittle, tender-the discharge is more copious and more offensive-the horn gradually disappears-a mass of hardened mucus usurps its place-this easily peels off, and the sensible frog remains exposed - the horse cannot bear it to be touched-fungous granulations spring from it-they spread around-the sole becomes under-run, and canker steals over the greater part of the foot.

Therc are few errors morc common or more dangerous than this, that the existence of thrush is a matter of little consequence, or even, as some suppose, a benefit to the horse- a discharge for superabundant humours - and that it should not be dried up too quickly, and in some cases rot dried up at all. If a young colt, fat and full of blood, lias a bad thrush, with much discharge, it will be prudent to accompany the attempt at cure by a dose of physic or a course of diuretics. A few diuretics may not be injurious when we are endeavouring to dry up thrush in older horses: but the disease can scarcely be attacked ton soon, or subdued too rapidly, and especially when it steals on so insidiously, and has such fatal consequences in its train: If the heels once begin to contract through the baneful effect of thrush, it will, witl difficulty, or not at all, he afterwards removed.

There are many recipes to stop a running thrush. Almost every application of an astringent, but not of too caustic nature, will have the effect. The common Airyptiacum (vinegar boiled with honey and verdigrease) is a good liniment; but the most effcctual and tho safest-drying up the discharge speedily, but not suddenly -is a paste composed of blue vitriol, tar, and lard, in proportions according to the virulence of the canker. A pledget of tow, covered with it, should be introduced as deeply as possible, yet without force, into the cleft of the frog every night, and removed in the morning before the horse goes to work. Attention should at the same time, as in other diseases of the foot, be paid to the apparent cause of the complaint, and that cause should be carefully obviated or removed. Before the application of the pastc, the frog should be examined, and every loose part of the liorn or hardened discharge removed; and if much of the frog is then exposcd, a larger and wider piece of tow, covered with the paste, may be placed over it, in addition to the pledget introduced into the cleft of the frog. It will be neccssary to preserve the frog moist while the cure is in progress, and this may be done by filling the feet with tow, covered by 
common stopping, or using the felt pad, likewise covered with it. Turning out, would be prejudicial rather than of benefit to thrushy feet, except the dressing is continued, and the feet defended from moisture.

\section{CANKER}

Is a separation of the horn from the sensible part of the foot, and the sprouting of fungous matter instead of it, occupying a portion or even the whole of the sole and frog. It is the occasional consequence of bruise, puncture, corn, quittor, and thrush, and is exceedingly difficult to cure. It is more frequently the consequence of neglected thrush than of any other disease of the foot, or rather it is thrush involving the frog, the bars, and the sole, and making the foot in one mass of lank putrefaction.

It is oftenest found in, and is almost peculiar to, the heavy breed of cart horses, and partly resulting from constitutional predisposition. Horses with white legs and thick skins, and much hair upon their legs - the very character of many dray horses - are subject to canker, especially if they have had an attack of grease, or their heels are habitually thick and greasy. The disposition to canker is certainly hereditary. The dray horse has likewise this advantage, that in order to give him foot-hold, it is sometimes necessary to raise the heels of the hinder feet so high, that all pressure on the frog is taken away; its functions are destroyed, and it is rendered liable to disease. Canker, however, arises mostly from the peculiar injury to which the feet of these horses are subject from the enormous shoes with which they are covered - the bulk of the nails with which these shoes are fastened to the foot, the strain of the foot in the violent, although short exertion of moving heavy weights; but, most of all, neglect of the feet, and the filthiness of the stable in these establishments.

Although canker is a disease most difficult to remove, it is easily prevented. Attention to the punctures to which these heavy horses, with their clubhed feet and brittle hoofs, are more than any others subject in shoeing, and to the bruises and treads on the coronet, to which, from their awkwardness and weight, they are so liable, and the greasy heels which a very slight degree of negligence will produce in them, and the stopping of the thrushes, which are so apt in them to run on to the separation of the horn from the sensible frog, will most materially lessen the number of cankered feet. Where this disease often occurs, the owner of the team may be well assured that there is gross mismanagement either in himself or his horse-keeper, or the smith, or the surgeon, and it will rarely be a difficult matter to detect the precise nature of that mismanagement.

The cure of canker is the business of the veterinary surgeon, and a most painful and tedious business it is. The principles on which he proceeds are, first of all, to remove the extraneous fungous growth; and for this purpose he will need the aid of the knife and the caustic, or the cautery, for he should cut away every portion of horn which is in the slightest degree separated from the sensible parts beneath. He will have to discourage the growth of fresh fungus, and to bring the foot into that state in which it will again secrete healthy horn. Here he will remember that he has to do with the surface of the foot; that this is a disease of the surface only, and that there will be no necessity for those deeply-corroding and torturing caustics which penetrate to the very bone. A slight and daily application of the chloride of antimony, and that not where the new horn is forming, but on the surface which continues to be diseased, and accompanied by as firm but equal pressure as can be made - the careful avoidance of the slightest degree of moisture - the horse being exercised or worked in the mill, or wherever the foot will not be exposed to wet, and that exercise adopted as early as possible, and even from the neginning, if the malady is confined to the sole and frog - these means will succeed, if the disease is capable of cure. Humanity, perhaps, will dictate that, considering the long process of cure in a cankered foot, and the daily torture of the caustic, and the suffering which would otherwise result from so large or exposed a surface, the nerves of the leg should be divided, in order to take away the sense of pain; but then, especial care must be taken that the horse is placed in such a situation, and exposed to such work, that, being insensible to pain, he may not injuriously batter and bruise the diseased parts.

Medicine is not of much avail in the cure of canker. It is a mere local disease ; or the only cause of fear is, that so great a determination of blood to the extremities having existed during the long progress of cure, it may in some degree continue, and 
produce injury in another form. Grease has occasionally followed eanker. They have been known to alternate. It may, therefore, be prudent, when the cure of a cankered foot is nearly effected, to subject the horse to a course of alteratives or diuretics.

\section{OSSIFICATION OF THE CARTILAGES}

Mention has been made of the side cartilages of the foot, occupying (see cut, page 276) a considerable portion of the external side and back part of the foot. They are designed to preserve the expansion of the upper part of the foot, and especially when that of the lower part is limited or destroyed by careless shoeing. These cartilages are subject to inflammation, and the result of that inflammation is, that the cartilages are absorbed, and bone substituted in their stead. This ossification of the cartilages frequently accompanies ringbone, hut it may exist without any affection of the pastern joint. It is oftenest found in horses of heavy draught. It arises not so much from concussion, as from sprain, for the pace of the horse is slow. The cause, indeed, is not well understood; but of the effect, there are too numerous instances. Very few heavy draught-horses arrive at old age without this change of structure; and particularly if they are much employed in the paved streets. The change commences sometimes at the anterior part of the cartilage, but much of tener at the posterior and inferior part. "From the combined operation of great weight and high action, the feet, and particularly the heels, come with great force on the ground. The cartilages, being embedded in the heels of the feet, are, therefore, the parts that reccive the greatest degree of concussion, the consequence of which is, that subacutc inflammation is set up, and the secreting vessels deposit ossific instead of cartilaginous matter, in the room of that which is absorbed in the usual process of nature."

No evident inflammation of the foot, or great, or perhaps even perceptible lame ness, accompanies this change; a mere slight degree of stiffness may have been observed, which, in a horse of more rapid pace, wnuld have been lameness. Even when the change is completed, there is not in many cases anything more than a slight increase of stiffness, little or not at all interfering with the usefulness of the horse. When this altered structure appears in the lighter horse, the lameness is more decided, and means should be taken to arrest the progress of the change. These are blisters or firing; but, after the parts have become bony, no operation will restore the cartilage. Some benefit, however, will be derived from the use of leather soles. Advantage has resulted from bar-shoes in conjunction with leather.

Connected with ringbone the lameness may be very great. This has been spoken of in page $27 \%$.

\section{WEAKNESS OF THE FOOT.}

This is more accurately a bad formation, than a disease; often, indeed, the result of disease, but in many instances the natural construction of the foot. The term weak foot is familiar to every horseman, and the consequence is too severely felt by all who have to do with horses. In the slanting of the crust from the coronet to the toe, a less angle is almost invariably formed, amounting probably to not more than forty instead of forty-five degrees; and, after the horse has been worked for one or two years the line is not straight, but a little indented or hollow, midway between the coronet and the toe. This has been described as the accompaniment of pumiced feet, but it is often seen in weak feet, that, although they might become pumiced by severity of work, do not otherwise have the sole convex. The crust is not only less oblique than it ought to be, but it has not the smooth, even appearance of the good foot. The surface is sometimes irregularly roughened, but it is much oftener roughened in circles or rings. The form of the crust likewise presents too much the appearance of a cone; the bottom of the foot is unnaturally wide in proportion to the coronet; and the whole of the foot is generally, but not always, larger than it should be.

When the foot is lifted, it will often present a round and circular appearance, with a fulliness of frog, that would mislead the inexperienced, and indeed be considered as almost the perfection of structure; but, being examined more closely, many glaring defects will be seen. The sole is flat, and the smith finds that it will bear little or no paring. The bars are small in size. They are not cut away by the smith, but

* W. C. Spooner on the Foot of the Horse, page 249. 
they can be scarcely said to have any existence. The heels are low, so low that the very coronet seems almost to touch the ground; and the crust, if examined, appears scarcely thick enough to hold the nails.

Horses with these feet can never stand much work. They will be subject to corns, to bruises of the sole, to convexity of the sole, to punctures in nailing, to breaking away of the crust, to inflammation of the foot, and to sprain and injury of the pastern, and the fetlock, and the fiexor tendon.

These feet admit of little improvement. Shoeing as seldom as may be, and with a light yet wide concave web; little or no paring at the time of shoeing, and as little violent work as possible, and especially on rough roads, may protract for a long period the evil day, but he who buys a horse with these feet will sooner or later have cause to repent his bargain.

\section{CHAPTER XVI.}

\section{FRA C T U R ES.}

ACcidents of this description are not of frequent occurrence, but when they do happen it is not always that the mischief can be repaired: occasionally, however, and much more frequently than is generally imagined, the life of a valuable animal might be saved if the owner, or the veterinary surgeon, would take a little trouble, and the patient is fairly tractable, and that, in the majority of cases, he will soon become. The number of valuable animals is far too great that are destroyed under a confused notion of the difficulties of controlling the patient, or the incurable character of the accident. Messrs. Blaine and Percivall have given a valuable record of the usual cases and treatment of fracture which occur in the practice of the English veterinary surgeon, and the splendid work of Hurtrel d'Arboval contains a record of all that has been attempted or effected on the Continent. The author of this volume must confine himself to a rapid survey of that which they have described, adding a few cases that have been brought under his own observation, or communicated to him by others.

With the exception of accidents that occur in casting the animal for certain operations, and his struggles during the operation, the causes of Fracture are usually blows, kicks, or falls, and the lesion may be considered as simple, confined to one bone, and not protruding through the skin-or compound, the bone or bones protruding through the skin-or complicated, where the bone is broken or splintered in more than one direction. The duty of the veterinary surgeon resolves itself into the replacing of the displaced bones in their natural position, the keeping of them in that position, the healing of the integument, and the taking of such measures as will prevent any untoward circumstances from afterwards occurring.

In the greater number of cases of fracture, it will be necessary to place the horse under considerable restraint, or even to suspend or sling him.

The cut in the next page contains a view of the suspensory apparatus used by Mr. Percivall. A broad piece of sail-cloth, furnished with two breechings, and two breast-girths, is placed under the animal's belly, and, by means of ropes and pulleys attached to a cross beam above, he is elevated or lowered as circumstances may require. It will seldom be necessary to lift the patient quite off the ground, and the horse will be quietest, and most at his ease, when his feet are suffered just to touch it. The head is confined by two collar ropes, and the head-stall well padded. Many horses may plunge about and be difficult to manage at first, but generally speaking, it is not long ere they become perfectly passive.

The use of the different buckles and straps which are attached to the sail-cloth will be evident on inspection. If the horse exhibits more than usual uneasiness, other ropes may be attached to the corners of the sail-cloth. This will afford considerable relief to the patient, as well as add to the security of the bandages. 


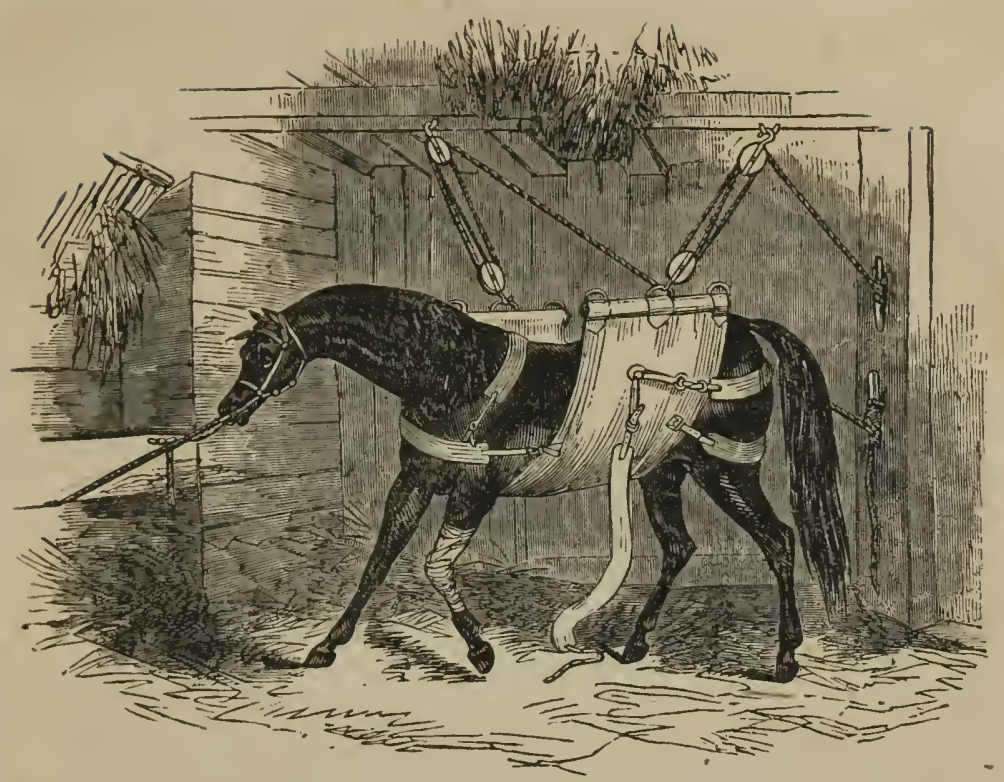

In many cases the fracture, although a simple one, may he visible on the slightest inspection; in others, there may be merely a suspicion of its existence. Here will be exhibited the skill and the humanity of the educated surgeon, or the recklessness and brutality of the empiric. The former will carefully place his patient in the position at once the least painful to the sufferer, and the most commodious for himself. He will proceed with gentleness, patience, and management-no rough handling or motion of the parts, inflicting torture on the animal, and adding to the injury alrearly received. It is interesting to observe how soon the horse comprehends all this, and submits to the necessary inspection; and how complete and satisfactory the examination terminates under the superintendence of the humane and cautious practitioner, while the brute in human shape fails in comprehending the real state of the case.

Heat, swelling, tenderness, fearfulness of the slightest motion, crepitus, and especially change of the natural position of the limb, are the most frequent indications of fracture.

The probability of reunion of the parts depends upon the depth of the wound connected with the fracture-the contusion of the soft parts in the immediate neighbourhood of it-the blood-vessels, arterial or venous, that have been wounded-the propinquity of some large joint to which the inflammation may be communicated dislocation of the extremities of the fractured joint-injuries of the periosteum - the existence of sinuses, caries, or necrosis, or the fracture being compound, or broken into numerous spiculæ or splinters.

In a horse that is full of flesh, the cure of fracture is difficult; likewise in an old or worn-out horse-or when the part is inaccessible to the hand or to instruments-or when separation has taken place between the parts that were beginning to unitc-or where the surrounding tissues have been or are losing their vitality - or when the patient is already afflicted with any old or permanent disease.

It may be useful briefly to review the various seats of fracture.

Fracture of THE skuLL. - The skull of the horse is so securely defended by the yielding resistance of the temporal muscle, that fracture rarely orcurs except at the occipital ridge; and should a depression of bone be there effected, it will produce complete coma, and bid defiance to all surgical skill. Fracture of the skull is generally accompanied by stupidity, convulsive motions of the head or limbs, laborious breathing, and a staggering walk. 'The eyes are almost or quite closed, the head is 
carried low, and the lower lip hangs down. Blows on the cranium, which the brutality of man too often inflicts, as well as many accidents, are very serious matters, and require considerable attention, for, although it may have been ascertained that the cranium is uninjured, there may be considerable concussion of the brain.

It having been known that a horse had received a violent blow on the head, the strictest examination of the part should take place. An artillery horse broke loose from his groom, and, after galloping about, dashed into his own stall with such force as sadly to cut his faee under the forelock. 'The farrier on duty sewed up the wound, proper dressings were applied, and in a littlc more than a fortnight the wound was healed and the horse dismissed, apparently well. Four days afterwards the patient moved stiffly; the jaws could not be separated more than a couple of inches, and there was evident locked jaw. The horse was cast, and the place where the wound had been was most carefully examincd. On cutting to the bottom of it, a fracture was discovered, and a piecc of bone three-fourths of an inch long was found on the centre of the parietal suture. This was removed-the wound was properly dressed, and a strong aloetic drink was given with great difficulty. The aloetic drink was repeated - the bowels became loosened - the tetanic symptoms diminished, and in less than three weeks the horse was perfectly cured.*

This is a very interesting case. There was some carelessness in intrusting the treatment of the wound to the farrier: but the surgeon afterwards repaired the error as well as he could, and no one was better pleased than he was at the result. A violent blow being received on the forehead, the part should always be most carefully examined.

Hurtrel D'Arboval relates three cases of fracture of the skull. One occurred in a mare that ran violently against a carriage. The skull was dcpressed, and a portion of bone was removed, but it was four months ere complete re-union of the edges was effected. Another horse received a violent kick on the forehead. The union of the depressed bones was effected after the external wound was healed, but there was always a depression, an inch in length. An aged mare met with the same accident. A depression here remained as large as a finger.

Fracture of the arch of the orbit of the eYe. A very interesting account of this, followed by perfect cure, is related at p. 136.

FRacture of THE NASAL Bones.-This will sometimes occur from falling, or be produced by a kick from another horse, or the brutality of the attendant or the rider. We have seen a passionate man strikc a horse abnut the hcad with a heavy huntingwhip. The danger of punishment of this kind is nbvious; and so would be the propriety of using the whip for another purpose. A fracture of this kind is generally accompanied by a laceration of the membrane of the nose, and considerable hæmorrhage, which, however, may generally be arrested by the applieation of cold water. The fractured portion of bone is usually depressed, and, the space for breathing being diminished, difficulty of respiration oecurs. The author had a case of fracture of both nasal bones. He was enabled to elevate the depressed parts, but the inflammation and swelling were so great, that the animal was threatened with suffocation. 'The operation of traeheotomy was resorted to, and the animal did well.

If there is fracture of the nasal bones, with depression, and only a little way from the central arch and the section between the nostrils, a slightly curved steel rod may be cautiously introduced into the passage, and the depressed portions carefully raised. If this cannot be cffccted, the trephine must be applied a little above or below the fracture, and the elevator, or steel rod, be introduced through the aperture. If the fracture is in any other part of the bone, it will be impossible to reach it with the elevator, for the turbinated bones are in the way. The trephine must then be resorted to in the first instance. The wound, if there is any, must be covered, and a compress kept on it.

A writer in a French journal, relates a case in which a horse was violently kicked, and there was a contused wound, with depression of bone. 'The trephine was applied.
Fiftcen splinters were extracted, and the case terminated well. It, nevertheless, too often happens that, in these injuries of the nasal membrane, the inflammation will cbstinately continue, in despite of all that the surgeon can do, and the natural termina- 
tion of every injury of the membrane of the nose, and, in fact, of every chronic disease of the frame, will appear-glanders.

If, however, glanders do not appear, some portion of bone may remain depressed, or the membrane may be thickened by inflammation. The nasal passage will then be obstructed, and a difficulty of breathing, resembling roaring, will ensue.

The superior maxillary, or UPPER Jaw-Bone, will occasionally be fractured. Mr. Cartwright had a case in which it was fractured by a kick at the situation where it unites with the lachrymal and malar bones. He applied the trephine, and removed many small pieces of bone. The wound was then covered by adhesive plaster, and in a month the parts were healed.

Mr. Clayworth speaks of a mare who, being ridden almost at speed, fell and fractured the uppcr jaw, three inches above the corner incisors. The front teeth and jaw were turned like a hook, completely within the lower ones. She was cast, a halling iron put into her mouth, and the surgeon, exerting considerable force, pulled the teeth outward into their former and proper situation. She was then tied up, so that she could not rub her muzzle against anything, and was well fed with bean-meal, and linseed tea. Much inflammation ensued, but it gradually subsided, and, at the expiration of the sixth week, the mouth was quite healed, and scarcely a vestige of the fracture remained.

A very extraordinary and alinost incredible account of a fracture of the superior maxillary bone is given in the records of the Royal and Central Society of Agriculture in France. A horse was kicked by a companion. There was fracture of the upper part of the superior maxillary, and zygomatic boncs, and the eyc was almost forced out of the socket. Few men would have dared to undertake a fracture like this, but M. Revel shrank not from his duty. He removed several small splinters of bone-replaced the larger bones-returned the eye to its socket-confined the parts by neans of sufficient sutures - slung the horse, and rendered it impossible for the animal to rub his head against anything. In six weeks, the cure was complete.

The MAXillary bone, or LowEr JAW, is more subject to fracture, and particularly in its branches between the tushes and the lower teeth, and at the symphysis between the two branches of the jaw. Its position, its length, and the small quantity of muscle that covers it, especially anteriorly, are among the causes of its fracture, and the same circumstances combine to render a reunion of the divided parts more easy to be accomplished. Mr. Blaine relates that, in a fracture of the lower jaw, he succeeded by making a strong leather frame that exactly encased the whole jaw. The author of this volume has effected the same object by similar means.

M. H. Boulay attended a horse, fracture of whose lower maxillary had taken place at the neck of that bone, between the tushes and the corner incisor teeth. The whole of the interior part of the maxillary bone in which the incisor teeth were planted, was completely detached from the other portion of the bone, and the parts were merely held together by the membrane of the mouth.

The horse was cast - the corner tooth on the left side extracted - the wound thoroughly cleansed - the fractured bones brought into contact-some holes were drilled between the tushes and the second incisor teeth, above and below, through which some pieces of brass wire were passed, and thus the jaws were apparently fixed immovably together. The ncek of the maxillary bone was surrounded by a sufficient compress of tow, and a ligature tied around it, with its bearing place on the tushes, and all motion thus prevented.

The horse was naturally an untractable animal, and in his efforts to open his jaws, the wires yielded to his repeated struggles, and were to a certain degree separated. 'The bandage of tow was, however, tightened, and was sufficient to retain the fractured edges in apposition.

The mouth now began to exhale an infectious and gangrenous odour; the animal was dispirited, and would not take any food; gangrene was evidently approaching, and Mr. Boulay determined to amputate the inferior portion of the maxillary bone, the union of which seemed to be impossible. The sphacelated portion of the maxillary was entirely removed; every fragment of bone that had an oblique direction was sawn away, and the rough and uneven portions which the saw could not reach, were rasped off.

Beforc night, the horse had recovered his natural spirits, and was searching for something to eat. On the following day, a few oats were given to him, and he ate 28 
them with so much appetite and ease, that no one looking at him would think that he had been deprived of his lower incisor teeth. On the following day, some hay was given to him, which he ate without difficulty, and in a fortnight was dismissed, the wounds being nearly healed.*

In the majority of these cases of simple fracture, a cure might be effected, or should, at least, be attempted, by means of well-adapted bandages around the muzzle, confined by straps. It will always be prudent to call in veterinary aid, and it is absolutely necessary in case of compound fracture of the lower jaw.

Fracture of the Spine.-This accident, fortunately for the horse, is not of frequent occurrence, but it has been uniformly fatal. It sometimes happens in the act of falling, as in leaping a wide ditch; but it of tener occurs while a horse is struggling during a painful operation. It is generally sufficiently evident while the horse is on the ground. Either a snap is heard, indicative of the fracture, or the struggles of the hind-limbs suddenly and altogether cease. In a few cases, the animal has been able to get up and walk to his stable; in others, the existence of the fracture has not been apparent for several hours: showing that the vertebra, although fractured, may remain in their place for a certain period of time. The bone that is broken, is usually one of the posterior dorsal or anterior lumbar vertebræ. There is no satisfactory case on record of reunion of the fractured parts.

In the human being, the depressed portion of the spinal arch, and of the fractured vertebræ, have been removed by a dextrous operation, and sensibility and the power of voluntary motion have, in cases few and far between, been restored; but in the horse, this has rarely or never been effected. We should consider him a bold operator, but we should not very much dislike lim, who made one trial, at least, how far surgical skill might be available here.

Mr. W. C. Spooner relates an interesting case, and many such have probably occurred. A horse had been clipped about three weeks, and was afterwards galloped sharply on rough ground, and pulled up suddenly and repeatedly, for the purpose of sweating him. After that he did not go so well as before, and would not canter readily, although he had previously been much used to that pace. Two days before he was destroyed, the groom was riding him at a slow pace, when lie suddenly gave way behind and was carried home, and could not afterwards stand. He had, doubtless, fractured the spine slightly, when pulled up suddenly, but without displacing the bones. $\dagger$

M. Dupuy was consulted respectirg a mare apparently palsied. She had an uncertain and staggering walk, accompanied by evident pain. After various means of relief had in vain been tried during five-and-twenty days, she was destroyed. A fracture of the last dorsal vertebra was discovered. It had never been quite complete, and ossific union was beginning to take place.

Fracture of THE RIBS.-These fractures are not always easily recognised. Those that are covered by the scapula may exist for a long time without being detected, and those that are situated posteriorly are so thickly covered by muscles as to render the detection of the injury almost impossible. A man was trying to catch a mare in a field. She leaped at the gate, but failing to clear it, sle fell on her back on the opposite side. She lay there a short time, and then got up, and trotted to the stable. She was saddled, and her master, a heavy man, cantered her more than three miles. She then became unusually dull and sluggish, and was left on the road. . She was bled; and on the following morning an attempt was made to lead her home. She was not, however, able to travel more than a mile. On the following morning she was evidently in great pain, and a veterinary surgeon, discovering a slight depression of the spinous processes of the eleventh and twelfth dorsal vertebræ and detecting a certain crepitus, ordered her to be destroyed. On post-mortem examination, the twelfth dorsal vertebra was found fractured, and the eleventh, twelfth, and thirteenth ribs on the near side were all fractured about two inches from their articulation with the vertebræ.

Hurtrel d'Arboval says that "the two ribs behind the elbow are the most subject to fracture, and the false ribs, from the yielding motion which they possess, are least liable." The ordinary causes of fracture are kicks and blows, or falls on the chest, and

* Rec. de Méd. Vét. Nov. 1838.

; Veterinarian. vol. iii. p. 681.

+ Veterinarian, vol, xi.p. 207. 
especially in leaping. The fractures are generally about their middle, and, in the true ribs, commonly oblique. They are occasionally broken into splinters, and if those splinters are directed inward, they may seriously wound the pleura or lungs. In order most certainly to detect the situation and extent of these fractures, it may be necessary to trace the rib through its whole extent, and, should there be any irregularity, to press firmly upon it above and below in order to ascertain the nature and extent of the injury.

If fracture is detected, it is not often that much essential good can be done. ' If there is little or no displacement, a broad roller should be tightly drawn round the chest, in order to prevent as much as possible the motion of the ribs in the act of breathing, and to throw the labour on the diaphragm and the abdominal muscles until the fractured parts are united. If the fractured parts protrude outwards, a firm compress must be placed upon them. If they are depressed, it will always be advisable to place a firm bandage over the seat of fracture, although, perhaps, there may be scarcely the possibility of elevating them to any considerable degree. Should much irritation be the consequence of the nature or direction of the fracture, proper means must be adopted to allay the constitutional disturbance that may be produced. General or local bleedings will be most serviceable.*

Fracture of the pelvis.-This is not of frequent occurrence, on account of the thickness of the soft parts which surround the pelvis, and protect it from injury, but it is of a most serious character when it does take place, on account of the violence which must have been necessary to produce it. The usual cases are falls from a considerable height, or heavy blows on the pelvis. The injury may have reference to the internal or external portion of the pelvis. In the first case, the danger may not be discovered until irreparable mischief is produced. When it is chiefly external, the altered appearance of the hip speaks for itself. It is rarely in our power to afford any assistance in cases like this, except when there are fractured portions of the bone that may be partially or entirely removed, or the projecting spine of the ilium is only partially fractured.

M. Levrat gives an interesting account of a case of fracture of the right side of the pelvis, near the acetabulum, in leaping a wide ditch when hunting. "The lameness which it occasioned," says he, "was such that the toe of the foot was scarcely permitted to touch the ground while the motion was at all rapid. When the motion was slow, the foot was placed flat on the ground, but with great difficulty moved forward. On applying my right hand to the fractured part, which did not exhibit any heat, and seizing with my left hand the point of the thigh, I felt a movement of the ischium, which easily enabled me to judge of the fracture and its seat, and to discover that none of the fractured parts were displaced. I ordered her to be kept quiet for three weeks, and then permitted to wander about the stable. At the end of two months she was mounted and exercised at a foot pace, and in another month she was enabled to sustain the longest day's work without lameness. In the following year she was placed in the stud of the Baron de Stael, where she produced some good foals.

The Annals of the school at Alfort contain the case of an old mare with fracture of the pelvis and of the left ischium, and in whom union of the bones was effected so promptly, that on the thirtieth day very little lameness remained, and she shortly returned to her usual work. She soon afterwards died from some other cause, and the state of the osseous parts was thoroughly examined. These cases, however, stand almost alone, and post-mortem examination discovers fractures of the ischium and the pelvis, and each bone divided into many pieces, so that it is impossible for the hind quarters of the animal to be supported-also fractures of the external angle of the ilium, which rarely is again consolidated, and roughness of the bony fragments, which produce sad laceration of the soft parts. Fracture of the ischium presents almost insuperable difficulties-that of the ilium is uniformly fatal.f

* Cases of anchylosis of the vertebræ of the horse are too frequent, from the heavy weights and sudden and violent concussion which are too frequently thrown on these parts. Complete anchylosis of all the dorsal and lumbar vertebre have been produced, extending even to the haunch. - Sandifort's Mus. A nat. vol. ii. p. 38 to 44, and iii. p. 243.

† Rec. de Méd. Vét., Nov. 1831, and Veterinarian, vol. vi. p. 390.

† Dict. Vét. Mar. Hurtrel d'Arboval, vol. ï. p. 586. 
Fracture of THE Tall.-This accident is not of frequent occurrence, except from accidental entanglement, or the application of brute force. The fracture is easily recognised, frequently by the eye and always by the fingers. If the tail is not ainputated, a cord passed over a pulley, and with a small weight attached to it, will bring the separated bones again into apposition, and in about a month the natural cartilage of the part will be sufficiently re-instated.

Fractures of tife limbs.-These, fortunately, are of rare occurrence in the horse, for although their divided edges might be easily brought again into apposition, it would be almost impossible to retain them in it, for the slightest motion would displace them. A rapid survey of each may not, however, be altogether useless.

Fracture of the shoulder.-The author is not aware of the successful treatment of this accident by any English veterinary surgeon. Mr. Fuller attempted it, but from the difficulty of keeping the divided edges of the bone in apposition with each other, and the natural untractableness of the animal, and symptoms of tetanus beginning to appear, the patient was destroyed. The fracture was a little above the neck of the scapula, and the muscles were dreadfully lacerated.*

It is not at all times easy to discover the existence and precise situation of fracture of the humerus. The lameness is very great-the animal will not bear at all upon the broken limb - he will drag it along the ground - he will move slowly and with difficulty, and his progression will consist of a succession of short leaps. The lifting of the foot will give very great pain. If he is roughly handled, he will sometimes rear, or tlirow himself suddenly down. By careful application of the hand a crepitus will more or less distinctly be heard. The chances are almost materially against the union of a fracture of the humerus. The patient must be kept constantly suspended, and splints and bandages carefully applied. M. Delaguette attended an entire draughthorse, whose humerus had been fractured by the kick of a mare. The fracture extended longitudinally througl two-thirds of the length of the bone, and the parts were separated from each other. They were brought again into apposition, and kept so by means of pitch plasters and splints. The horse was put into slings; the pavement of the stable was taken up; a hollow dug under the fractured limb, and this depression filled with straw, in order to afford a soft support for the foot. He was bled, gruel alone given as food and injections daily administered.

On the 25 th day the rollers were removed and replaced. On the 40th day he began to rest on the fractured limb. On the 60th day the bandages were removed-the fracture had been well consolidated, and the horse rested his weight upon it. It is reluctantly added that he was afterwards destroyed, on account of some disease of the loins. $t$

Fracture of the arm. - This accident is not of unfrequent occurrence. It commonly takes an oblique direction, and is usually first discovered by the displacement of the limb. Mr. Gloag, of the 10th Hussars, gives an interesting account of a case that occurred in his practice. "An entire black cart-horse was grazing in a field, into which some mares were accidentally turned. One of them kicked him severely a little above the knee. He, however, contrived to get home, and, being carefully examined, there was found a simple fracture of the radius, about an inch and a half above the knee. The ends of the fractured bone could be heard distinctly grating against each other, both in advancing the leg and turning it sideway from the body. He was immediately placed in a sling not completely elevated from the ground, but in which he could occasionally relieve himself by standing. The leg was well bathed with warm water, and the ends of the bone brought as true to their position as possible. Some thin slips of green wood were then immersed in boiling water until they would readily bend to the shape of the knee, and they were tied round the joint, reaching about nine inches above and six below the knee, the ends of them being tied round with tow.

A fortnight afterwards he became very troublesome, knocking his foot on the ground, and when, at the expiration of the sixth week, he was taken from the slings, there was a considerable bony deposit above the knee. This, however, gradually subsided as the horse regained his strength, and, with the exception of turning the leg a little outwards, he is as useful as ever for common purposes." $\rightarrow$

Fracture of THE ElBow.- This is far more exposed to danger than the two last

* Veterinarian, vol. viii., p. 143. † Journal Pratique, Dec. 1834. † Veterinarian, vol. iv, p. 422 
bones, and is oftener fractured. The fracture is generally an oblique one, and about two-thirds from the summit of the limb. It is immediately detected by the altered action, and different appearance of the limb. It is not so difficult of reduction as either the humerus or the scapula, when the fracture is towards the middle of the bone. A great quantity of tow saturated with pitch must be placed around the elbow, and confined with firm adhesive plasters, the ground being hollowed away in the front of the injured leg, so that no pressure shall be made by that foot.

Fracture of The Femur.-Considering the masses of muscle that surround this bone, and the immense weight which it supports, it would naturally be deemed impossible to reduce a real fracture of the femur. If the divided bones are ever united, it is a consequence of the simple repose of the parts, and their tendency to unite. Professor Dick, howcver, relates a very singular and interesting account of the cure of fracture of the femur. He was requested to attend a bay mare that had met with an accident in leaping a sunken fence. He found a wound in the stifle of the hind leg running transversely across the anterior of the articulation, about an inch and a half in length, and in it was a portion of bone that had been fractured, and that had escaped from its situation towards the inside of the stifle, where it was held by a portion of ligament. The isolated nature of the fractured portion, the difficulty, or rather impossibility of replacing it in its situation, and the few vessels which the connecting medium possessed, rendcred it impossible that union would be effected; he therefore determined to remove it.

Having enlarged the wound, and divided the portion of capsular ligament which retained it in its place, he extracted the bone, and found it to be the upper part of the inner anterior condyle of the femur, measuring three inches in length, one inch and a half in breadth, and about an inch in thickness, and being in shape nearly similar to the longitudinal section of a hen's egg.

After the removal of the bone, the animal seemed very much relieved; the wound was firmly sewed up, adhesive strapping applied over it, and the part kept wet with cold water.

Two days afterwards considerable swelling had taken place; she seemed to suffer much, and there was some oozing from the wound. Fomentations were again applied, and she was slung.

She now bcgan rapidly to improve, and, although one of the largest articulations in the body had been laid open and a part of the articular portion of the bone removed, the wound healed so rapidly that in three weeks shc walked with little lameness to a loose box. At the expiration of another three weeks the Professor again visited her. On being led out she trotted several times along the stable yard, apparently sound, with the exception of moving the limb in a slight degree wider than usual, and so completely was the part recovered that, had it not been for a small scar that remained, a stranger could not have known that such an accident had taken place.*

Fracture of the patella. - This does occasionally, though very seldom occur. It is usually the consequence of violent kicks, or blows, and if this singular bone is once disunited, no power can bring the divided portions of the bone together again.

Fracture of the tibla. - This affection is of more frequent occurrence, and of more serious consequence than we were accustomed to imagine it to be. Mr. Trump, twelve years ago, first called the attention of the profession to some singular circumstances connected with the tibia. A large draught-horse belonging to the Dowlais Iron Company, at Merthyr Tydvil, came in from his labour very laune in the near hind leg, but with no visible sign of any severe injury being received. The foot was searched, but nothing farther was done. He stood in the stable several days, and then was turned into a field, and was discovered one morning with the limb dependent, and a fracture of the tibia just above the hock.

Fourteen or sixteen months after that, another horse came home from a journey of seven miles, lame, with a slight mark on the inside of the thigh-a mere scratch, and very little tumefaction. There was nothing to account for such severe lameness: but, a few mornings afterwards, the tibia was seen to be fractured. The front of the bone was splintered as from a blow.

Two months after that, another horse had bcen observed to be lame seven or eight days. A slight scratch was observed on the inside of the thigh, with a little swell- 
ing, and increased heat and tenderness just above the hock. Mr. Trump had examined the foot during the time that the horse stood in the stable, not being satisfied that the apparently slight injury on the thigh could account for the lameness. He was turned to grass, and three days afterwards the tibia was found broken at the part mentioned, and evidently from a blow. Were there not positive proof of the circumstance, it would have been deemed impossible that a fracture, and of such a bone, could have existed so long without detection.*

Mr. J. S. Mayer gives an interesting account of the successful treatment of a case of fracture of the tibia. The simplicity of the process will, we trust, encourage many another veterinary surgeon to follow his example.

"A horse received a blow on the tibia of the near leg, but little notice was taken of it for two or three days. When, however, we were called in to examine him, we found the tibia to be obliquely fractured about midway between the hock and the stifle, and a small wound existing on the inside of the leg. It was set in the following manner:- The leg from the stifle down to the hock was well covered with an adhesive compound; it was then wrapped round with fine tow, upon which another layer of the same adhesive mixture was laid, the whole being well splinted and bandaged up, so as to render what was a slightly compound fracture a simple one. The local inflammation and sympathetic fever that supervened were kept down by antiphlogistic measures. At the end of six weeks the bandages and splints were removed, and readjusted in a similar way as before, and at the termination of three months from the time of the accident he was discharged, cured, the splints being wholly taken off, and merely an adhesive stay kept on the leg. The horse is now at work and quite sound, there being merely a little thickening, where the callus is formed."

Fracture of THE Hock. - This is not of frequent occurrence, but very difficult to treat, from the almost impossibility of finding means to retain the bone in its situation. A case, however, somewhat simple in its nature occurred in the practice of Mr. Cartwright. A colt, leaping at some rails, got his leg between them, and, unable to extricate himself, hung over on the other side. After being liberated it appeared on examination, that there was a simple horizontal fracture of the whole of the os calcis about the middle. A splint was contrived so as to reach from the middle of the tibia to that of the cannon bone, and this was applied to the front of the leg, keep. ing the hock from its usual motion, and relaxing the muscles inserted into the os calcis. Underneath this splint a charge was applied about the part, in order to form a level surface for the splint to rest upon. The whole was bound together by proper adhesive bandages, and he was ordered to be kept quiet in the stable, but not to be slung. In about two months the hock was fired and became perfectly sound.f

Fractire of the canion or shank Bone. - This is of more frequent occurrence than that of any other bone, on account of the length of the leg, and the danger to which it is exposed. There is rarely any difficulty in detecting its situation, but there is sometimes a great deal in bringing the divided edges of the bone again into apposition. A kind of windlass, or a power equal to it, is occasionally necessary to produce sufficient extension in order to effect the desired purpose: but the divided edges being brought into apposition are retained there by the force of the muscles above. Splints reaching from the foot to above the knee should then be applied. The horse should be racked up during a fortnight, after which, if the case is going on well, the animal may often be turned out.

In cases of compound fracture the wounds should be carefully attended to: but Mr. Percivall says that he knows one or two old practitioners, who are in the habit of treating these cases in a very summary and generally successful manner. They employ such common support, with splints and tow and bandages, as the case seems to require, and then the animal with his leg bound up is turntd out, if the season permits; otherwise he is placed in a yard or box, where there is not much straw to incommode his movements. The animal will take care not to impose too much weight on his fractured limb; and, provided the parts are well secured, nature will generally perform the rest. $\$$

* Veterinarian, vol, iii. p. 394.

+ The Transactions of the Vet. Med. Association. Some other cases of the successful treatment of fractures are related in this work.

† Veterirarian, vol. ii. p. 69. Tercivall's Hippopathology, vol. i. p. 269. 
Fracture of the sesajioid bones.-There are but two instances of this on record. The first is related by Mr. Fuller of March. He was galloping steadily and not rapidly a horse of his own, when the animal suddenly fell as if he had been shot. He was broken down in both fore legs. The owner very humanely ordered him to te immediately destroyed. Both the perforans and perforatus tendons of the near fore leg were completely ruptured, just where they pass over the sesamoid bone, which was fractured in a transverse direction. The sesamoid bone of the off leg was fractured in the same direction, but the tendons were entire.*

The second case is one described by Mr. Harris of Preston. A strong coachlike animal was galloped rapidly. He had not gone more than a hundred yards before he suddenly fell, and it was with great difficulty that he could be led home, a distance of about two miles. There was soon considerable swelling in the off fore leg-great pain on the animal's attempting to walk, and his fetlock nearly touclied the ground. Some slight crepitus could be detected, but the exact seat of it could not be ascertained. Mr. Harris considered the case as hopeless, but the owner would have some means tried to save the animal. He was accordingly bled and physicked, and cold lotions and bandages were applied to the foot. Two days afterwards some bony spiculæ began to protrude through the skin, and, the case being now perfectly hopeless, the animal was destroyed. The inner sesamoid bone was shivered to atoms. $f$

Fracture of The UPPER Pasters.-Thick and strong, and movable as this bone seems to be, it is occasionally fractured. This has been the consequence of a violent effort by the horse to save himself from falling, when he has stumbled, -it has happened when he has been incautiously permitted to run down a steep descent-and has occurred when a horse has been travelling on the best road, and at no great pace.

The existence of fracture in this bone is, generally speaking, easily detected. The injured foot is as lightly as possible permitted to come in contact with the ground. As little weight as may be is thrown on it, or, if the animal is compelled to use it, the fetlock is bent down nearly to the ground, and the toe is turned upward. If the foot is rotated, a crepitus is generally heard.

This, however, is not always the case. M. Levrat was requested to examine a horse tlat had suddenly become lame. The near hind leg was retracted, and the foot was kept from touching the ground. He carefully examined the foot, and discovered that much pain was expressed when the pastern was handled. He suspected fracture of the bone, but he could not detect it. He bled the animal, ordered cooling applications to the part, and gave a dose of physic. Three days afterwards he again saw his patient, and readily detected a fracture, taking a direction obliquely across the pastern.f

The probability of success in the trcatment of this fracture, depends on its being a simple or compound one. If it runs laterally across the bone, it may be readily and successfuHy treated-if it extends to the joints above and below, it will probably terminate in anchylosis, and if the bone is shivered, as it too frequently is, into various parts, there would scarcely seem the possibility of a successful treatment of the case. 'The instances, however, arc numerous in which the case terminates successfully. Hurtrel d'Arboval recommends that a bandage steeped in some adhesive matter should be applied from the coronet to the middle of the leg. On this some wet pasteboard is to be moulded, enveloped afterwards in a linen bandage. A small splint is now to be applied before and behind and on each side and the hollow places are filled with tow, in order to give them an equal bearing. If this does not appear to be sufficiently secure, other splints, thicker and broader, are placed over those extending to the knee or the hock.

'The case related by M. Levrat was treated in this way. It will be comparatively seldom that it will be necessary to suspend the patient. The animal, under the treatment of M. I.evrat, kept his foot in the air for nearly three weeks. At the end of that period he now and then tried to rest his toe on the litter. Six weeks after the accident, he bcgan to throw some weight on the foot; and a few days afterwards he was able to go to a pond, about fifty paces from his stable, and where, of his own accord, he took a foot-batli for nearly an hour at a time. At the expiration of another 
month he was mounted, and went very well at a walking-pace; he was, however, still lame when he was trotted.

Another horse, trcated by the same surgeon, was soon able to rest on the bad leg, in order to change his position-he was allowed three weeks after that, and then commenced his former daily work-the drawing of a heavy cart. He limped a little when he was trotted; but did as much slow work as he was ever accustoned to do.

Fracture of the Lower pastern.-Although this bone is much shorter than the upper pastern, there are several instances of fracture of it. The fractures of this bone are commonly longitudinal, and often present a lesion of continuity extending from the larger pastern to the coffin-bone. It is frequently splintered, the splinters taking this longitudinal direction. Hurtrel d'Arboval relates three cases of this, and in one of them the bone was splintered into four pieces. In several instances, however, this bone has been separated into eight or ten distinct pieces. When the fracture of the bonc is neither compound nor complicated, it may be perfectly reduced by proper bandaging, and, in fact, there have been cases, in which union has taken placc with slight assistance from art beyond the application of a few bandages.

M. Gazot relates a very satisfactory termination of fracture of this bone in a carriage-horse. The animal fcll, and was totally unable to rise again. He was placed on some hurdles, and drawn home. A vetcrinary surgeon being consulted, recognised fracture of the lower pastern in both feety and advised that the animal should be destroyed. It was a favourite horse, between five and six years old, and the owner determined to give it a chance of recovery.

M. Grazot was consulted. He plainly recognised a transverse fracture in the lower pastern of the right leg, and a longitudinal one in the left pastern. They were both of them simple fractures. The horse was managcable, and seemed to comprehend the whole affair. He was a favourite of the groom as well as the master, and it was determined to give him a chance of recovery. He had plenty of good litter under him, which was changed twice in the day. The first object that was attempted to be accomplished was the healing of the excoriations that had taken place in drawing him home, and abating the inflammation that was appearing about the pasterns.

At the termination of the first week all these were healed, the horse fed well, and was perfectly quiet, except that when he was tired of lying on one side he contrived to get on his knees and then to raise himself on his haunches, and, having voided his urine and his dung, he turned himself upon the other side, without the bandages round his pasterns being in the slightest degree interfered with.

At the expiration of the second week, he seemed to wish to get up. The groom had orders to assist him, and a sling was passed under him. Some oats were placed in the manger, and he seemed to enjoy the change for a little while. Soon afterwards he began to be uneasy, and a copious perspiration appeared on every part. He was immediately lowered, when, with evident delight, he stretched out his head and his legs, and lay almost without motion during several hours. On the following day he was again placed in the sling, and again lowered as soon as he appeared to be fatigued.

At the expiration of a month from the time of the accident he could get up without assistance, and would continue standing two or three hours, when he would lay down again, but with a degrce of precaution that was truly admirable. The bandages around the pasterns had been continued until this period, and had been kept wet with a spirituous embrocation. The horse was encouraged to walk a little, some corn being offered to him in a sieve. He was sadly lame, and the lameness was considerably greater in the left than in the right foot. A calculous enlargement could also be felt in the direction of the fracture on each pastern; but it was greatest in the left fetlock, and there was reason to fear the existence of anchylosis, between the pastern bones of the left lcg. That foot was surrounded with emollient cataplasms, and, two days afterwards, was pared out, and the cautery applied over both pasterns, the spirituous embrocation being continued.

A fortnight afterwards the cffect of the cautery was very satisfactory. The action of the part was more free, and there was no longer any fear of anchylosis. It was, howevcr, deemed prudent to apply the cautery over the right pastern. Walking exercise was now recommended, and in the course of another month the lameness was 
much diminished. It was most on the left side, which, however, had resumed its former degree of inclination.

At the expiration of four months, the horse was sent to work. His master, however, doubting the stability of the cure, sold him, for which he ought to have had his own legs broken, and he fell into bad hands. He was worked hardly, and half starved; nevertheless, the calculus continued to diminisll, and the lameness altogrether disappeared. He soon, however, passed into better hands. He was bought by a farmer at Chalons, in whose service he long remained, in good condition, and totally free from lameness. His last owner gave him the name of Old Broken Leg.*

FRACTURE OF THE COFFIN-BONE.-This is an accident of very rare occurrence, and difficult to distinguish from other causes of lameness. The animal halts very considerably - the foot is hot and tender-the pain seems to be exceedingly great, and none of the ordinary causes of lameness are perceived. According to Hurtrel D'Arboval, it is not so serious an accident as has been represented. The fractured portions cannot be displaced, and in a vascular bone like this, the union of the divided parts will be readily effected.

Mr. Percivall very properly remarks, that, "buried as the coffin and navicular bones are within the hoof, and out of the way of all external injury as well as of muscular force, fracture of them cannot proceed from ordinary causes. It is, perhaps, thus produced :-in the healthy foot, in consequence of the elasticity of their connections, these bones yield or spring under the impression they receive from the bones above, and thus are enabled to bear great weights, and sustain violent shocks without injury; but, disease in the foot is often found to destroy this elasticity, by changing the cartilage into bone, which cannot receive the same weight and concussion without risk of fracture. Horses that have undergone the operation of neurotomy more frequently meet with this accident than others, because they batter their senseless feet with a force which, under similar circumstances, pain would forbid the others from doing." $\dagger$

Fracture of the navicular bone has been sufficiently considered under the article "Navicular Joint Disease," p. 309.

Mr. Mayer sums up his account of the treatment of fractures in a way that reflects much credit on lim and the profession of which he is a member. "Let your remedies," says he, "be governed by those principles of science, those dictates of humanity, and that sound discretion, which, while they raise the moral and intellectual superiority of man, distinguish the master of his profession from the bungling empiric." $\ddagger$

\section{CHAPTER XVII.}

\section{ON SHOEING.}

THE period when the shoe began to be nailed to the foot of the horse is uncertain. William the Norman introduced it into our country.

We have seen, in the progress of our inquiry, that, while it affords to the foot of the horse that defence which seems now to be necessary against the destructive effects of our artificial and flinty roads, it lias entailed on the animal some evils. It has limited or destroyed the beautiful expansibility of the lower part of the foot-it has led to contraction, although that contraction has not always been accompanied by lameness-in the most careful fixing of the best shoe, and in the careless manufacture and setting on of the bad one, irreparable injury has occasionally been done to the horse.

We will first attend to the preparation of the foot for the shoe, for more than is generally imagined, of its comfort to the horse and its safety to the rider, depends on this. If the master would occasionally accompany the horse to the forge, more expense to himself and punishment to the horse would be spared than, perhaps, he

* Recueil de Méd. Vét. 1834, p. 7. No apology is offered for the introduction of cases like this. The cause of science and of humanity is equally served.

†Percivall's Hippopathology, vol. i., p. $272 . \quad \ddagger$ Vet. 'Trans. vol. i., p. 215. 
would think possible, provided he will take the pains to understand the matter himself, otherwise he had better not interfere.

The old shoe must be first taken off. We have something to observe even here. The shoe was retained on the foot by the ends of the nails being twisted off, turned down, and clenched. These clenches should be first raised, which the smith seldom takes the trouble thoroughly to do; but after looking carelessly round the crust and loosening one or two of the clenches, he takes hold first of one heel of the shoe, and then of the other, and by a violent wrench separates them from the foot: then, by means of a third wrench, applied to the middle of the shoe, he tears it off. By these means he must enlarge every nail-hole, and weaken the future and steady hold of the shoe, and sometimes tear off portions of the crust, and otherwise injure the foot. 'The horse generally shows by his flinching that he suffers from the violence with which this preliminary operation too often is performed. The elenches should always be raised or filed off; and, where the foot is tender, or the horse is to be examined for lameness, each nail should be partly punched out. According to the common system of procedure, many a stub is left in the crust, the source of future annoyance.

The shoe having been removed, the smith proceeds to rasp the edges of the crust. Let not the stander-by object to the apparent violence which he uses, or fear that the foot will suffer. It is the only means that he has to detect whether any stubs remain in the nail-holes; and it is the most convenient method of removing that portion of the crust into which dirt and gravel have insinuated themselves.

Next comes the important process of paring out, with regard to which it is almost impossible to lay down any specific rules. This, however, is undoubted, that far more injury has been done by the neglect of paring, than by carrying it to too great an extent. The act of paring is a work of much more labour than the proprietor of the horse often imagines. The smith, except he is overlooked, will frequently give himself as little trouble about it as he can; and that portion of horn which, in the unshod foot, would be worn away by contact with the ground, is suffered to accumulate month after month, until the elasticity of the sole is destroyed, and it can no longer descend, and its other functions are impeded, and foundation is laid for corn, and contraction, and navicular disease, and inflammation. That portion of horn should be left on the foot, which will defend the internal parts from being bruised, and yet suffer the external sole to descend. How is this to be ascertained? The strong pressure of the thumb of the smith will be the best guide. The buttress, that most destruxctive of all instruments, being, except on very particular occasions, banished from every respectable forge, the smith sets to work with his drawing-knife, and removes the growth of horn, until the sole will yield, although in the slightest possible degree, to the strong pressure of his thumb. The proper thickness of horn will then remain.

If the foot has been previously neglected, and the horn is become very hard, the owner must not ohject if the smith resorts to some other means to soften it a little, and takes one of his flat irons, and having heated it, draws it over the sole, and keeps it, a little while, in contact with the foot. When the sole is really thick, this rude and apparently barbarous method can do no harm, but it should never be permitted with the sole that is regularly pared out.

The quantity of horn to be removed, in order to leave the proper degree of thickness, will vary with different feet. From the strong foot, a great deal must be taken. From the concave foot, the horn may be removed until the sole will yield to a moderate pressure. From the flat foot, little needs be pared; while the pumiced foot should be deprived of nothing but the ragged parts.

The paring being nearly completed, the knife and the rasp of the smith must be a little watched, or he will reduce the crust to a level with the sole, and thus endanger the bruising of it by its pressure on the edge of the seating. The crust should be reduced to a perfect level all around, but left a little higher than the sole.

The heels will require considerable attention. From the stress which is thrown on the inner heel, and from the weakness of the quarter there, the horn usually wears away considerably faster than it would on the outer one, and if an equal portion of horn were pared from it, it would be left lower than the outer heel. The smith should, therefore, accommodate his paring to the comparative wear of the heels, and be exceedingly careful to leave them precisely level.

If the reader will recollect what has been said of the intention and action of the 
bars, he will readily perceive that the smith should be checked in his almost universal fondness for opening the heels, or, more truly, removing that which is the main impediment to contraction. The portion of the heels between the inflexion of the bar and the frog should scarcely be touched-at least, the ragged and detached parts alone should be cut away. The foot may not look so fair and open, but it will last longer without contraction.

The bar, likewise, should be left fully prominent, not only at its first inflexion, but as it runs down the side of the frog. The heel of the shoe is designed to rest partly on the heel of the foot and partly on the bar, for reasons that have been already stated. If the bar is weak, the growth of it should be encouraged; and it should be scarcely touched when the horse is shod, unless it has attained a level with the crust. The reader will recollect the observation which has been already made, that the destruction of the bars not only leads to contraction, by removing the grand impediment to it, but by adding a still more powerful cause in the slanting direction which is given to the bearing of the heels, when the bar does not contribute to the support of the weight.

It will also be apparent, that the horn between the crust and the bar should be carefully pared out. Every horseman has observed the relief which is given to the animal lame with corns, when this angle is well thinned. This relief, however, is often but temporary; for when the horn grows again, and the shoe presses upon it, the torture of the horse is renewed.

The degree of paring to which the frog must be subjected, will depend on its prominence, and on the shape of the foot. The principle has already been stated, that it must be left so far projecting and prominent, that it shall be just within and above the lower surface of the shoe; it will then descend with the sole sufficiently to discharge the functions that have been attributed to it. If it is lower, it will be bruised and injured; if it is higher, it cannot come in contact with the ground, and thus be enabled to do its duty. The ragged parts must be removed, and especially those occasioned by thrush, but the degree of paring must depend entirely on the principle just stated.

It appears, then, that the office of the smith requires some skill and judgment, in order to be properly discharged; and the proprietor of horses will find it his interest occasionally to visit the forge, and complain of the careless, or idle, or obstinate fellow, while he rewards, by some trifling gratuity, the expert and diligent workman. He should likewise remember that a great deal more depends on the paring out of the foot, than on the construction of the shoe; that few shoes, except they press upon the sole, or are made outrageously bad, will lame the horse; but that he may be very easily lamed from ignorant and improper paring out of the foot.

\section{THE PUTTING ON THE SHOE.}

The foot being thus prepared, the smith looks about for a shoe. He should select one that as nearly as possible fits the foot, or may be easily altered to the foot. He will sometimes, and especially if he is an idle and reckless fellow, care little about this, for he can easily alter the foot to the shoe. The toe-knife is a very convenient instrument for him, and plenty of horn can be struck off with it, or removed by the rasp, in order to make the foot as sinall as the shoe; while he cares little, although by this destructive method the crust is materially thinned where it should receive the nail, and the danger of puncture, and of pressure upon the sole, is increased; and a foot so artificially diminished in size, will soon grow over the shoe, to the hazard of considerable or permanent lameness.

While the horse is travelling, dirt and gravel are apt to insinuate themselves between the web of the foot and the sole. If the shoe were flat, they would be permancntly retained there, and would bruise the sole, and be productive of injury; but when the shoe is properly bevelled off, it is scarcely possible for them to remain. 'They must be shaken out almost every time that the foot comes in contact with the ground.

The web of the shoe is likewise of that thickness, that when the foot is properly pared, the prominent part of the frog shall lie just within and above its ground surface, so that in the descent of the sole, the frog shall come sufficiently on the ground to cnable it to act as a wedge, and to expand the quarters, while it is defended from the wcar and injury it would receive, if it came on the ground with the first and full shock of the weight.

The nail-holes arc, on the ground side, placed as near the outer edge of the shoe as 
they can safely be, and brought out near the inner edge of the seating. The nails thus take a direction inwards, resembling that of the crust itself, and have firmer hold, while the strain upon them in the common shoe is altogether prevented, and the weight of the horse being thrown on a flat surface, contraction is not so likely to be produced.

The smith sometimes objects to the use of this shoe, on account of its not being so easily formed as one composed of a bar of iron, either flat or a little bevelled. It likewise occupies more time in the forging; but these objections would vanish, when the owner of the horse declared that he would have him shod elsewhere, or when he consented-as, in justice, he should - to pay somewhat more for a shoe that required better workmanship, and a longer time in the construction.

It is expedient not only that the foot and ground surface of the shoe should be most accurately level, but that the crust should be exactly smoothed and fitted to the shoe. Much skill and time are necessary to do this perfectly with the drawing-knife. The smith has adopted a method of more quickly, and more accurately adapting the shoe to the foot. He pares the crust as level as he can, and then he brings the shoe to a heat somewhat below a red heat, and applies it to the foot, and detects any little elevations by the deeper colour of the burned horn. 'This practice has been much inveighed against; but it is the abusc, and not the use of the thing which is to be condemned. If the shoe is not too hot, nor held too long on the foot, an accuracy of adjustment is thus obtained, which the knife would be long in producing, or would not produce at all. If, however, the shoe is made to burn its way to its seat, with little or no previous preparation of the foot, the heat must be injurious both to the sensible and insensible parts of the foot.

The heels of the shoe should be examined as to their proper widtl. Whatever is the custom of shoeing the horses of dealers, and the too prevalent practice in the metropolis of giving the foot an open appearance, although the posterior part of it is thereby exposed to injury, nothing is more certain than that, in the horse destined for road-work, the heels, and particularly the seat of corn, can scarcely be too well covered. Part of the shoe projecting externally can be of no possible good, but will prove an occasional source of mischief, and especially in a heavy country. A shoe, the web of which projects inward as far it can without touching the frog, affords protection to the angle between the bars and the crinst.

of the manner of attaching the shoe to the foot the owner can scarcely be a competent judge; he can only take care that the shoe itself shall not be heavier than the work requires-that, for work a little hard the shoe shall still be light, with a bit of steel welded into the toe-that the nails shall be as small, and as few, and as far from the heels as may be consistent with the security of the shoe; and that, for light work at least, the shoe shall not be driven on so closely and firmly as is often done, nor the points of the nails be brought out so high up as is generally practised.

\section{CALKINS.}

There are few cases in which the use of calkins (a turning up or elevation of the heel) can be admissible in the fore-feet, except in frosty weather, when it may in some degree prevent unplcasant or dangerous slipping. If, however, calkins are used, they should be placed on both sides. If the outer heel only is raised with the calkin, as is too often the case, the weight cannot be thrown evenly on the foot, and undue straining and injury of some part of the foot or of the leg must be the necessary conscquence. Few things deserve more the attention of the horseman than this most absurd and injurious of all the practices of the forge. One quarter of an hour's walking, with one side of the shoe or boot raised considerably above the other, will painfully convince us of what the horse must suffer from this too common method of shoeing. It cannot be excused even in the hunting shoe. If the horse is ridden far to cover, or galloped over much hard and finty ground, he will inevitably suffer from this unequal distribution of the weight. If the calkin is put on the outer heel, in order to prevent the horse from slipping, either the horn of that heel should be lowered to a corresponding degree, or the other heel of the shoe should be raised to the same level by a gradual thickening. Of the use of calkins in the hinder foot we shall presently speak. 


\section{CLIPS.}

These are portions of the upper edge of the shoe, hammered out, and turned up so as to embrace the lower part of the crust, and which is usually pared out a little, in order to receive the clip. They are very useful, as more securely attaching the shoe to the foot, and relieving the crust from that stress upon the nails which would otherwise be injurious. A clip at the toe is almost necessary in every draught-horse, and absolutely so in the horse of heavy draught, in order to prevent the shoe from being loosened or torn off by the pressure which is thrown upon the toe in the act of drawing. A clip on the outside of each shoe, at the beginning of the quarters, will give security to it. Clips are likewise necessary on the shoes of all heavy horses, and of all others who are disposed to stamp, or violently paw with their feet, and thus incur the danger of displacing the shoe; but they are evils, inasmuch as they press upon the crust as it grows down, and they should only be used when circumstances absolutely require them. In the hunter's shoe they are not required at the sides. One at the toe is sufficient.

\section{THE HINDER SHOE.}

In forming the hinder shoes it should be remembered that the hind limbs are the principal instruments in progression, and that in every act of progression, except the walk, the toe is the point on which the whole framc of the animal turns, and from which it is propelled. 'This part, then, shonld be strengthened as much as possible ; and, therefore, the linder shoes are made broader at thic toe than the fore ones. Another good effect is produced by this, that, the hinder foot being shortened, there is less danger of overreaching or forging, and especially if the shoe is wider on the foot surface than on the ground one. The shoe is thus made to slope inward, and is a littlc within the toe of the crust.

The shape of the hinder foot is somewhat different from that of the fore foot. It is straighter in the quarters, and the shoe must have the same form. For carriage and draught-horses generally, calkins may be put on the heels, bccausc the animal will be thus enabled to dig his toe more firmly into the ground, and urge himself forward, and throw his weight into the collar with greater advantage: but the calkins must not be too high, and they must be of an equal height on each hecl, otherwise, as has been stated with regard to the forc feet, the wcight will not be fairly distributed over the foot, and some part of the foot or the leg will materially suffer. The nails in the hinder shoe may be placed nearer to the heel than in the fore shoe, because, from the comparatively little weight and concussion thrown on the hinder feet, there is not so much danger of contraction.

\section{DIFFERENT KINDS OF SHOES.}

The shoe must vary in substance and weight with the kind of foot, and the nature of the work. A wcak foot should never wear a heavy shoe, nor any foot a shoe that will last longer than a month. Here, perhaps, we may be permitted to caution the horse-proprietor against having his cattle shod by contract, unless he binds down his farrier or veterinary surgeon to remove the shoes once at least in every month; for if the contractor, by a heavy shoe, and a little steel, can cause five or six weeks to intervene between the shoeings, he will do so, although the feet of the horse must necessarily suffer. The shoe should never be heavier than the work requires, for an ounce or two in the weight of the shoc will sadly tell at the end of a hard day's work. This is acknowledged in the hunting shoe, which is narrower and lighter than that of the hackney, although the foot of the hackney is smaller than that of the hunter. It is more decidedly acknowledged in the racer, who wears a shoe only sufficiently thick to prevent it from bending when it is used.

\section{THE CONCAVE.SEATED SHOE.}

The proper form and construction of the shoe is a subject deserving of very serious inquiry, for it is most important to ascertain, if possible, the kind of shoe that will do the least mischief to the feet. A cut is subjoined of that which is useful and valuable for general purposes. It is employed in many of our best forges, and promises gradually to supersede the flat and the simple concave shoe, although it must, in many respects, yield to the unilateral shoe. 
It presents a perfectly flat surface to the ground, in order to give as many points of bearing as possible, except that, on the outer edge, there is a groove or fuller, in which the nail-holes are punched, so that, sinking into the fuller, their heads project but a little way, and are soon worn down level with the shoe. The ground surface of the common shoe used in the country is somewhat convex, and the inner rim of the shoe comes first on the ground: the consequence of this is, that the weight, instead of being borne fairly on the crust, is supported by the nails and clenches, which must be injurious to the foot, and often chip and break it.

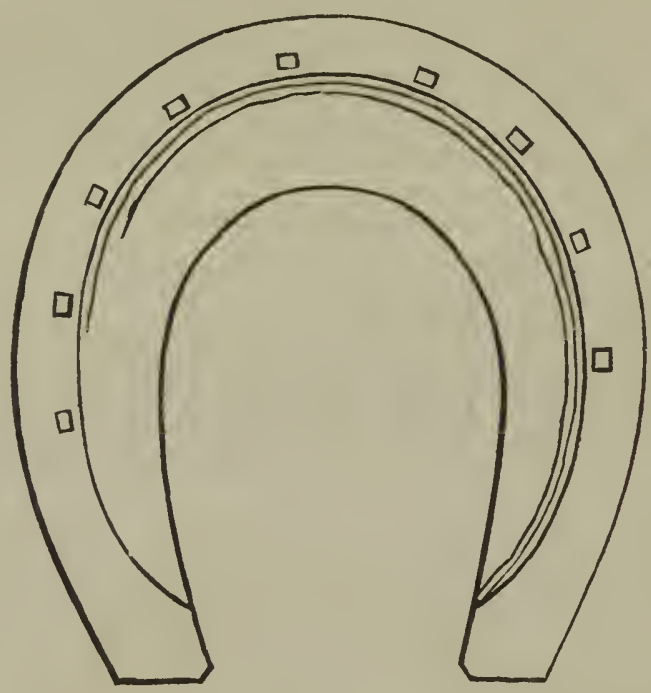

The web of this shoe is of the same thickness throughout, from the toe to the heel; and it is sufficiently wide to guard the sole from bruises, and, as much so as the frog will permit, to cover the seat of corn.

On the foot side it is seated. The outer part of it is accurately flat, and of the width of the crust, and designed to support the crust, for by it the whole weight of the horse is sustained.

Towards the heel this flattened part is wider and occupies the whole breadth of the web, in order to support the heel of the crust and its reflected part - the bar; thus, while it defends the horn included within this angle from injury, it gives that equal pressure from the bar and the crust, which is the best preventive against corns, and a powerful obstacle to contraction.

It is fastened to the foot by nine nails - five on the outside, and four on the inner side of the shoe; those on the outside extending a little farther down towards the heel, because the outside heel is thicker and stronger, and there is more nail-hold; the last nail on the inner quarter being farther from the heel on account of the weakness of that quarter. For feet not too large, and where moderate work only is required from the horse, four nails on the outside, and three on the inside, will be sufficient; and the last nail being far from the heels, will allow more expansion there.

The inside part of the web is bevelled off, or rendered concave, that it may not press upon the sole. Notwithstanding our iron fetter, the sole does, although to a very inconsiderable extent, descend when the foot of the horse is put on the ground. It is unable to bear constant or even occasional pressure, and if it came in contact with the shoe, the sensible sole between it and the coffin-bone would be bruised, and lameness would ensue. Many of our horses, from too early and undue work, have the natural concave sole flattened, and the disposition to descend and the degree of descent are thereby increased. The concave shoe prevents, even in this case, the possibility of much injury, because the sole can never descend in the degree in which 
the shoe is or may be bevelled. A shoe bevelled still farther is necessary to protect the projecting or pumiced foot.

\section{THE UNILATERAL, OR ONE SIDE NAILED SHOE.}

For a material improvement in the art of shoeing, we are indebted to Mr. Turner of Regent Street. What was the state of the foot of the horse a few years ago ? An unyielding iron hoof was attached to it by four nails in each quarter, and the consequence was, that in nine cases out of ten the foot underwent a very considerable alteration in its form and in its usefulness. Before it had attained its full developmentbefore the animal was five years old, there was, in a great many cases, an evident contraction of the hoof. There was an alteration in the manner of going. The step was shortened, the sole was hollowed, the frog was diseased, the general elasticity of the foot was destroyed-there was a disorganization of the whole horny cavity, and the value of the horse was materially diminished. What was the grand cause of this? It was the restraint of the shoe. The firm attachment of it to the foot by nails in each quarter, and the consequent strain to which the quarters and every part of the foot were exposed, produced a necessary tendency to contraction, from which sprang almost all the maladies to which the foot of the horse is subject.

The unilateral shoe has this great advantage: it is identified with the grand principle of the expansibility of the horse's foot, and of removing or preventing the worst ailments to which the foot of the horse is liable. It can be truly stated of this shoe, that while it affords to the whole organ an iron defence equal to the common shoe, it permits, what the common shoe never did or can do, the perfect liberty of the foot. shoe.

We are enabled to present our readers with the last improvement of the unilateral

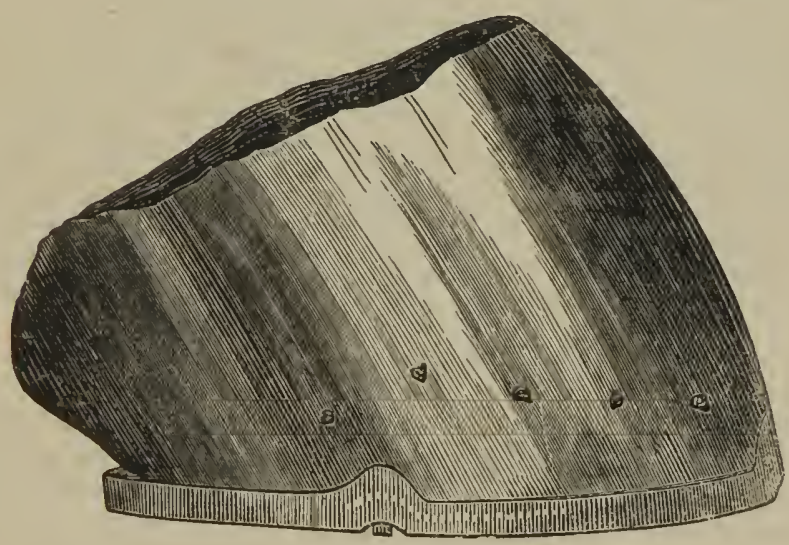

The above cut gives a view of the outer side of the off or right unilateral shoe. The respective situations of the five nails will be observed; the distance of the last from the heel, and the proper situations at which they emerge from the crust. The two clips will likewise be seen-one in the front of the foot, and the other on the side between the last and second nail.

The second cut gives a view of the inner side of the unilateral shoe. The two nails near the toe are in the situation in which Mr. Turner directs that they should be placed, and behind them is no other attachment, between the shoe and the crust. The portion of the crust which is rasped off from the inner surface of the shoe is now, we believe, not often removed from the side of the foot; it has an unpleasant appearance, and the rasping is somewhat unnecessary. The heel of this shoe exhibits the method which Mr. Turner has adopted, and with considerable success, for the cure of corns : he cuts away a portion of the ground surface at the heel, and injurious compression or concussion is rendered in a manner impossible. 


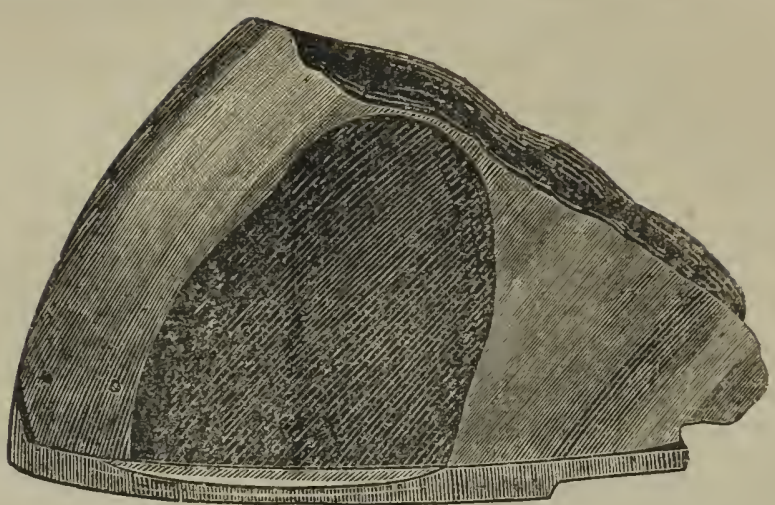

There can be no doubt that this one-sided nailing has been exceedingly useful. It has, in many a case that threatened a serious termination, restored the elasticity of the foot, and enabled it to discharge its natural functions. It has also restored to the foot, even in bad cases, a great deal of its natural formation, and enabled the horse to discharge his duty with more ease and pleasure to himself, and greater security to his rider.

It is difficult to tell what was the character of "the old English shoe." It certainly was larger than there was any occasion for it to be, and nearly covered the lower surface of the foot. The nail-holes were also far more numerous than they are at present. The ground side was usually somewhat convex. "The effect of this," says Mr. W. C. Spooner, "was to place the foot in a kind of hollow dish, which effectually prevented its proper expansion, the crust resting on a mere ledge instead of a flat surface; and, on the ground side, from the inner rim coming to the ground first, the weight was almost supported by the nails and clinches, which were placed, four or five on each side, at some distance from the toe, and approaching nearly to the heels."**

It was an improvement to make the ground surface flat, and to take care that it did not press on the sole. At length, however, came the concave-seated shoe of Osmer, which was advocated by Mr. Clark, of Edinburgh, improved by Mr. Moorcroft, and ultimately became very generally and usefully adopted.

\section{THE HUNTING SHOE.}

The hunter's shoe is different from that commonly used, in form as well as in weight. It is not so much bevelled off as the common concave-seated shoe. Sufficient space alone is left for the introduction of a picker between the shoe and the sole, otherwise, in going over heavy ground, the clay would insinuate itself, and by its tenacity loosen, and even tear off the shoe. The heels likewise are somewhat shorter, that they may not be torn off by the toe of the hind-feet when galloping fast, and the outer heel is frequently but injudiciously turned up to prevent slipping. If calkins are necessary both heels should have an equal bearing.

\section{THE BAR-SHOE.}

A bar-shoe is often exceedingly useful. It is the continuation of the common shoe round the heels, and by means of it the pressure may be taken off from some tender part of the foot, and thrown on another which is better able to bear it, or more widely and equally diffused over the whole foot. It is principally resorted to in cases of corn, the seat of which it perfectly covers-in pumiced feet, the soles of which may be thus elevated above the ground and secured from pressure,-in sand-crack, when the pres-

* A Treatise on the Foot of the Horse, by Mr. W. C. Spooner, p. 113. 
sure may be removed from the fissure, and thrown on either side of it, and in thrushes, when the frog is tender, or is become cankered, and requires to be frequently dressed, and the dressing can by this means alone be retained. In these cases the bar-shoe is an excellent contrivance, if worn only for one or two shoeings, or as long as the disease requires it to be worn, but it must be left off as soon as it can be dispensed with. If it is used for the protection of a diseased foot, however it may be chambered and laid off the frog, it will soon become flattened upon it; or if the pressure of it is thrown on the frog, in order to relieve the sand-crack or the corn, that frog must be very strong and healthy which can long bear the great and continued pressure. More mischief is often produced in the frog than previously existed in the part that was relieved. It will be plain that in the use of the bar-shoe for corn or sand-crack, the crust and the frog should be precisely on a level : the bar also should be the widest part of the shoe, in order to afford as extended bearing as possible on the frog, and therefore less likely to be injurious. Bar-shoes are evidently not safe in frosty weather. They are never safe when much speed is required from the horse, and they are apt to be wrenched off in a heavy, clayey country.

\section{TIPS.}

Tips are short shoes, reaching only half round the foot, and worn while the horse is at grass, in order to prevent the crust being torn by the occasional hardness of the ground, or the pawing of the animal. The quarters at the same time being free, the foot disposed to contract has a chance of expanding and regaining its natural shape.

\section{THE EXPANDING SHOE.}

Our subject would not be complete if we did not describe the supposed expanding shoe, although it is now almost entirely out of use. It is either seated or concave like the common shoe, with a joint at the toe, by which the natural expansion of the foot is said to be permitted, and the injurious consequences of shoeing prevented. There is, however, this radical defect in the jointed shoe, that the nails occupy the same situation as in the common shoe, and prevent, as they do, the gradual expansion of the sides and quarters, and allow only of a hinge-like motion at the toe. It is a most imperfect accommodation of the expansion of the foot to the action of its internal parts, and even this accommodation is afforded in the slightest possible degree, if it is afforded at all. Either the nails fix the sides and quarters as in the common shoe, and then the joint at the toe is useless; or, if that joint merely opens like a hinge, the nail-holes near the toe can no longer correspond with those in the quarters, which are unequally expanding at every point. There will be more stress on the crust at these holes, which will not only enlarge them and destroy the fixed attachment of the shoe to the hoof, but often tear away portions of the crust. This shoe, in order to answer the intended purpose, should consist of many joints, running along the sides and quarters, which would make it too complicated and expensive and frail for general use.

While the shoe is to be attached to the foot by nails, we must be content with the cnncave-seated or unilateral one, taking care to place the nail-holes as far from the heels, and particularly from the inner heel, as the state of the foot and the nature of the work will admit; and where the country is not too heavy nor the work too severe, omitting all but two on the inner side of the foot.

\section{FELT OR LEATHER SOLES.}

When the foot is bruised or inflamed, the concussion or shock produced by the hard contact of the elastic iron with the ground gives the animal much pain, and aggravates the injury or disease. A strip of felt or leather is, therefore, sometimes placed between the seating of the shoe and the crust, which, from its want of elasticity, deadens or materially lessens the vibration or shock, and the horse treads more freely and is evidently relieved. This is a good contrivance while the inflammation or tenderness of the foot continues, but a very bad practice if constantly adopted. The nails cannot be driven so surely or securely when this substance is interposed between the shoe and the foot. The contraction and swelling of the felt or leather from the 
effect of moisture or dryness will soon render the attachment of the shoe less firmthere will be too much play upon the nails-the nail-holes will enlarge, and the crust will be broken away.

After wounds or extensive bruises of the sole, or where the sole is thin and flat and tender, it is sometimes covered with a piece of leather, fitted to the sole, and nailed on with the shoe. This may be allowed as a temporary defence of the foot; but there is the same objection to its permanent use from the insecurity of fastening, and the strain on the crust, and the frequent chipping of it. There are also these additional inconveniences, that if the hollow between the sole and the leather is filled with stopping and tow, it is exceedingly difficult to introduce them so evenly and accurately as not to produce partial or injurious pressure. A few days' work will almost invariably so derange the padding, as to cause unequal pressure. The long contact of the sole with stopping of almost every kind will produce, not a healthy, elastic horn, but that of a scaly, spongy nature-and if the hollow is not thus filled, gravel and dirt will insinuate themselves, and eat into and injure the foot.

The general habit of stopping the feet requires some consideration. It is a very good or very bad practice, according to circumstances. When the sole is flat and thin it should be omitted, except on the evening before shoeing, and then the application of a little moisture may render the paring of the foot safer and more easy. If it were oftener used it would soften the foot, and not only increase the tendency to descent, but the occasional occurrence of lameness from pebbles or irregularities of the road.

Professor Stewart gives a valuable account of the proper application of stopping. "Farm horses seldom require any stopping. Their feet receive sufficient moisture in the fields, or, if they do not get much, they do not need much. Cart-horses used in the town should be stopped once a week, or oftener during winter, and every second night in the hot weeks of summer. Groggy horses, and all those with hight heels, concave shoes, or hot and tender feet, or an exuberance of horn, require stopping almost every night. When neglected, especially in dry weather, the sole becomes hard and rigid, and the horse goes lame, or becomes lame if he were not so before."*

One of two substances, or a mixture of both, is generally used for stopping the feet -clay and cow-dung. 'The clay used alone is too hard, and dries too rapidly. Many horses have been lamed by it. If it is used in the stable, it should always be removed before the horse goes to work. It may, perhaps, be applied to the feet of heavy draught-horses, for it will work out before much mischief is done.

Cow-dung is softer than the clay, and it has this good property, that it rarely or never becomes ton hard or dry. For ordinary work, a mixture of equal parts of clay and cow-dung will be the best application; either of them, however, must be applied with a great deal of caution, where there is any disposition to thrush. Tow used alone, or with a small quantity of tar, will of ten be serviceable.

In the better kind of stables, a felt pad is frequently used. It was first introduced by Veterinary Surgeon-General Cherry. It keeps the foot cool and moist, and is very useful, when the sole has a tendency to become flat. For the concave sole, tow would be preferable.

The shoe is sometimes displaced when the horse is going at an ordinary pace, and more frequently during hunting; and no person who is a sportsman needs to be told in what a vexatious predicament every one feels himself who liappens to lose a shoe in the middle of a chase, or just as the hounds are getting clear away with their fox over the open country.

Mr. Percivall has invented a sandal which occupies a very small space in the pocket, can be buckled on the foot in less than two minutes, and will serve as a perfect substitute for the lost one, on the road, or in the field; or may be used for the race-horse when travelling from one course to another; or may be truly serviceable in cases of diseased feet that may require at the same time exercise and daily dressing. The following is a short shetch of the horse sandal. 


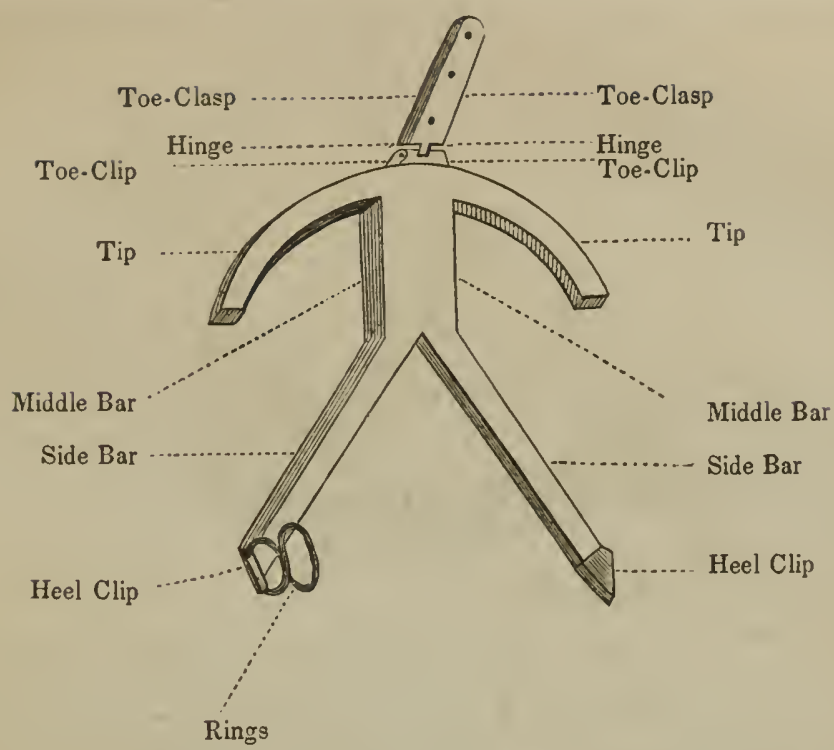

From an inspection of the above cut, it will be seen that the shoe, or iron part of the sandal, consists of three principal parts, to which the others are appendages; which are, the tip, so called from its resemblance to the horse-shoe of that name; the middle bar, the broad part proceeding backward from the tip; and the side bars, or branches of the middle bar, extending to the heels of the hoof. The appendages are, the toe-clasp, the part projecting from the front of the tip, and which moves by a hinge upon the toe-clip, which toe-clasp is furnished with two iron loops. The heel-clips are two clips at the heels of the side bars, which correspond to the toe-clip; the latter embracing the toe of the crust, while the former embrace its heels. Through the heel-clips run the rings, wlich move and act like a hinge, and are double, for the purpose of admitting both the straps. In the plate, the right ring only is represented ; the left being omitted, the better to show the heel-clip. The straps, which are composed of web, consist of a loof-strap and a heel and coronet-strap.

The hoof-strap is furnished with a buckle, whose office it is to bind the shoe to the hoof; for which purpose it is passed through the lower rings, and both loops of the shoe, and is made to encircle the hoof twice.

The heel and coronet-strap is furnished with two pads and two sliding loops; one, a movable pad, reposes on the heel, to defend that part from the pressure and friction of the strap; the other, a pad attached to the strap near the buckle, affords a similar defence to the coronet, in front. The heel-strap runs through the upper rings, crosses the hicel, and encircles the coronet; and its office is to keep the heels of the shoe closely applicd to the hoof, and to prevent them from sliding forward.

In the application of the sandal, the foot is taken up with one hand, and the sloee slipped upon it with the other. With the same hand, the shoe is retained in its place, while the foot is gradually let down to rest on the ground. As soon as this is done, the straps are drawn as tight as possible, and buckled.

The following cut represents an accurate delineation of the sandal, when properly fastened on the foot.

Horses occasionally fall from bad riding, or bad shoeing, or overreaching, or an awkward way of setting on the saddle. The head, the neck, the knees, the back, or the legs, will oftenest suffer. It is often difficult to get the animal on his legs again, especially if lie is old, or exhausted, or injured by the fall. The principal object is, to support the liead, and to render it a fixed point from which the muscles may act in supporting the body. 


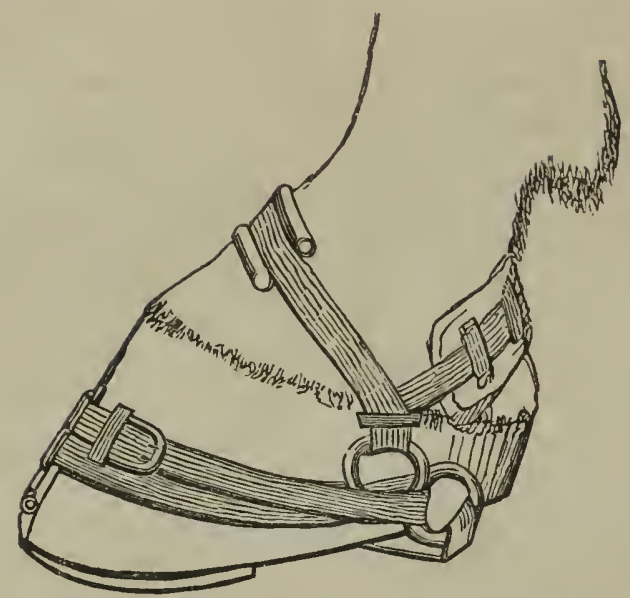

If the horse is in harness, it is seldom that he can rise until he is freed from the shafts and traces. The first thing is to secure the head, and to keep it down, that he may not beat himself against the ground. Next, the parts of the harness connected with the carriage must be unbuckled - the carriage must then be backed a little way, so that he may have room to rise. If necessary, the traces must be taken off; and after the horse gets up, he must be steadied a little, until he collects himself.

\section{CHAPTER XVIII.}

\section{OPERATIO NS.}

THESE belong $\mathrm{m}$ ore to the veterinary surgeon than to the proprietor of the horse, but a short account of the manner of conducting the principal ones should not be omitted.

It is frequently recessary to bind the human patient, and in no painful or dangerous operation should this be omitted. It is more necessary to bind the horse, who is not under the control of reason, and whose struggles may not only be injurious to himself, but dangerous to the operator.

The trevis is a machine indispensable in every continental forge; even the quietest horses are there put into it to be shod.

The side-line is a very simple and useful method of confining the horse, and placing him in sufficient subjection, for the operations of docking, nicking, and slight firing. The long line of the hobbles, or a common cart-rope, with a noose at the end, is fastened on the pastern of the hind-leg that is not to be operated on. The rope attached to it is then brought over the neck and round the withers, and there tied to the portion that comes from the leg. The leg may thus be drawn so far forward that, while the horse evidently cannot kick with that leg, he is disarmed of the other; for he would not have sufficient support under him, if he attempted to raise it: neither can he easily use his fore-legs; or, if he attempts it, one of them may be lifted up, and then he becomes nearly powerless. If necessary, the aid of the twitch, or the barnacles, may be resorted to.

For every minor operation, and even for many that are of more importance, this mode of restraint is sufficient, especially if the operator has active and determined assistants; and we confess that we are no friends to the casting of horses, if it can possibly be prevented. When both legs are included in the hobble, or rope - as in 
another way of using the side-line - the horse may appcar to be more secure; but there is greater danger of his falling in his violent struggles during the operation.

For castrating and severe firing, the animal must be thrown. The safety of the horse, and of the operator, will require the use of the improved lobbles, by which any leg may be relcased from confinement, and returned to it at pleasure; and, when the operation is ended, thc whole of the legs may be set at liberty at once, without danger. 'The method of putting the legs as closely together as possible before the pull - the necessity of the assistants all pulling together - and the power which one man standing at the head, and firmly holding the snaffle-bridle, and another at the haunch, pushing the horse when he is beginning to fall, have in bringing him on the proper side, and on the very spot on which lie is intended to lie, need not to be described. It twill generally be found most convenient to throw the patients on the off sidc, turning them over when it is required. This, however, is a method of securing the horse to which we repeat that we are not partial, and to which we should not rcsort, except necessity compelled; for in the act of falling, and in the struggles after falling, many accidents have occurred, both to the horse and the surgeon.*

Among the minor methods of restraint, but sufficient for many purposes, arc the twitch and the barnacles. The former consists of a noose passed through a hole at the cnd of a strong stick, and in which the muzzle is inclosed. The stick being turned round, thc muzzle is securely retained, while the horse suffers considerable pain from the pressure - sufficiently great, indced, to rcnder him comparatively inattentive to that which is produced by the operation; at the same time he is afraid to struggle, for every motion increases the agony caused by the twitch, or the assistant has power to increase it by giving an additional turn to the stick.

'The degree of pain produced by the application of the twitch should never be forgotten or unnecessarily increased. In no case should it be resorted to when milder measures would have the desired effect. Grooms and horsekeepers are too much in the habit of having recourse to it when they have a somewhat troublesome horse to manage. The degree of useless torture which is thus inflicted in large establishments is dreadful; and the temper of many a horse is too frequently completely spoiled.

The barnacles are the handles of the pincers placed over and inclosing the muzzle, and which, being compressed by the assistant, give pain almost equal to that of the twitch. These may appear to be barbarous modes of enforcing submission, but they arc absolutely indispensable. In a few instances the blindfolding of the horse terrifies him into submission; but this is not to be depended upon. The twitch should be resorted to when the least resistance is offered; and when that, as it occasionally does, renders the horse morc violent, rccourse must be had to the side-line or the hobbles.

In the painful examination of the fore-lcg or foot while on the ground, the other foot should bc held up by an assistant; or, if his aid is required in an operation, the knec may be fully bent, and the pastern tied up to the arm. When the hind-leg is to be examined in the same way, the fore-lcg on that side should be held or fastened up.

\section{BLEEDING.}

The operation of blecding has been already described (p. 189), but we would remind our readcrs of the nccessity, in evcry case of acute inflammation, of making a large orifice, and abstracting the blood as rapidly as possible, for the constitution will thus bc the more specdily and beneficially affected; and also of the propriety of never detcrmining to take a precise quantity of blood, but of keeping the finger on the artery until the pulse begins to falter, or the strong beating of fever hecomes softer, or the animal is faint, or the oppressed pulse of inflammation of the lungs is rounder and fuller.

In cases of inflammation, and in the hands of a skilful practitioner, bleeding is the shcet-anchor of the veterinarian; yet few things are more to be reprobated than the indiscriminatc bleeding of the groom or the farrier.

The change which takes place in the blood after it is drawn from the vein is diligently noticed by many practitioners, and is certainly deserving of some attention.

* The safest and best hobbles, are those invented by Mr. Gloag, and improved by Mr. Daws, as represented in the Veterinarian, vol. x. p. 108, and vol. xi. p. 163. The thumb-screw (fig. 3) should, however, be inverted. 
The blood coagulates soon after it is taken from the vein. The coagulable part is composed of two substances: that which gives colour to the blood, and that in whicn the red particles float. These, by degrees, separate from each other, and the red particles sink to the bottom. If the coagulation takes place slowly, the red particles have more time to sink through the fluid, and there appears on the top a thick, yellowish, adhesive substance, called the buffy coat. The slowness of the coagulation and the thickness of buffy coat are indicative of inflammation, and of the degree of inflammation.

In a healthy state of the system, the coagulation is more rapid, the red particles have not time to fall through, and the buffy coat is thin. These appearances are worth observing; but much more dependence is to be placed on the character and change of the pulse, and the symptoms generally. When the horse is exhausted and the system nearly broken up, the blood will sometimes not coagulate but be of one uniform black colour and loose texture. When the blood runs down the side of the vessel in which it is received, the coagulation will be very imperfect. When it is drawn in a full stream, it coagulates slowly, and when procured from a smaller orifice, the coagulation is more rapid. Every circumstance affecting the coagulation and appearance of the blood, the pulse, and the general symptoms, should be most attentively regarded.

A great deal of mystery is associated with bleeding in the management of the racer and the hunter. The labour of the turf and the field having ceased, there is frequently some difficulty in preventing a plethoric state of the constitution-a tendency to inflammatory complaints. If the horse is rapidly accumulating flesh, it may be prudent to abstract blood, dependent in quantity on the age and constitution of the animal. Attention to this may prevent many a horse from going wrong; but the custom that once prevailed of bleeding every horse a fortnight or more after the racing or hunting season had passed, is decidedly objectionable.

As preparatory to work, bleeding is far from being so much employed as it used to be. As a universal practice, when the horse is first taken from grass, it now scarcely exists. It would not always be objected to, if the horse was fat and full of flesh, but, otherwise, it is a custom more honoured in the breach than the observance. It certainly produces very considerable effect. More rapidly than any species of diet more rapidly than any sweating or purging; it reduces the condition of the horse, but, we have often thought, at the expense of those essentials to life and health that cannot be easily replaced.

\section{BLISTERING.}

We have spoken of the effect of BLISTERs, when treating of the various diseases to which they are applicable. The principle on which they act is, that no two intense inflammations can exist in neighbouring parts, or perhaps in the system, at the same time. Hence we apply some stimulating acrimonious substance to the skin, in order to excite external inflammation, and thus lessen or remove that which exists in some deeper seated and, generally, not far distant part. Hence, also, we blister the sides in inflammation of the lungs-the abdomen in that of the bowels-the legs in that of the cellular substance surrounding the sheaths of the tendons, or the sheaths themselves, and the coronet or the heel in inflammation of the navicular joint.

Blisters have likewise the property of increasing the activity of the neighbouring vessels: thus we blister to bring the tumour of strangles more speedily to a head-to rouse the absorbents generally to more energetic action, and cause the disappearance of tumours, and even callous and bony substances.

The judgment of the practitioner will decide whether the desired effect will be best produced by a sudden and violent action, or by the continuance of one of a milder character. Inflammation should be met by active blisters; old enlargements and swellings will be most certainly removed by milder stimulants-by the process which farriers call sweating down.

There are few more active or effectual blisters than the Spanish fly, mixed with the proportions of lard and resin that will be hereafter stated. The best liquid or sweating blister is an infusion of the fly in spirit of turpentine, and that lowered with neat's foot oil, according to the degree of activity required.

In preparing the horse for blistering, the hair should be clipped or shaved as closely as possible, and the ointment thoroughly rubbed in. Much fault is often found with 
the ointment if the blister does not rise, but the failure is generally to be attributed to the idleness of the operator.

The head of the horse should be tied up during the first two days; except that, when the sides are blistered, the body-clothes may be so contrived as to prevent the animal from nibbling and blemishing the part, or blistering his muzzle. At the expiration of twenty-four hours, a little olive or neat's foot oil should be applied over the blister, which will considerably lessen the pain and supple the part, and prevent cracks in the skin that may be difficult to heal. The oil should be applied morning and night, until the scabs peel off. When they begin to loosen, a lather of soap and water - applied with a sponge may hasten their removal, but no violence must be used.

Every particle of litter should be carefully removed from the stall, for the sharp ends of the straw coming in contact with a part rendered so tender and irritable by the blister, will cause a very great annoyance to the animal. After the sccond day the horse may be suffered to lie down; but the possibility of blemishing himself should be prevented by a cradle or wooden necklace, consisting of round strips of wood, strung together, reaching from the lower jaw to the chest, and preventing him from sufficiently turning or bending his head to get at the blistered part.

A blister thus treated will rarely produce the slightest blemish. When the scabs are all removed, the blister may be repeated, if the case should appear to require it, or the horse may be turned out.

In inflammations which threaten life, a blister can scarcely be too active or extensive. In inflammation of the lungs it should reach over the whole of the sides, and the greater part of the brisket, for, should a portion of the fly be absorbed, and produce strangury (inflammation, or spasmodic affection of the neck of the bladder,) even this new irritation may assist in subduing the first and more dangerous one. In blistering, however, for injuries or diseases of the legs or feet, some caution is necessary. When speaking of the treatment of sprain of the back sinews, p. 271, it was stated, that "a blister should never be used while any heat or tenderness remained about the part," for we should then add to the superficial inflammation, instead of abating the deeperseated one, and enlargements of the limb and extensive ulcerations might follow, which would render the horse perfectly unserviceable. When there is a tendency to grease, a blister is a dangerous thing, and has often aggravated the disease. In winter, the inflammation of the skin produced by blistering is apt to degenerate into grease; therefore, if it should be necessary to blister the horse during that season, great care must be taken that he is not exposed to cold, and, particularly, that a current of cold air does not come upon the legs.

The inhuman practice of blistering all round at the same time, and perhaps high on the legs, cannot be too strongly reprobated. Many a valuable horse has been lost through the excessive general irritation which this has produced, or its violent effect on the urinary organs; and that has been particularly the case, when corrosive sublimate has entered into the composition of the blister.

If strangury should appear, the horse should be plentifully supplied with linseed tea, which is thus best prepared-a gallon of boiling water is thrown on half a pound of linseed; the infusion suffered to stand until nearly cold, and the clean unucilaginous fluid then poured off. Three-quarters of a pound of Epsom salts should also be given, dissolved in a quart of water, and, after that, a ball every six hours, containing opium and camphor, with linseed meal and treacle.

Half a pound or a pound of good mustard powder, made into a paste with boiling water, and applied hot, will often produce as good a blister as cantliarides. It is a preferable one, when, as in inflammation of the kidneys, the effect of cantharides on the urinary organs is feared. Hartshorn is not so effectual. Tincture of croton makes an active liquid blister, and so do some of the preparations of iodine.

\section{FIRING.}

Whatever seening cruelty may attend this operation, it is in many cases indispensable. The principle on which we have recourse to it is similar to that which justifies the use of a blister-by producing superficial inflammation we may be enabled 10 get rid of a deeper-seated one, or we may excite the absorbents to remove an innatural bony or other tumour. It raises more intense external inflammation than we can produce by any other means. It may be truly said to be the most powerful agent that we have at our disposal. Humanity, however, will dictate, that on account 
of the inflammation which it excites, and the pain it inflicts, it should only be had recourse to when milder means rarely succeed.

The part which is to be submitted to the operation should be shaved, or the hair cut from it as closely as possible with the trimming scissors. This is necessary in order to bring the iron into immediate contact with the skin, and likewisc to prevent the smoke that will arise from the hurned hair obscuring the view of the operator. 'The horse must then be thrown. This is absolutely necessary for the safety both of the operator and the animal. The side line may be applied in a shorter time, and so many hands may not be wanted to cast the horse; but no person can fire accurately, or with the certainty of not penetrating the skin, except the animal is effectually secured by the hobbles. Although accidents have occurred in the act of casting, yet many more have resulted to the operator, the assistants, or the horse, in a protracted operation, when the side-line only has bcen used.

The details of the operation belong to the veterinary surgcon. The grand points to be attended to are to have the edge of the iron round and smooth-the iron itself at, or rather below a red heat - to pass it more or less rapidly over the skin, and with slighter or greater pressure, according to the degree of heat - to burn into the skin until the line produced by the iron is of a brown colour, rather light than dark, and, by all means, in common cases, to avoid penetruting the skin. Leaving out of the question the additional cruelty of deep firing, when not absolutely required, we may depend on it that if the skin is burned through, inflammation, and ulceration, and sloughing will ensue, that will be with much difficulty combated-that will unavoidably leave unnecessary blemish, and that has destroyed many valuable horses. It may happen, ncvertheless, that by a sudden plunge of the animal the skin will be unavoidably cut through. The act of firing requires much skill and tact, and the practitioner cannot be always on his guard against the struggles of the tortured beast. It will, also, and not unfrequently, occur that the skin, partially divided, will separate in two or three days after the operation. This must not be attributed to any neglect or unskilfulness of the surgeon, and the ulceration thus produced will be slight and easily treated, compared with that caused by actually burning through the skin.

A very considerable change has taken place in the breed of many of the varieties of the horse, and the labour cxacted from him. As illustrations of this we refer to the altered character and pace of the modern huntcr and the additional increase of speed required from the coach and the post horse; the cxertion being limited only by the degree to which every nuscle and cvery nerve can be extended, while the calculation between the utmost exaction of cruelty and the expenditure of vital powcr, is reduced to the merest fraction. The consequence of this is, that the horse is subjected to severer injuries than he used to be, and severer measures are and must be employed to remedy the evil. Hence the horrible applications of the actual cantery to the horse that have disgraced the present day. Lesions-gashes have been made on either side of the tendon of the leg, which it took no fewer than seven months to heal. Was there nothing short of this lengthened torture that could have been done to relieve the victim? Could he not have been more lightly fired for the road or for the purposes of breeding? Was there no pasture on which he had earned a right to graze? - or could he not have been destroyed? These sad lesions will occasionally come before the practitioner and the owner. It will be for the first, to advocate that, which, on a careful view of the case, mercy prompts; and the latter, except there is a reasonable prospect of ultimate enjoyment, as well as usefulness, should never urge a continuation of suffering.

Supposing, however, that prospect to exist, the surgeon must discharge his duty. These gashes, after a while, begin to close, and then commences the beautiful process of granulation. Little portions of the integument form on the centre of the wound, and the sides of the wound creep closer together, and the skin steals over the surface, until the chasm is perfectly closed. In order to insure the continuance of this, a ridge of contracted integument as hard as any cartilage, but without its elasticity, runs from one end of the lesion to the other, tighter. and harder, and more effectual every week, and month, and year, and lasting during the life of the animal. Therefore, the veterinary surgcon is not to be too severely censured, if, after due consideration, he is induced to undertake one of thesc fearful opcrations: hut let him do it as seldom as he can, ard only when every circumstance promises a favourable result. 
Some practitioners blister immediately after firing. As a general usage it is highly to be reprobated. It is wanton and uscless cruelty. It may be requircd in bony tumours of considerable extent, and long standing, and interfering materially with the action of the neighbouring joint. Spavin accompanied by much lameness, and ringbone spreading round the coronet and involving the side cartilages or the pastern joint, may justify it. The inflammation is rendered more intense, and of considerably longer duration. In old affections of the round bone it may be admitted, but no excuse can be made for it in slighter cases of sprain or weakness, or staleness.

On the day after the operation, it will be prudent gently to rub some neat's foot oil, or lard over the wound. This will soften the skin, and render it less likely to separate or ulcerate. A bandage would add to the irritation of the part. Any cracks of the skin, or ulccrations that may ensue, must be treated with the calamine ointment.

It will bc evident that there is an advantage derived from firing to which a blister can have no pretension. The skin, partially destroyed by the iron, is reinstated and healed, not merely by the formation of some new matter filling up the vacuity, but by the gradual drawing together and closing of the separatcd edges. The skin, therefore, is lessened in surface. It is tightened over the part, and it acts, as just described, as a salutary and permanent bandage. Of the effect of pressure in removing enlargements of every kind, as well as giving strength to the part to which it is applied, we have repeatedly spoken; and it is far from being the least valuable effect of the operation of firing, that, by contracting the skin, it affords a salutary, equable, and permanent pressure. It was on this principle, but the practice cannot be defended, that colts which were not very strong on the legs, used to be fired round the fetlock, and along the back sinew, or over the hock, in order to brace and strengthen the parts. It is on the same principle that a racer or hunter, that has become stale and stiff, is sometimes fired and turned out. For whatever reason the horse is fired, he should, if possible, be turned out, or soiled in a loose box, for thrce or four months at least. 'The full effect intended to result from the external irritation is not soon produced, and the benefit derived from pressure proceeds still more slowly. In the thickened and tender state of the skin, and the substance beneath, a return to hard work, for some weeks after firing, would be likely to excite new inflammation, and cause even worse mischief than that which before existed.

Some weeks pass before the tumefied parts begin to contract, and they only, who have had experience in these cases, can imagine how long, with gentle voluntary exercisc, the process of absorption is carried on. He who would expect that much good should accrue from the opcration of firing, must be content to give up his horse for three or four months; but if he will use him sooner, and a worse lameness should follow, let him blame his own impatience, and not the inefficiency of the means, or the want of skill in the surgeon.

The firing in every case should be either in longitudinal or parallel lines. On the back sinews, the fetlock, and the coronet, this is peculiarly requisite, for thus only will the skin contract so as to form the greatest and most equable pressure.

Some practitioners may pride themselves on the accuracy of their diamonds, lozenges and feathers, but plain straight lines, about half an inch from each other, will constitute the most advantagcous mode of firing. The destroying of deeply-seated inflammation, by the exciting of violent inflammation on the skin, is as well obtained; and common sense will determine, that in no way can the pressure which results from the contraction of the skin be so advantageously employed-to which may be added, that it often leaves not the slightest blemish.

\section{SETONS}

Are pieces of tape or cord, passcd, by means of an instrument rescmbling a large needle, either through abscesses, or the base of ulcers with deep sinuses, or between the skin and the muscular or other substances beneath. They arc retained there by the ends being tied together, or by a knot at each end. The tape is moved in the wound twice or thrice in the day, and occasionally wetted with spirit of turpentine, or some acrid fluid, in order to increase the inflammation which it produces, or the discharge which is intended to be established.

In absccsses, such as occur in the withers or the poll, and when passed from the summit to the very hottom of the swclling, setons are highly useful, by discharging the purulent fluid and suffering any fresh quantity of it that may be secreted to flow 
out; and, by the degree of inflammation which they excite on the interior of the tumour, stimulating it to throw out healthy granulations which gradually occupy and fill the hollow. In deep fistulous wounds they are indispensable, for except some channel is made through which the matter may flow from the bottom of the wound, it will continue to penetrate deeper into the part, and the healing process will never be accomplished. On these accounts, a seton passed through the base of the ulcer in poll-evil and fistulous withers is of so much benefit.

Setons are sometimes useful by promoting a discharge in the neighbourhood of an inflamed part, and thus diverting and carrying away a portion of the fluids which distend or overload the vessels of that part : thus a seton is placed with considerable advantage in the cheek, when the eyes are much inflamed. We confess, however, that we prefer a rowel under the jaw.

With this view, and to excite a new and different inflammation in the neighbourhood of a part already inflamed, and especially so deeply seated and so difficult to be reached as the navicular joint, a seton has occasionally been used with manifest benefit, but we must peremptorily object to the indiscriminate use of the frog-seton for almost every disease of the frog or the foot.

In inflammations of extensive organs, setons afford only feeble aid. Their action is too circumscribed. In inflammation of the chest or the intestines, a rowel is preferable to a seton; and a blister is far better than either of them.

On the principle of exciting the absorbents to action for the removal of tumours, as spavin or splent, a blister is quicker in its action, and far more effectual than any seton. Firing is still more useful.

\section{DOCKING.}

The shortening of the tail of the horse is an operation which fashion and the convenience of the rider require to be performed on most of these animals. The length of the dock, or stump, is a matter of mere caprice. To the close-cropped tail of the wagon-horse, however, we decidedly object, from its perfect ugliness, and because the animal is deprived of every defence against a thousand tortures. The supposition that the blood which would have gone to the nourishment of the tail, causes greater development and strength in the quarters, is too absurd to deserve serious refutation. It is the rump of the animal being wholly uncovered, and not partly hidden by the intervention of the tail, that gives a false appearance of increased bulk.

The operation is simple. That joint is searched for which is the nearest to the desired length of tail. The hair is then turned up, and tied round with tape for an inch or two above this joint; and that which lies immediately upon the joint is cut off. The horse is fettered with the side-line, and then the veterinary surgeon with his docking-machine, or the farmer with his carving-knife and mallet, cuts through the tail at one stroke. Considerable bleeding ensues, and frightens the timid and the ignorant; but if the blood were suffered to flow on until it ceased of its own accord, the colt, and especially if he were very young, would rarely be seriously injured. As, however, the bleeding would occasionally continue for some hours, and a great quantity of blood might be lost, and the animal might be somewhat weakened, it is usual to stop the hæmorrhage by the application of a red-hot iron to the stump. A large hole is made in the centre of the iron, that the bone may not be seared, which would exfoliate if it were burned with any severity, or drop off at the joint above, and thus shorten the dock. The iron rests on the muscular parts round the bone, and is brought into contact with the blecding vessels, and very speedily stops the hæmorrhage. Care should be taken that the iron is not too hot,and that it is not held too long or too forcibly on the part, for many more horses would be destroyed by severe application of the cautery, than by the blecding being left to its own course.

Powdered resin sprinkled on the stump, or indecd any other application, is worse than useless. It causes unnecessary irritation, and sometimes extensive ulceration; but if the simple iron is moderately applied, the horse may go to work immediately after the operation, and no dressing will be afterwards required. If a slight bleeding should occur after the cautery, it is much better to let it alone than to run the risk of inflammation or locked-jaw, by re-applying the iron with greater severity.

Some farmers dock their colts a few days after they are dropped. This is a com- 
mendable custom on the score of humanity. No colt was ever lost by it; and neither the growth of the hair, nor the beauty of the tail, is in the least impaired.

\section{NICKING.}

This barbarous operation was once sanctioned by fashion, and the breeder and the dealer even now are sometimes tempted to inflict the torture of it in order to obtain a ready sale for their colts. It is not, however, practised to the extent that it used to be, nor attended by so many circumstances of cruelty.

We must here introduce a small portion of the anatomy of the horse, which we had reserved for this place. The eighteen dorsal vertebræ or bones of the back (see $d$, p. 167), and the five lumbar vertebræ or bones of the loins $(f$, p. 167), have already been described. The continuation of the spine consists of the sacrum, composed of five bones ( $h, \mathrm{p} .167)$, which, although separate in the colt, are in the full-grown horse united into one mass. The bones of the ilium, the upper and side portion of the haunch, articulate strongly with the sacrum, forming a bony union rather than a joint. The spinal marrow and the blood-vessels here generally begin to diminish, and numerous branches of nerves are given out, which, joined by some from the vertebræ of the loins, form the nervous apparatus of the hind-legs.

The bones of the tail $(i, \mathrm{p} .167)$ are a continuation of those of the sacrum. They are fifteen in number, gradually diminishing in size, and losing altogether the character of the spinal vertebræ. Prolongations of the spinal marrow run through the whole of them, and likewise some arterial vessels, which are a continuation of those which supply the sacrum. Much attention is paid by persons who are acquainted with the true form of the horse to this continuation of the sacral and tail-bones. From the loins to the setting on of the tail the line should be nearly straight, or inclining only a slight degree downward. There is not a surer test of the breed of the horse than this straight line from the loins to the tail; nor, as was shown when the muscles of the quarters were described, is there any circumstance so much connected with the mechanical advantage with which these muscles act.

The tail seems to be designed to perfect the beauty of the horse's form. There are three sets of muscles belonging to the tail-the erector coccygis, situated on the superior and lateral part of it, and by the action of which $(d, \mathrm{p} .282)$ the tail may be both elevated and drawn on one side-the depressor coccygis, on the inferior and lateral part of it, by the action of which the tail may be both lowered and drawn on one sideand the curvator coccygis, by the action of which the tail may be curved or flexed on either side. The depressor and lateral muscles are more powerful than the erector ones, and when the horse is undisturbed, the tail is bent down close on the buttocks; but when he is excited, and particularly when he is at speed, the erector muscles are called into action, the tail is elevated, and there is an appearance of energy and spirit which adds materially to his beauty. To perpetuate this, the operation of nicking was contrived. The depressor muscles and part of the lateral ones are cut through, and the erector muscles, left without any antagonists, keep the tail in a position more or less erect, according to the whim of the operator or the depth to which the incisions have been carried.

The operation is thus performed. The side-line is put on the horse, or some persons deem it more prudent to cast him, and that precaution we should be disposed to recommend. 'The hair at the end of the tail is securely tied together, for the purpose of afterwards attaching a weight to it. The operator then grasps the tail in his hand, and, lifting it up, feels for the centre of one of the bones - the prominences at the extremities will guide him-from two to four inches from the root of the tail, according to the size of the horse. He then, with a sharp knife, divides the muscles deeply from the edge of the tail on one side to the centre, and, continuing the incision across the bone of the tail, he makes it as deep on the other side. One continued incision, steadily yet rapidly made, will accoinplish all this. If it is a blood-horse that is operate: l on, this will be sufficient. For a hunter, two incisions are usually made, the second being about two inches below the first, and likewise as nearly as possible in the centre of one of the bones.

On a hackney, or cocktail, a third incision is made; for fashion has decided that his 
tail shall be still more elevated and curved. Two incisions only are made in the tail of a mare, and the second not very deep.

When the second incision is made, some fibres of the muscles between the first and second will project into the wound, and must be removed by a pair of curved scissors. The same must be done with the projecting portions from between the second and third incisions. The wounds should then be carefully examined, in order to ascertain that the muscles have been equally divided on each side, otherwise the tail will be carried awry. This being done, pledgets of tow must be introduced deeply into each incision, and confined, but not too tightly, by a bandage. A very profuse bleeding will alone justify any tightness of bandage, and the ill consequences that have resulted from nicking are mainly attributable to the unnecessary force that is used in confining these pledgets. Even if the bleeding, immediately after the operation, should have been very great, the roller must be loosened in two or three hours, otherwise swelling and inflammation, and even death, may possibly ensue. 'Twenty-four hours after the operation, the bandage must be quite removed; and then, all that is necessary, so far as the healing of the incisions is concerned, is to keep them clean.

If, however, the tail were suffered to hang down, the divided edges of the muscles would again come in contact with each other, and close; the natural depression of the tail would remain; and the animal would have been punished for no purpose. The wounds must remain open, and that can only be accomplished by forcibly keeping the tail curved back during two or three weeks. For this purpose a cord, one or two feet in length, is affixed to the end of the hair, which terminates in another divided cord, each division going over a pulley on either side of the back of the stall. A weight is hung at either extremity sufficient to keep the incisions properly open, and regulated by the degree in which this is wished to be accomplished. The animal will thus be retained in an uneasy position, although, after the first two or three days, probably not one of acute pain. It is barbarous to increase this uneasiness or pain by affixing too great a weight to the cords; for it should be remembered that the proper elevated curve is given to the tail, not by the weight keeping it in a certain position for a considerable time, but by the depth of the first incisions, and the degree in which the wounds are kept open. By every ounce of weight beyond that which is necessary to keep the incisions apart, unnecessary suffering is inflicted. Some practitioners use only one pulley; others do not use any, but put on a light girth, and tie a cord from the end of the tail to the girth, bending it over the back. The double pulley, however, is the least painful to the horse, and more perfectly secures the proper elevation and straight direction of the tail.

The dock should not-for the first three or four days-be brought higher than the back. Dangerous irritation and inflammation would probably be produced. It may, after that, be gradually raised to an elevation of forty-five degrees. The horse should be taken out of the pulleys, and gently exercised once or twice every day; but the pulleys cannot finally be dispensed with until a fortnight after the wounds have healed, because the process of contraction, or the approach of the divided parts, goes on for some time after the skin is perfect over the incisions, and the tail would thus sink below the desired elevation.

If the tail has not been unnecessarily extended by enormous weights, no bad consequences will usually follow; but if considerable inflammation should ensue, the tail must be taken from the pulley and diligently fomented with simple warm water, and a dose of physic given. Locked-jaw has in some rare instances followed, under which the horse generally perishes. The best means of cure in the early state of this disease is to amputate the tail at the joint above the highest incision. In order to prevent the hair from coming off, it should be unplaited and combed out every fourth or fifth day. 


\section{CHAPTER XIX.}

\section{THE VICES AND DISAGREEABLE OR DANGEROUS HABITS OF THE HORSE.}

THE horse has many excellent qualities, but he has likewise defects, and these occasionally amounting to vices. Some of them may be attributed to natural temper, for the human being scarcely discovers more peculiarities of habit and disposition than does the horse. 'The majority of them, however, as perhaps in the human being, are the consequences of a faulty education. Their early instructor has been ignorant and brutal, and they have become obstinate and vicious.

\section{RESTIVENESS.}

At the head of all the vices of the horse is RESTIVENESS, the most annoying and the most dangerous of all. It is the produce of bad temper and worse education; and, like all other habits founded on nature and stamped by education, it is inveterate. Whether it appears in the form of kicking, or rearing, or plunging, or bolting, or in any way that threatens danger to the rider or the horse, it rarely admits of cure. A determined rider may to a certain extent subjugate the animal; or the horse may have his favourites, or form his attachments, and with some particular person he may be comparatively or perfectly manageable; but others cannot long depend upon him, and even his master is not always sure of him. It is a rule, that admits of very few exceptions, that he neither displays his wisdom nor consults his safety, who attempts to conquer a restive horse.

An excellent veterinary surgeon, and a man of great experience in horses, $\mathrm{Mr}$. Castley, truly said, in "The Veterinarian," - "From whatever cause the vicious habits of horses may originate, whether from some mismanagement or from natural badness of temper, or from what is called in Yorkshire a mistech, whenever these animals acquire one of them, and it becomes in some degree confirmed, they very seldom, if ever, altogether forget it. In reference to driving it is so true, that it may be taken as a kind of aphorism, that if a horse kicks once in harness, no matter from what cause, he will be liable to kick ever afterwards. A good coachman may drive him, it is true, and may make him go, but he cannot make him forget his vice; and so it is in riding. You may conquer a restive horse - you may make him go quiet for months, nay, almost for years together; but I affirm that, under other circumstances, and at some future opportunity, he will be sure to return to his old tricks."

Mr. Castley gives two singular and conclusive instances of the truth of this doctrine. "When a very young man," says he, "I remember purchasing a horse at a fair in the north of England, that was offered very cheap, on account of his being unmanageable. It was said that nobody could ride him. We found that the animal objected to have anything placed upon his back, and that, when made to move forward with nothing more than a saddle on, he instantly threw himself down on his side with great violence, and would then endeavour to roll upon his back.

"There was at that time in Yorkshire, a famous colt-breaker, known by the name of JUMPER, who was almost as celebrated in that country for taming vicious horses into submission, as the famed Wuisperer was in Ireland. We put this animal into Jumper's hands, who took him away, and in about ten dáys brought him home again, certainly not looking worse in condition, but perfectly subdued, and almost as obedient as a dog; for he would lie down at this man's bidding, and only rise again at his command, and carry double or anything. I took to riding him myself, and may say, that I'was never better carried for six or eight months, during which time he did not show the least vice whatever. I then sold him to a Lincolnshire farmer, who said that he would give him a summer's run at grass, and show him as a very fine horse at the great Horncastle fair.

"Happening to meet this gentleman in the following year, I naturally enough inquired after my old friend. 'Ol,' said he, 'that was a bad business - the horse turned out a sad rebel. The first time we attempted to mount him, after getting him 
up from grass, he in an instant threw the inan down witl the greatest violence, pitching him several yards over his head; and after that, he threw every one that attempted to get on his back. If he could not throw his rider, he would throw himself down. We could do nothing with him, and I was obliged at last to sell him to go in a stagecoach.",

In the next story, Jumper's counterpart and superior, the Irish Whisperer, is brouglit on the stage, and although he performed wonders, he could not radically cure a restive horse. "At the Spring Meeting of 1804, Mr. Whalley's King Pippin was brought on the Curragh of Kildare to run. He was a horse of the most extraordinary savage and vicious disposition. His particular propensity was that of fying at and worrying any person who came within his reach; and if he had an opportunity, he would get his head round, seize his rider by the leg with his teeth, and drag him down from his back. For this reason, he was always ridden with what is called a sword; which is a strong flat stick, having one end attached to the cheek of the bridle, and the other to the girth of the saddle, a contrivance to prevent a horse of this kind from getting at his rider.

"King Pippin had long been difficult to manage, and dangerous to go near to; but on the occasion in question, he could not be got out to run at all. Nobody could put the bridle upon his head. It being Easter Monday, and consequently a great holiday, there was a large concourse of people asscmbled at the Curragh, consisting principally of the neighbouring peasantry; and one countryman, more fearless than the rest of the lookers-on, forgetting, or perhaps never dreaming that the better part of courage is discretion, volunteered his services to bridle the horse. No sooner had he committed himself in this operation, than King Pippin seized him somewhere about the shoulders and chest, and, says Mr. Watts (Mr. Castley's informant), 'I know of nothing I can compare it to, so much as a dog shaking a rat.' Fortunately for the poor fellow, his body was very thickly covered with clothes, for on such occasions an Irishman of this class is fond of displaying his wardrobe; and if he has three coats at all in the world, he is sure to put them all on.

"This circumstance, in all probability, saved the individual who had so gallantly volunteered the forlorn hope. His person was so deeply enveloped in extra integuments, that the horse never got fairly hold of his skin, and I understand that he escaped with but little injury, beside the sadly rent and totally ruined state of his holyday toggery.

"The Whisperer was sent for, who, having arrived, was shut up with the horse all night, and in the morning he exhibited this hitherto ferocious animal, following him about the course like a dog-lying down at his command-suffering his mouth to be opened, and any person's hand to be introduced into it-in short, as quiet almost as a sheep.

"He came out the same meeting, and won his race, and his docility continued satisfactory for a considerable time; but at the end of about three ycars his vice returned, and then he is said to have killed a man, for which he was destroyed."

It may not be uninteresting, in this connexion, to give some account of this tamer of quadruped vice. However strange and magical his power may seem to be, there is no doubt of the truth of the account that is given of him. The Rev. Mr. Townsend, in his Statistical Survey of Cork, first introduced him to the notice of the public generally, although his fame had long spread over that part of Ireland. We, loowever, give the following extract from Croker's Fairy Legends and Traditions of Ireland, Part II, p. 200, for his performances seem the work of some elfin sprite, rather than of a rude and ignorant horse-breaker.

"He was an awkward, ignorant rustic of the lowest class, of the name of Sullivan, but better known by the appellation of the Whisperer. His occupation was horsebreaking. The nickname lie acquired from the vulgar notion of his heing able to communicate to the animal what he wished by means of a whisper; and the singularity of his method seemed in some degree to justify the supposition. In lis own neiglibourhood, the notoriety of the fact made it seem less remarkable; but I doubt if any instance of similar subjugating talent is to be found on record. As far as the sphere of his control extended, the boast of reni, vidi, vici, was more justly claimed by Sullivan, than even by Cæsar himself.

"How his art was acquired, and in what it consisted, is likely to be for ever unknown, as he has lately (about 1810) left the world without divulging it. His son, 
who follows the same trade, possesses but a small portion of the art, having either never learned the truc secret, or being incapable of putting it into practice. The wonder of his skill consisted in the celerity of the operation, which was performed in privacy, without any apparent means of coercion. Every description of horse, or cven inule, whether previously broken or unhandled, whatever their peculiar habits or vices might have been, submitted without show of resistance to the magical influence of his art, and in the short space of half an hour became gentle and tractable. 'This effect, though instantaneously produced, was generally durable. Though more submissive to him than to others, the animals seemed to have acquired a docility unknown before.

"When sent for to tame a vicious beast, for which he was either paid according to the distance, or generally two or three guineas, he directed the stable, in which he and the object of the experiment wcre, to be shut, with orders not to open the door until a signal was given. After a tête-à-lête of about half an hour, during which little or no bustle was heard, the signal was made, and, upon opening the door, the horse appeared lying down, and the man by his side, playing with him like a child with a puppy dog. From that time, he was found perfectly willing to submit to any discipline - however repugnant to his nature before. I once," continues Mr. Croker, "saw his skill tried on a horse, which could never before be brought to stand for a smith to shoe him. 'The day after Sullivan's half-hour's lecture, I went, not without some incredulity, to the smith's shop, with many other curious spectators, where we wcre eye-witnesses of the complete success of his art. This, too, had been a troophorse, and it was supposed, not without reason, that after regimental discipline had failed, no other would be found availing. I observed that the animal appeared terrified whenever Sullivan either spoke to, or looked at him ; how that extraordinary ascendency could have been obtained, is difficult to conjecture.

"In common cases this mysterious preparation was unnecessary. He seemed to possess an instinctive power of inspiring awe, the result, perhaps, of natural intrepidity, in which, I believe, a great part of his art consisted; though the circumstance of the lête-à-lête shows that, on particular occasions, something more must have been added to it. A faculty like this would, in some hands, have made a fortune, and I understand that great offers were made to him, for the exercise of his art abroad. But hunting was his passion. He lived at home in the style most agreeable to his disposition, and nothing could induce him to quit Duhallow and the fox-hounds."

Mr. Castley witnessed the total failure of the younger Sullivan. He says, "we have in the rcginent a remarkably nice horse, called Lancer, that has always been very difficult to shoe, but seven or eight years ago, when we first got him, he was downright vicious in that respect. When the regiment was stationed at Cork, the farrier-major sought out the present Sullivan, the son of the celebrated Whisperer, and brought him up to the barracks in order to try his hand upon Lancer, and make him more peaceable to shoe; but I must say this person did not appear to possess any particular controlling power over the animal more than any other man. Lancer seemed to pay no attention whatever to his charm, and at last fairly beat him out of the forge. Time, however, and a long perseverance in kind and gentle treatment, hava effected what force could not. The horse is now pretty reasonable to shoe."*

* An account, bcaring considerable resemblance to the feats of the English horse-tamcr, has been lately laid before the public.

Mr. Catlin has published an account, the veracity of which is unimpeached, of his travels among the North American Indians. He thus describes the manner in which the Indian tames the wild horse. "He coils his lasso on his arm, and gallops fearlessly into the herd of wild horses. He soon gets it over the neck of one of the number, when he instantly dismounts, leaving his own horse, and runs as $f \rightarrow t$ as he can, letting the lasso pass out gradually and carefully through his hands, until the horse falls for want of breath, and lies helpless on the ground. The Indian advances slowly towards the horse's head, keeping the lasso tight upon his ncck, until he fastens a pair of hobbles on the animal's two fore feet, and also loosens the lasso, giving the horse a chance to breathe, and passing a noosc round the under jaw, by which he gets grcat power over the affighted animal, that is rearing and plunging when it gcts breath, and by which, as he advances, hand over hand, towards the horse's nosc, he is able to hold it down, and prevent it from throwing itself over on its back. By this means he gradu. ally advances, until he is able to place his hand on the animal's nose and over its eyes, and at length, to breathe into its nostrils, when it soon becomes docile and conquered; so that he has little clse to do than to remove the hobbles from its feet, and lead or ride it to the camp. 


\section{BACKING OR GIBBING.}

One of the first kinds of restiveness, taking them in alphabetical order, is backing or gibbing. These are so closely allied that we hardly know how to separate them. Some horses have the habit of backing at first starting, and that more from playfulness than desire of mischief. A moderate application of the whip will usually be effectual. Others, even after starting, exhibit considerable obstinacy and viciousness. This is frequently the effect of bad breaking. Either the shoulder of the horse had been wrung when he was first put to the collar, or he had been foolishly accustomed to be started in the break up-hill, and, therefore, all his work coming upon him at once, he gradually aequired this dangerous habit.

A hasty and passionate breaker will often make a really good-tempered young horse an inveterate gibber. Every young horse is at first shy of the collar. If he is too quickly forced to throw his weight into it, he will possibly take a dislike to it, that will occasionally show itself in the form of gibbing as long as he lives. The judicious horse-breaker will resort to no severity, even if the colt should go out several times without even touching collar. The example of his companion will ultimately induce him to take to it voluntarily and effectually.

A large and heavy stone should be put behind the wheel before starting, when the horse finding it more difficult to back than to go forward, will gradually forget this unpleasant trick. It will likewise be of advantage, as often as it can be managed, so to start that the horse shall have to back up-hill. The difficulty of accomplishing this will soon make him readily go forward. A little coaxing, or leading, or moderate flagellation, will assist in accomplishing the cure.

When, however, a horse, thinking he has had enough of work, or has been improperly checked or corrected, or beginning to feel the painful pressure of the collar, swerves, and gibs, and backs, it is a more serious matter. Persuasion should first be

The animal is so completely conquered, that it submits quietly ever after, and is led or rode away with very little difficulty."

Mr. Ellis, B. A., of Trinity College, Cambridge, happened to read this account, and he felt a natural desire to ascertain how far this mode of HORSE-TAMING might be employed among British horses. He soon had the opportunity of putting the veracity of the story to the test. His brother-in-law had a filly, not yet a year old, that had been removed from her dam three months before, and since that time-had not been taken out of the stable. A great amateur in everything relating to horses was present, and at his request it was determined that the experiment of the efficacy of breathing into the nostrils should be immediately put to the test. The filly was brought, the amateur leading her by the halter. She was quite wild, and bolted, and dragged the amateur a considerable distance. He had been using a short lalter; he changed it for a longer one, and was then able to lead the little scared thing to the front of the house. The experiment was tried under manifest disadvantage, for the filly was in the open air, several strangers were about her, and both the owner and the amateur were rather seeking amusement from the failure than knowledge from the success of their experiment.

The filly was restive and frightened, and with great difficulty the amateur managed to cover her eyes. At length he succeeded, and blew into the nostrils. No particular effect seemed to follow. He then breathed into her nostrils, and the moment he did so, the filly, who had very much resisted having her eyes blindfolded, and had been very restive, stood perfectly still and trembled. From that time she became very tractable. Another gentleman also treathed into her nostrils, and she evidently enjoyed it, and kept putting up her nose to receive the breath.

On the following morning she was led out again. She was perfectly tractable, and it seemed to be almost impossible to frighten her.

A circumstance which, in a great measure corroborated the possibility of easily taming the most ferocious horses, occurrcd on the next day. A man, on a neighbouring farm, was attempting to break-in a very restive colt, who foilcd him in every possible way. After several manouvres the amateur succeeded in breathing into one of the nostrils, and from that moment all became easy. The horse was completely subdued. He suffered himself to be led quietly away with a loose halter, and was perfectly at command. He was led through a field in which were four horses that had been his companions. They all surrounded him ; he took no notice of them, but quietly followed his new master. A surcingle was bucklcd on him, and then a saddle, and he was finally fitted with a bridle. The whole experiment occupied about an hour, and not in a single instance did he rebel.

On the next day, however, the breaker, a severe and obstinate fellow, took him in hand, and, according to his usual custom, began to beat him most cruelly. The horse broke from him, and became as unmanageable as ever. The spirit of the animal had been subdued but
not broken. 
tried; and, afterwards, reasonable coercion, but no cruelty : for the brutality which is often exercised in attempting to compel a gibbing horse to throw himself habitually into the collar, never yet accomplished the purpose. The horse may, perhaps, be whipped into motion; but if he has once begun to gib, he will have recourse to it again whenever any circumstance displeases or annoys him, and the habit will be so rapidly and completely formed, that he will become insensible to all severity.

It is useless and dangerous to contend with a horse determined to back, unless there is plenty of room, and, by tight reining, the driver can make him back in the precise direction he wishes, and especially up-hill. Such a horse should be inmediately sold, or turned over to some other work. In a stage-coach as a wheeler, and particularly as the near-wheeler; or, in the middle of a team at agricultural work, he may be serviceable. It will be useless for him to attempt to gib there, for he will be dragged along by his companions whether he will or not; and, finding the inutility of resistance, he will soon be induced to work as well as any horse in the team. The reformation will last while he is thus employed, but, like restiveness generally, it will be delusive when the horse returns to his former occupation. 'The disposition to annoy will very soon follow the power to do it. Some instances of complete reformation may have occurred, but they are rare.

When a horse, not often accustomed to gib, betrays a reluctance to work, or a determination not to work, common sense and humanity will demand that some consideration should be taken before measures of severity are resorted to. The horse may be taxed beyond his power. He soon discovers whether this is the case, and by refusing to proceed, tells his driver that it is so. The utmost cruelty will not induce many horses to make the slightest effort, when they are conscious that their strength is inadequate to the task. Sometimes the withers are wrung, and the shoulders sadly galled, and the pain, which is intense on level ground and with fair draught, becomes insupportable when he tugs up a steep acclivity. 'These things should be examined into, and, if possible, rectified; for, under such circumstances, cruelty may produce obstinacy and vice, but not willing obedience.

They who are accustomed to horses know what seemingly trivial circumstances occasionally produce this vice. A horse, whose shoulders are raw, or have frequently been so, will not start with a cold collar. When the collar has acquired the warmth of the parts on which it presses, the animal will go without reluctance. Some determined gibbers have been reformed by constantly wearing a false collar, or strip of cloth round the shoulders, so that the coldness of the usual collar should never be felt; and others have been cured of gibbing by keeping the collar on night and day, for the animal is not able to lie down completely at full length, which the tired horse is always glad to do. When a horse gibs, not at starting, but while doing his work, it has sometimes been useful to line the collar with cloth instead of leather; the perspiration is readily absorbed, the substance which presses on the shoulders is softer, and it may be far more accurately eased off at a tender place.

\section{BITING.}

This is either the consequence of natural ferocity, or a habit acquired from the foolish and teasing play of grooms and stable-boys. When a horse is tickled and pinched by thoughtless and mischievous youths, he will first pretend to bite his torinentors; by degrees he will proceed farther, and actually bite them, and very soon after that, he will be the first to challenge to the combat, and, without provocation, seize some opportunity to gripe the incautious tormentor. At length, as the love of mischief is a propensity too easily acquired, this war, half playful and half in earnest, becomes habitual to him, and degenerates into absolute viciousness.

It is not possible to enter the stall of some horses without danger. The animal gives no warning of his intention; he is seemingly quiet and harmless : but if the incautious by-stander comes fairly within his reach, le darts upon him, and seldom fails to do some mischief. A stallion addicted to biting is a most formidable creature. He lifts the intruder - he shakes him - he attacks him with his feet - he tramples upon him, and there are many instances in which he effects irreparable mischief. A resolute groom may escape. When he has once got firm hold of the head of the horse, he may back him, or muzzle him, or harness him; 
but he must be always on his guard, or in a moment of carelessness he may be seriously injured.

It is seldom that anything can be done in the way of cure. Kindness will aggravate the evil, and no degree of severity will correct it. "I have seen," says Professor Stewart, "biters punished until they trembled in every joint, and were ready to drop, but have never in any case known them cured by this treatment, or by any other. The lash is forgotten in an hour, and the horse is as ready and determined to repeat the offence as before. He appears unable to resist the temptation, and in its worst form biting is a species of insanity."*

Prevention, however, is in the power of every proprietor of horses. While he insists on gentle and humane treatment of his cattle, he should systematically forbid this horse-play. It is that which can never be considered as operating as a reward, and thereby rendering the horse tractable; nor does it increase the affection of the animal for his groom, because he is annoyed and irritated by being thus incessantly teased.

\section{GETTING THE CHEEK OF THE BIT INTO THE MOUTH.}

Some horses that are disposed to be mischievous try to do this, and are very expert at it. They soon find what advantage it gives them over their driver, who by this manœuvre loses almost all command. Harsh treatment is here completely out of the question. All that can be done is, by some mechanical contrivance, to render the thing difficult or impossible, and this may be managed by fastening a round piece of leather on the inside of the cheek of the bit.

\section{KICKING.}

This, as a vice, is another consequence of the culpable habit of grooms and stableboys of teasing the horse. That which is at first an indication of annoyance at the pinching and tickling of the groom, and without any design to injure, gradually becomes the expression of anger, and the effort to do mischief. The horse likewise too soon recognises the least appearance of timidity, and takes advantage of the discovery. There is no cure for this vice; and he cannot be justified who keeps a kicking horse in his stable.

Some horses acquire, from mere irritability and fidgetiness, a habit of kicking at the stall or the bail, and particularly at night. The neighbouring horses are disturbed, and the kicker gets swelled hocks, or some more serious injury.. This is also a habit very difficult to correct if suffered to become established. Mares are far more subject to it than horses.

Before the habit is inveterately established, a thorn bush or a piece of furze fastened against the partition or post will sometimes effect a cure. When the horse finds that he is pretty severely pricked, he will not long continue to punish himself. In confirmed cases it may be necessary to have recourse to the log, but the legs are often not a little bruised by it. A rather long and heavy piece of wood attached to a chain has been buckled above the hock, so as to reach about half-way down the leg. When the horse attempts to kick violently, his leg will receive a severe blow: this, and the repetition of it, may, after a time, teach him to be quiet.

A much more serious vice is kicking in harness. From the least annoyance about the rump or quarters, some horses will kick at a most violent rate, and destroy the bottom of the chaise, and endanger the limbs of the driver. Those that are fidgety in the stable are most apt to do this. If the reins should perchance get under the tail, the violence of the kicker will often be most outrageous ; and while the animal presses down his tail so tightly that it is almost impossible to extricate the reins, he continues to plunge until he has demolished everything behind him.

This is a vice standing foremost in point of danger, and which no treatment will always conquer. It will be altogether in vain to try coercion. If the shafts are very strong and without flaw, or if they are plated with iron underneath, and a stout kicking-strap resorted to which will barely allow the horse the proper use of his hind limbs in progression, but not permit him to raise them sufficiently for the purpose of kicking, he may be prevented from doing mischief; or if he is harnessed to a heavy cart, and thus confined, his efforts to lash out will be restrained: but it is frequently 
a very unpleasant thing to witness these attempts, though ineffectual, to demolish the vehicle, for the shafts or the kicking-strap may possibly break, and extreme danger may ensue. A horse that has once begun to kiek, whatever may have been the original eause of it, ean never be depended upon again, and he will be very unwise who ventures behind him. The man, however, who must eome within reach of a kicker should eome as close to him as possible. The blow may thus beeome a push, and seldom is injurious.

\section{UNSTEADINESS WHILE BEING MOUNTED.}

When this merely amounts to eagerness to start-very unpleasant, indeed, at times, for many a rider has been thrown from his seat before he was fairly fixed in it - it may be remedied by an active and good horseman. We have known many instances in which, while the elderly, and inactive, and fearful man has been making more than one ineffeetual attempt to vault into the saddle, the horse has been dancing about to his annoyanee and danger; but the animal had no sooner been transferred to the management of a younger and more agile rider than he became perfectly subdued. Severity will here, more decidedly than in any other ease, do harm. The rider should be fearless - he should carelessly and confidently approach the horse, mount at the first effort, and then restrain him for a while; patting him, and not suffering him to proeeed until he becomes perfectly quiet. Horses of this kind should not he too highly fed, and should have sufficient daily exereise.

When the difficulty of mounting arises, not from eagerness to start, but unwillingness to be ridden, the sooner that horse is disposed of the better. He may be conquered by a skilful and determined horseman; but even he will not succeed without frequent and dangerous contests that will mar all the pleasure of the ride.

\section{REARING.}

This sometimes results from playfulness, earried, indeed, to an unpleasant and langerous extent; but it is oftener a desperate and occasionally successful effort to unhorse the rider, and consequently a vice. The horse that has twice decidedly and dangerously reared, should never be trusted again, unless, indeed, it was the fault of the rider, who had been using a deep eurb and a sharp bit. Some of the best horses will eontend against these, and then rearing may be immediately and permanently cured by using a snaffle-bridle alone.

The horse-breaker's remedy, that of pulling the horse backward on a soft piece of ground, should be practised hy reckless and brutal fellows alone. Many horses have been injured in the spine, and others have broken their neeks, by being thus suddenly pulled over; while even the fellow, who fears no danger, is not always able to extricate himself from the falling horse. If rearing proceeds from vice, and is unprovoked by the bruising and laceration of the mouth, it fully partakes of the inveteracy which attends the other divisions of restiveness.

\section{RUNNING AWAY.}

Some headstrong horses will occasionally endeavour to bolt with the best rider. Others with their wonted sagacity endeavour thus to dislodge the timid or unskilful nne. Some aro hard to hold, or bolt only during the excitement of the chase; others will run away, prompted by a vicious propensity alone. There is no certain cure here. The method which affords any probability of success is, to ride such a horse with a strong curb and sharp bit; to have him always firmly in hand; and, if he will run away, and the place will admit of it, to give him (sparing neither curb, whip, nor spur) a great deal more running than he likes.

\section{VICIOUS TO CLEAN.}

It would searcely be eredited to what an extent this exists in some horses that are otherwise perfectly quiet. It is only at great hazard that they can be cleaned at all. 'The origin of this is probably some maltreatment. There is, however, a great differc nce in the sensibility of the skin in different horses. Some seem as if they could searcely be made to feel the whip, while others cannot bear a fly to alight on them without an expression of annoyance. In young horses the skin is peculiarly delicate. If they have been eurricd with a broken comb, or hardly rubbed with an uneven brush, 
the recollection of the torture they have felt makes them impatient, and even vicious, luring every succeeding operation of the kind. Many grooms, likewise, seem to delight in producing these exhibitions of uneasiness and vice; although, when they are carried a little too far, and at the hazard of the limbs of the groom, the animals that have been almost tutored into these expressions of irritation are brutally kicked and punished.

This, howcver, is a vice that may be conquered. If the horse is dressed with a lighter hand, and wisped rather than brushed, and the places where the skin is most sensitive are avoided as much as thorough cleanliness will allow, he will gradually lose the recollection of former ill-treatment, and become tractable and quiet.

\section{VICIOUS TO SHOE.}

The correction of this is more peculiarly the business of the smith; yet the master should diligently concern himself with it, for it is oftener the consequence of injudicious or bad usage than of natural vicc. It may be expected that there will be some difficulty in shoeing a horse for the first few times. It is an operation that gives him a little uneasiness.-The man to whom he is most accustomed should go with him to the forge; and if another and steady horse is shod before him, he may be induced more readily to submit. It cannot be denied that, after the habit of resisting this necessary operation is formed, force may sometimes be necessary to reduce our rebellious servant to obedience; but we unhesitatingly affirm that the majority of horses vicious to shoe are rendered so by harsh usage, and by the pain of correction being added to the uneasiness of shoeing. It should be a rule in every forge that no sinith should be permitted to strike a horse, much less to twitch or to gag him, without the master-farrier's order; and that a young horse should never be twitched or struck. There are few horses that may not be gradually rendered manageable for this purpose by mildness and firmness in the operator. They will soon understand that no harm is meant, and they will not forget their usual habit of obedience ; but if the rcmembrance of corporal punishment is connected with shoeing, they will always be fidgety, and occasionally dangerous.

This is a very serious vice, for it not only exposcs the animal to occasional severe injury from his own struggles, but also from the correction of the irritated smith, whose limbs and whose life being in jeopardy, may be forgiven if he is sometimes a little too hard-handed. Such a horse is very liable, and without any fault of the smith, to be pricked and lamed in shoeing; and if the habit should be confirmed, and should increase, and it at length becomes necessary to cast him, or to put him in the trevis, the owner may be assured that many years will not pass ere some formidable or fatal accident will take place. If, therefore, mild treatment will not correct this vice, the horse cannot be too soon got rid of.

Horses have many unpleasant habits in the stable and on the road, which cannot be said to amount to vice, but which materially lessen their value.

\section{SWALLOWING WITHOUT GRINDING.}

Some grcedy horses habitually swallow their corn without properly grinding it, and the power of digestion not being adequate to the dissolving of the husk, no nutrimont is extracted, and the oats are voided whole. This is particularly the case when horses of unequal appetite feed from the same manger. The greedy onc, in his eagerness to get more than his share, bolts a portion of his corn whole. If the farmer, without considerable inconvenience, could contrive that cvery horse shall have his separate division of the manger, the one of smaller appetite and slower feed would have the opportunity of grinding at his leisure, without the fcar of the greater share
being stolen by his neighbour.

Some horses, however, are naturally grecdy feeders, and will not, even when alone, allow themselves time to chew or grind thcir corn. In consequence of this they carry but little flesh, and are not equal to severe work. If the rack was supplied with hay when the corn was put into the manger, they will continue to eat on, and their stomachs will become disterided with half-chewed and indigestible food. In consequence of this they will be incapable of considerable exertion for a long time aftcr fceding.

The remedy is, not to let such liorses fast too long. 'The nose-bang should be the companion of every considerable journey. 'The food should likewise be of such a 
nature that it cannot be rapidly bolted. Chaff should be plentifully mixed with the corn, and, in some cases, and especially in horses of slow work, it should, with the corn, constitute the whole of the food. This will be treated on more at large under the article "Feeding."

In every case of this kind the teeth should be carefully examined. Some of them may be unduly lengthened, particularly the first of the grinders: or they may be ragged at the edges, and may abrade and wound the cheek. In the first place the horse cannot properly masticate his food; in the latter he will not; for these animals, as too often happens in sore throat, would rather starve than put themselves to much pain.

\section{CRIB-BITING.}

This is a very unpleasant habit, and a considerable defect, although not so serious a one as some have represented. The horse lays hold of the manger with his teeth, violently extends his neck, and then, after some convulsive action of the throat, a slight grunting is heard, accompanied by a sucking or drawing in of air. It is not an effort at simple eructation, arising from indigestion. It is the inhalation of air. It is that which takes place with all kinds of diet, and when the stomach is empty as well as when it is full.

The effects of crib-biting are plain enough. The teeth are injured and worn away, and that, in an old horse, to a very serious degree. A considerable quantity of corn is often lost, for the horse will frequently crib with his mouth full of it, and the greater part will fall over the edge of the manger. Much saliva escapes while the manger is thus forcibly held, the loss of which must be of serious detriment in impairing the digestion. The crib-biting horse is notoriously more subject to colic than other horses, and to a species difficult of treatment and frequently dangerous. Although mary a crib-biter is stout and strong, and capable of all ordinary work, these horses do not generally carry so much flesh as others, and have not their endurance. On these accounts crib-biting has very properly been decided to be unsoundness. We must not look to the state of the disease at the time of purchase. The question is, does it exist at all ? A case was tried before Lord Tenterden, and thus decided: "a horse with crib-biting is unsound."

It is one of those tricks which are exceedingly contagious. Every companion of a crib-biter in the same stables is likely to acquire the habit, and it is the most inveterate of all habits. The edge of the manger will in vain be lined with iron, or with sheep-skin, or with sheep-skin covered with tar or aloes, or any otlier unpleasant substance. In defiance of the annoyance which these may occasion, the horse will persist in the attack on his manger. A strap buckled tightly round the neck, by compressing the wind-pipe, is the best means of preventing the possibility of this trick; but the strap must be constantly worn, and its pressure is too apt to produce a worse affection, viz. an irritation in the windpipe, which terminates in roaring.

Some have recommended turning out for five or six months; but this has never succeeded except with a young horse, and then rarely. The old crib-biter will employ the gate for the same purpose as the edge of his manger, and we have often seen him galloping across a field for the mere object of having a gripe at a rail. Medicine will be altogether thrown away in this case.

The only remedy is a muzzle, with bars across the bottom; sufficiently wide to cnable the animal to pick up his corn and to pull his hay, but not to grasp the edge of the manger. If this is worn for a considerable period, the horse may be tired of attempting that which he cannot accomplish, and for a while forget the habit, but, in a majority of cases, the desire of crib-biting will return with the power of gratifying it.

The causes of crib-biting are various, and some of them beyond the control of the proprietor of the horse. It is often the result of imitation; but it is more frequently the consequence of idleness. The high-fed and spirited horse must be in mischief if he is not usefully employed. Sometimes, but we believe not often, it is produced by partial starvation, whether in a bad straw-yard, or from unpalatable food. An occasional calse of crib-biting is the frequent custom of grooms, even when the weather is not severe, of dressing them in the stable. The horse either catches at the edge of the manger, or at that of the partition on each side, if he has been turned, and thus he forms the habit of laying hold of these substances on every occasion. 


\section{WIND.SUCKING.}

This bears a close analogy to crib-biting. It arises from the same causes; the same purpose is accomplished; and the same results follow. The horse stands with his neck bent; his head drawn inward; his lips alternately a little opened and then closed, and a noise is heard as if he were sucking. If we may judge from the same comparative want of condition and the flatulence which we have described under the last head, either some portion of wind enters the stomach, or there is an injurious loss of saliva. This diminishes the value of the horse almost as much as crib-biting; it is as contagious, and it is as inveterate. The only remedies, and they will seldom avail, are tying the head up, except when the horse is feeding, or putting on a muzzle with sharp spikes towards the neck, and which will prick him whenever he attempts to rein his head in for the purpose of wind-sucking.

\section{CUTTING.}

Of this habit, mention has been made at page 275 ; and we would advise the owner of a cutting horse, without trying any previous experiments of raising or lowering the heels, to put on the cutting foot a shoe of even thickness from heel to toe, not projecting in the slightest degree beyond the crust, and the crust itself being rasped a little at the quarters. The shoe should be fastened as usual, on the outside, but with only one nail on the inside, and that almost close to the toe. The principle on which this shoe acts, has been explained at page 339 .

\section{NOT LYING DOWN.}

It not uncommonly happens that a horse will seldom or never lie down in the stable. He sometimes continues in apparent good health, and feeds and works well; but generally his legs swell, or he becomes fatigued sooner than another horse. If it is impossible to let him loose in the saddle, or to put him into a spare box, we linow not what is to be done. No means, gentle or cruel, will force him to lie down. 'The secret is that he is tied up, and either has never dared to lie down through fear of the confinement of the halter, or he has been cast in the night, and severely injured. If he can be suffered to range the stable, or have a comfortable box, in which he may be loose, he will usually lie down the first night. Some few horses, however, will lie down in the stable, and not in a loose box. A fresh, well-made bed will generally tempt the tired horse to refresh himself with sleep.

\section{OVERREACH.}

This unpleasant noise, known also by the term "clicking," arises from the toe of the hind foot knocking against the shoe of the fore foot. In the trot, one fore leg and the opposite hind leg are first lifted from the ground and moved forward, the other fore leg and the opposite hind leg remaining fixed; but, to keep the centre of gravity within the base, and as the stride, or space passed over by these legs, is often greater than the distance between the fore and hind feet, it is necessary that the fore feet should be alternately moved out of the way for the hind ones to descend. Then, as occasionally happens with horses not perfectly broken, and that have not been taught their paces, and especially if they have high hinder quarters and low fore ones, if the fore feet are not raised in time, the hind feet will strike them. 'The fore foot will generally be caught when it has just begun to be raised, and the toe of the hind foot will meet the middle of the bottom of the fore foot. It is an unpleasant noise, and not altogether free from danger; for it may so happen that a horse, the action of whose feet generally so much interferes with each other, may advance the hind foot a little more rapidly, or raise the fore one a little more slowly, so that the blow may fall on the heel of the shoe, and loosen or displace it; or the two shoes may be locked together, and the animal may be thrown; or the contusion may be received even higher, and on the tendons of the leg, and considerable swelling and lameness will follow.

If the animal is young, the action of the horse may be inaterially improved; otherwise nothing can be done, except to keep the toe of the hind foot as short and as round as it can safely be, and to bevel off and round the toe of the shoe, like tha? 
which has been worn by a stumbler for a fortnight, and, perhaps, a little to lower the heel of the fore foot.

A blow received on the heel of the fore foot in this manner, has not unfrequently, and especially if neglected, been followed by quittor.*

'The heel most frequently suffers in overreaching, although the pastern is sometimes injured. It usually, or almost always, occurs in fast paces on deep ground. The injury is inflicted by the edge of the inner part of the shoe. The remedy is the cutting away the edge of the shoe. An account of the most successful treatment of overreach has been given in page 312 .

\section{PAWING.}

Some hot and irritable horses are restless even in the stable, and paw frequently and violently. Their litter is destroyed, the floor of the stable broken up, the shoes worn out, the feet bruised, and the legs sometimes sprained. If this habit does not exist to any great extent, yet the stable never looks well. Shackles are the only remedy, with a chain sufficiently long to enable the horse to shift his posture, or more in his stall; but these must be taken off at night, otherwise the animal will seldom lie down. Except, however, the horse possesses peculiar value, it will be better to dispose of him at once, than to submit to the danger and inconvenience that he may occasion.

\section{QUIDDING.}

A horse will sometimes partly chew his hay, and suffer it to drop from his mouth. If this does not proceed from irregular teeth, which it will be the business of the veterinary surgeon to rasp down, it will be found to be connected with sore-throat, and then the horse will exhibit some other symptom of indisposition, and particularly, the swallowing of water will be accompanied by a peculiar gulping effort. In this case, the disease (catarrh, with sore-throat) must be attacked, and the quidding will cease.

\section{ROLLING.}

This is a very pleasant and perfectly safe amusement for a horse at grass, but cannot be indulged in the stable without the chance of his being dangerously entangled with the collar rein, and being cast. Yet, although the horse is cast, and bruised, and half-strangled, he will roll again on the following night, and continue to do so as long as he lives. The only remedy is not a very pleasant one to the horse, nor always quite safe; yet it must be had recourse to, if the habit of rolling is inveterate. "'The horse," says Mr. Castley, "should be tied with length enough of collar to lie down, but not to allow of his head resting on the ground; becanse, in order to roll over, a horse is obliged to place his head quite down upon the ground."

\section{SHYING.}

We have briefly treated of the cause of this vice at page 91 , and observed that while it is often the result of cowardice, or playfulness, or want of work, it is at

* Mr. Simpson relates an interesting though unfortunate case of this interference, after the operation of neurotomy :- "An old but splendid horse had been sadly lame in the off forefoot during some months. Many plans of treatment were adopted, without the desired effect; and at length it was determined to have reconrse to neurotomy. A portion of the metacarpal nerve was excised on both sides, just above the fetlock. Three weeks afterwards, the horse being quite free from lameness, he was put into harness, and driven about twelve miles. $\mathrm{He}$ appeared to go very well, but, on arriving at his journey's end, it was found that the off hindfoot was covered with blood, and the heels of the neurotomised foot were dreadfully bruised and cut, from repeated blows from the corresponding foot behind. In order to remedy this, the toc of the hind-foot was ordered to be shortened as much as possible.

"Four days afterwards, he was driven again with the same contusions, but did not appear to fccl lhe slightest pain, either when the blows were inflicted, or when he was examined again some day's afterwards.

"There was not the same activity in this foot that there had been before the operation, and it could not get out of the way of the hind-foot, a circumstance that would hardly have been expected, for it is the general belief that, although sensation is destroyed in the foot, the locomotive powers of the leg are unimpaired. This deserves future inquiry." - The Veterinarian, vol. viii. p. 242. 
other times the consequence of a defect of sight. It has been remarked, and we believe very truly, that shying is oftener a vice of half or quarter-bred horses, than of those who have in them more of the genuine racing blood.

In the treatment of shying, it is of great importance to distinguish between that which is the consequence of defective sight, and what results from fear, or newness of objects, or mere affectation or skittishness. For the first, the nature of which we have explained at page 91 , every allowance must be made, and care must be taken that the fear of correction is not associated with the imagined existence of some terrifying object. The severe use of the whip and the spur cannot do good here, and are likely to aggravate the vice tenfold. A word half encouraging and half scolding, with a gentle pressure of the heel, or a slight touch of the spur, will tell the horse that there was nothing to fear, and will give him confidence in his rider on a future occasion. It should be remembered, however, that although a horse that shies from defective sight may be taught considerable reliance on his rider, he can never have the cause of the habit removed. We may artificially strengthen the human sight, but that of the horse must be left to itself.

The shying from skittishness or affectation is quite a different affair, and must be conquered: but how? Severity is altogether out of place. If he is forced into contact with the object by dint of correction, the dread of punishment will afterwards be associated with that object, and, on the next occasion, his startings will be more frequent and more dangerous. The way to cure him is to go on, turning as little as possible out of the road, giving a harsh word or two, and a gentle touch with the spur, and then taking no more notice of the matter. After a few times, whatever may have been the object which he chose to select as the pretended cause of affight, he will pass it almost without notice.

In page 253, under the head "breaking in," we described how the colt may be cured of the habit of shying from fear or newness of objects; and, if he then is accustomed as much as possible to the objects among which his services will be required, he will not possess this annoying vice when he grows to maturer age.

Mr. John Lawrence, in his last work on the Horse, says, "These animals generally fix on some particular shying butt: for example, I recollect having, at different periods, three hacks, all very powerful; the one made choice of a wind-mill for the object or butt, the other a tilted wagon, and the last a pig led in a string. It so happened, however, that I rode the two former when amiss from a violent cold, and they then paid no more attention to either wind-mills or tilted wagons than to any other objects, convincing me that their shying when in health and spirits was pure affectation; an affectation, however, which may be speedily united with obstinacy and vice. Let it be treated with marked displeasure, mingled with gentle, but decided firmness, and the habit will be of short endurance."

It is now generally admitter by all riding-masters and colt-breakers, that a great deal more is to be effected by lenient than by harsh treatment. Rewards are found to operate more beneficially than punishments; and therefore the most scientific and practised riding-masters adopt methods based upon the former. The writer of the present work remembers a very remarkable instance of the efficacy of this plan, or rather of its vast and decided superiority over violence of the worst description. A

* "We will suppose a case-a very common one, an every-day one. A man is riding a young horse upon the high-road in the country, and meets a stage-coach. What with the noise, the bustle, the imposing appearance altogether, and the slashing of the coachman's whip, the animal at its approach erects its head and crest, pricks his ears, looks affighted, and no sooner comes alongside of the machine than he suddenly starts out of the road. His rider, annoyed by this, instantly commences a round of castigation with whip, spur, and curb, in which he persists until the horse, as well as himself, has lost his temper; and then one whips, spurs, and pulls, and the other jumps, plunges, frets, and throws up his head, until both, pretty well exhausted by the conflict, grow tranquil again and proceed on their journey, though not for some time afterwards in their former mutual confidence and satisfaction. Should they in their road, or even on a distant day, meet with another coach, what is the consequence? The horse is not only more alarmed than before, but now, the moment he has started, being conscious of his fault and expecting chastisement, he jumps about in fearful agitation, making plunges to strike into a gallop, and attempting to run away. So that by this correction, instead of rendering his horse tranquil during the passage of a coach, the rider adds to thc evil of shying that of subsequently plunging, ard perhaps running away." - Tha

Veterinarian, vol. i., p. 96. 
vicious, thorough-bred horse had baffled the efforts of every one into whose hands he had been put in order to be rendered tractable : at length a foreigner of considerable repute among the equestrians of the "school," took him to make trial of; and in the course of a twelvemonth had rendered him so quiet that not only could any person ride him with the utmost safety, but, at the same time he was so docile and tractable that he could be induced, by certain signs, to lie down and permit his rider to mount before he arose again.

'The same forbearance and humanity have been practised with the same beneficial results upon shy horses. With all such persons as are best able to give counsel in cases of shyness, the language is now-a-days, "let the horse alone"- " take no notice of his shyness"- "work him well and accustom him to the objects he dislikes, and in time he will of himself leave off his trick of shying."

This is good advice; but, let it not be misinterpreted. Let it not be understood to mean that the animal is to receive any encouragement to shy; for by no other expression can be characterised that erroneous and foolish practice of patting the horse, or "making much of him," either just before or during the time he evinces shymess. The former is bad, because it draws the attention of the animal to the object he dreads; the latter is worse, because it fills him with the impression either that the object itself is really terrific, or that he has acted right in shying at it, and ought to do so again.

Whcther we are approaching the frightful object, or the horse is actually shying, "we should let him alone"- "we should take no notice whatever of him"-neither letting him perceive that we are aware that we are advancing towards anything he dislikes; nor do more with him, while in the act of shying, than is necessary for due restraint with a steady hand upon the rein. We may depend upon it, that battling on our part will only serve to augment affright and arouse resistance on his, and that the most judicious course we can pursue is to persevere in mild forbearant usage.

Shying on coming out of the stable is a habit that can rarely or never be cured. It proceeds from the remembrance of some ill-usage or hurt which the animal has received in the act of proceeding from the stable, such as striking his head against a low doorway, or entangling the harness. Coercion will but associate greater fear and more determined resistance with the old recollection. Mr. Castley gives an interesting anecdote, which tends to prove that while severity will be worse than useless, even kind treatment will not always break a confirmed habit. "I remember a very fine grey mare that had got into this habit, and never could be persuaded to go through a doorway without taking an immense jump. 'To avoid this, the servants used to back her in and out the stable; but the mare happening to meet with a severe injury of the spine, was no longer able to back; and then I have seen the poor creature, when brought to the door, endeavouring to balance herself, with a staggering motion, upon her half-paralysed hind extremities, as if making preparation and summoning up resolution for some great effort; and then, when urged, she would plunge headlong forward with snch violence of exertion, as often to lose her feet, and tumble down, altogether most pitiable to be seen. "This I merely mention," he continues, "as one proof how inveterate the habits of horses are. They are evils, let it always be remembered, more easy to prevent than to cure."

When the cure, however, is early attempted, it may be so far overcome that it will be unattended with danger or difficulty. The horse should be bridled when led out or in. He should be held short and tight by the head that he may feel he has not liberty to make a leap, and this of itself is often sufficient to restrain him. Punishinent, or a threat of punishment, will be highly improper. It is only timid or highspirited horses that acquire this habit, and rough usage invariably increases their agitation and terror. Some may be led ont quite at leisure when blindfolded; others when they have the harness bridle on; some will best take their own way, and a few inay be ridden through the doorway that cannot be led, By quietness and kindness, however, the horse will be most easily and quickly subdued.

\section{SLIPPING THE COLLAR.}

This is a trick at which many horses are so clever that scarcely a night passes without their getting loose. It is a very serious habit, for it enables the horse sometimes to gorge limself with food, to the imminent danger of staggers; or it exposes 
him, as he wanders about, to be kicked and injured by the other horses, while his restlessness will often keep the whole team awake. If the web of the halter, being first accurately fitted to his neck, is suffered to slip only one way, or a strap is attached to the halter and buckled round the neck, but not sufficiently tight to be of serious inconvenience, the power of slipping the collar will be taken away.

\section{TRIPPING.}

He must be a skilful practitioner or a mere pretender who promises to remedy this habit. If it arises from a heavy forehand, and the fore legs being too much under the liorse, no one can alter the natural frame of the animal: if it proceeds from tenderness of the foot, grogginess, or old lameness, these ailments are seldom cured. Also, if it is to be traced to habitual carelessness and idleness, no whipping will rouse the drone. A known stumbler should never be ridden, or driven by any one who values his safety or his life. A tight hand or a strong-bearing rein are precautions that should not be neglected, although they are generally of little avail ; for the inveterate stumbler will rarely be able to save limself, and this tight rein may sooner and farther precipitate the rider. If, after a trip, the horse suddenly starts forward, and endeavours to break into a sharp trot or canter, the rider or driver may be assured that others before him have fruitlessly endeavoured to remedy the nuisance.

If the stumbler has the foot kept as short and the toe pared as close as safety will permit, and the shoe is rounded at the toe, or has that shape given to it which it naturally acquires in a fortnight from the peculiar action of such a horse, the animal may not stumble quite so much; or if the disease which produced the habit can be alleviated, some trifling good may be done, but in almost every case a stumbler should be got rid of, or put to slow and heavy work. If the latter alternative is adopted, he may trip as much as he pleases, for the weight of the load and the motion of the other horses will keep him upon his legs.

\section{WEAVING.}

This consists in a motion of the head, neck, and body, from side to side, like the shuttle of a weaver passing through the web, and hence the name which is given to this peculiar and incessant and unpleasant action. It indicates an impatient, irritable temper, and a dislike to the confinement of the stable. A horse that is tlus incessantly on the fret will seldom carry flesh, or be safe to ride or drive. There is no cure for it, but the close tying-up of the animal, or at least allowing him but one loose rein, except at feeding-time.

\section{CHAPTER XX.}

\section{THE GENERAL MANAGEMENT OF THE HORSE.}

TH1s is a most important part of our subject, even as it regards the farmer, although there are comparatively few glaring errors in the treatment of the agricultural horse: but it comes more especially home to the gentleman, who is too often and too implicitly under the guidance of an idle, and ignorant, and designing groom.

We will arrange the most important points of general management under the following heads :

\section{AIR.}

The breathing of pure air is necessary to the existence and the health of man and beast. It is comparatively lately that this has been admitted even in the management of our best stables. They have been close, and hot, and foul, instead of airy, and cool, and wholesome. The effect of several horses being shut up in the same stable is completely to empoison the air; and yet, even in the present day, there are too many who carefully close every aperture by which a breath of fresh air can by possibility gain admission. In effecting this, even the key-hole and the threshold are not forgotten. What, of necessity, must be the consequence of this? Why! if one 
thought is bestowed on the new and dangerous character that the air is assuming, it will be too evident that sore throat, and swelled legs, and bad eyes, and inflamed lungs, and mange, and grease, and glanders, will scarcely ever be long out of that stable.

Let this be considered in another point of view. The horse stands twenty or twoand-twenty hours in this unnatural vapour bath, and then he is suddenly stripped of all his clothing, he is led into the open air, and there he is kept a couple of hours or morc in a temperature fifteen or twenty degrees below that of the stable. Putting the inhumanity of this out of the question, must not the animal thus unnaturally and absurdly treated be subjected to rheumatism, catarrh, and various other complaints? Does he not often stand, hour after hour, in the road or the street, while his owner is warming himself within, and this perhaps after every pore has been opened by a brushing gallop, and his susceptibility to the painful and the injurious influence of cold has been excited to the utmost?

It is not so generally known, as it ought to be, that the return to a hot stable is quite as dangerous as the change from a heated atmosphere to a cold and biting air. Many a horse that has travelled without harm over a bleak country, has been suddenly seized with inflammation and fever when he has, immediately at the end of his journey, been surrounded with heated and foul air. It is the sudden change of temperature, whether from heat to cold, or from cold to heat, that does the mischief, and yearly destroys thousands of horses.

Mr. Clarke of Edinburgh was the first who advocated the use of well-ventilated stables. After him Professor Coleman established them in the quarters of the cavalry troops, and there cannot be a doubt that he saved the government many thousand pounds every year. His system of ventilation, however, like many other salutary innovations, was at first strongly resisted. Much evil was predicted; but after a time, diseases that used to dismount whole troops, almost entirely disappeared from the army.

The stable should be as large, compared with the number of horses that it is destined to contain, as circumstances will allow. A stable for six horses should not be less than forty feet in length, and thirteen or fourteen feet wide. If there is no loft above, the inside of the roof should always be plastered, in order to prevent direct currents of air and occasional droppings from broken tiles. The heated and foul air should escape, and cool and pure air be admitted, by elevation of the central tiles ; or by large tubes carried through the roof, with caps a little above them, to prevent the beating in of the rain; or by gratings placed high up in the walls. These latter apertures should be as far above the horses as they can convenicntly be placed, by which means all injurious draught will be prevented.

If there is a loft above the stable, the ceiling should be plastered, in order to prevent the foul air from penetrating to the hay above, and injuring both its taste and its wholesomeness; and no openings should be allowed above the racks, through which the hay may be thrown into them; for they will perinit the foul air to ascend to the provender, and also in the act of filling the rack, and while the horse is eagerly gazing upward for his food, a grass seed may fall into the eye, and produce considerable inflammation. At other times, when the careless groom has left open the trap-door, a stream of cold air beats down on the head of the horse.

The stable with a loft over it should never be less than twelve feet high, and proper ventilation should be secured either by tubes carried through the loft to the roof, or by gratings close to the ceiling. 'These gratings or openings should be enlarged or contracted by means of a covering or shutter, so that during spring, summer, and autumn, the stable may possess nearly the same temperature with the open air, and in winter a temperature of not more than ten degrees above that of the external atmosphere.

$\boldsymbol{A}$ hot stable has, in the mind of the groom, been long connected witl a glossy coat. The latter, it is thought, cannot be obtained without the former.

To this we should reply, that in winter a thin, glossy coat is not desirable. Nature gives to every animal a warmer clothing when the cold weather approaches. The horse-the agricultural horse especially - acquires a thicker and a lengthened coat, in order to defend him from the surrounding cold. Man puts on an additional and a warmer covering, and his comfort is increased and his health preserved by it. He who knows anything of the farmer's horse, or cares about his enjoyment, will not object to a coat a little longer and a litile roughened when the wintry wind blows 
bleak. The coat, however, needs not to be so long as to be unsightly ; and warm clothing, even in a cool stable, will, with plenty of honest grooming, keep the hair sufficiently smooth and glossy to satisfy the most fastidious. The overheated air of a close stable saves much of this grooming, and therefore the idle attendant unscrupulously sacrifices the health and safety of the horse. When we have presently to treat of the hair and skin of the horse, this will be placed in a somewhat different point of view.

If the stable is close, the air will not only be hot, but foul. The breathing of every animal contaminates it; and when, in the course of the night, with every aperture stopped, it passes again and again through the lungs, the blood cannot undergo its proper and healthy change; digestion will not be so perfectly performed, and all the functions of life are injured. Let the owner of a valuable horse think of his passing twenty or twenty-two out of the twenty-four hours in this debilitating atmosphere? Nature does wonders in enabling every animal to accommodate itself to the situation in which it is placed, and the horse that lives in the stable-oven suffers less from it than would scarcely be conceived possible; but he does not, and cannot, possess the power and the hardihood which he would acquire under other circumstances.

The air of the improperly close and heated stable is still farther contaminated by the urine and dung, which rapidly ferment there, and give out stimulating and unwholesome vapours. When a person first enters an ill-managed stable, and especially early in the morning, he is annoyed, not only by the heat of the confined air, but by a pungent smell, resembling hartshorn; and can he be surprised at the inflammation of the eyes, and the chronic cough, and the disease of the lungs, by which the animal, who has been all night shut up in this vitiated atmosphere, is often attacked; or if glanders and farcy should occasionally break out in such stables? It has been ascertained by chemical experiment that the urine of the horse contains in it an exceedingly large quantity of hartshorn; and not only so, but that, influenced by the heat of a crowded stable, and possibly by other decompositions that are going forward at the same time, this ammoniacal vapour begins to be rapidly given out almost immediately after the urine is voided.

When disease begins to appear among the inhabitants of these ill-ventilated places, is it wonderful that it should rapidly spread among them, and that the plague-spot should be, as it were, placed on the door of such a stable? When distemper appears in spring or in autumn, it is in very many cases to be traced to such a pest-house. It is peculiarly fatal there. The horses belonging to a small establishment, and rationally treated, have it comparatively seldom, or have it lightly; but among the inmates of a crowded stable it is sure to display itself, and there it is most fatal. The experience of every veterinary surgeon, and of every large proprietor of horses, will corroborate this statement. Agriculturists should bring to their stables the common sense which directs them in the usual concerns of life, and should begin, when their pleasures and their property are so much at stake, to assume that authority and to enforce that obedience, to the lack of which is to be attributed the greater part of bad stablemanagement and horse-disease. Of nothing are we more certain than that the majority of the maladies of the horse, and those of the worst and most fatal character, are directly or indirectly to be attributed to a deficient supply of air, cruel exaction of work, and insufficient or bad fare. Each of these evils is to be dreaded-each is, in a manner, watching for its prey; and when they are combined, more than half of the inmates of the stable are often swept away.

Every stable should possess within itself a certain degree of ventilation. The cost of this would be trifling, and its saving in the preservation of valuable animals may be immense. The apertures need not be large, and the whole may be so contrived that no direct current of air shall fall on the horse.

A gentleman's stable should never be without a thermometer. The temperature should seldom exceed $70^{\circ}$ in the summer, or sink below $40^{\circ}$ or $50^{\circ}$ in the winter.

\section{LITTER.}

Having spoken of the vapour of hartshorn, which is so rapidly and so plentifully given out from the urine of a horse in a heated stable, we next take into consideration the subject of litter. The first caution is frequently to remove it. The early extrication of gas shows the rapid putrefaction of the urine; and the consequence of which will be the rapid putrefaction of the litter that has been moistened by it. 
Everything hastening to decomposition should be carefully removed where life and health are to be preserved. 'The litter that has been much wetted or at all softened by the urine, and is beginning to decay, should be swept away every morning; the greater part of the remainder may then be piled under the manger; a little being left to prevent the painful and injurious pressure of the feet on the hard pavement during the day. 'The soiled and macerated portion of that which was left should be removed at night. In the better kind of stables, however, the stalls should be completely emptied every morning.

No heap of fermenting dung should be suffered to remain during the day in the corner or in any part of the stable. With regard to this, the directions of the master should be peremptory.

'The stable should be so contrived that the urine shall quickly run off, and the offensive and injurious vapour from the decomposing fluid and the litter will thus be materially lessened: if, however, the urine is carried away by means of a gutter running along the stable, the floor of the stalls must slant towards that gutter, and the declivity must not be so great as to strain the back sinews, and become an occasional, although unsuspected, cause of lameness. Mr. R. Lawrence, well observes, that, " if the rcader will stand for a few minutes with his toes higher than his heels, the pain he will feel in the calves of his legs will soon convince him of the truth of this remark. Hence, when a horse is not eating, he always endeavours to find his level, either by standing across the stall or else as far back as his halter will permit, so that his hind-legs may meet the ascent of the other side of the channel."

'This inclination of the stall is also a frequent cause of contraction of the heels of the foot, by throwing too great a proportion of the weight upon the toe and removing that pressure on the heels which tends most to keep them open. Care, therefore, must be taken that the slanting of the floor of the stalls shall be no inore than is sufficient to drain off the urine with tolerable rapidity. Stalls of this kind certainly do best for mares; but for horses we much prefer those with a grating in the centre, and a slight inclination of the floor on every side towards the middle. A short branch may communicate with a larger drain, by means of which the urine may be carried off to a reservoir outside the stable. Traps are now contrived, and may be procured at little expense, by means of which neither any offensive smell nor current of air can pass through the grating.

The farmer should not lose any of the urine. It is from the dung of the horse that he derives a principal and most valuable part of his manure. It is that which earliest takes on the process of putrefaction, and forms one of the strongest and most durable dressings. That which is most of all concerned with the rapidity and the perfection of the decomposition is the urine.

Humanity and interest, as well as the appearance of the stable, should induce the proprietor of the horse to place a moderate quantity of litter under him during the day. The farmer who wants to convert every otherwise useless substance into manure, will have additional reason for adopting this practice: especially as he does not confine himself to that to which in towns and in gentlemen's stables custom seems to have limited the bed of the horse. Pea and bean-haum, and potato-tops, and heath, occupy in the stable of the farmer, during a part of the year, the place of wheaten and oaten straw. It should, however, be remembered, that these substances are disposed more easily to ferment and putrefy than straw, and therefore should be more carefully examined and oftener removed. It is the faulty custom of some farmers to let the bed accumulate until it reaches almost to the horse's belly, and the bottom of it is a mass of dung. If there were not often many a hole and cranny through which the wind can enter and disperse the foul air, the liealth of the animal world materially suffer.

\section{LIGHT.}

This neglected branch of stable-management is of far more consequence than is generally imagined; and it is particularly neglected by those for whom these treatises are principally designed. The farmer's stable is frequently destitute of any glazed window, and has only a shutter, which is raised in warm weather, and closed when the weather becomes cold. When the horse is in the stable only during a few hours in the day, this is not of so much consequence, nor of so much, probably, with regard to horses of slow work; but to carriage-horses and hackneys, so far, at least, 
as the eyes are concerned, a dark stable is little less injurious than a foul and heated one. In order to illustrate this, reference may be made to the unpleasant feeling, and the utter impossibility of seeing distinctly, when a man suddenly emerges from a dark place into the full blaze of day. The sensation of mingled pain and giddiness is not soon forgotten; and some minutes pass before the eye can accommodate itself to the increased light. If this were to happen every day, or several times in the day, the sight would be irreparably injured, or possibly blindness would ensue. Can we wonder, then, that the horse, taken from a dark stable into a glare of light, feeling, probably, as we should do under similar circumstances, and unable for a considerable time to see anything around him distinctly, should become a starter, or that the frequently repeated violent effect of sudden light should induce inflammation of the eye so intense as io terminate in blindness? There is, indeed, no doubt that horses kept in dark stables are frequently notorious starters, and that abominable habit has been properly traced to this cause.

Farıners know, and should profit by the knowledge, that the darkness of the stable is not unfrequently a cover for great uncleanliness. A glazed window, with leaden divisions between the small panes, would not cost much, and would admit a degree of light somewhat more approaching to that of day, and at the same time would render the concealment of gross inattention and want of cleanliness impossible.

If plenty of light is admitted, the walls of the stable, and especially that portion of them which is before the horse's head, must not be of too glaring a colour. The constant reflection from a white wall, and especially if the sun shines into the stable, will be as injurious to the eye as the sudden changes from darkness to light. The perpetual slight excess of stimulus will do as much mischief as the occasional but more violent one when the animal is taken from a kind of twilight to the blaze of day. The colour of the stable, therefore, should depend on the quantity of light. Where much can be admitted, the walls should be of a grey hue. Where darkness would otherwise prevail, frequent whitewashing may in some degree dissipate the gloom.

For another reason, it will be evident that the stable should not possess too glaring a light: it is the resting-place of the horse. The work of the farmer's horse, indeed, is confined prinçipally to the day. The hour of exertion having passed, the animal returns to his stable to feed and to repose, and the latter is as necessary as the former, in order to prepare him for renewed work. Something approaching to the dimness of twilight is requisite to induce the animal to compose himself to sleep. This halflight more particularly suits horses of heavy work, and who draw almost as much by the weight of carcass which they can throw into the collar, as by the degree of muscular energy of which they are capable. In the quietness of a dimly-lighted stable, they obtain repose, and accumulate flesh and fat. Dealers are perfectly aware of this. They have their darkened stables, in which the young horse, with little or no exercise, and fed upon mashes and ground corn, is made up for sale. The round and plump appearance, however, which may delude the unwary, soon vanishes with altered treatment, and the animal is found to be unfit for hard work, and predisposed to many an inflammatory disease. The circumstances, then, under which a stable somewhat darkened may be allowed, will be easily determined by the owner of the horse; but, as a general rule, dark stables are unfriendly to cleanliness, and the frequent cause of the vice of starting, and of the most serious diseases of the eyes.

\section{GROOMING.}

Of this, much need not be said to the agriculturist, since custom, and apparently without ill effect, has allotted so little of the comb and brush to the farmer's horse. The animal that is worked all day, and turned out at night, requires little more to be done to him than to have the dirt brushed off his limbs. Regular grooming, by rendering his skin more sensible to the alteration of temperature, and the inclemency of the weathcr, would be prejudicial. The horse that is altogether turned out, needs no grooming. The dandriff, or scurf, which accumulates at the roots of the hair, is a provision of nature to defend him from the wind and the cold.

It is to the stabled horse, highly fed, and little or irregularly worked, that grooming is of so much consequence. Good rubbing with the brush, or the currycomb, opens the pores of the skin, circulates the blood to the extremities of the body, produces free and healthy perspiration, and stands in the room of exercise. No horse will 
carry a fine coat without either unnatural heat or dressing. They both effect the same purpose; they both increase the insensible perspiration: but the first does it at the expense of health and strength, while the second, at the same time that it produces a glow on the skin, and a determination of blood to it, rouses all the energies of the frame. It would be well for the proprietor of the horse if he were to insist - and to see that his orders are really obeyed - that the fine coat in which he and his groom so much delight, is produced by honest rubbing, and not by a heated stable and thick clothing, and most of all, not by stimulating or injurious spices. The horse should be regularly dressed every day, in addition to the grooming that is necessary after work.

When the weather will permit the horse to be taken out, he should never be groomed in the stable, unless he is an animal of peculiar value, or placed for a time under peculiar circumstances. Without dwelling on the want of cleanliness, when the scurf and dust that are brushed from the horse lodge in his manger, and mingle with his food, experience teaches, that if the cold is not too great, the animal is braced and invigorated to a degree that cannot be attained in the stable, from being dressed in the open air. There is no necessity, however, for half the punishment which many a groom inflicts upon the horse in the act of dressing; and particularly on one whose skin is thin and sensible. The curry-comb should at all times be lightly applied. With many horses, its use may be almost dispensed with; and even the brush needs not to be so hard, nor the points of the bristles so irregular, as they often are. A soft brush, with a little more weight of the hand, will be equally effectual, and a great deal more pleasant to the horse. A hair-cloth, while it will seldom irritate and tease, will be almost sufficient with horses that have a thin skin, and that have not been neglected. After all, it is no slight task to dress a horse as it ought to be done. It occupies no little time, and demands considerable patience, as well as dexterity. It will be readily ascertained whether a horse has been well dressed by rubbing him with one of the fingers. A greasy stain will detect the idleness of the groom. When, however, the horse is changing his coat, both the curry-comb and the brush should be used as lightly as possible.

Whoever would be convinced of the benefit of friction to the horse's skin, and to the horse generally, needs only to observe the effects produced by well hand-rubbing the legs of a tired horse. While every enlargement subsides, and the painful stiffness disappears, and the legs attain their natural warmth, and become fine, the animal is evidently and rapidly reviving; he attacks his food with appetite, and then quietly lies down to rest.

\section{EXERCISE.}

Our observations on this important branch of stable-management must have only a slight reference to the agricultural horse. His work is usually regular, and not exhausting. He is neither predisposed to disease by idleness, nor worn out by excessive exertion. He, like his master, has enough to do to keep him in health, and not enough to distress or injure him: on the contrary, the regularity of his work prolongs life to an extent rarely witnessed in the stable of the gentleman. Our remarks on exercise, then, must have a general bearing, or have principal reference to those persons who are in the middle stations of life, and who contrive to keep a horse for business or pleasure, but cannot afford to maintain a servant for the express purpose of looking after it. The first rule we would lay down is, that every horse should have laily exercise. The animal that, with the usual stable feeding, stands idle for three or four days, as is the case in many establishments, must suffer. He is predisposed to fever, or to grease, or, most of all, to diseases of the foot; and if, after three or four lays of inactivity, he is ridden far and fast, he is almost sure to have inflammation of the lungs or of the feet.

A gentleman or tradesman's horse suffers a great deal more from idleness than he rloes from work. A stable-fed horse should have two hours' exercise every day, if he is to be kept free from disease. Nothing of extraordinary or even of ordinary labour can be effected on the road or in the field, without sufficient and regular exercise. It is this alone which can give energy to the system, or develope the powers of any animal.

Irow, then, is this exercise to be given? As much as possible by, or under the superintendence of, the owner. The exercise given by the groom is rarely to be 
depended upon. It is inefficient or it is extreme. It is in many cases both irregular and injurious. It is dependent upon the caprice of him who is performing a task, and who will render that task subservient to his own pleasure or purpose.

In training the hunter and the race-horse, regular exercise is the most important of all considerations, however it may be forgotten in the usual management of the stable. The exercised horse will discharge his task, and sometimes a severe one, with ease and pleasure; while the idle and neglected one will be fatigued ere half his labour is accomplished, and, if he is pushed a little too far, dangerous inflammation will ensue. How often, nevertheless, does it happen, that the horse which has stood inactive in the stable three or four days, is ridden or driven thirty or forty miles in the course of a single day! This rest is often purposely given to prepare for extra-exertion;-to lay in a stock of strength for the performance of the task required of him: and then the owner is surprised and dissatisfied if the animal is fairly knocked up, or possibly becomes seriously ill. Nothing is so common and so preposterous, as for a person to buy a horse from a dealer's stable, where he has been idly fattening for sale for many a day, and immediately to give him a long run after the hounds, and then to complain bitterly, and thirk that he has bcen imposed upon, if the animal is exhausted before the end of the chase, or is compelled to be led home suffering from violent inflanunation. Regular and gradually increasing exercise would have made the same horse appear a treasure to his owner.

Exercise should be somewhat proportioned to the age of the horse. A young horse requires more than an old one. Nature has given to young animals of every kind a disposition to activity; but the exercise must not be violent. A great deal depends upon the manner in which it is given. To preserve the temper, and to promote heal th, it should be moderate, at least at the beginning and the termination. The rapid trot, or even the gallop, may be resorted to in the middle of the exercise, but the horse should be brought in cool. If the owner would seldom intrust his horse to boys, and would insist on the exercise being taken within sight, or in the neighbourhood of his residence, many an accident and irreparable injury would be avoided. It should be the owner's pleasure, and it is his interest, personally to attend to all thesc things. He manages every other part of his concerns, and he may depend on it that he suffers when he neglects, or is in a manner excluded from, his stables.

\section{FOOD.}

The system of manger-feeding is becoming general among farmers. There are few horses that do not habitually wastc a portion of their hay; and by some the greater part is pulled down and trampled under foot, in order first to cull the sweetest and best locks, and which could not be donc while the hay was enclosed in the rack. A good feeder will afterwards pick up much of that which was thrown down; but some of it must be soiled and rendered disgusting, and, in many cases, one-third of this division of their food is wasted. Some of the oats and beans are imperfectly chewed by all horses, and scarcely at all by hungry and greedy ones. The appearance of the ding will sufficiently evince this.

The observation of this induced the adoption of manger-feeding, or of mixing a portion of chaff with the corn and beans. By this ineans the animal is compelled to chew his food; he cannot, to any great degree, waste the straw or hay; the chaff is too hard and too sharp to be swallowed without considerable mastication, and, while he is forced to grind that down, the oats and beans are ground with it, and yield more nourishment; the stomach is more slowly filled, and therefore acts better on its contents, and is not so likely to be overloaded; and the increased quantity of saliva thrown out in the lengthened maceration of the food, softens it, and makes it more fit for digestion.

Professor Stewart very properly remarks that "many horses swallow their corn in great haste, and when much is eaten, that habit is exceedingly dangerous. 'The stoinach is filled-it is overloaded beforc it has time to make preparation for acting on its contents - the food ferments, and painful or dangerous colic ensues. By adding chaff to his corn, the horse must take more time to eat it, and time is given for the coinmencement of digestion, before fermentation can occur. In this way chaff is very 
If, when considerable provender was wasted, the horse maintained his condition, and was able to do his work, it was evident that much might be saved to the farmer, when he adopted a system by which the horse ate all that was set before him; and by degrees it was found out that, even food somewhat less nutritious, but a great deal cheaper, and which the horse either would not eat, or would not properly grind down in its natural state, might be added, while the animal would be in quite as good plight, and always ready for work.

Chaff may be composed of equal quantities of clover or meadow hay, and wheaten, oaten, or barley straw, cut into pieces of a quarter or half an inch in length, and mingled well together; the allowance of oats or beans is afterwards added, and mixed with the chaff. Many farmers very properly bruise the oats or beans. The whole oat is apt to slip out of the chaff and be lost; but when it is bruised, and especially if the chaff is a little wetted, it will not readily separate; or, should a portion of it escape the grinders, it will be partly prepared for digestion by the act of bruising. 'The prejudice against bruising the oats is, so far as the farmer's horse, and the wagon horse, and every horse of slow draught, are concerned, altogether unfounded. The quaritity of straw in the chaff will always counteract any supposed purgative quality in the bruiscd oats. Horses of quicker draught, except they are naturally disposed to scour, will thrive better with bruised than with whole oats; for a greater quantity of nutriment will be extracted from the food, and it will always be easy to apportion the quantity of straw or beans to the effect of the mixture on the bowels of the horse. The principal alteration that should be made in the horse of harder and more rapid work, such as the post-horse, and the stage-coach horse, is to increase the quantity of hay, and diminish that of straw. Two trusses of hay may be cut with one of straw.

Some gentlemen, in defiance of the prejudice and opposition of the coachman or the groom, have introduced this mode of feeding into the stables of their carriage-horses and hackneys, and with manifest advantage. There has been no loss of condition or power, and considerable saving of provender. This system is not, however, calculated for the hunter or the race-horse. Their food must lie in smaller bulk, in order that the action of the lungs may not be impeded by the distension of the stomach; yet many hunters have gone well over the field who have been manger-fed, the proportion of corn, however, being materially increased.

For the agricultural and cart horse, eight pounds of oats and two of beans should be added to every twenty pounds of chaff. Thirty-four or thirty-six pounds of the mixture will be sufficient for any moderate-sized horse, with fair, or even hard work. The dray and wagon horse may require forty pounds. Hay in the rack at night is, in this case, supposed to be omitted altogether. 'The rack, howevcr, may remain, as occasionally useful for the sick horse, or to contain tares or other green meat.

Horses are very fond of this provender. The majority of them, after-having been accustomed to it, will leave the best oats given to them alone, for the sake of the iningled chaff and corn. We would, however, caution the farmer not to set apart too much damaged hay for the manufacture of the chaff. The horse may be thus induced to eat that which he would otherwise refuse; but if the nourishing property of the hay has been impaircd, or it lias acquired an injurious principle, the animal will either lose condition, or become diseased. Much more injury is done by eating damaged hay or musty oats than is generally imagined. There will be sufficient saving in the liminished cost of the provender by the introduction of the straw, and the improved condition of the horse, without poisoning him with the refuse of the farm. For old horses, and for those with defective teeth, chaff is peculiarly useful, and for them the grain should be hroken down as well as the fodder.

While the mixture of chaff with the corn prevents it from being too rapidly dcvoured and a portion of it swallowed whole, and therefore the stomach is not too loaded with that on which, as containing the most nutriment, its chief digestive power should be cxerted, yet, on the whole, a great deal of time is gained by this mode of feeding, and more is left for rest. When a horse comes in wearied at the closc of the day, it occupies, after he has eaten his corn, two or three hours to clear his rack. On the system of manger-feeding, the chaff being already cut into small pieces, and the beans and oats bruised, he is able fully to satisfy his appetite in an hour and a half. Two additional hours are thereforc devoted to rest. This is a circumstance desprving of much consideration even in the farmer's stable, and of immense conse- 
quence to the postmaster, the stage-coach proprietor, and the owner of every hard worked horse.

Manger food will be the usual support of the farmer's horse during the winter, and while at constant or occasional hard work; but from the middle of April to the end of July, he may be fed with this mixture in the day and turned out at night, or he may remain out during every rest-day. A team in constant employ should not, however, be suffered to be out at night after the end of July.

The farmer should take care that the pasture is thick and good; and that the distance from the yard is not too great, or the fields too large, otherwise a very considerable portion of time will be occupied in catching the horses in the morning. He will likewise have to take into consideration the sale he would have for his hay, and the necessity for sweet and untrodden pasture for his cattle. On the whole, however, turning out in this way, when circumstances will admit of it, will be found to be more beneficial for the horse, and cheaper than soiling in the yard.*

The horse of the inferior farmer is sometimes fed on hay or grass alone, and the animal, although he rarely gets a feed of corn, maintains himself in tolerable condition, and does the work that is required of him: but hay and grass alone, however good in quality, or in whatever quantity allowed, will not support a horse under hard work. Other substances containing a larger proportion of nutriment in a smaller compass, have been added. They shall be briefly enumerated, and an estimate formed of their comparative value.

In almost every part of Great Britain, OATs have been selected as that portion of the food which is to afford the principal nourishment. They contain seven hundred and forty-three parts out of a thousand of nutritive matter. They should be about or somewhat less than a year old, heavy. dry, and sweet. New oats will weigh ten or fifteen per cent. more than old ones; but the difference consists principally in watery matter, which is gradually evaporated. New oats are not so readily ground down by the teeth as old ones. They form a more glutinous mass, difficult to digest, and, when eaten in considerable quantities, are apt to occasion colic and even staggers. If they are to be used before they are from three to five months old, they would be materially improved by a little kiln-drying. There is no fear for the horses from simple drying, if the corn was good when it was put into the kiln. The old oat forms, when chewed, a smooth and uniform mass, which readily dissolves in the stomach, and yields the nourishment which it contains. Perhaps some chemical change may have been slowly effected in the old oat, disposing it to be more readily assimilated. Oats should be plump, bright in colour, and free from unpleasant smell or taste. The musty smell of wetted or damaged corm is produced by a fungus which grows upon the seed, and which has an injurious effect on the urinary organs, and often on the intestines, producing profuse staling, inflammation of the kidneys, colic, and inflammation of the bowels.

This musty smell is removed by kiln-drying the oat; but care is here requisite that too great a degree of hear is not employed. It should be sufficient to destroy the fun-

* Professor Stewart thus sums up the comparative advantages of chaff and racked feeding :-

"Where the stablemen are careful, waste of fodder is diminished, but not prcvented, by feeding from the manger.

"Where the racks are good, careful stablemen may prevent nearly all waste of fodder without cutting it.

"An accurate distribution of the fodder is not a very important object.

"No horse seems to like his corn the better for being mingled with chaff.

"A Among half-starved horses chaff-cutting promotes the consumption of damaged fodder.

" Full-fed horses, rather than eat the mixture of sound with unsound, will reject the whole, or eat less than their work demands.

"Chaff is more easily eaten than hay. This is an advantage to old horses and others working all day - a disadvantage when the horses stand long in the stable.

"Chaff insures complete mastication and deliberate digestion of the corn. It is of considerable, and of most importance in this respect. All the fodder needs not to be mingled with the corn, one pound of chaff being sufficient to secure the mastication and slow ingestion
of four pounds of corn.

"The cost of cutting all the fodder, especially for heavy horses, is rcpaid only when hay is dear, and wasted in large quantities.

"Among hard-working horses bad food should never be cut."-Stcwart's Stable Gicono. my, p. 225 . 
gus without injuring the life of the seed. Many persons, but without just cause, have considerable fear of the kiln-burnt oat. It is said to produce inflammation of the bladder, and of the cyes, and mangy affections of the skin. The fact is, that many of the kiln-dried oats that are given to horses were damaged before they were dried, and thus becamc unhealthy. A considerable improvement would be effected by cutting the untlireshed oat-straw into chaff, and the expense of threshing would be saved. Oat-straw is better than that of barley, but does not contain so much nu triment as that of wheat.

When the horse is fed on hay and oats, the quantity of the oats must vary with his size and the work to be performed. In winter, four feeds, or from ten to fourteen pounds of oats in the day, will be a fair allowance for a horse of fifteen hands one or two inches high, and that has moderate work. In sumnier, half the quantity, with grcen food, will be sufficient. Those who work on the farm have from ten to fourteen pounds, and the hunter from twelve to sixteen. There are no efficient and safe substitutes for good oats; but, on the contrary, we are much inclined to believe that they possess an invigorating property which is not found in other food.

Oatmeal will form a poultice more stimulating than one composed of linseed meal alone-or they may be mingled in different proportions, as circumstances require. In the form of gruel it constitutes one of the most important articles of diet for the sick horse-not, indeed, forced upon him, but a pail containing it being slung in his box, and of which he will soon begin to drink when water is denied. Few grooms make good gruel; it is either not boiled long enough, or a sufficient quantity of oatmeal has not been used. The proportions should be, a pound of meal thrown into a gallon of water, and kept constantly stirred until it boils, and five minutes afterwards.

White-water, made by stirring a pint of oatmeal in a pail of water, the chill being taken from it, is an excellent beverage for the thirsty and tired horse.

BARLEY is a common food of the horse on various parts of the Continent, and, until the introduction of the oat, seems to have constituted almost his only food. It is more nutritious than oats, containing nine hundred and twenty parts of nutritive matter in every thousand. 'There seems, however, to be something necessary besides a great proportion of nutritive matter, in order to render any substance wholesome, strengthening, or fattening; therefore it is that, in many horses that are hardly worked, and, indeed, in horses generally, barley does not agree with them so well as oats. They are occasionally subject to inflammatory complaints, and particularly to surfeit and mange.

When barley is given, the quantity should not exceed a peck daily. It should always be bruised, and the chaff should consist of equal quantities of hay and barley-straw, and not cut too short. If the farmer has a quantity of spotted or unsaleable barley that he wishes thus to get rid of, he must very gradually accustom his horses to it, or he will probably produce serious illness among them. For horses that are recovering from illness, barley, in the form of malt, is often serviceablc, as tempting the appetite and recruiting the strength. It is best given in mashes-water, considerably below the boiling heat, being poured upon it, and the vessel or pail kept covered for half an hour.

Grains fresh from the mash-tub, either alone, or mixed with oats or chaff, or both, may be occasionally given to horses of slow draught; they would, however, afford very insufficient nourishment for horses of quicker or harder work.

WhEAT is, in Great Britain, more rarely given than barley. It contains nine hundred and fifty-five parts of nutritive matter. When farmers have a damaged or unmarketable sample of wheat, they sometimes give it to their horses, and, being at first used in small quantities, they become accustomed to it, and thrive and work well : it must, however, always be bruised and given in chaff. Wheat contains a greater portion of gluten, or sticky, adhesive matter, than any other kind of grain. It is difficult of digestion, and apt to cake and form obstructions in the bowels. This will oftener be the case if the horse is suffered to drink much water soon after feeding upon wheat.

Fermentation, colic, and death, are occasionally the consequence of eating any great quantity of wheat. A horse that is fed on wheat should have very little hay. The proportion should not be more than one truss of hay to two of straw. Wheaten flour, boilcd in water to the thickness of starch, is given with good effect in over-purging, and especially if combined with chalk and opium. 
BraN, or the ground husk of the wheat, used to be frequently given to sick horses on account of the supposed advantage derived from its relaxing the bowels. There is no doubt that it does operate gently on the intestinal canal, and assists in quickening the passage of its contents, when it is occasionally given; but it must not be a constant, or even frequent food. Mr. Ernes attended three mills at which many horses were kept, and there were always two or three cases of indigestion from the accumulation of bran or pollard in the large intestines. Bran may, however, be useful as an occasional aperient in the form of a mash, but never should become a regular article of food.

BEans.-These form a striking illustration of the principle, that the nourishing of strengthening effects of the different articles of food depend more on some peculiar property which they possess, or some combination which they form, than on the actual quantity of nutritive matter. Beans contain but five hundred and seventy parts of nutritive matter, yet they add materially to the vigour of the horse. There are many horses that will not stand hard work without beans being mingled with their food, and these not horses whose tendency to purge it may be necessary to restrain by the astringency of the bean. There is no traveller who is not aware of the difference in the spirit and continuance of his horse whether he allow's or denies him beans on his journey. They afford not merely a temporary stimulus, but they may be daily used without losing their power, or producing exhaustion. They are indispensable to the hard-worked coach-horse. Washy horses could never get through their work without them; and old horses would often sink under the task imposed upon them. They should not be given to the horses whole or split, but crushed. This will make a meterial difference in the quantity of nutriment that will be extracted. They aro sometimes given to turf horses, but only as an occasional stimulant. Two pounds of beans may, with advantage, be mixed with the chaff of the agricultural horse, during the winter. In summer the quantity of beans should be lessened, or they should be altogether discontinued. Beans are generally given whole. This is very absurd; for the young horse whose teeth are strong, seldom requires them; while the old horse, to whom they are in a manner necessary, is scarcely able to masticate them, swallows many of them which he is unable to break, and drops much corn from his mouth in the ineffectual attempt to crush them. Beans should not be merely split, but crushed; they will even then give sufficient employment to the grinders of the animal. Some postmasters use chaff with beans instead of oats. With hardlyworked horses they may possibly be allowed; but, in general cases, heans, without oats, would be too binding and stimulating, and would produce costiveness, and probably megrims or staggers.

Beans should be at least a twelvemonth old before they are given to the horse, and they should be carefully preserved from damp and mouldiness, which at least disgust the horse if they do no other harm, and harbour an insect that destroys the inner part of the bean.

The straw of the bcan is nutritive and wholesome, and is usually given to the horses. Its nutritive properties are supposed to be little inferior to those of oats. The small and plump bean is generally the best.

Peas are occasionally given. They appear to be in a slight degree more nourishing than beans, and not so heating. They contain five hundred and seventy-four parts of nutritive matter. For horses of slow work they may be used; but the quantity of chaff should be increased, and a few oats added. They have not been found to answer with horses of quick draught. It is essential that they should be crushed; otherwise, on account of their globular form, they are apt to escape from the teeth, and many are swallowed whole. Exposed to warmth and moisture in the stomach, they swell considerably, and may painfully and injuriously distend it. The peas that are given to horses should be sound, and at least a twelvemonth old.

In some northern counties pea-meal is frequently used, not only as an excellent food for the horse, but as a remedy for diabetes.

LINSEED is sometimes given to sick horses-raw, ground, and boiled. It is supposed to be useful in cases of catarrh.*

* "Mr. Black, veterinary surgeon of the 14th Dragoons, snys that sugar was tried as an article of food during the Peninsular $W$ ar. Ten horses were selected, each of which got 8 pounds a day at four rations. They took it very readily, and their coats became fine, smooth. 
Herbage, green and dry, constitutes a principal part of the food of the horse. There are few things with regard to which the farmer is so careless as the mixture of grasses on both his upland and meadow pasture. Hence we find, in the same field, the raygrass, coming to perfection only in a loamy soil, not fit to cut until the middle or latter part of July, and yielding little aftermath; the meadow fox-tail, best cultivated in a clayey soil, fit for the scythe in the beginning of June, and yielding a plentiful aftermath; the glaucous fescue-grass, ready at the middle of June, and rapidly detoriorating in value as its seeds ripen; and the fertile meadow-grass, increasing in value until the end of July. These are circumstances the importance of which will, at no distant period, be recognised. In the mean time, Sinclair's account of the different grasses, or the condensation of the most important part of his work in Sir Humphry Davy's Agricultural Chemistry, or Low's Elements of Practical Agriculture, are well deserving of the diligent perusal of the farmer.

Hay is most in perfection when it is about a twelvemonth old. The horse perhaps would prefer it earlier, but it is neither so wholesome nor so nutritive, and often has a purgative quality. When it is about a year old, it retains or should retain somewhat of its green colour, its agreeable smell and its pleasant taste. It has undergone the slow process of fermentation, by which the sugar which it contains is developed, and its nutritive quality is fully exercised. Old hay becomes dry and tasteless, and innutritive and unwholesome. After the grass is eut, and the hay stacked, a slight degree of fermentation takes place in it. This is necessary for the development of the saccharine principle; but orcasionally it proceeds too far and the hay becomes mowburnt, in which state it is injurious, or even poisonous. The horse soon shows the effect which it has upon him. He has diabetes to a considerable degree-he becomes hidebound-his strength is wasted-his thirst is excessive, and he is almost worthless.

Where the system of manger-feeding is not adopted, or where hay is still allowed at night, and chaff and corn in the day, there is no error into which the farmer is so apt to fall as to give an undue quantity of hay, and that generally of the worst kind. If the manger system is good, there can be no necessity for hay, or only for a small quantity of it; but if the rack is overloaded, the greedy horse will be eating all night, instead of taking his rest - when the time for the morning feed arrives, his stomach will be already filled, and he will be less capable of work from the want of sleep, and from the long-continued distension of the stomach rendering it impossible for the food to be properly digested.

It is a good practice to sprinkle the hay with water in which salt has been dissolved. It is evidently more palatable to the animal, who will leave the best unsalted hay for that of an inferior quality that has been moistened with brine; and there can be no doubt that the salt very materially assists the process of digestion. The proferable way of salting the hay is to sprinkle it over the different layers as the rick is formed. From its attraction for water, it would combine with that excess of moisture which, in wet seasons, is the cause of too rapid and violent fermentation, and of the hay becoming mowburnt, or the rick catching fire, and it would become more incorporated with the hay. The only objection to its being thus used is, that the colour of the hay is not so bright; but this will be of little consequence for home consumption.

Of the value of TAREs, as forming a portion of the late spring and summer food of the stabled and agricultural horse, there can be no doubt. They are cut after the pods are formed, but a considerable time before the seeds are ripe. They supply a larger quantity of food for a limited time than almost any other forage-crop. The vicia sativa is the most profitable variety of the tare. It is very nutritive, and acts as a gentle aperient. When surfeit-lumps appear on the skin, and the horse begins to rub himself against the divisions of the stall, and the legs swell, and the heels threaten to crack, a few tares, cut up with the chaff, or given instead of a portion of the hay, will afford considerable relief. Ten or twelve pounds may be allowed daily, and half that

and glossy. They got no corn, and only 7 pounds of hay, instead of the ordinary allowance, which is 12 pounds. The sugar seemed to supply the place of the corn so well, that it would have been probably given abroad; but peace came, and the circumstances that rendered the use of sugar for corn desirable ceased, and the horses returned to their usual diet. That the sugar might not be appropriatcd to other purposes it was slightly scented with assafcotida, which did not produce any apparent effect upon them." 
weight of hay subtracted. It is an erroneous notion, that, given in moderate quantities, they either roughen the coat or lessen the capability for hard work.

RYE Grass affords a valuable article of food, but is inferior to the tare. It is not so nutritive. It is apt to scour and, occasionally, and late in the spring, it has appeared to be injurious to the horse.

Clover, for soiling the horse, is inferior to the tare and the rye grass, but nevertheless, is useful when they cannot be obtained. Clover hay is, perhaps, preferable to meadow hay for chaff. It will sometimes tempt the sick horse, and may be given with advantage to those of slow and heavy work; but custom seems properly to have forbidden it to the hunter and the hackney.

LUCERN, where it can be obtained, is preferable even to tares, and salN-Foin is superior to lucern. Although they contain but a small quantity of nutritive matter, it is easily digested, and perfectly assimilated. They speedily put both muscle and fat on the horse that is worn down by labour, and they are almost a specific for hidebound. Some farmers have thought so highly of lucern as to substitute it for oats. This may be allowable for the agricultural horse of slow and not severe work, but he from whom speedier action is sometimes required, and the horse of all work, must have a proportion of hard meat within him.

The Swedish Turnip is an article of food the value of which has not been sufficiently appreciated, and particularly for agricultural horses. Although it is far from containing the quantity of nutritive matter which has been supposed, that which it has seems to be capable of easy and complete digestion. It should be sliced with chopped straw, and without hay. It quickly fattens the horse, and produces a smooth glossy coat and a loose skin. It will be good practice to give it once in the day, and that at night when the work is done.

CARROTS.-The virtues of this root are not sufficiently known, whether as contributing to the strength and endurance of the sound horse, or the rapid recovery of the sick one. To the healthy horse they should be given sliced in his chaff. Half a bushel will be a fair daily allowance. There is little provender of which the horse is fonder. The following account of the value of the carrot is not exaggerated. "This root is held in much esteem. There is none better, nor perhaps so good. When first given it is slightly diuretic and laxative; but as the horse becomes accustomed to it, these effects cease to be produced. They also improve the state of the skin. They form a good substitute for grass, and an excellent alterative for horses out of condition. To sick and idle horses they render corn unnecessary. They are bcneficial in all chronic diseases connected with breathing, and have a marked influence upon chronic cough and broken wind. They are serviceable in diseases of the skin, and in combination with oats they restore a worn horse much sooner than oats alone."**

Poratoes have been given, and with advantage, in their raw state, sliced with the chaff; but, where it has been convenient to boil or steam them, the bencfit has been far more evident. Purging has then rarely ensued. Some have given boiled potatoes alone, and horses, instead of rejecting them, have soon preferred them even to the oat; but it is better to mix them with the usual manger feed, in the proportion of one pound of potatoes to two and a half pounds of the other ingredients. The use of the potato must depend on its cheapness, and the facility for boiling it. Half a dozen horses would soon repay the expense of a steaming boiler in the saving of provender, without taking into the account their improved condition and capability for work. $f$ A horse fed on potatoes should have his quantity of water materiully curtailed.

Furze has sometimes been given during the winter months. There is considerable trouble attending the preparation of it, althorgh its plentifulness and little value for other purposes would, on a large farm, well repay that trouble. The furze is cut down at about three or four years' growth; the green branches of that and the preceding year are bruised in a mill, and then given to the horses in the state in which they come from the mill, or cut up with the chaff. Horses are very fond of it. If

* Stewart's Stable Economy, p. 183.

+ Professor Low says that $15 \mathrm{lbs}$. of potatoes yield as mueh noxishment as four pounds and a half of oats. Von Thayer asserts that three bushels are equal to $112 \mathrm{lbs}$. of hay; and Curwen, who tried potatoes extensively in the feeding of horses, says that an acre goes as far as
four acres of hay. 
twenty pounds of the furze are given, five pounds of straw, the beans, and three pounds of the oats, may be withdrawn.

It may not be uninteresting to eonelude this eatalogue of the different artieles of horse-food with a list of the quantities of nutritive matter contained in eaeh of them; for although these quantities eannot be eonsidered as expressing the aetual value of eaeh, beeause other eireumstanees besides the simple quantity of nutriment seem to influenee their effect in supporting the strength and condition of the horse, yet many a useful hint may be derived when the farmer looks over the produee of his soil, and inquires what other grasses or vegetables might suit his land. The list is partly taken from Sir Humphry Davy's Agrieultural Chemistry :-1000 parts of wheat eontain 955 parts of nutritive matter; barley, 920 ; oats, 743 ; peas, 574 ; beans, 570 ; potatoes, 230 ; red beet, 148 ; parsneps, 99 ; carrots, 98 . Of the grasses, 1000 parts of the meadow eat's-tail eontain, at the time of seeding, 98 parts of nutritive matter; narrow-leaved meadow grass in seed, and sweet-scented soft grass in flower, 95; narrow-leaved and flat-stalked meadow grass in flower, fertile meadow grass in seed, and tall feseue in flower, 93 ; fertile meadow grass, meadow feseue, reed-like feseue, and ereeping soft grass in flower, 78 ; sweet-seented soft grass in flower, and the aftermath, 77 ; fiorin, eut in the winter, 76 ; tall fescue, in the aftermath, and meadow soft grass in flower, 74 ; eabhage, 73 ; crested dog's-tail and brome, when flowering, 71 ; yellow oat, in flower, 66; Swedish turnips, 64; narrow-leaved meadow grass, creeping beet, round-headed eocksfoot, and spiked fescue, 59 ; roughish and fertile meadow grass, flowering, 56 ; fiorin, in summer, 54 ; common turnips, 42 ; sain-foin, and broad-leaved and long-rooted clover, 39 ; white clover, 32 ; and lucern, 23.

The times of feeding should be as equally divided as convenience will permit; and when it is likely that the horse will be kept longer than usual from home, the nosebag should invariably be taken. 'The small stomaeh of the horse is emptied in a few hours; and if he is suffered to remain hungry mueh beyond his aeeustomed time, he will afterwards devour his food so voraeiously as to distend the stomach and endanger an attaek of staggers. When this disease appears in the farmer's stable, he may attribute it to various causes; the true one, in the majority of instances, is irregularity in feeding. If the reader will turn baek to page 97 , he will be eonvineed that this deserves more serious attention than is generally given to it.

When extra work is required from the animal, the system of management is often injudieious, for a double feed is put before him, and as soon as he has swallowed it, he is started. It would be far better to give him a double feed on the previons evening, which would be digested before he is wanted, and then he might set out in the morning after a very small portion of eorn has been given to him, or perhaps only a little hay. One of the most successful methods of enabling a horse to get well through a long journey, is to give him only a little at a time while on the road, and at night to indulge him with a double feed of corn and a full allowanee of beans.

WATER. - This is a part of stable management little regarded by the farmer. He lets his horses loose morning and night, and they go to the nearest pond or brook and drink their fill, and no harm results, for they obtain that kind of water whieh nature designed them to have, in a manner prepared for them by some unknown influenee of the atmosphere, as well as by the deposition of many saline admixtures. The difference between hard and snft water is known to every one. In hard water, soap will eurdle, vegetables will not boil soft, and the saeeharine matter of the malt cannot be fully obtained in the proeess of brewing. There is nothing in whieh the different effeet of hard and soft water is so evident, as in the stomach and digestive organs of the horse. Hard water, drawn fresh from the well, will assuredly make the coat of a horse unaceustomed to it stare, and it will not unfrequently gripe and otherwise injure him. Instinet or experience has made even the horse himself eonseious of this, for he will never drink hard water if he has aeeess to soft, and he will leave the most transparent and pure water of the well for a river, although the stream may be turbid, and even for the muddiest pool.* He is injured, however, not so much by the hardness of the well-water as by its eoldness - particularly by its eoldness in summer, and when it is many degrees below the temperature of the atmosphere. The water

* Some trainers have so much fear of hard or strange water, that they carry with them to the different courses the water that the animal has been accustomed to drink, and that which they know agrees with it. 
in the brook and the pond being warmed by long exposure to the air, as well as having become soft, the horse drinks freely of it without danger.

If the horse were watered three times a day, and especially in summer, he would often be saved from the sad torture of thirst, and from many a disease. Whoever has observed the eagerness with which the over-worked horse, hot and tired, plunges his muzzle into the pail, and the difficulty of stopping him until he has drained the last drop, may form some idea of what he had previously suffered, and will not wonder at the violent spasms, and inflammation, and sudden death, that often result.

There is a prejudice in the minds of many persons against the horse being fully supplied with water. They think that it injures his wind, and disables him for quick and hard work. If he is galloped, as he too often is, immediately after drinking, his wind may be irreparably injured; but if he were oftener suffered to satiate his thirst at the intervals of rest, he would be happier and better. It is a fact unsuspected by those who have not carefully observed the horse, that if he has frequent access to water, he will not drink so much in the course of the day as another will do, who, to cool his parched mouth, swallows as fast as he can, and knows not when to stop.

On a journey, a horse should be liberally supplied with water. When he is a little cooled, two or three quarts may be given to him, and after that, his feed. Before he has finished his corn, two or three quarts more may be offered. He will take no harm if this is repeated three or four times during a long and hot day.

It is a judicious rule with travellers, that when a horse begins to refuse his food, he should be pushed no farther that day. It may, however, be worth while to try whether this does not proceed from thirst, as much as from exhaustion, for in many instances his appetite and his spirits will return soon after he has partaken of the refreshing draught.

Management of THe FeEt. - This is the only division of stable management that remains to be corsidered, and one sadly neglected by the carter and groom. The feet should be carefully examined every morning, for the shoes may be loose and the horse would have been stopped in the middle of his work; or the clenches may be raised, and endanger the wounding of his legs; or the shoe may begin to press upon the sole or the heel, and bruises of the sole, or corn, may be the result; and, the horse having stood so long in the stable, every little increase of heat in the foot, or lameness, will be more readily detected, and serious disease may often be prevented.

When the horse comes in at night, and after the harness has been taken off and stowed away, the heels should be well brushed out. Hand-rubbing will be preferable to washing, especially in the agricultural horse, whose heels, covered with long hair, can scarcely be dried again. If the dirt is suffered to accumulate in that long hair, the heels will become sore, and grease will follow; and if the heels are washed, and particularly during the winter, grease will result from the coldness occasioned by the slow evaporation of the moisture. The feet should be stopped-even the feet of the farmer's horse, if he remains in the stable. Very little clay should be used in the stopping, for it will get hard and press upon the sole. Cowdung is the best stopping to preserve the feet cool and elastic; but, before the stopping is applied, the picker should be run round the whole of the foot, between the shoe and the sole, in order to detect any stone that may have insinuated itself there, or a wound on any other part of the sole. For the hackney and hunter, stopping is indispensable. After several days' hard work it will afford very great relief to take the shoes off, having put plenty of litter under the horse, or to turn him, if possible, into a loose-box; and the shoes of every horse, whether hardly worked or not, should be removed or changed once in every three weeks. 


\section{CHAPTER XXI.}

\section{THE SKIN AND ITS DISEASES.}

THE skin of the horse resembles in construction that of other animals. It consists of three layers, materially differing in their structure and office. Externally is THE: CUTICLE - the epidermis or scarf-skin - composed of innumerable thin, transparent scales, and extending over the whole animal. If the scarf-skin is examined by means of a microscope, the existence of scales like those of a fish, is readily detected. In the action of a blister they are raised from the skin beneath in the form of pellucid hladders, and, in some diseases, as in mange, they are thrown off in hard, dry, white scales, numerous layers of which are placed one above another. In every part of the body the scarf-skin is permeated by innumerable pores, some of which permit the passage of the hair-through others the perspirable matter finds a passage - others are perforated by tubes through which various unctuous secretions make their escape, while, through a fourth variety, numerous fluids and gases are inhaled. It is destitute of nerves and blood-vessels, and its principal use seems to be to protect the cutis from injury, and to restrain and moderate its occasional morbid sensibility.

There is at all times a singular change taking place in this outer covering of the animal. There is a constant alteration and renewal of every part of it, but it adheres to the true skin through the medium of the pores, and also numerous little eminences, or projections, which seem to be prolongations of the nerves of the skin. The cuticle is in itself insensible; but one of its most important functions is to prom tect and defend the parts beneath, which are so often exposed to the effects of a morbid sensibility.

Beneath the cuticle is a thin, soft substance, through which the pores and eminences of the true skin pass. It is termed the rete mucosum, from its web-like structure, and its soft mucous consistence. Its office is to cover the minute vessels and nerves in their way from the cutis to the cuticle. It is also connected with the colour of the skin. In horses with white hair the rete mucosum is white; it is brown in those of a brown colour-black in the black, and in patches of different colours with those the hue of whose integument varies. Like the cuticle it is reproduced after abrasion, or other injury.

The cutis, or true skin, lies beneath the rete mucosum. It is decidedly of a fibrous texture, elastic, but with difficulty lacerated-exceedingly vascular, and highly sensitive. It is the substance which is converted into leather when removed from the body, and binds together the different parts of the frame. In some places it does this literally and clings so closely to the substance beneath that it scarcely admits of any motion: this is the case about the forehead and the back, while upon the face, the sides and flanks, it hangs in loosened folds. In the parts connected with progression it is folded into various duplicatures, that the action of the animal may admit of the least possible obstruction. The cutis is thinnest, and most elastic, on those parts that are least covered with hair, or where the hair is altogether deficient, as the lips, the muzzle, and the inside of the flanks.

Whatever is the colour of the rete mucosum, the true skin is of a pale white; in fact, the cutis has no connection with the colour of the hair. Of its general character, Mr. Percivall gives a very accurate description:- "It appears to consist of a dense substratum of cellular tissue, with which are interwoven fibres of a ligamentous nature, in such a manner that innumerable areolæ, like the meshes of a net, are formed in it. These areolæ open, through correspondent pores in the cuticle, upon the external surface, and are for the purpose of transmitting thither bloodvessels and absorbents, giving passage to the hair, and lodging the various secretory organs of the skin." *

Over a great part of the frame lies a singular muscle peculiar to quadrupeds, and more extensive and powerful in the thin-skinned and thin-haired animals, than in 
those with thicker hides. It reaches from the poll over the whole of the carcase, and down to the arm before, and the stifle behind. By its contraction the skin is puckered in every direction; and if it acts strongly and rapidly, the horse is not only enabled to shake off any insect or fly that may annoy him, but sometimes to displace a great part of his harness, and to render it difficult for the most expert rider to keep his seat. This muscle also assists the skin in bracing that part of the frame which it covers, and, perhaps, gives additional strength to the muscles beneath. It is called the panniculus carnosus, or fleshy panicle or covering.

The skin answers the double purpose of protection and strength. Where it is necessary that the parts should be bound and knit together, it adheres so tightly that we can scarcely raise it. Thus the bones of the knees and the pasterns and the tendons of the legs, on which so much stress is frequently thrown, are securely tied down and kept in their places. It is in order to take additional advantage of this binding and strengthening power that we fire the legs of overworked horses, in whom the sinews have begun to start, and the ligaments of the joints to swell, or be displaced. The skin is tight along the muscles of the back and loins, and down the yet more powerful muscles of the quarters; but in other places it is loosely attached, that it may not interfere with the motions of the animal. About the brisket, and within the arms and at the flanks, it hangs even in folds.

Of its strength we have abundant proof, both in the living and dead animal. Its fibres are interlaced in a most curious and intricate manner, so as, when living, to be scarcely lacerable, and converted into leather after death.

It is, while the animal is alive, one of the most elastic bodies with which we are acquainted. It not only perfectly adapts itself to the slow growth or decrease of the body, and appears equally to fit, whether the horse is in the plumpest condition or reduced to a skeleton; but, when a portion of it is distended to an extraordinary degree, in the most powerful action of the muscles, it, in a moment, again contracts to its usual dimensions.

It is principally indebted for this elasticity to almost innumerable minute glands which pour out an oily fluid that softens and supples it. When the horse is in health, and every organ discharges its proper functions, a certain quantity of this unctuous matter is spread over the surface of the skin, and is contained in all the pores that penetrate its substance; and the skin becomes pliable, easily raised from the texture beneath, and presenting that peculiar yielding softness and elasticity which experience has proved to be the best proofs of the condition, or, in other words, the general health of the animal. Then, too, from the oiliness and softness of the skin, the hair lies in its natural and proper direction, and is smooth and glossy. When the system is deranged, and especially the digestive system, and the vessels concerned in the nourishment of the animal feebly act, those of the skin evidently sympathize. This oily secretion is no more thrown out; the skin loses its pliancy; it seems to cling to the animal, and we have that peculiar appearance which we call hide-bound. This, however, requires attentive consideration.

We observe a horse in the summer. We find him with a thin, smooth, glossy coat, and his extremities clean and free almost from a single rough or misplaced liair. We meet with him again towards the winter, when the thermometer has fallen almost or quite to the freezing point, and we scarcely recognize him in his thick, rough, coarse, colourless coat, and his legs enveloped in long, shaggy hair. The health of the horse is, to a certain degree, deranged. He is dull, languid, easily fatigued. $\mathrm{He}$ will break into a sweat with the slightest exertion, and it is almost impossible thoroughly to dry him. He may perhaps feed as well as usual, although that will not generally be the case, but he is not equal to the demands which we are compelled to inake upon him.

This process goes on for an uncertain time, depending on the constitution of the animal, until nature has effected a change, and then he once more rallies: but a great alteration has taken place in him-the hair has lost its soft and glossy character, and is become dry and staring. The skin ceases to secrete that peculiar unctuous matter which kept it soft and flexible, and becomes dry and scaly; and the exhalents on the surface, having become relaxed, are frequently pouring out a profuse perspiration, without any apparent adequate cause for it.

So passes the approach to winter, and the owner complains sadly of the appearance of his steed, and, according to the old custom, gives him plenty of cordial 
balls, - perhaps too many of them, - on the whole not being unserviceable at this critical period, yet not productive of a great deal of good. At length the animal rallies of himself, and although not so strong and full of spirits as he ought to be, is hardier and more lively than he was, and able to struggle with the cold of the coming winter.**

What a desideratum in the management of the horse would be a course of treatment that would render all this unnecessary! This desideratum has been founda free escape of perspiration, a moist and softened state of the skin, an evident increase of health and capability of enduring fatigue, and working on shorter supply of food than he could before. This is said to be performed by the clipping and singeing systems.

Mr. Thomas Turner, who was almost one of the earliest advocates of these systems, states that during the months of October and November an inordinate growth of hair is observed over the whole surface of the body, and in many horses as early as the beginning of September, and almost invariably prevails, more or less, in every horse that is not thorough-bred. The debilitating effects thereby induced are profuse perspiration on the least possible exertion-depression of the animal spirits, and temporary loss of appetite. The immediate removal of all the superfluous hair by close clipping, instantly proves so powerful a tonic to the animal, that he unhesitatingly affirms it to be inferior to none at present known in our pharmacopœia. Mr. Turner adds,- "Now, signal as the success of clipping has been, I do entertain a hope, and am of opinion that, in the majority of instances, it may be superseded by singeing under certain modifications." +

We may not, perhaps, be able satisfactorily to explain the apparently magical effects of clipping and singeing on the general constitution, and particularly the wind of the horse, or the respiratory functions generally, but there is no doubt of their existence. An increased tone is given to the system generally; and probably, in some way not yet sufficiently developed, the increased current of the electric fluid maj have much to do with it.

Mr. Snewing gives an interesting account of the effect of clipping on two horses in his establishment. He had a cob, with a fixed catarrh of several months' standing. It did not interfere with the animal's general health, but was a source of considerable annoyance. At length the owner determined to sell him; but first he had him clipped. After a few days his attention was drawn to the circumstance, that either the horse's cough must have left him, or, from repeatedly hearing it, he had ceased to regard it. He watched the animal, and, truly enough, he found that the cough had entirely disappeared. He rode him through the winter and the following summer, and there was no return of it.

'The other instance was in a mare which he had after this one was sold. In the months of August, September, and October, 1841, she was continually the subject of intermittent cough. He had her clipped, and in a few days she ceased to cough, and has not been heard to cough from that time.

\section{HIDE-BOUND.}

This is not so much a diminution of the cellular or fatty substance between the skin and the muscles beneath, as it is an alteration in the skin itself. It is a hardness and unyieldingness of the skin from the want of the oily matter on its surface

*.Mr. E. Gabriel, V. S., on the Treatment of the Horse in Autumn.-Veterinarian. vol. xiii. 627 .

† Veterinarian, vol. xiv., 18.

In justice, however, to an excellent sportsman, Nimrod, we must quote another opinion, nnd with that the subject shall be left to the consideration of our readers. "On the subject of clipping, I cannot agree with Mr. Gabriel as to the call for it, much less admit its almost universal adoption. I would clip road-coach horses, and a hunter that had been summered entirely at grass, despairing of condition on any other terms. It is a mere substitute for good grooming. As for its almost universal adoption, such is far from being the case. I did not see three clippcd horses last year (1840); at Melton, in the Quorn stables, not one, nor in Mr. Foljambe's. Singed ones I did see to a certain extent; but a hardy-riding Meltonian told me that he would have no more spirits of wine charged in his groom's book. 'A mere substitute,' said he, 'in my stable for the old-fashioned elbow-grease.' In my opinion the horse is not yet foaled which cannot be got into perfect condition without this outrage on nature." - The Veterinarian, vol. xiv., p. 35. 
and in its substance. It is the difference that is presented to the feeling by well curried and supple leather, and that which has become dry and unyielding.

The surface of the skin becoming dry and hard, the scalcs of the cuticle are no longer penetrated by the hair, but, separating themselves in every direction, givc that peculiar roughness to the coat which accompanies want of condition. It betokens impaired function of the vessels everywhere, and particularly those of the stomach and bowels. Hide-bound is not so much a disease as a symptom of disease, and particularly of the digestive organs; and our remedies must be applied not so much to the skin-although we have, in friction and in warmth, most valuablc agents in producing a healthy condition of the intcguments - as to the cause of the hide-bound, and the state of the constitution generally. Every disease that can affect the general system may produce this derangement of the functions of the skin. Glanders, when become constitutional, is strongly indicated by the unthrifty appearance of the coat. Chronic cough, grease, farcy, and founder, are accompanied by hidc-bound ; and diet too sparing, and not adequate to the work exacted, is an unfailing source of it. If the cause is removed, the effect will cease.

Should the cause be obscure, as it frequently is-should the horse wear an unthrifty coat, and his hide cling to his ribs, without any apparent disease, wc shall generally be warranted in tracing it to sympathy with the actual, although not demonstrable, suspension of some important secrction or function, cither of the alimentury canal or the respiratory functions. A few mashes, and a mild dose of physic, are first indicated, and, simple as they appear to be, they often have a very beneficial effect. The regular action of the bowels being re-established, that of all the organs of the frame will speedily follow. If the horse cannot be spared for physic, alteratives may be administered. There is no better alterative for hide-bound and an unthrifty coat, than that which is in common use, levigated antimony, nitrc, and sulphur. The peculiar effect of the antimony and sulphur, and electric influence on the skin, with that of the sulphur on the bowels, and of the nitre on the urinary organs, will be here advantageously combined.

Should the horsc not feed well, and there is no indication of fever, a slight tonic may be added, as gentian, or ginger ; but in the majority of cases, attended by loss of condition, and an unthrifty coat, and hide-bound, tonics and aromatics should be carefully avoided.

'The cause of the impaired action of the vessels bcing removed, the powers of nature will generally be sufficient, and had better be left to themselves. There are not any more dangerous medicines in common use in the stable, and especially in cases like these, than tonics and cordials. They often arouse to fatal action a tendency to fever that would otherwise have slept, or they produce a state of excitement near akin to fever, and apt to degenerate into it. By the stimulus of a cordial, the secretions may be suddenly roused, and among them, this unctuous secretion from the pores of the slin, so necessary to apparent condition; but the effect soon passes over, and a repetition of the stimulus is necessary - the habit is soon formed - the dose must be gradually increased, and in the mean time the animal is kcpt in a state of dangerous excitement, by which the powers of nature must be eventually impaired.

Friction may be employed with advantagc in the removal of hide-bound. It has repeatedly been shown that this is one of the most efficacious instruments we can use, to call into exercisc tlie suspended energies either of the absorbent or secreting vesscls. Warmth may likewise be had recourse to - not warmth of stable, which has been shown to be so injurions, but warmth arising from exercise, and the salutary, although inexplicable, influence of clipping and singeing. Before this can bc fully considered, the hair by which the skin is covercd must be described.

The base of the bulb whencc the hair procecds being beneath the true skin, it is fasy to perceive that the hair will grow again, although the cuticle may have been destroyed. A good blister, although it may remove the cuticle, and seemingly for a while the hair with it, leaves no lasting trace. Even firing, lightly and skilfully performed, and not penetrating through the skin, leaves not much blemish; but when, in broken knees, the true skin is cut through, or destroyed, there will always remain a spot devoid of hair. 'The method of hastening and perfecting the re-production of the hair, has been described in page $\$ 67$. 


\section{PORES OF THE SKIN.}

Besides the openings already mentioned, through which proeeeds the unctuous fluid that supplies and softens the skin, there are others more numerous, by means of whieh a vast quantity of aqueous fluid escapes, and perspiration is carried on. As in the human being, this aetually exists in a state of health and quietness, although impereeptible; but when the animal is exeited by exercise, or labours under some stages of disease, it beeomes visible, and appears in the form of drops.

This proeess of perspiration is not, however, so far under the eontrol of medieine as in the human being.

We are not aware of any drugs that will eertainly produee it. Warm clothing seems oecasionally to effect $i t$, but this is more in appearanee than reality. The insensible perspiration cannot eseape through the mass of clothing, and assumes a visible form. This, perhaps, is the ease when sheep-skins are applied over the baek and loins in "locked jaw." They produee a good effect, aeting as a warm poultice over the part, and so contributing to relax the inuseular spasms. There are, however, a few medieines, as antimony and sulphur, that have an evident and very considerable effeet on the skin in opening its pores and exeiting its vessels to aetion.

Of the existence of absorbent vessels ' $n$ the skin, or those whieh take up some fluid or substanee, and eonvey it into the eireulation, we have satisfaetory proof. A horse is even more easily salivated than the human being. Salivation has been produeed by rubbing a splint with mereurial ointment, previous to blistering; and a very few drachms rubbed on the inside of the thighs, will probably produee a greater effect than the praetitioner desires.

From some parts of the skin, there are peeuliar seeretions, as that of grease in the heel, and mallenders in the knee.

\section{MOULTING.}

Twice in the year, the hair of the body of the horse is ehanged. The short, fine coat of summer would afford little proteetion agrainst the winter, and that of the winter would be oppressive to the animal, if it appeared during the summer. 'The hair of the mane and tail remains. The bulbous root of the hair does not die, but the pulpy matter seems to be removed from the root of the hair, which, thus deprived of its nourishment, perishes and drops off, and a new hair springs at its side from the same bulb. The hair whieh is produced in the autumn, is evidently different from that whieh grows in the spring; it is eoarser, thieker, and not so glossy as the other. As moulting is a proeess extending over the whole of the skin, and requiring a very considerable expenditure of vital power, the health of the animal is generally affeeted at these times. That energy, and nervous and vital influenee, whieh should support the whole of the frame, is to a great degree determined to the skin, and the animal is languid, and unequal io mueh hard work. He perspires greatly with the least unusual exertion, and if he is pressed beyond his strength, becomes seriously ill.

'The treatment whieh the groom in this ease adopts, is most absurd and dangerous. 'The horse, from the deranged distribution of vital power, is disposed to fever, or he labours under a slight degree of fever, suffieiently indieated by the inereased quiel:ness of pulse, redness of nose, and heat of mouth. The lassitude and want of appetite whieh are the aceompaniments of this febrile state, are mistaken for debility; and eordials of various kinds, some of them exeedingly stimulating, are unsparingly administered. At length, with regard to the hunter, the raeer, and even in the haekney and the carriage horse, the scissors or the lamp are introdueed, and a new method is established of guarding against this periodieal debility, setting at defianee the oecasional exposure to eold, and establishing a degree of health and strength previously unknown. Friction may be allowed, to assist the falling off of the old hair, and to loosen the euticle for the appearanee of the new hair, but it is somewhat more gently applied than it used to be. The eurry-eomb is in a great measure banished, and even the brush is not applied too hard or too long. The old hair is not foreed off before the young hair is ready to take its place.

Nature adapts the eoat to the climate and to the season. 'The Sheltie has one as long and thiek as that of a bear; and, as the summer is short and eold in those northern islands, the eoat is rough and shaggy during the whole of the year. In the soutliern parts of our country, the short, and light and glossy coat of summer gradu- 
ally yields to the close and heary, and warm elothing of winter. In the deserts of Arabia, where the winter is rarely cold, the coat remains short and glossy throughout the year. These are wise and kind provisions of nature, and excite our admiration.

\section{COLOUR.}

The colour of the hair admits of every variety, and each colour becomes in turn fashionable. Like that of the skin, it is influenced by, or depends on, the mucous mesh-work under the cuticle. There are comparatively few perfectly white horses now remaining. The snow-white palfrey, with its round carcass and barb head, originally from Spain, or perhaps from Barbary, and rarely exceeding the size of a galloway, is nearly extinct. Some, however, yet remain in the possession of the Duke of Montrose. They are of good constitution, and pleasant in their paces. The majority of white horses are those that have become so. Light-grey colts begin to grow white before they are five years old, especially if they have not much dark mixturc about the joints.

Grey horses are of different shades, from the lightest silver to a dark iron-grey. The silver-grey reminds the observer of the palfrey, improved by an admixture of Arab blood. He does not often exceed fourteen hands and a half in height, and is round carcassed-thin-legged-with oblique pasterns, calculated for a light carriage, or for a lady's riding - seldom subject to disease - but not very fleet, or capable of liard work.

The iron-grey is usually a larger horse; higher in the withers, deeper and thinner in the carcass, more angular in all his proportions, and in many cases a little too long in the legs. Some of these greys make good hackneys and hunters, and especially the Irish horses; but they are principally used for the carriage. They have more endurance than the flatness of their chest would promise; but their principal defect is their feet, which are liable to contraction, and yet that contraction not so often accompanied by lameness as in many other horses.

The dappled grey is generally a handsomer and a better horse. All the angular points of the iron-grey are filled up, and with that which not only adds to symmetry, but to use. Whether as a hackney, or, the larger variety, a carriage horse, there are few better, especially since his form has been so materially improved, and so much of his heaviness got rid of, by the free use of foreign blood. There are not, however, so many dappled greys as there used to bc, since the bays have been bred with so much care. The dappled grey, if dark at first, generally retains his colour to old age.

Some of the greys approach to a nutmeg, or even bay colour. Many of these are handsome, and most of them are hardy.

The roans, of every variety of colour and form, are composed of white mixed with bay, or red, or black. In some it seems to be a natural mixture of the colours; in others it appears as if one colour was powdered or sprinkled over another. They are pretty horses for ladies or light carriages, and many of them easy in their paces, but they do not usually display much blood, nor are they celebrated for enduranec. If they should have white fore legs, with white hoofs, they are too often tender-footed, or become so with even a little hard work.

The strawberry horse is a mixture of sorrel with white; usually handsome and pleasant, but more celebrated for these qualities than for strength and endurance.

The pied horse is one that has distinct spots or patches of different colours, but generally of white with some other colour. They are not liked as hackncys, on account of their peculiarity of colour, nor in teams of horses; but they look well when tolerably matched in a phaeton or light carriage. Their value must depend on their breed. Of themselves they have no pcculiar character, except that a white leg and foot is as suspicious in them as it is in the roan.

The dun, of the Galloway size, and with considerable blood, is often attached to the curricle or the phaeton. The larger variety is a true farmer's or miller's horse, with no great spced or extraordinary strength, yet a good-tempered, good-feeding, good-constitutioned, useful horse enough. Varieties of the dun, shaded with a darker colour, or dappled, and with some breeding, and not standing too high, are beautiful animals, and much sought after for light carriages.

The cream-colour, of Hanoverian extraction, with his white iris and red pupil, is appropriated to royal use. Attached to the state-carriage of the monarch, he is a superb animal. His bulky, yet perfectly-formed body, his swelling crest, and his 
proud and lofty action, as if conscious of his office, qualify him for the service that is exacted from him, but we have little experience how far he would suit other purposes.

Of the chestnuts there are three varieties-the pale red or the sorrel, usually with some white, eitlier on the face or the legs-generally lightly made, yet some of them bulky cnough for the heaviest loads. Their colour is generally objectionable, and they are supposed to be somewhat deficient in endurancc.

'The light chestnut, with less red and a little more bay or brown, is considered a prefcrable animal, especially if he has little or no white about him; yet even he, although pleasant to ride, is sometimes irritable, and generally weak. We must except one variety, the Suffolk punch; a heavy horse, and adapted for slow work, but perfect of his kind-whom no labour can daunt, no fatigue overcome. This is a breed now, unfortunately, nearly extinct. The present variety, however crossed, is not equal to the old Suffolk.

The dark chestnut is as different a horse from the hackney-like chestnut as can be well imagined; round in the carcase; powerful in the quarters, but rather fine in the legs; possessed of great endurance, and with a constitution that rarely know's an ailment, except that the feet are small and disposed to contraction, and the horse is occasionally of a hot and unmanagcable temper.

Of the bays, there are many varieties, and they include the very best of our horses of every description. 'The bright yellow bay, although very beautiful, and especially if his mane and tail are black, is the least valuable-the lightness of his colour seems to give him some tenderness of constitution. The pure bay, with no white about him, and black from the knees and hocks to the feet, is the most desirable of all. He has generally a good constitution, and good feet; and, if his conformation is not faulty, will turn out a valuable horse for almost cvery purpose.

The bay-brown has not always so much show and action, but, generally, more strength and endurance, and usefulness. He has greater substance than the lighter bay, and more depth of leg; and, if he had the same degree of breeding, he would be as handsome, and more valuable.

When, however, we arrive at the browns, it is necessary to examine the degree of breeding. This colour is not so fashionable, and therefore these horses have been considerably neglected. There are many good ones, and those that are good are valuable; others, probably, are only a half or a quarter bred, and therefore comparatively coarse, yet useful for the saddle and for harness-for slow work, and, occasionally, for that which is more rapid.

The black-brown is generally more neglected so far as its breed is concerned, and should oe more carefully examined. It is valuable if it retains the goodness of constitution of the brown and bay-brown.

of the black, greater care has been taken. The heavy black of Lincolnshire and the midland counties is a noble animal, and would be almost beyond price if he could be rendered more active. The next in size constitute the majority of our wagonlorses, and perhaps our best; and, on a smaller breed, and to the improvement of which much attention has been devoted, many of our cavalry are mounted. A few black thorough-bred horses and black hunters are occasionally seen, but the improvement of horses of this colour has not been studied, except for the purposes that have been mentioned. Their peculiar high action, while not objectionable for draught, and desirable for the parade, wonld be unbearable in the roadster. Black horses have been said to be more subject to vice, disease, and blindness, than those of any other colour. 'This charge is not true to its full extent; but there certainly are a great many worthless black horses in every part of the country.

After all, there is an old saying, that a good horse cannot be of a bad colour; and that it is far more necessary to attend to the conformation and points of the animal than to his colour. The foregoing observations, however, although they admit of many exceptions, may be useful in guiding to the judicious purchase of the horse.

\section{SURFEIT.}

Large pimples or eruptions often appear suddenly on the skin of the horse, and especially in the spring of the year. Occasionally they disappear as quickly as they came. Sometimes they seem to be attended with great itching, but, at other times, the annoyance is comparatively little. When these eruptions have remained a few days, the cuticle frequently peels off, and a small scaly spot-rarely a sore-is left. 
This is called a surfeit, from its resemblance to some eruptions cn the skin of the human being when indigestible or unwholesome food has been taken. The surfeit is, in some cases, confined to the neck ; but it oftener spreads over the sides, back, loins, and quarters. The cause is enveloped in some obscurity. The disease most frequently appears when the skin is irritable during or after the process of moulting, or when it sympathises with any disorder of the stomach. It has been known to follow the eating of poisonous herbs or mowburnt hay, but, much oftener, it is to be traced to exposure to cold when the skin was previously irritable and the horse heated by exercise. It has also been attributed to the immoderatc drinking of cold water when the animal was hot. It is obstruction of some of the pores of the skin and swelling of the surrounding substance, either from primary affection of the skin, or a plethoric state of the system, or sympathy with the digestive organs.

The state of the patient will sufficiently guide the surgeon as to the course he should pursue. If there is simple eruption, without any marked inflammatory action, alteratives should be resorted to, and particularly those recommended for hidebound in page 476. They should be given on several successive nights. The night is better than the morning, because the warmth of the stable will cause the antimony and sulphur to act more powerfully on the skin. The horse should be warmly clothedhalf an hour's walking exercise should be given, an additional rug being thrown over him-such green meat as can be procured should be used in morlerate quantities, and the chill should be taken from the water.

Should the eruption continue or assume a more virulent character, bleeding and aloetic physic must be had recourse to, but neither should be carried to any extreme. The physic having set, the alteratives should again be had recourse to, and attention should be paid to the comfort and diet of the horsc.

If the eruption, after several of these alternate appearances and disappearances, should remain, and the cuticle and the hair bcgin extensively to peel off, a worse affection is to be feared, for surfeit is too apt to precede, or degenerate into, mange. This disorder, therefore, must next be considered.

\section{MANGE}

Is a pimpled or vesicular eruption. After a while the vesicles break, or the cuticle and the hair fall off, and there is, as in obstinate surfeit, a bare spot covered with scurf-some fluid oozing from the skin beneath, and this changing to a scab, which likewise soon peels off, and leaves a wider spot. This process is attended by considerable itching and tenderness, and thickening of the skin, which soon becomes more or less folded, or puckered. The mange generally first appears on the neck at the root of the mane, and its existence may be suspected even before the blotches appear, and when there is only considerable itchiness of the part, hy the esse with which the short hair at the root of the mane is plucked out. From the neck it spreads upward to the head, or downward to the withers and back, and occasionally extends over the whole carcass of the horse.

One cause of it, although an unfrequent one, has been stated to be neglected or inveterate surfeit. Several instances arc on record in which poverty of condition, and general neglect of cleanliness, preceded or produced the most violent mange. A remark of Mr. Blaine is very important:- "Among the truly healthy, so far as my experience goes, it rever arises spontaneously, but it does readily from a spontaneous origin among the unhealthy." "The most common cause is contagion. Amidst the whole list of diseases to which the horse is exposed, there is not one more highly contagious than mange. If it once gets into a stable, it spreads through it, for the slightest contact seems to be sufficient for the communication of this noisome complaint.

If the same brush or currycomb is used on all the horses, the propagation of mange is assured; and horses feeding in the same pasture with a mangy one rarely escape, from the propensity they have to nibble one another. Mange in cattle has been propagated to the horse, and from the horse to cattle. There are also some well-authenticated instances of the same disease being communicated from the dog to the horse, but not from the horse to the dog.

Mange has been said to originate in want of cleanliness in the management of the stable. The comfort and the health of the horse demard the strictest cleanliness. The eyes and the lungs frequontly suffer from the noxicus fumes of the putrefying 
dung and urine; but, in defiance of common prejudice, there is no authentic instance of mange being the result. It may, however, proceed from poverty. When the ani$\mathrm{mal}$ is half starved, and the functions of digestion and the power of the constitution are weakened, the skin soon sympathises, and mange is occasionally produced instead of surfeit and hide-bound. Every farmer has proof enough of this being the case. If a horse is turned on a common where there is scarcely sufficient herbage to satisfy his appetite, or if he is placed in one of those straw-yards that are under the management of mercenary and unfeeling men, and are the very abodes of misery, the animal comes up a skeleton, and he comes up mangy too. Poverty and starvation are fruitful sources of mange, but it does not appear that filth has much to do with it, although poverty and filth generally go hand in hand.

The propriety of bleeding in cases of mange depends on the condition of the patient. If mange is the result of poverty, and the animal is much debilitated, bleeding will increase the evil, and will probably deprive the constitution of the power of rallying. Physic, however, is indispensable in every case. It is the first step in the progress towards cure. A mercurial ball will be preferable to a common aloetic one, as more certain and effectual in its operation, and the mercury probably having some influence in mitigating the disease. In this, however, mange in the horse resembles itch in the human being-medicine alone will never effect a cure. There must be some local application. There is this additional similarity-that which is most effectual in curing the itch in the human being must form the basis of every local application for the cure of mange in the horse. Sulphur is indispensable in every unguent for mange. It is the sheet-anchor of the veterinary surgeon. In an early and not very acute state of mange, equal portions of sulphur, turpentine, and train-oil, gently but well rubbed on the part, will be applied with advantage. Farriers are fond of the black sulphur, but that which consists of earthy matter, with the mere dregs of various substances, cannot be so effectual as the pure sublimed sulphur. A tolerably stout brush, or even a currycomb, lightly applied, should be used, in order to rcmove the dandriff or sciurf, wherever there is any appearance of mange. After that, the horse should be washed with strong soap and water as far as the disease has extended; and, when he has been thoroughly dried, the ointment should be well rubbed in with the naked hand, or with a piece of flannel. More good will be done by a little of the ointment being well rubbed in, than by a great deal being merely smeared over the part. 'The rubbing should be daily repeated.

The sulphur seems to have a direct influence on the disease-the turpentine has an indirect one, by exciting some irritation on the skin of a different nature from that produced by the mange, and under the influence of which the irritation of mange will be diminished, and the disease more easily combated. During the application of the ointment, and as soon as the physic has set, an alterative ball or powder, similar to those recommended for the other affections of the skin, should be daily given. If, after some days have passed, no progress should appear to have been made, half a pound of sulphur should be well mixed with a pint of oil of tar, or, if that is not to be obtained, a pint of Barbadoes tar, and the affected parts rubbed, as before. On every fifth or sixth day the ointment should be washed off with warm soap and water. The progress towards cure will thus be ascertained, and the skin will be cleansed, and its pores opened for the more effectual application of the ointment.

The horse should be well supplied with nourishing, but not stimulating food. As much green meat as he will eat should be given to him, or, what is far better, he should be turned out, if the weather is not too cold. It may be useful to add, that, after the horse has been once well dressed with either of these liniments, the danger of contagion ceases. It is necessary, however, to be assured that every mangy place has been anointed. It will be prudent to give two or three dressings after the horse has becn apparently cured, and to continue the alteratives for ten days or a fortnight.

The cure being completed, the clothing of the horse should be well soaked in water, to which a forticth part of the saturated solution of the chloride of lime has been added; after which it should be washed with soap and water, and again washed and soaked in a solution of the chloride of lime. Every part of the harriess should undergo a similar purification. The currycomb may be scoured, but the brush should be burned. The rack, and manger, and partitions, and every part of the stable which the horse could possibly have touched, should be well washed with a hair-broom-a pint of the chloride of lime being added to three gallons of water. All the. wood- 
work should then be scoured with soap and water, after which a second washing with the chloride of lime will render all secure. Some farmers have pulled down their stables, when they have been thoroughly infected with mange. This is being unnecessarily cautious. The efficacy of the chloride of lime was not then known; but if that is carefully and sufficiently applied to every part of the stable and its furniture, there cannot afterwards be danger.

Every case of itchiness of the skin should be regarded with suspicion. When a horse is seen to rub the root of his tail, or his head, or neck, against the manger, the parts should be carefully examined. Some of the hair may have been rubbed or torn of, but if the roots remain firmly adherent, and there is only redness and not scurfiness of the skin, it probably is not mange, but only inflammation of the skin, from too great fulness of blood. A little blood should be abstracted-a purgative administered-and the alteratives given. 'The mange ointment cannot do harm, and may possibly prevent this heat of the skin from degenerating into mange, or arrest the progress of mange if it has commenced. If a scurfiness of skin should appear on any of the points that are pressed upon by the collar or harness, the veterinary surgeon will do right to guard against danger by alterative medicine and the use of the ointment.

\section{WARTS.}

'Tliese are tumours of variable size, arising from the cuticle, and afterwards connected with the true skin by means of the vessels which supply the grow th of the tumours. They are found on the eyelids, the muzzle, the ears, the belly, the neck, the penis, and the prepuce. There are some caustics available, but frequently they must be removed by an operation. If the root is very small, it may be snipped asunder, close to the skin, with a pair of scissors, and touched with the lunar caustic. If the pedicle or stem is somewhat larger, a ligature of waxed silk should be passed firmly round it, and tightened every day. The source of nutriment being thus removed, the tumour will, in a short time, die and drop off. If the warts are large, or in considerable clusters, it will be necessary to cast the horse, in order to cut them off close to the skin: the root should then be seared with a red-hot iron. Unless these precautions are used, the warts will speedily sprout again.

\section{VERMIN.}

Both the biped and the quadruped are subject to the visitation of insects, that fasten on the skin, and are a constant nuisance from the itchiness which they occasion. If the horse, after being turned out for the winter, is taken up in the spring, long and rough in his coat, and poor in condition, and with evident hide-bound, he will almost invariably be aflicted with vermin.

In our present imperfect acquaintance with natural history, it is difficult to account for the appearance of certain insects, and of those alone, on the integument of one animal, while others of an altogether different character are found on its neighbour. Fach one has a tormentor peculiar to itself.

The vermin of the horse is destroyed by an infusion of tobacco, or a solution of corrosive sublimate, the latter requiring the greatest caution. The skin being once eleansed of them, an attention to cleanliness will prevent their reappearance.

\section{CHAPTER XXII.}

\section{ON SOUNDNESS, AND THE PURCHASE AND SALE OF HORSES.}

There are ferw sources of greater annoyance both to the purchaser and the seller of the horse than disputes with regard to the soundness of the animal. Although, in describing the various parts of the horse, we have glanced at the connexion of certain natural conformations, and some alterations of structure, and accidents, and diseases, with the question of soundness or unsoundness, it may not be uninteresting to those for whom our work is designed, if we now bring into one point of view the substance of that which has been scattered over many pages.

That horse is sound in whom there is no disease, and no alteration of structure that 
impairs, or is likcly to impair, his natural uscfulness. The horse is unsound that labours under disease, or has some alteration of structure which does interfere, or is likely to interfere, with his natural usefulness.* The term "natural usefulness" must be borne in mind. One horse may posscss great speed, but is soon knocked up; another will work all day, but cannot be got beyond a snail's pace: a third with a heavy forehand is liable to stumble, and is continually putting to hazard the neck of his rider; another, with an irritable constitution and a loose, washy form, loses his appetite and begins to scour if a little extra work is exacted from him. The term unsoundness inust not be applied to either of these; it would be opening far too widely a door to disputation and endless wrangling. The buyer can discern, or ought to know, whether the form of the horse is that which will render him likely to suit his purpose, and he should try him sufficiently to ascertain his natural strength, endurance, and manner of going. Unsoundness, we repeat, has reference only to disease, or to that alteration of structure which is connected with, or will produce disease, and lessen the usefulness of the animal.

'These principles will be best illustrated by a brief consideration of the usually supposed appearances or causes of unsoundness.

BROKEN KNEES ccrtainly do not constitute unsoundness, after the wounds are healed, unless they interfere with the action of the joint; for the horse may have fallen from merc accident, or through the fault of the rider, without the slightest damage more than the blemish. No person, however, would buy a horse with broken knees, until he had thoroughly tried him, and satisficd himself as to his form and action.

CAPPED HOCKs may be produced by lying on an unevenly paved stable, with a scanty supply of litter, or by kicking generally, in neither of which cases would they constitute unsoundness, although in the latter they would be an indication of vice; but, in the majority of instances, they are the consequence of sprain, or of latent injury of the hock, and accompanied by enlargement of it, and would constitute unsoundness. A special warranty should always be taken against capped hocks.

Contraction is a considerable deviation from the natural form of the foot, but not necessarily constituting unsoundness. It requires, however, a most careful examination on the part of the purchaser or veterinary surgeon, in order to ascertain that there is no heat about the quarter, or ossification of the cartilage-that the frog, although diminished in sizc, is not diseased-that the horse does not step short and go as if the foot werc tender, and that there is not the slightest trace of lameness. Unless these circumstances, or some of them, arc detccted, a horse must not be pronounced to be unsound because his feet are contracted; for many horses with strangely contracted feet do not suffer at all in their action. A special warranty, however, should be required where the feet are at all contracted.

Corss manifestly constitute unsoundness. The portion of the foot in which bad corns are situated will not bear the ordinary pressure of the shoe; and accidental additional pressure from the growing down of the horn, or the introduction of dirt or gravcl, will cause serious lameness. They render it necessary to wear a thick and heavy shoe, or a bar shoe, in order to protect the weakened and diseased part; and they are very seldom radically cured. There may be, however, and frequently is, a difference of opinion as to the actual existence or character of the corn. A veterinary surgeon may consider it so slight and insignificant as not ap parently to injure the horse, and he pronounces the animal to be sound; but he should be cautious, for there are corns of every shade and degree, from the slightest degree to the most serious evil. They may be so slight and manageable as, though ranging under the class of morbid altcration of structure, yet not to diminish the natural usefulness of the horse in any degrec. Slight corns will disappear on the horse being shod with ordinary skill and care, even without any alteration in the shoe.

* Sinee the publication of our first edition, this definition or rule as to soundness or unsoundness has received very higli judicial sanction, Coates v. Stephens, 2 Moody and Robinson, 157; Scholeficld v. Robb, id. 210 . We shall adhere to it as our test of soundness or unsoundness throughout this chapter, not forgetting what is said in the following extract from a note to one of these cases. "As it may now be considered as settled law, that the breach of a warranty of soundness does not entitle the purchaser to return the horse, but only to reeover the difference of value of the horse with or without the partieular unsoundness, the question of temporary maladies, producing no permanent deterioration of the animal, would, generally speaking, only involve a right to damages nerely nominal." 
Covgr.-This is a disease, and consequently unsoundness. However slight may be its degree, and of whatever short standing it may be, although it may sometimes scarcely seem to interfere with the usefulness of the horse, yet a change of stabling, or slight exposure to wet and cold, or the least over-exertion, may, at other times, cause it to degenerate into many dangerous complaints. A horse, therefore, should never be purchased with a cough upon him, without a special warranty; or if - the cough not being observed-he is purchased under a general warranty, that warranty is thereby broken. It is not law, that a horse may be returned on breach of the warranty. The seller is not bound to take him back, unless he has contracted so to do; but he is liable in damages. Lord Ellenborough has completely decided this matter. "I have always held," said he, "that a warranty of soundness is broken, if the animal, at the time of sale, had any infirmity upon him that rendered him less fit for present service. It is not necessary that the disorder should be permanent or incurable. While he has a cough, he is unsound, although that may either be temporary or prove mortal."*

Roaring, Wheezing, Whistling, High-Blowing, and Grunting, being the result of alteration of structure, or disease in some of the air-passages, and interfering witl the perfect freedom of breathing, especially when the horse is put on his speed, without doubt constitute unsoundness. There are decisions to the contrary, which are now universally admitted to be erroneous. BROKEN wind is still more decidedly unsoundness.

CR1B-B1T1NG.-Although some learned judges have asserted that crib-biting is simply a trick or bad habit, it must be regarded as unsoundness. This unnatural sucking in of the air must to a certain degree injure digestion. It must dispose to colic, and so interfere with the strength, and usefulness, and health of the horse. Some cribbiters are good goers, but they probably would have possessed more endurance had they not acquired this habit; and it is a fact well established, that, as soon as a horse becomes a crib-biter, he, in nine cases out of ten, loses condition. $\mathrm{He}$ is not to the experienced eye the horse he was before. It may not lead on to strongly-marked disease, or it may rarely do so to any considerable degree; but a horse that is morbidly deficient in condition must, to that extent, have his capability for extraordinary work diminished, and so be brought within our definition of unsoundness. In its very early stage it may be a mere trick-confirmed, it must have produced morbid deterioration. The wear of the front teeth, and the occasional breaking of them, make a horse old before his time, and sometimes render it difficult or almost impossible for him to graze, when the state of the animal or the convenience of the owner requires that he should be turned out.

CUrв constitutes unsoundness while it lasts, and perhaps while the swelling remains, although the inflammation may have subsided; for a horse that has once thrown out a curb is, for a while at least, very liable to do so again, to get lame in the same place on the slightest extra excrtion; or, at all events, he would there first

* In deciding on another case, the same judge said, "I have always held it that a cough is a breach of the warranty. On that understanding I have always acted, and think it quite clear." It was argued on the other hand that two-thirds of the horses in London had coughs, yet still the judge maintained that the cough was a breach of warranty. When it was farther argued that the horse had been hunted the day after the purchase, and the cough might have bcen increased by this, the reply was singular, but decisive. "There is no proof that he would have got well if he had not bcen huntcd." This doctrine is confirmed by Parke, B., in the first case cited in p. 391 .

In p. 194 , it is very propcrly stated that roaring is unsoundness, because it impairs the func. tion of rcspiration. This was not always, however, the law of the bench. "Lord Ellenborough," quoting from Sir James Mansfield, says, "It has been held by very high authority that roaring is not necessarily unsoundness, and I entirely concur in that opinion. If the horse emits a loud noise, which is offensive to the ear, merely from a bad habit which he has contracted, or from any cause that does not interfcre with his general health, or muscular powers, he is still to be considered a souud horse. On the other hand, if the roaring proceeds from any disease or organic infirmity, which renders him incapable of performing the usual functions of a horsc, then it does constitute unsoundness. The plaintiff has not done enough in showing that this horse was a roarer. To prove a breach of the warranty he must go on to show that the roaring was symptoniatic of disease." These extracts are taken from a singular work, not always correct, yet from which much amusement, and instruction too, may be derived-"The Adventures of a Gentleman in Search of a Horse, by Caveat Emptor." 
fail on extraordinary cxertion. A horse, however, is not returnable, although he should spring a curb five minutes after the purchase; for it is done in a moment, and does not necessarily indicate any previous unsoundness or weakness of the part.

CurTinc, as rendering a horse liable to serious injury of the legs, and indicating that he is either weak, or has an awkwardness of gait inconsistent with safety, produces, rather than is, unsoundness. Many horses go lame for a considerable period after cutting themselves severely; and others have dropped from the sudden agony, and endangered themselves and their riders. As some doubt, however, exists on this subject, and as it is a very material objection to a horse, cutting, when evident, should have its serious consequences provided against by a special warranty.

EnLarged Glands.-The enlargement of the glands under the jaw has not been so much considered as it ought to have bcen in our estimate of the soundness of the horse. Simple catarrh will occasionally, and severe affection of the chest will generally, be accompanied by swelling of these glands, which docs not subside for a considerable time after the cold or fever has apparently been cured. To slight enlargements of the glands under the jaw much attention need not be paid; but if they are of considerable size, and especially if they are tender, and the glands at the root of the ear partake of the enlargement, and the membrane of the nose is redder than it should be, we should hesitate in pronouncing that horse to be sound. We must consider the swelling as a symptom of disease.

Enlarged Hock. - A horse with enlarged hock is unsound, the structure of this complicated joint being so materially affected that, although the horse may appear for a considerable time to be capable of ordinary work, he will occasionally fail even in that, and a few days' hard work will always lame him.

The Eves.-That inflammation of the eye of the horse which usually terminates in blindness of one or both eyes, has the peculiar character of receding or disappearing for a time, once or twice, or thrice, before it fully runs its course. The eye, after an attack of inflammation, regains so nearly its former natural brilliancy that a person even well acquainted with horses will not always recognise the traces of former disease. After a time, however, the inflammation returns, and the result is inevitable. A horse that has had one attack of this complaint, is long afterwards unsound, however perfect the eye may seem to be, because he carries about with him a disease that will probably again break out, and eventually destroy the sight. Whether, therefore, he may be rejected or not, depends on the possibility of proving an attack of inflammation of the eye, prior to the purchase. Next to direct evidence of this are appearances about the eye, of which the veterinary surgeon at least ought not to be ignorant. Allusion has been made to them in page 89. 'They consist chiefly of a puckering of the lids towards the inner corner of one or both eyes - a difference in the size of the cyes, although perhaps only a slight one, and not discovered except it be looked for-a gloominess of the eye-a dulness of the iris-a little dulness of the transparent part of the eye generally - a minute, faint, dusky spot, deep in the eye, and generally with little radiations of white lines proceeding from it. If these symptoms, or the majority of them, existed at the time of purchasc, the animal had assuredly been diseased before, and was unsound. Starting has becn considered as an equivocal pronf. It is usually an indication of defective sight, but it is occasionally a trick. Connected, however, with the appearances just described, it is a very strong corroborative proof.

LAMENEss, from whatever cause arising, is unsoundness. However temporary it may be, or however obscure, there must be disease which lessens the utility of the horse, and renders him unsound for the time. So says common sense, but there are contradictory decisions on the case. "A horse labouring under a temporary injury of hurt, which is capable of being speedily cured or removed, is not, according to Chief Justice Eyre, an unsound horse; and where a warranty is made that such a horse is sound, it is made without any view to such an injury; nor is a horse so circumstanced within the meaning of the warranty. To vitiate the warranty, the injury the horse had sustained, or the malady under which he laboured, ought to he of a permanent nature, and not such as may arise from a temporary injury or accident." **

On the contrary, Lord Ellenborough says: "I have always held, and now hold, that a warranty of soundness is broken, if the animal at the time of sale has any

* 2 Espin. Rep. 673, Garment v. Barrs. 
infirmity upon him which renders him less fit for present service. It is not necessary that the disorder should be permanent or incurable. While a horse has a cough he is unsound, although it may either be temporary or may prove mortal. The horse in question having been lame at the time of sale, when he was warranted to be sound, his condition subsequently is no defence to the action."* The decisions of Mr. Baron Parke, already referred to, confirm this doctrine.

Neurotony.-A question has arisen how far a horse that has undergone the operation of the division of the nerve of the leg (see p. 111), and has recovered from the lameness with which he was before affected, and stands his work well, may be considered to be sound. Chief Justice Best held such a horse to be unsound, and in our opirion there cannot be a doubt about the matter. The operation of neurotomy does not remove the disease causing the lameness, but only the sensation of pain. A horse on whom this operation has been performed may be improved by it-may cease to be lame-may go well for many years; but there is no certainty of this, and he is unsound, within our definition, unless nature gave the nerve for no useful purpose.

Ossification of THE lateral Cartilages constitutes unsoundness, as interfering with the natural expansion of the foot, and, in horses of quick work, almost invariably producing lameness.

PUMICED-FOOT.-When the union between the horny and sensible laminæ, or little plates of the foot (see p. 304), is weakened, and the coffin-bone is let down, and presses upon the sole, and the sole yields to this unnatural weight, and becomes rounded, and is brought in contact with the ground, and is bruised and injured, that horse must be unsound, and unsound for ever, because there are no means by which we can raise the coffin-bone again into its place.

QuidDing.- If the mastication of the food gives pain to the animal, in consequence of soreness of the mouth or throat, he will drop it before it is perfectly chewed. 'This, as an indication of disease, constitutes unsoundness. Quidding sometimes arises from irregularity in the teeth, which wound the cheek with their sharp edges; or a protruding tooth renders it impossible for the horse to close his jaws so as to chew his food thoroughly. Quidding is unsoundness for the time; but the unsoundness will cease when the teeth are properly filed, or the soreness or other cause of this imperfect chewing removed.

QuiT'ToR is manifestly unsoundness.

RiNG-Bone.- Although when the bony tumour is small, and on one side only, there is little or no lameness - and there are a few instances in which a horse with ringbone has worked for many years without its return - yet from the action of the foot, and the stress upon the part, the inflammation and the formation of bone may acquire a tendency to spread so rapidly, that we must pronounce the slightest enlargement of the pasterns, or around the coronet, to be a cause of unsoundness.

SandCrack is manifestly unsoundness. It may, however, occur without the slightest warning, and no horse can be rejected on account of a sandcrack that has sprung after purchase. Its usual cause is too great brittleness of the crust of the hoof; but there is no infallible method of detecting this, or the degree in which it must exist in order to constitute unsoundness. When the horn round the bottom of the foot has chipped off so much that only a skilful smith can fasten the shoe without pricking the horse, or even when there is a tendency in the horn to chip and break in a much less degree than this, the horse is unsound, for this brittleness of the crust is a disease of the part, or it is such an altered structure of it as to interfere materially with the usefulness of the animal.

SPAviN.-Bone spavin, comprehending in its largest sense every bony tumour on the hock, is not necessarily unsoundness. If the tumour affects in the slightest degree the action of the horse, it is unsoundness; - even if it does not, it is seldom safe to pronounce it otherwise than unsoundness. But it may possibly be (like splint in the fore-leg) so situated as to have no tendency to affect the action. A veterinary surgeon consulted on the purchase will not always reject a horse because of such a tumour. His evidence on a question of soundness will depend on the facts. The situation and
history of the tumour may be such as to enable him to give a decisive opinion in a
horse going sound, but not often. horse going sound, but not often.

Bog or BLood Spavin is unsoundness, because, although it may not be productive

\footnotetext{
* 4 Campbell, 251, Elton v. Brogden.
} 
of lameness at slow work, the rapid and powerful action of the hock in quicker motion will produce permanent, yet perhaps not considerable lameness, which can scarcely ever be with certainty removed.

SpLinT.-It depends entirely on the situation of the bony tumour on the shank-bone, whether it is to be considered as unsoundness. If it is not in the neighbourhood of any joint, so as to interfere with its action, and if it does not press upon any ligament or tendon, it may be no cause of unsoundness, although it is often very unsightly. In many cases it may not lessen the capability and value of the animal. This has been treated on at considerable length in page 268 .

Stringhalt.-This singular and very unpleasant action of the hind leg cannot be termed unsoundness. It is an irregular communication of nervous energy to some muscle of the thigh, observable when the horse first comes from the stable, and gradually ceasing on exercise. It has usually becn accompanied by a more than common degree of strength and endurance. It must, however, be traced to some morbid alteration of structure or function; and it rarely or never fails to deteriorate and gradually wear out the animal.

Tinickening of the Back Sinews.- Sufficient attention is not always paid to the fineness of the legs of the horse. If the flexor tendons have been sprained, so as to produce considerable thickening of the cellular substance in which their sheaths are enveloped, they will long afterwards, or perhaps always, be liable to sprain, from causes by which they would otherwise be scarcely affected. The continuance of any considerable thickness around the sheaths of the tendons indicates previous and violent sprain. 'This very thickening will fetter the action of the tendons, and, after much quick work, will occasionally renew the inflammation and the lameness; therefore, such a horse cannot bc sound. It requires, however, a little discrimination to distinguish this from the gumminess or roundness of leg, peculiar to some breeds. 'There should be an evident difference between the injured leg and the other.

Thoroughis, except it is of great size, is rarely productive of lameness, and therefore cannot be termed unsoundness; but as it is the consequence of hard work, and now and then does produce lameness, the hock should be most carefully examined, and there should be a special warranty against it.

Thrush.-There are various cases on record of actions on account of thrushes in horses, and the decisions have been much at variance, or perfectly contradictory. 'Thrush has not been always considered by legal men as unsoundness. We, however, dccidedly so consider it; as being a disease interfering and likely to interfere with the usefulness of the horse. Thrush is inflammation of the lower surface of the inner or sensible frog-and the secretion or throwing out of pus-almost invariably accompanied by a slight degree of tenderness of the frog itself, or of the heel a little above it, and, if neglected, leading to diminution of the substance of the frog, and separation of the horn from parts beneath, and underrunning, and the production of fungus and canker, and, ultimately, a diseased state of the foot, destructive of the present, and dangerous to the future usefulness of the horse.

Windgalis.- There are few horses perfectly free from windgalls, but they do not interfere with the action of the fetlock, or causc lameness, except when they are numerous or large. 'They constitute unsoundness only when they cause lamencss, or are so large and numerous as to render it likely that they will canse it.

In the purchase of a horse the buyer usually receives, embodied in the receipt, what is termed a warranty. It should be thus expressed :-

"Received of A. B. forty pounds for a grey marè, warranted only five years old, sound, free from vice, and quiet to ride and drive. " $£ 40$.

"C. D."

A receipt, including merely the word "warranted," extends only to soundness,"warranted sound" goes no farther; the age, freedom from vice, and quietncss to ride and drive, should be especially named. This warranty comprises evcry cause of unsoundness that can be detected, or that lurks in the constitution at the time of sale, and to every vicicus habit that the animal has hitherto shown. To establish a breach of the warranty, and to be enabled to tender a return of the horse and recover the diffcrence of price, the purchaser must prove that it was unsound or viciously disposed at the time of sale. In case of cough, the horse must have been heard to cough immediately after the purchase, or as he was led home, or as soon as he had entered 
the stable of the purchaser. Coughing, even on the following morning, will not be sufficient; for it is possible that he might have caught cold by change of stabling. If he is lame, it must be proved to arise from a cause that existed before the animal was in the purchaser's possession. No price will imply a warranty, or be equivalent to one; there must be an express warranty. A fraud must be proved in the seller, in order that the buyer may be enabled to return the horse or maintain an action for the price. The warranty should be given at the time of sale. A warranty, or a promise to warrant the horse given at any period antecedent to the sale, is invalid; for horseflesh is a very perishable commodity, and the constitution and usefulness of the animal may undergo a considerable change in the space of a few days. A warranty after the sale is invalid, for it is given without any legal consideration. In order to complete the purchase, there must be a transfer of the animal, or a memorandum of agreement, or the payment of earnest-money. The least sum will suffice for earnest. No verbal promise to buy or to scll is binding without one of these. The moment either of these is effected, the legal transfer of property or delivery is made, and whatever may happen to the horse, the seller retains, or is entitled to the money. If the purchaser exercises any act of ownership, by using the animal withont leave of the vendor, or by having any operation performed, or any medicines given to him, lic makes him his own. The warranty of a servant is considered to be binding on the inaster.*

If the horse should be afterwards discovered to liave been unsound at the time of warranty, the buyer may tender a return of it, and, if it be not taken back, may bring his action for the price; but the seller is not bound to rescind the contract, unless he has agreed so to do.

Although there is no legal compulsion to give immediate notice to the seller of the discovered unsoundness, it will be better for it to be done. The animal should then be tendered at the house or stable of the vendor. If he refuses to receive him, the animal may be sent to a livery-stable and sold; and an action for the difference in price may be brought. The keep, however, can be recovered only for the time that necessarily intervened between the tender and the determination of the action. It is not legally necessary to tender a return of the horse as soon as the unsoundness is discovered. The animal may be kept for a reasonable time afterwards, and even proper medical means used to remove the unsoundness; but courtesy, and indecd justice, will require that the notice should be given as soon as possible. Although it is stated, on the authority of Lord Loughborongh, that "no length of time elapsed after the sale will alter the nature of a contract originally false," yet it seems to have been once thought it was necessary to the action to give notice of the unsoundness in a reasonable time. The cause of action is certainly complete on breach of the warranty.

It used to be supposed that the buyer had no right to have the horse medically treated, and that he would waive the warranty by doing so. The question, however, would be, has he injured or diminished the value of the horsc by this treatment? It will generally be prudent for him to refrain from all medical treatment, because the means adopted, however skilfully employed, may have an unfortunate effect, or may he misrepresented by ignorant or interested observers.

The purchaser possibly may like the horse, notwithstanding his discovered defect, and he may retain, and bring his action for the depreciation in value on account of the unsoundness. Few, however, will do this, because his retaining the horse will cause a suspicion that the defect was of no great consequence, and will give rise to much cavil about the quantum of damages, and after all, very slight damages will probably be obtained. "I take it to be clear law," says Lord Eldon, " that if a person purchases a horse that is warranted, and it afterwards turns out that the horse was unsound at the time of the warranty, the buyer may, if he pleases, keep the horse, and bring an action on the warranty; in which he will have a right to recover the difference between the value of a sound horse, and one with such defects as existed at the time of warranty; or he may return the horse, and bring an action to recover the full money paid : but in the lattcr case, the seller has a right to expect that the horse shall be returned to him in the same state he was when sold, and not

- The weight of authority decides that the master is bound by the act of the servant. Lord Kenyon, however, had some doubt on the subject. 
by any means diminished in value; for if a person keeps a warranted article for any length of time after discovering its defects, and when he returns it, it is in a worse state than it would have been if returned immediately after such discovery, I think the party can have no defence to an action for the price of the article on the ground of non-compliance with tho warranty, but must be left to his action on the warranty to recover the difference in the value of the article warranted, and its value when sold."**

Where there is no warranty, an action may be brought on the ground of fraud; but this is very difficult to be maintained, and not often hazarded. It will be necessary to prove that the dealer knew the defect, and that the purchaser was imposed upon by his false representation, or other fraudulent means. If the defect was evident to every eye, the purchaser has no remedy - he should have taken more care; but if a warranty was given, that extends to all unsoundness, palpable or concealed. Although a person should ignorantly or carelessly buy a blind horse, warranted sound, he may reject it-the warranty is his guard, and prevents him from so closely examining the horse as he otherwise would have done; but if he buys a blind horse, thinking him to be sound, and withont a warranty, he has no remedy. Every one ought to excrcise common circumspection and common sense.

A man should have a more perfect knowledge of horses than falls to the lot of most, and a perfect knowledge of the vendor too, who ventures to buy a horse without a warranty.

If a person buys a horse warranted sound, and discovering no defect in hin, and, relying on the warranty, re-sclls him, and the unsoundness is discovered by the second purchaser, and the horse returned to the first purchaser, or an action commenced against him, he has his claim on the first seller, and may demand of him not only the pricc of the horse, or the difference in value, but every expense that may have been incurred.

Absolute exchanges, of one horse for another, or a sum of money being paid in addition by one of the parties, stand on the same ground as simple sales. If there is a warranty on either side, and that is broken, an action may be maintained: if there be no warranty, deceit must be proved.

The trial of horses on sale often leads to disputes. The law is perfectly clear, but the application of it, as in other matters connected with horse-flesh, attended with glorious uncertainty. 'The intended purchaser is only liable for damage done to the horse through his own misconduct. The seller may put what restriction he chooses on the trial, and takes the risks of all accidents in the fair use of the horse within such restrictions.

If a horse from a dealer's stable is galloped far and fast, it is probable that he will soon show distress; and if he is pushed farther, inflammation and death may ensue. The dealer rarely gets recompensed for this; nor ought he, as he knows the unfitness of his horse, and may thank himsclf for permitting such a trial; and if it should occur soon after the sale, he runs the risk of having the horse returned, or of an action for its price.

In this, too, he is not much to be pitied. The mischievous and fraudulent practice of dealers, especially in London, of giving their horses, by overfeeding, a false appearance of muscular substance, leads to the ruin of many a valuable animal. It would be a useful lesson to have to contest in an action or two the question whether a horse overloaded with fat can be otherwise than in a state of disease, and consequently unsound.

It is proper, however, to put a limit to what has been too frequently asserted from the bench, that a liorse warranted sound must be taken as fit for immediate use, and capable of being immediately put to any fair work the owner chooses. A hunter honestly warranted sound is certainly warranted to be in immediate condition to follow the hounds. The mysteries of condition, as has been shown in a former part of the work, are not sufficiently unravelled.

In London, and in most great towns, there are repositories for the periodical sale of horses by auction. They are of great convenience to the seller who can at once gret rid of a horse with which he wishes to part, without waiting month after month before he obtains a purchaser, and he is relieved from the nuisance or fear of having 
ME D I C I N E.

the animal returned on account of breach of the warranty, because in these places only two days are allowed for the trial, and if the horse is not returned within that period, he cannot be afterwards returned. They are also convenient to the purchaser, who can thus in a large town soon find a horse that will suit him, and which, from this restriction as to returning the animal, he will obtain twenty or thirty per cent. below the dealers' prices. Although an auction may seem to offer a fair and open competition, there is no place at which it is more necessary for a person not much accustomed to horses to take with him an experienced friend, and, when there, to depend on his own judgment, or that of his friend, heedless of the observations or manœuvres of the bystanders, the exaggerated commendation of some horses, and the thousand faults found with others. There are always numerous groups of low dealers, copers, and chaunters, whose business it is to delude and deceive.

One of the regulations of the Bazaar in King Street was exceedingly fair, both with regard to the previous owner and the purchaser, viz.-

"When a horse, having been warranted sound, shall be returned within the prescribed period, on account of unsoundness, a certificate from a veterinary surgeon, particularly describing the unsoundness, must accompany the horse so returned; when, if it be agreed to by the veterinary surgeon of the establishment, the amount received for the horse shall be immediately paid back; but if the veterinary surgeon of the establishment should not confirm the certificate, then, in order to avoid further dispute, one of the veterinary surgeons of the college shall be called in, and his decision shall be final, and the expense of such umpire shall be borne by the party in error."

\section{CHAPTER XXIII.}

\section{A LIST OF THE MEDICINES USED IN THE TREATMENT OF THE DISEASES OF THE HORSE.}

$\mathrm{H}_{\text {z }}$ will rarely consult his own interest, who, not having had the advantage of a veterinary education, undertakes the treatment of any of the serious diseases of his horses. Many of the maladies of the horse nearly resemble each other. They are continually varying their character, and require, in their different stages, a very different treatment, and in the plainest case not only the characteristic symptoms of disease are obscure, but even the indications of returning health, or increasing danger, are often scarcely ascertainable, consequently the sick horse, as well as the human being, needs the care of one whom study and experience have qualified for the task. A list of the drugs generally employed, with a slight account of their history, adulterations, and medicinal effects, will be interesting to the horse-proprietor as well as to the veterinary surgeon; and may occasionally be useful when professional aid cannot be obtained.

Frequent reference will be made to Professor Morton's most valuable Manual of Pharmacy. This work will be found to be a treasure to every veterinary surgeon. Mr. W. C. Spooner's' Materia Medica, in his recent compendium of White's account of the horse, will occasionally be laid under contribution.

Acacla Gumm1.-Many varieties of gum arabic are procured from Egypt, Arabia, and the East Indies. It is an exudation from the trunk and branches of various trees. It is employed in the form of a mucilage, made by dissolving it in water, in the proportion of one part of the gum to three or four of water. Various insoluble powders may be thus suspended, or oils rendered miscible or emulsions formed. Emulsions composed of gum arabic are supposed to be useful in urinary affections.

Acidum Aceticun, Acetic Acin, Vinegar.-Vinegar is a very useful application for sprains and bruises. Equal parts of boiling water and cold vinegar will form a good fomentation. Extract of lead, or bay salt, may be added with some advantage. As an internal remedy, vinegar is rarely given, nor has it, except in large doses, any considerable medicinal power. The veterinarian and the holse-owner should manu- 
facture their own vinegar. That which they buy frequently contains sulphuric acid and pungent spices, and irritates the inflamed part to which it is applied.

Acldum Arseniosum, Arsenic.- Were it not that some practitioners continue to use it as a tonic, in doses of from ten to twenty grains daily, and others employ it to core out old ulcers, we would not include it in our list, for we have little faith in it. There are better and safer tonics, and far better and safer caustics. The method of detecting the presence of arsenic, in cases of poisoning, has been described at page 227.

Acidum Muriaticum, or Hydrochloric Acid: Splrit of Salt. - This acid is formed by distilling corrosive sublimate with antimony. The butter-like matter which is produced (whence the common name, Butyr of Antimony) has a strong affinity for water, which it attracts from the atmospliere, and thus becomes converted into a fluid. The less water it is suffered to attract to itself the more powerful it remains, and therefore it should be kept in stoppered bottles. The proof of its goodness is its weight. It is decidedly the best liquid caustic we have. It is most manageable, and its effect can most readily be ascertained. As soon as it touches any muscular or living part, a change of colour is perceived, and the effect of the caustic can be fairly judged of by the degree of change. For corns, canker, indisposition in the sole to secrete good horn, wounds in the foot not attended by healthy action, and for every ease where the superficial application of a caustic is needed, this acid is unrivalled.

Acidum Nitricum: Nitric Acid, Aquafortis.-This is a valuable external application. It is both a caustic and an antiseptic. It destroys fungous excrescences. A pledget of tar should be dipped in the acid, and then firmly pressed on the cankerous surface. Every part with which the acid has come into contact will be deadened and slough off, and healthy granulations will spring up.

Acidum Hydrocianicum: Prussic Acid.-This, in a concentrated state, is truly a deadly poison; a few drops of it will kill a large animal. In a diluted form, it is a powerful sedative. In doses of six drops, largely diluted, it abates both pulmonary and gastric irritation. It may be worth trying in the form of enema in cases of Tetanus. It may also be given by the mouth in the same disease. Nothing is more likely to tranquillize the general excitement of the nervous system. The author of this work was the first person who applied the hydrocyanic acid for the purpose of allaying irritation of the skin in dogs. It seldom fails of producing the desired effect, and it has had a similar good effect in subduing itchiness and mange in the horse.

Acidum Sulphuricun, Sulphuric Acid.-When mixed with tar in the proportion of an ounce to the pound, it is a good application for thrush and canker: a smaller quantity mixed with olive oil makes a good stimulating liniment. If too much sulphuric acid is added, either by mistake or wilfully, it inflames and corrodes the stomach and bowels. The proper antidotes in this case are magnesia, or the carbonate of soda or potash, with soft soap. The acid might possibly be neutralized by this combination.

ADEPS, HoG's LARD, very properly forms the basis of most of our ointments. It is tasteless, inodorous, and free from every stimulating quality. That cannot be said of all the ingredients used in the composition of our unguents.

Alcohol, Rectified Spirit.-This is necessarily used in many of our tinctures and other preparations, and is sometimes given to the horse in almost a pure state. Some horses that are compelled to travel far and quickly, show evident fatigue before they arrive at the end of their journey. A cordial or carminative tincture, to the extent of three or four ounces, largely diluted, may occasionally be given, and they rally, and cheerfully pursue their course to the end. The groom or the stableman gives the gin or whiskey of the country, in preference to any other stimulant. In cases of thorough fatigue the Daffy's Elixir may be administered, and probably rendered more stimulant by the addition of pepper. Mr. Bracy Clark recommends four ounces of the tincture of allspice in cases of gripes. On the other hand, some veterinary surgeons have preferred simple hot water, or the infusion of several of our medicinal herbs, as peppermint, rosemary, \&c. We should be loath, except on extraordinary occasions, to advocate the use of any spirituous drink.

Aloes.-There are two kinds used in horse practice, the Barbadoes and the Cape. The Socotrine, preferred by the human surgeon, are very uncertain in their effect on the horse, and are seldom to be met with pure. Of the Barbadoes and the Cape, the first are much to be preferred. They are obtained principally from the island of Bar- 
badoes, and are the juice of the large leaves of the alce boiled to a considerablc thickness, and then poured into gourds in which they gradually harden. The true Cape are the extract of a species of aloes chiefly cultivated at the Cape of Good Hope. The Barbadoes aloes are black, with a shade of brown, of an unctuous fecling, with a stronger smell, broken with difficulty, and the fracture dull. The Cape are darker coloured, stronger smelling, very brittle, and the fracture perfectly glossy. Every veterinary surgeon who uses much aloes should buy them in the mass, and powder them at home, and then, by attending to this account of the difference of the two, he can scarcely be imposed upon. It is, however, the fact, that thesc are mostly adulterated, by their being melted together. Aloes purchased in powder are too often sadly adulterated.

The Cape aloes may be powdered at all times, and the Barbadocs in frosty wcather, when enough should be prepared, to be kept in closed bottles, for the year's consumption. They may also be powdered when they liavc bcen taken from the gourd, and exposed to a gentle heat for two or three hours before they are put into the mortar. In the proportion of fifteen ounces of the powder mixed with one ounce of powdered ginger, and beaten up with eight ounces of palm oil, and afterwards divided into the proper doses, it will form a purging mass more effectual, and much less likely to gripe, than any that can be procured by melting the drug. If the physic is given in the shape of a ball, it more readily dissolves in the stomach, and more certainly and safely acts on the bowels when mingled with some oily matter, like that just recommended, than when combined with syrup or honey, whicls arc apt to ferment, and be themselves the cause of gripes. It is also worse than useless to add any diuretic to the nrass, as suap or carbunate of soda. The action of these on one set of organs will weaken that of the aloes on another. A physic mass should never be kept more than two or three months, for, after that time, it rapidly loses its purgative property.

Directions for physicking will be found at page 237. We will only add that, as a promoter of condition, the dose should always be mild. A few fluid stools will be sufficient for every good purpose. Violent disease will alone justify violent purging.

The Barbadoes aloes have a greater purgative power than the Cape, exclusive of griping less and being safer. In addition to this, the action of the bowels is kept up longer by the Barbadoes aloes than by the Cape. If the horse is well mashed, and carefully exercised, and will drink plenty of warm water, the Cape may be ventured on, or at least mixed with equal quantities of the Barbadocs; but if there is any neglect of preparation for physic, or during the usual operation of the physic, the Cape are not always to be depended upon. The combination of alkaline compounds with aloes alters the results of the medicine. 'Their action is quickened, but thcir purgative properties are impaired, and they cease to operate specifically on the larger intestines. Such is the opinion of Professor Morton, and undoubtedly the latter would be an advantage gained. The activity of the aloes may be occasionally increased by a few drops of the croton oil. Mashes are useful helps when physic is administered.

Some persons are fond of what are called half-doses of physic. Three or four drachms are given on one day, and three or four on the following; and perhaps, if the medicine has not operated, as in this divided state it will not always, two or three additional drachms are given on the third day. The consequence is, that the bowels having been rendered irritable by the former doses, the horse is over-purged, and inflammation and death occasionally ensue. In physicking a horse, whatever is to be done should be done at once. Whatever quantity is intended to be given should be given in one dose.

'The system of giving small doses of aloes as alteratives is not good. These repeated minute doses lodging in some of the folds of the intestines, and at length uniting, often produce more effect than is desirable. It is never safe to ride a horse far or fast, with even a small dose of aloes within him.

Most of all objectionable is the custom of giving small doses of aloes as a nauseant, in inflammation of the lungs. There is so much sympathy bctween the contents of the chest and the belly in the horse, and inflammation of one part is so likely to be transferred to another, that it is treading on very dangerous ground, when, with mucl, inflammation of the lungs, that is given which will stiutulate and may inflame the intestines. 
Aloes are most commonly, because most easily, administered in the form of ball, but in a state of solution their effect is more speedy, effectual, and safe.

Aloes are useful in the form of tincture. Eight ounces of powdered aloes, and one ounce of powdered myrrh, may be put into two quarts of rectified spirit, diluted with an equal quantity of water. The mixture should be daily well shaken for a fortnight, and then suffered to stand, in order that the undissolved portion may fall to the bottom. This will constitute a very excellent application for wounds, whether recent or of long standing and indisposed to heal. It is not only a gentle stimulant, but it forms a thin crust over the wound, and shields it from the action of the air.

The principal adulteration of aloes is by means of resin, and the alteration of colour is concealed by the addition of charcoal or lamp-black. This adulteration is easily enough detected by dissolving the aloes in hot water. All aloes contain some resinous matter, which the water will not dissolve and which has very slight purgative effect. The excess of this resin at the bottom of the solution will mark the degree of adulteration.

Alteratives are a class of medicines the nature and effect of which are often much misunderstood, and liable to considerable abuse. It is a very convenient name in order to excuse that propensity to dose the horse with medicines, which is the disgrace of the groom, and the bane of the stable.

By alteratives we understand those drugs which effect some slow change in the diseased action of certain parts without interfering with the food or work; but by common consent the term seems to be confined to medicines for the diseases of the circulation, or of the digestive organs, or of the skin. If a horse is heavy and incapable of work from too good keep, or if he is off his food from some temporary indigestion-or if he has mange or grease, or cracked heels, or swelled legs, a few alteratives are prescribed, and the complaint is expected to be gradually and imperceptibly removed. For all skin affections there is no better alterative than that so often recommended in this treatise, consisting of black antimony, nitre, and sulphur. If there is any tendency to grease, some resin may be added to each ball. If the complaint is accompanied by weakness, a little gentian and ginger may be farther added, but we enter our protest against the ignorant use of mercury in any form, or any of the mineral acids, or mineral tonics, or heating spices, as alteratives. We indeed should be pleased if we could banish the term alterative from common usage. The mode of proceeding which reason and science would dictate is to ascertain the nature and degree of the disease, and then the medicine which is calculated to restore the healthy action of the part, or of the frame generally.

Alum is occasionally used internally in cases of super-purgation in the form of alum-whey, two drachms of the powder being added to a pint of hot milk; but there are much better astringents, although this may sometimes succeed when others fail. If alum is added to a vegetable astringent, as oak-bark, the power of both is diminished. Its principal use is external. A solution of two drachms to a pint of water forms alone, or with the addition of a small quantity of white vitriol, a very useful wash for cracked heels, and for grease generally; and also for those forms of swelled legs attended with exudation of moisture through the skin. Some add the Goulard lotion, forgetting the chemical decomposition that takes place; the result of which is, that the alumine, possessing little astringency, is detached, and two salts with no astringency at all, the sulphate of lead and the sulphate of potash, are formed.

The Burvt Alum is inferior to the common alum for the purposes mentioned, and we have better stimulants, or caustics, to apply to wounds.

Ammonia is, to the annoyance of the horse, and the injury of his eyes and his lungs, plentifully extricated from the putrefying dung and urine of the stable; but, when combined with water in the common form of hartshorn, it is seldom used in veterinary practice. It has been given, and with decided benefit, and when other things have failed, in flatulent colic; and is best administered in the form of the aromatic spirit of ammonia, and in doses of one or two ounces, in warm water.

Chloride of Ammonia, or sal ammoniac, is scarcely deserving of a place in our list. It is not now used internally; and as an astringent embrocation, it must yield to several that are more effectual, and less likely to blemish.

Anisi Semina, Avise-SEEd. This seed is here mentioned principally as a record of old times, when it was one of the sheet-anchors of the farrier. It is not yet quite liscarded from his shop as a stimulant, a carminative, and a cordial. 
AnoDynes.-Of these there is but one in horse practice: Opium is the only drug that will lull pain. It may be given as an anodyne, but it will also be an astringent in doses of one, two, or three drachms.

Antimonx.-There are several valuable preparations of this metal.

'The Black Sesqui-Sulphuret of Antimony, a compound of sulphur and antimony', is a good alterative. It is given with more sulphur and with nitre, in varying doses, according to the disease, and the slow or rapid effect intended to be produced. It should never be bonght in powder whatever troublc there may be in levigating it, for it is often grossly adulterated with lead, manganese, forge-dust, and arsenic. 'The adulteration may be detected by placing a little of the powder on a red-hot iron plate. The pure sulphuret will evaporate without the slightest rcsidue-so will the arsenic: but there will be an evident smell of garlic. A portion of the lead and the manganese will be left behind.

Antimonil Potassio Tartras, Euetic Tartar.-The tartrate of potash and antimony, or a combination of super-tartrate of potash and oxide of antimony, is a very useful nauseant, and has considerable effect on the skin. It is particularly valuable in inflammation of the lungs, and in every catarrhal affection. It is given in doses of from one drachm to a drachm and a half, and combined with nitre and digitalis. It is also beneficial in the expulsion of worms. It should be given in doses of two drachms, and with some mechanical vermifuge, as tin filings, or ground glass, and administered on an empty stomach, and for several successive days. Although it may sometimes fail to expel the worms, it will materially improve the condition of the horse, and produce sleekness of the coat. To a slight degree the emetic tartar is decomposed by the action of light, and should be kept in a jar, or green bottle. It is sometimes adulterated with arsenic, which is detected by the garlic smell when it is placed on hot iron, and also by its not giving a beautiful gold-coloured precipitate when sulphuret of ammonia is added to a solution of it. It has also been externally applied in chest affections, in combination with lard, and in quantities of from one drachm to two drachms of the antimony, to an ounce of the lard; but, except in extreme cases, recourse should not be had to it, on account of the extensive sloughing which it sometimes produces.

Pulvis Antimonil Compositus, The Compound Powder of Antimony.-Commonly known by the name of James's Powder. It is employed as a sudorific in fever, either alone or in combination with mercurials. The dose is from one to two drachms. The late Mr. Bloxam used to trust to it alone in the treatment of Epidemic Catarrk in the horse. It is, however, decidedly inferior to Emetic Tartar. It is often adulterated with chalk and burnt bones, and other white powders, and that to so shameful a degree, that little dependence can be placed on the antimonial powder usually sold by druggists. 'The muriatic or sulphuric acids will detect most of these adulterations.

AnTi-Spasmodics.-Of these our list is sca.$y$, for the horse is subject only to a few spasmodic discases, and there are fewer medicines which have an anti-spasmodic effect. Opium stands first for its general power, and that exerted particularly in locked-jaw. Oil of turpentine is almost a specific for spasm of the bowels. Camphor, assafœtida, and various other medicines, used on the human subject, have a very doubtful effect on the horse, or may be considered as almost inert.

Argentum, Silver.-One combination only of this metal is used, and that as a manageable and excellent caustic, viz., the Lunar Caustic. It is far preferable to the hot iron, or to any acid, for the destruction of the part if a horsc should have been bitten by a rabid dog; and it stands next to the butyr of antimony for tlie remoral of fungus generally. It has not yet been administered internally to the horse.

$\Lambda$ rsenicum, Arsenic.-This drug used to be employed as a tonic, in order to core out old ulcers; but it is now seldom employed, for there are better and safer tonics, and far better and sefer caustics. The method of detecting tlie presence of arsenic in cases of poisoning has been described at page $22 \%$.

BALIS. - The usual and the most convenient mode of administering veterinary medicines is in the form of balls, compounded with oil, and not with honey or syrup, on account of their longer keeping soft and more easily dissolving in the stomach. Balls should never weigl more than an ounce and a half, otherwise they will be so large as not to pass without difficulty down the gullet. They sliould not be more than an inch in diameter and three inches in length. The mode of delivering balls is not difficult to acquire; but the balling-iron, while it often wounds and permanently 
injures the bars, occasions the horse to struggle more than he otherwise would against the adrainistration of the medicine. The horse should be backed in the stall; - the tongue should be drawn gently out with the left hand on the off side of the mouth, and there fixed, not by continuing to pull at it, but by pressing the fingers against the side of the lower jaw. The ball, being now taken between the tips of the fingers of the right hand, is passed rapidly up the mouth, as near to the palate as possible, until it reaches the root of the tongue. It is then delivered with a slight jerk, and the hand being immediately withdrawn and the tongue liberated, the ball is forced through the pharynx into the cesophagus. Its passage should be watched down the left side of the throat; and if the passage of it is not seen going down, a slight tap or blow under the chin will generally cause the horse to swallow it, or a few guJps of water will convey it into the stomach. Very few balls should be kept ready made, for they bccome so hard as to be incapable of passing down the gullet, or dissolving in the stomach, and the life of the horse may be endangered or lost. This is peculiarly liable to be the case if the ball is too large, or wrapped in thick paper.

Bark, Peruvian.-A concentrated preparation of this is entitled the Sulphate of Quivine. The simple bark is now seldom used. If it has any good effect, it is in diabetes. The quinine, however, is strongly recommended by Professor Morton as singularly efficacious in the prostration of strength which is often the consequence of influenza.

$B_{\Lambda \text { SILicoN }}$ is a valuable digestive ointment, composed of resin, bees'-wax, and olive-oil. If it is needed as a stimulant, a little turpentine and verdigris may be added.

Belladonne Extractum, Extract of Deadly Nightshade. - The inspissated juice is principally used as a narcotic and sedative, and indicated where there is undue action of the nervous and vascular systems, as in tetanus, carditis, and nerrous affections generally. Externally, it is beneficially applied to the eye.

BLISTERS are applications to the skin which scparate the cuticle in the form of vesicles containing a serous fluid. They excite increased action in the vessels of the skin, by means of which this fluid is thrown out. The part or neighbouring parts arc somewhat relieved by the discharge, but more by the inflainmation and pain that are produced, and lessen that previously existing in some contiguous part. On this principle we account for the decided relief often obtained by blisters in inflammation of the lungs, and their efficacy in abating deeply-seated disease, as that of the tendons, ligaments, or joints; and also the necessity of previously removing, in these latter cases, the superficial inflammation caused by them, in order that one of a different kind may be cxcited, ond to which the deeply-seated inflammation of the part will be more likely to yield. The blisters used in horse-practice are compos 1 of cantliarides or the oil of turpentine, to which some have added a tincture of the croton-nut.

For some important remarks on the composition, application and management of the blister, sce page 346 .

Bole Armenian is an argillaceous earth combined with iron, and is supposed to possess somc astringent property. The propriety of its being administered inwardly is doubtful; for it may remain in the intestinal canal, and become the nucleus of a calculus. On account of its supposed astringency, it is employed externally to give consistence to ointments for grease. Even the bole Armenian has not escaped the process of adulteration, and is largely mixed with inferior earths. The fraud may he suspected, but not satisfactorily deterted, by the colour of the powder, which should be a bright red.

Calamine.-Sce Zinc.

Calomel.-Sce Mercury.

CAmpior is the produce of one of the laurus species, a native of Japan, and too often imitated by passing a stream of chlorine through oil of turpentine. According to Professor Morton, it is a narcotic. It diminishes the frequency of the pulse, and softens its tonc. When long exhibited, it acts on the kidneys. Externally applied, it is said to be a discutient and an anodyne for chronic sprains, bruises, and tumours. 'The camphor ball is a favourite onc with the groom, and occasionally administered by the veterinary surgeon. Mr. W. C. Spooner uses it, mixed with opium, in cases of locked-jaw, and in doses of from one to two drachms. In the form of camphorated oil, it promotes the absorption of fluids thrown ont beneath the skin, the removal of 
old callus, and the suppling of joints stiff from labour. Combined with oil of turpentine it is more effective, but in this combination it occasionally blemishes. .

CANTHARIDES are the basis of the most approved and useful veterinary blisters. The cantharis is a fly, the native of Italy and the south of France. It is destroyed by sulphur, dried and powdered, and mixed with palm oil and resin in the proportion directed at page 225 . Its action is intense, and yet superficial; it plentifully raises the cuticle, yet rarely injures the true skin, and therefore seldom blemishes. The application of other acrid substances is occasionally followed by deeply-seated ulcerations; but a blister composed of the Spanish fly alone, while it does its duty, leaves, after a few weeks have passed, scarcely a trace behind.

The art of blistering consists in cutting, or rather shaving, the hair perfectly close ; then well rubbing in the ointment, for at least ten minutes; and, afterwards, and what is of the greatest consequence of all, plastering a little more of the ointment lightly over the part, and leaving it. As soon as the vesicles have perfectly risen, which will be in twenty or twenty-four hours, the torture of the animal may be somewhat relieved by the application of olive or neat's-foot oil, or any emollient ointment.

When too extensive a blister has been employed, or, from the intensity of the original inflammation, the blister has not risen, (for no two intense inflammations can exist in neighbouring parts at the same time), strangury-great difficulty in passing urine, and even suppression of it-has occurred. The careful washing off of the blister, and the administration of plenty of warm water, with opium, and bleeding if the symptoms run high, will generally remove this unpleasant effect.

An infusion of two ounces of the flies in a pint of oil of turpentine, for several days, is occasionally used as a liquid blister; and, when sufficiently lowered with common oil, it is called a sweating oil, for it maintains a certain degree of irritation and inflammation on the skin, yet not sufficient to blister, and thus gradually abates or removes some old or deep inflammation, or cause of lameness.

Of late cantharides have come into more general use. They were recommended by Mr. Vines, in combination with vegetable bitters, as a stimulating tonic, in cases of debility. He next applied them for the cure of Glanders, and with considerable success. The Veterinary public is much indebted to Mr. Vines, for the steadiness with which he has followed up the employment of the Spanish fly. The dose is from five to eight grains given daily, but withheld for a day or two when diuresis supervenes.

Capsici Baccer, Capsicum Berries. - They are valuable as stimulants affecting the system generally, yet not too much accelerating the pulse. Their beneficial effect in cases of cold, has seldom been properly estimated. The dose is from a scruple to half a drachm.

Carul Semina, Caraway Seeds.-These and Ginger, alone or combined, are the best stimulants used in horse-practice.

Cascarilla Cortex, Cascarilla Bark.-Tonic as well as aromatic. It must not, however, be used with the sulphates of iron or zinc.

Castor Oil, Oleum Ricinl.-An expensive medicine. It must be given in large doses, and even then it is uncertain in its effects. Mild as is its operation in most animals, it sometimes gripes and even endangers the horse.

Catechu, Japan EarTh, yet, no earth, but extracted from the wood of one of the acacia trees, is a very useful astringent. It is given in super-purgation, in doses of one or two drachms, with opium, as a yet more powerful astringent; chalk, to neutralize any acid in the stomach or bowels; and powdered gum, to sheath the over-irritated micous coat of the intestines. It is not of ten adulterated in our country, but grossly so abroar-fine sand and aluminous earth being mixed with the extract. It is seldom given with any alkali, yet the prescription just recommended contains chalk : but, although the chalk, as an alkali, may weaken the astringency of the catechu, it probably neutralizes some acid in the stomach or bowels, that would have diminished the power of the catechu to a greater degree. It must not be given in conjunction with any metallic salt, for the tannin or gallic acid, on which its power chiefly or entirely depends, has an affinity for all metals, and will unite with them, and form a gallate of them, possessing little astringent energy. Common ink is the union of this tannin principle with iron.

A tincture of catechu is sometimes made by macerating three ounces of the powder in a quart of spirit for a fortnight. It is an excellent application for wounds; and, 
with the aloes, constitutes all that we want of a balsamic nature for the purpose of hastening the healing process of wounds.

Caustics arc substances that burn or destroy the parts to which they are applied. First anong them stands the red-hot iron, or actual cautery, and then pure alkalies, potash, and soda, and the sulphuric and nitrous acids. Milder caustics are found in the sulphate of copper, red precipitate, burnt alum, and verdigris. They are principally used to destroy fungous excrescences, or stimulate indolent tumours, or remove portions of cellular substance, or muscle infected by any poison.

Creta Preparata, Chalk, is principally used in combination with catechu and opium in cases of super-purgation. All adventitious matters are removed by washing, and the prepared or levigated chalk remains in the form of an impalpable powder. It is usually administered in doses of two or three ounces. It is externally applied over ulcers that discharge a thin and ichorous matter.

Chamomile, ANThemis. - The powder of the flower is a useful vegetable tonic, and the mildest in our list. It is given in doses of one or two drachms, and is exhibited in the carly stage of convalescence in order to ascertain whether the febrile stage of the diseasc is passed, and to prepare the way for a more powerful tonic, the gentian. If no acccleration of pulse, or heat of mouth, or indication of return of fever, accompanies the cautious use of the chamomile, the gentian, with carbonate of iron, may be safely ventured upon; but if the gentian had been first used, and a little too soon, there inight have been considerable, and perhaps dangerous return of fever.

Charcoar is occasionally used as an antiseptic, being made into a poultice with linseed meal, and applied to foul and offensive ulcers, and to cracked heels. It removes the foetid and unwholesome smell that occasionally proceeds from them.

Charess are thick, adhesive plasters spread over parts that have been strained or weakened, and, being applied to the skin, adhere for a considerable time. The following mixture makes a good charge-Burgundy or common pitch, five ounces; tar, six ounces; yellow wax, one ounce, melted together, and when they are becoming cool, half a drachm of powdered cantharides well stirred in. This must be partially melted afresh when applied, and spread on the part with a large spatula, as hot as can be done without giving the animal too much pain. Flocks of tow shonld be scattered over it while it is warm, and thus a thick and adhesive covering will be formed that cannot be separated from the skin for many months. It is used for old sprains of the loins, and also strains of the back sinews. The charge acts in three ways - by the slight stimulant power which it possesses it gradually removes all dcep-seated inflammation-by its stimulus and its pressure it promotes the absorption of any callus or thickening beneath; and, acting as a constant bandage, it gives tone and strength to the part.

CLYSTERs. -These are useful and too often neglected means of hastening the evacuation of the bowels when the disease requires their speedy action. The old oxbladder and wooden pipe may still be employed, and a considerable quantity of fluid thrown into the intestine; but the patent stomach and clyster pump of Mr. Reid is far preferable, as enabling the practitioner to inject a greater quantity of fluid, and in a less time.

Two ounces of soft or yellow soap, dissolved in a gallon of warm water, will form a useful aperient clyster. It will detach or dissolve many irritating substances that may have adhered to the mucous coat of the bowels. For a more active aperient, half a pound of Epsom salts, or even of common salt, may be dissolved in the same quantity of water. A stronger injection, but not to be used if much purgative medicine has becn previously given, may be composed of an ounce of Barbadoes aloes, dissolved in two or three quarts of warm water. If nothing else can be procured, warm water may be employed; it will ast as a fomentation to the inflamed and irritable surface of the bowels, and will have no inconsiderable effect even as an aperient.

In cases of over-purging or inflammation of the bowels, the injection must be of a soothing nature. It may consist of gruel alone, or, if the purging is considerable, and difficult to stop, the gruel must be thicker, and four ounces of prepared or powdered chalk well mixed with or suspended in it, with two scruples or a drachm of powdered opium.

No oil should entcr into the composition of a clyster, except that linseed oil may be used for the expulsion of the ascarides, or needle-worms. 
In epidemic catarrh, when the horse sometimes obstinately refuses to eat or to drink, his strength may be supported by nourishing clysters; but they should consist of thick gruel only, and not more than a quart should be administered at once. A greater quantity would be ejected soon after the pipe is withdrawn. Strong broths, and more particularly ale and wine, are dangerous ingredients. They may rapidly aggravate the fever, and should never be administered, except under the superintendence, or by the direction, of a veterinary surgeon.

The principal art of administering a clyster consists in not frightening the horse. The pipe, wen oiled, should be very gently introduced, and the fluid not too hastily thrown into the intestine; its heat being as nearly as possible that of the intestine, or about $96^{\circ}$ of Fahrenheit's thermometer.

Collyria, Lotions for the Eyes.-These have been sufficiently described when inflammation of the eyes was treated of.

Copalba, Balsam of CAPIv1.-The resin is obtained from a tree growing in South America and the West India Islands. It is expensive, much adulterated, and seldom used; for its properties differ but little from those of common diuretics.

COPPER.-There are two combinations of this metal used in veterinary practice : the verdigris or subacetate, and the blue vitriol or sulphate.

Verdigris or Subacetate of Copper is the common rust of that metal produced by subjecting it to the action of acetic acid. It is given internally by some practitioners, in doses of two or three drachms daily, as a tonic, and particularly for the cure of farcy. It is, however, an uncertain and dangerous medicine. The corrosive sublimate, with vegetable tonics, as recommended at page 138, is preferable. Verdigris is, however, usefully applied externally as a mild caustic. Either alone, in the form of fine powder, or mixed with an equal quantity of the sugar (superacetate) of lead, it eats down proud flesh, or stimulates old ulcers to healthy action. When boiled with honey and vinegar, it constitutes the farriers' Egyptiacum, certainly of benefit in cankered or ulcerated mouth, and no bad application for thrushes; but yielding, as it regards both, to better remedies, that are mentioned under the proper heads. Some practitioners use alum and oil of vitriol in making their Egyptiacum, forgetting the strange decomposition which is produced.

Blue Vitriol or Sulphate of Copper is the union of sulphuric acid and copper. It is a favourite tonic with many practitioners, and has been vaunted as a specific for glanders; while others, and we think properly, have no very good opinion of it in either respect. As a cure for glanders, its reputation has nearly passed away. As a tonic, when the horse is slowly recovering from severe illness, it is dangerous, and its internal use should be confined to cases of long-continued discharge from the nostril, when catarrh or fever has ceased. It may then be given with benefit in doses of from one to two drachms twice in the day, and always combined with gentian and ginger. It is principally valuable as an external application, dissolved in water in the proportion of two drachms to a pint, and acting as a gentle stimulant. If an ounce is dissolved in the same quantity of water, it becomes a mild caustic. In the former proportion, it rouses old ulcers to a healthy action, and disposes even recent wounds to heal more quickly than they otherwise would do; and in the latter it removes fungous granulations or proud flesh. The blue vitriol is sometimes reduced to powder and sprinkled upon the wound for this purpose: it is also a good application for canker in the foot.

Cordials are useful or injurious according to the judgment with which they are given. When a horse comes home thoroughly exhausted, and refuses his food, a cordial may be beneficial. It may rouse the stomach and the system generally, and may prevent cold and fever; but it is poison to the animal when administered after the cold is actually caught and fever begins to appear. More to be reprobated is the practice of giving frequent cordials, that by their stimulus on the stomach, (the skin sympathising so much with that viscus, ) a fine coat may be produced. The artificial excitement of the cordial soon becomes as necessary to enable the horse to do even common work, as is the excitement of the dram to sustain the animal spirits of the drunkard.

In order to recall the appetite of the horse slowly recovering from illness, a cordial may sometimes be allowed; or to old horses that have been worked hard and used to these excitements when yonng; or to draught horses, that have exhibited slight symptoms of staggers when their labour has been unusually protracted and their sto- 
machs left too long empty; or mixed with diuretic medicine, to fine the legs of the over-worked and debilitated animal; but in no other case should they obtain a place in the stable, or be used at the discretion of the carter or the groom.

Corrosive Sublimate.-See Mercury.

Creasote has very lately been introduced into veterinary practice, and is much valued on account of its antiseptic properties. It is obtained by the destructive distillation of various substances, as pyroligneous acid, tar, wood, smoke, \&c. Pure creasote is colourless and transparent; its odour is that of smoked meat, and its taste is caustic and burning. It coagulates the albumen of the blood, and hence has been lately employed in stopping hæmorrhages. It acts very powerfully on the general system, and quickly destroys small animals. Professor Morton gives a very interesting and faithful account of it. It is, according to him, both a stimulant and a tonic. In an undiluted state it acts as a caustic. When diluted it is a general excitant and an antiseptic. In the form of a lotion, a liniment, or an ointment, it has been useful in farcy and glanders, also in foot-rot, canker, and thrush,-mange, caries, excessive suppuration, and the repression of fungous granulations. As a caustic it acts as a powerful stimulant; and it is an antiseptic.

Croton Tigli Semina, Croton Seeds.-The croton-nut has not been long introduced into veterinary practice, although it has been used from time immemorial by the inhabitants of India as a powerful purgative. An oil has been extracted from it, and used by the surgeon; the meal is adopted by the veterinarian. It is given in doses from a scruple to half a drachm, and, from its acrid nature, in the form of a ball, with an ounce of linseed meal. When it does operate the effect is generally observed in six or eight hours, the stools being profuse and watery, and the patient frequently griped. On account of its speedy operation, it may be given in locked-jaw and staggers : and also in dropsy of the chest or belly, from the watery and profuse stools which it produces; but it is often uncertain in its operation, and its griping, and the debility which it occasions, are serious objections to it as common physic. When placed on the tongue of the horse in quantities varying from twenty to forty drops, it produces purging, hut the membrane of the mouth frequently becomes violently inflamed. This likewise happens, but not to so great a degree, when it is given in the form of a drink, or in a mash.

Demulcents are substances that have the power of diminishing the effect of acrimonious or stimulating substances. The first, by some oily or mucilaginous substance, sheaths the sensible parts. The other dilutes the stimulus, and diminishes its power. It will rarely be difficult to determine which effect should be produced, and the means by waich it is to be effected.

Diaphoretics are medicines that increase the sensible and insensible perspiration of the animal. As it regards the horse, they are neither many nor powerful. Antimony in its various forms, and sulphur, have some effect in opening the pores of the skin, and exciting its vessels to action, and especially when assisted by warmth of stable or clothing, and therefore is useful in those diseases in which it is desirable that some portion of the blood should be diverted from the overloaded, and inflamed, and vital organs of the chest, to the skin or the extremities. The only diaphoretics, however, on which much confidence can be placed, and especially to produce condition, are warm clothing and good grooming.

Digestives are applications to recent or old wounds, as mild stimulants, in order to produce a healthy appearance and action in them, and to cause them more speedily to heal. A weak solution of blue vitriol is an excellent digestive; so is the tincture of aloes, and the tincture of myrrh. The best digestive ointment is one composed of three parts of calamine ointment (Turner's cerate) and one of common turpentine.

Digitalis.-The leaves of the common foxglove, gathered about the flowering time, dried carefully in a dark place, and powdered, and kept in a close black bottle, form one of the most valuable medicines in veterinary practice. It is a direct and powerful sedative, diminishing the frequency of the pulse, and the general irritability of the system, and acting also as a mild diuretic: it is therefore useful in every inflammatory and febrile complaint, and particularly in inflammation of the chest. It is usually given in combination with emetic tartar and nitre. The average dose is one drachm of digitalis, one and a half of emetic tartar, and three of nitre, repeated twice or thrice in the day.

Digitalis seems to have an immediate effect on the heart, lessening the number of 
its pulsations; but effecting this in a singular manner - not by causing the heart to beat more slowly, but producing certain intermissions or pauses in its action. When these become marked - when at every sixth or seventh beat, the pulsations are suspended while two or three can be slowly counted, this is precisely the effect that is intended to be produced, and, however ill the horse may appear to be, or however alarming this intermittent pulse may secm to the standcrs-by, from that moment the animal will frequently bcgin to amend. 'The dose must then be diminished one-half, and, in a few days, it may be omitted altogether: but the emetic tartar and the nitre should be continued during some days after the practitioner has dcemed it prudent to try the effect of mild vegetable tonics.

There is no danger in the intermittent pulse thus produced; but there is much when the digitalis fails to produce any effect on the circulation. The disease is then too powerful to be arrested by medicine. Digitalis requires watching; but the only consequence to be apprehended from an over-dose is, that the patient may be reduced a little too low, and his convalescence retarded for a day or two.

In the form of infusion or tincture, digitalis is very useful in inflammation of the eyes. It is almost equal in its sedative influence to opium, and it may with great advantage be alternated with it, when opium begins to lose its power. The infusion is made by pouring a quart of boiling water on an ounce of the powder. When it is become cold, a portion of the liquid may be introduced into the eye. One or two drops of the tincture may be introduced with good effect. This may be olstained by macerating three ounces of the digitalis in a quart of spirit.

The infusion has been scrviceable in mange; but there are better applications.

Divretics constitute a useful but much abused class of medicines. 'They stimulate the kidneys to secrete more than the usual quantity of urine, or to separate a greater than ordinary proportion of the watery parts of the blood. The deficiency of water in the blood, thus occasioned, must be speedily supplied or the healthy circulation cannot be carried on, and it is generally supplied by the absorbents taking up the watery fluid in some part of the frame, and carrying it into the circulation. Hence the evident use of diuretics in dropsical affections, in swelled legs, and also in inflammation and fever, by lessening the quantity of the circulating fluid, and, consequently, that which is sent to the inflamed parts.

All this is effected by the kidneys being stimulated to increased action; but if this stimulus is too often or too violently applied, the cnergy of the kidney may be impaired, or inflammation may be produced. That inflammation may be of an acute character, and destroy the patient; or, although not intense in its nature, it may by frequent repetition assume a chronic form, and morc slowly, but as surely, do irreparable mischief. Hence the necessity of attention to that portion of the food which may have a diuretic power. Mow-burnt hay and foxy oats are the unsuspected causes of many a disease in the horse, at first obscure, but ultimately referable to injury or inflammation of the urinary organs. Hence, too, the impropriety of suffering medicines of a diuretic nature to be at the command of the ignorant carter or groom. In swelled legs, cracks, grease, or accumulation of fluid in any part, and in those superficial eruptions and inflammations which are said to be produced by humours floating in the blood, diuretics are evidently beneficial; but they should be as mild as possible, and not oftener given or continued longer than the case requires. For some cautions as to the administration of diuretics, and a list of the safest and best, the reader is referred to page 245. The expensive Castile soap, and camphor, so often resorted to, are not needed, for the common liquid turpentine is quite sufficient in all ordinary cases, and nitre and digitalis may be added if fever is suspected.

Drinks.-Many practitioners and horse-proprietors have a great objection to the administration of medicines in the form of drinks. A drink is not so portable as a ball, it is more troublesome to give, and a portion of it is usually wasted. If the drink contains any acid substance, it is apt to excoriate the mouth, or to irritate the throat already sore from disease, or the unpleasant taste of the drug may unnecessarily nauseate the horse. There are some medicines, however, which must be given in the form of drink, as in colic; and the time, perhaps, is not distant when purgatives will be thus administered, as more speedy, and safer in their operation. In cases of much debility and entire loss of appetite, all medicine should be given in solution, for the stomach may not have sufficient power to dissolve the paper in which the ball is wrapped, or the substance of the ball. 
An ox's horn, the larger end being cut slantingly, is the usual and best instrument for administering drinks. The noose of a halter is introduced into the mouth, and then, by means of a stable-fork, the head is elevated by an assistant considerably higher than for the delivery of a ball. The surgeon stands on a pail or stable-basket on the off-side of the horse, and draws out the tongue with the left hand; he then, with the right hand, introduces the horn gently into the mouth, and over the tongue, and by a dexterous turn of the horn empties the whole of the drink-not more than about six ounces-into the back part of the mouth. The horn is now quickly withdrawn, and the tongue loosened, and the greater portion of the fluid will be swallowed. A portion of it, however, will often be obstinately held in the mouth for a long time, and the head must be kept up until the whole is got rid of, which a quick, but not violent slap on the muzzle will generally compel the horse to do. The art of giving a drink consists in not putting too much into the horn at once; introducing the horn far enough into the mouth, and quickly turning and withdrawing it, without bruising or wounding the mouth, the tongue being loosened at the same moment. A bottle is a disgraceful and dangerous instrument to use, except it be a flat pint bottle, with a long and thick neck.

Ferrum, Iron.-Of this metal there are two preparations adopted by veterinarians. The rust, or Carbonate, is a mild and useful tonic in doses of from two to four drachms. The Sulphate (green vitriol or Copperas) is more powerful. It should never be given in the early stages of recovery, and always with caution. The dose should be the same as that of the carbonate. The sulphate has lately been recommended for the cure of that deceitful stage or form of glanders, in which there is nothing to characterise the disease but a very slight discharge from the nostrils. It is to be dissolved in the common drink of the horse. It is worth a trial, but too sanguine expectations must not be encouraged of the power of any drug over this intractable malady. The iron should be given in combination with gentian and ginger, but never with any alkali or nitre, or soap, or catechu, or astringent vegetable.

FEVEr.-For the nature and treatment of the fever, both pure and symptomatic, reference may be made to page 187 .

Forge-water used to be a favourite tonic with farriers, and also a lotion for canker and ulcers in the mouth. It owes its power, if there be any, to the iron with which it is impregnated.

Fomentations open the pores of the skin and promote perspiration in the part, and so abate the local swelling, and relieve pain and lessen inflammation. They are often used, and with more benefit when the inflammation is somewhat deeply seated, than when it is superficial. The effect depends upon the warmth of the water, and not on any herb that may have been boiled in it. They are best applied by means of flannel, frequently dipped in the hot water, or on which the water is poured, and the heat should be as great as the hand will bear. The benefit that might be derived from them is much impaired by the absurd method in which the fomentations are conducted. They are rarely continued long enough, and when they are removed, the part is left wet and uncovered, and the coldness of evaporation succeeds to the heat of fomentation. The perspiration is thus suddenly checked; the animal suffers considerable pain, and more harm is done by the extreme change of temperature than if the fornentation had not been attempted.

Gentian stands at the head of the vegetable tonics, and is a stomachic as well as a tonic. It is equally useful in chronic debility, and in that which is consequent on severe and protracted illness. It is generally united with chamomile, ginger, and, when the patient will bear it, carbonate of iron. Four drachms of gentian, two of chamomile, one of carbonate of iron, and one of ginger, will make an excellent tonic ball. An infusion of gentian is one of the best applications to putrid ulcers.

Ginger is as valuable as a cordial, as gentian is as a tonic. It is the basis of the cordial ball, and it is indispensable in the tonic ball. Although it is difficult to powder, the veterinary practitioner should always purchase it in its solid form. If the root is large, heavy, and not worm-eaten, the black ginger is as good as the white, and considerably cheaper. The powder is adulterated with bean-meal and the sawdust of boxwood, and rendered warm and pungent by means of capsicum.

Helleborus Albus, White Hellebore. - This is a drastic cathartic, and should be used with great caution. It is a powerful nauseant, and lowers both the force and frequency of the pulse, and is therefore given with good effect in various inflamma- 
tions, and particularly that of the lungs. In the hospital of the veterinary surgeon, or in the stable of the gentleman who will superintend the giving and the operation of every medicine, it may be used with safety; but with him who has to trust to others, and who does not see the horse more than once in twelve or twenty-four hours, it is a dangerous drug. If it is pushed a little too far, trembling and giddiness, and purging follow, and the horse is sometimes lost. The hanging of the head, and the frothing of the mouth, and, more particularly, the sinking of the pulse, will give warning of danger; but the medical attendant may not have the opportunity of observing this, and when he does observe it, it may be too late. Its dose varies from a scruple to half a drachm. In doses of a drachm it could not be given with safety; and yet, such is the different effect of medicines given in different doses, that in the quantity of an ounce it is said to be a diuretic and a tonic, and exhibited with advantage in chronic and obstinate grease.

Helleborus Niger, Black Hellebore.-This is used mostly as a local application, and as such it is a very powerful stimulant. Mr. E. Stanley, of Banbury, frequently resorts to it in fistulous affections of the poll and withers, and with considerable success. The abscess having formed, and exit being given to the imprisoned fluid, it is allowed to discharge itself, for two or three days, being dressed with an ordinary digestive ointment. When the pus assumes a laudable character, he introduces a few portions of the fibrous part of the root, passing them down to the bottom of the sinus, and letting them remain for a fortnight or more; in the mean time, merely keeping the surrounding parts clean. On examination, it will be found that the healing process has commenced.

Professor Morton adds, that an ointment, formed of the powder of either the black or white Hellebore, in the proportion of one part of the powder to eight of lard, will be found exceedingly active for the dressing of rowels and setons.*

HEMLOCK is used by some practitioners, instead of digitalis or hellebore, in affections of the chest, whether acute or chronic; but it is inferior to both. The dose of the powder of the dried leaves is about a drachm.

HYDrargyrum.-This metal is found native in many countries in the form of $\mathrm{mi}$ nute globules. It also occurs in masses, and in different varieties of crystallization. It has the singular property of being liquid in the natural temperature of our earth. It freezes, or assumes a singular species of crystallization, at $39^{\circ}$ below 0 of Fah., and at $660^{\circ}$ above 0 of Fah. it boils, and rapidly evaporates. In its metallic state it appears to have no action on the animal system, but its compounds are mostly powerful excitants, and some of them are active caustics.

The Common Mercurial Ointment may be used for ring-worm, and that species of acarus which seems to be the source, or the precursor of, mange. The compound mercurial ointment is also useful in the destruction of the same insect. For most eruptions connected with or simulating mange, the author of this work has been accustomed to apply the following ointment with considerable success :-

$$
\begin{aligned}
& \text { Sublimed sulphur } \ldots \ldots \ldots \ldots \ldots \ldots \ldots \ldots \ldots \ldots 1 \text { pound. } \\
& \text { Common turpentine } \ldots \ldots \ldots \ldots \ldots \ldots \ldots \ldots \ldots \ldots \ldots \ldots \ldots \ldots \ldots \text { oz. } \\
& \text { Mercurial ointment ................... } 2 \text { oz. } \\
& \text { Linseed oil .......................... }
\end{aligned}
$$

The Mercurial Ointment is prepared by rubbing quicksilver with lard, in the proportion of one part of mercury to three of lard, until no globules appear. The practitioner should, if possible, prepare it himself, for he can seldom get it pure or of the proper strength from the druggist. It is employed with considerable advantage in preparing splents, spavins, or other bony or callous tumours, for blistering or firing. One or two drachms, according to the nature and size of the swelling, may be daily well rubbed in; but it should be watched, for it sometimes salivates the horse very speedily. The tumours more readily disperse, at the application of a stronger stimulant, when they have been thus prepared. Mercurial ointment in a weaker state is sometimes necessary for the cure of mallenders and sallenders; and in very obstinate cases of mange, one-eighth part of mercurial ointment may be added to the ointment recommended at page 384 .

Calomel, the submuriate or protochloride of mercury, may be given, combined with

* Morton's Manual of Pharmacy, p. 175. 
aloes, in mange, surfeit, or worms. It is also useful in some cases of chronic cough, in farcy, and in jaundice. Alone it has little purgative effect on the horse, but it assists the action of other aperients. It is given in doses from a scruple to a drachm. As soon as the gums become red, or the animal begins to quid or drop his hay, it must be discontinued. Calomel has lately gained much repute in arresting the progress of epidemic catarrh in the horse. Mr. Percivall has succeeded in this attempt to a very considerable extent. In fact, the influence of calomel in veterinary practice seems to have been far too much undervalued.*

Corrosive Sublimate, the oxymuriate or bichloride of mercury, combined with chlorine in a double proportion, is a useful tonic in farcy. It should be given in doses of ten grains daily, and gradually increased to a scruple, until the horse is purged, or the mouth becomes sore, when it niay be omitted for a few days, and resumed. Some have recommended it as a diuretic, but it is too dangerous a medicine for this purpose. It is used externally in solution; in substance in quittor, as a stimulant to foul ulcers; and in the proportion of five grains to an ounce of rectified spirit in obstinate mange, or to destroy vermin on the skin. It is, however, too uncertain and too dangerous a medicine for the horse-proprietor to venture on its use.

Ethiop's II neral, the black sulphuret of mercury, is not often used in horse-practice, but it is a good alterative for obstinate surfeit or foulness of the skin, in doses of three drachms daily. Four drachms of cream of tartar may be advantageously added to each dose.

Infusions.-The active matter of some vegetałle substances is partly or entirely extracted by water. Dried vegetables yield their properties more readily and perfectly than when in their green state. Boiling water is poured on the substance to be infused, and which should have been previously pounded or powdered, and the vessel then covered and placed near a fire. In five or six hours the transparent part may be poured off, and is ready for use. In a few days, however, all infusions become thick, and lose their virtue, from the decomposition of the vegetable matter.

The infusion of chamomile is advantageously used instead of water in compounding a mild tonic drench. The infusion of catechu is useful in astringent mixtures; that of linseed is used instead of common water in eatarrh and cold; and the infusion of tobacco in some injections.

IoDiNE.-This substance has not been long introduced into veterinary practice. The first object which it seemed to accomplish, was the reduction of the enlarged glands that frequently remain after catarrh, but it soon appeared that it could reduce almost every species of tumour. Much concerned in the first introduction of iodine into veterinary practice, the writer of the present work bears willing testimony to the zeal and success of others, in establishing the claims of this most valuable medicine. Professor Morton has devoted much time and labour to the different combinations of iodine, and they are described at length in his useful "Manual of Pharmacy." He gives the formulæ of the composition of a liniment, an ointment, and a tincture of iodine, adapted to different species and stages of disease. He next describes the preparation of the iodide of potassium - the combination of iodine and potash, - and then the improvement on that under the name of the diniodide of copper-the union of two parts of the iodide of potassium with four of the sulphate of copper.

The action of this compound is an admirable tonic and a stimulant to the absorbent system, if combined with vegetable tonics, and, occasionally, small doses of cantharides. Professor Spooner and Mr. Daws applied this compound, and with marked success, to the alleviation of farcy, nasal gleet, and glanders. It is pleasing to witness these triumphs over disease, a little while ago so unexpected, and now so assured.

Juniper, O1L of.-This essential oil is retained because it has some diuretic property, as well as being a pleasant aromatic. It frequently enters into the composition of the diuretic ball.

Lead, Plumbum.-The Carbonate of Lead has a deleterious effect on the biped and the quadruped in the neighbourhood of lead works. They are subject to violent griping pains, and to constipation that can with great difficulty, or not at all, be overcome. something of the same kind is occasionally observed in the cider counties, and the

* Veterinarian, vol. xvi., or i., new series, pp. 325,441 , and 524 . 
"painter's colic" is a circumstance of too frequent occurrence-the occasional dreadful pains, and the ravenous appetite extending to everything that comes in the way of the animal. Active purgatives followed by opium are the most effectual remedies.

The Acetate of Lead, Plumbi Acetas.- Sugar of lead is seldom given externally to the horse, but is used as a collyrium for inflammation of the eyes.

The Liquor Plumbi Subacetatis, or Goulard's Extract, or, as it used to be termed at the Veterinary College, the Aqua Vegeto, is a better collyrium, and advantageously used in external and superficial inflammation, and particularly the inflammation that remains after the application of a blister.

Lime was formerly sprinkled over cankered feet and greasy heels, but there are less painful caustics, and more effectual absorbents of moisture. Lime-water is rarely used, but the Chloride of Lime is exceedingly valuable. Diluted with twenty times its quantity of water, it helps to form the poultice applied to every part from which there is the slightest offensive discharge. The fœid smell of fistulous withers, pollevil, canker, and ill-conditioned wounds, is immediately removed, and the ulcers are more disposed to heal. When mangy horses are dismissed as cured, a washing with the diluted chloride will remove any infection that may lurk about them, or which they may carry from the place in which they have been confined. One pint of the chloride mixed with three gallons of water, and brushed over the walls and manger and rack of the foulest stable, will completely remove all infection. Professor Morton, very properly, says that the common practice of merely whitewashing the walls serves only to cover the infectious matter, and perhaps to preserve it for an indefinite length of time, so that when the lime scales off, disease may be again engendered by the exposed virus. The horse furniture worn by a glandered or mangy animal will be effectually purified by the chloride. Internally administered, it seems to have little or no power.

LiNiments are oily applications of the consistence of a thick fluid, and designed either to soothe an inflamed surface, or, by gently stimulating the skin, to remove deeper-seated pain or inflammation. As an emollient liniment, one composed of half an ounce of extract of lead and four ounces of olive oil will be useful. For sprains, old swellings, or rheumatism, two ounces of hartshorn, the same quantity of camphorated spirit, an ounce of oil of turpentine, and half an ounce of laudanum, may be mixed together; or or an ounce of camphor may be dissolved in four ounces of sweet oil, to which an ounce of oil of turpentine may be afterwards added. A little powdered cantharides, or tincture of cantharides, or mustard powder, will render either of these more powerful, or convert it into a liquid blister.

LiNSEÈ.-An infusion of linseed is often used instead of water, for the drink of the horse with sore-throat or catarrh, or disease of the urinary organs or of the bowels. A pail containing it should be slung in the stable or loose box. Thin gruel, however, is preferable; it is as bland and soothing, and it is more nutritious. Linseed meal forms the best poultice for almost every purpose.

MAGNeS1A. - The sulphate of magnesia, or Epsom Salts, should be used only in promoting the purgative effect of clysters, or, in repeated doses of six or eight ounces, gently to open the bowels at the commencement of fever. Some doubt, however, attends the latter practice; for the dose must occasionally be thrice repeated before it will act, and then, although safer than aloes, it may produce too much irritation in the intestinal canal, especially if the fever is the precursor of inflammation of the lungs.

MAsHes constitute a very important part of horse-provender, whether in sickness or health. A mash given occasionally to a horse that is otherwise fed on dry meat prevents him from becoming dangerously costive. To the over-worked and tired horse, nothing is so refreshing as a warm mash with his usual allowance of corn in it. The art of getting a horse into apparent condition for sale, or giving him a round and plump appearance, consists principally in the frequent repetition of mashes, and, from their easiness of digestion and the mild nutriment which they afford, as well as their laxative effect, they form the principal diet of the sick horse.

They are made by pouring boiling water on bran, and stirring it well, and then covering it over until it is sufficiently cool for the horse to eat. If in the heat of summer a cold mash is preferred, it should, nevertheless, be made with hot water, and then suffered to remain until it is cold. This is not always sufficiently attended to by the groom, who is not aware that the efficacy of the mash depends principally 
on the change which is effected in the bran and the other ingredients by the boiling water rendering them more easy of digestion, as well as more aperient. If the horse refuses the mash, a few oats may be sprinkled over it, in order to tempt him to eat it; but if it is previously designed that corn should be given in the mash, it should be scalded with the bran, in order to soften it and render it more digestible. Bran mashes are very useful preparatives for physic, and they are necessary during the operation of the physic. They very soon hecome sour, and the manger of the horse, of whose diet they form a principal part, should be daily and carefully cleaned out.

When horses are weakly and much reduced, malt mashes will often be very palatable to them and very nutritive : but the water that is poured on a malt mash should be considerably below the boiling heat, otherwise the malt will be set, or clogged together. If the owner was aware of the value of a malt mash, it would be oftener given when the horse is rapidly getting weaker from protracted disease, or when he is beginning to recover from a disease by which he has been much reduced. The only exception to their use is in cases of chest affection, in which they must not be given too early. In grease, and in mange accompanied by much emaciation, malt mashes will be peculiarly useful, especially if they constitute a principal portion of the food.

Mustard, Sinapis.-This will be found occasionally useful, if, in inflammation of the chest or bowels, it is well rubbed on the chest or the abdomen. The external swelling and irritation which it excites may, to a greater or less degree, abate the inflammation within.

Mrrah may be used in the form of tincture, or it may be united to the tincture of aloes as a stimulating and digestive application to wounds. Diluted with an equal quantity of water, it is a good application for canker in the mouth, but as an internal medicine it seems to be inert, although some practitioners advocate its use, combined with opium, in cases of chronic cough.

Nitrous A:ther, Spirit of, is a very useful medicine in the advanced stages of fever, for while it, to a certain degree, rouses the exhausted powers of the animal, and may be denominated a stimulant, it never brings back the dangerous febrile action which was subsiding. It is given in doses of three or four drachms.

OLIVE OIL is an emollient and demulcent. Its laxative effect is very inconsiderable and uncertain in the horse.

Opium.- However underrated by some, there is not a more valuable drug on our list. It does not of ten act as a narcotic except in considerable doses; but it is a powerful antispasmodic, sedative, and astringent. As an antispasmodic, it enters into the cholic drink, and it is the sheet-anchor of the veterinarian in the treatment of tetanus or locked-jaw. As a sedative it relaxes that universal spasm of the muscular system which is the characteristic of tetanus; and, perhaps, it is only as a sedative that it has such admirable effect as an astringent, for when the irritation around the mouths of the vessels of the intestines and kidneys is allayed by the opium, the undue purging and profuse staling will necessarily be arrested.

Opium should, however, be given with caution. It is its secondary effect that is scdative, and, if given in cases of fever, its primary effect in increasing the excitation of the frame may be very considerable and highly injurious. In the early and acute stage of fever, it would be bad practice to give it in the smallest quantity; but when the fever has passed, or is passing, there is nothing which so rapidly subdues the irritability that accompanies extreme weakness. It becomes an excellent tonic, because it is a sedative.

If the blue or green vitriol, or cantharides, have been pushed too far, opium, sooner than any other drug, quiets the disorder they have occasioned. It is given in doses of one or two drachms, in the form of ball. Other medicines are usually combined with it, according to the circumstances of the case.

Externally, it is useful in ophthalmia. In the form of decoction of the poppy-head, it may constitute the basis of an anodyne poultice; but it must not be given in union with any alkali, with the exception of chalk, in over-purging; nor with the superacetate of lead, by which its powers are materially impaired; nor with sulphate of zinc, or copper, or iron.

From its high price it is much adulterated, and it is not always met with in a state of purity. The best tests are its smell, its taste, its toughness and pliancy, its fawn or brown colour, and its weight, for it is the heavicst of all the vegetable extracts 35 * 
except gum arabic; yet its weight is often fraudulently incrcased by stones and bits of lead dexterously concealed in it. The English opium is almost as good as the Turkish, and frequently sold for it; but is distinguishable by its blackness and softness.

PALM O1L, when genuine, is the very best substance that can be used for making masses and balls. It has a pleasant smell, and it never becomes rancid.

Plтch is used to give adhesiveness and firmness to charges and plasters. The common pitch is quite as good as the more expensive Burgundy pitch. The best plaster for sandcrack consists of one pound of pitch and an ounce of yellow beeswax melted together.

Physic.-The cases which require physic, the composition of the most effectual and safest physic-ball, and the mode of treatment under physic, have been already described.

Potash.-Two compounds of potash are used in veterinary practice. The Nitrate of Potash (Nitre) is a valuable cooling medicine and a mild diuretic, and, therefore, it should enter into the composition of every fever-ball. Its dose is from two to four drachms. Grooms often dissolve it in the water. There are two objections to this: either the horse is nauseated and will not drink so much water as he ought; or the salt taste of the water causes considerable thirst, and disinclination to solid food. Nitre, whilst dissolving, materially lowers the temperature of water, and furnishes a very cold and useful lotion for sprain of the back sinews, and other local inflammations. The lotion should be used as soon as the salt is dissolved, for it quickly becomes as warm as the surrounding air. The Bitartrate of Potash (Cream of Tartar) is a mild diuretic, and, combined with Ethiop's mineral, is used as an alterative in obstinate mange or grease. The objection, however, to its use in such an animal as the horse, is the little power which it seems to exercise.

Poultices.-Few horsemen are aware of the value of these simple applications in abating inflammation, relieving pain, cleansing wounds, and disposing them to heal. They are applications of the best kind continued much longer than a simple fomentation can be. In all inflammations of the foot they are very beneficial, by softening the horn hardened by the heat of the foot and contracted and pressing on the internal and highly sensible parts. The moisture and warmth are the useful qualities of the poultice; and that poultice is the best for general purposes in which moisture and warmth are longest retained. Perspiration is most abundantly promoted in the part, the pores are opened, swellings are relieved, and discharges of a healthy nature procured from wounds.

Linseed meal forms the best general poultice, because it longest retains the moisture. Bran, although frequently used for poultices, is objectionable, because it so soon becomes dry. To abate considerable iuflammation, and especially in a wounded part, Goulard nay be added, or the linseed meal may be made into a paste with a decoction of poppy-heads. To promote a healthy discharge from an old or foul ulcer; or separation of the dead from the living parts, in the process of what is called coring out; or to hasten the ripening of a tumour that must be opened; or to cleanse it when it is opened,-two ounces of common turpentine may be added to a pound of linseed meal: but nothing can be so absurd, or is so injurious, as the addition of turpentine to a poultice that is designed to be an emollient. The drawing poultices and stoppings of farriers are often highly injurious, instead of abating inflammation.

If the ulcer smells offensively, two ounces of powdered charcoal may be added to the linseed meal, or the poultice may be made of water, to which a solution of the chloride of lime has been added in the proportion of half an ounce to a pound. As an emollient poultice for grease and cracked heels, and especially if accompanied by much unpleasant smell, there is nothing preferable to a poultice of mashed carrots with charcoal. For old grease some slight stimulant must be added, as a little yeast or the grounds of table-beer.

There are two errors in the application of a poultice, and particularly as it regards the legs. It is often put on too tight, by means of which the return of the blood from the foot is prevented, and the disease is increased instead of lessened; or it is too hot, and unnecessary pain is given, and the inflammation aggravated.

Powders.- Some horses are very difficult to ball or drench, and the violent struggle that would accompany the attempt to conquer them may heighten the fever or inflammation. To such horses powders must be given in mashes. Emetic tartar and 
digitalis may be generally used in cases of inflammation or fever; or emetic tartar for worms; or calomel or even the farina of the croton nut for physic: but powders are too often an excuse for the laziness or awkwardness of the carter or groom. The horse frequently refuses them, especially if his appetite has otherwise begun to fail; the powder and the mash are wasted, and the animal is unnecessarily nauseated. All medicine should be given in the form of ball or drink.

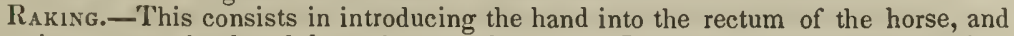
drawing out any hardened dung that may be there. It may be necessary in costivencss or fever, if a clyster pipe cannot be obtained; but an injection will better effect the purpose, and with less inconvenience to the animal. The introduction of the hand into the rectum is, however, useful to ascertain the existence of stone in the bladder, or the degree of distension of the bladder in suppression of urine, for the hladder will be easily felt below the intestine, and, at the same time by the heat of the intestine, the degree of inflammation in it or in the bladder may be detected.

Resin.- The yellow resin is that which remains after the distillation of oil of turpcntine. It is used externally to give consistence to ointments, and to render them slightly stimulant. Internally it is a useful diuretic, and is given in doses of five or six drachms made into a ball with soft soap. The common liquid turpentine is, however, preferable.

Rowels. - The manner of rowelling has been already described. As exciting inflammation on the surface, and so lessening that which had previously existed in a neighbouring but deeper-seated part, they are decidedly inferior to blisters, for they do not act so quickly or so extensively; therefore they should not be used in acute inflammation of the lungs or bowels, or any vital part. When the inflammation, however, although not intense, has long continued, rowels will be serviceable by producing an irritation and discharge that can be better kept up than by a blister. As promoting a permanent, although not very considerable discharge, and some inflammation, rowels in the thighs are useful in swelled legs and obstinate grease. If fluid is thrown out under the skin in any other part, the rowel acts as a permanent drain. When sprain of the joint or the muscles of the shoulders is suspected, a rowel in the chest will be serviceable. The wound caused by a rowel will readily heal, and with Jittle blemish, unless the useless leather of the farrier has been inserted.

SeCale cornutur, the Ergot of Rye.-This is well known to be an excitant in assisting parturition in cattle, sheep, and dogs. It has been used with success in the mare by Mr. Richardson, of Lincoln. It should only be applied in difficult cases, and the dose should be two drachms, combined with some carminative, and given every hour.

SeDatives are medicines that subdue irritation, repress spasmodic action, or deaden pain. We will not inquire whether they act first as stimulants: if they do, their cffect is exceedingly transient, and is quickly followed by depression and diminished action. Digitalis, hellebore, opium, turpentine, are medicines of this kind. Their effect in different diseases or stages of disease, and the circumstances which indicate the usc of any one of them in preference to the rest, are considered under their respective titles.

SoDA.-The Carbonate of Soda is a useful antacid, and probably a diuretic, but it is not much used in veterinary practice. The Chloride of Soda is not so efficacious for the removal of unpleasant smells and all infection as the chloride of lime; but it is exceedingly useful in changing malignant and corroding and destructive sores into the state of simple ulcers, and, in ulcers that are not malignant, it much hastens the cure. Poll evil and fistulous withers are much benefited by it, and all farcy ulcers. It is used in the proportion of one part of the solution to twenty-four of water.

Sodu Culoridur, Common Salt, is very extensively employed in veterinary practice. It forms an efficacious aperient clyster, and a solution of it has been given as an aperient drink. Sprinkled over the hay, or in a mash, it is very palatable to sick horses; and in that languor and disinclination to food which remain after severe illness, few things will so soon recall the appetite as a drink composed of six or eight ounces of salt in solution. To horses in health it is more useful than is generally imagined, as promoting the digestion of the food, and, consequently, condition. Externally applied, therc are few better lotions for inflamed eyes than a solution of half a drachm of salt in four ounces of water. In the proportion of an ounce of salt to the same quantity of water, it is a good embrocation for sore shoulders and backs; and if it 
does not always disperse warbles and tumours, it takes away much of the tenderness of the skin.

Sone Sulphas, - Sulphate of Soda._-Glauber's Salt.-This medicine is seldom used in the treatment of the horse. It appears to have some diuretic property.

Soap is supposed to possess a diuretic quality, and therefore enters into the composition of some diuretic masses. See Resin. By many practitioners it is made an ingredient in the physic-ball, but uselessly or even injuriously so; for if the aloes are finely powdered and mixed with palm oil, they will dissolve readily enough in the bowels without the aid of the soap, while the action of the soap on the kidneys will impair the purgative effect of the aloes.

STARCH may be substituted with advantage for gruel in obstinate cases of purging, both as a clyster, and to support the strength of the animal.

Stoppisgs constitute an important, but too often neglected part of stable management. If a horse is irregularly or seldom worked, his feet are deprived of moisture; they become hard and unyielding and brittle, and disposed to corn and contraction and founder. The very dung of a neglected and filthy stable would be preferable to habitual standing on the cleanest litter without stopping. In wounds, and bruises, and corns, moisture is even more necessary, in order to supple the horn, and relieve its pressure on the tender parts beneath. As a common stopping, nothing is better than cow-dung with a fourth part of clay well beaten into it, and confined with splents from the binding or larger twigs of the broom. In cases of wounds a little tar may he added; but tar, as a common stopping, is too stimulating and drying. Pads made of thick felt have lately been contrived, which are fitted to the sole, and, swelling on being wetted, are sufficiently confined by the shoe. Having been well saturated with water, they will continue moist during the night. They are very useful in gentlemen's stables; but the cow-dung and clay are sufficient for the farmer.

StrychNia.-This drug has frequently been employed with decided advantage in cases of paralysis in the dog; and lately, and with decided advantage, it has been administered to the horse. The dose is from one to three grains, given twice in the day.

Sulphur is the basis of the most effectual applications for mange. It is an excellent alterative, combined usually with antimony and nitre, and particularly for mange, surfeit, grease, hidebound, or want of condition; and it is a useful ingredient in the cough and fever ball. When given alone, it seems to have little effect, except as a laxative in doses of six or eight ounces; but there are much better aperients. The black sulphur consists principally of the dross after the pure sulphur has been separated.

TAR melted with an equal quantity of grease forms the usual stopping of the farrier. It is a warm, or slightly stimulant, and therefore useful, dressing for bruised or wounded feet; but its principal virtue seems to consist in preventing the penetration of dirt and water to the wounded part. As a common stopping it has been considered objectionable. From its warm and drying properties it is the usual and proper basis for thrush ointments; and from its adhesiveness, and slightly stimulating power, it often forms an ingredient in applications for mange. Some practitioners give it, and advantageously, with the usual cough medicine, and in doses of two or three drachms for chronic cough. The common tar is as effectual as the Barbadoes for every veterinary purpose. The oil, or spirit (rectified oil) of tar is sometimes used alone for the cure of mange, but it is not to be depended upon. The spirit of tar, mixed with double the quantity of fish oil, is, from its peculiar penetrating property, one of the best applications for hard and brittle feet. It should be well rubbed with a brush, every night, both on the crust and sole.

Tinctures.-The medicinal properties of many substances are extracted by spirit of wine, but in such small quantities as to be scarcely available for intermal use in veterinary practice. So much aloes or opium must be given in order to produce effect on the horse, that the quantity of spirit necessary to dissolve it would be injurions or might be fatal. As applications to wounds or inflamed surfaces, the tinctures of aloes, digitalis, myrrh, and opium, are highly useful.

Toвacco, in the hands of the skilful veterinarian, may be advantageously employed in cases of extreme costiveness, or dangerous cholic; but should never be permitted to be used as an external application for the cure of mange, or an internal medicine to promote a fine coat. 
Tonıcs are valuable medicines when judiciously employed; but, like cordials, they have been fatally abused. Many a horse recovering from severe disease has been destroyed by their too early, or too free use. The veterinary surgeon occasionally administers them injuriously, in his anxiety to gratify the impatience of his employer. The mild vegetable tonics, chamomile, gentian, and ginger, and, perhaps, the carbonate of iron, may sometimes be given with benefit, and may hasten the perfect recovery of the patient; but there are few principles more truly founded on reason and experience, than, that disease once removed, the powers of nature are sufficient to re-establish health. Against the more powerful mineral tonics, except for the particular purposes that have been pointed out under the proper heads, the horse proprietor and the veterinarian should be on his guard.

TurPentine. - The common liquid turpentine has been described as one of the best diuretics, in doses of half an ounce, and made into a ball with linseed meal and powdered ginger. It is added to the calamine or any other mild ointment in order to render it stimulating and digestive, and, from its adhesiveness and slight stimulating power it is an ingredient in mange ointments. The oil of turpentine is an excellent antispasmodic. For the removal of cholic it stands unrivalled. Forming a tincture with cantharides, it is the basis of the sweating blister for old strains and swellings. As a blister it is far inferior to the common ointment. As a stimulant frequently applied it must be sufficiently lowered, or it may blemish.

WAx. - The yellow wax is used in charges and some plasters to render them less brittle.

$\mathrm{Z}_{1 \mathrm{NC}}$.-The impure carbonate of zinc, under the name of Calamine Powder, is used in the preparation of a valuable healing ointment, called Turner's Cerate. Five parts of lard and one of resin are melted together, and when these begin to get cool, two parts of the calamine, reduced to an impalpable powder, are stirred in. If the wound is not healthy, a small quantity of common turpentine may be added. This salve justly deserves the name which it has gained, "The Healing Ointment." The calamine is sometimes sprinkled with advantage on cracked heels and superficial sores.

The sulphate of zinc, White Fitriol, in the proportion of three grains to an ounce of water, is an excellent application in ophthalmia, when the inflammatory stage is passing over; and quittor is most successfully treated by a saturated solution of white vitriol being injected into the sinuses. A solution of white vitriol of less strength forms a wash for grease that is occasionally useful, when the alum or blue vitriol does not appear to succeed.

ZiNGIBERIS RADIX.-Ginger Root.-This is an admirable stimulant and carminative. It is useful in loss of appetite and flatulent cholic, while it rouses the intestinal canal to its proper action. The cordial mass resorted to by the best surgeons consists of equal parts of ginger and gentian beaten into a mass with treacle. 



\title{
THE ASS AND THE MULE,
}

\author{
B Y J.S. S K I N N ER.
}

\author{
"He would \\ Have made them mules: who have their provender \\ Only for bearing burdens; and sore blowe \\ For sinkiag under them."
}

Against these humble animals there seems with many, to be a prejudice, more cruel, if not more inveterate, than that which prompts every son of Adam, whether he meet him on the high-way or the bye-way, to "bruise the serpent's head!" Can it be that these abiding antipathies to both, are perpetuated by the force of seriptural injunetions against the life of the one and the procreation of the other? "Thou shalt not let thy cattle gender with a diverse kind," saith the Scriptures: now, though this command may be admitted as binding upon the Jews not to breed mules, does it follow that a christian is forbidden the kind treat. ment and judicious use of them? The same ehapter and verse which denounees this experiment upon the proereative faculties of God's creatures, also warns the husbandman not to "sow mingled seed"- but what farmer, whether Jew or Gentile, refuses to reap a good crop of mixed elover and timotlyy? and besides, did not King David, a man after God's own heart, indicate his care for his son, and intend it as a compliment for both him and the mule, when he gave the order, "take with you the servants of your Lord, and eause Solomon my son to ride upon mine own mule, and bring him down to Gihon?" Let me then invoke the liberality of my readers to east aside all prejudice against this useful and too often abused hybrid, and impartially to hear me "for my cause."

To all, and there are many, who entertain a scornful contempt for the whole asinine family, might be commended Sterne's pathetic story of "The Dead Ass," for a touching pieture of faithful service, and of mutual friendship in the humblest walks of life-c" Shame on the world! said I to myself. Did we love each other as this poor soul loved his Ass-'t would be something."

Ameriea, as to its Agriculture, may be likened to a gallant ship, moored in a beautiful harbour, whose owners have no means to buy her cargo or hire sailors to man and send her to sea. The mildew blights her sails, and worms eat out her bottom. So it is with our lands; with millions on millions of acres, the growth of our population and national wealth is lamentably retarded for want of force to put them in good and profitable tillage. There is no country where labour, and all labour-saving animals and contrivances, are so much a desideratum as in ours! Henee the neeessity and the usefulness of every discussion which slall teach the land-holder how and in what form-with what animal or implement, he ean with the least outlay, command the greatest amount of productive power applicable to ngriculture. Tliat power, in a word, whether animate or inanimate, which will work the longest and the cheapest and with most cffeet. Among animals, is it not in the mule that we find this power or machine? This, reader, is the subjeet of our inquiry : and first it seems proper to look into its natural history and qualities, to see whether there be in fact any ground of preference between one and another, or whether a mule is a mule! all being alike, as too many scem to suppose; and finally to inquire and explain in what the difference of quality, imparting differenee of value, consists-such, reader, is the object of this dissertation.

Agriculturists, cren thoze who have enjoyed opportunities of becoming more familiar with the qualities and uses of this animal, seem to reason, as already hinted, or rather to conclude without reason, that all mules are alike; with the name and the sight of all is alike assoeiated the idea of jumping and kicking and all sorts of devilment inearnate! Hence has arisen the difficulty, the limited employment and the slowness in realising the improvements of which this animal is susceptible, like others, even the proud "lord of the ereation," by attention to breed and to education!

We must be allowed to premise that we hare not taken the subject in hand in any vain belief that we can add anything new to what bas been written upon their natural history; 
but rather with the hope of making some impression on the public mind, and inducing a higher appreciation of these animals, by presenting at one view the opinions, some of them hitherto unpublished, and believed to be very striking, of gentlemen who have enjoyed rare opportunities to judge of the different races of the Ass, and of the temper, habits and capa. bilities of the Mule. True, the Editor professes to be himself not altogether without experience on some of these points; having often, when a boy, been mounted on the back of one, and sent, on Saturday (always on Saturday) in spite of all pouting and sulking, to the weaver, the shoemaker, the tailor, or the country store. On these mournful occasions, the sense of hardship at being disappointed of some well-concerted scheme of rural sport, found vent, it may be easily imagined, in acts of spitefulness (not always unretaliated) towards the innocent mule-the poor beast being beaten and the rider sometimes thrown over his head! until now, that though near forty years have passed away since the close of this war of puerile injustice and mulish resentment, it may yet be questioned whether it be exactly fair, that one of the parties should assume to be the limner of the other ! We will en. deavour, however, in weighing the subject, to hold the scales with even hand; and here, lest it be elsewhere omitted, let one acknowledgment be made, and noted by the advocates of the more sightly and favoured horse,-that though the mule may, as already suggested, be the cause of falls in others, no man ever jet saw a mule fall down! but we must not anticipate.

As already stated, the first inquiry would seem to be as to the progenitors of the mule, to decide how far, on these, depend the qualities and value of the progeny. This point being discussed, the subject leads us to consider the qucstion of rearing and breaking-his age, strength and general usefulness compared with other animals. On all these points we shall rely as before admitted on the views of intelligent writers, and of gentlemen of close observation and of the highest respectability with whom we have recently corresponded. Before proceeding however to quote authorities on these points, there is one proposition or conclusion which reading and inquiry have led us to adopt, and which may as well be here expressed, without stopping to trouble the reader with all the particular grounds of it. It is that the best mules are produced by the union of the Jack with the mare, rather than from cohabitation between the Stallion and the Jennet. Independently of any particular facts, and of the few instances in which the Stallion is known to have been so employed, (that alone warrant. ing the inference against its eligibility) we should form the conclusion here announced, that the better produce would be, generally from the smaller sire and the larger dam; on the clear principles of breeding laid down by Professor Cline of London, in his essay on breeding domestic animals, which is elsewhere referred to and quoted in our introduction to the work on the Horse.

In the annals of American agriculture at least, the essay on the mule, which may be regarded as the most elaborate and of the highest authority, is one written by S. W. POMEROY, Esq., a gentleman who, whether farming, as then, near the "Literary Emporium," or as now, more profitably employed, as we learn and hope, in hcaving coal on the banks of the Ohio; brings light to every circle in which he moves. Of an essay so meritorious, we may be justified in telling the history; and the more so as by so doing we shall give to the positions it maintains more weight with the rcader than would any dictum of ours.

The writer of this, then the Editor of the old American Farmer, being himself bred on a "plantation" where mules were bred and in constant use, and anxious to have the minds of his numerous patrons disabused and enlightened as to the true qualitics and value of this, as compared with other and more favoured animals for the usual purposes of husbandry, without difficulty persuaded the late venerable CHARLEs Carroll of Carrollton to offer a premium for the best essay on that subject. The competitors were numerous, but the award of the plate, with its appropriate deviccs and inscriptions, was unanimously and without hesitation, to S. W. Pomeroy, then of Brighton Massachusetts. It is to that essay we shall now have free recourse; and first as to

\section{THE DIFFERENT RACES OF JACKS.}

It seems to be a well-established fact, that different races of the Ass exist with properties as distinctly marked as those which characterise the various species of camel. According to the learned Doctor Harris, author of the "Natural History of the Bible," four different races of asses are recognised in the original Hebrew Scriptures: viz. Para, Chamor, Aton, and Orud.

We find, says the author of the prize essay referred to, that at a very early period of sacred history, the common domestic ass, Chamor, was einployed in all the menial labours of a patriarchal family, while a nobler and more estimable animal (Aton) was destined to carry the patriarchs, the well-born, and thosc on whom marks of distinction were to be conferred. They constituted an important item in a schedule of pastoral wealth of those times. David, we are told, had an officer of high dignity appointed expressly to superintend his stud of high-bred asses! Atonoth. 
The difference betwcen the different races, for which all writers of research and the most observant travellers and agriculturists contend, may be plainly traced in the portraits drawn by G. W. Park Custis, Ese., of Arlington, of the two Jacks, the Royal Gift, and the KNight of Malta, presented to General IVasinseton about the year 1787-of these Mr. Custis says, "The $G$ ift, with a jennet, was a present from the king of Spain, and said to have been selected from the royal stud. The Knight I believe was from the Marquis de Lafayette, and shipped from Marseilles.

"The Glrt was a huge and ill-shaped Jack, near sixteen hands high, very large head, clumsy limbs, and to all appearance little calculated for active service; he was of a grey colour, probably not young when imported, and died at Mount Vernon but little valued for his mules, which werc unwicldy and dull.

"The KNight was of a moderate size, clean limbed, great activity, the fire and ferocity of a tiger, a dark brown, nearly a black colour, white belly and muzzle, could be managed only by onc groom, and that always at considerable personal risk. He lived to a great old age, and was so infirm towards the last as to require lifting. He died on my estate, in New Kent, in the state of Virginia, in the year 1802 or '3. His mules were all active, spirited, and serviccable, and from stout mares attaincd considerable size.

The Knight of Malta, here mentioned by Mr. Custis, is believed unquestionably to have becn "the first Maltese Jack ever brought to the United States." The second onc, says Mr. Pomcroy, came in the Frigate Constitution on her return, as he thinks, from the Mediter. ranean, and was sold, it is belicved, in the District of Columbia. Since that time a number have been introduced by officers of the Navy, and in merchant-ships.

The learned Professor WVilson, in an article in the Encyclopedia Brittanica, on the natural history of quadrupeds and whales, says of the Ass : "Tlic races of eastern origin are much more beautiful, with ghossy skins, carrying their heads loftily, and moving their limbs in a very graceful manner. They accordingly fetch a very high price."

There is no one within the rangc of our acquaintance whose dealings and whose experience on these subjects, cqual thosc of General James Shelby of Kentucky. Owning and rcsiding upon a magnificent estatc of "blue grass land," its resources have been in a good measure dedicated to rearing mules and cattle of improved breeds. The writcr had the pleasure to make him a visit in 1839 ; and while partaking festively and intellectually of the hospitalities of his mansion, to learn much of the mule trade, in its various branches. It was like going to New Bedford to bc instructed in all the art and mystery of the whaling business! The general's residence is cight miles from Lexington; and it may be taken as a proof of no mean powcrs of performancc in light harness, that we were taken to his house in his own carriage by a pair of his mulcs, then in common family use in that way, within the hour, and without a touch of the whip.

On the point under consideration, the different breeds of Jacks, General Shelby's opinion is positive, and should carry with it all the weight that habit of close observation and large cxpericnce can impart. He maintains, without question, that the Ass belongs to a family, possessing as many varieties as that of the horse; the size, form, and general appearance in the onc being as dissimilar, in different races, as in the other. By judiciously crossing, says he, the different varieties of horscs, other varieties have been obtained, bctter adapted to the particular purposes of the breeder-so likewise may the Jack be improved. This last suggestion is in strict accordance with the fact stated by Mr. Custis, who, in his letter to Mr.Pomeroy, after cxcmplifying the remarkable difference of properties which distinguished the Royal Gift and the Knight of Malta, says that General Washington bred a favourite Jack called Coupouxd from the cross of Spanish and Maltese, putting the Knight of Malta sent out by Gencral Lafayettc to the large jennet scnt out by the king of Spain along with the Royal Gift. The Jack produced by this cross, Mr. Custis says "was a very superior animal, very long bodied, well sct, with all the qualities of the Knight and the weight of the Spanish breed-he was sire of some of the finest mules at Mount Vernon, and died from accident.

In full support of these views and descriptions of diffcrence of breed in Jacks, we have yet in reserve an authority on which we pluce the highest confidence and value. It is that of J. N. Hambleton, Esq., of the United States Navy-whose professional duties carry hitn to different quarters of the world, and who, moreover, carries with him on his travels very rare advantages and habits, such as, be it said, en passant, it behoves all our young officers to acquire and to practise-lie has been studious to gain the command of languages, which he takes with him, as so many keys, to unlock and examinc the stores that contain whaterer is curious or useful, wherever he goes. With these advantages he combines an inquisitive disposition and the faculty of clcar discrimination. What fruitful sources, these, of intellcctual enjoyment! what surc guaruntces of extraordinary information and usefulness !

Mr. Hambleton, on the qucstion of different breeds of Asses, states, as the result of inquiry and personal obscrvation during years of scrvice and travel along the shores of the Mediterrancan, that "The Mallese Ass is without doubt the best-he has greater activity and endurance than the coarse Jack of Spain and France; and in his fine limbs and deer-like form, 
has immense power-the other breeds arc often clumsy and sluggish.-It is the blood-liorse against Conestoga. In Minorca the farmers were extremely anxious to brced from Jacks which our officers of the navy had brought from Malta, and confessed thcir superiority.There are two kinds at Malta, the black and the grey. The formcr is always most csteemed. I paid for Peter Simple two hundred and fifty Spanish dollars, and he cost me five hundred here. It was considered a high price, but he was known to be the best Jack of his age in the Island. His sire was carried to England for Adıniral Rowley." The Jack here spokcn of, Peter Simple, is one of, if not the finest we have ever seen. Mr. H. adds in a familiar letter in answer to one addressed to him on the subjects of this memoir gen. erally, somc interesting facts which we take the liberty to transcribe in the unstudicd lallguage (and the better for that) in which they are written by one friend to another. As to the ivell-known indifference, not to say antipathy, evinced by some Jacks to cohabit witl a mare, she being of a "diverse kind," he says, "I have heard that it was common for jacks to refuse mares in Spain, and hence the risk of buying them untried. They do not like to sell their breeders, and ask high prices for them. In Majorca I have heard of some that were held as high as $\$ 1000$. I sent in two from Gibraltar which came from Ronda, in Andalusia: one was a grey, and the other milk-white with a sorrcl belly. I was told that lie, the white, was of an exccllent strain, originally from Barbary. He was short.legged, very broad over the back, and compactly made; and took on fat like a pig. He was not clumsy, and was the finest ambler I ever saw. Unfortunately he was very slack, and on that account of little value. His colts are good, but lave not the spirit of those of Peter Simple. Some of the latter from good mares can compare with the Kentucky mules in size."

We shall now bind all that has been asserted in support of the fact that $\mathrm{J}^{\circ}$ acks are of different races and tempers, and that the Maltese, among those within our reach and with which we are familiar, is the best, by the following quotation from a friendly lctter, written, to use his own expressive phrase, currente calamo, "just as if wc were sitting under a tree along shore," from Col. N. Goldborough of Maryland, whose attention to all such matters is known to be as critical as his judgment in them is allowed to be sound and superior.

Of Asses and Mules, says the Col., "I know but littlc of the natural history of the former, but have an expcrience of some thirty years of the latter. The Maltese Jack in the production of mules holds the same rank with the Arabian as to horses. I have never seen a dull mule got by the Jack I purchased of you, even from notoriously sluggish mares. I have often wondcred that the mulc had so mucli spirit, when the usual qualities attributed to the ass are taken into consideration. I have bred the same mare at different periods to the ass, and to the blood-horse--the horse of fine spirit too, and the progeny of the ass has possessed as much spirit, and in one instancc far more than that of the horse." It would be superfluous to multiply authorities or opinions in proof or in description of different races of Jacks, possessing distinct qualities as to conformation and temper: than those already quoted, none can bc higher or more conclusive. It was, however, deemed necessary to say thus much, bccause if, as we expect to show, the mule be highly worthy of more general regard, as an animal whose employment is attended with great economy, is it not cssential that those who may be led to breed or purchase, should understand that their value, no less than that of the horse, is affected by and depends in a great measure upon breed? and that if this fact be not kept constantly in mind, botl animals are liable to deterioration, leading in time, as with respect to the mule it has already done, to disparagement and rejection. Having indicatcd, by the opinion of the most competent judges, how much the progeny de. pends for its value on the quality of the sire, it will be seen in the sequel that the influence of the mare is no less than that of the Jack-we have heard large mule traders contend that it was grcater and more obvious. It is doubtless the greater prevalence of blood in the Kentucky marcs, for example, which stamps the mules of that state with a blood-like look and air of superiority, which so plainly distinguish them from the coarser mules of Ohio-where racing, until very latcly, lias been considered almost an "abomination in the sight of the Lord."

We procecd now to view the mule as he is, in a practical point of view-that is in respect of the cost and mode of rearing him-his capacitics and uses: to this end we shall take leave to publish, without stopping to separate and systematise the facts they contain, and the arguments they advance, some portions of letters from the friends already spoken of, as well as further quotations from respectable writers who have given their attention to this subject, than which, it is not easy to think of one morc interesting to the American husbandman.

The great nurscries of the mule, for the supply of Maryland and the yet greatcr demand for the Southern plantations, have for years past bcen Kentucky, and more recently Ohio. Before the commencement of this century, the breeding of the mule for sale in our own country, and for the plantations in the Wcst Indies, had been confined to New.England; of its listory thcrc-the sort of jack employed, and kind of mule then and there produced, the following account is given in the prize essay already spoken of, and which we commend to the readcr for proof at once of the eagcrncss and the accuracy of the writcr's inquiries into the qualities of the mule. 
In Sir Gcorge Staunton's account of Lord Macartney's embassy to China, we are told that mules arc valued in that cconomical cmpirc at a nuch higher pricc than horses. In our own country, prior to the war of the revolution, a fow Jacks of an ordinary kind were im. ported-a small number of inulcs bred; and all exported to the West Indies. I have refcrencc to New-England, as I am not aware that any attention was paid to the system in the Middle or Southern States, though it is not improbablc that some valuable nules may have been raised by the farmers and planters for their own use. When peace took place, the price of mules in the West Indies excited attention to the breeding of them, which was principally confincd to Connccticut; and several cargoes of the small race of Jacks were imported from the Cape de Vcrd Islands, and St. Michael's, one of the Azores. It should be observed that the exportation of jacks from Spain, or any of her colonies, was strictly prohibited, and continued to be until after the Peninsular war. There might have been, however, a few smuggled from the Spanish part of Hispaniola into Cape François, and from thence introduced, but they were vastly inferior to the Spanish Jacks. From this miserable stock a system of breeding mules commenced, the best calculated to detcriorate any race of animals that has bcen, or could bc devised, since thcir creation. The purchaser of a Jack, when about to cominence mule dealer, madc little inquiry concerning him but of his capacity to propagate a mule. He placed him in a district where there was the greatest number of mares of qualities so inferior that their colts would not compensate their owners for the expense of putting them to a horse, and contracted to purchase their mules at four months old. Those are kept in herds, with prccarious shelter in winter, having ample opportunities affordcd them to mature and transfer that propensity for kicking, which seems at first merely playful, into an habitual nieans of defencc, to be excrcised when the biped or any other race of animals approach them. In this kicking seminary they remain two years, and are then driven to market. At subsequent periods, a few Jacks of higher grades were procured, from which a small number of good-sized nules were bred, and a fow of them broke. The breed of Jacks has somewhat improved, and mule dealers are now located in most of the New-England states and somc parts of New-York. But the system as above detailed, with few exceptions, has continucd; and it is from such a race of Jacks, and such a system of breeding and manageincnt, that the mulcs have bcen produced, with which the farmers and planters of Maryland and Virginia, and the Southern States, have been supplied from Nero-England; and such have furnished a criterion for a great portion of our countrymen to form an estimate of the valuc and properties of this degraded animal.

On the sharc of the mare, in affecting the value of the mule, Mr. Custis says cmphatically, that General Washington brcd nules from "his best coach marcs; and found the value of the inule to bcar a just proportion to the value of the dam. Four mules sold at the sale of lis effects for upwards of $\$ 800$, and two more pair at upwards of $\$ 100$ each pair. One pair of these mules was nearly sixteen hands high." -Now, although it be not here affirmed that these "best coach mares" were blood marcs, the fact may be very safely assumed that they were deep in thc blood, when we consider that the General hinself was of the "race-horse region,"-a member and officer of the jockey club at Alexandria - sometimes acting as judge of the race-fond of the turf and of thc chase; in which, according to one, of all men living, most familiar with his labits, lie was "always superbly mounted, in true sporting costume, of blue coat, scarlet vest, buckskin brecches, top-boots, vclvet cap and whip with long thong, he took the field at day dawn, with his huntsman WILL LEE, his friends and neighbours; and none rode nore gallantly in the cliase, nor with voice more cheerly awakcned ccho in the woodland, than he wlo was afterwards destined, by voice and example, to chcer his countrymen in their glorious struggle for independence and empire."-Thus mounted on his famous hunter Blue-skin, says the author of his yet unpublished memoirs, Washington was always " in at the death, and yielding to no man the honour of the brush." Being himself brccder and runner of thorough-bred stock, and well acquainted with the gcod effect of a generous sprinkling of blood, as well for the road as for the battle-field, it may be fairly inferrcd that these "best coach mares" had a heavy dash of it, from which were bred mules that commanded $\$ 200$ each, and were nearly sixteen hands high, "active and spirited."

It is well remembercd as the opinion of the late Frederick SkivNer, (blessed be his memory,) father of the writer of this memoir, who sent his jennets several years from Calvert County, to the Jacks at Mount Vernon, and who was withal a connoisseur in all such cases, -it was his often-expresscd conviction that the activity, endurance, and value of mules was greatly enhanced when bred from mares deep in the blood. But we cannot dismiss our respected and cautious author of the prize essay, without availing yet inore largely of the result of his careful researches and reflections, founded on personal experience, and so we proceed to transcribc his remarks on the several points of breeding and rearing-economy of kcep-steadincss to labour-docility of temper-exemption from disease-and longerity of the animal.

The im prcssions received, says he, when on a visit to the West Indies in my youth, by observing, in the sugar plantations, the severe labour performcd by mules in cane mills, induced me, 
when I commenced farming, to purchase the first well-broke mule I could light on; and notwithstanding he was so small as to require a vehicle and harness constructed purposely for him, his services were found so valuable, and the economy of using those animals so evident, that I was stimulated to great exertions for procuring several others of larger size; in this I succeeded, after great difficulty, to such an extent, as to have had morc labour performed by them on farm and road for thirty years past, than any person, I presume, in New England; and every day's experience has served to fortify my conviction of the supa rior utility of the mule over the horse, for all the purposes for which $I$ have proposed him as a candidate. And it should be considered that those $I$ have used were of an ordinary brecd, vastly inferior to such as may be easily produced in our country, by attention to the intro. duction of a suitable race of Jacks, and a proper system of breeding and management.

Tlye question occurs, how is this to be effected? I will premise, that there exists a strong analogy between three varieties of the horse, and those of the domestic ass, considered the most valuable. We have the Arabian, the hunter, and the stout cart-horse. There is the heavy Spanish Jack, with long slouching ears, which Mr. Custis has described, that answcrs to the cart-horse; another Spanish breed called the Andalusian, with ears shorter and erect, of tolerable size, plenty of bone, active, more spirited, and answering to the hunter. Then comes the Arabian Jack, with ears always erect, of a delicate form, fine limbs, and full of fire and spirit. Judicious crosses from these varieties, will be requisite to produce such kind of mules as may be wanted for general purposes. From the small Jack of African origin, with a list down his back and shoulders, are bred a small race of mules, by far the most hardy of any. With attention to selection in breeding the Jacks, with, perhaps, a dash of some cross of the foregoing description, a stock of mules may be produced, preferable to all others for the light lands and cotton culture of the middle and southern states.

To procure any number of Arabian Jacks from their native country, is hardly practicable at the present time. Egypt has been celebratcd by Sonnini and other travellers, for superb Jacks of the Arabian breed, which probably has bcen often improved by those introduced by the pilgrims from Mecca. I apprehend no great difficulty in obtaining them from that country. There is, however, no question but the Maltese Jacks are of the Arabian race, more or less degenerated. The most of those brought to this country that $I$ have seen, were selected on account of their size, and had been used to the draught. I should recommend the selection of those that are esteemed most suitable for the saddle, as likely to possess greater purity of blood. A Jack of this kind was, a number of years since, imported from Gibraltar, that had been selected by a British officer at Malta; and very much rescmbled the Knight of Malta, described by Mr. Custis. I found, upon a careful examination, that he differed but little from the description I had heard and read of the true Arabian race; indeed I could discover some prominent points and marks, that agreed with those found, by Profcssor Pallas, to belong to the Hemionus or wild mule of Mongalia. From this Jack I have bred a stock, out of a large Spanish Jennet of the Andalusian breed, that corresponds very minutely with Mr. Custis's description of Compound, bred by General Washington, and also a mule that now, not three years old, stands fifteen hands, and has other points of great promise.

My attention has been but lately directed to breeding inules; and those intended only for my own usc. The system adopted is to halter them at four months, and have the males emasculated before six months old; which has great influence on their future conduct, and is attended with much less hazard and trouble, than if delayed until they are one or two years old, as is the general practice. If they are treated gently, and fed occasionally out of the hand, with corn, potatoes, \&c., they soon become attached; and when they find that "every man's hand is not against them," will have no propensity to direct their heels against him, and soon forget they have the power. In winter they should be ticd up in separate stalls, and often rubbed down. By such treatment there is not more danger of having a vicious mule than a vicious horse-and $I$ am decidedly of opinion, that a high-spirited mule so managed, and well broke, will not jeopard the lives or limbs of nen, women, or children by any means so much as a high-spirited horse, however well he may have been trained.

The longevity of the mule has become so proverbial, that a purchaser seldom inquires his age. Pliny gives an account of one, taken from Grecian history, that was eighty years old; and though past labour, followed others that were carrying materials to build the templc of Minerva at Athens, and seemed to wish to assist them; which so plcased the pcople, that they ordered he should have free egress to the grain market. Dr. Rees mentions two that were seventy years old in England. I saw, myself, in the West Indies, a mule perform his task. in a cane mill, that his owner assured me was forty years old. I now own a mare mule twenty-five years old, that $I$ have had in constant work twenty-one years, and can discover no diminution in her powers; she has within a year past often taken upwards of a ton iveight in a wagon to Boston, a distance of more than five miles. A gentleman in $\mathrm{my}$ neighbourhood has owned a very large mule about fourteen years, that cannot be less than 
irocnty-eight years old. He informed me a few days since, that he could not perceive the lcast failure in him, and would not exchange him for any farm horse in the country. And I am just informed, from a source cntitled to perfect confidence, that a lighly respectable gentleman and eminent agriculturist, ncar Centreville, on the eastern shore of Maryland, owns a mule that is thirty-five years old, as capable of labour as at any former period.

From what has been stated respecting the longevity of the nule, I think it may be fairly assumed, that he does not deteriorate more rapidly after twenty years of age than the horse after ten, allowing the same extent of work and similar treatment to each. The contrast in the mule's freedom from malady or disease, compared with the horse, is not less striking. Arthur Young, during his tour in Ireland, was informed that a gentleman had lost several fine inules, by feeding them on wheat straw cut. And I have been informed that a mule. dealer, in the western part of New.York, attributed the loss of a number of young mules, in a severc winter, when his hay was exhausted, to feeding them exclusively on cut straw and Indian-corn sneal. In no other instance have I ever heard or known of a mule being attacked with any disorder or complaint, except two or three cases of inflammation of the intestines, caused by gross neglect in permitting them to remain exposed to cold and wet, when in a high statc of perspiration after serere labour, and drinking to excess of cold water.

From his light frame and morc cautious movements, the mule is less subject to casualties than the horse. Indeed it is not improbable that a farmer may work the same team of mules above twenty years, and never be presented with a farrier's bill, or find it necessary to exercise the art himself.

Sir John Sinclair, in his "Reports on the Agriculture of Scotland," remarks that " if the whole period of a horse's labour be fiftcen years, the first six may be equal in value to the remaining ninc; therefore a horse of ten years old, after working six years, may be worth half his original value." He estimates the annual decline of a horse to be equal to fifty per ccnt. on his price cvery six years, and supposes one out of twenty-five that are regularly employed in agriculture, to dic every year: for insurance against diseases and aecidents. Hc considers five acres of land, of medium quality, necessary for the maintenance of each horse, and the annual expense, including harness, shoeing, farriery, insurance and decline in value, allowing him to eost $\$ 200$, to exceed that sum about five per cent, which is the only difference betwcen the estimate of this illustrious and accurate agriculturist, and that of a respectable committee of the Farmers' Socicty of Barwell district, South Carolina, who in a report published in the Carleston Courier, of the $23 \mathrm{~d}$ of February last $(1825$, ) state, that" the annual expense of keeping a horse is equal to his value." The same eommittec also state, that, "at four years old a horse will seldom sell for morc than thc expense of rearing him." That "the superiority of the mule over the horse, had long been appreciated by somc of their most judicious planters; that two inules could be raised at less expense than onc horse; that a mule is fit for servicc at an earlier age, if of sufficient size; will perform as much labour; and if attended to when first put to work, his gait and habits may be formed to suit the taste of the owner." This report may be considered a most valuable document, emanating, as it does, from enlightened practical farmers and planters, in a section of our country where we may suppose a liorse can be maintained cheaper than in Maryland, or any state farther north.

I am convinced that the small breed of mules will consume less, in proportion to the labour they arc capable of performing, than the larger race; but I shall confine the comparison to the latter - those that stand from fourtecn and a half to rising of fifteen hands, and equal to any labour that a horse is usually put to. From repeated experiments, in the course of two winters, I found that three mules of this description, that were con'stantly at work, consumed about the same quantity of hay, and only one-fourth the provender that was given to twoo middling-sized coach horses, moderately worked. And from many ycars' attentive observation, I am led to believe that a large sized mule will not require more than from three-fifths to two-thirds the food, to kecp him in good order, that will be necessary for a horse performing the same extent of labour. Although a mule will work and endure on such mean and hard fare, that a horse would soon give out upon, he has an equal relish for that which is good; and it is strict economy to indulge him, for no animal will pay better for extra keep by extra work. But if by hard fare, or hard work, he is reduced to a skeleton, two or three weeks, rest and good kecping will put him in flesh and high condition for labour. I have witnessed several such examples with subjects twenty years old; so much cannot be said of a horse at lialf that agc. 'The cxpense of shocing a mule, the year round, does not amount to more than one-third that of a horse, his hoofs being harder, morc horny, and so slow in their growth, that the shoes require no remoral, and hold on till worn out; and the wear, from the lightness of the animal, is much less.

In answer to the charge gencrally prevalent against the mule, that he is "vicious, stubborn and slow," I ean assert, that out of about twenty that have been employcd on my estate at different periods during a course of thirty years, and those picked up, chiefly on account of 36 * 3 D 
their size and spirit, whercver they could be found, one only had any vicious propensities, and those might have been subdued by proper management when young. I have always found them truer pullers and quicker travellers, with a load, than horses. Their vision and hearing is much more aceurate. I have used them in my family carriage, in a gig, and under the saddle; and have never known one to start or run from any object or moise; a fault in the horse that continually causes the maiming and death of numbers of human beings. The mule is more steady in his draught, and less likely to waste his strength than the horse; henee more suitable to work with oxen; and as he walks faster, will habituate them to a quicker gait. But for none of the purposes of agriculture does his superiority appear more conspicuous than ploughing among crops; his feet being smaller, and follow each other so much more in a line, that he scldon treads down the ridges or crops. The facility of instructing lim to obey implicilly the voice of his driver or the ploughman, is as. tonishing. The best ploughed tillage land I ever saw, I have had performed by two mules tandem without lines or driver.

There is one plausible objection often urged against the mule, that "on deep soils and deep roads, his fcet being so much sinaller than those of the horsc, sink farther in :" but it should be considered that he can extricate them with as much greater facility.

Few can be ignorant of the capacity of the mule to endure labour in a tempcrature of heat that would be destructive to the horse, who have any knowledge of the preference for him, merely on that account, in the West Indies, and in the Southern States.

It is full time to bring our comparison to a close; which I shall do by assuming the position, that the farmer, who substitutes mules for horses, will have this portion of his animal labour performed, with the expense of one spire of grass, instead of two; which may be equal, so far, to making "two spircs grow where one grew before." For although a large. sized mule will consume somewhat more than half the food necessary for a lorse, as has been observed, yet if we take into the account the saving in the expense of shoeing, farriery, and insurance against diseases and accidents, we may safely affirm, that a clear saving of one-half can be fully substantiated. But, in addition to this, the mule farmer may calculate, with tolerable certainty, upon the continuation of his capital for thirty years; whereas the horse farmer, at the cxpiration of fifteen years, must look to his crops, to his acres, or a Bank, for the renewal of his-or, perhaps, what is worse, he must commence liorse-jockey at an early period.

I cannot resist the impulsc to exhibit the mule in one other point of view. For the movement of machinery, the employment of this animal, when judiciously selected, has met with a most decided preference, in comparison with the horse, independent of the economy of using him. And if we consider the rapid and probably progressive increase of labour-saving machines, in every department where they can be made subservient to the requirements of society, it is evident there will be a corresponding demand for animal power, as well as for that, more potent, derived from the elements; and although the latter may vastly predominate, yet should the horse be einployed, and his increase for other purposes continue, as it now does, in the ratio of population, the number, at no very distant period, may become as alarming in our own, as it is at present in our mother country. And notwithstanding we may fecl secure, from the extent of our territory, and extrcme diversity of soil and climate, but, above all, from being in possession of Indian-corn,- the GoLden FleEce, found by our "Pilgriin Fathers," when they first landed on these shorcs; yet such peculiar advantages may not insure us against the visitations of one of the most distressing calamities that a feeling community can possibly be subjected to."

The reader cannot fail to be struck with the strong corroborative proof which is brought in support of the vicws of this well-informed writer, after a lapse of seventeen years, in the testimony which follows, from no less instruetive and intelligent obscrvers. On the preecding points generally, we now present the answers, of recent datc, unstudied in style, but deliberate as to facts; received in reply to, and corresponding in order with interrogatories propounded in desultory form to gentlemen whose names we have alrcady taken the freedom to introduce to the reader-beginning with the letter from General Shelby, whose testimony embraces the practical knowledge derived from many ycars of opportunity to view the subject well in all its aspects. "As to mules," says the General, their qualities niay be greatly varied from the same Jack, whether the diminutive donkey of three feet, or the Jack of Spain of sixteen hands, by reason of the great variety of mares bred to him. The Maltese Jack of fourteen hands, I consider entitled to the same rank and dignity in his race that is accorded to the Arabian Horse in his. A cross between liim and the Spanish Jack of sixteen hands, will be found to combine all the essential properties of size, form and action, and to facilitatc the breeding of mules possessing those requisites-I need only add that, in all respeets, whether in breeding, rcaring, breaking, using and in sclecting-the subject of the mule should be considered as in the same light precisely as that of the horsc-therefore the grounds of preference between one Jack and another; in other words, their good and bad points, resuit 
from the combination of sufficient size, form and action, and not from any one of those qualities. - The same as to mules.

Jacks have sold in Kentucky as high as $\$ 5000$. Their value at this time (April, 1842) is nominal-sixteen lands is the largest size-fifteen is quite common-mules of seventeen hands are sometimes to be met with. The quality of the mule is improved by the blood of the mare. It is quite common to work mares while going to the Jack, whilc in foal, and while suckling. Mules should be weaned at about five months old-we feed our mules on grain, corn, oats, or rye, the latter in the form of chop, from season to season until sold. I mean during the winter, our blue-grass being all-suffieient during the rest of the year. It is necessury, however, to grain feed them on the grass thrcugh the sumner they are fattened for market-we sell the majority of our stoek the fall after they are two-mostly to the cotton planters-a few of late to the Pennsylvania iron works, and a few to Cuba; the remainder we sell at a year older. The present priees at a given age are as variant as that of horses, cattle, or any thing elsc whose value depends upon its quality, and the demands and monetary condition of the country - sales were effected last fall at from $\$ 35$ to $\$ 125$. I have known mules sell at weaning-time for $\$ 150$, and when grown as high as $\$ 300$. They should be broke at the age you would break a horse; and, according to my observation, by the same systcm. They eat as much as horses, and reward a liberal allowance as wcll, though he may, when unavoidable, be able to withstand privation better. I have known mules to travel ten niles within the hour in light harness. I drove a pair from Lexington to the Blue Lick in six hours, stopping one hour by the way-the distance is forty milcs. What may be the precise difference in "the age of the mule as compared with the horse, under the same treatrnent, on a plantation," I eannot say; the advantagc, however, would be on the side of the former-I know of no particular inconvenience in using them in a earriage.

The mule trade in Kentueky is of about forty years' standing. For the first twenty years the number inereased gradually, to about cight hundred; during the next fifteen or sixteen years, it went up to four or five thousand; since when, it has gonc back to where it was twenty years ago. Our farmers who breed mules, prefer to sell them when they put their mares to the Jack, or at weaning time. The price rosc gradually from twenty to fifty dollars for colts. My last lot cost me in 1838 fifty dollars, and the season of my Jaek given in. The mares werc selected, and the eolts bargained for in the season of 1837. When the pricc went down with everything else a few years back, they discontinued, in a great degrce, the breeding of them; so that our present prices result from a greatly insuffieient supply for the ordinary dcmand. I sold my stock of three year olds, (seventy-tliree head) last fall at $\$ 70$. I was anxious to retain two or three pair (not the largest) at $\$ 250$ a pair, but the purchaser objected-but he was equally anxious to select for me some twenty liead (and not the least) at thirty-five dollars. I deelined taking thein. The number of mules annually exported from Kentueky, may be set down at the whole number raised-as the small number broke to service in this state, are sure, at last, to find their way to a foreign market-at a rough guess, I would fix the nett averagc value, in market, of our mules, at about $\$ 70$.

The reason why mules have been raised in sueh numbers in Kentucky more than in other states, is the better adaptation of our soil and climate to the production of grain and grass than any other statc, and for which we can obtain a market only in the form of live stock. The "cost of raising a mule to be three ycars old, when corn is twenty-five cents per bushel," charging from the usual time of weaning, 25th of September, may be computed at about thirty dollars, including a fair cquivalent for grazing and salting. I have not known of a case of a fcmale mule breeding-I wish you would tell me on what testimony the Norfolk casc rests [it shall be done] I am a seeptic.-Our Jacks arc doing but little this season.They stand at about five dollars to mares, and from that to fifty dollars for Jennies.-The proportion of foals from a Jack and a horse, does not vary materially, in a given number of mares."

So much for the views and opinions of one who has, perhaps, bought and sold a greater number of mules than any individual in the United States. We now present, in like manner, without leave of the writer, in so many words, and without any studied formality of diction, a letter from Mr. Hambleton, whieh the reader will agrec needs no higher polish of the pen, or greater amplification, to give it interest and value.

"I am now, March 5th, 1842, raising three mules, and their ration is four cars of corn a day, caeh, and straw $\dot{a}$ discretion. This from the 1 st of Oetober, to the 30 th of April, when they will go to grass, would be about one and a quarter barrels each of corn, allowing seven liundred cars to the barrel. At $\$ 3$ per barrel, one and a quarter barrels are $\$ 3.75$ the first year; second ycar add one third, $\$ 5$; the third year add one third, $\$ 6.62=\$ 14.37$, the cost for eorn at three ycars old. As our farmers never sell straw, and eonsider it a favour for any animal to work it up into manure, thic expensc of that is not counted. When two years old, the ration should be augmented one-third-you may sinile at my statistics, but I can assure you these colts keep in good order on this allowance. Eight years ago, I bought two three-year 
olds from a New. England drove, that had never eaten any grain. I gave $\$ 105$ for the pair, and there is onc of them that I would not take $\$ 100$ for now. Five ears of corn at a feed is suflicient for a working mule with corn blades. They will keep fat on it under the severest labour-I have worked them eight years, exclusively; never had one sick or lame, and find them fully efficient for any kind of farm labour, in this region (Talbot County, Maryland.) Our soil is extremely stiff, but a pair of inules will carry a plough through the toughest sward; and in carting, will move the heavicst loads. In forming our largc com. post beds of manure (sometimes 300 loads in a bed,) and having the raw materials to liaul, first under the cattle, and again to the field aftcr it is made, you may know that our teams havc little idle time. After the ground is broke, a single mule carries the plough in cultivating corn, or ploughing in wheat. Kentucky mules, of large size, three years old, sold last year in this county for $\$ 200$ a pair:-now they would not bring as much. I paid for one, raiscd by a neighbour, four ycars old, $\$ 70$; and after he was perfectly brokc, refused $\$ 100$ for him. They are easicr broke than horses, and do not kick or bite. Negroes, not accustomed to them, regard them as wild bcasts, are afraid of them, and thus many are spoiled in breaking.

"Mules are more used in Spain and Portugal than in any other countries I have visited. The king of Spain used them for his carriage when $I$ was in Madrid-and most of the grandees. In Lisbon I was told $\$ 1500$ was often paid for a pair of carriage mules. The Dutchess of Braganza (Don Pedru's widow, was a decided mule-woman, and drove six of the most splendid greys I ever saw. Doña Maria used English horses. I went through her stables with her coacliman, who was an Englishman. He told me that in that mountainous country, native horses were the best for service-inules better than either. I travelled in the Diligence from Barcelona to Madrid, via Valencia, 400 milcs, and back. Mules were used the whole route, six to the team, and travelled as fast as our stages usually do. Their public vehicles are much heavier than ours.

"They have a beautiful race of asscs in Egypt-small but exquisitely formed, and of great spirit. They are much used for the saddle. If you should ever go to Alexandria, you will never forget the importunity of the Jackass boys at the landing, where there are always hundreds ready for service. Our hackmen at a railroad depôt are nothing to them; and they all speak a little English.- "This a fine Jack, Sir, don't take that one, that fellow's a d-d rogue," \&c. The Egyptian Ass is generally of a mouse colour, with a black streak down the back and cross on the slioulder-some of them blue, (sacré bleu.)

"I cannot inform you the average number of mares impregnated in Talbot by Jacks. If I could, the criterion would not be fair-as it is known that an old Jack is much inore certain than a young onc; and they are not in their prime till fiftcen.* Mules, I think, would bring morc at three years old than horses from thc same dams. A respectable-looking man told me at the fair at Ellicott's nills, that he knew a Jack then covering at Pittsburg, that was sixty years old. Would it not be well to try to verify this? Judge Brackenridge could assist you in doing it.-My brother Edward told me that he kcpt a Jennet and Stallion some weeks together, but he would not notice her. Against this, I heard of a case of a Stallion covering a Jcnnet without producing a colt. It appcars to be a mcre matter of taste. When abroad I could get no satisfactory information as to breeding mules; but am of opinion that the best mules are not from the horse and jennet. I was told that they were so scary and timid as to be of little value. Your Jack is always the leader of a caravan of camels in Asia Minor. In Syria, I travelled from Beyrout to Damascus, 70 miles, and back, on a mule, over the Lebanon mountains. I could give you no idea of the badness of the road-the elevation is 6000 feet above the sea. The owner of our mules (a man about my size, and consequently above saddle-weight, ) rode a small Jack, and carried sundry bags filled with barley and cut straw. I doubt whether your old sorrel that ran away with Campino, could liave carried him as safely. In our expeditions to Balbec, over the same mountains, and to Jerusalem, we had mules. In Genoa the mules are large, but coarse. In Italy they are little used in carriages, and I believe not much in France; but they "go their death on them" in the Spanish possessions, Cuba, \&c.

"The relative expense of keeping, I think, is as 5 to 8 ; or, to be on the safe side, a mule can be kept at one-third less."

If the preceding views, in which the attentive reader will have noticed a remarkable coincidence generally, needed any further confirmation or support, none could be adduced more conclusive than the following, from CoL. N. Goldsborovgr. The inore especially so with all who, having the pleasure of his acquaintance, unite in their respect for his candour, and and in defcrence to his superior judgment in such matters.

"I regard," says he, "the point as scttled, that the mule is superior to the horse, for all

* Mares, grazing on clover, are supposed not to breed well. 
agricultural uscs and purposes; especially where not erushed nearly to death, by the brutal eonduet of man. The disposition to mischief proeeeds from neglect. Beeause it is a mule, it wants nothing to eat, forsooth! My mules are not more mischievous than horses of the same family; $(i$.e.) from the same mares.

"Sir John Sinclair has somewhere said, that wheat straw is unsuited to the nature of thc mule-that it is not eaten kindly, and does not agree with the animal. I must respeetfully dissent from suel high authority. My mules live on nothing else through the winter, with the addition of a little corn, and are always in good condition. They will haul the cart in all suitable weather, on six ears of corn at a feed, and plenty of clean wheat straw. They require less grain than the horse. I need not say to you how much longer they live and do good work. More free from disease-not so liable to gall-superior steadiness of draftand, when properly broke, treated and managed, will walk over as mueh ground in a dayblood horses to the eontrary notwithstanding. The mule is perhaps nowhere so remarkable as at the sweeps of a threshing-machine, where steadiness of draft is all-important. Horsez walking in a circle gall sorely where mules do not. I will add that the mule, in its three year old form, must be worked with moderation. It is seareely eapable of doing as much work as the horse at the same tender age. The many dull and sluggish ones that you see, are rendered so, by being erushed in spirit before being gradually inured to work; and they ever after remain so, the habit being onee formed. Upwards of twenty years ago, I had the largest mule ever seen on our shore. He was from one of Gordon's Jaeks. When three ycars old, he was put in the plough, and worked finely, and possessed good spirit. Some weeks after, the weather became very hot-he was ovcrworked-became dull, and finally could not be worked with any satisfaetion, alongside of any animal on the farm. He was doomed to work, solus, in the manure-cart, and in his prime I sold him. But two other mules bred from the same mare, had first-rate spirit; and this I attribute to their not being exposed to the same injurious treatment. One of them, now twenty five years old, is among the most efficient animals on my farm ! What would a horse bc worth at the same age?"

The Colonel in what he ascribes to Sir John Sinelair about the deleterious effect of wheat straw as food for the mule, perhaps confounds him, in his recolleetion, with Sir Arthur Young, both known to him as voluminous and eminent writers on British Agrieulture. The latter, during his tour in Ireland, was informed that a gentleman had lost several fine mules by feeding them on wheat straw cut. Mr. Pomeroy, too, was told that "a mule-dealer in the western part of New-York, attributed the loss of a number of young mules to their being fed exelusively on cut straw and Indian-corn meal, during a severe winter, when his hay was exhausted." He goes on to say, " in no other instanee have I ever heard or known of a mule being attacked with any kind of disorder or eomplaint, exeept two or three eases of inflammation of the intestines, eaused by gross negleet in permitting them to remain ex. posed to eold and wet when in a state of perspiration, after severe labour; and drinking to exeess of eold water. From his light frame and more eautious movements, the mule is less subject to casualties than the horse. Indeed it is not impossible that the farmer may work the same team of mules above twenty years and never be presented with a farrier's bill, or find it necessary to exereise the art himself." We are here prompted to add, by way of caution to the reader against that horrible disease, the glanders (fully treated in this work on the Horse, ) that within two years we were painfully made aequainted with the case of a drunken Irish diteher, bringing a glandered horse, (whieh was not worth, if well, a $\$ 50$ wl. Creek bank-note, ) on a gentleman's farm, on West River, to stay while he was to open some old ditclies.-The vile beast eommunieated his disorder, nor was it arrested until five valuable horses, and as many first-rate young mules, fell vietims to the loathsome disease.

On the point of mischief in the mule, however, we cannot but think that Col. G.'s spirit of rescntment at the injustice with which this valuable creature is too often denounced and outraged, has led him, in a measure, to overlook some of his natural proclivities. Some of these are doubtless the more excusable as being exercised in the right of self-proteetionsuch for instanee as dropping a negro over his head, when he attempts to beat him therc; and then kicking at him to make him lie still, as paddy does the eel, what won't lie still to be skinned. But after all, we suspeet, that if a skilful craniologist would examine the skull of a mule, he would somewhere find, more enlarged than the rest, that apartment in which the great artificer has stored away that quality ealled obstinacy, for whieh, be it noted, mulishness is occasionally used as a synonyme-and of this opinion, we dare say, was a eertain Abbess of Andouillets, spoken of by Sterne, who knew something of mule as well as human nature -as our friend will agree, when he recolleets the story he tells of the expedients to whieh the Abbess and the Nun resorted, to get the mules, "who had taken the stud" to go ahead, when night was eoming, in the absence of the muleteer, and they were afraid of being ravished.-He will there see what "a shrewd, crafty old devil" of a mule will sometimes do when-it won't do any thing else; and then for mischief-another friend and warm advoeate admits that they are "rank poison upon young calves !" And as for jumping, it has certainly been said that 
with yoke and clog on, they will yet roll down, or roll over a fence! But this argument proves too much, for will not many horses do the like? After all, it may be fairly argucd that in most cases the habit of jumping is first prompted by starvation; and that with mules as with man, bad habits are nore easily acquired than laid aside; to lay the spirit of jumping there is nothing like a good supply of what is vulgarly called "belly timber;" and when the farmer complains that his stock destroy his crops, he may well be suspected of having been himself, in some degree, the author of the mischief he deprecates. It is ten to one but you will find him deficient in good feeding or good fencing; and he who ncglects the one, is sure to have greater necessity for attention to the other. "For want of a nail the shoe was lost-for want of a sloe the horse was lost," saith poor Richard.

Any reader may make for himself an estimate of the saving to bc realized by the substitution of mule for horse power, to any given extent. For ourselves, we cannot suppose it to be less than $\$ 15$ pcr head per annum in favour of the mule, for mere difference of keep-for we must take into the calculation not only the differcnce in the grain consumed, but that coarser forage will subsist the mule-he moreover needs no grain when not at work, for it is characteristic of his family, on one side of the house, to browse on furze and thistles, and almost any coarse herbage. How many tlings, rcjected by the more fastidious taste of the horse, is gladly eaten by the Ass-"whose house I have made the wildernsss, and the barren land his dwelling: the range of the mountains is his pasture, and he seeketh after every green thing." The average saving among any given number of the two animals, in stabling, grooming, smithery and farriery, will make no inconsiderable item in the bill of costs, in favour of the mule; and when to these is added how much oftencr the capital in the horse is altogether sunk, and "swallowed up" in the grave-the difference, in favour of the mule, is so striking and remarkable, that the wonder is that the conviction of it is not carried out in the agricultural economy of the country, to the almost universal adoption of mule power.Have we not the evidence, that as a general rule it may be laid down, that a mule at twentyfive is as hearty, and capable of labour, as a horse at twelve? Has not Boz made soinebody ask Sammy Veller, or some one else, the question-Did you ever see a dead donkey? Did you ever see any body that ever saw a dcad donkey? Let any one take up the ccnsus and figure out the cost of supporting all the horses in the United States, and then strike off onethird of that sum, which would be saved by substituting them with mules, and he cannot fail to be amazed to think how many good and beneficent things might be accomplished by such a savings fund. Let him calculate what an enormous sum this saving would pay the interest of. True, the census has becn taken in many cases with so little skill, and so much carelessness, that it is impossible to found upon it any calculations on statistical and economical questions of the highest interest.-In regard, for example, to the very subject in hand-on turning to it, for data to form an opinion of the waste of national means which is committed by the use of horses instead of mules, for the common drudgery and uses of agriculture-a question of obvious importance, and one which any political economist might suppose would be raised by any curious inquirer or practical statesman; what do we find? Truly, that those who have taken the census, have mingled horses and mules under one head, and left the investigator of one of the most important problems in politico-agricultural economy without any means for its solution approaching to exactness! In the state of New-York, for example, instead of giving for each county the number of each, both horse and mule, the census tells us the gross number of "horses and mules!" Of these, jumbled together, the number is set down at 474,543.-In Maryland, "horses and mules," 92,220.-In the whole Union, horses and mules, 4,335,669. As before rcmarked, every reader may work his own sum. In Maryland we suppose it to be a large allowance to say that of the 92,220 "horses and mules," there are in the whole state 17,220 of the latter, leaving 75,000 horscs. In South Carolina the expense of the mule is rated at one-half that of the horse-but sup. posing the horse to be more expensive than the mule by only $\$ 10$ per annum, and here is an unnecessary annual outlay, or deduction from the agricultural resources of the state, of $\$ 750,000 !$ ! In how many years would that sum extinguish the state debt? How long would it require, with such a sum, to finish the Chesapeake and Ohio Canal-cutting one, pari passu, from Georgetown to Baltimore, which ought to be done? How many schools would such a sum establish-how much knowledge would it diffuse, and power create? for nothing is truer than the French maxim, le savoir est puissance! Who will say that our theme, in this view of the subject, does not swell at once into a question of national wealth and importance, that ought to command the regard of every friend and promoter of the agricultural and of the public interest?

Observers, of much more than ordinary experience, entertain the belief that a mule can be kept in good order, at the same work, on one-half the quantity of corn or oats necessary for a horse, provided he stands at hay, of which he will consume, they say, at least twenty-
five per cent. more tlan a horse.

At Ellicott's large iron works the feed for one horse is ten common-sized ears of corn three times a day, while that for a mule is seven ears twice a day; and so, it may be added, while borses and mules were employed on portions of the Baltimore and Ohio Rail-Road, the feed, 
as has been stated by one of the superintendents, was two bushels of chop (rye) and onc bushel of corn a day for six horses: the same number of mules getting one and a-half bushels corn only-our informant entertains the common impression that soft food is not suitable for thc mule, and that choppcd rye, cspecially, is ill-adapted to his constitution, scouring him, as it is said to do negroes, who have a great aversion to the substitution of corn with occasional rations of ryc, when the owner happens to have a larger supply of the latter than of the former; unground grain, in a word, of whatever kind, answers best for the mule-though it may bc contended that when ground the stomach can extract more completely its nutritious qualities, it is not to be forgotten that the toll for grinding is in no case less than an eighth for the miller, besides rats, and the labour of sending to mill!

The impressions of Mr. Andrew Ellicott, as to the economy and powers of the mule, solicited because of his extraordinary opportunities to speak upon the subject, cannot be better given than in lis own words :

"A mule, with one feed of six quarts of oats or rye, and furnished with good hay, will be supported in good order. A team of six mules, kept at hay, can be supported with one bushel and a half of ship-stuff with cut straw-or with one bushel of corn, divided into two fecds, per day. They do not require water in as great quantity, or as often as a horse, but they thrive bettcr by being watered often.

"A mule weighing 700lbs, at the Patuxcnt Furnaces, carries daily fifteen tons of ore, one and a half tons of shells, slag and sand ten tons, and three tons of siftings and dirt from the ore kilns.-The ore and shells are hauled up an elevation of thirty fect, and a distance of three hundred yards; the balance of the above quantities is hauled about the same distance, though at lcss elevation. This one mule has been at work at this rate since 1836 , a period of six years.

"Mules arc not subject to 'Botts.' Blceding at the mouth will cure thein of nearly erery diseasc; and by bcing turned out on pasture, will recover from almost any accident. This is wonderfully the case. Out of about one hundred mules, at the works, we have not lost, on an average, one in two ycars. We do not recollect cver to have seen a "wind-broken" one. They are scarcely ever defective in the hoofs, and although we keep them regularly shod, it is not near so important to do so, as in the case of a horse. Their skin is tougher than that of a horse, and, conscquently, are not so much worried by flies, nor do they suffer as much with the heat of summer. 'They are 'truer' in starting, and never give up if well driven. They are driven in the stages between Winchester and Staunton in Virginia.

"The instinct of the mule is very strong; and he has a much better memory, bctter judgment, and requires, in a greater degree, kind treatment. The manner in which he has been treatcd by his driver can always be told by the temper he exhibits in the presence of that functionary. If well-uscd, they are very docile and tractable, and show an attachment for their care-takcrs-but if abused, or bcaten, become exceedingly vicious and unmanageable, and manifest, for a long time, a recollection of such treatment. We have known them lick at, and endcavour to injure, one who has beaten them, after a lapse of three weeks. If they go astray, they may gencrally be found by pursuing a direct course towards the place from whence they were purchased. Their driver can go into their stable, after they become acquainted with him, at all hours in the night, without molestation, while it would be very dangerous for a stranger to attempt it.

"The ugly-hcaded mulc, or that approximating the nearest to the Jack, is the hardiest, while the handsomest and largest is generally inferior in value to the middle-sized. Our tcams are very often out from sunrise to late in the night-not feeding at noon, and are in first rate ordcr."

Hcre, as well as anywhere else, may be introduccd the proof in support of the "Norfolk casc of the breeding mule," referred to by General Shelby. Whatcrer doubt may arise hereafter, thcre is none now, of the truth of the fact. Were it worth the trouble, the testimony night bc had of yet living witnesses, the principal one, a most rcspectable farmer and gentleman, having died since this account was published.

We are indebted for a copy of the memoir of this extraordinary case from Ruffin's Magazine, where it would not have gained admittance if not wcll founded, to the kindness of that obscrvant naturalist, and zealous promoter of useful industry-Doctor G. B. Snirt, of Baltimore.

Baltimore, April 1, 1842

Dear Sir:-I comply with your request with plcasure. The case of breeding by a mule is recorded authentically in the Farmer's Register, volume 2, page 389; and volume 3, page 440. Supposing it no more than probable that you have not the Register to refer to, and having half an hour's lcisure, I procecd to copy the articles:- 


\title{
From the Farmer's Register, Vol.2, page 3.
}

\author{
A BREEDING MULE.
}

To the Editor of the Farmers' Register.

Spring Hill, Nansemond County (Va.,) May 2d, 1834.

A circumstance has occurred on my plantation, which seems to be against the gcneral principles of nature. On the 23d of April, 1834, a female mule of mine had a colt, ncver suspccted by me, until I saw its birth. I had worked her hard all last year, upon the farm, and on the rail-road, through the winter, hauling marl, and all the month of March, hauling logs from a distancc of two miles, six loads a-day, and thirty logs each load, making twenty. four miles each day. She was at work all April, hauling out manure, until the 23d. On that day I had gone, a little before night, from the labours of the day, owing to one of my family being sick; and about 5 o'clock in the evening, the boy that drove the mule, came running to the house, saying that Jenny (for that was her name) had a colt. I went out, and in a few minutes thereafter, the thing (for I know not what to call it,) was delivercd, and is doing well. I never suspceted the mother's being with foal, becausc I thought it contrary to nature, though I had for four or six weeks observed that her belly was enlarged, and so much so, that the cart had to be altered, as it rubbed her. She showed no other signsso J did not suspect it. She has little or no bag, though I believe she gives a plenty of suck, as her child is now getting fat. At first it was very poor. Now you will ask what is the father of it? I cannot say-but bclieve, a colt of mine, now three years old. He ran out on Sundays, with the mules, and the black boy tells me that there was cause for such an effect. So it is, the mulc has a colt, and it is exactly like the young stallion. If this is a matter of curiosity, you may give publicity to it, under my name. Hundreds can prove the fact, and several can testify that they were present at the birth.

Johs Thoupson Kil.By.

P. S. The mother certainly is $a$ mule, for she was fouled mine, and is now ten years old.

\section{From the Farmer's Register, Vol. 2, page 389.}

\section{DEATH OF THE MULE'S COLT.}

To the Editor of the Farmer's Register.

Nansemond, 22d October, 1834.

As the birth of the phenomenon, my mule-colt, was recorded in your Register, so I will with your permission, record his death, that the lcarned may speculate upon it. He was born, as I informed you, and as will be seen in your Register of May or June, 1834, on the $23 \mathrm{~d}$ of April, 1834; and died on the 20th of October, 1834, at night. The particulars are as follows: on Friday evening late, I was informed that the mule-colt was sick : upon examining him, I thought he had the staggers. He was freely bled, and put in a lot, and went to eating fodder; it was now dark, and I determined that in the morning I would commence blistering, purging, and the use of injections, which $I$ have never known to fail if taken in time. But in the morning he liad the lockjaw, and so nothing could be done effectually for him, and he died on the Monday night following. He was wcaned, and running in a good pasture with a horse-colt, also just weaned, which is doing well. Now was it the staggers, or what disease? Or was ever a colt delivered of a mule known to live? I should have bcen much pleased to raise it, and to have known if it could continue its species.

Johx T. KILDY.

\section{From the Farmer's Register, Vol. 2, page 440. ANOTHER COLT FROM A MULE.}

To the Editor of the Farmer's Register.

Spriug Hill, Nansemond County, Va., 17th September, 1835.

Permit me to record in your Register, the birth of a sccond mule colt of mine, on the 13th of August, 1835. The same mule brought a fine female colt, jet black, save a star in its forehead, and one foot whitc. It partakes, as did the other, more of the horse than of the mule, and is a much finer colt. It can be seen in my pasture by any and every one.

Jон. T. KiLвY. 
From the Farmer's Register, Vol. 4, page 357.

DEATH OF THE SECOND MULE'S COLT.

To the Editor of the Farmer's Register.

Spring Hill, Nansemond County, (Va.,) Aug. 28, 1836.

Dear Sir :-Permit me to record, in your Register, the death of my second colt, the issue of a mare mule, by a horse. The colt was born in August, 1835, and died on this day, having becn sick two or three days. Having lost one, I was desirous of raising this. It was in fine order-the mother doing nothing, upon a good pasture. It is true, the mother nor the colt had not been housed until the night before it was taken sick. I had another colt running in the same pasture, treated in the same way, and is as yet doing well. Everything was done for the mule's colt that could be done, but it suffered much and died at last. A passage could not be gotten through it, and when dead, I had it opened and all that could be discovered, was, that everything that had been given it was then in its stomach and had never passed on to the bowels. It was blistered on its forehead-the blister drew well, but in vain: and a question arises with me-can an offspring delivered of the body of a mongrel be raised? That question I should like to liear solved by those better informed upon that subject than I am. If it should be thought to be possible to raise one, I will then try the mare mule with a Jack, as suggested by A. B. C. (in No. 4, vol. 4,) whose opinion I should like to have upon this subject.

JoHN T. K.LBY.

There, sir-you have the whole history of the breeding mule, so far as published to my knowledge. It secms to me, you ought to write to Mr. Kilby to furnish the subsequent history of this mule, and the success that may have attended any subsequent attempt to brecd and raisc the foal. I would enclose the letter to Mr. Ruffin, who knows K.'s post-office, and will forward it to him."

Wc should have have done so, but that we have understood that Mr. Kilby has since deceased. There are, we may observe, a few other such cases recorded "in the books," but in all they seem to have come into the world as unwelcome and monstrous exceptions to a general decree; and then to have soon perished, as if Providence would stamp with early decay, all fruits of a passion so universal and intense, whenever it is gratified in violation of its edicts, and in a way that would engender infinite disorder and confusion.

J. S. S.

THE END. 
. 


\section{N D E X.}

AARON BURR, performance of, 57 ; height of, 65.

Acetabulum, description of the, 280 .

Acini, description of, 231.

Acetic acid, its properties, 398.

Adeps, properties of, 399.

Ethiop's mineral, an alterative, 411.

Athusa cynapium, poisonous, 226.

Age, natural, of the horse, 150 ; of the horse as indicated by the teeth, 145; other indications of, 150 .

Air, a supply of purc, necessary for the health of the horse, 366 .

Alcohol, its medicinal properties, 399.

Aloes, Barbadoes, far preferable to Cape, 399 ; description of the different kinds of, 400 ; principal adulterations of, 401 ; tincture of, its composition and use, $i b$.

Alteratives, the best, 401 ; nature and effect of, $i b$.

Alum, the use of, in restraining purging, 401; solution of, a good wash for grease, $i b$.; burnt, a stimulant and caustic for wounds, $i b$.

Ameriean Turf Register, 24; Sir Archy indebted to for his fame, 25 ; established by Mr. Skinner in 1829, 24 ; value of horses before its establisliment, 25 .

Americus, performance of, 57, 58.

American Trotter, 49 ; miscellaneous cxam. ples of, 58 ; pedigrees of, 54 .

America, best races in, 35 ; best pacing in, 58 .

American turf, opinions of B. O. Tayloe, 23, $24,32$.

Ammonia, given in flatulent colic, 401; va. pour of, plentifully extricated from dung and urine, most injurious to the eyes and lungs, $i b$.

Anchylosis of bones, what, 172.

Andrewetta, raee won by, 38 .

Animal poisons, an account of, 225 .

Animals, zoological divisions of, 67 .

Anisc-sced, its properties, 401.

Anodyne, opium the only one to be depended on, 402 .

Antea-spinatus musele, description of the, 260.

Antimonial powder, a good febrifuge, 402.

Antimony, black sulphuret of, method of de. tecting its adulterations, 402 ; used as an alterative, $i b$.; tartarized, used as a nauseant, diaphoretic and worm medicine, $i b$.

Antispasmodics, nature of, 402.

A poplexy, nature and treatment of, 95.

Aqucous fluid, an, why placed in the labyrinth of the car, 81 ; humour of the eye, deseription of the, 89 .

Arabian, Lindsay's, 34 ; Darby, 24; Darlcy, 21 ; Godolphin, 21 ; Ass, 424.
Arbaces, race won by, 38 .

Arched form of the skull, advantage of, 77 .

Ariel, race won by, 36 .

Arietta, race won by, 37 .

Arm, description of the, 261 ; action of, explained on the principle of the lever, 257 , 262 ; extensor muscles of the, 261, 262; flexor muscles of the, 263 ; full and swell. ing, advantage of, $i b$.: should be muscular and long, 261 ; fracture of the, 328.

Arsenic, medical use of, 402 ; treatment under poison by, 227 .

Arteries, description of the, 161 ; of the arm, 261 ; of the face, 124 ; neck, 161 ; shoulder, 255.

Ascaris, account of the, 240.

Ascot coursc, length of the, 41 .

Ass, history of, 419 ; account of two presented to Gen. Washington, 421 ; opinion of him by Prof. Wilson, ib.; ditto by Gen. Shelby, 421, 426; ditto by J. N. Hambleton, Esq., 421,427 ; ditto by Col. N. Goldsborough, 422,428 ; the Arabian, 424; price of, 427 ; cruel prejudice against, 419 ; mentioned in scripture, $i b$.; different races of, 420 .

Astor, race won by, 38 .

Astragalus, account of the, 285.

Atlas, anatomy of the, 157.

Auscultation, the importance of, 193.

A wful, performance of, 57; hcight of, 65 .

BACK, general description of the, 171 ; proper form of the, $i b$.; long and short, compara. tive advantages of, 172; anatomy of the, 171 ; muscles of the, 173 .

Backing, of the colt, 356 ; a bad habit of the horse, usual origin of it, $i b$.

Back-sinews, sprain of the, 269 ; thickening of the, constituting unsoundness, 395 .

Balie Peyton, race won by, 38 .

Balls, the manner of giving, 402 ; the manner of making, $i b$.

Barbary horse, description of, 21.

Barbs or paps, treatment of, 154.

Bark, Peruvian, the properties of it, 403 .

Barley, considered as food for the horse, 375.

Barnacles, use of the, as a mode of restraint, 345.

Bar-shoe, description and use of, 341 .

Bars, deseription and office of the, 297 ; proper paring of, for shoeing, 299 ; folly of cutting them away, 298; removal of, a cause of contraction, $i b$. ; corns, $i b$.

Basilicon ointment, 403.

Bay horses, description of, 387.

Bay Malton, performances of, 30 .

Beach horses, 26.

Beacon course, length of, 41. 
Beans, good for hardly worked horses, and that have a tendency to purge, 376,379 ; should always be crushed, 376 .

Bearing-rein, the use and abuse of, 140 .

Bees-wing, race won by, 37.

Beet, the nutritive matter in, 379 .

Belladonna, extract of, 403.

Bendigo, race won by, 36.

Bertrand, race won by, 38 .

Bethune, race won by, 36 .

Betsy Baker, performance of, 57 ; height of, 65 .

Biceps femoris, account of the, 282.

Bile, account of the, 230, 231.

Billy, performance of, 58 .

Bishoping the teeth, description of, 149.

Biting, a bad habit, and how usually acquired, 357.

Bit, the, often too sharp, 140 ; sometimes got into the mouth, 358 .

Bitting of the colt, 252.

Black horses, description and character of, 387.

Black Joke, performance of, 59 .

Black Maria, races won by, $36,37,38$.

Blacknose, races won by, 37 .

Bladder, description of the, 245 ; inflammation of, symptoms and treatment, 246 ; neck of, $i b$. ; stone in the, $i b$.

Bleeding, bcst place for general, 189, 345 ; directions for, 161,189 ; from veins rather than arteries, 161 ; finger should be on the pulse during, $i b . ;$ importance of, in inflammation, $i b$; at the toe described, 190 ; com. parison between the fleam and lancet, 189 .

Blindness, usual inethod of discovering, 89 ; discovered by the pupil not dilating or con. tracting, $i b$.; of one eye, $i b$.

Blistering all round at once, barbarity and danger of, 347,404 ; after firing, absurdity and cruelty of, 346,361 .

Blisters, best composition of, 346 ; the different kinds and uses of, $i b$; ; best mode of applying, $i b$; caution with regard to their application, $i b$.; the principle of their action, 403 ; use of, in inflammation, 346 ; comparison between them and rowels and setons, 350 .

Blood, change in after bleeding, 190 ; changes in during respiration, 179 ; coagulation of, 189 ; horses, very subject to contraction, 308 ; spavin, nature and treatment of, 188. Bloody urine, 245.

Blue Dick, races won by, 38 .

Bog spavin, nature and treatment of, 189, 287, 288.

Bole-Armenian, medical use of, 403 .

Bones, strength does not depend on the size of, 28.

Bone-spavin, nature and treatment of, 288.

Bonny Boy, performance of, 58 .

Bonnets-o'.Blue, race won by, 36 .

Boston, race won by, 39 .

Bots in the stomach, natural history of, 244; not usually injurious, $i b$.

Bowels, inflammation of the, 235 .

Brain, description of the, 78 ; its cortical and cineritious composition, $i b$; the office of each, 78, 79; compression of the, 78,94 ; pressure on the, $i b$.; inflammation of the, 38 . Bran, as food for the horse, 376.

Breaking in should commence in the second winter, 251; description of its various stages, $i b$.; necessity of gentlencss and patience in, 251, 252; of the farmer's horse, 251 ; of the hunter or hackney, $i b$.

Breast, muscles of the, 175.

Breathing, the mechanism of, 179 .

Breeding, qualities of the mare of as much importance as those of the horse, 248; the peculiarity of form and constitution inherited, $i b$; in-and-in, observations on, $26,249$.

Breeds, good effects of crossing them, 29 ; bad effects of ditto, $i b$.

Broken down, what, 270.

Broken knees, treatment of, 391 ; method of judging of the danger of, $i b$.; when healcd, not unsoundness, but the form and action of the horse should be carefully examined, $i b$.

Broken wind, nature and treatment of, 213 ; influenced much, and often caused by the manner of feeding, 215; how distinguished from thick wind, $i b$.

Brooklyn Maid, performance of, 57 .

Bronchial tubes, description of the, 166.

Bronchitis, nature and treatment of, 205.

Bronchocele, account of, 197.

Bronchotomy, the operation of, 165 .

Brood mare, description of the, 248; should not be too old, $i b$. ; treatment of, after covering, 250 ; after foaling, $i b$.

Brown horses, description of, 387 .

Brown, Capt. Thomas, opinions of with regard to climate, 32 .

Bryony, dangerous, 226.

Buckeye, race won by, 37 .

Buccinator muscle, description of the, 125.

Bull, the, Thompson's description of the, 54 .

CABBage, the nutritive matter in, 379.

Cæcum, description of the, 229 .

Cadmus, race won by, 37 .

Calamine powder, account of, 417 .

Calculi in the intestines, 238.

Calkins, advantages and disadvantages of, 336 ; should be placed on both heels, $i b$.

Camden, race won by, 37 .

Camphor, the medical use of, 403.

Canker of the foot, nature and treatment of, 320.

Cannon, or shank-bone, description of the, $26 \%$.

Cantharides, form the best blister, 225,401 ; given for the cure of glanders, 225, 404 .

Capillary vessels, the, 185 .

Capivi, balsam of, 406 .

Capped hock, nature and treatment of, 278 ; description of, 278,290 ; although not always unsoundness there should be a special warranty against it, 391 .

Capsicum Berries, their stimulating effect, 404.

Carbon of the blood got rid of in respiration, 206. 
Carbonate of iron, a mild tonic, 409.

Carraways, a good aromatic, 404.

Carrots, excellent effects of in discasc, 378 ; the nutritive matter in, 379 .

Cartilages of the foot, description and action of the, 300 ; ossification of the, 321,394 ; a cause of unsoundness, 394.

Caruncula lacrymalis, the, 117.

Cascarilla Bark, a tonic and aromatic, 404.

Cassandra, race won by, 36 .

Castlcy, Mr., on restiveness in the horse, 353.

Castor-oil, not a purgative for the horse, 404.

Castration, method of, 254 ; proper period for, $i b$. ; the operation by torsion, $i b$.

Cataract in the eye, nature of, 90 ; cannot be operated on in the horsc, $i b . ;$ method of examination for, $i b$.; the occasional appcarancc and disappearance of, 120 .

Catarrh, description and trcatment of, 192 ; distinguished from glanders, 193; distinguished from inflammation of the lungs, 192 ; epidemic, 197.

Catarrhal fever, nature and treatment of, 192.

Catechu, a good astringent, method of giving, and adulterations of, 404 .

Catheter, description of one, 247.

Cato, performances of, 57 ; height of, 65 .

Caustic, an account of the bcst, 405 .

Cawl, description of the, 231.

Centrcv:lle 'Trotting course, 63.

Cerebellum, description of the, 78 .

Cercbrum, description of the, 78 .

Chalk, its medicinal use in the liorse, 405.

Chaff, attention should be paid to the good. ncss of the ingredients, 373 ; best composition of, $i b . ;$ when given to the hard-worked horsc, much time is saved for repose, $i b$.; quantity of necessary for different kinds of horses, $i b$.

Chamomile, a mild tonic, 405 .

Chancellor, performances of, 59 .

Channel of the jaws, what, 144.

Charcoal, useful in a poultice, and as an anti. scptic, 405.

Chargcs, composition and use of, 405 .

Charlotte Tcmple, performances of, 57 ; height of, 65 .

Chest, anatomy of the, 167 ; proper form of the, 168,169 ; cut of the, 167 ; the importance of depth of, 167 ; narrow and rounded, comparisou betwcen, 169 ; the broad chest, 170 ; founder, description of, 175.

Chestnut horses, varieties of, 387 .

Chinked in the chine, what, 172.

Chloride of lime, an excellent disinfectant, 412; of soda, useful in unlealthy ulcers, 415.

Chorca, 109.

Choroid coat of the eye, description and use of the, 87 .

Chyle, the formation of, 229 .

Ciliary processcs of the eye, description of the, 89.

Cineritous matter of the brain, nature and function of the, 79 .

$37 *$
Clara Howard, races won by, 37, 38.

Clicking, causc and remedy of, 362 .

Clipping, recommendation of, 383.

Clips, when nccessary, 337.

Clover, considered as an article of food, 378, 379.

Clysters, the composition and great usefulncss of, 405 ; directions as to the administration of, $i b$.

Coat, fine, persons much too solicitous to pro. cure it, 371.

Cocktail horse, mode of docking, 351.

Coffin-bone, description of the, 300 ; the lamellæ, or leaves of, $i b . ;$ fracture of, 383.

Coffin-joint, sprain of, 277.

Cold, common, description and treatment of, 192.

Colic, flatulent, account of, 234 ; spasmodic, description and treatment of, 232.

Colocynth, is poisonous, 226.

Colun, description of the, $229,230$.

Colour, remarks on, 386 .

Colt, early treatment of the, 251 ; mules, death of, 454,455 .

Columbus, pcrformances of, 57 ; height of, 65 .

Complexus major, description of the, 159 ; minor, description of the, 160 .

Concave-seated shoe, the, dcscribed and recommended, 337.

Confidence, pcrformances of, 57 ; height, 65 .

Conium maculatum, poisonous, 226.

Conjunctiva, description of the, 87 ; appearance of, how far a test of inflammation, $i b$.

Consumption, account of, 215.

Contraction of the foot, nature of, 305,391 ; the peculiarity of the lamencss produced by, 308 ; how far connccted with the navicular diseasc, 307 ; is not the necessary conscquence of shoeing, $i b$.; produced by ncglect of paring, 306 ; wearing the shoes too long, 305 ; want of natural moisture, 306 ; the removal of the bars, $i b$.; not so much produced by litter as inagined, 307 ; the cause rather than the consequence of thrush, 305; best mode of treating, 308, 309 ; rarcly permanently cured, 309 ; does not necessarily imply unsoundness, 391 ; although not necessarily unsoundness, should have a special warranty against it, $i b$.; blood horses very subject to, 308 .

Convexity of the eye, the proper, not suff. ciently attended to, 87 .

Copaiba, account of the resin, 406.

Copper, the combinations of, used in veteri. nary practice, 406 .

Corded veins, what, 136.

Cordials, the use and abuse of, in the horse, 406.

Cornca, description of the, 87 ; mode of examining the, $i b . ;$ its prominence or flatness, $i b . ;$ should be perfectly transparent, $i b$.

Corns, the nature and treatment of, 317 ; produced by cutting away the bars, $i b . ;$ not paring out the foot between the crust and bars, $i b$.; pressure, $i b$; very difficult to cure, 318 ; constitute unsoundness, 391. 
Coronary ligament, description of the, 297; Docking, method of performing, 350. the crust principally produced fron, $i b$.; Dogs, dangcr of cncouraging them about the ring, description of the, $i b$.

Coronet, description of the, $\vdots b$.

Corrosive sublimate, treatment under poi- Don Juan, performances of, 57 . son by, 227; a good tonic for farcy, 227, Dosoris, race won by, 37. 411.

Cortical substance of the brain, description and fraction of, 78.

Cough, the nature and treatment of, 209, 210; constitutes unsoundness, 392 ; the occasional difficulty with regard to this, 395 .

Cow hocks, description of, 291 .

Cradle, a safe restraint upon the horse when blistered, 347 .

Cramp, the nature and treatment of, 106.

Cream.coloured horses, account of, 386 ; pecu. liarity in their eyes, 88.

Crcam of tartar, a mild diuretic, 414 .

Creasote, its use in veterinary practice, 407

Creath, races won by, 36,37 .

Crib-biting, description of, 361 ; causes and cure, $i b$.; injurious to the horse, $i b$.; constitutes unsoundness, $361,392$.

Cricoid cartilage of the windpipe, the, 163.

Cropping of the ear, absurdity of, 81 .

Crossing the breeds, good effect of, 29 ; bad effects of ditto, $i b$.

Crotoll, the farina of, used as physic, 407 .

Crust of the foot, description of the, 295 ; com. position of the, 296; consisting within of numerous horny plates, 298 ; proper degree of it, slanting, 296; proper thickness of the, $i b$.; brittleness of, remedy for, 298; the cause of sanderack, 311 .

Crystalline lens, description of the, 90.

$\mathrm{Cub}$, race won by, 37 .

Cuboid bones, description of the, 285 .

Cuneiform boncs, description of the, 77 , 285.

Curbs, naturc and treatment of, 287 ; constitute unsoundness, 392 .

Cuticle, description of the, 381 .

Cutis, or true skin, account of the, $i b$.

Cutting, cause and cure of, $275,276,362$; constitutes unsoundness, 393; away the foot, unfounded prejudice against, 306 .

DANDRIFF, the nature of, 381 .

Darley Arabian, 21.

Dcafness, 122.

Depressor labii inferioris muscle, description of the, 125 .

Diabctes, the nature and treatinent of, 245 .

Diaphoretics, their nature and effects, 407 .

Diaphragn, description of the, 176 ; rupture of, 177 ; its connexion with respiration, 178.

Digestion, the process of it described, 222 .

Digestives, their nature and use, 407.

Digitalis, higlily recommended in colds and all inflammatory complaints, 407.

Dilator magnus lateralis muscle, description of the, 285 ; naris lateralis muscle, description of the, $i b$.

$\begin{array}{ll}\text { Distance, 42. } & \text { Euphorbium, the abomin } \\ \text { Diuretic medicines, the use and abuse of, 408. } & \text { Eutaw, race won by, } 39 .\end{array}$

Drinks, how to administcr, 408 ; comparison between them and balls, $i b$.

Dropsy of the chest, 219; of the heart, 183.

Drover, performance of, 58.

Drum of the car, description and use of the, 81.

Duane, race won by, 39.

Dun horse, account of the, 386 .

Duodenum, description of the, 229 ; diseases of the, $i b$.

Dura mater, description of the, 78.

Dutchman, performances of, $57,60,61,62$; height of, 65 .

Dutchess, performances of, 57.

D. D. Tompkins, performances of, 57 ; height of, 65 .

Duvall, Judge G., services rendered to the turf by, 25 .

$\mathrm{E}_{A \mathrm{R}}$, description of the external parts, 81 ; in. ternal parts, $i b$, ; bones of the, description and use of, 81,82 ; labyrinth of tile, 81 ; indicative of the tcmper, $i b$, ; clipping and singeing, cruelty of, $i b$; treatment of wounds or bruises of, 121 ; cruel operations on the, $i b$.

Earl of Margrave, race won by, 37.

Eclipse, his performances, $30,39,41$; was a higlt-blower.

Edwin Forrest, performances of, 57 ; hcight of, 65 .

Elasticity of the ligament of the neck, 77.

Elatcrium, poisonous, 226.

Elbow, the proper form and inclination of, 264 ; capped, 261 ; fracture of, 328 ; punctured, 262.

Ellen Thompson, performances of, 57 .

Emctic tartar, used as a nauseant, diaphoretic, and worm medicine, 402.

Empress, performance of, 59.

Enamel of the teeth, account of the, 145.

English Eclipse, 24.

English steeplc-chasc, description of, 50 .

English aristocracy, advantages of, 32.

English trotters, examples of, 51 .

Ensiform cartilage, the, 169.

Entanglement of the intestines, description of, 239 .

Enteritis, account of, 235 .

Epidemic eatarrh, nature and treatment of, 197 ; malignant, nature and treatment of, 203.

Epiglottis, description of the, 163 .

Epilepsy, nature and treatment of, 109.

Epsom salts, used as a purgative, 412.

Epsom course, the length of, 41 .

Ergot of rye, the action of, 415 .

Ethmoid bonc, description of the, 77. 
Ewe-neck, unsightliness and ineonvenienee of, 160 .

Exchanges of horses stand on the same ground as sales, 397 .

Exercise, directions for, 371 ; the necessity of regular, $i b$.; want of, producing grease, 234 ; more injury done by the want of it than by the hardest work, $\mathbf{3 7 2}$.

Expansion shoc, description and use of the, 341.

Extcnsor pedis musele, description of the, 284.

Eye, deseription of the, 82 ; cut of the, 86 ; fraeture of the orbit of the, 93 ; healthy appearanee of the, 85 ; diseases of the, 116 ; inflammation of, common, 117 ; ditto, speeifie, $i b$. ; ditto, causcs, 118 ; ditto, medical treatment of, 118, 119; ditto, untractable nature of, 119, 120; ditto, consequences of, 119 ; ditto, marks of recent, 393 ; ditto, constitutes unsoundness, $i b$, d ditto, hereditary, 119; inethod and importance of examining it, 87,90 ; indicative of the temper, 82 ; the pit above, indicative of the age, 71 ; muscles of the, 92 .

Eyebrows, substitutc for, 83.

Eyclashes, description of, 83 ; folly of singeing them, 84.

Eyelid, description of, 83,84 .

Eyelids, diseases of the, 116 .

Exostosis on the orbit of the eye, 94 .

FACE, deseription of the, 122 ; cut of the mus. cles, nerves, and blood-vessels of, 125.

Falling in of the foot, what, 304.

False quarter, nature and treatment of, 313.

Fanny Wyatt, race won by, 39 .

Farey, a disease of the absorbents of the skin, 136,137 ; connected with glanders, 136; both generated and infectious, 138 ; symptoms of, 137; treatment of, 138 ; - buds, what, 137; the effect of cantharides in, 138, 139; diniodide of copper, 138.

Fashion, pcrformance of, 39 ; the winner of the race of races, 33 .

Feather-weight, a, 42.

Fceding, high, connected with grease, 294; regular periods of, necessity of attending to, 379 ; inanner of, has much influence on broken wind, 214.

Feet, the general management of, 380 ; atten. tion to, and stopping at night, recommend. ed, $i b$.

Felt soles, deseription and use of, 341 .

Femur, fracture of the, 329.

Fetlock, description of the, 275.

Fcver, idiopathic or pure, 187 ; symptoms of, ib. ; symptomatic, 188.

Fibula, deseription of the, 283.

Filly by Imp. Trustee, race won by, 37 .

Firing, the prineiple on which resorted to, 347 ; mode of applying, $i b$.; should not pcnetrate the skin, 349 ; absurdity and eruelty of blistering after, $i b$.; horse sliould not be used for some months after, $i b$.

Fistula lacrymalis, 81 ; in the poll, 157.
Fits, symptoms, causes, and treatment of, 109.

Fleam and lancet, comparison between them, 189.

Flexor of the arm, deseription of the, 263 ; metatarsi muscle, description of the, 284 ; pedis perforatus, the perforated muscle, de. scription of the, 263,284 ; pedis perforans, the perforating muscle, deseription of the, $264,269,284$.

Flirtilla, race won by, 38 .

Flying Childers, the ne plus ultra of suceess reached in his days, 29.

Foal, early treatment of, 251 ; early handling of, important, $i b$. ; importance of liberal feeding of, $i b$.; time for weaning, $i b$.

Fomentations, theory and use of, 409.

Food of the horse, observations on, 372 ; a list of the usual articies of, 374 ; should be ap. portioned to the work, 373 .

Foot, description of the, 295 ; diseases of the, 302 ; canker, 320 ; corns, 317 ; contraction, 305 ; false quarter, 313 ; founder, acute, 302 ; chronic laminitis, 304 ; inflammation, ib. ; navicular joint disease, 309 ; overreach, 312 ; prick, 315 ; pumiced, 304 ; quittor, 313 ; sandcrack, 311 ; thrush, 318 ; tread, 312 ; weakness, 321 ; wounds, 315

Forceps, arterial, the use of, 190.

Forehead, the different form of, in the ox and horse, 78 .

Fore-legs, description of, $25 \mathrm{j}$; diseases of them, 267 ; proper position of them, 278.

Forgc-water occasionally used, 409 .

Form, on the improvement of, 28.

Founder, acute, symptoms, cruses, and treatment of, 302 ; chronic, nature and treatment of, 304 .

Foxglove, strongly recommended in eolds, and all fevers, $407,408$.

Fracture of the' skull, treatment of, 93 ; gene. ral observations on fractures, 322 ; of the skull, 323 ; orbit of the eye, 324 ; nasal bones, $i b$.; superior maxillary or upper jaw . bone, 325 ; inferior ditto, $i b$. ; spine, 326 ; ribs, $i b$. ; pelvis, 327 ; tail, 328 ; limbs, ib. ; shoulder, $i b$.; arm, $i b$.; clbow, $i b$.; femur, 329 ; patella, $i b$. ; tibia, ib. ; hock, 330 ; leg, $i b$.; sessamoid bones, 331 ; pastern, $i b$.; lower pastern, 332 ; coffin bone, 333 ; navicular bone, $i b$.

Frog, horny, description of the, 299 ; sensible, description of the, 299,301 ; ditto, action and use of the, 299 ; pressure, question of the, $i b$; proper paring of, for shoeing, $i b$.; diseases of the, $i b$.

Frontal bones, description of the, 70 ; sinuses, deseription of the, 73 ; ditto, perforated to detect glanders, $i b$.

Furze, considered as an article of food, 378 .

Gallatin, racc won by, 37 .

Gall, account of the, 231 ; bladder, the horse has none, $i b$.

Gall-stones, 243

Gazan, race won by, 37. 
Gentian, the best tonic for the horsc, 409 .

George Martin, races won by, 36,38 .

Gibbing, a bad habit, cruse of, and means of lessening, 356.

Gigs, formation of, 154.

Ginger, an excellent aromatic and tonic, 409, 417.

Give and take plate, 42 .

Glanders, nature of, 129,131 ; symptoms, 74 , 129,134 ; slow progress of, 129,131 ; appearanees of the nose in, $74,129,131$; detected by injecting the frontal sinuses, 73 ; how distinguished from eatarrh, 131 ; ditto from strangles, $i b$.; connected with farey, 130,132 ; treatment of, 135 ; causes, 133 ; both generated and contagious, 133,134 , 429 ; oflenest produced by improper stable management, 133 ; mode of communieation, 134 ; prevention of, 135 ; account of its speedy appearance, 132, 133.

Glands, enlarged, it depends on many circum. stances whether they constitute unsoundness, 393.

Glass-eye, nature and treatment of, 121.

Glauber's salt, its effeet, 416.

Glutæi muscles, description of the, 281, 282.

Godolphin Arabian, Sir Archy regarded as the, of Ameriea, 25.

Goulard's extract, the use of it much over. valued, 412.

Gracilis musele, description of the, 281, 284.

Grains, occasionally used for horses of slow work, 375.

Grapes on the heels, treatment of, 294 .

Grasses, neglect of the farmer as to the proper mixture of, 377 .

Grease, nature and treatment of, 292 ; cause of, $i b$; farmer's horse not so subject to it as others, 294 ; generally a mere local complaint, 293.

Greenwich Maid, performanccs of, 57 ; beight, 65.

Grey Eaglc, race won by, 37.

Grey Medoc, raee won by, 39 .

Grey horses, aecount of the different shades of, 386 .

Grinders, construction of the, 145 .

Grinding, of the food, accomplished by the mechanism of the joint of the lower jaw, 146 ; swallowing without, 360 .

Groggincss, account of, 275.

Grooming, as important as exercise to the horse, 370 ; opens the pores of the skin, and gives a fine coat, 371 ; directions for, $i b$.

Grunter, the, description of, 215 ; is unsound, 392.

Gullet, description of the, 221 ; foreign bodics in, 223.

Gum-arabic, for what purposes used, 398.

Gutta serena, nature and treatment of, 121.

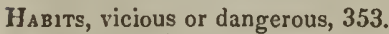

Hæmaturia, 245.

Hair, account of the, 381 ; question of cutting it from the heels, 295.

Haras, established by Napoleon, 33.
Haunch, description of the, 279; wide, ad. vantage of, $i b$.; injuries of the, $i b$.; joint, singular strength of it, $i b$.; also of the thigh bones, advantage of the oblique direction of, $i b$.

Haw, curious mechanism of the, 85 ; diseasce of, 117 ; absurdity and cruelty of destroy. ing it, 85,86 .

Hay, considered as food, 373 ; mowburnt, in jurious, 377 ; old preferable to new, ib.

Head, anatomy of the, 70 ; the numerous bones composing it, the reason of this, 70 , 71 ; section of the, 72 ; beautiful provision for its support, 76 .

Healing ointment, account of the, 417.

Hearing of the horse, the very acute, 81.

Heart, deseription of the, 181 ; its aetion described, 182; inflammation of the, 183 ; dropsy of the, $i b$.

Heels, question of cutting the hair from then, 295 ; low, disadvantage of, 322 ; proper paring of, for shoeing, 334; wasling of the, produeing grease, 294.

Height of trotting horses, 64.

Hellebore, white, used in inflammation of the lungs and fevers, 409 ; black, its use, $i b$.

Hemloek, given in inflammation of the chest, 410.

Henry, match won by, 57 ; height, 65 .

Hepatic duct, the, 231.

Hernia, the nature and treatment of, 240.

Hide-bound, the nature and treatment of, 383 .

High-blower, a description of the, 195,315 ; is unsound, 392 .

Hind legs, description of the, 279.

Hip-joint, the great strength of the, 280 .

Hips, ragged, what, 279 .

Hobbles, description of the best, 344 .

Hock, the advantage of its numerous separate bones and ligaments, 290 ; capped, 278. 291 ; cow, ib.; deseription of the, 285 ; enlargement of thc, nature of and how affecting soundness, 286, 393; inflammation of the small bones of, a frequent cause of lameness, 286,287 ; the principal seat of lameness behind, 286 ; lameness of it, without apparent cause, 290 ; fracture of, 330 .

Hogs' lard, properties of, 399 .

Hoof, cut of the, 295 ; deseription of the, 296.

Horn of the crust, secreted principally by the coronary ligament, 298; once separated from the sensible part within, will ncver again unite with it, $i b$.

Hornet, sting of the, 225 .

Horse, the first allusion to him, 17; in England and America, 17 ; English, 20; Barb, 21; the different colours of the different breeds, 386 ; his fossil remains found in every part of the world, 17, 31 ; the general manage. ment of, 366 ; sublime account of, by Job, 18; first mention of race-horse in English annals, 21; Arabian race, 27, 28; height of trotting, 64 ; price of, in Solomon's time, 18 ; sagacity of, $i b$.; can see almost in darkness, 88; English, improved under William the Conqueror, 21,22 ; zoological descrip- 
tion of, 67; numerous in Britain at the in. Jejunum, description of the, 229. vasion of the Romans, 20.

Jerry, performance of, 58 .

Horse, Flanders, introduced by King John, 22 ; Lombardy, imported by Edward II., $i b$.; Spanish, imported by Edward III., ib.; Flemish, characteristics of, $i b$.; Darby Arabian, 24 ; revolution in the system of breed. ing brought about by the invention of gun. powder, 22 ; first classification for war, the turf, the chase, the road, and the coach, $i b$; ; value of before the establishment of the Turf Register, 25; Beach, anecdotes of, 26 ; thrives best within or near the torrid zone, 31 ; influence of climate and food on the form and character of, 31 ; value of since the establishment of the Turf Register, 32 ; ancestors of the present stock of American, 40 ; good blood in, important in a military point of view, 33 ; prevalence of blood of, in Lec's Legion, 33; American trotting, 49 ; superiority of the American trotting over the English, 49, 51 ; speed of, 50, 51 .

Houri, (Imp.), race won by, 36 .

Humerus, description of the, 260 .

Hunter, the, general account of, 48 ; proper degree of blood in, $i b$; f form of, $i b$.; spirit of, $i b$.; English, $i b$.; shoe, description of the, 340 .

Hunting Park course, 64.

Hydrocyanic acid, poisoning by it, 226; its occasional good service, 399 .

Hydrothorax, symptoms and treatment of, 219.

ILEUM, description of the, 229.

Inflammation, naturc of, 185 ; treatment of, 186 ; hot or cold applications to, guide in the choice of, $i b$; importance of bleeding in, 185, 345; when proper to physic in, 186 ; of the bowels, 235 ; ditto, distinction between it and colic, 233; brain, 98; eye, 117 ; foot, 302 ; kidneys, 244 ; larynx, 193 ; lungs, 206 ; stomach, 223 ; trachea, 194 ; veins, 161 .

Influenza, nature and treatment of, 197.

Infusions, manner of making them, 411 .

Insanity, 115.

Intercostal muscles, description of the, 169 .

Intestines, description of the, 228.

Introsusception of the intestines, treatment of, 238.

Invertebrated animals, what, 67.

Iodine, usefulness of, in reducing enlarged glands, 411 .

Iris, description of the, 89 .

Iron, the carbonate of, a mild and useful tonic, 409 ; sulphate of, a stronger tonic, $i b$; ditto, recommended for the cure of glanders, $i b$.

Itchiness of the skin should always be regarded with suspicion, 390 .

JACrs. See the Ass.

James's powder, 402.

Jaundice, symptoms and treatment of, 243,244.

Jaw, the lower, admirable mechanism of, 142 ; upper, description of, 141.

Jim Bell, races won by, 36,39 .

Jockeys, superiority of American, 51, 65.

Jockey Club, rules and regulations of, 42 .

John Barcombe, race won by, 39.

John Causin, race won by, 36 .

John R. Grymes, race won by, 37.

Jointed shoe, the description and use of, 341.

Jugular vein, anatomy of the, 190.

Jumper, the horse-breaker, anecdotes of his power over animals, 353.

Juniper, oil of, use of, 411.

Kate Kearnex, her dam sold for 13 pounds tobacco currency, 24; her fame established by Col. J. M. Selden, $i b$.

Kicking, a bad and inveterate habit, 358 .

Kidneys, description of the, 243; inflamma. tion of, symptoms and treatment of, 244.

King Pippin, anecdotes of him as illustrating the invetcrateness of vicious habits, 354 .

Knee, an anatomical description of the, 264; tied in below, 269 ; broken, treatment of, 265,391 .

Knowledge of the horse, how acquired, 69.

LABYRINTH of the ear, description and use of the, 81 .

Lachrymal duct, description of the, 84 ; gland, description and use of the, $i b$.

Lady Clifden, race won by, 39.

Lady Suffolk, performances of, $57,63,64$; hcight of, 65 .

Lady Victory, performances of, 57; heiglit of, 65 .

Lady Warrington, performances of, 57 ; hcight of, 65 .

Lady Kate, performances of, 58 .

Lamellæ or laminze, horny, account of the, 298 ; fleshy, account of the, $i b$.; weight of the horse, supported by the, $i b$.

Lameness, shoulder, method of ascertaining, 255 ; from whatever cause, unsoundness, 393.

Lampas, nature and treatment of, 142 ; cruelty of burning the bars for, $i b$.

Laminæ of the foot. See Lamellæ.

Lancet and fleam, comparison between them, 189.

Laryngitis, chronic and acute, 193.

Larynx, description of the, 163 ; inflammation of the, 193.

Laudanum, the use of in veterinary practice, 413.

Lead, the compounds of, used in veterinary practice, 411, 412; extract of, its power much overvalued, 412 ; sugar of, use of, $i b$; white, use of, $i b$.

Leather soles, description and use of, 341.

Leg, cut of the, 112; description of the, 267; fracture of the, 332 .

Legs, fore, the situation of, 255 ; hind, anatomical description of the, $i b$.; swelled, 291.

Levator humeri muscle, description of the, $160,259$. 
Lever, muscular action explained on the principle of it, 257.

Ligament of the neck, description and elasticity of the, 76.

Light, the degrec of, in the stable, 369.

Limbs, fracture of the, 328.

Lime, the chloride of, exceedingly useful for bad smelling wounds, \&c., 412; the chloride of, valuable in cleansing stables from infection, $i b$.

Lindsay's Arabian, 34.

Liniments, the composition and use of, $i b$.

Linseed, an infusion of, used in catarrh, 376, 412; meal forms the best poultice, 412 , 414.

Lips, anatomy and uses of the, 139 ; lips the hands of the horse, $i b$.

Litter, the, cannot be too frequently removed, 368 ; proper substances for, 369 ; contraction not so much produced by it as some imagine, 307.

Liver, the anatomy and use of it, 230 ; diseases of the, 241.

Liverpool, account of the course at, 42 .

Locked jaw, symptoms, cause, and treatment of, 103.

Locomotive, performances of, 57 ; height of, 65.

Loins, description of the, 172.

Longissimus dorsi muscle, description of the, 173.

Lucern, considered as an article of food, 378.

Lumbricus teres, the, 240.

Lunar caustic, a very excellent application, 402.

Lungs, description of the, 181 ; symptoms of inflammation of the, 206 ; causes of, $i b$.; how distinguished from catarrh and distemper, 207, 208; treatment of, 208, 209; importance of early bleeding in, 209; blisters preferable to rowels or setons in, 210 ; consequences of, $210,212,215$.

MaDness, the symptoms and treatment of, 100.

Magnesia, the sulphate of, 412 .

Mallenders, the situation of, 278 ; the nature and treatment of, 291.

Mammulia, the, an important class of animals, 67.

Manchester, account of the course at, 42 .

Mane, description and use of the, 160 .

Mange, description and treatment of, 388 ; causes of, 388,389 ; ointment, recipes for, $i b$; highly infectious, 389; method of purifying the stable after, $i b$.

Manger-feeding, the advantage of, 373.

Mare, put to the horse too early, 248, 250; deterioration in, 249 ; her proper form, $i b$. ; breeding in-and-in, $i b$.; time of being at heat, 250 ; time of going with foal, $i b$.; best time for covering, $i b$; management of, when with foal, ib.; management of, after foaling, 250.

Maria Duke, race won by, 36.
Mark of the teeth, what, 146.

Marsk, his performances, 30 .

Mashes, importance of their use, 412 ; best method of making them, $i b$.

Masseter muscle, description of thc, 125, 144.

Master Henry, race won by, 38.

Matchem, his performances, 30 .

Maxillary bones, anatomy of the, 141 ; fractures of, 325 .

Meadow grasses, the quantity of nutritive matter in, 379.

Medicines, a list of the most useful, 398.

Medullary substance of the brain, its nature and function, 72, 78, 79 .

Megrims, cause, 94 ; symptoms, 95 ; treatment, $i b . ;$ apt to return, $i b$.

Melt, description of the, 231.

Mercurial ointment, the use of, in veterinary practice, 410.

Mercury, its use in epidemic catarrh, 201.

Mesentery, description of the, 229.

Metacarpals, description of the, 267.

Midriff, description of the, 176.

Minstrel, race won by, 36 .

Mischief, performance of, 59 .

Miss Foote, races won by, 39.

Mount Holly, performance of, 58 .

Modesty, performance of, 57 ; height of, 65 .

Moisture, want of, a cause of contraction, 307.

Moon-blindness, the nature of, 117.

Moulting, the process of, 385 ; the horse usually languid at the time of, $i b$.; no stimulant or spices should be given, $i b$.; mode of treatment under, $i b$.

Mounting the colt, 253.

Mouth of the horse, description of the bones of, 141 ; should be always felt lightly in riding, $i b$.; importance of its sensibility, $i b$.

Mowburnt hay injurious, 377.

Mule, the, 419 ; as he is, 422 ; value of, in China, 423 ; value of the breed of Gen. Washington, $i b$.; more valuable when bred from blooded mares, $i b$. ; longevity of, 424 ; Pliny's account of $a, i b$; does not deteriorate more rapidly after twenty years of age than the horse after ten, 425 ; health of, $i b$. economy in food, \&c., $i b . ;$ is more steady in his draught than the horse, 426 ; trade in Kentucky, 427; his obstinacy, 429 ; bad habits, 429, 430 ; number of in the United States, 430 ; a breeding, 432 ; birth of two colts, $i b . ;$ death of ditto, 432,433 .

Muriatic acid, its properties, 399.

Muscles of the back, description of the, 173 ; breast, ditto, 175 ; eye, ditto, 92 ; face, ditto, 125 ; neck, ditto, 158; ribs, ditto, 169 ; shoulder-blade, 255; lower bone of the shoulder, $i b . ;$ the advantageous direction of, more important than their bulk, 256, 257,258 ; should be large, 28.

Muscular action, the principle of, 261 .

Mustard, the use of, 413.

Myrrh, the use of, for canker and wounds, 413 . 
Nasalis labii superioris muscle, description Omentum, description of the, 231. of the, 125.

Nasal bones, fracture of, 324 ; description of, 72.

Oneida Chief, performance of, 58.

Opacity of the eye, the nature and treatment of, 118.

gleet, 127.

polypus, 126.

Navicular bone, description of the, 301 ; the action and use of it, $i b$.

Navicular joint, disease, nature and treatment of the, 309; how far connected with contraction, 310 ; the cure very uncertain, $i b$.; fracture of, 333.

Neck, anatomy and muscles of the, 158, 159 ; description of the arteries of the, 161 ; description of the veins of the, $i b$,; bones of the, 158; proper conformation of the, $i b$.; comparison between long and short, 159; loose, what, $i b$.

Nerves, the, construction and theory of, 70 ; spinal, the compound nature of, 79 ; of the face, 125.

Neurotomy, or nerve operation, object and effect of it, 111; manner of performing it, 112 ; cases in which it should or should not be performed, 113; a vestige of the performance of it, constitutes unsoundness, 394.

Nicking, the method of performing, 351 ; use. less cruelty often resorted to, 352 .

Nimrod, his objection to clipping, 383 ; admits the superiority of American trotters, 49,51 .

Nitre, a valuable cooling medicine, and mild diuretic, 414.

Nitric acid, for what employed, 399.

Nitrous æther, spirit of, a mild stimulant and diuretic, 413.

Norman Leslie, match won by, 57 ; height of, 65.

Nose, description of the bones of the, 122 , 123 ; spontancous bleeding from, $i b$; the importance of its lining membrane, 123, 191 ; the nose of the horse slit to increase his wind, 124.

Nosebag, importance of the, 379 .

Nostrils, description of the, 122 ; pcculiar inflammation of the membrane of the, 74 ; the membrane of, important in ascertaining disease, 126, 191; importance of an expanded one, 124 ; slit by some nations to increase the wind of the horse, $i b$.

Nutriment, the quantity of, contained in the different articles of food, 379 .

OAts, the usual food of the horse, 374,379 ; should be old, heavy, dry, and sweet, 374 , 375 ; kiln-dried, injurious to the horse, 375 ; proper quantity of, for a horse, $i b$.

Oatmeal, excellent for gruel, and sometimes used as a poultice, 375 .

Occipital bonc, description of the, 74 .

Enanthe fistulosa, poisonous, 226.

Esophagus, description of the, 221.

Olfactory nerves, the importance of them, 124.

Olive oil, an emollient, 413.

Omega, races won by, $38,39$. 344.

Ophthalmia, 117

Opium, its great value in veterinary practice, 412 ; adulterations of it, $i b$.

Orbicularis muscle of the eye, description of it, 92.

Orbit of the eye, fracture of, 93.

Os femoris, account of, 282.

Ossification of the cartillages, cause and treatment of, 321.

Over-reach, the nature and treatment of, 312 , 362 ; often producing sanderack or quittor, 363.

Ozena, account of, 128.

Pachydermata, an order of animals, 68.

Pack-wax, description of the, 76, 157.

Palate, description of the, 163 .

Palm-oil, the best substance for making up balls, 414 .

Palsy, the causes and treatment of, 109 .

Pancreas, description of the, 243.

Paps or barbs, 154.

Parietal bones, description of the, 74 .

Paring out of the foot for shoeing, directions for, 334 ; neglect of, a cause of contraction, 306.

Parotid gland, description of the, and its diseases, 125, 153.

Parsnips, the nutritive matter in, 379.

Passenger, race won by, 37 .

Pastern, upper, fracture of, 331 ; lower, fracture of, 332 ; description of thc, 272,276 ; bones of the, $i b$. ; cut of the, 272 ; proper obliquity of the, 274.

Patella or stifle bone, description of the, 283; fracture of, 329.

Paul Pry, performance of, 58.

Pawing, remedy for, 363 .

Payment of the smallest sum completes the purchase of a horse, 396.

Peacemaker, racc won by, 37.

Peas, somtimes used as food, but should be crushed, $376,379$.

Pectineus muscle, the, 281.

Pectorales muscles, description of the, 175,260.

Pedigrees of American trotters, 54.

Pelham, performance of, 58.

Pelvis, fracture of the, 327 .

Pericardium, description of the, 181.

Peronæus muscle, dcscription of the, 284.

Perspiration, insensible, no medicines will certainly increase it, 385 .

Pharynx, anatomy of the, 157 .

Phrenitis, 38.

Phthisis pulmonalis, description of, 215.

Physic balls, method of compounding the best, 401 ; should never be given in inflam. mation of the lungs, 181 .

Physicking, rules for, 23\%.

Pia mater, description of the, 78 . 
Pied horse, account of the, 386.

Pigmentum nigrum, account of the, 88 .

Piper, description of the, 215.

Pit of the eye, the, indicative of the age, 71.

Pitch, its use for charges and plasters, 414.

Pithing, a liumane method of destroying animals, 158.

Pleura, description of the, 179.

Pleurisy, the nature and treatment of, 181 , 217.

Pneumonia, the nature and treatment of, 206.

Poisons, account of the most frequent, 226, 227 ; tests of the different ones, 227.

Poll-evil, the cause and treatment of, 157 ; importancc of the free escape of the matter, $i b$.

Popliteus muscle, description of the, 284.

Porter's Spirit of the Times, opinion of, 51.

Postea spinatus muscle, description of the, 260.

Post Boy, race won by, 37.

Post Match, 42.

Potash, the compound of, 414.

Potatoes, considered as an article of food, 378 , 379.

Poultices, their various compositions, manner of acting, and great use, 414.

Powders, comparison between them and balls, 415.

Pressure, race won by, 37.

Pressure on the brain, effect of, 94.

Prick, in the foot, treatment of, 315 ; injurious method of removing the horn in searching for, 317.

Prussic acid, treatment of poisoning by, 226.

Puffing the glims, a trick of fraudulent horse. dealers, 71 .

Pulse, the natural standard of the, 184 ; varieties of the, $i b$, ; importance of attention to the, 185; the most convenient place to feel it, $i b$; the finger on the pulse during the bleeding, $i b$.

Pumiced feet, description and treatment of, 304 ; do not admit of cure, $i b$, ; constitute unsoundness, 394.

Pupil of the eye, description of the, 89 ; the mode of discovering blindness in it, $i b$.

Purchase, to complete the, there must be a memorandum, or payment of some sum, however small, 396.

Purging, violent, treatment of, 235.

QUARTERs of the horsc, description of the, 281 ; importance of their muscularity and depth, $i b$.; foot, description of, 297 ; the inner, crust thinner and weaker at, 298; folly of lowering the crust, $i b$.

Quidding the food, cause of, 363; unsound. ness while it lasts, 394 .

Quinine, the sulphate of, 403.

Quittor, the nature and treatment of, 313 ; the treatment often long and difficult, exercising the patience both of the practitioner and owner, 314, 315; is unsoundness, 394.

Rabies, symptoms of, 100 .
Racc-courses, different lengths of, 41.

Races, among the Arabs, 27 ; best in America on record, 35 ; at mile heats, 36 ; at two mile heats, 37 ; at three mile heats, 38 ; at four mile heats, 39 ; miscellaneous examples of, 40 ; prejudices against, 33 .

Racers may beget trotters, 52,53 .

Racks, no openings should be allowed above them, 367.

Radius, description of the, 261.

Ragged-hipped, what, 279 ; no impediment to action, $i \vec{b}$.

Raking, the operation of, 415 .

Rattler, matches won by, 57,59 ; height of, 65 .

Reality, race won by, 37.

Rearing, a dangerous and inveteratc habit, 359.

Recti muscles, of the neck, description of, 158; of the thigh, 280.

Rectum, description of the, 229, 230 .

Red Bill, races won by, 36,38 .

Reins, description of the proper, 140.

Resin, its use in veterinary practice, 415.

Respiration, description of the mechanism and effect of, 179 .

Respiratory nerves, the, 79 .

Restiveness, a bad habit, and never cured, 353 ; anecdotes in proof of its inveterateness, 353, 354.

Retina, description of the, 91.

Retractor muscle of the eye, description of it, 92 .

Rheumatism, 110.

Rifle, performance of, 57.

Ribbed-home, advantage of being, 171.

Ribs, anatomy of the, 168,169 .

Richard of York, race won by, 37 .

Ringbone, the nature and treatment of, 277 , 278 ; constitutes unsoundness, 394.

Ripple, race won by, 38 .

Ripton, matches won by, $57,63,64$; height of, 65 .

Roach-backed, what, 172.

Roan horses, account of, 386

Roaring, the nature of, 194,215 ; curious history of, 195 ; constitutes unsoundness, 392 ; from tight reining, 196; from buckling in crib-biting, $i b$.; treatment of, 197.

Robin Hood, race won by, 36 .

Rocker, race won by, 37 .

Rolling, danger of, and remedy for, 363.

Roman nose in the horse, what, 122.

Round-bone, the, can scarcely be dislocated, 282.

Round course, length of, 41.

Rowels, manner of inserting, and their opera. tion, 415 ; comparison between them, blisters, and setons, 350 .

Rules and regulations of the New York Jockey Club, 42.

Rules and regulations of the New York Trotting Club, 54.

Running away, method of restraining, 359.

Rupture, treatment of, 240 ; of the suspensory ligament, 193.

Rye-grass, considered as an article of food, 378. 
SADDLES, the proper construction of, 174 ; Shoulder-blade, muscles of the, 255 ; why points of, $i b$.

Saddle-backed, what, 172 ; galls, treatment of, 175.

Saddling of the colt, 253.

Sailor Boy, race won by, 36.

Sainfoin used as an article of food, 378

Sal ammoniac, the nedical use of, 401.

Saliva, its nature and use, 153.

Salivary glands, description of the, $i b$.

Sallenders, nature and treatment of, 291.

Sally Shannon, race won by, 37 .

Sally Miller, match won by, 57 ; height of, 65.

Sally Walker, race won by, 38 .

Salt, use of in veterinary practice, 415 ; valuc of, mingled in the food of animals, 377 .

Sandal, Mr. Percivall's, 343.

Sandcrack, the situation of, 278 ; the nature and treatment of, 311 ; most dangerous when procccding from tread, 312 ; liable to return, unless the brittleness of the hoof is remedied, 313 ; constitutes unsoundness, 394.

Sarah Bladen, race won by, 38.

Sarah Washington, race won by, 38.

Sartorius muscle, dcscription of the, 281.

Savin, dangerous, 226.

Seapula, description of the, 255 .

Sclerotica, description of the, 87.

Scouring, general treatment of, 234 .

Screwdriver, pcrformances of, 57 ; height of, 65.

Secale cornutum, the effect of, 415 .

Sedatives, a list of them, and their mode of action, 415.

Serratus major muscle, description of the, $168,255,259$.

Sessamoid bones, admirable use of in obviating concussion, 273 ; fracture of, 331 .

Setons, mode of introducing, 349 ; cascs in which they are indicated, $i b . ;$ comparison between them and rowels and blistcrs, 350 .

Shakspeare, performance of, 57 ; height of, 65.

Shank-bono, thc, 267.

Shark, his performances, 30,36 .

Shoe, the concave-seaicd, cut of, 338 ; described and recommended, 337 ; the manner in which the old one should be taken off, 334 ; the putting on of the shoe, 335 ; it sloould be fitted to the foot, and not the foot to the shoe, $i b$.; description of the hinder, 337 ; the unilateral, or one side nailed slioe, 339 ; the bar shoc, 340 ; the tip, 341 ; the hunting, 340 ; the jointed, or expansion, 341 .

Shoeing, not necessarily productive of contraction, 307 ; preparation of the foot for, 333 ; the principles of, 334.

Shoulder, anatomical description of the, 255; slanting direction of the, advantageous, 256,257 ; when it should be oblique, and when upright, 258; sprain of the, 255 ; lameness, method of ascertaining, $i b$.; fracture of the, 328 . united to the chest by muscle alone, $i b$.; lower bone of the, description of, 260 ; mus. cles of the, 262, 263.

Shying, the probable cause of, 91,363 ; treatment of, 364 ; on coming out of the stable, deseription of, $i b$.

Side-line, description of the, 344 .

Siglit, the acute sense of, in the horse, 80 .

Silver, the nitrate of, an excellent caustic, 402.

Singeing, recommendation of, 383 .

Sinuses in the foot, necessity of following them as far as they reach, 319 ; frontal, of the head, 72.

Sir Archy, indebted for his fame to American Turf Register, 25 ; regarded as the Godolphin Arabian of America, $i b$.

Sir Lovel, race won by, 37.

Sir Pcter, match won by, 57 ; heiglit of, 65 .

Sir William, race won by, 37 .

Sitfasts, treatment of, 174 .

Skeleton of the horse, description of the, 68 , 69.

Skin, anatomical deseription of the, 381 function and uses of it, 381,382 ; pores of it, 385 ; when the animal is in health, is soft and elastic, 382 .

Skull, anatomical description of the, 70 ; arcls. ed form of the roof, 77 ; fracture of the, 93 , 323.

Slipping the collar, remedy for, 365,366 .

Smell, the sense and seat of, 124 ; very acute in the horse, $i b$.

Snewing, Mr., his advocacy of clipping, 383.

Soap, its use in veterinary practice, 416 .

Soda, chloride of, its use in ulcers, 415 ; sulphate of, $i b$.

Sole, the horny, description of, 298; descent of, $i b$.; proper form of, $i b$.; management of, in shocing, $i b$.; the sensible, 299 ; felt or leather, their use, 341.

Sore-throat, symptoms and treatment of, 193.

Sorrow, (imp.), race won by, 37 .

Soundness, consists in their being no disease or alteration of structure that does or is likcly to impair the usefulness of the horse, 390,391 ; considered with reference to the principal causes of unsoundness, 391 .

Spasmodic colic, nature and treatment of, 232.

Spavin, blood, the nature and treatment of, 188; is unsoundness, 394 ; bog, cause, nature and treatment of, $188,189,287$; bone, 288 ; why not always accompanied by lameness, 289 ; is unsoundness, 394 .

Spavined horses, the kind of work they are capable of, 289.

Speedy-cut, account of, 269.

Sphenoid bone, description of the, 77.

Spinalis dorsi muscle, description of the, 173.

Spine, description of the, 167 ; fracture of, 326.

Spirit of the Times, remarks of, 30 .

Splcen, description of the, 231, 243 .

Splenius muscle, description of the, 158. 
Splint, nature and treatment of, 268,278 ; when constituting unsoundness, 395 ; bones, description of the, 268.

Sprain of the back sinews, trcatment of, 269, 278 ; sometimes requires firing, 271 ; any remaining thickening constitutes unsoundness, 395 ; sprain of the shoulder, 255.

Stables, dark, an occasional cause of inflammation of the eyc, 119; hot and foul, a frequent one of inflammation of the eye, ib.; ditto, lungs, 367 ; ditto, glanders, 133 , 134; should be large, compared with the number of horses, 367 ; the management of, too much neglected by the owner of the horse, $i b$; the ceiling of, should be plastered, if there is a loft above, $i b$.; should be so contrived that the urine will run off, 369 ; the stalls should not have too much decli. vity, $i b$.; should be sufficiently light, yet without any glaring colour, 369,370 .

Staggers, stumach, symptoms, cause, and treatment of, $95,96,379$; generally fatal, 96 ; producing blindness, 98; sometimes epidemic, $i b . ; \mathrm{mad}$, symptoms and treat. ment, $i b$.

Staling, profuse, cause and treatment of, 245.

Stallion, description of the proper, for breed. ing, 248; size and form of, prescribed by Henry VIII., 22 ; contests between, 26.

Starch, useful in supcrpurgation, 416.

Stargazer, the, 159.

Sternum, or breast-bone, description of the, $168,260$.

Stifle, description of the, 283 ; accidents and diseases of the, 285.

Stomach, description of the, 221, 222 ; very small in the horse, 222 ; inflammation of the, 223 ; pump recommended in apoplexy, 97.

Stone in the bladder, symptoms and treatment of, 246 ; kidney, $i b$.

Stoppings, the best composition of, and their great use, 416.

Stranger, perfornıance of, 38.

Strangles, symptoms and treatment of, 154 ; distinguished from glanders, 131 ; the im. portance of blistering early in, 155 .

Strangury, produced by blistering, 347 ; treatment of, $i b$.

Strawberry horse, account of the, 386 .

Stringhalt, nature of, 107 ; is decidedly unsoundness, 109, 395 .

Structure of the horse, importance of a knowledge of, 69 .

Strychnia, account of, 416 .

Stud-book, English, reliance to be placed on, 23.

Stureshly, race won by, 37 .

Stylo-maxillaris muscle, description of the, 125.

Sublingual gland, description of the, 154 .

Submaxillary glands, description of the, 153 ; artery, description of the, 126.

Sub-scapulo hyoidcus muscle, description of the, 125.

Sugar of lead, use of, 412.
Sullivan, the Irish whispercr, anecdotes of his powcr over the horse, 354 ; the younger, did not inherit the power of his father, anecdotc of this, 355 .

Sulphate of coppcr, use of in veterinary practice, 406; iron, 409 ; magnesia, 412; zinc, 417.

Sulphur, an excellent altcrativc and ingredient in all applications for mange, 416.

Surfeit, dcscription and treatment of, 387 ; im. portancc of bleeding in, 388 .

Suspcnsory ligament, beautiful mechanism of the, 275 ; rupture of the, 276 ; suspensory muscle of the eye, description of the, 92.

Swallowing without grinding, 360 .

Swelled legs, cause and treatment of, 291 ; most frcquently conncctcd with debility, 292.

Sweetbread, description of the, 231.

Sympathetic nerves, description of the, 80 .

TA1L, anatomy of the, 167 ; fracture of the, 328 ; docking, 350 ; nicking, 351 .

Tar, its use in veterinary practice, 416.

Tares, a nutritive and healthy food, 377 .

Tartar, cream of, 413 .

Tayloe, B. O., his views of the American turf, $23,24,32$.

Tears, the secretion and nature of the, 84 ; how conveyed to the nose, $i b$.; sometimes shed by the horse from pain and grief, $i b$.

Teeth, description of the, as connected with age, 144 ; at birth, $i b . ; 2$ months, $i b . ; 12$ months, 145 ; 18 months, 146; the front sometimes pushed out, that the next pair may sooner appear, and thc horsc seem to be older than he is, $147 ; 3$ years, $146 ; 3 \frac{1}{2}$ years, $147 ; 4$ years, $i b$. ; $4 \frac{1}{2}$ years, 148 ; 5 years, $i b . ; 6$ years, $i b . ; 7$ years, 149 ; 8 years, $i b$; change of the, 146 ; enamel of the, 145; irregular, inconvenience and danger of, 151 ; mark of the, 145 ; frauds practised with regard to the, 147 ; diseases of the, 151.

Temper denoted by the eye, 82 ; by the ear, 80.

Temperature, sudden change of, injurious in its effect, 367.

Temporal bones, description of the, 74 .

Tendons of the leg, 267.

Tetanus, symptoms, causes and treatment of, 103.

Thick wind, nature and treatment of, 212 , 214,215 ; often found in round-chested horses, 213.

Thigh and haunch bones, description of, 279 ; form of, 280 ; should be long and muscular, $i b$. ; description of the muscles of the inside of the upper bone of, $i b . ;$ do. of the outside, $i b$. ; mechanical calculation of their power, 281.

Thompson's description of the bull, 54 .

Thorough-pin, the nature and treatment of 285 ; is not unsoundness, 395.

Thrusb, nature and treatment of, 318 ; the 
conscquence, rather than the cause of con. traction, 319 ; its serious nature and consequences not sufficiently considered, $i b$; ; constitutes unsoundness, 395.

Thymus gland, the, 175 .

Thyroid cartilage of the windpipe, description of the, 163.

Tibis, account of thc, 283,285 ; fracture of, 329.

Tied in below the knee, nature and disadvantagc of, 269.

Timoleon, race won by, 36 .

Tinctures, account of the best, 417 .

Tips, description and use of, 341 .

Tobacco, when used, 417.

Toe, bleeding at the, described, 190.

Toin Thumb, his performances, $58,59$.

Tongue, anatomy of the, 152 ; diseases of, $i b . ;$ bladders along the under part of, 153 .

Tonics, an account of the best, 417 ; their use and danger in veterinary practice, $i b$.

Topgallant, performance of, 57,58 ; height of, 65 .

Top Sawyer, performance of, 58 .

Torsion, the mode of castration by, 254 ; forccps, description of, $i b$.

Trachea, or windpipe, description of, 164 ; inflammation of, 194 .

Tracheotomy, 165 ; operation of, $i b$.

Trapezius muscle, description of the, 258.

Trapezium bone, description of the, 265 .

Tread, nature and treatment of, 312 ; often producing sanderack or quittor, $i b$.

Treasurer, races won by, 37,38 .

Trenton, race won by, 37.

Tripping, an annoying and inveterate habit, 366.

Trochanter of the thigh, description of the, 280.

Trochlearis muscle, the, 93.

Trotter, American, 49.

Trotters, American, 49 ; superiority over English, 49, 51 ; speed of, 50,51 ; speed of American attributed to management rather than to breed, 51 ; should not be put in training too young, 52 .

Trotting, American horses excel English, 49; grcat number of clubs in America, 50 ; extraordinary match, 60; height of horses, $64,65$.

Trotting on the Beacon coursc, 63 ; tables, 57 ; horses should do nothing but trot, 54 .

Turbinated bones, description of the, 124 .

Turner, Mr. T., on clipping, 383.

Turnips, considered as an article of food, 379.

Turpentine, the bcst diuretic, 243 ; a useful ingrcdient in many ointments, 417.

Tushes, description of the, 198, 199.

Twitch, description of the, 345 .

Ulcers in the mouth, treatment of, $151,152$.

Ulna, description of the, 261.

Unguiculata, a tribe of animals, 67

Ungulata, a tribe of animals, 68.

Unilateral shoe, 339.

Unsoundness, contraction does not always cause it, 307 ; being discovered, the animal should be tendered, 397 ; ditto, but the tender or return not legally necessar $y, i b$.; the horse may be returned and action brouglit for depreciation in value, but this not ad. visable, $i b$.; medical neans may be adopted to cure the horse, they are, however, better declined, lest in an unfortunate issue of the case they should be misrcpresented, 396 .

Unsteadiness whilst mounting, remedy for, 359.

Urine, albuminous, 245 ; bloody, $i b$.

VAstus muscle, description of the, 280.

Veins, description of the, 188 ; of the arm, description, \&c., 285 ; of the neck, ditto, 161 ; of the face, ditto, 125 ; of the shoulder, ditto, 252; inflammation of the, treatment of, 161.

Velocity, race won by, 37.

Vena portarum, the, 231.

Verdigris, an uncertain medicine, when given internally, 406 ; a mild caustic, $i b$.

Vermin, account of, 390 .

Vcrtebræ, the dorsal and lumbar, 167.

Vertebrated animals, what, 67.

Vices of horses, account of the, 353.

Vicious to clean, a bad habit that should be conquered, 359 ; to shoe, a bad habit that may also be conquered, 360 .

Vinegar, its use in veterinary practice, 398.

Vines, Mr., his use of the Spanish fly in glanders, 404.

Viper, account of the bite of, 225 .

Vision, theory of, 88.

Vitreous humour of the eye, account of the, 91.

Vitriol, blue, usc of, in veterinary practice, 406.

Volcano, performance of, 58 .

W AGNER, races won by, 39.

Wall-eyed horses, what, 89 ; whether they become blind, $i b$.

Warbles, treatment of, 174.

Warranty, the form of a, 395 ; breach of, how established, $i b$.; no price will imply it, 396 ; when there is none, the action must be brought on the ground of fraud, $i b$.

Warts, method of getting rid of, 390 .

Washington, match won by, 57 ; height of, 65.

Washing of the heels, productive of grease, 295.

Washy horses, description and treatment of, 236.

Wasps, treatment of the sting of, 225.

Water-dropw ort, poisonous, 226; hemlock, poisonous, $i b$.; parsley, poisonous, $i b$.

Water, generally given too sparingly, 379 ; management of on a journey, 380 ; the difference in effect, between hard and soft, 379 ; spring, principally injurious on account of its coldness, $i b$.; stomach of the horse, the, 230.

Water farcy, nature and treatment of, 138. 
Wax used in charges and plasters, 417.

Weakness of the foot, what, 321 .

Weaving indicating an irritable temper, and no cure for it, 366 .

Whalebone, performance of, 57,59 ; height of, 65 .

Wheat, considered as food for the horse, 375, 379 ; inconvenience and danger of it, 375 .

Wheezer, description of the, 215 ; is unsound, 392.

Whisperer, the anecdotes of his power over the horse, 354.

Whistler, description of the, 215 ; is unsound, 392.

White lead, use of, 411 ; vitriol, its use in veterinary practice, 417.

Wind, broken, nature and treatment of, 213 ; galls, description and treatment of, 271, 278 ; ditto, unsoundness when they cause lameness, or are likely to do so, 395 ; thick, nature and treatment of, 212 .

Windpipe, description of the, 164 ; should be prominent and loose, 165.

Wind-sucking, nature of, and remcdy for, 362.

Withers, description of thc, 158, 173; high, advantage of, $i b$. ; fistulous, treatment of, 174.

Worms, different kinds, and treatment of, 239.

Wounds in the feet, treatment of, 315 .

YaNkeE Sal, performance of, 58.

Yellows, symptoms and treatment of the, 242. Yew, the leaves of, poisonous, 226.

ZiNc, its use in medicine, 417.

Zoological classification of the horse, 67.

Zygomatic arch, reason of the strong con. struction of the, 75 .

Zygomaticus muscle, description of the, 125. 
To be completed in 24 PARTS, embracing near 1900 Pages. with ELEVEN HUNDRED Engravings, and over 80 Maps.

Specimen.

T H E

ENCYCLOPADIA

of

\section{GEOGRAR I :}

COMPRISING $A$

COMPLETE DESCRIPTION OF THE EARTH, PHYSICAL, STATISTICAL, CIVIL, AND POLITICAL; EXHIBITING ITS RELATION TO THE HEAVENLY BODIES,

ITS PHYSICAL STRUCTURE,

THE NATURAL HISTORY OF EACH COUNTRY, AND THE INDUSTRY, COMMERCE, POLITICAL INSTITUTIONS,

AND CIVIL AND SOCIAL S'TATE

or

ALL NATIONS.

BY HUGH MURRAY, F.R.S.E.

ASSISTED IN

ASTRONOMY, \&c. BY PROF. WALLACE, BOTANY, \&c. BY PROFESSOR HOOKER, GEOLOGY, \&c. BY PROF. JAMESON, ZOOLOGY, \&c. BY W. SWAINSON, ESQ

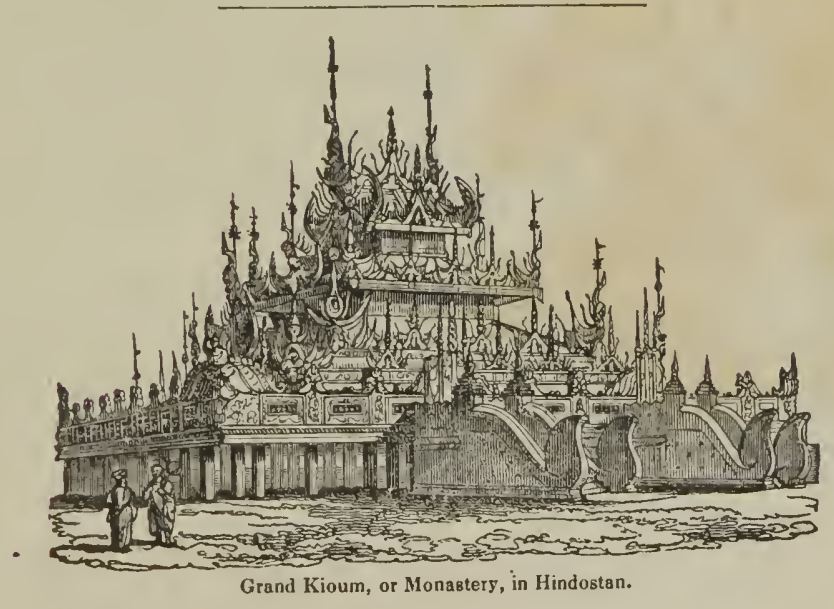

REVISED, WITH ADDITIONS, BY THOMAS G. BRADFORD.

THE WHOLE BROUGHT UP TO THE PRESENT TIME.

PHILA DELPHIA:

L E A ND BLA NCHARD,

SOLD BY ALL BOOKSELLERS AND NEWS AGENTS IN THE UNITED S'TATES.

A part to be issued every Two Weeks, and form, when complete, Three large Volumes, for Six Dollars. 
THE value and importance of the study of Geography are so obvious, and indecd so universally acknowledged, as to require little illustration. Nothing can be more interesting to man, or more gratify his thirst for knowledge, than a survey of the earth which he inhabits, peopled as it is by bcings of the samc nature with himself. 'To visit and observe foreign climes and regions is an object of general desire, and forms one of the most effectual means of enlarging and enlightening the human mind. This wish, however, unless in the case of a few individuals, can be gratified only to a very limited extent, and in none can embrace more than a small portion of the vast variety of intercsting objects which the earth comprises. This necessary defect of personal observation may, howcver, le in a great measure supplied, by collecting the reports and narratives of those intelligent individuals who have explored and described its various regions, and forming out of these a general description of the world and its inhabitants.

During the last half century the most civilized nations of Europe have been contending with each other for the glory of discovery; and thcre is now scarcely a shore, however remote, or the intcrior of a continent, however barbarous or difficult of access, which has not been explored and described. Materials have thus been provided for a more complete, interesting, and authentic description of the carth than could have been drawn up at any former period.

Deeply impressed with a sense of the great extent and difficult execution of a coinplete Geographi. cal work, the Editor, during nearly ten ycars in which he has been engaged upon it, lias uscd the utmost exertion to procure from every quarter information and aid. He has studiously collected the most recent, authentic, and accurate accounts of the extent, natural features, population, productions, industry, political constitution, literature, religion, and social state of the various regions of the globe, with the leading details as to their districts and cities. The sciences connected with the natural history of the earth have, however, attained to such an extent and importance, that a thorough knowledge of them can only be possessed by individuals who have especially devoted themselves to one particular branch. The Editor, therefore, considered it essential to procure the co-operation of writcrs who had risen to acknowledged eminence in the departments of Geology and Mineralogy, Zoology and Botany. He considered that he had fully succeeded, when Professor Jameson undertook to delineate the geological structure of the globe, and the distribution of minerals over its surfacc; Mr. Sivainson to explain the distribution of animals, and the most remarkable of those found in each particular region; and Dr. Hooker to perform the same task in regard to the vegetable kingdom. Professor Wallace has illustrated the relations of the earth as a planet, the trigonometrical surveys, the construction of maps, and other subjects connected with mathematical science. These tasks havc been executed in a manner which, it is hoped, will fully support the high reputation of their respective authors. Various parts relating to remote countries have been revised by gentlemen recently returned from them.

The Maps, which are so numerous as to form a complete Atlas, have been executed from drawings by $\mathrm{Hall}$; and having been carefully revised by the Editor, they will, it is hoped, be found to be accurate, and to include all the most recent discoveries. Notwithstanding the smallness of the scale, they are illustrated by the letter-press in a manner which enables them to comprise equal information with others of much larger dimensions.

The other Wood Engravings are mostly original, or have been carefully sclected from the most faithful representations of the objects described ; and they are executed in the best style by the eminent artists whose names appear on the title-page. They exhibit the most remarkable plants and animals, the chief citics, public buildings, natural curiosities, and picturesque scenery, with the characteristic figures and costumes of the natives, in the countries described. It is not believed that any work of this kind is similarly embellished, at least to nearly the same extent. 'These representations are by no means introduced for the sake of mere ornament ; they will be found of the greatest utility, conveying an infinitely better idea of the objects than could be dcrived from the most laboured description.

\section{AMERICAN EDITION.}

The American edition of the Excrclopjera of Geograpux has been carcfully revised and corrected throughout, and brought down to the period of its publication by such modifications of tlie original text as the naturc of the changes to be made seemed to require. Thus new and more recent statements of the commercial, financial, political, and other relations of countries have bcen oftcn substituted for those given in the English edition of the work; and the results of late discoveries have been interwoven with the original matter, or have served to rectify soine antiquated error, the gradual removing of which from our manuals forms at present an important part of the task of the geographical compiler. The portion of the work relating to the Unitcd States has been written anew, and fills over two hundred pages; a new and larger map of this country has also been given, and wood

cuts have been added to the chapter devoted to its description. 


\section{CON'IENTS OF VOL. II.}

BOOK I.-EUROPE.

\section{CHAP. XI.}

................Page

I. General Outline and Aspect............... 5

II. Natural Geography $\ldots \ldots \ldots \ldots \ldots \ldots \ldots \ldots \ldots \ldots$.

III. Ilistorical Gcography................... I9

IV. Political Geography $\ldots \ldots \ldots \ldots \ldots \ldots \ldots \ldots .21$

V. Productive Industry $\ldots \ldots \ldots \ldots \ldots \ldots \ldots \ldots, \ldots \ldots \ldots, 21$

Vi. Civil and Social State $\ldots \ldots \ldots \ldots \ldots \ldots \ldots \ldots .24$

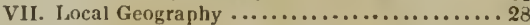

1. Ecclcsiastical States ....................29

2. San Marıno ............................. 36

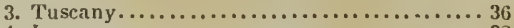

4. Lncca ................................. 38

5. Parına................................. 38

6. Modena ............................. 38

7. Lombardo.Venetian Kingdom,............ 39

8. States of the King of Sardinia ............. 41

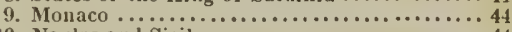

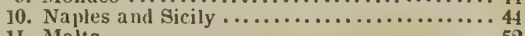

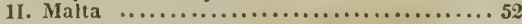

CHAP. XII.

Switzerland ..............

I. Feucral Outline and Aspect $\ldots \ldots \ldots \ldots \ldots \ldots \ldots, 52$

II. Natural Geography ..................... 56

III. I Iistorical Gcography................. 62

IV. Political Geography $\ldots \ldots \ldots \ldots \ldots \ldots \ldots \ldots, 6^{\circ}$

V. Productive Industry.....................64 64

VI. Civil and Social State $\ldots \ldots \ldots \ldots \ldots \ldots \ldots \ldots \ldots \ldots, 65$

VIi. Local Geography ...................... 65

\section{CHAP. XIII.}

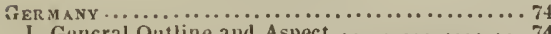

I. Gencral Outline and Aspect............... 74

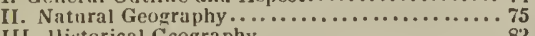

III. Ilistorical Gcography................... 8

IV. Political Geography ...................... 84

1. Germanic Body $\ldots \ldots \ldots \ldots \ldots \ldots \ldots \ldots \ldots, 84$

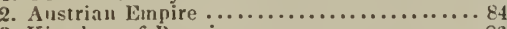

3. Kingdon of Prussia ................... 86

4. Sinaller States ....

V. Productive Industry....

VI. Civil and Social State ................... 93

VII. Incal Gengraphy ..................... 95

I. Austrian Dominions . . . . . . . . . . . . . . . 96

2. Prussian Dominions .................. I03

3. Sunaller Statcs ........................ 108

1. Bavaria........................... I08

2. Virtemberg ......................... 110

3. Baden ............................... III

4. Saxony............................ II

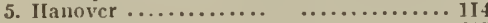

6. Electoral Ilesse........ $\ldots \ldots \ldots \ldots \ldots 115$

7. Grand Duchy of IIesse... - .............. 115

8. Sinaller States.................... I16

\section{CHAP. XIV.}

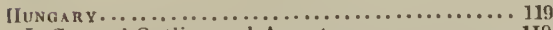
I. General Outline and Aspect ............... 1I9 II. Natural Geography $\ldots \ldots \ldots \ldots \ldots \ldots \ldots \ldots \ldots \ldots \ldots \ldots$

III. Hlistorical Gcography.................. I22

IV. Political Geography ................... 122

V. Productive Industry ....................... 123

Vi Civil and Social State $\ldots \ldots \ldots \ldots \ldots \ldots \ldots \ldots . . .124$

VII. Local Geography.................... 125

\section{CIIAP. XV.}

Poland, with Ducal Prussia................. 129

I. Fencral Outline and Aspect............... 129

Ii. Natural Geograpliy.................... 130

III. IIistorical Geography................. 130

IV. Political Geography $\ldots \ldots \ldots \ldots \ldots \ldots \ldots, 133$

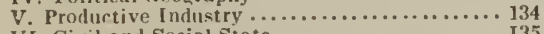

VI. Civil and Social Statc $\ldots \ldots \ldots \ldots \ldots \ldots \ldots$ I 35

VII. Local Gcography ................... 136

I. Prussiau Poland, witlı Ducal Prussia...... 136

2. Austrian Poland....................... I38

3. Kingdom of Poland .................... 140

4. Cracow............................ 14I

5. Russian Provinces ................... 142
CHAP. XVI.

Russia in EuRoPE ..................... 143

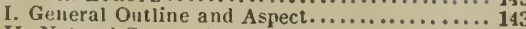

II. Natural Geography ................... 146

III. Historical Geogra phy ................ 150

IV. Political Geograply .................... 157

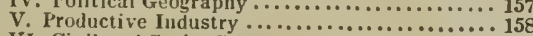

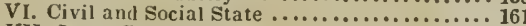

VII. Local Geography .................... 164

CHAP. XVII.

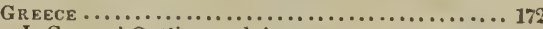

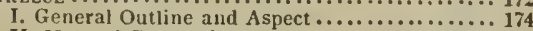

II. Natural Geography .................. 175

III. IIistorical Geography ................. 175

IV. Political Geograpliy .................... 176

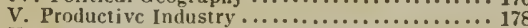

Vi. Civil aul Social State $\ldots \ldots \ldots \ldots \ldots \ldots \ldots \ldots \ldots$

VII. Local Geography ....................... 180

VIII. Ionian Republic..................... 19I

\section{CHAP. XVIII.}

TuRREy th EuRope...................... 192

I. General Outline and Aspect................. 194

II. Natural Geography..................... 194

III. Historical Geograpliy .................. 201

IV. Political Geography ................. 209

V. Productive Industry ....................... 205

VI. Civil and Social State ......................... 206

VII. Local Geography ....................... 208

Tabelar View of El:Rotean States.......... 213

\section{BOOK II.-ASIA.}

CHAP. I.

Gener al View of Asta .................... 2I6

I. General Otıtline and Aspect ............. 216

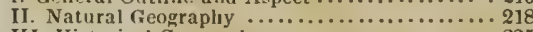

II I. Historical Geography ................ 225

IV. Political Gcography ................... 227

V. Productive Indwstry .................. 228

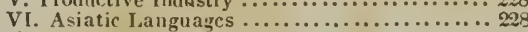

VII. Local Geography ................... 233

\section{CIIAP. II.}

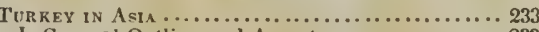

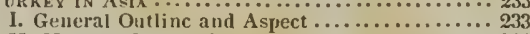

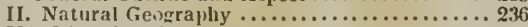

III. Historical Gcography.................. 244

IV. Political Gcography $\ldots \ldots \ldots \ldots \ldots \ldots \ldots \ldots \ldots .245$

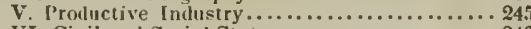

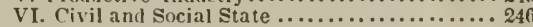

VII. Local Geography ....................... 249

1. Palestinc.........................................249

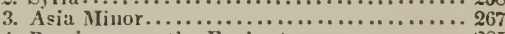

4. Provinecs on the Euphrates.............. 281

CIIAP. III.

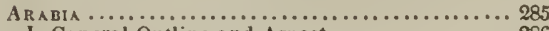

I. General Outlinc and Aspect................... 286

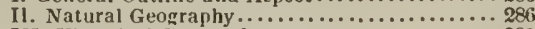

III. Historical Geography $\ldots \ldots \ldots \ldots \ldots \ldots \ldots \ldots .289$

IV. Political Geography $\ldots \ldots \ldots \ldots \ldots \ldots \ldots \ldots \ldots 290$

V. Productive Industry .................... . 291

VI. Civil and Social State. .................. 292

VII. Local Geograplıy .................. 294

CHAP. IV.

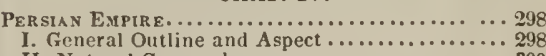

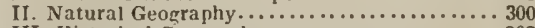

III. Historical Geography ................... 302

IV. Political Geography ................... 303

V. Productive Industry ..... ............... 304

VI. Civil and Social State ............... 306

VII. Local Geography.................. 300 
CHAP. V.

Independent Persia ..................... Page 3II

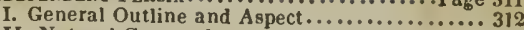

II. Natural Geography $\ldots \ldots \ldots \ldots \ldots \ldots \ldots \ldots \ldots \ldots . \ldots \ldots$

III. Historical Geography ..................... 315

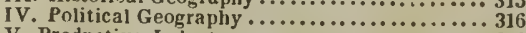

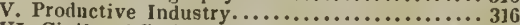

VI. Civil and Social State $\ldots \ldots \ldots \ldots \ldots \ldots \ldots \ldots \ldots . \ldots \ldots \ldots \ldots \ldots \ldots$

ViI. Local Geography .................... 319

CHAP. VI.

Hindostan.

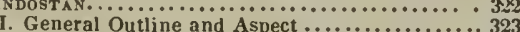

II. Natural Geography ................... 328

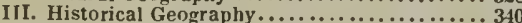

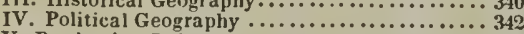

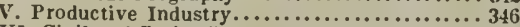

VI. Civil and Social State ................... 349

VII. Local Geography ...................... 355

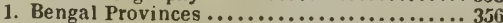

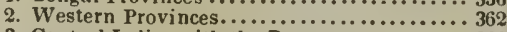

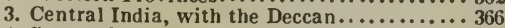

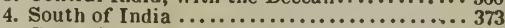

5. Countries on the Himmaleh............ 380

b. Ceylon .......................... 386

\section{CHAP. VII.}

Further India......................... 388

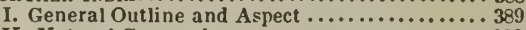

II. Natural Geography . .................... 389

III. Historical Geography ................. 390

IV. Political Geography .......................... 391

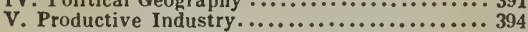

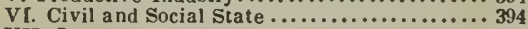

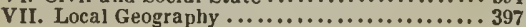

\section{CHAP. VIII.}

Chrna ......................................... 401

Aspect............... 402

II. Natural Geography................... 402

III. Historical Geography............... 403

IV. Political Geography ................... 409

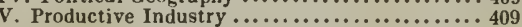

VI. Civil and Social State ............... 412

VII. Local Geography .................. 420

\section{CHAP. IX.}

THIBeT.

I. General Outline and Aspect $\ldots \ldots \ldots \ldots$

II. Natural Geogra phy ................. 426

III. Historical and Political Geography......... 429

IV. Productive Industry $\ldots \ldots \ldots \ldots \ldots \ldots \ldots \ldots \ldots .430$

V. Civil and Social State ................430

VI. Local Geography.................... 432

\section{CHAP. X.}

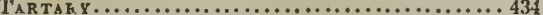

I. General Outline and Aspect............. 434

II. Natural Geography $\ldots \ldots \ldots \ldots \ldots \ldots \ldots \ldots \ldots \ldots 435$

III. Historical Geography ............... 436

IV. Political Geography $\ldots \ldots \ldots \ldots \ldots \ldots \ldots \ldots \ldots 437$

V. Productive Industry . .................. 438

VI. Civil and Social State ................ 439

VII. Loral Geography . . . . . . . . . . . . . 44I

1. Mandshuria....................... 44I

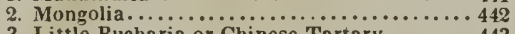

3. Little Bucharia or Chinese Tartary ...... 443

4. Turkistan ........................ 444

CHAP. XI.

Rtusgia on the Caspian .................. 447

I. General Outline and Aspect............ 448

II. Natural Geography ................... 450

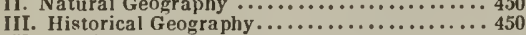

IV. Political Geography ................. 45

V. Productive Industry .................. 451

VI. Civil and Social State ............... 45

VII. Local Geography . ................. 452
CHAP. XII.

SIBERIA .......................... 457

1. General Outline and Aspect............ 457

II. Natural Geography .................. 460

III. Historical Geography.................. 468

IV. Political Geography ............... 470

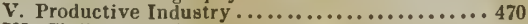

VI. Civil and Social State .............. 473

VII. Local Geography ................... 475

CHAP. XIII.

$\mathrm{J}_{\triangle \mathrm{PAN}} \ldots \ldots \ldots \ldots \ldots \ldots \ldots \ldots \ldots \ldots \ldots \ldots \ldots \ldots \ldots \ldots, \ldots \ldots 1$

I. General Outline and Aspect............... 48

II. Natural Geography................... 483

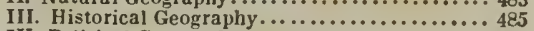

IV. Political Geography .................... 486

V. Productive Industry ................. . 487

VI. Civil and Social State ................ 489

VII. Local Geography . ................... 491

CHAP. XIV.

East Indian Archipelago............... 499

I. General Outline and Aspect $\ldots \ldots \ldots \ldots \ldots \ldots . . \ldots 99$

II. Natural Geography $\ldots \ldots \ldots \ldots \ldots \ldots \ldots \ldots \ldots \ldots .491$

III. Historical Geography ................. 509

IV. Political Geography ................ 510

V. Productive Industry ................... 511

VI. Civil and Docial State $\ldots \ldots \ldots \ldots \ldots \ldots \ldots \ldots$ 5I4

VII. Local Geography .................... 518

\section{BOOK III.-AFRICA}

CHAP. I.

General View or Atrica................. 526

I. General Outline and Aspect ............. 526

II. Natural Geography $\ldots \ldots \ldots \ldots \ldots \ldots \ldots \ldots \ldots .527$

III. Historical Geography .............. 532

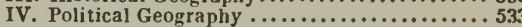

V. Productive Industry ................ 533

VI. The African Languages .............. 534

CHA P. II.

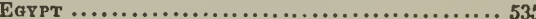

I. General Outline and Aspect .............. 535

II. Natural Geography $\ldots \ldots \ldots \ldots \ldots \ldots \ldots \ldots \ldots \ldots 57$

III. Historical Geography ................ 546

IV. Political Geography .............. 547

V. Productive Industry.................. 548

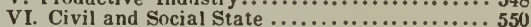

VII. Local Geography ..................... 553

1. The Delta, or lower Egypt.............. 553

2. Vostani, or Middle Egypt .............. 557

3. Said, Thebaid, or Upper Egypt ........... 561

\section{CHAP. III.}

NoBtA. .......................... 579

I. General Outline and Aspect ............... 579

II. Natural Geography................ 579

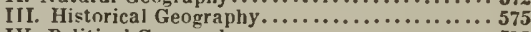

IV. Political Geography ................. 575

V. Productive Industry ..................... 575

VI. Civil and Social State. ............. 57

VII. Local Geography ................... 576

CHAP. IV.

ABYssinia ........................ 581

I. General Outline and Aspect .............. 581

II. Natural Geography.................. 58

III. Historical Geography $\ldots \ldots \ldots \ldots \ldots \ldots \ldots \ldots \ldots \ldots . \ldots \ldots \ldots$

IV. Political Geography . . . . . . . . . . . . . . 586

V. Productive Industry ......................

VI. Civil and Social State ................ 587

VII. Local Gengraphy.................... 589 
than flowing. At the new and full moon the tides attain the greatest height, and the interval between two high waters is least, viz. $12^{\mathrm{h}} 19^{\mathrm{m}} 28^{\circ}$. At the quarters of the moon the tides are the least, and the intervals the greatest, viz. $12^{\mathrm{h}} 30^{\mathrm{m}} \mathrm{F}^{*}$. The time of high water is mostly regulated by the moon; and in general, in the open sea, is from two to three hours after that planet passes the meridian, either above or under the horizow. On the shores of large continents, and where there are shallows and obstructions, great irregularities take place in this respect; and when these exceed six hours, it may seem as if the high water preceded the moon's passage over the meridian. Though the tides seem to be regulated chiefly by the moon, they appear also in a certain degree to be under the influence of the sun. Thus, at the syzigies, when the sun and moon come to the meridian together, the tides, every thing else considered, are the highest. At the quarters, when the sun and moon are $90^{\circ}$ distant, the tides are least. 'The former are called the spring, the latter the neap tides. The highest of the spring tides is not that immediately after the new or full moon; but is in general the third, and in some cases the fourth. The lowest of the neap tides occurs much about the same time after the quarters. The total magnitude of the tide is estimated by the difference between the heights of high and low water. The higher the flood tide rises, the lower the ebb tide gcnerally sinks on the same day. At Brest, the medium spring tide is about 19 feet, and the mean neap tide about 9 . On other parts of the coast of France opposite to England, the waters, being confined, rise to a great height, and do so on both sides of the Channel. At St. Malo it is from 45 to 50 feet. Nearly as high tides occur at Annapolis Royal, in Nova Scotia. It is the obstruction which the land presents to the motions of the waters which occasions tides of any consequence at all: were the globe entirely covered with water, the tides would be very insignificant. Thus, in the Pacific Ocean, the spring tide amounts only to 5 feet, and the neap to from 2 to 2.5 feet. On the other hand, a free communication with the ocean is indispensable, to produce a high tide. Thus, in inland seas, the tides are very trifling, because the luminaries act nearly equally over the whole surface at the same time.

The height of the tide increases as the sun or moon is nearer the earth, but in a higher ratio. The rise of the tides is likewise greater when the sun or rnoon is in the equator, and less as they decline from it. When the observer and the moon are on the same side of the equator, the tide which happens when the moon is above the horizon is greater than whell she is below it. The reverse occurs when the observer and the moon are on opposite sides of the equator. If the tides be considered relatively to the whole globe and to the open sea, it appears that there is a meridian about $30^{\circ}$ eastward of the moon, where it is always high water, both in the hemisphere where the moon is and in the opposite. On the west side of this circle the tide is flowing; on the east it is ebbing; and on the meridian, which is at right angles to the same, it is everywhere low water. These meridian circles move westward, keeping nearly at the same distance from the moon: only approaching nearer to her when new or full, and withdrawing at the quarters. In high latitudes the tides are very inconsiderable. It is probable that at the poles there are no diurnal tides; but there is some ground for thinking that the water will rise higher at the pole to which the luminaries are at any time nearest, than at the opposite.

The rmont wave which follows the moor as above described, and constitutes the tide, is to be considered as an undulation or reciprocation of the waters of the ocean; in which there is, except when it passes over shallows or approaches the shore, very little progressive motion. In all this we are as yet overlooking the operntion of local causes, winds, currents, \&c., by which these general laws are modified, overruled, or even reversed. Most people find little difficulty in conceiving how the waters should rise on the side of the globe which is next the moon; but there can scarcely be a harder task than bringing many to see why the waters should at the same time rise on the side which is turned from the moon. We must, however, confine ourselves to a very brief and palpable explanation. The force by which the moon draw's any particle of our globe towards her is greater when it is nearer to her, and less when more remote. The force, therefore, with which the moon attracts the particles on the side nearest her is greater than the average force which slie exerts on the whole globe. These particles, therefore, rise or endeavour to come near the moon. On the other hand, the force by which the moon draws the particles which are farthest from her being less than the average force, these particles endeavour to recede from the moon, and in so doing they also recede from the earth's centre; that is, they rise higher than the gerieral level. The action of the sun is similar to that of the moon; but his being almost four hundred times as distant, greatly diminishes his effect. At the new and full moon the luminaries act together, and produce spring tides. The highest of all are a little after the autumnal, and before the vernal, equinox; and the least spring tides occur a little after the solstices. At the quarters of the moon her action is opposed by that of the sun, and therefore neap tides are the result.

The time of higl water deserves consideration. The preceding is sufficient to show that the phenomena of the tides are effects that might be expected from the principle of attraction or gravitation; but since the waters necessarily occupy some time in moving from one 
manders have been recently discovered, and the celebrated Siren is an inlabitant of the muddy lakes of Georgia and Carolina; this singular reptile had long perplexed naturalists, some thinking it a tadpole, or imperfect frog; it is now, however, fully ascertained to be an adult animal.

The ichthyology of this great region has been but imperfectly examined, although its seas, lakes, and rivers swarm with a great variety of delicious fish. The Cod ( $f i g .1107$.$) ,$ so well known in commerce, are found only in the northern seas. Their great rendezvous is on the banks of Newfoundland, and other sand-banks that lie off the coasts of the Northern States; these situations they prefer, by reason of the quantity of worms produced in those sandy bottoms, which tempt them to resort there for food. Some conception may be formed of their amazing fecundity, from the fact that nearly $10,000,000$ eggs have been counted in a codfish of a moderate size. The Mackarel and Alewife of our coasts also give employment and food to great numbers of persons.

1107

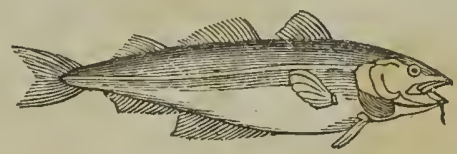

Codfish.

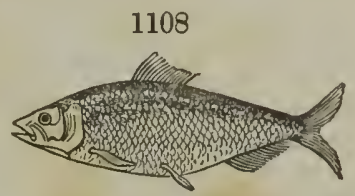

Shad.

Nearly allied to the latter is the Shad ( fig. 1108.), which is taken in nearly all our rivers in the spring, when it ascends them to spawn in the shallow waters. It is larger than the herring, weighing from five or six to ten or twelve pounds. It is taken in large quantities, and in the season is highly esteemed; but in the autumn, or when caught at sea, it is dry, and of a disagreeable flavour. The Salmon is also taken in the rivers in the spawning season, but it is confined to the colder climates.

Among the fish of the interior lakes, one of the most esteemed is the White Fish, or Tit-

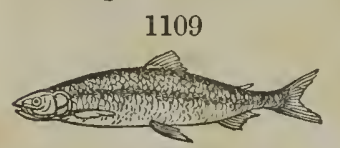

White Fish. tameg of the traders (Coregonus albus) ( $f$ ig. 1109.). It weighs from three or four to ten or twelve pounds, and seems to be found in all the lakes, from the great Canadian chain to the Arctic seas. It is a delicious article of food, and nearly 900 barrels have been taken at a single place in Lake Superior, in a season. It is taken from April to June, when it is in the best condition, and also in Cctober and November.

The rivers and lakes abound with a surprising number of Bivalve shells, exhibiting on their internal surface a lustre nearly equal to the oriental pearl counters, and other ornaments made from the pearl oyster; they do not, however, appear to have been turned to any other

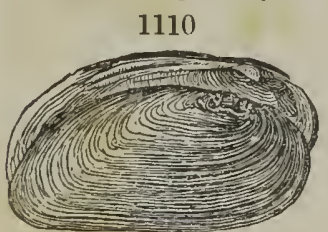

Unio complanatus. account than the making of sleeve buttons. The Unio complanatus (fig. 1110.) of Solander, is usually of a fine purple inside, and several other species have the same character. The great varieiy of form, the various shades of colour, and the exterior beauty, some being furnished with tubercles, otners with folds or rays, have caused then to be eagerly sought after by naturalists of all countries, for their cabinets. The Ohio and its tributaries are particularly rich in possessing a vast number of species, and we are greatly within bounds, when we say that more species have been described from them than from all the rivers of Europe, Asia, and Africa together. The number of different species in the rivers and lakes east of the Alleghany Mountains, bears no comparison with that from the west of them, and the dividing ridge of this great chain seems almost as completely to divide the shells as it does the waters. There are but three or four known species which are common to both waters. This may be considered a remarkable feature in the geographical distribution of animals. Some writers have hazarded the opinion, that they are all mere varieties

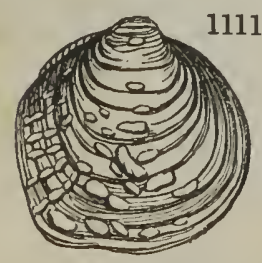

Unio Pustulosus.

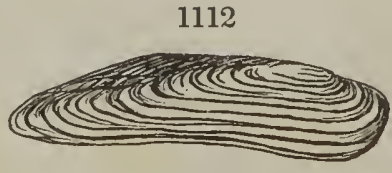

Unio Shepardianus.

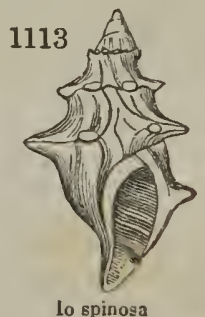

Lo spinosa

of one species. A glance at two of the figures, Unio pustulosus ( $f g r .1111$.), and Unio Sliepardianus ( $f g$. 1112.), two shells described by Mr. Lea in the American Philosophicai 

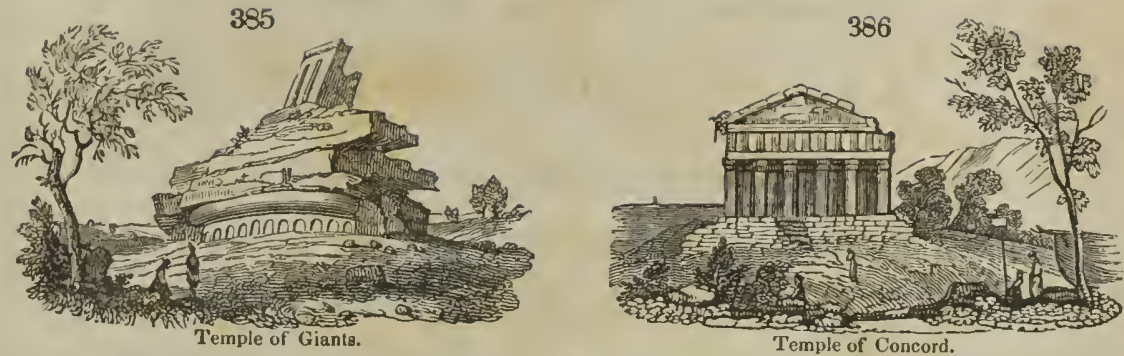

Farther to the east at Selinunti, the ruins of Selinus present a scene still more striking and

387

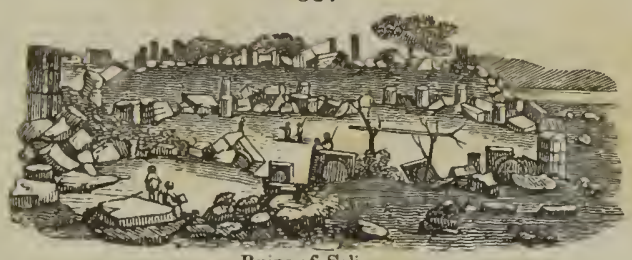

awful. Here may be distinctly traced three noble temples, of which the materials still remain, but only a few solitary columns are standing; all the rest lie on the ground, in huge and shapeless blocks, forming the most stupendous mass of ruin to be found in Europe. It is generally supposed that an earthquake has been the cause of this extraordinary destruction, - that, as Mr. Swinburne expresses himself, nature has been chiefly concerned in this triumph over the pride of art (fig. 387.).

Trapani, the ancient Drepanum, poetically distinguished as the place where Anchises

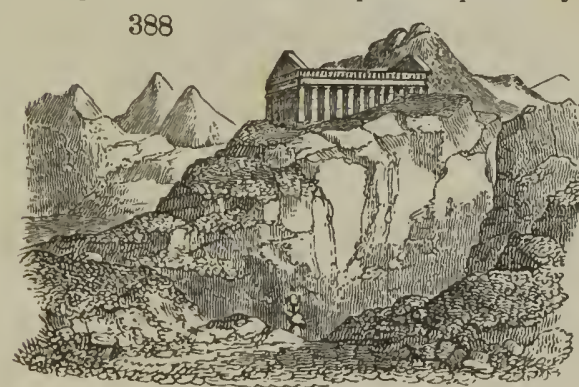

Temple of Segeate. died, and where Fneas celebrated his obsequies, is still a considcrable town, near the western promontory of Sicily, the ancient Lilybæum. It is well fortified, and has a good harbour, where there is a considerable trade in the export of salt made in its vicinity, and of barilla. It carries on briskly the fisheries of tunny and of coral, which last is obtained both from the coast of the island and that of Africa. Not far from Trapani is Segeste; a simple, grand, and almost entire edifice, standing on a solitary hill ( $f \mathrm{ig}$. 388.). Marsala, almost on the very site of Lilybrum, is a consider. able town, exporting wine that is much esteemed. Near it the quarries of Mazzara appear to have furnishcd the stone of which the edifices in this part of Sicily have been constructed.

The ascent of Etna is a general object with Sicilian travellers. In proceeding from Cata-

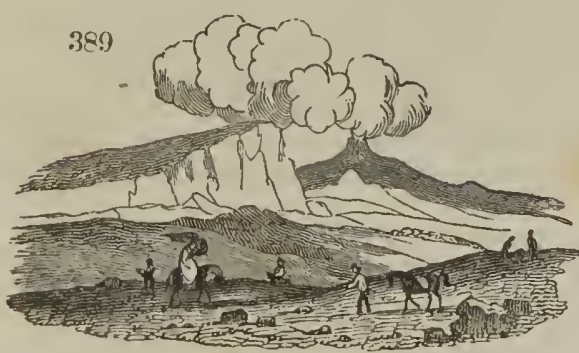

Summit of Etna. nia, they pass through three successive zones: first that of rich cultivated fields, then that of plants and aromatic shrubs; and, lastly, the region of scoriæ, ashes, and pcrpctual snow. On reaching the sumnit (fig. 389.), they view the crater filled with vast volumes of smoke, and obtain a fine panoramic view over all Sicily and the ad. joining shores of Italy.

The Lipari Islands, twelve in number and situated from twelve to thirty-five miles northward from tine Sicilian coast, arc entirely volcanic, and appear to have been thrown up from the sea by the action of firc. Lipari itself contains a hill of white pumice, which forms an article of trade, and its crater displays various specimens of beautifully crystallised sulphur. Stromboli has a volcano, remarkable for being in perpetual activity. Every day, at short intervals, the eruptions issuc forth like great discharges of artillery, and the sides of the mountain arc covered with the red-hot stoncs that are cjected, and rush dosinn into the sea. The inhabitants of these islands are a bold, active, and industrious race. The activity of submarine fires has becn manifested on another side of Sicily, by the recent rise of Graham's Island, onlv, indeed, a rolcanic rock, which has again sunk under water. 


\section{Knovledge for the People.}

LEA A N D B L A N C H A D,

P H I L D E L P H I A,

ARE NOW PUBLISHING IN PARTS,

A CHEAP EDITION OF

MURRAY'S GREAT WORK,

THE

ENCYCLOP ADIA OF GEOGRAPHY.

The whole work, embracing nearly NINETEEN HUNDRED large imperial pages, and embellished with nearly TWELVE HUNDRED SPLENDID ENGRAVINGS AND MAPS, executed in the best style on wood, will be completed in TWENTY-FOUR PARTS, at the low price of TWENTY-FIVE CENTS EACH.

The Publishers believe themselves justified in adopting the opinion of an English Journal, which says,-

"There is no work of the present day which can competc with this Encyclopædia, either in originality of design, amount of illustration, or beauty of execution. Though termed an 'Encyclopxdia of Greography,' it might, with almost as much propriety, be termed an Encyclopædia of Nature and Art ; for there is scarcely anything remarkable on the surface, or in the bowels of the earth-an animal, a plant, or a mineral-which it does not enter into its plan to describe and to illustrate. Nor are the manners, the industry, the commerce, or the political institutions of the different nations of the earth forgotten; for to each and to all as ample justice has been done as the size of the work, and the variety of subjects cmbraced, could possibly admit. Of the wood-cuts but one opinion can be entertained, and that is, that they are as truly deserving of praise for their execution as they are numerous and true to nature."

In the preparation of this book, the Publishers have expended a large sum, and now offer it at a price so low that it should command an extended circulation, as a standard work.

They append a few of the many notices of the work.

"One of the most learned, accurate, and entertaining works on Greograpby."-Gentleman's Mag.

"The most perfect book on its subject."-Atlas.

"One of the nost valuable works on Geography in our language."-Scots Times.

"By far the most complete and comprehensive of its kind at this moment in existence. Its information is singularly full and minute, and its scope generally so ample, that no subject of the smallest interest connected with the various regions of the earth is left untouched. Unquestionahly the first of its class. 'The very neat and correct wood-cuts by which the written descriptions of places and things are illustrated, greatly enhance the value of the work, by their giving, to the impressions desired to be made, on the reader, all the vividness and accuracy which it is possible to convey through any artificial medium."- Scotsman.

"Of this work we cannot speak too highly_in every point it is perfect. Though nominally an 'Encyclopædia of Geography,' it might with justice be entitled an abridged history of the world; as it contains an outline of the civil, social, and natural history of all the nations in the world. While it affords pleasure and improvement to the learned from the simplicity of the style, and the excellence of the arrangement, it beers intelligible to the most Bœotic and stunted mind." - Dublin Freeman's Journal.

"Every quality appears to be here combined in ordex to render it one of the most uscful and gratifying publications of the kriesent times."-Doncaster Gazette.

"This work may be termed a philpophical hisfonj of the kith rather than a mere gengraphical outline of the countries on the world's surfaee, as misht be imayined from it Stite. The subjerts treated of in the second num

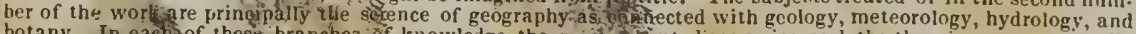
botany. In eachaf these branches $\mathrm{g}$ knowledge the mosictecent discoveries and the theories now generally adopted by men of science arê stated clearly and concisely, ärat a field of research is open every step of which affords most lutersting införmation:"--Worcester Herald.

To be had of alt Booksellers and Periodical ig gents throughout the United States and the Canadas. 
PUBLISHED BY LEA \& BLANCHARD;

\section{Murray's Encyclopadia of Geography,}

BROUG

PUBLISHED BY SUBSCRIPTION.

TH E

ENCYCLOPFDIA OF GEOGRAPHY: C O M PRISING

A COMPLETE DESCRIPTION OF THE EARTH. PUYBICAL, STATISTICAL, COMZARCIAL, AND POLITICAL; EX II ВITIN G

ITS RELATION TO THE HEAVENLY BODIES-ITS PHYSICAL STRUCTURE -TIE NATURAL IISTORY OF EACH COUNTUY;

$$
\text { A N D T II E }
$$

INDUSTRY, COMMERCE, POLITICAL INSTITUTIONS, ANN CIVIL AND SOCIAL STATE OF ALL NATIONS;

\section{BY HUGH MURRAY F.R.S.E.}

\section{$\triangle S$ SISTED IN}

ASTRONOMY, \&C. BY PROF. WALLACE, BOTANY, \&c. BY PROF. HOOKFR, GEOLOGY, \&c. BY PROF. JAMESON, \%OOLOGY, \&c. BY W. SWAINSON.

ILLUSTRATED BY EIGETY-TWO IMAPS,

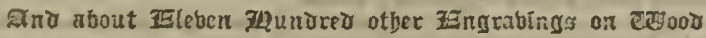

Reprcaenting the moet remarkablo objoots of Natsaro and Art in every ragion of the Globe ; TOGETHER WITH

A MAP OF TIE UNITED STATES,

Drawn by Dragtnn, from Tanner's Map, and Engraved on Copper, in which is embodied the latest information rolating to the Internal Improvements of this cuuntry.

$$
\text { REVISED, CORRECTED, }
$$

AND BROUGHT DOWN TO THE PRESENT PERIOD, AND TRE PORTION RELATING TO TUE UNITED STATES THITTEN ANEW,

$$
\text { BY T. G. BRADFORD, }
$$

In Three handsome Royal Octavo Volumes, various biadings.

Persons can be supplied by sending their names to the Pullishers, or the general Agent,

G. W. GORTON.

PHILA DEL PHIA. 


\title{
WALPOLES INRIVALEN IBTTHRS:
}

THE ONLY COMPLETEEDITION.

THE

\section{LETTERS OF HORACE WALPOLE,}

\section{EARL OF ORFORD,}

\author{
CONTAINING
}

MEARIY TEREE BONDREDIETTERS,

Now first published from the originals, forming an uninterrupted series, from the year 1735 to 1797 ; containing his letters to George Montago, Esq.; Sir Morace Mann; Richard West, Esq.; Lady Craren; Gray (the poct ;) Hon. H. Seymour Conway ; John Chute, Esq.; Sir David Dalrymple; Rev. William Mason; Lady Herrey; the Earl of Hertford; Richard Bentley, Esq.; Earl of Strafford; Mrs. Hannah More; David Hume, Esq., \&c., \&c., with a pplendid Portrait of the Author, in Four beautiful - Volumes.

" Besides ite unrivalled beauty and brilliancy, the collection has the more important merit of being the liveliest picture of manners, and the best epitome of political hig. tory that not only this, but any country possesses."-Quarterly Reviow.

"No general collection of the letters of Horace Walpole has ever heen made which will at all compare in fulness with the preent work." - North Am. Reoioro.

"Horace Walpole may decidedly claim preeminence for ease and liveliness of ex. pression, terseness of remark, and felicity of narration above almost all the epistolary writers of Great Britain."-Qkarterly Review.

"Walpole's Letters are full of wit, pleasantry, and information, and written with singular neatness and sprightliness." - Edinburg Revieno.

"One of the most useful and important publication that has issued from the prese for the last quarter of a century. It is illuetrated with notes, drawn up with con summate tact. Such a work, so enriched with all that is necessary to render it complete, is one of the most valuable that any lover of sterling English literature can possess." - Sun.

"As a bouk of reference, this edition of Walpole's Letters must henceforth take its place among the memnirs and histories of the time. As a hook of gossip, it is perhaps the completest work of the kind in the English language."-The Timcs.

"One of the very hest works of its class, if not unique, in the English language: a work full of information, full of anesdote, and full of amusement; equally fit for the library of the scholar, the dilettante, the artist, the statesman, and the general reader."-Literary Gazette.

"Walpole's Letters are unequalled in our language; delightful in themselves, and a most amusing and instructive commentary on the history of parties, and of the country, from 1735 to $3797 . "$ - Athenaw

"It is the oviy complete edition of the incomparable letters of this "prince of epistolary writers, as he has been justly called; and the letters themselves are arrapged in chronological order."-Dublin Enening Mail.

"Those who have never yet read Horace Walpole's lettere-and they muet be gtill in their teens-have much elljoyment before them; those who are familiar with bis style, including all who deserve to read, will bere renew the pleasure they havs so often experienced."-Morking Herald.

SOLD BY ALL BOOKSELLERS. 
Upon Questions relating to Public Rights, Duties and Interests, WITH HISTORICAL INTRODUCTIONS;

In Two handsome Volumes, bound in embossed cloth, or law sheep.

\author{
C O N T E T T.
}

Military Flogging-Queen Caroline-Libel on the Durhan ClergyDissertation on the Law of Libel-Commerce and Manufactures-Agricultural and Manufacturing Distress-Army Estimatcs-Holy AllianceSlavery-Law Reform-Parliamentary Reform-Education-Poor Laws - Scotch Parliamentary and Burgh Reform - Scotch Marriage and Divorce Bill - Establishment of the Liverpool Mechanic's Institute Specch on Neutral Rights - Affairs of Ireland - Specch at the Grey Festival - Change of Ministry in 1834 - Business of Parliament - Mal. treatment of the North American Colonies - Speech on the Civil List Privilege of Parliament.

"The period embraced by these two volumes extends over a space of thirty yeark, from 1810 to 1840 , a unost exciting period, during all of wbich Mr. Brougham, or Lord Brougham, played a nost distinguisthed part; and upon the character and events of which he exerted no mean influence.

"In bricf, the hiographical ligaments which bind together the subjects so ably handled in these volumes, impart conpactness, strength, and beanty to the whole, and the head of a family who introduces such works to his sons and daughters, secures to them an inheritance which must endure to them for the whole period of existence."-National Intelligencer.

"Who does not desire 10 possess all the speeches of this great philantiropist on the subject of the poor laws, the education of the pcople, the law of libcl. and other great topics of universal concernment ? In the two large volumes before us, all these proud efforts of buman learning, genius, and intcllect, are emhodied-each speech being preceded hy \& historiral introduction of the occasion and circumstances under which it was defwerte. Nu Euglish library will be complete without these volumes." - New York Commercial.

"These volumes contain a mine of literary and politlcal wealth strongly characteristic, both $\mathrm{i}_{\text {. }}$ manner and matter, of tlsis great original goniuq. The independence, the vigour, the manliness of thought, which is liere displayed, and the stores of wisdom and learning with which the volumes abound, cannot fail to gecure for their auth $r$ a more full appreciation than he has in this country especially enjoyed." Madisonian. .

THE ECCLESIASTICAL AND POLITICAL HISTORY OF TH E

\title{
POPES OF ROME,
}

DURING THE SIXTEENTH AND SEVENTEENTH CENTURIES,

\section{BY LEOPOLD RA N E E,}

PROFESSOR IN THE UNIVERSITY OF BERIIN;

Translated from the German by Sarah Austin. In Two Volumes.

"To the ligh qualifications of profound rescarch, careful accuracy, great fairness and candour, with a constant reference to the genjus and spirit of each successive age, common to the historians of Germany, Mr. Ranke adds the charm of a singularly lucid, terse and agrecable style."-Quarterly Rcviez.

SOLD BY ALL BOOKSELLERS. 


\section{THE WORKS OF MRS. HEMANS, CO I P I IT工;}

\section{INCLUDING A MEMOIR BY HER SISTER,}

AND AN ESSAY ON HER GENIUS, BY MRS. SIGOURNEY.

A new and beautiful Edition, printed on fine paper, with a Portrait of the Authoress, handsomely bound in embossed cloth, or in calf and morocco, extra, with gilt edges, forming a beautiful and appropriate present for ladies; in 7 vols. royal $12 \mathrm{mo}$.

This is the only complete edition of the works of Mrs. Hemans, and containg many new poems, together with other matter not embraced in any other edition of her works.

" Of the poems of Mrs. Hemans it is unnecessary for us to speak. They have been too long known, too much admired, and too widely circulated to need our commen. dation: but we must express gratitude to the publishers for the elegant and complete manner in which this edition is issued, and express the hope that it may be the firsside companion of all who love nature and a pure unaffected expression of the rindest affection of a heart imbued with the pure love which springs from true religion." -
Boston Times.

\section{A Third Edition of the Biography and Poetical Remains OF THE IATE}

\section{MARGARET MILLER DAVIDSON,} BY WASHINGTON IRVING;

In One Volume, handsomely bound in embossed cloth.

"The volume here preaented is very attractive. The Biography by Irving derives a great interest from the affectionate dignity with which a motber, not unworthy of such daughters, seems to lave preserved the record of the development of the powers of mind, and graces of character, of her gifted and fated child; while the prose and pnetical remains attest the taste and talent which a premature grave snatched from the world."-Neso York American.

\section{THE POETICAL REMAINS OF THE LATE}

\section{U C R E T I A M. D A I D SON, \\ Collected and Arranged by her Mother,}

WITH A BIOGRAPHY BY MISS SEDGWICK, In One handsomo Volume, to match Irving's Biography of Margaret.

"We have read the contents of these volumes with serene and gober delight. They possess a charm which, to us, is irresistible, and which forbids the intrusion of any other feeling than one of respect, of wonder, or of love. The pieces in the volume now before us, (which is printed and bound in a style to correspond with the Remains of Margaret,) are mostly tinctured with the hue of melancholy; there are few of them that do not convey a moral; and many appear to have been written under the influence of gerious impression and deep devotional feelings."-Boston Courior.

THE POETICAL WORKS OF

SIR. WALTER. SCOT T;

A fine edition, in Six Volumes, royal $12 \mathrm{mo}$.

SOLD BY ALL BOOKSELLERS. 
PUBLISHED BY LEA \& BLANCHARD;

\section{Washington Irving's Worlss.}

A NEW AND BEAUTIFUL EDITION OF

THE WORLS OP WASTINGTONIRVING,

EM B RACING

The Sketch Book, Knickerbocker's New York, Bracebridge Hall, Tales of a Traveller, The Conquest of Granada, The Alhambra;

In Two Tiogal Octabo Uolumes, with a Fortuait of the \$utbor.

Each of the Works embraced in this edition may be bad scparately, in two volumes, $12 \mathrm{mo}$.

THE ROCKY MOUNTAINS;

OR SCENES, INCIDENTS, AND ADVENTURES IN THE FAR WEST,

With Two large Maps. In Two Volumes.

\section{A S T O R I A;}

Or Anecdotes of ain Enterprise beyond the Rocky Mountains, In Two Volumes.

A HISTORY OF THE LIFE AND VOYAGES OF

\section{CHRIST OPHER COLUMBUS;}

Revised and corrected by the Author. In Two Volumes, octavo.

\section{THE CRAYON MISCELLANY;}

Containing a Tour on the Prairies, Abbotsford and Newstead Abbey, Le. gends of the Conquest of Spain. In Three Volumes, $12 \mathrm{mo.}$

\section{THE BEAUTIES OF WASHINGTON IRVING;}

A small volume for the pocket, neatly done up in extra cloth. 
PUBLISIFD BY LEA \& BLANCHARD;

\section{DICKENS'S WORKS COMPLETE.}

\section{BAR N A B R UDGE,}

WITH MA NY BEAUTIFUL ILLUSTRATIONS,

Engraved by Yeager, together with over Fifty Illustrations on Wood; in Onc handsome Royal 8vo. Volume.

\section{TII}

With many additional Illustrations,

Engraved by Yeager, from Designs by Sibson. This cdition contains, in all, upwards of One Hundrcd Illustrations.

\section{POSTHUMOUS PAPERS OF THE PICKWICK CLUB,}

WITI FORTY-FIVE ILI,USTRATIONS.

\section{O LIVER TWIST;}

\section{or ehe Hatish=2301's 3mogtess,}

With a new Prcface, and Twenty-four Illustrations.

THE LIFE AND ADVENTURES OF

\section{NICHOLAS NICKLEBY,}

Containing a Portrait of the Author, cngraved on Steel, and Thirty-ninc Illustrations.

\section{SK E T CHE S,}

Illustrative of every-day Life and every-day People.

WITH TWENTY ILIUSTRATIONS.

All the above works are printcd on fine paper-the Illustrations on tinted papcr-and liandsomely bound in cmbossed cloth, to match. Eacli work may be had separately.

Cheap editions of these worke, without plates, arc also published by Lea and Blanchard, and can bc had of all booksellcrs.

\section{THE PIC-NIC PAPERS,}

By various hands. Edited by Charles Dickens, Esen, author of "Oliver Twist," Niclolas Nicklcby," \&ce., in Two Volumcs.

SOLD BY ALI, BOOKSELLERS. 
PUBLISHED BY LEA \& BLANCHARD;

A TEXT BOOK OF

PRACTICAL GEOLOGY AND MINERALOGY,

With instructions for the qualitative analysis of Minerals,

BY JOSHUA TRIMMER, F.G.S.,

WITH TWO EUNDRED AND TWEIVE WOOD OOTS,

A handsame Octaro rolume, bound in embossed cloth.

This is a systematic introduction to Mineralogy, and Geology, admirably calculated to instruct the student in those sciences. The organic remains of the various formations are well illustrated by numerous figures, which are drawn with great accuracy.

THE HRIDGEW ATER TREATISES ON THE POW ER, WISDOM AND GOODNESS OF GOD, as manifested in the Creation, containing Bell, Chalmers, Kidd, Whewell, Prout, Kirby, Roget and Buckland, with numerous engravings, wood cuts, and maps. The whole series forms a beautiful set of books, in 7 volumes, 8 vo, to be had in handsome cloth or half bound with calf backs and corners.

The following Three Treatises can be had separately :

GEOLOGY AND MINERALOGY, considered with reference to Natural Theology, by the Rev. Wm. Buckland, D. D., Canon of Christ Church, and Reader in Geology and Mineralogy in the University of Oxford; with nearly 100 copper-plates and large coloured maps; a new edition, from the late London edition, with supplementary notes and additional plates.

ROGETS' ANIMAL AND VEGETABLE PHYSIOLOGY; with nearly 500 wood cuts, in two volumes; second American edition.

THE HISTORY, HABITS AND INSTINCTS OF ANIMALS; by Rev. Wm. Kirby, M. A., F. R. S.; illustrated by numerous copperplate engravings.

\section{A. POPULAR TREATISE ON \\ VEGETABLE PHYSIOLOGY;}

Published ander the auspices of the Society for the Promotion of Popular Instruction;

WITH NUIMROUS WOOD CUTS,

In One Volume, $12 \mathrm{mo}$.

THE MILLWRIGHT AND MILLER'S GUIDE. By Oliver Evans. The Tenth Edition with Additions and Corrections, by the Professor of Mechanics in the Franklin Institute of Pennsylvania ; and a Description of an Improved Merchant Flour Mill. With Engravings. By C. \& O. Evans, Engineers.

This is a practical work, and has had a very extended sale.

. SOLD BY ALL BOOKSELLERS. 
THE SFCOND SFIEIES OF MISS STRICKLAND' IIVES OF THE QUEENS OF ENGLAND; containing Elizabeth of York, surnamed the Good Queen of Henry the VII., the Six Queens of Henry the VIII., and Queen Mary the First, in 2 vols., 12mo.

LORD BROUGIIAM'S HISTOIRCAL SKETCHES OF STATHSHEY WHO FLOURISIIED IN THE TIME OF GEORGE III. - Containing Lord Chatham, Lord North, Mr. Fox, Mr. Shcridan, Mr. Pitt, Mr. Canning, Mr. Wilberforce; Mr. Grattan, Washington, Franklin, Charles Carroll, Napoleon, Talleyrand, La. fayette, \&c., 2 vols. Fourth cdition.

THE UNITED IRISHMEN, their Lives and Times, by R. R. Madden, M. D., author of Travels in the East, \&c. ; in two volumes, $12 \mathrm{mo}$.

RONANTIC BIOGRAPHY OF THE AGE OF ELIZABETH, or Sketches of Life from the By-ways of History by the Benedictine Brethren of Glendalough. Edited by W. Cook Taylor, LL. D. \&c. of 'Trinity College, Dublin, author of "The Natural History of Society," in 2 volumes, 12 no.

HIVES OF LIINENT LITERARY AND SCIENTIFIC MEN UF ITALY. By Mrs. Shelley, Sir David Brewster, James Montgomery and others. Containing Dante, Petrarch, Boccaccio, Lorenzo de Medici, Galilco, Tasso, \&c., \&c., 2 vols.

A MEMOIR OF TIIE IIFE AND WIRTINGS OF MIS. IIEH A NS. By her Sister, Mrs. IIughes, 1 vol., $12 \mathrm{mo.}$

TIE MOST EMINENT FIRENCH WIRTERS. By Mrs. Shelley and others. Containing Racine, Fenelon, Rousseau, Molière, Corneile, \&c., \&c. 2 vols.

SKFTCIIES OF CONSPICUOUS LIVHNG CHARACTERS OF FIR A N CE. Containing Thiers, Chauteaubriand, Laffitte, Guizot, La Martine, \&c., \&c. 'I'ranslated by R. M. IValsh.

TII CIRITICAL, AND MISCELLANEOUS WRITINGS OF LOIRD BROUGHAM, with a sketch of his Character. Two vols., royal $12 \mathrm{mo}$.

THE CIITICAL AND MISCELXANEOUS WRITINGS OF SIR EDWARD CYTTYON IULWE⿺, Author of "Pellam," "The Disowned," \&c.

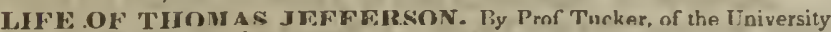
of Virginia ; 2 vols., 8 vo.

GEISIEIR'S TEX'T BOOK OF ECCIESIASTICAT HISTORY. Translated from the third Gcrman edition. By Francis Cunningham. 3 vols., 8 vo.

AN INQUIRY INTO THE VALIDITY OF TIE BHTISH CLAIM TO A IRIGIIT ON VISITATION AND SEARCII of American vessels suspected to be engaged in the African Slave Trade. By Flenry Wheaton, LL. D., Minister of the United States at the Court of Berlin. Author of "Elements of International Law," \&cc. In one volume.

LOCKIIAR'T'S LIFE OF SIR WALTER SCO'T'T, a fine edition with a portrait, in 7 vols., $12 \mathrm{mo}$.

THE COURT AND TIMES OE FREDERICK THE GREAT, edited with an introduction, by Thomas Campbell, Esq., author of the Pleasurcs of Hope, The Life of Petrarch, \&c.; 2 vols., $12 \mathrm{mo.}$

MADAMH DF SEVIGNE AND HER CONTEMPORATIES, comprising sketches of above one hundred of the most eminent persons of her times, 2 vols., $12 \mathrm{mo}$.

SOLD BY ALL BOOKSELLEPS. 
MRS. ELLIS'S TEMPERANCE TALES, or Hints to those who would Make Home Happy, by Mrs. Ellis, late Miss Stickney, author of The Women of England, \&c., \&.c. Containing-The Dangers of Dining Out, Confessions of a Maniac, Somerville Hall, The Rising Tide, The Favourite Child, First Impressions, and The Minister's Family, in 2 vol., $12 \mathrm{mo}$.

"The tendency of this work is one of the best and noblest, and the scenes and persons described are, in most instances it is believed, Portraits, aiming, as it does, at the correction of a too prevalent vice, that of intemperance, it is expected to command, amongst the serious and thinking part of the community, the same popularity that Pickwick and Humphrey's Clock have done in their peculiar circle."-Publishers Circular.

KEBLE'S CHRISTIAN YEAR. Thoughts in verse, for Sundays and Holidays, throughout the year. The third edition, in one neat volume.

THE CHILD'S CHRISTIAN YEAR. Hymns for every Sunday and Holiday, compiled for the use of Parochial schools, first American from the second London edition, adapted more especially to pastoral and domestic teachings; a small pocket volume to match the 'Christian Year.'

BISHOP HEBER'S POETICAL WORKS. Complete in one neat volume, to match 'Keble's Christian Year.'

TALES AND SOUVENIRS OF A RESIDENCE IN EUROPE. $\mathrm{By}$ the Lady of a distinguished Senator of Virginia. In one volume, extra embossed cloth.

THE QUEEN OF FLOWERS, OR MEMOIRS OF THE ROSE, a beautiful little volume, with coloured plates, and handsomely done up with gilt edges.

THE SENTIMENTS OF FLOWERS, OR THE LANGUAGE OF FLORA. Embracing an account of nearly 300 different Flowers with their powers in Language. With coloured plates. A small volume, embossed cloth, gilt edges.

THE LANGUAGE OF FLOWERS, with illustrative Poetry. To which is now first added The Calendar of Flowers. Revised by the Editor of 'The Forget-Me-Not.' The sixth American edition, with coloured plates. Handsomely done up in embossed leather, gilt edges.

THE YOUNG WIFE'S BOOK. A Manual of religious, moral, and domestic duties. A small pocket volume.

THE YOUNG HUSBAND'S BOOK. A Manual of the duties, moral, religious, and domestic, mposed by the relations of married life. A small volume, to match 'The Young Wife's Book.'

STORIES FOR VERY YOUNG CHILDREN, illustrated by numerous wood cuts, containing Winter, Spring. Summer, and Autumn, by Mrs. Marcet, author of Conversations on Chemistry.

LAWS OF ETIQUETTE, OR RULES AND REFLECTIONS FOR CONDUCT IN SOCIETY. By a Gentleman. A small pocket volume. Many thousands of which have been sold.

ETIQUETTE FOR THE LADIES. With Hints on the Preservation, Improvement, and Display of Female Beauty. A small volume to match the Laws of Etiquette.

THE CANONS OF GOOD BREEDING; by the author of 'The Laws of Etiquette ;' a small pocket volume in embossed cloth.

SOLD BY ALL BOOKSELLERS. 
PUBLISHED BY LEA \& BLANCHARD;

\section{A LIBRARY EDITION OF THE \\ SELECT WORKS OF HENRY FIELDING,}

WITH A MEMOIR OF THE LIFE OF THE AUTHOR,

BY BIR WALTER BCOTT:

And an Essay on his Life and Genius, by ArtuUr MURPhy, Eea., with a

Portrait. Bound in One or Two Volumes, and in various styles, to suit the Purchasers.

ALSO, TO MATCH THE ABOVE, THE

SELECT WORKS OF TOBIAS SMOLLET;

With a Memoir of the Life and Writings of the Anthor,

BY S IR W A L TER SCOTT;

With a Portrait. Bound in One or Two Volumes, to match Fielding.

\section{S T A N L E T H OR N,}

BY HENRY COCKTON,

Author of "Valentine Vox, the Ventriloquist," \&c., with numerous Illustratione, designed by Cruikshank, Leech, \&cc, and Engraved by

Yeager. In one Royal Octaro Volume, bound in embossed cloth.

\section{IIJ PORCIIAIN TOWIR;}

\section{OR NINE STORIES OF CHINA:}

Compiled from original sources; with Illustratione. In One Volume.

\section{G U Y F A W K E S ;}

\section{OR, THE GUNPOWDER TREASON;} AN HISTORICAL ROMANCE,

BY WILLIAM HARRISON AINSWORTH,

Author of "The Tower of London," "Jack Sheppard," \&c., in One Volume, 8vo., with Plates.

BEAUCHAMPE, OR THE KENTUCKY TRAGEDY, by the A uthor of "Richard Hurdis," \&cc, in Two Volumes, 12 mo.

CONFESSIONS, OR THE BLIND HEART, by the Author of "The Kinsmen, \&c., \&cc., in Two Volumes, $12 \mathrm{mo}$.

ROB OF THE BOW Shoe Robineon," in Two Volumes, $12 \mathrm{mo}$.

THE DAMSEL OF DARIEN, by the Author of "The Yemasee," "Guy Rivers," \&cc., in Two Volumes, $12 \mathrm{mo}$.

THE ADVENTURES OF ROBIN DAY, by the Author of "Nick of the Woods," \&c., in Two Volumes, $12 \mathrm{mo}$.

SOLD BY ALL BOOKSELLERS. 


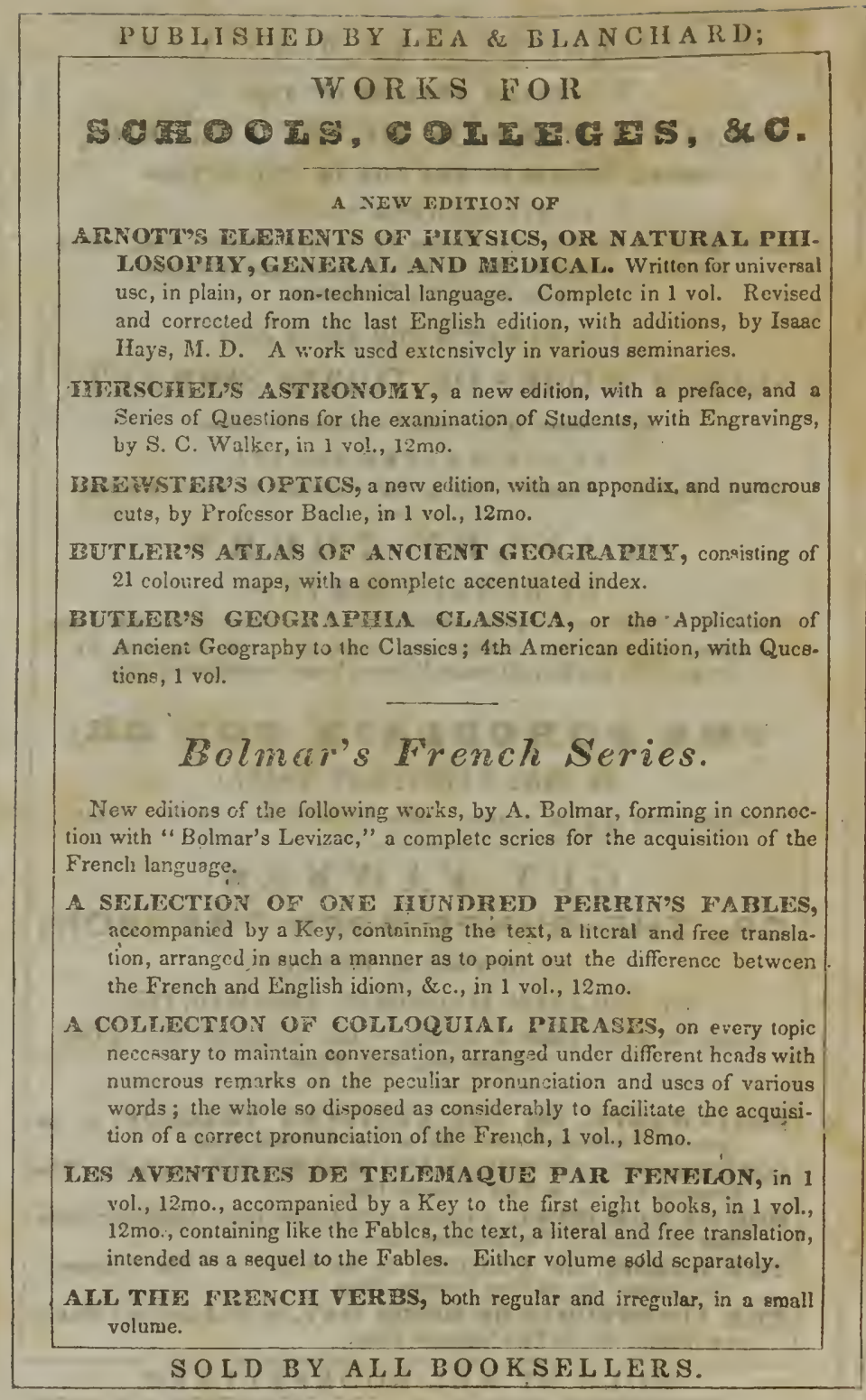




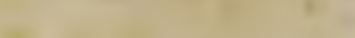

-

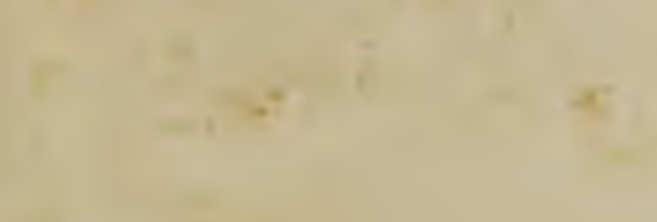




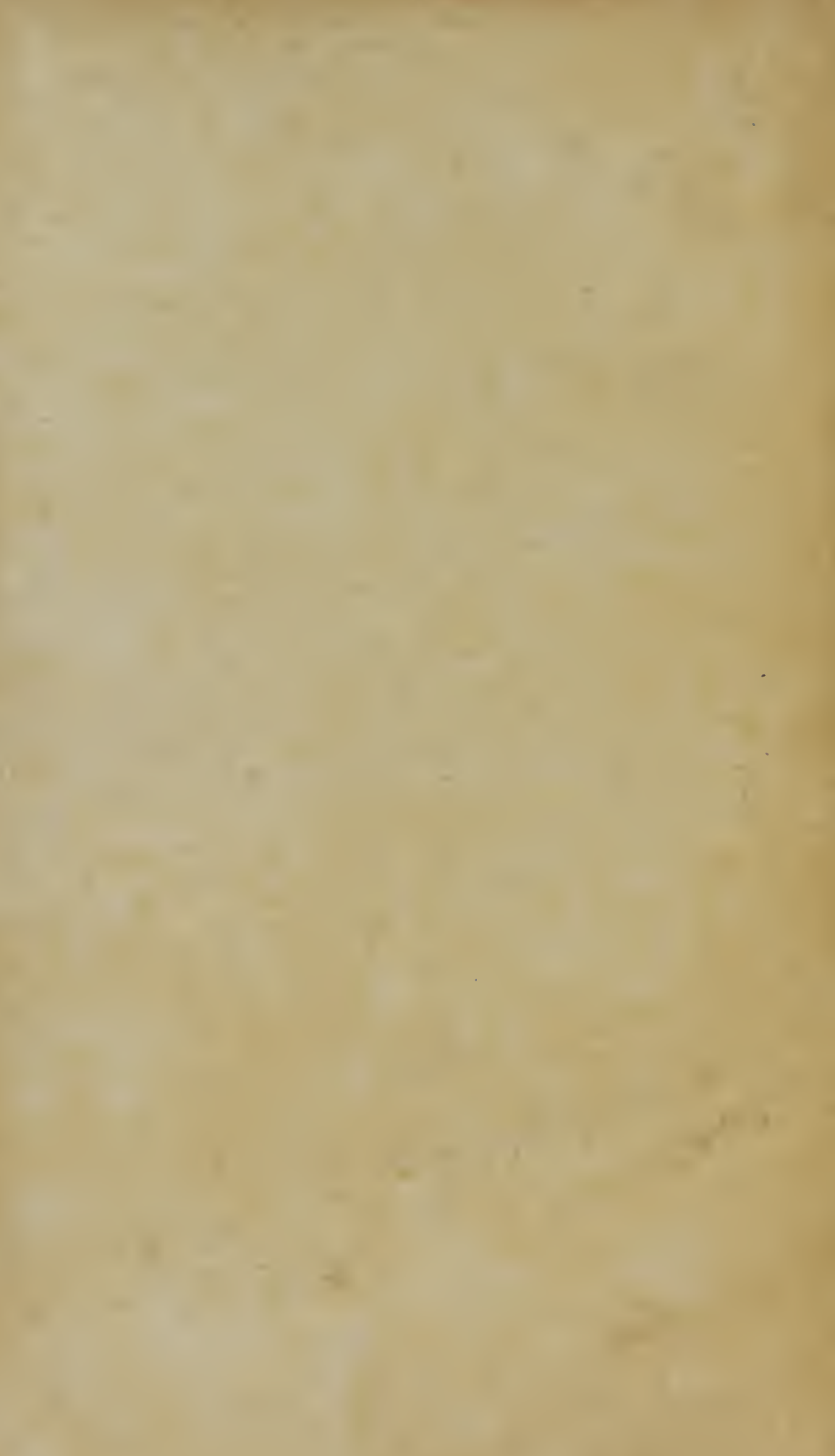





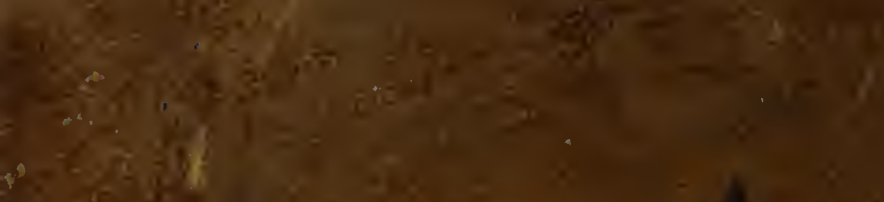

$+1=x$

ik:

$x^{2}+$

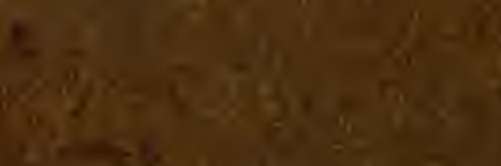

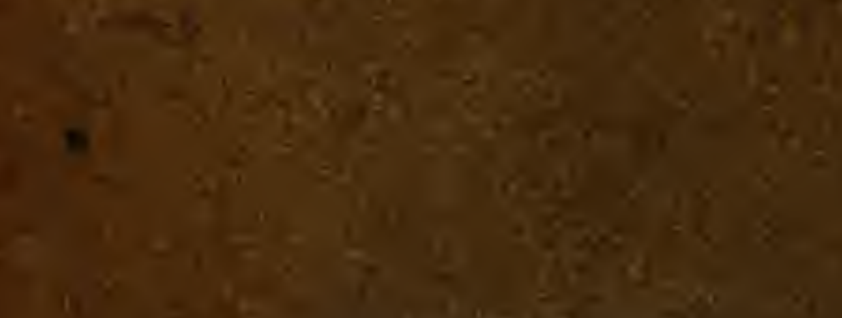

$y=1+2$

$\therefore$
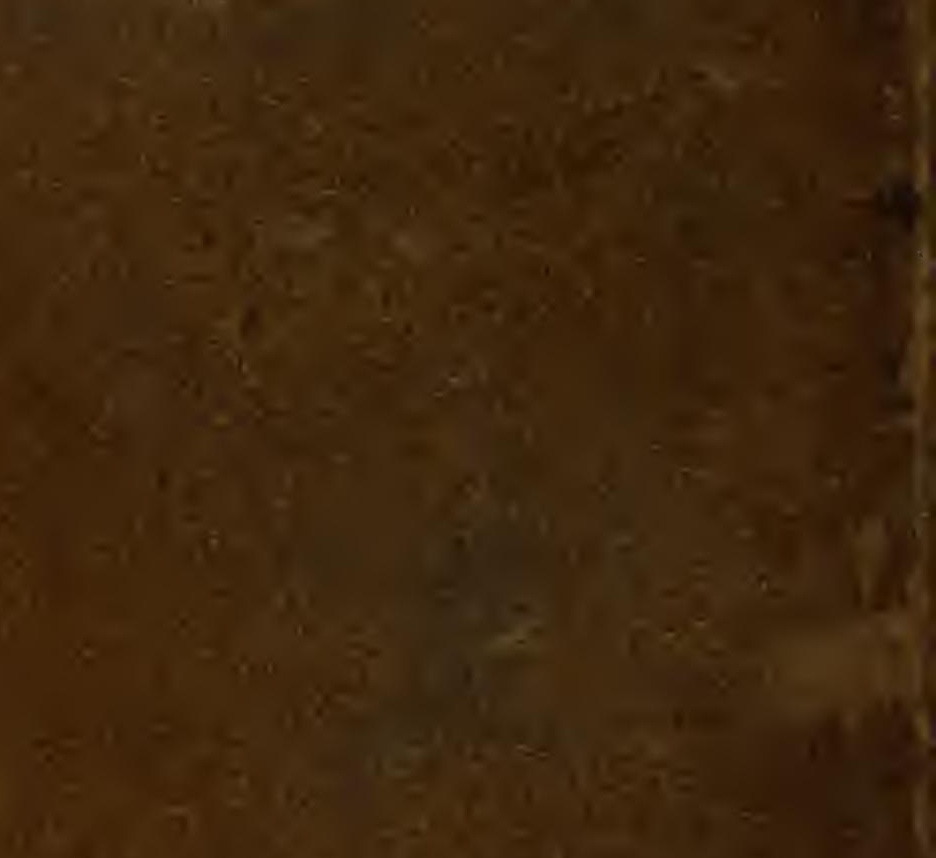